\title{
The tension between rules regulating the (liberal) professions and EC competition law : reason and passion in discussing professional regulation
}

Citation for published version (APA):

Wendt, I. E. L. E. (2009). The tension between rules regulating the (liberal) professions and EC competition law : reason and passion in discussing professional regulation. [Doctoral Thesis, Maastricht University]. Datawyse / Universitaire Pers Maastricht. https://doi.org/10.26481/dis.20091208iw

Document status and date:

Published: 01/01/2009

DOI:

10.26481/dis.20091208iw

Document Version:

Publisher's PDF, also known as Version of record

Please check the document version of this publication:

- A submitted manuscript is the version of the article upon submission and before peer-review. There can be important differences between the submitted version and the official published version of record.

People interested in the research are advised to contact the author for the final version of the publication, or visit the DOI to the publisher's website.

- The final author version and the galley proof are versions of the publication after peer review.

- The final published version features the final layout of the paper including the volume, issue and page numbers.

Link to publication

\footnotetext{
General rights rights.

- You may freely distribute the URL identifying the publication in the public portal. please follow below link for the End User Agreement:

www.umlib.nl/taverne-license

Take down policy

If you believe that this document breaches copyright please contact us at:

repository@maastrichtuniversity.nl

providing details and we will investigate your claim.
}

Copyright and moral rights for the publications made accessible in the public portal are retained by the authors and/or other copyright owners and it is a condition of accessing publications that users recognise and abide by the legal requirements associated with these

- Users may download and print one copy of any publication from the public portal for the purpose of private study or research.

- You may not further distribute the material or use it for any profit-making activity or commercial gain

If the publication is distributed under the terms of Article 25fa of the Dutch Copyright Act, indicated by the "Taverne" license above, 
THE TENSION BETWEEN

Rules Regulating THE (LiberaL) PROFESSIONS AND

EC COMPETITION LAW 
Printed by Datawyse/ Universitaite Pers Maastricht, 2009

The paintings on the cover are by Honoré Daumier.

Ftont: Two Lawyers. c. 1855-57. Oil on panel. Foundation E.G. Bührle Collection, Zürich, Switzerland.

Back: Don Quixote and Sancho Panza. c. 1866-68. Oil on canvas, $40.2 \times 33 \mathrm{~cm}$. The Atmand Hammer Museum of Art and Cultural Center, Los Angeles, USA.

Cover design by Josh Moll, Mixed Media 


\title{
THE TENSION BETWEEN RULES REgULATING THE (LIBERAL) PROFESSIONS AND EC COMPETITION LAW
}

\author{
Reason and Passion \\ in Discussing Professional Regulation
}

\author{
DISSERTATION \\ to obtain the degree of Doctor at \\ the Maastricht University, \\ on the authority of the Rector Magnificus, \\ Prof. dr. G.P.M.F. Mols, \\ in accordance with the decision of the Board of Deans, \\ to be defended in public \\ on Tuesday 8 December 2009, at 14:00 hours
}

by

Ida Elisabeth Liselotte Edeltraud WENDT 


\section{Supervisors}

Prof. dr. Hildegard Schneider

Prof. dr. Wouter Devroe (Katholieke Universiteit Leuven, Belgium / UM)

\section{Assessment Committee}

Prof. dr. Michael Faure (chair)

Ptof. dr. Walter van Gerven (Katholieke Universiteit Leuven, Belgium / UM)

Prof. dr. Ellen Vos

Prof. dr. Bruno de Witte (European University Institute Florence, Italy / UM)

Prof. mr. Marc van der Woude (Erasmus Universiteit Rotterdam) 


\title{
Acknowledgements
}

\author{
To my Family \\ Ancestors, Contemporaries, Descendants \\ Yesterday, today, tomorrow
}

To write a doctoral thesis on competition law and the professions is not something that just happened to me. It was a choice made a few years after a wonderful experience that I had had as an Etasmus (exchange) student in 1996/1997. That time had been marked by the intensity of the European Law Moot Court Competition through which my teammates and I were successfully guided by one of my supervisors, Hildegard Schneider. As probably for many others in and outside Europe, this competition has been so infectious that it did not leave my system for a long time. I am grateful to Hildegard for having encouraged me to research the topic of that year's edition more fully and for her generous support and knowledgeable guidance towards the final thesis. I equally owe a great deal of thanks to Wouter Devroe who persisted in challenging my thinking. Whilst tefraining from imposing his own thoughts and ideas upon my work, he has provided encouragement and teassurance throughout. His humour, commitment and acuity of thought provided the earthing to my writing process.

I am particularly indebted to Joeti Michielsen, Matianne Gijzen and Katja Lubina. Without the support of their friendship, I doubt this book would have seen completion. Joeri always helps to understand things without the necessity of judging, and I hope to enjoy our congeniality of nature and thought for many and a lot more decades to come. Marianne is a friend who takes me through the rough times with her ceaseless optimism that things will be fine in the end, as long as we make decisions. Katja's verve and creative persistence outcompeted my low point in the process and kept me writing, week after week. I cannot think that I will ever be so lucky with an (absent) office-mate again.

The most important words of gratitude are owed to my parents, who brought me up to believe that I could achieve anything and that education was the key to giving me choices in life. I am not sure if they would have wished me to pursue my education so far, or if they are thrilled with the choices I have made, but I know that they are proud, that I am loved, and that they are content with my choices as long as I am. One could not ask for more.

Most of this book was written at Maastricht University where I was adopted in a heartwarming manner by all colleagues of the Maastricht Institute for Transnational Legal Research (Metro), and I am grateful to the law faculty for having allowed me to conduct the research that I wanted. The time spent in Maastricht will always be dear to me. I am grateful too to my new colleagues at the Erasmus School of Law in Rotterdam, and in particular to Fabian Amtenbtink and Flora Goudappel for expressing their knowledgeable patience during busy months in which I started a new job.

I also owe thanks to a number of persons who have facilitated my research. Hans Gilliams allowed me access to the scientific material his law firm had gathered in preparing the representation of Mr. Wouters before the Court of Justice. Pierre Larouche and Ruth Jussen warmly welcomed me to stay in their house in Brussels during the period in 2003 that I worked for the Directorate General for Competition. The time spent with D.3 provided me 
with an invaluable insight into the Commission's initiative to modernise the professions, and I am grateful to the colleagues of that time - especially Lowri Evans, Maija Laurila, Ben Collins and Sandra De Waele - for having encouraged my research. I am grateful, too, to Bo Vesterdorf for being receptive to a few ideas on my research that I sketched during a visit to the Court of First Instancc.

Among the friends and colleagues without whom the time spent on this doctoral thesis would have been much the poorer - especially René, Sophia, David, Sanne, Fidel, Milou, Karolina, Katja Neumann, Anne, Christian and Astrid, Isa, Josipa, Ute, Tatjana, Yasmine, Christian van Tellingen, Peter Thran, Minke, Pim, Ilse, Eva, Kees, Josh and Sytse, 'Türkan, Ulla and Helena - I owe particular thanks to Enrico Milano, Denise Prévost, Nicls Philipsen, Bas van der Scheur, Cees van Duin and Marianne who made time to read and comment on parts of my manuscript. Joeri has patiently proof-read every chapter, and Katja has read drafts of various stages on a weekly basis. Morag Goodwin showed an untiring willingness to discuss the ins and outs of the English language and legal concepts (besides having proved to be an excellent cook). All have attempted to improve the presentation of my ideas; where they have succeeded, the credit is theirs. Bastiaan Rijpkema and Caroline Peters helped me uncomplainingly in applying the final touches to the bibliography and in producing the Dutch summary. Remaining errors are fully mine.

Rotterdam, October 2009

"Daß in Lebre und Rechtsprechung ständig gegen die Grundregeln des Denkens verstoßen wird, ließe sich obne weiteres durch die Tag für Tag erscbeinenden Veröffentlicbungen belegen. So kommt es auch, dass zablreiche juristische Kontroversen und Diskussionsn nur auf Definitionsfeblem, Begriffsvertauscbungen, Scblußfeblern und Trugschlïssen beruben. Wenn es stimmt-und dieser Meinung bin ich-, daß der Stand einer Disziplin wesentlich davon abbängt, wie viele seiner Mitglieder selbständig denken können, dann liegt bei den Juristen einiges im argen. Dem gilt es entgegenquwirken. Deshalb sollte sich jeder mit der Kunstlebre des Denkens, also mit der Logik, einigermaßen vertraut machen.

Icb bin weit davon enffernt, solche Kenntnisse $z^{u}$ überscbätzen. Im Text ist immer wieder bervorgeboben, daß die Logik keine Lebre von der Erkenntnis der Wahrheit ist. Jedoch lassen sich Wabrbeiten nur begründen, einsicbtig machen und beweisen, wenn richtiges Denken vorausgebt."

Schneider E., Logik für Juristen 


\section{Contents - Overview}

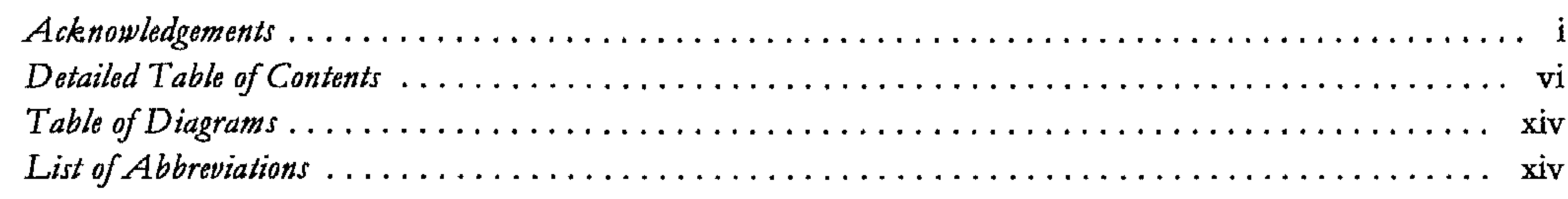

\section{Chapter 1}

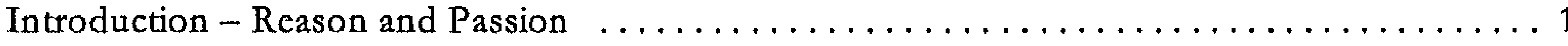

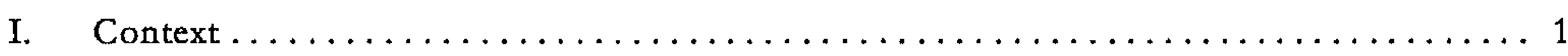

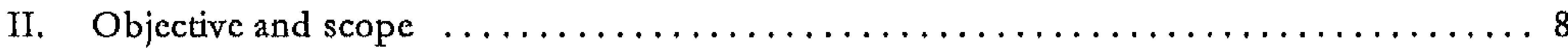

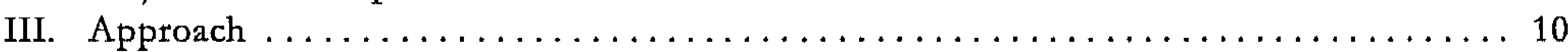

\section{Chapter 2}

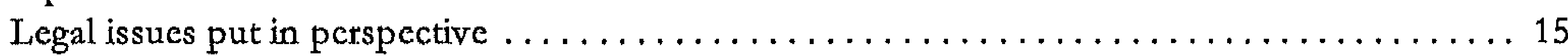

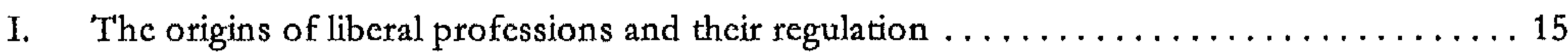

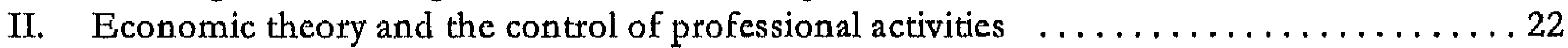

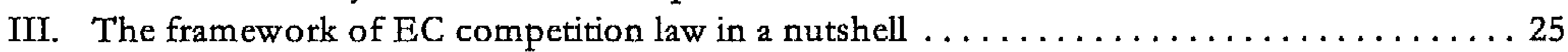

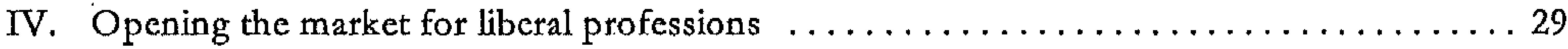

V. The case law applying EC competition law to the liberal professions $\ldots \ldots \ldots \ldots \ldots . \ldots 34$

VI. More recent developments to modernise the professions in terms of competition law ....53

\section{Chapter 3}

Liberal professions in the remit of EC competition law: two jurisdictional elements $\ldots \ldots \ldots \ldots 65$

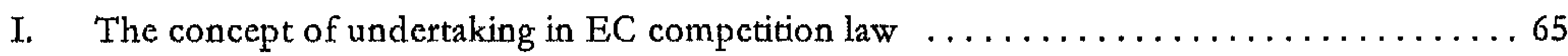

1. Members of a profession as undertakings in the sense of competition law $\ldots \ldots \ldots 70$

2. Certain categories of members of the professions not qualifying as undertakings . . . . 74

3. Professional associations as undertakings? ........................ 117

II. Community dimension - The potential of professional regulations to affect trade

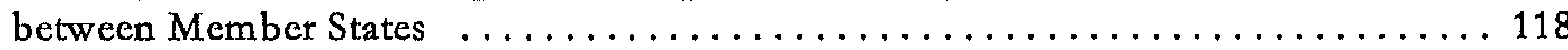

1. A broad interpretation - Professional regulations capable of affecting trade between Member States ............................... 120

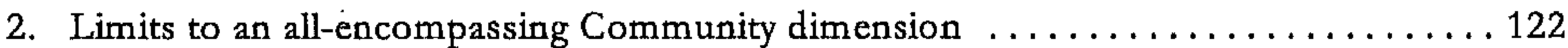

3. National instances applying EC competition law to liberal professions $\ldots \ldots \ldots \ldots 131$

III. Closing remarks: in favour of a universal applicability of EC competition law $\ldots \ldots \ldots 134$ 
Chapter 4

Article 81(1) EC and its Field of Application with Regard to Professional Self-Regulation . . . 142

I. Collective professional regulation and the jurisdictional scope of Article 81(1) EC ....142

1. Collective self-regulation within the remit of Article 81(1) EC .............. 143

2. Collective professional regulation not having a character that would justify

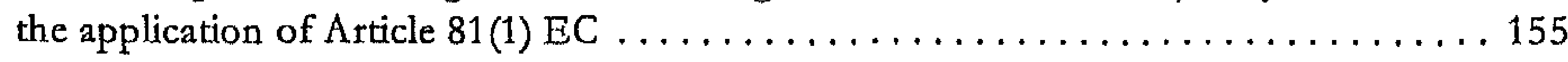

II. Substantive assessment under Article 81(1) EC: the object and effect of

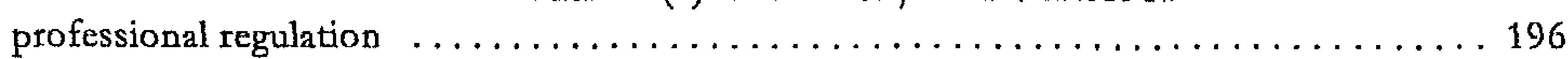

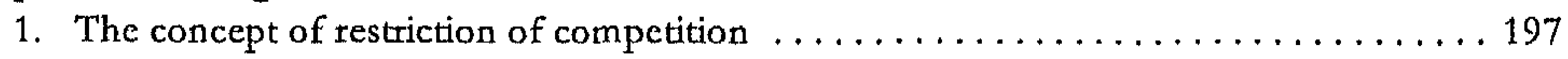

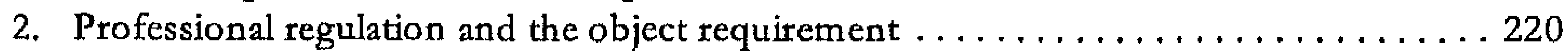

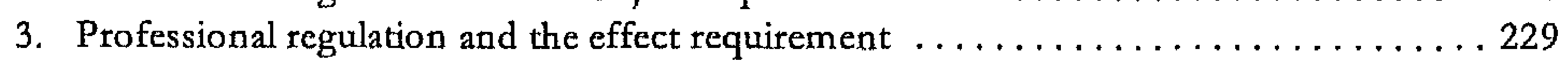

4. Limiting the prohibition of Article 81(1) EC: the overall context of

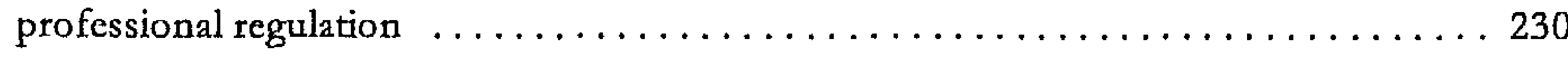

Chapter 5

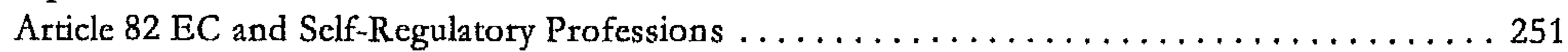

I. The concept of collective dominance and collectively organised professions $\ldots \ldots \ldots 252$

1. Connective links and the collectivity of liberal professions . . . . . . . . . . 260

2. Measuring dominance and the market power of liberal professions ........... 264

3. Dominance on a substantial part of the common market and effect on intra-community trade . ................................ 267

II. The competition related concept of abuse and its meaning in relation to

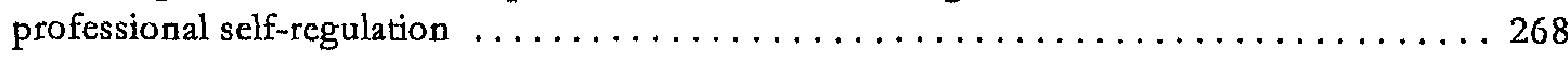

1. Joint or individual manifestation of collective dominance: 'collective abuse' versus 'abuse by proxy' . . . . . . . . . . . . . . . . . . . . . . . . . . . . . . . 269

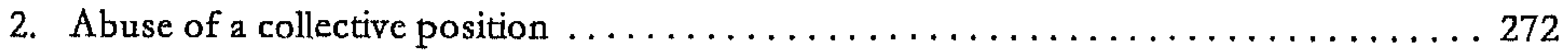

3. Objective justification, efficiency gains and the principle of proportionality $\ldots \ldots .300$

Closing Chapters 4 and 5: comparing the application of Articles 81 and $82 \mathrm{EC}$

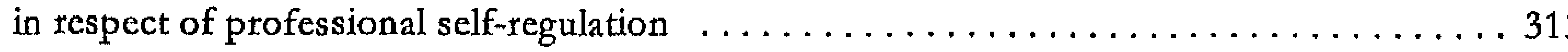

Chapter 6

State Involvement in Professional Regulation and its competition restrictive effects

I. A duty on Member States to respect the competition provisions

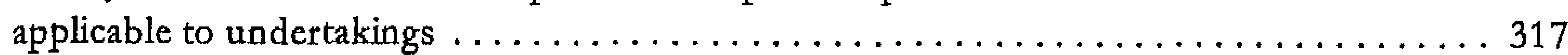

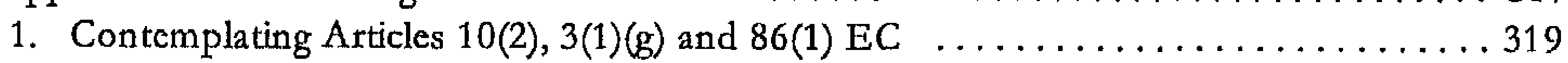

2. Contemplating Protocol no 27 on the internal market and

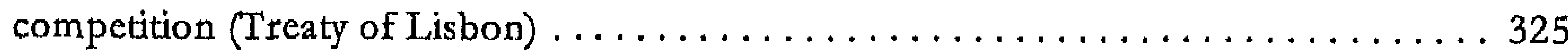

II. Case law built standard to control State intervention in self-regulatory markets $\ldots \ldots \ldots 328$

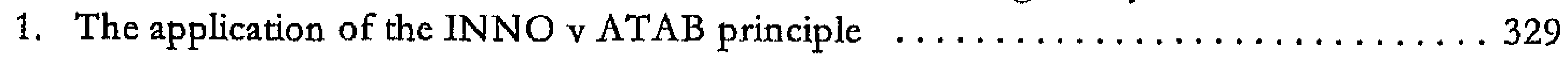

2. The case law's application of Article $10 \mathrm{EC}$ to State intervention in the professional services sector . . . . . . . . . . . . . . . . . . . 337

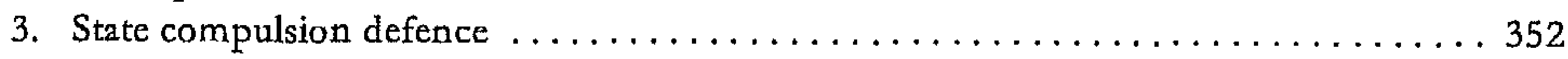

III. Closing remarks: Some pointers towards a legitimate level of competition law control of State measures 
Chapter 7

Justifying Professional Regulation - Solutions Reflecting the Structure

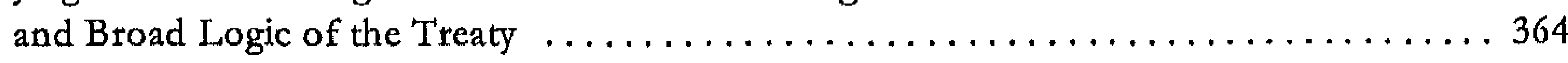

I. Article 81 (3) EC: the competition specific exemption $\ldots \ldots \ldots \ldots \ldots \ldots \ldots \ldots \ldots$

1. A positive balancing act: the four cumulative criteria of

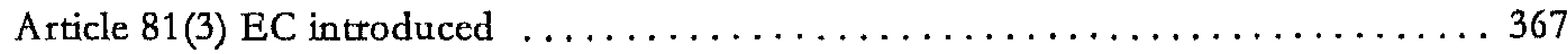

2. Objective efficiencies indispensable to compensate restrictive effects $\ldots \ldots \ldots \ldots . \ldots 372$

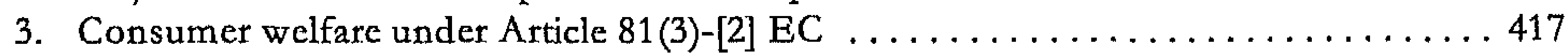

4. Limiting the limit in accordance with Article 81(3)-[4] EC: no elimination of competition in respect of a substantial part of the professional services . . . . . . 419

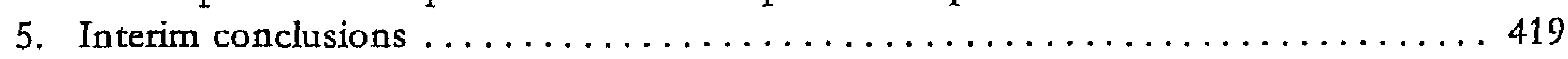

II. Article 86(2) EC: the general justification avenue - professional regulation

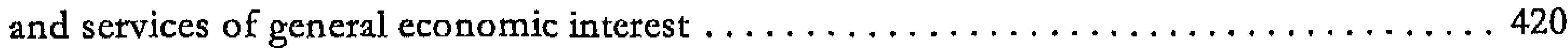

1. The scope of Article $86(2)$ EC with regard to professional regulation $\ldots \ldots \ldots \ldots . \ldots 24$

2. Proportionality test: obstruction of the performance

of the undertakings' task to provide an SGEI $\ldots \ldots \ldots \ldots \ldots \ldots \ldots \ldots \ldots \ldots, \ldots \ldots$

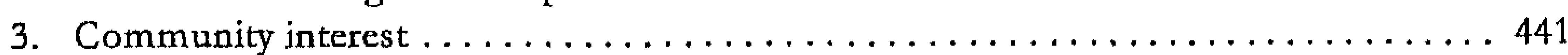

III. Closing temarks: the possible prospect of formulating policy guidelincs? $\ldots \ldots \ldots \ldots 441$

Chapter 8

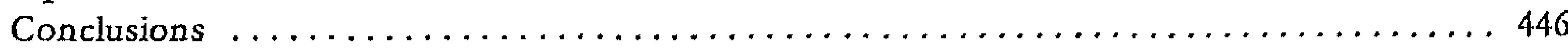

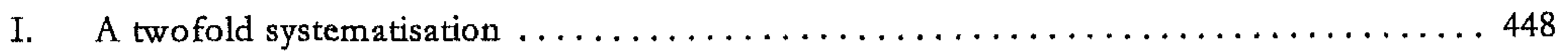

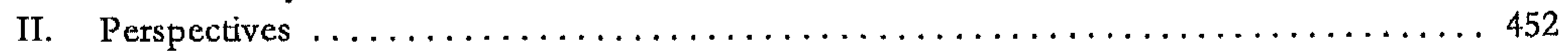

Samenvatting ................................ 460 


\section{Detailed Table of Contents}

\section{ChAPTER 1}

INTRODUCTION - REASON AND PASSION

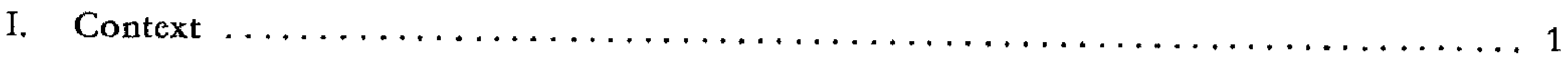

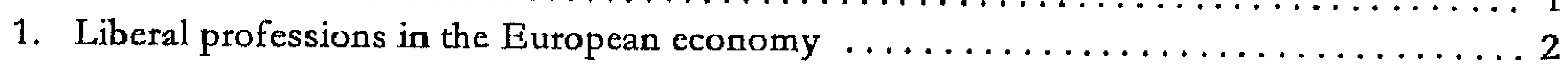

2. Liberal professions and their regulatory environment $\ldots \ldots \ldots \ldots \ldots \ldots \ldots \ldots \ldots$

3. Better regulation in regulated professions to enhance

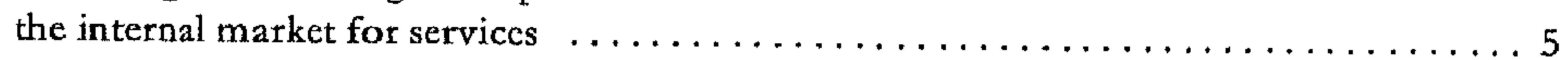

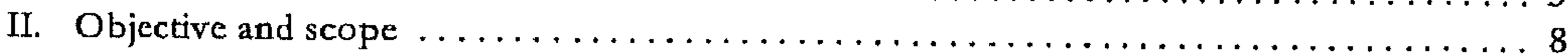

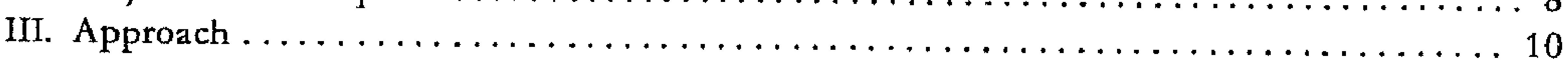

\section{CHAPTER 2}

I.EGAL ISSUES PUT IN PERSPECTIVE

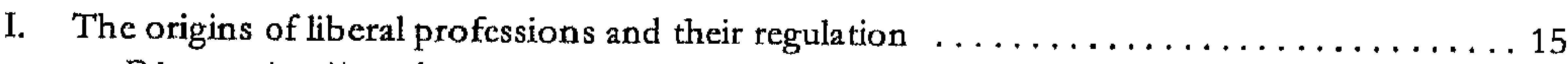

Diagram (no. 1) on the actors in the field of professional regulation $\ldots \ldots \ldots \ldots \ldots \ldots \ldots \ldots \ldots$

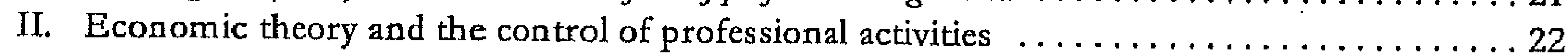

III. The framework of EC competition law in a nutshell $\ldots \ldots \ldots \ldots \ldots \ldots \ldots \ldots \ldots \ldots$

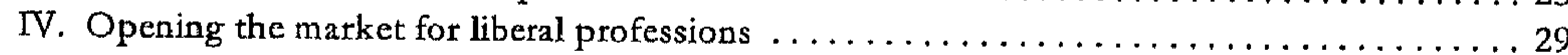

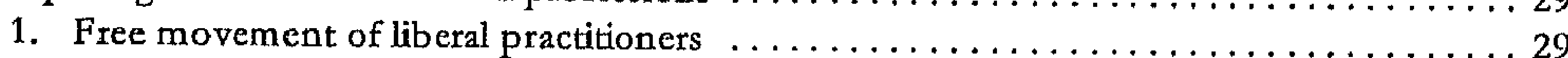

2. Towards applying EC competition law to professional regulation $\ldots \ldots \ldots \ldots \ldots \ldots \ldots \ldots \ldots$

$\mathrm{V}$. The case law applying $\mathrm{EC}$ competition law to the liberal professions $\ldots \ldots \ldots \ldots \ldots 34$

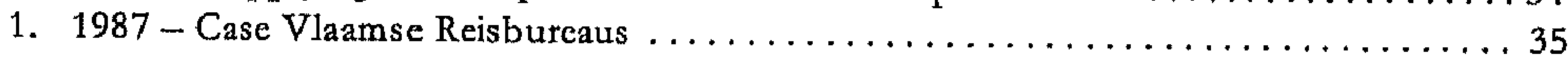

2. $1993,1998,2000$ - Case (trilogy) Consiglio Nazionale degli Spedizionieri

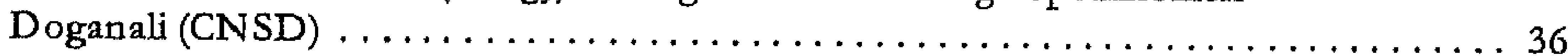

3. 1995 - Case Colegio Oficial de Agentes de la Propriedad Industrial (COAPI) . . . . . . 38

4. 1995, 1997 - Case Bilanzbuchhalter v Commission . . . . . . . . . . . . . . . . . 39

5. 1999, 2000, 2001 - Case Institute of Professional Representatives before

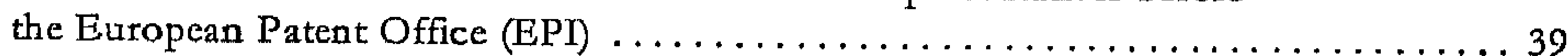

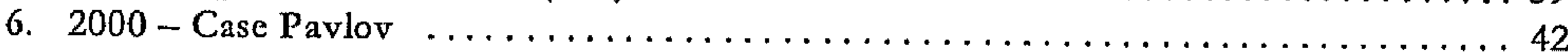

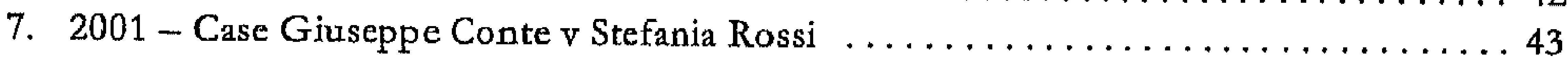

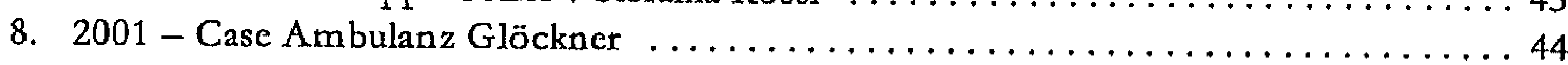

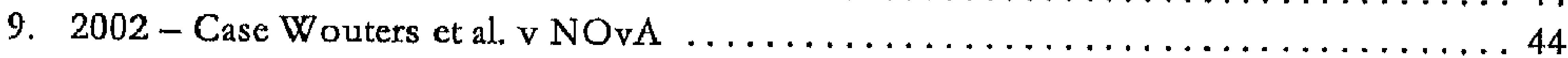

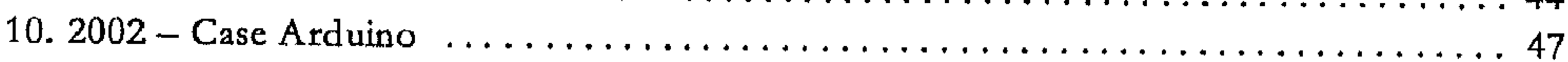

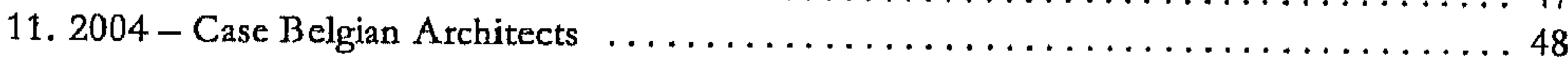

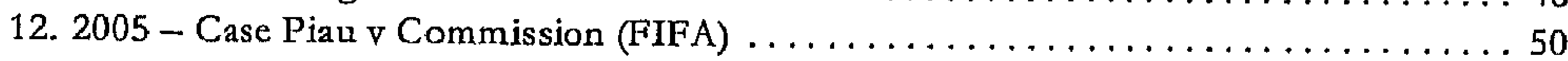

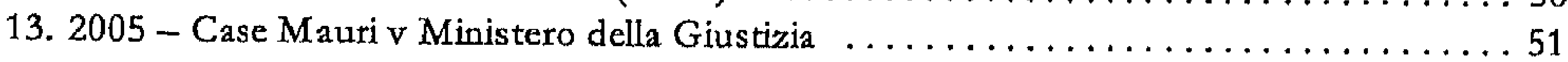

14. 2006 - Case Servizi Ausiliari Dottori Commercialisti v Giuseppe Calafiori . . . . . . . 51

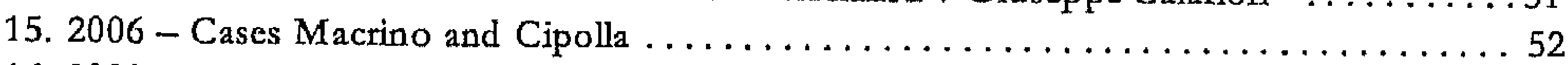

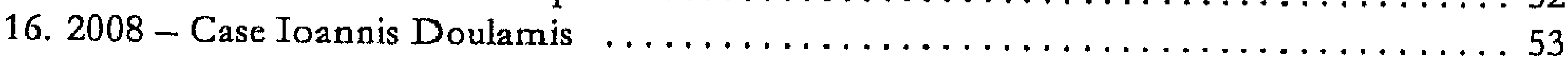

VI. More recent developments to modernise the professions in terms of competition law $\ldots .53$

1. At Community level - the modernisation of professional regulation $\ldots \ldots \ldots \ldots \ldots$

2. At national level - between deregulation, re-regulation and inertia $\ldots \ldots \ldots \ldots \ldots \ldots$ 


\section{CHAPTER 3}

LIBERAL PROPESSIONS IN THE REMIT OF EC COMPETITION LAW:

TWO JURISDICTIONAL ELEMENTS

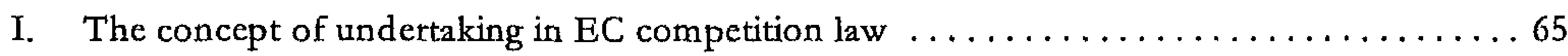

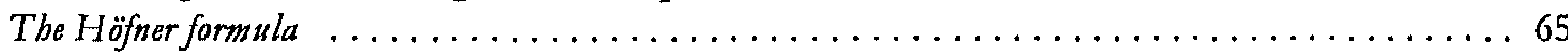

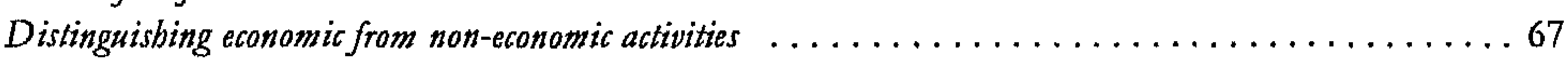

1. Members of a profession as undertakings in the sense of competition law . . . . . . 70

1.1. Höfner formula: Every entity engaged in an economic activity... $\ldots \ldots \ldots \ldots 70$

1.2. ...regardless of the legal status of the members of a profession $\ldots \ldots \ldots \ldots \ldots 73$

2. Certain categorics of members of the professions not qualifying as undertakings .....74

2.1. Profession-specific concerns to outweigh the economic character

of activities exercised by members of a profession? . . . . . . . . . . . . . . 75

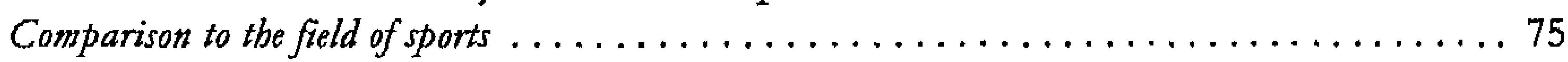

Diagram (no. 2) on the distinction made in Meca-Medina II $\ldots \ldots \ldots \ldots \ldots \ldots \ldots 77$

Trying the relativity of the concept of undertaking: nature of an activity versus

motives for certain rules ................................... 77

2.2. Höfner contrasted with activities not having a character justifying

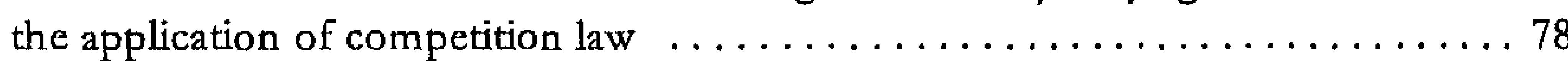

2.2.1. Background: the necessary exercise of public authority is not covered

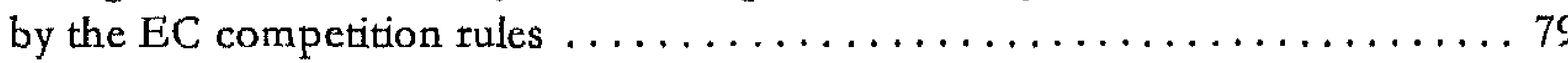

2.2.2. Critical discussion of the case law disregarding

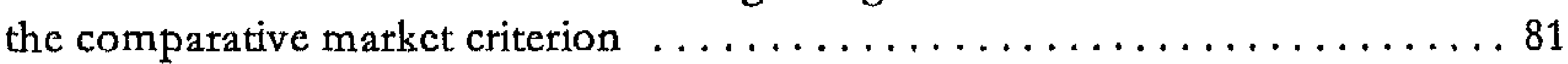

2.2.2.1. Assessing the 1994 case SAT/Eurocontrol and the 1997 case Cali . . . . . 82

The exercise of public authority as a substantive consideration $\ldots \ldots \ldots \ldots \ldots \ldots . \ldots 84$

The exercise of public authority corelating to classical State prerogatives $\ldots \ldots \ldots \ldots .85$

A seeming objective standard revealing a case by case approach $\ldots \ldots \ldots \ldots \ldots \ldots 85$

A contrasting example from the aviation control sector $\ldots \ldots \ldots \ldots \ldots \ldots \ldots . \ldots . \ldots 8$

Diverting from 'necessary' to 'typical' powers of public authority . . . . . . . . . . . 89

2.2.2.2. Contrasting the case law with the 2001 case Glöckner . . . . . . . . . 90

2.2.2.3. Activities not to be carricd out under market conditions ...........99 91

Activities gentinely devoid of an economic character? .................. 91

More case law to be contrasted: the 2006 case SELEX ................... 92

Diagram (no. 3) on the latitude of the jurisdictional scope of $(E C)$ competition law ...99

Preparing a more fundamental critique of the case law ................... 94

2.2.3. Justiciable or not: fundamental critique on the criterion of

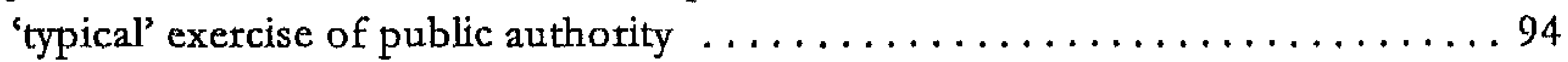

2.2.3.1. First fundamental critique: the criterion does not respect

the objective character of the concept of undertaking $\ldots \ldots \ldots \ldots \ldots 9$

More opposition to an imperative public authority criterion $\ldots \ldots \ldots \ldots \ldots \ldots \ldots 9$

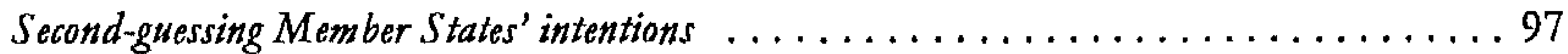

Dr. Jekyll and Mr. Hyde ................................. 97

2.2.3.2. Second fundamental critique: more tangible criteria are required $\ldots \ldots 100$

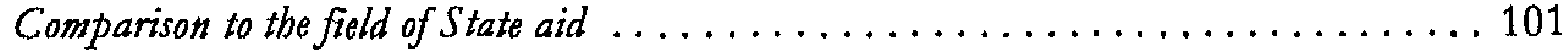

In search of a predictable standard: securing essential functions

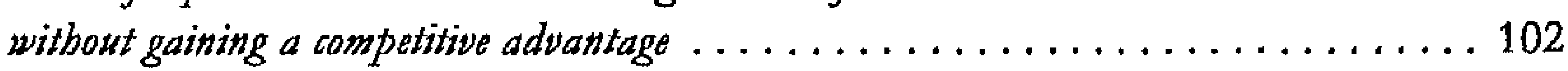

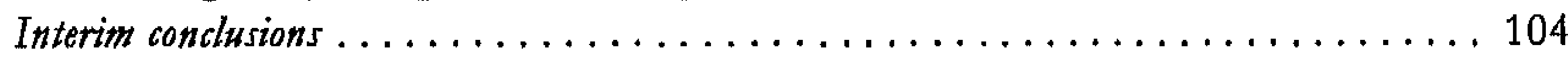

2.2.4. Illustration by particular professional sectors $\ldots \ldots \ldots \ldots \ldots \ldots \ldots \ldots \ldots \ldots$

2.2.5. Preliminary conclusion: Limiting the limits $\ldots \ldots \ldots \ldots \ldots \ldots \ldots \ldots \ldots$

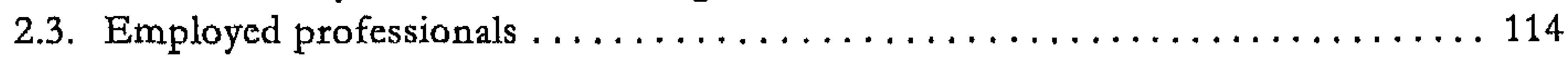




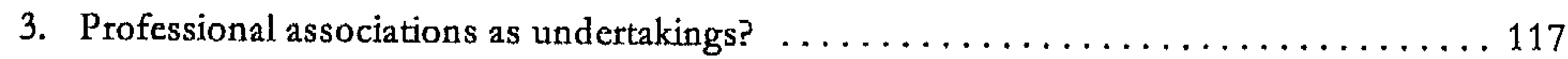

II. Community dimension - The potential of professional tegulations to affect trade between Member States

1. A broad interpretation - Professional regulations capable of affecting trade between Member States

2. Limits to an all-cncompassing Community dimension $\ldots \ldots \ldots \ldots \ldots \ldots \ldots \ldots \ldots$

2.1. Objective factors for a sufficient predictability of an effect on interstate trade

2.1.1. Possible effects on suppliers and customers of the sector concerned $\ldots \ldots \ldots 123$

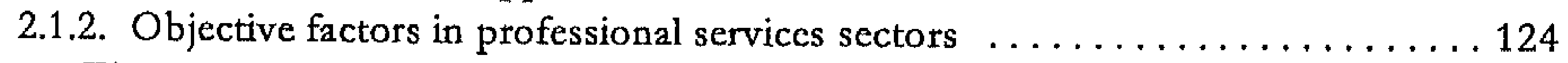

The nature of professional rules . . . . . . . . . . . . . . . . . . . . . 125

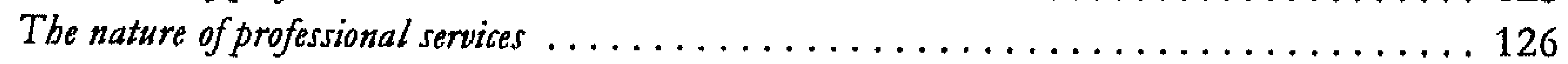

2.2. Appreciability of the potential effect on interstate trade $\ldots \ldots \ldots \ldots \ldots \ldots \ldots 128$

Professional activities regulated at national level . . . . . . . . . . . . . . . . . . . . . . . . . 129

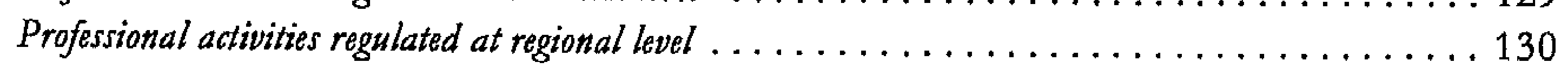

3. National instances applying EC competition law to liberal professions $\ldots \ldots \ldots \ldots 131$

III. Closing rematks: in favour of a universal applicability of EC competition law ........ 134

\section{CHAPTER 4}

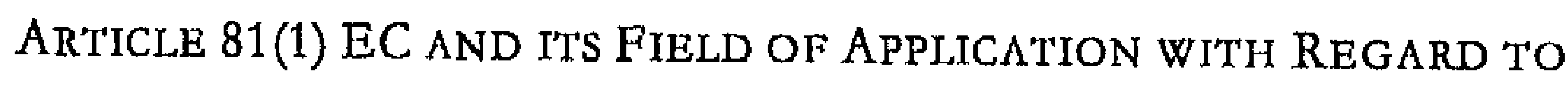

Professional Self-Regulation

I. Collective professional regulation and the jurisdictional scope of Article 81(1) EC .....142

1. Collective self-regulation within the remit of Article $81(1) \mathrm{EC} \ldots \ldots \ldots \ldots \ldots \ldots 143$

1.1. The accessory concept of association of undertakings:

A body organising economically active members . . . . . . . . . . . . . . 143

1.1.1. Professional bodies as associations of undertakings $\ldots \ldots \ldots \ldots \ldots \ldots \ldots 145$

1.1.2. Associations with members that are no undertakings . . . . . . . . . . . 146

Professional associations with employee members . . . . . . . . . . . . . . . . . 147

Professional associations composed of professional associations $\ldots \ldots \ldots \ldots \ldots \ldots \ldots 147$

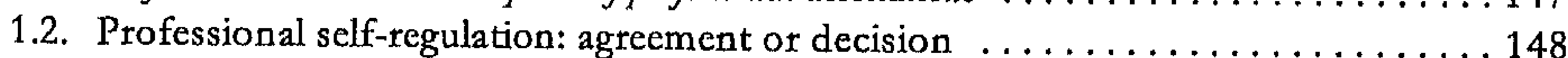

1.2.1. Decision of association: a telative concept reflecting

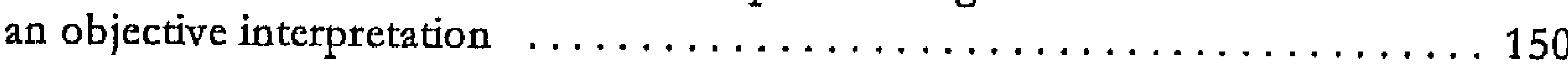

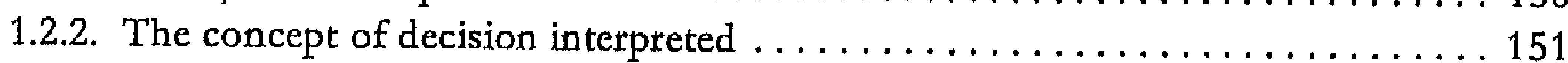

1.2.3. The practical difference between agreement and decision illustrated . . . . . 153

2. Collective professional regulation not having a character that would justify the application of Article 81(1) EC

2.1. Limiting the jurisdictional scope ratione personae I:

professional associations exercising activities connected with powers

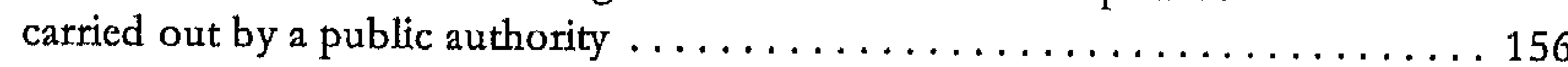

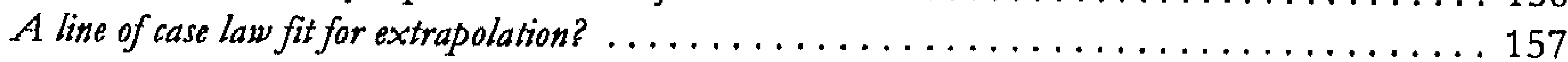

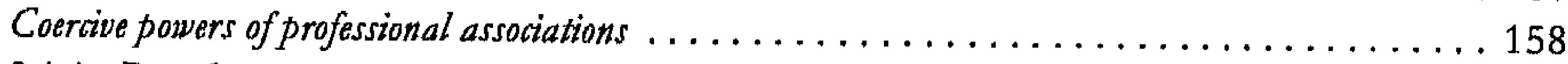

2.1.1. Regulatory powers of professional associations $\ldots \ldots \ldots \ldots \ldots \ldots \ldots 16 \ldots \ldots$

2.1.2. Supervisory powers of professional associations $\ldots \ldots \ldots \ldots \ldots \ldots \ldots \ldots$

2.2. Limiting the jurisdictional scope ratione pcrsonae II: professional associations subject to control by a public authority .......... 165

2.2.1. Composition of self-regulatory bodies . . . . . . . . . . . . . . . 166

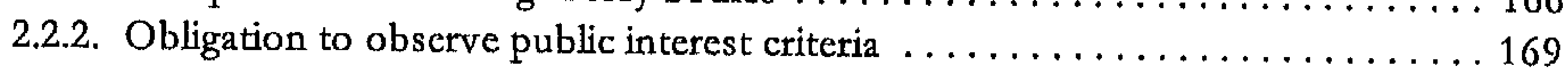


2.3. Preliminary conclusions on the scope ratione personae:

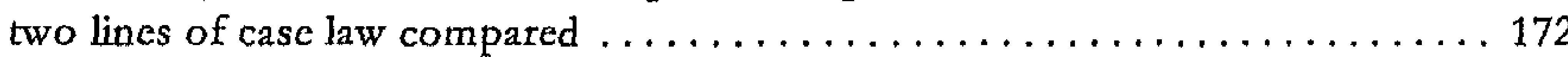

2.4. Particular professional sectors: the exception ratione personae II

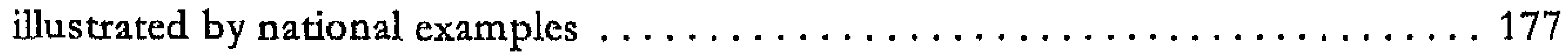

Examples from the legal sector ................................... 177

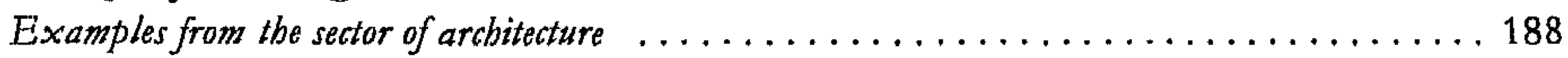

Examples from the medical sector ................................ 190

Interim observations . . . . . . . . . . . . . . . . . . . . . . . . . . . . 191

2.5. Exception ratione materiac: Regulation of 'purely ethical issues' . . . . . . . . . 192

II. Substantive assessment under Article 81(1) EC: the object and effect

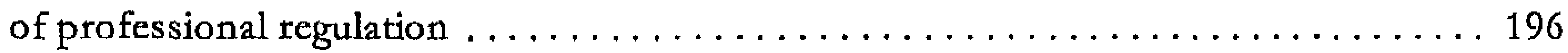

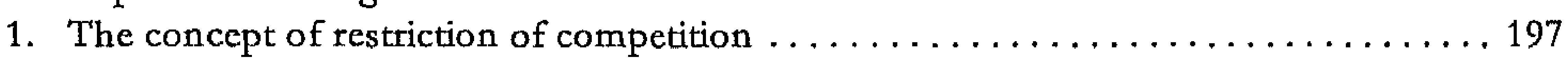

An economic concept interpreted objectively: Allocative (in)efficiencies and relative rise in price . . . . 198

1.1. The distinction between restriction by object and by effect .............. 199

Restrictions by object: presuming intention to restrict competition $\ldots \ldots \ldots \ldots \ldots \ldots \ldots 200$

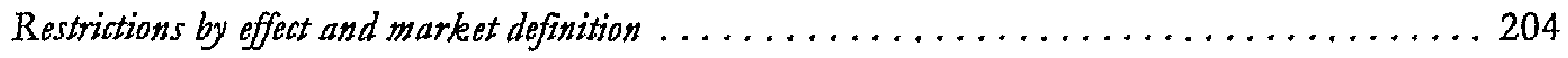

1.2. Confining the substantive scope of Article 81(1) EC . . . . . . . . . . . 206

1.2.1. Net effect of teduced competitive forces: context versus immunity . . . . . 207 Article 81 (1) EC is thot a mere jurisdictional clause ................... 208

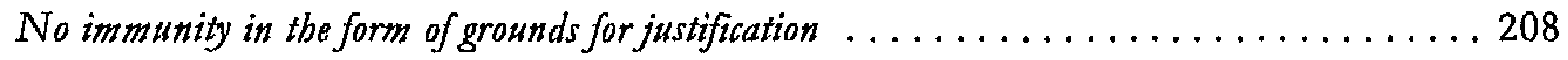

No rule of reason due to the bifurcated structure of Article 81 EC ............. 210

1.2.2. Giving shape to the boundaries of the substantive element of

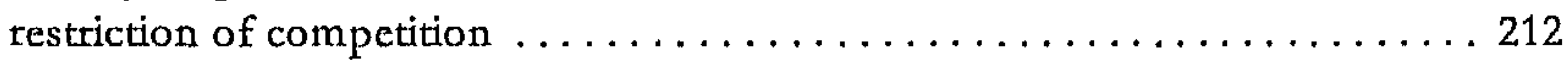

Ancillary restraints doctrine implementing an objective necessity testing ............ 213

Ancillary restraints and restrictions by object: an integrated test of rebutting

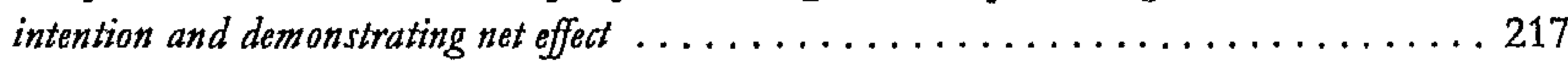

Diagram (no. 4) illustrating the different steps in deciding whether a certain

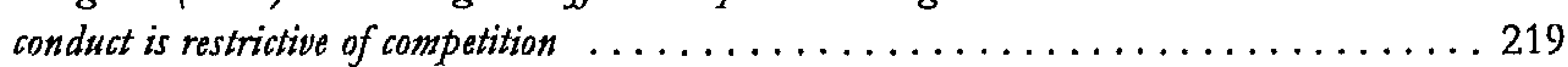

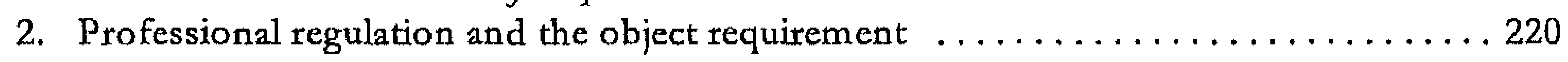

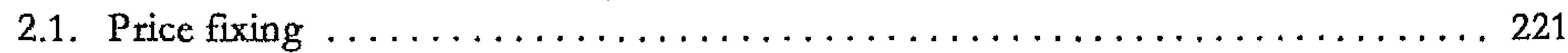

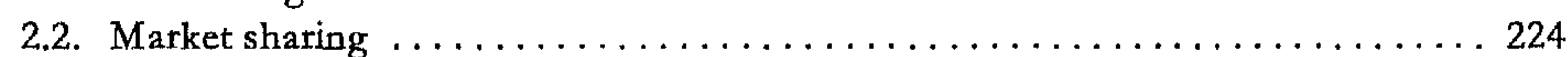

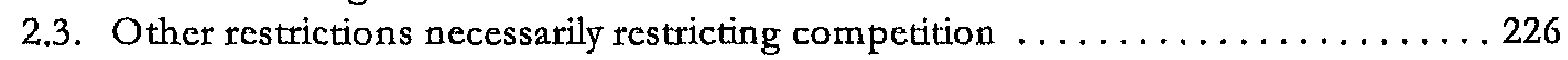

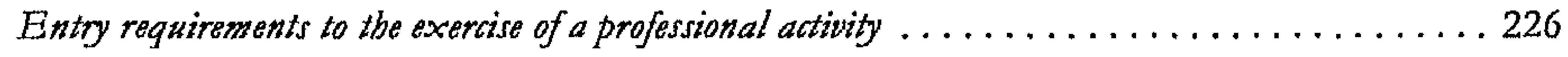

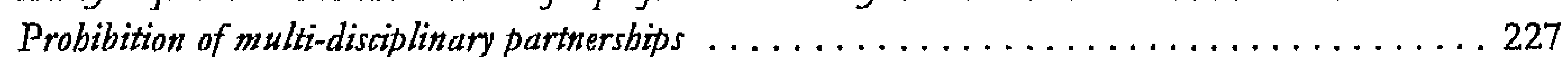

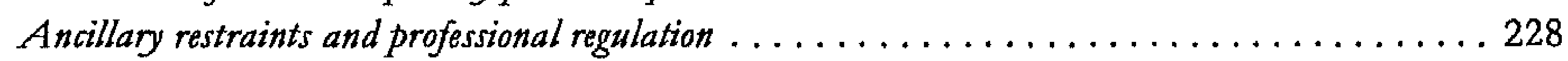

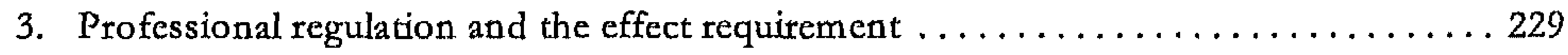

4. Limiting the prohibition of Articlc 81(1) EC: the overall context

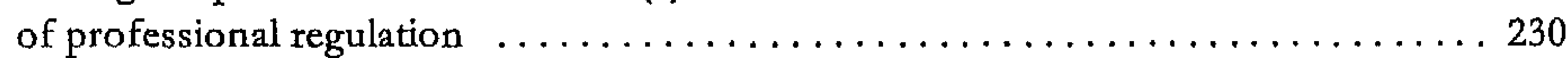

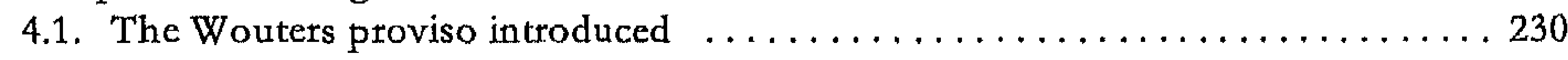

4.2. Ancillary restraints sift through: Wouters compared with

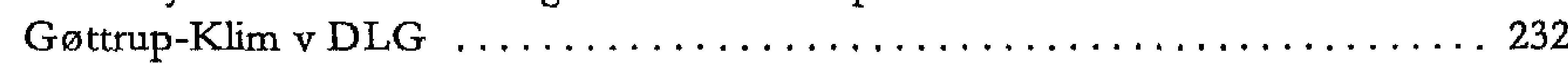

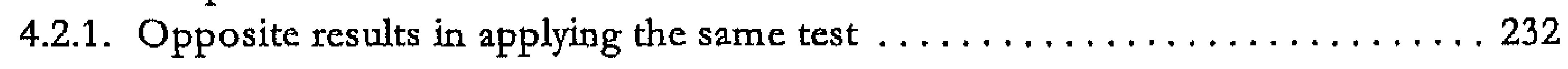

4.2.2. Beyond ancillary restraints: limiting the reach of

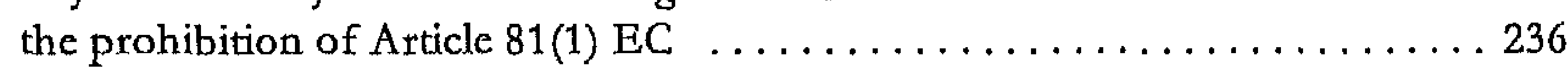

Diagram (no. 5) illustrating the effect of the Wouters proviso $\ldots \ldots \ldots \ldots \ldots \ldots 239$

A shift in paradigm: 'proper' commercialisation of professional services $\ldots \ldots \ldots \ldots \ldots 239$

Commercial versus 'regulatory' versus 'deontological' ancillarity? . . . . . . . . . . 240

Contra legem development of the law to achieve a just solution $\ldots \ldots \ldots \ldots \ldots \ldots \ldots 240$

Conflicting interest: regulatory vacuum versus legal stability $\ldots \ldots \ldots \ldots \ldots \ldots \ldots \ldots 245$

Alternative solution: limiting the legal consequences in time $\ldots \ldots \ldots \ldots \ldots \ldots \ldots 246$

4.3. Concluding remarks ................................. 249 


\section{ChAPTER 5}

ARticie 82 EC AND SEl.F-Regul.htory Professions

I. The concept of collective dominance and collectively organised professions $\ldots \ldots \ldots 252$

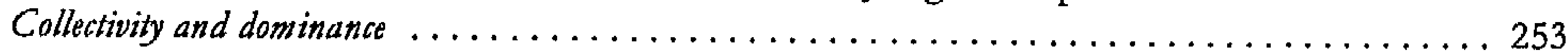

The ECJ and CFI applying Article $82 E C$ in collectively regulated sectors: a conflict? . . . . . . . 254

Diagram (no. 6) comparing Wouters and Piau on collective dominance $\ldots \ldots \ldots \ldots \ldots \ldots 257$

1. Connective links and the collectivity of liberal professions $\ldots \ldots \ldots \ldots \ldots \ldots \ldots 260$ Ability to know bow otber members are bebaving (common policy) ................. 261 Incentive not to depart from the common policy of the market . . . . . . . . . . . . . . 262 The foreseeable reaction of other market forces does not jeopardise the common palicy . . . . . . . 263

2. Measuring dominance and the market power of liberal professions . ........... 264

3. Dominance on a substantial part of the common market and effect

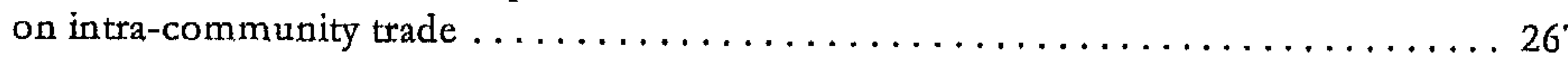

II. The competition related concept of abuse and its meaning in relation to

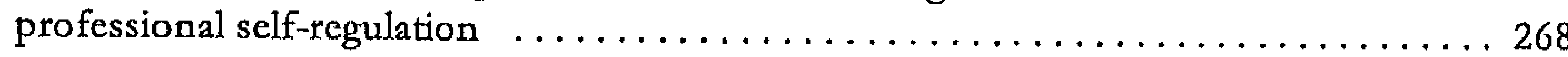

1. Joint or individual manifestation of collective dominance: 'collective abuse'

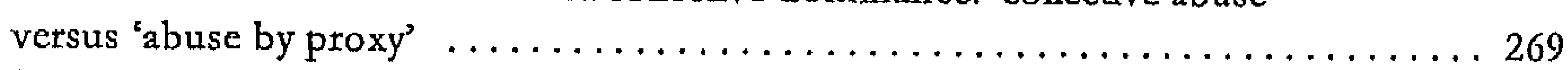

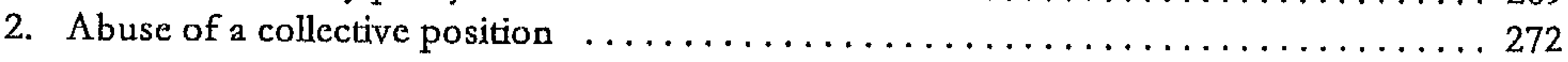

2.1. The concept of abuse: Special responsibility of the dominant entity . . . . . . . 272

2.1.1. Instrumental use of market power (exploitation) $\ldots \ldots \ldots \ldots \ldots \ldots \ldots 275$

2.1.2. Market structure abuses: connecting likely effects and intent (exclusion) . . . . 278

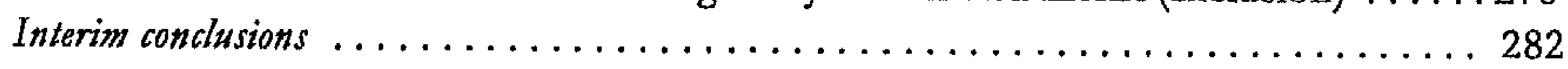

2.2. Self-regulated professions abusing of collective dominance $\ldots \ldots \ldots \ldots \ldots \ldots 284$

2.2.1. Illustrating exploitative conduct by liberal professions $\ldots \ldots \ldots \ldots \ldots \ldots 284$

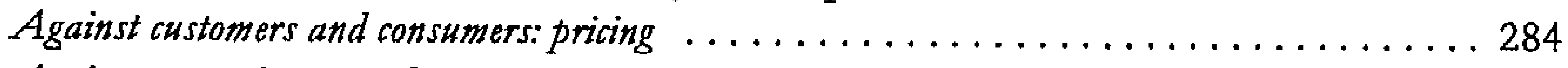
Against competitors: gatekeeping .......................... 289

Against competitors: the prevention of emerging new types of professional services . . . . . . 290

2.2.2. Illustrating exclusionary conduct by liberal professions . . . . . . . . . . . 294

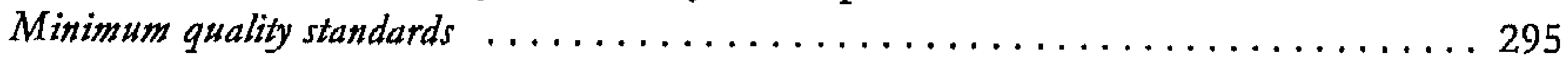

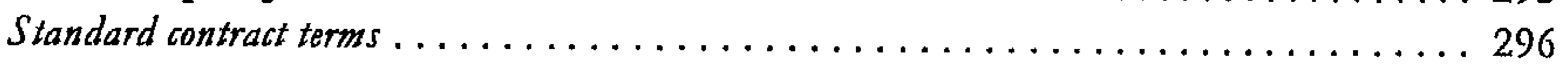

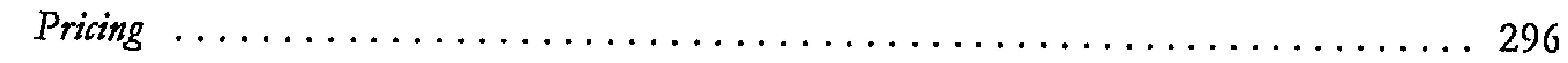

2.2.3. Interim conclusions: Abuse of collective dominance by a profession - a question of degree? . . . . . . . . . . . . . . . . . . . . . . . 297

2.3. Liability for an abuse of collective dominance . . . . . . . . . . . . . . . . . . 299

3. Objective justification, efficiency gains and the principle of proportionality ............. 300

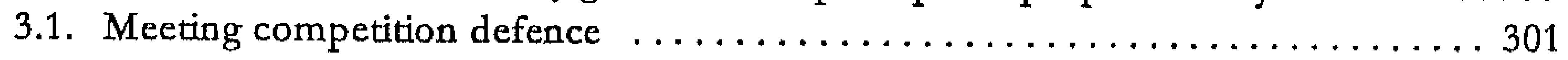

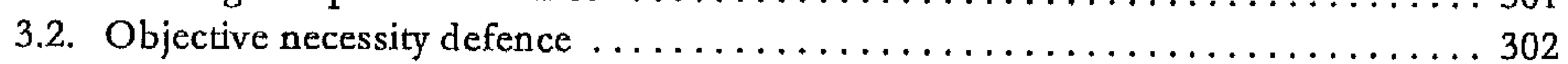

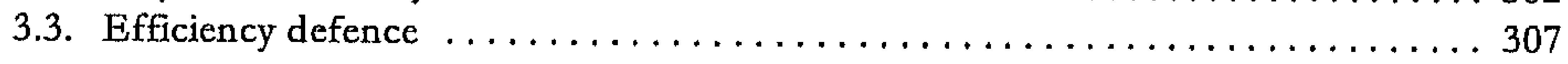

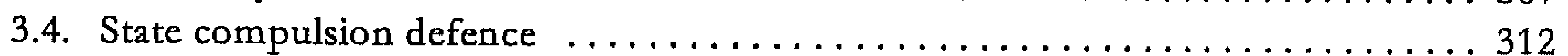

Closing Chapters 4 AND 5: Comparing the application of Articles 81 AND 82 EC IN RESPECT OF PROFESSIONAL SELF-REGULATION 
CHAPTER 6

STATE INVOLVEMEN'T IN Professional Regulation AND ITS

COMPETITION RESTRICTIVE EFFECTS

State involvement in anti-competitive professional regulation meeting legal review $\ldots \ldots \ldots \ldots \ldots \ldots$

I. A duty on Member States to respect the competition provisions applicable

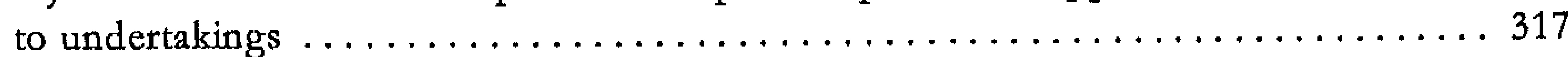

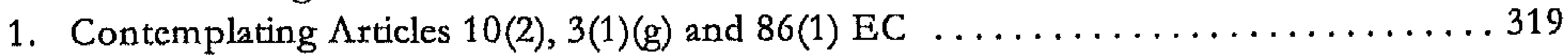

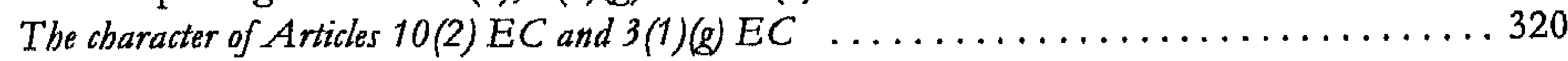

Parallelism between Article 86(1) EC and the general duty under Articles 10(2) EC ........ 324

2. Contemplating Protocol no 27 on the internal market and competition

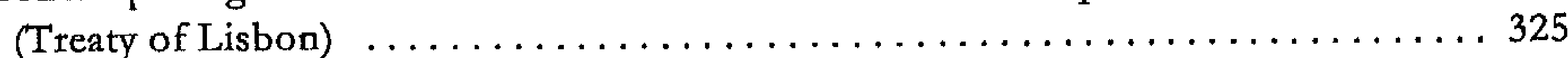

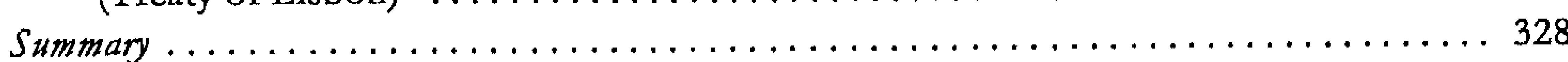

II. Case law built standard to control State intervention in self-regulatory markets $\ldots \ldots \ldots 328$

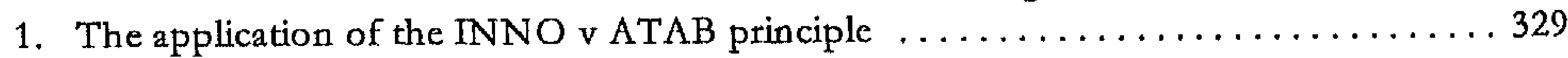

1.1. Member States' duty in respect of Article 81 EC: the Van Eycke standard .... 329

1.2. Member States' duty in respect of Article 82 EC: the Spediporto test . . . . . . . 332

1.3. Comparing the standards under Van Eycke and Spediporto ............... 334

2. The case law's application of Article $10 \mathrm{EC}$ to State intervention

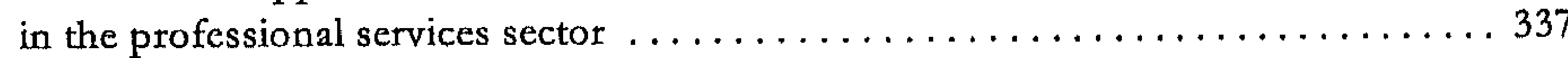

2.1. The three prongs of the Van Eycke test applied . . . . . . . . . . . . . . 338

Member States depriving their legislation of its official character: gross violation of

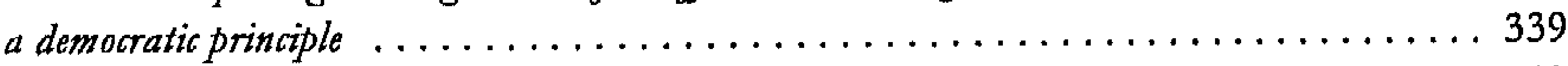

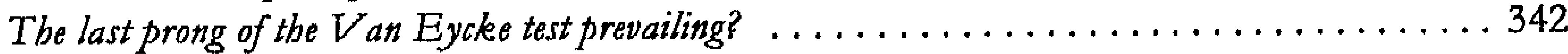

2.2. Focussing on the third Van Eycke prong: Arduino and after $\ldots \ldots \ldots \ldots \ldots 344$

2.2.1. Review of public ex ante control mechanisms .................. 344

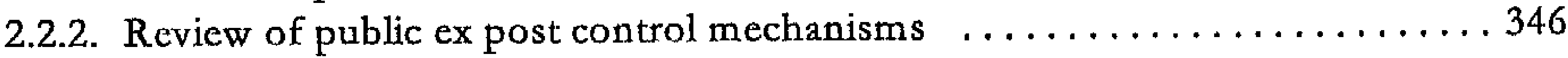

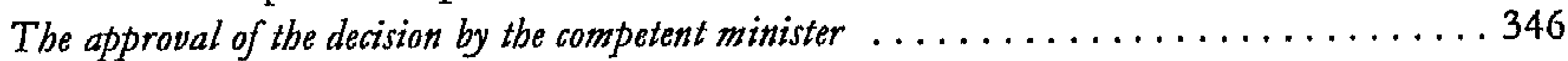

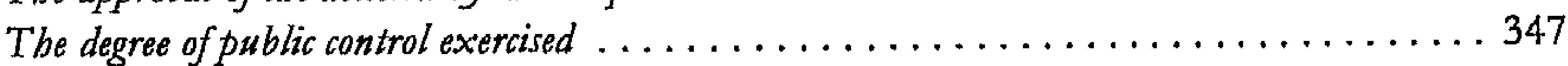

The role taken by the judiciary in establishing individual fees $\ldots \ldots \ldots \ldots \ldots \ldots \ldots . \ldots . \ldots . \ldots . \ldots 349$

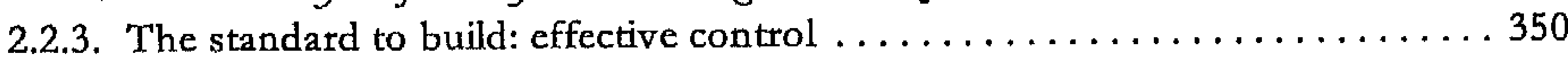

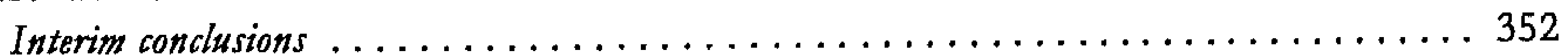

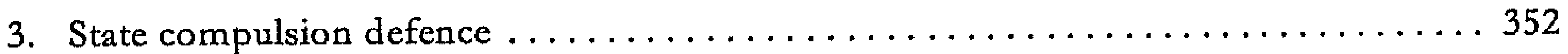

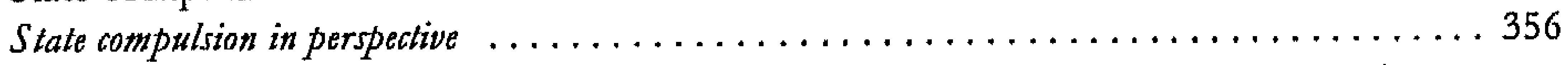

III. Closing remarks: Some pointers towards a legitimate level of competition law control

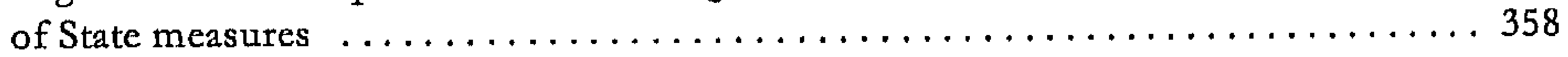

CHAPTER 7

Justirying Professional Regulation - SOlutions Reflecting the StruCture AND BROAD LOGIC OF THE TREATY

Which roads lead to Rome? - Immunity in competition law and the structure of the Treaty .......... 364

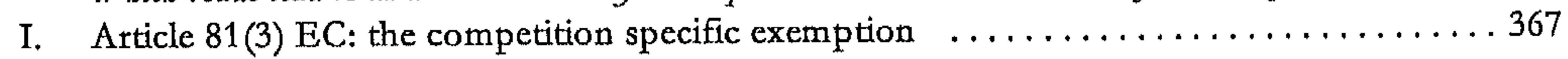

1. A positive balancing act: the four cumulative criteria of Article 81 (3) EC

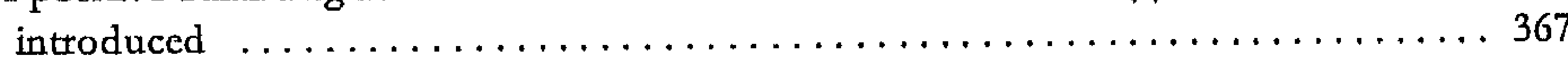

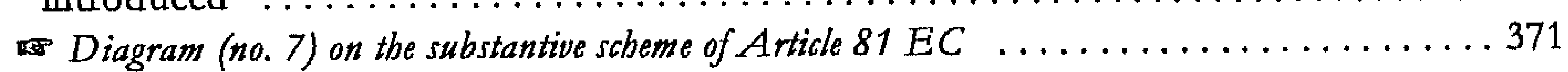

2. Objective efficiencies indispensable to compensate restrictive effects $\ldots \ldots \ldots \ldots \ldots 372$

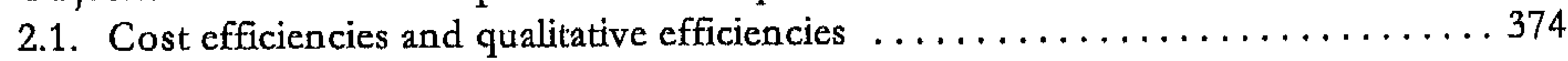

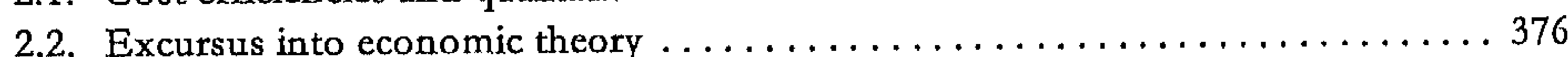

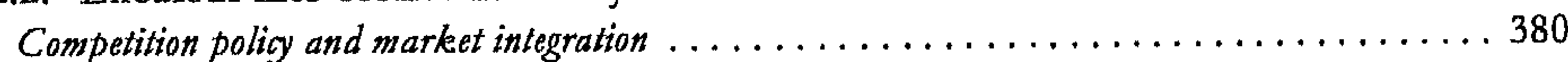


2.3. The bounds of Article 81(3)-[1] EC

Diagram (no. 8) categorising economic and non-economic public interest concerns in regulation.

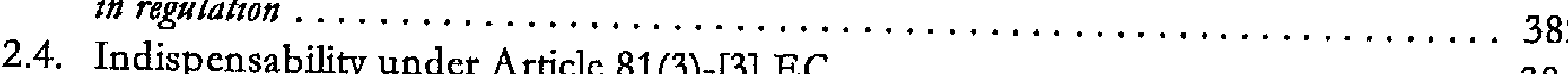

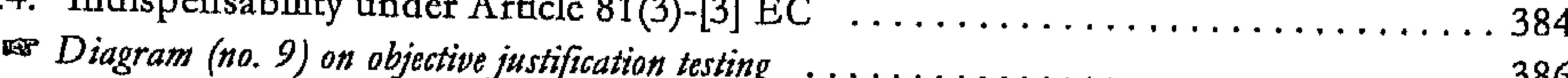

2.5. Economically beneficial effects of professional regulations $\ldots \ldots \ldots \ldots \ldots \ldots \ldots \ldots \ldots \ldots$

2.5.1. Cost efficiencies in advertising restrictions and tariff schemes $\ldots \ldots \ldots \ldots \ldots . \ldots 387$

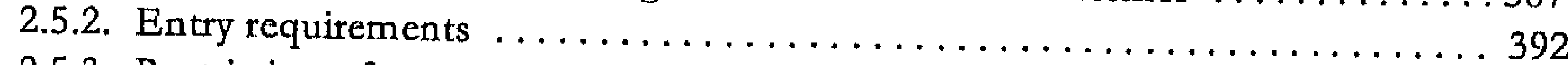

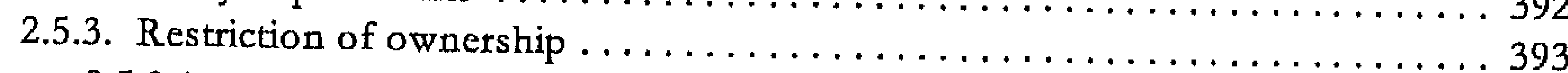

2.5.3.1. Legitimate justification grounds in Wouters . . . . . . . . . . . 395

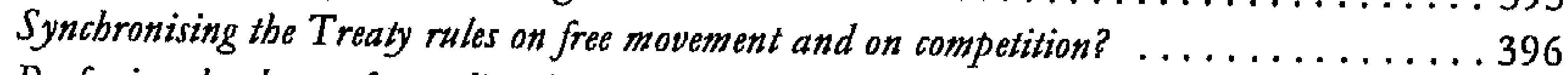

Professional values safeguarding (economic) public interests . . . . . . . . . . . . 399

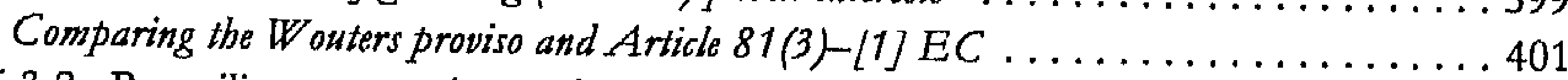

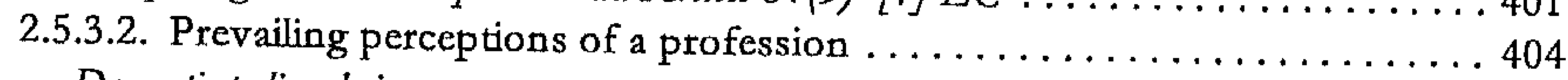

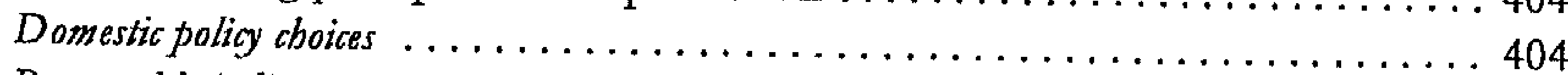

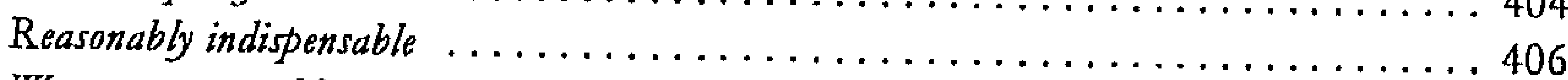

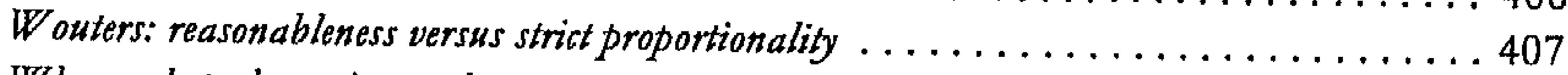

Whose role to determine professional standards $\ldots \ldots \ldots \ldots \ldots \ldots \ldots \ldots \ldots \ldots \ldots \ldots$

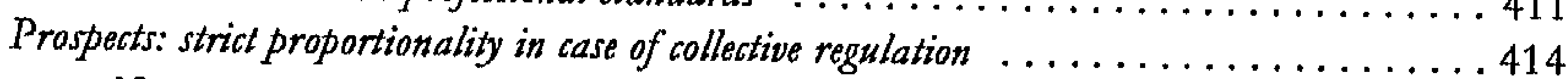

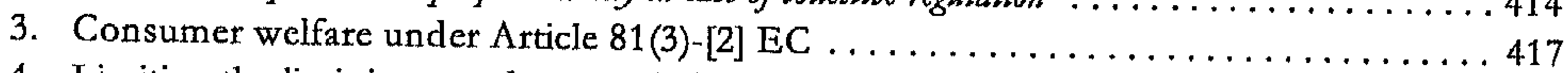

4. Limiting the limit in accordance with Article 81(3)-[4] EC: no elimination

of competition in respect of a substantial part of the professional services ........419

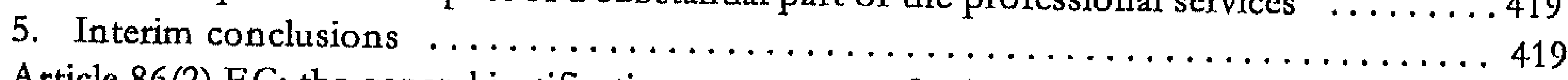

II. Article 86(2) EC: the gencral justification avenue - professional regulation

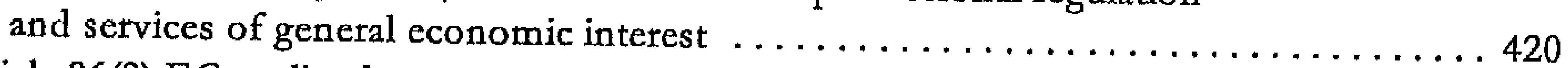

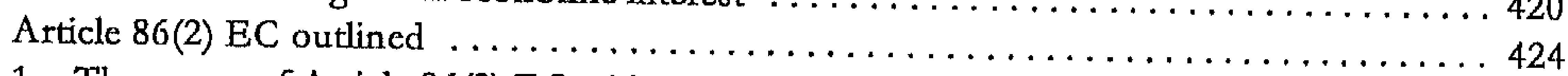

1. The scope of Article $86(2) \mathrm{EC}$ with regard to professional tegulation $\ldots \ldots \ldots \ldots \ldots 424$

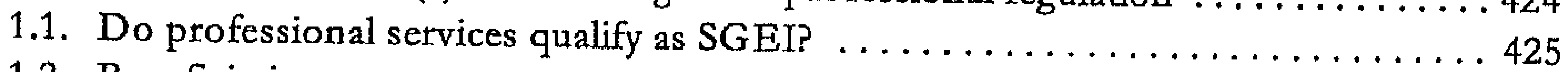

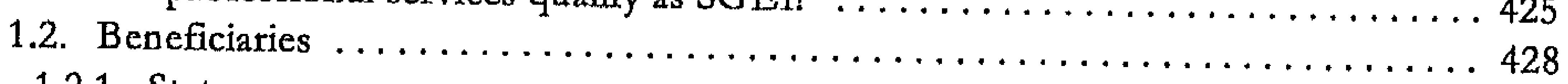

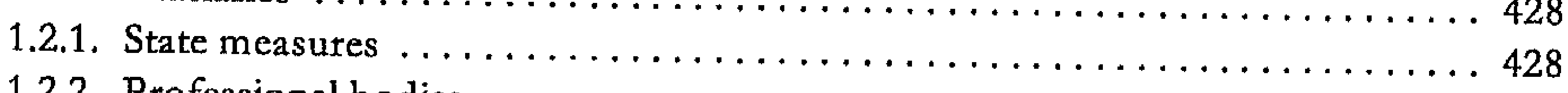

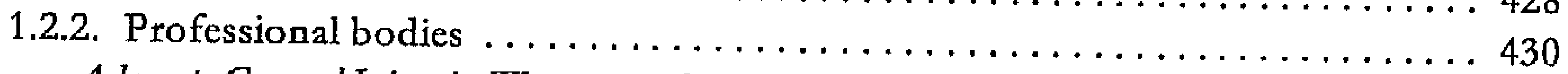

Advocate General Léger in Wouters applying Article 86(2) EC to the professional body . . . 431

Necessary exemption due to the subject matter of professional regulation? $\ldots \ldots \ldots \ldots \ldots 431$

Associating collective self-regulation with undertakings charged with an $S G E I$. . . . . . . . 432

Including collective self-regulation for their affinity with State measures? $\ldots \ldots \ldots \ldots \ldots 433$

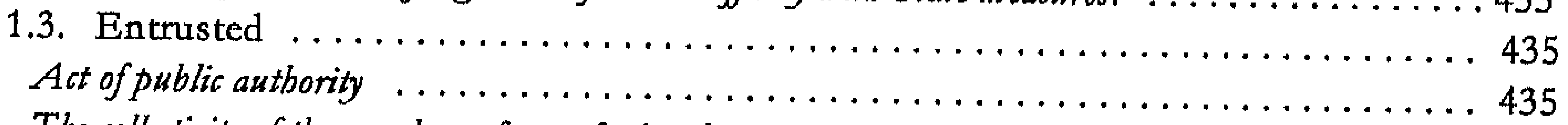

The collectivity of the members of a professional group as specific undertakings

entrusted in a distinguishable manner?

2. Proportionality test: obstruction of the performance of the undertakings' task to provide an SGEI

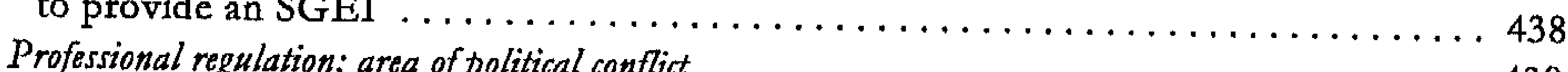

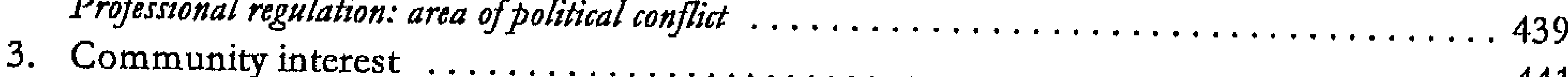

III. Closing temarks: the possible prospect of formulating policy guidelines? $\ldots \ldots \ldots \ldots \ldots \ldots 44$ 


\section{CHAPTER 8}

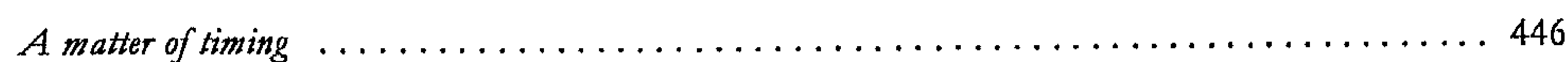

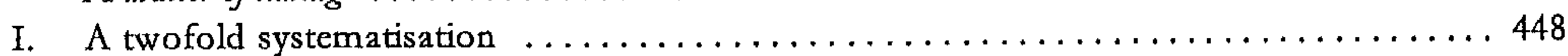

1. Systematising the application of competition law to the professions $\ldots \ldots \ldots \ldots \ldots 448$

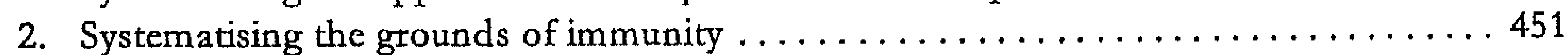

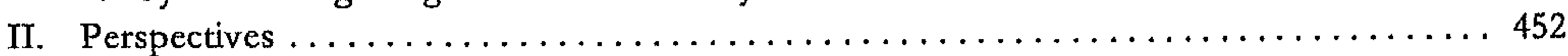

1. Legal implications of the principle of free competition in the common market $\ldots \ldots .452$

Developing touvards a uniform legal approach for professional State and self-regulation? . . . . . . 453

Monitoring the legality of professional regulation by competition rules $\ldots \ldots \ldots \ldots \ldots \ldots \ldots 45$

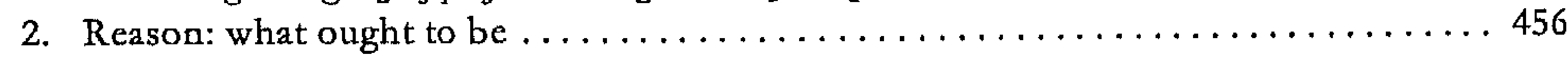

Concerning the field of application of the competition probibitions $\ldots \ldots \ldots \ldots \ldots \ldots \ldots \ldots 7$

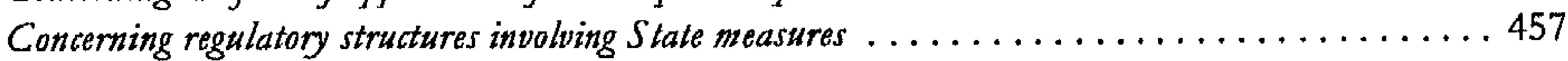

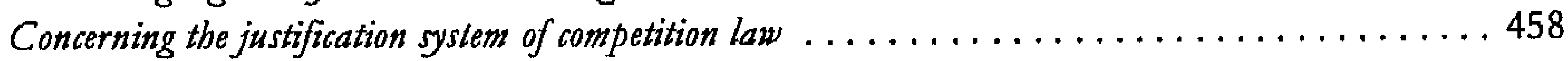

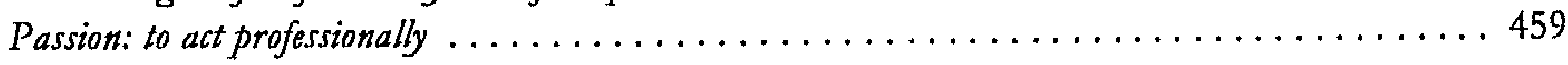

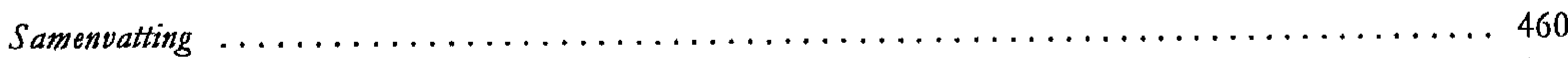

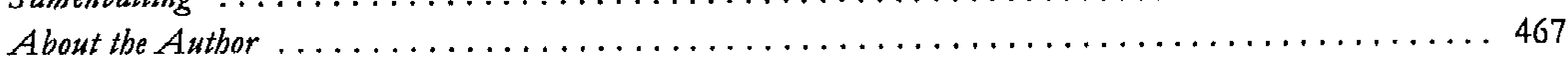

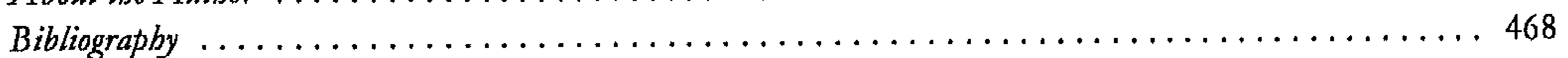




\section{Table of Diagrams}

Diagram (no. 1) on the actors in the field of professional regulation $\ldots \ldots \ldots \ldots \ldots \ldots \ldots \ldots$

Diagram (no. 2) on the distinction made in Meca-Medina $I I \ldots \ldots \ldots \ldots \ldots \ldots \ldots \ldots$

$\leftrightarrow$ Diagram (no. 3) on the latitude of the jurisdictional scope of $(E C)$ competition law . . . . . 93

Diagram (no. 4) illustrating the different steps in deciding whether a certain conduct is restrictive of competition . . . . . . . . . . . . . . . . . . . . . . . . . 219

Diagram (no. 5) illustrating the effect of the Wouters proviso

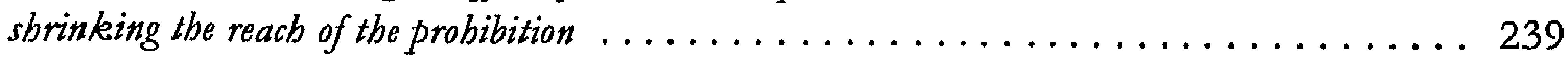

Diagram (no. 6) comparing Wouters and Piau on collective dominance $\ldots \ldots \ldots \ldots \ldots \ldots$

Diagram (no. 7) on the substantive scheme of Article $81 \mathrm{EC} \ldots \ldots \ldots \ldots \ldots \ldots \ldots$

Diagram (no. 8) categorising economic and non-economic public interest concerns in regulation . . 382

Diagram (no. 9) on objective justification testing $\ldots \ldots \ldots \ldots \ldots \ldots \ldots \ldots \ldots \ldots$

\section{List of Abbreviations}

$\begin{array}{ll}\text { ABA } & \text { American Bar Association } \\ \text { AG } & \text { Advocate General } \\ \text { AGCM } & \text { Autorità Garante della Concorrenza e del Mercato } \\ \text { ArchG } & \text { Architektengesetz } \\ \text { ATM } & \text { Air Traffic Management } \\ \text { AW } & \text { Advocatenwet (Lawyers Act, Netherlands) } \\ \text { B to C } & \text { Business to consumer } \\ \text { B to B } & \text { Business to business } \\ \text { BGBl. } & \text { Bundesgesetzblatt } \\ \text { BGH } & \text { Bundesgerichtshof } \\ \text { BNotO } & \text { Bundesnotarsordnung } \\ \text { BORA } & \text { Berufsotdnung für Rechtsanwälte } \\ \text { BRAGO } & \text { Bundesrechtsanwalts-Gebührenordnung (former Lawyers Fees Act, } \\ \text { BRAK } & \text { Germany) } \\ \text { BRAO } & \text { Bundesrechtsanwaltskammer (German bar association) } \\ \text { BSB } & \text { Bundesrechtsanwaltsordnung (Federal Jawyers Act, Germany) } \\ \text { BVerfG } & \text { Bar Standards Board } \\ \text { BVerfGE } & \text { Bundesverfassungsgeticht (German constitutional court) } \\ \text { CAT } & \text { Bundesverfassungsgericht - Entscheidungssammlung (court report) } \\ \text { CC } & \text { Competition Appeals Tribunal } \\ & \text { Competition Commission (UK) }\end{array}$


CCBE Comité Consultative des Bareaux Européens - Council of Bars and Law Societies of Europe

CEPLIS European Council of Liberal Professions

CFI

Court of First Instance of the European Communities

CMLR Common Market Law Report

CNUE Conférence des Notariats de l'Union Européenne

COMP DG Competition of the European Commission

DG Comp Directorate General for competition

DG Directorate General (e.g. for competition)

DGFT Directorate General of Fair Trading (formerly UK competition authority)

EC EC Treaty (Treaty of Amsterdam and Nice)

EC European Community

ECJ European Court of Justice of the European Communities

ECN Eutopean Competition Network

EEA European Economic Area

EFTA European Free Trade Association

EPO European Patent Office

EU European Union

EU EU Treaty (Treaty of Amsterdam and Nice)

FIFA Fédération internationale de football association

FLR Front Line Regulators

FSA Financial Services Authority

GDP Gross domestic product

GEI General economic interest

KNB Koninklijke Notariële Beroepsorganisatic

LSA Legal Services Authority

LSB Legal Services Board

LSC Legal Services Commission

MArchG Musterarchitektengesetz

MDP multi-disciplinary partnership

MDW Marktewerking, Deregulering, Wetgevingskwaliteit (Dutch projects on competition, detegulation, legislative quality)

Mw Mededingingswet (Dutch competition act)

NATS National Air Traffic Services

NATS National Air Traffic Services Limited

NB nota bene

NCA(s) national competition authority(-ies)

NL the Netherlands

NMa Nederlandse Mededingingsautoriteit (Dutch competition authority)

NOvA Nederlandse Orde van Advocaten (Dutch bat association)

OCPA Office of the Commissioner for Public Appointments 
OECD

OFT

Organisation for Economic Cooperation and Development

OJ C Office of Fair Trading (UK competition authority)

OJ L Official Journal of the European Communities/ Union $\mathrm{C}$-series for communications

OLC

PBS L-series for legislative acts

Office for Legal Complaints

RPC

Ptofessional business services

SGEI

Restrictive Practices Court

Rechtsanwaltsvergütungsgesetz (Lawyers Fees Act, Germany)

SGI

Services of general economic interest (which should be ESGI-economic services of general interest, see Cbapter 7.1.1.1.)

Service(s) of general interest

Stb. Staatsblad

TEU

TFEU

$\mathrm{UK}$

Treaty on European Union (Treaty of Lisbon)

Treaty on the Functioning of the European Union (Treaty of Lisbon)

US

viq.

WNA

United Kingdom

United States of America

videlicet (lat.): that is to say

Wet op het Notarisambt (Notaries Act, Nethetlands) 


\section{Introduction - Reason and Passion}

\section{Context}

'The concept of liheral professions is an unsettled one that differs from country to country and covets various professional groups.' The common denominator, however, is that in the different Luropean Member States liberal professions are regulated professions." This means that the admission to a profession and the exercise theteof are subject to detailed statutory and self regulatory rules. While these rules inevitably interfere with the freedom of action of liberal profession practitioners, they do not necessarily restrict the latter's freedom of competition. ${ }^{4}$ The relationship between professional regulation, on the one hand, and principles of competition law, on the other, seems to be a strained one, and an attempt at rapprochement has not resulted in romance. Nevertheless experts of competition law and representatives of the liberal professions started meeting a few years ago. While competition authorities ate looking for a match, representatives of the liberal professions play hard to get and need persuasion to date. Their coyness may be motivated by thoughts of a future in which their offspring-professionals practice a once prestigious and learned profession in cheap back-street dives."

It is not merely from a desire to court the liberal professions that the European Union recognises the importance of services in the European area." 'The background to this recognition is the adoption of the Lisbon strategy for growth and employment in

1 In the UK (and other countries with a common law background) the expression 'tiberal profession' does not actually exist. 'There the denomination is contented with 'profession' as opposed to 'business'. This distinction from 'business' corresponds with the still prevailing view in civil law countries that 'liberal professions' are not trade or business in the legal sense. However, with the Commission of the European Communities leading an investigation into the economic impact of regulation in the field of the professions and the European Parliament adopting a Resolution on market regulations and competition nules for tbe liberal profersions (16.12.2003), the expression 'liberal professions' used in English seems to be established as Euro-speak. The present work will only be reinforcing this fact, even if native English speakers may continue to wonder what '(Continental) Europeans' would exactly mean by the expression 'liberal professions'. Not least for this reason has the word 'liberal' in the title of this brook been put in parentheses.

2. See also OECD, Competition in Professional Senvices, (200(0)), 7: although details vary from country to country all OECD countries regulate the activities of a number of occupations and professions. See also European Commission, Keport on Competition is Professional Senvices, of 09.02.04; European Commission, Professional Services Scope for more reform, of 05.09.2005.

3 The latter refers to rules adopted by the professional services sector itself.

4 For details see Chapter 4.1.1.2. and 4.11.1. See also Case C.309/99, Wouters et al. v NOvA, [2002], para. 97.

"Image conjured by van Mourik M.J.A., (2006), 16.

- The Iuropean Union operates a project targeting an internal market for services, which started with European Commission, The impact and effectiveness of the Single Market, of 30.10.1996; I turopean Commission, The Strategy for lisrope's Intemal Market, of 29.11.1999; European Commission, An Internal Market. Strategy for Senvices, of 29.12.2000). 
March 2000, in which the European Union set its ambition to become the world's most competitive and dynamic knowledge-based economy by $2010 .^{7}$ However, as these high aspirations were not confirmed in the following years by economic data ${ }^{8}$, it soon looked as though the Jisbon strategy was more words than deeds. New momentum needed to be given to the strategy, and in March 2005 the European Union decided to refocus its efforts on a limited number of goals of a more concrete nature. ${ }^{9}$ The revitalised Lisbon Programme presented in July 2005 lists two new top priorities to boost the performance of the European Union's economy. First, the simplification of the regulatory environment in which business operates and, second, the completion of the internal market for services. ${ }^{10}$ Before going into both aspects, the role of the liberal professions in the European economy shall be sketched.

\section{Liberal professions in the European economy}

As they account for a significant part of the services provided in the European Union, liberal professions contribute considerably to the economic performance therein. In 2001, libetal professions in the EU 15 reptesented an estimated 400 to 500 billion Euro, or about $2.4 \%$ of the total turnover of the EU. ${ }^{11}$ Also in terms of employment they contribute to the about 12 million people that were employed in 2004 in the larger category of 'other business services', and which amount to $6.4 \%$ of total employment. In Germany about 3 million people were working as or for a liberal practitioner in 2001. This is $7 \%$ of all persons engaged in a gainful activity generating about $8 \%$ of GDP. About $20 \%$ of those working in private practice belong to the group of liberal professions. ${ }^{12}$ Conversely, in the latter group about $25 \%$ work in private practice. French statistics for 2003 report that the sector of services provided to business ${ }^{13}$ generated a turnover of 327 billion Euro and employed 2.9 million persons. ${ }^{14}$ Within the sector of services provided to business, legal, accountancy and consultancy services account for $27 \%$ of the services and for $14 \%$ of employment; atchitectural services and engineering accounted for $18 \%$ of the services and $11 \%$ of employment, together accounting for about $2.62 \%$ of all employment; services to business account for about $25 \%$ of all employment in France. Of new firms $18.5 \%$ have

\footnotetext{
7 European Council, Presidency Conclusions, of 23./24.03.2000.

${ }^{8}$ For instance Creel J., et al., Delegation in Inconsistency: The "Lisbon strategy » Record as an Institutional Failure, (Paris) (2005).

9 European Council, Presidency Conclusions, of 23.03.2005, $2 \mathrm{ff}$.

${ }^{10}$ Eutopean Commission, Common Actions for Growth and Employment, of 20.07.2005, 4, $7 \mathrm{f}$.

${ }^{11}$ These figures derive from European Commission, Professional Services -Scope for more reform, of 05.09.2005, para. 1, and Kroes N. (Competition Policy Commissionet), "Better Regulation of Professional Services", (21.11.2005) SPEECH/05/711, 3. The source the Commission refers to is Eurostat, Statistics in Focus 11/2005: Industry, Trade and Services - Developments for tumover and employment indices for services during the third quarter of 2004 (2005), which however could not be found to report on data of 2001 or the EU 15 as alleged in the Commission's documents. ${ }^{12}$ Bundesministerium für Wirtschaft und Technologie (BMWI), Die Lage der Freien Berufe, of June 2002, 6.

${ }^{13}$ Services aux entreprises as opposed to services provided to private customers. According to INSEE 'l'entreprise est une unité économique, juridiquement autonome, organisée pour produire des biens ou des services pour le marché. On distingue: l'entrcprise individuelle (personne physique) et l'entreprise sociétaire."

${ }^{14} \mathrm{See}<\mathrm{http}: / /$ www.insee.fr>, for instance "Les entreprises des services en 2003", Insee Résultats, sétie Économie, $\mathrm{n}^{\mathrm{n}} 22,2005$. About $70 \%$ of all employment is created in the services sector in France, about $75 \%$ in the Netherlands and the UK, $65 \%$ in Germany and $62 \%$ in Italy, see Eurostat, Enquête sur les forces de travail, at http://epp.eurostat.ec.europa.eu/portal/page/portal/product_details/publication?p_product_code=KS-S F-08-078. These numbers have slightly increased in more recent years, sce Eurostat, Data in Focus: European Union Labour Force Survey-Annual results 2007, 27/2008, table 2.
} 
been set up in the sector of services provided to business; approximately half still existing after more than five years on the market. The legal services market alone in England and Wales generated 19 billion Pounds Sterling, or $1.73 \%$ of the UK's GDP in 2003. This was an increase in teal terms of almost $60 \%$ since 1995. The volume of UK legal services exported totalled 1.9 billion Pounds Sterling, which was three times that of $1995 .{ }^{15}$ Total imports of legal services were worth 403 million Pounds Sterling over the same period, showing that the legal services sector is a net exporter to the value of 1.5 billion Pounds Sterling. ${ }^{16}$

The economic role of the liberal professions is not limited to creating turnovet and employment. The importance of their services can also be measured in input for other sectors of the economy that spend on professional services. The quality, prices and competitiveness of the latter have effects that spill over into the whole economy. ${ }^{17}$ For instance, in 2001 about $1 \%$ of the GDP of Ireland, or over 1 billion Euro, had been spent as costs on legal services alone. ${ }^{18}$ In Italy an average of $6 \%$ of the costs of exporting firms are due to expenditure on professional services. ${ }^{19}$

\section{Liberal professions and their regulatory environment}

As stated, the liberal professions are above all regulated professions. While the focus of this thesis is on the rules regulating the professions rather than on their status, it is worthwhile to briefly consider what the liberal professions are. Essentially there is no agreed definition that would explain in tangible terms in how fat certain professions are 'liberal' in character - and thus should be treated differently in law than other activities. ${ }^{20}$ The

\footnotetext{
${ }^{15}$ Kroes N. (Competition Policy Commissioner), "Better Regulation of Professional Services", (21.11.2005) SPEECH/05/711, 3 .

${ }^{16}$ Legal Services Bill - Full Regulatory Impact Assessement of 24.11.2006, paras. 1.1. f.

${ }^{17}$ European Commission, Report on Competition in Professional Services, of 09.02.04, paras. $11 \mathrm{ff}$.

${ }^{18}$ European Commission, Professional Services - Scope for more reform, of 05.09.2005, para. 1.

${ }^{19}$ European Commission, Report on Competition in Professional Services, of 09.02.04, paras. $11 \mathrm{ff}$. See Tesauro G. "Regulation of Professional Services", (28.10.2003), 2, referring to the 2002 annual report of the Italian competition authority.

${ }^{20}$ See for instance Michalski L., (1989). The EC Treaty neither defines nor directly addresses the role of (liberal) professions; it simply indicates the existence of the professions in Articles 50, 47(3) and 257 EC. In fact, Article 257 EC deals with the Economic and Social Committee and refers explicitly to representatives of 'professional occupations'. While it thereby emphasises the perceived importance of the professions in Europe and society, the Treaty otherwise only speaks of activities (i.e. 'services') and not of the different professions and occupations themselves. This seems logical since every occupation and profession is named or set up differently in every Member State not least for historical reasons. See also for instance Article 1[1](c) of Council Directive $89 / 48$ of 21 December 1988 on a general system for the recognition of higher-education diplomas awarded on completion of professional education and training of at least three years' duration, which defines 'regulated profession' as "the regulated professional activity or range of activities which constitute this profession in a Member State", and in Article 1[1](d) defines 'regulated professional activity' as "a professional activity, in so far as the taking up or pursuit of such activity or one of its modes of pursuit in a Member State is subject, directly or indirectly by virtue of laws, regulations or administrative provisions, to the possession of a diploma. The following in particular shall constitute a mode of pursuit of a regulated professional activity: - pursuit of an activity under a professional title, in so far as the use of such a title is reserved to the holders of a diploma governed by laws, regulations or administrative provisions,

- pursuit of a professional activity relating to health, in so far as remuneration and/or reimbursement for such an activity is subject by virtue of national social security arrangements to the possession of a diploma.

Where the first subparagraph does not apply, a professional activity shall be deemed to be a regulated professional activity if it is pursued by the members of an association or organization the purpose of which is, in particular,
} 
Commission of the European Communities (hereafter the Commission), in its report on competition in professional services, suggests a polyvalent description of the liberal professions: they "are occupations requiring special training in the liberal arts or sciences, for example lawyers, notaries, engineers, architects, accountants and pharmacists. The sector is usually characterised by a high level of regulation, in the form of either State regulation or self-regulation by professional bodies". ${ }^{21}$

In the Member States various definitions are operated. Where countries have endeavoured to establish a legal definition of what constitutes the (liberal) professions, they have used a general wording. ${ }^{22}$ Sometimes non-exhaustive lists of 'typical' professions are incorporated in the law to illustrate which professions qualify for the attribute 'liberal. ${ }^{23}$ They cover for instance (in tandom order) physicians, dentists/ dental surgeons, veterinary surgeons, lawyers, notaries public, patent lawyers, geometers/ surveyors, engineers, architects, trade chemists, chartered accountants, tax advisors, advisory political economists and business administrators, sworn auditors, fiscal representatives, non-medical practitioners, dental technicians, physiotherapists, journalists, photo-reporters, interpreters, translators, pilots and 'similar professions'. Particular circumstances arguably determine the professions' 'liberal' character. ${ }^{24}$ Yet, for the purpose of this book it is not of primary importance whether

to promote and maintain a high standard in the professional feld concerned and which, to achieve that purpose, is recognized in a special form by a Member State and:

- awards a diploma to its members,

- ensures that its members respect the rules of professional conduct which it prescribes, and

- confers on them the right to use a title or designatory letters, or to benefit from a status corresponding to that diploma.

A non-exhaustive list of associations or organizations which, when this Directive is adopted, satisfy the conditions of the second subparagraph is contained in the Annex. Whenever a Member State grants the recognition referred to in the second subparagraph to an association or organization, it shall inform the Commission thereof, which shall publish this information in the Official Journal of the European Communities."

Article 3(1) (a) of Directive 2005/36/EC of 7 September 2005 on the recognition of professional qualifications, defines regulated profession as "a professional activity or group of professional activitics, access to which, the pursuit of which, or one of the modes of pursuit of which is subject, directly or indirectly, by virtue of legislative, regulatory or administrative provisions to the possession of specific professional qualifications; in particular, the use of a professional title limited by legislative, regulatory or administrative provisions to holders of a given professional qualification shall constitutc a mode of pursuit." Other professions practised by members of five Irish and $38 \mathrm{UK}$ associations and organisations are treated as regulated professions, see $A$ rticle $3(2)$, and Annex I, of the Directive. Article $3(1)(f)$ of the same Directive furthermore defines "professional experience" as "the actual and lawful pursuit of the profession concerned in a Member State". To this definition is referred to in Article 4(11) of Directive 2006/123/EC of the European Parliament and of the Council of 12 December 2006 on services in the internal market.

${ }^{21}$ European Commission, Report on Competition in Professional Services, of 09.02.04, para. 1. For a biting criticism of the Commission's definition see Cooke J.D., (2006).

${ }^{22}$ For instance, France, Germany, Greece and Italy have laid down a legal definition. In Germany and Greece the legal definition of liberal professions is to be found in the tax laws, see the German Einkommensteuergesetr: $§ 18(1) 1,2^{\text {nd }}$ sentence EStG. Italy has a specific section in the codice civile, see Libero Quinto: Del Lavoro- Titolo III: Del lavoro autonomo - Capo II: Delle professioni intellettuali, which however does not determine which professions are 'liberal'. See OECD, (1985), paras. 10 and 14. Most countries nowadays apply the concept of (liberal) professions in a broad way, meaning that many more professions are covered by the (legal) definition than previously when the expression basically referred to members of the clergy, medical doctors and lawyers. For more details on the historical background see Chapter 2. Countries that apply the term (liberal) profession still in a rather narrow sense are: Ireland, Denmark and the USA. Conversely, Germany, Australia, Japan, France, Greece, Netherlands, Belgium and Spain apply it broadly.

${ }^{23}$ See also above note 1 .

${ }^{24}$ For details see Chapter 2, which also sheds light on "the liberal arts and sciences", to which the European 
an additional profession qualifies as 'liberal'. Relevant in the delimitation of the subject has been the more general background to the concept of 'liberal professions', which is their regulatory environment. It controls the access to and the exercise of a particular professional activity. In fact, for a subset of the group of regulated professions, the means and shape of a regulatory framework are ardently defended. The scope of this book therefore refers to rules regulating a number of professions that traditionally are accepted to form part of the 'liberal' professions in all Member States, and are also included in the Commission's description mentioned before, like architects, doctors, lawyers and notaries.

\section{Better regulation in regulated professions to enhance the intermal market for services}

For some time research has been undertaken into the economic consequences of professional rules, which traditionally regulate both the access of service providers to the market of professional services (in the form of admission rules, e.g. licensing or certification) and the exercise of professional activities (in the form of rules on professional conduct). Given the economic importance of the (liberal) professions, their traditional rules on, for instance entry, monopoly rights, advertisement restrictions, fee schedules, or forms of establishment or cooperation have great potential to limit professional markets. While lawyers have gone to great lengths to explain how the guarantees in the EC Treaty on the free movement of persons, the freedom of establishment and the freedom to provide services across intra-Community borders (Articles 39, 43, 49 EC) apply to practitioners and their clients ${ }^{25}$, similar efforts to explain in a comprehensive way the legal implications of the

Commission refers in its polyvalent description, see above note 21.

${ }^{25}$ Since the early Seventies these three fundamental freedoms of EC law have been explored with regard to the (liberal) professions. For an account of the case law on the free movement of lawyers see Claessens S., (2008), ch 2 . See also the codification in the field of the professions, including Council Directive 75/362/EEC of 16.06.1975 concerning the mutual recognition of diplomas, certificates and other evidence of formal qualifications in medicine, including measures to facilitate the effective exercise of the right of establishment and freedom to provide services (doctors); Council Directive 77/249/EEC of 22 March 1977 to facilitate the effective exercise by lawyers of freedom to provide services; Council Directive 85/384/EEC of 10 June 1985 on the mutual recognition of diplomas, certificates and other evidence of formal qualifications in architecture, including measures to facilitate the effective exercise of the right of establishment and freedom to provide services; Council Directive 85/433/EEC of 16.09 .1985 concerning the mutual recognition of diplomas, certificates and other evidence of formal qualifications in pharmacy, including measures to facilitate the effective exercise of the right of establishment relating to certain activities in the field of pharmacy (pharmacists-recognition); CouncilDirective $89 / 48$ of 21 December 1988 on a general system for the recognition of higher-education diplomas awarded on completion of professional education and training of at least three years' duration; Council Directive 92/51/EEC of 18 June 1992 on a second general system for the recognition of professional education and training to supplement Directive 89/48/EEC; Council Directive 98/5 of 16 February 1998 to facilitate practice of the profession of lawyers on a permanent basis in a Member State other than that in which the qualification was obtained; Directive 1999/42/EC of the European Parliament and of the Council of 07.06.1999 establishing a mechanism for the recognition of qualifications in respect of the professional activities covered by the Directives on liberalisation and transitional measures and supplementing the general systems for the recognition of qualifications; Directive 2001/19/EC of the European Parliament and of the Council of 14May 2001 amending Council Directives $89 / 48 / \mathrm{EEC}$ and $92 / 51 / \mathrm{EEC}$ on the general system for the recognition of professional qualifications and CouncilDirectives 77/452/EEC, 77/453/EEC, 78/686/EEC, 78/687/EEC, 78/1026/EEC, 78/1027/EEC, 80/154/EEC, 80/155/EEC, 85/384/EEC, 85/432/EEC, 85/433/EEC and 93/16/EEC concerning the professions of nurse responsible for gencral care, dental practitioner, veterinary surgeon, midwife, architect, pharmacist and doctor; and most recently Directive 2005/36/EC of 7 September 2005 on the recognition of professional qualifications. On the most recent developments in the field see also the Commission's internal market strategy for services 
principle of free competition within the common market (Articles 81 et seq. EC) are lacking. The reason for this absence probably is that the Commission and the Community Courts have applied the EC competition rules to the professions and their regulations at a substantially later stage than the fundamental freedom rights. Both sets of rules are, however, constituent for the internal market. ${ }^{26}$ To mitigate this want is the innovative strength of this book.

In a consequent attempt to foster the completion of the internal market for services as envisaged in the Lisbon Programme, the European Commission, and more particularly its Directorate General for Competition, together with the competent national authorities, have engaged in an effort to modernise the (liberal) professions from a competition law perspective. They challenge the legitimacy of professional regulations in order to spur economic growth. ${ }^{27}$ The Commission stresses that the nature and impact of existing professional tegulations have a testrictive character unnecessarily hindering competition, and that the introduction of more competition in the professional services sector will benefit the EU economy, business and consumers. In particular more competition between practitioners, but also with members of different professions and even with other service providers, will promote cost-efficiency, lower prices, better quality and new and innovative services. Conversely, typical restrictions in the professional sectors (concerning both access and exercise) remove incentives for innovation. Moreover, the availability of better and more varied services will increase demand, which in turn will have a positive impact on job creation in the high-skill, high-wage sector of professional services. ${ }^{28}$

The Commission underlines that its initiative to modernise the liberal professions and to conduct a major teview of the existing rules regulating the professions $\mathrm{s}^{29}$ does not entail deregulation, but better regulation. First of all, the target of the better regulation agenda is to achieve professional tegulation for which clear evidence exists that it climinates hatmful practices, and does so in a proportionate way. This means, as can be distilled from the case law, that regulatory choices (e.g. the imposition of a prohibition or an obligation to adopt certain professional conduct) have to be suitable, necessary and commensurable in view of combatting professional practices that are identified as harming the European (services) economy. Moreover, the perceived benefits of professional tules have to justify cleatly the cost for their imposition on practitioners. Secondly, the means to realise the better regulation agenda is to improve new legislation, to simplify existing regulation, and to review or abolish obsolete rules. $^{30}$

The subject of better regulation in the professions appears to be politically sensitive.

\footnotetext{
$<$ http://ec.europa.eu/internal_market/services/index_en.htm>.

${ }^{26}$ See Articles 14, 4 and 98 EC.

${ }^{27}$ Kroes N. (Competition Policy Commissioner), "Better Regulation of Professional Services", (21,11.2005) SPEECH/05/711, 2. See also the earlier initiatives of the competition service of the European Commission: Monti M. (Competition Policy Commissioner), "Competition in Professional Services: New Light and New Challenges", (21.03.2003) ; Monti M. (Competition Policy Commissioner), "Comments and concluding remarks of Commissioner Montiat the Conference on Professional Regulation", (28.10.2003) ; see also Ehlermann C.-D., (1993); Ehlermann C.-D., (1995).

${ }^{28}$ Kroes N. (Competition Policy Commissioner), "Better Regulation of Professional Services", (21.11.2005) SPEECH/05/711, 3. See Arruñada B., (2006), 9.

${ }^{29}$ European Commission, Professional Services - Scope for more reform, of 05.09.2005; European Commission, Progress by Member States in reviewing professional services, of 05.09.2005.

${ }^{30}$ Kroes N. (Competition Policy Commissioner), "Better Regulation of Professional Services", (21.11.2005) SPEECH/05/711, 2.
} 
While the fundamental freedoms of movement, establishment and to provide services are limited to cases that concern a cross-border telationship of the practitioner with her (potential) client ${ }^{31}, \mathrm{EC}$ competition rules apply also to domestic matters. ${ }^{32}$ Consequently, a strict application of the EC competition rules, as expressed in the progressive stance taken by the Directorate General for Competition, has the potential for a wide-ranging impact on traditional regulatory and disciplinary powers. Exactly how deep the knife of competition law cuts is, however, controversial within the European Commission itself with a pro-active competition service and a more cautious legal service. ${ }^{33}$

In a nutshell, proponents and opponents of the application of competition rules to professional regulation argue about whether the (liberal) professions and their rules should be immune against such application. In legal terms this conflict is more complex as it involves a two-stepped application of the law at two levels. On the one hand, the power to regulate and supervise the professions is assumed in the Member States at a self-regulatory level, but also at a State regulatory level. The application of EC competition rules at the latter level is not an obvious exercise and may interfere with Member States' competence, in the absence of Community legislation, to adopt economic regulation in the sector of professional services. ${ }^{34}$ On the other hand, an immunity against the application of the competition prohibitions of the EC Treaty (Atticles 81(1) and $82 \mathrm{EC}$ ) may mean two different things in law: that either the elements of the relevant prohibition clause will not be fulfilled, or, if they are, that a prima facie restriction of competition can nevertheless be exempted from the prohibition clause on the basis of further considerations.

Not least inspired by the persisting vigour with which the discussion is led, for instance within the project of the European Commission to modernise the liberal professions ${ }^{35}$, the present study sets out to examine the tension between rules regulating the (liberal)

${ }^{31}$ Throughout the book, the female grammatical gender will be systematically used for reference to all professionals. Obviously, male professionals are subject to exactly the same rights and duties as their female counterparts.

${ }^{32}$ For details see Chapter 3.II.

${ }^{33}$ In the few cases before the Court of Justice (ECJ) that involved the application of compctition law to a profession the Commission, represented by its Legal Service, has evidenced a careful if not apprchensive course, see e.g. AG Léger in Case C-309/99, Wouters et al. v NOvA, [2002], paras. $105 \mathrm{ff}$. Whether the Commission's position taken in the recent Joined Cases C-94/04 and C-202/04, Cippolla and Macrino, [2006], rings in a change in approach, which is driven by its Directorate General for Competition, remains to be seen. For details on Cipolla see Chapter 2.V. and Chapter 6.

${ }^{34}$ The taking-up and the exercise of a liberal profession as well as the rules on professional conduct and discipline are still regulated at national, and even at sub-national level. There is no Community system of regulation and discipline of the liberal professions that are being exercised in the EU - not even for individual professions - and the ECJ has recognised that in the absence of Community tules, each Member State is free to regulate its own liberal professions and the exercise theteof, sce Case 107/83, Klopp, [1984], para. 17; Case 222/86, Heylens, [1987], para. 10; Case 292/86, Gullung, [1988], 139; Case C-3/95, Reisebüro Broede v Gerd Sandker, [1996], para. 37; Case C309/99, Wouters et al. v NOvA, [2002], para. 99. However, Member States do not have carte blanche in adopting economic regulation. For details on the Community loyalty clause contained in Article $10 \mathrm{EC}$, see Chapter 6.

${ }^{35}$ Organising a conference on the topic of (liberal) professions and competition law surely provokes agitation in the representatives of the professions, for instance in October 2003, when the Directorate General for Competition of the European Commission invited stake holders to comment on its stocktaking excrcise with regard to professional regulations in the MemberStates. Sce <http://ec.europa.eu/comm/competition/sectors/ professional_services/conferences/20031028/index.html>, providing video files of the discussions with interested parties present at that particular conference. Before the renovation of the Commission's website the relevant link also included scans of the written questions and remarks that were put forward from vatious interested parties. 
professions and EC competition law. The passionate defence by quite a few representatives of the professions and policy makers of the perceived legitimacy of professional regulations should, however, not out-compete the application of legal reason. Only the latter will ensure a reliable basis to explore the ins and outs of the competition law rules contained in the Treaty, including its system of immunities. ${ }^{36}$

\section{Objective and scope}

For more than a decade, EC competition law has, every now and then, been applied to the liberal professions by the European Commission and the Community Courts. ${ }^{37}$ Their respective case law has, however, not solved, or even addressed, the full range of legal questions that EC competition law poses when applied to the specific sector of the professions. It is the aim of this book to give a comprehensive account of those problems ${ }^{38}$ and therewith to achieve a twofold systematisation.

First of all, this study sets out to systematise the criteria for the application of the relevant prohibition clauses of EC competition law (Articles 81(1) and 82 EC) with regard to the rules regulating the access to and the exercise of a professional activity. A comprehensive survey of the constituent elements of the two prohibition clauses will be given in Chapters 3 to 6, including the obligations deriving from Articles 86(1) and 10(2) EC for Member States. Leading up to that survey, Chapter 2 will provide the broader background to this exercise, including an outline of the historical development of the (liberal) professions, the necessary foundations in economic theory, the framework of EC competition law in a nutshell and the developments towatds and in the application of EC competition law to the (libetal) professions. The elaborations in Chapters 3 to 6, while comprehensive, will necessarily remain fairly abstract. Therefore, to put my theoretical findings in concrete terms I have chosen to illustrate them with examples of existing tules governing the members of the professions. Later in this chapter I explain more in detail from which examples I draw inspiration in order to concretise my general legal themes.

Secondly, in Chapter 7 this book aims to systematise the grounds of justification that warrant immunity from the two competition prohibition clauses with their - otherwise inevitable - legal consequence of illegality, if not nullity. ${ }^{39}$ Drafting a comprehensive survey of the grounds for immunity in EC competition law is particularly challenging in the field of professional regulation. To start with, the justification grounds embodied in EC competition law (i.e. Articles $81(3)$ and $86(2) \mathrm{EC}$ ) have not yet been applied in a systematical way to the liberal professions and their regulations by the Commission and the Community Courts. Moreover, their application has so far been discussed only to a limited extent in both legal writing and policy documents of, for instance, the Commission and national authorities.

Furthermore, the economic element of the competition law rules meets a systemic public

\footnotetext{
${ }^{36}$ The passionate defence of professional rules, especially by representatives of the legal professions, has determined the choice of this book's sub-title. It is further inspired by a lecture that Advocate General Poiares Maduro gave on "Passion and Reason on European Constitutionalism" on 23 June 2006 on the occasion of the closing ceremony of the LL.M. programme Magister Iuris Communis of the Law Faculty of Maastricht University. His semantic choice distinguishes Passion as representing politics and Reason as representing the law.

${ }^{37}$ The sector-specific casc law is summarised in Chapter 2.V.

${ }^{38}$ For instance, the application of Article $82 \mathrm{EC}$ to the professions (i.e. the prohibition of an abuse of market power) has, to my knowledge, not been discussed in any detail so far. It will be addressed in Chapter 5 .

${ }^{39}$ Article 81(2) EC may be regarded as more strict in its legal consequence than Article $82 \mathrm{EC}$ in that it provides that measures contrary to the prohibition norm of Article 81(1) EC are automatically void.
} 
interest defence put forward by both representatives of the professions and State authorities involved in ptofessional regulation. This defence tefers to the fact that the modus operandi of the (libetal) professions of restricting entry and practice is claimed to be in the public interest. The assertion is that the professions, besides their importance in cconomic terms, also assume a socictal or public role. This means a respect not only for individual interests of their clients from whom they earn their livings, but also for the interest of society at large in having effective systems of, for instance public health care, the administration of justice, ot other values recognised to guarantee the fundamentals for the functioning of a society based on the rule of law. ${ }^{40}$ The ambition of this book therewith is to meet the challenge that Advocate General Léger aptly put into words in his opinion in the Wouters case:

"One of the challenges raised by the issue of the application of Community competition law to the professions is how to identify solutions which will reflect the structure and broad logic of the Treaty provisions.".41

While this statement, at first, may seem self-evident, it is not. Rather it summarises in a perfect nutshell the fundamental question that characterises the complexity of the legal issues dealt with in this book. More specifically, the question to which this book aims to provide some answers is twofold. Firstly, to what extent does EC competition law cater for public interest considerations that are being argued to cover restrictive professional regulations? This aspect will be incorporated in Chapter 7 but will appear also in the earlier chapters dealing with the elements for the application of the relevant competition prohibition rules. Secondly, to what extent can existing professional rules be justified on grounds of public interest recognised in EC competition law? Obviously these two questions describe two sides of the same coin.

The bearing of Advocate General Léger's statement can be taken beyond the immediate application of the exemption provisions of the EC Treaty. Since professional regulation often is adopted at two different levels, i.e. in the form of self-regulation and State regulation, and since the distribution of the respective regulatory and supervisory powers is left to chance in the sense that each profession in each Member State is otganised differently $\mathrm{y}^{42}$, it would - at least at first sight - seem arbitraty if the chance to justify a particular professional tule depended on its regulatory origin. This idea leads to the question of whether and to what extent it is possible to develop a uniform legal approach towards justifying both self-regulatory and State measures in professional regulation. In addressing this question, Chapter 8 will provide more than a summary of the following chapters.

\footnotetext{
40 coThis is not to deny that the profit motive may sometimes be the dominant consideration within a professional organisation. Doctors' partnerships are not just concerned with the health of their patients but equally, with the income they are able to generate by working in that way. Law firms are in many respects normal businesses that seek to increase their return in financial terms by means of mergers and cooperative arrangements. Also, the separate professional values and standards will carry more weightin one professionalorganisation than in another. This does not climinate the fact that those professional values and standards will always be of greater or lesser significance", Wetenschappelijke Raad voor het Regeringsbeleid (WRR - Netherlands Scientific Council for Government Policy), Safeguarding the Public Interest - Summary of the 56th Report to the Govermment (2001), 35.

${ }^{41}$ AG Léger in Case C-309/99, Wouters et al. vNOvA, [2002], para. 111. In the new millennium the Wouters case of the ECJ has been a major point of reference in the discussion on the legitimacy of restrictive professional rules. The facts of the case are presented more fully in Chapter 2.V.

${ }^{42}$ See above note 34.
} 


\section{Approach}

In the analysis of FC: competition law and professional regulation essentially a legal, i.c. rule-oriented, approach is taken. The specific frame of reference is provided by the 'Treaty rules on competition "applying to undertakings", i.e. Articles 81 to 80 l:C. "The substantive scope of this book is limited to these atticles since no scondary legislation at Community level exists that would subject the sector of professional activities to a market order deviating from the general system of $\mathrm{FC}$ : competition law. Because of the gencral character and wording of the applicable tules (including for mstance $A$ rticle 10 : $:(\%)$, the legal analysis by and latge will explure the case law of both the Commission and the Community (iourts. The scrutiny thereof will not be limited to the relatively small number of sector specific cases. ${ }^{44}$ It also sets out to test the application of well-established and less established principles derived from case law in different sectots with a view to contributing to the development of the law in the field of the professions. Fiventually this will lead to an outlook on the potential of $\mathrm{FC}$ Competition law in monitoring the legality of professional regulations.

Moreover, this book will concentrate on a qualitative analysis of, first, the elements constituting the scope of application of the prohibition clauses Articles $81(1)$ and $82 \mathrm{EC}$ (Chapters 3 to 6), and second, the justification grounds (Chapter 7). The qualitative analysis of the relevant legal elements requires that the object of research be determined in tangible terms. The scrutiny of the professional sector therefore does not so much take the status of the libetal professions as a starting point since status very much depends on perceptions and traditions difficult to define in law. ${ }^{45}$ Instead, the point of reference for the legal analysis will be the rules that organise and regulate the professions.

'The qualitative analysis of the justification grounds in EC competition law will not only concentrate on the relevant legal elements thereof, but also on the economic and noneconomic considerations that are discussed at national level to test the legitimacy of regulatory intervention in the professional sector. In order to find out to what extent the justification grounds for self-regulatory and State regulatory professional rules resemble or diverge in substance, it will first of all be necessary to scrutinise the relevant case law that allows either form of professional regulation to be immune from the competition prohibitions. Secondly, it will be necessary to compare the substantive considerations that lead the Court to accept in concreto an immunity from the competition law prohibitions. Even though such a substantive comparison will have to remain tentative in the face of the case law as it stands after Wouters and Meca-Medina ${ }^{46}$, on the one hand, and Arduino and Macrino ${ }^{47}$, on the other, the comparison will have the advantage of bringing out the deference with which professional regulation is dealt with by the Court. Since the Wouters judgment, the justification standard for self-regulatory measures resembles, at least it seems, a mandatory requirements test ${ }^{48}$ with a verification of the reasonableness with which the self-regulatory

\footnotetext{
${ }^{43}$ Title VI Chapter 1 Section 1 of the EC Treaty, Articles 81 to 86 IEC is entitled "Rules on Competition-Rules applying to undertakings".

${ }^{4}$ The sector-specific case law is summarised in Chapter $2 \mathrm{~V}$.

45ee for instance Michalski I.., (1989). See also above note 1 and later Chapter 2.I, on the origins of liberal professions and their regulation.

"4o Case C.-300/99, Wowters et al. עNOVA, [2002]; Case C-519/04 P, Meca-Medina II, [2006], summarised in Chapter 2.V.

"Case C.35/99, Manuale Arduino, [2002]; Joined Cases (. .94/04 and C.202/04, Copolla and Macrino, [2006], summarised in (hapter $2 . \mathrm{V}$.

${ }^{48}$ This test refers in particular to (Case 120/78, Cassis de Dijon, [1979], para. 8. For details see Chapter 7.1.2.
} 
body could assume the necessity of the restriction at stake. Conversely, the review standatd applied for State regulation boils down to a formalistic test of non-delegation, i.e. whether the competent State authority has retained the power to make decisions of last resort. ${ }^{49} \mathrm{In}$ terms of legal certainty it would of course be desirable if the justification grounds for both self-regulatory and State regulatory professional rules could be shifted towards an objective and uniform standard of (strict) proportionality in EC competition law..$^{50}$

While rules regulating the professions have a clear, if not intended, effect on professional services markets, and ate thus economic regulation, no explicit economic or performanceoriented approach will be adopted in this book, mainly for two reasons. First of all, the general legal themes are already sufficiently complex, and a competing approach, applied in a systematic manner, risks blurring the clarity of the presentation. Second, economic theory on the rationale and effectiveness of economic regulation, and in particular with regard to (liberal) professions, is by now well developed in doctrine. ${ }^{51}$ This book therefore does not attempt to survey the state of economic discussion, but uses its conclusions that have become - at least to economists - common property. While the Member States, when signing the Treaty of Rome 50 years ago, had a clear vision of the economic character of the European Community, many lawyers, but also representatives of other professions, are unaccustomed, it seems, to taking an economic view, in particular when it comes to the rules regulating their own profession. It is yet inherent in the nature of the subject matter of this study that economic, and at times also political and sociological, aspects have to be taken into consideration in order to give a complete view of the underlying legal issues.

To highlight my general legal themes, and in particular to illustrate the practical relevance of the legal solutions developed in this book, selected examples of existing national regulations and organisations of the professions will be introduced in the different chapters. An illustrative approach, rather than one of a comprehensive coverage, is justified because, first, the examples chosen are fair representations of the various facets that professional regulation in Europe knows, has known or may see reemerge, if the efforts of the Commission (DG Competition) to modernise the libetal professions should go unheard by professional associations and national regulators. ${ }^{52}$ Second, the range of professional activities governed by regulatory instruments is highly diverse. The accounts of the law in specific professions thus are not - and not intended to be - definitive.

The selection of the individual examples has been made from the professional groups of the 'classical' liberal professions ${ }^{53}$, i.e. the legal, medical, technical and accountancy

\footnotetext{
${ }^{49}$ For details on the relevant case law see Chapter 6.II.2. See also Baquero Cruz J., (2002), 156, 159 ff., who proposes different degrees of review depending on the democratic legitimacy of the author of the restrictive measure. He conceptualises a sliding scale of review standards.

${ }^{50}$ The Commission strongly advocates the application of a proportionality test that should be used to assess to what extent existing restrictive professional regulations and rules truly serve a clearly defined public interest and can be objectively justified, Kroes N. (Competition Policy Commissioner), "Better Regulation of Professional Services", (21.11.2005) SPEECH/05/711, $3 \mathrm{f}$.

${ }^{51}$ See e.g. Ogus A., (1994); Faure M.G., et al., (2001); Maks J.A.H. / Philipsen N.J., (2002); Philipsen N.J., (2003); Adriaansens C.A., et al., (2005); Van den Bergh R., (2006). Schaumans C. / Verboven F., Entry and RegulationEvidence from Healtb Care Professions, (2006). Arruñada B., (2006).

${ }^{52} \mathrm{It}$ will be interesting to see how the Commission will manage to streamline these modcrnisation efforts with the recent initiative of its Directorate General for the Internal Market and Services to promote European codes of conduct by professional organisations under Directive 2006/123/EC of 12 December 2006 on services in the internal market. For details see <http://ec.europa.eu/internal_market/services/services-dir/conduct_en .htm>.

${ }^{53}$ See above note 24.
} 
professions. I decided to concentrate mainly on four European jurisdictions: France, Germany, the Netherlands and the United Kingdom. The decision to take the examples from those four jurisdictions is due, on the one hand, to their established tradition of professional regulation and, on the other, their diverse experiences in applying competition law to the professions. ${ }^{54}$ Where appropriate further telling examples from other countries have been included in the course of this book, and in particular Italy has a place in this since some of the most relevant case law of the Community Courts concerns professional regulation originating in that Member State..$^{55}$

The intensity with which the different professions are regulated differs, first, across borders, but also across professions within one and the same Member State. ${ }^{56}$ The UK and the Netherlands prove to have a relatively low level of professional tegulation that combines with an advanced activity to open up markets for professional services. The situation in the UK is a particulatly suitable research subject because of the constructive approach that the British competition authorities take vis-à-vis the liberal professions in terms of competition law, and which dates back as early as the 1970 s. $^{57}$ The British efforts persist ${ }^{58}$, and today the UK, according to the European Commission, is in the lead group of Member States that take a structural approach to the modernisation of the rules on the liberal professions. The Netherlands, with a pro-active ministry of economic affairs, similatly are at the cutting edge of the discussion on the modernisation of the liberal professions in Europe. ${ }^{59}$ The Dutch ministry was one of the early national authorities seeking cooperation in 2003 with the Directorate General for Competition of the European Commission in the field of the liberal professions, an initiative that finally led to the setting up of a European Competition Network for the liberal professions. ${ }^{60}$ Similarly, the Dutch competition authority (Nederlandse

\footnotetext{
${ }^{54}$ Obviously, the survey could be further complemented by a comparative analysis. This would mean a need to scrutinise existing regulations of various (liberal) professions in a number of Member States, and to compare the approach that, on the one hand, national self- or State regulatory bodies and, on the other, national competition authorities and national courts take with regard to the enforcement of (EC) competition law in the field of the professions. This book includes this idea only in a tentative way. A comprehensive overview of existing professional regulation and its match with competition law will have to wait for future research. For a sound analysis of what is meant by comparative law and its various aims and functions, see Zweigert $\mathrm{K}$ / Kötz $\mathrm{H}$., (1998).

${ }_{55}$ The sector-specific case law is summarised in Chapter 2.V.

${ }^{56}$ For details on the intensity of professional regulation in the Member States differentiated according to groups of professions, see Paterson I., et al., Economic impact of regulation - Case studies, (2003). European Commission, Stocktaking Exercise on Regulation of Professional Services - Overview of Regulations in the EU Member States, of October 2003; European Commission, Stocktaking Exercise on Regulation of Professional Services, of 10/2004; European Commission, Professional Services - Scope for more reform, of 05.09.2005.

${ }^{57}$ See Monopolies and Mergcrs Commission, Report on the general effect on the public interest of certain restrictive practices sofar as they prevail in relation to the supply of professional services (1970); Monopolies and Mergers Commission, Advocates' services. $A$ report on the supply by Senior Counsel alone of their services (1976); Monopolies and Mergers Commission, Barristers' services. A report on the supply by Her Majesty's Counsel alone of their services (1976); Monopolies and Mergers Commission, Advocates' services. A report on the supply of advocates' services in relation to restrictions on advertising (1976); Monopolies and Mergets Commission, Bamislers' services. A report on the supply of barristers' services in relation to restrictions on advertising (1976).

${ }^{58}$ And they do so in particular after the recent changes to the UK Competition Act that abolished the statutory exemption for rules adopted by professional bodies (former Annex 2 to the Competition Act 1998).

${ }^{59}$ See for instance Ministerie van Economische Zaken / Bos D.I., Marktwerking en Regulering: Theoretische aspecten en ervaringen in Nederland en bet buitenland (1995). For details see Chapter 2.

${ }_{60}$ The first meeting with the Directorate General for Competition took place in Brussels at the request of Marc Hameleers from the Dutch ministry of economic affairs, a meeting during which the author of this book was present. For details on the ECN for the liberal professions see Chapter 2.VI.
} 
Mededingingsautoriteit, $N M a$ ) is determined to engage in an effective application of competition law to the professional services sector and has already gathered experience in case work and market investigations. ${ }^{61}$

The levels of professional regulation in France and Germany, but also Italy, are in general considerably higher than in the UK and the Netherlands. ${ }^{62}$ Although the initiatives in France and Germany to modernise the liberal professions are less pronounced in the perception of the Commission, they are still noticeable. ${ }^{63}$ While the French competition authorities were early in prohibiting, for instance, tariff schemes adopted by professional associations under their national competition rules ${ }^{64}$, the German competition authotity (Bundeskartellamt), in its turn, has been reluctant so far to deal with the liberal professions despite the country's well developed competition law. ${ }^{65}$ Its reluctance has to do with the fact that in Germany many professional rules are based on statutory provisions, which the national competition law cannot challenge, basically due to the separation of powers. Established case law of the Court of Justice (ECJ) requires, however, that national measures, even of a legislative nature, must not result in the restriction by economic operators and their representative organisations of competition in the common market. ${ }^{66}$ The Court furthermore affirms that national competition authorities have a duty to disregard such national measures. ${ }^{67}$ Consequently, the Bundeskartellamt may see itself obliged to change its reluctant

${ }^{61}$ For details sce Chapter 2.VI.2.

${ }^{62}$ Paterson I., et al., Economic impact of regulation - Main Report, (2003).

${ }^{63}$ The intensity with which the Member States pursue regulatory reform in the libetal professions varies across the Member States and in 2005 it ranged from no activity to structured programmes of pro-competitive or regulatory reform, European Commission, Professional Services - Scope for more reform, of 05.09.2005, paras. $17 \mathrm{ff}$, and Table 1, and the accompanying Staff Working Document:

Level of activities:

No activity $\Rightarrow$

Minor reforms $\Rightarrow$

Czech Republic, Cyprus, Finland, Greece, Malta, Spain, Sweden

Analytical work in progress $\Rightarrow$

Minor reforms \& analytical work $\Rightarrow$ France, Germany, Ireland, Lithuania, Slovakia

Substantial structural reform $\Rightarrow \quad$ Denmark, Netherlands, UK.

Note that the Commission's table does not take account of activities by the national competition authorities (i.e. case work) in the professional scrvices sector, but concentrates on advocacy and policy building with ministries and national regulators.

${ }^{64}$ For instancc Decision Conseil de la Concurrence - Pratiques mises en oewure par le Conseil national de l'Ordre des architectes, (1997).

${ }_{65}$ Germany was early in having an advanced competition law, and when EC competition law started to develop from the mid-1960s onwards it drew on the German experience with its Gesetz gegen Wettbewerbsbescbränkungen of 1958. Conversely, the competition law rules of the EC Treaty have largely inspired the modelling of many of the national competition acts in the past twenty years, thus leading to a silent harmonisation of the substantive rules on competition in the Member States. For some Member States competition acts are of fairly recent origin as was the establishment of central competition authorities with general powers to control market behaviour of economic operators. This is true not only for the twelve (not so) new Member States that had the chance to introduce competition laws only after the abolishment of the former communistic regimes. France, Germany and the UK had already a long tradition of applying competition rules. The general attitude of the UK authorities appeared to give paramountcy to Community law even before the re-enactment of its competition laws in 1998, Furse M., (2002), 32. Other Member States, however, applied their rules only in a scattered way beforc amending them to align to EC competition provisions. This probably had to do with the lack of a central organ controlling the strict implementation of the competition rules. For instance Italy and the Netherlands have established their competition authorities only during the $1990 \mathrm{~s}$. For an overview on the different applicable national competition laws before the last two enlargement rounds, see Vogelaar F.O.W., et al. (Eds.), (2000).

${ }^{66}$ This obligation is based on Article 10(2) EC. For details see Chapter 6.

${ }^{67}$ Case C-198/01, CIF v AGCM, [2003]. See already Case 103/88, Fratelli Costanzo SpA v Comune di Milano, [1989], 
attitude with regard to professional regulation in Germany. The Italian competition authority (Autorità Garante della Concorrenza e del Mercato, AGCM) takes a more pronounced stance than the German competition authority vis-à-vis regulation in which State authotities have a role. ${ }^{68}$ Already a few years after its establishment in the late 1990s the Autorita targeted to investigate the professional sector. ${ }^{69}$ However, the current political circumstances in Italy do not seem to allow the AGCM to further develop a strictly proactive competition policy to modernise the professions.

All instances of greater of lesser application of competition law principles in the field of professional regulation in the European Union evidence that many representatives of the professions, and even policy makers, have not fallen yet for the idea of modernising the professions through the enforcement of competition law. ${ }^{70}$ Whether love will emerge at second, or perhaps third, sight depends not least on the power of persuasion with which the European Community proposes to embrace the (economic) benefits of the completion of the internal market for services as set out in the relaunched Lisbon strategy.

para. 31: the principle applies to all organs of a Member State, including administrative authoritics. For details see Chapter 6.I. and 6.II.3.

${ }^{68}$ See Case C-198/01, CIF v AGCM, [2003].

${ }^{69}$ Autorità Garante della Concorrenza e del Mercato, Indagine conoscitiva nel settore degli ordini e collegi professionali (1997); Autorità Garante della Concorrenza e del Mercato, "The Competition Authority has submitted a rcport on competition and regulation", press release of 16.01 .2002 .

${ }^{70}$ More details on (national) initiatives in respect of competition and professions are outlined in Chapter 2.VI. 


\section{Legal issues put in perspective}

Subjecting the liberal professions to a competition law scrutiny does not seem to be a matter of course. This has to do with the traditional self-image of the (liberal) professions. For a better understanding of the vigour with which the issue of applying competition law to professional regulation is discussed at times, a brief outline of the origins of professional (self-)regulation is presented, as well as an outline of arguments in economic theory for and against professional regulation. The current opening-up of professional services markets in Europe is a consequence of earlier developments in EC law, and in particular of the case work by the European Courts and the Commission. After briefly highlighting the impact that the Treaty rules on the free movement rights (of persons and services) had on the professions, this chapter will summarise the sector-specific case law in which the European Courts and the Commission have applied the competition law provisions. The survey will serve to indicate in a chronological order the legal problems that emerged in the case work in respect of competition law and professional regulation. The chapter will be round off with a brief overview of the more recent developments in the modernisation of professional regulation at both Community and national level.

\section{The origins of liberal professions and their regulation}

Liberal professions are above all regulated professions. They are characterised by the fact that they are bound by a varying mix of State laws and collective regulation adopted by their professional associations. ${ }^{71}$ Two components may thus be identified that constitute the liberal professions in the Member States: their collective organisation and based thereon their strong self-regulatory tradition. Self-regulation is one of the traditional characteristic features of liberal professions ${ }^{72}$, and in this sense 'professionalism' refers not only to certain ethical standatds of professional behaviour but also to self-governing mechanisms allowing for the

\footnotetext{
${ }^{11}$ See van den Heuvel Rijnders J., et al., Public interests and market regulation in the liberal professions, (2004), 10, who speak about the 'classic' liberal professions and the modern liberal professions, the former often being regulated by the State and public authorities (however, representing only a small proportion of the total number of liberal professions), the latter, by contrast, often not being publicly but privately regulated (as there would be no public interests at stake).

${ }^{72}$ The German federal govemment in its report on the state of the liberal professions emphasises that it is selfgovernment and self-control (Selbstrenvallung als Ordnungselement), which actually determine the traditional self-image of the German libetal professions, Bundesministerium für Wirtschaft und Technologie (BMWI), Die Lage der Freien Berufe, of June 2002, 4. Accordingly, the creation of professional regulation is presented as the legal aspect for the determination of liberal professions, Michalski L., (1989), 11, 14. The question remains, however, whether the professions have been regulated in a certain way because they are liberal in character, or whether they qualify as liberal because they obtained respective regulations?
} 
collective organisation and regulation of a profession. ${ }^{73}$ Collective organisation usually takes place through the establishment of professional associations or bodies that are composed exclusively, or at least predominantly, of members of the same profession.

A brief survey of the general characteristics of the liberal professions as defended in the different Member States will be given here in order to introduce the concept more fully, despite the fact that there is no agreed definition in the Member States. The description is necessarily limited as it is not intended to give a full account of the developments that the concept of liberal professions underwent in the Member States. Sources from the different national systems, be they statutory or published by professional bodies and their umbrella organisations, name various 'chatacteristics' to define the (liberal) character of a profession. Headwords are:

- the importance of professional services;

- working in private practice, being self-employed or 'independent';

- the independence in professional competence (professional autonomy), or put differently, the fact of not being subject to directives;

- the personal responsibility to the client or functional bond of trust, professionalism;

- an intellectual, specialised activity;

- the high level of:

* social status,

* education, extensive study, specialised knowledge,

$*$ income,

* ethical standards - codes of conduct;

- professional associations for organisation, self-regulation and supervision;

- quality of services;

- consumer protection;

- entry restrictions;

- title protection;

- respect for the rule of law. ${ }^{74}$

${ }^{73}$ See Crayencour J.-P., (1982), 24 ff.

${ }^{74}$ The respect for the rule of law is explicitly named in Austria. See also Whelan C.J., (2001), 938 on the ABA (American Bar Association) and the CCBE (Council of Bars and Law Societies of Europe). See OECD, (1985), paras. $4 \mathrm{ff}, 7 \mathrm{ff}$.: For the UK seven characteristics have been enumerated: practitioners apply a specialised skill enabling them to offer a specialised service; the skill has been acquired by intellectual and practical training in a well-defined area of study; the service calls for a high degree of detachment and integrity on the part of the practitioner in exercising her personal judgment on behalf of her client; the service involves direct, personal and fiduciary relations with the client; the practitioners collectively have a particular sense of responsibility for maintaining the competence and integtity of the occupation as whole; the practitioners tend or are required to avoid certain methods of attracting business; the practitioners are organised in bodies which, with or without State intervention, are concerned to provide machinery for testing competence and regulating standards of competence and conduct. See Monopolies and Mergers Commission, Report on the general effect on the public interest of certain restrictive practices so far as they prevail in relation to the supply of professional services (1970).

In the Netherlands an attempt to standardise professional incomes has led to define liberal professions as being characterised by self-employment, advanced training and intellectual work.

Relevant elements in Germany are: private practice; personal service under the direction and responsibility of the professional; primarily intellectual service based on specialised training. See Bundesregietung, Die Lage der Freien Berufe (1979); Bundesregienung, Antwort auf die Kleine Anfrage zur 'Lage der Freien Berufe' (1983); Bundesregienung, Lage der Freien Berufe im Zuge der Schaffung des europä̈schen Binnenmarktes (1989); Bundesregierung, Fortscbreibung des Berichts über die Lage der Freien Berufe (1991); Bundesministerium für Wirtschaft und Technologie (BMWI), Die Lage der Freien Berufe, of June 2002.

Headwords in France are: intellectual activity; involvement of a scientific skill; independent practice. 
Some of the qualifying criteria listed above are much interrelated. Two key notions are personal responsibility and independence. These notions are further refined as the rendering (of services) in person, the fact of not being subject to directives ${ }^{75}$ (as part of personal tesponsibility), and the in dependence in economic terms (i.e. being self-employed). ${ }^{76}$ The fact of not being subject to directives as such is, however, not the reason for obtaining the status of a liberal profession. ${ }^{77}$ Equally, mere empirical evidence of accumulated occurrence of personal responsibility or independence within certain professional groups is not sufficient in order to qualify certain activities as 'liberal'. The decisive factors should be the nature and the societal function of a particular activity. ${ }^{78}$

Some of the aspects in particular seem to have become a myth in modern days. For instance, the independence in the form of being self-employed does not correspond any longer to realities with large numbers of employed professionals (e.g. employed lawyers working for law firms, insurances, corporates; employed doctors working for hospitals;

In Belgium the law defines a liberal profcssions as the predominantly intellectual practice that is performed on a personal basis for a fee (Article 36 of 1976 economic legislation.

In contradistinction, Canada assigns the same legal status to all service industries.

The statutes of the European Council of Liberal Professions (CEPLIS), Article 5.1, of 15 May 1998, define liberal professionals as: "Those persons who, being duly qualified in a particular profession, supply intellectual services personally, under their own responsibility and independently in the common interest of their principals, clients and patients and of society as a whole. Exercising their professions is subject to complying with certain moral and ethical requirements (...). These professions may be exercised individually or within companies." See CEPLIS European Council of Liberal Professions,"European Comncil of Liberal Professions - CEPLIS", (2000).

Sec also Schneider H.E.G.S., (1995), 35, referring to high quality of education; personal responsibility; independence in professional practice/ exercise/ competence; professional duties. Herrmann H., (1996), 44, referring to functional/objective bond of trust (Sachliches Vertrauensverhältnis); economically self-supporting/ self-employed (wirtschaftlich selbständig); independence in professional competence (Eigenverantwortlichkeit und fachliche Unabhängigkeit).

See also Australian Competition and Consumer Commission (ACCC): while there is no agreed definition of a profession, the ACCC has adopted the definition proposed by the Australian Council of Professions which defines a profession as: "A disciplined group of individuals who adhere to high ethical standards and uphold themselves to, and arc accepted by, the public as possessing special knowledge and skills in a widely recognised, organised body of learning derived from education and training at a high level, and who arc prepared to exercise this knowledge and these skills in the interest of others. Inherent in this definition is the concept that the responsibility for the welfare, health and safety of the community shall take precedence over other considerations."See <http://www.accc.gov.au/content/index.phtml/itemId/277772/fromItemId/6193>. The definition is taken from John Southwick, "Australian Council of Professions" view", in Can the professions survive under a national competition policy? Proceedings of a joint conference on competition law and the professions, Perth, April 1997 (not available online).

${ }^{75}$ See for instance $\iint 57(1), 60 \mathrm{StBerG}$ (German Act on Tax Advice), in which the personal responsibility comprises the provision in person and the independence from directives.

${ }^{76}$ Actually, the idca of being self-employed is an inherent feature of the concept of 'iberal' professions in the Member States, see for instance the recent change to code of conduct of the bar association in the UK (31.10.2004): the word self-employed was to replace the word independent - One of the characteristics of the professions frequently referred to is their independence which translates among other into their activity being exercised in private practice or self-employment. Hence, working in private practice used to be one important aspect of being 'independent', a notion which thus not only refers to independence in professional competence or professional autonomy. In consequence, professionals traditionally practised in small economic units, and professional services markets are usually marked by little concentration; they are generally heterogenous.

77 'Ultimately, independence is a state of mind, it is not a question of status and it is not a question of who the client is. It is a state of mind which has to be taught, which has to be developed by the professional bodies and which so it seems to me must also be protected by the state", Edward D.A.O., (1999), 150.

${ }^{78}$ Michalski L., (1989), 16, 103. 
public employees, etc.).$^{79}$ Today it does not seem to be a realistic anymore to use the fact of not being subject to directives as an indicator of the independence in economic terms. The increasing number of employed practitioners slowly erodes the independent character of the professions and contributes to a development away from the traditional self-image of the liberal professions. Changed circumstances in production technologies and contractual technologies have changed the provision of professional services ${ }^{80}$, and the exercise of a liberal profession is different from what it was in previous centuries. The changes have resulted in adjustments of the professional tegulations in the Member States, but - as the Commission does not become tired of emphasising - the liberal professions are still highly regulated. ${ }^{81}$ The high level of regulation, whether State or self-regulation, taises the question whether the liberal professions are indeed as liberal as the term might suggest in its literal meaning. ${ }^{82}$ Rather, calling certain professions 'liberal' seems to be a contradiction in terms. ${ }^{83}$ An excursus into the etymological development of the term 'liberal' may help to shed more light on the concept of professions and the origins of their regulation and organisation.

On the one hand, the atchaic meaning of the attribute 'liberal' refers to something of or befitting a man of free birth. On the other, a more modern meaning refers to someone broad-minded, i.e. not bound by authoritarianism or traditional forms, but progressive and tolerant in attitude, and having political or social views favouring reform and progress. ${ }^{84}$ Certain liberal professions, however, seem to be much vested in traditions and traditional forms. For instance lawyers since centuries weat black gowns - with or without creative decoration. ${ }^{85}$ British barristers and judges are proud to put on little greyish wigs when entering the courtroom. Pharmacists wear white coats although they hardly mix medicine themselves anymore but most of the time simply sell industrial drugs over the counter (even if on prescription).

The expression 'liberal profession' dates back to mediaeval times when it was derived from the Roman artes liberales. ${ }^{86}$ While not being a perfect literal translation of the Latin expression, the term 'liberal profession' designated those professions that were considered to come closest to the artes liberales and were then recognised as science. They were the professions of theology, medicine and jurisprudence. In Classical antiquity, the term 'liberal arts' designated the education proper of a freeman as opposed to a slave who in turn was

\footnotetext{
${ }^{79}$ For details see Chapter 3.I.2.3.

${ }^{80}$ Arruñada B., (2006), 9 f.

${ }^{81}$ European Commission, Report on Competition in Professional Senvices, of 09.02.04; European Commission, Professional Services - Scope for more reform, of 05.09.2005.

${ }^{82}$ The adjective liberal' would indicate someone 1. Not narrow or conservative in thought, cxpression, or conduct: broad, broad-minded, open-minded, progtessive, tolerant in attitude; or 2. Favouring civil liberties and social progress: liberalistic, progressive in politics; or 3. Characterised by bounteous giving: free, freehanded, generous, handsome, lavish, munificent, openhanded, unsparing, unstinting.

${ }_{83}$ Precisely this contradiction in terms has been pointed out by Ogus at the Commission's conference in October 2003, see below note 260. De Waele S. (European Commission - agent of DG Competition), "Intervention", (1011.11.2005), 1. The Dutch Ministry speaks of 'modern liberal professions' that are 'liberalised', and 'classic' liberal professions that are protected, van den Heuvel Rijnders J., et al., Public interests and market regulation in the liberal professions, (2004), 32.

${ }^{84}$ See <http://www.merriam-webster.com/dictionary/liberal $>$.

${ }^{85}$ See e.g. Römermann V. / Hartung W., (2002). See also Article 14 Advocatenwet (as amended on 02.02.1989) (Lawyers Act) (1952): 'De advocaten pleiten staande, gekleed in het kostuum bij het bijzondere regelement op dat onderwerp bepaald, des goedvindende met gedekten hoofde." Judges participate in the fashion and particular jurisdictions wear colours, furs or gold threads.

${ }^{86}$ Probably mentioned for the first time by Cassiodorus in the sixth century CE.
} 
marked with the image of moral and political bondage associated with (physical) labour. In the medieval Western university, the seven liberal arts were grammar, thetoric, and logic (the trivium), and geometry, arithmetic, music, and astronomy (the quadrivium). ${ }^{87}$ These arts specified the educational ideal of antiquity referting to knowledge and skills of a superior kind which one acquired for their very own purpose, or which one used to render personal service in a friendly turn or ex officio as holder of an office. In such an ideal (as interpreted by more recent times) the Roman appointee held an honotary office, and only the well-off freemen could apply themselves to the liberal Articles Even where a freeman was acting on a private basis, a consideration in the form of a honorarium was phased in only later. It thus becomes apparent that the arts were called 'liberal' because a liberal mind was the privilege of the free who - financially - could allow themselves the preoccupation with the artes liberales.

With the introduction of universities in the middle ages ${ }^{88}$ the chatacter of the liberal professions was moulded. The foundation course to the initial three fields of study (theology, medicine, jurisprudence) was dedicated to the liberal arts and reserved to members of the well-off families who, however, were taking up the studies not only anymore for educational arrogance but also as a necessary activity (however worthy of a freeman). Once the branches of study were multiplying with other special studies, the latter took up the labelling artes liberales; theology, medicine and jurisprudence then became the liberal professions. It is this almost literal translation from the term artes liberales with hardly any consideration for its historic meaning that creates the terminological difficulties persisting today with the expression 'liberal professions' ${ }^{89}$

On face value the English language seems to have better respected the historic developments by calling the professions also 'learned' professions, ${ }^{90}$ an expression stressing

\footnotetext{
${ }^{87}$ The scope of the liberal arts has changed with society. In modern colleges and universities, the liberal arts include the study of literature, languages, philosophy, history, mathematics, and science. 'Tiberal arts' also refers to a college or university curriculum aimed at imparting general knowledge and developing general intellectual capacities, in contrast to a professional, vocational, or technical curriculum, <http://www.britannica.com/ $>$. ${ }^{88}$ Bologna 1048; Sorbonne in Paris 1150; Oxford 1167; Salerno 1173.

${ }^{89}$ See Michalski L., (1989), 17 ff., and Michalski L., (1989), 6.

${ }^{20}$ The consequence of the classification 'learned' probably is solely of a social dimension. In the UK (and other countries with a common law background) the supplemented expression liberal profession' does not actually exist. There the denomination is contented with 'profession' as opposed to 'business'. This distinction from 'business' corresponds with the still prevailing view in civil law countries that 'liberal professions' are no trade or business in the legal sense. The terminological dichotomy in the English language of 'profession' and 'business' creates an interesting confusion when translating the terminology of the continental European countries literally into English. Continental Europe juxtaposes the liberal' professions to other activities by calling the latter simply 'professions'. Those are 'less intellectual' occupations as, for instance, of a butcher, baker, plumber, merchant, silversmith or clectrician, and correspond to 'trades' in English proper.

It seems that a comparison between the different national denotations leaves the expression 'liberal profession' either contrary to or the same as 'profession', which in turn is either contrary to or the same as 'business' depending on the national usage. It may be noted at the side that the term 'profession' thereby becomes Janusfaced and may actually foster a discussion of competition law not only with regard to liberal' professions but also with regard to rules regulating 'business' professions. For present purposes both variants of the term are therefore used concurrently - with or without the attribute liberal - and specified only where necessary. However, with the European Commission leading an investigation into the economic impact of regulation in the field of the professions, the 'English' notion of 'liberal professions' seems to be established as Euro-speak; the present work will only be reinforcing this fact, even if English native speakers may continue to wonder what 'the Europeans' would exactly mean by the expression 'liberal' professions. See European Commission, Report on Competition in Professional Services, of 09.02.04.
} 
the fact that the said professions require knowledge of an advanced type in a field of science and liberal atts acquired by a prolonged course of specialised intellectual instruction and study. ${ }^{91}$ Traditionally, and just as the 'liberal' professions, the 'learned' professions referred to the three professions of law, medicine and theology. This threesome has been opened up in more recent times but still a distinction is made from occupations requiring a rather general academic education, an apprenticeship and training in the performance of routine mental, manual, or physical processes. With the rise of technology and occupational specialisation in the 19th century, other bodies began to claim 'professional' status: engineers, paramedics, educationalists and even accountants, until today almost any occupational group can - at least unofficially - aspire to professional rank and cachet ${ }^{92}$, and populat tecognition of this trend has made the widespread recognition of prostitution as 'the oldest profession' possible.

At the time when the (liberal) professions evolved as distinct above other occupations feudalism was the predominant form of government. Under that political and sociological system, the learned and liberal professions managed to acquire and maintain a special status vis-à-vis the feudal master in that they were not subject to his erratic and discretionary authority. As an influential gtoup they were accorded the power to organise, regulate and control themselves as a profession similar to a guild.$^{93}$ In this way a limited number of professions became 'free' to self-regulate and they were not subject to the laws of the king. Instead the professions acquired the 'liberty' to set their own rules on professional conduct and thereby could exclude individuals from the exercise of the professional activity. At the time the individual practitioner thus became subject to the regulations imposed by a professional body tather than public authority. Consequently, and in the traditional view, the qualification as 'liberal' justifies that a profession be treated different in law than other business and occupations, and in particular to exclude them from the application of certain general laws.

In modern times the right to self-regulate as a principle has so far remained unchallenged. However, social and legal circumstances in Europe have evolved such that nowadays a profession does not risk anymore being subject to an erratic sovereign. In a modern democracy with the rule of law a vacuity from the control of democratically elected Parliaments could be seen as atbitratily privileging the self-regulated professions over other social groups. ${ }^{94}$ The excursus into the historical development of the liberal ptofessions shows that the qualification as 'liberal' has become an arbittary criterion to justify self-regulation by a profession unduly testricting the freedom of competition. ${ }^{95}$ In particular, a concession of

\footnotetext{
${ }^{91}$ See for instance Code of Federal Regulations, Title 29, section 541.301, at <http://www.dol.gov/esa/regs/fedreg/final/Regulation_541.pdfs.

${ }^{22}$ See also Article 150 EC on education, vocational training and youth, which speaks about "vocational training" and "industrial change", thereby indicating the difference with 'professions".

${ }^{93}$ See <http://www.wordiq.com/definition/Profession/>: "Sociologists have been known to define professionalism as self-defined power elitism or as organised exclusivity along guild lines, much in the sense that George Bernard Shaw characterised all professions as 'conspiracies against the laity'. Sociological definitions of professionalism involving checklists of perceived or claimed characteristics (altruism, self-governance, esoteric knowledge, special skills, ethical bchaviour, etc) became less fashionable in the late 20th century."

${ }^{94}$ Evans L., et al., (2006), 10. Van den Bergh R.J., (2006), 6.

${ }_{95}$ The [Irish] Competition Authority, Study of Competition in Legal Senvices - Preliminary Report, of 24.02.2005, stresses that mostly the different layers of competition restrictions have arisen over decades, and in some cases even over centuries, of self-regulation by professional bodies that group the individual members of the profession to represent their interests.
} 
principle to exclude the liberal professions from the application of certain general laws is not accepted anymore for the field of competition law. ${ }^{96}$

Notwithstanding, certain characteristics of a profession may play a role in assessing the legitimacy of some professional tules regulating the access to and the exercise of a professional activity. However, instead of legitimising regulation in reference to the (acquired or claimed) status of a professional group, the point of departure for regulation needs to be objectivised and related to the nature of the activity provided by liberal practitioners. For instance, where the activity exceeds its economic function of earning its provider her living and contributes to the interest of society at large, the undetlying motivation for regulation of the professions are public policy considerations. Public policy considerations, where properly identified, may indeed justify restrictive arrangements. ${ }^{97}$

The ensuing question is which body or authority is best placed to issue professional regulation to safeguard public interests possibly associated with the exercise of a liberal profession. Professional rules originate from different authors. In particular, professional associations assume a dual role, which covers not only the representation of the interests of the profession, but also regulatory, supervisory and disciplinary powers. Professional selfregulation, i.e. arrangements adopted collectively, may also be adopted by the individual members of a profession amongst themselves. Both forms of self-regulation will be the object of the competition law scrutiny in Chapters 3 to 5 . A third category of actor in the field of regulated professions are $S$ tate authorities. Their legislative and regulatory activities organising professional markets are analysed in Chapter 6.

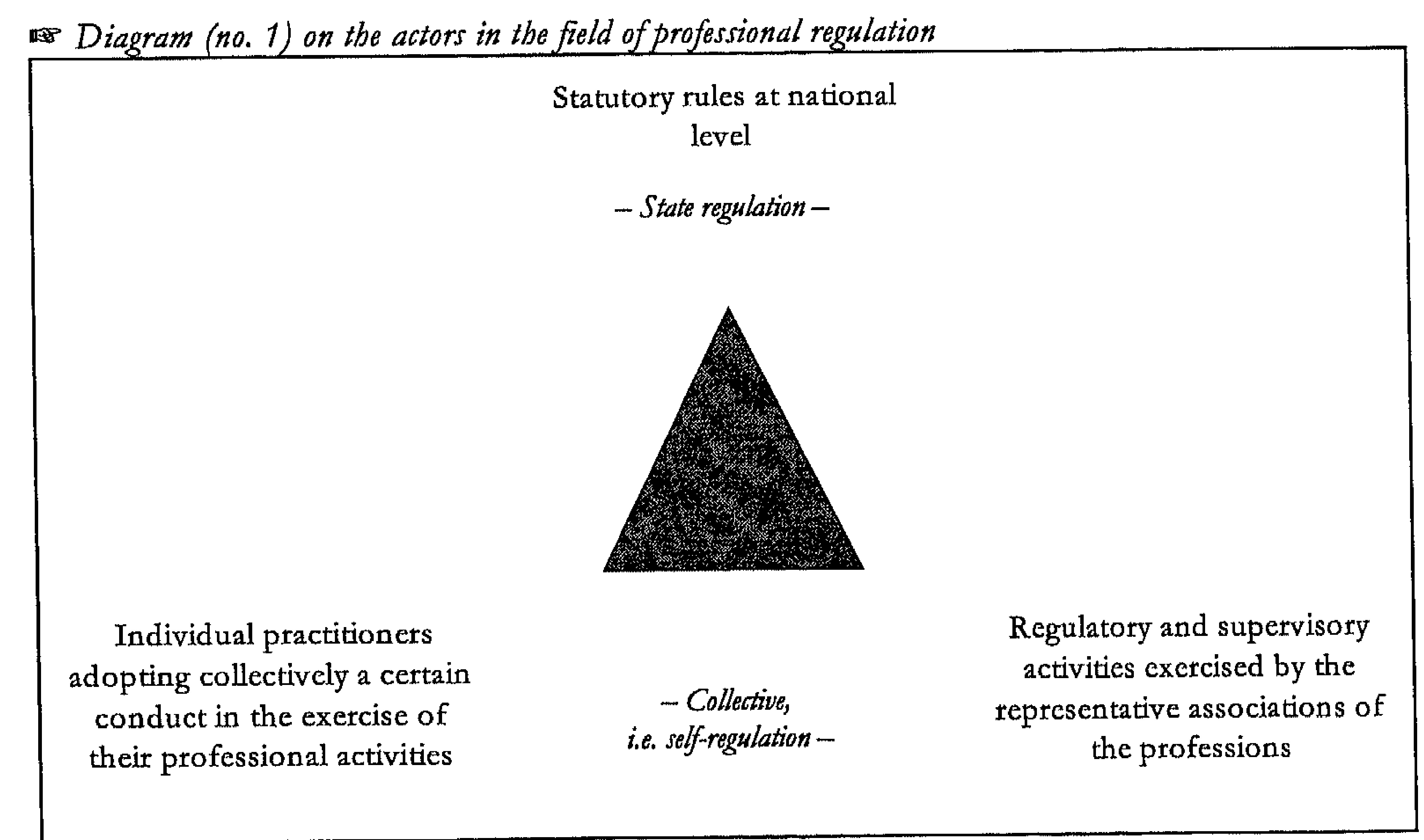

Not only the changes in social and legal circumstances justify to revisit the regulatory

${ }^{96}$ For instance, recent changes in respect of the UK Competition Act 1998 have abolished the exemption for rules adopted by professional bodies that had been contained in Annex 2. A different treatment in law of the liberal professions is often granted in tax matters, e.g. in Germany, Luxemburg, Greece, and in company law. ${ }^{97}$ For details see Chapter 7. 
structures of professional regulation; the role of professional regulation also needs to be put in to perspective of the changed economic circumstances in the professional services sector. Economic theory explains the need to control professionals when taking influence in the regulation of their own activities.

\section{Economic theory and the control of professional activities}

The intervention by regulation possibly limiting the freedom of action is - of at least should be - motivated by malfunctions of, or undesired effects in, the provision of professional services. Economic theory scrutinises the properties of professional services and the behaviour of professionals to explain the basis for regulatory intervention. It does not take any peculiarities of the professions for granted but looks at the nature of a particular service and the adverse effects that a certain professional activity may have. ${ }^{98}$ A short survey of the arguments for and against regulatory intervention in professional services markets shall give the background to the current competition policy discussion in the field of professional regulation.

Generally speaking there are two approaches to regulation. ${ }^{99}$ The public interest approach concentrates on the nature of the professional services provided. The private interest approach to regulation stresses the role of interested groups in the formation of regulation. While the public interest approach provides arguments for the motivation of regulatory intervention based on perceived shortcomings of the market system that lead to less social welfare (market failures), the private interest approach rather concentrates on the author of regulatory intervention (the State or professional associations).

Both aspects are relevant for the legal discussion of professional regulation. The public interest approach contributes to the discussion on the objectives pursued by regulation. Closely related to this issue is the form that regulatory intervention takes (e.g. licensing and certification, quality standards, information regulation) and which should incite practitioners to respect and foster the objectives pursued by professional regulation. The question is whether a regulatory measure is effective in implementing the pursued objective.

Furthermore, the level and the content of regulation can be influenced by private interests of interest groups, who provide the author of the regulation with input. In particular, the private interest approach warns for rent-seeking behaviour by interested groups like professionals organised in associations. On the one hand, the latter may try to influence the level and the content of public regulation to their benefit. According to economic theory every branch of industry which is powerful enough to do this will lobby the government for the implementation of entry bartiers to keep the supply by market entrants artificially low and thereby keep up relatively high prices. The lobbying will also be for direct rules on professional conduct, like the prohibition to advertise, because they lead to less transparent markets where prices can and will be higher that in a market without those

\footnotetext{
${ }^{98}$ Adverse effect is a concept in medicine where it defines a harmful and undesired effect resulting from a medication or other intervention such as chemotherapy or surgery. An adverse effect may be termed a 'side-effect' (when judged to be secondary to a main or therapeutic effect) and may result from an unsuitable or incorrect dosage or procedure (which could be due to medical error). - See also Ministerie van Economische Zaken, Pamphlet on the Liberal Professions - a practical guide to public interests and regulatory instruments, of 10.12.2004, emphasising that the general theory is applicable to all markets, including the market for professional services. ${ }^{99}$ A discussion of the relevant economic literature is presented by Philipsen N.J., (2003), 9-45, who scrutinises the basis of economic theory, the motives for choices made by professionals and their clients, the various arguments for and against regulation and particular forms of regulatory intervention in services markets.
} 
restrictions. ${ }^{100}$ The risk of rent-secking behaviour is even more pressing when sclf-regulation is involved. This is due to the fact that it does not require lobbying in the public rule-making process. ${ }^{101}$

Under the public interest approach the nature of professional services is determined by its private and public character. While the provision of professional services is primarily determined by the relationship betwcen the professional and her client, the professional service is provided in a more complex system of relations with third parties that are either involved in the provision of the services or in an indirect way experience consequences form it, e.g. partners, regulators, informers, assessors, etc. ${ }^{102}$ The individual relationship between practitioner and customer is often characterised by an information asymmetry because the professional generally has an information lead over her lay client. Many professional services are called experience goods or trust goods. This means that the customer can hardly judge the quality of the services before it is provided, or even after it has been provided. ${ }^{103}$ Economic theory argues that this leads to adverse selection. The idea is that information asymmetry will lead to the deterioration of quality. Where consumers of professional services cannot evaluate the quality of such services ${ }^{104}$, but can only discriminate on price, professionals have no incentive to provide high quality services, as those will be more costly in their 'production'. Consequently, the market price will reflect only the average quality level and will thus attract average quality professionals. ${ }^{105}$ The result will be a decrease in the average quality level perceived by consumers, which in turn will lead to a reduction of the market price, and so on. ${ }^{106}$ According to the public interest approach the ultimate scenatio is that good professionals will be driven out of the market by less performing professionals.

In a broader context, and in particular in the multilateral relationship professional - client - third parties, a decreased level of quality results in extennal costs born by others than the service provider. In the professions 'costs' are to be understood as the risk resulting from the provision of low quality services, for instance by a poorly trained or negligent professional, that result in physical, economic or emotional harm to the customer or third parties. ${ }^{107}$ Examples are collapsing buildings that are not designed or constructed according to the state of the art, or mistakes by medical professions that have an impact not only on the patient but also her family and possibly others, like the employer or persons put at a risk of infection. To remedy such negative externalities political decisions oblige certain private services providers to also provide certain public services (i.e. to produce positive

100 Philipsen N.J., (2003), 25. For details see Chapters 4 and 7.

101 Philipsen N.J., (2003), 42. Certainly, more can be said about the benefits of self-regulation, for instance the information benefits on the side of the regulated profession and the reduction of enforcement costs. See Van den Bergh R.J., (2006).

${ }_{102}$ Arruñada B., (2006), 3.

103 The propertics of experience goods or services can only be assessed with the help of highly technical standards. For such services there is no learning through the repeat purchase mechanism. If consumers are not able to reliably judge the quality of a service before and after the transaction, the only factor to save on information costs becomes trust in the professional providing the scrvice. Philipsen N.J., (2003), 15. The differences between search goods, experience goods and credence goods are described by Tirole J., (1992), 106. See also Jenny F., (2006), $4 \mathrm{f}$.

104 In particular where the professionals are inhibited from providing information because of advertisement restrictions.

105 Philipsen N.J., (2003), $15 \mathrm{f}$. See also the famous example of the market for used cars presented by Akerlof G., (1970).

106 Van den Bergh R., (1999), 126.

107 Van den Bergh R, (1999), 108; Philipsen N.J., (2003), 18; Cox C. / Foster S., (1990), 10. 
externalities).

The parameters for the provision of both private and public services by a professional are determined by three aspects typifying professional activities. ${ }^{108}$ First of all, demand or consumer preferences are heterogeneous, i.e. professional services as legal advice or medical examination are very much tailored to the individual needs of the customer. Standardisation of professional services might be possible, however, for recurting needs and typical situations. This in turn can affect quality as perceived by the customer. ${ }^{109}$ The second and third aspect typifying professional services result to a certain extent from the first one: professional services require the application of specific 'human capital' with a high degree of specific knowledge that has practically no value outside the profession. Moreover, the heterogeneity of the demand and the specificity of the services require professional judgment in individual cases.

Notwithstanding it is argued in economic theory that the resulting information asymmetry between professionals and customers and the risk of low quality today are of secondary importance to the regulation of external effects. The argument is that markets are better capable of resolving information asymmetry than is the State, partly due to the existence of durable firms with considerable reputation investments. ${ }^{110}$ The adverse selection argument presented above therefore seems to become less important. The presence of professional firms on modern services markets also relativises the role of professional associations in regulating and imposing competitive restraints in the professionals' conduct. Thus, by emphasising the changed organisation of the professions in a modern world Arruñada forwards the argument that "much of the discussion on professional tegulation would be more relevant for policymaking in the $19^{\text {th }}$ than in the $21^{\text {st }}$ century because the discussion ignores the fact that professional services are (or in the absence of competitive restraints would be) provided through professional firms." ${ }^{111}$

The approach focussing on the external effects means that the (economic) discussion on the legitimacy or efficiency of professional regulation nowadays shifts towatds emphasising the role of professional activities in their contribution to the public interest. Conversely, the role of professional associations in implementing and controlling legitimate policy considerations needs redefinition. In economic terms the public interest and thus the legitimacy or efficiency of professional regulation can be measured in terms of costs generated by competitive testrictions (limited innovation) and the loss of welfare caused by higher prices and consequently a relative decrease of quality and quantities of professional services. Such an exercise would require to survey prices and the quality levels influenced by professional regulation, and those that are to occur in the absence of regulation. Such a scrutiny would, however, exceed the scope of the present research dealing with the legal assessment of competitive restrictions imposed by rules regulating the professions. Lowti Evans, the former director responsible for liberal professions within the Commission's DG Competition, has an outspoken view on the need to control self-regulatory professional bodies:

${ }_{108}$ Arruñada B., (2006), $2 \mathrm{f}$.

109 Arruñada B., (2006), 2, who points out that not only technological but also psychological considcrations inhibit standardisation, as was experienced decades ago by non-professional service firms which pioneered 'services industrialisation'.

110 More serious information asymmetries than in professional markets have been solved by marked mechanisms, e.g. concerning the safety of automobiles or buildings. Arruñada B., (2006), 8, 10.

i11 Arruñada B., (2006), 2. 
"If a group has a role in pursuing the general interest, then such a general interest should be specified and monitored by a public authority and not by a self-regulating body. It could be imagined that such a public authority is independent, like the authorities monitoring telecommunications or financial services, or itcould be imagined that more explicit 'co-regulation' models could be developed. The point here is that in a mature democracy there could be a need to separate clearly the public role from the influence of peets."112

\section{The framework of EC competition law in a nutshell}

EC competition law is contained in Chapter 1 of Part III of the EC Treaty. Together with the guarantees of the economic fundamental freedoms the competition rules constitute the core of the common market, the creation of which has been one of the EC Treaty's main goals from the beginning (Article $2 \mathrm{EC}^{113}$ ). The insertion of the competition rules in the Treaty of Rome serves the purpose of preventing actors others than the Member States from delimiting the Common market alongside national borders. One has to keep in mind that much of EC law is aimed at a macro cffect to eliminate obstacles to the free movement of goods, services, persons and capital. The removal of these obstacles in itself promotes competition within the Community. ${ }^{114}$ Btoadly speaking the attainment of the aim can be jeopardised not only through State measures limiting the fundamental freedoms, but also by business engaging in agreements or conduct that have the effect of dividing the territory of one Member State from another. When the Treaty of Rome came into force in 1958 it was, however, hardly conceived that the competition rules set therein were to apply to the liberal professions and the rules regulating their activities. The crux was that at the time the liberal professions were regarded not to pursue an economic activity the exercise of which would bring them within the ambit of the competition rules.

The Treaty includes two articles prohibiting undertakings the distortion of competition within the common market or in a substantial part of it to the extent that they may affect intra-Community trade. Article 81(1) EC prohibits any collusive behaviour between several economic operators that distorts competition; it is automatically null and void. ${ }^{115}$ Article 82 EC prohibits abusive behaviour exercised unilateral by a monopolist or a collectivity of economic operators that are able to behave independently of their competitors and the consumers. ${ }^{116}$

The Treaty's competition provisions refer to the central concept of 'undertaking' rather than to more commonly known rubrics of companies, businesses or enterprises. ${ }^{117}$ The

112 Evans L., et al., Ibid., 10 (emphasis added).

113 Article $2 \mathrm{EC}$ : ${ }^{\circ}$ The Community shall have as its task, by establishing a common market and an cconomic and monetary union and by implementing common policies or activities referred to in Articles 3 and 4, to promote throughout the Community a harmonious, balanced and sustainable development of economic activities, [...] a high degree of competitiveness and convergence of economic performance, [...]".

114 Whish R., (2003), $50 \mathrm{f}$.

115 The first paragraph of Article 81 EC prohibits "all agreements between undertakings, decisions by associations of undertakings and concerted practices which may affect trade between Member States and which have as their object or effect the prevention, restriction or distortion of competition within the common market". The second paragraph provides that "any agreements or decisions prohibited pursuant to this article shall be automatically void."

116 Article $82 \mathrm{EC}$ prohibits "any abuse by one or more undertakings of a dominant position within the common market or in a substantial part of it shall be prohibited as incompatible with the common market in so far as it may affect trade between Member States."

117 In the French texts of the Treaty and secondary legislation the word 'entreprise' is used, which has no exact equivalent in the English language used in UK commercial law. Furse M., (2002), 18. 
concept is central to EC competition law because it determines the scope of the EC competition rules ratione personae. A definition of the term 'undertaking' is not provided for in the EC Treaty or secondaty legislation, but in light of the objectives of the competition provisions it has been interpreted broadly to include entities that exercise an independent economic activity. The definition of the undertaking in any particular case depends on the economic and factual reality of the situation, and not on the legal structure or status of the entity. Their legal status or the way they are financed are immaterial in this respect. ${ }^{118}$

Differently from Article $82 \mathrm{EC}$ the prohibition of Article 81(1) EC also addresses to associations of undertakings that integrate the behaviour of its members. These can be trading associations, or any other association grouping 'undertakings' as their members. The underlying reason to include them in the scope of the prohibition is that associations provide a forum for competitors of a specific sector to get together and to discuss matters which may be to their mutual interest and may provide the vehicle to coordinate their behaviour. ${ }^{19}$ Also their legal status is irrelevant, i.e. whether the association is set up by statute, or whether some of the members ate appointed by the government. As long as it represents the membets' (trading) interest, also a professional body comes within the ambit of Article 81(1) EC. ${ }^{120}$ The survey of the case law below shows that libetal practitioners and their collective representative bodies respectively have been held time and again to qualify as undertakings and associations of undertakings in the sense of EC competition law.

The next question in competition law then is which kind of conduct is considered to distort competition. Article 81(1) EC prohibits collusive conduct between a multitude of undertakings that has the object or effect to prevent, restrict or distort competition within the common market. The concept of restriction of competition is presented as an economic concept that requires an economic analysis to determine whether a certain conduct or measure adopted by undertakings or their association has an adverse impact on competition on a certain market. ${ }^{121}$ Article 81 (1) EC contains an illustrative list of agreements or conduct that may be caught, such as price fixing and market sharing. In the field of liberal professions such restrictions might translate into fee scales, rules that prohibit the members of a profession to advertise their services in particular ways, educational and qualification requirements, title protection or other, that might result in a restricted market access or restrict the professionals' freedom to organise the exercise of the profession in economically reasonable terms. ${ }^{122}$

Article $82 \mathrm{EC}$ prohibits the abuse of a dominant position by one or several undertakings. This article therefore requires that the undertaking or undertakings be in a dominant position before the prohibition on abusive behaviour is applicable. Any undertaking will only have market power in the context of the supply of particular goods or services in a particular geographical atea and at a certain point in time. The application of what constitutes dominance thus necessitates an economic analysis, and more particularly in relation to the product or services market and the geographical market during a certain period of time.

Together Articles 81 and 82 EC constitute a coherent legal system protecting free competition. They are thus important companions of each other. ${ }^{123}$ Whereas Article 81 EC

118 Case C-41/90, Höfner and Elser, [1991], para. 21. For details see Chapter 3.I.

11 Jones A. / Sufrin B., (2004), 147; Whish R, (2003), 97.

120 See Case C-309/99, Wouters et al. v NOvA, [2002].

121 Whish R, (2003), 108, 117.

122 For details see Chapter 4.II.

123 Whish R., (2003), 175. 
concerns collusive conduct of a multitude of actors on the market, Article $82 \mathrm{EC}$ addresses the unilateral behaviout of undertakings with a hegemonic position on the market. Generally speaking Article $82 \mathrm{EC}$ forms the basis of actions far less often than does Article $81 \mathrm{EC}$ because it necessarily applies to fewer undertakings being among the latger organisations. More particularly professional services markets are often little concentrated not allowing individual professional firms to accumulate economic power to abuse of. In large part this book therefore concentrates on Article $81 \mathrm{EC}$. However, Article $82 \mathrm{EC}$ not only targets unilateral behaviour of a single entity, but also behaviour of several undertakings abusing of a 'collective' or 'joint' dominant position. The Court accordingly developed the concept of collective dominant position. ${ }^{124}$ It is conceivable that a liberal professional group occupies a collective dominant position and abuses of it through its rule-setting competences or its powers to exclude members or other operators from (the exercise of) the profession. ${ }^{125}$

EC competition law not only prohibits anti-competitive measures. A prima facie restriction of competition may be justified if certain requirements are fulfilled. Where the restriction imposed by a professional rule does meet the criteria of either prohibition clause, the legal consequence generally is illegality. In such a case, illegality can be averted only if the professional rule, in a second step, benefits from an exemption. The EC Treaty contains two explicit exemption provisions (Articles 81(3) and 86(2) EC) that apply in competition law cases and have the purpose of safeguarding ceratin public policy choices. ${ }^{126}$

An agreement of undertakings or a decision by an association of undertakings that is held to be contrary to Article 81(1) EC can gain exemption from the prohibition under Article 81(3) EC. Four cumulative conditions must be satisfy: (I) the agreement or decision must improve the production or distribution of goods ${ }^{127}$ or promote technical or economic progress; (ii) consumers must receive a fair share of the resulting benefit; (iii) it must contain only restrictions which are indispensable to the attainment of the objectives pursued; and (vi) it cannot lead to the elimination of competition in respect of a substantial part of the products in question. Where the requirements of the competition specific exemption under Article 81(3) EC are not met, or in cases of an abuse of a dominant position under Article $82 \mathrm{EC}$, a further exemption possibility is provided for in Article 86(2) EC. Article $86(2) \mathrm{EC}$ is not specific to competition law cases but provides more generally that "undertakings entrusted with the operation of services of general economic interest or having the character of a revenue-producing monopoly shall be subject to the rules contained in this Treaty, in particulat to the rules on competition, in so far as the application of such rules does not obstruct the performance, in law or in fact, of the particular tasks assigned to them. The development of trade must not be affected to such an extent as would be contrary to the interests of the Community."

The exemption possibility under Article 81(3) EC in principle is based on the idea of the increase of economic efficiency (i.e. the weighing of anti- and pro-competitive aspects). At the same time the wider Community aims and objectives set out in Articles 2 and $3 \mathrm{EC}$ may lead to a broad interpretation of the four criteria of Article 81(3) EC to authorise prima facie restrictive agreements or decisions that provide benefits from other policy perspectives, e.g.

${ }^{124}$ Joined Cases T-68 to 77 and 78/89, Italian Flat Glass, [1992]; Joined Cases C-395/96 P and C-396/96 P, CMB (Cewal) II, [2000].

${ }_{125}$ For details see Chapter 5.

126 For a categorisation of public interest considerations in regulation see Chapter 7.I.2.3.

127 Services have been omitted in the wording but have to be read into the text. See also the Dutch Competition Act modelled on the EC competition law which in its Article 17 explicitly names also services. 
cultural, environmental, regional, social or industrial policy perspective. ${ }^{128}$ The extent to which public policy considerations peculiar to the liberal professions exist and have to be taken into account under Article 81(3) EC is considered later in Chapter 7.I.

To place the importance of Article 81(3) EC in the field of professional tegulation it is necessary, as a background, to briefly address the enforcement system that follows from what has been called the 'modernisation' of the application of EC competition law. With Regulation 1/2003, which has taken effect since May 2004, this modernisation has established a system of parallel competences of the Commission and the Member States competition authorities and courts for the application of both Articles 81 and 82 EC. ${ }^{129}$ More particularly Regulation 1/2003 abolishes the notification and authotisation system that its predecessor, Regulation 17, had established. ${ }^{130}$ Under the previous regime the Commission had exclusive competence to grant an exemption according to Article 81(3) EC upon notification only. The new Regulation establishes, with regard to Article $81 \mathrm{EC}$, the following principles that are directly enforceable by national competition authorities and before national courts. According to Article 1(1) of Regulation 1/2003 agreements or decisions that are covered by Article $81(1) \mathrm{EC}$ and do not satisfy the conditions of Article 81(3) EC ate prohibited and void, again no ptior decision to that effect being required. Conversely, and according to Article 1(2) of that Regulation, agreements or decisions that are covered by Article 81(1) EC but satisfy the conditions laid down in Article 81(3) EC are not prohibited, no prior decision to that effect being required. In contrast to the old system under Regulation 17 such agreements and decisions are valid and enforceable from the moment that the conditions of Article 81(3) EC ate satisfied and for as long as this remains the case. ${ }^{131}$ Hence, professional rules that fulfil the conditions of Article 81(3) EC can be effectively invoked before any national court or competent (competition) authority against practitioners and, depending on the circumstance, also their competitors who are no members of the profession concerned.

The system of written immunities for prima facie restrictions of competition has been shaken by the Court in 2002 in Wouters. ${ }^{132}$ There the Court in essence found that a rule adopted by a professional association, while constituting a clear restriction of competition, was "necessary in order to ensure the proper practice of the legal profession, as it is organised in the Member State concerned", and therefore did not infringe Article $81(1)$ EC. ${ }^{133}$ With this judgment, I will argue, the Court accepted a case of immunity from competition law thus far extraneous to the system of EC competition law. ${ }^{134}$

Under Article 86(1) EC also Member States are prohibited form enacting or maintaining in force any measure contrary to the competition rules. ${ }^{135}$ As can be appreciated from its

128 Jones A. / Sufrin B., (2004), 234; Monti G., (2002).

129 Council Regulation (EC) No 1/2003 of 16.12.2002 on the implementation of the rules on competition laid down in Articles 81 and 82 of the Treaty.

130 Council Regulation No. 17 of 10.02.1962, First Regulation implementing Articles 85 and 86 of the Treaty (now Arts. 81 and $82 \mathrm{EC}$ ).

131 European Commission, Guidelines on the application of Article 81(3) EC, para. 10.

132 The case is summarised further below in this chapter.

133 Case C-309/99, Wouters et al. v NOvA, [2002], paras. $97 \mathrm{ff} ., 107,110$. Reluctant to extend this case law the Court only recently made a limited application thereof in Case C-519/04 P, Meca-Medina II, [2006], para. 42.

${ }^{134}$ For details see Chapters 4 and 7.

135 Or any other rules contained in the Treaty: "In the case of public undertakings and undertakings to which Member States grant special or exclusive rights, Member States shall neither enact nor maintain in force any measure contrary to the rules contained in this Treaty, in particular to those rules provided for in Article 12 and 
wording, Article 86(1) EC normally applies in conjunction with other atticles of the Treaty since its function is to limit the ways in which State measures protecting certain undertakings hinder the operation of the Treaty provisions. Therefore a certain anti-competitive behaviour in the sense of either Article 81(1) EC or Article $82 \mathrm{EC}$ needs to be established on the part of the undertakings before the Member State can be found to infringe Article 86(1) EC. The same structural issue is enshrined in the case law according to which the Court established an obligation on the part of Member States not to adopt or maintain in force any measure which could deptive the competition rules, as applied to undertakings, of their effectiveness (INNO $\vee A T A B$ rule). ${ }^{136}$ This jurisprudence is based on Articles $3(1)(\mathrm{g}), 10(2) \mathrm{EC}$ in conjunction with Articles 81 or $82 \mathrm{EC}$. It draws its rationale from the purpose and aims of the competition rules in the Treaty and their effet util, and is based in particulat on the principle of Community loyalty, which requires Member States to abstain from measures that could jeopardize the attainment of the Treaty's objectives. However, it is not enough to establish the anti-competitive impact of a Member State's rule. It needs to be linked to a certain (autonomous) behaviour on the part of the undertakings, which is testrictive of competition, as otherwise EC competition law will not apply. ${ }^{137}$ But also in a case of unilateral State regulation, i.e. without involvement of any private operator, the Member State will have to make sure not to infringe other Treaty provisions, and in particular the guarantees of the free movement rights (Articles 39, 42, $49 \mathrm{EC}$ ).

\section{Opening the market for liberal professions}

The changes in societal and economic circumstances in the European market for the regulated professions finally led to a gradual process of opening up. It has evolved in different cycles that mark different developments in Community law. In the early years the process has been strongly influenced by the case law of the European Court of Justice on the interpretation of the Treaty's free movement of persons provisions, i.e. in particular the freedom of establishment and to provide services. The Court's interpretation and application of the non-discrimination principle (Articles 12, 39, 43, 49 EC) was the reason that many obstacles to professional activities have been removed. Conversely, the application of EC competition law to rules governing the liberal professions and the exercise of their activity had to wait the formal establishment of the internal market in 1992. It is toughly since the 1990s that the Commission and the Court have adopted decisions in respect of professional regulation and competition law. ${ }^{138}$

\section{Free movement of liberal practitioners}

The increasing enforcement of the Treaty rules guaranteeing the fundamental freedoms in the common market have perforated the barriers that national legislators and professional

\footnotetext{
Articles 81 to $89 . "$

136 Case 13/77, INNO v ATAB, [1977], para. 31.

137 See Case C-2/91, Meng, [1993]; Case C-245/91, Obra, [1993];]oined Cases C-180 to 184/98, Pavlov, [2000].

138 Commission Decision CNSD, (1993); Case C-35/96, Commission vItalian Republic (CNSD II), [1998]. See already Case 311/85, Vlaamse Reisbureaus, [1987], concerning a regulated though not liberal profession of travel agents in Belgium. The case concerned ptice fixing rules according to which travel agencies were prohibited to pass on to their customers commissions they had obtained or to grant them rebates on tours organised by tour operators. For details see below section V.1.
} 
associations have erected to protect their markets, education and training systems against the competition from professionals from or trained in another Member State. It was, however, not before the 1970s that the European market for the regulated professions has been effectively opened up. ${ }^{139}$ In two landmatk decisions of the cases Reyners ${ }^{140}$ and Van Bindsbergen $n^{141}$ the Court abolished certain nationality and domicile requirements as directly discriminatory on grounds of nationality. Since then the Court proceeded to develop a broader interpretation of the non-discrimination principle that led to a stricter control in the field of frec movem ent of persons. By now the Court disapproves of restrictions of the free movement of persons regardless of whether they are discriminatory or non-discriminatory (i.e. measures that render less attractive the trans-boundary exercise of the free movement tights). ${ }^{142}$ The development towards the extended interpretation of the non-discrimination principle took about twenty years. Until the end of the 1980 s the Court was mainly concerned with national restrictions that were either directly or indirectly discriminatoty against persons invoking their free movement rights under the Treaty. ${ }^{143}$ It was only in the 1990 s that the Court seized the opportunity to clarify that also non-discriminatory measure, i.e. restrictions indistinctly applicable to nationals and to non-nationals, whether trained inland or abtoad, are prohibited in the field of the free movement of persons ${ }^{144}$ - unless they are justified by an overriding reason of the general interest. ${ }^{145}$

The development of the case law has lead to a strict but parallel interpretation of the non-discrimination principle in the field of the free movement of persons, and provides professionals with a broad protection of their right to exercise their profession across the border (be it as a temporary service provider, an established migrant or a migrant returning to her home Membet State). The culminating case in this respect, Kraus ${ }^{146}$, coincided with the completion of the internal market at the turn of 1992. In Kraus the Court seized the opportunity to interpret the free movement rules in light of the internal market conception, i.e. the principle of mutual recognition. ${ }^{147}$

This conception goes back to an initiative that the Commission took in the mid-1980s to boost the establishment of an internal (or single) matket. The Commission had realised that the legislative contributions of the Community to the common matket in the form of harmonisation of laws was not sufficient anymore to meet the agenda of the Community.

139 In 1961 the Council adopted General Programmes for the abolition of restrictions on freedom of establishment and on freedom to provide services, OJ 2,15.01.1962, p. 32. The programmes were intended as a basis for the abolition of identified restrictions. These objectives were, however, not achieved despite the adoption of various directives. Schneider H.E.G.S., (1995), $39 \mathrm{f}$

140 Case 2/74, Reyners, [1974].

141 Case 33/74, van Bindsbergen, [1974].

${ }_{142}$ This development was similarly to the development in the field of the free movement of goods, in which the Court began to eliminate discriminatory measures. More particularly the Court extended Article 28 EC to also prohibit measures that are indistinctly applicable to imports but which indirectly restrict access to the market of goods from other Member State, Case 8/74, Dassonville, [1974], para. 7.

143 Case 71/76, Thieffry, [1977]; Case 11/77, Patrick, [1977]; Case 107/83, Klopp, [1984]; Case 182/83, Fearon, [1984]; Case 211/85, Commission v Belgium (Clinical Biology Services), [1987]. Schneider H.E.G.S. / Claessens S.,
(2005), 127.

${ }^{144}$ In particular with regard to the freedom of establishment. Case C-340/89, Vlassopoulou, [1991]; Case C-

104/91, COAPInmobiliaria, [1992]; Case C-106/91, Ramrath, [1992]; Case C-19/92, Kraus, [1993].

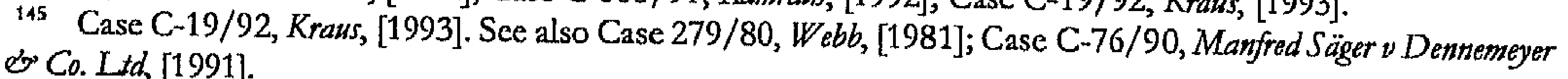

146 Case C-19/92, Kraus, [1993].

147 Schneider H.E.G.S., (1995), 88. 
Secondary legislation existed at the time in the form of several sectoral ${ }^{148}$ directives that had been adopted in the aftermath of the case law Reyners and Van Bindsbergen. ${ }^{149}$ These specific directives first of all governed access to a number of regulated professions separately (mainly in health care). Sectoral directives were not only adopted with a view to diploma recognition, but secondly also to guarantee the effective exetcise of the freedom to providc services, in particular for lawyers. ${ }^{150}$ This form of sectoral harmonisation of laws required the Member States to agree on detailed measures, a fact which slowed down if not aborted the legislative process. The sectoral harmonisation method was associated with lengthy procedures and the great difficulties to adapt to new developments. ${ }^{151}$

Owing to the incapacity of the other Community institutions to act the Commission in 1985 therefore published a White Paper on the internal market ${ }^{152}$ in which it announced the need for a new strategy. Under the new strategy the Commission abandoned the sectoral harmonisation approach and redirected harmonisation towards the concept of mutual recognition, a concept which the Court had introduce in the case Cassis de Dijon ${ }^{153}$ in the field of the free movement of goods. However, the Court's contribution to market integration was essentially 'negative' and deregulatory by applying the Treaty prohibition of restrictions imposed by national measures. Conversely, the Commission's strategy in the White Paper built on to use the concept of mutual recognition for positive market integtation through harmonising Community legislation, and in particular to extend the concept to the other free movement rights. The intention of the Commission was that also workets and self-employed persons benefit from the new conception. ${ }^{154}$ They should be able to exercise their profession in another Member State without being obliged to undergo any additional formalities that could prevent them from taking a decision to cross borders. ${ }^{155}$ In Vlassopoulou the Court later confirmed that the principle of mutual recognition extends to the free movement of persons. ${ }^{156}$

The new approach initiated under the internal market programme lead to the adoption

148 That is to say instruments by which recognition of diplomas is provided per individual sector, profession by profession, with a minimum harmonisation or co-ordination of the education and training required for each profession in the Member States; see Schneider H.E.G.S. / Claessens S., (2005), 137.

149 In the 1960s more than thirty transitional directives had been introduced that concerned the recognition of working experience to facilitate access to certain occupations or professions in another Member State. The measures were called transitional because of the pending harmonisation before the end of the transitional period, which ended on 31.12.1969; the transitional directives were consolidated only in 1999 by the third general system directive, Directive 1999/42/EC of the European Parliament and of the Council of 07.06.1999 establishing a mechanism for the recognition of qualifications in respect of the professional activities covered by the Directives on liberalisation and transitional measures and supplementing the general systems for the recognition of qualifications.

150 Council Directive 77/249/EEC of 22 March 1977 to facilitate the effective exercise by lawyers of freedom to provide services; Council Directive $98 / 5$ of 16 February 1998 to facilitate practice of the profession of lawyers on a permanent basis in a Member State other than that in which the qualification was obtained.

151 Schneider H.E.G.S. / Claessens S., (2005), 139.

152 European Commission, White Paper on completing the internal market, of 14.06 .1985 , paras. $63 \mathrm{f}$

153 Case 120/78, Cassis de Dijon, [1979], para. 14. The principle means that once goods have been lawfully marketed in one Member State, they should be free to be marketed in any other Member State without restriction, unless the restriction is justified by mandatory requirements and proportionate to the envisaged aim. For details on the mandatory requirements doctrine see Chapter 7.I. - See also Gormley L., (1981) on the Commission's Communication on the consequences of Cassis and the reactions thereto.

154 Schneider H.E.G.S., (1995), 31.

155 The White Paper proposed an approach combining mutual recognition and harmonisation.

156 Case C-340/89, Vlassopoulou, [1991]. 
of general system directives, in particular with regard to diploma recognition. They do not focus anymore on vertical regulation of individual professions with a minimum harmonisation and co-ordination of the education and training required for each profession in the Member States. Instead in the general system directives a horizontal approach is adopted that allows mutual recognition of diplomas without prior harmonisation of the rules applicable in the Member States. ${ }^{157}$ The general system Directives are based on the premise that the programmes of study and training in the different Member States that prepare for a particular regulated profession are in principle equally valid. As long as certain minimum conditions are met, completion of any of these programmes should provide access to the same regulated profession in any Member State, so that no prior harmonisation of the different study programmes is necessary.

In the new millennium the next step of secondary regulation to take in the field of the free movement of professionals is an even more prestigious project of the Commission, namely the complete consolidation of the systems of diploma recognition. That consolidation, which is a project started in light of the Lisbon strategy for growth and employment ${ }^{158}$, resulted in one single Directive covering all possible issues of recognition of diplomas. ${ }^{159}$ However, sectoral directives continue to exist with regard to issues that, while relating to the freedom to provide services and the freedom of establishment, exceed the recognition of diplomas. ${ }^{160}$ The Commission has taken further harmonisation efforts in order to effectively guarantee these fundamental freedoms under the approach of mutual recognition and to achieve a genuine internal matket for services by removing legal and administrative batriers to the development and provision of service activities between Member States. While the latter objective seems to have been successful, the mutual recognition principle has been heavily discussed in the media, in particular in France and Germany, in the period before the elections to the European Parliament in 2004. Finally, the Services Directive was adopted in 2006, and has to be implemented in to national laws before 28.12.2009. ${ }^{161}$ One of the less well-known and yet essential features of the Services Directive is the chapter dealing with quality of services, which aims at ensuring the high quality of services by encouraging, among other things, self-regulation, if need be through the elaboration of European codes of conduct. The ultimate goal is to facilitate the free

157 See Council Directive 89/48 of 21 December 1988 on a general system for the recognition of highereducation diplomas awarded on completion of professional education and training of atleast three years' duration; Council Directive 92/51/EEC of 18 June 1992 on a second general system for the recognition of professional education and training to supplementDirective 89/48/EEC; Directive 1999/42/EC of the European Parliament and of the Council of 07.06.1999 establishing a mechanism for the recognition of qualifications in respect of the professional activities covered by the Directives on liberalisation and transitional measures and supplementing the general systems for the recognition of qualifications. Both systems created by the vertical and horizontal directives have been adapted to the SLIM principle (Simpler Legislation for the Internal Market, See <http://europa.eu.int/comm/internal_market/simplification/index_en.htm>.

158 The Lisbon Strategy has been sketched in Chapter 1. In order to make the reference to the agenda more accessible and understandable to citizens the Commission considers to complement or replace "Tisbon" with the more self-explanatory "Growth and Jobs", "Lisbon Strategy for Growth and Jobs: Commission's annual progress report - frequently asked questions", press release MEMO/06/23 of 25.01.2006, 8.

159 Directive $2005 / 36 / \mathrm{EC}$ of 7 September 2005 on the recognition of professional qualifications; Schneider H.E.G.S. / Claessens S., (2005), 157.

160 Council Directive 77/249/EEC of 22 March 1977 to facilitate the effective exercise by lawyers of freedom to provide services; Council Directive 98/5 of 16 February 1998 to facilitate practice of the profession of lawyers on a permanent basis in a Member State other than that in which the qualification was obtained.

161 Directive 2006/123/EC of 12 December 2006 on scrvices in the internal market. 
movement of services in the Internal Market. ${ }^{162}$

\section{Towards applying EC competition law to professional regulation}

The internal matket integration for the regulated professions has been influenced not only by the implementation of the fundamental freedoms. Competition policy has an equally crucial role since the increased degree of European economic integration pursued by the Community with the adoption of the Single European Act in 1986 is promoted by both free movement and competition. ${ }^{163}$ The establishment of the internal market can therefore be understood as a catalyst not only for an intensified application of the free movement guarantees but also for an emerging application of the competition law to the regulated professions. Competition policy has been included in the EC Treaty as one of the Community activities since the inception of the Community in 1958, and EC competition law can be said to serve two masters: effective competition and the imperative of internal market integration. ${ }^{164}$ Hence, the opening of the European market for regulated professions was ready to enter a further stage in the 1990 s when market building had largely been achieved with the establishment of the internal market. ${ }^{165}$ With market maintenance consequently becoming predominant ${ }^{166}$, the realisation was that not all measures restricting access to and the exercise of professional activities can be reviewed under the free movement guarantees of the 'Treaty. In contrast to the EC competition rules their application depends on the existence of a trans-boundary element, i.e. that either the professional, her client or the professional services cross the border into another Member State. Conversely, to enjoy the economic rights of free competition no such crossing of a Member State's border is strictly necessary. Even where professional rules are imposed within one Member State only, may they have an impact on the European market and trade between Member States ${ }^{167}$, and thus fall within the scope of EC competition law. Finally the Commission and the Court started engaging in case work and applying the competition rules to rules regulating professions that traditionally qualified as 'liberal' in the Member States. ${ }^{168}$

More generally speaking the development towards applying EC competition law to rules regulating the liberal professions coincides with the evolvement that competition law takes in Europe since the 1990s. There is a dual aspect that has a certain impact on the

162 For details on the directive, its handbook on implementation, economic studies, policy backgrounds and selfregulation issues, see the Commission's website <http://ec.europa.eu/internal_market/services/services-dir/ index_en.htm>. See also Claessens S., (2008).

163 See Baquero Cruz J., (2002); Jones A. / Sufrin B., (2004), 36.

164 Jones A. / Sufrin B., (2004), 36.

165 The completion of the internal market was set to be achieved by 31.12.1992, see Article 14EC. See also Case C-198/01, CIF v AGCM, [2003], para. 47: "since the Treaty of Maastricht entered into force, the EC Treaty has expressly provided that in the context of their economic policy the activities of the Member States must observe the principle of an open market economy with free competition (see Articles 3a(1) and 102a of the EC Treaty (now Article 4(1) EC and Article 98 EC))." For details on Member States' tesponsibilitics in respect of the freedom of competition, see Chapter 6.

166 Reich N., (1999), 339

167 For details see Chapter 3.II.

168 See also Ehlermann C.-D., (1993), who at the time served as Director General of the Commission's Directorate-General for Competition and announced that the Commission would be looking into a more active enforcement of the Treaty's competition provisions with regard to the liberal professions. Nowadays the Commission is strongly opting for advocacy rather than strict enforcement of the competition law principles, see below section VI.1. 
modernisation of the rules regulating the liberal professions. First of all, a fundamental tevision of the national competition laws took place in the 1990s and brought the national competition laws in line with Community competition law. This process is continued with the accession of new Member States to the Community in 2004 and 2007. Few of them had no competition law under Communism, and during the accession negotiations they were convinced to copy Community rules. Secondly, competition law in Europe has taken a further step of modernisation in respect of the implementation of EC competition. Regulation $1 / 2003^{169}$ provides for the full application of the EC rules not only by the Commission but also the competent national instances (competition authorities and courts) and establishes a vertical relationship between the Commission and the national enforcers that is hierarchical and allows the Commission to continue using competition law as a policy tool. In particular, the principles of EC competition law have to be respected by the national enforcers in the decentralised application of EC competition law. To facilitate a smooth implementation of EC competition law Regulation 1/2003 provides for the setting up of a European Competition Network managed by the Commission. It enables the use of documents acquired by one member of the network for proceedings before other members. Within the European Competition Network the Commission has set up a particular subgroup for the liberal professions. ${ }^{170}$ The extent to which the further opening of the European market for regulated (liberal) professions and the modernisation of their tules can be said to constitute a flagship in the process of the modernisation of competition law in Europe will be considered below after the survey of the competition law case work by the Commission and the Court in the specific sector of the liberal professions. In any event, it is to be expected that the liberalising effects of the Community walking ahead in the application of the competition concepts to rules regulating the liberal professions will reflect in the work of the competent national authorities and courts applying their national rules. A mutually fructifying effect on the work of the Commission by the national competition authorities is perceivable (see below section VI).

\section{The case law applying EC competition law to the liberal professions}

In the vast case law on the interpretation of the $\mathrm{EC}$ competition rules there are a number of cases that have a factual background in regulated professions. Their summaries here below are intended to highlight the development that the case law has taken so far in respect of this sector, and to facilitate the cases' referencing later in this book. The presentation of this sector-specific case law follows in principle a chronological order.

To date only a small number of cases have been initiated by the Commission. The Commission has used its formal powers under Article $85 \mathrm{EC}$ to implement Articles 81 and $82 \mathrm{EC}$ and to adopt decisions vis-à-vis professional associations for having issued rules determining their members' market behaviour (CNSD, COAPI, EPI, Belgian Arcbitects and Piau). In three of these cases the Commission's decisions have been challenged before the Court of First Instance (CNSD, EPI and Piau). In respect of professional regulation by Member States the Commission has used its powers under Article 226 EC only once to bring an action against Italy for failure to fulfil its obligations under Articles $3(1)(\mathrm{g}), 10(2)$ and

169 Council Regulation (EC) No 1/2003 of 16.12.2002 on the implementation of the rules on competition laid down in Articles 81 and 82 of the Treaty.

170 Evans L., et al., (2006), 4 ff. European Commission, Progress by Member States in reviewing professional services, of 05.09.2005, para. 23. 
$81 \mathrm{EC}$ (CNSD II). The peculiarity of CNSD is that the Commission effectively took the view that not only the tariffs adopted by the relevant professional body, but even the national legislation at the root of the tariff setting were infringing the effectiveness of EC competition law.

The majority of cases involving professional tegulation and EC competition law have been decided by the ECJ in preliminary rulings referred by national courts in accordance with Article $234 \mathrm{EC}$. These cases concern tules stemming from both self-regulation and State regulation, as national courts have been confronted with both types of regulations in, for instance, disciplinary or criminal proceedings against a professional (Vlaamse Reisbureaus, Wouters, Doulamis), civil actions brought between private parties (Arduino), between professionals (Calafior) or between a professional and the client (Conte $v$ Rossi, Cipolla and Macrino), or proceedings brought against administrative decisions precluding economic actors from certain reserved professional activities (Pavlov, Glöckner, Maurn).

\section{1987 - Case Vlaamse Reisbureaus}

In Vlaamse Reisbureaus ${ }^{171}$ the Court applied the competition tules to the regulated though not liberal profession of travel agents in Belgium. The case concerned price fixing rules according to which travel agencies were prohibited to pass on to their customers commissions they had obtained or to grant them rebates on tours organised by tour operators. The professional association of Flemish travel agencies first had included the rules in a code of conduct and a framework agreement with tour operators. Later the same rules were incorporated in a royal decree. The rules were enforceable under national law and thereby binding on all travel agents.

The case came before the Court as a preliminary proceeding. As the national proceedings brought by the professional association against a travel agent for the infringement of national legislative rules, the main question addressed by the Court concerned the compatibility of the royal decree with the tequirements of Article $81 \mathrm{EC}$ in conjunction with Article 10(2) EC. In order to answer that question the Court in a very sober way first assessed that there was a system of agreements both between the agents themselves and between the agents and tour operators that restricted price competition between travel agents. The Court then turned to confirm that "by transforming an originally contractual prohibition into a legislative provision [that provision] reinforces the effect of the agreements in question between the parties, inasmuch as the rule acquires a permanent character and can no longer be rescinded by the parties." The case was aggravated by the fact that the national law first of all allowed the enforcement of the fixed price mechanism to private parties (i.e. to other travel agents complying with the rules), and secondly, threatened any infringement with the withdrawal of the license to operate as a travel agent.

The judgement is interesting for its conciseness and clear finding of an infringement by a Member State. Moreover, since the profession at stake was not defined as a liberal one, the Court did not bother to address the point whether travel agents are actually 'undertakings' in the sense of competition law, i.e. whether they exercise an economic activity. 
2. 1993, 1998, 2000-Case (trilogy) Consigho Nagionale degli Spedizionieri Doganali (C.NSD)

The (NSI) trilogy is the first application of the ER competition rules to a liberal profession. It concened the prufession of Italian custums agents a liberal profession according to domestic law) and the tariff tates they were required tu charge for the provision of custums clearance services. These compusory tariff rates had been adopted by the national professional assuciation of the agents. Not unly had those tariffs been approved by ministerial dectee, but the national legialation prohibuted registeted customs agents from derogating from the tarifs on pain of exclusion, suspension ur removal from the register. Consequently, the Commission initiated two different procedures to safequard the freedom of competition. First, complaints of industral, commercial and transport companies about the tariffs had prompted the commission to adopt a decision addressed to the CNSD. according to which it had to cease the imposition of the compulsory munimum and maximum tariffs. ${ }^{12}$.'his decision was later challenged before the Court of First Instance. ${ }^{173}$ Secondly, the Commission resolved to bring an action before the European Court of Justice against the Italian Republic under Articlc $226 \mathrm{JC}$. for fallure to fulfil its obligations under Articles 10 and $81 \mathrm{HC}$ insofar as Italy required the (NSD to adopt a decisinn contraty to Article $81 \mathrm{EC}^{1 / 4}$

The CNSD trilogy raised two main questions of competition law. The first concerned the point whether liberal professionals qualify as undertakings and their representative bodies as associations of undertakings, i.e. whether members of a liberal profession engage in an economic activity. ${ }^{175}$ 'The second crucial point focussed on whether Member States can be held responsible for a restriction of competition committed by such an association. ${ }^{176}$ The ECJ and the CFI followed the Commission in its affirmative assessment of these questions without ambiguity. In addressing the questions this case law embraced competition law principles that had been developed earlier with regard to sectors other than services provided by liberal professionals.

First, both the ECJ and the CFI rejected the arguments of the respective parties (CNSD and Italy) that liberal professionals would not qualify as undertakings, and that the public law status of the national professional body (CNSD) would preclude the application of the $\mathrm{EC}$ competition law rules. The judges thereby followed the functional approach adopted in the case law with regard to interpreting what constitutes an undertaking and economic activity in the sense of $\mathrm{EC}$ competition law. They thus made clear that granting professionals or their associations a particular status in law does not preclude the applicability of competition law. Any lobbying to that effect by the stakeholders therefore is vain. ${ }^{177}$

172 Commission Dexision CNSD, (1993).

173 Case T $513 / 93$, CNSD $I I I,[2000]$

17 Case $(-35 / 96$, Commisson o lalian Repablic (CN.SD II), [1998]. In an earlier proceeding the Commission had tried to challenge the Italian rules under the free movement of goods provisions of the Treaty. It had claimed that the Italian Republic had infringed Articles 23 and $25 \mathrm{EC}$ (ex Articles 9 and $12 \mathrm{E}$ (.T) by approving the tariff scheme. The claim was dismissed though on the ground that the tariffs did not constitute charges equivalent to customs duties as there was no obligation on an importer to have recourse in all circumstances to the services of a professional customs forwarding agent, see Case C.-119/92, Comorision v latian Republic (CNST) 0), [1994], para. 46.

17. For details see Chapters 3.1. and 4.1.

17. l'or details see ('hapter 6.

17. ()nly where the majority of the self -regulatory bexly had becn compssed of independent representatives and/ or where that bedy was required by law to observe various public interest criteria in adopting the 
Also in the proceedings CNSD II against the Italian Republic did the ECJ confirm the Commission's finding, namely that the Italian Republic was to be held responsible for the restriction of competition committed by the professional body in fixing the tariff rates. The Italian legislation "not only required the conclusion of an agreement contrary to [Article 81 $\mathrm{EC}$ ] and declined to influence its terms, but also [assisted] in ensuring compliance with that agreement." 178 The Court thereby reinforced the more general rule developed in previous case law according to which Member States, under the combined application of Articles $3(1)(\mathrm{g}), 10(2)$ and 81 or $82 \mathrm{EC}$, are tesponsible not to introduce or maintain in force measures, even of a legislative nature, which may render ineffective the competition rules applicable to undertakings. This rule had been introduced by the Court some twenty years earlier ${ }^{179}$ and meanwhile has been substantiated to prohibit Member States to "require or favour the adoption of agreements, decisions or concerted practices contrary to [Article $81 \mathrm{EC}$ ] or to reinforce their effects, or to deprive its own rules of the character of legislation by delegating to private economic operatots responsibility for taking decisions affecting the economic sphere". ${ }^{180}$ In CNSD II the Court applied this Van Eycke rule in a concise and rigorous way to find that Italy had effectively violated its obligations under Articles 10 and $81 \mathrm{EC}$.

In the appeal proceedings of CNSD III, which the professional association had brought against the primary Commission's decision, the CFI had to resolve the further question of whether the professional body, in the process of fixing and imposing the tariff rates, had acted autonomously of the powers that the State authorities had exercised. ${ }^{181}$ This question was answered in the affirmative, and the CNSD therefore was held responsible for the restriction of competition independently of the Member State's responsibility for measures that had enabled the CNSD to adopt and impose the disputed tatiff scheme. The decisive factor for the CFI was that the Italian legislation had "not as such [precluded] the continued existence of a certain amount of competition", which the CNSD subsequently and autonomously had restricted. ${ }^{182}$ The CNSD enjoyed a matgin of discretion in the implementation of the national legislation which, according to the CFI, "it should have used in order to apply the Italian legislation whilst maintaining the level of competition which could be left to exist after that legislation had been implemented."183 The CFI thereby rejected the argument related to what is called a State compulsion defence. ${ }^{184}$ According to this defence (associations of) undertakings charged with an infringement of the competition rules in Articles 81 or $82 \mathrm{EC}$ can claim that their conduct falls outside the scope of the prohibitions where it was required by national legislation or where the national legal framework itself eliminated any possibility of competitive activity on their part.

professional rules, might the Courts recognised an exception. An exception may also be conceivable if a professional association exercised powers of a public authotity. For details see Chaptex 4.I.2.

178 Case C-35/96, Commission v Italian Republic (CNSD II), [1998], para. 55.

179 The Court stated this obligation for the first time in Case 13/77, INNO $\nu$ ATAB, [1977], para. 31. See also Case 229/83, Leclerc $\nu$ Au Blé Vert, [1985], para. 14. For details see Chapter 6.

180 See Case 267/86, Van Eycke, [1988], para. 16.

181 The CFI had stayed its proceedings in anticipation of the ECJ's judgment. The CFI reiterated the findings of the ECJ that the public law nature of the CNSD or its decisions did not have an impact on the applicability of the EC competition rules to the liberal professions.

${ }_{182}$ Case T-513/93, CNSD III, [2000], para. 72.

183 Para. 73 of the CNSD III judgment.

184 The concept is also called State action defence following its development in US law. For details see Chapter 6.II.3. 
The CNSD trilogy shows that the legal assessment of self-regulation and State regulation under competition law depends on the respective roles assumed by the self-regulatory body in restricting competition, on the one hand, and by the State authorities in the rule setting process, on the other, that eventually leads to anti-competitive conduct by (an association of) undertakings, or reinforces the effects thereof.

\section{1995 - Case Colegio Oficial de Agentes de la Propriedad Industrial (COAPI)}

Only about a week after it had adopted its decision against the Italian customs officets in CNSD I the Commission initiated the second case in which the EC competition rules have been applied to a liberal profession. Similarly to CNSD the case concerned compulsory minimum scales of charges for services, this time provided by industrial property agents, that had been adopted by the professional association on the basis of State legislation. ${ }^{185}$ The Commission found that the Spanish official association of industrial property agents (COAPI) had restricted competition contrary to Article 81(1) EC. According to the domestic law membership to COAPI was compulsory. Its members, through their representative body, had collectively renounced their freedom to fix their own individual prices. The COAPI cnjoyed powers to regulate the fees and the professional activities and to ensure that the regulations and acts of the COAPI would be complied with by the associations' members on pain of fines or exclusion. ${ }^{186}$ The finding of an infringement of the EC competition rules was not altered by the fact that the association's regulations were approved by royal decree shortly after they had been adopted by COAPI.

In particular the Commission refused the argument of the COAPI that the competition law rules could not be applied to its regulations and acts because of it being governed by public law, and its acts allegedly being in the nature of State rules. Moreover, the COAPI could not take cover from the application of the competition rules for the reason that the legislative national framework enabled it to adopt and impose the minimum fee scales. The Commission established that the national law did "not in itself fix scales of charges not even the criteria for fixing these scales, leaving the professional association the responsibility for doing so" and that therefore competition was not restricted as an effect of the national legislation itself but by the acts of the association. That the adoption of the scales were permitted by the Spanish legislation was irrelevant. Any responsibility of the Member State under the INNO $\vee$ ATAB-rule ${ }^{187}$ would not mitigate the association's responsibility for its own acts. Later the CFI in CNSD III used a similar though more elaborate reasoning to find that the professional association had infringed the competition rules 'autonomously' of the responsibility of the Member State for limiting competition. ${ }^{188}$

Despite the fact that the COAPI had not notified its tariff scheme to the Commission, as had been required at the time under Article 4 of Regulation $17^{189}$, the Commission seized the opportunity to reiterate that price fixing does not meet the requirements of Article 81(3) EC for the grant of an exemption from the prohibition of Article 81(1) EC.

185 Commission Decision COAPI, (1995).

186 Similar to CNSD where the national law prohibited to derogate from the professional rules.

187 Case 13/77, INNO vATAB, [1977], para. 31. For details see Chapter 6.

188 Despite the factual similatities between $C N S D$ and $C O A P I$ it is not entitely clear why the Commission initiated an action against the Member State in the former but not in the later case.

189 Before modernisation, Council Regulation No. 17 of 10.02.1962, First Regulation implementing Articles 85 and 86 of the Treaty (now Arts. 81 and 82 EC). 
The Commission took the care that even in the field of liberal professions price fixing is an inapproptiate means to ensure high-quality services since price fixing does not prevent the provision of poor-quality services. Instead it constitutes a disincentive for more efficient agents "to seek to alter their working practices to enable them to reduce their costs". ${ }^{190}$ Despite the violation of Article 81(1) EC no fines had been imposed in COAPI.

\section{1995, 1997 - Case Bilanzbuchbalter v Commission}

In Bilanzbuchbalter $v$ Commission ${ }^{191}$ the German Tax Advisors Act (Steuerberatungsgesetz) was at stake. That act reserved the right to pursue the activity of tax advice and related matters to tax consultants, auditors, lawyers and sworn accountants. The professional association of qualified accountants lodged a complaint with the Commission in which it argued that the German Tax Advisors Act would among other infringe Articles 49 and $82 \mathrm{EC}$ in as much as it excluded professional groups like the plaintiff from the activity of tax advice. However, the Commission refused to start proceedings against Germany. The plaintiff challenged the Commission's decision under Article 230(4) EC for not initiating actions against Germany. First the CFI, and subsequently the ECJ on appeal, dismissed the action of the plaintiff. One reason why the Bundesverband succumbed with its competition law argument was that it did not challenge the conduct of undertakings but instead called into question the national "legislation of genetal application". ${ }^{192}$ The case thereby shows that judicial review of rules regulating the professions not only depend on their anti-competitive character but also on the regulatory form they take. The case thus contributed to 'delimitating' the applicability of competition law principles.

\section{1999, 2000, 2001 - Case Institute of Professional Representatives before the European Patent Office (EPI)}

The same year that the Commission adopted the COAPI decision it statted formal proceedings against a code of conduct adopted by the Institute of professional representatives before the European Patent Office (EPI). According to that code the members, i.e. all European patent representatives, were both prohibited from individual advertising and required to charge reasonable fees. After the Commission's statement of objections the EPI amended and notified its code of conduct several times under Regulation $17^{193}$ to retain only some form of prohibiting comparative advertising. The Commission finally granted an individual exemption under Atticle 81(3) EC for a transitional time period. ${ }^{194}$ This was the first and also last time that an individual exemption was granted under Article 81(3) EC for tules governing a profession.

190 See paras. 41 to 43 of the decision. For details see Chapter 4.II.2.1. See also AG Léger in Case C-35/99, Manuele Arduino, [2002], para. 47.

191 Case T-84/94, Bundesverband der Bilanzbucbhalter e.V.v Commission, [1995]; Case C-107/95P, Bundesverband der Bilanzbucbhalter e.V. $\nu$ Commission, [1997].

${ }_{192}$ Case T-84/94, Bundesverband der Bilangbuchbalter e.V. v Commission, [1995], para. 27.

193 Before modernisation, Council Regulation No. 17 of 10.02.1962, First Regulation implementing Articles 85 and 86 of the Treaty (now Arts. 81 and 82 EC).

194 Commission Decision EPI Code of Conduct, (1999). The petiod ran until the date on which Directive 97/55 on misleading advertising had to be transposed by the Member States, 23.04.2000. Since the Commission's decision was also relevant in terms of the EEA Agreement, the exemption was also based on and Article 53(3) of the EEA Agreement. For details on Article 81(3) EC sec Chapter 7.I. 
The factual background to the case is noteworthy in that it concerned a 'European profession' that - rather than being subject to national rules - is regulated by rules adopted under the auspice of an intergovernmental organisation. The professional body EPI was set up by the Administrative Council of the European Patent Organisation. ${ }^{195}$ The Administrative Council had adopted regulations according to which the EPI was granted, first, regulatory powers on the conduct of professional representatives, and second, disciplinary powers over its members. The relation between the Administrative Council and the EPI were such that the formet could not amend or repeal any rules of conduct ('code') that the EPI adopted. The Administrative Council could exercise its supervisory powers only through changing the legal basis on which the EPI was established and adopted its rules of conduct. ${ }^{196}$ The intergovernmental level of the organisation had little influence on the legal assessment of this regulatory relationship under competition law. Similarly as in COAPI the Commission found that the EPI had to assume its own tesponsibility for using its regulatory powers despite the fact that a public authority ${ }^{197}$ had delegated those powers. This statement built on preexisting case law of the Court. ${ }^{198}$

The decision is remarkable for the Commission's standard to test the (potentially) competition restrictive character of the various rules contained in the EPI code of conduct, and the consequences thereof for the bifurcated character of Article $81 \mathrm{EC}$ (i.e. containing a prohibition clause in paragraph 1 and an exemption clause in paragraph 3 ). In order to decide whether or not certain rules on professional conduct restrict competition the Commission broadened the standard normally applied within the prohibition clause of Article 81(1) EC, according to which an economic assessment of an agreement or decision is required in its factual and legal circumstances. ${ }^{199}$ Exceeding a purely economic assessment of the effects that the EPI rules of conduct had on competition, the Commission embraced considerations that refer to "the specific characteristics of the profession in question and the rules governing it". ${ }^{200}$ In particular the Commission recognised that professional "duties of competence, impartiality, integrity and responsibility and to avoid conflicts of interest, maintain professional secrecy and not to engage in misleading advertising [...] must be deemed legitimate and consistent with the ethics of the profession". Once the mentioned characteristics of the profession were established, the Commission proceeded to a scrutiny of whether a certain professional rule is necessary to guarantee one of the legitimate objectives, despite its restrictive character. In the reasoning of the Commission a certain rule restricting professional conduct thus can be justified, and will therefore not be liable to restrict competition in the first place. "Even if in other circumstances it might constitute a restriction of competition to prohibit [for instance] fees from being determined according to outcome, that prohibition is necessary in the economic and legal context specific to the profession in question in order to guarantee impartiality on the part of the representatives and to ensure the proper functioning of the [European Patent Office]. A prohibition of this nature should therefore not be covered by [Article 81(1) EC]" if applied objectively and

195 Which in turn was set up under the European Patent Convention of 1973.

196 Case T-144/99, EPI, [2001], para. 13.

197 I.e. the Administrative Council of the European Patent Organisation composed of representatives of the contracting States

${ }_{198}$ Case 13/77, INNO v ATAB, [1977], paras. 30-34; Case 123/83, BNIC v Clair, [1985], para. 17.

199 For details see Chapter 4.ПI.1.2.

200 Para. 34 of the Commission decision in EPI code of conduct. 
without discrimination. ${ }^{201}$

With the standard introduced in this decision the Commission allows to take account of particular aspects of the ethics of a profession, and thereby seems to acknowledge sectorspecific rather than economic considerations. The remarkable point here is that the Commission did so within the prohibition clause of Article 81(1) EC rather than incorporating these considerations within the scope of the third paragraph of Article $81 \mathrm{EC}$, and despite the fact that at the time the Commission still had the sole competence to grant an individual exemption under Article 81(3) EC. Only in respect of other restrictions ascertained in EPI did the Commission make use of these powers. The ensuing tension between the prohibition clause and the exemption clause of Article 81 EC provokes the question whether the non-commercial but sector-specific considerations are genuinely not suitable for an application of Article 81(3) EC. ${ }^{202}$ It is noteworthy, however, that the Commission did not accept to apply the new standard across the board. In the same decision it refused the argument of the EPI that the rules prohibiting comparative advertising and the supply of unsolicited scrvices would have been necessary for the profession's reputation. This time the Commission indeed engaged in an economic assessment of the effects of the prohibitions by stating that providing information to the consumers and comparative advertising are important elements of the competitive process, which make it easiet for new opetators to establish themselves on the market, and which stimulate innovation in the means of providing services. It therefore came to the conclusion that the prohibitions restricted the ability of more efficient representatives to develop their services to the detriment of less efficient representatives.

On appeal the CFI partly upheld and partly quashed the Commission's decision. ${ }^{203}$ First of all, the Court emphasised that tules organising the exetcise of a profession, as a matter of principle, do not fall outside the scope of Article 81(1) EC merely because they are classified as rules of professional conduct by the competent authorities. Moreover, the fact that rules on professional conduct pursue an aim in the general interest in a Member State does not impair the general applicability of competition $\operatorname{law}^{204}$, even where the general interest considerations may lead to the conclusion that the same professional rules do not infringe the principles of freedoms of establishment and to provide services under Articles 43 and 49 EC.

Secondly, the Court found that the Commission had misinterpreted the scope and meaning of two of the contested rules of the EPI code of conduct and had mis-assessed theit capacity to restrict competition. The interesting part of the judgment relates to the Commission's approach to take sector-specific but non-commercial considerations into account in order to exclude certain professional rules from falling within the scope of the prohibition clause of Article 81(1) EC. The CFI indirectly approved of this apptoach where such rules are "objectively necessary in order to preserve the dignity and rules of conduct of the profession concerned". ${ }^{205}$ What the ruling does not make entirely clear is whether certain rules of professional conduct do not restrict competition - and for that reason fall

201 Paras. 35, 38 of the Commission decision in EPI Code of Conduct. Three years later the Court in Wouters adopted a similar line of reasoning. For details on price regulation see Chapter 4.II.2.

${ }^{202}$ For details see Chapter 4.I.2.5. and Chapter 7.I.

${ }^{203}$ Case T-144/99, EPI, [2001]. The application for interim relief to suspend the Commission's decision was dismissed, Case T-144/99 R, EPI-interim relief, [2000].

204 Para. 66 of the judgment in EPI.

205 Para. 78 of the judgment in EPI. See also paras. $28 \mathrm{ff}$. of Commission decision in EPI Code of Conduct. 
outside the scope of Article 81(1) EC - or whether such rules fall outside the scope of the competition prohibition despite their character restrictive of competition. The emphasis of the CFI on the general applicability of the competition rules to professional tegulations may suggest the latter alternative. However, imposing a principle according to which anticompetitive regulations may be immune from the competition prohibition on the basis of sector-specific considerations tisks to undermine the bifurcated character of Article $81 \mathrm{EC}$. It may effectively lead to a discrimination in respect of other sectors and industries. ${ }^{206}$ To a certain extent, the issue was taken up eleven months later by the ECJ in its ruling in Wouters summarised below.

Regardless, EPI Code of Conduct is also an illustration of the bifurcated chatacter of Article 81 EC. In accordance with Article 81(3) EC the Commission had granted an individual exemption. With regatd to the EPI rule prohibiting any form of comparative advertisement the CFI upheld the Commission's finding of a restriction of competition. The Court also approved of the limited duration of the exemption gtanted. The Commission's granting of the exemption was mainly motivated by the otherwise conceivable damage that an abrupt lift of the longstanding and extensive prohibitions would have on the public ${ }^{207}$ and, consequently, on the administration of justice. ${ }^{208}$ Curiously, this motivation for granting the individual exemption under Article 81(3) EC thereby took account of the reputation of the profession, an argument that the Commission had refused to accept when assessing the anticompetitive character of the advertisement restrictions imposed by EPI. This book will scrutinise the disctepancy between the recognition of non-commercial reasons that, on the one hand, may make professional regulations fall outside the scope of the competition prohibition altogether and, on the other, may motivate an exemption under Article 81(3) EC or even under Article 86(2) EC. ${ }^{209}$

\section{2000 - Case Pavlov}

The CNSD trilogy did not provide the occasion to explicitly address the question of whether Member States could be found to infringe their obligations under Articles 10(2) and 3(1) (g) EC (i.e. not to render ineffective the application of the competition rules in their application to undertakings) in the absence of an actual restrictive conduct on the part of the professionals or their representative bodies. The occasion presented itself two years after CNSD II in respect of another professions case in Pavlov. ${ }^{210}$

The background to Pavlov forms an occupational pension scheme that the Dutch medical specialists' representative body set up on the basis of State legislation. In accordance with those rules the professional association applied to the public authorities to make membership to the pension scheme compulsory for all members of the particular profession. The tension evoked in Pavlov between competition law and professional regulation concerned in particular the relationship between the responsibilities of a self-regulatory professional body and those of the State authorities for measures restricting competition under Article 81(1) EC.

206 For details see Chapter 4.I.2.5. and 4.II.4.2.2.

207 An abrupt lift of the prohibitions of comparative advertising could possibly have led to confusion in the mind of the public about the legitimacy of the behaviour of the profession.

208 Damage could have resulted from the - altered - image that professionals give to institutions participating in the administration of justice, i.e. the European Patent Office.

209 For details see Chapter 3.I.2., Chapter 4.I.2. and Chapter 7.

210 Joined Cases C-180 to 184/98, Pavlov, [2000]. 
The Court decided that attributing a testriction of competition to a Member State under Article 10(2) EC necessarily depends on the anti-competitive character of decisions taken by the professional association. In the view of the Court, the measures adopted by the professional association to first set up the pension fund and subsequently apply to the public authorities for making affiliation to the fund compulsory, did not appreciably restrict competition and thus not fulfil one of the elcments of Article 81(1) EC. Therefore, in the view of the Court, there was no basis to attribute any anti-competitive effects to the responsibility of the Member State. The Court therefore decided that the decision by the Member State to make membership to the pension fund compulsory for all members of the profession was not contrary to Article 10(2) EC in conjunction with Article 81(1) EC. ${ }^{211}$ Advocate General Jacobs criticised the Court, however, for establishing an automatic link between the legality of private conduct and a Member State measure. ${ }^{212}$

A part from this matter of principle Pavlov further contributes to a consolidation of earlier case law in that it clarifies several points on the application of competition law to the liberal professions. First of all, the Court made clear that the application of the competition rules does not depend on the nature or declared purpose of a code of conduct. Moreover, the Court made clear that medical specialists exercise an economic activity and that, consequently, their professional association must be considered an 'association of undertakings' within the meaning of Article 81(1) EC. The Court confirmed that the legal framework in which the association operates and takes its decisions is irrelevant for the applicability of the Community rules on competition. ${ }^{213}$ The Court also confitmed its case law with regard to the composition of the association. It found that the medical specialists body did not fall outside the scope of Atticle 81(1) EC as it had not been composed of a majority of independent representatives and was not required to observe various public interest criteria in taking a decision. ${ }^{214}$

\section{2001 - Case Giuseppe Conte v Stefania Rossi}

Also Conte $v$ Ross ${ }^{215}$ raised the question on the comparability of national legislation with Article $10 \mathrm{EC}$ in respect of Article $81 \mathrm{EC}$. The case contributes a detail to the issue on the respective responsibilities assumed by Member States authorities and professional associations in the procedure for setting professional regulation. The case was about tariffs for services provided by engineers and architects. In principle a compulsory tariff scheme applied, which the minister for justice had adopted for certain services on a proposal from the national councils of engineers and architects. Member State Rossi had initiated proceedings against $\mathrm{Mr}$ Conte, her client, for recovering the expenses for her services. The services she had provided to $\mathrm{Mr}$ Conte were, however, not covered by the compulsory tariff scheme. Notwithstanding, the competent professional association had been involved in the fee setting of Member State Rossi. In accordance with the Italian Code of Civil Procedure

211 Para. 100 of the judgment in Pavlov.

212 AG Jacobs in Joined Cases C-180-184/98, Pavlov, [2000], paras. $161 \mathrm{ff}$. See also Case C-2/91, Meng, [1993], and Case C-245/91, Obra [1993], requiring that to test the responsibility of a Member State for anti-competitive effects of regulations, they must be linked "with conduct on the part of undertakings of the kind referred to in [Article 81(1) EC]". In Pavlov the Court did not explicitly refer to this earlier case law, thus not responding to AG Jacob's critique. See also Case C-266/96, Corsica Ferries II France, [1998], para. 51. For details see Chapter 6.

213 See already CNSD and COAPI.

214 For details see Chapter 4.I.2.2.

215 Case C-221/99, Conte $v$ Rossi, [2001]. 
Member State Rossi had her invoice endorsed by the opinion of the competent lucal association of architects. Under national law the national court deciding on her claim finally was bound by that opinion when adjudicating on the amount of her professional fees. ${ }^{214}$

While the professional assmciation had taken a cettain tole both in setting the individual fees and during the judicial procedinge for tecovering of Member State Rossi's expenses, the EC.J made clear that a Member State does not engage its resprinsibility under Article 10(2) $\mathrm{EC}$ (in conjunction with Article 81 (1) $\mathrm{FC}$, where the fees due are specified on an individual basis and apply inter partes only, rather than being subject to an compulsury tariff. 'Thus, the $\mathrm{EC}$. J dismissed the argument that the opinion of the professional association had an effect on competition since it did not have a general application to the group of professionals. 'The Court therewith reiected that the opinion issued by the professional body would constituted a decision of an association of undertakings in the sense of Article $81(1)$ lic.

\section{2001 .. Case Ambulanz Cibockner}

The Clockner case concerned the operation of ambulance transport services in Germany, which is subject to public law regulation and licensing tequirements. ${ }^{217}$ While the operation of ambulance transport services is not itself an activity of medical practitioners, the Clockener case is of interest for present purposes as it concerned services connected with the maintenance of the medical care system. 'I'his maintenance could serve as an argument to exclude from the jurisdictional ambit of competition law activities that are connected therewith as the organisation of ambulance services is sensible for a good functioning of a medical care system. However, the Court finally did not decide to do so. The case therewith may be the basis to challenge earlier case law limiting the jurisdictional scope of $\mathrm{EC}$ competition law ratione personal. ${ }^{218}$

\section{2002 - Case Wouters et al. v NOnA}

The judgment in Wouters received much attention for its unorthodox backing of selfregulatory professional rules banning multi-disciplinary partnerships between lawyers and accountants in the Netherlands. The Dutch association of lawyers (Nederlandse Orde van Advocaten, NOvA) had adopted rules according to which members of the lawyers' association are allowed to set up "professional partnerships ${ }^{219}$ only - if not with other lawyers - with "members of another professional category accredited for that purpose by the General Council" of the NOvA. For that purpose the NOvA distinguishes sharply and so far strictly refuses accountants. ${ }^{220}$ The $\mathrm{NO}$ vA derives its powers to issue regulations from parliamentary

216 Articles $636 \mathrm{ff}$. of the Italian Code of Civil Procedure.

217 Case C.475/99, Glockener, [2001].

218 For details see Chapter 3.1.2.2.2.2.

219 l.e. fully integrated partnerships where the members, under a collec tive name, share their revenues, or carry on their common practice in an integrated way (1.e. sharing control or final responsibility with each other); Article 1.b, 7 and 8 Samonverkingsverordening 1993; Mernori van Toelichting Adv.bl. 1993, bijl. bij nr. 20.

23 Until now the NOYA recognised the Royal Notarial Association, the Netherlands Order of T'ax Consultants and the Order of Patent Agents. While there are no restrictions in the Netherlands as to the professions with which a lawyer can enter into a partnership, i.e. no numerks clansws, the 1993 Samenwerkingsverordening imposses persinal criteria un members of other professions before they will be admitted to start a multi-disciplinary partnership with lawyers. In conformity with the provisions of Article 6 of the 1993 Regulation multi-disciplinary 
legislation (Article 28 of the Advocatenwet). ${ }^{221}$ The regulations drafted by the NOvA are communicated to the ministry of justice and published in the official journal. Atticle 30 of the Advocatenwet specifies that the minister has the power to suspended or annulled draft regulations by royal decree only in so far as they are contrary to law or the public interest, but the minister has no powers to amend a draft.

$\mathrm{Mr}$ Wouters and Mr Savelbergh, both members of the NOvA, respectively had (intended to) set up a co-operation with tax consultants in the Netherlands who in turn were members of, respectively, Artbur Anderson \& Co., advocaten en belastingadviseurs and Price Waterbouse Belastingadviseurs $B V .{ }^{222}$ The particulatity of the case is that the NOvA prohibited the partnerships as contrary to Article 4 of the Samenwerkingsverordening 1993 despite the fact that the envisaged partners of both $\mathrm{Mr}$ Wouters and $\mathrm{Mr}$ Savelbergh were tax consultants in the Netherlands working for a tax consultants bureau. Thus, they were members of a profession that the NOvA recognises to be compatible with the essential characteristics of the lawyer's profession. The question is which motives made the NOvA prohibit the respective projects of $\mathrm{Mr}$ Wouters and $\mathrm{Mr}$ Savelbergh. The reason for the non-compatibility lay in the structure of Arthur Andersen and Price Waterhouse. ${ }^{223}$

The judgment mainly concerned two legal issues. First of all the Court seized the opportunity to give a clear decision on the anti-competitive character of rules set by a professional body that are adopted in the exercise of its regulatory powers under the national legislation and intended to bind its members in the exercise of their profession. At the same time, however and secondly, the ECJ enunciated that certain professional rules do not fall under the cartel prohibition of the Treaty where such rules appear to be necessaty for the 'proper practice' of the profession concerned. The Court's decision to salvage the Dutch tules thereby seems to be motivated by one of the traditional characteristics of the liberal

practices may be granted recognition under the following cumulative conditions. The requirements are imposed in order to maintain the essential characteristics of the legal profession. The requirements are strict as cach partner of the envisaged multi-disciplinary partnership has to fulfil these personal criteria:

1. the members of the other professional category are practitioners of a liberal profession (which is an arbitrary criterion, see above on the origins of the liberal professions and Chapter 1.I.2.);

2. the exercise of that profession requires a university or equivalent education;

3. the members of that professional category are subject to disciplinary rules comparable to those applicable to lawyers; and

4. enteting into a partnership with members of such other professional category would not conflict with the provisions of Articles 2 and 3 of the 1993 Samenverkingsverordening on the safeguard of the free and independent practice of the lawyers.

${ }_{221} \Lambda$ dvocatenwet (as amended on 02.02.1989) (Lawyers Act) (1952). The NOvA was established under the Advocatenwet that lays down also the internal regulations.

${ }_{222}$ Belastingadviseurs are tax consultants. At the time both companies formed part of the so-called Big Five.

${ }^{223}$ At the time Arthur Andersen \& Co., was a co-operative company and established in Geneva that had Member Firm Interfirm Agreements (MFIAs) with the different branches of Arthur Andersen, amongst others with Arthur Andersen Accountants in the Netherlands. The NOvA considered these MFIAs to form a network such where all the participating member firms share the responsibility and power of decision, especially where it concerns the use of a common name, to have a common management and financial agteements. This assessment was reinforced by the advertisement activities of one of the plaintiffs. From these facts the supervisory board of Rotterdam found, by decision of $27 \mathrm{July} 1995$, that $\mathrm{Mr}$ Wouters by associating with $A$ ABelastingadisiseurs also established a prohibited collaboration relationship with $A A$ Accountants in the sense of the 1993 Regulation. As to $\mathrm{Mr}$ Savelbergh and Price Waterhouse, the Council of Supervision of Amsterdam by decision of 5 July 1995 found that Price Waterbouse Belastingadviseurs BV is a subsidiary of the international undertaking Price Waterhouse including both tax consultants and accountants. On appeal the orders were upheld until the Raad van State referred the issue under Article $234 \mathrm{EC}$ to the ECJ for a preliminary ruling. 
professions, namely that in exercising their activities they serve society at large.

In legal terms the intriguing point of the judgment is, however, not so much the Court's willingness to salvage the NOvA rules from the nullity sanction of Article 81(2) EC; it is the method by which the Court came to this tesult. In fact, as of paragraph 97 of the judgment the Court effectively adopted a legal solution extraneous to EC competition law, as will be explained more in detail in Chapter 4.II.4. The salvaging of the NOvA rules was not based on one of the existing exemption mechanisms particular to EC competition law and provided for by the Treaty, i.e. Article 81(3) EC or Article 86(2) EC. Instead the Court seemed to have paved a new justification path into EC competition law, which - some say recalls the Court's case law in the field of the internal market free movement rights with its mandatory requirements doctrine. ${ }^{224}$ It has been observed by others that the relevant part of the Wouters judgment reads like a dissenting opinion. ${ }^{225}$ This book challenges the appropriateness of the approach adopted in Wouters in respect of EC competition law and uses the expression 'Wouters proviso' as shorthand for identifying paragraphs 97 to 110 of the judgment. While the judgment in Wouters bears out many sensible conclusions for the application of competition law in the field of the professions, the legal stringency of its arguments with regard to the justification of tules testricting competition can be challenged from a systematic point of view. It is therefore that the judgment has not been given a central position in this thesis, but that an independent approach has been chosen. In particular Chapter 7 will turn to the question whether and to what extent the professionspecific considerations accepted by the Court in Wouters may be fitted into the existing systematics of EC competition law to reflect the structure and broad logic of the Treaty provisions.

In particular, to establishing the $W$ outers proviso within the fabric of the first paragraph of Article $81 \mathrm{EC}$ does not seem to square with the bifurcated pattern of rule and derogation of the article as a whole. ${ }^{226}$ Nothing in the wording of Article $81 \mathrm{EC}$, or in the implementing legislation, suggests the possibility for an exception to the applicability of Article 81(1) EC - except for cases of course that do not fulfill the criteria of the scope of that first paragraph in the first place. Conversely, where one discards the systematic or structural argument on the relationship between Article 81(1) and (3) EC - the latter being the derogation to the rule of the former - this entails allowing considerations outside the strict requirements of Article 81(1) EC.

On the one hand, the Wouters case may be understood to contribute to a nascent line of case law according to which EC law would not preclude rules that ate necessarily inherent to the exercise of a particular activity and thus ate accepted not to infringe neither of the Treaty obligations teferting to the free movement rules or the competition tules. ${ }^{227}$ If indeed nascent this line of case law would actually match the view of the Commission expressed in EPI Code of Conduct, namely that 'genuine deontological rules', i.e. 'rules inherent to a particular profession' and reflecting the 'essential character of a profession', should not come

\footnotetext{
224 According to that doctrine State measures impairing the free movement rights may be justified if they are not (directly) discriminating on the basis of nationality or origin and are adopted for an overriding reason of public or general interest (also mandatory requirements) that they protect in a proportionate way.

${ }^{225}$ van de Gronden J.W. / Mortelmans K.J.M., (2002), para. 14. The relevant part are paras. 97-110 of the judgment.

${ }_{226}$ See also diagram no. 7 in Chapter 7.I.

${ }_{227}$ See for instance, Joined Cases C-51/96 and C-191/97, Deliège, [2000], particularly para. 64. See also Case T313/02, Meca-Medina I, [2004], para. 42, referencing the Wouters proviso.
} 
within the ambit of Article 81, first paragraph, EC.

On the other hand, the fact that the modetnised enforcement system of Regulation $1 / 2003$ is applicable only since May 2004 may put a new complexion on the Wouters judgment. As the case had been decided two years before that date, one may claim that the Court had been caught in a quandary in which it was not (yet) competent to apply the third paragraph of Article $81 \mathrm{EC}$ and in which the NOvA rules had been notified far too late to the Commission to apply for the grant of an individual exemption under that provision. Accepting, however, that the restrictive NOvA rules express concern for values 'necessary for the proper functioning' of the profession (c.g. its integrity and independence), the Court came to the conclusion that the rules did not fall under the prohibition of Article 81(1) EC - irrespective of the fact that the rules do come within the article's scope. In fact, had the Court decided that the disputed national rules would indeed fall foul of Article 81(1) EC, the consequence at the time would inevitably have been that of Article 81(2) EC: the nullity of the NOvA rules. Hence, one could actually claim that the Court found an elegant exit to the dilemma allowing it to keep the apparent boundaries of Article $81 \mathrm{EC}$. The validity of this view is challenged in Chapter 4.II.4. where an alternative solution to the Wouters proviso will be proposed.

\section{2002 - Case Arduino}

Arduino was decided the same day as Wouters. Here, the Court was confronted with Italian legislation that imposes a compulsory tariff scheme for legal services provided by members of the Bat in respect of civil and criminal procedures and out-of-court work. ${ }^{228}$ The rather brief judgment in Arduino is important for the question on the responsibility of a Member State in regulating the professions. The particulat circumstances that gave rise to the reference for the preliminary ruling concerned the amount of legal fees that Mr Arduino was ordered to pay in compensation for Mr Dessi's expenses against him on the basis that Mr Arduino had damaged Mr Dessi in a toad accident. Under the national law the professional association of lawyers (Consiglio Nazionale forense, $\mathrm{CNF}$ ) adopted minimum and maximum tariffs every two years and submitted them for approval to the minister of justice. The CNF has to base its draft on ctiteria of the monetary value of disputes, the level of the court seized and, in criminal matters, the duration of the proceedings. In the process of approving the draft tariff the minister has to obtain two opinions, one of the inter-ministerial committee on prices (Comitato interministeriale dei prezzi, CIP) and the Council of State. Once the tariff scheme is approved and applicable, a national court seized to settle the fees in a particular case is bound to remain within the maximum and minimum limits thus established. The reference for a preliminary ruling was triggered because of conflicting national case law on whether the tariff scheme constitutes a restriction of competition contrary to EC competition law.

The importance of this case lies with the development that the Court gave to the interpretation of the Van Eycke standard, according to which a Member State infringes Article 10(2) EC in respect of Article 81(1) EC if it "requires or favours the adoption of agreements, decisions or concerted practices contrary to [Article $81 \mathrm{EC}$ ] or reinforces their effects, or where it divests its own rules of the character of legislation by delegating to private economic operators responsibility for taking decisions affecting the economic

228 Case C-35/99, Manuele Arduino, [2002]. 
sphere" ${ }^{229}$ On the facts the case is quite similar to CNSD II on the Italian customs officers summarised above. However and differently from the CNSD II case, the Court in Arduino concluded that Italy had not infringed its obligations to respect the effectiveness of the competition rules applicable to undertakings. The Court reached this conclusion by emphasising the powers that the national legislation granted the State authorities to exercise control over the content of the tariff scheme. The fact that the CNF is an association representing the economic interests of its members and that a State measure required it to adopt a price fixing schedule could not tip the balance to find Italy responsible for the resulting restriction of competition.

While the Court did not assess whether the CNF qualified as an association of undertakings in the sense of Article 81(1) EC, and whether the draft tariff it adopted actually restricted competition, this omission does not imply a reversal of the case law exemplified in Pavlov, which requires a link between the legality of a private behaviour and a Member State's measure. On the basis of earlier case law it was clear that the establishment of minimum and maximum fees by a professional association comes within the ambit of Article 81(1) EC, and the Court probably did not feel the need to elaborate thereupon. From a theoretical point of view it would have been interesting to see whether the CNF could have been hold responsible for an infringement of competition law independently of the question on the responsibility of the Member State. However and differently from CNSD III, this point did not need to be addressed by the Court since the reference for a preliminary ruling was restricted to the question of the validity of the domestic legislation that was at the basis of the lawyer's fee, and which Mr Arduino was ordered to compensate.

\section{2004 - Case Belgian Arcbitects}

The Belgian Arcbitects case is the most recent decision that the Commission has taken in the field of professional regulations. ${ }^{230}$ Within the regulatory powers provided for in the national law the national council of the Belgian architects' association had adopted a minimum fee scale. The Commission found that the association had infringed Article 81(1) EC and imposed a fine of $€ 100.000{ }^{231}$ The decision particularly focuses on the question of whether the national council as an association of undertakings had adopted a decision that restricted competition, and the Commission used the case to reinforce the application of competition law to the liberal professions as a matter of principle. ${ }^{232}$

229 For details see Chapter 6.

230 Commission Decision Belgian arcbitects, (2004).

231 The Commission considered the infringement to be a serious one because of the extended application for 35 years. It intended to increase the amount by $10 \%$ per year that the restriction had been operated, resulting in a basic amount of $€ 4.5$ million. On the other hand, the Commission accepted attenuating circumstance in exercising its discretion regarding the setting of fines. It accepted that it was plausible that there had been reasonable doubt on the part of the association as to whether its fee scale did indeed constitute an infringement - at least until the Commission adopted its 1993 CNSD decision prohibiting the fixed fee scale of the Italian customs agents. Moreover, the Commission also deemed it appropriate to take into account the fact that it had not imposed a fine for the fixed fee scale of Italian customs agents in its 1993 CNSD decision, and had imposed only a symbolic fine of $€ 1000$ for the circulation of recommended tariffs of the association of Dutch forwarding agents, Commission Decision Fenex, (1996).

${ }_{232}$ This fact becomes clear from the reasoning of the decision taking elaborate account of the interpretation that the Court has given to the requirements of Article 81(1) EC. Morcover, the Commission kept on pursuing the case despite the fact that the National Council had withdrawn the contested provisions after the Commission had notified its statement of objections to the association in 2003. Moreover, at para. 137 of the decision the 
The contentious minimum fee scale was adopted on the basis of a series of rules. The national law ${ }^{233}$ provided for the national council to adopt a code of ethics, which was approved by royal order. This code of ethics provided for the setting of minimum fee scales by means of standards. The fee scales finally adopted and subsequently amended by the national council had never been approved of by the competent minister ${ }^{234}$ who actually had refused to turn it into a royal decree. The fee scale was intended to cover all architectural services provided by the association's members regardless of whether the intervention of an architect was required by the law in the process of a project. The scale linked the architect's fees to the cost of building work but did not relate to the costs actually incurted by the architect. 235

The Commission made clear that there was not sufficient evidence in the State rules to exclude the responsibility of the association for the authorship of the restrictive rules. In particular the Commission seized the opportunity to distinguish the case from Arduino, underlining that the application and coming into force of the fee scale did not depend on the (denied) approval of the competent minister, and therefore was not a mere prepatatory act to a State measure. The Commission understood the regulatory framework in a way that it did not tequire the association to adopt the minimum fee scales, but left a significant margin of discretion to the association as to whether and how to draft the tariff scheme, and thus adopting a conduct autonomous of the State rules. The Commission did not consider whether Belgium could be tesponsible for the restriction of competition for providing the legal basis on which the code of conduct and the minimum fee scales had finally been adopted by the ptofessional association. ${ }^{236}$

Moreover, the Commission indirectly seized the opportunity to emphasise which kind of (price) information a professional association may circulate to the members of the profession. It appears that a descriptive codification of existing rules and practices or usages followed on the market would not be considered an independent decision of the association. ${ }^{237}$ This embodies the opinion expressed by the Commission elsewhere in the decision that, under certain circumstance, the reference to historical price information may be legitimate. ${ }^{238}$ On the overall, however, the Commission came to the conclusion that the association's measures hamper price competition amongst architects. In particular the instructions given by the association have the effect of diverting the undertakings from taking direct account of their own costs when they individually determine their prices or

Commission made an explicit reference to its policy, set out in its report of 9 February 2004, which "is to encourage the national regulatory authorities and professional bodies to revise and amend their restrictive rules, and give them the opportunity to do so." European Commission, Report on Competition in Professional Services, of 09.02.04. See also the 2004Reporton Competition Policy, para. 80, <http://europa.eu.int/comm/competition/ annual_reports $/>$.

233 Articles 37 and 38 of the Act of 26 June 1963 establishing an Architects' Association.

234 Minister for Small and Medium-sized Enterprises, the Professions and the Self-employed.

235 The cost of the work only has an influence on the architect's costs in that it is a determining factor in the insurance premium to be paid by the architect.

236 It was the 1985 Code of Ethics that provided in its Article 12 that "... The National Council shall set the minimum fee scales by means of standards made binding in accordance with Article 3...."Article 3 stipulated that the Code of Ethics "... may be clarified by means of binding rules approved by Royal Order discussed in Cabinet, on a proposal from the National Council of Association, or by means of recommendations issued by the National Council of the Association." (Emphasis added.)

237 Paras. 55 ff. of the Commission decision.

238 See paras. 87, 99, 110 of the Commission decision. 
fees. ${ }^{239}$ The case was aggravated by the fact that the minimum fee scalc was being applied in disciplinary cases.

The Commission furthermore seized the opportunity to clarify that for minimum scales no argument can be accepted that would justify them as inherently necessary for the proper practice of the ptofession. ${ }^{240}$ The Commission took the view that minimum fees are not indispensable to safeguard quality because they do not prevent unscrupulous architects from offering poor quality. ${ }^{241}$

\section{2005 - Case Piau v Commission (FIFA)}

The case Piau so far is a unique specimen in that it concerned not only the application of Article $81 \mathrm{EC}$, but also of Article $82 \mathrm{EC}$ in the field of professional tegulation. The background to the case was a complaint to the Commission by Mr Piau against rules adopted by the Fédération internationale de football association (FIFA), which is located in Switzerland. Mr Piau wanted to carry out the occupation of football players' agent. ${ }^{242} \mathrm{He}$ complaint that certain regulations of the FIFA were too restrictively regulating the activities of players' agents, and in fact infringed Articles 81 and $82 \mathrm{EC}$. In order to place football playets the FIFA requires agents to possess a specific licence that is issued exclusively by the FIFA through one of its members, i.e. through national associations that group amateur and professional football clubs.

These standards of the FIFA Players' Agents Regulations were the result of amendments after Mr Piau had complaint to the Commission. The previous regulations had been the object of a statement of objections by the Commission and addressed to the FIFA in accotdance with Regulation 17 . In the statement of objections the Commission had mainly criticised the FIFA's powers to sanction clubs and players that were using the services of non-licensed agents, the ban on corporate firms to be licensed as players' agents, and the mandatory payment of a non-returnable bank guarantee of CHF 200,000 (approximately $€ 136,000$ at the time). While the FIFA in the following substantially reviewed only the latter aspect, it managed to reach a compromise with the Commission, according to which the FIFA committed to base the relevant tules on objective and transparent criteria. ${ }^{243}$ In consequence thereof the Commission subsequently rejected Mr Piau's complaint for lack of a continued Community in terest in upholding the procedure. ${ }^{244}$

Mt Piau brought the case before the CFI who considered the applicability of both Articles 81 and 82 EC. ${ }^{245}$ For the purpose of Article $82 \mathrm{EC}$ the CFI recognised that national

239 Despite the fact that price regulation generally is considered to constitute a so-called hard-core restriction that, in principle, inevitably has the object of restricting competition, the Commission carcfully examines the terms of the fee scale, the legal and economic context, and the conduct of the association to conclude on the restriction of competition.

240 See also EPI Code of Conduct and Wouters.

241 For details see Chapter 4.II.2.1. and above the text with note 105.

242 They effectively function like 'private employment agencies', and their use has become more widespread after the judgment in Case C-415/93, Bosman, [1995]. Although the occupation of sport agent has become more professional in recent years, a somewhat stained reputation of sports agents persists due to incidents of fraud, excessive fees and the abuse of young players. Regulation of the profession of players' agents by various actors in the international football world have tried to remedy and prevent professional misconduct.

243 See European Parliament's Committee on Internal Market and Consumer Protection, et al, Professional Sport in the Intemal Market (commissioned by the European Parliament), of 09/2005, $46 \mathrm{ff}$.

241 Commission Decision Piau, (2002).

245 Case T-193/02, Piau I, [2005]. 
football associations and their sport clubs, as organised within the FIFA, occupy a collective dominant position. Therefore the FIFA itself was considered to be covered by that article despite the fact that it does not itself engage in an economic activity. In particular the CFI stated that the FIFA can be regarded as the 'emanation' of its members due to their affiliation to the FIFA and the binding character of the regulations adopted by the latter. ${ }^{246}$ The CFI held that it is irrelevant that the FIFA is not itself an economic operator on the relevant market, since it operates on that market through its members (i.e. the national associations and the football clubs) as their emanation. ${ }^{247}$ The case was upheld by the ECJ on appeal. ${ }^{248}$

\section{2005 - Case Mauri v Ministero della Giustizia}

Mr Mauri was aspiring to become an advocate in Italy but had failed the written part of the necessary State examination. The assessment of his written test had been done by a State examination committee composed of five members appointed by the minister of justice (two judges, a professor of law and two advocates). Under the relevant Italian legislation the national Bat association (Consiglio nazionale forense, $\mathrm{CNF}$ ) nominates the two advocates who are appointed as president and vice-president to the State examination committee. Mr Mauri claimed that the rule on the composition of the committee did not allow an impartial assessment, and that the influence of the CNF on the composition of the examination committee resulted not only in a qualitative but also a quantitative selection of candidates linked to market imperatives.

The case ${ }^{249}$ provided the Court with an opportunity to reiterate the principles it had developed with regard to the Member States' duty under Articles 10(2) EC not to obstruct the effectiveness of the competition rules. In particular, the Court confirmed the interpretation it had given to the Van Eycke rule in Arduino with regard to the supervisory role assumed by public authorities in the process of adopting professional regulation. The Court felt that Italy had "not given up the exercise of its powers in favour of private economic operators", and in particular had "[not] divested its own rules on access to the profession of advocate of the character of legislation" and thus not been "delegating to advocates responsibility for taking decision concerning access to their profession".

\section{2006 - Case Servizi Ausiliari Dottori Commercialisti v Giuseppe Calafiori}

The case Calafion ${ }^{250}$ concerned Italian legislation on tax advice services usually provided by professionals like lawyers and accountants. The legislation in this case has been such to reserve the right to provide certain types of tax advice to a single category of operators. At the same time the legislation denies other economic operators in the sector who are

${ }^{246}$ See paras. 69-72 of the judgment where the CFI qualifies the FIFA as an association of undertakings. It defines the sporting clubs as 'undertakings' (for which the practice of sport is an economic activity), the national associations grouping the clubs as 'associations of undertakings' (which in turn carry out an economic activity as being holders of exclusive broadcasting and transmission rights for sporting events), and the FIFA finally as 'association of undertakings'.

247 Case T-193/02, Piau I, [2005], paras. 107 ff., esp. 112 and 116. For details see Chapter 5.I.

248 Case C-171/05 P, Piau II, [2006].

249 Case C-250/03, Mauri, [2005].

250 Case C-451/03, Calafiori, [2006]. 
professionally qualified to provide the particular tax and accounting advice ${ }^{251}$ the opportunity of providing, on the same terms and conditions, the reserved type of advice. ${ }^{252}$ The authorised operators are called Tax Advice Centres (TAC), which can be set up by recognised employer or workers organisations to provide the particular types of tax advice specified in the law. A TAC has to adopt the form of a company with share capital and with its object restricted to the particular tax advice specified in the law. The operation of such a centre has to be authorised by the Ministry of Treasury. More than 70 Tax Advice Centres had been created. ${ }^{253}$ The claimant company Servizi Ausiliati Dottori Commercialisti had not obtained the status to operate as a TAC, but nevertheless wanted to extend its object to provide also the reserved types of tax consultancy to undertakings and workers. It brought proceedings against notary Calafiori who had refused to register the modified object at the companies registry because of the legal monopoly for companies in the form of TACs. The referring national court asked amongst others whether the statutory rules reserving the particular types of tax advice to TACs are compatible with Articles 4, 10, 82, 86(1) and $98 \mathrm{EC}$. The case is interesting for present purposes since it directly challenges State measures granting exclusivity rights for the exercise of professional services. ${ }^{254}$

\section{2006 - Cases Macrino and Cipolla}

In the two cases Cipolla and Macrino ${ }^{255}$ the Coutt has been confronted once more with the Italian legislation regulating the fee fixing mechanism for the activities of lawyers that had been at stake in the Arduino. While the regulatory background of the cases is the same, the factual backgrounds differ a bit. Macrino concerned the fees for legal advice and consultation of a lawyer unrelated to court work. The Italian legislation still imposes the same minimum and maximum fees without distinction to either type of activity. Any fee agreement between lawyers and their clients will be null and void under the national legislation. Even where the particular activity is not teserved to the members of the Bar and the parties could have employed a non-lawyer, the Italian legislation still requires that the lawyer's fees be determined in accordance with the legal provisions. Cipolla conccrned services for legal proceedings before a court and thus can be understood as a supplement of the issue addressed in Arduino. The case, however, goes further than questioning the manner in which the fee scale was drawn up. In particulat, the referring court in Cipolla wanted to know whether the absolute prohibition to divert from minimum fees is compatible with Article $81 \mathrm{EC}$ in conjunction with Articles 3(1)(g) and 10(2) EC.

251 The national court refers to doctors, commercial accountants, lawyers and work consultants.

252 The case recalls the situation of Bilanzbucbbalter summarised above, in which the German qualified accountants challenged the statutory exclusivity for tax advice.

253 AG Colomer specifies at note 15 that of this number seven are employer centres, ten are worker centres, some fifty are centres for undertakings treated as taxpayers' substitutes and five are subject to professional associations or collegiate professional bodies.

254 Advocate General Colomer rejected the application of Articles 82 and 86(1) EC though since he considers that the TACs do not qualify the requirements of Article $82 \mathrm{EC}$. In particular he stated that they would not occupied collectively an alleged dominant position since the entities establishing the TACs are very different and defend competing interests in ideological and political terms. It would therefore not be "reasonable to believe that they would make common front, to the prejudice of their members, in abusing any alleged collective dominant position in the market for advice on the simplified assessment of income tax."

255 Joined Cases C-94/04 and C-202/04, Cipolla and Macrino, [2006]. AG Poiares Maduro in Cases C-94/04 and C-202/04, Cipolla and Macrino, [2006]. 
The Commission explicitly had invited the ECJ to teverse the case law of Arduino in respect of the combined application of Articles 10(2), 81 and $82 \mathrm{EC}$. The Coutt however restated its reasoning in respect of the competition law questions. The judgment in Cipolla is nevertheless remarkable for its findings on the restriction of the freedom to provide services that the Italian legislation constitutes. In determining whether the application of a compulsory tariff scheme is prohibited under Article $49 \mathrm{EC}$, the Court applied a pronounced test of proportionality, namely whether the national legislation was actually necessary in view of the possible consumer protection arguments related to minimum prices and therewith achieved a result similar to what the Commission had suggested, albeit not under competition law but by being strict under Article $49 \mathrm{EC}^{256}$

\section{2008 - Case Ioannis Doulamis}

The case of Mr Doulamis illustrates the dramatic consequences that professional regulation can have as it concerned the reference for a preliminary ruling made in criminal proceedings before the national judge. ${ }^{257} \mathrm{Mr}$ Doulamis, a dental technician, was prosecuted for the infringement of a State law governing the exercise of the dental and medical profession and in particular the advertising in dental care matters in Belgium. As a case of a rather classical professional rule it concerned the prohibited placing of advertisements in a telephone directory for a dental laboratory and dental clinic. As was clear from the order for reference from the national court, the prohibition concerned State legislation with no evidence that private actors had intervened in the rule setting process. The sole question referred by the national court was whether Atticle $81 \mathrm{EC}$, read in conjunction with Articles $3(1)(\mathrm{g})$ and 10(2) EC, precluded the national law prohibiting any person or dental cate provider from engaging in any kind of advertising dental care services. The case did not provide any legal challenges for the ECJ as it clearly lacked a potentially anti-competitive arrangement between economic operators to implement the said prohibition. As the Court was confronted with professional regulation adopted as plain State legislation, the ECJ was bound to rule that it was not precluded by Articles $10(2)$ and $3(1)(\mathrm{g}) \mathrm{EC}$, read in conjunction with Article 81 EC.

VI. More recent developments to modernise the professions in terms of competition law

\section{At Community level - the modernisation of professional regulation}

At the time that the imminent cases Wouters and Arduino were pending before the Court, the Commission announced to develop a more comprehensive approach towards competition for professional services rather than telying on case work only. ${ }^{258}$ In order to obtain a better understanding of the regulation of liberal professions and its effects the Commission set out to undertake a substantial stocktaking exercise, which began in 2001 with a tender for a study on the economic impact of regulation in the field of the liberal

256 For details see Chapter 6.II.2.2.3.

257 Case C-446/05, Doulamis, [2008].

258 In the face of the assertiveness with which the Commission denounces the high degree of anti-competitive effects of professional regulation it may surprise that it so far adopted only four decisions finding restrictions of competition. 
professions. In March 2003 the Commission published the study accomplished by the Vienna Institute for Advanced Studies (IHS). ${ }^{259}$ The IHS study underlines a wide disparities in levels of regulation across the EU15 in economic terms. The stance of the IHS study is that, on the one hand, countries like Austria, Germany and Italy maintain very high levels of regulation for most of the liberal professions, whilc on the other hand Denmark, Iteland, the Nethetlands and the UK have considerably more liberal regulations.

In the further pursuit of the stocktaking exercise the Commission invited interested parties to comment on regulation in the liberal professions, and ultimately organised a public hearing at a conference in Brussels in late 2003. ${ }^{260}$ On the basis of this stocktaking excrcise the Commission, on the one hand, evaluated the market failures existing in the professional services sector and, on the other, surveyed the regulatory tegimes in the different Member States. After the enlatgement of the European Union in May 2004 the fact-finding was extended to overview also the levels and types of professional regulation in the ten new Member States. ${ }^{261} \mathrm{~A}$ rather high level of regulation has been identified for Cyprus and Czech Republic. While Slovenia, Poland and Hungary are located at the lower end of regulatory intensity, they have a higher level of regulation than six of the EU15 Member States.

The fact-finding addresses both State regulation and self-regulatory rules adopted by professional bodies. Taking the results of the study as starting point, the Commission in early 2004 adopted a report on competition in professional services in which it explains its thinking on the scope of reform or modernisation of specific professional rules. ${ }^{262}$ With this 2004 report the Commission largely called on regulatory authorities and professional bodies to voluntarily review existing professional regulations in order to reform or eliminate rules that seem not to be necessary in view of identified market failures they are supposed to remedy. ${ }^{263}$ The Commission concluded that restrictive professional regulations should be subject to a proportionality test to assess to what extent anti-competitive professional regulations and rules truly serve the public interest and can be objectively justified. The Commission seeks to establish this proportionality test to apply actoss the board, i.e. not only with regard to State regulation but also self-regulatory rules. ${ }^{264}$

It has reinforced this approach in a follow-up teport published in September 2005,

259 Paterson I., et al., Economic impact of regulation - Main Report, (2003); - Part 2-Case studies; - Part 3 - References and Annexes.

260 Europcan Commission, Regultation in Liberal Professions and its Effects - Invitation to comment, of 27.03.2003; European Commission, Invitation to Comment - Regulation in Liberal Professions an its Effects - Summary of Responses, of October 2003. About 260 representatives of the professions, their clients, consumer organisations, competition authorities, policy makers and academics came together. The Directorate General for Competition published a separate web page with recordings of the conference, which are accessible at: <http://ec.europa.eu/competition/sectors/professional_services/conferences/20031028/index.html>.Before the renovation of the Commission's website the relevant link also included scans of the written questions and temarks that were put forward from various interested parties.

${ }_{261}$ European Commission, Stocktaking Exercise on Regulation of Professional Services, of 10/2004.

262 European Commission, Report on Competition in Professional Services, of 09.02.04, paras. $92 \mathrm{ff}$. Interestingly enough the referring national court in Doulamis made explicit reference to this report of the Commission in ascertaining that restrictions on advertisement in the professional services sector constitute interference with free competition, see Case C-446/05, Doulamis, [2008], para. 10.

${ }_{263}$ See above section II. In particular information asymmetry between professionals and their customers, externalities and the production of public goods that are of value for society in general, Amato $F_{\text {., }}$ et al., (2004), $72 \mathrm{f}$.

${ }^{264}$ Kroes N. (Competition Policy Commissioner), "Better Regulation of Professional Services", (21.11.2005) SPEECH/05/711, 4; Amato F., et al., (2004), 73. See also the stance adopted by the Court in Cipolla in respect of Article $49 \mathrm{EC}$ and proportionality, discussed in Chapter 6.II.2.2.3. 
which gives an overview of the progress made by individual Member State in the review and removal of unjustified regulatory restrictions. ${ }^{205}$ It also teports on the enforcement actions that national competition authorities and the Commission have taken in the field. In a separate but annexed document (staff working paper) the Commission analyses the information that the then EU25 Member States provided about the reviews they (plan to) undertake. ${ }^{266}$ In this staff working paper the Commission critically evaluates the reasons that Member States and professional associations put forward to justify the maintenance of restrictive professional rules. Its ambition is to understand the professional rules in their proper context. Furthermore, with reference to past modernisation efforts in the field of professional services in some Member States the Commission underlines that it does not simply want to eliminate anti-competitive rules. Rather the Directorate General for Competition recognises that its work is not only about enforcing competition law but perhaps even stronger about policy making and competition advocacy to increase transparency and enhance consumer empowerment (best practice) ${ }^{267}$

In its $2005 \mathrm{Report}^{268}$ the Commission urges the Member States to bring about systematic pro-competitive reform in the professional services sector. In order to ground the modernisation of the liberal professions the Commission calls on Member States to conduct analytical work of existing professional regulation. It has proposed a two-tir proceeding in which Member States should first of all identify those rules that, in the assessment of the Commission, do not require an in-depth analysis of their anti-competitive chatacter. In this respect the Commission refers to certain fixed and minimum prices and certain advertisement restrictions. ${ }^{269}$ Secondly, Member States are expected to conduct a more substantial and structural analysis of other professional tules in order to determine the authority and need of those rules. In particular the Commission points out that the regulatory structures should be scrutinised, i.e. the relationship between State regulation and selfregulation. It recognises that this touches upon the Member States' pretogative to determine the regulatory competences assumed by the States themselves and those allocated to selfregulatory professional bodies. The Commission tries to increase the speed of reform by expecting Member States to "make good progress by 2010 " on their way to opening up the sector.

The Commission has placed its wotk on competition in professional services within the broader context of the Lisbon strategy for growth and employment in the European

\footnotetext{
265 European Commission, Professional Services - Scope for more reform, of 05.09.2005.

${ }_{266}$ European Commission, Progress by Member States in reviewing professional services, of 05.09.2005.

267 European Commission, Report on Competition in Professional Services, of 09.02.04, para. 97; European Commission, Report on Competition Poligy 2004 - Volume 1, 112 f.; European Commission, Professional Services - Scope for more reform, of 05.09.2005, para.31; European Commission, Progress by Member States in reviewingprofessional services, of 05.09 .2005 , para. 24. It proposes, for instance, active monitoring by consumer associations, collection and publication of survey based historical data by independent organisation or public announcements of the abolition of tariffs. Sec also Lowe P., (2006), 2: "Competition advocacy is perhaps even mote important at the national level, as national regulation may also introduce or maintain barriers to competition. DG Competition thus tries to encourage a more systematic competition-input into national legislation. This input can be either hard or soft. The area of professional services is ptobably the best known example of the latter. As you know, we published a report in February 2004 as part of a long running programme of advocacy and reform. The discussions with Member States and professional bodies in order to modernise the applicable rules are ongoing."

268 European Commission, Professional Services - Scope for more reform, of 05.09.2005, paras. 24 ff., 29.

269 For details on the reasons why such analysis is not required for measures that restrict competition by object (hard core restrictions), see Chapter 4.II.1.1.
} 
Union. ${ }^{270}$ Since the relaunch of this strategy in March 2005 (at the Spring European Council in Brussels) ${ }^{271}$ and the adoption of two new top priorities to, first, improve and simplify the regulatory environment in which business operates and, second, to complete the internal market for services ${ }^{272}$, also the Competition Service of the Commission refocused its efforts to promote the modernisation of the liberal professions in terms of better regulation of professional services. ${ }^{273}$ The follow-up report from September $2005^{274}$ ties in with this approach, and in November 2005 a special seminat was dedicated on "better tegulation of professional services". ${ }^{275}$ The Commission emphasises that the aim is not to prevent regulation but to improve its quality. ${ }^{276}$ In order to serve the purpose of better regulation in the professional services sector the Commission urges Member States to built into their National Reform Programmes, which they are required to adopt and implement under the Lisbon strategy, the issue of modernising the rules affecting the professions. ${ }^{277}$ The Commission's work in the field of professional services may be compared to a sector inquiry under Article 17 of Regulation 1/2003. ${ }^{278}$ The future has to show whether this will grow into a sectoral action plan, which is a tool in the broader programme to simplify existing legislation under the reinvigorated Lisbon Agenda. ${ }^{279}$ The Spring European Council in 2006 has reinforced the commitments of better regulation in the Member States. By the same token the "European Council recognises the importance of a pro-active competition policy, a regulatory framework that eases market access and a reform of State aid as key policy instruments to set incentives for innovation and to allocate productive resources efficiently". ${ }^{280}$

In December 2006 a further conference was organised by the Commission's Directorate

270 See for instance MontiM. (Competition Policy Commissioner), "Competition in Professional Services: New Light and New Challenges", (21.03.2003) .

271 The EU leaders refocused the economic teform strategy on economic growth and jobs and urged national Member States to take ownership of the strategy by presenting National Reform Programmes (national action plans) before 15 October 2005. These are available at <http://europa.eu.int/growthandjobs/index_en.htm>.

272 European Commission, Common Actions for Growth and Employment, of 20.07.2005, 4, 7 f.

273 'Better regulation' is often understood as the simplification and scaling down of the body of EU legislation.

In the context of liberal professions teference is necessarily made to regulation at national level though.

274 See above note 265. Sec also Grady J. / Paserman R., (2005).

275 The conference was organised by the UK presidency of the Council of the European Union. The conference papers are accessible at <http://ec.europa.eu/competition/sectors/profcssional_services/con ferences/20051121/index.html>, last visited on 17.12.2008.

276 Albers M., (Head of Unit, Directorate General for Competition), (2005), 5.

277 Kroes N. (Competition Policy Commissioner), "Better Regulation of Professional Services", (21.11.2005) SPEECH/05/711; Grady J. / Paserman R., (2005), 67. A first evaluation of National Reform Programmes has been presented by the Commission in January 2006, available at <http://europa.eu.int/growthandjobs/index _ en.htm>.

278 Council Regulation (EC) No 1/2003 of 16.12.2002 on the implementation of the rules on competition laid down in Articles 81 and 82 of the Treaty. Kroes N. (Competition Policy Commissioner), "Better Regulation of Professional Services", (21.11.2005) SPEECH/05/711, 2.

279 See European Commission, Common Actions for Growth and Employment, of 20.07.2005, 7.

${ }^{280}$ See European Council, Presidency Conclusions, of 23./24.03.2006, 21: "The European Council welcomes the Commission's intention to table an analysis of the progress to date and of where further work is needed to continue to make progress in all areas of better regulation: simplification, impact assessment, repeals and withdrawals, codification, sectoral analysis, reduction in administrative burdens, business involvement, small and medium sized enterprises (SMEs). The European Council recalls that better regulation is also a matter for Member States to implement in their domestic law-making and in the transposition of Community law and reaffirms its commitment to making progress in all of these areas." 
General for Competition on "the economic case for professional services reform". "It brought together policy officials responsible for regulating the professions in Member States and representatives from the European-level professional bodies. The key aim of the conference was to discuss recently published economic studies which have examined the case for reform in the area of professional services. It was the first public occasion to discus the preliminary findings of an external study commissioned by DG Competition into the impact of professional services regulation on the functioning of the EU conveyancing services market (the full report was published about a year later ${ }^{282}$ ). Secondly, it provided the platform to present two national experiences on the impact of regulatory environments: first, the Finnish experience with the delivery of professional services in a low regulatory envitonment and, second, the Italy experience in reforming professional services.

The broader context for the modernisation of the liberal professions in the Community Lisbon Strategy is the completion of the internal market for services. This initiative predominantly concentrates on the effective implementation of the free movement rights in the EC Treaty. In particular the Commission submitted in 2004 a proposal for what proved to be a politically highly controversial directive on services in the internal market. The adopted directive is based on a mix of mutual recognition, administrative cooperation, harmonisation where strictly necessary, and encouraged the drawing up of European codes of conduct and professional rules by interested parties at Community level. ${ }^{283}$ In particular

281 The conference was organised jointly by the Finnish National Competition Authority and the European Commission on the occasion of the Finnish Presidency. The conference documents are available at $<$ http://ec.europa.eu/competition/sectors/professional_services/confcrences/20061230/index.html>, last visited on 17.12.2008.

${ }^{282}$ European Commission, "Competition: Commission publishes study on EU conveyancing services market", press release IP/08/101 of 29.01.2008: "The study, surveying $21 \mathrm{EU}$ countries, is the first of its kind and integrates a legal and economic approach. The different regulatory systems under which conveyancing services are provided were categorised into four regulatory models for analysis: The traditional, highly regulated Latin notary system which exists in most continental EU countries. This model is characterised by mandatory involvement of notaries, quantitative restrictions on entry (numerus clausus), fixed fees and strict market conduct regulation. The deregulated Dutch notary system under which no numerus clausus exists. Fees are negotiable and market structure and conduct regulation is less strict. The lawyer system existing in the UK, Ireland, the Czech Republic, Slovakia and - to a lesser extent - Austria. This features quality control of professionals through licensing and professional exams, negotiable fees and lower levels of market structure and conduct regulation. The Scandinavian licensed real estate agent system under which real estate agents provide legal services too. This system exists in Sweden, Finland and Denmark, each with its own characteristics. This model has little regulation on market entry, conduct and structure and has negotiable fees. The legal part of the study assesses the justifications for restrictive professional regulation in this market. The study comes to the conclusion that, when put to the test, most of the arguments put forwatd do not seem to justify restrictions of the sort that feature in highly regulated systems. The economic part examines empirically how professional regulation affects the market for conveyancing services by measuring the degtee of regulation, the quality of services in a broad sense (using the results of a user survey) and level of fees. It examines the interplay between these using different classical econometric methods. This concludes that high levels of regulation generally go hand in hand with high prices whilst not resulting in higher levels of quality. The Commission will now present the study to Member States, highlighting its results and asking for their reactions while encouraging them, when necessary, to consider appropriate reforms." The full report is Schmid C.U., et al., Conveyancing Services Market - Study for the European Commission, COMP/2006/D3/003, (2007).

283 Sec above section IV.1. In particular the directive recognises the specific characteristics of each profession or field of activity. More particularly, it recognises the specific nature of the regulated professions and the particular role of self-regulation. For example, the directive contains specific provisions on certain activities such as professional insurance and guarantees (Article 23), commercial communications by the regulated professions (Article 24) or multidisciplinary activities (Article 25). 
Article 37 Services Directive interfaces with Commissinn's competition service's efforts to open up the regulatory framework of the liberal professtons. In 2007 the Commission Directorate General for the Internal Matket and Services conducted a public on line consultation, inviting professional otgansations to provude information on their existing or planned codes of conduct, and to give their view on the best possible way of catablishing codes of conduct at liuropean level. An overview of the teplies is put into a document the purpose of which is "t" promote liuropean codes of conduct by stressing their importance not only for scrvice provides, but also for recipients and the competent national authorities, and by encouraging luropean professimal organisations 10 draw up such cudes and to cnsure compliance with them by their members." "The Commission therewith puts itself in the challenging situation of possibly promoting with the une hand the basis for exceptions and rules for the liberal professions that the other hand, i.e. the Directurate Cieneral for Competition attempts to litrit or even abolish.

\section{At national level .. between dergulation, re regulation and inertia}

The background work to the different reports published by the Commtssion in the field of competition in professional services have been contacts with different actors at national level (regulatory authorities, professional bodies ${ }^{25}$, consumer associations, academics ${ }^{284}$ ). As early as 2002 the Commission invited the competition authorities of what was to become the EU25 Member States, the EFTA Surveillance Authority and some national regulatory authorities to particularly discuss the impact of the cases Arduino and Wouters. ${ }^{2 \text { in }}$. These

234 European (ommission, The rote of 1 ianepean codes of condwat (2007), 5: "A significant number of replies were received (172 professional organisations representing mure than 25 different services sectors and 25 Member States) from professional organisations representing service sectors such as architects, lawyers, teal estate services, accountants, tax advisers, health services, engineers, veterinarians, surveyors, financial services, tourism, security, distribution/ commercial services, traditional crafts, construction services, etc. ... the majority of the replies recerved come from the regulated professinns sector, non-regulated professions accounting for abrut $25 \%$ of the replies received ... about $35 \%$ of the professional organisation ... stated that they possess a kiuropean crode of conduct. ... some of the replies received come from services sectors excluded from the scope of the Services Directive, such as the health profession.... [The document] uses the tesults of the public consultation to draw up an inventory of European coxdes of conduct, in force or under preparation, and specifies their scope and content and their relationship with national codes. Its purpose is not to lay down a European model code, or to oblige professional organisations to engage in self regulation, but merely to give an overview of existing codes and to provide a source of information and inspiration for professional organisations wishing to draw up their own codes."

${ }_{285}$ The Commission held bilateral meetings with the European professional bodies of lawyers, notaries, accountants, tax consultants, architects and pharmacists to discuss the justification for the existing professional rules: "These meetings enable the Commission to clarify which restrictions appear to be excessive and might need to be eliminated or justified. They provide an opportunity for the European professional bodies to explain their understanding of the public interest objectives in their domain and to come to an agreement with the Commission on more pro-ompetitive mechanisms to achieve those objectives. The Furopean professional bodies should then relay the Commission's concerns to the relevant national professional organisations", European Commission, Report on Competition Policy 2004 - Volume 1, para. 327.

${ }_{286}$ See for instance the event organised at the European University Institute in Florence in the summer of 2004. The annual EU Competition Iaw and Policy Workshop was dedicated on the relationship between competition law and the (iberal) professions and organised by the former Director (ieneral for Competition who, in the carly 1990s, had announced that the Commission would be losking into a more active enforcement of the 'Treaty's compretition provisions with regard to the liberal professions. Ehlermann C.D. / Atanasiu I. (Eds.), (2006); lihlermann (..D., (1993).

287 livans 1., et al., (2006), 6 . 
informal contacts grew into regular and structured ones within the European Competition Network (ECN), which is a forum for discussion and cooperation in the application and enforcement of EC competition policy. ${ }^{288}$ The discussions with the national competition authorities (NCAs) take place within the liberal professions subgroup of the ECN and have continued during and after the stocktaking exercise of 2003 and 2004. ${ }^{289}$ Moreover, the first semestral European Competition Day in 2005 was dedicated to the competition rules and the liberal professions, which brought together a range of reptesentatives from the national competition authorities, national administrations and professions to exchanged their views. ${ }^{290}$

As indicated in Chapter 1 the Member States embrace the modernisation of the liberal profession in different forms and at different paces. In some Member States a systematic approach of pro-competitive or regulatory reform has been started, whereas other $\mathrm{Member}$ States have teported no or little reform activities. ${ }^{291}$ Here follows a short overview of the most advanced reform initiatives engaged in by policy makers for tegulatory teform on the one hand and national competition authorities on the other, in order to indicate the view at national level of professional regulation and competition. The aim is mcrely to indicate current developments without going into detail of all of them as that would necessarily do injustice to existing initiatives at national level. ${ }^{292}$

The Commission stresses that the reported activities in the Member States have to be seen against the level of existing regulation. This means that Member States with a low level of restrictive regulation ${ }^{293}$ have less to do in terms of reform than other Member States. ${ }^{294}$ While Denmark, the Netherlands and the UK, are praised for having already a low level of professional regulation ${ }^{295}$, they have put in place structured programmes for further procompetitive regulatory reform. A close partnership between government and national competition authorities generally seems to foster the implementation of the reform programmes. ${ }^{296}$

288 European Commission, Commission Notice on cooperation within the Network of Competition Authorities, European Commission, Progress by Member States in revienving professional services, of 05.09.2005, para. 23.

289 Amato F., et al., (2004), 71. There are 15 ENC sectoral subgroups on Banking, Securities, Insurance, Food, Pharmaceuticals, Professional services, Healthcare, Environment, Energy, Railways, Maritime Transport, Motor vehicles, Telecoms, Media, and Sports, see European Commission, Report on Competition Policy 2006 - Including Commission StaffW orking Document. In 2006, the professional services subgroup discussed reforms and transparency in the professional scrvices sector across the EU. The sectoral subgroups ensure good upstream coordination and engender a common approach and broad consistency in the application of EU competition law, beyond individual cases.

290 Ministère de l'Économic et du Commerce extérieur,"11e Joumée européenne de la concurrence - 3 mai 2005 a Luxembourg - The competition rules and the liberal professions", (2005). The European Competition Day has first been launched in 2000 by Mario Monti, at the time serving as Commissioner in charge of competition issues. The competition day is organised twice a year and hosted by the Member State in charge of the presidency of the European Council. The objective of the competition day is to allow the public to gain knowledge of EC competition law and the objectives of competition policy.

291 European Commission, Progress by Member States in reviewing professional services, of 05.09 .2005 , paras. $32 \mathrm{ff}$. See also European Commission, Professional Services - Scope for more reform, of 05.09.2005, paras. $17 \mathrm{ff}$, and its Table 1, which does, however, not take account of the case work done by national competition authorities in the professional services sector.

292 Some details are also presented in Chapter 4.I.2.4.

293 As established in the IHS study, Paterson I., et al., Economic impact of regulation - Main Report, (2003), and the follow-up report European Commission, Stocktaking Exercise on Regulation of Professional Services, of 10/2004.

294 European Commission, Professional Services - Scope for more reform, of 05.09.2005, paras. $17 \mathrm{ff}$.

295 See Paterson I., et al., Economic impact of regulation - Main Report, (2003).

296 European Commission, Professional Services - Scope for more reform, of 05.09.2005, para. 18. 
The Danish government in 2003 decided to initiate a broader deregulation project aimed at reducing the number of rules restricting competition in Danish law. The project's object has been to analyse a number of selected areas and to identify possible changes in regulation that restricts competition in an unnecessary way. These changes should, however, not deviate from considerations of other public interests such as consumets, health etc. The analyses covered rules on liberal professions like lawyers, dentists or surveyors, and were carried out by the Danish ministry of economics and business affairs, the Danish competition authority and the Danish ministry of finance, in cooperation with other relevant ministries. ${ }^{297}$

The Netherlands have engaged in a structural approach to open up different professional services matkets more than a decade ago. Since the second half of the 1990 s government strives to bting mote competition to the sector. These efforts to liberalise certain liberal professions ate based on a broader policy approach. Between 1994 and 2003 an interdepartmental centre had been charged with the coordination of the MDW projects (Marktwerking, Deregulering, Wetgevingskwaliteit - competition, deregulation, legislative quality) in which considerable attention has been given to problems of market entry, the position of consumets, deregulation, liberalisation, self-regulation and the protection of public interests. ${ }^{298}$ Several sectors have been scrutinised ${ }^{299}$, for instance the legal services ${ }^{300}$, notaries, accountancy ${ }^{301}$, the conveyancing market, and the health sector. ${ }^{302}$ In particular the Dutch ministry of economic affairs initiated several studies that have been cartied out to develop a broader economic policy perspective. These studies served as a basis fot, first, what the ministry considers the necessary changes to existing professional regulation and, second, new measures to introduce more competition in professional services matkets. The ministry's work currently pursues to identify and categorise the different public interests that would justify market regulation in professional services. ${ }^{303}$

This effort combines with the initiative taken by the Dutch ministry of justice concerning a reform of the legal profession. ${ }^{304}$ The minister of justice commissioned a study

297 See <http://www.ks.dk/english/publications/2004/KBR-notat/>.

${ }^{298}$ Ministerie van Economische Zaken / Bos D.I., Marktwerking en Regulering: Theoretische aspecten en ervaringen in Nederland en bet buitenland (1995); (MDW), Accountancy (1997); Ministerie van Economische Zaken, Kansen voor meer marktuverking in de vrije beroepen (2003); Baarsma B., et al., Zelf doen? Inventarisatiestudie van zelfreguleringsinstrumenten, (2003); Baarsma B., et al., Goed(koop) geregeld: Een kosten-baten antalyse van wetgeving en zelfregulering, (2004).

299 Ministerie van Justitie, (MDWW), Domeinmonopolie advocatuur (1995); (MDW), Gezondheidszong (1997); Baarsma B., et al., Recbtszekerbeid als publiek belang, (2004). See also Baarsma B. / Felsö F., Het proces als domein - Over de effecten van betprocesmonopolie van de advocatuur - Eindrapport (commissioned by the association of insurers - Verbond van Veryekeraars), (2005); Plug P.J., et al., Mededinging versus domeinmonopolie en ministerieplicht - Over de gevolgen van marktwerking in het notariaat, (2003). See also (MDW), Makelaars (1998), (MDW), medische vrije beroepen, of 07/2001; (MDW), Drempels slecbten voor de switchende consument (2002).

300 Admission to the Bar was simplified, recommended charges were abolished and the regulatory powers of the Bar were restricted.

301 The powers, duties and protection of accounting (organisations) were reviewed.

302 In order to improve access to the medical profession an MDW working group has proposed improvements in establishment opportunities and changes in (para)medical training courses (new capacity plans, new financing arrangements and encouragement of more diverse supply).

303 See in particular van den Heuvel Rijnders J., et al, Public interests and market regulation in the liberal professions, (2004); Ministerie van Economische Zaken, Pampblet on the Liberal Professions - a practical guide to public interests and regulatory instruments, of 10.12.2004. Hameleers M., et al., (2006).

304 More competition had been introduced in the notaries profession in 1999, when the Wet op het notarisambt (WNA) (Notarial Act 1999) (1999), had been re-adopted. This new act has recently been evaluated, see Commissie evaluatie wet op het notarisambs Hammerstein Report, of 09/2005. See also Commissie Monitoring Notariaat, Eindrappont. periode 1999-2003, of 12.02.2003; Plug P.J., et al., Mededinging versus domeinmonopolie en ministerieplicbt-Over 
to address a number of key issues in the organisation of the legal profession. A committee had been asked to give advices about the institutional organisation of the legal profession, the mechanisms to guarantee the quality of legal services, the integrity of the professionals, and the effective supervision of the profession and its members. The conducting of the study, which takes aboard the influence that competition law has on the provision of legal services, coincides with a conflict that has arisen between the Dutch competition authority (NMa, Nederlandse Mededingingsautoriteit) and the minister of justice concerning a particulat tariff rule of the Dutch Bar association. The background to the conflict is a rule of the Dutch Bar association, which hitherto prohibited its members to conclude fee agreements with their clients according to which the amount of the fee is conditional on the positive or negative outcome of the case. This means that where there would be 'no cure', 'no pay' would be due either. The NMa informed the Bar association that it considers the prohibition of such a rule restrictive of competition. The Bar association therefore intended to engage in an experiment to allow a no cure no pay or quota pars litis rule. ${ }^{305}$ In the minister's view such a rule encroaches on the independence of a lawyer, in particular not to have a personal interest in the outcome of a case. Moreover, allowing a 'no cure no pay' rule would incite more proceedings due to a reduced tisk to engage one own's funds. The minister therefore used his statutory powers to interfere with the rules adopted by the Bar association and annulled the authorisation of the specific 'no cure no pay' rule. Subsequently, the minister considered to adopt a statutory prohibition thereof. ${ }^{306}$ To better inform his decision he commissioned the study mentioned before to scrutinise the experiences that other countries have with conditional fee agreements.

In its turn the NMa is focussing more concretely on the application and enforcement of the competition tules to the professions and their rules. Recently it critically scrutinised the status of a number of professions and the justification for their self-regulatory rules. In 2004 the NMa drew up an inventory of the self-regulatory rules adopted by four liberal professions: lawyers, notaries, accountants and architects. ${ }^{307}$ Based on this scrutiny the NMa engaged in discussions with the different professional associations and plans to publish the results thereof and to continue the scrutiny. ${ }^{308}$

A comprehensive effort to introduce more competition in the professions has also been undertaken in the UK. ${ }^{309}$ In particular, the Office of Fair Trading (the British competition

de gevolgen van marktwerking in bet notariaat, (2003); Vogels R.J.M., et al., Gegevensverzameling Notariaat, (2002).

305 Verordening op de praktijkuitovening (onderdeel Resultaatgerelateerde Beloning) (Regulation on professional practice (quota pars litis)) (2004), NOvA, "Advocaten akkoord met experiment no cure no pay", press release of 26.03.2004, NOvA, "No cure no pay geen Trojaans paard", press release of 08.10.2004.

306 No cure no pay en letselschadezaken - Letter of 04.03.2005 to the Tweede Kamer, (2005).

307 Nederlandse mededingingsautoriteit (NMa), Consultatiedocument NMa-agenda 2004, 7; Nederlandse mededingingsautoriteit (NMa), Agenda 2004, of 23.01.2004. Nederlandse mededingingsautoriteit (NMa), Inventarisatie vrije beroepen: notariaat, of $03 / 2006$.

308 Nederlandse mededingingsautoriteit (NMa), Consultatiedocument NMa-agenda 2006, 14.

309 See Office of Fair Trading, The Competition Act 1998 and public bodies, of 08/2004, 6 f.: "Important steps have recently been taken to make competition scrutiny of regulation in the UK mote systematic. First, the Enterprise Act has strengthened the powers of the OFT and the CC [Competition Commission] to examine and make recommendations to Government on regulatory restrictions and distortions of competition. The OFT proposes to amend its guidance on market investigation references in order to enhance further the potential role of the CC in this regard. Second, since 2002 competition scrutiny has been built into the regulatory impact assessment of legislative proposals. The assessmentis primarily done by Governmentdepartments. The OFT provided guidance to Government departments on when and how to carry out competition assessment, and assists on cases as necessary. Third, this summer the Competition Forum was established. This is a cross-government forum for 
authority, OFT) has taken the initiative to introduce mote competition in the professions ${ }^{310}$ on which the government has reacted. ${ }^{311}$ Its scrutiny of several sectors of the professional services market includes pharmacy, dentistry, veterinary and the legal markets. ${ }^{312}$ Similarly to the developments in the Netherlands, it is the legal profession that attracts particular attention by the UK authorities. While the aim is to introduce more competition, the intention is to also allow due account to be taken of the specificities of the profession and the needs of consumers. ${ }^{313}$ The UK government builds on the earlier activities of the OFT in the field of legal services ${ }^{314}$ and more recently adopted a White Paper in which it proposes far-reaching reforms to the regulatory framework for legal services in England and Wales that concern the structure and supervision of the professions. ${ }^{315}$ The aim is to "put the consumer first', i.e. to balance consumer needs with the independence of the legal professions.

The novelty of the proposal is to explicitly set out statutory objectives and principles that have to be tespected in the regulatory process by the competent bodies. Regulation and supervision are to be put into the hands of a new regulatory and supervisoty authority (Legal Services Board, LSB) that is independent of government and the (existing) professional bodies. ${ }^{316}$ Subject to competency and governance requirements the latter can be authorised by the LSB to establish day to day tegulations (as Front Line Regulators, FLR). ${ }^{317}$ The

discussion of relationships between market competition and government bodies. The work of the Forum will include helping to identify markets where competition appears not to be working well."

310 Office of Fair Trading, Competition in Professions, of March 2001; Office of Fair 'Trading, Competition in Professions - Progress statement, of April 2002. - Under the Enterprise Act 2002 the OFT became the British competition authority as a Crown body. Under the Fair Trading Act 1973 the OFT was not a statutory body, but simply the administrative support to the Director General of Fair Trading (DGFT). The OFT's name traditionally has been used when publicising and explaining the DGFT"s work.

311 Lord Chancellor's Department, In the public interest?, of July 2002; UK Government, Competition and regulation in the legal services market, of 27.07.2003.

${ }^{312}$ Office of Fair Trading, The control of entry regulations and retail pharmacy services in the UK, of 17.01.2003 (revised in March 2003); Office of Fair Trading, The private dentistry market in the UK, of 03/2003; Office of Fair Trading, Consultation on the future regulatory framework for legal services in England and Wales - Response from the Office of Fair Trading, of June 2004. See also Competition Commission, Veterinary Medicines - A report on the supply within the United Kingdom of prescription-only veterinary medicines, of 03/2003.

313 UK Government, Competition and regulation in the legal services market, of 27.07.2003; ClementiD., $A$ Consultation Paper, (2004); Law Society, $A$ discussion draft of the Law Society's response to the consultation paper of the Review of the regulation of legal services in England and Wales, of 02.02.2004; Office of Fair'Trading, Consultation on the future regulatory framework for legal services in England and Wales - Response from the Office of Fair Trading, of June 2004; Clementi D., Revien of the Regulatory Framework for Legal Services in England and Wales - Final Report, (2004).

314 See already Monopolies and Mergers Commission, Barristers' services. A report on the supply by Her Majesty's Counsel alone of their services (1976); Monopolies and Mergers Commission, Barristers' services. A report on the supply of barristers' services in relation to restrictions on advertising (1976).

315 Department for Constitutional Affairs, Wbite Paper: The Future of Legal Services: Putting Consumers First, of 17.10.2005.

316 Iike the existing I Jaw Society, the Bar Council, the Council for Licensed Conveyancers, the Institute for Legal Executives and others. The LSB will be made up of a majority of non-lawyers, and funded by the sector it regulates. Department for Constitutional Affairs, White Paper. The Future of Legal Services: Putting Consumers First, of 17.10.2005.

317 Department for Constitutional Affairs, White Paper: The Future of Legal Services: Putting Consumers First, of 17.10.2005, 112: "Leaving the day-to-day regulations as far as possible to the FLRs would also be more likely to increase the commitment of suppliers to high standards, reducing the risk of rising monitoring and enforcement costs. [...] The fact that day-to-day regulatory functions would be performed by FLRs themselves would support the principle that the legal profession should be independent of Government to be demonstrated more clearly [...]. This should mitigate any potential impact on UK legal services' international standing. In particular, this 
proposal requites to strictly separate the regulatory from the representative functions of the professional bodies. Moreover, a separate single and independent body will be set up to deal with complaints from consumers who are not satisfied with the service provided (Office for Legal Complaints, OLC). Further details of the initiative's findings are discussed in Chapter 4.I.2.4. The scrutiny given there of the project to reform the regulatory framework and supervisory model may be yielding insights also for other professions in the UK and even in other Member States.

Apart from this "top of the class", other Member States have set out to open up various professional services. The Irish competition authority has engaged in a systematised scrutiny of the professional services sector. In 2002 it commissioned a study to analyse methods and practices in the medical, legal and construction professions. ${ }^{318}$ Following up on that study the Irish competition authority has initiated investigations into the architects, legal ${ }^{319}$, engineets ${ }^{320}$, dentistry and optometry ${ }^{321}$ markets. The aim is to identify restrictions on competition arising from legal provisions, professional rules or customs, and to scrutinise the benefits that ate claimed to arise for consumers. In particular it analyses whether the identified restrictions of competition are necessary and proportionate to the achievement of any such benefits of public interest. Furthermore, concerns of transparency and accountability of the regulatory system are being considered. 'Taking the example of the legal profession the Irish competition authority makes over 40 proposals for reform. Similarly to the project of the UK government the Irish competition authority proposes the setting up of an independent Legal Services Commission (LSC), which would take responsibility for regulating the legal profession as a whole and be composed of a majority of non-lawyer members. ${ }^{322}$

What can be distilled from the various initiatives to modernise the professions in terms of competition is a discernible shift towards an objectivised testing of professional rules, with a dual frame of reference emerging. First, the legitimacy of professional rules is no longer taken for granted by reference to the status of a profession. Instead, the call for objectively motivated professional rules becomes more and more pronounced. Eventually this means the requirement of the legal test of proportionality to justify a restrictive professional regulation. Second, when it comes to determining regulatory systems for the

should reduce the risk of withdrawal of foreign purchasers and supplier of legal services from the UK legal services market, and the likelihood of English lawyers being prohibited from carrying out legal work within the foreign jurisdictions post-reform [...]."

318 The [Irish] Competition Authority, Study ofProfessional Services-Preliminary Consultation Document, of 01.05.2001; Indecon International Economic Consultants, Assessment of Restrictions in the Supply of Profersional Services (Prepared for the Irish Competition Authority), of 20.03.2003.

319 "This report identifies a number of restrictions to competition within the profession and puts forward various proposals for change. The report also seeks submissions in relation to a number of specific issues." See also OECD, Regulatory Reform in Ireland - Regulatory Reform in Electricity, Gas, Pharmacies, and Legal Services, (2001).

320 "Following the resolution and clarification of most of the concerns highlighted in its preliminary report the Authority has concluded that the current regulatory regime in the engineering profession facilitates competition. However the Authotity has issued two recommendations in its final report to address outstanding issues." 321 "The Preliminary Reports assess how well competition is working for consumers in dentistry and optometry. While consumers are largely able to benefit from competition in optometry, the Authority has found that numerous layers of unnecessary laws and regulations impede competition in dentistry. The Authority makes a number of recommendations to improve competition in both professions, and a consultation on the preliminary reports and their recommendations now commences."

${ }_{322}$ The [Irish] Competition Authority, Study of Competition in Legal Services - Preliminary Report, of 24.02.2005, iii f., 21. 


\section{Legal Issues Put in Perspective}

implementation of certain policy choices of professional regulation, transparency and accountability in the rule setting emerge as indispensable yardsticks to legitimise professional (self-)regulation. While these points of reference should be common property in representative democracy, they are not in respect of professional regulation. Looking back at the varying intensity with which the Member States pursue the regulatory reform in the libetal professions and the level of activity that the Commission observed in its 2005 followup report ${ }^{323}$, one is inclined to conclude that the Member States with the 'lowest' level of regulation also do the most to further reduce restrictions of the freedom of competition, and that the Member States with a higher level of regulation also have a 'lower level of activities'.

323 For the level of activities per Member State see one of the last footnotes in Chapter 1, and European Commission, Professional Services - Scope for more reform, of 05.09.2005, patas. $17 \mathrm{ff}$., and Table 1, and the accompanying Staff Working Document. 


\section{Liberal professions in the remit of EC competition law: two jurisdictional elements}

The purpose of this chapter is to explain two specific elements of EC competition law that determine its general field of application or jurisdiction. The first jurisdictional element refers to the concept of 'undertaking', which determines the ambit of competition law ratione personae. In applying this concept to the liberal professions it is necessary to distinguish between two perceivable actors: the professionals and their associations. Secondly, the application of the Community rules on competition depends on the Community dimension of a case. The question here is whether professional regulations adopted at national and/ or regional level may have an impact on intra-Community trade patterns. The two jurisdictional elements will be dealt with consecutively hereafter (part I and part II). Their relevance is twofold. First of all, they need to be established in every competition case. Secondly, they apply without prejudice to any substantive assessment concerning the question of whether a certain self- or State regulatory arrangement has a competition restrictive character. Whether it has is a question that is dealt with in Chapters 4 and 5 respectively. Finally this chapter will end with a few closing remarks in favour of the universal applicability of EC competition law to the case of the liberal professions.

\section{The concept of undertaking in EC competition law}

\section{The Höfner formula}

The concept of undertaking is a universal one that is common to all competition law rules in the EC Treaty. ${ }^{324}$ While it is not further specified in the Treaty itself ${ }^{325}$, the Court in Höfner and Elser held that

"the concept of an undertaking encompasses every entity engaged in an economic activity, regardless of the legal status of the entity and the way in which it is financed". ${ }^{326}$

324 Articles 81-89 EC. In light of the Treaty aims and objectives stated in Articles 2 and 3 EC the concept of undertaking is a universal one in EC competition law and is universally applicable in all five branches of EC competition law, see for instance Joined Cases T-68 to 77 and 78/89, Italian Flat Glass, [1992], para. 358; and AG Mischo in Case 118/85, AAMS, [1987]. The five branches of EC competition law cover: 1) restrictive agreements, decisions, concerted practices (known as cartels), 2) abuse of dominant position (known as monopolies), 3) concentration control (known as merger regulation), 4) State aid, and 5) public undertakings and services of general interest.

325 In the French texts of the Treaty and secondary legislation the word 'entreprise' is used, which has no exact equivalent in the English language used in UK commercial law. Furse M., (2002), 18.

326 Case C-41/90, Höfner and Elser, [1991], para. 21. See also Joined Cases C-159/91 and C-160/91, Poucet and Pistre, [1993], para. 17; Case C-244/94, FFSA v MAP, [1995], para. 14; Case C-55/96, Job Centre coop. arl., [1997], 
It follows from this formula that being an undertaking within the meaning of EC competition law depends on the nature of the particular activity rather than the nature or the status of the actor. ${ }^{327}$ The definition therefore is, in ptinciple, all-encompassing, leaving no room for per se exceptions from the applicability of EC competition law for activities that are offered on markets. In particular, the qualification of undertaking is indifferent to whether a Member State reserves a particular activity to entities governed by public law. ${ }^{328}$ The formula in Höfner has become settled case law $^{329}$, and its rationale is that the entities under scrutiny are fulfilling the function of an undertaking, tegardless of their status in law. This functional approach makes the concept of undertaking an objective, but also a relative one. ${ }^{330}$ In other words it is quite possible for an entity to be treated as an undettaking with regard to some of its activities, while other of its activities may fall outside the sphere of competition law. ${ }^{331}$ The concept of undertaking therefore requires that the economic nature of a particular activity be assessed case-by-case in order to decide on the activity's actor's quality as undertaking.

For the case of the liberal professions this means that only if their members, or their tepresentative associations, qualify as undertakings is competition law applicable to their respective conduct. As pointed out in Chapter 2 that conduct either takes the form of professional activities exercised by the members of a profession in the provision of services or it takes the form of regulatory and supervisory activities of their representative associations. ${ }^{332}$ Either type of conduct is scrutinised in the following sections. However, before turning to illustrate further the functional approach of the Höfner formula by applying it to the liberal professions in sections I.1. and I.3. respectively, it shall be pointed out that the Höfner formula does not go unlimited and that at times the Court felt the need to restrict its openness. The theoretical framework of the limits shall be briefly outlined here before they will be elaborated and tested on the case of the liberal professions in section I.2. more specifically.

para. 21; Joined Cases C-264/01, C-306/01, C-354/01 and C-355/01, AOK, [2004], para. 46; Case C-205/03 P, FENIN II, [2006], para. 25.

327 The Court thereby confirms the interpretation made by the Commission, for instancc in Commission Decision Polypropylene, (1989), p. 1, para. 99, where the Commission stated that the concept of undertaking tefers "to any entity engaged in commercial activities", and is "not identical to the question of legal pcrsonality for the purpose of company law and fiscal law".

${ }^{328}$ The concept of undertaking has been interpreted widely by the Court and the Commission, thereby taking account of the aims and objectives of the EC Treaty set out in its Articles 2 and $3 \mathrm{EC}$ to establish a common market. See Case 6/72, Continental Can, [1973], para. 25. Aicher / Schuhmacher, (2004), paras. 9, 17 ff. - The ECJ often uses a teleological interpretation of EC law, thereby construing Community law in the broad system of the Treaty aims and objective stated in Articles 2 and 3 EC. EC competition law, and in particular Article $81 \mathrm{EC}$, has been interpreted by the Community Courts and the Commission in a far more teleological way than would have done, for instance an English court or administrative agency, Goyder D.G., (2003), 59.

329 See only Case C-309/99, Wouters et al. v NOvA, [2002], para. 46. AG Jacobs in Case C-222/04, Cassa di Risparmio di Firenze, [2006], para. 74: "It is commonplace that the Court has sanctioned a functional notion of undertaking for the purposes of the EC competition tules."

330 For a discussion of the functional approach generally adopted by the Court with regard to the concept of undertaking, see for instance Odudu O., (2006), chapter 3.

331 Case 118/85, AAMS, [1987], para. 7; AG Poiares Maduro in Case C-205/03 P, FENINII, [2006], para. 10; Case T-155/04, SELEX/Eurocontrol, [2006], paras. 54 ff.; Case C-49/07, MOTOE, [2008], para. 25. Stockenhuber P., (2001), no. 51; Whish R, (2003), 82; Jones A. / Sufrin B., (2004), 107.

332 Associations are explicit addressees of Article 81(1) EC but not commonly mentioned in the other EC competition law provisions. For details see Chaptcr 4.I. 


\section{Distinguishing economic from non-economic activities}

In order to differentiate economic from non-economic activities the Court uses different concurrent criteria. ${ }^{333}$ The starting point is a certain comparative criterion, which can be made out in the case law on the basis of the Höner formula and centres around the core idea of economic activity. It requires to compare whether the actors under scrutiny are operating on the same or similat markets and according to similat principles as other enterprises, firms or business, regardless of whether the actors under scrutiny are organised according to private or public law ${ }^{334}$ (hereafter 'comparative market criterion'). Put differently and following a positive approach, the question is whether a particular activity, in principle, can be carried out under market conditions, i.e. by a private actor with a view to profit. ${ }^{335}$ This openness of the comparative market critetion makes one realise that virtually any activity with an economic importance is susceptible to be carried out by private entities, and therefore to come within the ambit of EC competition law. ${ }^{336}$ Reinforcing the openness of the positive determination the Court at times has adopted a negative approach, according to which all activities have an economic character that are not necessarily carried out by public authorities. ${ }^{337}$ The point can be illustrated by considering that a State is not hindered to contract out, for instance, and as has happened before, its military defence ${ }^{338}$, or the

${ }^{333}$ A concise survey of the case law is given by AG Poiares Maduro in Case C-205/03 P, FENIN II, [2006], paras. 10 ff. See also Di Via L., (1994), 301. Sec also Beeston S. / Hoehn T., (1999); Lasok Q.C. K.P.E., (2004); Louri V., (2002).

334 Case C-35/96, Commission v Italian Republic (CNSD II), [1998], paras. 36 ff.; AG Jacobs in Case C-67/96, Joined Cases C-115/97, C-116/97 and C-117/97 and Case C-219/97, Albany/Brentiens'/Drijuende Bokken, [1999], paras. 214,311

335 Case C-475/99, Glöckner, [2001], para. 20; AG Tesauro in Joined Cases C-159/91 and C-160/91, Poucet and Pistre, [1993], para. 8; AG Tesauro in Case C-364/92, SAT/ Eurocontrol, [1994], para. 9; AG Jacobs in Case C475/99, Glöckner, [2001], para. 67; AG Jacobs in Case C-67/96, Joined Cases C-115/97, C-116/97 and C-117/97 and Case C-219/97, Albany/Brentjens'/Drijuende Bokken, [1999], para. 311. AG Jacobs points out that the basic test formulated in Höfner essentially covers activities "which could, at least in principle, be carried out by a private actor in order to make profits". See also US anti-trust law where the basic starting point is equally the question whether an activity can be provided for profit.

336 AG Jacobs in Case C-475/99, Glöckner, [2001], para. 67; AG Jacobs in Joined Cases C-264/01, C-306/01, C-354/01, C-355/01, AOK, [2004], para. 27; AG Jacobs in Case C-222/04, Cassa di Risparmio di Firenze, [2006], paras. 78 f. See also AG Léger in Case C-309/99, Wouters et al. v NOvA, [2002], para. 137. See also Drijber B.J., (2005).

337 Case C-41/90, Höfner and ELser, [1991], para. 22; Case C-475/99, Glöckner, [2001], para. 20; AG Tesauro in Joined Cases C-159/91 and C-160/91, Poucet and Pistre, [1993], para. 12. The Court stresses that a certain activity is economic in character if it has not always been, and is not necessarily, carricd out by public authorities or entities. From this it can be infcrred that if it were, the activity would constitute the exercise of public authority by public entities, which as such are no addressees of competition law. In particular, are excluded from Articles 81(1) and $82 \mathrm{EC}$ such activities of (public) bodies which depend on the exercise of their official powers, Case T-128/98, Aéroports de Paris v Commission, [2000], para. 96; and which could not, at least in principle, be carried out by a private undertaking in order to make profits, AG Jacobs in Case C-222/04, Cassa di Risparmio di Firenze, [2006], paras. 76 to 83 .

${ }_{338}$ AG Poiarcs Maduro in Case C-205/03 P, FENIN II, [2006], para. 12; Hallo de Wolf A., (2004), 1687 f.; Singer P.W., (2003); Foreign and Commonwealth Office, Private Military Companies: Options for Regulation, of 12.02.2002, paras. $17 \mathrm{ff}$., on the extent of private military company and mercenary activities, with reference to the particular examples of Angola, Sierra Leone and the Balkans; see paras. $32 \mathrm{ff}$. on the debate on private military companies. Also security guard services do not constitute direct and specific participation in the exercise of official authority, see the action brought by the Commission on 23.12.2005 to the ECJ, Case C-465/05, Commission v Italian Republic (private security services), [2005]. 
administration of prisons. ${ }^{339}$ Even the rendering of justice is not necessarily integral with public authority. ${ }^{340}$ Within the necessary circumstances these activities ate thus economic in character.

However, the Court has qualified the potentially unlimited application of the Höfner formula by confining the openness of the comparative market criterion to apply to activities that are carried out on markets. The decisive point is not the mete possibility that the activity may, in theory, be carried out by private operators, but the fact that the activity is, or has been in the past, carried out under matket conditions ${ }^{341}$ (hereafter 'market participation criterion'). The first and main conclusion to be drawn from this is that any activity effectively offering goods and/ or services on a given market is an economic activity ${ }^{342}$ While it is not necessary that the activity be pursued in order to make profits, or actually gains profits ${ }^{343}$, any ptofit-motive reinforces the economic character of the activity. More in general, the economic nature of the activity is indicated where an actor accepts the financial risks connected with the offering of goods and/ or services on a given market, and in particular bears the risk of any imbalance between expenditure and teceipts. ${ }^{344}$ Past evidence of private operators exercising the specific activity substantiates the economic character thereof. ${ }^{345}$

Applying a market participation criterion leads to the further conclusion that in the case law of the Court the decision on whether some activity is economic in character finally depends on the circumstances of existing markets and not strictly on the application of a truly objective concept of undertaking. The tationale obviously is to compare the concept with economic reality. ${ }^{346}$ While as such this grounding is laudable, it may prevent the Court from

339 Aman A.C.J., (2005), $105 \mathrm{ff}$, in particular on the (re-)use of private prisons in the US since 1976 (Weaversville Intensive Treatment Unit in Pennsylvania), and with further references to point out that the prison from the outset was infused with private ownership and control. Disguised forms of private detention were used even after the introduction of public penitentiary, i.e. in the form of forced labour turned over to private contractors. Private prisons are also used in other countries: Australia (since 1990 with $20 \%$ of private prison accommodation), England and Wales (since 1992 with $10 \%$ of private prison accommodation), Scotland (1997), New Zealand (1998), Netherlands Antilles (1999), and South Africa (1999).

${ }_{340}$ Drijber B.J., (1995), 1045, who, in particular, refers to the area of rendering justice through alternative dispute settlement systems like private arbitration.

${ }_{341}$ Case 118/85, AAMS, [1987], para. 7; AG Poiares Maduro in Case C-205/03 P, FENINII, [2006], para. 13. This point did not have an effect in Höfner despite the case concerning a legal monopoly right conferred upon the public employment agency. In that case there was an indirect participation on the markct in that the German authorities allowed private actors to carry out employment procurement.

342 This is settled case law, Casc C-309/99, Wouters et al. vNOvA, [2002], para. 47; Casc 118/85, AAMS, [1987], para. 7; Case C-35/96, Commission v Italian Republic (CNSD II), [1998], para. 36. See also Joined Cases C-180 to 184/98, Pavlov, [2000], para. 75.

${ }_{343}$ Case C-244/94, FFS A vMAP, [1995], para. 21; Case C-67/96, Albany, [1999], para. 85; Joined Cases C-115 to 117/97, Brentjens', [1999], para. 85; Case C-219/97, Drijvende Bokeken, [1999], para. 75; Joined Cases C-180 to 184/98, Pavlov, [2000], para. 117.

344 Joined Cases 40 to $48 / 73,50 / 73,54$ to $56 / 73,111 / 73,113$ and 114/73, Suiker Unie, [1975], para. 541. In Case 170/83, Hydrotherm, [1984], para. 11, the Court has also stated that, in the context of competition law, the term 'undertaking' must be understood as designating an economic unit for the purpose of the subject-matter of the agreement or practice in question even if in law that economic unit consists of several persons, natural or legal. Case C-217/05, CEPSA, [2006], para. $40 \mathrm{ff}$. The point is dealt with in detail by Wils W., (2000), $102 \mathrm{f}$. in particular.

345 See Case C-41/90, Höfner and Elser, [1991], para. 22; Case C-475/99, Glöckner, [2001], para. 20; AG Tesauro in Joined Cases C-159/91 and C-160/91, Poucet and Pistre, [1993], para. 12.

346 While it is laudable to verify whether the application of legal rules fit reality, this procedure bears an inherent risk to undermine a stringent objective approach in determining the concept of undertaking. This is in contrast with the aspiration for a strictly objective interpretation of legal concepts as explicated by G.W.F. Hegel. 
verifying whether it makes good sense not to expose certain activities to market conditions, which the competition law rules warrant. The question thereby is provoked whether the caveat of market participation that qualifies the openness of the comparative market criterion, brushes the Höfner rule the wrong way.

Advocate General Jacobs is a repeat player in expressing the view that "an entity should qualify as an undertaking for the purposes of the EC competition rules [...] also when it carries out [any such] activities which are economic in nature and which could lead to distortions in a market where competition exists." Most importantly he joins the conclusion that "the emphasis when interpreting whether an activity is economic in nature should be placed on whether that activity could, at least in principle, be carried on by a private undertaking in order to make profits." ${ }^{347}$ This conclusion stands out due to its objective standard in ascertaining whether a particular activity is economic in nature, and thus can aptly serve as autonomous definition that is independent from any political, historical or other comprehension. It stipulates a strong view and thus bears an inherent critique on the Court who allows itself the softness to partially put in to question the trueness of the Höfner rule by reading into the comparative market criterion a requirement of market participation. ${ }^{348}$ Fundamentally, Advocate General Jacobs' view rightly insists on the spirit of Höfner, the asset of which is to establish a tule that is independent of individual circumstances.

From the case law that thus classifies certain activities as not belonging to the sphere of economic activity for the purpose of EC competition law emerge two aspects that ate televant for present purposes of putting liberal professions to the competition law test. One aspect concerns the narrower definition of the citcumstances under which certain activities are held to be non-economic in nature. As indicated before the qualifying case law in essence perceives certain activities as not being carried out under competitive market conditions or, put differently, as representing functions that would not reflect market conduct. Secondly, the case law at times has reinterpreted the aspect of economic importance that an activity proves to have - not least by the fact that it is cartied out against some form of remuneration - as intrinsic to the organisation of something that the Court qualifies as noneconomic. ${ }^{349}$ Both points will be further scrutinised and tested with regard to the liberal professions in section I.2. Before that follows the application of the Höfner formula to the members of the libetal professions (section I.1.), which ultimately will also be tested on the

According to the philosophy of Hegel the history of the world is a process in which the objective reason develops. Zippelius summarises Hegel's basic idea in this respect as follows: "Diese [objektive Vernunft] würde sich im Geist, auch in den Gesetzen und Sitten, der Völker konkretisieren. In diesem Prozeß hätten auch Gesetzgebcr und Gerichte bloße Mittler zu sein. Hicrvon ausgehend müßte die Auslegung anstreben, unter den möglichen Wortbedeutungen eines Gesetzes die objektiv vernünftigste zu wählen. Damit verwandt ist die Ansicht, daß der Machthaber von dem lebendigen 'objektiven Geist' getragen bleibe und diesem lediglich 'Bewußtsein, Initiative, Aktionsfähigkeit’ verleihe. Gesetze wären dann ‘Objektivationen’ jenes objektiven Geistes. So müßte der Interpret nach den Wortbedeutungen suchen, die den in der Gemeinschaft herrschenden und lebendigen Vorstellungen am besten entsprechen.", Zippelius R., (2005), 23, with reference to Hegel G.W.F., (1830), paras. 548 ff., and Hartmann, N., Etbics, (1932), chap. 35 b, 44 c, 57, 58 b.

${ }_{347}$ AG Jacobs in Case C-222/04, Cassa di Risparmio di Firenze, [2006], paras. 78 (emphasis added respectively). Already AG Jacobs in Joined Cases C-264/01, C-306/01, C-354/01, C-355/01, AOK, [2004], para. 28. See also above and below notes 335, 474.

348 AG Poiares Maduro in Case C-205/03 P, FENINII, [2006], paras. $11 \mathrm{f}$. and $13 \mathrm{f}$., has referred to the Court's qualification of Höfner as the comparative and market participation criteria - hence the dichotomy chosen here of comparative market criterion $\nu$ market participation criterion. For details on this point of his opinion see below text with note 486 .

349 In particular Case C-343/95, Cali $\nu$ SEPG, [1997], para. 24. For details see section I.2.2. 
associations representing the professions (section I.3.).

\section{Members of a profession as undertakings in the sense of competition law}

\subsection{Höfner formula: Every enlity engaged in an economic activity...}

Representatives of the liberal professions have traditionally contested the application of competition law by asserting that their members' professional activities would not have an economic character at all. According to that standpoint liberal professionals would not exercise a trade or business in the ordinary or the legal sense $\mathrm{e}^{350}$, and they would not exercise their activities in a pursuit of gain; in particular they would tather be remunetated than paid. This sophisticated differentiation between payment and remuneration is intended to reinforce the particular position that the professions assume in society and underlines that theirs is not the exercise of a regular (economic) activity, but intrinsically a service of specific public importance that catries an idealistic value to society at latge. ${ }^{351}$ The claim is that the consequential drawing up of tariff schemes would be the expression of the necessity to regulate the remuneration of liberal professionals in order to safeguard that professionals concentrate on providing quality services rather than low cost services. ${ }^{352}$

This view is contrasted by the fact that the exercise of a profession allows the professionals to earn their living and can therefore not be merely altruistic in chatacter. The activities carried out by accountants, architects, doctors, lawyers, notaties, pharmacists, etc., are services that are provided for a fee to a range of different customers. What is more is that one of the basic conceptual ideas of the liberal professions is that their members are independent. ${ }^{353}$ The concept of independence not only embraces professional competence or professional autonomy, but also the idea of economic independence. This means that a liberal profession is commonly exercised by natural persons on an individual basis and in the form of self-employment. ${ }^{354}$ To deny the economic character of a professional activity does not square with the fact that a self-employed practice necessarily is determined by the financial aspect of offering services on the market against payment. In particular, this involves the economic risk that any imbalance between expenditure and receipts in the provision of the professional services in question has to be borne by the professionals. 'The

350 Some national laws include a statutory definition that liberal professions do not exercise a trade or business in the legal sense. For instance, German law stipulates that the legal profession does not exercising a Geverbe; see \$2(2) BRAO, $\$ 2$ BNotO. In French law Article 111 Décret 91-1197 (Decrec organising the lawyer's profession) (1991) states that the profession of lawyer is incompatible with an activity of a commercial character, be it exercised directly by the professional in question or through an intermediary. Not least Dutch specialists in notarial law persist that notaries public would be no entrepreneurs "in the undiluted sense", see van Mourik M.J.A., (2006), 14, evidencing a patent unawareness of, or disrcgard for, the Höfner jurisprudence.

351 For instance barristers were traditionally not to accept any pay, but clients were free to give them a reward into a little purse that would hang from the barrister's back, so that the client could put the money without the barrister being embarrassed of being seen to receive cash up front, Cooke J.D., (2006), 2.

352 This view implies that low cost professional services would necessarily be of a dubious quality, which obviously is nothing more than a speculation and, moreover, seems to contradict the idea of 'remuneration' mentioned before.

353 See Chapter 2.I.

354 In the continental Member States the idea of being self-employed is a traditional and inherent feature of the concept of 'iberal' professions, and working in private practice used to be one important aspect of being 'independent'. The situation in the UK is comparable, see the change of 31.10.2004 to the code of conduct of the Bar Association, which has brought "self-employed" to replace "independent". 
acceptance of this tisk generally indicates the economic character of the professional activity. ${ }^{355}$ To include the professional activities of liberal practitioners within the ambit of the EC competition rules fits the generally broad scope of application of the competition rules $^{356}$, and meets in particular the objective character of the latter, for which the legal classification of an activity at domestic level is indifferent. Furthermore, the fact that revenues are regulated does not in itself take away the economic character of an activity. The existence of fee scales can be explained by other reasons than that the activities of members of the professions would lack an economic character. They could for instance constitute a remedy to market failures ${ }^{357}$ or, quite to the contrary, evidence collusive behaviour. ${ }^{358}$

The stance that practitioners of the liberal professions would not cxercise an economic activity, and thus not qualify as undertakings within the meaning of competition law, was based on a deliberate distinction made in the classification of service providers. A differentiation between professionals and business allows to treat either group differently in (national) law despite the fact that they both provide services. ${ }^{359}$ A qualification of setvice providers as either professional or business basically boils down to stating that professionals are no business because they would not share the same principles or values as the latter in the exercise of their respective activities. However, a cleat legal classification is difficult to realise, not least because of different traditions in the different Member States. ${ }^{360}$ While, according to the traditional view, it is possible to differentiate between (liberal) profcssions and business or trade, and hence to differentiate between 'professional services' and 'business services', it is delicate to hold on to such a (terminological) dichotomy.

Especially in economic terms professional services do not have a different nature than services provided by (other) business. Just as the latter professional service providers offer their services for a fee, have a turnover and have to pay income taxes and VAT. ${ }^{361}$ Moreover,

355 The case law clcarly states that liberal professionals exercise an economic activity, Case C-309/99, Wouters et al. v NOvA, [2002], para. 48; Joined Cases C-180 to 184/98, Pavlov, [2000], para. 76; Commission Decision EPI Code of Conduct, (1999), para. 23; Case C-35/96, Commission v Italian Republic (CNSD II), [1998], para. 37. See also above note 344. On the (non-)economic character of legal aid, health care services provided free of charge, and notarial services, see below section I.2.2.4. On health care services see AG Poiares Maduro in Case C-205/03 P, FENIN II, [2006].

356 Lenk J., (2006), 64.

357 Like c.g. the occurrence of damaging low quality, excessive pricing, price wars, tace to the bottom in quality. See already Chapter 2.II.

358 Interestingly enough, and as the summaries of the sector-specific case law in Chapter 2.V. demonstrate, most of the professionals cases brought before the Court of Justice under competition law actually concerned fee schedules. Competition law qualifies price regulation as necessarily restricting competition. For details sec Chapter 4.I.2.1.

359 For this book, when it comes to denominate the activity of (liberal) practitioners, the terminology of 'professional activities' or 'professional services' has been chosen to indicate the performances that members of the (liberal) professions provide.

360 See also Chapter 2.I. See also Bundesministerium für Wirtschaft und Technologie (BMWI), Die Lage der Freien Berufe, of June 2002, 1: "The great variety of professions and job descriptions [or profiles] which according to the general public or legal criteria qualify as liberal professions makes it difficult to define and demarcate them from business" (my translation).

361 This does not prevent legal privileges for the liberal professions in tax matters. Note the shock and resentment with which representatives of the liberal professions have reacted when the German govemment in spring 2003 discussed plans to subject the liberal professions to trade taxes just like 'ordinaty' busincss. Bundesverband der Freien Berufe (BFB),"Gevperbesteuer/ Gemeindefinanzreform Stellungnabme", (2003); BRAK, "Anwaltstätigkeit unterliegt nicht der Gewerbesteuerpflicbt", (2002). For a self-test whether one exercises a liberal profession rather than a business or trade under German law, see IFB (Institut für. Freie Berufe),"Freier Beruf oder Generbe? - Kurffassung", (2006), 4 f. See also Michalski L., (1989). The exemption from trade tax in Germany 
a distinction between profession and business is not always properly made. The OECD, for instance, qualifies certain activities as business services despite the fact that they are provided by (libetal) professionals (teferring to legal and accountancy services). At times the OECD even uses a mixed term of "professional business services" (PBS), which it juxtaposes to "other professional services such as health care". ${ }^{362}$ The European Commission does not always apply a strict usage of terminology either. ${ }^{363}$ The different authorities seem to shift their focus from the service provider to the service receiver, thereby sometimes calling business service any service that an enterprise may be interested in purchasing in the course of its business. ${ }^{364}$ Furthermore, the equally economic character of professional and business services appears to be taken for granted, as evidence the discussions during the drafting and adoption of the most recent Service Directive for the internal market. ${ }^{365}$ Without any further distinction rapporteur Evelyne Gebhardt simply referred to 'commercial services" opposed to services of general interest (SGI), which should not be open to commercial practices. ${ }^{367}$

The undivided notion of undertaking within the meaning of EC competition law makes that no account can be taken of idealised conceptions cherished at domestic level or by interest groups about the characteristics of a particular profession. Otherwise a uniform interptetation of the objective concept 'undertaking' independent of any national reading

repeatedly raises constitutional law questions on grounds of unequal tax treatment, see BRAK - Ausschuss Verfassungsrechtund Ausschuss Steuerrecht, Stellingnabme der Bundesrecbtsanwallskammer zu der Anfrage des Präsidenten des Bundesverfassungsgerichts vom 25.01.2007 zur Gewerbesteuer (1 BvL 2/04), (2007).

362 OECD, Competition in Profersional Services, $(2000)$, pp. 21, 29, 31. Its background note is the chapter 3 on Regulatory Reform and Professional Business Services from OECD, The OECD Report on Regulatory Reform Volume I: Sectoral Studies, (1997). Also Bruzzone G., (2001), 6: "banking, retail distribution, the liberal professions and other professional business services" (emphasis added).

363 European Commission, Report from the Commission to the Council and the European Parliament on The State of the IntermalMarket for Services, of 30.07.2002; on p. 26 under the heading Cross-border use of business services (emphasis added): "In order to engage in its particular activities, an enterprise normally requires the input not only of manpower but also of a variety of 'business services'. According to the Commission, these may range from legal assistance and accounting services, through marketing services, website design, equipment leasing or hire, to transport and after-sales services."

364 'Therefrom follows a further terminological distinction between services provided 'B to B' (business to business) and 'B to C' (business to consumer). The European Commission, Professional Services - Scope for more reform, of 05.09.2005, para. 13, distinguishes between professional services provided to small and big business, consumers and the public sector. More details on different professional services markets are given in European Commission, Progress by Member States in reviewing professional services, of 05.09.2005.

365 Directive 2006/123/EC of the European Parliament and of the Council of 12 December 2006 on services in the internal market. The Directive will have to be implemented by the Member States by the end of 2009. The Commission stresses that this Directive is aimed at eliminating obstacles to trade in services, thus allowing the development of cross-border operations. It is intended to improve the competitiveness not just of service enterprises, but also of European industry as a whole. It will remove discriminatory barriers, cut red tapc, modernise and simplify the legal and administrative framework - also by use of information technology - and make Member State administrations co-operate much more systematically. The Commission expresses the belief that the Directive will also strengthen the rights of users of services.

366 European Parliament, debate of 14.02.2006, <http://www.europarl.europa.eu/sides/getDoc.do?pubRef $=-1 / \mathrm{EP} / / \mathrm{TEXT}+\mathrm{CRE}+20060214+\mathrm{ITEM}-012+\mathrm{DOC}+\mathrm{XML}+\mathrm{V0} / / \mathrm{EN}>$, last visited on 30.05.2007. See also van den Heuvel Rijnders J., et al., Public interests and market regulation in the liberal professions, (2004), 25: 'The liberal professions are part of the commercial scrvices sectot."

367 But available to all citizens equally. European Commission, White Paper on Services of General Interest, of 12.05.2004; see also European Commission, 2001 Communication on Services of General Interest in Europe. For details on the impact of the concept of services of (general) economic interest in the field of professional services see Chapter 7.II., which particularly deals with the general justification clause of Article 86(2) EC. 
would be thwarted. A distinction between (liberal) professions and business therefore does not add to the assessment of the economic character of an activity, but at most remains at a sociological level. ${ }^{368}$ Thus far it can be concluded that the traditionally alleged noble or altruistic character of the professions does not prevent to qualify their services as economic in nature, and therefore does not exclude that prima facie EC competition law can be applied to the professions.

\section{2. ... regardless of the legal status of the members of a profession}

Despite the economic characteristics of professional activities representatives of the liberal professions and Member States have put forward arguments to demonstrate specifically that liberal professionals are no undertakings. In the CNSD case ${ }^{369}$ it was argued that customs agents could not be regarded as undertakings within the meaning of EC competition law, because of, first, their status as liberal professions and, second, the intellectual nature of their services. The argument ran that the professional activities in question would not be operated via an organised production structure but could be pursued in the absence of an organisational factor, i.e. a combination of material, non-material and human tesources. ${ }^{370}$ In Coapi and EPI similar arguments were put forward to the effect that professional representatives would not qualify as undertakings because of the services' intellectual, technical or specialised nature, and because of the personal and direct basis on which the services were provided. ${ }^{371}$

At the early stage of assessing the applicability of EC competition law, that is its jurisdictional scope, and on the basis of the broad Höfner formula the Court and the Commission have, however, repeatedly rejected any such non-economic argument put forward with the intention of outbalancing the economic nature of a professional activity. The decisive argument, first of all, has been the fact that members of a profession assume the financial risks involved in the exercise of their activity. ${ }^{372}$ Furthermore, the assessment that liberal professions thus participate in a market is not altered by the fact that the exercise of the relevant activity is regulated, of that the access to a profession requires authorisation. ${ }^{373}$ It may well be that particular obligations that derive from public regulation render the service provision less competitive compared to similar services provided by other operators not bound by such obligations. ${ }^{374}$ However, as long as professional services are offered on a market and under market conditions, it is not conceivable that their generally economic nature would be excluded by features that are linked to the creation of the services or the access to the market. Therefore, any particular legal status that liberal professionals may enjoy in a Member State under domestic law is irrelevant to their qualification as

368 See BVerfG - [1960], BVerfGE 10, 354.

369 The case is summarised in Chapter 2.V.

370 See Case C-35/96, Commission v Italian Republic (CNSD II), [1998], paras. 37 f.; Case T-513/93, CNSD III, [2000], para. 33.

371 See Commission Decision COAPI, (1995), para. 32; Commission Decision EPI Code of Conduct, (1999), para. 23, partially annulled on appeal but not on this point, Case T-144/99, EPI, [2001]. Both cases are summarised in Chapter 2.V.

372 See the case law referenced in note 344.

${ }^{373}$ Case C-35/96, Commission vitalian Republic (CNSD II), [1998], para. 37 f.; Case T-513/93, CNSD III, [2000], para. 38; Joined Cases C-180 to 184/98, Pavlov, [2000], para. 77; Case C-309/99, Wouters et al v NOvA, [2002], paras. 48 f.; Commission Decision COAPI, (1995), para. 32; Commission Decision EPI Code of Conduct, (1999), para. 23. 374 Case C-475/99, Glöckner, [2001], para. 21. 
undertaking according to competition law.

Contrariwise, disregarding the economic side of a professional activity (with a view to excluding the latter from the ambit of competition law at the outset) would actually boil down to granting the liberal professions a privilege over other sectors, for which it is not that commonly accepted that they also transport values other than profit. ${ }^{375}$ Conversely, to adhere strictly to the Höfner formula ensures a clear classification that allows a systematic development of the scope of application ratione personae that is easy to apply. The clear advantage of this typical European approach is that no per se exceptions to the ambit of EC competition rules are allowed for particular sectors, and that their organisation in a particular Member State is meaningless. ${ }^{376}$

\section{Certain categories of members of the professions not qualifying as undertakings}

As indicated above, liberal professionals gain their living from their professional activities and participate in services markets in similar ways as do other service providers. They therefore clearly qualify for the legal criteria 'undertaking' in the sense of competition law. Still the question arises whether valid arguments can be made that divest, as it were, professional activities of their basic economic character, with the consequence that the members of a profession would not come within the ambit of competition law ratione personae. As the assessment of the element of 'undertaking' under the Höfner formula relies on objective circumstances, so must conceivable exceptions to the rule allowing that goods or services offered for a fee would not qualify as economic activity. Circumstances that are profession-specific and referring to the 'proper practice' of a profession may form a first possible objective reference point (section 2.1.) ${ }^{377} \mathrm{~A}$ different reference point is the particular interest that public authorities may take in the activities exercised by members of the professions (section 2.2.). Both discussions will centre around specific case law already briefly referred to above, which qualifies certain activities as not belonging to the sphere of economic activity for the purpose of EC competition law. Considerations to divest professional activities may in particular draw on case law that, first, perceives certain activities as not being carried out under competitive market conditions and, second, reinterprets the aspect of economic importance of a particular activity. A third conceivable consideration is that the reality of the liberal professions has changed over time, and in particular that a considerable number of professionals renounce to take up a self-employed activity and instead prefer a dependent employer-employee telationship. Evident examples are lawyers working as associates in law firms, or doctors in hospitals. This aspect raises the question whether employees exercise an economic activity in the sense of competition law, which will be looked at in section 2.3.

375 For instance, one could just as well argue that the production and selling of, e.g. refrigerators contributes considerably to the general wealth by creating employment and improving public hygienics and health and, therefore, should not that strictly be regarded as an economic activity. However, qualifying an activity as economic in nature does not exclude to take due account of legitimate considerations at a later stage of the competition law scrutiny that might result in the non-application of a competition prohibition, see below text with notes 395 and 396. For details see Chapter 4.II.1.2. and Chapter 7.

376 On US anti-trust law and its recognition of per se exceptions in accordance with a rule of reason, see Chapter 4.II.1.2.1.

377 See for instance Case C-309/99, Wrouters et al. vNOvA, [2002], paras. $107 \mathrm{ff}$. See also Article 26 of the Dutch Advocatenwet. What actually is referred to with 'the proper practice of a profession' will be discussed in Chapter 4.II.4.2.2. and Chapter 7.I.2.5.3. 


\subsection{Profession-specific concerns to outweigh the economic character of activities exercised by members of a profession?}

The question first is whether profession-specific considerations could outweigh the economic importance of professional services. In particular where the professions exercise functions that are intended to contribute to social aims tather than reflect market conduct is it conceivable to reassess their generally economic character. Such an approach could possibly try to realise a sophisticated implementation of the functional approach that the Höfner rule adopts, and in particular make use of the market participation criterion embraced by the Court. ${ }^{378}$ As explained above the functional approach distinguishes economic from non-economic functions that an entity may pursue through various activities. Such a differentiation obviously is a laborious task, even more so if clear standards are to be developed to come to a conclusive assessment in an individual case. To explote the beating of distinguishing economic from non-economic activities inspiration may be drawn from the field of sports, where a parallel argumentation has been tried.

\section{Comparison to the field of sports}

The traditional argument put forward by sporting federations and Member States to avert the application of EC law to sport is to point at the non-economic character of the very sporting activity at stake, or at least to emphasise its sport-specific charactetistics so as to downplay the importance of its economic features. ${ }^{379}$ While the Court has constantly held that sport generally falls within the ambit of Community law, it has specified that sport does so only insofar as it constitutes an economic activity within the meaning of Article 2 EC. ${ }^{380}$ This case law let the CFI to accept in 2004 that sport, in its essence, would serve a purely social function and therefore not be linked to market conduct. ${ }^{381}$ Purely sporting rules, which organise the exercise of sporting activities, would not - at least not predominantly - be motivated by economic considerations but by the preservation of the noble competition and other ideals of sport, and thus not qualify as economic in nature or come within the ambit of EC competition law. ${ }^{382}$ In Meca-Medina, a case on a campaign and rules against doping of the International Swim Federation (FINA), the CFI held in particulat that

"[T]he principles extracted from the case-law, as regards the application to sporting regulations of the Community provisions in respect of the freedom of movement of persons and services, are equally valid as regards the Treaty provisions relating to competition. The fact that purely sporting legislation may have nothing to do with economic activity, with the result, according to the Court that it does not fall within the scope of Articles $39 \mathrm{EC}$ and $49 \mathrm{EC}$, means, also, that it has nothing to do with the economic relationships of competition, with the result that it also does not fall within the scope of Articles $81 \mathrm{EC}$ and $82 \mathrm{EC}$. Conversely, legislation which, although adopted in the fleld of sport, is not purely sporting but concerns the economic activity which sport may represent falls within

378 This book does not subscribe to the market participation criterion, see above text with note 348 .

379 See for instance the allegations of the various interested parties in Case C-415/93, Bosman, [1995], paras. 70 ff. See e.g. European Commission, The application of the EU's competition rules to sports, of 05.06.2002; and European Commission, XXIXth Report on Competition Policy 1999, paras. 140-141. See also Van den Bogaert S., (2005), $15 \mathrm{ff.}$ 380 Case 36/74, Walrave and Koch, [1974], para. 4; Case 13/76, Donà, [1976], para. 12; Case C-415/93, Bosman, [1995], para. 73; Joined Cases C-51/96 and C-191/97, Deliège, [2000], para. 41; Case C-176/96, Lebtonen, [2000], para. 32; Case C-519/04 P, Meca-Medina II, [2006], para. 22.

${ }_{381}$ Case T-313/02, Meca-MedinaI, [2004], paras. 41 f., 49. See also European Parliament's Committee on Internal Market and Consumer Protection, et al., Professional Sport in the Internal Market (commissioned by the European Parliament), of 09/2005, 55 ff.; and Case T'-193/02, Piau I, [2005], para. 105.

382 See also AG Cosmas in Joined Cases C-51/96 and C-191/97, Deliège, [2000], paras. 50, 74. 


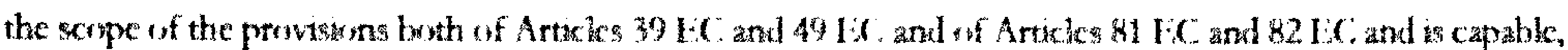

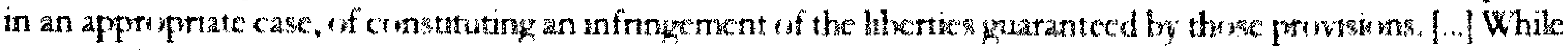

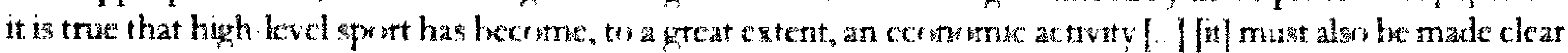

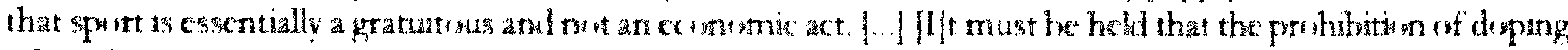

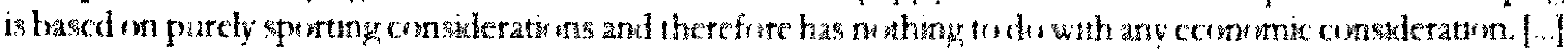

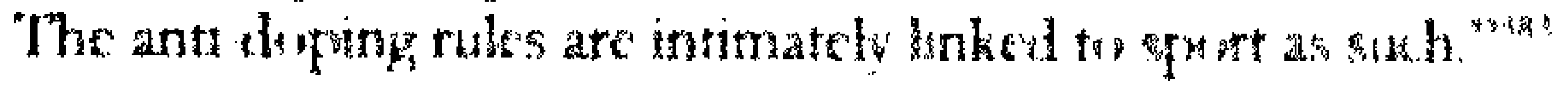

The case has been appealed to the $I: C$ on the ground that, among others, the Court of lirst Instance would have been wrong wh hold that Articles 4\%,81 and 82 l:C would apply only to rules laid dow $n$ in the field of sport that cuncern the connmic aspect of sport, to

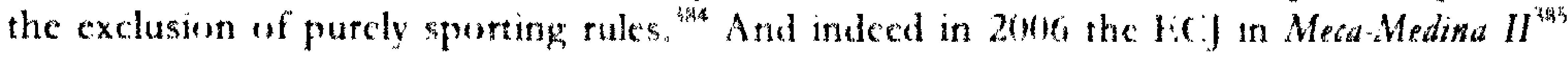
quashed the interpretation that the (II had inferred from the previous case law in the ficld of sport. In particular the ICI did not follow the (II in its conclusion that the would be a coherent and single concept of economic attivity in the 'reaty that would ultimately go back to $\Lambda$ rticle 2 IC: ${ }^{3 u_{3}}$ While the (H had considered that purely sporting rules might have nothing to do with connme activity in the sernse of $\Lambda$ rticles 39 and 49 ISC and, on that ground, concluded that the FIN $A$ anti doping rules would equally fall outside the scope of Articles 81 and $82 \mathrm{EC}^{32}$, the $\mathrm{ECJ}$, in assessing more generally whether the sporting sector has a competition law dimenswon, seems to have been inspired by the opinion adopted by Advocate General Poiares Maduro in lHEN $I I$, who firmly objects to an automatic phasing of the scope of freedom of competition and that of the freedom to provide services. ${ }^{3}$ More particularly, the ECJ stressed that the specific requirements of Articles 81 and $82 \mathrm{EC}$ make it "necessary to determine $[. .$.$] whether the rules which govern [the relevant] activity emanate$ from an undertaking" " within the meaning of Articles $39 \mathrm{EC}$ et seq. or $49 \mathrm{EC}$ et seq. (and ultimately of Article $2 \mathrm{EC}$, see paragraph 22 of the judgment) may be a different one than in determining whether an entity is an undertaking, i.e. engaging in an 'cconomic activity'.

For the purpose of competition law the I:CJ in Meca-Medina II has made a fine distinction between, on the one hand, the rules governing sporting activity and, on the other, the person engaging in the activity and the body making rules with regard to that activity respectively. The situation that presents itself is thus a triangular one in which the activity can be seen as a coupler between the actors and the rules that the latter adopt.

Diagram (no. 2) on the distinction made in Meca-Medina II

\begin{tabular}{|cccc|}
\hline $\begin{array}{c}\text { rules } \\
\text { regulating }\end{array}$ & a & an activity & $\begin{array}{c}\text { regulated or exercised by } \\
\text { actors }\end{array}$ \\
\hline
\end{tabular}

383 Case T-313/02, Meta-Medina I, [2004], paras. 42-47.

3.4 See AG Léger in Case C-519/(04 P, Meca-Medita II, [2006], paras. $13 \mathrm{f}$. For a critical comment on the CFI's decision see Weatherill $S$., (2005).

${ }_{385}$ Case C.519/04 P, Meca-Medina II, [2006], paras. 30 ff. See also, Kienapfel P. / Stein A., (2007), 7 f.

38 Buendia Sierra J.1.., (1999), $30 \mathrm{f}$., emphasises that cutside the field of competition law no coherent single concept of undertaking exists in Community law, not even with regard to other fields within the FC'Treaty. See also AC Kokott in Case (.-360)/04, Hutchison 3(, 20007, paras. $57 \mathrm{ff}$.

38. See above note 381.

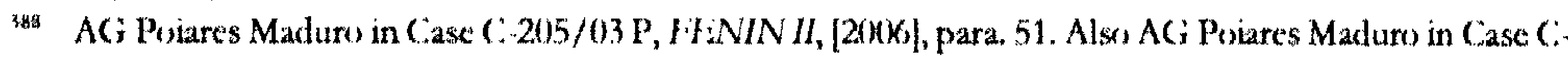

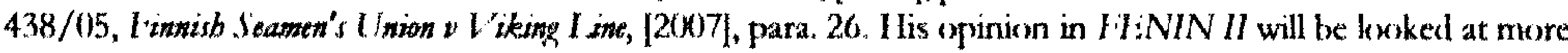
specifically betow in section 1.22 .3 .1 .

3月9 Case (. 519/04 P, Meca-Medisa II, [21)(6)], para. 30. 
What the Court clearly expresses with this distinction is the opinion that in order to ascertain the scope ratione personae of the competition rules it is not valid to have recourse to an exccption ratione materiae: "[...] the mere fact that a rule is purely sporting in nature does not have the effect of removing from the scope of the Treaty the person engaging in the activity governed by that rule or the body which has laid it down". ${ }^{390}$

Trying the relativity of the concept of undertaking: nature of an activity versus motives for certain rules

In light of the relativity of the Höfner concept of undertaking the misconceived differentiation that the CFI previously had struck with regard to purely sporting rules at first may sound plausible, and similar atguments about the ideals to which the liberal professions adhere in the exercise of their professional activities have been put forward. ${ }^{391}$ However, it is relatively easy to imagine that rules organising the access and/ or exercise of sporting and professional activities respectively, and despite their economic repercussions, may ambiguously be motivated by the preservation of noble ideals of sport or the professions. ${ }^{392}$ The provision of services by the members of the (liberal) professions does not pursue an idle purpose of its own that could discernibly be severed from its economic nature. While domestic law may take a deliberate decision to the contrary, such resolution would not respect economic reality. For instance according to Belgian commercial law a liberal professional cannot be a 'bandelaar', i.e. a 'merchant' or businessperson. This goes back again to the traditional distinction between business and profession (see above section I.1.1.), but in fact boils down to a petitio principii: to assume the truth of that which is intended to be proven. ${ }^{393}$ In exercising their professional activity liberal professionals generally behave as market actors. Their services contribute considerably to the volume of the national and Community economies and have a considerable economic spillover on other sectors. ${ }^{394} \mathrm{~A}$ privileged exception ratione materiae for professional services from the scope of competition law is not justified.

On a more general scale, one can make the following observation. To sever sectorspecific coneerns, which are not linked to market conduct in relation to a particular activity, from the activity's economic features seems to shift the focus away from the nature of the activity (Höfner) towards emphasising the motives for certain rules that surround the activity in question. Not only does such an approach bear the danger of unnecessarily hollowing the functional approach of the Höfner rule. It also is not necessaty for the matter of identifying the actors covered by competition law. At the early stage of determining the economic - character of an activity (i.e. the applicability of competition law rationae personae), it seems unnecessary to take account of the objectives of rules adopted by the sector in question that - supposedly - determine the substance of the (economic) activity. Instead, any such particular purpose may be taken into account at a later stage of the competition law scrutiny,

390 Case C-519/04 P, Meca-Medina II, [2006], para. 27 (emphasis added). NB The distinction between rules adopted by professional bodies and the activities regulated by such rules will play a particular role in Chapter 4.I.1.2.

391 See above text with note 368 and note 371 , respectively.

392 See Völcker S.B., (2005), 1697.

393 Schneider E., (1995), $218 \mathrm{ff}$. Moreover, it is not the function of (domestic) provisions to describe, define or state factual circumstance in which the law applies, but to define provisions that direct human actions, Zippelius R, (2005), $2 \mathrm{ff}$. This diagnosis goes back to the distinction stressed in particular by Immanuel Kant, but also David Hume, between statements in respect of what one shall do and statements in tespect of what is.

394 See numbers in the introduction, Chapter 1.I.1. 
mainly at two specific moments: first, at the juncture of assessing whether the behaviour required by the challenged rules is anti-competitive ${ }^{395}$; or secondly, at the ultimate stage of considering whether an exemption from the competition prohibitions can be justified under Articles $81(3)$ or $86(2) \mathrm{EC}^{396}$

Since it is not necessary, and even dangerous, to allow a cunning implementation of the functional approach adopted in Höfner by privileging sector-specific concerns over undeniable economic aspects of professional activities, the consistent interpretation of the broad concept of undertaking hence results in a systematic inclusion of liberal practitioners into the ambit of the competition law rules. This approach is consistent with the general approach in European law according to which the general scope of application of rules is universal; exceptions have to be applied restrictively as otherwise they forfeit being the exception.

\subsection{Höfner contrasted with aclivities not baving a character justifying the application of competition law}

Most members of the professions no longer contest being undertakings in the sense of $\mathrm{EC}$ competition rules. ${ }^{397}$ However, two liberal professions in particular withstand this conclusion: the health professions and the notary profession. They stress that they should not fall within the ambit of competition law because of the public role that they assume in exercising their professional activity, a role which would exclude that their activities be economic in character. ${ }^{398}$ This is a further plea for an exception ratione personat, which shall be discussed here. ${ }^{399}$

More particularly, a theoretical frame of reference for such an exception shall be tried in view of the case law according to which certain activities do not have an (economic) character justifying the application of the EC competition rules. First, the background to such framework shall be clatified, which lies with the explicit addressees of the competition rules of the Treaty (section 2.2.1.). Subsequently, as will be explained, one may argue that in building upon the background of addressees the Court developed a specific approach in which it reassesses the economic importance that an activity proves to have, considering that

395 For details sec Chapter 4.II.1.2., in particular on the doctrine of ancillary restraints, according to which certain restraints contribute and are necessary to achieve a main transaction with a commercially beneficial aim. 396 AG Jacobs in Joined Cases C-264/01, C-306/01, C-354/01, C-355/01, AOK, [2004], para. 27. AG Jacobs in Case C-67/96, Joined Cases C-115/97, C-116/97 and C-117/97 and Case C-219/97,Albany/Brentjens'/Drijuende Bokken, [1999], para. 330: "Contrary to the contentions of the [parties], [the issue on the concept of undertaking] is to be distinguished from the separate question whether and to what extent the grant of certain exclusive rights is necessary for the fulfilment of tasks in the public interest. The latter question is only relevant for the purposes of Article [86(2) EC]. It follows from Article [86 EC] that the fact that the grant of exclusive rights is necessary does not of itself deprive an entity's activities of their economic naturc." For details see Chapter 7, which deals with both Articles 81(3) EC and 86(2) EC. It also deals with the specific problematic issues raised by the Wouters proviso, which - as I will explain in Chapter 4.II.4. - is an alien in competition law as it provides for a supplementary way of immunity from the competition prohibition rule of $\Lambda$ rticle 81(1) EC, sec Case C-309/99, Wouters et al. v NOvA, [2002], paras. $97 \mathrm{ff}$.

397 For the position of, for instance, the Dutch lawyers association, see Unger E., (2006), 33.

398 See De Waele S. (European Commission - agent of DG Competition), "Intervention", (10-11.11.2005), 6. See also the position of the Dutch cabinet of ministers that the core values of the notary's office would prevent the function of the office to become a purely commercial one, Ministerie van Justitic, "Publieke functie notaris staat voorop", press release of 03.02.2006.

399 This plea had actually been invoked by the parties in Wouters and discussed by the Court in that case, but the Court did not embrace it, paras. 56-59 of the judgment. 
it would be intrinsic to something that the Court perceives not to represent an economic function (section 2.2.2.). This stance evidently calls for a critical discussion in order to verify whether it is sensible to develop a test that restricts the EC competition rules' universal application (section 2.2.3.). Thirdly, the alleged particulatity of the two professions mentioned shall be put to the possible test (section 2.2.4.), after which preliminary conclusions will be offered (section 2.2.5.).

\subsubsection{Background: the necessary exercise of public authority is not covered by the EC competition rules}

The activities that, for the purpose of competition law, are classified as either economic or non-economic form a pair, but are mutually exclusive - or so one thinks. One type of activities that emetges from the case law is a 'frontier runner' between the two: activities carried out by a public authority. These activities are addressed by the Court to be of an economic nature only if they are not necessarily, and have not always been, carried out by public authorities or bodies. ${ }^{400}$ Inverting this finding leads to the statement that activities necessarily carried out by a public authority do not have a character that justifies the application of EC competition law. ${ }^{401}$ This is the consequence of the consideration that Member States, where they exercise functions of public authority, are no (direct) addressees of the EC competition rules. ${ }^{402}$ This statement is a reservation to the Höfner formula in that it suggests that the necessary exercise of public authority is non-economic (hereafter imperative public authority criterion). However, strictly speaking it is merely an assertion inspired by the wording of the competition rules rather than by drawing a conclusion on the basis of the Höfner rule. As is known the two competition prohibitions in Articles 81 and $82 \mathrm{EC}$ address behaviout of undertakings only.

At this juncture it shall be stressed that not all activities de facto carried out by a public authority are non-economic, but only those that are necessarily done so. The case law often enough confirms that where a public authority engages in an economic activity it will be regarded as undertaking for the purpose of competition law. ${ }^{403}$ This observation can be matched with the comparative market criterion strongly recommended by Advocate General Jacobs who repeatedly emphasises that an activity comes within the ambit of competition law where it could, at least in principle, be carried out by a private undertaking in order to make profits. ${ }^{404}$ This yardstick can be understood as the actual counterpart to activities necessarily carried out by public authorities, meaning that in the latter instance the

400 See the case law in note 337 , and the text with note 333.

401 AG Jacobs in Case C-67/96, Joined Cases C-115/97, C-116/97 and C-117/97 and Case C-219/97, Albany/Brentjens'/Drijvende Bokken, [1999], paras. 314, 330: "it seems to follow from paragraph 22 of the judgment in Höfner that the competition rules do not apply if the activity in question has always been and is necessarily carried out by public entities. [...] it is clear from the general case-law on the concept of undertaking - particularly the judgment in Höfner and paragraph 20 of the judgment in FFS A - that the decisive factor is whether a certain activity is necessarily carried out by public entities or their agents." (emphasis in original).

${ }^{402}$ The statement is not without caveat. For details see Chapter 6.

${ }_{403}$ This was the whole point in Höfner. Case C-343/95, Cali SEPG, [1997], para. 16: "As regards the possible application of the competition rules of the Treaty, a distinction must be drawn between a situation where the State acts in the exercise of official authority and that where it carries on economic activities of an industrial or commercial nature by offering goods or services on the market". See also Case 118/85, AAMS, [1987], paras. 6-16; and Case C-387/93, Banchero, [1995], para. 50

404 See above note 347 . 
activity cannot, at least not in principle, be cartied out by a private undertaking in order to make profits. This approach effectively allows to delimit the respective remit of the two parts to the pair of economic and non-economic activities, therewith striking a fine and objective balance between activities that do and those that do not come within the jurisdictional ambit of EC competition law.

The Court in its turn - arguably in continuation of the functional approach in Höfner has made explicit that the Treaty provisions on competition are applicable to those activities of an entity "that can be severed from those in which it engages as a public authority" ${ }^{405} \mathrm{In}$ certain cases this consideration brings the Court to determine whether the activity in question is sufficiently connected with powers cartied out by or under the control of a public authority. If it is, the Court classifies the activity as being "not of an economic nature justifying the application of the Treaty rules of competition". ${ }^{406}$

This statement is interesting, if not intriguing. ${ }^{407}$ Taking a look at the way the Court reasons in a suitable case, one can observe the following. On the one hand, the Court starts off its analysis with reference to the Höfner formula and the statement that, "In order to determine whether [the activities in question] are those of an undertaking within the meaning of [...] the Treaty, it is necessary to establish the nature of those activities". ${ }^{408}$ On the other hand, however, the Court does not engage in the comparative market critetion - a reflex one would expect in light of the importance that the Court attaches to the Höfner test. Instead the Court chose in the relevant case law to establish the nature of the activities in question as being connected with the exercise of powers that are typically those of a public authority. Therewith the Court actually diverts from the standard described just before of powers necessarily exercised by a public authority. That effect will be discussed more fully shortly below. ${ }^{409}$

What still needs to be pointed out here is that the ensuing finding of the Court is that the activities in question are thus not economic, and therefore do not justify the application of the EC competition rules. ${ }^{410}$ With this determination the Court, in essencc, says the following: are no economic activities that do not belong to the sphere of economic activity. Solving this error of logic ${ }^{411}$ requires to acknowledge that in particular circumstances the Höfner rule, despite its universal chatacter, is simply out-competed, if not overtidden ${ }^{412}$, by

405 Case 107/84, Commission v Federal Republic of Germany, [1985], paras. 14 f.; Case T-128/98, Aéroports de Paris v Commission, [2000], para. 108; Case T-155/04, SELEX/Eurocontrol, [2006], para. 54.

406 Case C-364/92, SAT/ Eurocontrol, [1994], para. 30; Case C-343/95, Cali v SEPG, [1997], paras. 22 f. See also Case C-309/99, Wouters et al vNOvA, [2002], para. 57, with reference, "to that effect", to Joined Cases C-159/91 and C-160/91, Poucet and Pistre, [1993], paras. $18 \mathrm{f}$.

407 NB Referring to an activity as being "not of an economic nature justifying the application of the Treaty rules of competition" is a tautology. The quote can be read as either simply saying that the activity in question is "not of an economic nature", or that the activity in question is "not of a nature justifying the application of the Treaty rules on competition", making the mention of the word "economic" superfluous since economic activities, by definition of the Höfner rule ("every entity"), are covered by the competition rules.

408 Case C-364/92, SAT/ Eurocontrol, [1994], para. 19.

409 In particular see p. $89 \mathrm{f}$.

410 Case C-364/92, SAT/ Eurocontrol, [1994], para. 30: "Taken as a whole, [the activities in question], by their nature, their aim and the rules to which they are subject, are connected with the exercise of powers [...] which are typically those of a public authotity."

${ }_{411}$ Petitio principii or circular statement, by which is assumed what needs to be demonstrated.

412 This conclusion differs from AG Poiares Maduro in Case C-205/03 P, FENIN II, [2006], para. 15, who assumes that "Such a classification [as non-economic] allows, a contrario, the scope of Community competition law to be defined." It is doubtful that 'e contrario' is a helpful shorthand for denominating the line of case law that 
a rival principle, namely that public authority actors (i.e ultimately the Member States) ate no (direct) addressees of the EC competition rules. ${ }^{413}$ This valuation explains why the Court in the relevant case law, which is discussed more fully hereafter, carefully distegarded the comparative market criterion. ${ }^{414}$ The following discussion will help to bring out the principles, if any, that motivate a specific line of case law, and to test whether they can be applied to the liberal professions.

\subsubsection{Critical discussion of the case law disregarding the comparative market criterion}

The instances that the Court so far held to be outside the jutisdictional scope of EC competition law ratione personae can be summarised in two branches: first, where an entity exercises powers of a public authority and, second, where an entity fulfills essential social functions of the modern welfare State under the control of a public authority. ${ }^{415} \mathrm{With}$ regard to the first branch the Court considers certain activities to be outside the sphere of economic activities because of their nature, their aim and the rules to which they are subject. ${ }^{416}$ The second branch concerns activities with social objectives that organise and manage social security and certain insurance schemes in accordance with the principle of solidarity, and

curtails the openness of the Höfner rule, since 'e contrario' is a concept used in logic. One cannot define the scope of competition law e contrario, but only infer from the formulation of the case law referenced in note 337 that activities necessarily carricd out by a public authority are the exercisc of public authority, the author of which (i.e. the Member States) as such is not an addressee of the competition law rules. While this conclusion almost looks like a reasoning e contrario, it is actually a tautology. It shall be granted, however, that the Advocate General intended to express this conclusion. Credit for pointing out the incongruity in using the concept $e$ contrario as short reference goes to Wouter Devroe.

${ }^{413}$ In Case 118/85, $A A M S$, [1987], para 7, the Court recognised "that the State may act either by exercising public powers or by carrying on economic activities of an industrial or commercial nature by offering goods and services on the market. In order to make such a distinction, it is therefore necessary, in each case, to consider the activities exercised by the State and to determine the category to which those activities belong."

414 See also note 333. While in Joined Cases C-159/91 and C-160/91, Poucet and Pistre, [1993], paras. $18 \mathrm{f}$. (to which the Court refers awkwardly in Wouters at para. 57, see above note 406) the Court still classifies an activity as not being an economic activity that relates to "exclusively social functions", it blatantly did not test whether the activity in question could be, or possibly has been in the past, provided under market conditions. The same is true for the specific case law discussed hereafter and referenced in notes 416 and 417. In Chapter 4.I.2.1. this case law is referred to as limiting the jurisdictional scope ratione personae $I$.

415 See Case C-309/99, Wouters et al. v NOvA, [2002], para. 57; AG Kokott in Case C-284/04, T-Mobile Austria, [2007], para.60. Odudu O., (2006), 36 ff., suggests to distinguish the two branches on the basis that "the Court has accepted two activities from which profit can never be made. These are redistribution and the provision of public goods". While this categorisation certainly is helpful to stimulate the discussion of the relevant case law (in particular also from a law and economics point of view), I do not share all of Odudu's findings, and prefer a more careful and balanced consideration, hopefully leading towards an even more ptincipled discussion of the issues involved. The present discussion can give only a glimpse of the conceptual and normative discussion necessary for clarifying which activities cannot, and will not, be provided under market conditions, regardless of the body that provides them, or the legal regime that they are subject to. Later on in section I.2.2.3.2., at p. 102 et seq. this book suggests a new and hopefully workable standard to strike a balance between the comparative market criterion and the impcrative public authority criterion in the form of a negative economic test. An actor motivated by a charitable rather than an economic objective should be allowed to demonstrate that any (financial) reward gained in the exercise of a particular activity does not confer a competitive advantage, butis a mere compensation of costs incurred in the discharge of the charitable obligation.

${ }_{416}$ Case C-364/92, SAT/ Eurocontrol, [1994], para. 30: "taken as a whole, Eurocontrol's activities, by their nature, their aim and the rules to which they are subject" are not of an economic nature. Case C-343/95, Cali $\nu$ SEPG, [1997], para. 23: a non-economic activity "by its nature, its aim and the rules to which it is subject" is connected with the exercise of powers which are those of a public authority. 
under the supervision of the State. ${ }^{417}$ What is common to both branches is not so much that the activities in question could not be provided under market conditions - as pointed out before the Court in the relevant case law did not engage in discussing whether the activities in question could, at least in theory and in accordance with the comparative market criterion, be carried out by a private undertaking in order to make profits. ${ }^{418}$ Rather the relevant case law identified circumstances that it equals with 'non-market' conditions. In consequence, certain activities must not be assimilated to market conduct of private opcrators - despite being remunerated in some form - because, according to the two-branched case law, they are carried out by or under the control of a public authority.

For several reasons explored hereafter it may be doubted whether these two branches are still good case law - and in particular after the 2001 judgment in the Glöckner case - or even suitable to apply to the case of the professions. In preparing to discuss both issues a brief look shall be taken at two particular cases of the first branch on entities arguably participating in the exercise of powers of public authorities. This exercise will allow to better understand also the concept of essential functions of a modern welfare State underlying the second branch, however without digression into the specific area of social security and insurance schemes. ${ }^{419}$ The relevant cases to be discussed are $S A T /$ Eurocontrol and Cali ${ }^{420}$, which were decided in the mid-1990s. The specific problems they raise with regard to the jurisdictional scope of the competition law rules are introduced in the following (section 2.2.2.1.) before they are compared to the more recent case law in Glöckner (section 2.2.2.2.) and criticised more fundamentally in sections 2.2.2.3. and 2.2.3.

\subsubsection{Assessing the 1994 case SAT/Eurocontrol and the 1997 case Cali}

Eutocontrol is an organisation responsible for the safety of air navigation in certain areas of the Community. ${ }^{421}$ The airline company SAT challenged under EC competition law the amount of route charges that Eurocontrol wanted to collect for flights made by SAT. The Court did not follow this approach since it found that Eurocontrol did not qualify as an

417 Joined Cases C-180 to 184/98, Pavlov, [2000], para. 118; Case C-218/00, INAIL, [2002], paras. $37 \mathrm{ff}$. The following cases have developed on the principle of solidarity, i.e. the absence of any direct link between the contributions paid and the benefits granted: Joined Cases C-159/91 and C-160/91, Poucet and Pistre, [1993], para. 18; Case C-218/00, INAII, [2002], para. 31: "According to settled case-law, Community law does not affect the power of the Member States to organise their social security systems", with reference, in particular, to Case C158/96, Kobll, [1998], para. 17, and Case C-157/99, Geraets-Smits and Peerbooms, [2001], para. 44. Sec also Case T319/99, FENIN I, [2003], upheld on appeal. Conversely, in the following cases social security and insurance schemes were held to be undertakings for the purpose of competition law: Case C-244/94, FFS A vMAP, [1995]; Case C-67/96, Albany, [1999], para. 86; Case C-219/97, Drijvende Bokken, [1999], para. 76; Joined Cases C-115 to 117/97, Brentjens', [1999], para. 86; Joined Cases C-180 to 184/98, Pavlov, [2000], para. 119.

418 See above section I.2.2.1, and text with note 347.

419 For the latter see the cases referenced in note 417. See also Case T-168/01, GlaxoSmithKline, [2006], paras. $104 \mathrm{ff}$., on prices set or controlled by the public authorities. There the Court emphasises that "it is only where the sector in which the agreement is applied is subject to regulations which preclude the possibility of competition that might be prevented, distorted or restricted by that agreement that Article 81(1) EC is inapplicable", refcrring to Joined Cases C-359/95 P and C-379/95 P, Commission and France $\nu$ Ladbroke Racing, [1997], paras. 32 ff. 'To the latter effect also AG Jacobs in Case C-198/01, CIF ע AGCM, [2003], paras. $66 \mathrm{f}$.

420 See above note 416.

421 Eurocontrol is the European Organisation for the Safety of Air Navigation. This civil and military organisation, which currently numbers 37 States as members, has as its primary objective the development of a seamless, pan-European AirTraffic Management (ATM) system, <http://www.eurocontrol.int/corporate/pub $\mathrm{lic} /$ standard_page/org_ourorganisation.html>, last visited on 21.10.2006. 
undertaking. According to the Court Eurocontrol "carries out, on behalf of the [...] States, tasks in the public interest [that are] aimed at contributing to the maintenance and improvement of air navigation safety". The Court specified that taken as a whole, Eurocontrol's activities, "by their nature, their aim and the rules to which they are subject, are connected with the exercise of powers [...] which are typically those of a public authority." ${ }^{422}$ The argument used to deny the applicability of EC competition law is thus based on the exercise of public authority. This emphasis recalls the concept of sovereign immunity, a principle of public international law, in which a territotial aspect determines its scope. The territorial aspect in $S A T /$ Eurocontrol is apparent. ${ }^{423}$ While Eurocontrol is an international organisation established by a multilateral international convention, the organisation has a regional character, and its competences to control air traffic can be located on the map.

In public international law the principle of sovereign immunity traditionally is one of procedural law. This means that it can be invoked by the defendant State to deny the jurisdiction of a national court over another, i.e. the defendant State (jurisdictional immunity - par in parem non babet imperium). However, in SAT/Eurocontrol the ECJ did not decline jutisdiction over an international organisation, but left that question, if necessary, to be addressed by the Belgian Court of Cassation, which had made the request for the preliminary ruling to the ECJ. ${ }^{424}$ In particular, the ECJ took the view that it was not asked to interpret the international convention that established Eurocontrol - in which case it would indeed not have been competent to hear the case on the validity of an act taken by an international organisation in conflict with EC law, since there is no hierarchy between different international legal orders in the absence of an arbitration court to which parties accept to abide. Instead, the Court in $S A T /$ Eurocontrol underlined that it was asked within the boundaties of the procedure for a preliminary ruling under Article $234 \mathrm{EC}$ to interpret the EC Treaty rules on competition.

\section{The exercise of public authority as a substantive consideration}

In rejecting to qualify Eurocontrol as an undertaking within the meaning of competition law the Court thus referred to the exercise of public authority as a substantive consideration. The judgment therewith gives the distinct impression of being inspired by an act of State doctrine, according to which the lawfulness of legislation is not questioned in the courts of another State. ${ }^{425}$ The Court has been criticised for this approach, due to the procedural tather than substantive legal character of the principle of State sovereignty. Basically, the case has

422 Case C-364/92, SAT/ Eurocontrol, [1994], para. 30. In earlier decisions the ECJ had already recognised Eurocontrol to exercise public authority, Case 29/76, LTU Eurocontrol, [1976];Joined Cases 9 and 10/77, Bavaria Fluggesellschaft, [1977].

423 The Court referred to Article 1 of the Convention on International Civil Aviation, signed at Chicago on 7 December 1944 (United Nations Treaty Series, Vol. 15, No 105): "The Contracting States recognize that every State has complete and exclusive sovereignty over the air space above its territory". The Court found, "It is in the exercise of that sovereignty that the States ensure, subject to compliance with the provisions of the applicable intemational conventions, the supervision of their air space and the provision of air navigation control services", para. 20 of the judgment. Morcover, the Court stated that Eurocontrol would have been vested with particular rights and powers that derogate from the ordinary law, in the exercise of which it must ensure, among others, the territorial security of the Contracting States concerned, para. 24 of the judgment.

424 Paras. 8-11 of the judgment in $S A T /$ Eurocontrol.

425 Vcdder C. / Folz H.-P., (1996), 113 f.; Jennings RY. / Watts A.D., (1992), 368. 
been criticised for not having observed principles of public international law. ${ }^{426}$ If it had, the conclusion to be drawn by the ECJ should have been either to decline its jurisdiction ot, since it did not do so, to refrain from making a reference to the exercise of public authority in view of striking a distinction on the substance of EC (competition) law. In essence the critique thus is that the Court mixed aspects of procedural and substantive law.

A further observation may be juxtaposed to the previous. If, for the sake of the atgument, one grants that the ECJ had not so much been influenced by the specific character of Eurocontrol as a subject of international law, the language of the Court's further reasoning on the substance suggests that Euroconttol could equally have been qualified as 'public undertaking, ${ }^{427}$ In paras. $26 \mathrm{ff}$. of the judgment, and in particular paragraph 29, the Court underlined that Eurocontrol would not really have any influence, in particulat, over the amount of the route charges it charges for the control of air navigation, but that it is the Contracting States that set the amount of the rates per unit. As such this observation should not turn the balance in favour of a non-applicability of EC competition law. More specifically Article 86(1) EC, which addresses public undertakings, evidences that even this particular type of undertakings is generally subject to EC competition rules. ${ }^{428}$ The same is true for the further category of undertakings entrusted with the operation of services of general economic interest referred to in Article 86(2) EC, under which Eutocontrol may have been fitted. ${ }^{429}$ The $S A T /$ Eurocontrol judgment thus is, to say the least, controvertible. Before critically analyse in how far it lends itself to contribute to the establishment of a more general rule that could be applied to other sectors, like the activities of liberal professions, the case Cali shall be briefly presented.

Cali concerned anti-pollution surveillance services in an oil port. The Court considered that these services would be "a task in the public interest which forms part of the essential functions of the State as regards protection of the environment in matitime ateas". ${ }^{430} \mathrm{It}$ continued, "Such surveillance is connected by its nature, its aim and the rules to which it is subject with the exercise of powers relating to the protection of the environment which are typically those of a public authority." With an explicit reference to the (until then unprecedented ${ }^{431}$ ) case law $S A T /$ Eurocontrol the Court concluded that the anti-pollution surveillance "is not of an economic nature justifying the application of the Treaty rules on competition". The finding in Cali may again be explained with reference to the idea of tertitorial sovereignty - although there is no actual indication in the judgment itself that the overall protection of the environment could not be separated from the territory of the State on which the surveillance services has to be secured with the means of public authority.

\footnotetext{
426 Seidl-Hohenvelder I., (1994), $259 \mathrm{ff}$.

427 Moussé J., (1994), 23.

${ }_{228}$ For details see Chapter 6.

429 For details on Article 86(2) EC see Chapter 7.II.

430 Case C-343/95, Cali $\nu$ SEPG, [1997], para. 22.

431 I do not count Joined Cases C-159/91 and C-160/91, Poucet and Pistre, [1993], paras. 16-19, as a precedent for $S A T /$ Eurocontrol as the Court followed a distinct, while similar, approach. In Poucet the Court stated (after reiterating the Höfner tule) that the activity at stake (management of social security system) was an "exclusively social function ... based on the principle of national solidarity" and "accordingly, [was] not an economic activity" (emphasis added). This tesolute result does not allow for the sophisticated consideration that an activity may not be of a character justifying the application of EC competition law, irrespective of a patent economic clement to it, see above note 407 and the text presented therewith.
} 


\section{The exercise of public authority corelating to classical State prerogatives}

More precisely Cali, and also $S A T /$ Eurocontrol for that sake, may be understood to carry the idea of classical prerogatives ${ }^{432}$ that States assume on the basis that certain activities are perceived as inherently connected with the exercise of public authority. These prerogatives are corollaries of territorial sovereignty. ${ }^{433}$ Sovereignty has two aspects, an external and an internal one. Examples of external sovereignty telate to national and public security, defence, customs control on outgoing ships in 'contiguous zone', or police controls in tertitorial waters. ${ }^{434}$ Internal sovereignty telates to the prerogatives exercised by State authorities within the botders of the State and in relation to the people subject to its jurisdiction. This includes again public security; for instance, the investigation and prosecution in criminal matters very closely link to the authority exercised by a State within its borders, and so do particular police powers. ${ }^{435}$

Arguably, the exercise of anti-pollution surveillance services in Cali may be perceived as coming close to the exercise of particular police powers, namely where the task of protecting the environment needs to be secured with the means of public authority, and thus relates to internal sovereignty. ${ }^{436}$ This aspect can also be found back in $S A T /$ Eurocontol, where the Court made explicit reference to Eutocontrol being "vested with rights and powers of coercion which derogate from ordinary law and which affect users of air space." 437

\section{A seeming objective standard revealing a case by case approach}

As indicated before, the question to be addressed here is, first, whether a more general rule can be derived from the two cases, and if so which. The subsequent question is whether and how such rule applies to possibly disqualify professional activities from the sphere of economic activity. ${ }^{438} \mathrm{~A}$ first observation is that - not least due to the relativity of the concept of undertaking - it can be assumed that $S A T /$ Eurocontrol and Cali have been very much determined by the factual circumstances of the individual cases. This makes it generally difficult to deduce universally valid rules that would allow an easy differentiation between activities that should, and those that do not, qualify for an prima facie exception from the universal concept of undertaking within the sense of competition law. ${ }^{439}$ In particular it may

${ }^{432}$ Frenz W., (2006), para. 371.

433 The three classical clements of the concept of State comprise territory, people and authority, see Jellinek $G$., (1914), 394-434.

434 Custom controls of ships in the contiguous zone, i.c. the 12 miles zone beyond territorial waters, on outgoing ships, or police controls in territorial waters are classical prerogatives of the State that are corollaries of territorial sovereignty and the concept of State immunity.

435 Case C-405/01, COMME, [2003], para. 42, referring to police powers and powers connected to the maintenance of safety, powers of investigation, coetcion and punishment that go beyond the requirementmerely to contribute to maintaining public safety by which any individual is bound. Sce however AG Jacobs in Case C283/99, Commission v Italian (private security services), [2001], paras. 36, $39 \mathrm{ff}$., stating that private security guards are merely assisting the police and in that are not exercising greater powers than individuals, who, in particular, have powers to arrest suspected malefactors.

436 See before note 435.

437 Para. 24 of the judgment.

138 See Case C-309/99, Wouters et al. v NOvA, [2002], para. 57.

139 Frenz W., (2006), para. 370. AG Stix-Hackl in Case C-233/00, Commission v French Republic (environmental information), [2003], para. 51, points out that the law of Cali is limited to the statement that surveillance involved with environmental protection is typically connected with the exercise of public authority, but that it does not 
be suspected whether the main concern of the Court in $S A T /$ Eurocontrol and Cali was not to interfere too drastically with the, as such crucial, tasks of air traffic control and surveillance services in environmental protection, respectively. ${ }^{440}$ In the first case the Court may have had the practical possibility to avoid interference by not assuming jurisdiction under public international law (and actually not to mix considerations of procedural and substantive law, see above), albeit at the price of laying itself open to the reproach of declining its primary obligation to render justice. However, in Cali this clearly was no option.

The decisive argument that the Court used in both cases was that the respective activities were tasks in the pubic interest and where - by their nature, their aims and the rules to which they are subject - connected with the exercise of powers of a public authority. ${ }^{441}$ The threefold reference (nature, aims, rules) appears to establish an objective standatd for the determination of whether a particular activity concerns the exercise of public authority, itself outside the application of competition law. What the Court therewith says is that, first of all, the aims and nature of a particular activity and, secondly, the legal tegime to which the activity in question is subject are indicators of public authority.

What is problematic in both cases, however, is that the Court seems to equal the exercise of public authority with public interests. ${ }^{442}$ While public authority should indeed be exercised in the public interest in order to be legitimate, not every activity in the public interest necessitates the exercise of public authotity. Consequently, while the first criterion on the aims of an activity may indeed help to indicate a public interest involved, a public interest component as such is not sufficient to establish, in accordance with the imperative public authority criterion, that the activity in question would necessatily be connected with the exercise of public authority and therewith outside the sphere of competition law. Secondly, the reference to the nature of an activity seems to be somewhat cryptic, raising the suspicion whether it serves the purpose of veiling that it does not carry a reasoning but a contention. On closer investigation the reference to the public interest in the two judgments seems misplaced in the sense that the EC Treaty itself provides for taking account of considerations of the general interest within the field of competition law: Article 86(2) EC. However, this article is to be applied at a later stage of scrutiny only: it provides for an exemption from the, in principle, applicable competition rules if the application of the latter should obstruct the performance, in law ot in fact, of the particular general interest tasks assigned to an entity. ${ }^{43}$

The third criterion on the rules to which an activity is subject seems to be an even more problematic criterion for establishing whether an activity is connected with the exercise of public authority. In fact, granting that the legal regime may make a difference in establishing

extend to cover any activity that is somchow connected to the exercise of public authority (in casu information on the environment). See also Competition Appeals Tribunal - Case 1006/2/1/01 "BetterCare Group Ltd v DGFT" [2002], CAT 7, paras. $176 \mathrm{f}$. See also Schwarze J., (2001), $72 \mathrm{ff}$.

440 A more elegant way of taking account of the value of such crucial tasks would certainly have been to use the Treaty provision that provides for the possibility to remove certain tasks from the sphere of competition law if the application of the latter obstructs their performance, in law or in fact Article 86(2) EC. This approach basically had been adopted in Case 10/71, Muller (Port of Mertert), [1971], paras. 10 ff., where the Court was not prepared to test against competition law principles an entity that first, maintained close links with the public authorities and, second, was responsible for ensuring the navigability of the State's most important waterway. For details on Article 86(2) EC and its relevance in the field of liberal professions, see Chapter 7.II.

441 AG Tesauro in Case C-364/92, SAT/ Eurocontrol, [1994], paras. 22 ff., 27, 30; Case C-343/95, Caliv SEPG, [1997], paras. $22 \mathrm{f}$.

442 Ibid.

443 See already note 440 . 
whether a particular entity is within or without the jurisdictional scope of the competition rules is problematic in two ways: first, it gives Member States the possibility to withdraw from the universal field of application of competition law entities that it prefers not to be subject to matket conditions. At that stage the concept of undertaking will cease to have a Community character independent of the interpretation thereof in the different Member States. Secondly, while such consideration may in theory have a certain appeal in light of the principle that the EC competition rules do not apply to $\mathrm{Mcmber}$ States, such consideration not only is an inroad to Article 86(2) EC, but also to the Höfner formula, which emphasises that an entity engaged in an economic activity comes within the ambit of competition law regardless of the legal status of the entity. In this respect the Höfner rule and Article 86(2) EC should be seen as complementary. Whete the former adopts a universal approach allowing the scrutiny of activities involving the public interest, the latter allows to reconsider whether the application of the Treaty with its competition rules should be prevented in order not to obstruct the provision of services of general economic interest. Exempting from the jurisdictional scope of competition law activities that involve powers exercised only typically, but not necessarily, by or under the control of a public authority (even if presumably exercised in the public interest) would risk the practical consequence that general (economic) interest tasks would not fall under the competition prohibitions in the first place. ${ }^{444}$ If that were the case, the explicit exemption of Article 86(2) EC would be devoid of any practical application. Without anticipating on the substance of Article 86(2) EC $\mathrm{E}^{445}$ this consideration of the systematic structure of the EC competition provisions reinforces the idea that any exception to the concept of undertaking must be interpreted strictly.

It thus must be challenged whether the law of $S A T /$ Eurocontrol and Cali is an appropriate, i.e. objective one that could be extrapolated to other sectors. In particular it is doubtful whether it was inevitable to classify the respective activities in $S A T /$ Eurocontrol and Cali as essential domains of societal order outside the jurisdictional scope of Articles 81 and $82 \mathrm{EC}$. More specifically one should be wary of the fact that the perception of essential functions of State is relative itself and varies over time. What may be regarded as essential at times, may be regarded as negotiable at others. As pointed out earlier, a State is not hindered to contract out, for instance, and as has happened before, its military defence ${ }^{446}$, or the administration of prisons ${ }^{447}$ Even the rendering of justice is not necessatily integral with public authority. ${ }^{448}$ It is therefore not evident that there had been any necessity to decide the cases $S A T /$ Eurocontrol and Cali in the way they were.

\footnotetext{
444 See AG Fennelly in Case C-266/96, Corsica Ferries II France, [1998], note 72, stating with regard to the activity of undertakings rather than of associations that a supposed public service objective does not suffice to "denude" a service in the general economic interest of its inherent commercial nature. On the particular question whether also associations can invoke Article 86(2) EC, or whether the latter is strictly limited to undertakings due to its wording and on the ground that the concept of undertaking as a Community concept is the same for all competition provisions of the Treaty, see Chapter 7.II.1.2.2. - Repeatedly critical also AG Jacobs in Case C475/99, Glöckner, [2001], para. 69; AG Jacobs in Case C-222/04, Cassa di Risparmio di Firenze, [2006], paras. 76 to 83.

445 For details see Chapter 7.II.

446 See above note 338 .

447 See above note 339.

448 Sce above note 340. Differently obviously AG Léger in Case C-280/00, Altmark, [2003], para. 63.
} 


\section{$A$ contrasting example from the aviation control sector}

As explained before, it is striking that the Court in $S A T /$ Eurocontrol and Cali did not scrutinise whether the activities in question could effectively be offered under market conditions and did thus not apply the comparative market criterion - or even the attenuated market participation criterion according to which an activity is economic if it is, or has been in the past, provided under market conditions. ${ }^{449}$ More specifically the Court in $S A T /$ Eurocontrol clearly disregarded indications that private parties could, at least in principle, provide air traffic control in order to make profits. One has to acknowledge that the question of economic activity in that case could have been assessed differently. ${ }^{450}$ The example of the UK authorities proves the point who have realised the privatisation of air traffic control. In 1996 the National Air Traffic Services Limited (NATS) has been established as a Company Act company and turned into a Public Private Partnership in 2001. In August 2005, NATS extended to win its first overseas contract with a three-year agreement to provide air traffic control services for the Royal Air Force Gibraltar. In March 2006, NAT'S re-branded to demonstrate its coming of age as a commcrcial, customer-focussed service provider. ${ }^{451} \mathrm{It}$ is noticeable that the UK privatisation was first mooted in 1992 , i.e. at a time when the case $S A T /$ Eurocontrol just had been referted to the ECJ for a preliminary ruling. The point to be made in this regard is that already at the time there had been room for assessing the circumstances of $S A T /$ Eurocontrol in respect of the Höfner rule, and more particularly the comparative market ctiterion. Notwithstanding, in 1997 the Court repeated the approach adopted in $S A T /$ Eurocontrol, the year in which the European aviation market was liberalised with the removal of toute licensing restrictions. ${ }^{452}$ In both cases the Court chose to rather apodictically state that the respective activities were connected with powers that are "typically those of a public authority" 453 - without explaining so much why it would be so 'typical' to attribute powers of ait traffic control, or anti-pollution services, to State authority. ${ }^{454}$

449 This is one of the major critiques that the case law of $S A T /$ Eurocontrol and Cali counter. With regard to the second branch of case law, which restricts the universal applicability of $E C$ competition law (sec above note 417), the Court did not refer to the comparative market (participation) criterion either, see Joined Cases C-159/91 and C-160/91, Poucet and Pistre, [1993], paras. 19 to 21.

${ }_{450}$ The applicant party in $S A T / E$ urocontrol effectively put the argument forward that in some Member States it is private undertakings that exercise air navigation control, and, in the alternative, that at least the collection of charges, which gave rise to the dispute in the particular main proceedings, is a commercial activity. The applicant party referred to the fact that Eurocontrol had brought actions for tecovery before the Brussels Commercial Court, see para. 15 of the ECJ's judgment.

$451<\mathrm{Http}: / /$ www.nats.co.uk/>.

452 The Community aviation market has been liberalised in particular by Council Regulation (EEC) No 2408/92 of 23.07.1992 on access for Community air cartiers to intra-Community air toutes, abolishing the restrictions regarding cabotage with effect from 1 April1997, thus permitting air carriets from all Member States access to all intra-Community routes for the domestic and international transportation of passengers, cargo and mail. 453 Case C-364/92, SAT/ Eurocontrol, [1994], para. 30; Case C-343/95, Cali v SEPG, [1997], para. 23.

454 In the field of social security and insurance schemes (see above note 417 ) basically the same question can be raised, namely why certain social security and insurance activities that are supervised by the State do not have to meet the comparative market criterion. If such activities shall not be put to the test of competition law, it would be more consistent to require that they fulfil the criteria of Article 86(2) EC (sce above note 440). Very similar AG Jacobs in Case C-475/99, Glöckner, [2001], paras. 67 to 69, with reference to Case C-67/96, Albany, [1999], para. 86, and AG Jacobs in Case C-222/04, Cassa di Risparmio di Firenze, [2006], paras. 76 to 83. See, however, AG Poiares Maduro in Case C-438/05, Finnish Seamen's Unionv Viking Line, [2007], para. 27. 


\section{Diverting from 'necessary' to 'typical' powers of public authority}

Earlier it has been explained that in particular circumstances the Höfner rule, despite its universal character, is out-competed or overridden by the rival principle that public authority actors are no (direct) addressees of the EC competition rules. ${ }^{455}$ That assessment explains why the Court, in spite of using the word 'economic' in its finding, effectively recognised that the activities in question could be excluded from the ambit of competition law regardless of the economic character they evidently (also) had. ${ }^{456}$ The Court resolved the tension between, on the one hand, the economic nature of the activities in the two cases discussed and, on the other, the exercise of public authority as follows. In Cali the Court stated that the levying of a charge for the surveillance services was an integral part of the activities that it had found to be connected with the exercise of powers that would typically be those of a public authority. ${ }^{457}$ In $S A T /$ Eurocontrol, the Court held that the collection of route charges "cannot be separated from [Eurocontrol's] other activities", which the Court in turn qualified as outside the economic sphere. ${ }^{458}$

At this juncture it is necessary to point out that what is seen here as a problematic stance of the Court could actually draw on an awkward formulation in earlier case law, and in particular the Höfner ruling itself. In that case the Court established the economic nature of the activity in question not least by reference to the fact that it had "not always been, and is not necessarily, carried out by public entities". ${ }^{459}$ In note 337 of this chapter (and section I.2.2.1.) I have explained that this formulation allows to infer that, if an activity is necessarily carried out by or under the supervision of public authotity, it is not covered by the competition law rules (coined here as imperative public authotity criterion). What the Court in SAT/Eurocontrol and Cali does, however, is to conveniently neglect the word "necessarily" to the benefit of "typically", therewith granting a margin within which it is the de facto practice by public authorities that determines the jurisdictional scope of competition law tather than objective criteria. This meets a fundamental critique. $S A T /$ Eurocontrol and Cali effectively undermine the fine balance between those activities that do, and those that do not, come within the jurisdictional ambit of EC competition law. ${ }^{460}$ The law of the two cases seems to be that a systematic application of the competition rules should be curtailed in recognition of public interest circumstances, therewith overruling the comparative market criterion.

In light of the subsequent ruling in Glöckner it is doubtful, however, whether $S A T /$ Eurocontrol and Cali are still good case law. Generally speaking, the fact that certain activities are exercised under the supervision of State authorities does not rule out that service providers compete under market conditions - albeit under particularly regulated

455 See above text with note 407.

456 Moussé J., (1994), 32. See also above note 431 on Poucet and Pistre.

457 At para. 24 of the judgment in Cali (emphasis added).

458 At para. 28 of the judgment in $S A T /$ Eurocontrol (cmphasis added).

459 Case C-41/90, Höfner and Elser, [1991], para. 22 (emphasis added).

460 See above note 347. The Court's view in SAT/Euroconirol and Cali collides certainly with AG Jacobs in Case C-67/96,Joined Cases C-115/97, C-116/97 and C-117/97 and Case C-219/97, Albany/Brentjens' DrijuendeBokken, [1999], para. 330: "Contrary to the contentions of the [parties], [the issue on the concept of undertaking] is to be distinguished from the separate question whether and to what extent the grant of certain exclusive rights is necessary for the fulfilment of tasks in the public interest. The latter question is only relevant for the purposes of Article [86(2) EC]. It follows from Article [86 EC] that the fact that the grant of exclusive rights is necessary does not of itself deprive an entity's activities of their economic nature." (Emphasis added). 
conditions. ${ }^{461}$ Put differently, and as the Court effectively held in Glöckner, "Public service obligations may, of course, render the services provided by a [...] organisation less competitive than comparable services rendered by other operators not bound by such obligations, but that fact cannot prevent the activities in question from being regarded as economic activities." ${ }^{362}$

\subsubsection{Contrasting the case law with the 2001 case Glöckner}

The Glöckner case concerned the operation of ambulance transport services in Germany, which is subject to public law regulation and licensing requirements. While the operation of ambulance transport services is not itself an activity of medical practitioners, the Glöckner case is of interest for present purposes as it concerned services connected with the maintenance of the medical care system. This maintenance could serve as an argument to exclude from the jurisdictional ambit of competition law activities that are connected therewith. More particularly, the coordination of ambulance transport services could potentially be compared to the control and coordination activities in the sector of air traffic because it equally is required to take place in the control toom. The organisation of ambulance services is sensible for a good functioning of a medical care system, just as air traffic control makes sense to prevent major catastrophes ('externalities' in the language of economic theory). Notwithstanding, the Court in Glöckner and $S A T /$ Eurocontrol respectively drew different conclusions when answering whether the (economic) activities in question justified the application of competition law, and thus filled the concept of undertaking differently. The diverging finding in Glöckner and $S A T /$ Eurocontrol may be explained by the incontrovertible evidence that the activity of ambulance transport had been carried out in the past by private undertakings with a view to making profits. ${ }^{43}$ In light of the UK example of privatising air traffic control this seems a cold comfort to come to terms with the $S A T /$ Eurocontrol case though.

Strikingly enough the reasoning applied in $S A T /$ Eurocontrol and Cali conceivably could have been parallelled in the Glöckener case by arguing that ambulance transport services are intrinsically connected with an essential function of the modetn welfare State. To that end one could atguably take the view that the maintenance of an effective health care system 'typically' is subject to the control by public authorities. The fact that ambulance transport had been catried out to earn money could, in light of the judgments in $S A T /$ Eurocontrol and Cali, have been qualified as integral to the activity and thus, in the logic of $S A T /$ Eurocontrol and Cali, not necessarily have formed an obstacle to exclude ambulance transport from the ambit of competition law. However, as pointed out, the Court has not adopted this stance in Glöckner. Since the Court did not repeat this approach, my contention therefore is that the opportunity has emerged for the case law to develop towards a more coherent approach concerning the balance between activities that are necessarily carried out by or under the

461 See the examples mentioned in notes 338,339 and 340. It has been argued that the air traffic surveillance services of Eurocontrol was not susceptible to competition because having it carried out by several operators would lead to an unwarrantable risk in air traffic, AG Tesauro in Case C-364/92, SAT/ Eurocontrol, [1994], para. 13; Seidl-Hohenvelder I., (1994), 271. However, even if that were true, competition could be triggered at the gate by conducting public procurement procedures.

462 Case C-475/99, Glöckner, [2001], para. 21, therewith sharing the view that AG Jacobs adopted in para. 69 of his opinion in the case.

${ }^{463}$ Case C-475/99, Glöckner, [2001], para. 20. 
control of public authority (i.e. the imperative public authority ctiterion), and those that can, at least in principle, be provided in order to make profits (i.e. the comparative market criterion).

\subsubsection{Activities not to be carried out under market conditions}

In matching both the comparative market criterion and the imperative public authority criterion the relevant question is whether and which activities cannot be, and for that sake are not, carried out under competitive market conditions. A conceivable point of departure is the following. Modern societies are organised in a system of State authorities, which ideally safeguard that the interests of socicty at large ate effectively realised. ${ }^{464}$ The realisation of such interests, e.g. internal and external security, or legal certainty and a stable and effective judicial system, can be defined as essential to the functioning of society, and hence of the State. Certainly, these responsibilities ate of fundamental value to the local, national and international economy. ${ }^{465}$ Not only that they cause costs, which have to be gained by someone, they are more fundamentally a necessary condition for a reliable and lasting, or sustainable, development of economic life as the basis for our physical existence. They raise the question of whether activities related to their realisation are truly devoid of an economic character.

\section{Activities genuinely devoid of an economic character?}

To take the extreme example of political discussion, which eventually leads to legislation (or the absence thereof), it should be clear that, in a democracy, it cannot be negotiated on a potential market for political activism. Nevertheless, after the Second World War parliamentary activities in the western wotld have become remunerated. This example could lead to two, though different, conclusions. One may be, and in fact support the Court's approach in $S A T /$ Eurocontrol and Cali, that certain activities, even if remunerated, are not economic in nature. The second conclusion one could draw, and which is actually outside the scope of the present research, is that parliamentary activities should not be remunerated for they are not economic in nature, but a responsibility and duty towards society at large that should remain immaculate of any financial in terest, i.e. to gain one's living through the presence in parliament.

The example can be viewed from yet another perspective that is inspired by an economic analysis of the law, and in particular by the theory of public choice. This theory is concerned with the question how individual preferences can be met through voting rules and other procedures adopted by institutions for collective decision-making, and to understand the consequences that these have for social welfare more generally. ${ }^{466}$ In particular Stigler ${ }^{467}$ has

464 This idealised conception, and also that such tasks are necessarily exercised by public authorities, is broadly accepted, see for instance Odudu O., (2006), $36 \mathrm{ff}$., reflecting traditional views. For a fresh view on the underlying causes and conditions for a fruitful and productive polity, see Martin P.C. / in collaboration with LüftlW., (1986), $225 \mathrm{ff}$., and Heinsohn G. / Steiger O., (1996), $418 \mathrm{ff} ., 436 \mathrm{ff}$.

465 See also Case T-155/04, SELEX/Eurocontrol, [2006], para. 60, concerning the development of technical standards for air traffic management (ATM) systems to ensure reliable transfer of control of flights between national control bodies. The Court finely distinguishes that "the need to adopt standards at an international level does not necessarily mean that the body which sets those standards must" be a public authority.

466 Ogus A., (2006), $16 \mathrm{f}$.

467 Stigler G.J. / Friedland C., (1962), published the results of an empirical study of the electricity industry which 
made a clean break with the traditional assumption that regulation (i.e. parliamentary activities in the example chosen here) was introduced for, and served to fulfil, the public interest and not the interest of those, mainly industries and firms, whose power it was designed to curb.

"In the 1971 paper, Stigler drew on the empirical study to formulate a theory of regulation. Its central hypothesis is simple: the state by means of its coercive power can impose losses and confer benefits on different sectors of the community and it does so through its legislative and regulatory powers. Those exercising power wish to preserve it, for which political supportis essential. That political support can be offered as a 'price' by groups who benefit by the legislation. In short there is a 'market' for legislation in which, like any other markct, trade takes place on the basis of supply and demand."

The merit of the public choice theory is to point out that the interests involved in tule setting justify the general prediction that legislation will tend to favour professional and industrial groups more than those representing, for example, consumers or taxpayers, whose interests are much more diffuse. ${ }^{469}$

\section{More case law to be contrasted: the 2006 case SELEX}

So far the case law has not proved to be open to these considerations of general ptediction as has evidenced most recently the CFI in SELEX. ${ }^{470}$ This case again concerned activities of Eurocontrol, this time however not its ait traffic controlling functions but its task to produce (but not adopt) standards and technical specification relating to air traffic management (ATM) systems, so that the control of flights is reliably transferred between national control bodies. Starting from the consideration that the only purchasers of standards prepared by Eurocontrol could be the States in their capacity as air traffic control authorities, the CFI took the view that the case did not concern an activity that would be effectively offered on markets as are goods and services. The Court therefore ruled that SELEX had not demonstrated that there is a market for technical standardisation services in the sector of ATM equipment. ${ }^{471}$

This finding requires a number of observations. First of all, the Court's reasoning evidences a lopsided emphasis of the market participation criterion ${ }^{472}$, therewith strictly limiting the comparative market criterion derived from the Höfner tule. Even though and secondly, the point made by the CFI can be disproved on factual grounds, namely on the basis of the aforementioned example of the UK liberalisation of air traffic control with the establishment of NATS. ${ }^{473}$ Thirdly, the approach chosen by the CFI supposes that a market exists only if parties, whether private or public, purchase goods and services outside the capacity of a public authority. The CFI therewith not only disregards the comparative market criterion favoured here but also omits the aspect of activities being necessarily exercised by public authorities. In order to respect the Höfner rule and the imperative public authority criterion formulated in that same judgment, the CFI in SELEX could merely have stated that there is no economic activity where purchases are necessarily made within the capacity of

showed that the regulatory system did not, as was its purpose, lead to lower prices.

468 Ogus A., (2006), 17 f., referring to Stigler G.J., (1971).

469 Posner RA., (1974), referenced by Ogus A., (2006), 18.

470 Case T-155/04, SELEX/Eurocontrol, [2006], paras. 59 ff., 61.

471 Paras. 59 and 61 of the judgment in SELEX.

472 See above page 68.

473 See above page 88. 
a public authority. However, the CFI did not scrutinise this latter aspect as demonstrates its distegard for the UK example of NATS.

Fourthly, while the SELEX judgment differs from the judgments in $S A T /$ Eurocontrol and Cali, it shares at the same time a mote fundamental point criticised here. The difference lies in that the CFI in SELEX did not extend on the yardstick developed by the ECJ in $S A T /$ Eurocontrol and Cali that is based on an activity's nature, its aim and the rules to which it is subject. Taking the comparative market criterion and the imperative public authority criterion as points of reference, which lie at the two ends in determining the jurisdictional scope of competition law, the yardstick of $S A T /$ Eurocontrol and Cali can be located somewhere in between those two ends.

\section{Diagram (no. 3) on the latitude of the jurisdictional scope of (EC) competition law}

Comparative

market criterion
Imperative public authority criterion

\section{Market participation criterion? $1-$ \\ $\rightarrow$ Powers typically exercised by public authority}

It is in this that the judgment in SELEX shares a commonality with $S A T /$ Eurocontrol and Cali. The market participation criterion, on which the CFI heavily telied, ranges between the same ends. In actual fact the CFI's approach confirms the diagnosis made before, namely that the Court at times disregards an activity's economic character, therewith abstaining from striking the balance between the comparative market criterion on the one hand and the imperative public authotity criterion on the other. Instead, the case law evades this issue by watering down the comparative market criterion to one of actual market participation (SELEX) or by watering down the imperative public authotity criterion through the introduction of an even further criteria of powers "typically" exercised by public authorities ( $S A T /$ Eurocontrol and Calì). A consistent application of the approach expressed in all three judgments would lead to consider that, for instance, the outsourced administration of prisons $^{474}$ could not qualify as economic activity, because it is public authorities that 'purchase back' the related services in their capacity as a public authority. Such opinion clashes with the opinion of Advocate General Jacobs, referred to before and which is shated in this book, who firmly puts forward that

"an entity should qualify as an undertaking for the purposes of the EC competition rules not only when it offers goods and serviccs on the market but also when it carries out other activities which are economic in nature and which could lead to distortions in a market where competition exists. As I have suggested in a previous Opinion, the emphasis when interpreting whether an activity is economic in nature should be placed on whether that activity 'could, at least in principle, be carried on by a private undertaking in order to make profits.'”475

\section{Preparing a more fundamental critique of the case law}

To adopt such a principled approach would, however, require the Court to explain in greater detail exactly why certain activities do not justify the application of the competition 474 See above note 339.

475 AG Jacobs in Case C-222/04, Cassa di Risparmio di Firenze, [2006], paras. 76 to 83 (emphasis added), reinforcing AG Jacobs in Joined Cases C-264/01, C-306/01, C-354/01, C-355/01, AOK, [2004], para. 28. 
rules. The question raised by $S A T /$ Eurocontrol, Cali and also SELEX is whether an activity typically organised by or under the control of the State should be outside the ambit of competition law, regardless of whether the activity is or could, at least in principle, be exercised by private parties. To adopt an affirmative stance to this question would be diametrically opposed to the Höfner rule. ${ }^{476}$ While EC competition rules are not directly addressed to Member States, the latter nevertheless have to respect those rules where they engage in an economic activity themselves, for instance through public undertakings (Article 86(1) EC). ${ }^{477}$ The rationale is that Member States shall not be allowed to determine whether certain economically interested operators escape the application of competition law by, e.g. nationalising them (despite the fact that the Treaty is agnostic towards the systems of property ownership in the Member States, Article 295 EC). Moreover, and as a matter of principle, not just any activity related to a task of socictal or public interest can be excluded from the ambit of competition rules, as that would deprive Article 86(2) EC of its function. ${ }^{478}$ Conversely, it has been argued that a systematic application of the two competition prohibitions (Articles 81 and $82 \mathrm{EC}$ ) to activities organised by or under the control of a public authority will have the result of requiring Member States to justify their measures under Article 86(2) EC as a matter of course, and that that would be meaningless. ${ }^{49}$

The decision whether to meet or to parry in particular the last consideration depends on whether it is legitimate to require Member States to explain, as a matter of course, measures involving activities that could, at least in principle, be carried out on competitive matkets. Put differently the question is whether it is well-founded that some activities, regardless of a certain economic aspect to them, fall outside the jurisdictional scope of and are thus not justiciable under EC competition law, as suggest $S A T /$ Eurocontrol and Cali. Entering into these questions will lead to a more fundamental critique of the critetion stemming from that case law.

\subsubsection{Justiciable or not: fundamental critique on the criterion of 'typical' exercise of public authority}

With refetence to two different btanches of EC law it shall be illustrated that the criterion deriving from $S A T /$ Eurocontrol and Cali of powers typically exercised by a public authority first of all unnecessarily perforates the universal applicability of competition law, and secondly is too vague to warrant legal certainty in determining which activities would not fall within the jurisdictional scope of competition law. The argument that Member States could not be required to justify their measures under Article 86(2) EC as a matter of course shall be looked at with a first reference to the Treaty rules on the rights to free movement in order to assess the value of the argument. The concern is that this argument tisks not to respect the objective character of the Community concept of undertaking (section 2.2.3.1.). A second comparative reference shall be made to the field of State aid in order to assess the technique used by the Court in $S A T /$ Eurocontrol and Cali to exclude from the jurisdictional scope of competition law measures that assimilate public service obligations. The reference

176 See also the opinion by AG Poiares Maduro in the FENIN appeal's case referred to above. His opinion will be looked at more specifically below in section I.2.2.3.1.

$477 \mathrm{It}$ is settled case law that public bodies engaging in economic activities are to be regarded as undertakings, sec Case 118/85, AAMS, [1987], paras. 6 ff.

478 See already notes 440 and 444, 560. See also AG Kokott in Case C-369/04, Hutchison 3G, [2007], para. 59. 479 AG Poiares Maduro in Case C-205/03 P, FENINII, [2006], para. 27. On the application of Article 86(2) EC see below Chapter 7.II. 
is based on the fact that in the field of State aid the Court addressed a structurally similar question of whether, and if so how, to limit the jutisdictional scope of a competition law provision where public interest tasks are involved (section 2.2.3.2.).

\subsubsection{First fundamental critique: the criterion does not respect the objective character of the concept of undertaking}

In the latger context of EC law the mechanism of Member States having to account for their action as a matter of course is not breaking news. Under the Treaty rules on the four free movement rights all sovereign acts are in principle justiciable since the respective Treaty rules are directly addressed to Member States. At the same time the review of sovereign actions under the free movement provisions is confined to State actions that are not in the general interest or, at least, not proportionate to achieving a specific public interest aim. ${ }^{480}$ Put differently Member States are required to use the mechanism of justifying their actions in respect of the prohibition provisions of the internal market rules. The ensuing conclusion is that it is perfectly possible to require Member States under EC law to explain their measures as a matter of course where they restrain the free movement of goods, persons, services or capital. ${ }^{481} \mathrm{It}$ is not apparent why this pattern could not be extrapolated to the field of competition law in the case of activities that first can, at least in principle, be carried out under market conditions and, second, are not necessarily related to the exercise of powets of a public authority. Where indeed some public or general interest may be involved in the exercise of a particular activity it is thus possible to take account thercof at a later stage of appraisal rather than at the outset of determining the jurisdictional scope of competition law. ${ }^{482}$ To pursue such an approach has the benefit of avoiding to perforate the universal applicability of competition law, notwithstanding that the effect may be to justify particular policy measures relating to economic activities under Article 86(2) EC as a matter of course, namely in cases that do not meet the imperative public authority criterion.

\section{More opposition to an imperative public autbority criterion}

A stringent application of the imperative public authotity criterion has not only withstood the Court in $S A T /$ Eurocontrol, Cali and SELEX. In the appeal's procedure in FENIN II Advocate General Poiares Maduro undertook to distinguish two different concepts of economic activity, namely for the purpose of competition law, on the one hand, and for the purpose of the free movement rules, on the other. In doing so he has attempted the laudable cause to shed a systematic light on the case law that overtides the Höfner rule, taking not only $S A T /$ Eurocontrol and Cali as a statting point, but also including the case law on social security and insurance schemes. ${ }^{483}$ His attempt is also noteworthy for it is driven

480 See Articles 30, 39(3), 46(1), 55, 58(1)(b) EC and the case law applying a mandatory requirements doctrine referenced in Chapter 7.I.2.5.3.1.

481 An exception is established, though, for goods in Joined Cases C-267 and 268/91, Keck and Mithouard, [1993], for State measures that restrict trade but not specifically interstate trade. In fact the (underlying) assumption in Keck is that such a measure is affecting all traders in goods in the same way and therefore does not qualify as a restriction in the meaning of Article $28 \mathrm{EC}$.

482 Compare with AG Kokott in Case C-369/04, Hutchison 3G, [2007], para. 59; AG Kokott in Case C-284/04, T-Mobile Austria, [2007], para. 62.

483 AG Poiares Maduro in Case C-205/03 P, FENIN II, [2006], paras. $15 \mathrm{ff}$. The two respective branches of case law are referenced above in notes 416 and 417. 
by the concern to establish a clearer and easier to apply criterion than has developed the case law in delimiting the potentially unlimited Höfner formula.

The background to FENIN is the Spanish national health system in which certain medical services are provided free of charge on a universal cover. Despite the fact that patients receive particular treatment without paying the providers of the treatment (i.e. the hospitals and practitioners) the latter still receive a compensation within their national health system. Therefore, and with respect to the free movement rules, the Court had already found earlier that such services come within the ambit of Article $49 \mathrm{EC}{ }^{484}$ In the opinion of Advocate General Poiares Maduro this fact does not, however, prejudge the economic nature of the activity for the purpose of competition law, in spite of the economic basis that underlies also the free movement rules of the Treaty (Article $2 \mathrm{EC}{ }^{485}$. The quintessence of his opinion is that services (in casu health care services) should not come within the ambit of competition law where they are provided free of charge and on the basis of universal cover. In addition Advocate General Poiares Maduro strictly interprets the comparative market criterion flowing from Höfner as one that positively requires market participation. ${ }^{486} \mathrm{The}$ thus redoubled comparative market criterion must, in his view, be disproved in a negative way. This means that the factual evidence must not prove that private entities, i.e. undertakings in the sense of competition law, take part in the provision of the activity in question.

In seatch of a better critetion than the reference to powers 'typically' exercised by a public authority, the Advocate General's survey of the case law has lead him to propose a redistribution requirement as the applicable criterion to delimit the potentially unlimited Höfner formula. ${ }^{487}$ Accepting the competence of a State to pursue tedistribution policies the Advocate General defined that under a dual condition certain activities would not bear any telation to the market. Accordingly, are excluded from the jurisdictional scope of competition law those activities that are subject to strict State regulation if the latter implements the principle of solidarity. Solidarity is the principle according to which the members of a public or societal system organise their unity and polity, and thus serves as a parameter for redistribution policies. ${ }^{488}$ In particular, the Advocate General stresses that "the State assumes two distinct roles, depending on whether it is acting as an operator on a market or whether it is acting for political purposes, inspired by considerations of solidarity" in order to sustain his fundamental conclusion that a Member State "is free to withdraw certain activities from the market" under the mentioned condition. ${ }^{489}$ His conclusion is that "More generally, all cases which involve the exercise of official authority for the purpose of regulating

484 Case C-157/99, Gerats-Smits and Peerbooms, [2001], para. 58; Case C-158/96, Kobll, [1998]; Case C-120/95; Decker, [1998].

485 AG Poiares Maduro in Case C-205/03 P, FENIN II, [2006], paras. 51 ff. At first glance AG Maduro therewith, and to a certain extent, seems to match the position adopted by the ECJ in 2006 in Meca-Medina II (see above section I.2.1.), albeit from an opposite starting point. I will come back to offset the ECJ's approach with that of the Advocate General below, sce note 554.

486 Paras. $11 \mathrm{f}$. and $13 \mathrm{f}$. of the opinion.

487 Paras. $26 \mathrm{ff}$. and $47 \mathrm{ff}$. of the opinion. The idea of redistribution as a factor to exclude that an activity be economic in nature is also described by Odudu O., (2006), $37 \mathrm{ff}$. Other authors are more critical, if not cynical, vis-à-vis the task of identifying redistributive activities as non-economic, Buendia Sierra J.L., (1999), 59; Schepel H., (2002), 44-47. What is clear is that in social security and insurance matters the Court treats activities implementing the principle of solidarity as non-economic in order to shield them from the strictures of competition law, see the case law referenced in above in note 417.

488 For case law on the principle of solidarity and competition law see above note 417.

489 Para. 27 of the opinion in FENIN II (emphasis added). 
the market and not with a view to participating in it fall outside the scope of competition law."490

\section{Second-guessing Member States' intentions}

The thus developed standard is particularly problematic from a view point of legal certainty. First of all, it does not allow to accurately determine whether a Member State effectively has decided to withdraw certain activities from the market, but opens the door for second-guessing Member States' intentions in organising specific markets. While Advocate General Poiares Maduro generally recognises the power of Article 86(1) EC, his standard recognises some leeway for Member States to authoritatively determine which activities should or should not be considered to be economic in nature. He explicitly allows that the way of how Member States organise an activity should have a bearing on the applicability of competition law. ${ }^{491}$ The reference that a Member State "cannot shelter behind the pretext of solidarity in order to avoid economic operators being subject to competition law"492 does not seem to provide a strong gate keeper to withhold Member States from excluding the application of competition law to activities prone of an economic character. The practical difficulty may be pointed at with reference to social security services that are not entirely provided free of charge. For instance a health care system in which services are provided merely almost free of charge, will not meet the more tangible requirements of the test developed by the Advocate General. Still, if the redistribution criterion were accepted as a standard to delimit the broad Höfner formula it is conceivable that such services would nevertheless be qualified as not having a relation to the market but to implement the principle of solidarity. Therewith the redistribution criterion would tisk to extend rather than to narrow the exception to the universal application of competition law as the general law.

\section{Dr. Jekyll and Mr. Hyde}

Secondly, in light of the comparison with the width of scope of the Treaty rules on the fundamental freedoms the solution proposed by Advocate General Poiares Maduro creates the perplexity that certain activities should be recognised as having a sufficient economic character for the purpose of those Treaty rules, but at the same time to be outside any market structures and, therefore, outside the ambit of competition law. ${ }^{493}$ The consequence of the solution proposed by the Advocate General in FENIN II is that national rules organising certain activities that could be provided under market conditions are subject to control under the free movement rules but not under the competition rules. While the Advocate General admits that it would be desirable to adopt the same qualification of economic activity in the field of the fundamental freedoms and that of the freedom of competition, he defends the differentiation made, despite the fact that both sets of Community rules seek to attain the same common objective of the completion of the

490 Para. 15 of the opinion in FENIN II (emphasis added).

491 This cleatly follows from the inverted reading of para. 51 of the opinion: "By contrast, the way in which an activity is organised at the national level has no bearing on the application of the principle of the freedom to provide services."

422 Para. 27 of the opinion in FENIN II (emphasis added).

493 At this pointhis finding is contradicted by the later Case C-519/04 P, Meca-Medina II, [2006], which has been discussed above in section I.2.1. 
internal market. ${ }^{494}$

It is however difficult to discover which basis should justify the differentiation. The Advocate General seems to be careful enough not to justify it on the basis of the relative concept of undertaking since the relativity refers to the notion of undertaking and not to the notion of economic activity. This means that an activity is either economic or not, and depending on that assessment, and only with regard to the particular activity assessed, is an entity either considered as an undertaking or not in competition law. In other words the same entity may qualify as both an undertaking and a non-undertaking at the time, depending on the activity one looks at. ${ }^{495}$

Conversely, and for the field of competition law the nature of an activity cannot be economic and non-economic at the time. Aware of this effect the Advocate General chose to state that "There is nothing to prevent a transaction involving an exchange being classified as the provision of services, even where the parties to the exchange ate not undertakings for the purposes of competition law". " ${ }^{496}$ emphasising the provision of services rather than the (non-)economic character of the activity in question the Advocate General implicitly seems to divert the focus from the jurisdictional requirement (economic activity) to the object of a possible restriction (freedom to provide services). If one followed this slip of focus and applied it in the field of competition law one would not end up at the jurisdictional element of 'undertaking' but the object of unrestricted competition - which is a substantive element to be dealt with only in the following two chapters. ${ }^{497}$ Therefore, and notwithstanding the apparent advantage of carving out manageable criteria (services provided free of charge, universal cover), the stance of the Advocate General in FENIN II, albeit in a restrained manner, sustains what is considered here as an unnecessary perforation of the field of application of the competition rules at a premature stage of appraisal.

Unnecessary such perforation is in light of the fact that Member States already are obliged, as a matter of course, to explain and justify their measures that (may) affect trade between Member States. ${ }^{498}$ To follow the opinion of Advocate General Poiates Maduro in FENIN II would only reinforce the dichotomy of the concept of economic activity. ${ }^{499}$ What the opinion in that latter case accentuates is, however, that already $S A T /$ Eurocontrol and Cali

494 AG Poiares Maduro in Case C-205/03 P, FENIN II, [2006], para. 51, referring to AG van Gerven in Case C-145/88, Torfaen Borough Councilv B \& Q Plc, [1989], para. 22; Casc T-313/02, Meca-Medina I, [2004], para. 42; and Mortelmans K., (2001), 613.

495 See for instance Commission Decision AAMS, (1998), para. 21, in which the Commission found that AAMS (the Italian tobacco monopoly) qualified as an undertaking despite certain public authority powers it enjoyed. The Commission separated these powers from the business activities of AAMS addressed in the decision, clearly applying the functional approach to define the addressee of the EC competition rules.

${ }^{496}$ Para. 51 of the opinion (emphasis added).

497 It is this double standard applied unawares that has inspired the reference to the "Strange Case of Dr Jekyll and Mr Hyde", a novella written by the Scottish author Robert Louis Stevenson and first published in 1885 . The work is known for its vivid portrayal of the psycho-pathology of a split personality; in mainstream culture the very phrase "Jekyll and Hyde" has come to mean a person who may show a distinctly different character, or profoundly different behaviour, from one situation to the next, as if almost another person.

498 The difference between the rules on the fundamental freedoms and those on the freedom of competition is that the required Community dimension to determine the jurisdictional scope of the respective EC rules differs. For details see below part II.

499 The ECJ has not taken up the same line of argumentation as its Advocate General, and avoided the discussion by focussing on the downstream use of the services compensated in the national health care system. Case C-205/03 P, FENIN II, [2006]. See already Case T-319/99, FENIN I, [2003]. 
distespect the objective and Communitarian character of the concept of undertaking. ${ }^{500}$

What remains is that the effect of qualifying activities with an economic importance differently in the different fields of EC law cannot be linked to the fact that the concept of undertaking is a relative one, and the approach can be criticised on a larger scale. The practical consequence of favouring a third criterion that does neither meet the comparative market criterion nor the imperative public authority criterion is that the same activity may be considered to have a different character - either economic or non-economic - depending on whether the particular national rules of different Member States fulfill the specific conditions developed in the case law ('typical') or preferred by the Advocate General in FENIN II ('free of charge'). The crucial point is that the concept of undertaking thereby loses part of its Community chatacter that it has notwithstanding the Member States' competence to make certain policy choices and implement economic regulation. ${ }^{501}$ It is worrisome that in this way it is left to the hands of the Member States to organise the activities of certain sectors in a way that allows them to withdraw - as AG Poiares Maduro explicitly recognises - these activities from the jurisdictional scope of competition law in motivation of national policy considerations. In the words of the UK Competition Appeals Tribunal (CAT) it is not appropriate to find an 'escape route' in the form of the undertaking issue when the real issues concern the application of the substantive competition provisions. ${ }^{502}$ Nevertheless limiting the jurisdictional scope in this way risks to lead to a disparity in the application of EC competition law actoss the Community. Both the casc law discussed above and the view of Advocate General Poiares Maduro put Member States in the position to undermine the Community concept of undertaking in spite of Articles 86(1), (2) and 10(2) EC, if they organise them in a way that no private actors may participate in the provision of those activities under market conditions, even where those activities could, at least in principle, be otganised under such conditions.

By not striking the balance according to the compatative matket criterion and the imperative public authority criterion the Advocate General and the Court respectively have introduced a further standard that, first of all, allows Member States to define certain activities within or outside the scope of competition law. Secondly, their respective standards

500 Just as the ECJ in SAT/Eurocontrol and Cali and the CFI in SELEX, AG Poiares Maduro in FENIN II contributes to minimise the imperative public authority criterion stemming from Höfner. Exceeding the scope the present research one may wonder whether AG Poiares Maduro was driven by a similar idea than was the Court with regard to the free movement of goods in Joined Cases C-267 and 268/91, Keck and Mithoward, [1993]. In order to limit what may otherwise be regarded too vast a field of application the (underlying) assumption in Keck is that State measures generally restricting trade (i.c. without restricting specifically interstate trade) affect all traders in goods in the same way and, therefore, do not qualify as a restriction in the meaning of Article $28 \mathrm{EC}$. This same idea seems to be expressed by the following strong statement of the Advocate General (para. 15 of his opinion in FENIN II): "More gencrally, all cases which involve the exercise of official authority for the purpose of regulating the market and not with a view to participating in it fall outside the scope of competition law" (emphasis added).

501 The exclusive competence of the Community in competition law matters does notmean that Member States could not adopt measures penetrating the sphere of economic activities.

${ }^{502}$ See also Rodger B.J.,"The Competition Act 1998 and State Entities as Undertakings:promises to be an interesting debate", (2003), p. 5, "The CAT rejected a number of other arguments put forward by the Director, the most pertinent being the argument that the application of the competition rules would interfere with the State's social priorities, on the basis that if competition law applied, the Director would interfere with policy choices regarding public funding in a sensitive area of social policy. Here we see the crux of the debate and although the CAT understood the Director's caution, they stressed that it was not appropriate to find an 'escape mute' in the form of the undertaking issue [see para. 265 of the judgment] when the real issues concerned the application of the substantive provisions of the 1998 Act" (emphasis added). 
carry the inherent risk that they be conveniently ranged closer to or further off the decisive criteria, therewith allowing to evade the hard question of whether a ceratio activity could, at least in principle, be carried out by a private actor in order to make profits ${ }^{503}$ or involves necessarily the exercise of powers of a public authority. ${ }^{504}$

The analysis of the case law has thus not brought us any closer to answering the question on the considerations necessary to strike a sensible balance between activities that are necessarily carried out by or under the control of public authority (imperative public authority criterion), and those that can, at least in principle, be provided in order to make profits (comparative market criterion). What is certain is that the imperative public authority criterion as formulated in Höfner excludes from the scope of competition law measures that are 'necessatily' catried out by a public authority. To include those measures would extend the scope of application of Articles 81 and $82 \mathrm{EC}$ in a way that is not warranted by the wording of the competition rules. Moreover and as stated before, Höfner and Article 86(2) EC can be understood to be complementary. In other words that what is not necessarily carried out by or under the control of public authorities, and thus is within the jurisdictional scope of competition law, may still be justified under Article 86(2) EC in order not to be prohibited under competition law. If the Court does not mean to water down the dichotomy of the comparative market (participation) criterion and the imperative public authority criterion, it should give more guidance on how to identify powers that are necessarily exercised by public authority.

\subsubsection{Second fundamental critique: more tangible criteria are required}

In the previous section it has been explained that the Court might neither strictly follow the imperative public authority criterion nor the comparative market criterion when establishing which activities eventually do not justify the application of the Treaty rules of competition in a case relating to essential functions of societal systems. It has become clear that the criterion of powers 'typically' exercised by a public authority constitutes a third standard that deviates from the range that both criteria stemming from Höfner provide in determining the temit of EC competition law. ${ }^{505}$ The criterion of 'typical' powers therewith most dangerously puts the Communitarian character of the concept of undertaking at tisk to be too openly influenced by national rules.

The consequence flowing therefrom may be that, in respect of the field of the present book, particularly the health professions and the notary profession invoke the defence that their professional activities should not be subject to a competition law scrutiny because of the typical role they assume in fulfilling an essential function of their respective national societal system. In fact it may be argued that those systems are regulated for the purpose of regulating the market and not with a view to participating in it. ${ }^{506}$ Applying the case law undermining the Höfner formula thus may be a basis for the liberal professions to argue that their activities would not bear a relation to the market. However, by pointing out the possibilities that exist to warrant both an objective interpretation of the first jutisdictional element of competition law and taking account of non-economic traits of an activity the following will turn to reinforce the argument made before that the case law's deviation is

503 See above note 347.

504 See above note 337.

505 See above diagram no. 3 on p. 93.

506 Compare AG Poiares Maduro in Case C-205/03 P, FENINII, [2006], para. 15. 
unnecessary. Subsequently, selected examples of the liberal professions will be tested in section 2.2.4. on theit non-economic traits.

\section{Comparison to the field of State aid}

In order to assess the room for development of the jurisdictional element a second brief comparison shall be made to a further branch of EC law, which is State aid law - despite the fact that obviously the raison d'être of the State aid provisions are State measures, whereas this is not the case for Articles 81 and $82 \mathrm{EC}$, quite to the contrary. The point here is, however, to make a comparison from a larger perspective by reference to a particular case, Altmark. In that case the Court recognised that State subsidies "escape the classification as State aid" in the sense of Article 87(1) EC, and thus "are not caught by" Article 87(1) EC, if two conditions are fulfilled. ${ }^{507}$ First, State subsidies have to be the compensation for activities that are provided by the recipient undertakings in order to discharge public service obligations. Secondly, the undertakings may not enjoy a teal financial advantage from the State measure so that they will not be put in a more favourable competitive position than the undertakings competing with them. The comparability for present purpose with the case law outcompeting Höfner thus stems from the fact that the Court is willing to exclude from the jurisdictional scope of competition law measures that assimilate public service obligations and public interest tasks respectively.

Altmark is particularly interesting for the following fact. In order to verify whether a measure qualifies for the conclusion not to be justiciable the Court in Altmark mapped four cumulative specifications. Most importantly the public service obligation must be clearly defined by the national authorities (legislative or administrative ones). ${ }^{508}$ The further three criteria emphasise two factors: how to determine the reasonable maximum amount of subsidy (the calculation method thereof has to be established beforehand) and how to select the beneficiary of the subsidy (strict public procurement procedure) ${ }^{509}$ Therewith, Altmark formulates tangible requirements that allow a technical control of whether a Member State has respected certain minimum standards in defining certain activities to be outside the jurisdictional scope of State aid law. ${ }^{510}$ Moreover, the four cumulative criteria in Altmark seem to wartant a certain democratic process in which public authorities have to take a

507 AG Léger in Case C-280/00, Altmark, [2003], paras. 87 f.

508 Para. 89 of the judgment in Altmark.

509 AG Léger in Case C-280/00, Altmark, [2003], paras. 88 ff. The exact four elements are that, first, the recipient must actually have clearly defined public service obligations to discharge; second, the parameters for the compensation for loss incurred in the discharge of those obligations must be established beforehand; third, the compensation cannot exceed what is necessary to cover all or part of those costs; fourth, the recipient must have been chosen pursuant to a strict public procurement procedure.

510 The Altmark test also has another clear relevance for the sector of liberal professions that is illustrated in Case C-451/03, Calafiori, [2006], paras. $54 \mathrm{ff}$. (The case is summarised in Chapter 2.V.) There the Court has found that "the payment of compensation from State funds to certain undertakings responsible for helping taxpayers in connection with the completion of tax declatations and filing them with the tax authorities must be classified as State aid within the meaning of Article 87(1) EC, where: - [1] the level of the compensation exceeds what is necessary to cover all or part of the costs incurred in the discharge of public service obligations, taking into account the relevant receipts and a reasonable profit for discharging those obligations, and - [2] the compensation is not determined on the basis of an analysis of the costs which a typical undertaking, well run and adequately provided with the means required so as to be able to meet the necessary public service requirements, would have incurred in discharging those obligations, taking into account the relevant receipts and a reasonable profit for discharging the obligations" (emphasis added). 
conscious decision about public service obligations and the way in which compensation thereof is attributed.

The requirements in Altmark, may still not constitute an adequate yardstick, considering that Member States more often have been found to be in breach of EC law (in particular the internal market rules on the free movement rights) in spite of having adopted measures (for instance legislation) within the framework of a democratic process. Also the more general critique that is voiced here with regard to $S A T /$ Eurocontrol and Cali can be repeated with regard to the Altmark test. First of all, it grants a Member State the possibility to define certain measures as outside the jurisdictional scope of Article 87(1) EC. In particular, the Court recognises that it is in the discretion of the Member States what a public service obligation is. ${ }^{511}$ Neither exception thus respects the objective character of the relevant concept determining the jurisdictional scope of application ('state aid' in the case of fArticle $87(1) \mathrm{EC}$ and 'undertaking' in the case of Articles 81 and $82 \mathrm{EC}$ respectively). ${ }^{512}$ 'The Court in Altmark therefore has been criticised to have

"in essence opened the floodgates of state aid, because many other requirements imposed by law on business can also be regarded as public service obligations. Public authorities, then, may attempt to exploit the loophole created by the Court to justify their granting of state aid on the grounds that they have imposed costly obligations on enterprises." ${ }^{3513}$

Secondly, the approach in Altmark to limit the jurisdictional scope of application similatly risks to deprive Article $86(2)$ EC of its effects. ${ }^{514}$

In search of a predictable standard: securing essential functions without gaining a competitive advantage

Despite the controvertible approach chosen by the Court in Altmark the point to be made here is that Altmark establishes a less indefinite test than do SAT/Eurocontrol and Cali with their reference to powers "typically" exercised by public authorities. While all three judgments employ criteria that can hardly be established in an objective, or autonomous way, i.e. irrespective of perceptions in the Member States, the result based on the somewhat stricter criteria of Altmark becomes more predictable when compared to $S A T /$ Eurocontrol and Cali. In particular, the reference to Altmark proves that there is room for developing stricter criteria than a blurred reference to 'typical' powers of public authority for assessing which activities are within or outside the jurisdictional scope of competition law. ${ }^{515}$ The

511 In Case C-451/03, Calafiori, [2006], paras. $60 \mathrm{ff}$. the Court in applying the Allmark test, underlines that " $a$ Member State could, conceivably, characterise as a 'public service' the tax assistance services provided by CAF [which are tax advice centres], in accordance with [thc national legislation], to employees and persons treated as such and intended to help taxpayers to fulfil their tax obligations and to facilitate the accomplishment of the tasks for which the tax authorities are responsible" (emphasis added). The Court therewith explicitly recognises the power of a Member State to determine which activities are outside the scope of State aid law despite the explicit exceptions provided for in the EC Treaty, see Article 87(2)-(3) EC and the regulations adopted under Article 89 EC. $\Lambda$ derogation from these exceptions can be granted only in exceptional circumstances by the Council following the procedure in Article 88(2), third subparagraph, EC. One may wonder whether the Altmark test in fact grants Member States the opportunity to circumvent a decision by the Council, thus becoming independent not only of the control by the Commission but also by the other Member States.

512 On the exception not respecting the objective character of the concept of State aid in Article 87(1) EC see AG Léger in Case C-280/00, Altmark, [2003], paras. $46 \mathrm{ff}$.

513 Nicolaides P., (2003), 567.

514 Moreover, the approach to limit the jurisdictional scope of the rules intended to control State aid diminishes the Commission's surveillance role in reviewing measures for financing public services.

515 In this regard the opinion of Advocate General Poiares Maduro in FENIN II also proves to be motivated 
objective character of the concept of undertaking even requires to develop more tangible criteria. Conversely, the weakness of $S A T /$ Eurocontrol and Cali is that typical powers of public authorities is a category that varies over times and from Member State to Member State. In this regard one may wonder what the 'typical perceptions' are, for instance, in the Member States that acceded lately and have a recent history of socialistic and communistic regimes. The vague case law of $S A T /$ Eurocontrol and Cali should thus be abandoned.

A workable standard to strike a balance between the comparative market criterion and the imperative public authority criterion could tequire to demonstrate that the author of the relevant activities is motivated not by an economic but rather a charitable objective. Such a fact can be proven by showing that the actor does not enjoy a competitive advantage, possibly in the form of not gaining a real financial advantage (see in this respect para. 87 of the Altmark judgment). Such a negative economic test has the advantage that it is not limited to apply only to cases in which an activity is subject to control by a public authority (be it in the form of exercising 'typical' powers of a public authority or a social function implementing the principle of solidarity), but that it can also be applied to purely private situations. The actor thus could rebut the comparative matket criterion by demonstrating that any (financial) reward is a mere compensation of costs incurred in the discharge of a 'charitable obligation', whether self-imposed or not. Putting the burden of proof on the entity engaging in the relevant activity would guarantee greater respect for the functional approach in determining what is an undertaking in competition law terms. Remarkably in Cassa di Risparmio di Firenze, the Court refers to the same idea of charitable activities to distinguish them from economic activities. ${ }^{516}$ Thus, while the Court in its case law outcompeting the Höfner rule still emphasises the role of public interest tasks, other developments in the case law suggest that the universal scope of competition law can be delimited by reference to charitable obligations, even where they are self-imposed.

A standard of charitable obligations has a triple advantage over the standard teferting to typical powers of public authority. First of all, it respects the complementarity between Höfner and Article 86(2) EC. Secondly, it allows to interpret the limits to the universal scope of competition law restrictively as is approptiate with an exception to a genetal rule. Moreover, it allows an application of the exception in a way independent of the particular national character of the regulatory framework in a Member State. This means that in a situation where an assessment of the (non-)economic character of a particular activity requires to take account of the applicable national rules as part of the circumstances in which the activity takes place, the assessment does not require an explicit acknowledgement of policy choices made by national authotities in deference of Member States' competence to adopt economic regulation, and thus can be conducted in an autonomous, i.e. objective way.

Furthermore, the criterion to be developed of not enjoying a competitive advantage actually may allow a reconciliation with the (negative) matket participation element favoured by the Court and Advocate General Poiares Maduro. In fact, the matket participation

to develop a less indefinite test than does the relevant case law, see above note 483 with text.

516 Case C-222/04, Cassa di Risparmio di Firenze, [2006], paras. $121 \mathrm{f} .:$ "...that activity is of an exclusively social nature and is not carried out on the market in competition with other operators. As regards that activity, a banking foundation acts as a voluntary body or charitable organisation and not as an undertaking. On the other hand, where a banking foundation, acting itself in the fields of public interest and social assistance, uses the authorisation given it by the national legislature to effect the financial, commercial, real estate and asset operations necessary or opportune in order to achieve the aims prescribed for it, it is capable of offering goods or services on the market in competition with other operators, for example in fields like scientific research, education, art or health" (emphasis added). 
criterion, can be interpreted to mean that the charitable exercise of an activity does not allow a competitive advantage vis-à-vis (potential) competitors, and thus is not evidencing participation under market conditions. Hence the body engaging in the charitable activity should not, with regard to that activity, be considered an undertaking for the purpose of competition law. The point is not so much whether a particular activity could not, at least not in principle, be exercised under market conditions due to the regulatory situation in a particular Member State, but whether the way, in which the activity in question is exercised, does not grant a competitive advantage. The difference is that a regulatory situation may exclude competition, but still and therewith grant a competitive advantage, for instance by granting a statutory monopoly. According to the comparative market criterion the activity exercised under such regulatory situation will be subject to the competition rules. Whether it passes the competition law test depends then on Article 86(2) EC. Rebutting the jurisdictional element of the comparative market criterion, however, tequires the defendant to demonstrate that the exercise of a particular activity is not intended to grant, and does not confer, a competitive advantage. A finding in this regard will, first of all, depend on the definition of the relevant market on which the activity could, at least in principle, be provided with a view to making profit. Secondly and most importantly, it will depend on a similat proportionality test as required by the Court in Altmark. ${ }^{517}$ This means that any financial benefits acquired in the exercise of the charitable activity may not exceed what is necessary to cover the realisation of the charitable objective. This question remains for a court to be determined on the basis of the facts and circumstances of a given case.

\section{Interim conclusions}

The case law as it stands at the moment with its limitation of the universal scope of the competition prohibitions that out-competes the Höfner tule can possibly best be explained on the basis of the purpose of the competition rules. Their purpose is not to render the exercise of essential functions of the State justiciable, since Member States ate legitimated, in accordance with international law principles (sovereignty and distribution of powers between the EC and the Member States), to exercise public power, which in turn they are presumed to exercise in the public interest. ${ }^{518}$ Under certain conditions activities relating to essential functions of States ate thus outside the jurisdictional scope of competition law. This finding encounters two principled objections. The first is that Member States already see their exercise of public powers subject to the control of EC law as a matter of course, namely to the rules of the free movement rights, which seek to attain the same common objective of the completion of the common market (Articles 2 to 4 EC). Secondly, the approach of the standing case law jeopardises the effectiveness not only of the competition prohibitions but also of Article 86(2) EC. While the difficulties in applying the latter article to the particular field of the liberal professions became apparent in the Wouters case ${ }^{519}$, it shall at this point be tecorded once more that the Court has not repeated the rule adopted in $S A T /$ Eurocontrol and Cali, and even refused to apply it in the particular field of the libetal professions. At paragraphs 56 et seq. of the Wouters judgment the Court, with explicit reference to that case law, correctly concluded that "When it adopts a regulation such as the

517 See above note 509.

518 See Odudu O., (2006), $46 \mathrm{f}$, with further references. This idea comes close to the act of State doctrine mentioncd above, see above text with note 425 .

519 AG Léget in Case C-309/99, Wouters et al. v NOvA, [2002], paras. 155 ff. For details see Chapter 7.II. 
1993 Regulation, a professional body such as the Bar of the Netherlands is neither fulfilling a social function based on the principle of solidarity, unlike certain social security bodies, nor exercising powers which are typically those of a public authority. [...] the practice of [the legal profession] constitutes an economic activity." 520

In the following I will scrutinise whether certain activitics exercised by the members of a number of liberal professions may qualify as not having an economic character, be it on the basis that they involve the exercise of public authority, or that they are exercised in a way not conferting a competitive advantage on the professionals. In particular, it may be conceivable that certain specified activities of the members of the (liberal) professions may relate to the exercise of essential functions of the State (e.g. to secure legal certainty through effective enforcement of justice) and connect with powers carried out by or under the control of a public authority. ${ }^{521}$ However, taking the deliberate openness of the Hönner formula serious requires a careful scrutiny.

\subsubsection{Illustration by particular professional sectors}

The question here is whether the liberal professions, with regard to certain of their activities, are integrated in the organisation of tasks essential to societal systems in a way so as to eliminate, for the purpose of EC competition law, the economic character of their professional activities. Thus far, no ruling to that effect has been given by the European Courts or the Commission. Instead, the case law emphasises the economic nature of professional services, as is forcefully illustrated in Wouters concerning one of the most traditional (liberal) professions. ${ }^{522}$ Notwithstanding, this section will describe a few examples of professional activities the organisation of which might be considered to be the translation of an essential function of the State. In this regard only the most promising examples of professional activities shall be sketched hereafter, which are legal aid, medical health care and notarial activities. The scrutiny will try to put in parallel both the interpretation that the so far standing case law out-competing Höfner provides for (criterion of the 'typical' exercise of public authority) and the test suggested in this book as the approptiate one to delimit the universal scope of EC competition law (competitive advantage criterion).

It shall be noted that in applying the standard of the case law as it stands on the essential functions of a State the more manageable indications developed by Advocate Gencral Poiares Maduro in FENIN II shall be taken as a starting point for the scrutiny here. Drawing on his proposition how to specify more tangibly the exception to the jurisdictional scope, the question is whether a Member State intends to regulate rather than participate in a professional services market. ${ }^{523}$ Extrapolating in particular the interpretation that the

520 Case C-309/99, Wouters et al. v NOvA, [2002], para. 58, with teference to Joined Cases C-159/91 and C160/91, Poucet and Pistre, [1993], para. 18 and Case C-364/92, SAT/ Eurocontrol, [1994], para. 30.

${ }_{521}$ The same case law will be discussed once more in Chapter 4.I.2. with regard to different activities of the liberal professions, namely the regulatory and supervisory activities exercised by the representative associations of the professions.

${ }_{522}$ "Members of the Bar offer, for a fee, services in the form of legal assistance consisting in the drafting of opinions, contracts and other documents and representation of clients in legal proceedings. In addition, they bear the financial risks attaching to the performance of those activities since, if there should be an imbalance between expenditure and receipts, they must bear the deficit themselves." Case C-309/99, Wouters et al. v NOvA, [2002], paras. 48.

${ }_{523}$ AG Poiares Maduro in Case C-205/03 P, FENINII, [2006], para. 15; Case T-313/02, Meca-Medina I, [2004], para. 41. 
Advocate General developed with regard to the solidarity principle, one would need to demonstrate the following: whether the costs for the relevant professional services are paid to a practitioner in a self-contained system that is organised by the State; and, at the same time, whether the costs are borne by the public on the basis of a redistribution of resources to the benefit of individual clients in need of the particular service that is provided by the members of the profession.

One of the conceivable examples are national systems of legal aid. ${ }^{524}$ Legal aid may be provided directly by subsidy from the State or indirectly through the professional bodies. ${ }^{525}$ For instance, the idea of pro bono publico work is to provide free legal advice and representation in deserving cases where public funding (legal aid) is not available or where the applicant is unable to afford legal assistance. Drawing on the proposition of Advocate General Poiares Maduro in FENIN II on how to specify more tangibly the exception to the jurisdictional scope, the question is whether a Member State intends to regulate rather than participate in a professional services market. ${ }^{526}$

Extrapolating in particular the interpretation that the Advocate General developed with regard to the solidarity principle, one would need to demonstrate the following: whether the costs for the relevant professional services are paid to a practitioner in a self-contained system that is organised by the State; and, at the same time, whether the costs are borne by the public on the basis of a redistribution of resources and to the benefit of individual clients in need of the particulat service that is provided by the members of the profession. Despite the fact that legal aid may be subject to public regulation it seems doubtful that a system of legal aid is funded on the basis of solidarity. The State will at least in principle teserve the right to recover at a later stage the expenses made for the legal services provided to the beneficiary of the legal aid. Whether to disqualify legal services as not economic in nature, and in accordance with the criteria developed by Advocate General Poiares Maduro, will therefore heavily depend on the particular details of the regulation that recognises and builds up the content of the legal aid.

In applying what is suggested in this book as a more objective test the question first is whether the provider of legal aid services is motivated by a charitable objective, albeit imposed by regulation organising legal aid in a Member State. Such motivation can very well be assumed for the case of legal aid. However, the point to be demonstrated in the second place is that the organised provision of legal aid does not confer a competitive advantage on the professional service provider involved vis-à-vis her (potential) competitors. At first sight this point could actually be argued considering the fact that legal aid is provided for cases in which the legal service is not provided to the particular client under normal market conditions because of her inability to pay for the service. Moreover, where the costs for the provision of legal aid is compensated by a State financed system rather than born by the professionals themselves, the amount paid may in fact be a mere compensation of the costs incurred in the discharge of the beneficial objective of legal aid. On the other hand, however, a competitive advantage may be conferred by a system organising legal aid in a different way

524 Including for instance the work of an assigned counsellor in criminal matters.

525 In the UK a specialised Bar Pro Bono Unit has been established in 1996, see $<\mathrm{http}$ //www.barprobono.org.uk/navigate/home.html>. In Minnesota, for example, the Rules of Professional Conduct for lawyers state that a lawyer should aspire to render at least 50 hours of pro bono publico legal services per year (rule 6.1).

AG Poiares Maduro in Case C-205/03 P, FENINII, [2006], para. 15; Case T-313/02, Meca-Medina I, [2004], para. 41. It shall be recalled that the latter case has been quashed on appeal, see above p. 76. 
than only in financial terms. For instance, the organisation of legal aid may confer a semistatutory monopoly for lowcost legal advice services to the detriment of (potential) competitors intending to specialise in that segment of the legal services matket.

As tegards the medical sector much would have depended on the outcome of the FENIN II case, and whether the ECJ would have adopted the position proposed by its Advocate General. On appeal, the appellant contended that the CFI had been wrong to classify the activity of providing free health care as non-economic by giving a wide interpretation to the concept of solidarity. Advocate General Poiares Maduro opined that the case should have been referred back to the CFI in order to establish the factual circumstances of whether other undertakings provided the health care services in question under matket conditions. ${ }^{527}$ The ECJ did not follow its Advocate General and preferted not to address the issue. Instead, the ECJ followed the approach of the CFI, and (re)directed the focus of the scrutiny to the purchasing activity of goods that was involved in the case. ${ }^{528}$ Due to this fact no helpful conclusion can be drawn from that judgment for the question of present concern, i.e. whether or not medical services that are provided by private operators may, under specific circumstances, be qualified as non-economic in nature. ${ }^{529}$ The question to address in this context, and for each national health system individually, is not so much whether particular medical services could also be provided by private operators, but whether the State has organised the provision thereof in a way that they may be provided only by operators that are strictly controlled by the State to the exclusion of independent private operators. This may prove to be true only for a very restricted part of a national health care system, for instance a compulsory surveillance system maintained by a State in order to prevent spreading disease.

Applying the competitive advantage test suggested in this book may prove to be even more difficult to be passed for the case of medical services. While medical people are trained to help people, there is no assumption that they provide medical treatment in a charitable way. Quite to the contrary they earn their living with the exercise of their medical profession. An assessment of the possibly non-economic nature of service provision in the medical sector will thus depend very much on the details of an individual case. It will certainly not suffice to invoke the fact that a health care system is publicly funded in order to rebut the jurisdictional element of economic activity.

Conversely, the European Parliament and the Commission seem to generally oppose the idea of public health services being subject to the control of EC law. They even exclude a control under the internal market rules ${ }^{530}$, and instead adopt a bold political stance which is

527 AG Poiares Maduro in Case C-205/03 P, FENINII, [2006], paras. 39-57. The Advocate General has heavily criticised the Court of First Instance for not having clearly distinguished between, on the one hand, medical services provided in a national health system and, on the other, health insurance services, which can equally be provided by the body responsible for the administration of the national health system.

528 Case C-205/03 P, FENINII, [2006], paras. 25 ff. In particular the Community Courts emphasised the noneconomic character of the down-stream activity that was meant to be exercised subsequently to the purchase with the purchased goods. The non-economic character of the down-stream activity determined the qualification of the purchasing activity in question as non-economic.

${ }_{529}$ See AG Poiares Maduro in Case C-205/03 P, FENIN II, [2006], paras. 28, $53 \mathrm{f}$.

530 In its Resolution on the European Commission, 2001 Communication on Services of General Interest in Europe, the European Parliament stresses that it "supports the Commission in its view that services in connection with national education, public bealth and compulsory basic social security schemes, which are matter of government, ... should be excluded from the application of competition and internal market rulcs" (emphasis added). In the light of the case law on air traffic control, environment protection services, social security and insurance schemes, this statement by the European Parliament implies that these activities are considered as services of a particular 
contrary to, what I would consider, the State of the law after the cases Smits and Peerbooms, Kobll and Decker. ${ }^{531}$

Notaries provide their services against the payment of a fee and the presumption therefore is that they are exercising an economic activity, as their activities are capable of being carried out, at least in principle, by a private undertaking with a view to profit. ${ }^{532}$ The question arises, however, whether some of their activities have to be classified as being necessatily connected with the exercise of official authority in a similar way as done by the Court in cases $S A T /$ Eurocontrol and Cali. ${ }^{533}$ In many Member States, notaries are considered to be an 'independent holder of a public office ${ }^{5344}$ or even a 'civil servant'. ${ }^{535}$ National provisions specify that the notary exercises a 'public office' in the field of the 'administration of precautionary justice' - and, according to the European code of conduct for notaries ${ }^{536}$, has been delegated State authority for the authentication of legal acts. This particular code states that the notary is subject to the strict control of the public authorities, which generally are the competent district court and the minister of justice. The question is whether this characterisation of the 'office of the notary' qualifies for the exception from competition law established by the ECJ. Although, in the light of the case law, it is not necessary that national

general interest that are non-economic, and for that reason should not come within the ambit of competition law, rather than being justified under Article 86(2) EC. On the application of the latter article sec below Chapter 7.II. 531 To embrace the exclusion even from the internal market rules seems to be in blatant conflict with the case law in Case C-157/99, Geraets-Smits and Peerbooms, [2001]; Case C-158/96, Kobll, [1998]; Case C-120/95, Decker, [1998]. See also van der Mei A.P., (2001).

${ }_{532}$ See Case 235/85, Commission $\nu$ Kingdom of the Netherlands, [1987], para. 9: "In view of the wide definition of the term 'economic activities', encompassing all the activities of the professions without a reservation in respect of professions regulated by statute, it must be concluded that, in so far as notaries and bailiffs in the Netherlands provide scrvices to private individuals on a permanent basis and in return for remuneration, they carry out an economic activity within the meaning of the Sixth Directive." - Lord Slynn of Hadley explicitly refers to this case in Housc of Lords - "Institute of Chartered Accountants in England and Wales (appellants) v Commissionets of Customs and Excise (respondents)" [1999]2 All ER 449, 2 CMLR 1333, para. 14, in which the question arose whether the activity of chartered accountants is economic in character: "The European Courthas had to deal with cases on both sides of the line. Thus, in Commission of the European Communities v. Kingdom of the Netherlands (Case 235/85) [1987] E.C.R. 1471, the question arose whether notaries and bailiffs supplying services to third parties in return for fees which they received for their own account, were taxable persons within the meaning of Article 4 of the Directive. It was held that they were, even if appointed by the State and carrying out functions regulated by the State. The Court held that the 'scope of the term 'economic activities' is very wide, in as much as it covers all the services provided by the liberal professions and that the term is objective in character, in the sense that the activity is considered per se and without regard to its purpose or result' (para. 8)."

533 See also Case C-405/01, COMME, [2003], para. 42, presenting authority referred on individuals in respect of notarial matters and exercised on a merchant ship as "participation in the exercise of tights under powers conferred by public law for the purpose of safeguarding the general interest of the [State under the flag of which the ship is flying]". See however AG Kokott in Case C-284/04, T-Mobile Austria, [2007], para. 60; AG Kokott in Case C-369/04, Hutchison 3G, [2007], para. 58.

534 See for instance: in Germany $₫ 1$ BNotO ("unabhängiger Träger eines öffentlichen Amtes"); in the Netherlands Articles 1-3 WNA ("ambtenaar"... "bij koninklijk besluit benoemd"); in Italy Article 1 legge notarile ("sono pubblici ufficiali").

535 In certain regions in Germany, e.g. in Baden, notaries are organised in a civil service relation with the Land, see $\iint 114$ and 115 BNotO.

536 Code Européen de déontologie notariale (1995), ratified by Austria, Belgium, France, Germany, Italy, Luxembourg, Netherlands and Spain. Its first provision refers to the resolution adopted by the notaries public of the European Union in Madrid in 1990 and reads as follows: "Le notaire est un officier public ayant rcçu délégation de l'autorité de l'Etat pour conférer le caractère d'authenticité aux actes dont il est l'auteur, tout en assurant la conservation, la force probante et la force exécutoire desdits actes. [... Le notaire exerce sa profession] en suivant des règles disciplinaires stictes sous le contrôle permanent de l'autorité publique [...]." 
legislation explicitly formulates a task of public interest, it needs to indicate the task in a sufficient way, so that a conclusion can be drawn as to whether the task forms part of the 'essential functions' of a State. ${ }^{537}$ As seen above, however, the mere fact that an activity is regulated is not sufficient to disqualify its economic character.

Therefore, it is necessary to consider the nature of the notarial services and the function of the notary in the provision thereof. The main activity of a notary (at least in the continental Member States) is the recording and authentication of documents. ${ }^{538}$ Under the different national laws notaries public are granted a particular status to confer probative force on particular acts. This means that a statement is made before the notary who records the entire content of the document in the form required by law, whereby the document acquires an official character that has the probative force comparable to a court's decision. For instance, the subject matters of such documents may concern the conveyancing of real estate, and the drawing up of wills and testaments, contracts in family matters and company law. ${ }^{59}$ The question is whether in exercising these activities a notary assumes a function which - following the case law - traditionally is one of a public authority.

One could argue that conferring probative force to legal documents contributes to the stability of the law and legal certainty in legal relations, and thereby is an essential requirement of the rule of law as guaranteed by public authorities. One of the functions of the State is to provide for a system that secures the enforcement of the claims and contracts between private parties. The State assumes a function vis-à-vis the parties that cannot, under the rule of law, be assumed by the parties themselves. For the enforcement of their rights and claims they are bound to have recourse to public institutions (courts, bailiffs) as the ultimate use of coercion in the enforcement of the law is reserved to the public authorities. ${ }^{540}$ However, the authentication of documents contributes mainly, if not only, to the stability of legal relations between private parties. The probative force of documents drawn up by a notary applies - just as the obligations contained in that document do - mainly inter partes (in certain cases possibly erga omnes) but not in the relation of the State sovereign towards its citizens. Despite the fact that the empowerment of a notary to confer probative force is a way of organising the task of the State to secure legal certainty in (private) transaction $s^{541}$, the aim of authentication as a requirement for the validity of the transaction, e.g. the transfer of land property, is not only to safeguard the legal certainty between the parties and towards

537 See e.g. Case C-343/95, Cali v SEPG, [1997], paras. 22 ff., where the Court accepted the task of antipollution surveillance in an oil port to have a public interest character without requiring further reference to a statutory classification to that effect. - This is different from cases falling under Article 86(2) EC where the national legislator needs to determine the service of general (economic) interest in question explicitly. For details see Chapter 7.II.1.

${ }_{538}$ See $\int 1$ BNotO ("Beurkundung von Rechtsvorgängen und anderer Aufgaben auf dem Gebiet det vorsorgenden Rechtspflege"); Article 2 WNA ("bevoegdheid ... om authenticke akten te verlijden"); Article 1 legge notarile ("attribuire ... pubblica fede") and Articles 2699-2700 codice civile.

${ }_{539}$ Notaries may also engage in other activities as for instance of an insolvency administrator, guardian or arbitrator, executor of wills or testaments, or in a scientific activity. These activities are, however, not intended by the national laws as the main professional activity, which is the drawing up of authentic documents. See for instance $₫ 8(4)$ BNotO.

540 See Case C-364/92, SAT/ Eurocontrol, [1994], para. 24. One of the decisive grounds for the Court to find that Eurocontrol carries out tasks in the public interest typically connected with the exercise of public powers was that "Eurocontrol is vested with rights and powers of coercion which derogate from ordinary law and which affect users of air space." In Case C-343/95, Caliv SEPG, [1997], paras. 16 ff., the Court rather implicitly accepted that the powers relating to environmental protection are typically those of a public authority.

541 See also Baarsma B., et al., Recbtszekerbeid als publiek, belang, (2004). 
other interested parties, but also to make the parties to the transaction aware of the serious implications (in economic terms and terms of legal rights and obligations) of their decision. Although an authentic document may help to reduce the costs in the enforcement of claims, it cannot prevent a legal dispute brought before a court if a party is not willing to conform to its obligations.

Moreover, legal certainty in conveyancing or relations under company law can be secured in several ways by the State. The State could just as well choose to restrict the authentication of documents necessary for the legal certainty in private transactions exclusively to public authorities. However, only in last instance is it the role of the State courts and the bailiff to materialise existing claims; they can use coercive powers, which "by their nature, aim and rules to which they are subject" are typically connected with the exercise of public powets. ${ }^{542}$ Conversely, the exercise of a notary's activities in drawing up authentic documents generally does not involve more 'coercive powers' than those to which the parties are already subject as a consequence of the contractual and statutory obligations that they themselves or the legislator impose on them rather than the notary.

The conclusion therefore is that notarial services are, generally speaking, provided under economic terms. This conclusion does not prevent that any particular professional duties may insulate a notary from competitive chances that are open to other operators not bound by such obligations (for instance legal advisors or estate agents). ${ }^{543}$ This may be illustrated for the duty of impartiality and to take due care in the interest of the parties. In economic terms these duties require certain organisational measures in the notary's office, and may oblige her to abstain from certain business behaviour (e.g. not to engage in the negotiation of a loan with the purchaser of a land or company). In drawing up legal documents a notary will obviously be bound by professional obligations to ensure that she will not abuse the particular attributes that are conferred on her for the recording of legal documents; for otherwise, she will engage her professional liability next to incurring the risk of criminal sanctions as the case may be. However, these considerations cannot prevent notarial activities from being regarded as economic in nature; the bottom line of the case law remains

542 In the field of the free movement rules Article $50 \mathrm{EC}$ with its refercncc to services "normally provided for remuneration" resulted in case law that had to give guidance on the differentiation between (commercial) services and activities that are considered to be the exercise of public authority. See also Case 263/86, Humbel, [1988], paras. $18 \mathrm{f}$. (courses offered by establishments forming part of a system of public education and financed, entirely or mainly, by public funds are no services, because no profit making is involved); Case C-109/92, Wirth, [1993], para. 17 (private university courses are services); Case C-76/05, Schwary [2007], paras. $37 \mathrm{ff}$. (private schooling services); Case C-158/96, Kobll, [1998]; Case C-157/99, Geraets-Smits and Peerbooms, [2001]. See moreover AG Mayras in Case 2/74, Reyners, [1974], 664, defining "official authority" as "that which arises from the sovereignty and majesty of the State; for him who exercises it, it implies the power of enjoying the prerogatives outside the general law, privileges of official power and powers of coercion over citizens." However, in the context of the fundamental freedoms as opposed to the competition law, AG Jacobs in Case C-283/99, Commission v Italian (private security services), [2001], para. 43, and the Commission in that case, seem to defend a different opinion, namely that the power to draw up public or authentic documents, the probative value of which is deemed to be legally proved unless it has been found to have been falsified or fraudulently established, is one official authority. See also Case C-405/01, COMME, [2003], para. 42, in which the Court found that notarial matters and the registration of births, marriages and deaths carried out by a master or chief mate of merchant ships are duties constituting "participation in the exercise of rights under powers conferred by public law for the purposes of safeguarding the general interest of the flag state".

${ }^{543}$ See Case C-475/99, Glöckner, [2001], para. 21. 
that, just as lawyers ${ }^{544}$, notaries offer their services for a fee. ${ }^{545}$

It shall be noted that applying to notaries the interpretation that Advocate General Poiares Maduro has given to the case law to achieve an implementation of the principle of solidarity does not make sense because of the fact that notary fees are fully paid by the parties to a transaction. To apply the competitive advantage test suggested in this chapter does not make sense either for the same reason. Mote particularly it can be assumed that notaries are usually not driven by motives of charity or benefaction in the exercise of their profession.

\subsubsection{Preliminary conclusion: Limiting the limits}

In conclusion it can be said that a limitation of the applicability of the competition tules cannot so much be based on the functional approach adopted in Hofner interpreting the concept of undertaking. The concept of economic activity flowing from it is abjective one that the Höfner rule determines positively through a comparative market criterion and negatively through an imperative public authority criterion. ${ }^{546}$ According to the former virtually any activity, at least in principle, can be offered on the market. However, in $S A T /$ Eurocontrol and $C$ ali the Court did not apply the compatative market criterion or even the attenuated market participation criterion, according to which an activity is economic if it is, or has been in the past, provided under market conditions. ${ }^{547}$ In those cases the Court clearly distegarded indications that private parties could, at least in principle, provide air traffic control or anti-pollution surveillance services in order to make profits. In assuming that the relevant activities typically would be connected with the exercise of powers carried out by or under the control of a public authority, that case law seems to be motivated by a teleological interpretation of the Treaty provisions ${ }^{548}$, drawing on a certain public-private divide in the Treaty. Such a divide has received specific attention in the learned discussion and refers to a possible divergence between the free movement rules and the competition rules with regard to the width of their respective scope of application. ${ }^{549}$ In fact, the differentiation between the two sets of Treaty ptovisions may be supported by the generally

544 Although impartial, a notary is a legal counsel. See for instance the Ricbtlinienempfehlungen der Bundesnotarkammer.

545 See Case C-475/99, Glöckner, [2001], esp. para. 21; Case C-244/94, FFSA vMAP, [1995], para.20; Case C67/96, Albany, [1999], para. 86; Case T-319/99, FENINI, [2003], para. 38. A separate question is whether any limitations in the exercise of the profession have implications for a possible derogation from the competition law prohibitions under either Article 81(3) or Article 82(6) EC. - On the argument about the non-applicability of Article $81 \mathrm{EC}$ because of public interest considerations see Monti G., (2002), $1086 \mathrm{ff}$.

546 Strictly speaking the imperative public authority criterion expresses a rival principle to the Höfnerrule, namely that public authority actors (i.e ultimately the Member States) are no (direct) addressees of the EC competition rules. See Case 118/85, $A A M S$, [1987], para 7: "...the recognition of the fact that the State may act either by exercising public powers or by carrying on economic activities of an industrial or commercial nature by offering goods and services on the market. In order to make such a distinction, it is therefore necessary, in each case, to consider the activities exercised by the State and to determine the category to which those activities belong."

547 This is one of the major critiques that the case law of $S A T /$ Eurocontrol and Cali counter. With regard to the second branch of case law that restricts the universal applicability of EC competition law see Joined Cases C159/91 and C-160/91, Poucet and Pistre, [1993], paras. 19-21. There the Court did not refer to the comparative market (participation) criterion either.

548 Joined Cases C-180 to 184/98, Pavlov, [2000], para. 69.

549 Pescatore P., (1987); Marenco G., (1987); Weatherill S. / Beaumont, (1999), 521 f.; Hatzopoulos V., (2000), 76 ff.; Mortelmans K. (2001), 622 f., 635 f.; Baquero Cruz J., (2002); Van den Bogaert S., (2002); O'Loughlin R., (2003); Whish R, (2003), 211; Odudu O., (2006), $46 \mathrm{ff.}$ 
different addressees to which the respective sets of EC rules refer (the Member States on the one hand and undertakings on the other). Only in more recent times has the awareness of the rules' interface and potential for conflict or convergence increased. ${ }^{550}$

At this point it shall be stressed that, at first sight, the technique of excluding certain public interest activities from the ambit of competition law at the early stage of testing the judicial critetion 'undertaking' appears to be in tune with the aim of the EC competition rules, which is to guarantee a system of undistorted competition as laid down in Article 3(1)(g) EC. This system, in its turn, serves the establishment and functioning of the common market warranted in Article 2 EC. ${ }^{551}$ Thus, the competition provisions aim to prohibit behaviour of private actors that would frustrate the functioning of the internal market and that would undermine the effectiveness of the Treaty provisions applicable to State measures. Activities 'typically' exercised as powers of a public authority (SAT/Eurocontrol and Cali) or subject to strict State regulation implementing the principle of solidarity (Advocate General Poiares Maduro in FENIN II) do not seem to be covered by this aim, the argument being that a systematic application of the two competition prohibitions (Articles 81 and $82 \mathrm{EC}$ ) will have the result of requiring Member States to justify their measures under Article 86(2) EC as a mater of course, and that that would be meaningless. ${ }^{552}$ However, this argument does not seem to take sufficient account of the fact that Member States already are obliged, as a matter of course, to explain and justify their measures under the Treaty rules on the free movement rights that serve the same aim of establishing the common market. ${ }^{553}$ The argument thus does not appear to cut ice but only to sustain what is considered here an unnecessary perforation of the field of application of the competition rules at a premature stage of appraisal.

In fact one may wonder whether the case law that excepts from the remit of EC competition law activities related to typical public interest functions has been a digression rather than an excursus on the limits of the concept of undertaking and economic activity. In this respect the ECJ's judgment in Meca-Medina II may ting in the necessary changes to the view point of an assumed public-private divide in the EC Treaty. ${ }^{554}$ At first sight, the judgment in Meca-Medina II may be deplorable for the same reason aired here and also recognised, at least in principle, by Advocate General Maduro in FENIN II, namely that it seems to suggest that the two sets of $\mathrm{EC}$ rules embrace diverging concepts of economic activity. ${ }^{55}$ However, Meca-Medina II may also be interpreted, and thus welcomed, as opening the door for an even more 'Communitarian', i.e. objective, interpretation of the competition law concept of undertaking, and therewith of economic activity. In fact, and for the purpose

550 For instance Mortelmans K, (2001); Baquero Cruz J., (2002); O'Loughlin R., (2003). See also Chapter 7.1.2.5.3.1.

551 Case 6/72, Continental Can, [1973], paras. $23 \mathrm{ff}$.

552 AG Poiares Maduro in Case C-205/03 P, FENIN II, [2006], para 59.

553 The difference between the rules on the fundamental freedoms and those on the freedom of competition is that the required Community dimension to determine the jurisdictional scope of the respective EC rules differs. For details see below part II.

554 Case C-519/04P, Meca-Medina II, [2006], presented above in section I.2.1. Compare also AG Kokott in Case C-369/04, Hutchison 3G, [2007], paras. 57 ff.; AG Kokott in Case C-284/04, T-Mobile Austria, [2007], paras. 60 f. Weatherill S., (2006). See also Case T-155/04, SELEX/Eurocontrol, [2006], paras. $59 \mathrm{ff}$., discussed before at page 92. But see AG Poiares Maduro in Case C-438/05, Finnish Seamen's Union v Viking Line, [2007], para. 27.

555 By the way, the discussion on the possible public-private divide in the Treaty sometimes comes to curious conclusions; for instance Odudu O., (2006), 52, opines that "the free-movement rules apply to non-economic activity". 
of competition law, the Court in that case disconnects the interpretation of the concept of economic activity from the one given in the area of the four freedoms. The fine distinction, which the ECJ in Meca-Medina II developed, is made between the rules surrounding a cettain activity and the person engaging in that activity. ${ }^{556}$ The situation that presents itself is thus a triangular one in which the activity can be seen as a coupler between the actors and the rules that the latter adopt. The consequent question is why not to apply the same distinction also in the field of the free movement rights in order to determine the applicability of those rules in an equally objective way. This question is, however, outside the scope of this book. Suffice it to note that, in view of the rather advanced case law, which in the past and for the specific field of sport has recognised certain tules of the game to be outside Articles $49 \mathrm{EC}^{557}$, the ECJ in Meca-Medina II may not have felt yet to take a further leap forward by applying across the board the same broad functional interpretation of what is an economic activity, i.e. the same autonomous concept for the entire field of EC law covered by Article $2 \mathrm{EC}$.

Not only the disparity with the free movement rulcs should incite the case law to review its approach adopted in $S A T /$ Eurocontrol and Cali. That approach, which Advocate General Poiares Maduro in FENIN II actually reinforces, must be questioned as it is liable to lead to a disparity in the application of EC competition law actoss the Member States. The criterion employed in SAT/Eurocontrol and Calì of powers typically exercise by a public authority opens the door for Member States to determine which activities are within and which are outside the temit of EC competition law. Advocate General Poiares Maduro even explicitly accepts as a decisive factor in excluding the economic nature of an activity the intention of Member States to tegulate (tather than to participate in) markets. However, such an approach is in stark contrast with the Community character of the concept of undertaking and the exclusive competence of the Community in competition matters. ${ }^{58}$ Granting Member States to organise certain activities in a way to actually withdraw them from the jutisdictional scope of application of EC competition law by reference to an essential function of their societal system goes beyond Member States' competence to make certain policy choices and implement economic regulation. The more general conclusion thus to be drawn here is one which actually exceeds the topic of liberal professions: the effect of being organised by or under the control of a public authority is not a standard sufficiently objective to delimit the jurisdictional scope of competition law.

As has been explained above, the exercise of a task in the proclaimed public interest is, in itself, not enough to conclude on the exercise of public authority. Not any public interest task is sufficient to except an entity from the universal scope of the competition law provisions. The public authority notion referred to in $S . A T /$ Eurocontrol and Cali can in particular not be equated to the concept of general economic interest mentioned in Article 86(2) EC. If that were the case, the exemption of Article 86(2) EC would be devoid of any practical application. ${ }^{559}$ In other words, equating a task of general economic interest in the sense of Article 86(2) EC with powers exercised by or under the control of a public

556 Vi₹ the body making the rules with regard to that activity. See above page 77.

557 Case law in note 380 above.

558 Provided that there is a Community dimension; for details see below part II of this chapter.

559 See above note 454. See AG Poiares Maduro in Case C-205/03 P, FENIN II, [2006], para. 26, who rightly observes at note 35: "While Article $16 \mathrm{EC}$ emphasises the need for guaranteeing the operation of services of general economic interest, it does not constitute a restriction on the scope of Article 86(2) EC, but instead provides a point of refercnce for the interpretation of that provision." 
authority, which presumably exercises these powers in the public interest, would lead to the practical consequence that general (economic) interest tasks would not fall under the competition prohibitions in the first place. ${ }^{560}$ Without anticipating on the substance of Article 86(2) EC in Chapter 7.II., the consideration of the systematic structure of the EC competition provisions makes clear that any exception to the concept of undertaking must be interpteted strictly.

On the basis of more recent case law like Meca-Medina II and Cassa di Risparmio di Firenze $e^{561}$ my contention is that the opportunity has emerged for the case law to develop towards a more coherent, i.e. objective, approach concerning the balance between activities that are necessarily carried out by or under the control of public authority (i.e. the imperative public authority criterion), and those that can, at least in principle, be provided in order to make profits (i.e. the comparative market criterion). This chapter suggests a criterion of charity or benefaction according to which the actor under scrutiny could rebut the comparative market criterion if she demonstrates that she exercises the activity in question with a view to doing charity. It would be necessary to prove that any financial attribution is a mere compensation of the costs incutred and does not go beyond what is necessary to discharge of the 'charitable obligation', whether self-imposed or not. Conversely, if the interpretation proposed by Advocate General Poiares Maduro in FENIN II were to materialise a more general approach towards the principle of solidarity as the applicable criterion in delimiting the jurisdictional scope of competition law, it shall be stressed that only in situations of strictly self-contained systems may certain professional activities, for instance a system of legal aid, conceivably be excluded from the ambit of competition law.

Moreover, as the discussion of the example on the notary's activities illustrates, the function of the operator and the role of the State in organising certain sectors form an amalgam that is difficult to differentiate for dogmatic purposes. One thing seems to be fot certain, namely that the mere emphasis on the function of the operator and the nature of an activity does not provide a basis for sector specific exceptions from the applicability of competition law for the liberal professions or even particular professional groups. ${ }^{562}$ Furthermore, to rebut the general suggestion that professional services are economic in nature, and hence that professional service providers are undertakings within the meaning of EC competition law, will certainly require a detailed scrutiny of the rules organising the exercise of a particular professional activity on a case by case basis.

\subsection{Employed professionals}

It is in accordance with the broad concept of undertaking to include the activities of liberal professionals in the scope of Articles 81 and $82 \mathrm{EC}$, at least where they are self-

560 See AG Fennelly in Case C-266/96, Corsica Ferries M France, [1998], note 72, stating with regard to activities of undertakings rather than of associations that a supposed public service objective does not suffice to "denude" a service in the general economic interest of its inherent commercial nature. On the particular question whether also associations can invoke Article 86(2) EC, or whether the latter is strictly limited to undertakings on the ground that the concept of undertaking as a Community concept is the same for all competition provisions of the Treaty, see Chapter 7.II.1.2. - Repeatedly critical also AG Jacobs in Case C-475/99, Glöckner, [2001], para. 69; AG Jacobs in Case C-222/04, Cassa di Risparmio di Firenze, [2006], paras. 76 to 83.

561 Case C-222/04, Cassa di Risparmio di Firenze, [2006].

${ }_{562}$ See above section I.2.1., Case C-519/04 P, Meca-Medina II, [2006], paras. 30 ff.; and Case C-309/99, Wouters et al. $\nu N O \nu A,[2002]$, paras. $48 \mathrm{f}$. 
employed. ${ }^{563}$ Self-employment traditionally marks the exercise of a liberal profession as a trait of one of the basic conceptual ideas of the professions, namely that they are independent. A qualification as undertaking is mote problematic with regard to employed professionals. In the recent past it has been recognised that professional activities may be exercised as dependent employment, and even that professionals may be employed by nonprofessionals. ${ }^{564}$ Consequently, the independence of liberal professions decreased at least as regards the numbers of self-employed members of the professions. More and more often liberal professionals are working as employees in hospitals, clinics, law firms, accountancy firms, engineering offices. For instance, in 1988 less than half of the doctors in Europe, i.e. 400,000 out of 941,000 were self-employed. ${ }^{565}$

The question is whether employed professionals qualify as undertakings. From an economic point of view one could argue that the activity of employed professionals against remuneration is similat to the sale of goods or the provision of services. According to the case law, however, employees, for the duration of their employment, form part of the economic unit of the company for which they work. ${ }^{566}$ They thetefore do not form an entity in the sense of EC competition law independent of their employer. ${ }^{567}$ The reason for this assessment first of all is a substantive argument:

"Dependent labour is by its very nature the opposite of the independent exercise of an economic or commercial activity. Employees normally do not bear the direct commercial tisk of a given transaction. They are subject to the orders of their employer. They do not offer services to different clients, but work for a single employer. For those reasons there is a significant functional difference between an employee and an undertaking providing services. That difference is reflected in their distinct legal status in various areas of Community [for instance Articles 39 and $49 \mathrm{EC}$ ) or national law." ${ }^{2568}$

Secondly, it is also in a teleological interpretation of the competition rules that employees

${ }_{563}$ As seen above the Court and also the Commission have no difficulties in establishing that professionals are undertakings within the meaning of EC competition law where "they carry on their activities as self-employed persons" supplying their services in return for payment and assuming the financial risks associated with the pursuit of this activity. Under the wide conception of the term undertaking in EC competition law it is justified to include self-employed libetal professionals in the scope of Article 81(1) EC. Commission Decision EPI Code of Conduct, (1999), para. 23. Case C-309/99, Wouters et al. $\nu N O v A$, [2002]. The criteria of accepting the financial risks of transactions more generally serves to determine the economic character of an activity, see for instance Joined Cases 40 to $48 / 73,50 / 73,54$ to 56/73, 111/73, 113 and 114/73, Suiker Unie, [1975], para. 541.

564 E.g. as in-house legal council who used not to be allowed to represent their employer in court. In the Netherlands, which claim to have the most liberal regime for notaries, the latter are allowed to work as employed rather than self-employed persons after the introduction of the new Act on notaries (Wet op bet notarisambi) in 1999. - Furthermore, where it may be established that professionals exercise a task of public authority (see above section I.2.2.2.), it should be immaterial whether they are employed by a private natural or legal person, as they act as representatives of public authority and at the service of the general interests of the State, see Case C-405/01, COMME, [2003], para. 43, on the application of Article 39(4) EC to masters and chief mates of merchant navy ships employed by private natural or legal persons. In contrast and two years earlier, AG Jacobs in Case C-283/99, Commission v Italian (private security services), [2001], 24 ff., still took the view that Article 39(4) EC "cannot conceivably cover employment by a private natural or legal person, whatever the duties of the employee."

565 Wasilewski R, (1993), 45. - Whether this fact of the majority of the members not working as self-employed would change their classification as liberal profession is, first, a question of national jurisdiction. Second, in accordance with the Höfnerrule, and due to its Communitarian, i.e. objective, interpretation, it is not relevant for the professionals' classification as undertakings under EC competition law that at national level the classification as 'liberal' would depend on the number of self-employed members.

566 Case C-22/98, Becu, [1999], para. 26.

567 Stockenhuber P., (2001), para. 60.

${ }^{568} \Lambda \mathrm{G}$ Jacobs in Case C-67/96, Joined Cases C-115/97, C-116/97 and C-117/97 and Case C-219/97, Albany/Brentjens'/Drijvende Bokken, [1999], paras. $209 \mathrm{ff}$. 
do not come within the ambit thereof:

"the system of Community competition law is not tailored to be applicable to employees. The examples of anticompetitive practices in Articles [81(1) and $82 \mathrm{EC}$ ] or the conditions for exemption in Article [81(3) EC] are clearly drafted with regard to economic actors engaged in the supply of goods or services. Article [81(1)(a) EC] for example refers to 'purchase or selling prices' and to 'other trading conditions'. Employees, on the contrary, are concerned with 'wages' and 'working conditions'. To apply Article [81(1) EC] to employees would therefore necessitate the use of uneasy analogies between the markets for goods and services and labour markets. ${ }^{2569}$

For employed (liberal) professionals a different assessment could, however, be perceivable as they remain subject to professional obligations of independence and confidentiality, and are bound to provide their services on an individual basis to their clients. Due to these professional obligations liberal professionals are less subject to instructions by their employer in the exercise of their profession than are employees in other sectors. Moreover, employed professionals are still members of the relevant professional bodies and their professional behaviour is subject to similar rules and control as is that of their selfemployed peers.

Taking account of the case law that the economic independence of an actor as such is not constituent for its quality as undertaking the question arises whether the professional independence in particular allows to qualify employees as undertakings. ${ }^{570}$ It should be clear however, that employed professionals do not qualify as undertakings where their economic reality is defined by the fact that they act for and work under the auspice of their employer, and where their success or failure is ascribed to the latter who, as the case may be, might engage her responsibility for the malfunctioning of the employee. This pattern of principal and agent is not broken by the fact that the practitioners, next to the employer, may simultaneously engage their professional liability. For the duration of their employment relationship practitioners are indifferently incorporated in the firms or clinics that employ them and are thus no economic entity independent of their employer. This assessment may, however, be different in certain borderline cases where a salatied professional does not exactly wotk under the direction of that employer and where her remuneration is directly linked to the employer's profits and losses. ${ }^{571}$ This can, for instance, be the case for professionals employed on the basis of a free-lance contract, in spite of exercising their activities in the premisses of the larger economic unit. A corresponding qualification as undertaking depends also on the legal status that salaried professionals have in the Member States. ${ }^{572}$ Irrespectively, the conclusion of this section is that under the current interpretation in the case law employed professionals do not generally come within the ambit of

569 AG Jacobs in Case C-67/96, Joined Cases C-115/97, C-116/97 and C-117/97 and Case C-219/97, Albany/Brentjens'/Drijvende Bokken, [1999], paras. $215 \mathrm{f}$.

570 Stockenhuber P., (2001), para. 62.

571 AG Jacobs in Case C-67/96, Joined Cases C-115/97, C-116/97 and C-117/97 and Case C-219/97, Albany/Brentjens'/Drijvende Bokken, [1999], para. 217; AG Léger in Case C-309/99, Wouters et al. v NOvA, [2002], para. 52.

${ }_{572}$ AG Jacobs in Case C-67/96, Joined Cases C-115/97, C-116/97 and C-117/97 and Case C-219/97, Albany/Brentjens' $/$ Drijvende Bokken, [1999], para. 215, see above notes 568, 569. This obviously undermines (once more) the Community character of the concept of undertaking. In fact, one may wonder whether employees do indeed not bear the commercial risks that employers have to take when operating in markets. After all, employees have to accept the burden flowing from not having looked for another employer in time (i.e. before insolvency), or from not having (been able to) put sufficient productivity in to the business of their - meanwhile uncompetitive, if not insolvent - employer. The point is that in the current optic the employees would not take or account for the necessary strategic business decisions. That is why AG Jacobs in Albany adds the words "direct" and "normally". 
'undertaking' or competition law.

\section{Professional associations as undertakings?}

The remaining question is whether professional associations come within the ambit of competition law. At this stage of the scrutiny this question translates into whether professional associations qualify themselves as undertakings, i.e. independently of their members, which they represent in their collectivity. Due to the relative concept of undertaking each activity of a professional association has to be addressed individually in order to decide whether it carries out an economic activity of its own.

Generally speaking professional associations group their members with a view to representing their interests. Furthermore, professional associations often assume regulatory and supervisory tasks, which they assume to organise the access to and/or the exercise of professional activities in (part of) a Member State, and to control the compliance with the respective rules. ${ }^{573}$ One should think that such regulatory and supervisory powers are not normally offered for a reward on a market, in which the professional associations would participate. ${ }^{574}$ Professional associations ate generally organised in a way that their regulations are either voted by the collectivity of the professionals or adopted by a representative body elected by the members of the profession. Although it is conceivable that the drafting of professional rules be commissioned to private operators, such rules would still need the approval of the collectivity of the profession in order to be commonly accepted by the members to apply. ${ }^{575}$ For instance, where lawyers, professors or other specialists draft the statutes of corporations, or design individual contracts or standard contract forms, they certainly engage in an economic activity provided on a market. This cettainly says something about the economic character of the lawyer's activity in regulating, i.e. drafting rules. However, it does not necessarily say something about the character of the activity that an association exercises when proposing or applying the thus drafted rules to the members of the profession.It is difficult to imagine that a private operator could, on its own initiative, undertake such regulatory and supervisory powers as an activity for profit. ${ }^{576}$ Moreover, and apart from their regulatory and supervisory activities, it is not perceivable that professional associations would engage on the same markets as their members and compete with them in the provision of the latter's professional services. This is true also where the professional association may organise the provision of certain services free of chatge, for instance pro bono publico work ${ }^{577}$, as it has the purpose to be provided to clients who normally would not create a demand on the market for lack of financial means. ${ }^{578}$

573 For a more detailed description of the organisation of and the statutory provisions on different professional associations in different Member States see Chapter 4.I.2.4.

574 See above page 91.

575 Sec also Case T-155/04, SELEX/Eurocontrol, [2006], making a comparable distinction with regard to the production and the adoption of ATM standards, see above page 92.

576 Sec AG Léger in Case C-309/99, Wouters et al. vNOvA, [2002], para. 143. Any other activity carried out by a professional association that might be provided on an economic basis - for instance auxiliary services made available to the professionals like database or accountancy services, or even supplementary insurance services are not relevant for present purposes, as the research focusses on the rules regulating the liberal professions and the exercise of their professional activities.

577 See above section I.2.2.4. In the UK a specialised Bar Pro Bono Unit has been established in 1996, see <http://www.barprobono,org.uk/navigate/home.html>.

${ }_{578}$ Pro bono work is carried out in case legal aid is not available, either because it has not been granted or is not 
Thus, in as far as regulatory and/ or supervisory activities of professional associations are considered as the relevant activities for present purposes, their authors, i.e. the professional associations, are no undertakings exercising an economic activity of their own and independently of their members. This does not, however, imply that professional bodies are immune for the application of EC competition law; quite to the contrary, Article 81(1) EC explicitly includes associations of undertakings in its scope. This is in contrast with Article $82 \mathrm{EC}$, which only mentions undertakings, not their association. The regulatory and supervisory activities of the latter might, however, be covered even under Article 82 EC where the association acts as the collective and dominant "emanation" of its economically active members. ${ }^{579}$ However, before turning to these prohibition provisions more specifically in Chapters 4 and 5 , the second general jurisdictional element that determines the applicability of EC competition law shall be depicted.

\section{Community dimension - The potential of professional regulations to affect trade between Member States}

The following part turns to the second jurisdictional element of EC competition law. Articles 81(1) and $82 \mathrm{EC}$, the two clauses prohibiting undertakings to interfere in markets in an anti-competitive way, apply only to conduct that "may affect trade between Member States". ${ }^{580}$ In terms of the present book the relevant question is whether professional conduct (be it determined by self- or State regulatory rules ${ }^{581}$ ) is capable of affecting trade between Member States to an appreciable extent. If it should not, the ensuing conclusion should be that its case does not have a Community dimension, i.e it has no significance under Community competition law. Yet, such professional conduct may be prohibited under national competition law, if - upon a substantive assessment - it is found to impair competition. The substantive assessment of whether a particular professional conduct or rule leads to a deterioration of competition on a particular market is, however, separate from the jurisdictional inquiry addressed here. ${ }^{582}$ The particular purpose of the interstate trade criterion

foreseen for particular procedures. See also the caveat drawing on the Altmark test above in note 515,561 . On legal aid see also Chapter 4.I.2.4.

579 See Case T-193/02, Piau I, [2005], para. 116.

${ }_{580}$ The same element applies also in State aid cases under Article $87 \mathrm{EC}$.

581 While members of a professions may align their economic conduct to rules that are adopted either collectively among the professionals themselves, through their representative associations, or even by Member State authorities, it is not necessary to differentiate too strictly between the relevant regulatory actors at this point of the scrutiny.

${ }^{582}$ This has already been pointed out in Chapter 2.II. While both criteria, i.e the Community dimension and the substantive assessment, are closely interrelated and have to be applied cumulatively in a given case, their analysis nevertheless has to be carried out separately. Goyder D.G., (2003), 83; Frenz W., (2006), para. 640. Yet another related but distinct question is the determination of the relevant (services) market. It is conceivable to scrutinise the interstate trade requirement only once the criteria of the relevant market and the particular conduct (which supposedly impairs competition) have been established under Article 81(1) EC or Article 82 EC. The Court has not applied a strict approach in this respect. Formetly, it but used to start with the interstate trade requirement before turning to the substantive assessment of actual impairment of competition, see for instance Case 56/65, STM v Maschinenbau Ulm, [1966], 303; Joined Cases 56 to 58/64, Consten and Grundig, [1960], 389 f.; Case 193/83, Windsurfing International, [1986], para. 96. On occasion the Court and the Commission have used a language that has blurred, rather than clarified, the difference between the two elements of Community dimension and substantive assessment. See for instance the notices on minor importance prior to 2001, e.g. European Commission, Commission Notice on agreements of minor importance which do not appreciably restrict competition under Article 81(1) of the Treaty establishing the European Community (de minimis). For details on the substantive assessment see the 
is to determine which cases are covered by Community competition law and which by the competition laws of the Member States. ${ }^{583}$

As the respective wording of both Articles 81(1) and $82 \mathrm{EC}$ indicates it is enough that interstate trade "may" be affected, and it is thus not necessary to demonstrate that there is an actual impediment of trade between Member States. Therefore and differently from the Treaty rules on the fundamental freedoms (which require an actual cross-border element for their applicability $\left.{ }^{584}\right) \mathrm{EC}$ competition rules apply also to situations that are purely internal to a Member State. The competition rules are intended to sustain the overall purpose of the Treaty to achieve a common market characterised by growing market integration. ${ }^{585}$ Although market integration is not the primary aim of the competition rules, their function of safeguarding free competition reinforces the opportunities for unrestricted transnational trade in goods and services. The interstate trade criterion therefore is the product of the Treaty aim to guatantee a system of undistorted competition within the internal market (Article $3(1)(\mathrm{g})$ EC) without so much requiring that an actual trans-boundary element be present in an individual case.

The competition law element of Community dimension raises three issues that shall be dealt with hereafter. First of all, the interstate trade criterion is, in principle, interpreted broadly. The yardstick for this broad interpretation is explained in section 1. and is employed with a view to establishing whether a certain professional practice is capable of affecting trade between Member States. Secondly, the broadness of the interstate trade criterion is qualified in a dual way (probability prognosis and appreciability) presented in section 2 . Thirdly, the question arises who - Community or national competition authorities - secure the competitive neutrality of professional tegulations, section 3 .

\section{following two chapters.}

583 This jurisdictional purpose had been recognised early, Case 56/65, STM v Mascbinenbau Ulm, [1966], 249; Joined Cases 56 to 58/64, Consten and Grundig, [1960]; Case 22/78, Hugin, [1979], para. 17. More recently Case C475/99, Glöckner, [2001], para. 47: "according to the case-law of the Court, the interpretation and application of the condition relating to effects on trade between Member States contained in Articles [81 and $82 \mathrm{EC}$ ] must be based on the purpose of that condition which is to define, in the context of the law govcrning competition, the boundary between the areas respectively covered by Community law and the law of the Member States. Thus, Community law covers any agreement or any practice whicb is capable of constituting a threat to freedom of trade between Member States in a manner which might harm the attainment on the objectives of a single market between the Member States, in particular by sealing off national markets or by affecting the structure of competition within the common market" (emphasis added).

584 See e.g. Case 175/78, Saunders, [1979], paras. 9 ff.; Case 298/84, Paolo Iorio, [1986], paras. 12 ff.; Case C299/95, Krempow, [1997], para. 16; Joined Cases 286/82 and 26/83, Luisi atd Carbone, [1984], para. 16. However, even in cases that concern a purely internal situation (i.c. having no cross-border implications) the case law moves to apply a more lenient test if national law requires a national court to extend to 'domestic citizens' the advantages that Community law confers on the citizens of the other Member States. In respect of goods see Joined Cases C-321/94 to C-324/94, Pistre and others, [1997], paras. 44 f;; and Case C-448/98, Guimont, [2000]; in respect of freedom to provide services see Case C-405/98, Gourmet International, [2001], paras. 37 f.; and Case C-6/01, Anomar, [2003], para. 41. In references for a preliminary ruling the Court therefore is willing to provide a national court with an interpretation of the fundamental freedom provisions even in purely internal situation. It applies a more generalised test of whether a national rule is liable to treat transnational situations less favourable than purely national situations, and therefore constitutes a restriction on the freedoms of movement, Case C-442/02, CaixaBank France, [2004], para. 12. AG Poiares Maduro in Cases C-94/04 and C-202/04, Cipolla and Macrino, [2006], paras. 19 and $55 \mathrm{ff}$.

585 Frenz W., (2006), paras. 2,13,15. The functions of the Treaty rules on competition and on the fundamental freedoms are complementary in their positive effect for the intermal market. In this they are equally important for the establishment and achievement thereof, Article 2 EC. Case C-475/99, Glöckner, [2001], para. 48; Case 30/87, Bodson, [1988], para. 24. 


\section{A broad interpretation - Professional regulations capable of affecting trade between Member States}

The question in this section is whether professional regulations that determine (the access to and the exercise of the economic activities of practitioners may have an effect on trade between Member States. Given that in many Member States the majority of liberal professions are organised and regulated at a national scale (be it by self- or State regulation), the question can be formulated even stronger, namely whether professional regulations might possibly contribute to holding up the economic interpenetration of professional services markets and/ or alter the structure of competition within the common market for professional services.

Since the intra-Community trade criterion is used to delimit the jurisdictional realm of Community competition it does not imply a substantive assessment of a particular economic practice. It thus can be interpreted broadly. According to the yardstick developed by the Court "it must be possible to foresee with a sufficient degree of probability [and] on the basis of a set of objective factors of law or fact that [a certain practice] may bave an influence, direct or indirect, actual or potential, on the pattern of trade between Member States, such as might prejudice the realisation of the aim of a single market in all the Member States. "2586 The Court specifies that the effect on intra-Community trade normally is the result of a combination of several factors which, taken separately, are not necessarily decisive. ${ }^{587}$ Conversely, it is not necessary that the practice (supposedly impairing competition ${ }^{588}$ ) actually affects trade between Member States, but it is sufficient that the practice is capable of having that effect. ${ }^{589}$

As a consequence of its broad conception it is not necessary that intra-Community trade be affected negatively, i.e. restricted or reduced. Patterns of trade can also be affected when

586 Case 42/84, Remia and Nutricia, [1985], para. 22 (emphasis added). For detailed indications how to interpret this formula on the Community dimension, scc European Commission, Guidelines on the effect on trade concept, paras. $36 \mathrm{ff}$, and $23 \mathrm{ff}$. The structure of this broad formulation has a good tradition in the Court's case law, see for instance in the field of the free movement of goods the famous Case 8/74, Dassonville, [1974], para. 5, in determining the jurisdictional scope ratione materiae of Article $28 \mathrm{EC}$ ("trading rules enacted by Member States which are capable of hindering, directly or indirectly, actually or potentially, intra-Community trade"). - For a more recent formulation of the intra-Community criterion in competition law, see Case C-407/04 P, Dalmine, [2007], para. 90: "If an agreement, decision or practice is to be capable of affecting trade between Member States, it must be possible to foresee with a sufficient degree of probability, on the basis of a set of objective factors of law or of fact, that they may have an influence, direct or indirect, actual or potential, on the pattern of trade between Member States in such a way as to cause concern that they might hinder the attainment of a single market between Member States. Moreover, that effect must not be insignificant", with reference to Case C306/96, Javico, [1998], para. 16; Joined Cases C-215/96 and C-216/96, Bagnasco, [1999], para. 47; Case C-475/99, Glöckner, [2001], para. 48. See also Case 56/65, STM v Mascbinenbau Ulm, [1960], 341; Joined Cases 56 to 58/64, Consten and Grundig, [1966].

587 Case C-250/92, Gottrup-Klim v DLG, [1994], para. 54. Case C-359/01 P, British Sugar, [2004], para. 27; ]oined Cases C-295/04 to C-298/04, Manfredi, [2006], para. 43. In Case C-238/05, Ausbanc, [2006], para. 35, the Court stresses that "In order to assess whether an arrangement has an appreciable effect on trade between Member States, it is necessary to examine it in its economic and legal context", with reference "to that effect" to Case C393/92, Almelo, [1994], para. 37. Moreover, the Court emphasises at para. 43 that "According to settled case-law, and as follows from paragraph 34 of this judgment, Article 81(1) EC does not require that the arrangements referred to in that provision have actually affected trade between Member States, but it does require that it be cstablished that those arrangements are capable of having that effect", with reference "to that effect" to Case 19/77, Miller, [1978], para. 15; and Case C-219/95 P, Ferriere Nord SpA v Commission, [1997], para. 19; and Joined Cases C-215/96 and C-216/96, Bagnasco, [1999], para. 48.

588 See above note 582 .

589 Case C-219/95 P, Ferriere Nord SpA v Commission, [1997], para. 19. 
an agreement or practice causes an increase in trade. ${ }^{590}$ More generally the jurisdiction of Community competition law can be established in cases where trade between Member States is likely to develop differently with the conduct at stake when compared to the way in which it would probably have developed in the absence of the agreement or practice. ${ }^{591}$ The interstate trade criterion thus bears a comparative element. ${ }^{592}$ That it can be met even in case of trade increases can be backed up not least with reference to Atticle 81(3) EC. That article provides for an exemption from the competition prohibition only in cases where an economic practice "contributes to improving the production or distribution of goods [or services] or to promoting technical or cconomic progress". 593 The neutral approach to possible changes in trade patterns reinforces the point that the effect-on-trade criterion is a jurisdictional one.

Because of its broad interpretation, the interstate trade criterion involves little difficulty to be establish in the majority of cases. In particular, intra-Community trade is affected where conduct of undertakings may have the effect of either sealing off national markets or affecting the structure of competition within the common market. ${ }^{594}$ For instance, it has been repeatedly held that economic practices that are organised to extend over the whole of the territory of a Member State hold up the economic interpenetration which the Treaty is designed to bring about. They thus reinforce, by their very nature, the partitioning of markets on a national basis. ${ }^{595}$ Furthermore, on some occasions - and in particular in the context of Article $82 \mathrm{EC}$ cases - the Court has suggested that the interstate trade condition will be satisfied by any alteration in the structure of competition within the common market. ${ }^{596}$ In the particular circumstances of Article $82 \mathrm{EC}$ cases one economic actor, or a collectivity thereof, ex bypothesis is in a dominant position. ${ }^{597}$ This means that the structural fabric of the market, i.e. competition, will already be a matter of $\operatorname{concern}^{598}$, and that the intra-Community trade criterion thus can be established easily.

In light of this case law, it appears that cases of professional, i.e. collective regulations extending to the whole territory of a Member State come within the ambit of EC competition law because they have, by their very nature, the effect of reinforcing the partitioning of markets on a national basis, thereby holding up the economic interpenetration that the Treaty is designed to bring about. ${ }^{599}$ The required probability prognosis, which will be scrutinised more in detail in section 2.1., hence is inherently answered to the affirmative. Moreover, where professional regulations even prove to impact activities exercised across

\footnotetext{
590 Joined Cases 56 to 58/64, Consten and Grundig, [1966].

591 Joined Cases 209 to 215 and 218/78, van Landenyck, [1980], para. 172; Case T-61/89, Dansk Pelsdyravlerforening (DPF), [1992], para. 143. Case 22/71, Béguelin, [1971], 960; Case 5/69, Völk, [1969], paras. 5, 7; Case 19/77, Miller, [1978], para. 15; Case 27/87, Eraun-Jacquery, [1988].

592 European Commission, Guidelines on the effect on trade concept, para. 35.

593 For details on Article 81 (3) EC see Chapter 7.I.

594 Case C-475/99, Glöckner, [2001], para. 47. Case 22/78, Hugin, [1979], para. 17.

595 Case 8/72, Cementhandelaren, [1972], para. 29; Case 42/84, Remia and Nutricia, [1985], para. 22.

596 Case 23/67, Brasserie de Haecht, [1967]; Joined Cases 6 and 7/73, Commercial Solvents, [1974]; Case 7/82, GVL, [1983].

597 For details see Chapter 5.I.

598 Whish R, (2003), 144. The Commission has applied this structurc-of-competition-test also in decisions concerning Article $81 \mathrm{EC}$.

599 Case C-35/96, Commission vitalian Republic (CNSD II), [1998], para. 48; Case C-309/99, Wouters et al. $\nu N O v A$, [2002], para. 95; Case C-35/99, Manuele Arduino, [2002], para. 33; Commission Decision Belgian architects, (2004), para. 100; Joined Cases C-94/04 and C-202/04, Cipolla and Macrino, [2006], para. 45. In such cases there is no need to calculate the actual volume of the professional services sectors that are affected by collective regulation.
} 
the border, the Community dimension will be fulfilled without further ado. ${ }^{600}$ Yet, it shall be pointed out that it is not necessary to inquire whether a professional practice actually has, or had, an effect on trade between Member States. Consequently, while the facts of a case may be purely internal to the territory of a Member State, its situation will still be covered by EC competition law where it may affect intra-Community trade.

The picture may have to be qualified if it can be established that professional regulations have, as suggested by representatives of the Commission, their "centre of gravity" in one Member State only. In other words the question is whether to restrict the broad applicability of Community competition law where it is foreseeable, with a sufficient degree of probability, that the effects of professional regulations on trade may be limited to the territory of one Member State, because for instance they generally do not apply abroad. This argument seems to be all the more relevant where professional codes are adopted to apply only in a part of the national territory. For instance, architects and doctors in Germany apply regional regulations that apply at the level of the Länder. ${ }^{602}$ In order to verify the validity of the particular concern a number of objective factors have to be taken into account hereafter.

\section{Limits to an all-encompassing Community dimension}

In order to determine the limits of what otherwise would seem to be an allencompassing definition of the Community dimension the Court draws on two dimensions. To begin with only that conduct comes within the jurisdiction of EC competition law the effects of which on trade between Member States can be predicted on the basis of objective factors and with a sufficient degree of probability (probability prognosis). 'This standard will be tested on professional conduct (be it determined by self- ot State regulatory measures) in section 2.1. Moreover, not any conduct capable of affecting trade between Member State comes within the ambit of the Community rules on competition, but only if it does so to an appreciable extent, section 2.2 .

\subsection{Objective factors for a sufficient predictability of an effect on interstate trade}

While the criterion of probability prognosis ${ }^{603}$ bears to broaden the scope of EC competition law it also bears to control too broad an application thereof. In order to carty out the probability prognosis necessaty to assess the Community dimension of an economic practice, it is necessary to

"take account of the legal and factual environment in which the [economic] practice operates. The relevant

600 Commission Decision CNSD, (1993), paras. 49 ff.; Commission Decision COAPI, (1995), para. 40; Commission Decision EPI Code of Conduct, (1999), para. 45. In such circumstances not only EC competition law will be applicable, but also the rules on the freedom to provide services, Article 49 EC. Sce Joined Cases C-94/04 and C-202/04, Cipolla and Macrino, [2006], para. 58, where the Court held that the prohibition to derogate from minimum fees for lawyers "is liable to render access to the Italian legal scrvices market more difficult for lawyers established in a Member State other than the Italian Republic and therefore is likely to restrict the exercise of their activities providing services in that Member State. That prohibition therefore amounts to a restriction within the meaning of Article $49 \mathrm{EC}$." The cases are summarised in Chapter 2.V.

601 Evans L., et al., (2006), 2. See also Bicho M.-J., (1999), 26; Ehlermann C.-D., (1993), 143. The indication is that in such cases the enforcement of the competition rules may be left to the national competition authorities.

602 While efforts often have been taken to develop model laws at federal level, they are not binding of itself, see e.g. Musterarchitektengesetz (MArchG) of 23.05.2002.

603 See for instance Case C-407/04 P, Dalmine, [2007], quoted above in note 586. 
economic and legal context provides insight into the potential for an cffect on trade between Membcr States. If there are absolute barriers to cross-border trade between Member States, which are external to the [economic] practice, trade is only capable of being affected if those barriers are likely to disappear in the foreseeable future. In cases where the barriers are not absolute but merely render cross-border activities more difficult, it is of the utmost importance to ensure that [economic] practices do not further hinder such activities. [Economic] practices that do so are capable of affecting trade between Member States."

The limits of the Community dimension have been exemplified by the Court in Bagnasco, a case that is selected here fot it concerns collective regulations. ${ }^{605}$ In a consequential approach the Court illustrated that the question whether an economic practice may have an effect on trade between Member States, or otherwise has to be excluded from the jurisdiction of Community competition law, has to be assessed from both the supply and the demand side, which (may) determine the market of a particular sector. The approach is distilled in section 2.1.1. before it will be applied in extrapolation to the professional services sectors in section 2.1.2.

\subsubsection{Possible effects on suppliers and customers of the sector concermed}

The case Bagnasco concerned collective regulation adopted by the Italian banking association for the provision of current-account credit facilities that are secured by general guarantees. In cartying out the probability prognosis of whether the collective rules at stake had a possible effect on trade between Member States, the Court adopted a negative approach, leading to the overall conclusion that the economic practice at stake did not possibly have an effect on intra-Community trade. This conclusion was mainly based on the factual determinants in the market for the provision of current-account credit facilities (secured by general guarantees), but also its legal circumstances. The issue that Bagnasco raised is one that Commission officials utter also in respect of professional regulation, namely whether certain transactions are necessarily limited to taking place within the territory of one Member State, so that the foreseeable effects of certain collective rules (which, subject to a substantive assessment, supposedly impair competition) are equally limited to the territory of that Member State. ${ }^{606}$ In such instance the conclusion is that the foreseeable effects are not possibly capable of affecting trade between Member States, but at best only within one Member State - in which case national competition law will be applicable.

The way the Court handled the scrutiny in Bagnasco is that it first established the conceivable potential of the collective regulations at stake to restrict trade between Member States. In particular the Court distinguished between, on the one hand, non-domestic competitors who may provide the services in question domestically and, on the other, domestic consumers who may look abroad for the services the provision of which is testricted domestically. ${ }^{607}$ Secondly, the Court went into the actual potential of the disputed regulations to affect intta-

604 European Commission, Guidelines on the effect on trade concept, para. 32 (emphasis added).

605 Joined Cases C-215/96 and C-216/96, Bagnasco, [1999], paras. 46 ff., 51 f., 15.

606 See above on the "centre of gravity", note 601. For details see the following section M.2.1.2.

607 Para. 49 of the judgment in Bagnasco. The Court did so by establishing that the subsidiaries or branches of non-domestic competitors might be obliged to apply the disputed collective regulations, and thus forgo the possibility of applying more favourable conditions in the provision of the relevant services. With regard to the customers wishing to conclude a contract for a current-account credit facility, the Courtobserved that they might find that their choice of bank was restricted where the conclusion of such a contract depended upon the provision of a surety governed by the disputed collective regulations, to which, the Court specified, no exceptions for the most part were possible. 
Community trade by illustrating objective factors of law and of fact that could be inferred from the circumstances of the case (mainly as reported by the Commission) ${ }^{608}$

In this scrutiny the Court first concentrated on factors determining the provision of the services subject to the disputed collective regulations. Subsequently, the Court turned to concentrate on factors that may possibly determine (potential) providers and purchasers to participate in the necessary transactions. With regard to the services in question the Court noted - and followed in this respect the Commission's opinion in this respect - that, because of either contractual provisions or by reason of their very nature, the economic activities in questions had to be carried out only within the domestic territory. Since these activities were thus limited to national territory, they had a very limited influence on trade between Member States, if at all. In tespect of the potential customers possibly considering to purchase the services in question across borders, the Court observed that the main customers of nondomestic competitors did not have a great recourse to such services. Moreover, the Court pointed out that there was no indication of a sufficient degree of probability that the reservations entertained by domestic customers were of such kind as to have an appreciable effect on inter-Community trade. ${ }^{609}$ In respect of providers potentially trading the service in question across intra-Community borders, the Court followed the Commission in its observation that the participation of non-domestic competitors was limited. ${ }^{610}$ The Court in particular noted that the choice of the non-domestic competitors - as to whether or not establish themselves in the Member State in which the disputed regulations have been adopted - does not decisively depend on whether their customers use such services. ${ }^{11}$ The bottom line of what the Court seems to say is that there simply is no trans-national market for current-account credit facilities secured by general guarantees, whether actual or potential.

Obviously, one must be wary about an argument built on the assertion that no relevant cross-border transactions would take place, whether actual or potential. In fact, the absence of such transactions might be the effect of the very restriction, which would suggest that the rules in question do have a likely effect on trade between Member States. ${ }^{612}$ For currentaccount credit facilities secured by general guarantees the Court has decided the question. But what about the case of professional regulation?

\subsubsection{Objective factors in professional services sectors}

In conducting the probability examination with regard to professional regulations and their possible effect on interstate trade, the following objective factors shall be considered: the nature of professional rules; the nature of professional services covered by these rules; and the position, importance, and incentives of the providers and purchasers of professional services covered by these rules. ${ }^{613}$

Before going into these aspects, it should be noted that it is not necessary that every

608 Para. $50 \mathrm{ff}$. of the judgment in Bagnasco.

609 Para. 52 of the judgment in Bagnasco. For details see below section II.2.2.

610 Paras. 51 and 15 of the judgment in Bagnasco.

611 Para. 51 of the judgment in Bagnasco.

${ }^{612}$ For instance the nationality requirement that many Member States maintain for the exercise of the notaries profession inhibits actual cross-border supply of notarial services, see below note 636 .

${ }_{613}$ See Case C-306/96, Javico, [1998], para. 17; Case 22/71, Béguelin, [1971], para. 18. European Commission, Guidelines on the effect on trade concept, para. 28. 
detail of every professional rule needs to be capable of affecting trade between Member States. It is sufficient that the economic practice as a whole has such effect. ${ }^{614}$ Such an approach is justified on the basis that a probability prognosis cannot but produce abstract conclusions. ${ }^{615}$ Thus, to establish the point in a given case the particular types of testrictions have to be considered that are contained, for instance, in a professional code of conduct, like advertisement restrictions or tariff schemes. Once identified one can assess the effect that their kind may have on intra-Community trade in the particular sector. This entails that the particulat shape of, for instance, an advertisement restriction has to be looked at in its generality. ${ }^{616}$ Continuing on this example, it is necessary to consider the particular form that an advertisement restrictions takes, i.e. for instance whether it prohibits comparative advertisement, or whether it prohibits to approach clients who already have (had) a relationship with another practitioner. ${ }^{617}$ Only then can the necessary prognosis be made whether and to what extent such type of economic practice probably may affect intraCommunity trade in the relevant sector.

\section{The nature of professional rules}

Looking first at the nature of professional rules provides an indication of the ability of those rules to affect trade between Member States from a qualitative point of view. ${ }^{618}$ The nature of professional regulations is to generally apply to all members of a profession. This means in particular that they apply actoss the board to services provided by registered members, tegardless of whether clients are established domestically or in another Member State. A direct effect on trade between Member States will be provoked, for instance, by tariff schemes that are applied by all members of a profession ${ }^{6{ }^{69}}$ Indirect effects on interstate trade may occur where professionals or other competitors from abroad may find it difficult to access the national market ${ }^{620}$ because national clients may find it more convenient to turn to professionals registered domestically, be it for language and other practical reasons ${ }^{621}$, or factors of law. ${ }^{622}$ Also where national rules either teserve the professional activity to registered members or exclude its provision altogether may they impede non-domestic professionals and other competitors to ptovide a particular type or form of service in to the

614 Case 193/83, Windsurfing Intermational, [1986], para. 96.

${ }_{615}$ The Court and the Commission have illustrated how they conduct this probability examination in the professional services sector, Commission Decision CNSD, (1993), paras. 49 ff.; Case C-35/96, Commission v Italian Republic (CNSD II), [1998], paras. 45 ff;; Case T-513/93, CNSD III, [2000], paras. 78 ff.; Commission Decision EPI Code of Conduct, (1999), para. 45 (this point has not been disputed on appeal to the CFI); Commission Decision COAPI, (1995), para. 40; Commission Decision Belgian architects, (2004), paras. $100 \mathrm{ff}$.; Case C-309/99, Wouters et al. vNOvA, [2002], paras. $95 \mathrm{f}$. Notwithstanding, the Court in Wouters made the fine distinction that, while the professional rules at stake fulfilled all elements of the scope of Article $81(1) \mathrm{EC}$, they did not fall under the competition prohibition. For details on that fine distinction see Chapter 4.II.4.

616 See Joined Cases C-215/96 and C-216/96, Bagnasco, [1999], (discussed in the previous section), where the Court looked at the particular form that the restriction of current-account facilities took, namely by requiring the provision of guarantees to secure the current-account that derogates from the general law on guarantees.

617 See Commission Decision EPI Code of Conduct, (1999); Case T-144/99, EPI, [2001].

618 European Commission, Guidelines on the effect on trade concept, para. 29.

${ }^{619}$ See European Commission, Guidelines on the effect on trade concept, para. 37.

620 See European Commission, Guidelines on the effect on trade concept, paras. $38 \mathrm{f}$.

621 Commission Decision COAPI, (1995), para. 40.

${ }^{622}$ For instance where the certification of transfer of property is reserved to nationals, see below note 636 . 
Member State in question. ${ }^{623}$ On the overall, professional rules thus bear to increase the costs and complexity for non-domestically established professionals, other competitors, and clients who all might intend to provide, or seek, professional services across the border. These rules therewith bear to alter the trade patterns in professional services sectors. It shall be noted that this finding remains the same in case domestic professional tules not only affect the provision into the territory of a Member State, but also out of the territory on which a professional is established. ${ }^{624}$

\section{The nature of professional services}

Secondly, the question is whether the nature of the relevant professional services is such as to create only a limited demand actoss the border. ${ }^{625}$ It is necessary to first determine the range of relevant services. In doing so one might ask: who are the possible players in a specific sector - ate they big, small, in private partnership, associated? Consequently, what are the opportunities that they are possibly looking for? Are they for instance looking for transactions with private or corporate clients, for small or big scale transactions? Once these parameters have been determined, the following issue can be addressed: is the execution of the relevant transactions not determined by the place of establishment of the service provider and customer or, conversely, do transactions take place only domestically? ${ }^{26}$

On the assumption that professional rules in principle apply indistinctly to members of a particular profession, i.e. regardless of the shape and size of the potential non-domestic competitors (whether independent practitioners or associated firms, e.g. law firms, medical clinics, architect firms, internet pharmacies) and their particular field of expertise, the conclusion should be that the services concerned are generally suitable to be demanded across the border. A conclusion to the contraty may be drawn only where certain professional rules are limited to apply to specific types of transactions that are provided only on a national scale - which in turn may be delimited by the group of possible service providers and/ or their customers. ${ }^{627}$

A factor in determining whether certain professional rules are capable of being supplied only locally is to look at market structures. Since the liberal professions are traditionally defined as exercising an independent activity in the sense of being self-employed ${ }^{628}$, professional services markets used to be characterised by a heterogeneous group of small scale practitioners and firms. ${ }^{629}$ As referenced before ${ }^{630}$, for important professional services

${ }^{623}$ Professional services often are the reserve of a specific professional group. See for instance Case C-309/99, Wouters et al. $v N O v A$, [2002], para. 95, concerning a national prohibition of 'one stop' shop services, i.e. integrated services provided by lawyers and accountants jointly.

624 See Case C-384/93, Alpine Investment, [1995].

625 See above on Joined Cases C-215/96 and C-216/96, Bagnasco, [1999]. European Commission, Guidelines on the effect on trade concept, para. 30: "When by their nature products [or services] are easily traded across borders or are important for undertakings that want to enter or expand their activities in other Member States, Community jurisdiction is more readily established than in cases where due to their nature there is limited demand for products [or services] offered by suppliers from other Member States or where the products [or services] are of limited interest from the point of view of cross-border establishment or the expansion of the economic activity carried out from such place of establishment. Establishment includes the setting-up by undertakings in one Member State of agencies, branches or subsidiaries in another Member State."

${ }^{626}$ See para. 51 of the judgment in Bagnasco.

627 See above on Bagnasco, in particular para. 51 of that judgment.

${ }_{628}$ For details see Chapter 2.I.

629 See Case C-309/99, Wouters et al. vNOvA, [2002], paras. 91-94. For instance the legal services market in Italy 
sectors this picture does no longer correspond entirely to reality. For instance the accountancy market is highly concentrated, as has observed the Court in Wouters. ${ }^{631} \mathrm{Also}$ medical clinics are certainly to be regarded as big players in the market. Furthermore, one may wonder whether the fact of traditionally heterogeneous professional markets is the very tesult of professional rules, seen that the latter basically used to prohibit practitioners to enter into associations, and still restrict this possibility mostly to members of the practitioner's own profession. ${ }^{632}$ The same doubt can be raised with regard to professional markets that are restricted locally. ${ }^{633}$

While professional services may be determined by typical national factors, for instance where the content of the services is determined by the domestic legal system, it cannot generally be assumed that this would necessarily constitute a limitation to the interstate trade criterion. One only needs to consider that business from abroad need to have recourse to such services, e.g. legal or tax advice. Furthermore, professionals and other competitors from abroad may offer the same or similar services on the domestic market, albeit determined by their own legal systems, in particular for business established inland but active actoss the border. ${ }^{634}$ The growing practice of European or international law reinforces the point. ${ }^{635}$ More generally, changes in the legal context bring about changes in the economic context. In this respect it shall be recalled that practice, and therefore demand, across the border are actually facilitated by Community legislation on the recognition of diplomas, the frecdom to provide services and the right to establishment. ${ }^{636}$ Moreover, liberalisation measures aimed at eliminating legal barriers to trade - be they adopted at Community or national level - may

has traditionally been characterised by single practitioner firms, Galli B., (1998).

630 See above section I.2.3.

631 Case C-309/99, Wouters et al, v NOvA, [2002], para. 91.

632 Case law in the field of social security has had the effect of allowing the purchase of medical services across intra-Community borders, e.g. Case C-157/99, Geraets-Smits and Peerbooms, [2001].

633 See Case 107/83, Klopp, [1984], which concerned the prohibition of a second establishment for lawyers wanting to establish themselves (also) in Patis.

634 See European Commission, Guidelines on the effect on trade concept, para. 42: "Moreover, even if at a given point in time market conditions are unfavourable to cross-border trade, for example because prices are similar in the Member States in question, trade may still be capable of being affected if the situation may change as a result of changing market conditions. What matters is the ability of the agreement or practice to affect trade between Member States and not whether at any given point in time it actually docs so."

635 See Case C-309/99, Wouters et al. v NOvA, [2002]; see also the example of Joined Cases C-215/96 and C216/96, Bagnasco, [1999].

636 See Commission Decision Belgian arcbitects, (2004), para. 102. For notaries there is still a nationality requirement, and thus no actual cross-border supply of notarial services possible. For this reason the Commission has brought proceedings against $16 \mathrm{Member}$ States under Article 226 EC, European Commission, "Nationality requirements for notaries: Commission acts to ensure correct implementation of EU law in $16 \mathrm{Member}$ States", press release IP/06/1385 of 12.10.2006: "The Commission will formally request Austria, Belgium, France, Germany, Greece, Luxembourg and the Netherlands to modify their legislation allowing only nationals of their own country to become notaries, which is contrary to EC Treaty rules on freedom of establishment. [...] The Commission has also asked the Czech Republic, Estonia, Hungary, Latvia, Lithuania, Malta, Poland, Slovakia and Slovenia to submit their observations on similar legislation in their countries." A number of these cases have been decided in 2009. See also Article 4 of Council Directive 77/249/EEC of 22 March 1977 to facilitate the effective exercise by lawyers of freedom to provide services, where it is provided that the professional rules of the receiving Member State apply in case that representation before courts or public authorities are involved. For other regulated professions like medical doctors generally two sectoral directive are applicable on first minimum requirements for harmonisation and, second, on mutual recognition. This is not the case for architects where only the principle of mutual recognition, but no minimum harmonisation has been laid down. See also Schneider H.E.G.S. / Claessens S., (2005). 
stimulate cross-border practice and demand ${ }^{637}$ Before the adoption of the Internal Market Services Directive estimates were that inter-Community trade in commercial services could go up by 30 to $60 \% .{ }^{638}$ Whether this potential can be realised needs to be seen though, considering the fact that the ultimate text shatply falls short of the initial ambition of the Commission to fully introduce the already existing principle of mutual recognition ${ }^{639}$, mainly due to political tensions in particular in France and Germany.

Thirdly, the position and importance of the undertakings concerned are indicative from a quantitative point of view. ${ }^{640}$ This quantitative criterion is one that limits the broad interpretation of the interstate trade criterion to include only cases that possibly restrict intraCommunity trade to an appreciable extent, and hence is dealt with hereafter. In respect of the qualitative arguments so far presented and generally petceivable the conclusion is that professional regulations are generally capable of affecting trade between Member States.

\subsection{Appreciability of the potential effect on interstate trade}

In a given case it does not suffice to demonstrate that certain professional rules, in ptinciple, have the capacity to affect trade between Member States. It is also necessaty to establish that such effect is appreciable. ${ }^{641}$ This is a quantitative element to limit Community jurisdiction to economic practices of a certain magnitude. In other word, insignificant effects on Community trade and the weak position of undertakings in influencing the common market are not covered by the Community competition prohibitions. ${ }^{642}$ The appreciability of possible effects is approximated by, once more, interpreting the factual and legal circumstances in which the rules are applied. ${ }^{643}$ The appreciability of the possible effect on interstate trade depends in particulat on the importance of the transactions and undertakings concerned. This can be measured both in absolute terms (turnover) and in relative terms, i.e. by comparing the position of the undertakings concerned to that of other players on the market (matket share) ${ }^{644}$ Turnovers and market shares are, however, not relevant where the

637 European Commission, Guidelines on the effect on trade concept, para. 41.

${ }^{638}$ Centraal Plan Bureau (CPB) - Netherlands Bureau for Economic Policy Analysis, $A$ quantative assessment of the EU proposals for the Internal Market for Services, of 05.10 .2005 (revised), 2.

639 Directive 2006/123/EC of the European Parliament and of the Council of 12 December 2006 on services in the internal market, which envisages to abolish read tape in the provision of services across intra-Community borders. It reinforces the country of origine principle (as contrasted to the principle of mutual recognition), according to which the professional rules of the receiving country apply. See also Chapter 2.IV.1.

640 European Commission, Guidelines on the effect on trade concept, para. 31.

${ }^{641}$ See generally European Commission, Guidelines on the effect on trade concept, paras. 44-57.

${ }_{642}$ This is cven less the case with regard to Article $82 \mathrm{EC}$, which ex bypothesis presupposes a dominant position on the relevant market. With reference to Case 5/69, Völk, [1969], para. 7; Case C-7/95P, John Deere II, [1998], para. 77; Joined Cases C-215/96 and C-216/96, Bagnasco, [1999], para. 34, the Court in Case C-238/05, Ausbanc, [2006], para. 50, underlined that "while Article 81(1) EC does not restrict such an assessment to actual effects alone, as that assessment must also take account of the potential effects of the agreement or practice in question on competition within the common market, an agreement will, however, fall outside the prohibition in Article $81 \mathrm{EC}$ if it has only an insignificant effect on the market."

643 See Case 23/67, Brasserie de Haecht, [1967]. Note that this early case did not so much consider the appreciability element but rather the 'capable' element discussed above (section II.1.): "The existence of similar contracts is a circumstance which, together with others, is capable of bcing a factor in the economic and legal context within which the contract must be judged. Accordingly, whilst such a situation must be taken into account it should not be considered as decisive by itself, but merely as one among others in judging whether trade between Member States is capable of being affected through any alteration in competition."

644 European Commission, Notice on guidance letters, 47. 
collective measure or conduct in question extends over the whole of the territory of a Member State.

\section{Professional activities regulated at national level}

Consequently, where professional rules apply nationwide, the Court has repeatedly held that they have, by their very nature, the effect of reinforcing the partitioning of markets on a national basis, thereby holding up the economic interpenetration which the Treaty is designed to bring about. ${ }^{64}$ This apprehension in favour of the common matket (Article 2 EC) also absorbs a practical difficulty, namely that of establishing economic numbers in a sector where the potential of interstate trade is not known, and where turnovers and market shares of incumbent professionals are difficult to establish for particular services, as most of the time such kind of information is simply not available. ${ }^{646}$ The equation operated by the Court that rules extending on the whole territory are capable of appreciably affecting trade between Member States is a fair approximation, especially where it cannot, on the basis of qualitative considerations ${ }^{647}$ be excluded that the absence of appreciable cross-border trade in professional services is the very consequence of the professional rules in question. At this juncture it shall be stressed that a major barrier to interstate trade in services is the regulatory heterogeneity that exists between Member States. ${ }^{648}$

Case law illustrates how the Commission and the Court apply the quantitative element of the Community dimension to the professional services sector. In its Belgian architects decision the Commission considered the economic importance of cross-border architectural services from a viewpoint of architects established outside Belgium. The effect of the tariff scheme at hand was appreciable inter alia because, under the Belgian legislation, the most important projects in economic terms required recourse to an architect. ${ }^{649}$ Equally the growing importance of professional services markets across the border can be taken into account. $^{650}$

In case CNSD on collective regulation applicable to the Italian customs officers the Commission established the interstate criterion with reference to the share that imports have in telation to goods consumed in Italy, the share of Community origine of the imports, the share that exports have in relation to gross domestic product, and finally the percentage of exports with a Community destination. ${ }^{651}$

In Wouters the Court came to the obvious conclusion that the effect on trade between

645 See above the text with note 599.

${ }^{646}$ Philipsen N.J., (2003). Where turnovers and market shares can be established the Commission applies a 'negative presumption' for those practices that it considers to be outside the Community dimension (NAAT-rule, which stands for not appreciably affecting trade). The presumption is rebuttable and the Commission illustrates its approach for a number of common types of agreements and abuses in European Commission, Guidelines on the effect on trade concept, paras. $50 \mathrm{ff}$.

${ }_{647}$ See above section ПП.2.1.

${ }_{648}$ Centraal Plan Bureau (CPB) - Netherlands Bureau for Economic Policy Analysis, $A$ quantative assessment of the EU proposals for the Intemal Market for Services, of 05.10.2005 (revised), 2. The CPB document stresses that it would be less the intensity of but the disparity in national regulation that is the real burden to trade in services across the border.

${ }_{649}$ Commission Decision Belgian anbitects, (2004), pata. 101. The case is summatised in Chapter 2.V.

650 See Case C-309/99, Wouters et al. v NOvA, [2002], para. 95.

651 Commission Decision CNSD, (1993), para. 52. 
Member States "is all the more appreciable" where the professional regulation applies equally to visiting members of a profession who are tegistered in another Member State. ${ }^{652}$ In fact, once a regulated activity is being supplied into a territory, professional regulations usually require professionals to adhere to these rules regardless of whether the service provider is established domestically or not. ${ }^{653}$ The Court's a fortiori argument extends in particular to cases where such a universal application of the professional rules at stake combines with a legal monopoly tight that reserves certain professional services to a specific professional group. A legal monopoly not only affects trade but actually excludes professionals and other competitors that are not domestically registered. ${ }^{654}$ Moreover, in Wouters the Court motivated an appreciable effect of the professional rules in question with two more considerations, namely first the growing numbers of transnational transactions for which the professional services are needed; and second that those looking for particular practitioners - be it as service providers or ally in the provision of services - mote frequently operate internationally. ${ }^{655}$

\section{Professional activities regulated at regional level}

Finally, where professional rules are adopted regionally the question arises whether EC competition law may be applicable. The property of regional application does not as such justify to exclude the jurisdiction of the EC competition rules. It is sufficient to assume a Community dimension even in case of regional professional regulation - at least in the absence of further qualifying factors of law or of fact - where the volume of transactions concerned by the regional rules constitutes a substantial part of the of the common market. ${ }^{656}$ However, as pointed out before, it is difficult if not impossible to establish the relevant numbers for the professional services sectors. ${ }^{657}$

A further argument may therefore be drawn from the case law in which the Court established that cumulative effects of several similar agreements constitute a factor in ascertaining whether trade between Member States may be affected. ${ }^{658}$ In acknowledging that several similar agreements form parallel networks that possibly alter the structure of competition the Court applied a particular form of assessing the factual and legal context. Collective regulation first of all is bound to be applied repeatedly in individual instances and, by definition, constitutes the organisation of parallel effects. In its effects collective regulation thus can be compared to parallel networks of agreements between undertakings. In the particular case of regional regulation it can be reasoned that, if certain professional

652 Para. 96 of the judgment in Wouters.

653 See also Article 4 of Council Directive 77/249/EEC of 22 March 1977 to facilitate the effective exercise by lawyers of freedom to provide services.

654 In past years provisions have been made to cxtent the application of such monopolies also to comparable professions from other Member States, and the EFTA countries. Such a provision may, however, not be sufficient to lift the barriers that interstate trade encounters in particular from regulatory heterogeneity between the Member States.

655 Case C-309/99, Wouters et al. v NOvA, [2002], para. 96.

656 See for instance Case C-179/90, Merci Convenzionali, [1991], paras. 20, 15; Case C-475/99, Glöckner, [2001], para. 38. In European Commission, Guidelines on the effect on trade concept, para. 92, the Commission rightly points out that practices of a regional or local nature "some guidance may be derived from the case law concerning the concept in Article 82 of a substantial part of the common matket".

657 See however European Commission, Guidelines on the effect on trade concept, paras. $89 \mathrm{ff}$.

${ }_{658}$ Case 23/67, Brasserie de Haecht, [1967]; Case C-234/89, Delimitis, [1991], para. 14. 
rules or obligations are regulated in similar, if not identical, terms in other regions of a Member State ${ }^{659}$, or even the EU, a cumulative effect of reinforcing the particular regional regulation is created. This is an effect which will not only be capable of affecting trade between Member States, but which does so to an appreciable extent. ${ }^{660}$

At this point it shall be stressed that the scrutiny suggests that the Commission's wariness with regard to professional regulation and their "centre of gravity" ${ }^{\text {"661 }}$ is, in most cases, not indicated. In times in which the deficit in the completion of the internal market for services has been asserted with dismay, one should be rather prudent not to limit the applicability of the EC competition law principles too easily. While the alternative of applying national competition law may mitigate the effect that professional regulations may have in holding up the economic interpenetration intended by the Treaty ${ }^{662}$, it can do so only in an indirect way and depends on national competition laws being applied systematically across all Member States.

\section{National instances applying EC competition law to liberal professions}

Once the applicability of EC competition law has been ascertained, the question remains which authorities ate to secure the competitive neutrality of professional regulation. This point not only telates to the applicability of Community competition rules, but also to the competences of national authorities and courts to apply these rules. According to Article 3 of Regulation $1 / 2003^{663}$ national competition authorities and courts are obliged to apply the Community competition tules where the jurisdictional criterion for their application is fulfilled.

It would appear that nowadays it is less needed to assert a broad jurisdiction of the Community competition rules since most Member States have introduced new national

659 See above note 602.

${ }_{600}$ While the Court in the referenced case law rather concentrated on whether the measure at hand was capable of affecting trade between Member States, the Court's line of thought pollinates not only on the qualitative, but also quantitative element of the Community dimension, see European Commission, Guidelines on the effect on trade concept, paras. $56 \mathrm{f}$.

661 See above note 601.

662 See above note 599

${ }_{663}$ Article 3 of Council Regulation (EC) No 1/2003 of 16.12 .2002 on the implementation of the rules on competition laid down in Articles 81 and 82 of the Treaty:

"1. Where the competition authorities of the Member States or national courts apply national competition law to agreements, decisions by associations of undertakings or concerted practices within the meaning of Article 81(1) of the Treaty which may affect trade between Member States within the meaning of that provision, they shall also apply Article 81 of the Treaty to such agteements, decisions or concerted practices. Where the competition authorities of the Member States or national courts apply national competition law to any abuse prohibited by Article 82 of the Treaty, they shall also apply Article 82 of the Treaty.

2 . The application of national competition law may not lead to the prohibition of agreements, decisions by associations of undertakings or concerted practices which may affect trade between Member States but which do not testrict competition within the meaning of Article 81(1) of the Treaty, or which fulfil the conditions of Article 81 (3) of the Treaty or which are covered by a Regulation for the application of Article 81(3) of the Treaty. Member States shall not under this Regulation be precluded from adopting and applying on their territory stricter national laws which prohibit or sanction unilateral conduct engaged in by undertakings.

3. Without prejudice to general principles and other provisions of Community law, paragraphs 1 and 2 do not apply when the competition authorities and the courts of the Member States apply national merger controllaws nor do they preclude the application of provisions of national law that predominantly pursue an objective different from that pursued by Articles 81 and 82 of the Treaty." 
competition acts modelled on the EC rules, or amended their existing acts accordingly. ${ }^{664}$ While applying national competition law certainly has an indirect effect on facilitating the economic interpenetration of national services markets that the Treaty is designed to bring about, it only has a limited effect in cases where State regulation is involved in determining the conduct of liberal practitioners. In such cases a conflict between rules of the same level exists that confronts national competition law and domestic professional regulation. National competition law cannot solve this conflict because of the hierarchy of norms in which national competition rules are at the same level as (other) State rules regulating professional activities. Thus, in the field of professional regulation, and collective regulation more generally, a particular problem of competences at national level occurs that national competition law cannot generally aspire to solve.

This is different for the Community rules on competition. Due to the supremacy of EC law ${ }^{665}$ its competition provisions take precedence over Member States' legal provisions that in fluence markets in such a way as to bring economic operators to restrict competition, or to reinforce the effects of the anti-competitive behaviour of undertakings. The extent to which EC competition rules may indeed exert control, via Article $10 \mathrm{EC}$, on State measures that interfere in professional services markets is scrutinised in Chapter 6. Suffice it to stress here that in cases with a Community dimension national competition authorities have the power, and even the duty, to not apply national legislation that appears to legitimise or reinforce the anti-competitive effects of economic conduct or regulations adopted by the sector. ${ }^{666}$ While this power and duty cannot lead a national authority to repeal a State measure ${ }^{667}$, the obligatory distegard for a Member State measure (even of a legislative nature) proves a constitutional character of the control exercised under EC competition law - a power which its national counterparts do not possess.

As the Commission is careful to respect the principle of subsidiarity of Article 5 EC notwithstanding the exclusive competence of the Community in competition law matters and to leave the administrative enforcement of the EC competition rules to the national competition authorities wherever the impact of professional regulations is centred in one Member State, it may be expected that the Commission itself will not conduct too much case work in the field of professional regulation. Fitting the overall context of the modernisation concerning the application of Articles 81 and $82 \mathrm{EC}$ the Commission instead has chosen to make the (liberal) professions a pilot project in the European Competition Network. ${ }^{668}$ Therewith the Commission concentrates less on the enforcement of EC competition law

664 See Whish R., (2003), 137, and GoyderD.G., (2003), 88, interpreting Joined Cases C-215/96 and C-216/96, Bagnasco, [1999], as an indication that there would be less need for the Community to assume jurisdiction in cases of regional character, now that all Member States have national competition laws that can deal with such cases. ${ }_{665}$ In Case 26/62, Van Gend \& Loos, [1963], the ECJ ruled that the European Community, through the will of Member States expressed in the Treaty of Rome, "constitutes a new legal order of international law for the benefit of which the States have limited their sovereign rights albeit within limited fields". Subsequently, Case 6/64, Costa $\nu E N E L,[1964]$, established the supremacy of EC law. While Community law is accepted as taking precedence to the law of Member States, not all Member States share the analysis used by the European institutions about why EU law overrides national law, when a conflict appears: for the UK see, Factortame Ltd. v Secretary of State for Transport (No. 2) [1991] 1 AC 603; for Germany sec Solange II (Re Wuensche Handelsgesellschaft, BVerfG decision of 22 October 1986 [1987] 3 CMI R 225, 265); for Italy see Frontini v Ministero delle Finanze [1974] 2 CMLR 372; for France see, Raoul George Nicolo [1990] 1 CMLR 173.

${ }_{666}$ Case C-198/01, CIF v AGCM, [2003].

${ }^{667}$ Under the separation of powers between the legislature and the executive in the trias politica that would be the exclusive compctence of the legislator itself or the constitutional court (if established).

${ }^{668}$ See Evans L., et al., (2006). 
through case work, but concentrates to advocate with the stakeholders, i.e. representatives of the professions, national regulators, national competition authorities and consumer representatives, that professional regulation shall comply with competition principles.

Nevertheless, there is a task for the Commission to monitor the interpretation that national instances give to $\mathrm{EC}$ competition rules in order to guarantee the correct application of EC competition law. In this it is important to have a flawless task sharing between the European Commission and the competent national authorities. One cannot assume that national instances apply the interstate trade criterion correctly, and the wtong interpretation thereof can have a wide impact as has unfortunately been cxemplified by the Cour d'appel of Brussels in Koninklijke Gilde van Vlaamse Antiquairs. ${ }^{669}$ The case concerned collective regulation adopted by the Koninklijke Gilde, which is a trade association of antique dealers that organises antique fairs in Belgium. In particular it had prohibited its members, on pain of exclusion, to participate in antique fairs organised by other bodies than itself. While the Btussels court of appeal found the rule of the royal guild to be restrictive of competition in substance ${ }^{670}$ and affirmed moreover that in principle the rule affects trade between Member States, it nevertheless denied in concreto that the effect on interstate trade would be appreciable - despite the fact that antique dealers from outside Belgium participated in antique fairs in Brussels. The ensuing conclusion drawn by the court of appeal thus was that EC competition law was not infringed. Consequently, the Brussels court of appeal should have turned to apply its national competition law with tegard to the metits of the case. Instead, the court of appeal ruled that under the new tegime put in place by Article 3(2), first sentence, of Regulation $1 / 2003^{671}$ it would not be possible to prohibit the decision of the royal guild under national law. In refuting that the effect on trade between Member States was appreciable the court of appeal assumed that the decision of the toyal guild would be allowed under EC competition law. Therewith the court of appeal draws a conclusion that is not covered by the legal analysis of the case so far. In fact the conclusion that a certain conduct is not probibited under Community competition law for lack of jurisdiction of the EC rules does not prejudge the conclusion to be drawn with regard to the substantive competition law scrutiny on the national level. Unfortunately this did not seem to have occurred to the Brussels court of appeal, and it mertily found that national competition law could not, according to Article 3(2), first sentence, of Regulation 1/2003, prohibit what it ertoneously considered to be authorised by European Law. The court of appeal erted in reading this provision in that it confused the jurisdictional issue with the substantive competition law assessment of a case. In fact the jurisdictional issue is not addressed in Article 3(2), first sentence, of Regulation 1/2003. The provision merely states that in cases where no substantive restriction of competition can be found - despite a possible effect on trade between Member States - may the conduct in question not be prohibited according to national competition law. The rational of this provision obviously is to avoid diverging decisions on the merits, and therewith states actually nothing else than common sense. In not applying its national competition law the court of appeal contradicted common sense

669 Cour d'Appel de Bruxelles - Case 2002/MR/3 2003/MR/8 "Koninklijke Gilde van Vlaamse Antiquaires v MSA" [2004]. - See also the OECD on the case at <http://www.oecd.org/dataoecd/7/3/35110865.pdf>.

670 Taken from Reflets no 1/2005, at $\mathrm{p} 9$ : "En effet, la décision d'association d'entreprises litigieuse pourrait conduire à l'impossibilité pour MSA d'organiser ses foires et, partant, à une impossiblité pour ces marchands d'y vendre leur antiquités." - This is a restriction by object actually, and any going into detail by the Brussels court of appeal on the appreciability is necessarily in respect of the jurisdictional element of intrastate trade.

671 Cited above in note 663 . 
because it suddenly ignored its own findings on the substance, i.e. that the decision of the royal guild indeed was restrictive of competition. It would have been desirable if the European Commission at least had commented on that decision.

The mote general conclusion to be drawn here is that the competitive neutrality of professional rules can and will be controlled 'locally'. Whether the applicable standard will be that of the EC Treaty or the respective national standard modelled on Community competition law will in most cases be a question of degree as the same (substantive) competition principles are applicable at both levels. This assertion cannot be sustained, however, where Member States intervene in the regulation of the liberal professions. As will be explained more fully in Chapter 6 the application of Community competition law can make a world of a difference in such cases, even if applied by the NCAs.

\section{Closing remarks: in favour of a universal applicability of EC competition law}

Two essential, though distinct elements in determining the jutisdictional scope of EC competition law have been addressed in the two parts of this chapter. The first part focussed on whether the concept of undertaking, for the purpose of competition law, covers the members of the professions - or even the collective bodies affiliating them. It has been rounded off with illustrations from the sector of liberal professions. The second part turned to the respective jutisdiction of Community and national competition law, which depends on whether the patterns of intra-Community professional services markets may be affected by a particular professional practice. Both elements share that they have to be established in each individual competition case, irrespective of which substantive competition prohibition finally is applied (Articles 81 and/ or $82 \mathrm{EC}$ ). Furthermore, both elements are interpreted broadly since they do not prejudice the substantive assessment of a competition case. In fact the substantive assessment can be separated from the two elements examined here as it becomes relevant only at a subsequent stage of the competition law scrutiny. Hence, it will be dealt with in the following chapters.

With reference to the universal applicability of competition law, and thus in application of the comparative market criterion that follows from the Höfner formula, it has been argued in the first part that members of the liberal professions generally exercise an activity that is, or can be, provided under market conditions. Consequently, under the functional approach adopted to interpret the concept of undertaking their quality as economically active entities cannot be generally disputed for the purpose of competition law. As one of the core features of the libetal professions the independence of the professionals (in particular in the form of self-employment) sustains the argument that liberal practitioners assume the financial risks that are connected with the offering of professional services on a given market. More specifically they bear the risk of any imbalance between expenditure and receipts. ${ }^{672}$ Conversely, both salaried members of a profession and professional associations cannot, in general, be regarded to bear such financial risk. ${ }^{673}$ On the basis of the case law it has to be recognised that the latter two groups do not normally exercise economic activities distinct from either their employer or their members. Consequently, under the functional approach, they do not qualify as undertakings for the purpose of competition law. This does, however,

672 Case C-35/96, Commission vItalian Republic (CNSD II), [1998], para. 37; Commission Decision EPI Code of Conduct, (1999), para. 23; Joined Cases C-180 to 184/98, Pavlov, [2000], para. 76; Casc C-309/99, Wouters et ah v NOvA, [2002], para. 48.

673 See above note 572 . 
not prejudice that professional associations come within the remit of competition law, as will be discussed in the following two chapters.

Traditionally, representatives of the liberal professions have asserted that they are distinct from other - ordinary - business, that they perform a specific function in the public interest and that, consequently, they should not be regarded as exercising an economic activity for the purpose of competition law. The argument challenges the universality of the applicability of competition law as a general law. In this chapter it has been argued that the comparative market criterion does not allow for such an argument to be taken into account. ${ }^{674}$ This stance can be underpinned by the case law of the ECJ in Meca-Medina II on sporting rules. ${ }^{675}$ In order to identify the jurisdictional scope of competition law ratione personae the Court drew a fine distinction between the actors engaged in a particular activity, and the rules regulating that activity. The situation of a regulated activity thus presents itself as a triangular one in which the activity can be seen as a coupler between the actors and the rules adopted by the latter. While sporting or professional regulation may be motivated by a non-economic aim, e.g. the preservation of the noble ideals of sport or the profession respectively, the character of those rules is not sufficient an argument to prejudge as non-economic the nature of the regulated activity itself in order to limit the scope of competition law ratione personae. Quite to the contrary, the Court in Meca-Medina II has made clear that it is the activity only that is central to establishing the jurisdictional scope of competition law. In consequence, any rules specifying noteworthy obligations on the part of the professional service providers can necessarily be taken into account only at the subsequent stage of assessing the case of the professions on its merits, which are dealt with in the remainder of this book.

Concentrating on the activity itself rather than on the regulation thereof is in consistency with the Höfner rule with which the Court specifies the concept of undertaking for the purpose of competition law. The comparative market criterion deriving from that judgment is the starting point for differentiating economic from non-economic activities. In following a positive approach the question is wether a particular activity can, at least in principle, be carried out under market conditions (i.e. by a private actor with a view to profit). ${ }^{676}$ As has been observed this approach virtually covers any activity with an economic importance to come within the ambit of competition law. However, the Court in Höfner did not stop at that and joined a negative approach to the concept of economic activity, according to which all activities have an economic character that are not necessarily carried out by public authorities. ${ }^{677}$ Inverting this negative approach leads to what has been coined here as imperative public authority criterion. ${ }^{678}$ This criterion indicates the limits of the remit of competition law by defining what is outside the scope of competition law. In particular the idea of powers that are necessarily carried out by a public authority feeds back to the authoritative or imperative powers of Member States who are, as is known, no addressees of EC competition law. The imperative public authority criterion thus constitutes the counterpart to the comparative market criterion. In this chapter I argued that these two yardsticks effectively allow to delimit the two parts to the pair of economic and noneconomic activities, therewith striking a fine and above all objective balance between activities that do and those that do not come within the jutisdictional ambit of competition

674 See above note 373 and the text with it.

675 See above page 76.

676 See above notes 335,474 and 347 .

677 Sce above note 337.

678 See above section I.2.2.1. 
law.

In summary this approach delimits the remit of competition law in two ways. First of all, by inverting the Höfner formula itself, one can conclude that non-economic activities are those that cannot be offered under market conditions. In order to define which these are I have suggested a testing that takes account of activities for which a person or entity does not gain a competitive advantage. ${ }^{679}$ Secondly, are excluded from the jurisdictional scope of competition law activities that involve powers necessarily exercised by a public authority regardless of the economic import of an activity in question.

As has been explained in this chapter the Court, at times, has been deviating from both caveats to the scope of competition law ratione personae. The first caveat has never been addressed explicitly in the case law of the Community Courts. Instead of applying an inversion of the Höfner formula the Court has deflected its comparative market criterion in to a market participation criterion, the consequence of which is that only actual or past evidence of existing markets will give information about the economic character of a particular activity. This obviously constricts an objective application of the concept of undertaking and may even lead to discriminatory results across sectors. With regatd to the second caveat of noneligible addressces the Court has equally tefrained from an explicit application. Instead of indicating what are the parameters in determining powets that are necessarily exercised by a public authority, and thus failing to establish an objective shape of the imperative public authority criterion, the Court in $S A T /$ Eurocontrol and Cali considered that the activities at issue were not of a character that would justify the application of the competition rules. At first glance this does not seem to contradict the two-staged criteria detiving from Höfner. However, the core of $S A T /$ Eurocontrol and Cali is to exclude from the jurisdictional scope of EC competition law activities that are connected with the exercise of powers typically carried out by or under the control of a public authority. Therewith the Court deflected the negative approach following from $H$ öfner by conveniently converting the necessary in to the 'typical' exercise of public authority ${ }^{680}$ - without so much explaining however what typical powers of public authority are. In this chapter it has been argued that the approach in $S A T /$ Eurocontrol and Cali effectively out-competes the universal Höfner rule as it can be adopted despite an apparent economic interest represented by the activity involved. The theoretical foundation for this line of case law the Court so far has kept within the realm of its wisdom. Such foundation seems to be connected to the balance that the Court must find between the need to protect undistorted competition within the common market, on the one hand, and the respect for the powers of the Member States to adopt economic regulation, on the other. ${ }^{681}$

The main critique put forward in this chapter is that the Court's deviations from both the positive and negative approach it established in Höfner constitute an abertation from the objective concept of undertaking for the purpose of competition law. In particulat the emphasis on powers typically exercised by a public authority actually represents a change in paradigm. The approach by the Court in Höfner clearly confirmed the Community charactet of the concept of undertaking. This means that its content is independent of which meaning the concept may have under national law. In $S A T /$ Euroconlrol and Cali, however, the Court parted from such strict approach by allowing parties to have recourse to the defence of powers typically exercised by a public authority. Since traditions differ over time and space

679 See above page 102.

680 See above section 1.2.2.1.

681 Odudu O., (2006), $54 \mathrm{ff}$. 
the Court therewith cleatly allows Member States a margin in determining which activities are within and which are outside the ambit of $\mathrm{EC}$ competition law. With this stance, as Advocate General Poiares Maduro has pointed out, "the Court is entering dangerous territory". ${ }^{682}$ The dangerousness stems first of all from the attempt to strike the decision whether or not to hold a certain activity justiciable under competition law at the early stage of determining the addressee of competition law. Secondly, the dangerousness stems from the little concrete criteria that the Court offers in striking that balance.

Motivated to systematise some confusing case law that limits the universal scope of competition law ratione personae Advocate General Poiates Maduro in FENIN II has distilled $^{683}$ a standard with which to decide on the possible non-economic character of activities relating to essential functions of the modern welfare State. According to the Advocate General the applicability of EC competition law depends on whether the State intended to exclude the activity in question from all market considerations by regulating, tather than participating in, a particular market. To develop the case law not only of $S A T /$ Eurocontrol and Cali, but also on social security and insurance schemes - which has been left out for the purpose of this book ${ }^{684}$ - Advocate General Poiares Maduro suggests three cumulative elements to determine whether an activity has a character that justifies not to apply the competition rules. First, an activity has to be subject to strict State regulation; secondly, it may beat no relation to the market (i.e. the activity should be provided free of charge and on the basis of universal cover, and factual evidence must not prove that private entities take part in the provision of the activity); thirdly, the activity is governed solely by an objective of solidarity. While the Advocate General's approach has the advantage of giving a systematised overview of some difficult case law that concerns not only powers 'typically' exercised by a public authority but also the principle of solidarity, his approach is not shared by the present authot for reason of a mote principled critique. On the one hand, it may be true that the Advocate General's interpretation of some difficult case law may help to turn the latter into more readily understandable terms, which are less blurred than the formula of "powers that are typically exercised by a public authority". On the other, however, his opinion only reinforces the distespect for the objective concept of undertaking that the Court has introduced despite its commitment in Höfner to the universal applicability of EC competition law. Both the case law discussed and the view of Advocate General Poiares Maduro put Member States in the position to undermine the Community concept of undertaking in spite of Articles 86(1), (2) and 10(2) EC, if they organise them in a way that no private actors may participate in the provision of those activities under market conditions - despite the fact that those activities could, at least in principle, be organised under such conditions.

Therefore, an extrapolation to the liberal professions of the case law out-competing the Höfner tule is a delicate exercise, which even the Court has rejected to apply in Wouters. ${ }^{685}$ The illustration by examples taken from several professional sectors in this chapter has not provided a definite answer - such answer depends significantly on the particular details of national regulation recognising and building up the content of the relevant professional activity. In light of the fine distinction made in Meca-Median II between the rules regulating

682 AG Poiares Maduro in Case C-205/03 P, FENIN II, [2006], para. 26.

${ }^{683}$ See above section I.2.2.3.1.

684 See above note 417.

685 See above page 105. See also above my discussion of Glöckner in section I.2.2.2.2., and of FENIN II in section I.2.2.3.1. 
an activity and the persons exercising that activity (i.e. the addressees of competition law) ${ }^{686}$, it is strongly doubted whether, for the particulat case of the liberal professions, the case law based limitation to the universal applicability of competition law will catch on. Trying to nevertheless extrapolate Advocate General Poiares Maduro's approach to the case of the professions raises the question of whether a Member States intends to regulate, tather than to participate in, a particular professional services market. Coupled with the principle of solidarity a positive answer to this question can be given only where a self-contained system of professional service provision has been set up. The illustrations by professional sectors has shown that that may be the case for a system of legal aid. It shall be stressed once more, however, that it is not necessary to revert to criteria that in fact distespect the objective character of the concept of undertaking. For this purpose I have suggested a criterion of benefaction or chatity according to which a market player may not obtain a competitive advantage in order not to come within the scrutiny of competition law. The benefit of such a criterion is that it allows to develop an objective application thereof, independent of conventional, prevailing or typical views on the matter what should be outside the remit of, and thetefore not justiciable under competition law. Applied to the sector of liberal professions it proves to be apt to exclude from the scope of application the mentioned selfcontained system of legal aid, provided that the service providers do not gain a competitive advantage.

The second part of the chapter assessed the Community dimension of professional activities and regulation of both national and regional scale. Since the particular purpose of the interstate trade criterion again is a jurisdictional one, its broad application has not been disputed here, and the potential of professional practices to affect trade between Member States has been established. In particular, collective professional regulations that extend over the whole territory of a Member State come within the remit of EC competition law because they have, by their very nature, the effect of reinforcing the partitioning of matkets on a national basis, thereby holding up the economic interpenetration that the Treaty is designed to bring about. ${ }^{687}$

The broad interpretation of the Community dimension does not go unlimited. Outside the case in which the very nature of the professional practice or tules at stake makes that they are capable of affecting the Treaty aim of economic interpenetration of national markets, the factual and legal circumstance of a case have to be taken into account in order to make a probability prognosis of whether the professional practice or tules at stake are capable of affecting intra-Community trade. It has been argued in particulat that typical national factors determining a certain professional activity, and more specifically the domestic legal context, cannot generally exclude the applicability of the Community competition rules. This would be an anachronistic consideration in the face of secondary European legislation opening up the recognition of professional diplomas, the provision of services, the right to establishment, and even the free movement of students, who in the future often will exercise a liberal profession. Joined with the requirement of predicting the potential of professional practices to affect interstate trade is the question whether that potential is appreciable. Applied to the liberal professions this quantitative tather than qualitative criterion has led to the observation that, first, economic data from the professional sector is at least difficult to obtain and that, second, a fair approximation of the

686 See above section I.2.1.

687 See above the text with note 599. 
appreciability criterion can be assumed for cases of professional regulations that apply equally to visiting members of a profession who are registered in another Member State. ${ }^{688}$ The appreciable effect of professional rules can be accepted in particular in cases where the universal application of professional rules is combined with legal monopoly tights that reserve certain professional activities to registered members of a specific professional group.

In addition to identifying the Community dimension of professional practices and rules, the application of the EC competition rules by national authorities and courts has been considered. In light of the competences that Regulation 1/2003 confers upon national competition authorities and national courts to apply the Community rules on competition, it has been argued that national authorities shall not hesitate to realise the Community dimension that professional tules have. This yiclds the following legal consequences at national level. Although national competition laws have by now been modelled on the Community provisions, they lack the competence to control professional activities the exercise of which is determined by State rules. While national competition law cannot solve its conflict with other national rules, the supremacy of Community (competition) law results in the obligation of national competition authorities to set aside national measures, even of a legislative nature, where the latter influence market conduct of economic entities. ${ }^{69}$ The extent to which EC competition rules may indeed exert a substantive control on State measures that interfere in professional services markets is scrutinised in Chapter 6.

688 Para. 96 of the judgment in Wouters.

689 Case C-198/01, CIF ע AGCM, [2003]. 


\section{Chapter 4 and Chapter 5 introduced}

The following two chapters will in turn scrutinise the two competition law prohibitions of the EC Treaty and their application to self-regulatory professional rules. To start with, both chapters will deal respectively with the specific jurisdictional aspects of Articles 81 (1) and $82 \mathrm{EC}$ that go beyond the general elements discussed in the previous chapter. Secondly, the two chapters will assess in substance whether professional self-regulation - as distinct to State regulation ${ }^{690}$ - restricts competition in a way that is incompatible with the common market. 'The focus of Chapters 4 and 5 will lie with two of the three authors of professional regulation that have been typified in Chapter 2.I. Both the members of the professions and their associations as a forum of their collective interests will be subjected to the competition law testing for the following fact: they adopt self-regulatory practices and measures that organise professional conduct in a horizontal and a vertical way. Horizontal in this respect refers to the members of a profession as possibly colluding in an anti-competitive manner amongst themselves. Conversely, measures of a professional association may be seen as a means to unify professional conduct vertically within a profession. To come to a conclusion on the matter it will be necessaty in both chapters to trace whether it is at all conceivable that a large number of independent practitioners can exert, either horizontally or vertically, coordinative influence on the market behaviour of the individual member of a profession. Such coordination, be it tacit or explicit, is a prerequisite to the substantive scrutiny of whether certain professional practices impair the freedom of competition within the meaning of Article 81(1) EC and/ or Article $82 \mathrm{EC}$.

Coordinative behaviout between individual members of a profession can be scrutinised under Article 81(1) EC as either 'agreements between undertakings' or 'concerted practices'. Also vertical measures of professional bodies come within the scope of that article since its wording includes 'decisions by associations of undertakings'. Both types of conduct will be assessed in Chapter 4. Moreover, vertical measures may also be understood as unilateral actions prohibited under Article $82 \mathrm{EC}$ in case it can be established that collectively organised professional conduct translates as an abuse of a dominant position. One peculiar difficulty in this respect is that the second competition prohibition, in contrast to Article 81(1) EC, only refers to the concept of 'undertaking'. As has been pointed out in Chapter 3.I.3., professional bodies themselves do not qualify as undertakings for lack of an economic activity of their own and independent of theit members' economic activities (i.e. the provision of professional services). At first glance it may therefore seem that Article $82 \mathrm{EC}$ cannot be applied to measures adopted by professional associations. To submit to this reasoning would, however, leave the competition law scrutiny incomplete. Chapter 5 will therefore - and as far as I know for the furst time - investigate more closely

690 For details on State regulation of the professions and competition law see Chapter 6. 
whether and to what extent Article $82 \mathrm{EC}$ may prove a useful tool to control collective regulation in the professional services sectors.

In sum Chapter 4 will cover three issues that are specific to Article 81(1) EC, namely who are the actors (associations of undertakings as addressees), which form of conduct is prohibited (professional self-regulation as agreement or decision) and which harm is caused by it to the freedom of competition (object or effect of collective professional practices to restrict competition). Chapter 5 will turn to the same exercise with regatd to the specificities of Article $82 \mathrm{EC}$. There the relevant questions will be: who are the actors (professionals as one or more undertakings in a position of collective dominance, i.e. economic strength) and which harmful conduct is prohibited (self-regulated professions abusing of collective economic strength). 


\section{Article 81(1) EC and its Field of Application with Regard to Professional Self-Regulation}

Article 81(1) EC has been applied to collective regulations a number of times, and to liberal professions in particular. It is the aim of this chapter to give a comprehensive overview of the finer workings of the article as applied to professional self-regulation. For this purpose the chapter is divided into two parts, which first will deal with the specific clements of the jurisdictional scope of Article 81(1) EC before subjecting the case of the professions to the substantive competition assessment. Conducting the substantive assessment will involve a closer scrutiny of whether and to what extent professional rules, conduct or practices "have as their object or effect the prevention, testriction or distortion of competition". The second part will set out to analyse in particular the approach chosen by the Court in Wouters to delimit the scope of the first paragraph of Article $81 \mathrm{EC}$. In both parts attention will be paid to sector specific case law ${ }^{691}$, which will be critically compared to more general competition law principles elaborated in non-sector specific case law. At the end of the chapter a plea will be made for an application of Article 81(1) EC that is consistent with the more general competition law principles.

\section{Collective professional regulation and the jurisdictional scope of Article 81(1) EC}

Professional self-regulation, as the most evident means to coordinate the exercise of a professional, i.e. economic activity, is adopted in different ways. The first section of this part will above all concentrate on professional organisations as addressees of Article 81(1) EC and their acts. Their members, as already established in Chapter 3, come within the remit of competition law under the more general jurisdictional element of 'undertakings'. The first section of this part will turn to scrutinise the notion of 'agreements between undertakings' with regard to self-regulatory measures adopted between professionals and the notion of 'decisions by associations of undertakings' with regard to self-regulation adopted by professional associations.

In its second section this part will focus on whether it is indicated to limit the universal jurisdictional scope of Article 81(1) EC for the case of professional self-regulation. Similarly to Chapter 3.I.2. the question will be whether such limitation can be justified by reference to the nature and aim of collective professional self-regulation, which conceivably is intended to pursue objectives going beyond purely economic interests of the profession's members. The discussion is not least inspired by the similarities between regulatory activities of public authorities and the way in which representative affiliations regulate and supervise the liberal 
professions sections I.2.1. to I.2.4. In fact, professional associations often benefit from a close relationship with government in the sense that their regulatory and supervisory powers are underpinned by statutes that mandate regulation in view of particular interests and according to certain procedures. ${ }^{692}$ Possible limits to the universal applicability of Article 81(1) EC will also be considered with regard to circumstances where purely ethical issues are the alleged subject matter of ptofessional regulation and supervision section I.2.5. However, and as has emerged already from previous chapter, the issue of limiting the applicability of Article 81(1) EC will tequire a careful scrutiny.

\section{Collective self-regulation within the remit of Article 81(1) EC}

This section will in turn address the two jurisdictional elements that are specific to Article 81(1) EC and assess their application to the liberal professions. First, professional bodies as the non-cconomic author of professional self-regulation will be scrutinised in respect of the competition law concept of 'association of undertakings'. Thereafter, it will be verified whether the self-regulatory activities of the professions are agreements or decisions in the sense of Article 81(1) EC.

\subsection{The accessory concept of association of undertakings: $A$ body organising economically active members}

Associations of undertakings play an important tole when there are latge numbers of market actors. Economic research has revealed that apparently it is inevitable that already relatively small numbers of economic actors revert to an organised structure in a separate entity ${ }^{693}$ This tendency is confirmed in the professional services sector where the large number of individual service providers are traditionally and usually organised in professional federations, even often enjoying official recognition. ${ }^{694}$ Linked to this is the competition concern that actions of a body covering numetous independent firms can be a means to bring the latter to conform their conduct in the pursuit of a mutual interest and to facilitate the monitoring of their behaviour. Such mutual interest can be translated into competition law terms as seeking methods by which entities that engage in an economic activity can reduce uncertainties about future conduct of their competitors and fellow members. ${ }^{995}$ An association of undertakings may thus provide a platform for competitors in a specific sector to coordinate their business behaviour.

This is the reason why the scope of Article 81(1) EC is drafted to include associations of undertakings. Its aim is to effectively cover conduct that may have similat effects on competition like, but does not originate from, direct collusion between a multitude of undertakings. Put in the words of AG Léger in Wouters, Article 81(1) EC "seeks to prevent undertakings from being able to evade the rules on competition on account simply of the form in which they coordinate their conduct on the market. To ensure that this principle is

${ }^{692}$ See OECD, Competition in Professional Services, (2000), $22 \mathrm{f}$.

693 Bishop S. / Walker M., (2002), para. 5.19., refer to Hay D.A. / Delley G., "An Empirical Survey of Price Fixing Conspiracies", (1974) Joumal of Law and Economics, 13-38, who found that cartels with more than 15 members involved trade associations in more than 80 percent of the cases, and in all cases with more than 25 members.

${ }^{694}$ OECD, Competition in Professional Services, (2000), 22.

695 Coordination enables all the participants to predict with a reasonable degree of certainty what the business policy pursued by their competitors, especially concerning prices, will be, Case 8/72, Cementhandelaren, [1972]; Case T-41/96, Bayer AG v Commission, [2000], para. 64. Odudu O., (2006), 176. 
effective, Article [81(1) EC] covers not only direct methods of coordinating conduct between undertakings (agreements and concerted practices) but also institutionalised forms of cooperation, that is to say, situations in which economic operators act through a collective structure or a common body." ${ }^{696}$

As with undertakings, no specific definition of 'association' exists in the EC Treaty. "As a genetal rule, an association consists of undertakings of the same general type and makes itself responsible for representing and defending their common interests vis-a-vis other economic operators, government bodies and the public in general." ${ }^{697}$ This statement first of all reflects that the concept of association is an accessory one. This means that without economically active members (i.e. undertakings) a collective body will not qualify as association of undettakings for the purpose of competition law. In symmetry with the functional approach that the Community Courts and the Commission apply to the concept of 'undertaking', the concept of 'association' equally is a telative one. A body may thus qualify as an association of undertakings when cartying out some of its functions, but not when performing others. ${ }^{698}$ Secondly, an association is usually determined by some organisational structures, which in practical terms is necessary to materialise the more legal requirement flowing from the case law of vertical influence on the behaviout of the association's members. ${ }^{699}$ This means that an association is an entity legally separate from its members. However, it does not have to have a legal personality, or even any formal constitution. ${ }^{700}$ Still, some rules on the decision making within the association, and in particular on the appointment to the governing body, are usually to be found either in statutes or the constitution of an association - or even in statutory provisions in case a professional association is established by State legislation. ${ }^{701}$

Broadly speaking the classification as an association of undertakings in the sense of competition law depends on the objectives, tasks, rules and powers that determine its potential to influence and/ or control the behaviour of its members. The objectives of an association, e.g. a trade association, normally take some form of economic or commercial purpose. It is not necessary, however, that they be explicitly defined as pursuing the economic interests of the association's members or that the association itself has an economic motive. Even a non-profit-making collective body can qualify as association of undertakings for the purpose of Article 81 (1) EC. ${ }^{702}$ This is a logical consequence from the fact that an association usually does not exercise an economic activity - if it was, it would qualify as an undertaking, i.e. as an addressee of competition law in any event. Again the broad interpretation of the concept of association is justified by the fact that at this juncture we are still concerned with the jutisdictional scope of Article 81(1) EC, the width of which does not prejudge the result of the substantive competition law assessment that will be

696 AG Léger in Case C-309/99, Wouters et al. $v N O v A$, [2002], para. 62. It has been pointed out that this seems to be a rather circular approach that does not take the analysis much further, Rodger B.J.,"The Competition Act 1998 and State Entities as Undertakings: promises to be an interesting debate", (2003), 4. See also Rodger B.J. / MacCulloch A., (1999), 133.

697 AG Léger in Case C-309/99, Wouters et al. vNOuA, [2002], para. 61.

698 Whish R., (2003), 98.

699 For details see below section I.1.2.

700 Goyder D.G., (2003), 78.

701 This is the case for a number of liberal professions, for instance with regard to the chartered bodies in the UK, Kammern in Germany, ordes/ ordres in Belgium, the Netherlands and France, consiglio in Italy. For details see below section I.2.4.

${ }_{702}$ Case 123/83, BNIC $v$ Clair, [1985], paras. 20, 26. 
conducted at a later stage. Moteover, and as will be explained in greater detail below in section I.1.2., it is salient that an association is in the position to influence the conduct of its members ${ }^{703}$ by assuming the task and/ or powers to adopt measures that help to eliminate uncertainties inherent in the competitive situation, e.g. by disseminating information amongst the members, in particular about prices, or by defining standards of business conduct. The dissemination of such information or standards will significantly facilitate the business planning of the fellow members to an association. ${ }^{704}$ It is such vertical coordination of economic behaviour that Article 81(1) EC aims to prohibit.

\subsubsection{Professional bodies as associations of undertakings}

Generally speaking it appears sound to accept an equation according to which a body that unifies economically active members and represents their interests is an association of undertakings in competition law terms. ${ }^{705}$ As seen in the previous chapter self-employed and corpotate members of the liberal professions in principle qualify as undertakings in the sense of EC competition law under the functional approach of that concept. Their professional associations therefore have gencrally been qualified as coming within the ambit of Article 81 (1) $\mathrm{EC}^{706}$ In this respect it is not necessary that the professional body itself carries out an economic activity as long as its members qualify as undertakings. ${ }^{707}$

The more specific question here is whether associations grouping liberal professionals generally feature objectives, tasks, rules and powers that put them in the position to influence and/ or control the behaviour of their members, and hence qualify to come within the ambit of Article 81(1) EC. First of all, the apparent purpose of professional associations is to protect the rights and professional interests of their members in the exercise of their activities. Secondly, professional associations undertake the task to promote professional standards with their members that are regarded as essential to the exercise of the profession. Such standards cover integrity, independence, competence, responsibility, professional secrecy, and the avoidance of conflicts of interests ${ }^{708}$ and may be understood as facilitating quality control in the services provision. ${ }^{709}$

703 Case C-309/99, Wouters et al. $v$ NOvA, [2002], para. 63.

704 Goyder D.G., (2003), 80.

705 Case T-193/02, Piau I, [2005], para. 69.

706 The first occasion in which a professional association has been held to be an association of undertakings in the sense of competition law is Commission Decision CNSD, (1993), paras. 40 f. Sce also Commission Decision COAPI, (1995), paras. 32 f.; Commission Decision EPI Code of Conduct, (1999), paras. 23 f.; Joined Cases C-180 to 184/98, Pavlov, [2000], paras. 86-88; Case C-309/99, Wouters et al. v NOvA, [2002]; Commission Decision Belgian arcbitects, (2004), paras. $36 \mathrm{ff}$. The cases are summarised in Chapter 2.V.

707 Joined Cases 209 to 215 and 218/78, van Landenyck, [1980]. Conversely, wherc the association does qualify as an undertaking, an agreement between it and other undertakings may be caught by Article 81(1) EC, see Joined Cases T-25 to $26 / 95, \mathrm{~T}-30$ to $32 / 95, \mathrm{~T}-34$ to $39 / 95, \mathrm{~T}-42$ to $46 / 95$, T-48/95, T-50 to $65 / 95, \mathrm{~T}-68$ to $71 / 95$, T-87 to 88/95, T-103/95 and T-104/95, Cement, [2000], paras. 1325 and 2622.

708 See Tettinger P.J., (1997), 132 ff;; Commission Decision EPI Code of Conduct, (1999), paras. 34, 38. Some claim that if professional associations pursued exclusively economic objectives they would actually exceed their competences, Tettinger P.J., (1997), 144, with further references to national case law. Note that this assertion is limited to associations that are subject to a public law regime and vested with particular statutory powers in accordance with national legislation. Moreover, it is extraneous to EC competition law whether an association acts within or outside its powers, as the addressees of Article 81(1) EC are determined following a Community concept of undertakings and associations of undertakings, see alteady Chapter 3.I. and Frenz W., (2006), para. 439.

709 The plausibility of the argument to justify restrictive rules will be scrutinised in Chapter 7.I.2.5. 
In order to secure these standards professional associations regularly assume powers that cover various aspects, ranging from licensing and authorising the exercise of certain professional activities ${ }^{710}$, regulating professional obligations and conduct, to supervision and disciplinary powers. The regulatory and even supervisory powers are often entrusted to an organisational body within an institutionalised structure. Furthermore, these powers ate complemented by rules on membership that typically characterise associations of undertakings. ${ }^{711}$ This means that even where membership of a professional association is not made compulsory rules on the qualification for membership (and even more on the suspension and exclusion therefrom) have an influence on the behaviour of the members. Warnings and reprimands as the softer means to urge the members to conform to their professional obligations are a similarly powerful tool to influence the behaviour of the professionals in an otganised and synchronised way. ${ }^{712}$ Therefore, professional associations typically enjoy the necessary means to influence the behaviour of their membets in commercial matters where they adopt measures the adherence to which they can ensure by exercising, or threatening to exercise, their supervisory or disciplinary powers. Consequently, as long as a professional association has some organisational structures and means to control the conduct of the members of the televant profession, and to warrant compliance with its rules, it generally is covered by Article 81 (1) EC. ${ }^{713}$

\subsubsection{Associations with members that are no undertakings}

Following the accessory concept of association of undertaking the question arises whether a professional affiliation falls outside the scope of Article 81(1) EC where it comprises members that are considered not to be economically active in their own right, like

710 Professional associations may be charged with certification procedures as a result of which potential competitors may be precluded from penetrating the market of the association's members, with the consequence that non-members be excluded from business opportunities, Case 96/82, LAZ International, [1983]. Sce also Case 8/72, Cementbandelaren, [1972]. An illustration is the example of the UK professional bodies of the legal professions, which used to grant lawyers the right of audience and the right to conduct litigations, Section 41 of the Access to Justice Act 1999 and its Schedule 5. On the regulatory changes in the UK legal professionas and other national examples on the legal framework for the regulatory powers of different professional association, see below section I.2.4.

711 Goyder D.G., (2003), 80.

712 See Commission Decision EPI Code of Conduct, (1999). The case illustrates a professional body that is a non-profit organisation and financed by its own resources. It has disciplinary powers and is to promote compliance by its members with the rules of professional conduct. Any representative who fails to comply with these rules of conduct may incur a penalty, i.e. a warning, reprimand or fine, or deletion from the list of professional representatives for a temporary or indefinite period (thereby barring her from the practice as a professional representative), Article 4 of the Regulation on the establishment of the EPI. Breaches of the rules of conduct may be considered by the EPI/IPR Disciplinary Committee, the EPO disciplinary Board and the EPO Disciplinary Board of Appeal, Article 5 of the Regulation.

${ }^{713}$ See Commission Decision EPI Code of Conduct, (1999). Office of Fair Trading, Trade associations, professions and selfregulating bodies, of December 2004, para. 1.4: "Any body formed to represent the interests of its members in commercial matters may be an association of undertakings. An association of undertakings is deemed to represent the interests of those undertakings which have chosen to join, and it is therefore irrelevant how the association is organised. It is not necessary for it to have any formal constitution for its activities to fall within the scope of Article 81 and/or the Chapter I prohibition. An association of undertakings will fall within Article 81 and/or the Chapter I prohibition if its decisions, rules, recommendations or other activities lead to an appreciable restriction of competition, regardless of the exact form that the association takes", referring to Joined Cases 209 to 215 and 218/78, van Landenyck, [1980]; Case 96/82, LAZ International, [1983] (referred to by the OFT as NAVEWAv Commission); and Case 123/83, BNIC $\nu$ Clair, [1985]. 
employee members of a profession or members that are themselves associations. At first glance the answer seems to be an affirmative one.

\section{Professional associations with employee members}

As seen in the previous chapter employee members of a profession do not exercise an economic activity in the sense of competition law where they form an economic unit with their employer. ${ }^{714}$ Accordingly, an association will not qualify as an undertaking if exclusively composed of members that are considered to be economically dependent on their employer. However, does a professional association still come within the ambit of Atticle 81(1) EC where not all but several of its members work as employees? ${ }^{715}$ In light of the functional approach explained in the previous chapter on determining the addressee(s) of competition law, it seems to be evident that a professional association is an addressee of Article 81(1) EC - in spite of including employee members - where it (also) acts in the interest of its economically active members. In other words, membership of salaried members in a professional association does not generally influence the classification of such an association as one of undertakings for the purpose of competition law, even where the salaried members have a say in determining the provisions applicable to the self-employed members. ${ }^{716}$ Decisive is whethet the association exerts influence on the activities of its economically active members, regardless of whether the number of salaried professional members outnumbers the self-employed and independent members. ${ }^{717}$ Conversely, and again following the functional approach, in a situation in which an association should exclusively act to determine the behaviour of those members that work under an employer's direction, it will not for that purpose fall within the ambit of Article 81(1) EC. To make a relevant distinction, circumstances have to be evaluated case by case. ${ }^{718}$ While not based on empirical data, the assumption here is that the majority of professional associations do not exclusively group salaried professionals and thus do generally come within the ambit of Article 81(1) EC. This may be different for umbrella associations examined hereafter.

\section{Professional associations composed of professional associations}

Associations representing the interest of the professions are sometimes exclusively composed of members that ate themselves associations. For instance, federal or national umbrella associations group regional or local professional associations. Umbrella organisations exist also on a European or even international level; they unify national professional associations and adopt model laws. ${ }^{719}$

714 Joined Cases 40 to 48/73, 50/73, 54 to 56/73, 111/73, 113 and 114/73, Suiker Unie, [1975], pata. 539.

715 The argument had been put forward in Pavlov, buthad been of no relevance since the association in question at the material time was composed exclusively of self-employed, i.e. economically active members, Joined Cases C-180 to 184/98, Pavlov, [2000], paras. 72 ff., and the opinion of AG Jacobs in that case, paras. $124 \mathrm{f}$.

716 Commission Decision EPI Code of Conduct, (1999), para. 24; European Commission, Report on Competition in Professional Services, of 09.02.04, para. 67. AG Jacobs in Joined Cases C-180-184/98, Pavlov, [2000], paras. 124 f.; AG Léger in Case C-309/99, Wouters et al $\nu N O \nu A$, [2002], paras. $53 \mathrm{f}$.

717 As is the case for the medical profession in Europe, see Chapter 3.I.2.3.

718 See also AG Léger in Case C-309/99, Wouters et al. v NOvA, [2002], paras. $52 \mathrm{f}$, who states that the interpretation of the definition of association of undertakings is likely to be affected where a professional organisation includes both undertakings and employees.

719 For instance the legal profession in various Member States is organised in local Bar councils, which in turn 
To qualify an association of associations as addressee of Article 81(1) EC at first sight seems to conflict with a literal reading of that prohibition. However, the question of addressee is one that determines the jurisdictional scope of Article 81(1) EC and thus is interpreted in a teleological way. This allows a broad interpretation to include even associations that are not composed of undertakings themselves but again associations, provided they group (also) economically active members. The rationale is that no formal distinction should be made between associations of undettakings where the representation of the interests of the affiliated undertakings, and those where the influence on their behaviour can be traced back to the umbrella association of associations. This has been underlined by Advocate General Slynn in case BNIC $v$ Clair, stating that "whilc an association of associations of undertakings may be different in form ftom an association of undertakings, there is no difference in substance and no reason to exclude the application of Article [ $81 \mathrm{EC}]$ ]" ${ }^{720}$ Therefore, umbrella associations that are themselves composed of professional associations are included as addressees within the ambit of Atticle 81(1) EC.

\subsection{Professional self-regulation: agreement or decision}

The following section takes a closer look at the type of measures that collectively organised professions adopt. The wording of Article 81 EC distinguishes between 'agreements' and 'concerted practices' on the one hand and 'decisions' on the other. The difference between the two categories of conduct refers to the authorship of actors, and is thus closely related to the question of addressee. The first category of 'agreements' and 'concerted practices' requires coordinative behaviour of at least two undertakings adopted in telation to each other and leading to a concurrence of wills ${ }^{721}$ or a knowing coordination of actions. ${ }^{722}$ This means two things. First of all, 'agreements' and 'concerted practices' ate adopted between economic operators horizontally. ${ }^{723}$ Applied to the case of the professions

are organised at national level. In Germany the federal Bar association is composed of the local Bar associations, $\$ 75$ BRAO: "The regional Bars shall amalgamate to form the German Federal Bar." This is not necessarily the case for other national professional associations. In France or the Netherlands the national Bar councils are elected through the local Bar associations without it being clear whether the professionals or their local Bar associations are members of the respective national body, see Articles $19 \mathrm{ff}$. Décret 91-1197 (Decree organising the lawyer's profession) (1991), or Articles $19 \mathrm{ff}$. Advocatenwet (as amended on 02.02.1989) (Lawyers Act) (1952). - The European umbrella organisation for the legal profession is the CCBE (Comité Consultative des Bareaux Européens - European Bar Association), which is the liaison body in the European Community for the legal professiona in the Member States. Its Code of Conduct was adopted on 28 October 1988 as a framework of principles of professional conduct to be applicd to, among other things, all professional cross-border activities of lawyers in a Member State other than their own. The CCBE code has been implemented in the Member States and in the observer countries to the CCBE: Norway and Switzerland. In some countries the provisions are binding in law.

720 AG Slynn in Case 123/83, BNIC $\nu$ Clair, [1985], 396. The Court confirmed the view of its advocate general in the case, see paras. $19 \mathrm{~F}$. Sec also Commission Decision CEMATEX, (1971); Commission Decision Cemalex, (1983), para. 11. Frenz W., (2006), para. 432. Also Case T-193/02, Piau I, [2005], para. 69.

721 Case T-41/96, Bayer AG ע Commission, [2000], para. 69: "the concept of agreement within the meaning of Article [81(1) EC], as interpreted by the case-law, centres around the existence of a concurrence of wills between at least two parties, the form in which it is manifested being unimportant so long as it constitutes the faithful expression of the parties intention."

722 Dabbah M.M., (2004), 71.

723 See Joined Cases T-305 to 307/94, T-313/94 to T-316/94, T-318/94, T-325/94, T-328/94, T-329/94 and T-335/94, Limburgse Vinyl, [1999], para. 696, stating that with regard to 'agteements' and 'concerted practices' it is not required to sharply distinguish between the two terms (joint classification) for each and every collusive 
the element requires that their respective members take an active role in the cootdination of their respective business behaviour. An illustration will follow shortly. Secondly, the reference to coordinative behaviour emphasises the aim of Article 81(1) EC to prevent conduct that enables market participants to predict with a reasonable degree of certainty what the business policy pursued by their competitors will be. ${ }^{724}$ Hence, and to the extent that they restrict the freedom of competition ${ }^{725}$, agreements and concerted practices ate prohibited because they are a means to reduce uncertainty about the future behaviour of others in contradiction with the entrepreneurial tisk that is inherent to the idea of competitive processes. In this the first category of conduct covered by Article 81(1) EC corresponds with the second. It is established case law that Article 81(1) EC applies to both associations and undertakings "in so far as their activities [...] are calculated to produce the results which [Article 81(1) EC] aims to suppress. To place any other interpretation on [Article 81(1) EC] would be to remove its substance."726

However and in contrast to the first category, a 'decision of association' refers to vertical measures that are adopted by a collective body (on behalf of its affiliated member undertakings) to which the members conform. Put differently, a decision is a resolution by (the authorised organ of) an association to impose obligations on its members on the basis of particular procedural rules that have the effect of reducing their freedom of action. ${ }^{727}$ To include both categories of coordination within the scope of Article 81(1) EC indicates that both variants are considered equally harmful to competition. Their difference is not so much a substantive, but rather a practical one, as will be illustrated later on. While with tegatd to agreements and concerted practices it is the undertakings themselves that participate in coordinative conduct, decisions can be said to coordinate conduct by proxy. Here it can be recorded that both forms contribute to predict the future behaviour of competitors and, consequently, to reduce the freedom of action ${ }^{728}$ of the undertakings concerned.

Reverting to the example of professional self-regulation, further scrutiny will focus on the concept of decision rather than agreement for two reasons. Not only is professional regulation in the form of institutionalised self-regulation an evident means to influence the conduct of the members to a profession. It is also estimated to be the form that occurs most due to the dual effect that the numbers of professionals are constantly growing and that as of a certain number of undertakings association-forming is inevitable. ${ }^{729}$ In the following light will be shed on two specific points that determine the concept of decision. First, a look shall be taken at the consequences that the accessory nature of the concept association has for the concept of decision (section 1.2.1.). Secondly, the content of the concept of decision

behaviour between undertakings and for any given moment "in the context of a complex infringement..., as in any event both those forms of infringement are covered by [Article $81 \mathrm{EC}$ ]". In the course of this book reference to agreement therefore includes also the notion of concerted practices. For an elaborate survey of the distinction see Odudu O., (2006), 57 ff. See also Case T-1/89, Polypropylene (Rhône-Poulenc), [1991], paras. 125-127; Case T8/89, Polypropylene (DSM), [1991], paras. $234 \mathrm{f}$.

${ }^{724}$ Case 8/72, Cementhandelaren, [1972], stressing especially business policy concerning prices.

${ }^{225}$ For details see below section II.1.

726 Case 71/74, Frubo, [1975], paras. 30 f;; Joined Cases 209 to 215 and 218/78, van Landenyck, [1980], para. 88; Joined Cases T-25 to $26 / 95, \mathrm{~T}-30$ to $32 / 95, \mathrm{~T}-34$ to $39 / 95$, T-42 to $46 / 95, \mathrm{~T}-48 / 95$, T-50 to $65 / 95$, T-68 to 71/95, T-87 to 88/95, T-103/95 and T-104/95, Cement, [2000], para. 1320. See also Commission Decision COAPI, (1995).

${ }_{727}$ Goyder D.G., (2003), 80 f. See also Case C-309/99, Wouters et al. v NOvA, [2002], para. 97.

728 On the distinction between the freedom of action and the freedom of compctition, whereby the former encompasses the latter, see below section II.1.2.

${ }^{729}$ Sec above note 693. 
will be scrutinised more concretely as interpreted by the case law (section 1.2.2.). Moreover, a brief overview will be given of the rather practical difference between vertical and horizontal self-regulation in the professions' sector (section 1.2.3.).

\subsubsection{Decision of association: a relative concept reflecting an objective interpretation}

Professional regulation and measures adopted by a professional association can take various forms. It materialises, for instance, in articles of incorporation, the constitution of the association, regulations governing the association's operation, by-laws, rules or codes of conduct, or even recommendations that are declared not to be binding, but merely to be of an indicative character. ${ }^{730}$ Such regulatory measures emerge form a rule-making process that professional associations exercise eithet on their own authority or on the basis of State legislation. The legal framework within which professional associations adopt their measures, and in particular the public law status that they enjoy in some Member States, do not, however, have an impact on whether or not their measures qualify as decision within the meaning of Article 81(1) EC. ${ }^{731}$ According to the case law "the legal framework within which [...] decisions ate taken and the classification given to that framework by the various national legal systems are irrelevant as far as the applicability of the Community rules on competition, and in particular [Article $81 \mathrm{EC}$ ], ate concerned". ${ }^{732}$ This case law reflects the objective interpretation given to competition law concepts of a jurisdictional chatacter and is thus in tune with the Höfner formula. In the previous chapter it has been explained that this objective, or autonomous, interpretation results in an functional approach, which the Community Courts and the Commission follow in interpreting the coverage of the jurisdictional elements of competition law.

As the concept of association is accessory to the functional concept of undertaking, a decision taken by an association must seem to influence the economic behaviour or the commercial interests of its member undertakings. ${ }^{73}$ This means that the concept of decision in its turn is accessory to the finding that the activities of members of an association be economic. The jurisdictional scope of Article 81(1) EC thus contains a triple relativity, namely with regard to the respective concepts of undertaking, of association of undertakings and of decision of an association. This relativity implies that collective rules concerning noneconomic activities of the association's members are outside the jurisdictional scope of Article 81(1) EC. This means that some measures of a collective body qualify as decisions where these concern certain activities (i.e. where the body influences the economic activities of its members), but not when concerning others. In the words of the Court Article 81(1) EC thus "applies to associations insofar as their own activities or those of the undertakings belonging to them are calculated to produce the results which [Article 81(1) EC] aims

730 See for instance Commission Decision Belgian arcbitects, (2004), paras. $60 \mathrm{ff}$.

731 The case law stresses that associations come within the scope of Atticle 81(1) EC, regardless of the legal status that their acts have, Case 8/72, Cementhandelaren, [1972]; Case 45/85, Verband der Sachversicherer, [1987], para. 32; joint Joined Cases 209 to 215 and 218/78, van Landenyck, [1980], para. 86; Case T-66/89, Publishers' Association $\nu$ Commission no. 2, [1992], paras. 44 ff.; Commission Decision Belgian arcbitects, (2004), para. 64.

732 Case T-513/93, CNSD III, [2000], para. 39, referring to Case C-35/96, Commission v Italian Republic (CNSD II), [1998], para. 40. Also Case 123/83, BNIC v Clair, [1985], para. 17; Case C-309/99, Wouters et al v NOvA, [2002], patas. 65 f. See also AG Colomer in Case C-345/02, Pearle BV and Others, [2004], paras. $69 \mathrm{ff}$.

733 Case C-309/99, Wouters et al. ע NOvA, [2002], para. 64. See AG Jacobs in Case C-67/96, Joined Cases C115/97, C-116/97 and C-117/97 and Case C-219/97, Albany/Brentjens'/Drijvende Bokken, [1999], para. 214. 
to suppress". ${ }^{734}$ Hence, to the extent that they relate to the practice of the profession in question, professional self-regulatory measures are subject to the scrutiny under Article 81(1) EC.

\subsubsection{The concept of decision interpreted}

In assessing the ambit of the concept of decision it is not sufficient to merely observe that the measures at stake concern economic activities of the association's members. The case law also requires that a decision of an association must be determinative for the market conduct of its member undertakings. The Court has had the opportunity to stress this point in particular with regard to professional self-regulation. ${ }^{735}$ The question here is whether selfregulatory measures, in order to qualify as 'decision', necessarily have to be formally binding on the association's members or whether a factual influence on their conduct is sufficient. Firstly, if only formally adopted measures were covered, the prohibition of Article 81(1) EC could obviously be circumvented by the adoption of informal measures. ${ }^{736}$

Secondly, non-binding decisions of recommendations are equally likely to affect the behaviour of the association's members and to produce the results which Article $81 \mathrm{EC}$ aims to suppress. ${ }^{737}$ They are equally liable to result in a facilitated coordination between the members of a profession and to influence their conduct so as to restrict or distort competition. ${ }^{738}$ While no urge may be exercised by the professional association on its members to conform to the proposed rules, there is nevertheless the incentive to conform to them because of the expectation that also the other members will comply with the recommendation. Such collective compliance induces an economic 'premium' for the members since, fot instance higher prices for services will not be undercut by fellow members, or a restricted supply of services (be it in terms of quantity, quality or variety) will not be opened up by fellow members and thus result in higher prices. Moreover, recommended conduct, e.g. in the form of recommended prices, can mislead consumers as to what are the reasonable conditions for a contract, and as to whether the recommended price is negotiable. ${ }^{739}$ Hence, decisions of professional associations do not have to have legally binding effects on their professional members to have economic effects and thus be eligible for the scope of Atticle 81(1) EC. Any legally binding effect will make a case only more conclusive. ${ }^{740} \mathrm{It}$ is regardless of whether measures are in writing or oral, ${ }^{741}$ and also

734 Joined Cases 209 to 215 and 218/78, van Landenyck, [1980], para. 88 (emphasis added); see also Commission Decision COAPI, (1995). AG Léger in Case C-309/99, Wouters et al. v NOvA, [2002], para. 62

735 Case C-309/99, Wouters et al. vNOvA, [2002], para. 63. Whether professional regulations eventually restrict or distort competition between economic operators in the common market is a separate question that requires a substantive assessment of the measures at hand, and which is addressed only in the second part of this chapter. The severability of the two aspects demonstrates once more that the question on whose activities are subject to the competition law scrutiny is of a jurisdictional quality that does not prejudge the going into the merits of a casc. 736 Frenz W., (2006), para. 441.

737 Case 8/72, Cementhandelaren, [1972], para. 21; joint Joined Cases 209 to 215 and 218/78, van Landenyck, [1980], para. 88; Commission Decision Fenex, (1996), paras. 48 ff.; Commission Decision Belgian arcbitects, (2004), paras. 60 ff. See also Office of Fair Trading, Trade associations, professions and self-regulating bodies, of December 2004, parts 2 and 3, covering rules, recommendations and other activities.

738 Recommendation can form a point of reference for the individual practitioner that is followed by most or all.

739 European Commission, "Commission objects to recommended minimum fee scale of Belgian Architects' Association", press telcase IP/03/1500 of 05.11.2003.

740 See Case T-193/02, Piau I, [2005], para. 75; Case 45/85, Verband der Sachversicherer, [1987], paras. 29 ff.; Case 
measures that have expired are covered, provided their effects continue to be felt on the market and between the parties. ${ }^{742}$ This broad interpretation results in an all-embracing jurisdictional scope of Article 81(1) EC, which is justified in view of the effectiveness of its prohibition to safeguard undistorted competition in the common market.

The question arises of how to verify in a given case the relativity that flows from the functional approach in interpreting the concepts of association and decision. In other words: how to verify and substantiate the influence that professional regulation needs to exert on the market behaviour of practitioners? "This question becomes relevant with regard to nonbinding rules or recommendation. Their influence can be substantiated for instance if members of an association have tended to conform their conduct to the recommendations in the past. The evidence has to be that the members have conformed or might in the future conform their behaviour to the decision, at least to a certain extent. Moreover, non-binding rules will also come within the ambit of Article 81(1) EC if they constitute the faithful reflection of a resolve on the part of an association to coordinate the market conduct of its members in accordance with the terms of the recommendations or non-binding rules. ${ }^{743}$ In other words non-binding self-regulation needs to express the intention of the regulatory body to influence the competitive conditions on a market. Applied to the case of professional regulation it is this intention to have the practitionets act in a particular manner when carrying on their economic activity that brings the professional body within the scope of Article 81 (1) EC. ${ }^{744}$ However, since intentions are subjective it will be trying in vain to ascertain them. Therefore, the reference to the intention to influence the market behaviour has to be interpreted in an objectivised way. This means that it is the self-regulatory measure that can be understood as the objective element which expresses the required intention of the self-regulatory body. This sophistication is in line with, but partly anticipates, the scrutiny of the anti-competitive character of an act. If a contested measure has the object (rather than the effect) of restricting competition ${ }^{745}$, it is not necessary, even in case of a non-binding measure, to demonstrate the actual effect of that measure on the behaviour of the association's members. Examples of restrictions by object are price regulations and market compartmentalisation. ${ }^{746}$ In such cases the subjective intention to restrict competition will

C-309/99, Wouters et al. vNOvA, [2002], paras. 71, 73. See Jones A. / Sufrin B., (2004), 149.

741 Decisions Commission Decision Fenex, (1996), paras. 48 ff.; Commission Decision Belgian arcbitects, (2004), paras. $60 \mathrm{ff}$.

${ }^{742}$ For an overview of the extensive case law by the Community Courts and the Commission, see Whish R., (2003), 91 ff.; Ritter L. / Braun W.D., (2004), 100 ff.

${ }_{743}$ Case Case 8/72, Cementhandelaren, [1972]; Commission Decision Belgian architects, (2004), para. 64; case Case 45/85, Verband der Sacbversicherer, [1987], para. 32; joint cases Joined Cases 209 to 215 and 218/78, van Landenyck, [1980], para. 86; case Case T-66/89, Publishers' Association v Commission no. 2, [1992], paras. $44 \mathrm{ff}$.

${ }_{744}$ " $[\mathrm{H}]$ aving regard to its influence on the conduct of the members of the [profession] on the market in [professiona] services [...], [the Regulation adopted by the professional body] [...] constitutes the expression of the intention of the delegates of the members of a profession that [the members] should actin a particular manner in carrying on their economic activity", Case C-309/99, Wouters et al. vNOvA, [2002], paras. 63-64. See also Cour d'Appel de Bruxelles - Case 2002/MR/3 2003/MR/8 "Koninklijke Gilde van Vlaamse Antiquaires v MSA" [2004], in which the Flemish association of antique dealers prohibited its members on pain of exclusion to participate in antique fairs organised by other bodies than itself.

745 For details see below sections II.1. and II. 2.

746 See Case 96/82, LAZ International, [1983], paras. 23 ff., where the non-binding character of the recommendations was disregarded as the Court found that they had the natural and foreseeable effect to discriminate against dish-washer produced elsewhere in the EC. 
be presumed ${ }^{747}$, without it being necessary to demonstrate any concrete effects of a decision on the behaviour of the members to an association.

In the case of the Belgian arcbitects the Commission demonstrated how recommendations circulated by a ptofessional body qualify as decision of an association, despite their nonbinding character. While the association maintained that the recommended fee scales at issue were a mere guideline not intended to be binding on the members of the profession, the Commission found that several mechanisms had been in place to ensure that the recommended fee scale actually was an act of a prescriptive character, for which the ptofessional association was responsible, and which was intended to coordinate the members' behaviour. ${ }^{748}$ The relevant regulatory mechanism chosen by the Belgian association shall be briefly sketched for illustration purposes. The Commission stressed, firstly, the intentional tule-making or prescriptive tone that the association used in its recommendation and the preamble thereof; secondly, the threat of disciplinary penalties under the code of ethics for failure to comply with professional duties; and thirdly, the distribution by the professional body of a standard architect-client contract incorporating the fee scales into individual contracts.

In particular the threat of disciplinary measures can be an effective means to effectively influence the market behaviour of members of the professions, in particular if membership is compulsory. This latter point has been illustrated by the Commission decision in case EPI code of conduct. In order to underpin its finding that a code of professional conduct constitutes a decision by an association of undertakings, the Commission established several factors: it ascertained that the purpose of the code was to regulate the members' conduct; the fact that the code's provisions were binding on all members of the profession affiliated by compulsory membership; and that the professional association enforced the provisions of the code on the basis of penalties. ${ }^{749}$ This case in particular illustrates that self-regulatory rules can produce binding effects due to their enforcement through disciplinary procedures before either the professional body and/or procedures before State courts. In this regard it is immaterial whether the enforcement of the collective rules has been brought about by the association itself as the author thereof, or by a professional member who may have the right to initiate proceedings against an infringer of rules adopted by the association, either before a disciplinary body or ordinaty State courts. The infringer may be a peer, but may just as well be a practitioner of a different profession. The latter case may arise for example in the instance of legal monopoly rights that reserve the excrcise of particular activities to the members of a distinct professional group affiliated with a certain professional association. Thus, a decision of a professional associations can have far-reaching effects not only for the behaviour of its member undertakings.

\subsubsection{The practical difference between agreement and decision illustrated}

The main practical difference between horizontal and vertical self-regulation lies in the following. While an agreement applies only to the members who participated in and approved of the coordination in question, a decision applies also to those members who did not agree to it and may even not have taken part in the decision-making process. ${ }^{750}$ In fact

747 For details see below page 200 and Case C-219/95 P, Ferriere Nord SpA v Commission, [1997], paras. $13 \mathrm{ff.}$

748 Commission Decision Belgian arcbitects, (2004), paras. 60-74.

749 Commission Decision EPI Code of Conduct, (1999), para. 25.

750 Ritter L. / Braun W.D., (2004), $105 \mathrm{f}$. 
it is not necessary that members of the profession participate in the rule-setting process. In this tespect vertical self-regulation can be considered as unilateral. It may not always be easy, or even necessary, to sharply classify a certain behaviour either as agreement between undertakings or as decision of a body associating undertakings. ${ }^{751}$ The Commission in its COAPI decision has demonstrated that a professional code of conduct can be both an agreement between undertakings and a decision of an association. ${ }^{752}$ The case shows that the assessment generally depends on the nature and origin of the professional regulations at hand. The relevant regulations had originally been adopted among industrial property agents in a meeting and, consequently, in their origins formed an agreement between undertakings. Subsequently, the COAPI as an organisation was established by law in 1926, and its general meeting modified the regulations several times. Therefore, the Commission concluded that the COAPI Regulations also constituted a decision by an association of undertakings.

One and the same professional code thus can qualify as both an agreement and decision depending on its historical evolution. As both forms of measures are covered by Article 81(1) EC, the distinction appears to be above all of a historical interest of how, and in particular, by whom a professional code has been adopted. In practical terms it may depend on the size of a profession whether it can actually meet in its collectivity or whether its artangements necessarily need to be adopted by its representatives within a formalised professional body. ${ }^{753}$ However, it cannot be excluded that a certain professional behaviout stems from arrangements adopted outside a formalised organisation. Therefore, both the professional body, as well as the independent professional members of the profession in question, face the risk of being fined by the Commission if they should have participated in the same infringement and should be held accountable for restricting competition. ${ }^{754}$ Fines might even be imposed in parallel at both levels. ${ }^{755}$ Moteover, it should be noted that only

751 Case T-7/89, Polypropylene (Hercules), [1991]. Ritter L. / Braun W.D., (2004), 98: "the various types of action form a continuum with similar anticompetitive consequences which are treated alike".

${ }_{752}$ Commission Decision COAPI, (1995), paras. 34, 35. See also Michalski L. / Römermann V., (1996), 193.

753 See also note 693.

754 See European Commission, "Commission condemns Belgian architects' fee system", press release IP /04/800 of 24.06.2004, and the summary of the case in Chapter 2.V., which explains the fine imposed on the association of Belgian architects. Whish R, (2003), 93: "Where an agteement is entered into unwillingly, this may be significant in influencing the Commission to mitigate a fine, not to impose a fine or not to institute proceedings at all. The Commission may abstain from fining parties which had no input in the drafting of the agreements into which they have entered." See also Commission Decision Fenex, (1996).

755 Joined Cases T-25 to $26 / 95$, T-30 to $32 / 95$, T-34 to $39 / 95$, T-42 to $46 / 95, T-48 / 95, T-50$ to $65 / 95, T-68$ to $71 / 95, T-87$ to $88 / 95, T-103 / 95$ and T-104/95, Cement, [2000], para. 485: where the Commission, for particular reasons, intends to fine both the members of the associations and the association, it must make its intention clear in its statement of objections. See also Wils W., (2000), 116. See however the decision the Commercial Court of Lisbon in the case on the Portuguese professional association of veterinaries (VMA) in which this association had brought an appeal against a decision by the Portuguese competition authority that found the VMA's code of cthics to be in breach of Article 4(1) of Law 18/2003 and of Article 81(1) EC. Contrary to the NCA the Portuguese court decided that the relevant turnover for the basic calculation of the fine should be the VMA's specific turnover and not that of its members. Caimoto Duarte J., A Portuguese Court substantially upbolds the competition authority's decision finding the association of veterinaries liable for imposing minimum fees (Fixafãa de bonorários por uma ordem profissional)", (2006): the Lisbon court "disregarded the scope of the relevant Portuguese Competition Act provisions for the calculation of fines to associations of undertakings (and even to the relevant EC competition law framework in this regard, which could be used for interpretation purposes). Instead, the court applied the general regime for administrative offences directly (which is subsidiary to the Portuguese Competition Act's procedural provisions on antitrust infringements). It was held that the relevant turnover to be taken into account should be that of the 'legal entity' directly involved in the infringement, the VMA. In conclusion, the court ordered the VMA to cease immediatcly the infringement (i.e., the imposition to its associates of minimum fees, 
bodies having a legal personality can bc the addressees of a fine. Therefore, even where an association of undertakings is found to have adopted an anti-competitive decision, its members nevertheless will be fined if their association has no legal personality, and if they can be equally held accountable for a restrictive decision taken by their association. ${ }^{756}$

\section{Collective professional regulation not having a character that would justify the application of} Article 81(1) EC

From the foregoing it emerges that the regulatory and supervisory measures of professional associations are a potent means to influence the economic conduct of the members of a profession. In accordance with a functional approach they are therefore covered by the jurisdictional scope of Article 81(1) EC. The next question is whether the activity of setting and/ or monitoring professional rules may be excepted from the jurisdictional scope of Article 81(1) EC in light of an argument often put forward by professional associations, namely that their activities are the result of the representation of interests that go beyond the mere economic interests of their members. In particular they argue that they are assigned the task to guatantee the integrity, impartiality, independence and competence of the practitioners in the interest of consumers and the broader public. Regulating these issues may bring professional associations to a cross-section with public governance exercised in the public interest. The perceivable line of argumentation can refer to the combined fact that public interest considerations are usually in the realm of public authority, and that public authotity actors (i.e ultimately the Member States) are no (direct) addressees of the EC competition rules. ${ }^{757}$ The question therefore is whether professional associations, or in fact any self-regulatory body, should equally be immune against the application of Article 81(1) EC where they are involved in governance tegimes that are close to the realm of public governance.

Such argumentation obviously has to be squared with the objective interpretation of the jurisdictional scope of Article 81(1) EC, which does not cater for tegional differences in the application of EC competition law. A consequence hereof is, as has been stressed before, that neither the legal status, and in particular the public law status that professional otganisations enjoy in some Member States, nor the legal framework within which they exercise their powers, influence the universal applicability of Article 81(1) EC. ${ }^{758}$ This means that, as long as an association affiliates economically active members and influences their market behaviour, there is no perceivable reason to grant it an exception from the

by reference to specific approved charts), and declared void the relevant disciplinary provisions that were still in force. Finally, the court established that the fine applicable to the VMA should be $€ 18,000$ and not $€ 75,935$ as originally established by the [NCA]."

756 Goyder D.G., (2003), 79. According to Article 23 of Regulation 1/2003 a fine is calculated on the annual turnover in the preceding business year of the undertakings participating in the infringement, i.e. of all members of a professional association. The fine cannot exceed $10 \%$ of their cumulative turnover. See also on the Commission's fining policy, European Commission, Guidelines on the method of setting fines, European Commission, Commission Notice on immunity from fines and reduction in fines in cartel cases.

757 For details see Chapter 6. In Case 118/85, AAMS, [1987], para. 7, the Court recognised "that the State may act either by exercising public powers or by carrying on economic activities of an industrial or commercial nature by offering goods and services on the market. In order to make such a distinction, it is therefore necessary, in each case, to consider the activities exercised by the State and to determine the category to which those activities belong."

758 See above the text with note 731 . 
jurisdictional scope of Article 81(1) EC. However, when looking at the case law one has to recognise that this conclusion may not go unqualified in certain situations. The question is therefore whether and under which circumstances professional associations and professional self-regulation may avoid the application of Article 81(1) EC in their own right, i.e. irrespective of the economic nature of the activities exercised by the practitioners.

This section will first scrutinise once more the case law out-competing the universal Höfner-rule that has been analysed in Chapter 3.I.2., and which effectively constitutes an exception ratione personae for entities, the activities of which ate connected with powers carried out by a public authority. The aim will obviously be to test the impact that this case law may have on self-regulatory activities by professional associations (section 2.1.). A more general question thereby arises, namely whether more circumstances can be defined that justify not applying Article 81 (1) EC to collective bodies and their acts. The point will be further scrutinised in (section 2.2.) in light of a specific line of case law, which essentially has been developed, if not tailor made, by the Court with regard to professional associations. As a result the Court affirmed that the application of Article 81(1) EC may not be justified whete State measures sustain the acts of self-regulatory bodies, to the extent that the latter are mandated with the regulation and monitoring of professional activities, and that sufficient public control is being exercised on the composition and the obligations of the self-regulatory bodies. Both lines of case law limiting the universal jurisdictional scope ratione personae $I$ and $I I$ will be put into perspective in section 2.3. in an attempt to tationalise the limitations they impose. The ensuing exception will be illustrated in section 2.4 . with examples from vatious professional sectots.

The present section will close with scrutinising whether it is appropriate to apply an exception ratione materiae to the case of professional self-regulation (section 2.5.). Arguably one may build on the relativity of the concept of decision to opine that measures of a collective body do not qualify as decisions within the meaning of Article 81 (1) EC where the association is concerned with regulating and enforcing "purely ethical issues" rather than intending to influence the economic conduct of practitioners. ${ }^{759}$

\subsection{Limiting the jurisdictional scope ratione personae I: professional associations exercising activities connected with powers carried out by a public authority}

The consideration to extrapolate the case law out-competing $\mathrm{H}_{0} \mathrm{fner}^{760}$ is prompted by the willingness of the Court to exclude from the jurisdictional scope of competition law measures that assimilate certain public interest functions. The question hete is whether professional associations, in respect of their regulatory and supervisory activities, can be considered to organise essential functions of the State, and for that purpose should be associated with the exercise of official authority, which as such is not (directly) justiciable under competition law. The scrutiny into whether and to what extent the case law undetcutting the universal applicability of competition law can be extrapolated to the case of professional associations must be conducted carefully, not least due to the general rule of legal interpretation that an exception is to be applied restrictively to preserve its character of exception. Before going into details a few preliminary aspects have to be verified.

759 The Commission has suggested that certain professional self-regulatory rules dealing with 'purely ethical issues' would not come within the ambit of Article 81(1) EC, see Commission Decision EPI Code of Conduct, (1999), paras. 34 and 38.

${ }_{760}$ For details see Chapter 3.I.2.2. 


\section{A line of case law fit for extrapolation?}

First of all, it is necessary to verify whether the exception deriving from $S A T /$ Eurocontrol and $\mathrm{Cali}^{761}$ can at all be extrapolated to the case of institutionalised self-regulation. Since the case law undermining $H$ öfner has taken shape with regard to the question of whether a particular activity has an cconomic character or not, one might argue that it is redundant to extrapolate that case law and apply it to decisions of associations, as the latter are clearly not exercising economic activities of their own and independently of their members. ${ }^{762}$ It is however doubtful whether the Court would refrain from applying the exception ratione personae only on the basis that a particular case concerns the measures of an association rather than of undertakings. In fact, where one accepts the validity of that case $\operatorname{law}^{763}$, its extrapolation to activities of associations can be supported by the following consideration.

Within the ambit of Article 81(1) EC undertakings and associations are two coequal categories of addressees. It would not be conclusive to allow one category to put forward arguments related to the exercise of public authority, but to deny this possibility to the other. Both may be involved in the exercise of public authority; to distinguish between them in this respect is only a matter of degree. This point can be sustained by a further parallel with the concept of undertaking and the interpretation thereof. According to the comparative market criterion the eligibility of a particular entity to come within the jurisdictional scope of competition law depends on whether its activities are economic in nature. The latter is ascertained by testing whether the activity can, at least in principle, be carried out on a market with a view to profit. While the circumstances of a particular case may support an affirmative answer, and thus to qualify the entity in question as addressee in terms of Article 81(1) EC, the Court has not felt hindered to develop the specific exception ratione personae deriving from the case law undermining the universal applicability of competition law. ${ }^{764}$ Thus, extending the logic of this first specific line of case law one may state that noneconomic activities of professional associations may be excepted from the jurisdictional scope of Article 81(1) EC, despite the fact that they bear on the economic activities of their members.

The idea to exclude from the ambit of competition law activities, that the Court considers to be associated with essential functions of the State ${ }^{765}$ or the exercise of public

\footnotetext{
761 Case C-364/92, SAT/ Eurocontrol, [1994]; Case C-343/95, Calì v SEPG, [1997].

762 This position is taken by Lenk J., (2006), 76.

${ }^{763}$ It shall be recalled from Chapter 3 that it is doubtful whether the cases SAT/Eurocontrol and Cali should at all be taken as a basis to extract a general rule. More specifically, the case law is overruling rather than concretising the Höfnerrule and can be criticised for its arbitrariness in identifying which particular activities are exempted from the ambit of competition law. In particular it has been argued in the previous chapter that the exercise of the particular activities of air traffic control and anti-pollution surveillance services are not necessarily connected with powers of a public authority. Also the factual developments that took place meanwhile have proven the assessment of the case law to be questionable since air traffic control, for instance in Germany or the UK, is essentially offered by private providers.

764 As illustrated in the previous chapter it is perfectly perceivable that the activities that were at stake in $S A T /$ Eurocontrol and Cali are subject to market conditions - notwithstanding the fact that the Court refused to consider the activities from their economic side, but rather emphasised their affinity with public authority.

765 Where the self-regulatory activity of the association would provide to fulfil a social function based on the principle of solidarity it could be outside Article 81(1) EC. However, any social function potentially pursued with rules set by professional bodies (e.g. compulsory pension scheme tun by the professional association) is not covered by the present research as the topic appears to be too confined to be of relevance to the broader questions of professional regulation and its impacts in competition law. On social security systems see Joined
} 
authority, could mean in its application to decisions of an association that the influence the latter has on market conduct is irrelevant. These considerations show that the extrapolation is conceivable and not redundant. In addition - but only to the extent that the case law in question will not be discontinued by the Court ${ }^{766}$ - denying associations to invoke an exception, which the Court in particular circumstances concedes to undertakings, would result in a discriminatory application of Article 81(1) EC without apparent reason. In fact the exception had been invoked in Wouters, where the Dutch bar association NOvA atgued that "inasmuch as the Netherlands legislature created the Bar of the Netherlands as a body governed by public law and gave it regulatory powers in order to perform a task in the public interest, the Bat cannot be regarded as an association of undertakings within the meaning of Article [81 EC], particularly in connection with the exercise of its regulatory powers." While the argument was rejected on the merits, the judgment proves that the Court in principle accepted that the particular exception ratione personae can also be invoked by associations. ${ }^{767}$

Rather than to rule out its application the question is whether the case law overruling the universal applicability of Article 81(1) EC can be formulated in sufficiently abstract terms in order to apply outside the instances in which it initially occurred. The essence of that case law may be abstracted to sketch the idea that an entity - whether economically active or not - should not be subject to competition law control where its acts reflect the exercise of official authority. In paraphrasing the case law based exception ratione personae the relevant test to be applied in the following is thus whether we can exclude from the jurisdictional scope of Article 81(1) EC decisions of an association that, by its nature, its aim and the rules to which it is subject, is connected with the exercise of powers that are typically ${ }^{768}$ those of a public authority.

\section{Coercive powers of professional associations}

In returning to the libetal professions' sector the further query has to be into the typical functions of professional associations. They are of a representative and regulatory, supervisory and disciplinary nature. Arguably regulatory supervision could be exercised on behalf of the State. ${ }^{769}$ For instance it is conceivable that the regulation and supervision of a profession may be in the general interest where the respective powers are to satisfy considerations of public health (medical professions), public safety (engineering professions) or the judicial system (legal professions); the public may also have an interest in a reliable auditing practice ${ }^{770}$ to be safeguarded by strict and impartial controls of independent

Cases C-159/91 and C-160/91, Poucet and Pistre, [1993]; Case C-67/96, Albany, [1999]; Joined Cases C-115 to 117/97, Brentjens', [1999]; Case C-219/97, Drijvende Bokken, [1999]; Joined Cases C-180 to 184/98, Pavlov, [2000]; AG Jacobs in Case C-475/99, Glöckner, [2001].

766 See above note 763.

${ }^{767}$ Case C-309/99, Wouters et al. $v N O v A$, [2002], paras. 51, 56, 58. For details sce below section 1.2.1.1. Sec also AG Kokott in Case C-283/03, A. H. Kuipers, [2005], note 32, stating that in the field of agricultural products a statutory price fixing board and a private-law legal person entrusted with supervisory and inspection functions would not act as undertakings or an association of undertakings in implementing State rules on priccs. The fixing of price deductions and price supplements would not constitute an economic activity but rather an activity carried on by a public authority under the law and on behalf of the State.

${ }^{768}$ This refers to the yardstick effectively applied in the case law but is not shared by the present author, see Chapter 3.I.2.2.3.

${ }_{769}$ See Whish $\mathrm{R},(2003)$, 98. On the conceivable exercise of public authority by individual members of a profession, i.e. notaries, see Chapter 3.I.2.2.4

770 See also Case C-384/93, Alpine Investment, [1995], para. 44, where the Court held that maintaining the good 
auditors. However, not just any regulatory or supervisory activity carried out by a professional association is a function that associates with the exercise of public authority. Two basic remarks have to be made to demonstrate that the mere presence of regulation and supervision of a profession is not sufficient an argument to make a regulatory and supervisory bodies fall outside the scope of Article 81(1) EC.

The first observation relates to the attempt undertaken by Advocate General Poiares Maduro in FENIN II, explained in the previous chapter, to condense the Court's case law undermining the universal application of competition law, in order to integrate the diverging branches of case law concerning, on the one hand, social security and insurance schemes financed according to the principle of solidarity and, on the othet, the exercise of public authority. According to the interpretation given by Advocate General Poiares Maduro the particular circumstances of a case are outside the scope of competition law, if they involve the exercise of official authotity for the purpose of regulating rather than participating in the market. ${ }^{771}$ This interpretation cannot be transferred to associations of undertakings since it would be rather dangerous for the following reason. The fact that associations are almost by definition not participating in the market must not allow for the conclusion that their powers involve the exercise of official authority for the purpose of regulating the market, with the consequence of withdrawing them from the control of Article 81(1) EC, as could indeed be suggested on the basis of the Advocate General's opinion. Such an interpretation would, however, tender the jutisdictional criterion of 'association of undertakings' redundant for the case of self-regulation, therewith endangering the effectiveness of Article 81(1) EC, and thus resulting in an interpretation contra legem. ${ }^{772}$

reputation of the financial sector of the Member State to be an imperative reason of public interest capable of justifying restrictions on the freedom to provide financial services.

771 See Chapter 3.I.2.

772 This point has obviously been overlooked by Tord Slynn of Hadley and the consenting fellow Lords, in the case of House of Lords - "Institute of Chartered Accountants in England and Wales (appellants) v Commissioners of Customs and Excise (respondents)" [1999]2 All ER 449, 2 CMLR 1333, when considering whether regulatory activities of a professional association could be offered on the market as an economic activity. (The question in that case was whether the professional body is a taxable person or a public authotity.) He opined that: "On the basis of cases like Eurocontrol [...] and as a matter of ordinary language, I do not consider that what is done here by the Institute is such an economic activity. The Institute is carrying out on behalf of the State a regulatory function in each of these three financial areas to ensure that only fit and proper persons are licensed or autborised to carry out the various activities and to monitor what they do. This is essentially a function of the State for the protection of the actual or potential investor, trader and sharcholder. It is not in any real sense $a$ trading or commercial activity which might justify it being described as 'economic' and the fact that fees are charged for the granting of the licences (to be assessed overall on a break-even basis) does not convert it into onc" (emphasis added). The opinion obviously overlooks that a regulatory and supervisory task, by definition, is not an economic activity, but an activity that is accessory to such an economic activity, as explained above. - A similar reasoning was, at least in theory, ventilated by the Competition Appeals Tribunal - Case 1006/2/1/01 "BetterCare Group Ltd v DGFT" [2002], CAT 7, but not accepted in casu. The CAT was faced with the question whether a Health and Social Services Trust is acting as an undertaking when purchasing social care (1.e, nursing home and residential care services) provided by BetterCare. Eventually, the CAT did not think so, paras. $175 \mathrm{ff}$. It recalled at paras. $169 \mathrm{ff}$, that "there is a sharp distinction between activities which are to be classified as 'economic' in character, and those where the State 'acts in the exercise of official authority' [referring to case Diego Cali]. The latter activities are outside the scope of the competition rules. This distinction is emphasised in the opinion of Advocate General Jacobs in Ambulanz Glöckner at paragraphs 71 to 81 [...] where he considers whether the refusal by a public authority of a licence to run a public ambulance service is an 'economic activity' or 'the exercise of official authority'. Mr Jacobs concludes that the refusal of such a licence is to be regarded as 'a typical administrative decision taken in the exercise of prerogatives conferred by law which are usually reserved for public authorities,' and cannot 'be assimilated to the offering of goods or services on given markets' (paragraph 76 of his opinion)." The CAT continues with a hypothetical 
The second observation concerns professional associations that act as gate keeper to a certain profession. A gate keeper is a body that has been granted compulsory powers to authorise or license persons who intend to exercise certain professional activities. Licensing and authorisation are activities that can be organised in two ways: on the one hand, they may be organised by the State with coercive powers even if delegated to an association or, on the other, on a voluntary basis as amongst business players for the standardisation of products or services in order to allow that the properties and quality thereof can be assessed by customers. In the latter instance no public authority is involved. Conversely, where the regulation and control of access to a profession is organised in a compulsory system, it resembles procedures 'typically' used by State authorities that subject individuals or companies to authorisation procedures.

One could therefore argue that a professional association is exercising typical prerogatives of the public authorities. However, this conclusion is only apparent. Where an association carries out, on behalf of the State, regulatory or supervisory powers, it is usually equipped with coercive powers in order to be able to enforce its authority. ${ }^{773}$ Thus, in a system of compulsory or semi-compulsory authorisation or licensing procedures, it is the exercise of the associated coercive powers that brings these procedures close to the exercise of public authority. ${ }^{774} \mathrm{~A}$ consideration that the substance of the regulated activity would be linked to a public interest is thus not relevant. The ensuing danger is that with the decision to attribute coercive powers to an association, a Member State would be in the position to deliberately ensure entities a waiver from the control of Article 81(1) EC - even where associations interfere with the competitive freedom of their members, their members' competitors, and the freedom of choice of consumers and customers. ${ }^{775}$ Such an approach would jeopardise the objective interpretation of the jurisdictional scope of Article 81(1) EC

illustration of the Advocate General's considerations for the medical sector: "To give an example in the context of the present case, the refusal by an HSS [Health Social Services] Board to register a [residential care] home under the [national Order] or the fixing by an HSS Board of the registration fees under that Order, would, it seems to us, be 'an exercise of official authority' falling outside the competition rules, tather than an 'economic activity'." It's not clear whether the CAT finally falls for the same inadvertence as the Law Lords.

773 As illustrated in Chapter 3.I.2.2.2., essential functions of public authority relate, first of all, to the idea of sovereignty. Sovereign authority expresses in prerogatives that are outside the general law, and that are privileges of official power, and that allow powers of coercion over citizens. See also AG Mayras in Case 2/74, Reyners, [1974], 664, defining under the free movement rules (Article 45 EC) "official authority" as "that which arises from the sovereignty and majesty of the State; for him who exercises it, it implies the power of enjoying the prerogatives outside the general law, privileges of official power and powers of coercion over citizens."

774 See Case C-364/92, SAT/ Eurocontrol, [1994], para. 24. One of the decisive grounds for the Court to find that Eurocontrol carries out tasks in the public interest typically connected with the exercise of public powers was that "Eurocontrol is vested with tights and powers of coercion which derogate from ordinary law and which affect users of air space." In Case C-343/95, Caliv SEPG, [1997], paras. 16 ff., the Court rather implicitly accepted that the powers relating to environmental protection are typically those of a public authority. - Case C-405/01, COMME, [2003], para. 42, refers to police powers and powers connected to the maintenance of safety, powers of investigation, cocrcion and punishment that go beyond the requirement merely to contribute to maintaining public safety by which any individual is bound: "Such duties constitute participation in the exercise of rights under powers conferred by public law for the purpose of safeguarding the general interests of the flag State." See also AG Jacobs in Case C-283/99, Commission v Italian (private security services), [2001], paras. 36, $39 \mathrm{ff}$., observing that private security guards are merely assisting the police and in that are not exercising greater powers than individuals, who, in particular, have powers to arrest suspected malefactors. Insofar as security is concerned the Court distinguishes surveillance and protection tasks carried out on the basis of relations governed by private law that do not involve powers of constraint, but could be exercised by any individual, which is called on to contribute to the maintenance of public security; Case C-114/97, Commission v Kingdom of Spain, [1998].

775 NB This consideration is not specific to activities of the liberal professions but applies to any sector. 
as explained in the previous chapter.

The conclusion to be drawn here thus is that the regulation of professional qualifications and the control of the capacity of practitioners to exercise certain activities are not intrinsically, i.e. by their nature and their aim, linked to essential functions of the State. A criterion focussing on the vesting with coercive powers is rather arbitrary and hence does not warrant a general exception ratione personae from the scope of Article 81(1) EC. To assess whether a professional body may be associated with the exercise of public authority a mote refined scrutiny is necessary, which differentiates between the regulatory and supervisory functions of a professional association.

\subsubsection{Regulatory powers of professional associations}

The Court in Wouters has considered to apply the case law created exception ratione personae concerning the exercise of public authority to the representative and regulatory activities of a professional association. ${ }^{776}$ In that case the professional body claimed that it would not qualify as an association of undertakings because it had to fulfil a statutory task in the public interest for which it was granted statutory powets, namely to exercise regulatory powers. Three intervening governments added to these arguments and emphasised that due to its task in the public interest the bat association would exercisc public authority. ${ }^{777}$ The interveners therewith aimed more specifically at the application of the line of case law undermining the universal application of competition law.

The Court did not accept the arguments invoked by the professional association and the intervening governments. On the merits the Court could not identify any circumstances that justified the recognition of public authority being exercised by the professional association in question. Instead, the Court upheld the general appreciation that self-regulatory measures are intended to regulate the economic activities of an association's members and are, thus, included in the ambit of competition law. ${ }^{778}$ To come to this conclusion it identified the relevant activity at hand to be a regulatory one. The general conclusion that may be drawn from this particular part of the Wouters case is that the exercise of self-regulatory functions are presumed not to involve powers of public authority, especially where the professional body exercises its regulatory functions in respect of economic activities of its members. ${ }^{779}$ This finding is not altered where State legislation formally entrusts an association with regulatory powers and the task of protecting the rights and interests of the members of the profession. ${ }^{780}$ Where national law appears to attach a public character to such a task, it "cannot a priori exclude [the] professional organisation from the scope of application of Article $[81 \mathrm{EC}]$, even where it performs its role of regulating the practice of the profession". 781

776 Case C-309/99, Wouters et al. v NOvA, [2002], paras. $56 \mathrm{ff}$. Sec also AG Colomer in Case C-345/02, Pearle BV and Others, [2004], paras. $67 \mathrm{f}$,, on the question whether, within the scope of EC State aid law, a trade association qualifies as a body linked to the State by either being integrated in the structure of the State or by exercising powers characteristically vested in a State. In that context AG Colomer considered the reasoning used by the Court in Wouters that is described here.

777 Intervening governments of Austria, Germany and Portugal, see paras. $51 \mathrm{ff}$. of the judgment in Wouters.

778 Paras. 58 and 63 f. of the judgment in Wouters.

779 Paras. $58 \mathrm{f}$. of the judgment in Wouters.

780 As is, for instance, foreseen in the Dutch notaries act for the national professional association, Article 61 WNA 1999.

781 Paras. 56-59 of the judgment in Wouters. With regard to medical practitioners sec Joined Cases C-180 to 
This conclusion of the Court is sound on account of the consideration that there are many forms of rule setting even between purely private parties without any intervention of public authority. The authority of such rules is created by their author and the parties that accept to obey these under the rule of law. Professional associations thus engage in private governance regimes and their regulation cannot be considered a priori to be a task of public authority. Such an assertion would incorrectly assume that rule making powers would necessatily and typically involve the exercise of public authority. In consequence, monopolising any regulatory activity would allow a professional body, with the support of State legislation, to deliberately withdraw self-regulatory rules from the control of competition law, thereby frustrating the effectiveness of EC law.

At this juncture it shall be recalled that the public interest task that the Court allows to result in an exception from the application of competition law has been restricted to typical powers of public authority and essential functions of a State. This testriction ensures that a Member State will not be in a position to withdraw an entity from the ambit of competition law through the grant of specific powers that the Member State itself defines as being of public authority. While it is appropriate to go about sensitive areas of social and economic life with approptiate caution, the type of reasoning undermining the universal application of competition law should not be used as an easy escape route for the jurisdictional determination of the addressee. The concept of association of undertaking should not be interpreted in a way to avoid the issue of justiciability of self-regulatory measures intervening in the market, just because the regulatory body has a hybrid status somewhere between the State and market actors. ${ }^{782}$

\subsubsection{Supervisory powers of professional associations}

The next question is whether supervisory and disciplinary activities are connected with the exercise of public authority. As such, any supervisory or disciplinary powers that relate to self-regulatory tules serve the implementation of the latter, and consequently follow their fate. ${ }^{783}$ Conversely, supervisory or disciplinary powers may be associated with the exercise of public authority, and thus fall outside the scope of Article 81(1) EC, where they meet the dual condition of fulfilling an essential function of the State and being the translation of typical powers of a public authority. ${ }^{784}$ This could be the case where a Member State entrusts a professional body with the control of professional behaviour that touches upon essential functions of the State. From a theoretical point of view it may be argued that the supervisory (and disciplinary) powers of a professional association might be vested with public authority if they were to ensure compliance with rules that the State authorities impose in the pursuit of a particular public interest, itself related to an essential function of the State for certain professional activities. Any activities taken to implement the supervisory powers may qualify

184/98, Pavlov, [2000], para. 86.

782 See Competition Appeals Tribunal - Case 1006/2/1/01 "BetterCare Group Ltd v DGFT" [2002], CAT 7, para. 265; Rodger B.J.,"The Competition Act 1998 and State Entities as Undertakings: promises to be an interesting debate", (2003), 5, 15; AG Poiares Maduro in Case C-205/03 P, FENIN II, [2006], para. 27, criticising the CFI on the same issue of determining the addressee in the particular field of social policy.

783 See also Case C-309/99, Wouters et al. $\nu$ NOvA, [2002], para. 63.

784 Sce also AG Jacobs in Joined Cases C-180-184/98, Pavlov, [2000], para. 173. AG Jacobs found that the surveillance that a pension fund carries out over insurance contracts, which its affiliated members conclude with private insurets, would be an activity that translates the exercise of public authority and in fact would compare to the activities in cases Eurocontrol and Cali. 
as decisions taken in the exercise of the State's sovereign authority where the supervisory powers may be presumed to relate to an essential function of the State and to be exercised on behalf of the State.

In testing the merit of this idea, it may be fruitful to draw inspiration from Article 13(1) of the data protection Directive 95/46/EC. Similarly to the idea tested here that article allows to restrict the jurisdictional scope of the Directive "when such a restriction constitutes a necessary measure to safeguard", amongst others, "a monitoring, inspection or tegulatory function connected, even occasionally, with the exercise of official authority" (it. f). ${ }^{785}$ In this instance the addressees of the article (i.e. Member States) may be excepted from their obligations under the Directive where the exercise of official authority is connected with, public security (lit. c), important economic or financial interests ${ }^{786}$ of a Member State or even the European Union ${ }^{787}$ (lit. e), or - most eminently for ptesent purposes - with the prevention, investigation, detection and prosecution of breaches of ethics for regulated professions (lit. e). In particular the last reference suggests that the control of breaches of professional ethics can be associated with official authotity. At the same time, and contrary to what has been conclude above in section 2.1.1., the directive insinuates that already the regulation of professional ethics would be inherently linked to the exercise of official authority.

However, also on the basis of the Directive itself, it is doubtful whether both conclusions may validly be drawn. Firstly, the word choice of 'ethics' implies that not any professional obligation imposed on practitioners can be linked to public authority. As explained earlier, regulating the professions is not as such an exercise of public authotity. Secondly, it is surprising that the article puts the prevention and prosecution of breaches of professional ethics on a level with criminal offences. Are breaches of, for instance, advertisement prohibitions to be compared to theft or fraud? The provision of the article should, therefore, be interpreted narrowly, namely to be limited to professional ethics that are related to one of the other grounds of official authority to which subparagraph (f) of the article refers, i.e. subparagraphs (c) and (e). This means that only those supervisory powers may be considered as part of essential functions of State that relate to public security and important economic or financial interests of a Member State or the European Union. While one has to be cautious with applying a method that draws on secondary legislation to interpret primary legislation, the point here is to give an illustration of what could constitute supervisory powers relating to essential functions of the State.

In summary, it must be doubtful whether the general control of abidance to professional regulation can be tegarded as typically connected with essential functions of the State. Consequently, under Article 81(1) EC it is not sufficient that a professional association demonstrates that, in exercising its supervisory activities, it pursues a public interest. ${ }^{788}$ It also

785 Directive 95/46/EC of 24 October 1995 on the protection of individuals with regard to the processing of personal data and on the free movement of such data

786 Including monetary, budgetary and taxation matters, Article 13(1)(c) of the data protection Directive.

${ }^{787}$ Despite the fact that the interest of the European Union transcends the borders of a State strictly speaking.

${ }^{788} \mathrm{It}$ is generally questionable whether services of public interest are necessarily linked with the exercise of public authority, see Chapter I.2.2. See also Case C-384/93, Alpine Invesiment, [1995], para. 44. The case concened the prohibition of what is called cold calling methods, i.e. the contacting of individuals by telephone without their prior consent in writing in order to offer services to them. The Court held that maintaining the good reputation of the financial sector of the Member State to be an imperative reason of public interest capable of justifying restrictions on the freedom to provide financial services. In determining the public interests recognised to justify restrictions in the field of the fundamental freedoms the Court allows Member States a large margin of 
needs to establish that it exercises a genuine public authority function. Two observations need to be made in this regard. First of all, the particular role of an association in the exercise of an identified public interest task has to be examined case by case to verify whether the nature, the aim and the rules to which its supervisory activity is subjected justifies an exception from the application of the competition rules ratione personae. This will not be an obvious assignment as indicated by the discussion on Article 13 of Directive 95/46/EC. Secondly, while public health, public safety or, fot instance, the reputation of a professional sector ${ }^{789}$ may be of a distinct interest to the State authorities, not every supervisory activity related to those interests can be classified as one of typical State powers: to recognise that certain interests should warrant special protection in law does not stringently imply that these interests are of a nature that would typically be inseparable of public authority.

In spite of the general preparedness of the Court to extrapolate the case law outcompeting the universal applicability of competition law ${ }^{790}$, the conclusion at this point is that professional associations may hardly qualify, for any of their functions, as being entrusted with a public interest task that would be inherently linked to essential functions of the State. Both their regulatory and supervisory (including disciplinary) acts qualify as decisions of an association of undertakings within the meaning of Article 81(1) EC.

This assessment is endorsed by a further consideration that professional bodies themselves advocate, namely that professional bodies should remain independent vis-à-vis the public authorities and the public. ${ }^{791}$ Accordingly, the organisation of a profession by State rules is often pexceived as intruding the remit of the professions. At the same time professional associations nevertheless claim that they act in the public interest, and that they have the task to safeguarde, in particular, the in tegrity, impartiality and independence of the practitioners, the quality of professional services, and consumer protection. In my view, these considerations will not normally lead to equate certain functions of professional associations with the exercise of public authority to a degree that satisfies the requirements of the case law limiting the jurisdictional scope of Article 81(1) EC ratione personae. Moreover, the argumentation by the professional associations is inconsistent because they object to something to which they lay claim to for themselves. A different question is whether these considerations may, at a later stage of the competition law appraisal, contribute to justify the content of professional regulations. ${ }^{792}$

appreciation. It shall be stressed that the relevant public interests that may be taken aboard for justification purposes in the field of the fundamental freedoms are broader than the public interest tasks that may delimit the universal scope of application and may result in the exclusion of entities as addressees of the competition law rules. For details on justification possibilities on grounds of public interest considerations, see Chapter 7 , in particular sections 7.I.2.3. and 7.1.2.5.

789 See Case C-67/96, Albany, [1999].

790 Sec paras. $56 \mathrm{ff}$. Of the judgment in Wouters, with reference to cases Poucet and Pistre, Eurocontrol, and Diego Cali.

791 Sec Chapter 2.I. For the legal profession, sce for instance Council of Europe, Recommendation of the Committee of Ministers to Member States on the freedom of exercise of the profession of lanyer, of 25.10 .2000 , Principle IV(2): "Bar associations or other professional lawyers' association should be self-governing bodies, independent of the authorities and the public." - This standpoint is in sharp contrast to the stance taken by the UK regulator described below in section I.2.4., which in turn is criticised by the Law Society for the Government plans to modernise the profession, in particular to separate the representative and the regulatory functions of the professional associations for lawyers.

${ }_{792}$ For details on the justification grounds, i.e. Articles 81(3) and 86(2) EC, see Chapter 7. 


\subsection{Limiting the jurisdictional scope ratione personae II: professional associations subject to control by a public authority}

This section turns to a further yet different line of case law developing an exception ratione personae to the scope of application of Article 81(1) EC. This specific body of case law covers committees that are involved in the process of adopting rules, alongside the competent public authorities, to regulate certain aspects of various sectors of the economy. While there is an undeniable affinity with the case law discussed in the previous section, the respective reference points are different. Earlier the reference point was the public authority that an association of undertakings possibly would exercise over its members. Here the starting point is the control that an association itself may be subjected to by public authorities. The subjacent issue underlying the case law discussed here is whether a body that neither is part of the public administration ${ }^{793}$ nor exercises public authority can evade its responsibility under Article 81(1) EC due to the role it takes in the rule-making process of sectoral regulation influencing market conduct of undertakings.

On several occasions the Court felt the need to scrutinise whether self-regulatory bodies and committees that in some way contribute in the rule-setting process of the government are truly the representatives of the undertakings involved or whether they rather are representatives of the public interest. Similarly to the rationale of the case law discussed in the previous section and in Chapter 3.I.2.2., the idea reflected in this case law is that private interest driven acts ought to be subject to competition law analysis, whereas public interest driven acts are assumed to be in the realm of the States and their authotities ${ }^{794}$ - which as such are no addressees of competition law. ${ }^{795}$

In order to tell public governance apart from private governance the case law developed two criteria as televant public interest safeguards. They require national legislation to foresee "procedural arrangements and substantive requirements capable of ensuring, with reasonable probability, that [a self-regulatory body] conducts itself like an arm of the State working in the public interest." ${ }^{\text {796 }}$ The first condition of procedural atrangements translates as a structural one that bears on the composition of and appointment to the govetning bodies of a collective entity. The second, i.e. 'substantive' requirement concerns the interests that a collective body takes account of in the exercise of its self-regulatory powers. Accordingly, a body does not qualify as an association of undertakings within the meaning of Article 81(1) EC where, first of all, it is composed of a majority of representatives of the public authorities or of independent experts appointed by the public authorities and, secondly, it is required

793 In Case C-2/91, Meng, [1993], paras. $12 \mathrm{f}$., the Court considered that the regulatory body in question was an administrative authority under the auspices of the competent minister. The Court, therefore, had not regarded the responsible body to qualify as an association of undertakings: "It can be inferred from the instruments governing the Supervision Office and the powers vested in it that those measures constitute State rules."

794 See Case C-185/91, Reiff, [1993], paras. 17-19 (on road haulage); Case C-153/93, Delta, [1994], paras. 16-18 (on waterway traffic); Casc C-96/94, Spediporto, [1995], paras. 23-25 (on road haulage); Case C-35/96, Commission vItalian Republic (CNSD II), [1998], paras. 41-44; joint Joined Cases C-180 to 184/98, Pavlov, [2000], para. 87. AG Alber in Case C-38/97, Autotrasporti Librandi, [1998], paras. 37-40; Case C-35/99, Manuele. Arduino, [2002], para. 37; A G Léger in Case C-35/99, Manuele Arduino, [2002], 53 ff.; A G Léger in Case C-309/99, Wouters et al vNOvA, [2002], para. 70. See however the carlier case law, Case 123/83, BNIC v Clair, [1985], paras. 18-20.

795 Schepel H., (2002), 36, speaks of "a cloak of official status" that renders private behaviour unobjectionable, i.e. not justiciable, in competition law terms. On the 'indirect' application of Articles 81 and $82 \mathrm{EC}$ to State measures, i.e. in conjunction with Articles $3(1)(\mathrm{g}), 10(2) \mathrm{EC}$, but also Articles 4 and $98 \mathrm{EC}$, see Chapter 6.

796 Case C-35/99, Manuele Arduino, [2002], para. 39. 
by national legislation to observe various public-interest criteria when taking its decisions. ${ }^{797}$ While the case law applies these public interest safeguards cumulatively ${ }^{798}$, they shall be scrutinised separately in the following two sections before the case law will be compared to the first case law created exception ratione personae in section 2.3.

\subsubsection{Composition of self-regulatory bodies}

At this juncture it shall be recapitulated that associations grouping or representing economic operators are assumed to act in the private or economic interest of their members. However, according to the case law this assumption of directly or immediately representing the interests of economic operators in a specific sector may be rebutted where the bodies actually taking decisions within the meaning of Article 81(1) EC are composed of members who may be presumed not to act in the private interest of (individual) economic operators, but to act in the public interest. In fact, decisions by an association of undertakings can be adopted through various different bodies. These can be the governing bodies of an association, i.e. the organs assuming competence to take decisions that the outside world can apprehend. Governing bodies may take the shape of executive boards, supervisory organs or a general assembly. Decisions can also be taken by committees that are established by national measures, or any other organised group that is linked to an interested collectivity.

The assumption of representing private interests can be rebutted, the Court has held, where the majority of the committee members are independent from group interests. This means that they have to be either "independent experts" or "representatives of the public authorities". Independent experts are those members of a committees (e.g. a tariff committee) who are not bound by orders or instructions from the undertakings or associations that proposed these members. They are not regarded as representatives of undertakings in the sector in question. ${ }^{799}$ The Court equally presumes governing bodies or committees not to represent the interest of the undertakings in the sector where they are composed, at least in majority, of reptesentatives of the public authorities. This is the case where their members are either public officials ${ }^{800}$ or where they have been appointed by the public authorities. ${ }^{801}$

In the past the Court has insisted on the idealised point of view that committees composed of 'independent experts' would not act in the truly private or economic interest of the sector. ${ }^{802}$ The same idealised presumption applies for committee members who, in spite of being members of the sector concerned, are appointed by the public authorities, tegardless whether they have been proposed by the relevant professional association. ${ }^{803}$ Where the majority of the body's members are such 'independent' reptesentatives appointed

797 See the case law in note 794 . The cases that concern professional associations specifically are summarised in Chapter 2.V.

798 This becomes apparent for instance from Case C-35/99, Manuele Arduino, [2002], para. 37.

799 Case C-185/91, Reiff, [1993], paras. 17, 24, concerning tariff experts in the relevant branches of the long-distance haulage industry, chosen by the Federal Minister of Transport from among the persons suggested to him by the undertakings or associations in the sector concerned; Case C-153/93, Delta, [1994], paras. 16, 18; Joined Cases C-140-142/94, DIP, [1995], paras. $18 \mathrm{f}$.

${ }_{800}$ Case C-96/94, Spediporlo, [1995], para. 23.

801 Sec Case C-185/91, Reiff, [1993], para. 22; Case C-153/93, Delta, [1994], para. 18; Case C-250/03, Mauri, [2005], paras. 32, 34 .

802 See Schepel H., (2002), 44.

803 See Case C-153/93, Delta, [1994], para. 18. 
by the public authorities the Court is willing to recognise that a decision taken by the body should not be justiciable under competition law.

Unfortunately, the case law of the Court proves that the two aspects of independent experts and an appointment by the public authorities are not strictly applied in a congruent manner. Even for bodies composed of members of the sector concerned and not appointed by the public authorities the Court has recognised their 'independence'. For instance, in DIP the Court has been confiding that 'the members appointed or nominated by traders" organizations are present as experts on distribution problems and not in order to reptesent their own business interests" ${ }^{804}$ This conclusion of the Court drew its inspiration from the domestic law, which expressly indicated this stance of the committee's members.

At this point the Court effectively assumes that the representatives of a certain sector wear different hats, which - as a matter of procedural arrangements - they could easily change at the entry to the committee meeting. The foundation for this credit is doubtful. As Advocate General Jacobs rightly pointed out "it can be presumed that private economic actors normally act in their own and not in the public interest when they conclude agreements between themselves. Thus, the consequences of their agreements are not necessarily in the public interest. Competition authorities should therefore be able to scrutinise private actors' agreements even in special areas of the economy." consents to the opinion of Advocate General Jacobs. Procedural requitements on the composition of a committee wartant no more than the assumption that the members will act according to their background. If their background stems from the interested sector common sense suggests as fairly probable that their decisions are coloured by the group's interests. ${ }^{806}$ Common sense also suggests that neither the appointment by the public authority nor the changing of the hat can remedy the connection with the sector in the sense of effective checks and balances. Consequently, excluding the applicability of competition law ratione personae to self-regulatory bodies composed of membets of the sector concerned curtails the effet util of competition law as it excludes the justiciability of their actions under the substantive competition law analysis. 'The Court's assumption thus proves to be nothing but an idealised point of view.

The Court has not always defended such little realistic view point. In the 1980s the Court in BNIC $\nu$ Clair took the position that, despite their appointment by the public authorities, the committee members in question had to be regarded as in fact representing the economic operators in the negotiation, conclusion and adoption of agreements or decisions. The decisive point was that the committee members were proposed for appointment by the trade

804 Joined Cases C-140-142/94, DIP, [1995], para. 18 (emphasis added). One has to concede, however, that the members appointed by the sectors were in a minority on the municipal committees, "side by side with workers' representatives, representatives of public authorities and experts appointed by the latter". The municipal committees had a consultative function in issuing or trading licences for the opening of new shops in Italy. 805 AG Jacobs in Case C-67/96, Joined Cases C-115/97, C-116/97 and C-117/97 and Case C-219/97, Albany/Brentjens'/Drijvende Bokken, [1999], para. 184. The particular circumstance of that case concerned the question of a sector specific exception from the scope of Article 81(1) EC for collective negotiations between employers and employees. AG Jacobs stresses that the Treaty "contains only a very limited number of sectoral exceptions to the applicability of the competition rules based solely on the subject-matter of the agreement [...] the Court should continue to construe those exceptions narrowly." It should be noted that he discusses the issue as a limitation to the scope ratione materiae rather than ratione personae due to the fact that the EC Treaty particular encourages the conclusion of collective agreements between management and labour in Articles $117 \mathrm{ff}$. EC. 806 See Case C-35/96, Commission v Italian Republic (CNSD II), [1998], para. 41. 
organisations directly concerned. ${ }^{807}$ The subsequent case law explained above seems to contradict this finding. However, the subsequent case law can be assessed as inconsistent with regard to the yardstick it applies since it ptesented the composition requirement as a self-contained test. The meaning of the composition requirement has finally been clatified in the case Autotrasporti Librandi. In that case the Court emphasised that the composition of self-regulatory bodies, taken as such, is only an indication to consider the immunity of the collective body. The case constituted the sequel to Spediporto. ${ }^{808}$ The Italian legislation regulating tariffs for road haulage initially provided for a majority of representatives of the public authorities and a minority of the representatives of associations of economic agents. A few years later the law was changed to reverse the proportion to the detriment of the public authority representatives. This could not unnerve the Court who found that "the change in the majority-minority relationship within the central committee does not warrant the conclusion that a restrictive agreement ${ }^{809}$ within the meaning of Article [81 EC] exists when, under the national legislation in question, the central committee must continue to observe, in adopting its proposals, the public-interest criteria defined by the Italian Law." Thereby the Court refers to the second safeguard it developed to wartant public interest considerations (which will be turned to shortly below). Since Librandi it is clear that the second public interest requirement, i.e. that a self-regulatory body has "to observe various public interest criteria", has a greater importance than the composition criterion to the extent that the second public interest related criterion is both necessary and sufficient to except a self-regulatory body from the competition law analysis. ${ }^{811}$

This does, however, not mean that the Court would have abandoned the composition requirement, which remains to have an indicative value for the determination of whether a body acts as an association of undertakings within the meaning of Article 81(1) $\mathrm{EC}^{812}$ or rather as an administrative authority. ${ }^{813}$ This seems to refer back to the functional approach on the concept of association of undertakings and thus implies that an administrative body may be engaging in an economic activity. ${ }^{814}$ The composition requirement in any event should not be overestimated in its 'probative force' to determine the addressee of the competition rules. The independence of members of a committee that is empowered to take decisions affecting the economic sphere cannot be build on assumptions made by the Court in the case law prior to Librandi. Such assumptions would allow a Member State to withdraw self-regulatory measures from the application of competition law, regardless of whether they have the same effects as cartels (e.g. tariff schemes restricting price competition). ${ }^{815}$ That

807 Case 123/83, BNIC v Clair, [1985], para. 19.

${ }^{808}$ Case C-96/94, Spediporto, [1995].

${ }^{809}$ NB The fact that the Court referred to the term of restrictive agreements between economic agents when considering the proposals of the committee in question shall not detract from the fact that the case could have been tested with regard to the concept of decision of association. The point proves that the distinction between agreement and decision depends very much on the facts of a case and, as has been explained above in section I.1.2.3., results above all in practical differences.

810 Case C-38/97, Autotrasporti Librandi, [1998], para. 34.

811 Schepel H., (2002), 45 f.; Lenk J., (2006), 89.

${ }^{812}$ See Case C-35/96, Commission v Italian Republic (CNSD II), [1998]; Case C-35/99, Manuele Arduino, [2002], paras. $38 \mathrm{f}$.

${ }_{813}$ See Case C-2/91, Meng, [1993], para. 14; Case C-250/03, Mauri, [2005], para. 32.

814 See also AG Cosmas in Case C-35/96, Commission v Italian Republic (CNSD II), [1998], paras. $51 \mathrm{f}$.

815 See Schepel H., (2002), $44 \mathrm{f}$. He points out that the composition requirement should not be understood as a conditio sine qua non, since an immunity on the ground of a majority of representatives of public authorities would be inconsistent and conceptually flawed because it would "come suspiciously close to hiding a State action 
would clearly contravene the idea that the addressees of EC competition law are determined objectively and independently of national conceptions.

The question remains whether the second public interest related criterion ('substantive requirements $\left.{ }^{816}\right)$ is an effective means to dissociate self-regulatory bodies from private governance and assure that they act like an arm of the State working in the public interest.

\subsubsection{Obligation to observe public interest criteria}

The Court will be satisfied that a collective self-regulatory body does not act in the interest of its economically active members - and thus does not qualify as an association of undertakings - where national law requires the body to observe various public interest criteria when taking decisions affecting the economic sphere. ${ }^{817}$ However, not any public interest reference in the law will do as a survey of the case law evinces.

The first case in which the dual public interest criterion was formulated the Court found that the national legislation did not allow the committee in question, which was composed of representatives of the relevant sectors, to fix tariffs "solely by reference to the interests of undertakings or associations of undertakings engaged in transport". ${ }^{818}$ Moreover the Court emphasised that the national legislation required the members of the committee to take account of the interests also of other sectors that were affected by the tariffs so established. The Court therefore found it justified that the committee in question fell outside the jurisdictional scope of Article 81(1) $\mathrm{EC} .{ }^{819}$ In the cold light of day the stance evidenced in this case law is a deferential one as it merely allows for a formalistic control of whether a Member State has defined public interest safeguards in its laws, and seems to belie the Court's demand for 'substantive requirements'. The Court has rightly been criticised for this deferential approach. ${ }^{820}$

Subsequently, the obligation to observe various public interest motives as a criterion to limit the scope of Article 81(1) EC consolidated into a stricter testing by the Court. The case law started specifying that the relevant public interest criteria have to be defined in the law

doctrine in the definition of "association of undertakings'." On the State action defence sec Chapter 6.II.3. 816 Case C-35/99, Manuele Arduino, [2002], para. 39. See also Schepel H., (2002), 46: "the public majority argument is not qualitatively different from finding that a committee merely reflects a balance of interests". ${ }_{817}$ Joined Cases C-180 to 184/98, Pavlov, [2000], para. 87; Case C-96/94, Spediporto, [1995], paras. 23-25; Case C-35/96, Commission uItalian Republic (CNSD II), [1998], paras. 41-44; Case C-309/99, Wouters et ah vNOvA, [2002], para. 61; Case C-35/99, Manuele Arduino, [2002], 37ff. See also AG Jacobs in Case C-198/01, CIF ע AGCM, [2003], para. 70. See also Council of Europe, (2003), 92: "The independence of the Bars and their relationship with the public authorities".

818 Case C-185/91, Reiff, [1993], paras. $15 \mathrm{ff}$.

819 In particular, they had to take account of the interests of "the agricultural sector and of medium-sized undertakings or regions which are economically weak or have inadequate transport facilities", para. 18 of the Reiff judgment. The Court continued (para. 19): "It follows that, under a system for the fixing of road haulage tariffs like that introduced by the [national legislation], the members of the Tariff Boards, although chosen by the Federal Minister of Transport on a proposal from the trade organizations directly concermed, cannot be regarded as representatives of the latter, called on to negotiate and conclude an agreement on prices" (emphasis added). The reasoning was repeated shortly thereafter in Case C-153/93, Delta, [1994], para. 17, a case on a similar piece of German legislation on waterway traffic.

${ }_{820}$ Schepel H., (2002), 50, who emphasises that the norm developed in the case law "implies deference to public authorities which impoverishes the notion of the public interest and reduces the idea of democratic governance to formal structures of accountability and constitutional hierarchy. Moreover, by insisting on public power over the economy, it holds on to the territorial frame of State and market and has no way of addressing transnational governance regimes." 
and may be specified in derived legislation like decrees or bye-laws. ${ }^{821}$ In several more recent cases that concerned the (libetal) professions more specifically the stricter stance of the Court resulted in the finding that the respective national legislation did not satisfy the requirement of substantive public interest safeguards. First, in CNSD the Court simply diagnosed that "no rule in the national legislation in question [was] obliging, or even encouraging, the members of either the [national professional body or the departmental councils of the profession] to take into account public-interest criteria". ${ }^{222}$ In Wouters the Court similarly refused to limit the scope of competition law ratione personae for the Dutch lawyets association due to the lack of specific public interest criteria in the national legislation that the professional association would have to observe in the adoption of selfregulatory rules on the exercise of the profession. In this regard it was not enough that the association assumed its rule making powets on the basis of a statutory authotisation. Stronger than in CNSD the Court in Wouters was dissatisfied with the national law, since the latter did no more than require the self-regulatory regulations to "be in the interest of the proper practice of the profession". ${ }^{823}$ The Court thereby identified the proper practice of the profession as a category of interests it is not willing to accept as public interest criteria in order to delimit the scope of Article 81(1) EC ratione personae. ${ }^{824}$ Thus, while it may be conceded at this point that the proper practice of the profession may be in the broader interest of the public and the consumers, in particular to guarantee the integrity, independence, competence, professional secrecy and responsibility of the profession, and to avoid conflicts of interests, these considerations are not of a quality that can justify an exception to the universal applicability of EC competition law.

Also in Arduino the Court held that the relevant national legislation did "not lay down public-interest criteria, properly so-called". ${ }^{225}$ It was dissatisfied with the criteria that the Italian legislation specified, and explicitly rejected the criteria within the margin of which the Bar association was obliged to propose minimum and maximum tariffs. That margin concerned the monetaty value of disputes, the level of the court seized and, in criminal matters, the duration of the proceedings. In tejecting that the national legislation would have determined public interest considerations to a sufficient extent, the Court showed itself willing to apply a high standard before it would find that an association of undertakings and its acts ate withdrawn from the competition law analysis at the eatly stage of testing their status as addressee of Article 81(1) EC. ${ }^{826}$ Since the same Italian legislation formed the basis

${ }^{821}$ Case C-96/94, Spediporto, [1995], para. 24; Case C-35/96, Commission vItalian Republic (CNSD II), [1998], paras. 41-44, esp. 43; Case C-38/97, AutotrasportiLibrandi, [1998], para. 34; Joined Cases C-180 to 184/98, Pavlov, [2000], para. 87; Case C-35/99, Manuele Arduino, [2002], paras. 37 ff.; Case C-309/99, Wouters et al. $v$ NOvA, [2002], para. 62.

822 Case C-35/96, Commission v Italian Republic (CNSD II), [1998], para. 43. See also Case C-198/01, CIF v $A G C M$, [2003], para. 77: "nothing in the relevant national legislation prevents [them] from acting exclusively in their own interests".

${ }^{823}$ Para. 62 of the judgment in Wouters.

${ }^{824}$ Later in the judgment the Court returned to the "proper practice of the profession" (paras. 97, 105), however not to construe an exception eo ipso from the jurisdictional scope of Article 81(1) EC, but to acknowledge the possibility for an exemption from the prohibition contained in Article 81 (1) EC, taking the proper practice of the profession to bear some aspects similar to public interest considerations. This important differentiation flowing from the judgment is discussed more fully below in section II.4. and in Chapter 7.I.2.5.3. See also Tettinger P.J., (1997), 132 ff.; Commission Decision EPI Code of Conduct, (1999), paras. 34, 38.

${ }_{225}$ Case C-35/99, Manuele Arduino, [2002], pata. 38.

826 The main question of the preliminary ruling in Arduino was about the responsibility of the State for any anticompetitive effects of the tariff fixing scheme. The Court finally found that Italy had not divested "its own tules 
for the decision in Cipolla and Macrino the Court only briefly referred to the same conclusion it had taken in Arduino. ${ }^{827}$

Further below in section 2.4. follows a brief survey of a number of liberal professions in several Member States to investigate whether existing legislation meets the standards that the case law discussed in this section requires. What is already clear at this stage is that selfregulatory activities by professional associations, even where mandated by the legislator, are justiciable under competition law if national legislation does not strictly stipulate specific public interest requirements beyond the interests of the regulated sector. The case law rightly formulates this requirement as an obligation ("must"). Consequently it is for the parliamentary legislator to explicitly specify the relevant public interest criteria. As is apparent from the case law, the determination and interpretation of such interests cannot be left to the professional associations themselves ${ }^{228}$, as that would be setting the fox to keep the geese. Thus, the mere fact that a professional body aspires to act in the public interest, even without being required to do so by law, does not dissociate it from private governance and therefore does not disqualify it as an association of undertakings within the meaning of Article 81(1) EC.

Two conclusions can be made at this stage. First of all, the eligible public interests must be determined outside the sphere of the self-regulated sector. This means that a regulatory body, first, must not take account of the interests of its member undertakings and, second, is obliged to also take account of the public interest and the interests of undertakings in other sectors or users of the services in question. The fact that a professional association or its members assume a task in the public interest that is related to the exercise of the profession (integrity etc.) will not justify to declassify the professional body as addressee of Article 81(1) EC. Notwithstanding, the point may be taken aboard at a later stage of the competition law scrutiny, which involves a substantive assessment of a case and allows to consider reasons whether to justify immunity from the competition prohibition clause. ${ }^{829}$ Secondly, the relevant public interests must be determined by the (national) legislative. ${ }^{830}$ Such statutory determination has to be in explicit terms. A general reference in the law to 'the general interest' will not do since the Court requires national legislation to foresee procedural arrangements and substantive tequirements capable of ensuring, with reasonable probability, that a self-tegulatory body conducts itself like an atm of the State working in the public interest. ${ }^{831}$ This means that the national legislator is required to provide for an effective ex ante public interest control. It is then for the national courts to determine

of the character of legislation by delegating to private economic operators responsibility for taking decisions affecting the economic sphere", and thus gave an overall negative answer to the question of whether EC competition law had been infringed in that particular case. For details see Chapter 6 .

827 Joined Cases C-94/04 and C-202/04, Cipolla and Macrino, [2006], para. 49. Like in Arduino the main question in this case was on the responsibility of the State for any anti-competitive effect of the professional rules in question.

${ }_{828}$ See Case C-309/99, Wouters et al. עNOvA, [2002], para.62. See also BVerfG - [1987], BVeffGE 76, 171; and BVerfG - [1987], BVerfGE 76, 196, where the German Constitutional Court stated that the parliamentary legislator must define the essential standards of professional regulation and may not leave this task to professional bodies (Parlamentsvorbebalt). The two decisions are presented in Chapter 7.1.2.5.3.2.

${ }^{829}$ The same is true for the case law created exception ratione personae on the exercise of public authority by private parties discussed above in section I.2.1. and in Chapter 3.I.2.2. For details see Chapter 7, and in particular on Article 86(2) EC. See also AG Léger in Case C-309/99, Wouters et al. $\nu N O v A$, [2002], paras. 56 and 79 f.; Case 123/83, BNIC V Clair, [1985], paras. 16 E.

830 See also Ogus A., (1994), 111, on accountability of regulators.

${ }^{831}$ Case C-35/99, Manuele Arduino, [2002], para. 39. 
whether the public interest criteria defined in the national legislation are observed in practice. $^{832}$

\subsection{Preliminary conclusions on the scope ratione personae: two lines of case law compared}

The combination in the case law of the public interest criteria and the composition requirement in order to exclude representative bodies of economic actors from the ambit of Article 81(1) EC ratione personae can be understood as a twin sister to the first case law created exception ratione personae on the exercise of public authority discussed previously. The rationale for both exceptions are in fact similar. In both instances the State is assumed to take decisive influence in controlling the activities of a self-regulatory body intervening in the market with binding measures that are - supposedly - intended to serve the general interest.

With regard to the first case law created exception ratione personae on the exercise of public authority by addressees of competition law the Court has not laid down standatds for the control on the activities of the entities involved. While this seems to be due to the subject matter of the exception, its approach as represented in particulat in $S A T /$ Eurocontrol and Cali is not shared in this book. ${ }^{833}$ Generally speaking, the exercise of public authority is the translation of essential functions of the State and therefore is immune from the competition law control. The Court proves unwilling to interfere with the sovereignty of the Member States in this regard and implicitly accepts that it needs to leave the matter to the domestic constitutional control mechanisms chatged to guarantee the accountability of selfregulatory bodies at national level. Rather the Court confines itself to identify whether an activity is to be associated with typical functions of the State.

It appears from the scrutiny of this first exception ratione personae that the reference to 'typical' functions undermines the autonomous character of the Community concepts of undertaking and association. Yet the Court will not accept any claim by a professional association or a Member State that a particular activity would be essential to State functions. So far the argument has been tried only once - unsuccessfully - in respect of a selfregulatory association. In Wouters the Court emphasised that its distegard for the public law status of a professional association under national law does not contradict the principle of institutional autonomy. ${ }^{834}$ Moreover, only where a Member State "is careful to define the public-interest criteria and the essential principles with which [the association's] rules must comply and also retains its power to adopt decisions in the last resort", ate the professional tegulations in question "not covered by the Treaty rules applicable to undertakings" because "in that case the rules adopted by the professional association temain State measures". Otherwise, the regulations set by a professional body remain attributable to it alone. "The fact that the two systems [of self-regulation and State regulation] [...] produce different

\footnotetext{
832 Case C-38/97, Autotrasporti Librandi, [1998], para. 45.

${ }_{833}$ The particular case law has been fundamentally criticised in Chapter 3.1.2.2.3. and 3.I.2.2.5.

834 See Case C-309/99, Wouters et al. vNOvA, [2002], paras. 54 f., 67. The German Government had argued that it is for the competent legislative bodies of a Member State to decide, within the framework of national sovereignty, how they organise the exercise of their tights and powers. Delegation of the power to adopt universally binding nules to a body possessing democratic legitimacy, such as a professional body, would fall within the limits of that principle of institutional autonomy. The argument continues that if bodies entrusted with such regulatory duties were to be treated as associations of undertakings within the meaning of Article $81 \mathrm{EC}$, this would frustrate the operation of that principle.

${ }^{835}$ Paras. $67 \mathrm{ff}$. of the judgment in Wouters (emphasis added).
} 
results with respect to [the applicability of] Community [competition] law in no way circumscribes the freedom of the Member States to choose one in preference to the other. ${ }^{2836}$

The issue therewith addressed by the Court is similar to the motive of the second case law created exception ratione personae, namely whether an entity acts as if it were (an atm of) a public authority within the respective remits. ${ }^{837}$ This second line of case law can be summarised as follows. In the event that an association is predominantly composed of private economic operators, and is not subject to an explicit public interest obligation, the assumption is that its regulations and decisions concern the economic conduct of its members and, consequently, that the body itself is an association of undertakings. This assumption may be reversed only by the dual fact that, first, the competent authorities retain the power to overrule the association's measures to adopt decisions in the last resort and, second, the competent authorities are advised by other organs representing the interests of all other concerned parties. While this further requirement of the case law may sound reasonable, it is susceptible to a more fundamental critique. The first point is that the requirement referring to the power to overrule the association's measures says something about the responsibility of the Member State for anti-competitive effects of professional regulations rather than about that of the associations. It should therefore not affect the qualification of the professional entity as association of undertakings. The powers of the Member State to set aside a decision of an association are separable in this respect. They are therefore considered further below in Chapter 6, which deals with the responsibility of Member States for regulations that produce an effect that the competition rules aim to suppress. Suffice it to say here that the issue of whether the competent public authorities effectively assume their responsibility in the rule-making process of self-regulatory measures by exercising effective control is one that the Court leaves to the discretion of the Member State. ${ }^{838}$ While the joined cases Cipolla and Macrino had provided the Court the opportunity to remedy this 'security gap' in concurrence with the opinion of Advocate General Poiares Maduro, the Court did not grasp the occasion and instead reinforced Arduino, at least on the point discussed at this juncture. ${ }^{839}$

Overall the caution of the Court to recognise the involvement of private parties in the process of sector specific rule-making can be understood as the willingness of the Court not to interfere with the reasons why Member States involve interest groups or 'experts' ${ }^{840}$ To the extent to which the Court continues to adhere to the composition criterion ${ }^{841}$ the accountability of self-tegulatory bodies lies with the public authorities who, the Court seems to trust, cannot be tempted to represent the private interest of individual operators. ${ }^{842}$ 'The Court's deferential attitude in this regard appears from the effect that the Court grants professionals to be experts in their fields, which makes them in the view point of the Court 'independent experts' who cannot be biased by their professional background. However, whether someone is independent is a personal or subjective quality the presence of which

\footnotetext{
836 See para. 70 of the judgment in Wouters.

837 Casc C-35/99, Manuele Arduino, [2002], para. 39.

838 See only Case C-35/99, Manuele Arduino, [2002].

839 The case will be further discussed in Chapter 6 .

840 Schepel H., (2002), 44. See also Neergaard U.B., (1998), 100 f.; Fenger N. / Broberg M.P., (1995).

841 See above page 168.

842 Schepel H., (2002), 49 and 44 f.: "To insist on a public majority would constitute a conceptual flaw. Granting immunity to regulatory bodies on the grounds that it consists in majority of representatives of public authorities comes suspiciously close to hiding a State action doctrine in the definition of "association of undertakings'."
} 
can hardly be inferred from the function a person holds. The independent exercise of regulatory powers can conclusively be safeguarded best by imposing an obligation to apply and observe objective criteria in the rule making process, regardless of a person's capacity as an expert of the sector. The advantage thereof would be that such objective criteria are susceptible to judicial review. The problematic point with the Court's case law on the composition criterion is that an affirmation of someone being an 'independent expert' obscures what in reality is a simple negative testing: whether the self-regulatory committee is not composed of biased experts. Identified as a negative test the composition criterion emerges as the lowest standard possible.

The Court's deferential attitude with regard to the observance of public interest criteria manifests itself in two regards. First of all, the Court does not interfere with determining the kinds of interests that a Member State considers to be in the general or public interest. While as such this diagnosis may not be astonishing, it becomes remarkablc where it results in limiting the jurisdictional scope of Article 81(1) EC. Since the concept of association of undertakings is a Community concept it should be assessed autonomously, i.e. independently of parameters defined by the Member States. This means that if we have to accept public interest considerations to justify an ipso facto immunity of self-regulatory bodies from the applicability of competition law, the Court should provide objective parameters to determine relevant public interests. In this respect the critique expressed here matches the one uttered in Chapter 3.I.2.2.3. It needs to be stressed again that the question whether nationally defined public interest criteria have a legitimate impact on the competition law analysis is a question on justification grounds arising at a later stage of the scrutiny. ${ }^{843}$

Notwithstanding, the Court had to explain what it meant by its frequent reference to the public or general interest and in Arduino it seemed that the Court went a step further to strengthen the public interest standard that self-regulatory bodies may be required to take into account. There the Court effectively engaged in scrutinising whether the public interest considerations written into the national law were acceptable in order to justify an ipso facto immunity of self-regulatory bodies from the application of competition law. ${ }^{844}$ Such scrutiny helps to ensure that a certain level of standard is put in place, and that the competent national competition authorities and/ or courts thus have a yardstick to control selfregulatory bodies and their measures. However, whether professional associations effectively satisfy the advanced public interest considerations when taking decisions is a question that the Court leaves to the control of the competent public authorities.

What emerges as a second point of critique in terms of the deferential attitude by the Court is that it does not intend to challenge the effectiveness of the public interest safeguards put in place by the national legislation, but only tests whether "the interests of the collectivity had to prevail over the private interests of individual operators". 845 Unlike the clear procedural composition requirement the 'substantive' condition is more difficult for the courts and competition authorities to verify. While an explicit fixing of the public interests that self-regulatory instances have to observe can be reconstructed in the investigator's or judge's mind, she may hesitate whether the interests listed in the law are such as to prevent the application of Article 81(1) EC. At this stage it is clear that the eligible public interest considerations must lie outside the interests of the regulated sector itself.

843 For details see Chapter 7.

844 It finally came to a negative answer; the Court held that the national law "does not lay down public-interest criteria, properly so-called", Case C-35/99, Manuele Arduino, [2002], para. 38 (emphasis added).

${ }_{845}$ Case C-38/97, Autotrasporti Librandi, [1998], para. 40. 
However, at times the Court seems to be uneasy about whether to verify the 'legitimacy' of a particular public interest. In Librandi and Spediporto the Court granted the Member State a broad margin of appreciation in this regard. ${ }^{846}$ Both cases concerned the criteria or parameters that the self-regulatory body should have taken into account when proposing tariffs. The Court was satisfied with criteria that the national legislature described as being in the public interest and did not verify whether they indeed were. In the more recent case Arduino the Coutt took a different stance in respect of a similarly formulated provision of the Italian law. This time the Court was willing to have a closer look at the requirements that self-regulatory bodies are obliged by the national legislation to take in to account when proposing tatiff schemes. Yet the Court did not demonstrate how to conduct a substantive scrutiny of whether 'valid' public interest considerations had been effectively safeguarded by self-regulatory bodies. This effect is due to the initial deferential attitude of the Court in Librandi and Spediporto. Furthermore, it is due to the weak formulations in the national rules that the Court had the occasion to scrutinise in CNSD, Wouters, Arduino, Cipolla and Macrino.

The Court's deferential stance is regrettable in view of the effet util of the competition law prohibition. It would be more satisfying if the Court clearly required professional associations and/ or the Member State (if involved in professional rule making ${ }^{847}$ ) to demonstrate that the relevant public interests have been effectively safeguatded through, for instance the actual consultation of all parties potentially affected by the envisaged professional rule. Only a meaningful participation of all parties (i.e. not only the members of a sector but also their competitors, customers, tepresentatives of public interest and consumers) will ensure that all opinions have been voiced in order to wartant a fair degree of probability that all interests will be taken in to due account. ${ }^{848}$ The aim of such a procedure is to prevent the enhancement of lopsided interests, and thus to allow an equality of arms between the various parties concerned. At this point it shall be acknowledge that a structural participation of the concerned parties must also breed ambivalent effects as it asks for an institutionalised lobbying with public authorities. This observation calls for two comments. First of all, the effect of institutionalised lobbying already takes place today, albeit only by those parties that manage to claim sufficient political support in order to voice and bring to bear their interests. Secondly, the confrontation with the issue of creating a structural platform for lobbied interests may be the stepping stone to a candid discussion of whether institutionalised lobbying is at all a legitimate way of participating in power in modern constitutional States. ${ }^{849}$

It emerges that the case law so far provides only weak if not inadequate standards to verify whether professional self-regulation effectively is subject to (national) public interest requirements that would justify their exception from the competition law scrutiny, despite

846 Case C-38/97, AutotrasportiLibrandi, [1998], paras. 30, 35 and 13, and Case C-96/94, Spediporto, [1995], paras. 24,27 and 11.

847 For details see Chapter 7.

${ }_{848}$ Schepel H., (2002), 50.

${ }_{849}$ See Evans L., et al., (2006), 10, quoted in Chapter 2.II. See also the note in Chapter 7.I.2.5.3.2. on the (voluntary) lobbyist register launched by the Commission in June 2008. See also the critique formulated in Chapter 3.I.2.2.2.3. where the merit of the public choice theory is undetlined, namely to point out that the interests involved in rule setting justify the general prediction that legislation will tend to favour professional and industrial groups more than those representing, for example, consumers or taxpayers, whose interests are much more diffuse; Posner R.A., (1974), referenced by Ogus A., (2006), 18. 'Tn short there is a 'market' for legislation in which, like any other market, trade takes place on the basis of supply and demand", Ogus A., (2006), $17 \mathrm{f}$,, in referring to Stigler G.J., (1971). 
the fact that they are capable and intended to influence the market conduct of the members of the professions. ${ }^{850}$ Not least due to its Community character the jurisdictional scope of Article 81(1) EC should not be conceived and interpteted in a way that allows for the opportunity to make strategic use of the organisation of a sector so as to effectively grant sector-specific exceptions ratione personae not recognised in the Treaty. ${ }^{851}$ The present study shares the critique that the relevant decisions of the Court are without theoretical basis or legal definition. ${ }^{852}$ As matters stand as a result of the case law it looks as though it has to be accepted that under certain circumstances acts of self-tegulatory bodies are not justiciable under competition law despite their influence on matket conduct of professional service providers. In order to mitigate the negative effects for the applicability of Article 81(1) EC the opinion adopted here is that the Court should impose an additional requirement that guarantees effective democratic or parliamentary control of the regulatory powers assumed by professional associations. To the extent that the case law associates self-regulatory bodies with the remit of public governance, it is justified to subject those bodies to effective democtatic control as is any other public authority in the exercise of its powers. ${ }^{853}$ This does not trespass on the Member State's responsibility to assure compliance with national statutory safeguards, but allows a comprehensive control of self-regulatory activities that influence market conduct of professional service providers. ${ }^{854}$ In this regard competition law scrutiny may provide a complementary control mechanism of a constitutional character at European and national level.

The following section will look at a number of national systems of organising particular professions in a double tracked system of State regulation and self-regulation by the sector in order to test to which extent they qualify to come within the ambit of Article 81(1) EC.

850 See also AG Poiares Maduro in Cases C-94/04 and C-202/04, Cipolla and Macrino, [2006], para. 35.

${ }_{851}$ See AG Jacobs in Case C-67/96, Joined Cases C-115/97, C-116/97 and C-117/97 and Case C-219/97, Albany/Brentjens'/Drijvende Bokken, [1999], paras. 184 ff.

852 Leroy C., (2001), $59 \mathrm{ff}$. I do, however, not assent fully to the viewpoint of Leroy for the following reasons. He claims that the Treaty (i.e. competition law?) should be revised to make the concept of public interest a pillar of EC law equivalent to competition law. It is true, however, that his article has certain advantages, namely to point out the vagueness with which the Court uses the term public/ general interest as a tool to interpret the law without explaining the theoretical basis or legal definition thereof. I for one have tried to explain a theoretical basis on which the Court conceivably draws on, but do not agree with the use that the Court makes thereof. I certainly do not think that the concept of public interest should be the means to limit what is exposed here as a mere jurisdictional issue, not allowing to say anything about the (substantive) value of the public interest involved in a particular case. For a refreshed categorisation of public interest considerations in regulation see Chapter 7.I.2.3. and diagram no.7.

853 See also Schepel H., (2002), 31 f.: "Globalization and the increased reliance on private governance regimes in modern regulation has led to an emerging consensus among public lawyers that traditional administrative law methods of determining the province of 'government' need to be reconsidered. Moreover, it seems by now widely accepted that the objective of regulatory law should be to infuse these private regimes with fundamental procedural notions of good governance rather than devise ways of locking them into the constitutional frame of political accountability. More radical analyses still hold that public law, however reconceptualized, is per definition State-centred and hierarchical and hence inadequate for the purpose of regulating transnational private law structures in order to 'constitutionalize' these self-regulatory arrangements. By analysing the way 'public' governance is separate from 'private' anti-competitive behaviour, this article sets out to argue that EC competition law can contribute in significant ways to democratically legitimate private regulation", with more references. He also refers to Aman A.C.J., (2005), who argues for the extension of scope of the Administrative Proccdure Act to private parties in order to ensure that global private governance regimes be subjected to the public law values of participation and due process.

${ }_{854}$ See also the case law of the German constitutional court illustrated in Chapter 7.I.2.5.3.2. 


\subsection{Particular professional sectors: the exception ratione personae II illustrated by national examples}

This section will illustrate, by means of a selected number of professional associations and their respective national legislative circumstances, the extent to which they are able to influence the market behaviour of their members, while being themselves subject to control by public authorities and/ or to obligations of public interest observance. It provides the opportunity to look into current developments in some Member States to modernise the liberal professions like the UK and the Netherlands. Since these developments do not follow a shared pattern across sectors or Member States, some of the illustrations will be more elaborate than others. ${ }^{855}$ Rather than a full survey of the regulatory realities in the Member States the intention is to give a few illustrations of my general themes elaborated before. In particulat the reference to disciplinary powers of professional associations will be used as a quick scan to determine the capacity of professional associations to take decisions of associations' within the meaning of Article 81(1) EC in light of the far-reaching consequences of such powers to influence market behaviour of professionals. As regards a possible exception ratione personae this section will focus on the application of the second line of case law on the composition criterion and the obligation to observe public interest criteria. The reason to proceed in this way is not so much that the first line of case law created an exception ratione personae concerning the exercise of public authority could not also be applied to associations of undertakings and their decisions (as some argue ${ }^{856}$ ), but because regulatory activities cannot be said to be typically or even necessarily connected with powers of a public authority. ${ }^{857}$ In the end it is for the professional associations to demonstrate that they do not only represent the (economic) in terests of their members but effectively are bound by public interest safeguards recognised in the case law.

\section{Examples from the legal sector}

The legal services sector in the UK, and more specifically in England and Wales, is recently undergoing remarkable tegulatory changes following an extensive assessment of its organisational and tegulatory structure. On 30 October 2007 the Legal Services Act was enacted by Royal Assent, and has partially come into force on $7 \mathrm{March} 2008{ }^{858}$ It sets out the framework for reforming the way legal services in England and Wales are regulated and puts the consumer interest at the heart of the regulatory framework. For present purposes the most interesting development of this reform is the setting up of a Legal Services Board, which will be charged to supervise professional bodies that assume tegulatory functions. The main sectoral professional bodies in England and Wales are currently the Law Society (representing solicitors), the Bar Council (representing barristers) and the Institute of Legal Executives. ${ }^{859}$ So far the influence of professional associations on the conduct of lawyers is

855 See already Chapter 1.III.

856 See above note 762.

857 See above page 162.

858 Commencement No.1 and Transitory Provisions Order 2008, <http://www.statutelaw.gov.uk/content. aspx?LegType $=$ All + I cgislation \&PageNumber $=1 \& N$ avFrom $=3 \&$ parent Active TextDocId $=3446018 \&$ activetc $x$ tdocid $=3446027>$.

859 Solicitors constitute by far the biggest branch of the legal profession next to barristers, legal executives and notaries (public) or scriveners. A solicitor usually briefs a barrister on a case in the higher courts. The barrister then presents the case to court. However, a solicitor may choose to gain higher rights in order to offer a complete service to a client - from initial advice through to case preparation and representation before the courts. - 
extensive as they are authorised by the Lord Chancellor (minister of justice) to grant lawyers the right of audience and the right to conduct litigations. ${ }^{860}$ Professional bodies thus act as gate keeper to an important part of the legal services sector. Moreover, their regulations are reinforced in a particular way, namely in the form of a statutory assertion that lawyers' ethical duties override all their other legal obligations. The sectoral regulations thus have an immense influence on the market behaviour of the respective legal profession's members. ${ }^{861}$ Furthermore, the governing bodies of the professional associations are so far not required to be composed of members appointed by the public authorities; they come from within the respective legal profession. With regard to their rule making powers, neither the Courts and Legal Services Act 1990 nor the Access to Justice Act 1999 (including their respective Schedules) specify public interest criteria to be observed by the professional associations in adopting rules of conduct. While for instance the Law Society claims to have a public interest role ${ }^{862}$, the conclusion at this point is that the legislative circumstances of the past do not meet the requirements for an exception ratione personae from the scope of Article 81(1) EC.

Clear competition law concerns against various professional regulations in the legal services sector wete formulated in 2001 and 2002 by the Office of Fair Trading. ${ }^{863}$ Its report marked the kickoff of an assessment and consultation process by the Department for Constitutional Affairs ${ }^{864}$, which finally resulted in the legislative process towards the Legal Services Act 2007. ${ }^{865}$ The Act will start to take effect over the next couple of years. The reform has two main aims, namely to increase the competitiveness of the legal services sector and to improve the performance of the complaints handling system so far provided by the

Traditionally solicitors were effectively barred from presenting cases before a court. This 'division of labour' is also undergoing changes as the OFT (Officc of Fair Trading) conducted a major review of the matter. - Another aspect of the Access to Justice Act 1999 will be dealt with below in Chapter 6, namely the amendment to the Courts and Iegal Services Act 1990 (1990) concerning the power of the Lord Chancellor, with the approval of Parliament, to change rules of conduct adopted by the professional bodies which unduly restrict rights of audience or rights to conduct litigation or the excrcise of such rights.

860 See Section 41 Access to Justice Act 1999 (1999), and its Schedule 5.

861 See also Office of Fair Trading, Trade Associations, Professions and Self-Regulating Bodies (1998).

862 <Http://www.lawsociety.org.uk/ncwsandevents/pressreleases/view=newsarticle.law?NEWSID =264720>, visited on 08.03.2006.

863 Office of Fair Trading, Competition in Professions, of March 2001; Office of Fair Trading, Compelition in Professions - Progress statement, of April 2002.

864 In 2003 Lord Falconer, the Lord Chancellor, announced the independent review of the regulation of the legal profession and chose Sir David Clementi, an accountant and a former deputy governor of the Bank of England, to carry out that revicw. Clementi spent several months examining existing regulation before launching a consultation paper in March 2004. That attracted responses from a host of groups and organisations, upon which Clementi and his team retired to prepare their report. The handling of the consultation process has been widely appreciated and the final report of December 2004 delivered a robust assessment of the needs of the profession and put forward well-balanced proposals for its reform. Clementi received particular praise for addressing the interests of consumers (source: $<\mathrm{http}: / /$ www.thelawyer.com $/ \mathrm{cgi}-$ bin $/$ item.cgipid $=113349 \& \mathrm{~d}=301$ $\& \mathrm{~h}=24 \& \mathrm{ff}=46>$, visited on 06.03.2008). Lord Chancellor's Department, In the public interest?, of July 2002; UK Government, Competition and regulation in the legal services market, of 27.07.2003; Department for Constitutional Affairs, Constitutional reform: the future of Queen's Counsel, of 07/2003; Clementi D., A Consultation Paper, (2004); Clementi D., Review of the Regulatory Framework for Legal Services in England and Wales - Final Report, (2004); Department for Constitutional Affairs, White Paper: The Future of Legal Services: Putting Consumers First, of 17.10.2005. ${ }_{865}$ The bill was first introduced with the House of Lords on 23.11.2006, and in the House of Commons on 16.05.2007.

This is a fast law making process: first preparation in 2002/3, final report in December 2004, barely two years of consideration, and only one year of legislative process. 
Law Society ${ }^{866}$ In particular the review process was initiated to improve control of the exercise of regulatory powers by the professional bodies. "The Government responded to the OFT's 2001 Report, Competition in Professions, with a wide-ranging public consultation exercise. Consumers were clear that their needs were not being met. They felt that legal services lacked sufficient orientation towards the consumer; they did not have confidence in self-regulation alone; and prior experience of poor complaints handling had undermined their confidence in the legal profession." "T67 The assessment of the Department for Constitutional Affairs has been clear in that "the current framework is out-dated, inflexible, over-complex and insufficiently accountable or transparent". ${ }^{868}$ Consequently, the terms of reference for the teview process were set to consider what regulatory framework would best promote competition, innovation and the public and consumer interest in an efficient, effective and independent legal sector; and to recommend a framework which will be independent in representing the public and consumer interest, comprehensive, accountable, consistent, flexible, transparent, and no more restrictive or burdensome than is clearly justified. ${ }^{809}$

The government finally considered two options (apart from changing nothing) that would either foresee for a new single regulatory authority ${ }^{870}$ or an oversight regulator. The Legal Services Act 2007 implements the latter option with the Legal Services Board (LSB), which will assume the roles and responsibilities of oversight tegulator, providing consistent

866 The framework for reform set out in the Legal Services Act 2007 (2007) furthermore includes the setting up of an Office for Legal Complaints, which will administer an ombudsman scheme that will deal with all consumer complaints about legal services, and enabling legal services to be provided under new business structures. While the chair and the board members of the Legal Services Board and the Office for Legal Complaints may be appointed throughout 2008, either board may not be empowered until carly 2010 and autumn 2010 respectively (the Legal Services Board to supervise approved regulators etc; and the Office for Legal Complaints to handle complaints) (source: <http://www.sra.org.uk/legal-services-act.page\#q2>, visited on 06.03.2008).

867 Legal Services Bill - Full Regulatory Impact Assessement of 24.11.2006, para. 1.46. Until the Access to Justice Act 1999 (1999), complaints about solicitors (the biggest branch of the legal profession in England and Wales) were handled by the Office for the Supervision of Solicitors, which is an arm of the Law Society. The Law Society's powers to discipline solicitors were contained in the Solicitors Act 1974 (or, where solicitors practices were incorporated as companies, in the Administration of Justice Act 1985 which provided for that form of organisation). Serious disciplinary cases were heard by the independent Solicitors Disciplinary Tribunal, which consists of experienced solicitors and lay members appointed by the Master of the Rolls.

868 UK Government, Competition and regulation in the legal services market, of 27.07.2003, para. 65.

${ }_{869}$ Legal Services Bill - Full Regulatory Impact Assessement of 24.11.2006, para. 1.47. Clementi D., Reviens of the Regulatory Frametyork for Legal Services in England and Wales - Final Report, (2004), $1 \mathrm{f:}$. "The current system is flawed. In part the failings arise because the governance structures of the main frontline professional bodies are inappropriate for the regulatory tasks they face. A further cause is the over-complex and inconsistent system of oversight regulatory arrangements for existing frontline regulatory bodies ... There are no clear objectives and principles which underlie this regulatory system; and the system has insufficient regard to the interests of consumers. Reforms have been piecemeal, often adding to the list of inconsistencies. The complexity and lack of consistency has caused some to refer to the current system as a maze."

${ }_{870}$ It would have been named Legal Services Authority (LSA) and largely based on the model of the Financial Services Authority (FSA), thus exercising full regulatory control over the provision of all legal services, Legal Services Bill - Full Regulatory Impact Assessement of 24.11.2006, para. 4.3. The LSA's functions would have been analogous to those of the FSA (which is an independentnon-governmental organisation responsible for regulating financial services in the UK and is given statutory powers by the Financial Services and Markets Act 2000), including the setting and enforcement of the rules and codes governing service provision, giving guidance and advice on general policy, and exercising investigative, cnforcement and disciplinary powers. Regulatory power would be taken away from existing self-regulating bodies and vested in the ISA, with the existing professional bodies relegated to a solely representative role. 
and appropriate oversight of 'approved regulators', i.e. professional bodies seeking to perform the day-to-day regulatory functions. This includes the power of the LSB to grant and withdraw authorisation of professional or other bodies to act as 'approved regulators'. The latter have to satisfy statutory requirements in having appropriate governance arrangements that provide for a clear split in the exercise of their regulatory and representative functions. ${ }^{871}$ The regulatory choice for the Legal Services Board (rather than a Legal Services Authority) has been made to "be able to utilise the expertise of the legal professional bodies while providing an oversight body that has the powers to ensure that regulation is set according to consumers' interest." 872

These statutory changes prompt two observations. First of all, the Legal Services Act 2007 does not change the nature of the relevant professional bodies despite defined statutory obligations. This means that as long as the professional bodies (intend to) influence the market conduct of the members of the legal professions as 'approved regulators', their qualification as association of undertakings within the meaning of Article 81(1) EC is unchanged. The reaction of the Bar Council to the consultation ptocess is interesting as it exemplifies the stance of a 'classic' liberal profession. Despite the substantial criticism voiced of the current system, the Bar Council resisted the creation of a fully independent day-to-day regulatory body. ${ }^{873}$ While it proposed and established a 'Bar Standards Board' (BSB) ${ }^{874}$ answerable to the statutory 'Legal Services Board', its proposal how to organise the separation of the regulatory and the representative functions of the barrister's profession seems to have been inspired by withholding a clear degree of control under the influence of the representative body. Although the Bar Council concedes that a 'substantial proportion of the membership' of the 'Bar Standards Board' be lay members, this does not qualify for the ECJ's requirement that the majority of the members be independent representatives possibly appointed by the public authorities. ${ }^{875}$ Instead the members of the 'Bar Standards

871 See Section 27 of the Legal Services Act 2007: "(1) In this Act references to the 'regulatory functions' of an approved regulator are to any functions the approved regulator has- (a) under or in relation to its regulatory arrangements, or (b) in connection with the making or alteration of those arrangements. (2) In this Act references to the 'representative functions' of an approved regulator are to any functions the approved regulator has in connection with the representation, or promotion, of the interests of persons regulated by it."

Section 29 of the Legal Services Act 2007: "(1) Nothing in this Act authorises the Board to exercise its functions in relation to any representative function of an approved regulator. (2) But subsection (1) does not prevent the Board exercising its functions for the purpose of ensuring - (a) that the exercise of an approved regulator's regulatory functions is not prejudiced by its representative functions, or (b) that decisions relating to the exercise of an approved regulator's regulatory functions are, so far as reasonably practicable, taken independently from decisions relating to the exercise of its representative functions."

${ }^{872}$ Legal Services Bill - Full Regulatory Impact Assessement of 24.11.2006, para. 4.8., "Most importantly, the LSB will have the power to ensure that the regulation of the profession is consistent with all the objectives of the Government's reform of the regulatory framework for legal services in England and Wales."

${ }^{873}$ See General Council of the Bar, Model for the Separation of the Regulatory and Representative Functions of the Bar Council: Consultation Paper, (2005).

874 "The Bar Standards Board was established in January 2006 as a result of the Bar Council separating its regulatory and representative functions. As the independent regulatory board of the Bar Council, we are responsible for regulating barristers called to the Bar in England and Wales. We take decisions independently and in the public interest and are not prejudiced by the Bar Council's representative function. Our purpose is to promote and maintain excellence in the quality of legal services provided by barristers to support the rule of law. We do this by setting standards of entry to the profession and by ensuring that professional practice puts consumers first" (Source: <http://www.barstandardsboard.org.uk/ >, visited on 06.03.2008.)

${ }^{875}$ In the presentation the members of the 'BarStandards Board' are eight barristers and seven lay persons; only for three of the barrister members the Bar Council provides for them not to cumulate their office with an office 
Board' as the regulatory arm of the Bat Council are to be appointed by an Appointments Body, the members of which can also be members of the Bar Council (i.e. the governing body; thereby the door is opened for a plurality of offices).

Moreover, the Bar Council proposed that the 'Bar Standards Board' will be a parent committee for four regulatory committees ${ }^{876}$; especially the 'rule making committee' will have the power to make recommendations to the already existing regulatory instruments; the 'Bar Standards Board' will only have the power to 'approve' changes to the professional rules, to monitor and to be consulted during the process, but no tight to alter the recommendations put forward by the Bar Council. While the members of the regulatory committees are to be appointed by an Appointments Body, they can also be members of the Bar Council (again plurality of offices is made possible). Furthermote, the Bar Council foresees for representative committees that should complement the work of the regulatory committees. Read together with the limited commitment to a 'substantial', 'increased' or 'significant' number of lay members in the regulatory bodies, the tentative of the Bar Council to tetain the power to influence the work of an regulatory body bears the risk that the representation of the public interest be compromised for lack of a majority of independent members on the regulatory bodies. Under the Legal Scrvices Act 2007 the Legal Services Board will be the body to prevent such risk from arising.

The Law Society, on the other hand, welcomed the changes to the legal professions as long-overdue modernisation of the legal services market. At the same time it discerns potential threats to the independence of the legal profession. ${ }^{877}$ These have been taken aboard in the Legal Services Act 2007. With effect from 1 January 2006, the Law Society responded to the second aim of the Legal Services Act 2007 and separated the governance of its regulatory and complaints-handling functions from its representative functions. ${ }^{878}$

The second observation on the statutory changes concerns the fact that the introduction of the Legal Services Act 2007 has not the aim to eliminate professional regulation in the legal services sector from the scope of application of competition law - quite to the contraty. The Legal Services Act 2007 is a frank confession that competition law is a concern in professional regulation and that thus its applicability should not be eliminated at the outset. in the Bar Council.

${ }_{876}$ The Bar Standards Board tuns its work through regulatory committees each of which reports to the Board. They are: the Complaints Committee (responsible for investigating complaints and taking action against batristers who have breached the Code of Conduct or provided poor service); the Qualifications Committee (responsible for looking at individual applications from people wishing to become barristers but who may be exempted from the normal training requirements); the Quality Assurance Committee (responsible for monitoring standards and encouraging professional excellence at the Bar); the Standards Committee (responsible for the Code of Conduct which all barristers must comply with and issuing guidance on good practice); the Education and Training Committee (responsible for setting the standards of education and training that people must pass before being able to practise as bartisters, together with the further training requirements that barristers must comply with throughout their careers); the Performance and Best Value Committee (responsible for reviewing the corporate governance structures of the Board and its committees to ensure that they are working economically and effectively).

${ }^{877}<$ Http://www.lawsociety.org.uk/newsandevents/pressreleases/view=newsarticle.law?NEWSID=264720>: "The Law Society [...] warns of the dangers of Ministers being able to make appointments themselves to key positions of influence over the solicitors' profession or change regulatory objectives through secondary legislation." Sec also Council of Europe, Recommendation of the Committee of Ministers to Member States on the freedom of exercise of the profession of lawyer, of 25.10.2000, Principle IV(2): "Bar associations or other professional lawyers' association should be self-goveming bodies, independent of the authorities and the public.".

${ }_{878}$ For this purpose a Regulation Board has been established. The Law Society, The Future of Legal Services Putting Consumers First: Response of the Law Society's Regulation Board to the Wbite Paper, of 19.01.2006. 
This is being reinforced for instance by the LSB's duty to consult with the Office for Fair Trading in the process of authorising new professional associations to adopt day-to-day regulations, or when adding to or removing from the list of reserved legal services (e.g. the right of audience and the right to conduct litigations). Consequently, the teform of the legal services sector in England and Wales actually affirms the result of the critical discussion above of the case law created exceptions ratione personae, namely that the criteria introduced by that case law are hardly appropriate to exclude the applicability of Article 81(1) EC. Rather the need for an effective control on the regulatory activities of professional bodies requires that they be subject to the general law, including competition law. The Legal Services Act 2007 responds to the need for mote transparency and accountability in professional regulation in order to meet modern standards of regulatory responsibility towards the public and last but not least the consumer. ${ }^{879}$

In this regard the approach taken in the UK implements the assertion that competitive markets are the most effective vehicles for generating economic growth. This constitutes a revision of the previous policy choices. While the Competition Act 1998 in its Schedule 4 foresaw that certain professional rules (including services of barristers, advocates or solicitors) were excluded from the competition prohibition equivalent to Article 81(1) EC, the Enterprise Act 2002 repealed Schedule 4 of the Competition Act 1998 effective 1 April 2003 (in advance of the main substantive changes to competition law and consumer protection law).

Professional regulation of lawyers in Germany is partly laid down in federal and regional State laws and partly in self-regulatory measures ${ }^{80}$ The self-regulatory part is adopted within the federal lawyers association BRAK (Bundesrechtsanwaltskammer). A 'special assembly' (Satzungsversammlung) rather than the general assembly of the BRAK is chatged with the competence to adopt professional regulations. ${ }^{881}$ The members of this special assembly are

879 Legal Services Bill - Full Regulatory Impact Assessement of 24.11.2006, paras. 1.17. ff., highlights as drivers for reform of the regulatory framework in the legal services professions, first, the need for a more effective regulatory structure, second, the need for more effective competition and, third, the need for more effective and independent complaints handling arrangements: "The problems associated with the current regulatory framework can be seen in terms of regulatory proliferation, confusion and fragmentation; the propensity of the current structure to create regulatory anomalies and gaps; and the difficulties of interface and co-operation. [...] Potential conflicts of interest also arise in the existing framework, with most of the regulators of legal professionals also performing a representative rolc, acting as advocates for their members. This raises concerns as, arguably, there is a risk that the regulators' judgments might be unduly influenced by putting the interests of the members above those of consumers of legal services and thus undermining public confidence in the legal services sector. Even when this is not the case, the perception of undue influence on regulators' considerations may be damaging to the image of the profession. However, largely in response to the recommendations made by Sir David Clementi, the Law Society and the Bar Council have recently announced that they are to establish separate arms to deal with regulation of their respective professions, which will be ring-fenced from representative interests." - Section 57 of the Legal Services Act 2007 provides for the OFT to prepare reports when it is concerned that the regulatory arrangements of a professional body that assumes regulatory competences "prevent, restrict or distort competition within the market for reserved legal services to any significant extent, or are likely to do so". While the basis for the powers of the OFT is stated elsewhere, Sections 57 et seq. establish a procedure in which the Iegal Services Board has to give full and proper consideration to a report made by the OFT. This clearly stresses the import that the legislator (following the conspicuous critique by David Clementi) attaches to the competitiveness of the sector to the ultimate benefit of the consumer.

${ }_{880}$ See $\iint 18 \mathrm{ff} ., 43 \mathrm{ff}$. , and esp. $\iint 59 \mathrm{~b}, 191$ a ff. BRAO (Federal Lawyers Act).

${ }_{881} \int S 191 \mathrm{aff}$. BRAO. These statutory provisions and the specialised self-regulatory body have been introduced as a result of two decisions of the Constitutional Court, BVerfG - [1987], BVerfGE 76, 171; BVerfG - [1987], $B V$ erfGE 76, 196, in which the BVerfG found the previous pattern of self-regulatory rule-making by the lawyers 
all elected from amongst the members of the profession. The public authorities do not interfere in the nominations for this body (or any other of the governing bodies), and no public interest criteria are specified in the law that should be taken into account in the adoption of professional regulations. The Federal Lawyers Act ( $\$ 59 \mathrm{~b}$ BRAO) merely defines the subject matters that the professional self-regulation should cover, but no public interest needs to be observed. The Federal Lawyers Act is based on the idea that the federal and regional lawyers associations represent the interests of the professionals and the profession only ${ }^{882}$ None of the requirements of the case law created exception ratione personae are thus addressed in respect of the profession of German lawyers and the BRAK therefore qualifies as 'association of undertakings' within the meaning of EC competition law.

German notaries are similarly regulated under a mix of State regulation and selfregulation. The competence to regulate the notaries' profession lies with the regional associations. ${ }^{883}$ They are empowered to adopt directives on office duties and other obligations that notaries have to observe in the exercise of their activity. ${ }^{84}$ The federal association (Bundesnotarkammer) merely has the task to issue recommendations for the directives that the regional associations adopt. ${ }^{885}$ No public interest criteria is defined in the federal legislation, and no independent representatives of the public authorities are present on the governing bodies of the regional or federal associations. Hence, the associations at both levels qualify as associations of undertakings.

According to the Dutch Lawyers Act (Advocatenwet - AW) all governing bodies of the Dutch lawyers association (NOvA - Nederlandse Orde van Advocaten), including the supervisoty or disciplinary boards, are composed of members of the profession ${ }^{886}$ Moreover, and as the ECJ observed in Wouters, the Dutch Lawyers Act does not explicitly specify any general interest criteria for the regulatory task with which the NOvA is cntrusted. Its Article 28 merely refers to the powers of the College of Delegates/ Committee of Representatives ${ }^{87}$ (College van Afgevaardigden) to adopt regulations in the interest of the proper practice of the profession. 'The governing bodies' responsibility to ensure the proper practice of the profession is also teferred to in Article $26 \mathrm{AW}$. However, no definition is provided in the Act of what the proper practice should be and whether it embraces criteria of public interest. While Article $30 \mathrm{AW}$ provides for the interference by the Crown, i.e. the minister of justice, if decisions adopted by the organs of the NOvA should be contrary to the law or the public interes ${ }^{888}$, the Dutch Lawyers Act does not further define such public interest criterion. As explained above the Court did not consider the reference to the proper practice sufficient to exclude the NOvA or its regulations from the jurisdictional scope of Atticle 81(1) EC. ${ }^{889}$ The NOvA therefore qualifies as association of undertakings.

profession to infringe the Constitution. The decisions are discussed also in Chapter 7.I.2.5.3.2.

882 See $\iint 73,89$ BRAO.

883 \65 BNotO; the notaries are geographically organised per Oberlandesgerichtsbezirk (district of the Higher Regional Court).

884 See 15 67(2), 71(4) BNotO.

885 \78(1) no.5 BNotO.

886 Articles $17 \mathrm{ff}$. AW.

${ }_{887}$ 'College of Delegates' is used by the ECJ, and 'Committee of Representatives' by AG Léger in Case C309/99, Wouters et al. v NOvA, [2002].

${ }_{888}$ The minister of justice has exercised this power once in the matter of the no cure, no pay rule, that the NOvA had introduced by way of experiment and following the advocacy by the Dutch competition authority. For details see Chapter 2.VI.2. and Chapter 7.II.2. See also Engelgeertegen Nederlandse Orde vanAdvocaten - 'no cure, nopay', (2002).

889 See Case C-309/99, Wouters et al. v NOvA, [2002], paras. $60 \mathrm{ff}$. 
Currently the position, including the regulatory competences, of the NOvA are reviewed by the minister of justice who set up a committee to analyse the bar. ${ }^{890}$ The committee issued recommendations ${ }^{891}$ according to which the lawyers association should be reformed under the current Lawyers Act to, among others, set up a regulatory council for the bat (Regelgevende Raad voor de Advocatuur) with a majority of independent experts that should be appointed by the minister of justice. The regulatory council should take care of all rule making to cover the access to the profession, the structure and exercise of the profession, the promotion of competitive professional markets, unless regulation would be laid down in statutory provisions. The committee stresses that the Lawyers Act should be amended to bind the regulatory council to follow a double objective, namely of safeguarding the public interest and of striving for a good balance in regulating the profession to correct imperfections of the profession and in regulating the legal services market to correct market imperfections. No regulation should be adopted without hearing the advice from the Algemene Raad and the College van Afgevaardigden. ${ }^{892}$ While the majority of the members of the regulatory council should be independent, their appointment should be made by the minister of justice. ${ }^{893}$

The further recommendation is that the rule-making process of the sector should be subject to an ex ante control by the minister of justice. This means that no regulation would be effective without approval by the minister. ${ }^{894}$ The report explicitly refers to the competition case law of the ECJ, and in particular $S A T /$ Eurocontrol and Cali. The setup of the relevant part of the report makes clear that the whole exercise on the reforming the selfregulatory structures of the Dutch legal services sector is driven by the desire to exempt the legal profession from the general law in the form of competition law. ${ }^{895}$ In this it differs hugely from the apptoach taken in the UK, which has clearly parted from that position ever since Schedule 4 to the Competition Act 1998 has been abolished. On this point the proposal can be criticised from an even wider perspective, namely that the increased role of the minister of justice jeopardises the independence of the profession from undue government influence ${ }^{896} \mathrm{It}$ is not mere illusion, as the report alleges, to fear that the State

890 Letter of 23.12.2004 to the Tweede Kamer (Instellen van Commissie Advocatuur), (2004).

891 Commissie Advocatuur, et al., Een maatschappelijke Orde, (2006).

${ }_{892}$ Commissie Advocatuur, et al., Een maatschappelijke Orde, (2006), 14.

893 Commissie Advocatuur, et al, Een maatschappelijke Orde, (2006), 36.

${ }^{894}$ Commissie Advocatuur, et al., Een maatschappelijke Orde, (2006), 14, 37: "Met name het aspect van centrale en samenhangende besluitvorming verdient andacht. Bij de voorgestelde samenhangende besluitvorming door één gelegitimeerd orgaan is volgens de Commissie (met uitzondering van commissielid Van den Bergh) interventie van andere organen dan de minister van Justitie namelijk niet nodig en niet beoogd." (Emphasis in original) Note: "Het Commissielid Van den Bergh kan zich met deze zienswijze niet verenigen, omdat naar zijn mening ook bij een meerderheid van onafhankelijke deskundigen in de Regelgevende Raad de behoefte aan controle door een onafhankelijke mededingingsautoriteit blijft bestaan." From the discussion above follows that the present author shares this latter view.

895 Commissie Advocatuur, et al., Een maatschappelijke Orde, (2006), 37: "Handelingen van ondernemingen of ondernemersverenigingen zijn onttrokken aan de werkinssfeer van artikel 81 lid $1 \mathrm{EG}$ wanneer sprake is van de uitofening van een overheidsprerogatief' (with reference to $S A T /$ Eurocontrol and Cali).

896 Sec above on the fine balance on this point that the UK reform legislation aims at. Commissie Advocatuur, et al., Een maatschappelijke Orde, (2006), 37, does not wince to state that "Op het eerste gezicht lijkt preventief toczicht [door de minister van Justitie vooraf aan het vaststellen van regelgeving door een Regelgevende Raad] te leiden tot meer zeggenschap van de overheid dan bij repressief toezicht het geval is. Dat zou kunnen afdoen aan de onafhankelijkheid van de advocatuur. Dat is echter slechts schijn [sic]. Bij toepassing van beide vormen van toezicht is het eindeffect immers gelijk: het besluit is na ministeriële bemoeienis zonder werking. Preventief toezicht kan in de hiervoor geschetste opzet bijdragen aan een zorgvuldige afweging van de inbreng vanuit de beroepsgroep en aan de kwaliteit van de besluitvorming." 
could gain more influence on the profession and thus impair the independence of the profession from the executive powers of State. Rather the argument used ("bet eindeffect [is] immers gelijk", i.e. the final result is nevertheless the same) only proves that government in the person of the minister of justice should perhaps not have a direct role in the supervision of the legal profession. What the proposal clearly evidences with its further references to Wouters, and more particularly Arduino, is that it is above all driven by securing for the legal profession an exception from the applicability of the general law in the form of competition law. ${ }^{897}$

The alarming about this is that the committee's determination ${ }^{898}$ to secure the legal profession an exception from the applicability of competition law comes at the price of the profession's independence from government influence - rather than daring to devise a smarter organisation and regulation of the legal profession. This is particularly striking since the committee was fully aware of the deliberate considerations taken by the Department for Constitutional Affairs and the UK government in modernising the legal services sector in

897 Commissie Advocatuur, et al., Een maatschappelijke Orde, (2006), 37 f.: 'Tn het arrest Arduino beoordeelde het Hof of de besluiten van de Italiaanse Orde waren aan te merken als besluiten van een ondernemersvereniging. In die zaak oordeelde het Hof dat het besluitvormend orgaan van de Italiaanse Orde weliswaar niet in meerderheid uit onafhankelijke deskundigen bestaat, en geen wettelijke waarborgen kentmet vastomlijnde criteria waarin het algemeen belang wordt ingekaderd, maar dat uit de betrokken wettelijke regeling blijkt dat de Italiaanse staat de bevoegdheid aan zich heeft gehouden om in laatste instantie over het betrokken onderwerp te beslissen, doordat de in die zaak aan de orde zijnde regeling van de Italiaanse Orde pas in werking treedt na goedkeuring van de minister."

${ }^{898}$ See for instance p. 37 of the report: "Op basis van het voorgaande zijn er twee modaliteiten om brede regelgeving door één gelegitimeerd orgaan van de Orde mogelijk te maken en wel zonder dat sprake is van ecn ondernemersvereniging met de daaraan verbonden mededingingstoetsing..." (emphasis in the original). The further formulation of the report must revolt the advocate of an independent advocacy, e.g. "Geheel eensluidend is de Europese rechtspraak op ditpunt echter niet. Aan de hierboven geciteerde rechtsoverweging 68 van het Wouters arrest zou men ook kunnen ontlenen dat de twee vormen in feiten één modaliteit zijn. In dat geval zijn beide modaliteiten samen nodig omhet geoogde effect te bereiken. Het lijkt ook om deze reden verstandig daar veiligheidshalve voor te kiezen" (emphasis added). - Consequently, the Dutch lawyers association NOvA rightly observes that "Hetvoorstel van de commissie ten aanzien van de bestuurlijke structuur van de Orde roept echter vragen op. Volgens de Commissie Advocatuur moet er een Regelgevende Raad voor de Advocatuur worden ingesteld met een meerderheid van onafhankelijke deskundigen die wordt benoemd door de minister van Justitie. Deze nieuwe bestuurslaag zou boven het huidige bestuur van de Orde komen te functioneren. De nieuwe bestuurslaag vormt een bedreiging voor de onafhankelijkheid van de advocatuur. Onvermijdelijk komt die in het gedrang als derden de regels bepalen voor de beroepsgroep. Een dergelijk model geldt voor geen enkel ander beroep, en in geen enkel ander land. Voor een dergelijke drastische ingreep bestaat bovendien geen enkele noodzaak, nu de commissie zelf constateert dat 'de Orde kan bogen op een traditie van prudent gebruik van haar bevoegdheden'. Ook is het vreemd dat de commissie onafhankelijkheid als kernwaarde van de advocatuur vooropstelt, maar tegelijkertijd een voorstel doet dat die onafhankelijkheid fundamenteel ondergraaft", <http://www.advocatenorde.nl/nieuws/default.asp?view=details\&cartikel=37>, visited on 10.03.2008. Instead of a Regelgevende Raad the NOvA proposes a Raad van Advies (advisory council), which should be operational during 2008, < http://www.advocatenorde.nl/nieuws/default.asp?view=details\&artikel=102>, visited on 10.03.2008: "Het parlement van de Nederlandse Orde van Advocaten, het College van Afgevaardigden, is dinsdag unaniem akkoord gegaan met de instelling van een Raad van Advies. De Raad van Advies gaat het bestuur van de Orde (de Algemene Raad) en het College op hoofdpunten van beleid adviseren. Op deze wijze moet het maatschappelijk draagvlak voor de Orde-regelgeving worden vergroot, iets waatvoor de door de regering ingestelde Commissie Advocatuur en vervolgens de regering hebben gepleit. De Orde was niet verplicht nu al een Raad van Advies in het leven te roepen, maar heeft hiermee volgens landelijk deken Willem Bekkers 'een welwillend signaal naar Den Haag' afgegeven. De Raad van $\Lambda$ dvies zal bestaan uit ten minste vijf en ten hoogste zeven leden, in meerderheid van buiten de advocatuur. Dit najaar zullen kandidaten aangezocht worden, zodat de Raad van Advies begin 2008 met zijn werkzaamheden kan beginnen." 
England and Wales. ${ }^{899}$ Thus, while the report tries hard to respect the patameters set by the case law in SAT/Eurocontrol, Cali, Wouters and Arduino at the same time, it sends out the counterproductive signal that those cases would actually state good rules in terms of democratic legitimacy. ${ }^{900}$ In accordance with the recommendations of the committee the Regelgevende Raad would be subject to influence from two sides, namely the professional bodies and the minister of justice. The position of the Cabinet is slightly more sophisticated on that point and prefers, in concurrence with the NOvA, the creation of an advisory council to the regulatory bodies of the NOvA. ${ }^{901}$ Nevertheless the Cabinet fully embraces the recommendations to adopt an ex ante control of self-tegulatory measures by the NOvA. ${ }^{902}$ In view of the menace for the independence of the legal profession from government intervention it is curious that the Dutch Lawyers Association has not repeated its objections to such a control mechanism. ${ }^{903}$ On the ovetall the position taken by the government on the composition and the regulatory powers of an Adviesraad evidences an approach that carries an old-fashioned imprint of regulatory superpower of the State organs. This is even more astonishing in light of the eatlier regulatory reform model applied to the legal services sector in England and Wales, which does not define a positive tole for the minister of justice, not even in the appointment process of the Legal Services Board. ${ }^{904}$

899 See note 4 of the committee's report, which refers to Clementi D., Review of the Regulatory Framework for Legal Services in England and Wales - Final Report, (2004).

900 The committee motivates its preference for ministerial intervention ex ante with an improvement of uniform quality, equality of arms, fair play and transparency in the field of the monopoly right to represent clients in specific types of court proceedings, page 38 of its report.

${ }_{901}$ Government, Reactie van bet kabinet op de aanbevelingen van de Commissie advocatuur, of 13.10.2006, 14: "Het kabinet zal daarom bevorderen dat in de Advocatenwet een basis wordt opgenomen voor een door de Orde in te richten adviesraad, voor het merendeel bestaande uit niet-advocaten, waaraan de Algemene Raad advies vraagt over alle ontwerpregelingen die door hem zijn opgesteld. Dit advies wordt door de Algemene Raad samen met de ontwerpregeling voorgelegd aan het College van Afgevaardigden. Het spreekt voor zich dat afwijking van het advies dient te worden gemotiveerd. Het is an de Orde de intichting van de adviesraad bij verordening nader te tegelen."

${ }_{902}$ Government, Reactie van het kabinet op de aanbevelingen van de Commissie advocatuur, of 13.10.2006, 14: "Het kabinet heeft, in navolging van de Commissie, tevens voor ogen om het repressicve toezicht van de minister van Justitie op de regelgeving van de Orde te vervangen door een preventief toezicht zoals bedoeld in artikel 10:25 van de Algemene wet bestuursrech, een methode die vergelijkbaar is met de totstandkoming van regelgeving in de Wet op het notarisambt en daar bevredigend werkt. Het kabinet is immers van mening dat de minister van Justitie altijd de mogelijkheid moet hebben om verordeningen te toetsen aan het algemeen belang, waarbij het met name van belang is dat de betrokken regelgeving zich beweegt binnen het kader van de kernwaarden. Dit is in het bijzonder relevant in die gevallen waarin de Orde afwijkt van het advies van de adviesraad. Een toetsing vooraf doet ook recht aan de verantwoordelijkheid van de minister van Justitie voor een goed functionerend rechtsbestel en draagt ook bij aan de minister van Justitie aanspreckbaar is op zijn beleid op dat punt."

${ }_{904}^{903}$ See note 898 (towards its end).

$<\mathrm{Http}: / /$ www.tribalmicrosites.co.uk/lsbmembers/index.cfm?page=Foreword_from_the_Lord_Chancellor_ and_Secretary_of_State_for_Justice>, last visited on 12.03.2008: "a commitment to fairness and transparency is enshrined in the recruitment process itself, which is being regulated by the Office of the Commissioner for Public Appointments (OCPA)." - "The ISB will be independent from government and the legal professions. It will be a public body sponsored by the Ministry of Justice (MoJ). The LSB Chair and other board members will be responsiblc for the design and outlook of the organisation, for establishing the new regulatory framework and for providing oversight of approved regulators and licensing authorities. It is expected that the Chair and other board members will form a positive working relationship with all stakeholders, including the $\mathrm{MoJ}$, and ensure that consumer needs drive the decision making process. [...] The exact size and structure of the LSB will be determined by the Chair and other board members and by the demands of the market. However, based on analysis carried out by PricewaterhouseCoopers (PWC: Financial Analysis to Support the Draft Legal Services Bill) 
The Koninklijke Notarielle Beroepsorganisatie (KNB), the royal notaries association in the Netherlands, has different governing bodies ${ }^{905}$, which all are composed of members of the profession (either notaries or candidate notaries). Only the disciplinary chambers are organised in conjunction with the State judiciary. The latter are composed of two judges, two (candidate) notaries and a judicial auxiliary, thereby keeping the majority on the side of the public authorities. However, the Dutch Notaries Act 1999 (Wet op bet notarisambt WNA 1999) does not specify an obligation to take specific public interest criteria into account and thus does not satisfy the second public interest safeguard that the second case law created exception ratione personae imposes. Under the Act the KNB merely has the task to promote with its members the good exercise of the profession and their expertise (vakbekwambeid), and to maintain the dignity and prestige of the notarial office. In particular, the law does not qualify the exercise of the KNB's regulatory powers to be in the public interest. Article 61 WNA 1999 simply adds that apart from rules of conduct the KNB may adopt rules that relate to the promotion of the expertise of the profession's members. ${ }^{906}$ Mention of the public interest is made only in Article 91 WNA 1999, which is similar to Article 31 of the Lawyers Act. It States that any regulation adopted by the KNB requires the approval of the minister of justice, and that such approval may be withheld if the proposed regulation is contrary to the law or the general interest. Although the law thus mentions the general interest, it does not specify any particular public interest, let alone making the KNB subject to an obligation to take account thereof. Therefore, despite Article 91 WNA the KNB comes within the jurisdictional ambit of Article 81(1) EC. The organisation of the disciplinary powers with the State judiciary does not alter this conclusion as this trait only satisfies a bare minimum requirement of accountability. In accordance with the case law of the ECJ it is more important to look at the statutory standards that these disciplinary

the expectation is that it will need in the region of thirty-seven members of staff excluding the Chair, other board members and the Chief Executive." See also < http://www.ocpa.gov.uk/>, last visited 12.03.2008: "The Office of the Commissioner for Public Appointments (OCPA) supports the work of the Commissioner for Public Appointments, a position which is independent of the government. This position is now held by Mrs Janet Gaymer, CBE. The Commissioner's role is to regulate, monitor, report and advise on appointments made by UK Ministers and by members of the Welsh Assembly Government to the boards of around 1,100 national and regional public bodies. Some bodies within Northern Ireland also fall under Commissioner's remit. [...] Government departments are required to follow the Commissioner's Principles and detailed Code of Practice [PDF $179 \mathrm{~KB}, 84$ pages] when making these public appointments. The Commissioner is also responsible for investigating complaints. The Commissioner and OCPA do not themselves make any appointments; their role is regulatory." From the Code of Practice, section 3.36 under the heading "Final ministerial decision" it appears that: "Apart from exccptional circumstances, which must be explained in the submission to ministers, ministers will be offered a choice of candidates and at least two names should be put forward for each vacancy. It is for departments to decide how this should be done, after consultation with their minister. However:

- the overriding principle remains appointment on merit and no candidate can be recommended to ministers unless they have been judged as suitable against the established selection criteria;

- ministers will wish to balance boards in terms of diversity of skills and experience as set out in the role description and person specification at the commencement of the process;

- under no circumstances, however, should a candidate who has been judged unsuitable for an appointment be rccommended in order to achieve that balance on a board."

905 Articles 62 ff. WNA 1999.

906 Article 61 WNA 1999: "1. De KNB heeft tot taak de bevordering van een goede beroepsuitoefening door de legen en van hun vakbekwaamheid. Haar taak omvat mede de zorg voor de eer en het aanzien van het notarisambt.

2. Bij verordening worden beroeps - en gedragstegels van de leden van de KNB vastgesteld. Tevens kunnen bij verordening tegels worden gesteld betreffende de bevordering van de vakbekwaamheid van de leden." 
chambers are bound to. Since the WNA does not refer to any particular public interest, the KNB qualifies as 'association of undertakings' within the meaning of Article 81(1) EC. ${ }^{907}$

The French notaries profession is regulated by State laws, regulations and decrees. According to Article 4 Regulation no. $45-2590^{908}$ the remits of the departmental chambre de notaires are, amongst others, to adopt regulations on the custom or usual practice of the profession as well as on the relations amongst notaties and with their clients ${ }^{909}$ and to denounce infringements of disciplinary provisions. Disciplinary proceedings ate not only denounced, but also decided by the profession itself. ${ }^{10}$ More generally all the governing bodies of the profession are composed of members of the profession. No public interest criteria is formulated in the State rules regulating the profession, and therefore, the representative bodies of the French notaties profession qualifies as 'associations of undertakings'.

In Italy the Act no. $220 / 1991^{111}$ empowers the National Notaries Council (consiglio nazionale del notariato) to draw up principles of professional deontology. Although the consiglio underlines that the code of conduct adopted on the basis thereof guarantees the quality of the services that the notary provides for the 'community', Italian law does not specify any particulat public interest to be taken into account by the consiglio when regulating the exercise of the profession. ${ }^{912}$ Thus, there is no reason to disqualify the consiglio from the jurisdictional scope of Article 81(1) EC.

\section{Examples from the sector of arcbitecture}

In the UK professional conduct of architects is regulated by the Architects Registration Board, and Article 13 Architects Act 1997 gxants it a general competences to lay down "standards of professional conduct and practice expected of registered persons" without, however, giving any indications on the more concrete content of such standards, not to mention any particular public interest. The Architects Registration Boatd is composed, on the one hand, of seven architect members (elected by and from amongst the profession's members) and, on the other, of eight members appointed by the Privy Council. ${ }^{913}$ This

907 See also Nederlandse mededingingsautoriteit (NMa), Inventarisatie urije beroepen: notariaat, of 03/2006.

908 Ordonnance n. 45-2590 relative au statut du notariat of 02.11 .1945 (Regulation on the status of the profession of notary (public)) (1945).

${ }_{909}$ They have to be submitted for approval to the minister of justice (Garde des $S$ ceaux). Before that submission the conseil régional des notaires also gives its opinion on the dtaft regulations, Article 5 Regulation 45-2590.

910 See Article 5-1 (créé par Loi n"2004-130 du 11 février 2004 Article 43 (JORF 12 février 2004)): "Le conseil régional siégeant en chambre de discipline prononce ou propose, selon le cas, des sanctions disciplinaires. Cette formation disciplinairc comprend au moins cinq membres, de droit et désignés parmi les délégués au conseil régional. En sont membres de droit le président du conseil régional qui la préside, les présidents de chambre départementale ainsi que, le cas échéant, les vice-présidents de chambre interdépartementale. Toutefois, dans les départements d'outre-mer, la formation disciplinaire est composée d'au moins trois membres. Un décret en Conseil d'Etat fixe les conditions d'application du présent article." That dectee is Décret 45-0117 (Implementing decree on the status of the profession of notary (public)) (1945).

911 Legge 27 giugno 1991 n. 220.

912 See Autorità Garante della Concorrenza e del Mercato, Indagine conoscitiva nel settore farmaceutico (1997), 75. The codice deontologico was deliberated on 24.02.1994.

${ }^{113}$ The Privy Council is a body of advisors to the British Sovereign. The Privy Council was formerly a powerful institution, but its substantial decisions are now controlled by one of its committees, the Cabinet. The Council also performs judicial functions, which are for the most part delegated to the Judicial Committee. It consists of all the members of the Cabinet, former Cabinet ministers, and other distinguished persons appointed by the Sovereign. Its functions include issuing Orders-in-Council, granting Royal Charters, and acting as a court of appeal 
majority of members of the Board cannot be registered architects and is appointed after consultation with the secretary of State and such other persons or bodies as the Privy Council deems fit. ${ }^{914}$ Thus, the majority of the Board members are appointed by the public authorities, and thereby one of the conditions of the ECJ's case law for an exception ratione persona is fulfilled. However, the question is whether the further and more important requirement of the case law on the compulsory taking account of public interest is met by the provisions of the Architects Act 1997. On the one hand, Schedule 1 paragraph 3 of the Atchitects Act 1997 stipulates that the eight members are appointed by the Privy Council "to represent the interests of users of architectural services and the general public". This suggests an obligation of these members to exercise their office in the interest of the users and the general public.

On the other hand, and in the light of the ECJ's case law, two critical observations can be made: first of all, no specific public interest is laid down in the law. The "interests of users of architectural services" may cover a very broad range of concrete interests. The same goes for the interests of the general public. At least mention should be made of the kind of general interest that members of the Board should take into account, e.g. safety. The second critical note is that, although eight members of the Board are appointed to represent the mentioned interests, there is no explicit statutory obligation on these members to actually exercise their office in furtherance of a specific public interest. Instead paragraph 3 of Schedule 1 concerns the rights and obligations of the Privy Council in appointing eight members of the Architects Registration Board and thereby only substantiates what earlier has been exposed as a bare minimum requirement of not accepting biased experts. Moreover, if any such obligation of public interest observance could be inferred from paragraph 3 of Schedule 1, such obligation would only be on the eight members appointed by the Privy Council and not on the elected architect members of the Board. While paragraph 9 of Schedule1 provides for a quorum of which at least four members should be non-architect members and thereby could be understood as a procedural safeguard in the sense of the Court's case law discussed earlier to wartant the mentioned interests (of users and the general public), such procedural measure does not make up for the lack of a substantive obligation that would bind all Board members to observe specific public interest criteria.

The ensuing conclusion is that the Architects Registration Board qualifies as 'association of undertakings'. 'This conclusion cannot be altered by the fact that a specialised body within the Architects Registration Board is responsible to elaborate the rules of conduct. According to the amended paragraph 13 of Schedule 1 to the Architects Act $1997^{915}$ the Professional Conduct Committee consist of four elected members of the Board (i.e. architects), three appointed members of the Board (i.e. non-architects appointed by the Privy Council), three persons nominated by the President of the Law Society (i.e. probably lawyers, but possibly also architects), and six persons appointed by the Board, including three registered persons ${ }^{916}$ (i.e. architects). This means that (at least) seven - if not up to ten - membets of the Professional Conduct Committee are architects versus nine - if not merely six - nonarchitect members. This means that therefore only at a ratio of seven to nine does the majority of the members of the Committee presumably tepresent interests other than those

from British Courts in overseas territories. The Cabinet remains formally a committee of the Privy Council.

914 Schedule 1 paragraph 3(2) Architects Act 1997 (1997).

915 Architects (Professional Conduct Committee) Amendment Order 2004 in force since 1st April 2004.

916 The statutory formulation seems to be agnostic as to whether this is a minimum or a minimum and maximum number of architect members. 
of the professionals. The ration of seven to nine is one out of four possible combinations and thus seems to be a weak arrangement to satisfy the requirement of procedural safeguard, which in turn states only a mere minimum requirement. Also the necessary quorum does not provide for a majority decision by members not representing the interests of the profession. The only requirement on the quorum in this respect is that at least one non-architect person (excluding the members appointed by the Law Society) should be present (but not necessarily heard) adopting its decisions and tules of conduct. The example of these tather complex composition and majority rules merits two more general remarks: while important to avoid biased experts, they risk to be a charade.

In Germany architects are regulated separately in each Land. Taking the Architects Act of the Saar (ArchG) as an example one finds that the governing bodies of the professional

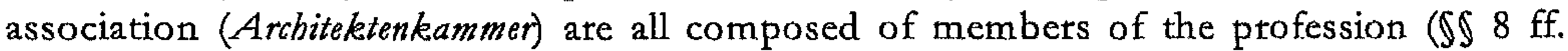
Arch G), and that the regulatory powers ate not subject to public interest criteria. One of the statutory tasks of the association is to define the professional obligations of the architects and to control their fulfilment $(\$ 10 \mathrm{Arch} G) \cdot{ }^{917} \$ 16$ of the Act merely specifies that rules on the exercise of the profession lay down the obligations that a member has to observe in order to safeguard the prestige and standing of her profession. The control of the association lies with the competent ministry (ministry of the environment, $\$ 21 \mathrm{Arch} G$ ) to ensure that the association exercises its tasks in conformity with the law and under the terms of the statutes of the association. ${ }^{918}$ The Act makes no mention of any particular public interest criteria.

In view of a standardisation of the applicable law within the federal territory the ministers of the Länder for building and planning in 2002 have adopted a model law (Musterarcbitektengeseto, MArchG). ${ }^{919}$ Curiously enough the $M \Lambda$ rchG omits any regulatory powers concerning professional regulations. The impression thereby created is that the professional body would not interfere with the economic activity of its members and, thus, not qualify as an 'association of undertakings'. What the MArchG does mention is that the Architektenkammer has the task "to advise the members of the profession in the exercise of their activitics", $₫ 12$ no $8 \mathrm{MArchG}$. Where the professional body uses this opportunity to issue recommendations for its members concerning the exercise of their economic activities, the Architektenkammer qualifies as association of undertakings in the meaning of Article 81(1) EC. ${ }^{920}$ This conclusion appears justified also in light of $\ 12$ no 2 and $\$ \int 25$ ff. MArchG, which require the Architektenkammer to control the exercise of its members' professional activities.

\section{Examples from the medical sector}

For the medical professions in the UK the National Health Service Reform and Health Care Professions Act 2002 establishes a Council for the Regulation of Health Care Professionals. This body has the statutory function to, amongst others, promote the interests

${ }^{917}$ It is the general assembly who adopts the professional regulation, $₫ 12$ ArchG.

918 The statutes are set by the association itself, $\$ 15$ ArchG.

12 A draft was presented by the Wirtscbaftsministerkonferenz (Conference of the ministers for economic affairs of the Länder) on 22 and 23.11. 2001, see <http://www.bmwi.de>, which has been adopted by the Bauministerkonferenz (Conference of the ministers for building and planning of the Länder) on 23 and 24.05.2002, see <http://www.bmwa.bund.de>.

${ }_{920}$ See also Commission Decision Belgian architects, (2004). 
of patients and other members of the public with the professional associations ${ }^{921}$; to formulate principles relating to good professional self-regulation; and to encourage regulatory bodies (i.e. the professional associations) to conform to them. ${ }^{922}$ Sections $26 \mathrm{ff}$. of the Health Act 2002 provide for a certain degree of regulatory supervision exercised by the Council for the Regulation of Health Care Professionals over the professional associations representing the different health care professions. The Council can interfere with the professional associations if not satisfied with the rules set by the associations, or with various disciplinary decisions taken by them. However, these powers are not sufficient to shelter the governing bodies of the health care professions, in accordance with the criticised case law of the ECJ, from the application of Article 81(1) EC, as they do not include a detailed reference to specific public interest obligations.

\section{Interim observations}

The aforementioned examples illustrate that professional associations in general qualify for the element of 'association of undertakings' within the meaning of Article 81(1) EC (despite general allegations in the sector that the professions would not conduct an economic activity in the legal sense, i.e. under national law), and sustain the universal application of competition law. Whether a professional association qualifies the double tequirement of the second case law created cxception ratione personae (i.e. composition and public interest criteria) - let alone the classification out-competing the Höfner rule - depends very much on the initiative of the national legislator in organising the respective profession, as demonstrates the unfortunate trend set for the future regulatory framework in the Dutch legal services sector.

The developments in the legal services sector in the UK aiming for a strict separation of the regulatory and representative functions of professional bodies make it conceivable that the way into the regulatory future of the professions will lead to governing bodies that, as a minimum requirement, are composed in their majority of independent personages and, moreover, are obliged to observe explicit public interests specified by parliament. Often, however, the boards and other organs of professional associations are elected by the members of the profession from their midst. If at all, States only take a very limited role in the composition of professional regulatory bodies, and their influence often does not go beyond making membership compulsory. ${ }^{923}$ Moreover, the governing bodies of the professions in the Member States are often not required to adopt their measures by reference to explicit public interest criteria, which would be sufficiently determined in the law.

The conclusion adopted in this book is that in terms of a modern understanding of democratic structures the specific case law of the ECJ on possible exceptions ratione personae for private governance regimes that are at the cross-section with public governance does not meet current standards of societal and political needs. It is worrisome that the case law with its sheer minimum standards is accepted to be so influential as to curb a critical social dialogue $^{924}$ on the desitable high quality standards that should determine the regulation and

921 These are mainly the General Medical Council, the General Dental Council, the General Optical Council, the General Osteopathic Council, the General Chiropractic Council, the Royal Pharmaceutical Society of Great Britain, and the Pharmaceutical Society of Northern Ireland.

922 Section 25 Health Act 2002 (2002).

${ }_{223}$ As for instance in Joined Cases C-180 to 184/98, Pavlov, [2000].

924 As evidence the political discussions in the Netherlands on the future regulation of the legal services sector, 
structuring of the professions in accordance with modern requirements of democracy. Conversely, the UK chose to sent a remarkably powerful signal by entrusting the department for constitutional affairs with the assessment and consultation process in the legal services sector. Suffice it to cmphasis that, in providing the regulatory framework for the professions, there is still a task for the parliamentary legislators to realise in consultation with all affected societal groups the requirements of modern govcrnance subject to democratic principles and the rule of law. ${ }^{925}$ This task is not fostered if competition law should be interpteted to be necessarily agnostic as to the effectiveness of statutory provisions on the composition and the public interest criteria professional associations have to take account of in their decisions.

\subsection{Exception ratione materiae: Regulation of 'purely ethical issues'}

Limitations to the jurisdictional scope of Article 81(1) EC are conceivable not only ex ratione personae but also ex ratione materiae. The question here is whether professional regulations (rather than the body adopting them) merit an exception from the applicability of competition law because of specific values that they defend (e.g. professional ethics). The issue requires careful attention since $\mathrm{EC}$ competition law does not recognise sector specific exceptions unless foreseen in the Treaty or specific Community legislation. ${ }^{926}$ In particular no such exception has been recognised by the Community Courts for the particular field of professional regulations. The CFI unmistakably stated that "it cannot be accepted that rules which organise the exercise of a profession fall as a matter of principle outside the scope of Article 81(1) EC merely because they are classified as rules of professional conduct by the competent bodies." 927

Notwithstanding this clear position a possible exception ratione personae is ventilated hete because of the Commission who has evidenced a different point of view for the particulat field of professional regulation. In its decision EPI Code of Conduct it recognised that certain professional rules are necessary to safeguard the impartiality, competence, integrity, responsibility of the profession, to prevent conflict of interests and misleading advertisement, to protect professional secrecy or to guarantee the proper function of an institution within the framework of which the members of the profession provide their

see above.

225 See also Schepel H., (2002), 51, on the constitutionalisation of ptivate governance.

926 For instance Article $36 \mathrm{EC}$ on the production of and trade in agricultural products, sce joined Joined Cases 209 to $213 / 84$, Asjes, [1986], para. 40. Article $296 \mathrm{EC}$ on the production of and trade in arms and war material. - The Court exceptionally has recognised a limited immunity in the field of social policy by stressing that Community law itself encourages the conclusion of collective agreements between management and labour, see Articles 136 to 143 EC, and the Agreement on Social Policy concluded between the Member States of the European Community with the exception of the United Kingdom of Great Britain and Northern Ireland. It stated that social policy objectives may be seriously undermined if certain inherently competition restrictive agreements were subject to Article 81(1) EC, Case C-67/96, Albany, [1999], para. 60; Case C-219/97, Drijvende Bokken, [1999], para. 47; joined Joined Cases C-115 to 117/97, Brentjens', [1999], para. 57. AG Jacobs in Case C67/96, Joined Cases C-115/97, C-116/97 and C-117/97 and Case C-219/97,Albany/Brentiens'/Drijuende Bokken, [1999], paras. $183 \mathrm{f}$. ("limited antitrust immunity"). This expresses the balancing of different policy choices made in the Treaty. Accordingly the Court recognised that it follows "from an interpretation of the provisions of the Treaty as a whole which is both effective and consistent that agreements concluded in the context of collective negotiations between management and labour in pursuit of [social policy] objectives must, by virtue of their nature and pupose, be regarded as falling outside the scope of Article [81(1) EC]" (emphasis added). NB 'This wording actually evokes the exercise of public authority-test the Court applied in $S A T /$ Eurocontrol and Cali.

${ }_{927}$ Case T-144/99, EPI, [2001], para. 64 (emphasis added). See also above note 824. 
services. ${ }^{928}$ It appears from the Commission's decision that 'necessary' professional tules would fall outside the ambit of competition law because the Commission defines them as "not [being] liable to restrict competition".929 This approach effectively results in distinguishing two categories of professional rules on the basis of the subject matter that they cover. ${ }^{930}$ One category [would] concerns rules that are capable of having prima facie restrictive effects on competition in the ptofessional sector and thus fall within the jurisdictional ambit of the prohibition provision. The other category concerns professional obligations that, according to the Commission, "must be deemed legitimate and consistent with the ethics of the profession" and thus not to be prima facie restrictive of competition. ${ }^{931}$

At first sight the Commission's approach seems to be in line with the dogmatics of competition law since the formulation that purely ethical rules are "not liable to restrict competition" specifically and in order to assess the point, the Commission placed its 'necessity test' in the economic and legal context specific to the profession in question. ${ }^{933}$ However, the reference to both a potential restriction of competition and the economic and legal context is at the botderline with the substantive issue of assessing whether a certain type of professional rules is anti-competitive in character. The approach of the Commission in EPI Code of Conduct in fact anticipates the substantive assessment to be conducted once it has been established that a given case comes within the jurisdiction of competition law. In particular the Commission's approach bears the risk that a professional association succeeds to withdraw from the jurisdictional scope of the competition law analysis rules that it manages to present as necessary in the economic and legal context specific to the profession in question. This would not only be in contrast with the universal application of EC competition law but also with the autonomous determination of what constitutes a restriction of competition under Community competition law. ${ }^{934}$ The approach of the Commission thus provokes a similar criticism expressed above with regard to the two case law created exceptions ratione personae.

In particular the reference to specific values comes close to the idea of the public interest obligation of the second case law created exception ratione personae. A limitation of the personal scope would, however, not actually require such an obligation of public interest observance. It tather boils down to whether the rules in question are an effective tool to warrant legitimate public interest considerations. Such an approach is problematic for the reason that associations themselves will be put in the position to determine which of their measures are outside the competence of competition law. ${ }^{935}$ While this may not necessarily

${ }^{928}$ Commission Decision EPI Code of Conduct, (1999), paras. 34 ff., 38. In casu the Commission took the view that the proper functioning of the European Patent Office in Munich was safeguarded by certain rules on the professional conduct of the patent agents. The case is summarised in Chapter 2.V. See also Bicho M.-J., (1999), 26: "Graduellement, la Commission essayera de tracer une ligne de démarcation entre d'une part les règles vraiment déontologiques qui échappent au champ d'application des règles de concurrence et d'autre partles règles ou pratiques interdites." Bicho M.-J.,"Concumence dans les professions libérales: quels avantages pour le consommateur?" $(2000), 7$.

929 Para. 38 of the decision in EPI Code of Conduct.

930 See also Ehlermann C.-D., (1993), 144; Bicho M.-J., (1999), 26.

931 Commission Decision EPI Code of Conduct, (1999), paras. 34 and 38.

${ }_{932}$ Para. 38 of the decision in EPI Code of Conduct. The qualification to this general finding of the Commission is that such purely ethical rules have to be applied objectively and without discrimination.

${ }_{933}$ Paras. 35 and 38 of the decision.

${ }^{934}$ For details see below part III.

935 Conversely, in respect of rules adopted by Member States such an exception is arguable on the basis of the fact that competition law is not (directly) addressed to Member States. 
preclude a Communitarian, i.e. objective interpretation if applied consistently actoss the EC, it compromises legal certainty. Allowing an exception ratione materiae not formally recognised in the Treaty or secondary EC law undermines a consistent interpretation of the jurisdictional concepts of competition law. Most importantly, as soon as collective selfregulation influences, or is intended to influence, the conduct of the association's members on markets, a coherent interpretation of the autonomous concept of economic activity requires to include self-regulatory measures in the jurisdictional scope of Article 81(1) EC, regardless of any parallel objective that those measures may pursue. ${ }^{936}$

Apparently the Commission was aware of the potential of its standpoint in EPI Code of Conduct. It tried to limit the effect of professional associations relying on the economic and legal context specific to the profession in question, to withdraw their rules from the competition law analysis. The Commission enumerated concrete professional duties that, it considered to warrant an exception from the application of competition law. On appeal this approach seems to have obtained a certain backing of the CFI. ${ }^{937}$ Yet the CFI has not made entirely clear on which ground purely ethical rules may fall outside the scope of Article 81(1) EC - because they would either be classified as unrestrictive of competition, or because they are not covered by the probibition of Article 81(1) EC regardless of their anticompetitive character. 'The CFI first formulated the question of whether a specific selfregulatory rule on professional conduct constitutes a restriction of competition before turning to the issue of an exception ratione materiae. ${ }^{938}$ The CFI stresses that an exception ratione materiae can only be recognised whete certain activities explicitly have been removed from the ambit of the EC competition rules by the Community legislator. ${ }^{939}$ While the CFI thereby, and as a matter of principle, has rejected a subject-related exception from the scope of Article 81(1) EC, it has still given an appreciation of the argument that the anticompetitive professional rule might have been "objectively necessary in order to preserve the dignity and rules of conduct of the profession concerned" and therefore might not have had to fall "within the scope" of Article 81(1) EC. 940 The CFI thereby seems to have recognised a theoretical principle that allows to inherently justify anti-competitive conduct within the first paragraph of Article $81 \mathrm{EC}$, i.e. outside the explicit exceptions laid down in Articles 81(3) and 86(2) EC. ${ }^{941}$

There are two problems with this approach. First of all, the Commission did not provide any authority for the exception to the general jurisdictional scope of Article 81(1) EC other than the need to safeguard the 'proper functioning' of an institution within which the professionals provide their services (in casu the European Patent Office, EPO). According

\footnotetext{
936 See already Chapter 3.I.2.1. on the fine distinction made by the ECJ in Case C-519/04 P, Meca-Medina II, [2006], para. 27.

937 See Case T-144/99, EPI, [2001], para. 78.

${ }_{938}$ Paras. 63-67 of the judgment in EPI.

239 Para. 67 of the judgment in EPI.

940 Paras. $78 \mathrm{f}$. of the judgment in EPI. See also the clear critique by AG Léger in Case C-309/99, Wouters et al. $\nu N O v A$, [2002], para. 106, pointing out that the Commission's decision in EPI Code of Conduct may prove nothing but a procedural opportunism driven by the concern to avoid notifying the professional rules by EPI in the various Membet States. For details on the Wouters judgment and the notification obligation due to the exclusive competence of the Commission to take decisions based on the third paragraph of Articlc $81 \mathrm{EC}$ before May 2004, see below section II.4.2.2. The Court in Wouters however adopted exactly this solution criticised by AG Léger. The EPI judgment of the CFI therefore may be understood as the precursor to the Wouters judgment of the ECJ, and in particular paras. 97 to 110 thereof.

${ }^{941}$ For details on Article 81(3) EC see Chapter 7.I.
} 
to the Commission the proper functioning of that institution required the professionals to comply with rules of professional conduct. The Commission apparently assumed as selfevident that the proper functioning of the EPO is necessary to be safeguarded. Why that functioning is best or necessarily safeguarded through professional obligations the Commission left unexplored. It is noteworthy that these professional obligations had not been adopted by the institution itself but had been left to the collective representation of profcssionals who provide services in competition with other service providers. ${ }^{942}$ The regulation of the relevant professional conduct was thus left to representatives of the economic interest of the members of the profession in question. This is not a reason to exclude the application of Article 81(1) EC, quite to the contrary. ${ }^{943}$

An alternative explanation for the non-application could conceivably have been the wellfunctioning of the administration of patent protection necessary in the interest of legal certainty. However, a reference to the well-functioning of the patent protection system would have revealed that the Commission's decision expanded into aspects that are not relevant in terms of the competition considerations as foreseen by the first paragtaph of Article $81 \mathrm{EC}$. Rather the Commission would have needed to ventilate its considetations within the frame of either Article 81(3) EC or $\Lambda$ rticle 86(2) EC instead.

Secondly, the professional duties listed by the Commission as legitimate and consistent with the ethics of the concerned profession are not final or exhaustive as they depend on the specific (i.e. national) characteristics of the respective profession and the rules governing it. ${ }^{944}$ While that approach warrants flexibility in determining the professional duties that are allegedly indispensable to a profession, it contrasts to a certain extent with the absolute character of the professional ethics that the Commission seemed to imply in order to motivate an exception ratione materiae. The question thus arises whether the listed professional obligations are self-sufficient or whether they have to be determined each time again for every profession in a specific Member State or region. In the appeals proceedings the CFI stressed that "only an examination on a case-by-case basis permits an assessment of the validity of [a rule of professional conduct] under Article 81(1) EC, in particular by taking account of its impact on the freedom of action of the members of the profession and on its organisation and also on the recipients of the services in question." ${ }^{245}$ The conclusion that can be drawn here is that the Community institutions may be willing to save certain professional rules from the full force of competition law by implicitly granting an exception ratione materiae.

942 For instance, for the filing of patent applications with that institution.

943 See above section I.1.2.

944 Para. 34 of the decision. The Commission enumerates as professional dutics those of competence, impartiality, integrity, responsibility, avoiding conflicts of interest, maintaining professional secrecy and not engaging in misleading advertising. Note that the decision and the appeal respectively were decided three years and one year before the ECJ ruled on the Wouters case. While the legal solution adopted in the latter case does not have recourse to Article 81 (3) or 86 (2) EC either, it presents a reasoning according to which professional regulations, which positively restrict competition, may not fall within the probibition laid down in Article 81(1) EC. Although using a different legal technique the ECJ in Wouters similarly referred to the overall context in which the decision of the professional association was taken or produces its effects, Case C-309/99, Wouters et al. $\nu$ NOvA, [2002], para. 97: 'More particularly, account must be taken of its objectives, which are here connected with the need to make rules relating to organisation, qualifications, professional ethics, supervision and liability, in order to ensure that the ultimate consumers of legal services and the sound administration of justice are provided with the necessary guarantees in relation to integrity and experience." For a more in depth analysis of this Wouters proviso see below section II.4. and Chapter 7.I.2.5.3. See also above note 940.

945 Case T-144/99, EPI, [2001], paras. $64 \mathrm{f}$. 
While the effort to save certain 'core values' of the professions is acknowledgeable to warrant a solid basis for the functioning of the professions - rather than an institution extraneous to the profession (like the EPO) - the approach of the Commission and the CFI in EPI Code of Conduct have to be criticised for creating yet another exception to the jurisdictional ambit of competition law, this time however even without requiring an explicit or inherent reference to the public interest and the interests of other groups affected by the professional rules, as is required by the two case law created exceptions ratione personal discussed above. It is doubtful whether, for the purpose of determining the jurisdictional scope of Article 81(1) EC, a sensible line of demarcation ${ }^{946}$ can be drawn to identify, on the one hand, provisions that serve the aims of guaranteeing the ethics, dignity and reputation of the profession, as well as the quality of the services provided by the televant profession and, on the other, provisions which simply protect the interests of a profession and ate not necessary to guarantee the aforementioned aims - without going into the substantive scrutiny of whether such rules restrict the freedom of competition. To draw such a distinction appears hazardous in light of the fact that even 'purely ethical' rules invariably affect the economic activities of the members of the profession. ${ }^{947}$

Moreover, each Member State and even each group of regulated profession have different standards of deontology and different perceptions of which types of regulation touch upon ethics and which do not. One may ask a German and French lawyer about the fixing of their fees: whereas the French lawyer is free to set her fees as she likes to ${ }^{948}$, the German lawyer is bound by the RVG establishing a fixed fee for almost every kind of activity. This mechanism of German law is said to protect the client who cannot be surprised by the fees established by her lawyer, and to guarantee the independence of the lawyer from her client. ${ }^{949}$ To abide the approach adopted by the Commission in EPI Code of Conduct bears the risk that the assessment of whether a certain type of professional tegulations comes with the jurisdictional scope of EC competition rules may in the end depend on the national background of the case handler at the Commission. Therefore, an exception to the scope of Article 81(1) EC ratio materiae should be excluded.

\section{Substantive assessment under Article 81(1) EC: the object and effect of professional regulation}

Heretofore this chapter has discussed the jutisdictional elements specific to Article 81(1) EC. The chapter's second part turns to the article's substantive element of competition law assessment, which focusses on whether the identified actors (undertakings and association), through their conduct (agreement or decision), inhibit what

946 Ehlermann C.-D., (1993), 144.

947 See note 936.

948 Although bound to determine her fees in agreement with her client and in compliance especially with the principle of scrupulousness. She even can conclude an agreement which provides, in addition to the remuneration of the services rendered, for an additional fee to be fixed depending on the result obtained or the service rendered. Fixing fees as being solely dependent on the legal result, however, is forbidden. See Article 3.5 of the Laws of the Paris Bar. In France fee tariffs of liberal professions have been prohibited by the Commission de la concurrence, see Ehlermann C.-D., (1993), 144.

949 Rechtsanwaltsvergütungsgesetz (RVG, Lawyers Fees Act), formerly BRAGO (Lawyer Fees Act) (1957). Note that the relevant rules are not adopted by the professional association but are laid down in a federal law. However, for the sake of the argument that fact does not play a role as tariff fixing also occurs at the level of professional associations, see for instance the Belgian Architects case summarised in Chaptcr 2.V.11. 
Article 81(1) EC aims to protect. This refers to the freedom of competition and, within the subject of this book, leads to the overall question of whether and to what extent professional self-regulatory rules "have as their object or effect the prevention, restriction or distortion of competition within the common market" (Article 81(1) EC).

In four sections a systemic approach will be proposed on how to interpret, determine and apply the substantive critetion of Article 81(1) EC. The first section will explain the general interpretation of the concept of restriction of competition, the distinction between restrictions by object and by effect, and the boundaries that the case law sets the concept of restriction. The second and third sections respectively will turn to scrutinise various types of professional tules that impact on the entry to, and conduct of the professionals on, a specific market for professional services. In particular the question will be which types of professional rules are liable to restrict competition by object or by effect. The fourth section will shed light on the solution that the Court adopted in Wouters in delimiting the scope of the first paragraph of Article $81 \mathrm{EC} .{ }^{950}$ The scrutiny will be on whether that case law in fact circumscribes the element of substantive assessment under Article 81(1) EC or whether it constitutes a (further) case law created exception to the scope of Article 81(1) EC ex ratione materiae $^{951}$ that is alien to an objective interpretation of the concept of restriction of competition. While some scholars ably rationalise the Court's final approach by reference to the ancillary restraints doctrin $\mathrm{e}^{952}$, I challenge that the ECJ in Wouters applied a variant of that doctrine to the professional rules of the Dutch lawyers association. ${ }^{953}$ More particularly the fourth section will examine whether and to which extent the Court exceeded the substantive scope of the first paragraph of Article $81 \mathrm{EC}$ - in spite of formally remaining therein - by importing considerations that belong to the sphere of justification grounds and thus are usually to be tested at a later stage of the scrutiny.

\section{The concept of restriction of competition}

The substantive scope of Article 81(1) EC is defined by the concept of restriction of competition, which is the heart of that article. ${ }^{954}$ In brief the concept refers to methods by which undertakings can reduce uncertainty about the future conduct of other market participants, be it through agreements, concerted practices or decisions, and which serve the purpose of orchestrating their economic activities. ${ }^{955}$ Article 81(1) EC prohibits such methods as they are in conflict with the aim of competition law, which is to foster the

950 Case C-309/99, Wouters et al. v NOvA, [2002], from para. 97 onwards.

951 In EPI code of conduct the Commission applied that classification as not restrictive of competition, and again more recently in case Piau. While in EPI the CFI upheld the Commission's findings as a matter of principle (but did not completely follow the Commission's findings down the line), see before. The Commission and the CFI in Piau were less explicit on the criterion of anti-competitive restrictiveness of the rules regulating the profession of football players' agents. While the Commission applied an objective justification test, it did not use it to argue a case of ancillary restraints, but to conclude that there was no "Community interest" in continuing the EC competition procedure with regard to a number of restrictions imposed by the FIFA on professional football players' agcnts, Case T-193/02, Piau I, [2005], para. 22. The CFI found no manifest error in that assessment, paras. 80-96 of the Piau judgment.

952 See the (helpful) analyses to this effect by Loozen E., (2006), 39, devcloping a concept of 'deontological ancillarity'; and Whish R, (2003), $120 \mathrm{ff}$, developing a concept of 'regulatory ancillarity'. For details on the ancillary restraints doctrine see below section II.1.2.2.

953 For details see below section II.4.

954 Jones A. / Sufrin B., (2004), 158.

955 See above note footnote 695 . 
process in competitive markets. ${ }^{956}$ Such markets require competitors to compete for better prices, better quality and better choices in terms of variety. A certain level of uncertainty on future conduct, market power and developments is inherent to markets being competitive.

\section{An economic concept interpreted objectively: Allocative (in)efficiencies and relative rise in price}

While being a legal requirement of Article 81(1) EC, the concept of restriction of competition is an economic one. To start with it needs to be interpreted autonomously, i.e. independently of national preferences. In abstract terms the commitment to the process in competitive markets implies that firms produce what buyers want and are willing to pay for. ${ }^{957}$ In economic theory this is referred to as allocative efficiency, i.e. effective allocation of resources to their best use. The guarantor for allocative efficiencies is the unimpeded market mechanism, which - at least in an idealised world and from a macroeconomic perspective - allows market participants and users to operate in a way that makes efficient and spating use of all resources, such as raw materials, goods, workforce, capital, knowledge and proficiency, time, the environment. ${ }^{958}$ Therewith, the mechanism contributes to economic stability, which is one of the fundamentals for a peaceful coexistence and understanding between peoples and societies.

In competitive markets undertakings and customers choose best use of scarce resources by ordering preferences; they make choices within constraints to maximise results (benefits, not necessarily monetary ones, e.g. quality) and minimise efforts (costs). Consequently, and formulated negatively, firms should not produce what buyers do not want and/ or are not willing to pay for, namely restricted output in terms of quality, quantity and variety, as these

956 In the following the three different terms (prevention, restriction, distortion) are used synonymously to include the other two respectively as they represent different forms of inhibitions that are equally harmful to the development of markets. See also Ritter I., et al., (2000), 96.

${ }^{257}$ Van den Bergh R. / Camesasca P.D., (2006), 18, 29.

${ }^{258}$ In economic theory the counterpart to the individual economic freedom of action is the guarantee of allocative efficiency. This implies that firms produce what buyers want and are willing to pay for. In its origins the law of Article 81(1) EC has been inspired by ordo-liberal ideas, which advocate the individual economic freedom of action. Consequently, the stance that the Community Courts and the Commission have taken in interpreting Article 81(1) EC reflects a broad understanding of what constitutes a restriction of economic freedom that an entity may engage in. Ordo-liberal ideas in competition have been developed in Germany in the Freiburg School. "The Freiburg School was a neo-liberal School of thought that emerged in the 1930s and which played a significant role after the Second World War in the development of economic policy and competition law in Germany and in Europe. Its most prominent representatives were the economist Walter Eucken and the lawyer Franz Böhm. Thus, contrary to what is often believed, inter-disciplinary research in Competition Law and Economics did not start at the University of Chicago in the 1950s. It was preceded by the German ordo-liberals, who endorsed a clear instrumentalist view of the legal system by viewing legal rules, such as cartel prohibition, as tools to attain economic goals. As stated by Franz Böhm, the language of economics must be translated into the language of legal science to crate the conditions for an effectively functioning competitive market," Van den Bergh R.J. / Camesasca P.D., (2006), 65, and 56; Gerber D.J., (1998), 46. Until the 1990's the ordo-liberal appreciation of competition in the $\mathrm{EC}$ was little influenced by the two main economic schools of thought in the US, the Chicago and the Harvard schools, although the analytical model of the latter complemented European competition policy, Van den Bergh R.J. / Camesasca P.D., (2006), 56. The Chicago School is based on neoclassical price theory, see Posner R.A., (1998). "Chicago lawyer-cconomists caused a revolution in thinking about antitrust issues. [...] The confrontation between the classical, legal dogmatic approach to antitrust law and the micro-economic mode of analysis gave rise to an extremely rich new theory based on efficiency", Van den Bergh RJ. / Camesasca P.D., (2006), 78. Since the mid-1990s, European competition policy started to be substantially revised. Many ideas of modern industrial economic theory have been taken into account in the formulation of recent secondary legislation. 
will only result in higher prices. In other words, where players manage to raise their prices - without counterbalancing competitive market forces compelling them to adjust their prices again to a level that is reasonable in view of the quality offered - there is a distortion of competition. In fact, a restriction of competition can be identified as an artificial raising of prices in relation to quality or quantity of products and services. ${ }^{959}$ Hence, an attificial price tise is to be determined in a relative sense.

This means that it not only may occur in an obvious way by taising the amount of money to be paid for a defined quality, but it can also take the form of maintained prices with a reduced quality. An artificial reduction in quantity results in a respective, i.e. indirect raise of prices. A decrease in prices may also reflect a distortion of competition if at the same time the respective quality of the goods or services is lowered even further. In other words, where the ratio price-quality (including the demanded quality level) becomes artificially unbalanced, competition will be restricted. Conversely, a taise in absolute prices does not necessarily reflect a distortion of competition if the quality is raised accordingly. ${ }^{960}$ This is also true if the quantity of the product or services decreases due to circumstances outside the sphere of influence of the parties. The assessment whether a certain measure (adopted between undertakings or by an association) has an adverse impact on competition on a given market thus requires an economic analysis ${ }^{961}$ of the context in which an agreement or decision occurs. Before turning to examining in more detail the extent to which the context determines the boundaries of the substantive element in section 1.2., the following section will explain the distinction that Article 81(1) EC draws between conduct that either has the object to restrict competition (hatd core restrictions) or the effect of doing so.

\subsection{The distinction between restriction by object and by effect}

Competition law is concerned with the prevention of restrictions of competition to occur or the dismantling of any such testrictions. In this it is agnostic as to the motives of conduct. Consequently and due to the objective interpretation of the concept of restriction, no actual proof of subjective intent - on the side of the undertakings or an association - to restrict competition is required when scrutinising the substantive criterion of Article 81(1) EC. ${ }^{962}$ While this is evident for the second vatiation of the substantive element of Article 81(1) EC - which looks into the effects of an agreement or decision - it is also true for its 'object' variation as will be explained below. In a given case it is not necessaty to demonstrate both object and effect to restrict competition. It is sufficient that the circumstances of a case lead to the conclusion of either as the two variations are alternatives of the substantive element and therefore need to be read disjunctively. ${ }^{963}$ They need not be tested cumulatively, but alternatively. ${ }^{964}$ The two categories can be thus dealt with separately

959 Odudu O., (2001), 262 f., with further references to relevant literature in his notes 8 and 9. Lugard P. / Hancher I., (2004).

${ }_{960}$ Oversupply, i.e. the supply of a higher quality than wished by the customer, may, however, also constitute a distortion of competition despite a simultaneous raise of price.

961 See for instance Whish R, (2003), 108, 117.

962 Goyder D.G., (2003), 97.

${ }_{963}$ Case 56/65, STM $\nu$ Maschinenbau Ulm, [1960], p. 249: "The fact that these are not cumulative but alternative requirements, [is] indicated by the conjunction 'or'." See also Case T-1/89, Polypropylene (Rbône-Poulenc), [1991], para. 115; Case T-8/89, Polypropylene (DSM), [1991], para. 221; Case C-219/95 P, Ferriere Nord SpA v Commission, [1997], paras. $13 \mathrm{ff}$.

${ }_{964}$ This means that in a given case it is first necessary to consider the object of a decision or clause. Only if it 
to bring out their differences. Moreover, a substantive assessment of a particular agreement or decision cannot be conducted in the abstract and it thus is necessary to define the relevant market in which the agreement or decision occurs. However, the extent to which this market needs to be determined differs with the circumstances and usually requires a more elaborate economic analysis in respect of the 'effect' requirement in respect of which it therefore will be presented later in this section.

\section{Restrictions by object: presuming intention to restrict competition}

In competition law certain conduct is considered particularly harmful to the competitive process in the market. As a matter of competition policy, the law defines a limited class of agreements and decisions to have as their object the restriction of competition. In a non exhaustive way Article 81(1)(a)-(e) EC lists particularly grave examples of restrictions of competition, which can be understood to indicate a restrictive object. ${ }^{965}$ For instance, arrangements that restrict prices or market access, but also typical 'Common market restrictions', like the partitioning of the market along geographical borders, are considered to be hard core restrictions of competition without it being necessary to look into their actual effects. They are prohibited $a b$ initio, provided that the other requirements of Article 81 (1) EC are met. ${ }^{966}$ Further typical 'object' restrictions are price fixing (and the exchange of price information $)^{967}$, market sharing ${ }^{968}$, the limiting of output, collective boycotts ${ }^{969}$, information exchange ${ }^{970}$, export restrictions (market integration) ${ }^{971}$.

The injurious nature of such conduct is due to the fact that it has the objective to artificially organise the operation of the market. According to the orthodox view an agreement or decision has the object to restrict competition because it is so likely to affect competition that it necessarily has the effect of restricting competition. ${ }^{972}$ In the same vein, this presumes the anti-competitive effect and reasons on this basis that no actual effect on competition needs to be demonstrated. The result of this view is that such presumption of

is not clear whether the object of an arrangement is to harm competition is it necessary to consider whether it might have the effect of doing so. See Case C-306/96, Javico, [1998], para. 22, and the case law referenced below in note 995. Whish R, (2003), 109 ff.; Odudu O., (2001), 60; Bellamy \& Child / Rose V,, (1993), para. 2.-097.

${ }^{965}$ These are agreements or decisions which: "(a) directly or indirectly fix purchase or selling prices or any other trading conditions; (b) limit or control production, markets, technical development, or investment; (c) share markets or sources of supply; (d) apply dissimilar conditions to equivalent transactions with other trading parties, thereby placing them at a competitive disadvantage; (e) make the conclusion of contracts subject to acceptance by the other parties of supplementary obligations which, by their nature or according to commercial usage, have no connection with the subject of such contracts."

966 In particular, they have to have an appreciable effect on trade between Member States, see Chap. 3.II., and on competition. This means that where parties argue that their behaviour, in a quantitative sense, does not appreciably affect competition or trade between Mcmber States, their argument conceptually concerns a different matter from arguing that the practice is not restrictive of competition, Whish R., (2003), 111.

967 See Case C-264/96, ICI, [1998].

368 Sce Whish R, (2003), 478.

969 Case 71/74, Frubo, [1975].

970 Case C-359/01 P, British Sugar, [2004].

971 See Joined Cases 56 to 58/64, Consten and Grundig, [1966].

972 For instance Goyder D.G., (2003), 96; Hildebrand D., (2001), 35. The teference for the orthodox view is to Case 19/77, Miller, [1978], para. 7. AG Jacobs in Case C-67/96, Joined Cases C-115/97, C-116/97 and C117/97 and Case C-219/97, Albary/Brentjens'/Drijuende Bokken, [1999], para. 252: "clear-cut tules, which simply identify restrictions of conduct of individual traders, normally provide a valid basis forpresuming an anticompetitive effect and also promote desirable legal certainty" (emphasis added). 
anti-competitive effects becomes irrefutable.

This would, however, overstate the concept of restriction by object and Odudu aptly explains that it is not so much the anti-competitive effect of an agreement or decision that can be presumed under the object requirement, but the subjective intention of the (association of) undertakings to have their conduct have the effect to restrict competition. ${ }^{973}$ The presumption of intention is again rebuttable by demonstrating other prevailing motives that evidence an intention either not to harm or even to increase the competitive process. ${ }^{974}$

To presume subjective intention is possible on the basis of objectively observable conduct, in which the subjective intention has manifested itself. ${ }^{975}$ This deductive process is necessary because subjective intention cannot be proven as a fact as it is not possible to look in to the human mind. ${ }^{976}$ Moreover, in cases where the actor's legal personality rests in a corporate structure the latter does not have a mind of its own to develop a subjective will. The conduct of corporate structures could thus never qualify the object requirement. The invariably injurious nature of per se restrictions is based on an agreement's or decision's natural and foreseeable consequences that facilitate the partitioning of the (common) market. Within the frame of Article 81 (1) EC the Court of Justice simply tejects the idea that the test of intention is subjective. Instead it 'objectivises' the idea of subjective intention by relying on necessary effects. ${ }^{977}$ Such objectivised intention thus can be established not only with

973 Odudu O., (2001), esp. $384 \mathrm{f}$.

974 Odudu O., (2001), esp. 384 f.: "The Court of Justice uses 'nccessary effect' as an indicator of subjective intention, drawing a distinction between the meaning of object and the way that the object requirement is satisfied. It is because the presumption of intent from effect is rebuttable that practices with the same necessary consequences can be treated differently". For details on the possibilities to rebut the presumption of intention, see below section II.1.2. on net effects and ancillary restraints. See Case 107/82, AEG-Telefunken, [1983], para. 34; Case 262/81, Coditel (No. 2), [1982], para. 16. In his note 36 Odudu stresses that the "potential for legitimate schemes being used to cloak prohibited intentions explains the need for the selection criteria to be objective and qualitative."

975 Odudu O., (2001), 385.

976 The law should not sanction a human's character but her deeds. Odudu O., (2001), 69 f., accurately explains how subjective intention is objectively determined not only in a competition law context but also in criminal law (intent) and even contract law (subjective meeting of the minds). The objective determination is a means by which to determine subjective intention "since we can only know what is in a man's mind from external manifestations." See also Lianos I., "Collusion in Vertical Relations under Article 81 EC", (2007), 42: "An instrumental approach to the definition of the concept of collusion should aim to develop administrable ctiteria that will link the finding of collusion to the existence of harm to competition. 'These criteria should also recognize that it is not the objective of Article 81 to sanction any type of conduct that may produce negative consumer welfare effects but that this provision exclusively aims at collusive behaviour. It follows that if the conduct of the parties is perfectly consistent with individual profit-maximizing behaviour and that it is not the result of inducement or constraint from another market actor, Article 81 should not apply. Nevertheless, a counterfactual test that would attempt to identify the most profitable strategy for the firm, in the absence of an agreement, and compare it with its actual conduct in order to find the existence of collusion would impose on the competition authority or judge the impossible task of second-guessing the strategy of the firm, without having adequate information on its incentives, its costs and estimated short or long-term profits. Such a test should be avoided. In the absence of any direct evidence of an agreement, the inquiry should focus on observable patterns of behaviour, which along with a thorough analysis of the incentives of the parties would indicate the exercise of inducement or constraint to adopt the specific conduct."

977 Odudu O., (2001), 384. Joined Cases 29/83 and 30/83, CRAM and Rbeinzink, [1984], para. 26: "Tn order to determine whether an agrcement has as its object the restriction of competition, it is not necessary to inquire which of the two contracting parties took the initiative in inserting any particular clause or to verify that the parties bad a common intent at the time when the agreement was concluded. It is rather a question of examining the aims pursued by the agreement as such, in the light of the economic context in which the agrcement is to be applied" (emphasis added). See also Bavasso A., (2005), 620, explaining the differences in analytical approaches between 
regard to undertakings but also with regard to associations of undertakings. Hence, a breach of Article 81(1) EC by associations can be established "insofat as their own activities or those of the undertakings belonging to them are calculated to produce the results which Atticle [81(1) EC] aims to suppress.".978

Where the subjective intention of the parties to restrict competition can be presumed on the basis of the objective (i.e. the factual and legal) circumstances in which an agreement or decision is adopted and/ or applied, this is sufficient to prohibit the agreement or decision. The presence or absence of actual effects can neither confirm nor deny subjective intention and thus the presumption of subjective intention (however objectivised) makes it redundant to look into actual effects. ${ }^{979}$ Consequently, no concrete anti-competitive effects on the market need to be demonstrated by the competent authority or a claimant. ${ }^{980}$ The rationale for not looking at effects is that 'object' restrictions are considered to be invariably injurious, so that an enquiry into the actual effects, which requires a costly market analysis, is superfluous. ${ }^{91}$

There is a twofold explanation why under its object requirement Article 81(1) EC can be breached without it being necessary to demonstrate actual harmful effects on competition. The first is a preventive atgument and the second a punitive one. ${ }^{982}$ The aim of Article 81(1) EC is to prevent restrictive effects from occurting, and it does so by prohibiting undertakings and their associations to pursue conduct that invariably is considered to be injurious to competition. Moreover, in economic terms the attempt to restrict competition is just as problematic as is succeeding in testricting competition (for instance due to the resources that are consumed in such an attempt), and it is therefore justified to prohibit agreements and decisions the natural and foreseeable (or "necessary") consequences of which are to restrict competition without it being required that those consequences actually occur. The punitive rationale behind the prohibition of 'object restrictions' is the classical justification in criminal law for punishing attempt. ${ }^{93}$ Whether an attempt succeeds often is

legal and economic thinking: "we need to recognise those differences to avoid a communication failure...".

978 Joined Cases 209 to 215 and 218/78, van Landenyck, [1980], para. 88 (emphasis added); see also Commission Decision COAPI, (1995). AG Léger in Case C-309/99, Wouters et al. v NOvA, [2002], para. 62: Article 81(1) EC "seeks to prevent undertakings from being able to evade the rules on competition on account simply of the form in which they coordinate their conduct on the market. To ensure that this principle is effective, Article [81(1) EC] covers not only direct methods of coordinating conduct between undertakings (agreements and concerted practices) but also institutionalised forms of cooperation, that is to say, situations in which economic operators act through a collective structure or a common body."

979 Odudu O., (2001), 71. The Court frequently reaffirmed the position that, if the object of an agreement or decision is the restriction of competition, there is no need also to show that it might have an anti-competitive effect. See Joined Cases 56 to 58/64, Consten and Grundig, [1966], p. 342: where an agreement has the abject of restricting competition, "for the purpose of applying [Article 81(1) EC], there is no need to take account of the concrete effects.". This point is actually shared by the view presented here and the orthodox view. See also Joined Cases T-374/94, T-375/94, T-384/94 and T-388/94, European Night Services Ltd (ENS) e.a., [1998], para. 136; Commission Decision TACA II, (1999), para. 381; Commission Decision FETTCSA, (2000), para. 135; Case T-213/00, CMA CGM and others v Commission, [2003], para. 183; Commission Decision Amino Acids, (2001), para. 230. However, the effect that an 'object restriction' may have is relevant to determine the seriousness of an infringement and hence the amount of any fine, Commission Decision Amino Acids, (2001), paras. 261-298.

980 A further consequence is that in order to establish a restriction by object it is not necessary that all parties to the agreement share the same subjective intention to restrict competition.

981 Consequently, where an agreement or decision is found to have the object to restrict competition, the absence of an anti-competitive effect cannot rebut the illegality of the agreement or decision.

${ }_{982}$ Odudu O., (2001), 71.

${ }_{983}$ In fact the present section evidences the proximity of competition law with criminal law, which in recent 
a function of chance rather than of choice, but the choice is sufficient in itsclf. The element of restriction by object therefore does not require actual effects to be proven or even that they occur. The advantage resulting from this is a rule that is simple to administer and predictable. ${ }^{984}$

However, this rule becomes more complex once a party manages to demonstrate that its conduct did not serve the purpose of restricting competition, thereby rebutting the presumption of its subjective intention to do so. In fact, an undertaking or association may establish that it was without any anti-competitive intention by demonstrating that it was participating in an agreement or decision, or any meetings leading to the adoption thereof, in a spirit that was not to restrict competition. For instance an undertaking might be able to establish that it had indicated to its competitors that it was participating in a spirit that was different from theirs. ${ }^{985}$ It thus depends on the circumstances of a specific agreement or decision whether certain typical 'object' restrictions - like price fixing or market sharing will ultimately be scrutinised as 'effect' restrictions. ${ }^{986}$ On the other hand, once it is determined that the object of an agreement or decision is to restrict competition no possible favourable effects of the agreement or decision can be taken into account, at least not under the first paragraph of Article 81 EC. ${ }^{987}$

The gravity of the object category of restriction of competition finds its reflection in the fact that, generally speaking, hard core restrictions cannot normally be exempted from Article 81(1) EC in another way than by an individual assessment on the basis of Article 81(3) EC. ${ }^{988}$ For instance, no exemption by way of regulation is available for object restrictions. Block exemption regulations adopted under Article $83 \mathrm{EC}$, which give effect to Article 81(3) EC, generally exclude per se restrictions from the benefit of an abstract exemption applicable to classes of covenants adopted by undertakings and their associations. The reason is that object restrictions do not invariably meet the conditions for exemption of Article 81(3) EC and reflected by the Block Exemption Regulations (a 'Schengen visa' for competition restrictions). In other words, they are not normally considered to contribute to the improvement of the production or distribution of goods or services, or to promote the technical or economic process, while allowing consumets a fair shate of the resulting benefit to the undertakings. ${ }^{989}$

years has become more pronounced by the introduction of criminal sanctions for competition infringements in several jurisdictions.

984 Odudu O., (2001), 62 f. Odudu refers to Webb T.R., (1983), 709 f.

985 For instance Joined Cases C-403/04 P and C-405/04 P, Sumitomo Metal, [2007], para. 47.

986 See Whish R, (2003), 108, 113-115, who is pointing out that, in certain circumstances, even agreements on prices may be considered as 'cffects' restrictions rather than 'objet' restrictions. This becomes evident where the object requirement is understood as a presumption of the intention to restrict competition, a presumption that can be rebutted. If so, one needs to look at (actual or potential) effect.

${ }_{987}$ Joined Cases 56 to 58/64, Consten and Grundig, [1966], p. 343. Sec also AG Slynn in Case 123/83, BNIC v Clair, [1985], pp. 398 f.; and AG Tesauto in Case C-250/92, Gettrup-Klim v DLG, [1994], para. 16. For details on the boundaries of Article 81(1) EC under the ancillary restraints doctrine, sce below section II.1.2.2. For details on taking account of beneficial effects of a measure that are outside the question of allocative efficiencies see Chapter 7.

988 See Joined Cases T-374/94, T-375/94, T-384/94 and T-388/94, European Night Services Ltd (ENS) e.a., [1998], para. 136: "In the [...] case [of an agxecment containing obvious restrictions of competition], such restrictions may be weighed against their claimed pro-competitive effects only in the context of [Article 81(3) EC], with a view to granting an exemption from the prohibition in [Article 81(1) EC]" (emphasis added).

${ }^{989}$ Subject to the further conditions of Article 81(3) EC, i.c. that the restrictions do not impose on the undertakings concerned restrictions that are notindispensable to the attainment of the objectives referred to, and 
The same idea of requiring an individual or case-by-case assessment is also reflected in the Commission notice on agreements of minor importance. ${ }^{990}$ This notice gives guidance on how to apply the requirement stemming from the case law that a restriction of competition must be 'appreciable' to fall within the scope of Article 81(1) EC. ${ }^{991}$ In other words, in assessing the substantive element of Article 81(1) EC account must be taken of the 'ponderable' impact of a restrictive conduct on competition. The de minimis notice exemplifies categories of circumstances in which an agreement or decision lacks sufficient importance to be capable of appreciably restricting competition. However, object restrictions cannot benefit from the general assumption of the notice. ${ }^{992}$ An individual assessment may nevertheless lead to the conclusion that a particular object restriction does not restrict competition to an appreciable extent. It is for the competent authority to take a decision to this effect. This does, however, not mean that the de minimis rule would require the demonstration of any actual or potential effect of an agreement or decision. ${ }^{993}$ The whole purpose of the object requirement as presumed subjective intention would be temoved if this intention had to manifest itself in some concrete anti-competitive effect, whether ponderable or not. ${ }^{994}$

\section{Restrictions by effect and market definition}

Whete an agreement or decision does not have the object to restrict competition it is necessary to scrutinise its effects on the market. ${ }^{95}$ The criterion used to determine whether an agreement or decision is liable to restrict competition consists of considering competition within the actual context in which it would occur in the absence of the agreement. ${ }^{996}{ }^{\mathrm{Th}} \mathrm{Th}$

that the restrictions do not afford such undertakings the possibility of eliminating competition in respect of a substantial part of the products or services in question. See Chapter 7.I.

990 European Commission, Commission Notice on agreements of minorimportance wbich do not appreciably restritt competition under Article 81(1) of the Treaty establishing the European Community (de minimis). While Commission notices are not legally binding, they serve the purpose to present the interpretation of competition law concepts in a systematic way and as distilled from the case law. However, it is for the Court to ultimately interpret EC law provisions (Article 220 EC).

991 The de minimis doctrine was first formulated in Case 5/69, Völk, [1969], which in fact concerned an object restriction.

${ }_{922}$ The notice includes a list of hard core restrictions that are incapable of benefiting from the de minimis threshold.

${ }_{993}$ Faull J. / Nikpay A. (Eds.), (1999), para. 2.68, argue to that effect.

${ }_{994}$ According to Odudu O., (2001), $61 \mathrm{f}$., three interpretations suggest themselves when considering the function of de minimis in determining whether the object condition of Article 81(1) EC is satisfied: "It may be that parties must subjectively intend appreciably to restrict competition. Aiming at a small restriction is insufficient to satisfy the condition. An alternative approach is that once we show that the object of the agreement [or decision] is to restrict competition, the burden of proof shifts, leaving it for the parties to show the agreement does not have an appreciable effect. The final approach is that in 'object' cases the de minimis requirement is only considered when looking at the affect on interstate trade. Either approach is preferable to an interpretation that requires demonstrating an actual effect." - Whilst I agree with the propositions I suggest that the requirement of an affect on interstate trade is a generally applicable one, see Chapter 3.II.

295 Joined Cases T-374/94, T-375/94, T-384/94 and T-388/94, European Nigbt Services Ltd (ENS) e.a., [1998], para. 136. Case 23/67, Brasserie de Haecht, [1967], p. 40; Case 5/69, Völk, [1969]; Case C-234/89, Delimitis, [1991]; Case T-7/93, Langnese-Iglo, [1995]; Case T-328/03, O2 (Germany), [2006], para. 68.

${ }_{996}$ Case 56/65, STM vMascbinenbau Ulm, [1966], p. 250; Case 22/71, Béguelin, [1971], para. 17; Case 42/84, Remia and Nutricia, [1985], para. 18; Case 31/80, L'Oréal, [1980], para. 19; Case 31/85, ET A Fabriques d'Ébauches, [1985], para. 11. 
is a more onerous task than demonstrating the 'object' of an agreement or decision ${ }^{997}$, which either the Commission or the party claiming an infringement of Article 81(1) EC has to conduct. The effects requirement of Article 81(1) EC prohibits both actual and purely potential anti-competitive effects arising from the agreement or decision at stake. ${ }^{998}$ They have to be sufficiently appreciable. "999 "For an agreement to be restrictive by effect it must affect actual or potential competition to such an extent that on the relevant market negative effects on prices, output, innovation or the variety or quality of goods and services can be expected with a teasonable degree of probability."1000

Whether an agreement or a decision qualifies for this substantive element of Article 81(1) EC depends on the economic interpretation of the tested conduct and thus requires an analysis of its market context. More than with regard to the object requirement the assessment of the effects of a decision has to take account of the actual conditions in which the arrangement functions. This means to take account of the economic and legal context in which the undertakings operate, the products or services covered by the or decision and the actual functioning and structure of the market concerncd. ${ }^{1001}$ The difference between the object and the effect requirement in this respect is that the market analysis usually is more extensive with regard to the latter since the former, as explained before, merely looks at the natural and foreseeable (or 'necessary') effects. ${ }^{1002}$ Conversely, the effect category requires to look at the actual effects that occurred or yet have to occur in the relevant market.

The extent of the relevant market definition does not need to be all-embracing though. The Court has specified that only to the extent that the competition restrictive character of an agreement or decision cannot be established without an extensive market definition will the competent authority have to conduct such market scrutiny.

" $[\mathrm{t} t]$ is settled case-law that, for the purposes of applying Article 81(1) EC, the reason for defining the relevant

927 One of the important differences between the object requirement and the effect requirement is that the former is easier to administer since it does not require a full and costly market analysis. Also see Odudu O., (2006), stating that competition authorities try as often as possible to make an 'object' case rather than an 'effects' case, due to the different requirements for proving the case. See however the 'counterfactual' analysis recently required by the CFI in Case T-168/01, GlaxoSmithKline, [2006].

${ }_{998}$ One has to look at the actual effects if the arrangement is implemented, or at the effect it will have if it is yet to be implemented, Goyder D.G., (2003), 98. A distinction between implemented and non-implemented agreements or decisions does not need to be struck with regard to the object requirement. That category takes account of the 'necessary effects' regardless of the implementation of an 'object arrangement', see above page 202.

999 Case T-35/92, John Deere I, [1994], para. 61. Where the analysis would "not reveal the effect on competition to be sufficiently deleterious, the consequences of the agreement should then be considered and for it to be caught by the prohibition it is then necessary to find that those factors are present which show that competition has in fact been prevented or restricted or distorted to an appreciable extent", Case 56/65, STM v Marcbinembau Ulm, [1960], p. 249.

1000 European Commission, Guidelines on the application of Article 81(3) EC, paras. $24 \mathrm{ff}$.

1001 Joined Cases T-374/94, T-375/94, T-384/94 and T-388/94, European Night Services Ltd (ENS) e.a., [1998], para. 136; Case C-234/89, Delimitis, [1991], paras. 16 ff.; Case C-250/92, Gottrup-Klim v DLG, [1994], para. 31; Case T-9/93, Scbäller Lebensmittel GmbH \& Co. KG v Commission, [1995], paras. 39 f; Case C-399/93, Oude Luttikhuis, [1995], para. 10; Case T-77/94, Groothandelaren in Bloemkswekerijprodukten, [1997], para. 140.

1002 See Case 23/67, Brasserie de Haecbt, [1967], p. 415. Joined Cases T-374/94, T-375/94, T-384/94 and T388/94, European Night Services Ltd (ENS) e.a., [1998], para. 136: "it must be borne in mind that in assessing an agreement under [Article 81(1) EC], account should be taken of the actual [and legal] conditions in which it functions [...] unless it is an agreement containing obvious restrictions of competition such as price-fixing, market-sharing or the control of outlets" (emphasis added). 
market is to determine whether an agreement [or decision] ... has as its object or effect the prevention, restriction or distortion of competition within the common market .... Consequently, there is an obligation on the Commission to define the market in a decision applying Article 81(1) EC only where it is impossible, without such a definition, to determine whether the agreement, decision by an association of undertakings or concerted practice at issue ... bas as its object or effect the prevention, restriction or distortion of competition within the common market ...". .003

The resulting definition of the relevant market (i.e. the relevant services market, the relevant geographical market, plus a time element) is the starting point for determining whether an agreement or decision falls foul of the substantive scope of Article 81(1) EC. Its aim is to compare market situations with and without the challenged agreement or decision. ${ }^{1004}$

Once the televant market has been defined the scrutiny of the agreement's or decision's effect can take place, even where it has not yet been implemented. ${ }^{1005}$ In situations where the agreement or decision has been implemented the basic test is whether a telative price increase has taken place due to the agreement or decision. Conversely, in situations where it has not been implemented one has to look at predictors that indicate a relative price increases if the agreement or decision will be implemented. ${ }^{1006}$ Those predictors may refer to the duration of the agreement of decision, the market share of the undertakings, and their market power. ${ }^{1007}$ It is the (likely) consequence of an agreement or decision that is relevant in order to determine its effects to restrict competition in the market. ${ }^{1008}$

\subsection{Confining the substantive scope of Article 81(1) EC}

This section will explore the boundaries of the substantive scope of Article 81(1) EC. While it has become apparent from the aforementioned that the concept of restriction of competition allows for a broad interpretation, too broad an interpretation of the concept puts its value as substantive element into question. The issue then is how to delimit its reach in order to prevent it becoming a mere jurisdictional element covering any conduct having some impact on markets. The starting point is the economic nature of the concept to be assessed from the perspective of a larger context in which an agreement of decision occurs (section 1.2.1.). Looking at the larget context is also the basis for the ancillary restraints doctrine presented in section 1.2.2., according to which certain restrictions of the freedom

1003 Case T-48/02, BrouverijHaachtNV v Commission, [2005], para. 58 (emphasis added). The Court refers to Case T-29/92, Boupnijuerheid, [1995], para. 74; Joined Cases T-25 to 26/95, T-30 to 32/95, T-34 to 39/95, T-42 to 46/95, T-48/95, T-50 to 65/95, T-68 to 71/95, T-87 to 88/95, T-103/95 and T-104/95, Cement, [2000], para. 1093; Case T-62/98, Volkswagen AG v Commission, [2000], para. 230; and Joined Cases T-374/94, T-375/94, T384/94 and T-388/94, Eumpean Night Services Ltd (ENS) e.a., [1998], paras. 93 ff., 105. The same idea is applied in respect of whether a decision is liable to affect trade between Member States, see Chapter 3.II.

1004 Case 56/65, STM v Mascbinenbau Ulm, [1966], p. 250.

1005 The preventive objective of Article 81(1) EC allows to intervene before the restriction actually occurs.

1006 Odudu O., (2001), $266 \mathrm{f}$.

1007 Market power is, however, not a necessary condition for an infringement of Article 81(1) EC as such a requirement would remove much of the distinction between Articles 81 and 82 EC. Odudu O., (2001), 267, points out that Community law applies a system of block exemptions under Article 81(3) EC to vertical agreements between parties that have no significant market power. This implies that Article 81(1) EC can be infringed by parties without significant market power. Conversely, market power does not necessarily translate into dominance as targeted in Article $82 \mathrm{EC}$.

${ }_{1008} \mathrm{NB}$ The further requirement of the case law that the restriction of competition be appreciable (see above note 991 and the accompanying text) does not necessarily relate to the parties' market share or power, but rather to their ability to sustain the effect, see Joined Cases T-374/94, T-375/94, T-384/94 and T-388/94, European Night Services Ldd (ENS) e.a., [1998], para. 102; Case 30/78, Distillers Company Limited v Commission, [1980], para. 28; Case T-77/92, Parker Pen, [1994], para. 46. 
of action are found not to have restrictive effects on the freedom of competition because they are 'ancillary', i.e. "directly related and necessary to the implementation of a main opetation" that itself is not restrictive of competition. ${ }^{1009}$

\subsubsection{Net effect of reduced competitive forces: context versus immunity}

In order to identify a testriction of competition (which results in allocative inefficiencies) it is necessary to look at a conduct's effects, be they simply natural and foresecable (i.e. 'necessary') for the sake of the object requirement, or actual or likely to occur for the sake of the effect requirement of Article 81(1) EC. Due to the economic nature of the concept of restriction one has, however, to look not only at the prima facie restriction of quality, quantity or vatiety of the traded goods or services in question in order to conclude on an artificial price increase. One has to ascertain also whether the measure in question results in reduced competitive forces across the market as a whole. In this regard the Court frequently refers to the overall context ${ }^{1010}$, i.e. the factual and legal circumstance, in which an agreement or decision has been adopted. ${ }^{1011}$ If overall the effect of an agreement or decision is to increase the quantity or quality of a particular type of goods or services available to the market, no restriction of competition will be established. The likely manifestation is a price reduction in real terms across the market. Conversely, if the agreement results in a reduction of the quantity or quality of the goods or services available to the market then this is a price increase in teal terms and the agreement has the effect of restricting competition.

Taking account of the actual conditions in which an agreement or decision functions in a given matket translates into assessing the net effect thereof. ${ }^{1012}$ It would be erroncous to focus on the 'critical effects' immediately related to a testraint (i.e. the changes in the price and output of a particular firm) ${ }^{1013}$ Such a limited view would risk to equate any restriction of conduct or action with a restriction of the freedom of competition. In refusing this equation the concept of restriction of competition is different from, for instance, the UK doctrine of restraint of trade and similar doctrines in the laws of other Member States (e.g. the Beruffreibeit in German law, Article 12 of the German Constitution). Such doctrines reflect a person's freedom to future conduct. However, in competition law a "restraint is present and harms competition on the market not when the agreement eliminates someone's freedom, but when it allows the price to be bigher than it would have been from the unhampered

1009 Case T-112/99, Métropole (M6), [2001], para. 104.

1010 Case 23/67, Brasserie de Haecht, [1967], 40.

1011 Joined Cases T-374/94, T-375/94, T-384/94 and T-388/94, European Night Services Ltd (ENS) e.a., [1998], para. 136. Case T-168/01, GlaxaSmithKline, [2006].

${ }_{1012}$ On net effects in the same market and on a different market see Odudu O., (2001), 267-274. In referencing Case 161/84, Pronuptia v Scbillgalis, [1986], Odudu explains how the net effects are relevant in the assessment of whether an agreement is restrictive of competition. The case concerned a selective distribution system with an almost exclusive supply obligation in a franchising agreement for wedding paraphernalia of the distributor Pronuptia. "Whilst able to restrict the amount of Pronuptia goods, by establishing Pronuptia as a market supplicr there are more firms bringing goods to market. A system that allows a new entrant upstream [1.e. at the producer or distributor level, although allowing the distributor some measure of protection, does nothave a restrictive effect on competition if the new entrant adds increased competitive forces across the market as a whole. The consequences are not restrictive if the average price of goods in the market remain the same or fall. The requirement is also met if the quantity or quality of goods produced increases" (emphasis added). See Lugard P. / Hancher L., (2004), $412 \mathrm{f}$. European Commission, Guidelines on the application of Article 81(3) EC, paras. $24 \mathrm{ff} ., 101$.

${ }^{1013}$ See Odudu O., (2001), 269 (his note 49), with further teference. 
play of supply and demand". ${ }^{1014}$

\section{Article 81(1) EC is not a mere jurisdictional clause}

Not just any agreement or decision that influences the economic conduct of market participants can be qualified as restrictive of competition. If the concept of restriction of competition were to be interpreted so broadly as to cover any restrictions of the freedom of action (e.g. any contractual obligation), the competent authorities would be unable to deal with them efficiently. In particular such a vigorous view would result in a positivistic application of Article 81(1) EC and degrade it to a mere jurisdictional provision that would gather any agreement or decision "with the potential to conflict with Treaty aims but requiring substantive assessment". Therewith Atticle 81(1) EC would cease "to separate permissible from impermissible conduct".

The Commission has been criticised for defining the substantive criterion of Article 81(1) EC too broadly, i.e. catching agreements that were never intended or meant to restrict competition. According to Goyder for instance the width of the interpretation of the concept of restriction of competition depends on whether Article 81(1) EC is understood as a jurisdictional clause or as a clause to assess the justification of particular arrangements adopted by undertakings and associations. ${ }^{1015}$ However, an approach to the latter effect limits the substantive scope of Article 81(1) EC and leads to the jurisdictional problem of excluding from the control of EC competition law (and the competent authorities) a substantial number of measures that may, either individually or cumulatively, have an effect on competitive structures or processes.

Therefore, a balance must be sought in which the concept of restriction of competition is positioned between the two extremes that understand Article 81(1) EC as either being a mere jurisdictional clause or a clause to assess the justification of a particular restraint. Understanding Article 81(1) EC as a clause that would allow to assess the justification of a particulat restraint is a misconception since justification arguments result in agreements or decisions being immune from the application of Article 81(1) EC. Discussing immunity is an unproductive way of determining the substantive scope of the provision. The assessment of whether something is restrictive of competition is to be assessed objectively and thus is different from justifying a certain conduct with reference to considerations other than allocative efficiencies. Any legitimate justification not connected to the question of allocative inefficiencies has thus to be accommodated outside that provision. Moreover, in the order for scrutiny it does not make sense to look at justification in the absence of a restriction. Consequently, the Court and the Commission have adopted a comprehensive approach towards the 'object or effect' tequirement of Article 81(1) EC.

\section{No immunily in the form of grounds for justification}

The present book advances the view that delimiting the substantive scope of Article 81(1) EC is not to be equated with limiting the teach of the probibition that the provision stipulates. Limiting the prohibition is to concede an immunity against the application of Article 81(1) EC in spite of allocative inefficiencies. In this respect one

1014 Amato G., (1997), 13 (emphasis added). For details see above page 199.

1015 Goyder D.G., (2003), 91 f. 
particular point shall be clarified that often leads to dangerous confusion in respect of the question whether a certain professional measure falls under the prohibition of competition law, in particular when discussing the Wouters judgment. In that judgment the Court of Justice found that the professional rules at stake did not "fall within the probibition laid down in Article [81(1) EC]". ${ }^{1016}$ It is important to note that this is not the same as stating that the measure at stake would not qualify for the substantive element of Article 81(1) EC. In fact, in the paragraphs preceding para. 97 of the judgment in Wouters the Court made very cleat that the professional rules in question were restrictive of competition. ${ }^{1017}$ Therefore, the present book uses the expression 'Wouters proviso' as shorthand for identifying the part of the Wouters judgment that, as some have observed, reads like a dissenting opinion (i.e. paras. 97-110 of the judgment). ${ }^{1018}$ The notion 'Wouters proviso' is preferred here to the notion of 'Wouters rule' or 'Wouters exception'1019 in order to avoid the impression that the Court in paras. $97 \mathrm{ff}$. has established an accepted standard in applying the law.

Only in two situations does the prohibition of Article 81(1) EC not take effect. In a first situation the substantive assessment of a case may result in the finding that a certain conduct is simply not restrictive of competition. In this event the circumstances of a case do not meet the legal requirements of the article and thus do not bring on the legal consequence laid down therein. ${ }^{1020}$ Conversely, in a second situation where the substantive assessment leads to the conclusion that a certain conduct prima facie is restrictive of competition, a further substantive assessment may lead to the conclusion that yet the conduct under scrutiny does not fall foul of the prohibition of Article 81(1) EC despite the allocative inefficiencies it produces (or is likely to produce). Such further substantive assessment obviously has to be based on considerations that are outside the concept of restriction of competition. Such considerations may thus justify the conduct under scrutiny. What happens is that a different legal assessment, or value judgment in terms of policy choices, is made to deliberately deviate from the basic assessment under Article 81(1) EC and its concept of restriction of competition. This has been done explicitly in Articles 81(3) and 86(2) EC, which immunities against the prohibition of Article 81 (1) EC will be dealt with as justification grounds in Chapter 7.

While an agreement or decision may benefit the competitive process from a larget perspective - i.e. despite its allocative inefficiencies - this does not imply that, within the scope of the probibition clause of Article 81(1) EC, the pro-competitive effects of the agreement or decision would have to be balanced against the anti-competitive effects thereof. The assessment of pro-competitive effects can, and even must, be separated from the initial question of whether something restricts competition in terms of allocative inefficiencies and thus is a means to orchestrate the cconomic activities of market participants to the detriment of competitors and ultimately the consumers.

The potential of beneficial effects to the competitive process is reserved to the third paragraph of Article $81 \mathrm{EC}$. According to Article 81(3) EC (read in conjunction with Regulation 1/2003) the prohibition of Article 81 (1) EC is inapplicable ${ }^{1021}$ if a prima facie

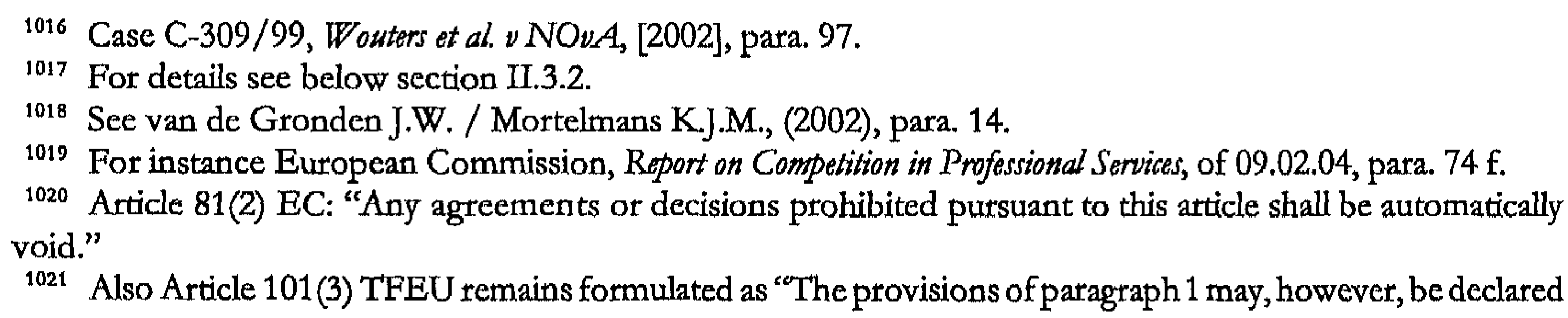


restrictive measure "contributes to improving the production or distribution of goods [or services] or to promoting technical or economic progress" ${ }^{1022}$ This represents a justification for which the prohibition rule does not need to cater and thus encourages a broad interpretation of the latter. This point illustrates also the conceptual difference between EC competition law and US anti-trust law dealt with hereafter.

\section{No rule of reason due to the bifurcated structure of Article $81 \mathrm{EC}$}

The conceptual structure, or substantive scheme, of Article $81 \mathrm{EC}$ being bifurcated into prohibition and exemption effectively allows a close control of arrangements that restrict competition by object or effect, and to ultimately impose conditions on the behaviour of market actors ${ }^{1023}$ where they want to see their arrangements exempted (under Article 81(3)) EC from the prohibition of Article 81(1) EC. The bifurcated structure of Article 81 EC distinctively distinguishes EC competition law from the US American antitrust rules (Sherman Act 1890). ${ }^{1024}$ The latter does not provide for an explicit exemption to be granted for agrcements that are found to restrict competition. US antitrust law therefore is known for its case law built exception called 'rule of reason', according to which a balancing of the agreement's pro- and anti-competitive effects has to take place in the process of deciding whether a clause or agteement will be deemed to be testrictive of competition (constituting a selection $a b$ initio). ${ }^{1025}$ This weighing in economic terms determines the question of whether an agreement at all falls within the jurisdictional scope of section 1 of the Sherman Act. In legal writing various forms of a 'tule of reason' have been discussed with regard to EC law, but no single concept thereof exists. ${ }^{1026}$ The Court of Justice has

inapplicable in the case of [...]" (emphasis added).

1022 Three further requirements that have to be fulfilled cumulatively under Article 81(3) EC. For details see Chapter 7.I.

${ }_{1023}$ The Commission calls such conditions 'undertakings', which is correct in English language but confirms the awkwardness of the term 'undertaking' used in the EC Treaty to refer to economic operators.

1024 See AG Léger in Case C-309/99, Wouters et al. v NOvA, [2002], para. 101: "The rule of reason theory was developed in the American law on agreements. In the United States, section 1 of the Sherman Act prohibits all obstacles to competition without distinction as to degree or motive. Unlike Article [ $81 \mathrm{EC}$ ], that legislation does not provide for any possibility that the authorities might exempt an agreement. Faced with the rigidity of that provision, the United States courts swiftly found it necessary to interpret the Sherman Act in a more reasonable way. In the first place, they developed the theory called ancillary restrictions: they held that restrictions of competition necessary to the performance of an agreement lawful in itself fell outside the prohibition laid down in section 1 of the Sherman Act. Then, the Supreme Court of the United States of America changed its point of view and adopted what might be called the competition balance-sheet method."

1025 Sce Case T-112/99, Métropole (M6), [2001], paras. $75 \mathrm{ff}$.

1026 Odudu O., (2001), 268: "Despite numerous opportunities for the Court of Justice to confirm the existence of a rule [of reason] and describe its nature, to date it has avoided doing so. The reality is that whatever the rule, it is curiously lacking in definition, making it unclear how to apply it." Whish R, (2003), $124 \mathrm{f.:}$ "Discussion of the rule of reason under Article 81(1) is often very imprecise. It is sometimes used as little more than a slogan by opponents of the judgments of the Courts and, in particular, decisions of the Commission. In so far as the call for a rule of reason is a request for good rather than bad, or reasonable rather than unreasonable, judgments and decisions, no one could disagree with it. However, if proponents of the rule of reason mean that US jurisprudence on the rule of reason under the Sherman Act 1890 should be incorporated into EC competition law, this seems to be misplaced: EC law is different in many ways from US law, not least in that it has the 'bifurcation' of Article 81(1) and Article 81(3), which does not exist in the Sherman Act, and that it is concerned with the promotion of a single market as well as with "conventional' competition law concerns". - See also below note 1056 on Case T-328/03, O2 (Germany), [2006], para. 69. 
rigorously rejected such a rule where it takes the form recognised in US anti-trust law. ${ }^{1027}$

The argument generally put forward in favour of an application of such a rule of reason in EC competition is the complaint that Article 81(1) EC has been applied too broadly, catching any agreements or decisions that are not in teality detrimental to competition. ${ }^{1028}$ However, to discuss an alleged 'rule of reason' in the context of Article 81(1) EC and its substantive scope leads to confusion rather than clarity. ${ }^{1029}$ Not only is the argument unconvincing in light of the structural differences between US and EC competition law. Also the 'need' for limiting the scope of Article 81(1) EC has diminished as a result of the modernisation of EC competition law on the implementation of Articles 81 and $82 \mathrm{EC}{ }^{1030}$ As outlined in Chapter 2 Regulation 1/2003 abolished the exclusive competence of the Commission to grant an individual exemption for an agreement or a decision in accordance with Article 81(3) EC. Parties now need to self-assess their business practices. Under the former regime of Regulation $17 / 62^{1031}$ it was compulsory that the agreement between undertakings or the decision of an association of undertakings had to be notified to the Commission. Any individual exemption could take effect only as of the date of notification. Since 1 May 2004 it is no longer necessary to argue that an agreement falls outside the substantive scope of Atticle 81(1) EC for the procedural reason that it is not block exempted and has not been notified to the Commission for an individual exemption. Since that date the Commission shates with the courts and national competition authorities the power to make decisions on the application of the entire Article $81 \mathrm{EC}$, including the exemption in its third paragraph. ${ }^{1032}$

"It follows that [...] there is no longer a procedural tail to wag the substantive dog. Of course it is still important to apply Article 81(1) EC with intellectual rigour, and to apply it only to agreements that really do restrict competition: but a determination that an agreement infringes Article 81(1) EC no longer has the serious procedural consequences that it used to have."1033

Moreover, the employment of the term 'rule of reason' in EC competition law is highly regrettable, even where the proponents of a rule intend to express something different from the US jutisprudence. In legal writing on the Treaty's free movement rights the case law built

1027 See only Case T-112/99, Métropole (M6), [2001], paras. $75 \mathrm{ff}$. The CFI expressly rejected the suggestion that a rule of reason of the US antitrust style existed under Article 81(1). In its Europcan Commission, White Paper on Modernisation of the Rules Implementing Articles 85 and 86 of the EC Treaty, of 28.04.1999, para. 57, the Commission stated that it would "be paradoxical to cast aside [Article 81(3) EC] when that provision in fact contains all the elements of a "rule of teason"' and that the adoption of the US rule of reason under Article 81(1) EC would "run the risk of diverting [Article 81(3) EC] from its purpose, which is to provide the legal framework for the economic assessment of restrictive practices and not to allow application of the competition rules to be set aside because of political considerations". For comment on the Mérropole judgment see Manzini P., (2002).

${ }_{1028}$ In the years before the adoption of Regulation 1/2003 the Commission itself had become more amenable to the suggestion that it should adopt a 'reasonable' approach to the application of Article 81(1) EC. It appeared to be more willing to conclude that an agreement fell outside Article 81(1) altogether, rather than to find an infringement of Article 81(1) and then to grant an individual exemption or to close the file with an Article 81(3) comfort letter, Whish R., (2003), 108.

${ }^{1029}$ Goyder D.G., (2003), 92.

${ }^{1030}$ Doubts on maintaining a broad interpretation of the substantive scope of Article 81(1) EC had been cast also by the amount of case work that the Commission's Competition Directorate General has to do and which required structural changes in distributing the case work.

1031 Council Regulation No. 17 of 10.02.1962, First Regulation implementing Articles 85 and 86 of the Treaty (now Arts. 81 and 82 EC).

1032 For a brief outline see Chapter 2.III.

1033 Whish R., (2003), 107. 
justification path of the mandatory requirements doctrine ${ }^{1034}$ tegularly is referred to as 'rule of reason ${ }^{\text {1035 }}$, which G.Monti therefore refers to as 'European style of rule of reason'. ${ }^{1036}$ The coining in EC free movement law has been induced by the phrasing in the relevant case law of the Court ('reasonable to consider'). To te-adopt the term of 'rule of reason' in EC competition law, however, ignores the struggle that the CFI clearly has resolved in Métropole télévision $M 6$ in favour of Article 81(3) EC and a broad interpretation of the substantive scope of Article 81(1) EC. ${ }^{1037}$

A further comment needs to be made at this juncture, which however anticipates to a certain extent the reflections on the Wouters proviso below. In GlaxoSmitbKline ${ }^{1038}$ the CFI made a peculiar reference to the Wouters proviso by juxtaposing it to Métropole télévision M6. The oddity of this juxtaposition stems from the consideration that the Woulers ptoviso is often presented in legal writing as an embodiment of a competition rule of reason, whereas Métropole télevision M6 is the decision that forcefully rejects such rule for the system of EC competition law. ${ }^{1039}$ The CFI in GlaxoSmithKline juxtaposed the two reference as if they would state the same, namely that "not every agreement which restricts the freedom of action of the participating undertakings, or of one of them, necessarily falls witbin the probibition in Article 81(1) EC" ${ }^{1040}$ Below in section II.4. it will become clear that this statement is correct only with regard to the concept of ancillaty restraints, sincc in Wouters the ECJ clearly affirmed that the professional regulation did restrict competition. A similar erroneous approach is presented by where the Advocate General presents the reference to the Wouters proviso as if it stated that a behaviour that can be objectively justified would not constitute a restriction of competition. However, as this study points out the Court has been unequivocal in stating that the NOvA regulation did testrict competition but did not fall under the probibition of Article 81(1) EC. ${ }^{1041}$

\subsubsection{Giving shape to the boundaries of the substantive element of restriction of competition}

While the bifurcated structure of Article $81 \mathrm{EC}$ makes the application of a rule of reason similar to US antitrust law superfluous, the Community Courts have recognised in various cases that certain conduct or clauses do not infringe Article 81(1) EC in spite of the fact that they have certain restrictive effects. The fine distinction that the Community Courts draw in this respect is first of all between restrictions of the freedom of action and restrictions of the freedom of competition. Secondly, certain restrictions are considered not to be restrictive of competition because they are directly related and necessaty to the implementation of a main operation that itself is not restrictive of competition. ${ }^{1042}$

${ }^{1034}$ For details sce Chapter 7.I.2.5.3. The European rule of reason often referred to by legal writers in the field of the fundamental freedoms of the Treaty is inferred from cases like Casc 120/78, Cassis de Dijon, [1979] and Case C-415/93, Bosman, [1995]. See also the conclusive view of 'Timmermans, below note 1171.

1035 Whish R, (2003), 107, his note 244.

${ }^{1036}$ Monti G., (2002).

1037 Odudu O., (2001), note 43, points out, however, that not all commentators agree that the US anti-trust rule of reason requires balancing as described in reference to Article 81(3) EC or that it can be feasibly carried out.

${ }^{1038}$ Case T-168/01, GlaxoSmithKline, [2006], para. 171.

${ }^{1039}$ See above notes 1026, 1024, and below page 215.

1040 Case T-168/01, GlaxoSmitbKline, [2006], para. 171 (emphasis added).

1041 AG Kokott in Casc C-49/07, MOTOE, [2008], para. 89 and her note 61.

1042 Case T-112/99, Mélropole (M6), [2001], paras. 104 ff. Case 161/84, Pronuptia v Schillgalis, [1986], paras. 15 ff.; Case 27/87, Eraww-Jacquery, [1988], paras. 10 f. and 20; Case C-250/92, Gottrup-Klim $\nu$ DLG, [1994]; Joined Cases 
"[In] cases involving specific sectors or specific categories of agreement, the Court has gone beyond [the] mechanistic approach [of applying clear-cut rules for presuming an anticompetitive cffect] and has adopted a more searching analysis. In view of the subject-matter and nature of the agreements concerned [...], their economic context and the sometimes complex underlying economic rationale have therefore to be taken into account". ${ }^{1043}$

This approach is known as the ancillary restraints doctrine or the concept of ancillaty restriction. ${ }^{1044}$ Its argument is that without the restriction the undertakings or their association would be deprived of a mechanism necessary to have a reliable basis for implementing the legitimate purpose of the intended operation or function.

The applicable standard is an objective necessity test tailored to verify whether in the absence of a particular restraint the main commercial operation may not have come about, or not to the intended extent. ${ }^{1045}$ While having some impact on the freedom of competition, ancillary restraints are not considered to be restrictive of competition in the legal sense because of their (necessary) contribution to the main operation, which in turn does not restrict competition but rather enhances the competitive process across markets.

\section{Ancillary restraints doctrine implementing an objective necessity testing}

The necessary assessment to be undertaken under the ancillaty restraints doctrine is to consider whether the overall effect of a particular arrangement is to not restrict competition in spite of the fact that a certain conduct of clause prima facie seems to be competition restrictive if looking only at the latter's 'critical effects'. The intellectual operation that needs to be conducted in deciding whether or not an agreement or decision is restrictive of competition in the sense of Article 81(1) EC presents itself in two steps. The first step is to assess net effect (as indicated above) of the arrangement under scrutiny in order to identify which conduct is permissible under Article $81(1) \mathrm{EC}$ and which is not. More particularly, it is necessary to evaluate whether the overall effect of the arrangement is to increase or reduce competitive forces across the market. ${ }^{1046}$ This evaluation across the market transcends the

C-319/93, C-40/94 and C-224/94, Melkunie, [1995]; Case C-399/93, Oude Luttikbuis, [1995], para. 10; Commission Decision P of I Clubs, (1999). See also already in Case 258/78, Nungesser, [1982], paras. 43 and 58; Case 262/81, Coditel (No. 2), [1982]; Commission Decision Reuter/BASF, (1976); Casc 42/84, Remia and Nutricia, [1985], paras. 18 ff.; and Case 26/76, Metro I, [1977], para. 27. See Whish R., (2003), 118 ff.

1043 AG Jacobs in Case C-67/96, Joined Cases C-115/97, C-116/97 and C-117/97 and Case C-219/97, Albany/Brentjens'/Drijuende Bokken, [1999], para. 252 (emphasis added). The relevant cases referenced are Case C250/92, Gattrup-Klim v DLG, [1994], para. 31; Case C-399/93, Oude Luttikbuis, [1995], para. 10; Joined Cases T374/94, T-375/94, T-384/94 and T-388/94, European Night Services Ltd (ENS) e.a., [1998], paras. 136 f.; Case 56/65, STM vMaschinenbau Ulm, [1966]; Case C-234/89, Delimitis, [1991]; Case 78/70, Deutscbe Grammopbon, [1971]; Case 258/78, Nungesser, [1982]; Case 161/84, Pronuptia v Schillgalis, [1986]. See also Joined Cases 32 and 36 to $82 / 78, B M W,[1979]$, paras. $22 \mathrm{ff}$.

1044 Case T-112/99, Métropole (M6), [2001], paras. 104 ff., referring to European Commission, Commission Notice on Ancillary Restraints, which has since been replaced by European Commission, Commission Notice on restrictions directly related and necessary to concentrations. Mostrecent is European Commission, Commission Notice on restrictions directly related and necessary to concentrations. - For a critical discussion of the concept of ancillary restraints as applied by the Commission, Lugard P. / Hancher L., (2004), 416 f.

1045 Case T-112/99, Métropole (M6), [2001], para. 109: "examination of the objective necessity of a restriction in relation to the main operation". Commission Decision Reuter/BASF, (1976); Case 42/84, Remia and Nutricia, [1985], paras. $18 \mathrm{ff}$.: "it is necessary to examine what would be the state of competition if those clauses did not exist". ${ }_{1046}$ See AG Léget in Case C-309/99, Wouters et al. v NOvA, [2002], paras. 103 f.: "irrespective of any terminological dispute, the rule of reason in Community competition law is strictly confined to a purely competitive balance-sheet of the effects of the agreement. Where, taken as a whole, the agreement is capable of encouraging competition 
previously established relevant (product or service) market. In a second step it is necessary to establish that in view of achieving the identified net effect of the main operation the more specific conduct adopted by the undertakings or theit associations is legitimate.

The test of the Court with regard to establishing net effect presents itself as follows. First, one has to look at the competition situation on the televant market. Where it becomes apparent that an agreement or decision has restrictive effects thereupon - be they simply natural and foreseeable (i.e. 'necessary') for the sake of the object tequirement, or actual or likely to occur for the sake of the effect requirement of Article 81(1) EC - the focus turns to the "actual context" operation". ${ }^{1048}$ While in Métropole télétision (M6) the Court underlines that this context is broader than the "competition situation on the relevant market", it seems to be less rigorous in distinguishing the competition situation from the (supposedly broader) main operation in the case $02{ }^{1049}$ The decisive differentiation is not so much on the wording (competition situation versus main operation) but rather one of focus. On the one hand, the focus is on the relevant market and, on the other, it is on the broader or actual context in which a particular restriction of conduct is adopted and/ or applied. What the Court reveals in $\mathrm{O} 2$ with regard to the concept of ancillarity is that the characteristics of the "actual", "specific" or "overall" context are commercial in nature. ${ }^{1050}$

The pursuit of a commercial aim under the ancillary restraints doctrine is in line with the aims and the framework of Article 81 EC. Stressing the commercial character of the overall context seems to be stating the obvious in view of both the fact that EC competition law concerns itself with economic activities and the objective and autonomous interpretation of Article 81(1) EC. ${ }^{1051}$ In summary, to decide whether an agreement or decision is restrictive of competition it is necessary, but not enough, to consider the "competition situation on the relevant market" (i.e. net effects) ${ }^{1052}$ In developing the concept of ancillaty restraints the Court stresses that it is also necessary to consider the factual and legal circumstances in which an agreement or decision is taken or applied ${ }^{1053}$ and to take account of "the specific context of the main operation". ${ }^{1054}$

The relevant test with regard to establishing that the more specific conduct adopted by the undertakings or their associations is legitimate in view of achieving the identified net effect of the main operation is a proportionality test. In this second step the advantages that the parties gain directly from the restrictive arrangement are compared with the net effect

on the market, the clauses essential to its performance may escape the prohibition laid down in Article [81(1) EC]. The only legitimate goal which may be pursued in accordance with that provision is therefore exclusively competitive in nature. [...]" (emphasis added). While the Advocate General used the terminology of "rule of reason', he in fact summarised the application of what otherwise is referred to as ancillary restraints doctrine by the Court.

1047 Case T-328/03, O2 (Germany), [2006], para. 68.

${ }_{1048}$ Case T-112/99, Métropole (M6), [2001], para. 136.

1049 Case T-328/03, O2 (Germany), [2009], paras. 68-73.

${ }^{1050}$ See also AG Léger in Case C-309/99, Wouters et al. $\nu$ NOvA, [2002], 104.

1051 Even a subsequent exemption under the third paragraph of Article $81 \mathrm{EC}$ requires the establishment of an efficiency gain to contribute to improving the provision or distribution of services or to promote technical or economic progress, see Chapter 7.I.

${ }_{1052}$ Case T-112/99, Métropole (M6), [2001], para. 109 (emphasis added). On net effects sec above section II.1.2.1. ${ }^{1053}$ Joined Cases T-374/94, T-375/94, T-384/94 and T-388/94, European Nigbt Services Ltd (ENS) e.a., [1998], para. 136.

${ }_{1054}$ Emphasis added, Case T-112/99, Métropole (M6), [2001], para. 109; Case T-328/03, O2 (Germany), [2006], paras. $68 \mathrm{ff}$. (cmphasis added). 
across the market that can be achieved with the implementation of the arrangement. The analysis that the Court conducts compares whether the adopted behaviour or measure is necessary to realise the envisaged commercial operation increasing the competitive forces across the market. The Court is clear that it is not interested in the commercial viability of a particular commercial operation (that tisk is for the parties), but in its contribution to the overall market situation, i.e the overall competitive situation in which the scrutinised behaviour occurs. If the identified restraint is directly related and objectively necessary to implement the main commercial operation (which in turn contributes to the increase in competitive forces) the restraint does not satisfy the substantive requirement of Article 81(1) EC in the first place.

"It is not a question of analysing whether, in the light of the competitive situation on the relevant market, the restriction is indispensable to the commercial success of the main operation but of determining whether, in the specific context of the main operation, the restriction is necessary to implement that operation. If, without the restriction, the main operation is difficult or even impossible to implement, the restriction may be regarded as objectively necessary for its implementation" (emphasis added). ${ }^{1055}$

This examination of the objective necessity, the Court adds, cannot but be relatively abstract. The Court stresses that it is not the actual commercial success of an operation that is necessary to be looked at (that success may depend on many factors, and also on chance) but the necessary potential of the restriction to lead to the success of the main operation, a success which in turn and in relatively abstract terms has the potential of increasing rather than decreasing the competitive forces in the market as established in the first step of the scrutiny. Whilst recognising that the potential commercial success of the main operation is an intermediate step necessary in the mental exercise of the scrutiny, the Coutt reveals that competition law is concerned only to safeguard the effect that an arrangement does not decrease the competitive forces in a market.

Differently from Article 81(3) EC the scrutiny within the scope of the article's first paragraph hence is a negative one that does not balance any pro-competitive factors; it simply sees to it that no anti-competitive factors will be realised. This is an important nuance to explain the difference in balancing that is undertaken within Article 81(1) EC and Article 81(3) EC respectively. ${ }^{1056}$ Furthermore, the Court made clear that the concept of ancillary restriction is not to be confused with the 'rule of reason' under US Ametican

1055 Case T-112/99, Métropole (M6), [2001], para. 109.

1056 Case T'-328/03, O2 (Germany), [2006], para. 69: "Such a method of analysis, as regards in particular the taking into account of the competition situation that would exist in the absence of the agreement, does not amount to carrying out an assessment of the pro- and anti-competitive effects of the agreement and thus to applying a rule of reason, which the Community judicature has not deemed to have its place under Article 81(1) EC", referring to Case C-235/92 P, Montecatini SpA $\nu$ Commission, [1999], para. 133; Case T-112/99, Métropole (M6), [2001], paras. 72-77; Case T-65/98, Van den Bergh Foods, [2003], paras. 106 f. Surely, in a given case it is a difficult task to clearly identify whether, on the one hand, a restriction does not lead to a restriction of competition, either in the form of not decreasing the competitive force or even increasing them (test of Article 81(1) EC), or whether, on the other, a restriction actually contributes to the improvement of the production or distribution of goods or services, or to promote the technical or economic process (while allowing consumers a fair shate of the resulting benefit to the undertakings) (test of Article 81(3) EC). For details see Chapter 7.I. for an illustration of the difference see Case 161/84, Pronuptia v Schillgalis, [1986], para. 24: "It is of course possible that a prospective franchisee would not take the risk of becoming part of the chain, investing his own money, paying a relatively high entry fee and undertaking to pay a substantial annual royalty, unless he could hope, thanks to a degree of protection against competition on the part of the franchisor and other franchisees, that his business would be profitable. That consideration, bowever, is relevant only to an examination of the agreement in the light of the conditions laid down in Article [81(3) ECP' (emphasis added). 
antitrust law ${ }^{1057}$, according to which an analysis of the positive and negative effects on competition of a principal restriction is conducted. Determining an ancillary restriction under EC competition law and the objective necessity of a measure is a relatively abstract matter that does not require a full market analysis as would a balancing of the pro- and anticompetitive effects of the restriction under either Article 81(3) EC or the US rule of reason. ${ }^{1058}$

In order to establish whether a certain restriction of the freedom of action is legitimate, and thus outside $\Lambda$ tticle 81 (1) EC, the Court basically has developed three criteria. ${ }^{1059}$ They allow to determine whether the restriction is indispensable to realise the potential of the main operation not to decrease, but rather increase, the competitive forces on the ovetall market. The first criterion relates to the type of product or service that is being traded by the parties. It must be of a type the commercialisation of which necessitates the particular type of restriction ${ }^{1060}$, in the specific context of the main operation. ${ }^{1061}$ In other words, a direct relation is required between the restriction and the commercially legitimate aim pursued with the main operation. Secondly, the restriction needs to be applied uniformly and in a nondisctiminatory way. For instance, and unlike quantitative restrictions that constitute a discriminatory barrier for potential competitors to access a particular market (therewith constituting a restriction by object), qualitative restrictions may be legitimate if they are not used to discriminate against certain (groups of) undertakings. Thirdly, the measure constituting a restriction must pass the proportionality test. This means that the conduct must be suitable and necessary to realise the purpose of the main operation to, in abstract terms, increase net effects actoss markets. In particular, the measure must be proportionate strictu sensu ${ }^{1062}$, i.e. there must be no less restrictive, but equally effective, means in view to attain the main operation (e.g. to protect the quality of the product or service in question).

${ }^{1057}$ For instance in Case T-112/99, Métropole (M6), [2001], paras. $107 \mathrm{ff.}$., See also above notes 1024 and 1026. ${ }^{1058}$ Case T-112/99, Métropole (M6), [2001], para. 109. See also Case 56/65, STM v Mascbinenbau Ulm, [1966], 250: "Although the competition in question must be understood within the actual context in which it would occur in the absence of the agreement in dispute. In particular it may be doubted whether there is an interference with competition if the said agrecment seems really necessary for the penelration of a new area by an undertaking" (emphasis added). ${ }^{1059}$ See Case 26/76, Metro I, [1977]. Whish R., (2003), $605 \mathrm{ff.}$

${ }^{1060}$ For instance selective distribution prima facie has the object to restrict competition in that it necessarily reduces the numbers of distributors or retailers. With regard to the legitimacy of selective distribution systems the Court has recognised three categories: 1 ) technically complex products (for instance in Case 26/76, Metr I, [1977]; Joined Cases 56 to 58/64, Consten and Grundig, [1966]); 2) brand image ([...][Case T-19/92, Leclerc (YSL Parfums), [1996]; Case T-88/92, Leclerc (Parfums Givencby), [1996]); 3) special characteristics (e.g. newspaper and its short shelf-life).

${ }_{1061}$ See for instance Joined Cases T-374/94, T-375/94, T-384/94 and T-388/94, European Night Services L dd (ENS) e.a., [1998], para. 136; Case T-112/99, Métropole (M6), [2001], para. 76. See also below the text with notes $1207 \mathrm{ff}$.

${ }^{1062}$ The full proportionality test can be divided in three steps: the suitability of the measure in view of the envisaged purpose; the appropriateness or necessity of the measure; and thirdly its proportionality strictu sensu, i.e. whether it does not go beyond what is necessary. The subdivision of the full proportionality test in three parts in EC law is inspired by German law where the concept of proportionality is firmly embodied in constitutional law. 


\section{Ancillary restraints and restrictions by object: an integrated test of rebutting intention and demonstrating net effect}

Under the ancillary restraints test parties have to demonstrate that their more specific conduct is legitimate in view of achieving the identified net effect of the main operation. This requirement in rebutting the application of the competition prohibition has to be met irrespective of whether one is confronted with a restraint by object or a restraint by effect. In fact, the concept of ancillary testraints has been applied to both categorics of restraints. While it is more difficult to demonstrate that a restriction by object has the net effects not to restrict competition, it is nevertheless feasible. ${ }^{1063}$ As the case may be restraints that as such affect competition, i.e. by object, may still serve the purpose to yield net effects across the market. ${ }^{1064}$ Consequently, by invoking the ancillary restraints doctrine the parties first of all intend to rebut the presumption of their intention to restrict competition. ${ }^{1065}$ Once the parties to a restriction by object can establish that the restriction of conduct is not intended to restrict competition "it falls on others to show that the restriction of conduct has the effect of reducing the quantity and quality and thus increase price."1066

At this stage of the scrutiny the parties to an object restriction can reinforce their rebutting argumentation by following the three criteria of the ancillary restraints test presented above. From the foregoing follows that, when applying the ancillary restraints doctrine in cases of object restrictions, the Court proceeds to an integrated test ${ }^{1067}$ in which the plausible demonstration that the undertakings or their association pursue a different objective than to restrict competition is the same than testing the restriction's net effect across the market under the effects category of Article 81(1) EC.

What does differ at this point is the burden of proof that the parties to an agreement or decision and the competent competition authority or a claimant (e.g. a competitor or customer) have to bear respectively. Once it has become apparent that an arrangement has the object to restrict competition it is on the parties to rebut the presumption of their intent by demonstrating net effect. Conversely, if the object to restrict competition cannot be established right away, it is upon the claimant or competition authority to demonstrate negative effects. ${ }^{1068}$

In both instances, i.e. of rebutted object restrictions and not-clearly-object restrictions,

1063 Odudu O., (2001), 71 ff. Similarly according to Goyder D.G., (2003), $100 \mathrm{ff}$., but not Whish R, (2003), 117 ff., who sorts ancillary restraints with 'effect restrictions'. Probably Whish does so since the relevant scrutiny of ancillary restraints in any event turns to the effects of the agrecment or decision. However, there is one relevant difference in applying the concept of ancillary restraints to the different cases of object restrictions and effect restrictions: the burden of proof is allocated differently between the presumed perpetrator and the competition authority or claimant to demonstrate effects (non-)restrictive of competition, see hereafter.

${ }^{1064}$ The application of the concept of ancillary restraints will be particularly exemplified with regard to 'object restrictions' in the professional services sector, see below page 228 on Wouters.

1065 This seems to be fostered by the Wouters proviso. Its para. 97 reads like the description, for instance of the exception for selective distribution agreements where it formulates that "...It has then to be considered whether the consequential effects restrictive of competition are inberent in the pursuit of those objectives." For a critical review of this point see below section II.4.2.

1066 Odudu O., (2001), 264.

1067 Legitimate aims have to be of a commercial character, i.e. the relative decrease of prices or the relative increase of quality and/ or quantity (supply), see diagram on p. 219. See also Case T-59/02, Midland, [2006], paras. $340 \mathrm{ff}$.

${ }^{1068}$ See Case C-306/96, Javico, [1998], para. 22. 
parties have to assume the (further) burden of demonstrating that there had not been ${ }^{1069}$ or will not be $e^{1070}$ any net restrictive effects (see diagram hereafter). The former may be done for example by showing that prices have remained the same or decteased since the agreement entered into force, the latter by showing that the parties do not possess market power. ${ }^{1071}$

Now that the relevant test and the distribution of the burden of proof are clarified what remains is the question in respect of substance. When does the probable and foreseeable effect fail to show 'intention' to restrict competition?

"The problem is one of the probative value of facts and assumptions in determining intention. The reason why the Court's treatment of different types of agreements appears to differ is not because different rules are applied to different types of agreements, but because different factors constitute evidence of intention to restrict competition in different contexts. Whilst certain clauses may have no justification in one context, thus indicating intention to restrict competition, they may be essential to bringing about positive effects in another contexts thus failing to indicate the prohibited intention." 1072

In summary, the main difference between the object requirement and the effect requirement is that the object requirement is easier to administer since it does not require a full and costly market analysis. Moreover, the distinction between the two categories of restraints is significant with regard to the burden of proof of the relevant facts. In conclusion it can be established that the ancillary restraints test is inherent to the scrutiny under the effects requirement of Article 81(1) EC. The relevant tests with regard to the alternative elements of restriction by object and restriction by effect interface in case the parties to an object restriction can plausibly demonstrate that they pursue a different commercial aim than to restrict competition. Only where - after an analysis of the relevant market - it is unambiguous that the natural and foreseeable effect is to restrict competition does the ancillary testraints test not play a role.

1069 I.c. in case the agreement or decision has already been implemented.

1070 I.e. in case the agreement or decision has not yet been implemented.

1071 Odudu O., (2001), 387.

1072 Odudu O., (2001), 387. NB 'Necessary consequences may also serve a role under the 'effect' condition. Even if these consequences are insufficient to show an intention to restrict competition, they may raise the presumption, under the 'effect' condition, that the agreement will or has had the effect of restricting competition. This shifts the burden [back] to the parties engaging in the practice to show that the agreement will not or has not had a restrictive effect on competition." 
The Object and Effect of Professional Regulation 219

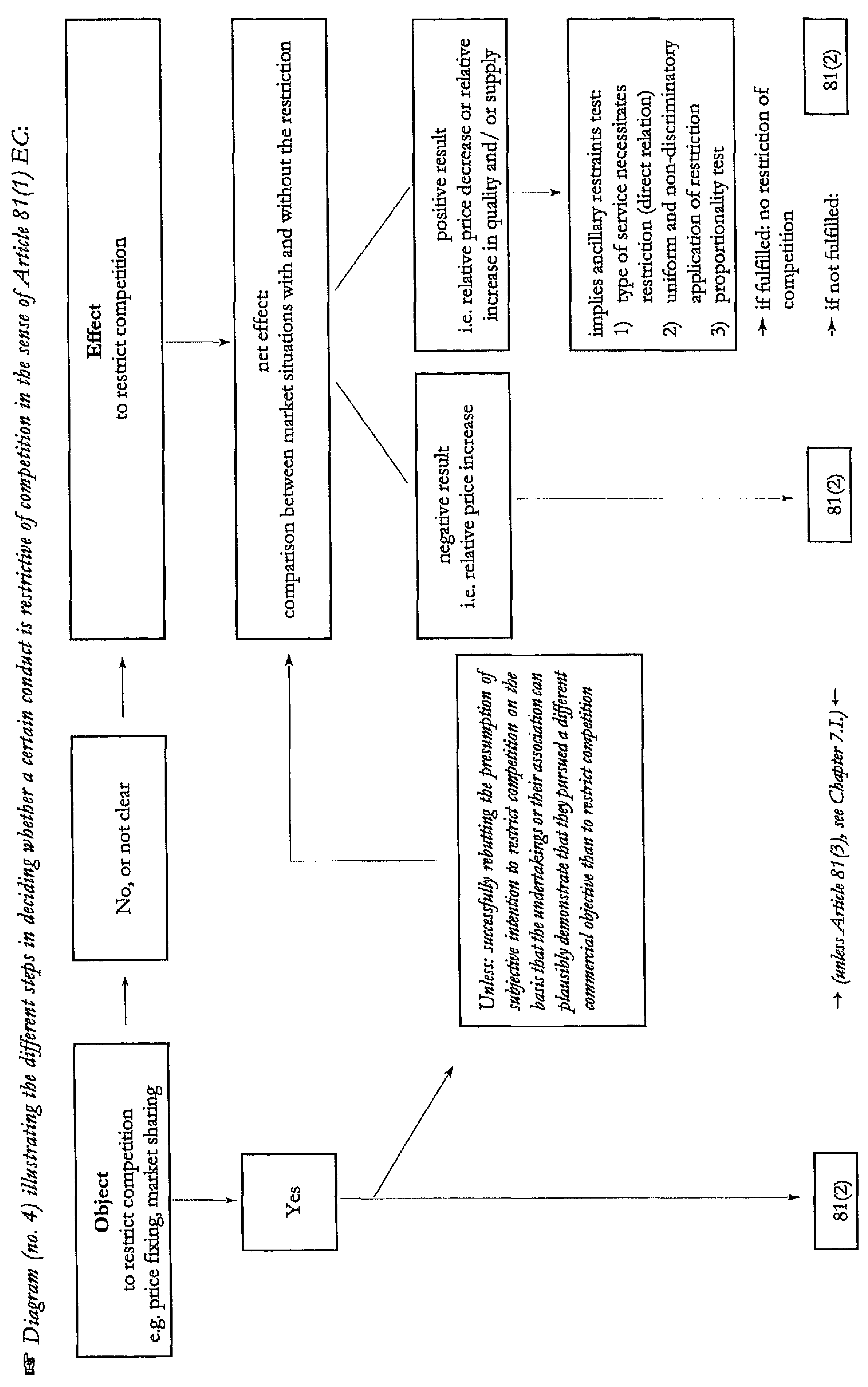


The expose on the more general classification of conduct that is prohibited due to its object and conduct that is anti-competitive by virtue of its effects on the market has highlighted the considerations that must be taken into account in applying the concept of restriction of competition to professional self-regulations. More than in previous years, the liberal professions not only have to take on the challenges and opportunities guaranteed to them by the free movement of persons and services under the EC Treaty, they also have to face competition from other professional groups, for instance lawyers from tax advisors or accountants, notaries from estate agents (and vice versa), or pharmacists from corporate internet distributors. ${ }^{1073}$ As explained above in section 1.2. professional rules affect the economic behaviour of professionals on the respective services markets. Case law of the Court and the Commission confirms that professional regulations will be found to infringe Article 81(1) EC where their object or effect is to prevent, restrict or distort competition within the common market, i.e. restricting competition between the members of the relevant profession themselves as well as in relation to members of other professions to the detriment of the ultimate consumer. ${ }^{1074}$ Whether a professional rule falls under the prohibition of Article 81(1) EC depends on the economic interpretation of the professional rule. The following section, rather than presenting a comprehensive list of anti-competitive professional rules, will scrutinise some typical types of professional rules that either have the object or the effect of restricting competition.

\section{Professional regulation and the object requirement}

The proclaimed objective of professional regulations or a code of conduct usually is to ensure a high standard of professional practice and to safeguard the 'ethics' of the

1073 See Case C-322/01, DocMorris I, [2003]. The follow up of the case has been decided on the merits by the Landgericht Saarbrücken (civil court) on 09.08.2006. Henceforth, DocMorris (which has been founded in 2000 and employs about 330 employees) does not content itself with the distribution of medicine via the internet, but has opened a sales point in Germany close to the French-Luxembourgian border for non-prescription or overthe-counter medicine. The regional Apothekenkammer(professional body), the Apothekerverband (privately organised interest group) and three pharmacists continue to resist DocMorris and claim that only approbated pharmacists are allowed to run a pharmacy, but no corporate entity. They therefore brought further proceedings before the administrative courts against the licence that the competent authority has granted DocMorris to run its pharmacy in Saarbrücken. Heinz-Günter Wolf, the president of Bundesvereinigung Deutscher Apotbekerverbände worries for the independent consultation of pharmacists if corporate entities are allowed in the market. Employed pharmacists would only focus on profit maximisation and not on the optimal care for patients. Meanwhile the case has been referred for a preliminary ruling, asking the Court of Justice on the extent of the tight of establishment under Articles 43 and $48 \mathrm{EC}$. The Court rendered its judgment on 19.05.2009, Joined Cases C-171/07 and C-172/07, DocMorris II, [2009], finding that Articles 43 and $48 \mathrm{EC}$ do not preclude national legislation that allows only persons having the status of pharmacists to own and operate pharmacies. The Court found it had not been established that another less restrictive measure would make it possible to ensure just as effectively the level reliability and quality in the provision of medicinal products to the public, and in particular that an obligation to take out insurance for vicarious civil liability would not prevent the non-pharmacist operator from exerting influence over the employed pharmacist as it only takes effect after an injurious event, see paras. $56 \mathrm{ff}$. of the judgment. See also C-531/06, Commission v Italian Republic (pharmacies by pharmacists), [2009], paras. 84 ff., 105. On grounds possibly justifying professional rules restrictive of competition and the proportionality principle see Chapter 7.

${ }_{1074}$ Commission Decision CNSD, (1993); Case C-35/96, Commission v Italian Republic (CNSD II), [1998]; Case T513/93, CNSD III, [2000]; Commission Decision COAPI, (1995); Commission Decision EPI Code of Conduct, (1999); Case T-144/99 R, EPI - interim relief, [2000]; Case T-144/99, EPI, [2001]; Case C-309/99, Wouters et al. vNOvA, [2002]; Case C-35/99, Manuele Arduino, [2002]; Commission Decision Belgian arcbitects, (2004). 
profession. The different aspects that are intended to be embraced for the sake of a "proper practice" 11075 of a profession include, for instance, the independence of the professional, the protection of professional secrecy, confidentiality, a high level of quality, professional fairness towards other members of the profession, avoidance of misleading information. ${ }^{1076}$ Therefore, at first glance, one would not tend to presume that professional rules have as their object the prevention of competition. Alleged ethical aspects are yet no evidence of the absence of an economic objective of professional rules. ${ }^{1077}$ In fact, agreements and decisions create an institutional framework through which the parties sacrifice their autonomous competitive conduct and instead observe group discipline. ${ }^{1078}$ Consequently, it is not necessary to scrutinise in the following the declared aims of professional self-regulation, but their objectively discernable purpose. ${ }^{1079}$ In other words the question here is whether and which types of professional tules have the natural and foreseeable effects to restrict competition - irrespective of any (systematic) implementation or effectiveness of a selfregulatory measure.

\subsection{Price fixing}

Professions make use of fee fixing quite regularly. ${ }^{1080}$ They claim that minimum and even maximum fee scales are adopted in the best interest of the consumer to safeguard high quality services. The argument runs that fee schedules prevent professionals to compete on prices. With fee schedules professionals would be induced to concentrate on providing services of high quality rather than reducing quality to offer their services at a lower cost. Moreover, where a client cannot choose the professional service provider on the basis of price comparison she would concentrate on choosing the most efficient professional providing the best services tailored to her needs. In COAPI the professional association put forwatd the argument that "[if] a consumer has no choice in the matter of prices he will select the agent offering the best guarantees of honesty, experience, diligence and the like, which will result in an improvement in the quality of services and prevent dishonest agents from deceiving consumers by providing poor service." ${ }^{1081}$

This reasoning at best expresses a pious hope and can be disproven for two reasons. Firstly, common sense suggests that fixed fees and guaranteed prices do not generally induce innovation to further develop the provision of (ptofessional) services. Innovation is not triggered where it goes at a cost since that would reduce profits. This is a real competition concern since, generally speaking, the pressure from competition urges for lower prices,

${ }^{1075}$ See Case C-309/99, Wouters et al. v NOvA, [2002], paras. $107 \mathrm{ff}$.

${ }^{1076}$ See also the professional values typified in Chapter 2.I.

1077 Theoretically, the purpose of professional self-regulation could be seen as distinct from the association's purpose to represent and promote the interests of its members. However, where a professional body acts as regulator it is hardly conceivable that for this activity it distegards of its function as representative of the interested professionals. The association wears two distinct hats that are not necessarily compatible. See already above section I.2.4. See also Russel B., (1936), who promotes that the assessment of a code should be independent of its declared aims and "that the question whether a code is good or bad is the same as the question whether or not it promotes human happiness".

${ }_{1078}$ Ritter L. / Braun W.D., (2004), 113.

${ }^{1079}$ For an overview of typical features of the markets for professional services from a competition law perspective, see AG Jacobs in Joined Cases C-180-184/98, Pavlow, [2000], paras. 71-92.

${ }_{1080}$ See most of the cases summarised in Chapter 2.V. where State regulation is involved in the adoption of fee scales, that aspect is dealt with in Chapter 6.

1081 See Commission Decision COAPI, (1995), para. 31 lit. i. 
which can be achieved by reducing costs in the process of providing the professional services. Moreover, fee fixing (in the form of both minimum and maximum scales) prevents that tariffs can be adapted to various quality levels or various contents demanded for professional services. In consequence fee fixing limits choices in professional services markets because no compctitive advantage can be gained from the potential of diversified services.

The second problem concerns the standard of quality that should be maintained or even boosted by fixed prices, i.e. the absence of price competition. First of all, quality of professional services should be high anyhow because of the high entrance standards that exist for liberal professions (university degree, training, examination), and the professional obligations practitioners have to observe once they managed to enter the professional market (e.g. advanced training obligations). Second of all, professional associations and interested groups in favour of strict professional regulation, and in particular of quality regulation, maintain that customers are not in the best position to assess the quality of the professional service. This is so because professional services are characterised by a strong intellectual aspect, i.e. the fact that a high level of knowledge is required to tailor the service to the needs of the client (e.g. a doctor should find the cause and not only cure the symptoms; a lawyer should solve the case in the most efficient way without lapsing into reflex of appealing to the courts, etc.). Since a customer has not undergone the same education as the professional she can hardly assess the possible solutions to her problems. Before 'consuming' or purchasing professional services she cannot know whether and how a lawyer or a doctor can help her. Certainly she expects a solution to her problem, but will not be able to judge whether the professional she chose will or even can give her the advice and services she needs. In economic theory this phenomenon is known as information asymmetry. ${ }^{1082}$

Even after having received the advice or treatment the client will often not be able to tell whether the professional provided the appropriate service with the appropriate effort. Not only is there a general risk that the professional provides a low level of services. There is also a risk of the reverse, namely of oversupply where a client receives an elaborate service that is not required by the circumstances of the client. While oversupply might not harm the cause, it does harm the purse of the client or even the general public. Telling in this regard is the private statement of a physician to the present author that treating the sick makes him earn his living; treating also the other patients makes him earn well. While tariffs in the health sector are commonly negotiated between the insurance companies and professional representatives (with the involvement of the government at a certain stage), this procedure is not perfectly in the interest of low cost and high quality health services (which should include affordable health services for all). The parties involved in the tariff negotiations do not have to decide on their own money but that of the insured and the working members of society. While it is not a serious claim that a patient should first start negotiating the price for a trcatment upon entering a consulting room, other forms ate conceivable to determine the price for medical treatment (or any other professional service for that sake) in more competitive ways.$^{1083}$

Taking the reasoning of the interested professional groups serious, where price regulation competition would mainly be focussed on quality, reveals a slight schizophrenia. ${ }^{1084}$ Accepting that the client can hardly assess the quality of professional

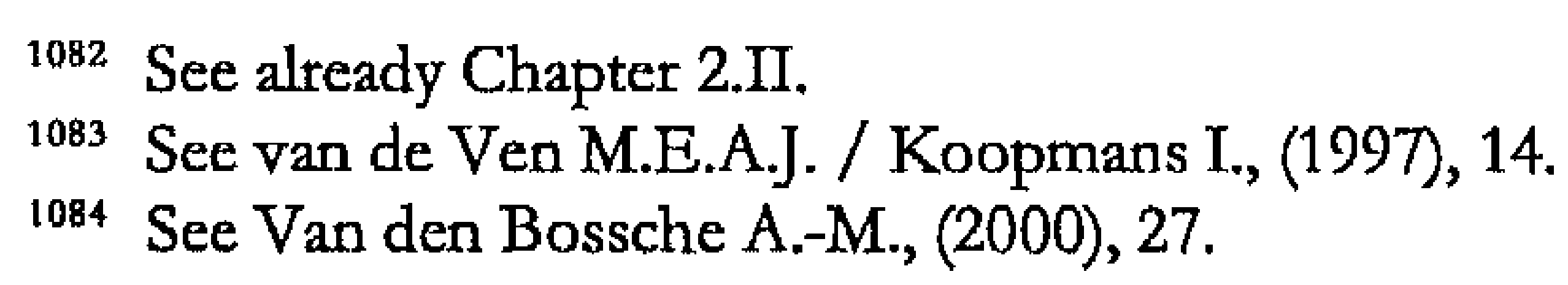


services because of an information asymmetry towatds the professional demonstrates that competition on quality hardly is triggered in professional services. The point is not disproven by business clients who may be much more specialised and experienced in choosing a professional service provider than ate private consumers. Most of the time business clients know exactly what kind of service and which standard thereof they require. Just as in any other 'industry' business, repeat users are in a more informed position to select professional services on quality. Curiously, they are also in a position to select professional services on price since the prices they pay are often not bound by a tariff scheme or fee schedule. ${ }^{1085}$ Hence, to apply fee schedules to professional services provided to (small) consumers does not make sense from a competition point of view and moreover discriminates between the bargaining powcrs held tespectively by small consumers and (tepeat) business clients.

Competition authotities have seized the opportunity to scrutinize fee scales adopted by professional associations. For instance in COAPI the Commission found that compulsory minimum scales of charges for (almost) all services in the field ${ }^{1086}$ have as their object to restrict competition; by fixing the scales through the general meeting, acting on the proposal of the administrative board, the profession's members had "collectively renounced their freedom to fix their own individual scales of charges for payment of services provided to clients". The Commission furthermore found that the object to restrict appreciably the freedom of action of the profession's membets was reinforced by imposing sanctions on any member charging below the scales in question. ${ }^{1087}$

In the Belgian architects cas $\mathrm{e}^{1088}$ minimum fees were adopted in the form of a percentage of the value of the works tealised by the entrepreneur. The Commission found that these fees seek to coordinate the pricing behaviour of architects in Belgium and therefore violate Article 81 EC. As said Mario Monti, the Commissioner for Competition at the time, "Recommended prices can mislead consumers as to what is a reasonable price for the service they are receiving and as to whether this recommended price is negotiable." ${ }^{1089}$ The Commission further specified that professional fees should teflect the professional's skills, efficiency and costs and perhaps reputation, but should not be dependent solely on the value of the works or the ptice of the entrepreneur. The Commission clearly stated that a professional should determine her fee independently of competitors and in agreement with the client only.

Also national competition authotities conduct investigations into price fixing in the liberal professions sector. For instance the French Conseil de la concurrence imposed sanctions

\footnotetext{
1085 See e.g. Whelan C.J., (2001), 942: "In short, the relationship between the clients of global law firms and the state is very different from the typical one envisayed by professional codes. Transactions are likely to be very large scale financially and in terms of the law firm resources devoted to them. As one partner in Allen \& Overy, a major U.K. firm, put it: '[W] are only interested in clients that can afford us."'

${ }_{1086}$ Minimum fees had been established for all services in the field of industrial property except in the case of services where the price is difficult to determine in advance (drafting of memoranda, appeals, cases where industrial property has lapsed, etc.).

${ }^{1087}$ Commission Decision COAPI, (1995), paras. $36 \mathrm{ff}$.

1088 European Commission, "Commission condemns Belgian architects' fee system", press release IP/04/800 of 24.06.2004. The Commission imposed a fine of $€ 100,000$ on the Belgian architects association. Setting this sum follows a gradual approach: in its first decision against a professional body concerning fixed tariffs the Commission did notimpose a fine, see Commission Decision CNSD, (1993). In a decision of 1996 on recommended tariffs of the association of Dutch forwarding agents the Commission imposed a symbolic fine of $€ 1,000$, see Commission Decision Fenex, (1996).

${ }_{1089}$ European Commission, "Commission condemns Belgian architects' fee system", press release IP/04/800 of 24.06.2004.
} 
on the French architects association that had elaborated and distributed fee scales to its members. ${ }^{1090}$ The OFT was opposed to the British architects (Royal Institute of British Architects, RIBA) giving indicative fee guidance, thereby facilitating collusion between the members of the profession. While the RIBA did not refrain from fee guidance, it proposed to base this guidance on historical information and collation of price trends that do not provide a lead on the current year's prices, a system which the OFT (seem to have) accepted. ${ }^{1091}$ The initiative taken by the Dutch competition authority to open up price regulation in the legal profession by having the NOvA experiment with a quota pars litis rule has so far been thwarted by the minister of justice. ${ }^{1092}$

\subsection{Market sharing}

Competition may be restricted between independent market operators in other ways than through direct or indirect price fixing. For instance sharing markets can be much more effective than price fixing. Since each operator participating in market sharing is reserved a part of a certain market ${ }^{1093}$, price competition is excluded, and thereby the efforts to coordinate prices are avoided. Generally speaking, market sharing therefore has the object of restricting (even eliminating) competition. ${ }^{1094}$

Certain professional rules can be interpreted to partition the (common) market. For instance, rules according to which professionals may locate or establish their office or practice only within one district can easily amount to the partitioning of the market. Such rules apply in the Member States, or werc applied until recently, for instance for doctors, pharmacists, lawyers and notaries. Where such rules are combined with the prohibition of branch offices or to provide services outside the allocated or chosen district the local markets are reserved to the professionals established within the respective local professional services matket. Although not scrutinised under the EC competition rules the situation of the well-known case of Klopp illustrates the problem. ${ }^{1095}$

Mr Klopp was not admitted to the Paris Bar, i.e. to exercise his profession in the form he wanted to, on the ground that he simultaneously maintained an establishment in Germany. At the time the Paris Bar had internal tules according to which a lawyer was not allowed to establish secondary offices outside one and the same geographical area in which the lawyer was established. ${ }^{1096}$ Such type of regulation restricts the geographical market to the locally established professionals. However, with an improved technological infrastructure a lawyer can advice her clients even if separated by many kilometres, and physical presence

${ }^{1090}$ Decision no. 97D45 of 10.06.1997.

1091 The information is reported in European Commission, "Commission condemns Belgian architects' fee system", press release IP/04/800 of 24.06.2004.

${ }_{1092}$ For details see Chapter 2.VI.2.

1093 For instance apportioning may concern geographical markets or markets according to classes of customers. ${ }^{1094}$ Whish R., (2003), 477 f.: "Geographical market sharing is particularly restrictive from the consumer's point of view since it diminishes choices: at least where the parties fix prices a choice of product remains and it is possible that the restriction of price competition will force the parties to compete in other ways. Market-sharing agreements in the EC context may be viewed particularly seriously because, apart form the obvious anticompetitive effects already described, they serve to perpetuate the isolation of geographical markets and to retard the process of single market integration which is a prime aim of the EC Treaty."

${ }^{1095}$ Case 107/83, Klopp, [1984].

1096 Article 83 of Decree No $72-468$ (Joumal Officiel de la Republique Francaise of 11 . 6. 1972) and Article 1 of the Internal Rules of the Paris Bar. 
on the spot as in former centuries is not indispensable anymore. A lawyer surrounded by fax machine, computer, mobile phone, car and Blackberry is not limited anymore to the boundaries of the court circuit in which she is enrolled in order to guarantee a dutiful counselling of her client. ${ }^{1097}$

In Klopp the potential competition came from abroad, and the case atose at a time that the Court did not yet apply the competition law provisions to regulated professions ${ }^{1098}$, so that the case was solved under the free movement rules of the EC Treaty. The difference between the two sets of EC law lies in the fact that, while professionals exclusively subject to the rules of one Member State cannot revert to the free movement rules, they can revert to the competition rules under the EC Treaty. ${ }^{1099}$ This is important to be aware of since the relevant professional rules restrict just as well the potential competition from professionals established outside the local area, while being established within the same Member State's territory .

An argument in favour of market sharing sometimes put forward is that by allotting certain parts of a geographical market, or a class-of-customers market, the operators have lower costs in distributing their services, and hence customers could benefit from lower prices. This argument is not conclusive since the market operator can always decide of her own free will to avoid extra distribution costs (if she finds it profitable to do so) by refraining from exploiting a different market, independently of any professional rule to this effect. Professional regulation preventing practitioners from providing their service outside the district of their establishment removes the possibility of potential competition; this has the same negative effects on consumer welfare than have other restrictions, namely reduced output and increased prices. ${ }^{1100}$

A further argument could be raised to rebut that the partitioning of professional services markets has the object to restrict competition. The numbers of professionals have strongly increased in the past years; at the same time most of the liberal professions are characterised by a low level of concentration; therefore, it could be argued that geographic restrictions or similar measures are not necessarily eliminating all price competition (in case price competition for professional services is allowed anyway). However, such argumentation bears on the actual effects of market partitioning measures. Since the latter have the 'object' to restrict competition they fall foul of the competition prohibition without it being necessary to prove any actual effects on the market. Moreover, the argument is not instrumental to rebut the presumption of intention to restrict competition by demonstrating net effects to increase competitive forces across markets.

\footnotetext{
1097 In former times when transportation and communication still was not systematic it was probably reasonable to require that a lawyer had to stay within the court district in order to guatantee an effective client-agent and court-agent relationship. This was not only a question of the lawyer keeping effective contact with her client, but also that (prospective) clients knew where and how to contact the lawyer in case of need. Nowadays the means of communication are much more sophisticated and allow a more rapid contacting of a lawyer or the client than in former days, and physical presence of the practitioner in the form of the authorisation to act only within one court district cannot be required anymore as a rule.

${ }^{1098}$ For details see Chapter 2.IV.

1099 For details see Chapter 3.II.

1100 See Whish R., (2003), 479.
} 


\subsection{Other restrictions necessarily restricting competition}

Two further examples shall be presented here in order to illustrate restrictions that necessarily restrict compctition other than price fixing and market sharing. The first example refers to entry requirements in the form of licensing, which is regularly found in professional regulation. The second example reiterates the facts of Wouters ${ }^{1101}$ concerning the prohibition of multi-disciplinary partnerships between lawyers and accountants.

\section{Entry requirements to the exercise of a professional activity}

Entry requirements to the exercise of a professional activity gencrally constitute a bartier for candidates to access a specific professional services market regardless of the fact whether the candidates are trained professionals or (potential) competitors from other sectors. There are different regulatory forms that subject candidates to requirements they must fulfil before they are allowed ('admitted' or 'fully qualified') to provide a certain professional service. Barriers to access can take the form of exclusive rights that are reserved to licensed, certified or registered members of a profession. Certification is a less strict form of entry regulation than licensing since it organises the profession as a voluntary function, which in principle does not hinder access of non-certified individuals to the market. There are two forms of certification. One possibility is that the rules permit any person to offer the specific professional service, but prescribe that only those persons who have qualified by examination may use the title of the profession when the services are offered to the public. A second and somewhat weaker form of certification is where the rules again permit any person to offer professional services and to perform the relevant tasks; however, those persons periodically have to pass certain examination (administered by the State and/ or professional association) in order to keep the certification. In contrast to the first form of certification, professionals can choose their level of human capital and thereby the quality level of their services. ${ }^{102}$

Where the determination and/ or application of entry requirements are left to the sector one can speak of 'gatekeeping'. Where the professions of doctors, lawyers, architects, etc. assume self-tegulation, they often undertake a gatekeeping role, in particular where State legislation confers them the respective powers to administer licensing and certification, of those seeking to join and/or remain part of the profession. Two forms of gatekeeping can be distinguished. One is the power to decide who will be admitted to 'join the club' of a

1101 Case C-309/99, Wouters et al. v NOvA, [2002].

${ }_{102}$ See Brosio G., (1997), 3 f. Paterson I., et al, Economic impact of regulation - Main Report, (2003), 20: "Many economists have preferred arrangements of certification to licensing systems becausc consumers are in the position of being able to orientate their market decisions by reference to certified producers, but may choose to purchase from non-certified practitioners, especially when lower quality needs are served by lower purchase price. On the other hand, a study of pharmacies in Netherlands and Belgium warns of the deleterious effects caused by the costs of measures taken by the licensing body to increase quality (c.g. increased education) being passed on to customers in a higher mark-up, tesulting in some customers refraining from buying medicines. While most studies of licensing have been carried out among States in the USA, a study of lawyers, architects, physicians, and pharmacists in Bclgium showed that higher degrees of licensing restrictiveness was related to higher prices and higher earnings. Finally, the suggestion that formation of several self-regulating bodies, in competition with each other (for professional members) has been put forward: under conditions of competition, the economic rents will be dissipated or, at least, reduced. Such a situation exists in practice in some member States, as we have seen, under models of certification, but not where self-regulation is conducted in a licensing mode." See also Scarpa C., (2001). 
particular group of service providets. This is comparable to the control of outlets, which the Court qualified as obvious restriction of competition. ${ }^{1103}$ The second is the power to determine which forms or types of services may be provided. Such rules have the effect of allowing or excluding 'candidates' from the provision of the relevant professional services.

The Court in Piau clearly established that a licence requirement constitutes a testriction by object in the sense of Article 81(1) EC: "the actual principle of the licence [...] constitutes a bartier to access to [an] economic activity and therefore necessarily affects competition."1104 $\mathrm{Had}$ the parties intended to disqualify the licence requirement from the category of 'object restrictions' they would have needed to plausibly demonstrate that they pursued different objectives than to restrict competition, therewith rebutting the presumption of intent. In controlling the Commission's decision the CFI did not perceive any such allegations but swiftly turned to the exemption ground under Article 81(3) EC..$^{1105}$

\section{Probibition of multi-disciplinary partnerships}

Conversely, the ECJ in Wouters did not engage in a scrutiny of Article 81(3) EC despite having established an object restriction. In particular the Court held that "A prohibition of multi-disciplinaty partnerships of members of the Bar and accountants [is] liable to limit production and technical development within the meaning of Article [81(1)(b) EC]". ${ }^{106}$ Several aspects lead the Court to conclude that the prohibition of multi-disciplinary partnerships necessarily restricts competition. The prohibition inhibits, first, the complementarity of the professional expertise of lawyers and accountants, which allows for the provision of new types of professional services by single structures (one-stop shop advantage for the client). Second, it inhibits the professionals' capacity to adapt to national and international legislation resulting from an increased interpenetration of markets. And third, it inhibits the potential of economies of scale to lead to reduced prices of services. ${ }^{1107}$ From the Court's comparison of market situations with and without the challenged decision follows the overall conclusion that multi-disciplinary partnerships make it possible to offer a wider range of services and to propose new ones at better prices. Hence, the prohibition thereof necessarily testricts competition. ${ }^{108}$

${ }^{1103}$ Joined Cases T-374/94, T-375/94, T-384/94 and T-388/94, European Night Services Ltd (ENS) e.a., [1998], para. 136.

1104 Case T-193/02, Piau I, [2005], para. 101. The facts of the case are summarised in Chapter 2.V.

1105 "[The principle of the licence] can therefore be accepted only in so far as the conditions set out in Article 81 (3) EC are satisfied, with the result that the [...] regulations might enjoy an excmption on the basis of this provision if it were established that they contribute to promoting economic progress, allow consumers a fair share of the resulting bencfit, do not impose restrictions which are not indispensable to the attainment of these objectives, and do not eliminate competition", Case T-193/02, Piau I, [2005], paras. $101 \mathrm{ff}$. For details on Article 81(3) EC see Chapter 7.I.

1106 Case C-309/99, Wouters et al. v NOvA, [2002], paras. 86-90.

1107 Economies of scale are the reduced costs for the production of an additional 'service-unit' in the face of the fixed costs that a provider has to invest to operate in the market.

${ }_{1108}$ According to the applicants the professional regulations at stake were designed to necessarily restrict competition due to the self-regulatory requirement that the primary purpose of each partner's activity-including the non-lawyer partner's activities - in a multi-disciplinary partnership has to be the practice of the law (Article 3 Samenwerkingsverordening 1993), see Case C-309/99, Wouters et al. vNOvA, [2002], paras. $74 \mathrm{ff.}$., esp. 79. Indeed such a provision can be understood as inhibiting multi-disciplinary partnerships and thus to inherently prevent competition from such entities. 


\section{Ancillary restraints and professional regulation}

Notwithstanding and as explained above, parties can undertake to rebut the presumption of their intention to restrict competition by demonstrating that they pursued different objectives. In Wouters it was the Luxembourgian government that claimed at the hearing that a prohibition of multi-disciplinary partnerships had a positive effect on competition, because it helped "to maintain a large number of operators on the market" (i.e. a high level of supply, which translates into a relative inctease of quantity). By "forbidding members of the Bar to enter in to partnership with accountants, the national rules in issue [...] made it possible to prevent the legal services offered by members of the Bar from being concentrated in the hands of a few large international [accountancy] firms". ${ }^{1109}$ While the argument of preserving a sufficient degree of competition on the legal services market was not presented by the author of the challenged professional regulation (i.e. the Dutch Bar association NOvA) ${ }^{1110}$ the Court considered whether that argument could refute the presumption that the professional regulation at issue was intended to restrict competition. The Court did not reject the validity of that rebutting or 'net effect' argument. ${ }^{1111}$ Although the Court in Wouters did not explicitly refer to the ancillary restraints doctrine the arguments ventilated at paragraphs 91-94 of the judgment cleatly breath its spirit. As explained above the idea behind the ancillary restraints doctrine is that a particular measure restrictive of competition is necessary for the effective pursuit of another commercial function or operation. The interesting detail in this respect is that the author of the relevant restriction in Wouters was not an undertaking but an association of undertakings, and therefore by definition did not pursue an economic activity of its own, let alone a commercial function to be realised on the overall market of legal services.

There are nevertheless good reasons why the ancillary restraints test can be applied to associations of undertakings. First of all the wording of Article 81(1) EC covers their actions. Secondly, professional associations assume the task to represent the interests of their members, and in doing so they adopt rules that influence the exercise of their members' economic activities. Where professional associations are conscious to avoid competition restrictive effects of their regulations, there is no reason why they could not maintain to regulate the envisaged conduct of their members in view of a broader commercial purpose to be realised across the market. Thus, while originating with a body different from the undertakings concerned, a particular restriction of conduct nevertheless can be necessary for the effective pursuit of a certain commercial function that the undertakings' regulated conduct represents on the market, and thus contribute to the competitive process.

In order to fully assess the argument of the Luxembourg government the Court in Wouters considered the economic context and the actual structure of the overall market. To this end the Court compared the services of the two professional groups concerned, and in particular compared the degree of concentration in the accountancy services market and the

\footnotetext{
1109 Arguments summarised by the Court in Case C-309/99, Wouters et al. v NOvA, [2002], para. 85.

${ }_{1110}$ From a perspective of allocation of burden of proof it would have been on the NOvA to demonstrate that the prohibition of multi-disciplinary partnerships was indispensable to realise an increase of the competitive forces across the market in order to rebut the presumed intention to restrict competition. At times it secms as if the Court moves away from such an allocation of the burden of proof, e.g. where it requires the Commission, in case of a restriction by object, to take account of counterfactual evidence or situation, i.e. the competitive environment existing if the breach had not taken place, see Case T-168/01, GlaxoSmithKline, [2006], paras. $171 \mathrm{f}$. See also Case T-201/04, Microsoft Corp. $v$ Commission, [2007], para. 1036.

1111 Case C-309/99, Wouters et al. $\nu$ NOvA, [2002], paras. 87 ff. For details see also above section II.1.2.2.
} 
legal services market. The Court stated that the respective markets for accountancy services and legal services are different in that the accountancy market is highly concentrated, whereas the legal market is less so. This, the Court said, is due to the structural limit that is put to extensive concentration of law firms and imposed by the prohibition of conflicts of interest (which is a prohibition that lawyers in all Member States are required to comply with). The Court further explained that, consequently, law firms only have reduced opportunities of benefiting from economies of scale or of entering into structural associations with members of highly concentrated professions, like accountants. The underlying idea is that lawyers would need to concentrate more in order to meet the (size of) a potential partner that is a member of a highly concentrated profession. The Court concluded that allowing multi-disciplinary partnerships carties the potential to "substantially" reducing the number of practitioners on the legal market, and eventually could lead to an overall decrease in the degree of competition prevailing on the legal services market. ${ }^{1112}$

However, the Court did not accept that the unconditional prohibition of multidisciplinary partnerships between lawyers and accountants was proportionate in view of the aim pursued. The Court thereby proceeded to the proportionality test required under the ancillary restraints test and stated that an absolute prohibition of multi-disciplinary partnerships is too strict a measure to preserve a sufficient degree of competition on the legal services market. As a less restrictive ("extreme") measure the Court suggested a teference to the respective size of the firms to enter a multi-disciplinary partnership. ${ }^{1113}$ Thus, the testriction contained in the NOvA regulation was possibly suitable but not necessary to the pursuit of a legitimate commercial aim, i.e. the safeguard of a sufficient degrec of competition. On the overall, the presumption of the intent to restrict competition was therefore not successfully rebutted by Luxembourg's arguments. In concession to the demands of clarity and expediency the specificity of the further scrutiny applied by the Court in Wouters is presented after the following section.

\section{Professional regulation and the effect requirement}

Where a testriction on professional conduct does not have the evident object to restrict competition, one has to consider the effects of the agreement or decision on competition. Applying the effect requirement in the field of professional tegulations means that they need to be analysed carefully in order to determine the net effects of their interplay in the market. An assessment of the effects of professional tegulation tequites to take account of the services covered by the rules, the actual structure of the market concerned, and the factual and legal circumstances, in particular the economic context in which the service providers operate. ${ }^{1114}$ The relevant scrutiny covers what has been written in the professional regulations, but also the context in which they have been made, and in which they are

1112 Paras. 91 to 94 of the Wouters judgment; see also para. 85 with regard to the claim made to that effect by the Luxembourgian government.

${ }^{1113}$ Where, however, the Court recognises that the prohibition of conflict of interests can be operated as a structural limit to the degree of concentration in the legal services market a reference to the size of the firms would not be strictly necessary. Yet such a reference is a much more objective yardstick than the prohibition of a conflict of interest. A limit to the size of firm can also be understood as the expression of that prohibition of conflict of interest. Other means to prevent any conflict could be possible though and the question temains whether a numetical limit would be necessary. Anyhow, a large scale cooperation would itself be subject to the competition rules on concentrations, see e.g. Commission Decision Price Waterbouse/Coopers or Lybrand, (1998), p. 27. ${ }^{1114}$ For details see above sections I.1.1. and I.1.2. 
applied. Such an assessment can be made in the abstract only to a limited extent; it "will depend on the particular clauses [...] and the economic conditions prevailing on the markets concerned."1115 Conceivable examples of professional regulation are advertising restrictions as described in EPI Code of Conduct. ${ }^{1116}$ However, in a theoretical work as the present the relevant scrutiny will necessarily be more limited than compared to a full case investigation.

\section{Limiting the probibition of Article 81(1) EC: the overall context of professional regulation}

So far it has been demonstrated that various forms of professional tegulation are restrictive of competition. It has also been explained that the ancillary restraints doctrine, which delimits the boundaries of the substantive concept of restriction of competition, applies in principle to ptofessional self-regulations, as illustrated in the Wouters judgment. ${ }^{117}$ In ruling firmly on the two concepts of restriction of competition and of ancillary restriction the Court demonstrated that it is not willing to accept a prima facie exception from the scope of application of Article 81(1) EC for the liberal professions. However, while the facts of this case did not reveal commercial net effects as required by the ancillary restraints doctrine, the Court used a similar sounding reference to the "overall context in which the decision of the association of undertakings was taken or produces its effects" to nevertheless come to the final finding that the professional regulation at stake did not infringe Article 81(1) EC. ${ }^{1118}$

The following three sub-sections will scrutinise more carefully the approach that the Court adopted with (what is here referred to as) the Wouters proviso (paragraphs 97-110 of the judgment). In particular the stake will be to verify the extent to which it sets out a valid method of limiting the substantive scope of Article 81(1) EC. The expression 'Wouters proviso' will be used as shorthand for identifying this passage of the judgment. ${ }^{1119}$ It will be more fully introduced in the following. Subsequently, a comparison will be made with the case Gottrup-Klim v DL $G^{1120}$ with which the Court explicitly credits its approach under the Wouters proviso. Section 4.3. finally will explore the limits of both the ancillary restraints doctrine and the Wouters proviso.

\subsection{The Wouters proviso introduced}

The Wouters judgment was bound to cause manifold comments for the unusual distinction it draws within the framework of the first paragraph of Article $81 \mathrm{EC}$ : on the one hand, and as has been explained above, the Court found that the professional regulation at stake was clearly testrictive of competition by object and thus came within the scope of Article 81(1) EC. On the other, the Court found that the professional regulation did not fall within the probibition laid down in that article, and hence did not infringe the article. ${ }^{1121}$ This differentiation between, first, the constituent elements of Article 81(1) EC (which, according to its wording, result in the prohibition of all agreements or decisions meeting those

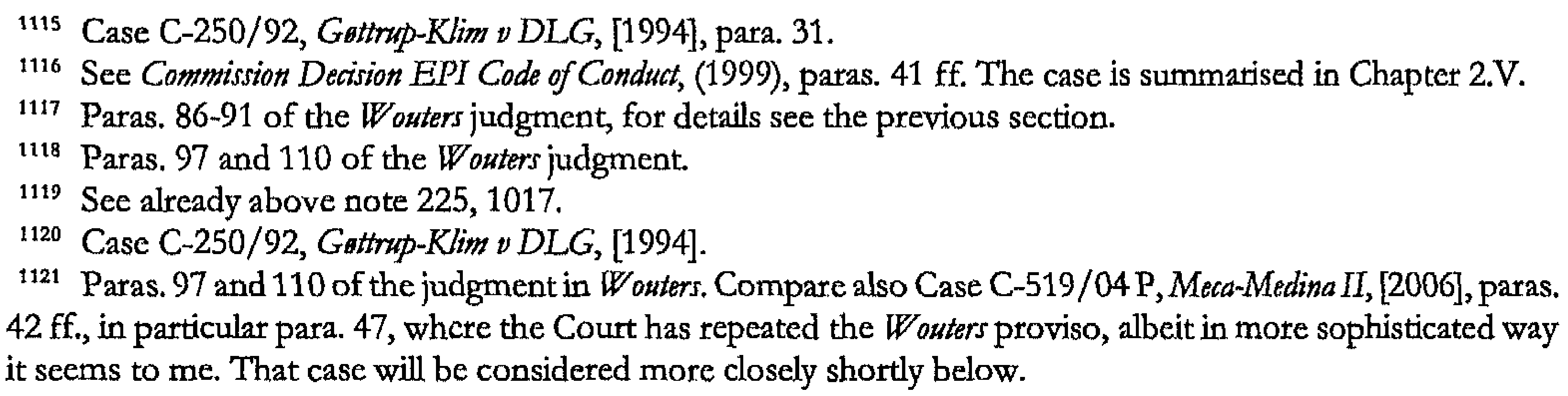


elements) and, second, the reach of the article's probibition recalls the clear bifurcated structure of Article $81 \mathrm{EC}$, according to which the prohibition of the first paragraph may be inapplicable under certain conditions. As the legal representative of $\mathrm{Mr}$ Wouters before the Court of Justice rightly pointed out:

"After finding that the regulation had restrictive effects on competition and affected trade between Member States, [the Court] could have confirmed that the regulation at issue came within the scope of the first paragraph of Article 81, and have left it to the Commission to ascertain whether the regulation qualified for an exemption under the third paragraph of Article 81 EC (the regulation had been notified by the NOvA to the Commission for an exemption). ${ }^{.1122}$

The startling effect of the Court's approach in Wouters is that, while it did not have recourse to Article 81(3) EC, it still granted an "escape toute" "1123 for the professional regulation by using the same mechanism as Article $81(3) \mathrm{EC}$, namely not to apply the prohibition of Article 81(1) EC. Starting from the overall context that must be taken into account "for the purpose of application" of Article 81(1) $\mathrm{EC}^{1124}$, the Court reasoned that the effects restrictive of competition were inherent in the pursuit of the objectives of the professional regulation. ${ }^{1125}$ Thus, the Court first of all counted the objectives pursued by the professional regulation as part of the "overall context in which the decision of association of undertakings was taken or produces its effects". ${ }^{1126}$ These objectives were acknowledged by the Court to be "connected with the need to make rules relating to organisation, qualifications, professional ethics, supervision and liability, in order to ensure that the ultimate consumets of legal services and the sound administration of justice ate provided with the necessary guarantees in relation to integrity and experience". ${ }^{1127}$

The Court continued that the professional tegulation at stake (i.e. the ban on multidisciplinary partnerships) could reasonably be considered necessary to ensute the properpractice of the legal profession as organised in the Netherlands, and that thus the professional regulation did not infringe Article 81(1) EC. ${ }^{1128}$ The Court, hence, equalled the proper practice of a profession with the earlier mentioned objectives of the professional regulation that are connected with "the need to make rules" relating to a number of professional values. ${ }^{1129}$ Subsequently, the Court presented these objectives as if necessarily implying the professional rules to be competition restrictive in view of the "necessary guarantees in relation to integrity and experience" mentioned in paragraph 97 of the judgment.

In tracing the considerations that turned the balance from 'restrictive of competition' to 'not falling within the prohibition laid down in Article 81(1) EC',1130 one step in the Wouters proviso catches particular attention. In paragraph 109 of the judgment the Court stated that "it does not appear that the effects restrictive of competition [which result from the professional regulation at stake] go beyond what is necessary in order to ensure the proper

${ }^{1122}$ Gilliams H., (2006), 23.Forrester I.S., (2006); van de Gronden J.W. / Mortelmans K.J.M., (2002), para. 14, observing that as of para 97 the judgment reads like a dissenting opinion.

${ }_{1123}$ Gilliams H., (2006), 22.

1124 Para. 97 of the judgment in Wouters.

1125 Paras. 97 and 110 of the judgment in Wouters.

${ }_{1126}$ Para. 97 of the judgment in Wouters.

1127 Para. 97 of the judgment in Wouters.

${ }_{1128}$ Paras. 107 and 110 of the judgment in Wouters.

${ }_{1129}$ As has been pointed out before one should note that these objectives were not connected with a commercial main operation - in contrast to the ancillary restraints doctrine the arguments of which the Court had ventilated in paragraphs $91-94$ of the Wouters judgment.

${ }^{1130}$ See paras. 97 and 110 of the Wouters judgment. 
practice of the legal profession". To underpin its overall conclusions the Court referred "to that effect" to Gottrup-Klim v DLG. ${ }^{1131}$ This reference surprises because in that case application had been made of the ancillary restraints doctrine as will be explained hereafter.

\subsection{Ancillary restraints sift througb: Wouters compared with Gotlrup-Klim $v$ DLG}

The succinct reference in the Wouters proviso to the concept of ancillary restraints provides the opportunity, and even requires, to carefully compare Wouters with Gottrup-Klim v DLG. While in both decisions the Court has emphasised the importance of the context in which the respective measures were taken ${ }^{1132}$, the question arises whether the two cases share the same principles or whether in Wouters the Court established a different principle merely cloaked in the guise of the DLG-test. Hete follows a short description of the facts of GottrupKlim $\nu D L G$ and of the less apparent, but significant differences with the Wouters case (section 4.2.1.) before going into the apparent (tather than real) similatities concerning the purpose of the respective rules that were at stake in the two cases (section 4.2.2.).

\subsubsection{Opposite results in applying the same test}

The Gottrup-Klim v DLG case concerned a Danish agricultural cooperative with the aim of purchasing basic agricultural products for its members at the lowest price possible. Membership was categorised in four groups (A-, B-, C-and D-members). The B-members were local cooperatives charged with the negotiation and/or production of goods DLG had in its range of products. These members were dissatisfied with the prices DLG offered for fertilisers and pesticides. Thus, in 1975 the B-members founded their own cooperative association $\mathrm{LAG}^{1133}$ in order to import those products themselves. In 1988 the DLG reacted to the situation by changing their statutes stipulating that its members were prohibited from double membership in other cooperative associations competing with $D L G$ in large scale sales for the two lines of products. As a result the B-members had to quit DLG; they were compensated though for the capital they had contributed during the past ten years, and received the balance of their accounts. At the same time the minimum period for membership with DLG was reduced from ten to five years. Following these changes the Bmembers brought proceedings before the Danish judge for, amongst others, breach of Articles 81 and $82 \mathrm{EC}$.

The main legal considerations in the preliminary ruling in Gottrup-Klim $\nu$ DLG can be summarised as follows. First of all, the ECJ stated that a purchase cooperative is a voluntary association of persons established for the common pursuit of commercial interests. Whether the statutes of such an association are compatible with competition law depends above all on their specific provisions and the economic situation on the relevant market. ${ }^{1134}$ Secondly, the Court tightly stressed that fertilisers and pesticides (which the Court euphemistically calls plant protection products) are "the only farm supplies in respect of which a direct

\footnotetext{
${ }^{1131}$ See para. 109 of the Wouters judgment. Curiously, the addition "to that effect" in referring to Gottrup-Klim $v D L G$ has not been made in the Dutch version of the judgement, which is the authentic version, see note 1163. ${ }_{1132}$ Para. 97 of the Wouters judgment and para. 31 of the Gottrup-Klim v DLG judgment. See also above section II.1.2.1.

${ }^{1133}$ Landsforeningen of Andels Grovvareforeninget.

1134 Para. 31 of the Grttrup-Klim v DLG judgment.
} 
relationship exists between sales volume and price". ${ }^{1135}$ The Court continued that on markets on which prices vary in accordance with the quantity of orders purchase cooperatives can be an important counterweight against the contractual power of large producers. This is an economic reasoning according to which the purchase cooperatives' contractual counterweight actually contributes to better competitive conditions on the concerned markets (i.e. the supply markets of fertilisers and plant protection products). In Gottrup-Klim $\nu D L G$ the Court held that a parallel membership in a competing association can lead to a weakening of this capacity of the first cooperative. Consequently, a provision prohibiting double membership can actually have beneficial consequences for competition, and thus does not necessarily restrict competition in terms of net effects, and thus does not necessarily reduce competitive forces across markets. ${ }^{1136}$ With this conclusion the Court found the first condition of the ancillary restraints test fulfilled, i.e. that the trading of the products or services concerned necessitated the particular type of restriction.

On the other hand the Court in Gottrup-Klim v DLG recognised that the prohibition of double membership can also have harmful effects on competition in that it discourages the members to obtain their supplies elsewhere. In this respect the ECJ adopted the same reasoning that it adopted later in paragtaphs $91-94$ of the Wouters judgment ${ }^{1137}$ and looked in to the prospective negative effects of the restraint at hand. This consideration brought the Court in Gottrup-Klim v DLG to emphasise the principle that in order to be acceptable the restrictive provisions have to be limited to what is necessary. ${ }^{1138}$ In casu the proportionality test had been fulfilled for the following reasons: first of all, the challenged provisions of the DLG statues were limited to cover only products having direct implications on the quantity of agricultural products to grow (i.e. fertilisers and pesticides). Thereby the disputed provisions were reflecting the aim beneficial to competition of a purchase cooperative to balance contractual power by influencing the price - sales volumes relation. Secondly, nonmembers could continue to get their supplies from DLG "on the same commercial terms and at the same prices as members, except that 'non-members' [were] obviously not entitled to receive a yearly discount on the amount of the transactions carried out". And thirdly, as for the remaining members of DLG, they were authorised to buy their products without using DLG as an intermediary. ${ }^{1139}$ The Court thereby not only demonstrated the suitability

1135 Para. 37 of the Gottrup-Klim v DLG judgment.

1136 Paras. 33-34 of the Gottrup-Klim v DLG judgment: "Where some members of two competing cooperative purchasing associations belong to both at the same time, the result is to make each association less capable of pursuing its objectives for the benefit of the rest of its members, especially where the members concemed, as in the case in point, are themselves cooperative associations with a large number of individual members. 34 It follows that such dual membership would jeopardize both the proper functioning of the cooperative and its contractual power in relation to producers. Prohibition of dual membership does not, therefore, necessarily constitute a restriction of competition within the meaning of [Article 81(1) EC] and may even have beneficial effects on competition."

${ }^{1137}$ Discussed above in section II.2.3.

${ }^{1138}$ Para. 35 of the Gottrup-Klim v DLG judgment:"So, in order to escape the prohibition laid down in Article [81(1) EC], the restrictions imposed on members by the statutes of cooperative purchasing associations must be limited to what is necessary to ensure that the cooperative functions properly and maintains its contractual power in relation to producers." Sec also Serras F., (1995), 344. See also the case law referenced above in notes $1059 \mathrm{ff}$.

1139 Paras. 38-39 of the judgment: "Finally, DLG's statutes authorize its members to buy fertilizers and plant protection products without using DLG as an intermediary, provided that such transactions are carried out otherwise than through an organized consortium. In that context, each member acts individually or in association with others but, in the latter case, only in making a one-off common purchase of a particular consignment or 
and necessity of the prohibition of double membership - as requirements of the ptoportionality test - but also showed that the restriction was applied in a non-discriminatory way, i.e. in accordance with the second condition of the ancillary restraints test. ${ }^{1140}$ The Court continued that the restrictions imposed on the members of DLG were proportionate strictu sensu in view of the aim pursued (i.e. to maintain DLG's contractual power as counterweight to the contractual power of large producers) by finding that there were no less restrictive but equally effective means. ${ }^{141}$ Furthermore, the Court considered that also the sanctions for non-compliance with the statutes and the minimum period of membership, (i.c. the time that the members of the association were bound by those statutes) were proportionate. ${ }^{1142}$

The pattern applied in Gottrup-Klim $v$ DLG to remove provisions adopted by an association of undertakings from the scope of Article 81(1) EC thereby presents itself as follows: first, the challenged measure must have positive net effects on competition. The yardstick is the specific context of the competition situation in which the agreement or decision was adopted or produces its effects. The ensuing restriction must be necessary, and thus is not restrictive of competition in the legal sense, if its elimination was to jeopardise the positive net effects on competition. ${ }^{1143}$ This requires a direct relation between the restraint and the main purpose of the transaction itself. Secondly, the restriction must be applied in a uniform and non-discriminatory manner. Thirdly, the associated negative impact - rather than being outweighed by other positive effects - must be limited to what is necessary. In other words, the provisions intended to implement and guarantee the positive effects on competition have to be proportionate ${ }^{1144}$ in the specific context of the main operation to realise the aim thereof. Only if these requirements are met can the restrictions at issue be qualified as not testrictive of competition, or ancillary, and therefore fall outside the scope of Article 81(1) EC. ${ }^{145}$ Only where a limitation on the freedom of (commercial) activity has the effect of restricting competition across the matket will Article 81(1) EC apply. ${ }^{1146}$

shipload."

${ }_{1140}$ For details see above p. 216.

${ }_{1141}$ Para. 40 of the Gottrup-Klim v DLG judgment.

1142 See paras. 41-43 of the judgment: "41 As regards the penalties imposed on the plaintiffs as a result of their exclusion for infringing DLG's rules, these would not appear to be disproportionate, since DIG has treated the plaintiffs as if they were members exercising their right to withdraw. 42 So far as concems the membership period, this has been reduced from ten to five years, which does not seem unreasonable. 43 It is significant, in the last analysis, that after their exclusion, the plaintiffs succeeded, through LAG, in competing vigorously with DLG, with the result that in 1990 their market share was similar to DLG's."

1143 See para. 34 of the Gottrup-Klim $\nu$ DLG judgment. On net effect see above section II.1.2.1.

1144 Sce paras. 36-40 of the Gottrup-Klim v DLG judgment. For details on the difference between ancillary restraints and Article 81 (3) EC, see above page 215 and note 1056.

${ }^{1145}$ It shall be noted that Gottrup-Klim $v D L G$ is not necessarily contradicting an earlicr case on a Danish cooperative decided by the CFI two years earlier, see Case T-61/89, Dansk Pelsdyravlerforeniting (DPF), [1992]. The latter case did not concern a purchase but a sales cooperation. See also Boutard-Labarde M.-C., (1995), 128: "La disposition examinée [dans l'affaire DLG]... n'cmporte, quant à elle, aucune obligation d'exclusivité au profit de la coopérative [comme dans l'affaire DPF] mais limite seulement les modalités selon lesquelles ses membres sont autorisés à agir en dehors d'elle et en concurrence avec elle." For a contrasting view see Serras F., (1995), 344: "Ta portée essentielle de cet arrêt [DPF] résidait dans le refus de tenir compte des spécificités des coopératives, au stade du bilan concurrentiel, et dans l'affirmation qu'elles devaient être traitées comme n'importe quel autre groupement d'entreprises."

${ }^{1146}$ 'The plaintiffs in DLG had presented an argument to this effect by maintaining that the limitation imposed by the statutes of DLG had been intended to consolidate the already strong position held by DLG regarding distribution of the products in question, and that thus the regulation in question would further reduce competition 
Comparing the cases Gottrup-Klim v DLG and Wouters seems to reveal a number of similarities, at least at fist sight. First of all, both cases concern provisions adopted by an association of undertakings that prohibit their members to adopt a certain conduct. Second, in dogmatic terms both cases exclude the disputed restrictive rules from the scope of Article 81 (1) EC rather than trying to justify or exempt their restrictions under the third paragraph of Article $81 \mathrm{EC}$. A third similarity is the adoption of a larger perspective beyond the specific negative impact of the self-regulatory measures at stake. In both cases certain beneficial aspects wete considered that the associations in question pursued.

However, while in Gottrup-Klim v DLG the Court minutely examined all relevant factors to give a full appreciation of the competitive benefits and the associated harms of the measure at stake to eventually come to a positive conclusion, the application of the concept of ancillary restraints in Wouters revealed negative net effects on competition. ${ }^{1147}$ It is noteworthy that the Wouters proviso in para. 109 reinforces the finding that the absolute prohibition of multi-disciplinary partnerships between lawyers and accountants is clearly restrictive of competition. ${ }^{1148}$ This means that, different from Gottrup-Klim $\nu D L G$, the Court in Wouters did not disqualify the rules of the association of undertakings from being restrictive of competition. ${ }^{1149}$ Thus, based on the respective facts in Gottrup-Klim $v$ DLG and Wouters the Court came to opposite results in assessing the substantive concept of restriction of competition in Article 81(1) EC. The conclusion to be drawn at this point therefore is that with the salvation of the challenged NOvA regulation the Court in Wouters went beyond the dogmatics of the Gattrup-Klim v DLG decision and earlier case law: the disputed NOvA provisions were not the least restrictive means to serve a legitimate commercial aim and thus did clearly not meet the first and thitd condition of the DLG-test on ancillary restraints.

The following section will turn to critically scrutinise which broader perspective the Court exactly adopted with the Wouters proviso, and in particular which criteria the Court applied to come to the final finding that the NOvA regulation did not infringe Article 81(1) EC.

between DIG and third parties. The argument is addressed by AG Tesauro in Case C-250/92, Gottrup-Klim v $D L G,[1994]$, para. 13. In this context it shall be recalled that not any restriction of conduct, or the freedom of (commercial) action, necessarily amounts to a restriction of competition, see above section II.1.2.1., and Odudu O., (2001), 263; Amato G., (1997), 7 to 10. Compare also with the common law restraint of trade doctrine mentioned above, which is broader in that it protects a person's freedom of future conduct, see the text with note ?.

${ }^{1147}$ See paras. 86-94 of the Wouters judgment. Para. 90: "A prohibition of multi-disciplinary partnerships of members of the Bar and accountants, such as that laid down in the 1993 Regulation, is therefore liable to limit production and technical development within the meaning of [Article 81(1)(b) EC]." See also para. 101 of the judgment which reinforces the restriction-by-object nature of the NOvA prohibition on multi-disciplinary partnerships: "Those obligations of professional conduct have [...] considerable implications for the structure of the market in legal services, and more particularly for the possibilities for the practice of law jointly with other liberal professions which are active on that market."

1148 The Court stated that "it does not appear that the effects restrictive of competition [... resulting from the professional rules] go beyond what is necessary in order to ensure the proper practice of the legal profession". ${ }_{1149}$ Only where less restrictive means would have been of no avail could the absolute prohibition of multidisciplinary partnerships in Wouters have qualified as not restricting competition in the sense of the ancillary restraints doctrine under Article 81(1) EC. See paras. $93 \mathrm{f}$. of the Wouters judgment. Where professional rules "are in fact capable of encouraging or guaranteeing normal competition on the market for [...] services [they] might fall outside the prohibition laid down in Article [81(1) EC].", AG Léger in Case C-309/99, Wouters et al. vNOvA, [2002], para. 112. 


\subsubsection{Beyond ancillary restraints: limiting the reach of the probibition of Article 81(1) EC}

So far it has become clear that by salvaging the NOvA rules the Court in Wouters was bound to step outside the system of Article $81 \mathrm{EC}$, and in particular outside the concept of restriction of competition and the interpretation thereof, if it did not intend to leave it to the Commission to ascertain whether the disputed regulation qualified for an exemption under the third paragraph of Article 81 EC. ${ }^{1150}$ However, by referring to Gottrup-Klim $v$ DLG the Court in Wouters presented its findings in patagraphs 97-110 as if they stayed within the boundaries of the ancillary restraints test. On face value it appears that the patterns of the two decisions indeed tesemble each other, namely insofar as they employ a similat language:

DLG: " "... it would not scem that restrictions laid down in the statutes [...] go beyond what is necessary to ensure that the cooperative functions properly and maintains its contractual power in relation to producers"1151;

Wouters. "...it does not appear that the effects restrictive of competition [...] resulting [...] from a regulation [...] go beyond what is necessary in order to ensure the proper practice of the legal profession". ${ }^{1152}$

However, while both decisions respectively refer to the 'proper functioning' and the 'proper practice', these two references are different in character. To begin with, the proper functioning of the purchase cooperative in Gottrup-Klim $v$ DLG had been defined in commercial terms (namely to maintain its contractual power) - as one can actually expect within the frame of Article 81(1) EC. More particularly, the proper functioning in DLG refers to that of the association in question as the author of the restrictive rules. Conversely, in Wouters the proper practice refers to the activity of the members of the association in question (namely by referring to the "proper practice of the legal profession" "153). Reapplying this logic to the case of Gottrup-Klim $\nu D L G$ would read as the 'proper practice of the agricultural profession or sector'. Clearly, this was not the point of reference of the Court in Gottrup-Klim v DLG.

'The resulting shift in reference - i.e. from the 'proper functioning' of the author of restrictive self-regulatory rules in Gattrup-Klim v DLG to the 'proper functioning' of the regulated activity in Wouters - can be explained by the different characters of the two associations at hand. The DLG was considered to exercise an economic activity itself in the sense of competition law, whereas the NOvA did not qualify as an undertaking for lack of an economic activity independent of that of its members. ${ }^{1154}$ As a consequence, the DLG had a commercial relationship towards its members. ${ }^{1155}$ By accepting the ancillarity of the DLG statutes the Court actually provided for a 'right of (commetcial) self-protection' of the DIGG against its dissident members. ${ }^{1156}$ Conversely, while the NOvA very well interfered with the economic activity of others - as was DLG - it did not regulate for its own economic activity

\footnotetext{
${ }^{1150} \mathrm{Sec}$ above the text with note 1122 . For details on the possible motive of the Court to hand down the Wouters proviso see shortly below.

${ }_{1151}$ Para. 40 of the judgment in DLG (emphasis added) under the heading 'testriction of competition'. NB Whilc the ECJ joins the parts of the clause with the conjunction 'and' as a linguistically appropriate way of ordering the relevant information, my reading of the judgment is that the 'proper functioning' of the cooperative is defined by the maintenance of its contractual power in relation to producers. My suggestion therefore is that the conjunction 'and' could be replaced with 'meaning that it' or 'and thus'.

${ }^{1152}$ Para. 109 of the judgement in Wouters (emphasis added), which includes the reference to Gottrup-Klim $\nu D L G$.

1153 See para. 110 of the Wouters decision. Compare also Commission Decision EPI Code of Conduct, (1999), paras. $34 \mathrm{ff}$, discussed above in section I.2.5.

${ }^{1154}$ See in particular para. 48 of the Gettrup-Klim v DLG decision and para. 111 of the Wouters decision.

1155 Compare also Case C-399/93, Oude Luttikhuis, [1995], para. 14.

1156 Bolze C., (1995), 555.
} 
as DLG had been doing. ${ }^{1157}$ Since the 'proper functioning' of the NOvA itself could thus not be decisive in commercial terms, it could not be the linchpin for the Wouters proviso. The focus thus naturally turned to the regulated activity as the subject of the competition law scrutiny. However, as becomes apparent from the Court's reasoning preceding the Wouters proviso, the reference to 'properness' did not concern the proper economic practice of the legal profession, as that would have resulted in accepting the ancillary restraints defence as suggested by the government of Luxembourg. ${ }^{1158}$ Therefore, the Wouters proviso could not but exceed the limits of the purely commercial purpose that the ancillary restraints doctrine sets. ${ }^{1159}$

The fundamentally different character of the Wouters proviso can be revealed by analysing the exact connection that the Court established between the two cases. To start with, it needs to be pointed out that the Wouters proviso did not actually refer to paragraph 40 of Gottrup-Klim $v$ DLG as reproduced above, but to paragraph 35 of that judgment. While there is no substantive difference between the two passages, they differ in that paragraph 35 carries an 'addendum' that is crucial in tracing the logic of the Wouters proviso: "So, in order to escape the probibition laid down in Article [81(1) EC], the restrictions imposed on members by the statutes of cooperative purchasing associations must be limited to what is necessary to ensure that the cooperative functions properly and maintains its contractual power in relation to producers" (emphasis added). By referencing in particular the opening of paragraph 35 of Gottrup-Klim $\nu$ DLG the Wouters proviso diverts the attention from the concept of restriction of competition towatd the agreement or decision ascaping the probibition of Article 81(1) EC. In Gottrup-Klim vDLG these two ideas stand for the same, since a measure not restricting competition is not within the substantive scope of Article 81(1) EC and thus necessarily 'escapes' the prohibition laid down therein. The NOvA regulation, however, clearly came within the substantive scope of Article 81(1) EC, as the Court has underlined in Wouters. ${ }^{1160}$

Consequently, the Court's reference to paragraph 35 of Gattrup-Klim v DLG deludes into

1157 Of course the Court must have been aware of this structural difference between the two cases; that is at least how I interpret the wording of its teference to Gottrup-Klim v DLG in Wouters at para. 109 ("see, to that effect, Case C-250/92 DLG...") ("in diesem Sinne Urteil vom 15. Dezember 1994...") ("voir, en ce sens, arrêt du 15 décembre 1994, DLG...") ("v., in questo senso, sentenza 15 dicembre 1994...") ("véase en este sentido, la sentencia de 15 de diciembre de 1994, DLG, ...") [emphasis added]. Curiously, the Dutch language version (which has been the language of the Wouters case) differs in this respect and simply presents the case as an application of Gottrup-Klim $\nu D L G$ ("zie arrest van 15 december 1994, DLG,..." instead of "zie in die zin" as for instance used in para. 97 of the judgment).

${ }_{1158}$ See paras. 91-94 of the Wouters judgment. For details see above section II.2.3.

1159 See also AG Léger in Case C-309/99, WWouters et al v NOvA, [2002], paras. 103-105: "105. In this casc, the argument put forward by the interveners and the Commission goes far beyond the scope of the competition balance-sheet allowed by the Court's case-law. The parties do not maintain that the effect of the Regulation is to encourage competition on the market in legal services. As the observations made in response to the first [preliminary] question indicate, the partics believe that the prohibition of multi-disciplinary partnerships between lawyers and accountants is necessary in order to protect aspects of the profession - independence and loyalty to the client - which are essential in a State governed by the rule of law. Their reasoning therefore amounts to introducing into the provisions of Article [81(1) EC] considerations which are linked to the pursuit of a public-interest objective."

${ }_{1160}$ See paras. 86-94 of the judgement in Wouters. NB A further difference can be traced between Gettrup-Klim $\nu D L G$ and the Wouters proviso on the basis of the wording of the two quotations reproduced above. In the context of Gottrup-Klim $v D L G$ the reference to 'restrictions laid down in the statutes' has to be read as restrictions of the freedom of action rather than the freedom of competition. Conversely, para 109 of the Wouters judgment in clear terms refers to "effects restrictive of competition". 
thinking that the concept of ancillary restraints would (also) offer a plain escape route from the prohibition laid down in Article 81(1) EC "despite the effects restrictive of competition". ${ }^{1161}$ This reference thus leads to believe that the Wouters proviso would be an application of the concept of ancillary restraints - which, however, constitutes in turn a finetuncd interpretation of the substantive element of Article 81(1) EC of restriction of competition. ${ }^{162}$ This misguidance of the Wouters proviso is provoked by taking paragraph 35 of Gottrup-Klim v DLG out of its context. The ensuing result is twofold: first of all, GottrupKlim $v D L G$ is presented to formulate a more sweeping rule than it actually does, namely to limit the reach of the probibition of Article 81(1) EC, rather than to refine the concept of restriction of competition. ${ }^{163}$ Secondly, safeguarding a clear competition restrictive measure that is proved not to qualify as an ancillary restraint, and which is not tested under Article $81(3)$ EC or Article $86(2)$ EC, constitutes a contra legem interpretation of Article 81(1) EC since that article states that all agreements, decisions and concerted practices shall be probibited as incompatible with the common market.

1161 Para. 110 of the Wouters judgment.

1162 The questionable approach of the Wouters proviso appears to have been motivated by the result to achieve, i.e. to salvage the self-regulatory measure at stake from the legal consequence of Article 81(2) EC. For details on the motivation of the Court's approach in Wouters see shortly below. See also Simon D., (1981), 137: "Il n'est pas du tout évident que le taisonnement exprimé dans les motifs d'un arrêt coïncide avec la démarche effectivement suivie par le juge pour forger sa conviction: au contraire, dans la pluspart des cas, la décision sur l'issue du litige précède la motivation, qui a pour seule fonction de justifier la solution décourverte par d'autres moyens." An even more pessimistic view on the interpretation of the law (Auslegung) can be found by Radbruch G., (1952), 161: "Dic Auslegung ist also das Ergebnis - ihres Ergebnisses, das Auslegungsmittel wird erst gewählt, nachdem das Ergebnis schon feststeht, die sogenannten Auslegungsmittel dienen in Wahrheit nur dazu, nachträglich aus dem Text zu begründen, was in schöpferischer Ergänzang des Textes bereits gefunden war, und wie diese schöpferische Etgänzung auch lauten mag, immer steht das eine oder das andere Auslegungsmittel, der Schluß aus der Ähnlichkeit oder der Umkehrschluß, zu ihrer Begründung bereit."

${ }^{1163}$ The reading that the Wouters proviso goes beyond Gottrup-Klim $\nu D L G$ is confirmed in Case C-399/93, Oude Luttikbuis, [1995], paras. 13 f., which equally refers to para. 35 of Gottrup-Klim v DLG: "13 However, it does notfollow that the provisions in the statutes governing relations between the association and its members, in particular those relating to the termination of the contractual link and those requiring the members to reserve their milk production for the association, automatically fall outside the probibition in Article 81(1) EC. 14 In order to escape that prohibition, the restrictions imposed on members by the statutes of cooperative associations intended to secure their loyalty must be limited to what is necessary to ensure that the cooperative functions properly and in particular to ensure that it has a sufficiently wide commercial base and a certain stability in its membership" (emphasis added). The misguidance is particularly strong in the Dutch version of the Wouters judgment, in which the Court plainly referred to para. 35 of Gettrup-Klim $\nu D L G$ without the addition "to that effect", see above note 1157. Intriguing at this stage is that only the Dutch version of the judgment is authentic since Dutch was the language of the case, see Article 29(3), read in conjunction with Article 31 of the Rules of Procedure of the Court of Justice (01.03.2008): "The language of the case shall in particular be used in the [...] decisions of the Court." "The texts of documents drawn up in the language of the case [...] shall be authentic." The Rules of Procedure of the Court of First Instance of the European Communities (01.01.2007) contain identical provisions in Articles 35 and 37. 


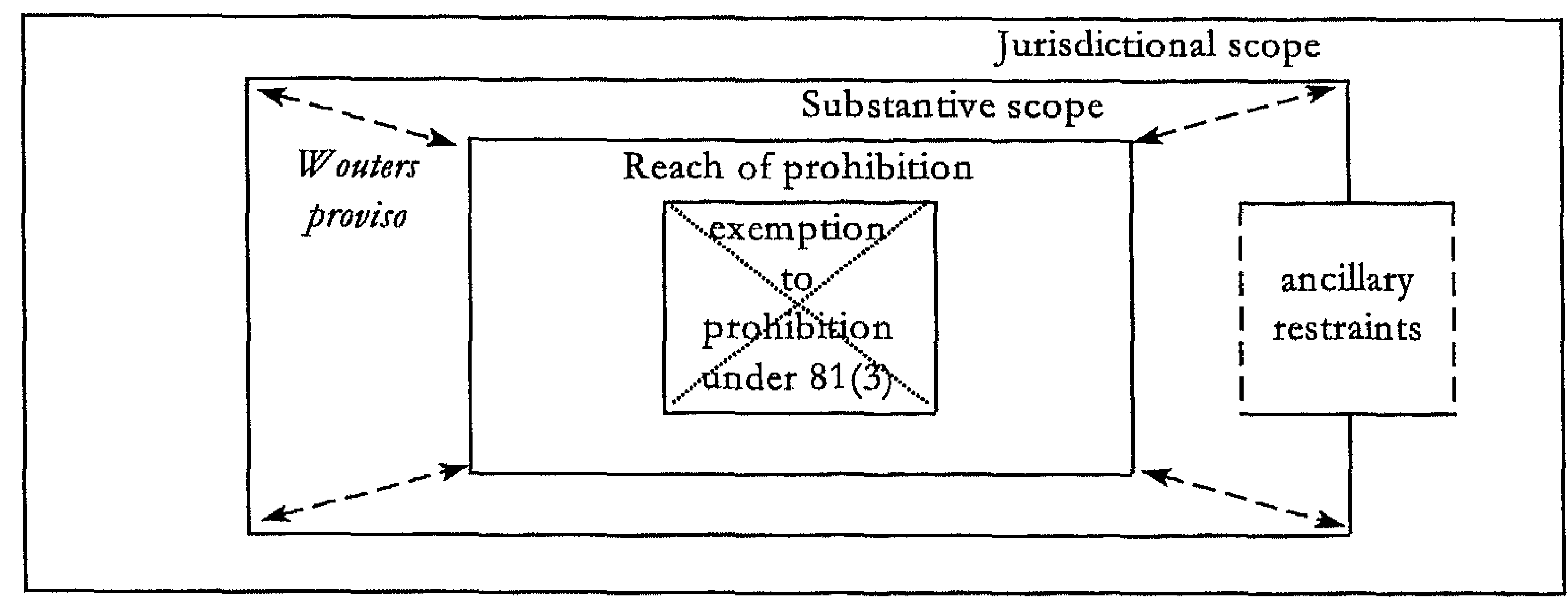

Diagram (no. 5) illustrating the effect of the Wouters proviso shrinking ${ }^{1164}$ the reach of the probibition

In order to grasp the precise twist that the Wouters proviso applies to the scope of Article 81(1) EC it shall be further contrasted with the concept of ancillary restraints. The result of that exercise will allow to assess whether the $W$ outers proviso, by limiting the reach of the prohibition of Article 81(1) EC, establishes a sector specific exception or actually leads to a more principled exception from the article's scope.

\section{A shift in paradigm: 'proper' commercialisation of professional services}

As set out earlier particular types of restrictions may not be prohibited under Article 81(1) EC if, in accordance with the first criterion of the ancillary restraints doctrine, they are necessary for the commercialisation of a particular type of product or service. This criterion was not met in Wouters as the commercialisation of legal services does not necessitate the unqualified prohibition of multi-disciplinary partnerships. The Court nonetheless recognised that it was justified to limit that commetcialisation. Hence, squating the prominent formulation of the Wouters proviso with the first criterion of the ancillary restraints doctrine reveals that the Wouters proviso cannot but mean to stipulate that it is the 'proper commercialisation' of legal service that necessitated the disputed type of restriction. ${ }^{165}$ 'T'o build a legal reasoning on some thought of 'proper commercialisation' almost has a moralising overtone. At this juncture it becomes clear that the Wouters proviso accepts as legitimate a main operation that pursues an aim other than to increase commercial net effects actoss the market. The concrete consideration of the Court in this respect will be scrutinised shortly below. Suffice it to state for now that the stance of the Court represents a deflection of the economic objective of Article 81(1) EC toward non-economic considerations. A concept of properness thus determines a standard that is not anchored in the actual wording or objective of Article 81(1) EC and hence marks more than a simple shift in reference point.

1164 See also Lugard P. / Hancher L., (2004), who argue that with the Europcan Commission, Guidelines on the application of Article 81(3) EC, the scope of Article 81(1) EC would be significantly reduced due to the adoption of a consumer welfare test, limiting the application of Article 81(1) EC to agteements involving market power. For details on the application of Article 81(3) EC to professional services sectors, see Chapter 7.I.

1165 The expression of 'proper practice' in Wouters is inspired by the language used in the relevant Dutch legislation ('de goede uitoefening van het beroep', Art. 26 of the Advocatenwet: '...ensure the proper practice'). The ECJ adopted the formulation in paras. $100 \mathrm{ff}$. of the judgment. In other language versions it has been translated as: 'ordnungsgemäße Ausübung'; 'el buen ejercicio'; 'l'exercice correct'; 'il corretto escrcizio'. 
Assuming a concept of properness is problematic for two reasons. First of all, it is prone to value judgements beyond the objective interpretation applied to the substantive concept of restriction of competition. Secondly, since it is not a concept of EC (competition) law, it opens the door for the legitimacy of a restriction of an economic activity to be determined at national level, therewith undermining once more the autonomous, i.e. Communitarian character of Article 81(1) EC. ${ }^{1166}$ These observations hence suggest that the Wouters proviso introduces a shift in paradigm by going beyond the Communitarian concept of ancillary restraints.

\section{Commercial versus 'regulatory' versus 'deontological' ancillarity?}

Notwithstanding this shift in paradigm it has been proposed in legal writing ${ }^{167}$ - but also disputed $^{1168}$ - that the line of reasoning of the Wouters proviso breathes the spirit of the ancillary restraints doctrine. In order to mark the difference between the ancillary restraints doctrine that warrants a commercial overall aim and the solution found by the Court in Wouters Whish respectively uses the terms of 'commercial' and 'regulatory' ancillarity. ${ }^{1169} \mathrm{He}$ argues that a certain structural similarity exists between the Wouters proviso and the 'traditional' ancillary restraints doctrine since both requirc a direct relation between the restriction and a legitimate aim and that the restriction is necessary for the pursuit of that aim. Also Loozen observes a similarity with the ancillary restraints doctrine and presents the argument that the Court in Wouters created a sector-specific exception, which she describes as "deontological ancillarity"."1170

Both approaches are helpful in that they bring out clearly that the Wouters proviso embraces values that are not commercial in aim, and that the Court thus is deviating from the aims proper of Article 81(1) EC. At the same time both approaches corroborate the misleading reference that the Court made in the Wouters proviso to the concept of ancillary restraints. It has to be stressed once more, however, that the Wouters proviso is inherently different from the concept of ancillary restraints as it is limiting the reach of Article 81(1) EC and not interpreting the substantive scope thereof. The following section will analyse to what extent the Wouters proviso is a judge made law deviating from the clear provision of Article 81(1) EC, therewith changing its hard rule.

\section{Contra legem development of the law to achieve a just solution}

A court may, in the interest of finding an equitable and just decision, desire to depart from the letter of a legal provision, despite the fact that a case at hand meets all the legal requirements of the relevant provision. A court can do so only by way of either a

1166 Sec already Chap. 3.I.2.2.3.1. See also Gilliams H., (2006), 24 ff.

1167 Whish R, (2003), 120 ff.; Loozen E., (2006).

${ }^{1168}$ Gilliams H., (2006), 22.

1169 Whish R, (2003), 119 ff., 122: "perhaps the use of these two terms would be useful in, first, demonstrating a continuity with the earlier case law, through the common use of the idea of ancillarity, while also capturing the difference between the two situations, by distinguishing commercial and regulatory cases." At the same time Whish specifies that he uses the term 'commercial ancillarity" "to connote a broader concept than the narrowlyfocussed 'ancillary restraints doctrine' considered in the Métropole judgment". See also AG Trstenjak in Case C209/07, Irish Beef Industry, [2008], para. 54 (note 35) who categorises without hesitation as an example of ancillary arrangements necessary to pursue a primary objective the cases of Wouters and Meca-Medina II.

1170 Loozen E., (2006), $39 \mathrm{ff}$. 
complementary or a corrective development of the law, therewith leaving the ground of a (however inventive) interpretation of the legal provision and its concepts. ${ }^{171}$ The result thus is to apply a change to the hard rule. For instance, where the legal consequences associated with the application of the hard rule appear unjust in a particular case, a court can ascertain that a gap exists in the legal system in respect of (legitimate) justification grounds or grounds for exemption. ${ }^{172}$ Such an approach contributes to respect the principle of equality, according to which fundamentally different issues need to be treated differently than cases fitting a certain (general) rule. Since the function of the law is to solve legal problems equitably ${ }^{1173}$, the crucial question hence is whether the sense of justice would be violated if the hard rule is applied in a particular case that factually meets the legal requirements thereof. The judge's critique on a statutory provision thus is legitimate only for grounds of justice and equity. ${ }^{1174}$

More generally, the sense of justice risks to be compromised where there is a conflict between, on the one hand, the principles of separation of powers and legal certainty requiring to apply the hard rule and, on the other, the feeling for justness when looking at the ensuing legal consequences associated with the hard rule. In a particular case the

1171 Zippclius R., (2005), 62. Sec also Timmermans C.W.A., (2005), viii f.: "[There does not exist], in my view, a generally accepted method of interprctation allowing the Community Courts to interpret hard rules and regulatory prohibitions as implying a rulc of reason, that is, an unwritten rule allowing for reasonable exceptions. It is because of the absence of such a rule that the application by the Court of an unwritten Rule of Reason has attracted so much attention of legal doctrine. There is much more to this than a simple method of interpretation according to common sense. Indeed, is not the Court when applying an unwritten Rule of Reason, undoing what the legislature has donc, or doing what the legislature has not considered necessary to do? [...] To give you my own answer or the beginning of an answer to my earlier question [...], I would regard it as too simple to argue the issue in such terms. Indeed, to come back to the free movement of goods, the prohibition of Article $28 \mathrm{EC}$ certainly is a hard rule, but the Treaty itself is not at all defining the object of that prohibition, that is, how the notion of a measure having equivalent effect should be understood. It is the Court that has interpreted that notion and that in a very strict way. So you cold say, when the Court in a next stage is softening that strict interpretation by introducing a Rule of Reason, it is finally doing no more than accommodating its own interpretation. It is not changing the rule. It is simply trying to ensure that its interpretation of the law, in the end, achieves a reasonable result."-This accommodation as meant by Timmermans can be extrapolated to Article 81(1) EC for the ancillary restraints doctrine only, but not for the Wouters proviso as the latter does not concern the interpretation of the substantive concept of restriction of competition. The Court in Wouters is thus changing the hard rule of Article 81(1) EC. - Also a comparison to other fields of frec movement does not yicld a different result. While the example of Joined Cases C-51/96 and C-191/97, Deliège, [2000], para. 64 (on sporting profession), seems to limit the substantive scope of $\Lambda$ rticle $49 \mathrm{EC}$ in a similar way (the Court refers to a limitation being inherent in the conduct, but avoids the language use of 'proper practice'), it's technique does not comparc to the Wouters proviso because Deliège gives an interpretation of the concept of restriction. - See also Gilliams H., (2006): Wouters seems to create a new law for the professions, at least the legal profession.

${ }_{1172}$ An equivalent result in terms of logic can be achieved by applying additional or qualificatory criteria to the requirements of the hard rule, Zippelius R, (2005), 69. In the paragtaphs preceding the Wouters proviso the ECJ was, however, positive that it did not intent to alter the legal requirements of Article 81(1) EC for the case of professional regulations.

${ }_{1173}$ Ius est ars boni et aequi (the Digests, 1, 1, 1). Zippelius R, (2005), 66, $68 \mathrm{ff}$.

1174 The classical example in the sphere of German law is the case of abortion. In the beginning of the $20^{\text {th }}$ century abortion was incontestably prohibited due to the persistent consequences of Christian inquisition, which intended to outright eradicate any form of population control, and the knowledge thereof, in order to drastically increase the devastatingly reduced number of labour forces after the Black Death (pestilence) in the $14^{\text {th }}$ century, see Heinsohn G. / Steiger O., (1989). In Reichsgericht - "Abortion" [1927]RGSt 61, 242, 252 ff., the Reichsgericht considered that the outright prohibition of any abortion violated the then sense of justice in case the abortion is the means to save the life of the pregnant woman. The Reichsgericht thus identified a gap in the law with regard to the grounds of justification and formulated the missing exemption from the hard (prohibition) rule. 
consideration of these conflicting legal principles needs to be optimised with a view to better satisfying than hitherto an imperative and legitimate need that arises from existing legal relations. Because of the principles of separation of powers and legal certainty the threshold to legitimise a judicial development of the law is particularly high in case the judge intends a contra legem adjustment of the hatd rule. ${ }^{1175}$ Only values of a constitutional order or otherwise well-grounded general conceptions of justice accepted by society can justify to set aside the conflicting principles of legal certainty and separation of powers. ${ }^{176}$

The Wouters proviso has to be tested against these standards as the ECJ indeed applied a contra legem adjustment to the law of Article 81(1) EC. The foregoing considerations lead to the question whether the sense of justice would have been offended if the NOvA regulation had been prohibited under Article 81(1) EC, or rather been automatically void following Article 81(2) EC. Only an answer in the affirmative could allow the ECJ to develop the law of Article 81 EC. The Court proceeded to the contra legem deviation "in order to ensure that the ultimate consumers of legal services and the sound administration of justice are provided with the necessary guarantees in relation to integrity and experience" of the professionals concerned. ${ }^{1177}$ By deviating from the hard rule of Article 81 (1) EC the Court implicitly proved that it diagnosed a gap in the grounds for justification. ${ }^{1178}$ This observation necessarily directs the look to the existing justification grounds. In Article 81(3) EC one finds a competition specific exemption and Article 86(2) EC contains a general exemption ground. It is striking that the Wouters proviso accepted a supplementary ground for justifying a clear restriction of competition without going as far as even mentioning the existing exemption provisions contained in the EC Treaty. Apparently, the Court sensed a quandary in which it felt unable to apply either Article 81(3) EC or Article 86(2) $\mathrm{EC}^{1179}$ - but also felt that the application of Articles 81(1) and 81(2) EC would not provide an adequate solution to the situation of professional self-rcgulation prohibiting multi-disciplinary partnerships between lawyers and accountants.

The Court's unorthodox solution in Wouters can probably best be appreciated against the backdrop of the at the time not yet realised modernisation of the application of the EC competition rules. In February 2002, when Wouters was decided, the Commission was the sole competent authotity to grant an exemption under Article 81(3) EC. At the time the Court thus could not possibly have applied that exemption, even if it might have seen a possibility for the NOvA rules to fulfil the cumulative conditions of Article 81(3) EC. ${ }^{1180}$ The Court could have given an interpretation of the conditions of Article 81(3) EC with regard to the self-regulatory rules of the NOvA only if the latter, under the old compulsory notification system, had notified its rules in time and if, consequently, the Commission had adopted a decision under Article 81(3) $E C^{1181}$ - presumably upholding the NOvA rules on

1175 Zippelius R, (2005), 71.

1176 Zippelius R., (2005), 71.

1177 Para. 97 of the Wouters judgment.

1178 See also above note 1172.

1179 AG Léger in Case C-309/99, Wouters et al. $\nu$ NOvA, [2002], paras. $155 \mathrm{ff}$., advocated to solve the case by applying Article 86(2) EC. For details see Chapter 7.II.

${ }_{1180}$ For details on Article 81(3) EC as applied to professional regulation see Chapter 7.I.

1181 See already above text with note 1031 . Under the current regime of Regulation $1 / 2003$ no notification may be made anymore to the Commission, and (associations of) undertakings have to self-assess their arrangements that have an effect on competition and may affect trade between Member States, see Article 1 of Regulation 1/2003. They may, however, ask the Commission for informal guidance: "Legal certainty for undertakings operating under the Community competition rules contributes to the promotion of innovation and 
similar arguments eventually discussed by the Court in the Wouters proviso. ${ }^{1182}$ However, since the NOvA had not notified its regulations in time, i.e. before interdicting Mr Wouters and $\mathrm{Mr}$ Savelbergh by way of decisions to set up (indirect ${ }^{183}$ ) collaboration with accountants, its decisions would necessarily have been void under Article 81(2) EC. As a consequence, $\mathrm{Mr}$ Wouters and Mr Savelbergh would have been allowed, at least for the period before the NOvA had notified its regulation to the European Commission, to pursue their respective partnerships with companies engaged in accounting.

The conceivable consequence of handing down a judgment without the Wouters proviso would have been that, across the EU, professional associations would have felt the need to notify all their professional regulations to the Commission (or the competent national competition authority in cases lacking a Community dimension). ${ }^{1184}$ As a consequence the Commission would suddenly have been confronted with an abundance of cases in which it would have been forced to carve out its stance with regard to the objective benefits of professional regulation. ${ }^{185}$ Conversely, as regards professional associations, they would have been confronted with members of the profession, as well as the latter's competitors, challenging a potential series of decisions that might have been based on professional regulations that were both flawed by anti-competitive effects within the meaning of Article 81(1) and not notified to the Commission.

Such reactions by both the professional associations and the addressees affected by competition restrictive professional self-rcgulations might have been unattractive in the eyes of the Court and the Commission, and they might have been undesirable from a broader perspective of legal policy. In fact, if the Court had seen a fair chance that the NOvA rules could have been eligible for an exemption under Article 81(3) EC on the basis of the arguments that the Court effectively used in the Wouters proviso, the effect to the contrary (by applying stringen tly the law as it stood at the time, i.e. before May 2004) might have been disconcerting to face. On the one hand, one and the same set of self-regulatory rules would have been automatically void under Article 81(1) and (2) EC for the time before their notification but, on the other, valid, i.e. exempted under Article 81(3) EC, for the time after their notification. ${ }^{1186}$ Thus, in Wouters the Court was confronted with the perplexing choice to possibly state a 'precedent' according to which a series of professional regulations and

investment. Where cases give rise to genuine uncertainty because they present novel or unresolved questions for the application of these rules, individual undertakings may wish to seek informal guidance from the Commission", recital 38 of Regulation 1/2003 and European Commission, Notice on guidance letters, para. 5.

${ }^{1182}$ It is for instance conceivable that the Commission could have come to similar considerations as in Commission Decision EPI Code of Conduct, (1999), para. $34 \mathrm{ff}$. For details on the latter case see above section I.2.5.

${ }^{1183}$ See the case summary in Chapter 2.V.9.

${ }^{1184}$ Notification to national competition authorities would have been required in those Member States where the national law was already similar to the EC rules even before the modernisation of 2004, and in particular in the five Member States in which NCAs had already been authorised by their national laws to apply the EC competition rules.

${ }_{1185}$ See AG Léger in Case C-309/99, Wouters et al. v NOvA, [2002], para. 106: "I regret the fact that the Commission has not set out the legal reasoning supporting its position. As academic legal writing has shown, it is possible that [the decision in EPI Code of Condud] is explained more by the concern to avoid notifying the professional rules adopted by the association authorities in the various Member States. We know that as Community law now stands the Commission alone has power to adopt decisions providing for exemption pursuant to Article [81(3) EC]."

${ }_{1186} \mathrm{NB}$ It is conceivable that Mr Wouters could have started proceedings against the NOvA for damage[s] he might have suffered, for instance the costs that he had incurred in view of the prospected and undertaken partnership with Arthur Andersen \& Co. 
individual decisions taken on their basis would have been automatically void ${ }^{1187}$, but could have been adopted anew once the professional regulations were notified.

This perplexity is, however, a classical issue and, hence, teferring to it as a possible precedent needs to be done in inverted commas. This means that the sketched consequences of a stringent application of the general framework of EC competition law had to be faced by many other sectors many times before, and even after, the Wouters ruling. However, the stringent application of the competition rules (i.e. Articles $81(1)$ and $81(2)$ EC) would have been a precedent in a rather non-legal sense, at least in the perception of the professional services sector. While a number of national competition authorities had, in the past, effectively applied their national competition laws to a number of (liberal) professions, it is fairly probable that the request by Mr Wouters and Mr Savelbergh for a strict application of the competition law provisions to professional rules other than tariff schemes was an eyeopener for the Court or Justice on the potential of the competition provisions. ${ }^{1188}$

The Court might have felt that the adoption of the stringent legal solution sketched above would have been particularly delicate since, at the time the Court handed down its judgement, modernisation of the application of the competition rules (with the abolition of the compulsory notification system) was already in preparation. ${ }^{1189}$ With the approaching abandonment of the exclusive competence of the Commission to evaluate the eligibility for an Article 81(3) EC exemption, professional self-regulation effectively would have needed notification to the Commission for a period of about two years (calculated from the date of the judgment in Wouters), after which time no such notification in fact is possible any more. However, this was again a general issue that all sectors had to face before May 2004 in their considerations whether to adopt or maintain a certain agreement or decision. In actual fact the direct applicability of Article 81 (3) EC by all competition authorities and (national) courts since May 2004 may put a new complexion on Wouters. Had the case come up two years later the Court would have been competent to scrutinise the eligibility of the case with regatd to an Article 81(3) EC exemption, instead of reverting to a case law created immunity, which is alien to $\mathrm{EC}$ competition law.

Not possibly anticipating the Court's solution in Wouters, Advocate General Léger - in an attempt to respect the Treaty system of competition law - had advocated the application of Article $86(2) \mathrm{EC}$ to achieve the same tesult of salvaging the NOvA regulation. ${ }^{1190}$ The

1187 An exemption could not be granted retrospectively under the regime of Regulation 17. Before May 2004 a retrospective immunity under the law of Article $81(3)$ EC could have been granted only in accordance with Commission Regulation (EC) No 2790/1999 of 22 December 1999 on the application of Article 81(3) of the Treaty to categories of vertical agreements and concerted practices, which introduced this possibility for the first time in EC competition law. Hence, if the Court had been determined to apply a retrospective immunity in accordance with the law as it stood before Regulation 1/2003 becoming effective, it would have needed to establish that the facts of the Wouters case concerned a vertical restriction cxcmpted under Regulation 2790/1999. This book will ignore Regulation 2790/1999 and concentrate on the scrutiny of Article 81(3) EC directly rather than the implementation that this article found in the specific block exemption regulation.

${ }_{1188}$ One might argue that the Court in Wouters took account of the critique that Article 81(1) EC should not catch any conduct that is not in reality detrimental to competition, see above note 1026 . However, the Court actually was very clear that it was not driven by that consideration as it explicitly stated that "despite the effects restrictive of competition" the professional regulation at stake did not infringe Article 81(1) EC.

${ }_{1189}$ See European Commission, White Paper on Moderniration of the Rules Implementing Articles 85 and 86 of the EC Treaty, of 28.04.1999.

1190 "One of the challenges raised by the issue of the application of Community competition law to the professions is how to identify solutions which will reflect the structure and broad logic of the Treaty provisions.", AG Léger in Case C-309/99, Wouters et al. vNOvA, [2002], para. 111. 
Court, however, did not even mention, let alone discuss, this second exemption ground foreseen in the Treaty that could, at least in theory, have provided the legal ground for a justification of the clearly established restriction of competition. Whether the Court rightly felt that the facts of the case did not meet the requirements of Article 86(2) EC is scrutinised in Chapter 7.II. The relevant point here lies in what the Court thus omitted, namely to flesh out the conflict of interests that it apprehended in Wouters.

\section{Conflicting interest: regulatory vacuum versus legal stability}

Admittedly, the option of handing down a judgment without the Wouters proviso would potentially have had far teaching consequences for professional self-regulatory measures existing in the Member States that have the object or effect of restricting competition. It would have resulted in heralding the fate of such professional self-tegulation to be automatically void, i.e. as of the moment of its adoption (ex tunc, Article 81(2) EC). Consequently, such a ruling potentially would have left numerous professional services sectors in the EU without regulation, or at least with fragmentary regulation only. Finally, such a situation could have lead to a period of legal uncertainty as to which self-regulatory tules professionals have to follow in the exercise of their profession.

The question here is whether the Court rightly considered that the interest of preventing a partial regulatory vacuum in the professional services sector is a value of constitutional order or otherwise a well-grounded general conception of justice accepted by society to override the application of Articles 81(1) and 81(2) EC. In the face of the inherently conflicting principles of separation of powers ${ }^{1191}$ and of legal certainty the ECJ needed to demonstrate the legitimacy of its intention not to apply these provisions. In particulat the principle of equality requires that similar cases be treated similatly. In other words, if we accept that professional services sectors are no different from other sectors in terms of their economic character (as has been demonstrated in Wouters by the Court itself before turning to its proviso), their self-regulatory anti-competitive rules may not benefit from a judge created extra-statutory exemption - unless their prohibition would offend the sense of justice and equity. ${ }^{192}$ While a partial tegulatory vacuum can be consideted to constitute a threat to the peaceful administration of justice (Recbtsfrieden, as part of maintaining law and order), it is questionable whether a threat to the administration of justice is a sufficient consideration in terms of a more general concept of justice and equity that finally may justify a contra legem development of the law.

Two observations need to be made at this juncture. First of all, the Court did not openly identify a possible partial tegulatory vacuum as a concern in the Wouters proviso. Instead it teferred to the objectives of the decision taken by the association of undertakings. The pointer in this regatd is paragraph 97 of the judgment, which states that

"For the purposes of application of [Article 81(1) EC] to a particular case, [...] account must be taken of [the decision's] objectives ${ }^{193}$, which are here connected with the need to make rules relating to organisation, qualifications, professional ethics, supervision and liability, in order to ensure that the ultimate consumers of legal

1191 By creating an exception to the applicable rule the judge encroaches upon the legislator's authority.

${ }^{1192}$ See above text with note 1173.

${ }^{1193}$ NB This search for the objectives of the decision taken by the NOvA must not be confused with the object of the NOvA regulation to restrict competition. Moreover, the consideration of scrutinising the purpose of a regulation is different from ascertaining the economic character of the conduct covered by that regulation, see Case T-313/02, Meca-Medina I, [2004], para. 65. 
services and the sound administration of justice ${ }^{1194}$ are provided with the necessary guarantees in relation to integrity and experience."

Although this statement as such reflects a prudential consideration, it is striking that the Court did not explicitly link it to the idea of an unjust or inequitable result. This makes it difficult not only to verify the motivation of the Court to deviate from the hard rule of Articles 81(1) and 81(2) EC, but also to test the legitimacy of the solution found by the Court.

This leads to a second point, which is to raise doubts about the proportionality of the Wouters proviso. While a partial regulatory vacuum in the professional services sectors may constitute a sufficiently considerable menace to unbalance the stability of legal relations, the question is whether the radical solution to limit the reach of the prohibition of Article 81(1) EC was necessary and appropriate to prevent that menace. Put differently, the question is whether the sense of justice would really have been offended by an effective prohibition of the NOvA regulation (itself banning multi-disciplinary partnerships between lawyers and accountants). Such a stance can hardly be credible in light of the fact that such forms of partnerships are allowed in other Member States. What may, however, be unbalancing the sense of justice is the legal consequence associated with the prohibition of self-regulatory decisions restricting competition, i.e. the automatic voidness thereof ex tunc.

\section{Alternative solution: limiting the legal consequences in time}

Where it felt the need to avoid the 'precedent' sketched above the Court could have chosen an altetnative solution to the Wouters proviso, namely to limit the effects of Article 81(2) EC in time. It would for instance have been possible to rule that the NOvA regulation in principle was prohibited, but remained in force for a transitional period of two years, or until the time that Regulation 1/2003 came into force. ${ }^{1195}$

The advantage of a solution working with the effects of Article 81(2) EC would have been manifold: first of all, it would have allowed to avoid a regulatory vacuum in the professional services sector. At the same time it would have opened the sector's eyes to the competition law concerns that professional self-regulation raises. Moreover, the sector would have been forced to make use of the transition period to scrutinise their self-regulatory measures for the need of adaptation in the form of re-regulation or deregulation. Limiting the effect of Atticle 81(2) EC rather than limiting the reach of Article 81(1) EC would thus have safeguarded the effectiveness and credibility of the prohibition rule (Article 81 (1) EC) and the existing statutory grounds for justification (Atticles 81(3) and 86(2) EC). ${ }^{1196}$

1194 The Court's reference to the sound administration of justice can probably be understood to meet what has been denoted here as the peaceful administration of justice. The Court's reference translates into "de goede rechtsbedeling", "Rechtspflege", "la bonne administration de la justice", "la buona amministrazione della giustizia", "la buena administración de justicia", and thus refers to administrative (i.e. supervisory or procedural) guarantees rather than to a general, i.e. substantive concept of justice necessary to justify a contra legem development of the law.

${ }_{1195}$ Compare also for instance Commission Decision EPI Code of Conduct, (1999), in which the Commission had limited the individual exemption granted under Article 81(3) EC (for professional rules prohibiting comparative advertising) until the date on which Directive $97 / 55$ on misleading advertising had to be transposed by the Member States.

1196 Compare also the temporal effect of the judgment in Case 43/75, Defrenne II, [1976], paras. $69 \mathrm{ff}$., where the Court was confronted with a similar scenario in which the recognition of the directly applicability of a Treaty provision ( $\Lambda$ rticle $141 \mathrm{EC}$ on the principle of equal pay) would have meant that innumetous cases would have 
Secondly, while limiting the effect of Article 81(2) EC also constitutes a contra legem application, this approach has the advantage of strictly limiting in time the transgression on the principles of separation of powers, legal certainty and equality. Therewith, this approach not only is a less restrictive means to parry a regulatory vacuum. It also is a more efficient one as it would have spurred the professional services sector into action of regulatory reform within a transitory period, thus constituting a more proportionate solution. At the same time the Commission would have had the opportunity to expeditiously develop guiding policy measures for the sector of professional services.

By developing the law into limiting the reach of the prohibition of Article 81(1) EC the Court necessarily had to recognise objectives other than the competition policy considerations pursued by that provision. More specifically, paragraph 97 of Wouters lists values like the organisation of the profession, qualifications, professional ethics, supervision and liability, and the necessary guarantees in relation to integrity and experience of the members of the legal profession. ${ }^{197}$ Conversely, the solution proposed here of limiting the legal consequences of Article 81(2) EC in time would not require the orientation towatds objectives other than net effects across competitive markets. Once allowing to openly point at the undesirable effects of a partial legal vacuum in terms of legal certainty in a sector that traditionally is heavily regulated ${ }^{1198}$, it becomes possible to mitigate these effects in a more finetuned manner than does the Wouters proviso.

In summary, the Wouters case law leaves us with the problem that its proviso, first of all, is not limited in time. Secondly and more importantly, it undermines the credibility of Articles 81(1), 81(3) and 86(2) EC and their policy choices. This effect builds a negative example ${ }^{1199}$, which is amplified by two factors: the importance of the professional services sector in economic terms (which represents about $2.4 \%$ of the total turnover of the $\mathrm{EU}^{1200}$ ) and the traditionally distinguished status that has gained the libetal professions a privileged position in the government and administration of our States and social structures. Thirdly, the Wouters proviso with its inevitable reference to the proper functioning of a profession other than the 'proper economic functioning' thereof leaves us with the issue of determining what the proper non-commetcial functioning of a profession is.

The immediate problem is which types of values or interests may legitimately justify the non-application of Article 81(1) EC, i.e. present an extra-statutory ground for exemption. It has been suggested that the values identified by the Court in paragraph 97 of Wouters (especially its reference to the sound administration of justice) can be understood as public interest considerations more generally, i.e. as different from the specific public interest that

risen with legitimate claims even for the past. In balancing "important considerations of legal certainty affecting all the interests involved, both public and private," against considerations of direct effect the Court found that claims could be made only for the time after its judgment, unless they had been lodged already before that time. 1197 The Court abstracted these objectives in the following as the proper practice of the legal profession, see paras. $100,107,109,110$ of the judgment.

${ }_{1198}$ Underlining that collective regulation may have traditionally grown since some time may be an explanation, but not an excuse for the authors of anti-competitive professional regulation to plead that they did not seriously wonder about the application of competition law to the professional services sector. It cannot be an excuse or justification as otherwise the principle of equality before the law would be violated. At best it could lead to a reduction of the finc imposed, see one of the notes in Chapter 2.V.11. on Commission Decision Belgian architects, (2004).

${ }^{1199}$ If the Wouters proviso is a good rule it has to be such that it can be abstracted from the circumstances of the particular case as can be done for instance for the concept of ancillary restraints.

${ }^{1200}$ See Chapter 1.I.1. 
competition policy pursues. ${ }^{1201}$ Whether this is a correct assumption shall be scrutinised in Chapter 7.

The difficulty of deciding whether a certain non-commercial consideration is crucial for the 'proper functioning' of an (economic) activity is intrinsically linked with the question of who decides on that matter and according to which standards. ${ }^{1202}$ The Wouters proviso emphasises the proper practice of the profession "in the Member State concerned" and "the prevailing perceptions of the profession in that State" ${ }^{1203}$ It therewith becomes clear that the substance of the extra-statutory justification ground created with the Wouters proviso is not determined autonomously or on a meta-level that is independent from traditional national choices conceptualising objectives of professional regulation. This is in stark contrast with the Communitatian character of EC competition law for which the Community is exclusively competent. There is a serious risk that a necessaty case-by-case application of the Wouters proviso leads to different results in similar cases across Member States. ${ }^{1204}$ Therefore, this book suggests that traditional national views must not maculate the objective legal order that the Treaty system of competition law established. Consequently, after the Wouters proviso there is a need for a ' $V$ an Gender Loos of competition law', i.e. a case law emphasising the independence of $\mathrm{EC}$ competition law concepts from traditional national choices in the field of professional regulation. This does not exclude that a more sophisticated point of view in respect of national choices may be possible for the grounds of justification discussed in Chapter 7.

The problem with the Wouters proviso is that the Court did not openly formulate to which extent the application of Article 81(1) and (2) EC to the NOvA regulation offended the sense of justice to justify a judicial development of the law. Instead of considering a limited impact on the sense of justice - namely in so far as a regulatory vacuum may have occurred as a practical consequence of the full application of the competition law as it stood at the time of the tuling - the Court seemed to assume that that application bluntly offended the sense of justice. In this the Wouters proviso has overshot the mark of a conceivable legal policy aim to maintain legal certainty for a necessary period of time (transition period), and thus planted the seed for more legal uncertainty. The danger is that the Wouters proviso thetewith de-conceptualises the scope of application of Article 81(1) EC by making the object of scrutiny (in casu professional regulations) the yardstick by which to measure the appropriateness of a restriction. ${ }^{1205}$ This approach comes close to a citcular teasoning, if not constituting one. Above all, it is different from the ancillary restraints doctrine. The latter's yardstick of increasing commercial net effects across the market is one of competition policy that is anchored in the law (Article 81(1) EC) tather than being derived ad hoc from the agreement or decision at hand to which it is applied.

While the respective test of the Wouters proviso and the concept of ancillary restraints

1201 See AG Léger in Case C-309/99, Wouters et al. v NOvA, [2002], para. 105.

1202 Gilliams H., (2006).

1203 Para. 105 of the judgment. See also paras. 107 and 110 of the judgment.

1204 See Gilliams H., (2006).

${ }^{1205}$ In coming back to the comparison with the ancillary restraints doctrine this point triggers the following observation. Where the proper functioning of an association is concerned, it seems logical that the association itself may determine what the appropriate means are (cf. Gettrup-KlimvDLG), butobviously subject to the control by the Commission and the Court. If however the proper practice of a profession, i.e. an abstract group rather than a concrete entity, is at stake, its function(-ing) transcends the commercial interests of the individual practitioners as represented by their association. It is then not evident anymore that that association should be allowed to determine the standard of restriction, even if subject to the control by the courts. 
share the pattern of combining a legitimate aim with a proportionality testing ${ }^{1206}$, their similarity is only apparent. To require a direct link between a restriction and a legitimate aim for which the restriction is necessary is a pattern that is not peculiar to the ancillary restraints doctrine. It also is a principle that can be found in the third paragraph of Article $81 \mathrm{EC}$ in the form of the statutory exception from the competition prohibition. Since the Wouters proviso has been identified here as an extra-statutory exemption, which, unlike the concept of ancillary restraints, does not interpret the substantive scope of Article 81(1) EC, the discussion of its application by the judicature will be continued in Chapter 7 .

\subsection{Concluding remarks}

The fundamental critique formulated in the previous section is the tesult of the fact that the Court in Wouters did not explicitly set out why it is legitimate to broaden the frame of reference used under the ancillary restraints doctrine. Instead of adhering to the framework of the 'specific economic context of a case' the Wouters proviso refers to the overall context in which the professional regulation was taken or produces its effects. The reference to the "overall context" has been newly introduced by the Wouters proviso as it is different from the case law on the concept of ancillary restraints, which in accordance with the aim and purpose of Article 81(1) EC refers to the "particular features of the case"1207, the "actual conditions"1208, the "specific context of the main operation"1209, the "economic context"1210, the "specific context"1211, or the "economic and legal context"1212, and the factual and legal circumstance in which an agreement or decision has been adopted or applies. ${ }^{1213}$ The Court therewith created the leeway it needed to take the non-commercial objectives of the association's regulation in to account. As a result the Court did not explicitly formulate why the identified objectives of the NOvA regulation as such justify the granting of an extrastatutory exemption from Article 81(1) EC. Only in a subordinate clause in the Wouters proviso is the relevant point of reference identified as "the ultimate consumers of legal services and the sound administration of justice". ${ }^{1214}$

The reasoning of the ECJ hence runs as follows. The Court assumed that the ultimate consumers and the sound administration of justice have a vital interest in the integrity and experience of professionals. To guarantee these interests it is necessary, according to the Court, to make (professional) rules. More specifically the Court found that in casu there was a need to make rules relating to organisation, qualifications, professional ethics, supervision and liability. This is of course an assertion, which needs to be demonstrated to justify the judicial development of an extra-statutory exemption. To do so the Court could have had recourse to a teleological argument building on the objective of competition law, which is

1206 See Whish R, (2003), $119 \mathrm{ff}$.

1207 Case C-250/92, Gottrup-Klim v DLG, [1994], para. 36.

${ }_{1208}$ Joined Cases T-374/94, T-375/94, T-384/94 and T-388/94, European Night Services Ltd (ENS) e.a., [1998], para. 136; Case T-112/99, Métropole (M6), [2001], para. 76; Case C-399/93, Oude Luttikbuis, [1995], para. 10.

1209 Case T-112/99, Métropole (M6), [2001], para. 109.

1210 Case 161/84, Pronuptia v Scbillgalis, [1986], para. 27.

1211 Case T-112/99, Mérropole (M6), [2001], para. 168.

1212 Case 27/87, Eraun-Jacquery, [1988], para. 20.

1213 Sce Joined Cases T-374/94, T-375/94, T-384/94 and T-388/94, European Night Services Ltd (ENS) e.a., [1998], para. 136, in the French and German language versions, and Case T-112/99, Méropole (M6), [2001], para. 79. See also above note 1047.

1214 Para. 97 of the Wouters judgment. 
to prevent undertakings from reducing the welfare of the final consumer of the services in question. $^{1215}$

The challenge is to square the legitimacy of possible non-market aims with this ultimate competition objective. Formulated in the style of the CFI in GlaxoSmithKline this would lead to ask whether the established restriction of competition is not detrimental, but rather beneficial, to the final consumer of professional services. ${ }^{1216}$ The balance in Wouters, however, was tipped by the proper practice of the legal profession, as organised in the Member State concerned. With this statement the Court simply accepted that the professional values be legitimate without formulating a theoretical foundation as, for instance, the CFI had done in $M 6$ for the concept of ancillary restrictions. ${ }^{1217}$ Once the open notion of proper practice of the profession had been established in the Wouters proviso it was relatively easy to bridge the facts of the case with the idea of the judge-made extra-statutory exemption. However, without an explicit reference to the threats of a regulatory vacuum to legal certainty, the statement that the restriction of competition was necessary to attain the aim of the proper practice of the profession (or the proper conduct of professional sport in the case of Meca-Medina In) remains anchorless, if not arbitrary - at least within the framework of the first paragraph of Article $81 \mathrm{EC}$.

Irrespective the fundamental critique for dogmatic reasons and regardless of the coming into force of the competition law modernisation in May 2004, the Court corroborated the Wouters proviso in Meca-Medina $I I$ in almost identical terms with regard to the field of sport regulation. Taking the starting point of the Wouters proviso for granted and taking the principle of equality serious requires in fact not to shrink away from abstracting the Wouters proviso and test its applicability for any other sector. ${ }^{1218}$ This is about whether the nonmarket purpose of self-tegulatory measures forms a sufficient basis for granting the judge made extra-statutory exemption from Article 81(1) EC. Because of its structural similarity with Article 81(3) EC to limit the reach of the prohibition in Article 81(1) EC, a conceivable extrapolation of the Wouters proviso will be further discussed in Chapter 7.I. The foregoing insinuates already that the suggestion there will be to refocus the operation of limiting the reach of the ptohibition in objective terms.

${ }^{1215}$ See Case T-168/01, GlaxoSmitbKline, [2006], para. 171

1216 See Case T-168/01, GlaxoSmithKline, [2006], para. 171.

1217 See Case T-112/99, Métropole (M6), [2001], paras. $104 \mathrm{ff}$.

${ }^{1218}$ I therefore resist the view of Loozen E., (2006), or Gilliams H., (2006), that the Wouters proviso is a profession specific exemption. In this regard the view of Whish $\mathrm{R}$, (2003), $119 \mathrm{ff}$, is preferable as it explains a 'regulatory', i.e. a categotised ancillarity outside the substantive scope of application of Article 81(1) EC. 


\section{Article 82 EC and Self-Regulatory Professions}

This chapter will investigate more closely whether and to what extent Article $82 \mathrm{EC}$ may prove a useful tool to control collective regulation in the professional services sector. The reason that no systematic scrutiny has been done before ${ }^{1219}$ may be the subject of the article, which mainly is the control of unilateral behaviour of a dominant firm. Dominance is a situation of economic strength (market power) that enables an undertaking to prevent effective competition being maintained on the relevant market. ${ }^{1220}$ The provision of Article $82 \mathrm{EC}$ covers also abusive behaviour by more than one undertaking. A market jointly dominated by a number of economic operators is traditionally called an oligopolistic market, oligo meaning a few. ${ }^{1221}$ Different from oligopolistic markets, however, professional services matkets ate usually heterogenous and often marked by little concentration. Not least in light of continuously growing absolute numbers of the members of the professions it seems, at first sight, hardly conceivable that collective professional regulation be the expression of the economic will of a dominant few in professional services markets.

This perception can, however, not be taken for granted, especially since the judgment in Piau. This case concerned collective regulation adopted by FIFA (Fédération internationale de football association) on the matter of services provided by football players' agents. ${ }^{1222}$ The CFI recognised that for the purpose of Article 82 EC the national football associations and theit membet sport clubs, as organised within the FIFA, occupied a collective dominant position on the purchase market of services provided by football players' agents. The CFI furthermore considered that the members' affiliation makes the FIFA the emanation of its members and, therefore, the FIFA itself was considered to be covered by Article $82 \mathrm{EC} .{ }^{1223}$ The analogy for present purposes imposes itself by considering the idea that the members of the professions are affiliated with their professional bodies. After Piau,

1219 For an occasional reference to the applicability of Article $82 \mathrm{EC}$ to the professions see for instance Vickers J.C.o.tO.o.F.T., (2003), 6 f. The Commission so far has not considered the discussion of Article $82 \mathrm{EC}$ in the field of the professions, see European Commission, Report on Competition in Professional Services, of 09.02.04, para. 7.

1220 Case 27/76, Uniled Brands, [1978], para. 65.

1221 Different terms are used to describe the same phenomenon of dominance by two or more undertakings. Collective, joint and oligopolistic dominance are usually used interchangeably. The term of collective dominance is employed most, and in particular by the Court as has been observed by Joined Cases C-395/96 P and C-396/96 P, CMB (Cewal) II, [2000], para. 15. See also Monti G., (2001), 131; Whish R, (2000), 583. In the case of liberal professions it is not very appropriate to use the term 'oligopolistic' dominance as they are too numerous to speak of oligopoly, 'oligo' meaning a few.

${ }_{1222}$ Case T-193/02, Piau I, [2005]. The case is summarised in Chapter 2.V.

${ }^{1223}$ This finding is remarkable taking account of the conflicting fact that, first, Article 82 EC only applies to undertakings but, second, FIFA does not itself engage in an economic activity on the particular market of the case. 
but also since the opinion of Advocate General Léger in Wouters ${ }^{1224}$, it is inescapable to test whether and to what extent the liberal professions have to be perceived in their collectivity rather than their numerousness.

The purpose of the present chapter is to carve out the particular legal issues that the jurisdictional and substantive requirements specific to Article $82 \mathrm{EC}$ provoke when applied to professional self-regulation. The chapter is divided into two parts. First, the concept of collective dominance will be fathomed to apply it on the case of ptofessional self-regulation. The second part will turn to scrutinise the meaning of the competition related concept of abuse in tespect of professional self-regulation. Since collective regulation does not represent the 'classical' unilateral behaviour of a single firm, the second part will also deal with the question of how a collectivity of professionals may exercise its economic strength leading to the possible abuse thereof: through their professional association, their members individually, or both taken together.

\section{The concept of collective dominance and collectively organised professions}

The case law has developed the concept of collective dominance on the basis of Article $82 \mathrm{EC}$, which addresses the abusive conduct of 'one or more undertakings'. 'This means that the article not only applies to single-firm dominance but also to situations in which two or more undertakings jointly hold a position of economic strength. The objective of Article $82 \mathrm{EC}$ to not only cover single-firm behaviour stems from the consideration that competitive market mechanisms may equally fail where a number of economic operators jointly exercise market powet to reap the benefits of restricting output and charging prices above the competitive level.

The notion of collective dominance rests on the theoretical concepts of tacit coordination ${ }^{1225}$, interdependence, output restrictions and joint profit maximisation. ${ }^{1226}$ These are more likely to occur in oligopolistic markets. The problem of oligopolistic matkets is that their members often manage to adjust their relationships with competitors to mutual advantage without the need to expressly enter in to agreements or concerted practices. ${ }^{1227} \mathrm{It}$ is in this that the concept of collective dominance is distinct from the scope of application of Article 81(1) EC. The concept of collective dominance therewith adds to the competition law control of the exercise of collective market power. This does, however, not imply that the application of Article $82 \mathrm{EC}$ depends on the tacitness of coordination. ${ }^{122}$ In fact, obligations of professional conduct are typically laid down in explicit self-regulatory measures. To assess the added value of applying Article $82 \mathrm{EC}$ to professional selfregulation, it is necessary to give an overview of the interpretation that the case law has given the concept of collective dominance. Conversely, the abusiveness of the relevant conduct of a dominant group remains unrelated to whether the conduct is tacit or not.

\footnotetext{
1224 See below note 1239.

${ }^{1225}$ The thrust of economic literature speaks of 'tacit collusion', an expression which jars with lawyers. They associate the term of collusion with active conspiracy of the kind captured by Article 81 EC. Whish R., (2003), 505 , therefore suggests that the notions 'conscious parallelism', 'tacit coordination' and 'coordinated effects' may be preferable to 'tacit collusion', in that they express the idea of parallel conduct "without attaching the opprobrious term 'collusion"'.

${ }_{1226}$ Niels G., (2001), 169. Goyder D.G., (2003), 328; Whish R, (2000), 583.

1227 See also note 1221.

${ }^{1228} \mathrm{NB}$ Tacit coordination is of primary concern in concentration control cases, see below note 1230 .
} 


\section{Collectivity and dominance}

The concept of joint or collective dominance started to evolve in the 1990 s just before the application of the competition rules to the liberal professions was recognised in EC law. The Commission had dabbled with the idea of collective dominance under Article $82 \mathrm{EC}$ in the early 1970 s but until the 1990 s the Commission relied upon the concept only occasionally. ${ }^{1229}$ The concept developed considerably in the late $1990 \mathrm{~s}$ in the decisional practice of the Court and the Commission, both with regard to Article $82 \mathrm{EC}$ and concentration control. ${ }^{1230}$ In the Italian Flat Glass case the CFI for the first time squarely addressed the concept after the Commission had held that three firms had abused a collective dominant position. ${ }^{1231}$ On the basis of this judgment two aspects can be explained into which the concept of collective dominance resolves. The first is a dominance aspect and the second a collectivity aspect.

With regard to the dominance aspect the CFI built on the concept of dominance developed earliet in respect of single-firm behaviour. ${ }^{1232}$ Accordingly, dominance is a situation of economic strength (market power) that enables one or more undertakings to prevent effective competition being maintained on a market. The situation of economic strength affords the 'one or more undertakings' the power to behave to an appreciable extent independently of their competitors, their customers and ultimately of the consumers. ${ }^{1233} \mathrm{With}$

${ }^{1229}$ See European Commission, Report on the Behaviour of the Oil Companies, of 10.12.1975; Commission Decision European Sugar, (1973), in which two companies were considered to jointly dominate the Dutch sugar market. On appeal the Court did not address the issue for it found that there was no abuse by the companies anyway, Joined Cases 40 to $48 / 73,50 / 73,54$ to 56/73,111/73, 113 and 114/73, Suiker Unie, [1975]. See also Joined Cases 6 and 7/73, Commercial Solvents, [1974]. See also Case 247/86, Alsatel v Novasam, [1988], para. 21.

${ }^{1230}$ The Commission sought in particular to supplement the concept of single dominance to control merger transactions that could not be caught otherwise due to the lack of a clear market leader post-merger. See Commission Decision flat glass, (1989). The conccpt of collective dominance is of particular interest for concentration control cases where it allows to prevent mergers that lead to market structures in which (tacit) coordination between the merging parties and their competitors becomes more likely. In contradistinction to Article $82 \mathrm{EC}$ the Community concentration control system docs not explicitly refer to a dominant position enjoyed by 'one or more undertakings'. This does, however, not mean, and as the case law on the concept of collective dominance proves, that concentration control cases only cover situations of single firm dominancc, sec c.g. Joined Cases C68/94 and C-30/95, Kali \& Sals [1998], paras. $165 \mathrm{ff}$. Nota bene the starting point for the legal assessment in merger cases is a different one from abuse cases under Article $82 \mathrm{EC}$. One requires an ex ante examination, the other an ex post examination of the situation on the market. This difference in approach docs, however, not concern the concept of collectivc dominance in its aspect of 'collectivity'. It is the threshold for the establishment of a prohibition that is higher under the concentration control regime than under Article 82 EC. For an overview of the development that the concept of collective dominance took in the case law, see Whish R., (2000), $585 \mathrm{ff}$,, 600 f. See also Briones J. / Padilla A.J., (2001). See also Monti G., (2001), 137 f.; Niels G., (2001). Meanwhile, the replacement of the criterion of dominance in Article 2 of the Merger Regulation by the test of whether the envisaged merger will lead to a 'substantial lessening of competition' may have changed the uniform interpretation of the concept of collective dominance in the two quite different categorics of concentration and abuse cases, Goyder D.G., (2003), 331.

${ }^{1231}$ Joined Cases T-68 to 77 and 78/89, Italian Flat Glass, [1992].

1232 See also Monti G., (2001), $136 \mathrm{ff.}$

1233 Case 27/76, United Brands, [1978], para. 65; Case 85/76, Hoffmann-La Roche, [1979], para. 38; Joined Cases C-68/94 and C-30/95, French Republic and Société commerriale des potasses et de l'azote (SCPA) and Entreprise minière et chimique (EMC) $v$ Commission, [1998], para. 221; Joined Cases C-395/96 P and C-396/96 P, CMB (Cewal) II, [2000], para. 34; Case T-193/02, Piau I, [2005], para. 109. Whish R, (2003), 179, rightly points out that both the buying as well as the selling side of the market are covered by this definition. The accrued buying power of a strong purchaser may allow it to behave independently of its sellers who are not normally depicted as 'customers'. The liberal professions confront buying power for instance in the medical health sector where insurances remunerating 
regard to the collectivity aspect the CFI confirmed that there "is nothing, in principle, to prevent two or more independent economic entities from being, on a specific market, united by such economic links that, by virtue of that fact, together they hold a dominant position vis-à-vis the other operators on the same market." "234 While in a particular case both aspects are inseparably amalgamated, the following presentation will focus particularly on the collectivity aspect to better grasp the concept's bearing.

The case law specified that two or more economic entities legally independent of each other may hold a dominant position, provided that from an economic point of view they present themselves or act together on a particular market as a collective entity. The concept of a collective dominant position thus refers to situations where "correlative factors" or "connecting links or factors" exist between undertakings such that they are able to adopt a common policy on the market and act to a considerable extent independently of their competitors, their customers, and also of consumers. ${ }^{1235}$

The question here is whether the members of a profession can, in legal terms, be perceived to "present themselves on [a] market as a collective entity vis-à-vis their competitors, their trading partnets and consumers." 1236 Since the wording of Article 82 EC covers only undertakings and not their associations the latter do not, at least at first, come within the ambit of Article $82 \mathrm{EC}$. Consequently, the starting point for the scrutiny here are the members of a profession. ${ }^{1237}$ Notwithstanding, in light of the recent judgment in Piau, it is necessary to analyse whether the affiliation to a professional body constitutes the relevant connecting link required in establishing the jurisdictional element of collective dominance. Before fully testing the case of the professions, the case law of Piau shall be introduced more fully to assess whether it overrules the approach adopted by the ECJ in Wouters in respect of Article $82 \mathrm{EC}$.

\section{The ECJ and CFI applying Article 82 EC in collectively regulated sectors: a conflict?}

Apart from the legal issues dealt with in Chapter 4 in respect of Article $81 \mathrm{EC}$, the ECJ in Wouters had been confronted by the national court with the question of whether Article $82 \mathrm{EC}$ could be applied to liberal professions and their regulations. First of all, the Court rightly pointed out that "since it does not carry on any economic activity, [the professional body] is not an undertaking within the meaning of Article [82 EC]."1238

medical services have a reinforced bargaining position vis-à-vis individual service providers. See Case T-319/99, FENIN I, [2003]; AG Poiares Maduro in Case C-205/03 P, FENIN II, [2006].

${ }_{1234}$ Para. 358 of the Italian Flat Glass judgment. Since then this finding has become settled case law, sce Case C393/92, Almelo, [1994], para. 42; Case C-96/94, Spediporto, [1995], paras. 32 f.; Joined Cases C-140-142/94, DIP, [1995], paras. 25 f.; Joined Cases C-68/94 and C-30/95, Kali \& Salo, [1998], para. 221; Joined Cases T-24 to 26/93 and 28/93, CMB (Cewval) I, [1996], para. 60; Joined Cases C-395/96 P and C-396/96 P, CMB (Cewal) II, [2000], para. 36; Case T-193/02, Piau I, [2005], para. 110. "The expression 'one or more undertakings' in Article $82 \mathrm{EC}$ implies that a dominant position may be held by two or mote economic entities legally independent of each other, provided that from an economic point of view they present themselves or act together on a particular market as a collective entity." See also Case 30/87, Bodson, [1988], in which a group of undertakings with a parent company had been examined under Article $82 \mathrm{EC}$ for its cxploitation practices under an exclusive concession for funerals services in parts of France.

${ }^{1235}$ Joined Cases C-68/94 and C-30/95, Kali \& Salo, [1998], para. 221.

1236 AG Iéger in Case C-309/99, Wouters et al. v NOvA, [2002], para. 151. See also Muñiz Fernandez, (2000).

${ }^{1237}$ While a professional association represents the economic interests of its members, it does not normally engage in economic activities itself and thus does not qualify as undertaking. For details see Chapter 3.I.

${ }^{1238}$ Case C-309/99, Wouters et al. v NOvA, [2002], 112. 
Moreover, the Court held that the members of the legal profession in the Netherlands could neither be regarded to hold a collective dominant position. According to the Court they were not sufficiently linked to each other to adopt the same conduct on the market (collectivity aspect) with the result of eliminating competition (dominance aspect). ${ }^{1239}$ In particular the Court underlined that the legal profession in the Netherlands is highly heterogenous and characterised by a high degree of internal competition. On the basis of this observation the Court concluded that no "sufficient structural links" existed between the members of the Dutch Bar and thus rejected the existence of a collective dominant position in Wouters. ${ }^{1240}$ Clearly the ECJ had difficulties in considering how the large number of law firms should align their behaviour as one collective entity on the market. However, one should realise that with its emphasis on the heterogeneity of the legal services market the Court merely said that that market is not a traditional oligopolistic one. ${ }^{1241}$ As such this observation does not necessarily imply a conclusive finding on the collectiveness of a supposed dominant position.

Conversely, the CFI in Piau was willing to take up the argument of collective organisation of a large number of undertakings in a representative body. The background to the case was a complaint to the Commission by Mr Piau who wanted to carry on the occupation of football players' agent. ${ }^{1242}$ In order to place football players the FIFA requires

1239 Paras. 113 f. of the judgment. The Court refers to Case C-96/94, Spediporto, [1995], paras. 33-34. AG Léger in Wouters finally suggested to interpret the particular question for a preliminary ruling that the national court had asked with regard to Article $82 \mathrm{EC}$ in a literal way, i.e. that the Raad van State would not have had inquired about collective dominance, see para. 146 of his opinion. The formulation of the third preliminary question required a very literal reading indeed: 'Is the term 'undertaking' in Article [82 EC] to be interpreted as meaning that [a professional body] must also be considered to be an undertaking or group of undertakings for the purposes of that provision, even though it pursues no economic activity itself?" (emphasis added). While both the Court and the $A G$ addressed the point of collective dominance, they both came to the conclusion that an association is not an undertaking in the sense of Article $82 \mathrm{EC}$. To finally reject collective dominance in casu, AG Iéger found that the file did not contain the matters of law and fact necessary to resolve the various questions connected with establishing a collective dominance, see paras. $153 \mathrm{f}$. of his opinion. Conversely, the Court stated that "The legal profession is not concentrated to any significant degree. It is highly heterogenous and is characterised by a high degree of internal competition. In the absence of sufficient structural links between them, members of the Bar cannot be regarded as occupying a collective dominant position for the purposes of Article [82 EC]" and referred "to that effect" to Joined Cases C-68/94 and C-30/95, Kali \& Salz [1998], para. 227, and Joined Cases C-395/96 $\mathrm{P}$ and C-396/96 P, CMB (Cewal) II, [2000], paras. 36 and 42. The ECJ continued that "Furthermore, as is clear from the documents before the Court, members of the [Dutch] Bar account for only $60 \%$ of turnover in the legal services sector in the Netherlands, a market share which, having regard to the large number of law firms, cannot of itself constitute conclusive evidence of the existence of a collective dominant position on the part of those undertakings" and refcrred "to that effect" again to the same two cases cited, at paras. 226 and 42 respectively. 1240 Para. 114 of the judgment. AG Iéger in Case C-309/99, Wouters et al. v NOvA, [2002], paras. 147-154, had no principled difficulties to picture a collective dominance of the legal profession and developed a reasoning that lays the foundation for the application of Article $82 \mathrm{EC}$ to the liberal professions: "in the light of the principles identified in the case-law, the possibility of applying that concept [of collective dominance] to the professions cannot be ruled out"

${ }^{1241}$ See also note 1221 . In the past, situations of a collective dominant position were limited to cover a manageable number of market players. The first case squarely addressing collective dominance concerned three companies, Joined Cases $T-68$ to 77 and 78/89, Italian Flat Glass, [1992], and the corresponding Cormmission Decision flat glass, (1989), paras. $78 \mathrm{f}$. Three companies were found to occupy a collective dominant position in Joined Cases T-24 to 26/93 and 28/93, CMB (Cewal) I, [1996]. See also Commission Decision P \& I Clubs, (1999), which concerned 19 non-profit-making undertakings that were providing protection and indemnity insurance to shipowners.

${ }^{1242}$ They effectively function like 'private cmployment agencics', and their use has become more widespread after the judgment in Case C-415/93, Bosman, [1995]. Although the occupation of sport agent has become more professional in recent years, a somewhat stained reputation of sports agents persists due to incidents of fraud, excessive fees and the abuse of young players. Regulation of the profession of players' agents by various actors 
agents to possess a specific licence that is issued exclusively by the FIFA through one of its members, i.e. through national associations that group amateur and professional football clubs. In considering the applicability of Article $82 \mathrm{EC}$ the CFI stated that due to the membets' affiliation to the FIFA and the binding character of the regulations adopted by it the FIFA acts as the emanation of its members (i.e. the national associations and the football clubs) ${ }^{1243}$ In contradistinction to the ECJ in Wouters, the CFI held that it is irrelevant that the FIFA is not itself an economic operator on the relevant matket, since it operates on that market through its members. The CFI thus came to the conclusion, first, that for the purpose of Article $82 \mathrm{EC}$ the national football associations and their sport clubs, as organised in the FIFA, occupy a collective dominant position and, second, that the FIFA itself was covered by that article.

It follows that in respect of Article $82 \mathrm{EC}$ the two cases clearly reach a different result. Before going into the reasoning in Wouters to reject the idea that collectively organised professions could come within the jurisdictional scope of Article $82 \mathrm{EC}$, it is necessary to verify whether the two cases have to be distinguished on the basis of their facts. Both concerned self-regulatory rules that have an influence on the access to and the exercise of specific professional activities. More particularly, the respective association of undertakings had adopted binding self-tegulatory rules that allowed the exclusion of non-members from providing certain activities, which their own members, however, did or could not offer. In Piau these services concerned the market for the ptovision of players' agents' services, in which the agents (non-members) ate the sellers of a service and the national football associations and sport clubs (the members of the FIFA) are the purchasers. In Wouters the relevant market was that of the provision of legal services and the NOvA regulation excluded non-members (accountants) from the integrated provision of legal and accountancy services in a multi-disciplinary partnership with NOvA-members (lawyers). ${ }^{1244}$ The only structural difference perceivable between the cases is the fact that the NOvA, according to national law, is subject to a public law regime and authotised to adopt self-regulation on the basis of a State law (the Advocatenwet). This point is however itrelevant for the applicability of EC competition law. ${ }^{1245}$ On the basis of the facts the two cases thus do not seem to differ substantially. Therefore, since in either case the collectivity of numerous undertakings does not meet the picture of a classical oligopoly, the question arises whether the two cases state conflicting law or whether their different conclusions are based on different points of departure in assessing the concept of collective dominance.

The ECJ in Wouters seems to have given a clear cut answer, namely that heterogenous,

in the international football world have tried to remedy and prevent professional misconduct.

${ }^{1243}$ Case T-193/02, Piau I, [2005], paras. $107 \mathrm{ff}$., esp. 112 and 116. See also paras. 69-72 of the judgment where the CFI qualifies the FIFA as an association of undertakings. It defines the sporting clubs as 'undertakings' (for which the practice of sport is an economic activity), the national associations grouping the clubs as 'associations of undertakings' (which in turn carry out an economic activity as being holders of exclusive broadcasting and transmission rights for sporting events), and the FIFA finally as 'association of undertakings'.

${ }^{1244}$ There is one factual difference between Wouters and Piau. In the former case the members of the association of undertakings act on the relevant market as providers of professional services, whereas in the latter case the members of FIFA act as purchasers of services. Both the selling and purchasing of services are activities exercised on a market and should yet not warrant a different treatment in legal terms. If at all, and only in particular circumstances, it is the purchasing activity for which the case law may accepta differentassessment in competition law terms. See Case T-319/99, FENINI, [2003], stressing that purchases made for final ends, i.e. which do not integrate the purchase in a further economic activity, do not, on the side of the purchaser, have an economic character for the purpose of competition law.

1245 For details see Chapter 3.I.1. 
i.e. non-oligopolistic markets would not be prone to the situation of collective dominance. ${ }^{1246}$ Conversely, the CFI in Piau focussed on the respective toles taken by the association and its members on the relevant market to come to the conclusion that a high number of market participants does not exclude the application of Article $82 \mathrm{EC} .{ }^{1247}$ At first sight the argument used by the ECJ in Wouters (no elimination of competition among the members of the allegedly dominant collectivity) supports the conclusion that the Dutch lawyers as unified in the NOvA could not be in a (collective) dominant position on the legal services market. However, an extrapolation of the approach used in Piau could have led to a different appreciation of the facts in Wouters. In fact already Advocate General Léger considered it "conceivable that members of a profession [...] [b]ecause of their compulsory membership [...] are part of a collective entity the object of which is to define and apply common conditions for the practice of the profession." ${ }^{1248}$ His opinion indicates that the point could conceivably have been decided differently already in Wouters. It reveals that the ECJ and the CFI actually chose different statting points in addressing the concept of collective dominance. Like Advocate General Léger, the CFI in Piau focussed on the collectivity aspect. Conversely, the ECJ in Wouters concentrated its attention on the (presumed absence of a) dominance aspect when it rejected the idea that a heterogenous market with a considerable degree of competition between the players could fall under Article $82 \mathrm{EC}$.

\section{Diagram (no. 6) comparing Wouters and Piau on collective dominance}

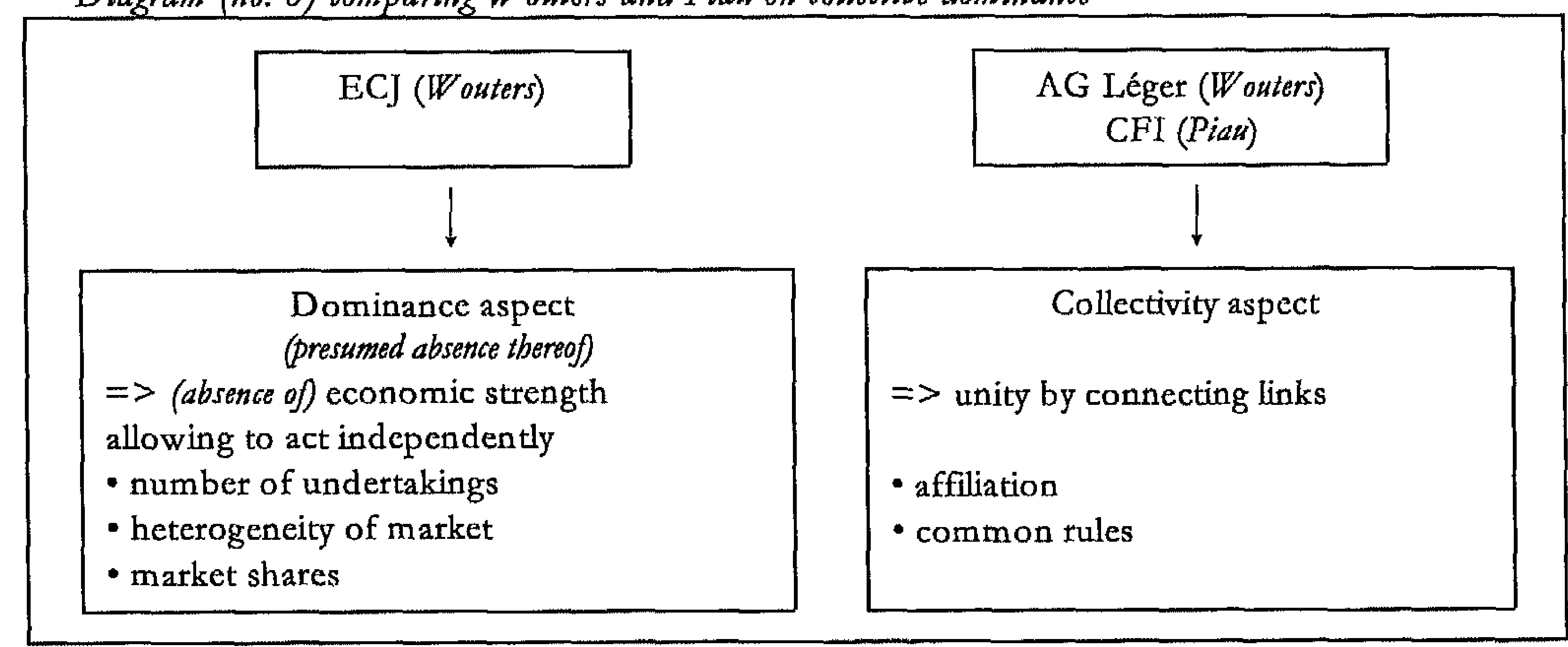

The interdependence between the dominance and the collectivity aspect first of all requires to consider the ECJ's concern in Wouters in respect of the perceived high degree of market internal competition. In grasping this concern reference shall be made to case law concerning single firm behaviour. According to that case law, it is not necessary that competition be precluded to establish dominance but that effective competition be prevented. This means that the presence of competition in a given market does not as such exclude the application of Article $82 \mathrm{EC}$. It is sufficient that the collectivity of operators are in a position

1246 Para. 114 of the Wouters judgment, sce above note 1239.

1247 See also AG Lenz in Case C-415/93, Bosman, [1995], paras. 227, 282, 285, who with reference to Joined Cases T-68 to 77 and 78/89, Italian Flat Glass, [1992], para. 358, stated that football clubs in a professional league could be "united by such economic links" as to be regarded as collectively dominant. The judgment in Bosman finally did not address the issue.

${ }^{1248}$ AG Léger in Case C-309/99, Wouters et al. vNOvA, [2002], para. 151 (emphasis added). 
to appreciably influence the conditions under which the 'remaining' competition develops on a certain market. ${ }^{1249}$ While the absence of (potential) competition is a relevant factor in assessing dominance ${ }^{1250}$, it is not necessarily a determinative one when taken separately. ${ }^{1251}$ Notwithstanding the ECJ in Wouters abridged the concept of collective dominance in a way as if the absence of competition was sufficient to exclude the application of Article 82 EC. ${ }^{1252}$ Such stance misses, however, that the absence of competition simply indicates a monopoly situation even if in the form of an oligopoly. A monopoly is only one but the strongest form of dominance.

Therefore, in a situation of collectivity the decisive assessment is whether, from an economic point of view, two or mote legally independent economic entities present themselves or act together on a particular market as a collective entity. ${ }^{1253}$ In order to determine whether the undertakings together hold a dominant position on a given market, it is necessaty to ascertain the factors connecting them. Where the connecting links enable them to act together (= collectivity aspect) and independently of their competitors, their customers and ultimately the consumers ${ }^{1254}$, they are (collectively) in a situation of economic strength (= dominance aspect). ${ }^{1255}$

While the Court in Wouters observed that the number of undertakings, their matket share and the heterogeneity of the market are factors that indicate the absence of sufficient structural links between the professionals ${ }^{1256}$, the suggestion here is that the Court resolved to address the issue of connecting links only partially. ${ }^{1257}$ In particular, the Court can be criticised for not having considered whether the affiliation to a professional body provides the necessary structural link between the members of the profession (= collectivity aspect) to behave independently of their competitors, customers and ultimately the consumers (= dominance aspect). The Court rather adamantly equated the high degree of profession-

${ }^{1249}$ Case 85/76, Hoffmann-La Roche, [1979], para. 39: "Such a position [of economic strength] does not preclude some competition, which it does where there is a monopoly or a quasi-monopoly, but enables the undertaking which profits by it, if not to detcrmine, at least to have an appreciable influence on the conditions under which that competition will develop, and in any case to act largely in disregard of it so long as such conduct does not operate to its detriment" (emphasis added). The case law has been confirmed in respect of collective dominance and with regard to the concept of collective dominance in Joined Cases T-191/98 and T-212/98 to T-214/98, TACA, [2003], para. 654, concerning 16 liners.

1250 The absence of (potential) competition is the strongest proof of dominance, and in fact of a monopoly, as it is the result of obstacles preventing new competitors from having access to the market. See Case 85/76, Hoffmann-La Roche, [1979], para. 48.

${ }_{1251}$ Above note 1249.

1252 See also Case C-96/94, Spediporto, [1995], para. 34.

${ }^{1253}$ Joined Cases C-395/96 P and C-396/96 P, CMB (Ceval) II, [2000], para. 36.

1254 Van Bael I. / Bellis J.-F., (2005), 120 f.; A G Léger in Case C-309/99, Wouters et al. vNOvA, [2002], para. 147. Joined Cases C-395/96 P and C-396/96 P, CMB (Cewal) II, [2000], have been particulatly important to resolve much of confusion and uncertainty about the concept of collective dominance. See also Joined Cases T-191/98 and T-212/98 to T-214/98, TACA, [2003]. Whish R, (2000).

1255 AG Léger in Case C-309/99, Wouters et al. v NOvA, [2002], paras. $147 \mathrm{f}$."[A] collective dominant position requires the undertakings to be sufficiently linked to each other to adopt the same conduct on the market. The precise meaning of the concept of the links that must connect undertakings is uncertain. As case-law now stands, it is possible to consider that those links can be structural, legal or economic." - Similarly numetous domestic systems recognise the phenomenon of collective dominance, for instance section 18 of the UK Competition Act 1998.

${ }_{1256}$ Para. 114 of the Wouters judgment (scc above note 1239).

${ }^{1257}$ Despite the distinguished manner in which its Advocate General addressed the point, see below page 261. 
internal competition with the absence of sufficient structural links. ${ }^{1258}$ Therewith it concentrated on links that could be defined in terms of company law rather than competition law with its emphasis on an economic analysis of a situation. The fact that lawyers are organised in an association has been considered by the ECJ - if at all - only to distinguish "registered members of the Bar" from other (potential) providers of legal services. ${ }^{1259}$

However, while the number of the compounded operators may be an indicator of the degree of the remaining competition, it is not necessarily the decisive factor to dismiss collective dominance. In a situation of assumed collective dominance the presence of 'perfect coordination' (i.e. a situation where a firm can rapidly detect and respond to 'cheating' by rivals) is in principle independent of the number of firms on the market. In other words (tacit) coordination could be sustained even with hundreds of firms in the market. ${ }^{1260}$ Whish rightly points out that there are many markets with few players that are highly competitive, and markets with many economic operators that yet result in a failure of the competitive market mechanism. The decisive consideration therefore has to be one of market power, which confers the ability to suppress output and to raise price to the detriment of consumers. "It is no doubt true that the fewer the number of players in a market, the more likely it is that market power will exist; however the identification of market power cannot simply be a matter of counting heads." 1261

Consequently, the CFI in Piau went further than the ECJ in Wouters and in order to establish 'collectivity' it considered the links that exist between the numerous members of the FIFA. These members are identifiable by way of their affiliation. While the ECJ in Wouters could have identified the collectivity of the members of the Dutch Bar in a similar way (i.e. by their affiliation to the NOvA), the ECJ merely perceived the members of the profession as abstracted from their association. It therewith adopted a limited interpretation of the concept of 'connecting links' required to establish collective dominance. Conversely, the assessment conducted by the CFI in Piau includes the structures that the collective body provides between its member undertakings. ${ }^{1262}$ The CFI thus concluded that the FIFA itself occupied a collective dominant position through its members and as the emanation of its members - despite the non-economic nature of its own activities. ${ }^{1263}$

In applying the concept of collective dominance in more detail to the case of the liberal professions in the following two sections will maintain the distinction between the

1258 Para. 114 of the Wouters judgment, see above note 1239.

1259 Para. 113 of the judgment in Wouters. "Second, [the Bar of the Netherlands] cannot be categorised as a group of undertakings for the purposes of [Article $82 \mathrm{EC}$ ], inasmuch as registered members of the Bar of the Netherlands are not sufficiently linked to each other to adopt the same conduct on the market with the result that competition between them is eliminated".

1260 Niels G., (2001), 171. Shapiro C., (1989), 366.

1261 Whish R., (2000), 583. For the same reason. Whish argues that one should not generally speak of 'oligopolistic' markets since the term only indicates few players. See also above note 1221.

1262 In this the approach of the CFI in Piau corresponds with the opinion of AG Léger in Case C-309/99, Wouters et al. v NOVA, [2002], para. 151, see above note 257. Sce also Commission Decision COAPI, (1995), where the Commission, in respect of an Article $81 \mathrm{EC}$ investigation, found that the COAPI members had a preponderant position over competitors by reason of their affiliation giving them an identifiable status with clients, namely as specialists, therewith enabling them to attract most of the business.

${ }^{1263}$ Case C-171/05 P, Piau II, [2006], para. 116: "The fact that FIFA is not itself an economic operator that buys players' agents' services on the marketin question and that its involvement stems from rule-making activity, which it has assumed the power to exercise in respect of the economic activity of players' agents, is irrelevant as regards the application of Article $82 \mathrm{EC}$, since FIF $A$ is the emanation of the national associations and the clubs, the actual buyers of the services of players' agents, and it therefore operates on this market through its members" (emphasis added). 
collectivity aspect and the dominance aspect. Finally section 1.3. will turn to the further jurisdictional element specific to Article $82 \mathrm{EC}$, which requires that (collective) dominance be established to exist in a substantive part of the common market.

\section{Connective links and the collectivity of liberal professions}

The notion of connective links relevant to determine collective dominance can be met by different types of connections between market players, provided they warrant a relationship of economic interdependence between them and thus allow them to act independently from other market forces like their competitors, their customers and the ultimate consumer. ${ }^{1264}$ While AG leeger in Wouters still found the precise meaning of the concept of 'links connecting legally independent undertakings' to be uncertain ${ }^{1265}$, the CFI at a slightly later date clearly held in Airtours that the collectivity aspect is determincd by three cumulative conditions to establish the necessary links from an economic point of view:

"first, each member of the dominant oligopoly must have the ability to know how the other members ate behaving in order to monitor whether or not they are adopting the common policy; second, the situation of tacit coordination must be sustainable over time, that is to say, there must be an incentive not to depart from the common policy on the market; thirdly, the foreseeable reaction of current and future competitors, as well as of consumers, must not jeopardise the results expected from the common policy."1266

Despite the fact that both terms of oligopoly and 'tacit' coordination used in Airtours do not generally suit the situation of the professions ${ }^{1267}$, the three conditions do not become marginal for testing the case of the (liberal) professions. Although one may doubt more generally the appropriateness of applying the Airtours criteria outside the specific field of concentration control ${ }^{1268}$, The three conditions are spelled out in sufficiently general terms

${ }^{1264}$ Mind however that this definition encounters heavy criticism, for instance Azevedo J.P. / Walker M., (2002), 364. It is not economically coherent to think of firms acting independently of customers and consumers to an appreciable extent. This can be explained by what economist call the discipline of the demand curve (it is not open to firms to raise prices and sell the same quantity as before). With regard to the "independence' of dominant firms from their competitors this encounters a measurement problem. The better test to apply, they suggest, would be 'the ability to restrict output substantialy in the market-place'. This would mean that a firm must have power over price. Moreover, the definition would be consistent with most of the standard factors usually considered relevant in the appraisal of dominance; restricting output is the key to most anti-competitive behaviour; and concentrating on output limitation enables cases where the observation of prices and costs cannot be achieved to be dealt with more easily. However, the Commission's internal review cannot change the definition of dominance because it has been laid down by the ECJ. Unless or until the Court is persuaded by the arguments of economists and others the 'power to behave to an apprcciable extent independently' will remain, Jones $\Lambda$. / Sufrin B., (2004), $265 \mathrm{f}$.

${ }^{1265}$ AG Jéger in Case C-309/99, Wouters et al. $\nu N O v A$, [2002], para. 148. He continues "As case-law now stands, it is possible to consider that those links can be structural, legal or economic. In addition, certain judgments give grounds for thinking that the notion of economic links covers mere economic interdependence between the members of an oligopoly."

${ }_{1266}$ This standard of three conditions has been spelled out by the CFI in merger control cases, Case T-342/99, Airtours/First Choice, [2002], para. 62; Case T-374/00, Robrverke, [2003], para. 121. In the latter judgment the CFI stresses that it has "consistently be held that a finding of a collective dominance depends on [these] three conditions being fulfilled" (emphasis added). The standard has been applied by theEC] also in Case T-193/02, Pian I, [2005], para. 111; and has been confirmed in Case C-413/06 P, Impala II, [2008], paras. 124 ff., after doubts about its applicability arose after the CFI watered down the three criteria in T-464/04, Impala I, [2006]. The Airtours criteria now seem definite.

${ }^{1267}$ See above note 1261 and text with note 1228 respectively.

${ }_{1268}$ van de Scheur S., The Limits of Articles 81 and 82 EC in the Control of Oligopolies (working title), (European 
to allow for an objective assessment of whether legally independent undertakings present themselves or act together on a particular market as collective entity - irrespective of the number of players in that market. They will be applied hereafter in turn.

\section{Ability to know bow other members are bebaving (common policy)}

Due to the existence and, mote importantly, the implementation of professional regulations members of a profession are in a position to anticipate how their fellow members will conduct their professional activity. For the application of Article $82 \mathrm{EC}$ it is therefore not strictly necessary that the conduct in question be tacit. ${ }^{1269}$ For instance where fee schedules are applied each member of a particular profession knows the prices adopted by any other member. The principle underlying the first criterion had been formulated by the $\mathrm{ECJ}$ in CMB (Cewal II), according to which a decision of an association of undertakings can, if implemented, have the result of linking the undertakings and their conduct on a particular market in a way that they present themselves on that market as a collective entity vis-à-vis their competitors, their trading partners and consumers. ${ }^{1270}$ A perfect application of this principle to the professions has been given by Advocate General Léger in Wouters.

"It is conceivable that members of a profession are in some way connected by structural or legal links within the meaning of the case-law. Because of their compulsory membership of the competent association, professionals are part of a collective entity the object of which is to define and apply common conditions for the practice of the profession. Moreover, the rules imposed on the members of the profession may limit, sometimes significantly, the competition which operates between them by means of prices, services and advertising. It is therefore possible that the rules governing the profession may on examination prove to be decisions of associations of undertakings which, when implemented, result in the undertakings concerned being so linked as to their conduct on the market that they present themselves on that market as a collective entity vis-à-vis their competitors, their trading partners and consumers". ${ }^{271}$

University Institute Florence) (forthcoming), who is of the opinion that, while tacitness is not a requirement for the applicability of Article $82 \mathrm{EC}$, an application of the Airtours criteria to structural or more explicit economic links (i.e. outside concentration control) is artificial and erroneous. He points out that, although it cannot be excluded that tacit coordination leads to collective dominance that can be abused contrary to Article $82 \mathrm{EC}$, such abuse of 'tacit collective dominance' will be extremely rare and probably only concern excessive pricing. It appears that the current thought considers collective dominance as a uniform concept under both Article $82 \mathrm{EC}$ and the concentration control regulation (e.g. Faull J. / Nikpay A. (Eds.), (2007), paras. 4.117, 114.124) and that as such the application of the Airtours criteria under Article $82 \mathrm{EC}$ is not wrong. Van de Scheur, however, argues in favour of separating merger control case law and Article $82 \mathrm{EC}$ case law for the purpose of collective dominance.

${ }_{1269}$ See European Commission, DG Competition discussion paper on exclusionary abuses, of 12/2005, para. 74: "A finding of abuse of a collective dominant position is typically based on showing that the collectively dominant undertakings have tacitly or expressly been following a common poligy on the market, at least in regard to the abusive conduct" (emphasis added).

${ }^{1270}$ Joined Cases C-395/96 P and C-396/96 P, CMB (Cewal) II, [2000], para. 44. See also AG Léger in Case C309/99, Wouters et al. $v$ NOvA, [2002], para. 148; and Case T-193/02, Piau I, [2005], para. 113.

${ }^{1271}$ Para. 151 of his opinion (emphasis added). See already Joined Cases C-395/96 P and C-396/96 P, CMB (Cewal) $I I$, [2000], paras. 44 f.; Joined Cases T-191/98 and T-212/98 to T-214/98, TACA, [2003], para. 610: "As the Court of Justice has already held, an agreement, decision or concerted practice [...] may, where it is implemented, result in the undertakings concerned being so linked as to their conduct on a particular market that they present themselves on that market as a collective entity vis-à-vis their competitors, their trading partners and consumers. The existence of a collective dominant position may therefore flow from the nature of the terms of an agreement, from the way in which it is implemented and, consequently, from the links or factors which give rise to a connection between undertakings which result from it" (emphasis added). See also Case T-228/97, Irish SugarI, [1999], para. 66, where the Court found that the repugned actions were undertaken from a position of joint dominance in view of a continuous overall policy of maintaining and strengthening that position. 
This position deals with all aspects of the issue and is to be preferred over the limited assessment adopted by the ECJ in Wouters. Basically the latter meets two objections. First, a lopsided assessment concentrating on the absence of direct economic and legal links between individual professionals in terms of company law ${ }^{1272}$ inevitably prevents that Article $82 \mathrm{EC}$ can be applied to self-regulatory measures. This seems to conflict with the fact that the organisation of a sector in an association assuming regulatory powers has great similarity with groups in other sectors to which Article $82 \mathrm{EC}$ is applied. ${ }^{1273}$

The second apprehension can be linked back to the motivation underlying the ruling in Wouters. In Chapter 4.II.4.2.2. it has been argued that the Court in Wouters implicitly diagnosed a gap in the legal system of justification grounds in order to prevent a (partial) regulatory vacuum in the professional services sector. While having felt obliged to proceed to a conlra legem interpretation of the law of Article 81(1) EC, the Court could evade such operation in respect of Article $82 \mathrm{EC}$ since no procedural tail is, or had been, attached to the substantive dog of Article $82 \mathrm{EC}$. Therefore it would not have been necessary to limit the jurisdictional scope of the latter provision by dismissing the 'collectivity' criterion. Instead, considerations to justify the NOvA regulations on grounds of legitimate regulatory objectives could have been included in the assessment of 'abuse. ${ }^{1274}$

\section{Incentive not to depart from the common policy of the market}

The second requirement laid down in Airtours concerns sustainable incentives not to depart from a common policy on the market. It can be applied to the professional services sector as follows. The uniform conduct in professional services markets is determined by, first, professional regulations or codes of conduct to which members of the professions are subject and, second, the capacity of professional associations to impose these rules on their members. This capacity sometimes even goes as far as to exclude non-members from a particulat activity. ${ }^{1275}$ It is vested not only in professional associations but also with the members of the profession who may be able to enforce professional regulations vis-à-vis fellow members, and even third actors, by respectively imposing sanctions or seizing the supervisory authorities for transgressions of the professional regulations adopted by the association. Sanctions can take the form of reprimands or fines, but may also result in, for

1272 Which the Court confusingly denotes as structural links, see para. 114 of the Wouters judgment.

${ }^{1273}$ Sec Case T-193/02, Piau I, [2005], paras. $107 \mathrm{ff}$. Article $82 \mathrm{EC}$ is also applied to shipping liner conferences, although their groups are not as numerous as some professions in some Member States. A shipping liner conference is an agreement between two or more shipping companies to provide scheduled cargo and/or passenger service on a particular trade route under uniform rates and common terms. See for instance Joined Cases T-191/98 and T-212/98 to T-214/98, TACA, [2003], which concerned 16 liners. The particular relevance of the concept of collective dominance in the maritime sector is due to Council Regulation (EEC) No 4056/86 of 22.12.1986 laying down detailed rules for the application of Articles 85 and 86 of the Treaty to matitime transport, which exempts certain agreements from the prohibition laid down in Article 81(1) EC in respect of services to or from Community ports. Allowed are for instance rate fixing, regulation of capacities for individual members, or allocation of revenue between the members. Decisions of liner conferences that are harmful to competition can nevertheless be addressed under Article $82 \mathrm{EC}$ where they amount to an abuse of a dominant position, Article 8 of the Regulation. See for instance Case C-381/93, Cabotage maritime, [1994]; Joined Cases T-24 to 26/93 and 28/93, CMB (Cenval) I, [1996]; Joined Cases C-395/96 P and C-396/96 P, CMB (Cenval) II, [2000]. See also Tillotson J. / MacCulloch A., (1998).

1274 For details see below part $\Pi$ of this chapter. See also Case C-171/05 P, Piau II, [2006], paras. 117-119.

1275 See Chapter 4.I.1.2.2. 
instance the exclusion from the assuciation or withdrawal of a licence, and hence in the exclusion from the market. ${ }^{12}$ "The 'incentive' not to depart from the professumal tegulations determining the conduct in the exetcise of the economic activity is cven stricter in case the professionals ate brund in an association by compulsory membership. ${ }^{12:}$ Compulsenty membership is, however, not decisive where the powers to supervise infringements of rules adopted by the professional association ate a sufficient deterrent for the members of the profession to align their conduct accordingly.

\section{The foreseable reaction of other market forter does not jeopardise the common policy}

The capacity to supervise and enforce the respect of professional regulations is also relevant for establishing the third requirement of collective dominance. According to the general rules on the burden of proof it is for the competition authority or a private claimant t' establish that the foresceable reaction of current and future competiturs, as well as of consumers, does not jeopardise the results expected from the common policy. 'I'his requires a probability reasoning, which when applied to the case of the professions serves to establish that the competitive conditions for the provision of certain professional services are removed from the influence of the practitioners' current and future competitors (i.e. either newcomers within the same profession or competitors from a different profession), costumers and consumers. ${ }^{1279}$ This appears to be the case where the members of a profession are bound to adhere to professional rules that lay down the conditions under which professional services are to be provided, since it is not realistic to assume that either competitors or consumets could jeopardise the result of those rules (i.e. the common policy of the collectivity). 'The point will be discussed more fully in section 1.2 . in respect of the dominance aspect and the ability of undertakings to behave independently of other competitors, customers and consumers.

So far it can be summarised that professional associations and their self-regulatory rules can generally be considered to provide the necessary (infra)structure that links their member professionals (i.e. the addressees of Article $82 \mathrm{EC}$ ) in such a way that they present them selves on a certain market as a collective entity vis-à-vis their competitors, their trading partners and consumers. The application of the concept of collective dominance to the (liberal) professions converges with the potential anti-competitive risks of such a market structure. ${ }^{22}$ The organisation in professional associations and their rules are the manifestation of the collectivity required for the applicability of Article $82 \mathrm{EC}$. The CFI therefore correctly ruled in Pian that, despite its non-economic character, it is the association

17' See Case T-193/02, Pian I, [2005], para. 114: "Because the regulations are binding for [the members], these bodies appear to be linked in the long term as to their conduct by rules that they accept and that other actors (players and players' agents) cannot break on pain of sanctions that may lead to their exclusion from the market, in particular in the case of players' agents."

2277 See also AG leger in Wouters at para. 151, quoted before.

12: See in particular Joined Cases T $191 / 98$ and $\mathrm{T}-212 / 98$ to $\mathrm{T}-214 / 98, T, A C A$, , 2003], paras. 595, 631: "it has been held that in order for the position of a number of undertakings to be assessed collectively on the relevant market it is sufficient that they are able to adopt a common policy on that market. On the other hand, there is no ned to show that thase undertakings bave in fact all adopted that common policy in all cincumstances" (emphasis added).

12:4ee Case 1 -193/02, Pua I, [2005], para. 114: "...through the rules to which they adhere, the clubs lay down the conditions under which the services in question are provided."

128) See Monti ( $; .,(2001), 136$, Collective dominance is to be analysed according to the effects that the undertakings' position has on the market and not on any formalistic definition of economic or structural links. 
itself that holds a collective dominant position on the relevant services market. ${ }^{1281}$ Contraty to what the ECJ concluded in Wouters, professionals are sufficiently linked to adopt the same line of action on the market through the affiliation to the same representative body. The affiliation creates a clear parallelism of interests ${ }^{1282}$ between the members of a profession, and it is in this sense that the association is the emanation of its members that is itself subject to Article 82 EC. ${ }^{1283}$ The jurisprudential requirements for a collective dominant position ("other factors", "economic assessment", "assessment of the structure of the market") ${ }^{1284}$ do not require that formal structures be directly established between the individual members of a profession. In this respect the argument used by the ECJ to reject the application of Article $82 \mathrm{EC}$ in Wouters (the heterogeneity of the legal market in the Netherlands) is little conclusive because the heterogeneity is in part due to the challenged rules in that case, a fact which the ECJ by the way recognised. ${ }^{1285}$

\section{Measuring dominance and the market power of liberal professions}

A self-regulating profession that is organised in an association and thus presents itself on a specific market as a collectivity within the meaning of Piau (and the extrapolated Airtours criteria) is not necessarily dominant in its collectivity. Whether or not undertakings are dominant - either in their collectivity or independently - is of central importance to the application of Article $82 \mathrm{EC}$. Usually (single firm) dominance is established by measuring market power. The question is which degree of market power is needed for Article $82 \mathrm{EC}$ to apply.

"Perfect competition is rarely encountered outside textbooks; almost all firms have some market power, though most have very little. Accordingly, the relevant question in antitrust cases is not whether market power is present, but whether it is important."1286

Market power is normally measured in terms of market shares, which, however, are not necessarily a conclusive circumstantial evidence. Further factors that need to be taken into account are, for instance, conduct on the market ${ }^{1287}$, the limited ability of trading partners to

1281 Case T-193/02, Piau I, [2005], paras. 115f,, 119: "It seems unrealistic to claim that FIFA, which is recognised as holding supcrvisory powers over the sport-related activity of football and connected economic activities, such as the activity of players' agents in the present case, does not hold a collective dominant position on the market for players' agents' services on the ground that is not an actor on that market" (emphasis added).

${ }^{1282}$ Jones A. / Sufrin B., (2004), 830.

1283 See paras. 112 and 116 of the Piau judgment.

1284 Joined Cases C-395/96 P and C-396/96 P, CMB (Cesval) II, [2000], para. 45; Joined Cases T-191/98 and T212/98 to T-214/98, TACA, [2003], para. 595.

1285 Para. 92 of the Wouters judgment: "the prohibition of conflicts of interest with which members of the Bar in all Member States are required to comply may constitute a structural limit to extensive concentration of law-firms and so reduce their opportunities of benefiting from economies of scale or of entering into structural associations with practitioners of highly concentrated professions."

1286 Schmalensee R, (1981), 1790. The traditional objection to the criterion of market power is the inefficiency of dominant undertakings. Jones A. / Sufrin B., (2004), 261: "Allocative inefficiency results from [the undertaking's] ability to limit output and increase price, and productivity inefficiency is likely to result from the ability to lead a quiet life. These problems will not atise if consumers have an alternative choice of products/services or suppliers. The increase in price or poor quality of the product or service will prompt consumers to look elsewhere. An undertaking should be found to be dominant, therefore, only if its conduct is not constrained by the existence of competitors producing competing products and services."

1287 In particular price discrimination. It has been criticised that conduct is used as an indicator for both dominance and abuse, Al-Dabbah M.M., (2000), 47. On the other hand a certain relationship cannot be denied 
switch to alternatives of supply, bartiers to entry ${ }^{1288}$, batriers to expansion, the existence of spare capacity, the fact of dominant undertakings being price setters and customers being price takers. ${ }^{1289}$

While a single dominant undertaking is presumed to have market power if it has a very large market share ${ }^{1290}$, the same presumption cannot necessarily be made in respect of an extended group of undertakings. ${ }^{1291}$ It would be misleading to merely count the combined market shares of a large collectivity whose members are not directly linked to each other. Without direct links coordination is more difficult and in spite of a large collective market share the ability to exercise market power can be diminished by other market conditions. ${ }^{292}$ Therefore, the ECJ in Wouters legitimately emphasised that a collective market share of $60 \%$ "cannot of itself constitute conclusive evidence of the existence of a collective dominant position", having regard to the large number of firms (i.e. the heterogeneity of the professional services market concerned). ${ }^{1293}$ However, as explained above the ECJ disregarded the fact that the lack of direct links between individual members of a profession can be largely compensated by the 'regulatory infrastructures' that (the affiliation to) the professional association represents with its regulatory, monitoring and even supervisory

to exist between the degree of market power and what behaviour is held abusive. The concept of 'dominant position' is a legal construct based on policy considerations. The dividing line of what constitutes a suspect dominant position and what is acccptable market power is not determined by economics. "For example, there could be an inverse sliding scale between the degree of power required and the invidiousness of the abusive or monopolizing conduct broad definitions of what constitute abusive conduct might prompt a higher threshold of market power, particularly where broad definitions of abuse capture competitively ambiguous conduct and run the tisk of inhibiting desirable competitive conduct (such as price reductions).", Hawk B.E., (1990), $788 \mathrm{f}$.

${ }^{1288}$ Particular interesting for present purposes are legal provisions that can operate as barriers to entry, especially where statutory monopoly rights are granted. Notorious examples of statutory monopoly rights are intellectual property rights, see, for instance, Case 22/78, Hugin, [1979]; Case T-69/89, RTE (Magill TV Guide), [1991] However, the beneficiary of a statutory right is not automatically in a dominant position if other products/ services compete with the protected product/ service and can be provided without it being necessary to have recourse to the protected product/ service or to infringe upon the exclusive right. In other words, dominance cannot be assumed where a statutory right does not create an effective monopoly excluding other providers. Other obvious examples of legal barriers to entry are government licensing requirements and planning regulations; statutory monopoly power, see Case 311/84, Télémarketing (CBEM), [1985]; and provisions of domestic law that shield providers on the domestic market from foreign competition. Such provisions give incumbents an absolute advantage over (potential) competitors. Whish R, (2003), 180. For details see below section II.2.2.1.

${ }^{1289}$ For instance fee schedules which customers perceive as binding. See also European Commission, "Commission condemns Belgian architects' fee system", press release IP/04/800 of 24.06.2004. In other words professionals are no price setters if fee schedules are not largely applied, for instance vis-à-vis business clients of lawyers in non-litigation cases, or repeat clients of architects, accountants or tax advisors.

${ }_{1290}$ See Case 62/86, AKZO Chemie BV $\nu$ Commission, [1991], para. 60.

1291 This may be different in a situation of oligopoly. The Commission in its TACA decision found the members of a liner conference with a collective market share of approximately $70 \%$ to jointly be in a dominant position, Commission Decision TACA II, (1999), paras. $532 \mathrm{f}$, confirmed on appeal, Joined Cases T-191/98 and T-212/98 to T-214/98, TACA, [2003], para. 254.

${ }^{1292}$ See also the position of the Commission in Joined Cases C-215/96 and C-216/96, Bagnasco, [1999], para, 56, in which the Commission stated that the mere fact that almost all undertakings in a specific sector are members to a collectively "is not a sufficient reason to conclude that its members together hold a collective dominant position" (making reference to Joined Cases C-140-142/94, DIP, [1995], paras. 26 f). The Court, however, did not exclude the possibility of a collective dominant position held by the members of the Italian banking association, see para. 59 of the judgment in Bagnasco.

1293 Para. 114 of the judgment in Wouters (emphasis added), with reference "to that effect" to the Court refers to Joined Cases C-68/94 and C-30/95, Kali or Saly [1998], para. 226, and Joined Cases C-395/96 P and C396/96 P, CMB (Cewal) II, [2000], para. 42. 
powers. ${ }^{1294}$ In other words, the dominance of a collectivity depends not only on the aggregate market power of the group but more precisely on the market circumstances in which a service is provided. In this sense the collective market shate may only be an indicator for dominance of the group. Therefore, other factors have to be identified to support whether a collectivity is in a position to act as a group and independently of other competitors, trading partners and consumers. ${ }^{1295}$

The ensuing question is which circumstances strengthen an indicated dominance of a profession. Apart from the already discussed regulatory infrastructures established by the fact of collective self-regulation, the position of a professional group may be further strengthened by the support that it receives by government. In fact professional self-regulation is often matked by some sort of State authorisation or statutory basis enabling self-regulation. The ECJ in Wouters neglected this aspect despite the fact that earlier case law had alteady recognised the role of government in assessing collective dominance. ${ }^{1296}$

The assessment of dominance of a collectivity has to stand the further test of whether the market concerned is contestable by competitors in spite of the self-regulation that the collectivity imposes on the sector and to which the members of the profession conform. 'Contestability' refers to the degree of competition that the incumbent gtoup has to face from other competitors. No competition has to be faced, however, where a professional sector enjoys exclusive statutory tights, i.c. monopoly rights, to exercise certain functions that allows it to effectively exclude other competitors. ${ }^{2297}$ In such a situation it is not necessary to prove additional circumstances to strengthen the argument of collective dominance. The point can be illustrated by reference to Piau where the FIFA assumed exclusive competence to regulate the exercise of and licensing for the activity of football players' agents. Consequently, the CFI did not need to explicitly scrutinise the dominance aspect as different from the collectivity aspect since the trading conditions on the relevant market were solely determined by the collectively dominant group, namely through the FIFA regulations.

The CFI's line of teasoning applies mutatis mutandis to professional self-regulation. Where the adoption and application of professional regulations and codes of conduct ate such to exclude competitors, customers and consumers from influencing the trading conditions of professional services, it can be generally assumed that the members of a profession present

\footnotetext{
${ }^{1294}$ See also Commission Decision COAPI, (1995), where the Commission, in respect of an Article 81 EC investigation, found that the COAPI members had a preponderant position over competitors by reason of their affiliation giving them an identifiable status with clients (as specialists), enabling them to attract most of the business.

${ }^{1295}$ Monti G., (2001), 137. The lower the collective market shares are the stricter the standards for indications complementing collective market share are, see Niels G. / Jenkins H., (2005), 606. See also Case C-309/99, Wouters et al. v NOvA, [2002], para.114. See Case 27/76, United Brands, [1978], para. 65; Case 85/76, Hoffmann-La Rocbe, [1979], para. 38. Commission Decision Continental Can, (1972), para. 3. While the ECJ in Case 6/72, Continental Can, [1973], annulled the Commission's decision on the ground of an erroneous definition of the market, the point about the aggregation of the activities of the group was not doubted.

${ }_{1296}$ See Joined Cases T-24 to 26/93 and 28/93, CMB (Cewal) I, [1996], and Joined Cases C-395/96 P and C396/96 P, CMB (Cewal) II, [2000]. In this case the dominant position was indicated by a combined market share of $90 \%$. It was confirmed that dominance was strengthened among others by the support that the arrangements of the liner shipping conferences received from the government of Zaire. Other factors taken into account concerned for instance the length of time for which the arrangements were in place.

${ }^{1297}$ Whish R, (2003), 180: true monopoly is rare, except where conferred by the State. The majority of cases have therefore had to deal with the problem of deciding at what point an undertaking, though not a true monopolist, has sufficient power over the market to fall within the ambit of Article $82 \mathrm{EC}$.
} 
themselves as a collective entity through their emanation of a professional association. ${ }^{1298}$ Similarly Advocate General Léger in Wouters emphasises the fact that liberal professions are characterised by compulsory membership, and that accordingly all professionals are part of a collective entity the object of which is to define and apply common conditions for the practice of the profession. ${ }^{1299}$ Advocate Genetal Léger only distegarded that not all provision of legal advice in the Netherlands is reserved to fully qualified lawyers that are members of the NOvA. The Court therefore had a point in looking into the collective market shares of the legal profession in the Netherlands. ${ }^{1300}$

In summary the assumption of collective dominance is particularly indicated where the collective market share is reinforced by statutory powers to regulate and supervise market entry and market conduct on the relevant professional services market. In particular State involvement in self-regulation tisks to define markets and to move away from an economic to a doctrinal definition of professional services matkets. This risk threatens the effectiveness of competition law and may therefore not lead to an atgument according to which any role taken by a State in the regulatory situation would limit the jurisdictional scope of Article 82 EC. Any compulsion by the State that the (association of) undertakings would have to follow in self-regulation may, however, constitute a defence against the liability flowing from competition law. ${ }^{1301}$

\section{Dominance on a substantial part of the common market and effect on intra-community trade}

In addition to the general jurisdictional element presented in Chapter 3.II. Article 82 EC requires that collective dominance be established for at least a substantial part of the common market. According to the Court it is not necessary that the whole territory of a Member State be covered by the activities of the collectivity; also strictly circumscribed and limited areas meet the tequirement. ${ }^{1302}$ It is however not a question of counting hectares. ${ }^{1303}$ A tole play also the volumes of business and the importance that activities have in the region as compared to the operations as a whole in the Member State concerned. ${ }^{1304}$ Applied to the case of the professions this means that the economic importance of their catchment area

${ }^{1298}$ See also Joined Cases T-24 to 26/93 and 28/93, CMB (Cewval) I, [1996], para. 65: "In this case, the Court finds, in view of the evidence set out in the contested decision, that the shipping companies formed a common entity, the Cewal shipping conference. It appears from the Decision that that structure formed a framework for a number of committees to which conference members belonged [...]. In addition, as emerges from Article 1 of Regulation No 4056/86, by virtue of its naturc that common structure is intended to define and apply uniform freight rates and other common conditions of carriage [...]. Consequently, Cewal presents itself on the market as one and the same entity" (emphasis added).

1299 See para. 151 of the opinion in Wouters.

${ }^{1300}$ Note that the relevant information to establish market share numbers in professional services markets are particularly difficult to obtain, and might even not exist, Philipsen N.J., (2003).

${ }_{1301}$ For details see Chapter 6.II.3. Furthermore, it is conceivable that the case law discussed in Chapter 4.I.2. could lead to limit the scope of Article $82 \mathrm{EC}$ by finding that certain collective professional regulation would "not have a character justifying the application of EC competition law". If valid, this case law may not be limited to Article 81(1) EC since the concept of undertaking is relevant also for the other branches of competition law. However, the critique on the case law undermining Höfner persists.

${ }_{1302}$ See for instance Case C-179/90, Merci Convenzionali, [1991], paras. $14 \mathrm{f}$. The territory of a Member State is likely to be a substantial part of the common market, see Case 226/84, British Leyland, [1986]; Case 127/73, BRT II, [1974]; Case 26/75, General Motors, [1975].

${ }_{1303}$ Jones A. / Sufrin B., (2004), 268.

1304 See Joined Cases 40 to $48 / 73,50 / 73,54$ to $56 / 73,111 / 73,113$ and 114/73, Suiker Unie, [1975]. 
within the Member State concerned has to be assessed, especially where they are organised and regulated locally tather than nationally. It can be assumed though that even locally restricted professional regulation generally concerns a substantial part of the common market. The purpose of this requirement is to exclude from the scope of Article $82 \mathrm{EC}$ the purely localised monopoly situations in which there is no Community interest. Together with the necessity that the abuse of a dominant position has an effect on trade between Member States ${ }^{1305}$, the requirement determines the limit of the Community jutisdiction. ${ }^{1306}$ For brevity reference is being made to Chapter 3.II.

II. The competition related concept of abuse and its meaning in relation to professional self-regulation

Heretofore this chapter has discussed under which conditions a number of undertakings may be regatded as dominant in their collectivity. While a position of (joint) dominance is a conditio sine qua non for the application of Article $82 \mathrm{EC}$, it is as such not constituent for an infringement thereof. Dominance may in fact be the proof of the economic success of the most quality and cost efficient firm(s). Therefore, despite competition law being concerned about market power, only the abuse thereof warrants intervention under Article $82 \mathrm{EC} .{ }^{1307}$ The substantive element of abuse necessarily is conduct related ${ }^{1308}$ and in a situation of collective dominance it is therefore necessary to ask whose behaviour expresses a possible abuse of the collective dominance. Section II.1. formulates this question more specifically for the case of self-regulatory professions: does the conduct associated with an abuse of joint dominance originate with the representative body adopting self-regulatory measures, with the profession's members who obey to those rules in the exercise of their professional activities, or with a combination of both? Subsequently, section II.2. will explain the substance of the concept of abuse and apply it to various forms of professional selfregulations. In particular the question will be addressed whether and to what extent the assessment of professional rules can be based on the substantive categories of abusive conduct by single-firms. Section II.3. will then turn to the question of justification grounds. While the wording of Article $82 \mathrm{EC}$ - differently from Article 81(3) EC - does not provide for such grounds, the case law allows dominant undertakings to demonstrate that some behaviour does not qualify as abusive, and thus is not prohibited, where it is objectively justified based on the principle of proportionality.

\footnotetext{
1305 Purely hypothetical or speculative effects that the conduct of an undertaking in a dominant position may have do not satisfy that criterion, Case C-49/07, MOTOE, [2008], para. 39.

${ }^{1306}$ Jones A. / Sufrin B., (2004), $267 \mathrm{f.}$

1307 The approach under the concentration control law is, however, different in that itaims to prevent the creation of dominance that if allowed, would facilitate subsequent abusive behaviour. Under that regime a dominant position need not be existent prior to the concentration and an abuse need not to take place through the concentration.

${ }^{1308}$ Case 85/76, Hoffmann-La Roche, [1979], para. 91: "The concept of abuse is an objective concept relating to the behaviour of an undertaking in a dominant position...". For collective dominance sce Joined Cases C-395/96 $\mathrm{P}$ and C-396/96 P, CMB (Cenval) II, [2000], paras. $37 \mathrm{f}$. At this point of the legal scrutiny Article 82 EC differs from Article 81 (1) EC. In respect of the latter the conduct (agreement, concerted practice, decision) still concerns the jurisdictional scope of the article. Consequently, the competition related assessment under Article 81(1) EC can be conducted irrespective of the form that the 'meeting of the minds' takes.
} 
1. Joint or individual manifestation of collective dominance: 'collective abuse' versus 'abuse by proxy'

It has been demonstrated in Chapter 4 that self-regulatory rules of conduct influence the economic activities of professionals. Here the question is, however, which conduct is apt of constituting an abuse: the economic conduct of the members of a profession that conform to the professional rules? Or the regulatory activity of the professional association itself? The Raad van State in Wouters formulated in its request for a preliminary ruling to the ECJ:

"If ... it must be held that an institution such as the Bar of the Nethetlands enjoys a [collective] dominant position, does such an institution abuse that position if it regulates the relationships between its members and others on the market in legal services in a manner which restricts competition?"'1309

I have altered the original formulation to include the word 'collective' for two reasons. First of all, it shall be recalled that a professional association itself does not qualify as an undertaking under EC competition law for want of an economic activity of its own. This means that it cannot occupy a dominant position of its own and eventually abuse it. As explained above the CFI in Piau has found a convincing way to nevertheless bring collective bodies within the scope of Article $82 \mathrm{EC}$. On a second score the 'reformulation' sets off what secms to be a conundrum: can a single entity abuse a position that a collectivity holds by imposing measures that relate to, but are autonomous of, the economic activity of its members?

While Advocate General Léger in Wouters explicitly refers to the behaviour of the professionals ${ }^{1310}$, the CFI in Piau was inclined to consider an abuse stemming from the regulations that the FIFA had adopted. ${ }^{1311}$ On the mexits both Advocate General Léger and the CFI did not conclude on an abuse, but did so for different reasons. The Advocate General considered that the case file did not contain the matters of law and fact necessary to assess the point. ${ }^{1312}$ The CFI, on the other hand, did not deem it necessary to give a strict reply on the abusiveness of the regulations of the FIFA since, according to the Court, the measures were in any event justified for considerations that the Commission had taken into account in respect of its assessment of an exemption under Article 81(3) EC. Despite the remarkableness of this solution ${ }^{1313}$ the crucial point here is that in Piau the Court was prepared to consider that the regulations adopted by the emanation of the collectivity constitute the relevant behaviour in assessing the concept of abuse by a dominant collectivity. Since the tespective point of teference (i.e. in the opinion of the Advocate General and the judgment of the CFI) concern actions of two different types of actors the question arises whether either action fits the concept of abuse of collective dominance.

${ }^{1309}$ See Case C-309/99, Whouters et al. v NOvA, [2002], para. 39.

${ }_{1310}$ AG Léger in Case C-309/99, Wouters et al. v NOvA, [2002], para. 152: "it could be necessary to consider whether the conduct of the members of the profession constitutes an abuse of a collective dominant position within the meaning of Article [82 EC]".

1311 Case T-193/02, Piau I, [2005], para. 117.

${ }_{312}$ Para. 153 of his opinion in Wouters. However, before drawing that conclusion AG Léger had listed in a programmatic way all conditions that the conduct of the members of a profession need to be subjected to in order to assess their behaviour under Article 82 EC. He did however not specify which conduct of the professionals he would have scrutinised if he had felt that the file contained "the matters of law and fact necessary to that end": the professional activity proper, the implementation or rather application of the professional rules by the members, or the adoption of the professional rules adopted by the practitioners' representatives (i.e. the reason why professional regulations qualify as a decision of an association under Art. 81(1) rather than an agreement between undertakings).

${ }_{1313}$ Case T-193/02, Piau I, [2005], para. 119. For details see below section II.3. and Chapter 7.I. 
The answer is to be found in Irish Sugar where the Court held that the situation of a collective dominant position does not require a likewise collective abuse by all undertakings in order to conclude on a breach of Article $82 \mathrm{EC}$. "Whilst the existence of a joint dominant position may be deduced from the position which the economic entities concerned together hold on the market in question, the abuse does not necessarily have to be the action of all the undertakings in question." 1314 This first of all indicates that the approach of Advocate General Léger in Wouters is a conceivable, but also the strictest approach in identifying the relevant conduct of a dominant collectivity. The ruling in Irish Sugar stressed that also other forms of action may constitute an abuse if they can be attributed to the dominant collectivity.

"[The abuse] only has to be capable of being identified as one of the manifestations of such a joint dominant position being held. Therefore, undertakings occupying a joint dominant position may engage in joint or individual abusive conduct. It is enough for that abusive conduct to relate to the exploitation of the joint dominant position which the undertakings hold in the market." 315

In applying the ensuing concept of a joint or individual manifestation of the collective dominance to the field of the professions it is conceivable to scrutinise both the behaviour of the collectivity of a profession as well as the behaviour of the individual members of the profession. The approach intimated by Advocate General Léger requires to vetify whether the members of a profession individually or collectively abuse the dominant position that their professional association represents. Conversely, the approach of the CFI in Piau triggers the question whether the case law in Irish Sugar can be understood to also cover 'individual' acts engaged in by the representative body, which is not itself a member of the collectively dominant group but, as the Court in Pian put it, is its emanation. The respective activities differ from each other in nature. On the one hand, we are confronted with a possible abuse through the (individual or collective, but above all) economic activities of individual members. On the other, there may be an abuse through the regulatory and/ or supervisory activities of their representative body. Put differently, it is conceivable that the relevant conduct can be identified with the collectivity as such and thus amount to a 'collective abuse'. Alternatively, it is conceivable that either a single member ot the professional body may represent an abuse by the collectivity, therewith leading to an 'abuse by proxy'.

My suggestion is that either conduct is a necessary ingredient in the scrutiny of a possible abuse by a collectively dominant profession, and that they are inherently related with each other. The point can be illustrated with reference to the case Cewal I. In that case the Commission and the Court considered the implementation of an agreement that Cewal (a liner conference with three members ${ }^{1316}$ ) had concluded with a third party (Ogefrem). In its decision the Court indifferently spoke of, first of all, the unilateral conduct on the part of Cewal, the cooperation agreement concluded between Cewal and Ogefrem, Cewal's attitude in implementing the agreement and, secondly, the dominant position occupied by the members of Cewal, and the members of Cewal infringing Article $82 \mathrm{EC}^{1317}$ Therewith, the Court intimated that the actions of the organisation (i.e. the implementation of the agreement concluded by Cewal) is congruent with the conduct of its members. The abusive behaviour

1314 Case T-228/97, Irish Sugar I, [1999], para. 66; Joined Cases T-191/98 and T-212/98 to T-214/98, TACA, [2003], para. 633. Sec also European Commission, D G Competition discussion paper on exclusionary abuses, of 12/2005, para. 74.

${ }_{1315}$ Case T-228/97, Irish Sugar I, [1999], para. 66 (cmphasis added). Case C-497/99 P, Irish Sugar II, [2001]. Whish R., (2003), 529. Monti G., (2001), 141 ff.

1316 See above note 1273 .

1317 Joined Cases T-24 to 26/93 and 28/93, CMB (Cewal) I, [1996], paras. 102 f., 105 ff. 
on the part of the organisation thus is the abuse of its members and vice versa.

The same idea of congruency can be illustrated for the field of the self-regulated professions. The regulatory activity of the professional association that may bear an abusive effect on the professional services market ${ }^{1318}$ is meaningless in terms of Article $82 \mathrm{EC}$ if there are no members that apply and implement the self-regulatory measures. No (actual or potential) abusive effects could accrue from professional regulations without individual practitioners applying them. This means that the adoption of self-regulatory rules as such is not a sufficient manifestation of a joint dominant position. Conversely, the behaviour of the individual members of a profession cannot be considered to be abusive in the absence of some sort of collective organisation. This follows from the consideration that otherwise the group would not qualify the definition of collective dominance in the first place. ${ }^{1319}$ In summary, it is not meaningful to assess the abusiveness of either the individual members' conduct or the professional association's conduct without having regard to the behaviour of the othet side.

One must, however, be careful not to reuse the same facts in establishing, first, the existence of a joint dominant position and, second, its abusive exploitation. Establishing collective dominance and an abuse thereof would otherwise be the same operation and lead to the fallacy that an abuse would actually not need to be established anymore. The obligation not to merely 'recycle' the facts that allow to prove the existence of collective dominance is respected where the factors that are drawn on to establish the necessaty connecting factors between the entities are not at the same time regarded as an abuse in themselves. ${ }^{1320}$ This means that the connecting factors between the professionals (i.e. the collective organisation in a professional association and the adoption and implementation of professional self-regulation) may not as such be regarded as constituting an abuse.

At this juncture the risk of recycling is rather apparent though. The abusive character of a certain behaviour does not so much stem from the fact that a collectivity acts and manifests joint dominance, but from the content of any such action. The substance of professional self-regulation, however, will be scrutinised only below. What is important here is that the exercise of a professional activity is determined by self-regulatory professional obligations. Where compliance with those rules may not be spontaneous, professional association more often than not have the possibility to take supervisory and/ or disciplinary measures against practitioners. Whether spontaneous or reinforced, only the actual implementation of professional rules through individual behaviour may produce effects in the professional services market. ${ }^{1321}$ Therefore, a meaningful manifestation of a joint dominant position

1318 For details see below section II.2.2.

1319 In which case Article 81(1) EC rather than Article $82 \mathrm{EC}$ is the applicablc provision. Compare also Jones A. / Sufrin B., (2004), 256, who point out that the questions whether an undertaking is in a dominant position and whether it has committed an abuse may be interrelated and intertwined.

1320 Case T-228/97, Irish SugarI, [1999], para. 67. See also Joined Cases T-68 to 77 and 78/89, Italian Flat Glass, [1992], para. 360; Joined Cases T-68 to 77 and 78/89, Italian Flat Glass, [1992], para. 360; Joined Cases T-24 to 26/93 and 28/93, CMB (Cewal) I, [1996], para. 67.

1321 In Case T-193/02, Piau I, [2005], para. 118, the Court considered an alternative claim of abuse of a collective dominant position. The plaintiff had claimed that an abuse not only had been committed by the FIFA, but also by the collectivity of the players' agents that had indeed managed to be licensed by the FIFA. Although the licensed players' agents are no members of the FIFA themselves, they are affected by the rules that the FIFA adopted with regard to the exercise of their profession. The conceivable abusive behaviour on the part of the licensed agents could have been the fact that they followed suit to the FIFA rules if the latter's implementation resulted in a strengthening of the licensed agents position in the market. However, no such abuse could be established as the Court felt that no collective dominance of the licensed agents had been demonstrated in the 
requires both professional self-regulations and professional conduct by individual members that obey those regulations. It follows from Cewal that the respective actions are necessarily complementary. In accordance with Irish Sugar the ensuing manifestation by proxy is sufficient and it is not necessary that all members collectively follow suit. Consequently, the lack of regulatory and supervisory activities on the side of the individual members of a profession may be 'compensated' by the fact that possible restrictions in the market are based on self-regulatory measures. In other words, these measures represent the manifestation of a dominant position that can be ascribed to the profession's members as the direct addressees of Article $82 \mathrm{EC}$.

In this sense it is innocuous that the factors drawn on to establish both the existence and the manifestation of a collective dominance converge. Conversely, whether the adoption and implementation of professional self-regulation is abusive on substance depends on the content of the regulation, and in particular whether it is the means to use the joint economic power of a profession to the detriment of customers, consumers and competitors. These issues are dealt with hereafter.

\section{Abuse of a collective position}

This section will first introduce more fully the interpretation that the case law has given the concept of abuse. It then will turn to illustrate its application in the context of professional self-tegulation.

\subsection{The concept of abuse: Special responsibility of the dominant entity}

Article $82 \mathrm{EC}$ does not itself define the concept of 'abuse', but lists particularly grave examples thereof in a non-exhaustive manner. According to the Court the concept is an objective one that relates to the behaviour of dominant undertakings. ${ }^{1322}$ The question of what behaviour constitutes an abuse of economic power depends on the assessment of the facts of the individual case and is closely linked with the diagnosis of dominance on a market. This means that some behaviour may be deemed competitive, or at least neutral, when engaged in by non-dominant undertakings, while being classified as abusive when engaged in by dominant undertakings. Dominant and non-dominant firms are thus in crucially different positions. ${ }^{1323}$ In consequence the abusiveness of a certain conduct cannot be established by simple classifications of a firm's behaviour. Rather the determination of what amounts to an abusive behaviour is a policy decision with a significant impact on the interpretation of the concept of abuse. ${ }^{1324}$ The "main and ultimate objective of Article 82 is

first place, and in particular it considered that no structural links were present between these agents. The reason for this outcome lies in the fact that the licensed agents have not been organised in a collective association and did not themselves adopt the challenged provisions, neither among themselves nor by a representative body. In order to still conclude on their collective dominant position in the absence of a professional association of the agents, Mr Piau would have needed to demonstrate that the FIFA, by regulating the exercisc of the licensed agents, had acted in the interest of and to a certain extent on demand of the licensed agents in regulating the exercise of their activities. Only then might the Court have felt prepared to recognise that sufficient links existed between the licensed agents, as it had with regard to the FIFA and its members, the football clubs and associations. See also note 1402 .

${ }^{1322}$ See above note 1308.

1323 Bavasso A., (2005), 617. Jones A. / Sufrin B., (2004), 258. See also Hawk B.E., (1990), $788 \mathrm{f}$.

1324 Jones A. / Sufrin B., (2004), 253. 
to protect consumers, and this does, of course require the protection of an undistorted competitive process on the matket." ${ }^{\text {1325 }}$

The behaviout of dominant firms is treated differently from that of non-dominant undertakings because the former have a special responsibility toward the competitive process on the market, i.e. towards consumers. ${ }^{1326}$ This implies also the prohibition of certain abusive behaviour that is practised vis-à-vis customers and competitors.

"[It] has been consistently held that Article $[82 \mathrm{EC}]$ imposes on an undertaking in a dominant position, irrespective of the reasons for which it has such a dominant position, a special responsibility not to allow its conduct to impair genuine undistorted competition on the common market. Thus Article [82 EC] covers all conduct of an undertaking in a dominant position which is such as to binder the maintenance or the growth of the degree of competition still existing in a market where, as a result of the very presence of that undertaking, competition is weakened."1327

The reason for the notion of special responsibility is an obvious one: it is the dominance that, first of all, has already weakened the degree of competition on the televant market (less competitive forces are present), and which, secondly, transfers the ability to cause (further) detrimental effects to competition. ${ }^{1328}$ The notion of special responsibility suggests that dominant firms are subject to a positive duty ${ }^{1329}$, namely to respect the competitive process. ${ }^{1330}$ This duty is determined by the corresponding negative obligation to abstain from behaviour that is considered to be abusive ${ }^{1331}$, i.e. detrimental to "genuine undistorted competition". In determining which conduct is detrimental in a situation of dominance the substantive test for the concept of abuse commonly resolves into the two categories of exploitative and exclusionary conduct. ${ }^{1332}$

First of all, the negative obligation to abstain from competition impairing conduct requires a dominant entity not to use its market power instrumentally, i.e. as the means for the exploitation of customers and consumers, for example by charging excessive prices. Furthermore, the positive duty ensuing from the case law implies that dominant undertakings have a special responsibility regardless of whether they actually use their economic strength. This imports that an instrumental use of market power constitutes only one perceivable form of abuse. Dominant undertakings impair genuine undistorted competition also where they interfere with the competition structure of a market. Often they do so through the exclusion of competitors (hence the name of the second category). ${ }^{133}$ The substantive distinction between the two types of abusive behaviour is also reflected in the non-exhaustive list of

${ }^{1325}$ Kroes N. (Competition Policy Commissioner), "Preliminary Thoughts on Policy Review of Article 82", (23.09.2005) SPEECH/05/537, 3.

${ }_{1326}$ Case 322/81, Michelin I, [1983], para. 57; Case T-228/97, Irish Sugar I, [1999], para. 112. See also Jones A. / Sufrin B., (2004), 279. Bavasso A., (2005), 616.

${ }^{1327}$ Emphasis added, Joined Cases T-24 to 26/93 and 28/93, CMB (Cewal) I, [1996], para. 106. Case T-83/91, Tetra Pak II, [1994], para. 114.

1328 Case 27/76, United Brands, [1978], para. 65.

${ }^{1329}$ Jones A. / Sufrin B., (2004), 280.

1330 See also Bavasso A., (2005), 619, who summarises the positive obligation as "a special responsibility to maintain an efficient competition that would have a positive impact on consumer welfare" (emphasis in the original). For details on efficiency arguments see below section II.3.3.

1331 Bavasso A., (2005), $617 \mathrm{f}$.

1332 On the distinction in exploitative and exclusionary (or anti-competitive) abuses see Commission Decision P \& I Clubs, (1999), paras. 127-136. Goyder D.G., (2003), 283; Whish R., (2003), 194 f. See also Ritter L., et al., (2000), 352 f.; Faull J. / Nikpay A. (Eds.), (2007), para. 4.142.

${ }_{1333}$ Abusive behaviour that leads to the reduction of the competitive forces in a dominated market are referred to as either exclusionary, market structure or anti-competitive abuses. In this context the term of anti-competitive abuse thus refers specifically to behaviour that is directed against a competitor. 
prohibited forms of behaviour in Article $82 \mathrm{EC}^{1334}$ and in the case law of Hoffmann-La Roche. To determine the substantive test by means of the bifurcated distinction that case law refers first to "methods different from those wbich condition normal competition in products or services on the basis of the transactions of commercial operators" (instrumental use), and second to "behaviour of an undertaking in a dominant position which is such as to influence the structure of a markel" (market structure abuse). ${ }^{1335}$

In 2005 the Commission statted conducting an internal review on the application of Article $82 \mathrm{EC}$. The purpose of the internal review of its policy under Article $82 \mathrm{EC}$ is to "evaluate policy, to assess how it could be made more effective, and to define ways in which we might make it more transparent" and hence to design a clear policy on the substantive interpretation of Article $82 \mathrm{EC} .{ }^{1336}$ The review became particularly necessary in light of the modernisation of competition law with Regulation 1/2003 tendering all NCAs competent to fully apply Article $82 \mathrm{EC}$ in parallel to the Commission's competences. The aim of the exercise is to set out in a clear and consistent manner theories of harm underlying the application of Article $82 \mathrm{EC}$ in order to develop practical and workable rules which take in to account the reality on the market. The Commission therefore is determined to base itself on a sound economic assessment. Moreover, it intends to set out a methodology for the assessment of some of the most common exclusionary practices. ${ }^{1337}$ The Commissions focus is currently on exclusionary conduct since it is the more important category in practice. Conversely, exploitative abuses and other instrumental use of market power will be the subject of future work by the Commission.

The theoretical background of the two categories of abuse will be dealt with in sections 2.1.1. and 2.1.2. respectively before applying them to the case of the liberal professions in section 2.2. A clear categorisation between the two forms of abuses does not mean, however, that they could not occur simultaneously. Market structure abuses may result

${ }^{1334}$ See Case 6/72, Continental Can, [1973], para. 26: "The provision states a certain number of abusive practices which it prohibits. The list merely gives examples, not an exhaustive enumeration of the sort of abuses of a dominant position prohibited by the Treaty. As may further be seen from letters (c) and (d) of Article [82 (2)], the provision is not only aimed atpractices which may cause damage to consumers directly, but also at those which are detrimental to them through their impact on an effective competition structure, such as is mentioned in Article $[3(1)(\mathrm{g}) \mathrm{EC}$. Abuse may therefore occur if an undertaking in a dominant position strengthens such position in such a way that the degree of dominance reached substantially fetters competition, i.c. that only undertakings remain in the market whose behaviour depends on the dominant one" (emphasis added).

${ }^{1335}$ Case 85/76, Hoffmann-La Roche, [1979], para. 91 (emphasis added). The two categories of abuse are not mutually exclusive and at times it has been suggested that there is a third category of 'reprisal abuses'. Those are specifically aimed at another firm and are made in response to behaviour of that other, see Temple LangJ., (1979), $363 \mathrm{f}$. Even another category can be distinguished which is concerned with practices that are considered to be detrimental to the single market, and which may concern both exploitative and exclusive (or anti-competitive) abuses, Whish R., (2003), 195, 207.

${ }^{1336}$ Lowe P. (Director General of DG Comp), "Speech at 30th Annual Conference on International Antitrust Law and Policy", (23.10.2003).

${ }^{1337}$ Such as tying, rebates and discounts. The most recent document is European Commission, Guidance on exclusionary conduct, of 09.02.2009, which however does not relate to conduct of collective dominance. The review is, however, also relevant for the exploitative conduct in that it addresses whether efficiency arguments by dominant players should be taken into account under Article $82 \mathrm{EC}$ in order to justify prima facie abusive behaviour, European Commission,"Article 82 Review", (2006). As Lowe P. (Director Gencral of DG Comp), "Speech at 30th Annual Conference on International Antitrust Law and Policy", (23.10.2003), 6, stressed two years before the review objective justification considerations can apply to any type of prima facie abusive conduct, whether in the form of exclusion or instrumental use of market power. For details on objective justification sec below section $\Pi 1.3$. 
in an instrumental use of market power, and both types may be used in combination. Incidentally, the exclusion of competitors is often at the basis of later exploitation of customers. ${ }^{1338}$

\subsubsection{Instrumental use of market power (exploitation)}

The first category of abusive behaviour concerns business practices that allow undertakings to employ their dominant market power in an instrumental manner to achieve a certain commercial aim. ${ }^{1339}$ This means that they exploit their dominant position vis-à-vis consumers or customers and, as the case may be, also vis-à-vis their competitors. For instance, conduct that imposes, directly or indirectly, unfair purchase or selling prices (like excessive, discriminatory and selective prices) or unreasonable terms and conditions directly aimed against customers and consumers, but also behaviour like the limitation of production, markets or technical development, constitute typical instrumental use of economic power. ${ }^{1340}$ They are considered to be particularly harmful for the trading partners of the dominant undertakings without it being necessary to look in to their actual effects.

In prohibiting the instrumental use of market power Article $82 \mathrm{EC}$ lays down a policy decision that is not strictly prompted by considerations of a mere economic character. This follows from the reverse of the following thought. A dominant undertaking can exploit its customers for a significant period of time only if the matket is not functioning. Conversely, the ability to reap supra-competition profits by, for instance, charging excessive prices should, in theory, act as a spur to attract new competitors on the market and constrain the dominant undertaking to return to competitive prices. It is in this perspective that it would not strictly be necessary to prohibit exploitative conduct to protect consumers. ${ }^{1341}$ However, "the [EEC] Founding Fathers' faith in competition as a process of tivalry between competitors was not strong enough to tolerate customer exploitation in the short run". 1342 Therewith, the prohibition of exploitative, or instrumental, use of dominance also contributes to the ordo-liberal idea that the economic liberties of parties should not be thwarted by the fact that they are being arbitrarily patronised by a dominant player in the relevant market. Moreover, the prohibition of instrumental abuses of market power makes an important contribution to safeguard the aim of EC competition law, which is to prevent undertakings from reducing the welfare of the final consumer of the products or services in question. ${ }^{1343}$

The instrumental use of economic power thus means that dominant undertakings exploit the fact that competition is weakened as a result of their very presence. ${ }^{1344}$ Strictly exploitative abuses describe an improper use of market power to the direct detriment of customers or suppliers. The abuse lies in the 'vertical' conduct to exploit the consumers' or customers' dependence on the dominant incumbent. Beyond this strict meaning the concept of instrumental use of market power also covers more generally conduct that itself distorts

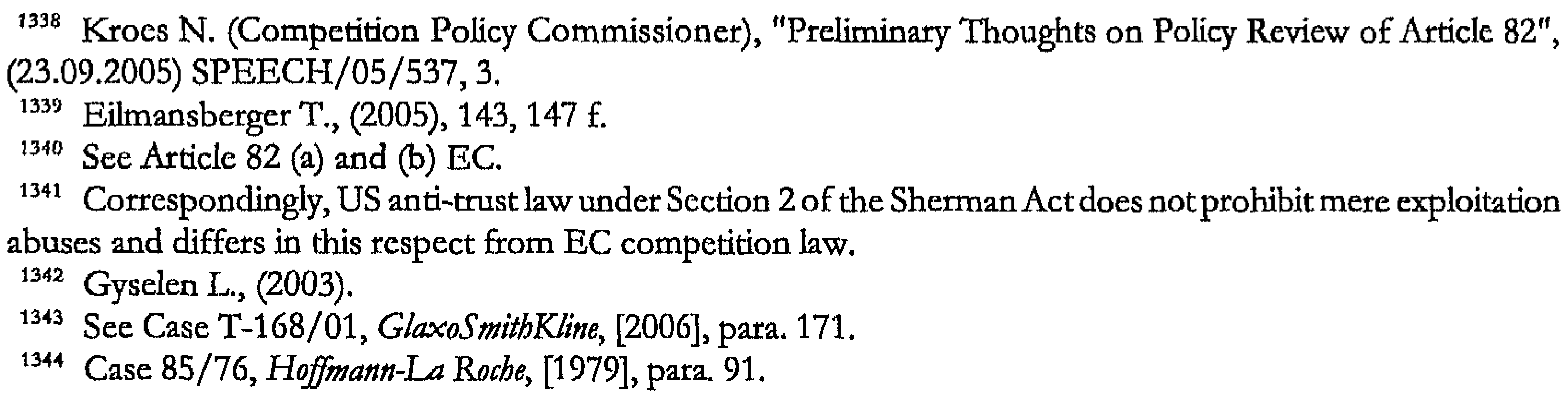


competition through market power. In other words, the concept covers behaviour with which the dominant firm is trying to achieve an otherwise legitimate commercial goal (to win customers or to capture markets, which boosts its market power) however, by unacceptable means. ${ }^{1345}$

The central abusive element is the use of dominance, i.e. market power, instead of superior business performance to achieve success on a market. ${ }^{1346}$ This inherently triggers a certain causality between dominance and (abusive) behaviour. ${ }^{1347}$ In this regard dominance is a necessary precondition for the abusive behaviour to take place under the category of instrumental use of market power. The point of causality does, however, not go any further. In particular, no causality needs to be established between the dominance and any actual effect of the behaviour on consumers, customers or the competitive structures of the market. ${ }^{1348}$ Rather the injurious nature of the instrumental use of economic power can be based on the conduct's natural and foreseeable consequences to directly cause harm on the side of customers and consumers (and possibly competitors). ${ }^{1349}$ The presumption that exploitative behaviour directly prejudices the interests of the party dependent on the dominant undertaking has three consequences.

First of all, no hatm ful effect on the structure of competition needs to be demonstrated. Secondly, it is commonly derived from the Court's reference to the concept of abuse as being an objective one that no subjective intention to abuse dominance needs to be demonstrated in a concrete case ${ }^{1350}$; rather such an intention is to be presumed. ${ }^{1351}$ This means that an instrumental use of economic power can be said to have the object to arbitratily exploit the dominance to the direct detriment of the dependent party and to hinder the maintenance or the growth of the degree of competition still existing in the relevant market. ${ }^{1352}$ The first category of exploitative behaviour thus constitutes an 'abuse in its own right' and is abusive as such. Thirdly, no advantage, either financial or competitive, needs to occur on the side of the dominant undertakings that would correspond to the harm

1345 Eilmansberger T., (2005), 143, 147 f.; AG Kirschner in Case T-51/89, Tetra Pak II, [1990], 67.

1346 "The leveraging of market-power clcarly is a dominance-specific distortion of competition and should be prohibited per se under Article 82 EC," Eilmansberger T., (2005), 152.

${ }_{1347}$ Case C-333/94 P, Tetra Pak III, [1996], para. 27: the "application of Article [82. EC] presupposes a link between the dominant position and the alleged abusive conduct". Case T-228/97, Irish Sugar I, [1999], para. 66: the abuse "has to be capable of being identified as one of the manifestations of such a joint dominant position". The distinction to be drawn in respect of the required causal link is that Article $82 \mathrm{BC}$ prohibits the abuse of a dominant position (thus requiring a certain causal link between the abuse and dominance on a particular market); it does, however, not prohibit abusive behaviour as such, i.e. either by a non-dominant firm or by a firm that is dominant on a different market not related to the one on which the abusive behaviour occurs. See also Eilmansberger, below in note 1358. See also Jones A. / Sufrin B., (2004), 278. - Partly mistakable on the point of causality Ritter L., et al., (2000), 354.

${ }^{1348}$ See also Niels G. / Jenkins H., (2005), 609, who suggest that it would be desirable to revisit the principle of the case Hoffmann-La Roche to the effect that there actually does not have to be a link between dominance and abuse.

${ }_{1349}$ See Commission Decision Football World Cap 1998, (2000), para, 100.

1350 Whish R., (2003), 194; Roth P.M., (2001), 218; Ritter L., et al., (2000), 355; Faull J. / Nikpay A. (Eds.), (2007), paras. 4.148 ff.; Gyselen L., (2003), para. 17

${ }_{1351}$ Compare also with the explanation in Chapter 4.II.1.1. on the restrictions by object under Article 81(1) EC. See also Eilmansberger T., (2005), 142 f., 148.

${ }_{1352}$ See the affirmative statement in Case 85/76, Hoffmann-La Roche, [1979], para. 91, at the end: "Behaviour ... which [is exploitative] through recourse to methods different from those which condition normal competition in products or services, bas the effect of hindering the maintenance of the degree of competition still existing in the market or the growth of that competition" (emphasis added). 
caused to customers and consumers (and possibly competitors as the case may be). This means that even in the absence of any gain on the side of the dominant undertakings, the instrumental use of market power can be properly prohibited ${ }^{1353}$, the teason being that the dominant firm's behaviour directly prejudices the interests of customers and consumers.

In the following a last explanation on exploitative behaviour shall be given in respect of a specific type of situation. As pointed out before strict economic logic does not generally require the prohibition of exploitative and instrumental conduct by dominant entities. That assessment is, however, reduced in cases of legal monopoly rights. In that instance the market is organised such that the monopoly cannot be challenged by competitors and potential market entrants. Since that market consequently is not subject to the stress of competitive, the intervention of competition law to control unilateral behaviour is particularly justified.

The following case may illustrate the point. In 1999 the Commission fined the French body organising the World Cup 1998 for the fact that it had applied different prices depending on whether the purchaser had a postal address in France or not. ${ }^{1354}$ In the absence of competition between the buyers of the tickets the imposition of dissimilar prices did not properly so distort downstream competition, and thus, in accordance with economic theory, the case would not have required the imposition of a fine. Furthermore, the organisation had not gained any commercial or other advantage from its actions. In that event the imposition of a fine, at least at first sight, does not appear to be consistent. However, the analysis cannot be content with such a conclusion. Rather the case must be identified as a typical example for an abuse of economic strength in the form of arbitrary behaviour. In particular, the organising body was able to reap the benefits of the fact that no other (potential) competitor was allowed to sell tickets for the World Cup. It thus did not need to fear competition from other ticket sellers offering tickets at a lower price, which would have diverted buyers to the latter. Accordingly, the Commission concluded that the imposition of the discriminatory prices had resulted in a limitation of the market to the prejudice of the consumers outside France. $^{1355}$

Markets in which a dominant position is effectively protected by statutory rights excluding potential competitors from the provision of the relevant services are particularly vulnerable to arbitrary conduct by the dominant incumbent. This holds true also for situations of collective dominance. Not only that the legally protected monopoly cannot be challenged by competitors, also the members of the collectively dominant group will not imperil it. This particular point will come back further below (section 2.2.1.) in respect of the legal monopoly tights that the (liberal) professions regularly enjoy to exercise certain

${ }^{1353}$ See Commission Decision Football World Cup 1998, (2000), para. 102. Jones A. / Sufrin B., (2004), 277. See also Niels G. / Jenkins H., (2005), 608.

1354 Commission Decision Football World Cup 1998, (2000).

1355 The fine imposed by the Commission (EUR 1000) had a mere symbolic calibre despite the fact that the discriminatory arrangement concerned the sale of 393200 tickets (through Pass France 98) and 181000 tickets relating to the opening match, quarter and semi-finals, third and fourth-place play-off and the final. The Commission imposed a symbolic fine only because "the issues raised in relation to the application of EC competition rules are of such a specific nature as not to enable conclusions to be easily drawn from previous Commission decisions or case-law of the Court of Justice" and that therefore the organiser of the World Cup had not, at the time, been aware that its sales arrangements were in breach of Community law. Furthermore, on the request of the Commission the organiser had amended its sales arrangements in order to give consumers throughout the EEA the chance to reserve 175500 individual entry tickets, Commission Decision Football World Cup 1998, (2000), paras. $121 \mathrm{ff}$. 
professional activities. Furthermore, it will be scrutinised whether, even in the absence of legal monopoly rights, the situation of collective dominance can be analysed in terms of instrumental conduct. ${ }^{1356}$

\subsubsection{Market structure abuses: connecting likely effects and intent (exclusion)}

Since a dominated matket is alteady weakened due to the very presence of a dominant undertaking or collectivity, a further reduction of competitive forces can lead to less choices for the ultimate consumer in terms of providers and quantity, quality and prices of goods or services. Article $82 \mathrm{EC}$ therefore prohibits business practices that impact the reduced competitive constraints remaining on a dominated market. "The essential objective of Article 82 when analysing exclusionary conduct is the protection of competition on the market as a means of enhancing consumer welfate and of ensuring an efficient allocation of resources." 1357 Examples of market structure, ot exclusionary, abuses are discriminatory pricing, the creation of bartiers to market entry, the weakening of competitors through raising their costs or refusing to deal with them.

However, not any behaviour by a dominant entity that impacts competitive forces and the structure of the market will be prohibited under Article $82 \mathrm{EC}$. For the legal assessment of exclusionary conduct it is not sufficient to cumulatively ascertain dominance and an effect on the competitive constraints that remain in the market. A mere concomitance of dominance and effect would risk to arbitrarily determine the threshold as of which the same type of behaviour is abusive or not, depending on whethet the undertaking or collectivity is dominant or not.

Two conclusions can be drawn from this. First of all, the category of exploitative behaviour does not strictly require a causal link between the economic power associated with dominance and the (presumed) abusive exercise thereof. ${ }^{1358}$ This means that dominance while being a conditio sine qua non for the application of Article $82 \mathrm{EC}^{1359}$ - is not the necessary means to influence the structures of a market. In other words the same conduct influencing the structure of the market may occur under circumstances absent dominance. It will generally be considered as normal and unobjectionable competitive behaviour by nondominant firms. ${ }^{1360}$ Secondly, the effect to influence the structure of a market is not

\footnotetext{
1356 See also Whish R, (2003), 527.

1357 European Commission, DG Competition discussion paper on exclusionary abuses, of $12 / 2005$, para. 54 . See also European Commission, Guidance on exclusionary conduct, of 09.02.2009, para. 5. The document does, however, not cover conduct by collectively dominant entities.

${ }_{1358}$ Sec Case 6/72, Continental Can, [1973], paras. 26 f; Case 85/76, Hoffmann-La Roche, [1979], para. 91; Case 322/81, Micbelin I, [1983], para. 70. Eilmansberger T., (2005), $142 \mathrm{ff}$, observes that in current legal writing there is a near unanimous agreement that a causation requirement does not exist in Article $82 \mathrm{EC}$ and virtually no discussion on the topic anymorc. However, he differentiates that for the category of market structure abuses the Court has dismissed only a rather limited variant of a causation requirement in Article 82. EC, "namely a strictly causal nexus between dominance and abuse where the economic power associated with the dominant position constitutes the instrument for the perpetration of the abuse. The rejection of such a narrow causation concept is of little surprise, as this would indeed exclude most, though not all, important anti-competitive abuses [read: exclusionary abuses, see above note 1333] from the scope of abuse control".

1359 From Case 85/76, Hoffmann-La Roche, [1979], para. 91 follows that where the market is not weakened by the presence of dominance, the same behaviour - even if influencing the structure of the market - is not prohibited as abusive.

${ }^{1360}$ In fact the relevant behaviour may as such be neutral in cconomic terms since it is legitimate for a firm to capture markets, to increase turnover and gain market share. More precisely, and in respect of market structure
} 
necessarily an abuse, even if triggered by a dominant entity. More specifically, "the putpose of Article 82 is not to protect competitors from dominant firms' genuine competition based on factors such as higher quality, novel products, opportune innovation or otherwise better performance". Rather the aim of Article $82 \mathrm{EC}$ is "to ensure that these [non-dominant] competitors are also able to expand in or enter the market and compete therein on the merits, without facing competition conditions which are distorted or impaired by the dominant firm."1361 In short a market structure abuse constitutes the use of an unobjectionable means to achieve a problematic goal, namely the artificial manipulation of the competitive process. ${ }^{1362}$ The prohibition thereof reinforces that Article $82 \mathrm{EC}$ represents a policy decision: dominant undertakings may not entirely act as they please due to their dominance (special responsibility).

Follows the question where to draw the line that distinguishes normal competitive behaviour from illegitimate behaviour. It emerges that in deciding which form of competition Article $82 \mathrm{EC}$ wants to foster and which to prohibit, a further factor is required. The suggestion is a test according to which the relevant conduct is abusive if the dominant

abuses, a condition of causation "would be fulfilled if the dominant position played a decisive role in the practice bringing about the relevant cffect, either because dominance was a conditio sine qua non for that effect to arise [e.g. in the case of price cut], or because it was a sufficient condition, i.e. the effect could also be caused by a normal firm taking such action but in the case of a dominant firm the effect would inevitably arise (c.g. acquisition of key technology of a competitor)", Eilmansberger T., (2005), 143.

${ }^{1361}$ European Commission, DG Competition discussion paperon exclusionary abuses, of $12 / 2005$, para. 54. - This could of course also be understood as "to the detriment of competitors", as indeed on first sight dominant entities will be ablc to prevent competitors to supply their competitive services at a competitive price. For a discussion of the issue, and of the influence of 'ordoliberalism' in the early days of the European Commission, see for instance Whish R, (2003), $19 \mathrm{f}$. Meanwhile the Commission itself has become "mindful that what really matters is protecting an effective competitive process and not simply protecting competitors. This may well mean that competitors who deliver less to consumers in terms of price, choice, quality and innovation will leave the market.", European Commission, Guidance on exclusionary conduct, of 09.02.2009, para. 6. It is appropriate to be that mindful as it is the ultimate consumer who pays the toll by either higher prices, lower quality, inferior priceperformance ratio (c.g. unwanted high quality for an even higher pricc) or limited product and service diversification. See also opinion of AG Kokott in Case C-95/04 P, British Airvays II, [2007], para. 68: "The starting-point here must be the protective purpose of Article $82 \mathrm{EC}$. The provision forms part of a system designed to protect competition within the internal market from distortions (Article 3(1)(g) EC). Accordingly, Article $82 \mathrm{EC}$, like the other competition rules of the Treaty, is not designed only or primarily to protect the immediate interests of individual competitors or consumers, but to protect the structure of the market and thus competition as such (as an institution), which has already been weakened by the presence of the dominant undertaking on the market. In this way, consumers are also indirectly protected. Because where competition as such is damaged, disadvantages for consumers are also to be feared."

${ }^{1362}$ Eilmansberger T., (2005), 143. At p. 149 f. Eilmansberger moreover underlines that the ECJ in Hoffmann-La Rocbe has clarified that "the generation of a certain effect is in itself not abusive, but must be accepted if it is the consequence of normal competition. Even a clear deterioration of the market structure, such as the elimination of a competitor from the market or from a certain segment thereof, must be accepted if this is the mere result of a form of competition which the antitrust regime wants to foster. A prohibition of such conduct would not contribute to the safeguard of a system based on competition on the merits. Instead, it would stifle competition, offer competitors a sort of safe haven against competition on the merits from dominant firms, giving them at the time an opportunity to prevail on the basis of inferior business performance, and would lead to the absurd outcome that business practices which may have helped the company to achieve its dominant position become illegal once the dominance threshold has been surpassed." See also p. 152 f.: "Dominant firms should not be prevented from employing normal commercial techniques merely because they might lead to the exit of one or all competitors, or hinder competitors in their efforts to increase their market share. Dominant firms should also be able to fight and even win." Sceptical in this respect Furse M., (2004). On competition on the merits (Leistungswettbewerb) see also Korah V., (2000), para. 3.3.; Lugard P. / Hancher L. (Eds.), (2005). 
incumbent were to use prima facie neutral practices to intentionally change the market mechanism to its (relative) advantage. In this respect two situations are conceivable. In a first instance the dominant firm or collectivity would use such practice with a view to reducing the competitive pressure exerted by other firms. In a second case the dominant firm or collectivity would seek to make it more difficult for other firms to win customers on the basis of superior performance. Intent is thus the factor that causes normal commercial conduct "to lose its innocent character and metamorphose into non-performance telated and improper behaviour. [...] to use the ECJ's words in Hoffmann-La Roche, [it is] the attempt 'to influence' the structure of the market by means of normal business practices which constitutes the specific non-performance competition caught by Article 82 EC." ${ }^{1363}$ In particular an interpretation of Article $82 \mathrm{EC}$ to generally exclude a requirement of subject intent has been criticised for drawing too far-treaching conclusions in respect of exclusionary conduct. The only safe inference that can be made from the objective character of the concept is that there is no fault requirement under Atticle $82 \mathrm{EC} .{ }^{1364}$ Accordingly, one needs to determine the tespective role and relevance taken by 'intent' to restrict competition and 'effect' of testricting competition in establishing exclusionary abuses.

The subsequent question concerns the yardstick according to which the intention of a dominant incumbent to alter the structure of the market to its advantage can be determined. Intent is often viewed sceptically because of its potential to cover any behaviour. In fact it is safe to say that most businessmen dislike their competitors or for that matter competition ${ }^{1365}$, and it is difficult to dissociate their unobjectionable desire to increase turnover and market share from the animus to defeat competitors. ${ }^{1366}$ Moreover, competition law must not be applied for 'ideological spying' and caution has to be utilised with regatd to the concept of intent. As it is not possible to tead the human mind or the 'mind' of a corporate structure it is necessary to strive for an objectivised concept. ${ }^{1367}$ Since subjective intention cannot be ascertained as a fact it can only be presumed on the basis of objectively petceivable actions of the undertaking(s) in question. Intent has to be objectivised, firstly, because the concept of abuse is an objective one. Furthermore, the scope of Article $82 \mathrm{EC}$ would otherwise be too broad and easily catch any behaviour as abusive that is wished to but does not have the effect of restricting competition, or behaviour that does restrict competition to a certain extent but which is part of rational business operations on the merits (e.g. strategic price cuts based on cost-related factors). It is those actions that allow to conclude with a sufficient degree of plausibility on the intent to impair the competitive constraints remaining on a dominated market. The necessary degree of intent to be proven

1363 Eilmansberger T., (2005), $150 \mathrm{f}$. See also Case 27/76, United Brands, [1978], para. 189; Case 62/86, AKZO Chemie BV v Commission, [1991], paras. $71 \mathrm{ff}$., with regard to selective price cutting (e.g. loyalty rebates, target discounts) and predatory pricing for which the Court has held that an undertaking engaging in pricing its products/ services between average variable and average total cost infringes Article $82 \mathrm{EC}$ if the thus established level of pricing is adopted as part of a plan to eliminate competitors from the market. For these cases it is acknowledged that intent is an integral part of establishing an infringement but at the same time it is stressed that intent is not a key component of the concept of abuse.

${ }_{1364}$ Eilmansberger T., (2005), 146 ff.; Bavasso A., (2005), $119 \mathrm{ff.}$

${ }_{1365}$ Bavasso A., (2005), 618, citing Judge Posner in Supreme Court of the United States (Opinion by Judge Posner) - "Olympia EquipmentLeasing Company and Others v Western Union Telegraph Company" [1986], 797 F.2d 370 (7th Cir. 1986).

${ }_{1366}$ O'Donoghue R., (2006), 34; Andrews P., (1998), 55; Ridyard, (2002), 300. See also Jones A. / Sufrin B., (2004), 280: "The competition authorities look to the effect (actual or potential) of the conduct, not the reason for it."

${ }^{1367}$ See already Chapter 4, sections II.1.1. and II.1.2.2. 
depends on the circumstances of a case and the degree of special tesponsibility that dominant firms have towards the competitive process. ${ }^{1368}$ At this juncture it needs to be stressed once again that the aim of Article $82 \mathrm{EC}$ is not to prohibit the hindrance of competitors, which prima facie may be neutral conduct. Rather the relevant point of reference in determining intent in exclusionary conduct is the envisaged alteration of the competitive mechanism of demand and supply on the market. ${ }^{1369}$ In this respect the hindrance of competitors may metely be the means cmployed.

While the Commission in its review on the application of Article $82 \mathrm{EC}$ does not reason in terms of intent and the presumption thereof, it nevertheless seems to confirm the view proposed here. In its proposed framework for analysis of exclusionary abuses the Commission refers not only to the aim of Article $82 \mathrm{EC}$, but also to "a likely market distorting foreclosure effect" that must be established. ${ }^{1370}$ The Commission thus underlines the importance of assessing the natural and foreseeable effects of the relevant practice in ascertaining its abusiveness in respect of the particular circumstances of the market. Where the relevant conduct is likely to impact the competitive constraints remaining on the dominated market to the detriment of the ultimate consumer (i.e. to reduce choice in terms of suppliers and quantity, quality and price of products or services), it is abusive in the sense of Article 82 EC. Put differently, where the subjective intention of a dominant undertaking or collectivity can be presumed on the basis of the objective circumstances in which the exclusionary conduct is adopted, this is sufficient to prohibit the conduct.

The mechanism of an objective test of intent has been explained in Chapter 4.II.1.1. in respect of 'restrictions by object' under Article 81(1) EC. What has been explained there, and is also relevant here, is the idea that an intent to alter the competitive process to the detriment of the ultimate consumer can be presumed on the basis of the natural and foreseeable effect that certain business practices have. In this it is not necessary to prove actual market distorting foreclosure effects ${ }^{1371}$ since the presence or absence thereof can

${ }^{1368}$ See for instance Case T-83/91, Tetra Pak II, [1994]. Proof of intent can in fact be direct, indirect or circumstantial. See also Eilmansberger 'T., (2005), $171 \mathrm{ff}$.: "Direct proof of the dominant firm's objectives is usually difficult, in particular as internal business documents displaying an aggressive attitude towards competitors in many cases will have only a limited evidential value. In many cases proof of intent will thus have to be indirect. The plaintiff (the public prosecutor or the private claimant in a civil case) has to establish that the practice was not exclusively motivated by normal commercial considerations including, but not restricted to, the aspiration to increase profits or market shares. [The plaintiff] needs to rebut the claim that the practice made economic sense for the firm, irrespective of the deterioration of the market structure it was likely or certain to cause."

${ }^{1369}$ Sec Case 85/76, Hoffmann-La Roche, [1979], para. 91.

1370 European Commission, D G Competition discussion paper on exclusionary abuses, of 12/2005, paras. 54 ff., esp. 58 : The Commission emphasises that the Court's definition of exclusionary abuses "implies that the conduct in question must in the first place have the capability, by its nature, to foreclose competitors from the market. To establish such capability it is in general sufficient to investigate the form and nature of the conduct in question. It secondly implics that, in the specific market context, a likely market distorting effect must be established. By foreclosure is meant that actual or potential competitors are completely or partially denied profitable access to a market. [...] Foreclosure is said to be market distorting if it likely binders the maintenance of the degree of competition still existing in the market or the growth of that competition and thus have as a likely effect that prices will increase or remain at a supracompetitive level" (emphasis added). The objective aim of the conduct is to directly foreclose competitors, see European Commission, DG Competition discussion paper on exclusionary abuses, of 12/2005, para. 81.

1371 European Commission, DG Competition discussion paper on exclusionary abuses, of $12 / 2005$, para. 58. See also para. 55: "Article 82 prohibits exclusionary conduct which produces actual or likely anticompetitive effects in the market and which can harm consumers in a direct or indirect way. The longer the conduct has already been going on, the more weight will in general be given to actual effects. Harm to intermediate buyers is generally presumed to create harm to final consumers. Furthermore, not only short term harm, but also medium and long term harm 
neither confirm nor deny subjective intention. In consequence, the presumption of subjective intention (however objectivised) makes it redundant to rely on the actual effects in the market (e.g. the exclusion of a competitor), which may in fact be nothing else than the result of a perfectly competitive behaviour of the dominant undertaking or collectivity. Consequently, it is not an actual change in market shares or market power that clinches the abuse matter but the attitude of the author of the challenged conduct. ${ }^{1372}$

\section{Interim conclusions}

Consequently, it is suggested here that the objectively traceable intent of the dominant entity is a factor that turns also a market structure abuse into a conduct being prohibited as such. ${ }^{1373}$ In other words, where the relevant conduct objectively supports the presumption that it is motivated by the intent to influence the structure of the relevant market, this connection between the conduct and the natural and foreseeable effect substantiates the finding of an abuse, regardless of whether the effect has already materialised. Only natural and foreseeable negative effects on competition need to be demonstrated. The relevant test for market structure abuses can be formulated as follows: Are negative effects on prices, output, innovation or the variety or quality of goods and services to be expected with a reasonable degree of probability?

In summary, both instrumental and market structure abuses are abusive as such. However, this may not mean an approximation of the respective substantive test of the two categories of abuses. Rather an approximation can be perceived between the respective tests for market structure abuses under Article $82 \mathrm{EC}$ and restrictions by object under Article 81(1) EC. This point can be easily illustrated by reference to price fixing, which is prohibited under Article 81(1) EC for its object to restrict competition. ${ }^{1374}$ It is only consequent to apply the same qualification under Article $82 \mathrm{EC}$ irrespective of whether pricing policies of a dominant undertaking or collectivity finally takes the shape of an instrumental or a market structure abuse. ${ }^{1375}$ A further comparison between the categories of behaviour respectively prohibited under Article $82 \mathrm{EC}$ and Article 81(1) EC reveals that no 'actual effects' based category is targeted under Article $82 \mathrm{EC}$. This can easily be explained by reference to the aim of the article to first of all prevent abusive behaviour. Moreover, the mere effect to alter market structures is not sufficient because it may just as well be the proof of a particularly competitive behaviour in the face of less efficient competitors who happen to be on a dominated market.

From this follows the cognition that exclusionary conduct of a collectivity may just as well be captured under Article 81(1) EC. However, while Article 81(1) EC is concerned to, first, prevent and, second, suppress anti-competitive effects, Article $82 \mathrm{EC}$ includes the policy decision that anti-competitive effects are to be prevented (if not suppressed) only

arising from foreclosure is taken into account" (emphasis added).

${ }^{1372}$ Note that the actual development of the competitors' market shares may be indicative of a foreclosure effect. An increase in the compctitors' market shares is, however, not conclusive for the absence of an abuse as the increase could have been even more marked in the absence of the practice by the dominant entity. Eilmansberger T., (2005), 148, 169. Sec Case T-219/99, British Airvays I, [2003], para. 298.

${ }_{1373}$ This suggestion builds on the view of Eilmansberger that it is the intent to alter the structure of the market by means of normal business practices that represents the specific non-performance competition caught by Article 82 EC, Eilmansberger T., (2005), 146 ff.

1374 For details see Chapter 4.II.2.1.

1375 For illustration see below section II.2.2. 
where economic power is accumulated with "one or more undertakings". In other words, the category of market structure abuses inherently comprises - in the language of Article 81(1) EC - distortions 'by object' and 'by effect' without, however, making an explicit distinction to this effect. ${ }^{1376}$ The crucial point that the present book identifies is that market structure abuses are not so much prohibited for their actual effects (however a fortiori also for those) but for their natural and foreseeable, or necessary, effects. The sophistication is important since it leads to a different allocation of the burden of proof, see Chapter 4.II.1.1. and 4.II.1.2. This does not belittle the import of effect, and indeed "the exercise of matket power must be assessed essentially on the basis of its effects in the market". ${ }^{1377}$ However, the important addition of the view presented in this book is that the prohibition of conduct impacting market structures is built on the natural and foreseeable effects of that conduct. The advantage of this approach is to parallel the legal standards employed under Article 81(1) EC (in respect of object restrictions) and Article $82 \mathrm{EC}$ (in respect of market structure abuses), namely to refer to the objectivised presumption of intent that can be rebutted (see Chapter 4.II.1.). Moreover the approach suggested here meets the concern that the same business practice may be the result of 'normal' competitive conduct based on competition on the merits. ${ }^{1378}$

In summary the added value to scrutinise collective behaviour under Article $82 \mathrm{EC}$ lies in the category of instrumental use of collective market power (exploitation), which - as has been expounded in section II.2.1.1. - does not require the demonstration of intent to prejudice customers and consumers. This type of conduct is not conceptualised under Article 81(1) EC as it is necessarily linked with the existence, or tather the use, of collective dominance. This does, however, not exclude that exploitative conduct of a collectivity may also be scrutinised under Article 81(1) EC. For instance, it will be explained shortly below how the facts in Wouters, which the Court deemed to be restrictive of competition under Article 81(1) EC, also represent exploitative conduct.

Conversely, the advantage of the approach suggested here in respect of exclusionary conduct is to conceptualise the application of Article $82 \mathrm{EC}$ in a way that allows both a predictable, i.e. objectivised, application of Article $82 \mathrm{EC}$ and the safeguarding of the legal position of dominant undertakings. First of all, and as explained in Chapter 4.II.1.1., the legitimacy to presume intent is twofold, namely a preventive argument to avoid distorting effects from occurring and a punitive argument for punishing attempt to influence the structure of the market. ${ }^{1379}$ Secondly, the safeguatd of the legal position of dominant

\footnotetext{
1376 At this point I therefore disagree with Eilmansberger T., (2005), his note 70, who states that market structure abuses "resemble restrictive arrangements under Art. $81 \mathrm{EC}$ which are prohibited because of their effects on the market only."

1377 Kroes N. (Competition Policy Commissioner), "Preliminary Thoughts on Policy Review of Article 82", (23.09.2005) SPEECH/05/537, 2.

${ }^{1378}$ Probably aiming at resolving the same issue, Eilmansberger T., (2005), 144, reflects on a causation requirement with regard to behaviour considered to constitute anti-competitive, or market structure, abuses. " The causation requirement [... defines] more precisely the kind of effect required to trigger Article 82 EC. It excludes all effects which do not require market power, but would at most be somewhat magnified by the dominant position of the firm. Thus, the mere hindrance of competitors, or the seizure of a smaller or larger market share from them, should be considered an irrelevant effect under Article $82 \mathrm{EC}$. The only type of effect requiring dominance, or for which dominance is at least a sufficient condition, is the alteration, or to put it more bluntly, the manipulation of the structure of the market, and the resulting interference with the market mechanism and the conditions under which competition unfolds" (emphasis in the original). See also Case 6/72, Continental Can, [1973], para. 26; Case 85/76, Hoffmann-La Roche, [1979], para. 91.

1379 See also Case 85/76, Hoffmann-La Rache, [1979], para. 91.
} 
undertakings follows from the fact that the presumption of intent, as explained in Chapter 4, can be rebutted where a dominant entity manages to demonstrate that its conduct did not serve the purpose of impairing the competitive process but was motivated by other prevailing motives that evidence an intent not to harm or even to increase the competitive process. ${ }^{1380}$ In summary the appropriate substantive test for abuse of a dominant position depends on the bifurcated distinction between abuses in the form of an instrumental use of market power and market structure abuses.

\subsection{Self-regulated professions abusing of collective dominance}

The following will investigate in how far the dominant collectivity of a profession may be said to have tecourse to exploitative and/ or exclusionary forms of conduct in view of a continuous overall policy of maintaining and strengthening their collective dominance.

\subsubsection{Illustrating exploitative conduct by liberal professions}

In this section a number of self-regulatory measures will be scrutinised for their potential to represent an instrumental use of a hegemonic position of a collectively organised profession. To start with, professional self-regulation will be put to the test of whether it is the translation of exploitative behaviour exercised directly against consumers and customers. Furthermore, this section will scrutinise whether certain types of professional self-regulation are used as an instrument to effectively limit competition to take place and thus are directed against competitors.

\section{Against customers and consumers: pricing}

One example of exploitative abuse is arbitrary pricing. Pricing policies by dominant entities can take different shapes and forms and not all constitute an instrumental use of market power. ${ }^{1381}$ Article 82(a) EC specifically prohibits the imposition of unfair purchase or selling prices, which are a monopoly premium for a dominant entity. Economic theory demonstrates that monopoly prices are likely to be higher than those in competitive markets and are thus excessive. ${ }^{1382}$ Excessive prices are of a particular concern in markets that are characterised by legal (quasi)monopoly. The latter constitutes an entry barrier for new competitors and thus allows the incumbent (quasi)monopolist to impose excessive prices not limited to a short term. In that instance market forces will not be able to compel the

\footnotetext{
${ }^{1380}$ With all possibilities outlined in Chapter 4.II.1.1. and 4.II.1.2., i.e.including the concept of ancillary restraints. This may even accommodate the view expressed by Kroes N. (Competition Policy Commissioner), "Preliminary Thoughts on Policy Review of Article 82", (23.09.2005) SPEECH/05/537, 5, on possible efficiencies of prima facie abusive conduct. Compare also with AG Léger in Case C-309/99, Wouters et al. $\nu$ NOvA, [2002], paras. 147 ff.: "152. In such a situation, it could be necessary to consider whether the conduct of the members of the profession constitutes an abuse of a collective dominant position within the meaning of Article [82 EC] or whether, on the contrary, their conduct is such as to strengthen competition on the market. Then, it might prove useful to establish whether the conduct of the profession may be justified objectively." (emphasis added).

${ }^{1381}$ Pricing conduct can be exploitative or exclusionary in character. For instance excessive pricing, predatory pricing, discriminatory pricing, discount and rebate schemes are exploitative of a dominant position. Moreover, "Abusive pricing policies cannot really be separated from other forms of abuses, such as tying policies or exclusive contracts, since [...] the former are often pursued in furtherance of the latter", Jones A. / Sufrin B., (2004), 379. ${ }^{1382}$ Excessive prices are, according to the Court, unfair prices, see Case 78/70, Deutsche Grammopbon, [1971].
} 
dominant entity to revert to markct prices. Conversely, in markets where the dominant position is not protected by a legal monopoly one may argue that excessive prices (resulting in high profit margins) are in fact a pro-competitive spur for new competitors to enter the market, and thus result only in a short term distortion of the competitive process, thereby raising more competition in the future. The prospect of the opportunity to charge monopoly prices in fact is an incentive for competitors to risk taking and induces innovation and economic growth. ${ }^{1383}$ However, this spur fails to deploy its effect where the barriers to entry for competitors are insurmountable, for instance due to a legal monopoly right to provide certain professional services.

The remuneration of liberal professionals is often regulated by tatiff schemes, and about half of the competition cases decided by the Commission and the Community Courts in the field of professional regulation effectively concerned tariff fixing by professional associations. ${ }^{1384}$ While neither the Court nor the Commission applied Article 82 EC in these cases, the question shall nevertheless be formulated here whether the setting and application of self-regulatory tariff schemes possibly constitute an exploitative abuse of the collective dominant position of a profession. Two points have to be considered at this stage. The first scrutiny is whether the relevant tariff scheme has been drawn up by the professional association as the emanation of the profession. If the application of similar tariffs turns out to be a practice of parallel behaviour - rather than being brought about by self-regulation it will exclusively fall within the scope of Article 81(1) EC for lack of sufficient connective links within the profession to constitute a unilaterally organised conduct of a (dominant) collectivity. ${ }^{1385}$ The second query is into the mechanism that a scheme prescribes in establishing tariffs. From a competition perspective it is decisive whether or not the scheme requires the individual professional to establish her remuneration with reference to the costs actually incurred in the provision of a specific professional service to a particular customer. Tariff schemes that are not based on cost factors remove the spur to return to competitive (i.e. cost-related) price setting mechanisms. Instead each member of the dominant collectivity can trust that all other members apply the same self-regulatory standard for price setting, be it at a certain (minimum or maximum) level or according to other criteria. ${ }^{1386}$

The ensuing question is under which circumstances a set level of fees is excessive. It is established case law that prices are excessive, and thus abusive, where they ate charged

1383 Jones A. / Sufrin B., (2004), 397.

1384 Cases CNSD (trilogy), Coapi, Giuseppe Conte, Arduino, Belgian Architects, Macrino and Cipolla, and to a certain extent also case EPI Code of Conduct. These cases are summarised in Chapter 2.V.

${ }^{1385}$ For details see above sections I.1. and II.1.

1386 For instance a rate depending on the value of the work, see the Belgian Arcbitects case. Whether a tariff scheme is compulsory in its application or a 'mere recommendation' is irrelevant as long as it is followed and applied by the members of the profession. See above section I.1. and also Chapter 4.I.1.2. Under Article 81(1) EC it is settled case law that the fixing of a price, even one which merely constitutes a target or tecommendation, affects competition because it enables all participants to predict with a reasonable degree of certainty what the pricing policy pursued by their competitors will be, especially if the provisions on target prices are backed up by the possibility of inspections and penalties. Commission Decision Belgian architects, (2004), para. 78; para. 88: "The circulation of recommended tariffs by a professional organisation is liable to prompt the relevant undertakings to align their tariffs, irrespective of their cost prices. Such a method dissuades undertakings whose costs are lower from lowering their prices and thus creates an artificial advantage for undertakings which have the least control over their production costs." Also Commission Decision Fenex, (1996), paras. 60-65. Although these decisions where adopted in applying Article $81 \mathrm{EC}$ their teasoning teferred to here is equally applicable also in respect of Article $82 \mathrm{EC}$. 
without having regard to the 'economic value' of the products or services in question. ${ }^{1387}$ Establishing the economic value of a professional service may be complex. Can that value be represented in 'production costs' per unit of professional service or tather by the price that customers are willing to pay for professional services? What is the economic value of, for instance, the treatment of a cut, a cancer of the intestine, a broken arm or hip, migraine, the advice of a notary in conveyancing, the services by a lawyer in the representation before a court, the supervisory task of an architect in the process of constructing a housc, a bridge or a road, the drawing up of the accounts, or the advice given in the process of making the necessary declarations before the tax authorities? The Court indicates that the excess of prices may be determined more generally by reference to the 'selling' and 'production' costs. ${ }^{1388}$ While the Court did not suggest the level at which profits would become excessive, it held that tariffs are excessive, and hence abusive, where there is no sufficient or reasonable relationship to teal costs or the real value of the services provided. ${ }^{1389}$ For the professional services sector this can be understood to mean that fees should reflect the skills, efficiency and costs of the practitioner. ${ }^{1390}$

The question thus is whether professional tariff schemes allow practitioners to take due account of their cost factors. One often finds that tariff schemes or tariff tecommendations for the remuneration of professional services refer to the value of the subject in respect of which the professional services are provided. For instance, architects may calculate their fees on the basis of the value of the works realised, i.e. the expenditure generally arising out of the construction (excluding taxes). ${ }^{1391}$ Also lawyers, tax advisots and notaries often calculate their fees with reference to the value of the claim that clients assert. In the example of the Belgian Architects the Commission found that the association had bluntly circulated a scale of minimum fees to its members rather than circulating information that would have enabled them to determine their fees according to their costs. ${ }^{1392}$ With regard to the calculation mode based on a specific percentage of the value of the construction work the Commission rightly emphasised that "the scale creates a somewhat artificial link between the cost of building work

1387 See Case 27/76, United Brands, [1978], para. 250.

${ }^{1388}$ See the case law in note 1233 above.

1389 Joined Cases C-147/97 and C-148/97, Deutsche Post (remailing), [2000], paras. 159-167.

1390 See European Commission, "Commission objects to recommended minimum fee scale of Belgian Architects' Association", press telease IP/03/1500 of 05.11.2003 ("fees charged for professional services should reflect the architect's skills, efficiency and his costs and perhaps his fame or notoriety and should not be dependent solely on the value of the works or the price of the entrepreneur. In any event, the architect should determine his fee independently of competitors and in agreement with the client only.") and European Commission, "Commission condemns Belgian architects' fee system", press release IP/04/800 of 24.06.2004. 1391 Commission Decision Belgian architects, (2004), para. 21: "The fee scale published on the Association's website from June/July 2002 set out five categories of building work, beginning with 'purely utilitarian structures designed very simply' and ending with 'restoration of historic buildings, monuments or interiors'. In each category there were six bands relating to the cost of the work - i.e. the total expenditure, real or presumed - to which a set percentage was applied. The fee level in the first category was $6.00 \%$ for band 1 (work costing from $€ 0$ to $€ 160000$ ), and $4.00 \%$ for band 6 (work costing over $€ 16600000$ ). The fee level in the fifth category was $15.00 \%$ for band 1 and $9.00 \%$ for band 6. (Annex: scale, 2002 version)". In view of the European Commission's statement of objections the application of the fee schedule in the particular casc of the Belgian architects had been ended in 2003. The Commission nevertheless pursued the case and used it to reinforce the application of competition law to the liberal professions as a matter of principle.

${ }^{1392}$ Commission Decision Belgian architects, (2004), para. 95: "...the scale constitutes a basis for negotiation between " the architect and his client over the architect's remuneration. The scale thus constitutes a yardstick that suggests " that the architect is not necessarily expected to base his fees on his own operating costs or possibly also on his reputation." 
and the architect's fees". ${ }^{1393}$ The only cost factor in the provision of architectural services that could indeed be linked to the total value of the building work was the insurance premium to be paid by the atchitect. However, as this premium was the only objective link between the value of the building work and the architects' costs - and as such too marginal - it did not alter the Commission's overall assessment that the tariff schemes by the Belgian architects association had the objective to restrict competition.

While the Belgian Architects case was decided under Article 81(1) EC, its conclusions retain their conclusiveness in respect of an Article $82 \mathrm{EC}$ scrutiny ${ }^{1394}$ The case is used here to point out that the mechanism to refer to a value external to the costs of the professional services provision is not objective but artificial and as such prone to establishing excessive prices. In particular, it is predictable that the reference to the value of a work (architects, engineers) or a case (lawyers, notaries, tax advisors) as a basis for assessing the amount of the professional fee constitutes an incentive for the professional to raise that value of that basis or even keep it growing. ${ }^{1395}$ The consequence is that practitioner and customer will see each other again before a court in order to determine what the 'reasonable' fee would be that the customet is obliged to pay. ${ }^{1396}$

The Commission has not always been as consistent as in Belgian architects in respect of the cost relation. In Piau Article 12 of the FIFA regulation provided that the remuneration of the football player's agent be calculated on the basis of the player's basic gross salary and, more particularly, that it will be $5 \%$ of that salary if the parties cannot reach agreement. The Commission wrongly considered that this provision would refer to an objective, transparent criterion (i.e. the player's basic gross salary) and would merely be a (subsidiary) mechanism for the settlement of disputes. ${ }^{1397}$ While the CFI did not directly confirm that view, it held that the "Commission did not make a manifest error of assessment [...] by implicitly excluding a classification as the fixing of imposed prices from the point of view of competition law". ${ }^{1398}$ Although the ptice building mechanism in Piau might be understood as an abstract reference, it is, however, nothing else than a non-cost related criterion, which consequently does not constitute an objective, but rather mechanical factor of pricing. Again, competition law is not about easy solutions, but allocation of resources. In this respect the qualification by the Commission of the abstract reference point in Piau as 'transparent' is misconceived.

The proposition made here is that a practitioner contributes to the abuse by her profession where she determines her fees by reference not to objective, i.e. cost related factors (such as the skills invested, the labour employed, other costs incurred), but by reference to criteria devised by the professional association that only have the appearance of being objective, namely where they refer to abstract factors that are external to the actual service provision (like the worth of a construction work or an asserted claim). ${ }^{1399}$ Coming

1393 Commission Decision Belgian architects, (2004), paras. $88 \mathrm{f}$. (emphasis added).

1394 Compare for instance under Article 82 EC Case T-219/99, British Ainvays I, [2003].

1395 'The reasoning can also be applied to other professions that are traditionally not among the so-called liberal profession. For instance, estate agents tend to establish their fees by reference to the amount of rent to be paid by the future tenant, or the selling price. This mode of determining the fees is bound to be an irresistible temptation to estate agents to increase the rent or selling price in order to raise their profits.

1396 See for instance Case C-221/99, Conte $v$ Rossi, [2001].

1397 See the Commission's position as referenced in Case T-193/02, Piau I, [2005], para. 87.

1398 Case T-193/02, Piau I, [2005], para. 90.

1399 See also Commission Decision Virgin/BA, (2000), where the Commission did not accept the argument that the British Airways' commission scheme (equivalent to a discount scheme) was abusive in its calculation of 
back to the economic theory considerations explained above, the adoption and application of such tariff schemes are exploitative of a collective dominance under Article $82 \mathrm{EC}$ where the collectively dominant profession is granted a legal (quasi-)monopoly to provide the professional services that fall within the tariff scheme. In the Membet States various liberal professions are granted statutory (quasi-)exclusive rights to provide, for instance, (certain) atchitectural or medical services, accountancy or pharmaceutical advice, notarial or medical certificates. These monopoly rights constitutes an entry batrier for new competitots and thus allows the incumbent (quasi)monopolist to impose excessive prices not limited to a short term.

Even where the relevant profession does not have an exclusive statutory right to provide certain services, but merely enjoys title protection, it is perceivable to argue an abuse of selfregulatory powers in the form of excessive prices. The self-regulatory profession may even have a relatively low collective market share. More specifically, an abuse is perceivable in the particular circumstances that a non-cost related fee scale of a profession is followed by the latger sector, including 'para-professionals' not coming within the protected title, and that State courts make use thereof to orientate their case law in remuneration disputes. In such circumstance the self-regulatory rule experiences, as it were, a 'dominant application' to a larger collectivity than the (not quite dominant) self-regulatory profession. In the Netherlands for instance architects that are formally recognised and otganised in a professional association represent about $40 \%$ of the providers of architectural services in the Netherlands. ${ }^{1400}$ Their professional association (BNA - Bond van Nederlandse Arcbitecten) has adopted regulations that determine the professional's fees in accordance with a price formula that is based on the investment costs for building. ${ }^{1401}$ While such a formula is an easy reference, it shall be reiterated that competition is not about 'easy solutions' but about allocative efficiency. The flaw of such a formula is that it does not telate to the costs of the professional service provider. Nevertheless, the formula is widely applied, namely also by service providers that are no members of the registered profession. Even the judiciary applies the formula as a seemingly 'objective' (but only abstract) reference. The national courts even apply it irrespective of the parties having declared the BNA regulations not to apply to their relationship. ${ }^{1402}$ This illustration demonstrates the fat reaching influence that professional price regulations have and, consequently sustains the special responsibility that the professions bear in self-regulatory activities, not only where they are dominant.

A critique that is often uttered in excessive pricing cases is that it is dangerous for competition authotities to engage in price control or even price fixing, as price fixing is the antithesis of the free market ${ }^{1403}$, and in fact the Commission is reluctant to do so. ${ }^{1404}$ For the

commission on ticket sales by travel agents because, among other, it was not strictly cost related.

1400 Onderzoeksinstituut OTB, et al., Architect en Tilelwet: Een evaluatieonderzoek, naar bet functioneren van de wet op de arcbitectentitel en bet architectenregister (uitgeverij 010, 2001), 57.

1401 See Adriaansens C.A., et al, (2005), 74f, who describe the relevant regulatory framework and the application thereof by the national courts. The variables taken into account in the formula are the cost index that is determined by the professional association (BNA) on a yearly basis, classes defined for the kind of works carried out and the investment costs.

${ }_{1402}$ Adriaansens C.A., et al., (2005), $61 \mathrm{f}$.

1403 See for instance Jones A. / Sufrin B., (2004), $379 \mathrm{f}$.

1404 The Commission is prepared to engage in price investigations in particular sectors that may be understood to play an important role for the de-compartmentalisation of the internal market, e.g the mobilc telephony or trans-border mailing. With regard to mobile telephone services in the common market the Commission found 14 cases of discrimination and high prices. It however closed the files when prices were reduced or actions taken by domestic regulators, see European Commission, "Commission launches inquiry into mobile and fixed 
field of collective tariff fixing it does not appear that the Commission (or any other competent authority or court applying either Article $82 \mathrm{EC}$ or the relevant national provision of competition law for that purpose) would need to engage in price fixing itself. Rather it seems desirable that competition authorities and courts exercise their power of control to the effect that the individual professionals are forced to set their individual fees by reference to factors that directly relate to the costs incurred in a particular professional service transaction. ${ }^{1405}$ In order to exercise such a control competition authorities and the competent courts do not need to establish themselves as price regulators. In particular, it is not necessary that these authorities determine the profit margins of practitioners. Instead their tole should be to impose on professionals an individual obligation to determine their fees anew, taking account of their costs, skills and efficiencies. This tesult can be achieved by sanctioning collective tariff schemes that set tariffs irrespective of the costs incurred individually by the members in the provision of a specific service to an individual customer. Conversely, no risk to align tariffs irrespective of cost prices is induced by the circulation of information "that would help the undertakings to calculate their own cost price structures so as to enable them to establish their selling prices independently." ${ }^{\text {1406 }}$ Consequently, circulating this particular form of information is not prohibited under competition law.

\section{Against competitors: gatekeeping}

An exploitative abuse may also be directed against competitors where dominant undertakings have the key to negatively influence and ultimately determine consumer demand. The limitation of output and barriers to entry have detrimental effects on choice in diversified services at competitive prices. The example to be scrutinised here is that of professions authorised by the State to adopt and/ or administer entry regulation. ${ }^{1407}$ The effect of entry regulation is to allow or exclude potential service providers and thus results in gatekeeping. Licensing as one form of gate keeping requires that the (potential) service provider has acquired a defined professional qualification. ${ }^{1408}$ Without such qualification she

telephony prices in the European Union", press release IP/98/141 of 09.02.1998; European Commission, "Commission concentrates on nine cases of mobile telephony prices", press release IP/98/707 of 22.07.1998; European Commission, "Commission closes mobile telecommunications cases after price cuts", press release IP/98/1036 of 26.11.1998. In Commission Decision Deutsche Post, (2001), it was established that the Deutsche Post had imposed excessive price on cross-border mail.

1405 This does not exclude 'standardisation' of fees for standardised services where the initial determination of the fee has been based on the standardised costs incurred in the provision of such types of services. Such standardisation of costs may even be based on histotical price information, see Commission Decision Belgian arcbitects, (2004), paras. 99, 110; and European Commission, Report on Competition in Professional Services, of 09.02.04, para. 39. 1406 "With regard to the limits of the instructions that may be given to members by a professional organisation, any help provided towards management must not directly or indirectly affect the free play of competition within the profession. In particular, any instructions given in this respect should not have the effect of diverting undertakings from taking direct account of their costs when they individually determine their prices or fees; instructions that do have that effect are evidence of a restrictive objective.", Commission Decision Belgian architects, (2004), paras. $88 \mathrm{f}$. Also Commission Decision Fenex, (1996), paras. 60 to 65.

${ }_{1407}$ Entry regulation for the exercise of various liberal professions can take the form of admission, licensing or certification. This means that those seeking to join and/or remain part of a regulated profession often have to fulfil certain requirements before they are allowed to exercise a certain professional activity.

${ }_{1408}$ For instance Case C-250/03, Mauri, [2005]. Office of Fair Trading, Assessment of market power, of 12/2004, $15 \mathrm{ff.:} \mathrm{para.} 5.16$ "Regulation may affect barriers to entry. For example, regulation may limit the number of undertakings which can operate in a market through the granting of licences. Also, licences may be restricted so that there is an absolute limit to the number of undertakings that can operate in the market. In this case a licence 
will not be admitted to the profession and the exercise thereof. Certification is a less strict form of entry regulation, which allows the profession to organise as a voluntary function not barting non-certificated individuals from the exercise of a particular professional activity. ${ }^{1409}$ Where market entry from members of a different group is precluded, the behaviour amounts to discriminatory abuse against competitors rather than an abuse through market power because it gives a preference to the members of the regulating profession. Conversely, an abuse through market power exists where the natural and foreseeable effect of the relevant professional regulation is to keep entry to its own profession limited in order to keep the group small, e.g. by raising standards for entry/ admission/ licensing to the profession.

Moreover, where it should appear that a professional collectivity exetcises its powers to determine and apply admission requirements in an arbitrary way, such use of the selfregulatory powers would constitute an instrumental discrimination against (potential) competitors. This finding is not so much founded on whether a collectively dominant profession has a monopoly to 'gatekeep', but on an arbitrary determination and application of requirements for the admission, certification or licensing of (potential) service providers. Arbitrary determination means the establishment of requirements that appear not to be necessary to attain a certain objective aim, like safeguarding the quality of professional service provision. A conceivable prima facie example of such an instrumental discrimination is the limitation of the (absolute or relative) number of practitioners that are admitted to a profession with a statutory monopoly to exercise particular professional activities. While a particular market may not be sufficiently profitable for an unlimited number of competitors, it is the competitive process that leads to eliminate the necessary number of practitioners. This effect is hampered for instance in Germany where the Notarkammer determines and limits the number of notaries public.

At the verge with gatekeeping is the imposition of self-regulatory standards for the provision of professional services. While gatekeeping concerns the power to decide who will be admitted to 'join the club' of a particular profession, professional standards determine the shape of professional services. Professional standards may have similar effects to licensing standards as shall be demonstrated heteafter.

\section{Against competitors: the prevention of emerging new types of professional services}

On the basis of the facts of the Wouters case it shall be scrutinised in what way a professional group may effectively make use of its collective market power and prevent what may be identified as superior business performance. In the Netherlands certain forms of legal activity may be provided by lawyers that are not fully qualified, i.e. licensed, and even by non-lawyers. Other forms of legal services, like the representation of clients before higher courts, are reserved by statutory monopoly to the members of the Dutch lawyers association

can be thought of as a necessary input before production can take place and so regulation will act as an cntry bartier.

${ }_{1409}$ Certification can take two different forms. The first concerns title protection, which permits any person to offer the specific professional service, but prescribes that only those persons who have qualified by examination may use the title of the profession when the services are offered to the public. The second and somewhat more open form of ccrtification is where again any person is permitted to offer professional services and to perform the relevant tasks; however, those persons periodically have to pass certain examination (administered by the State and / or professional association) in order to keep the certification. Under this form professionals can choose their level of human capital and thereby the quality level of their services, Brosio G., (1997), $3 \mathrm{f}$. 
(NOvA). ${ }^{1410}$ The NOvA groups all licensed lawyers who fulfill certain licensing requirements to be admitted to the Bar and provide legal services, using the title of 'advocaat'. Assuming its self-regulatory authority the Dutch Bar association has adopted Partnership Regulations (discussed in Chapter 4) that prohibit the structural cooperation between its members and accountants. ${ }^{1411}$

This prohibition of multi-disciplinaty partnerships with accountant results in a limitation of the customer's choice in differentiated services since - as the ECJ observed in Wouters the areas of expertise of members of the Bar and of accountants may be complementary. ${ }^{1412}$ The Partnership Regulation determines the circumstances under which the provision of a new service emerging from the structural and integrated cooperation between its members and members of a different profession is allowed. By regulating the exercise of integrated professional services the NOvA - and with it its members that are bound to adhere to these rules - are able to foreclose the emergence of a new type of professional services (namely those intended to be provided in multi-disciplinaty partnerships with accountants and at "one stop" for the customer). The prevention of the emergence of a new service does not constitute normal business behaviour as it is for the customer to decide in accordance with the law of the market whether a new service (or product) in practice is effectively supetior. It should be the customers' decision whether multi-disciplinary-partnetship-services are indeed a superior response for their needs compared to the separate provision of legal and accountancy services.

Preventing a new service amounts to an abuse in its own tight comparable to a refusal to deal or to license ${ }^{1413}$ that stifles competition on the downstream market. The Partnership Regulation of the NOvA certainly limits the competitive freedom of both its members and

${ }^{1410}$ Currently the legitimacy of this 'processmonopolie' or 'domcinmonopoly' is being discussed in the Netherlands, see Commissie Advocatuur, et al., Een maatschappelijke Orde, (2006); Baarsma B. / Felsö F., Helproces als domein - Over de effecten van hetprocesmonopolie van de advocatuur - Eindrapport (commissioned by the association of insurers Verbond van Verzekeraars), (2005); Commissie cassatie-advocatuur, Advies Commissie cassatie-advocatuur, of 21.07.2004 (presented to the Ministry of Justice on 17.08.2004). See also Ministerie van Justitic, (MDW), Domeinmonopolie advocatuur (1995).

1411 According to the Explanatory Note to the NOvA Partnership Regulation, M.v.T. Adv.bl. 1993, bijl bij nr. 20 , a structural cooperation requires the parties involved in a partnership agreement cither to share their revenues, or to share a large degree of integration in respect of a preponderant part of their common practice. According to the Explanatory Note, this integration definition refers to both the running of the practice (organisation and structure of the common practice), and the case handling (actual exercise of the practice). The underlying reason for regulating this close form of cooperation is the concern that it would threaten the prestige of the independent practice of lawyers. This concern applies especially with regard to professions whose attributes contrast with the principle of an independent practice of the lawyers' profession. Itis, however, doubtful whether this consideration is conclusive in respect of accountants not engaging in statutory auditing. Particularly puzzling in this regard is the fact that the NOvA allows structural cooperation with notaries, tax consultants and patent agents, Adv.bl. 1994, blz. 1026.

${ }_{1412}$ Case C-309/99, Wouters et al. v NOvA, [2002], paras. 87-90.

${ }^{1413}$ See Article 82(b) EC. To a similar effect, however in respect of intellectual property rights and essential facilities, see Eilmansberger T., (2005), 160. See also Case T-69/89, RTE (Magill TV Guide), [1991], paras. 66 ff.; Case C-7/97, Bronner v Mediaprint, [1998], paras. 41 ff.; Case C-418/01, IMS Health, [2004], para. 49. See also European Commission, DG Competition discussion paper on exclusionary abuses, of 12/2005, paras. 211, $225 \mathrm{ff.:} \mathrm{"211.}$ A refusal to supply by several companies that are in a collectively dominant position can also be an abuse. This could take the form of refusing access to an input that is collectively owned by a group of companies. In addition, several collectively dominant companies refusing access to their individually owned inputs also could be abusive." Lowe P. (Director General of DG Comp), "Speech at 30th Annual Conference on International Antitrust Law and Policy", (23.10.2003), 7, rightly points out that 'refusal to deal' alone is not sufficient to lead to the finding of an abuse. Rather it has to be combined with its natural and foreseeable effects. 
members of other professions to provide new integrated services, which they cannot provide without a member of the other group. It furthermore prevents customers and consumers to access the provision of combined services. The prohibition on multi-disciplinary partnerships therefore amounts to a prima facie abuse of the collective dominant position that the NOvA and its members have in the legal services market.

It shall be highlighted that the decisive aspect in establishing the exploitative nature of the abuse of the joint dominant position stems from the licensed profession's power to selfregulate the detailed conditions for the provision of licensed services. At this point a distinction needs to be struck between, first of all, the described effect of necessarily foreclosing competing forms of services and, secondly, the means to achieve this foreclosure effect by way of self-regulation. While the natural and foreseeable effect of foreclosure as such is indicative of exclusionary conduct, the use of regulatory powers to enforce this exclusion makes the conduct to be (also) exploitative of the profession's statutory monopoly to provide the licensed services. Consequently, in order to conclude on an instrumental use of the collective dominance it is not necessary that the licensed profession enjoys an allembracing monopoly right to provide typical services. It is sufficient that the fully licensed members have a legal monopoly for licensed, i.e. defined, services. Accordingly, it is the power to regulate the detailed conditions for the provision of such services that enables the licensed profession to foreclose the access to the reserved services as a necessary ingredient for new and integrated services provided with members of other professions.

In the example of Wouters the unconditioned foreclosure of accountants can be qualified as an instrumental abuse since the collectivity of licensed lawyers in the Netherlands has the exclusive power to limit the "production and technical development" on the market for licensed legal services "to the detriment of consumers". ${ }^{1414}$ In conclusion, the self-regulatory power is the means for not-so-tacit coordination and to exploit the legal monopoly for licensed services. The tesult is the blocking up of a secondaty market of integrated services for both competitors and customers. Again in the example of Wouters: if the NOvA and its members were not collectively dominant (i.e. no legal monopoly tight holders) and the NOvA did not have self-regulatory powers (as a gate keeper), the emanation and its members would not be in the position to prevent the emergence of integrated services between accountants and lawyers. In other words it is the regulatory monopoly that provides the means for the profession to exclude business forms (multi-disciplinary partnerships) capable of providing services identified with supetior business performance by creating greater choice for customers. ${ }^{1415}$ The exclusion thus constitutes an exploitative abuse.

Even where the focus is turned away from licensed legal services to the broader market of legal services, the refusal to allow access to one necessary ingtedient for new and integrated services amounts to a relevant restriction of competition. The reason is the same as before: the NOvA and its members still use the self-regulatory powers to prevent a new type of services from emerging. The fact that neither the NOvA nor its members obtain any direct financial or competitive advantage from the prohibition of multi-disciplinary partnerships with accountants does not play a role in light of the considerations explained earlier with regard to the Commission decision on the 1998 Football World Cup. A further but different question is whether such a foreclosure may be justified. An objective explanation may justify a prima facie restriction of competition and the relevant behaviour may finally not

1414 Scc Article 82(b) EC.

1415 See Case C-309/99, Wouters et al. v NOvA, [2002], paras. 87-90. 
amount to an abuse prohibited under Article 82 EC. ${ }^{1416}$

Extrapolating the foregoing findings one can state that a self-regulating profession uses its collective market power where its self-regulatory measures impose restrictions on ownership and business structures since such rules eventually prevent the emergence of new forms of services. At least in the traditional view the liberal professions ate perceived to be self-employed professional practitioners. ${ }^{1417}$ In consequence, they have been, and partly still are, subject to rules that restrict the exercise of their profession in a corporate form. Traditionally the liberal professions were allowed only to cooperate with fellow members of her own profession in the form of a partnership. The issue of allowing alternative business structures other than self-employment or partnerships restricted to members of the same profession was given a push in the 1990s, in particular in the legal market where international law firms (mainly from a US or UK background) started entering the continental market. The more general issue raised by Wouters is whether to allow members of different professions, professional corporations or even business persons not belonging to a liberal profession to provide integrated services in alternative business models with members of a particular (liberal) profession. ${ }^{1418}$ Depending on the needs of consumers, alternative business models have the potential to innovate, increase competition and offer better services to the public. ${ }^{1419}$ Restrictions however on alternative business structures, including restrictions on the number, staffing and activities of corporate professional entities, nip the emergence of new (forms of) services in the bud. Consequently, self-regulatory professional rules that restrict the choice of ownership and are adopted and applied by the dominant profession constitute an instrumental use of collective dominance against competitors to the direct detriment of the consumer's freedom of choice as both competitors and customers are blocked from accessing a particular services market.

A further example of the potency of self-regulatory professional tules to foreclose certain services from arising - thus limiting markets as prohibited under Atticle 82(b) EC - can be found in markets in which consumers may gain access to a 'services candidate' only through a member of a different profession. For instance exists the exclusive competence of physicians to determine medication and treatment at the exclusion of pharmacists or other medically trained professionals, e.g. physiotherapists. The latter often are allowed to perform their services only once a prescription has been issued by the doctor, at least in case of a patient insured under statutory health insurance. A similar exclusionary effect can occur where the statutory requirement is that medicine can be sold only from premises where a fully trained pharmacist is present; or that only fully trained pharmacists can substitute a presctipted drug with a identical but cheaper medicine. ${ }^{1420}$ Patients also may gain access to

\footnotetext{
1416 See Office of Fair Trading, Abuse of a dominant position - Understanding competition law, of 2004, para. 5.3. For details see below section II.3.

1417 See Chapter 2.I.

1418 Making use of corporate forms would for instance allow to limit the liability of the partners. Whether that is a development to be welcomed is a more general issue for the parliamentary legislator under the heading of company law and creditor protection, but not an issue that should be glossed over as a 'deontological' issue on which self-regulatory associations should decide. See also Zuck R., (1998); Seibert U., (1998); Heinz K.E., (1998); BRAK, "Abnahme der Rechtsanwalts-GmbHs 1999 um 56,4 Prozent - Zunahme der Partnerschaftsgesellschaft um 44,9 Prozent", press release of 11.04.2000; Dobelle F., (1997); Harrison S., (1997); OECD, Competition in Professional Services, (2000); Rivkin D.H., (1997).

${ }_{1419}$ Office of Fair Trading. The private dentistry market in the UK, of 03/2003, 55.

${ }^{1420}$ Sce Philipsen N.J., (2003).
} 
professionals who provide complementary services to dentistry only through a dentist. ${ }^{1421} \mathrm{~A}$ physiotherapist may start treatment only upon a prescription by a doctor. The effect of such a regulatory mechanism limits the freedom of professional service providers with a different training background, who offer services that are complementary, or even in competition to, dentistry, medicine, lawyering, etc. Such a mechanism limits the offer of professional services to the public, and restricts competition and choice in the market. In summary also this type of restriction constitutes an instrumental use of collective market power against competitors to the direct detriment of consumers where the restriction stems from self-regulatory measures of the dominant profession. ${ }^{1422}$

On a more general scale the question finally arises whether all self-regulatory professional standards that exclude competitors from certain services markets have to be assessed according to the substantive test of exploitative abuses. Where the effects of professional standards are tantamount to licensing standards, i.e. testricting access to the 'club' of services providers that are authotised to provide particular (forms of) professional services, these professional standards result in indirect discrimination against competitors that are no members of the self-regulating profession. ${ }^{1423}$ Whether indirect discrimination amounts to an exploitative or an exclusionary abuse depends on whether the imposition of certain professional standards is a normal business practice that is unobjectionable if occurring in circumstances that are not marked by collectively dominant market players. This question will be dealt with in the following section.

\subsubsection{Illustrating exclusionary conduct by liberal professions}

The question is whether, from an economic viewpoint, it make sense to impose certain (neutrally formulated) professional standards for the quality or form of services. If so, the ensuing restriction of competition is conduct that influences th structure of the market. To amount to an abuse a certain degree of (objectivised) intent to exclude competitors needs to be demonstrated. The difference in classifying indirect discriminatory measures as either exploitative or exclusionary lies in the burden of proof. Where they are considered as instrumental conduct the collective entity has to prove that the professional standards are necessary and objectively justified. ${ }^{1424}$ Conversely, where they are classified as exclusionary conduct their abusiveness (i.e. the natural and foreseable negative effects on competition) has to be demonstrated by the party invoking exclusion. This may be a (national) competition authotity or the practitioner indirectly discriminated against who claims that a certain self-regulatory practice is prohibited under Article $82 \mathrm{EC}$.

In accordance with the case law the adoption and application of particular professional self-regulatory measures may amount to a market structure abuse if their purpose is to strengthen the collective dominant position of the profession. ${ }^{1425}$ The point of reference in this has to be the intent to alter, or in the language of the Court the attempt 'to influence',

1421 Office of Fair 'Trading, The private dentistry market in the UK, of 03/2003, 55. See Vickers J.C.o.t.O.o.F.T., (2003), 7, who stresses that the OFT recommends deregulation in the private dentistry market to again allow new freedoms and opportunities to providers.

${ }^{1422}$ On State regulation see Chapter 6.

${ }_{1423}$ On indirect discriminatory conduct under Article 82 EC, see Joined Cases 56 to 58/64, Consten and Grundig, [1966], or Case 26/76, Metro I, [1977].

1424 For details on objective justification grounds under Article $82 \mathrm{EC}$ see below section II.3.

${ }_{1425}$ See Case T-65/89, BPB Industries, [1993], para. 69; Joined Cases T-24 to 26/93 and 28/93, CMB (Cewal) I, [1996], para. 107. 
the structure of the professional services market concerned (i.e. to influence the mechanism of demand and supply on that market). The point is whether the adoption and application of professional self-regulations take place in order to eliminate competition on the metits expressing in superior performance. ${ }^{1426}$ The characteristic element is the intended strategic alteration of the market structure, i.e. its manipulation to the intended advantage of the dominant firms. ${ }^{1427}$ Three examples of typical professional standards will be tested hereafter.

\section{Minimum quality standards}

Minimum quality standards for the provision of professional services may have similar effects to certification standards. While they do not regulate entry to a certain profession, their effect is to exclude the provision of certain services if not provided according to the set standards. Such self-regulatory standards for the provision of services may, at first, appear to have an objective character. However, an effects oriented scrutiny may come to the conclusion that the formulation of minimum quality standards naturally and foreseeable results in the reduction of the competitive restraints posed by other 'para-professional'1428 service providers who would supply the same service, but not according to the prescribed self-regulatory standards. Perceivably such minimum standards may inhibit the market strategies of 'para-professionals' or prevent the latter's entry to or expansion on the relevant services market. ${ }^{1429}$

Even where the minimum quality standards are formulated in an open, i.e. nondiscriminatory way they may turn out to constitute a more onerous obstacle for 'service candidates' who are no members of the self-regulating profession but who would, generally speaking, be in a position to provide services in competition with the members thereof. This effect is relative in the sense that the members of collectively dominant profession are, by their training, able to meet the self-regulatory minimum standards more easily than the 'service candidates'. For instance where minimum standards for the quality of advice are regulated by professional bodies ${ }^{1430}$, these minimum standards are formulated in a way that a trained professional can comply with them. Conversely, non-licensed or non-certificated practitioners will find it relatively more difficult to meet the minimum standards. The result is the foreclosure of and an indirect discrimination against other service providers who by their training are de facto able to provide the particular service but not de iure. Moreover, the definition of professional standards similar to licensing standards amounts to barriers that restrict competition from the side of (potential) competitors. If these standards were to

\footnotetext{
${ }^{1426}$ See Eilmansberger T., (2005), 149; see Case 85/76, Hoffmann-La Roche, [1979], para. 91.

1427 Case 22/78, Hugin, [1979], para. 17; Joined Cases 6 and 7/73, Commercial Solvents, [1974], para. 32; Case T69/89, RTE (Magill TV Guide), [1991], para. 76.

${ }_{1428}$ This expression is meant to summarise the idea of a services provider of a different training background who is not a member of the relevant self-regulating profession but who would be able to compete with the professional services providers, if admitted to the market.

${ }^{1429}$ In this respect see also Eilmansberger' T., (2005), $168 \mathrm{f}$. Office of Fair 'Trading, Assessment of market power, of 12/2004, 15 ff.: para. 5.17 "Sometimes regulation sets objective standards. Where these apply equally to all undertakings, such as health and safety regulations, they might not affect the cost for new entrants any more than they affect the cost for incumbents. However, regulation can lead to entry barriers when it does not apply equally to all undertakings. For example, incumbents might lobby for standards that are relatively casy for them to meet, but harder for a new entrant to achieve."

${ }^{1430}$ For instance the Royal Pharmaceutical Society of Great Britain and the Pharmaceutical Society of Northern Ireland regulates minimum standards for quality of advice, see Office of Fair Trading, The control of entry regulations and retail pharmacy services in the UK, of 17.01.2003 (revised in March 2003), $39 \mathrm{f}$.
} 
define superior performance they would actually not need to be formulated as compulsory rules for the professionals to apply; rather the professionals and para-professionals would spontaneously adopt them in order to attract business. On the other hand, the formulation of objective business standards could assist consumers and customers in determining the level of quality that they need in a particular professional services. Therefore, whether such a distortion of competition is justifiable on objective grounds, and therefore not abusive, is a question dealt with further below (section II.3.).

\section{Standard contract terms}

Another illustration of prima facie exclusionary behaviout by a collectively dominant entity relates to standard setting in the form of standard contract terms. This refers to the situation where professional services are offered to customers in accordance with terms that have been collectively agreed upon by the members of a profession. ${ }^{1431}$ For instance, the Dutch association for architects (BNA) has adopted Standaardregeling Recblsverhouding (standard or default regulations on legal relationships) that fill in the contractual relationship between the architect and principal and the interpretation thereof. The Standaardregeling connects in particular the definition of the tasks of the architect with the determination of a 'reasonable payment' of an architect. ${ }^{1432}$ 'The standard terms can be included in the individual relationship either by explicit consent or by way of default, namely in case the parties have omitted to lay down their respective contractual obligations. Remarkably, the effect of these standard forms is reinforced by the State courts, which use self-regulatory codes of conduct as presumed 'objective' reference in the interpretation of contractual obligations of the parties. ${ }^{1433}$ An abuse on the part of the collectively dominant profession is present where individual practitioners refuse to offer contract terms deviating from the collectively agreed standatd terms (abuse by proxy). As explained earlier, it is not necessary that the majority of the members of the profession insist on the application of the collectively agreed standard terms. In order to establish an abuse of a collective dominant position it is not necessary that the abuse be collective, but the refusal by one member of the profession is sufficient. ${ }^{1434}$

\section{Pricing}

A further exclusionary conduct by professional self-regulation can be identified where prices for particular professional services ate the result of collective bargaining - for instance where representatives of the medical professions negotiate with the public health insurance

1431 See Commission Decision TACA II, (1999); on appeal Joined Cases T-191/98 and T-212/98 to T-214/98, $T A C A$, [2003], where the members of a liner conference refused to offer their transport services on the basis of individually negotiated contracts, but instead only offered various transport services in accordance with terms that had been agreed upon collectively by the members of the liner conference.

1432 Adriaansens C.A., et al., (2005), $58 \mathrm{ff}$.

1433 See already text with note 1402. See the BVerfG - "Richtinien des anwaltichen Standesrechts kein Hilfsmittel zur Auslegung",Anwaltsblatt(1987), 598, 598, that annulled the self-regulatory measures by the German Federal lawyers association (BRAK) for lack of a relevant legal basis allowing the BRAK to adopt self-regulation. It took the national courts a while to adapt their case law that generally had granted interpretative force to selfregulatory measures. Meanwhile a specific provision has been introduce into the Federal legislation authorising a specific regulatory organ of the collective profession - rather than the BRAK itself - to adopt self-regulatory measures. See also for instance Case C-221/99, Conte v Ressi, [2001], summarised in Chapter 2.V.

1434 See Case T-228/97, Irish Sugar I, [1999]; Case C-497/99 P, Irish Sugar II, [2001]; Joined Cases T-191/98 and T-212/98 to T-214/98, TACA, [2003], para. 633. 
schemes prices for medical services that are covered by the public schemes. The natural and foreseeable result of such collectively negotiated prices for full ranges of medical services provided by licensed members is to eliminate potential competition from non-licensed professionals. Any would-be entrants to the market of services covered by the public health insurance schemes are strongly induced to provide their services in accordance with the conditions of the collectively negotiated price schemes because their services will otherwise not be reimbursed by the public health insurers. ${ }^{1435}$ To a certain extent the collective price bargaining between the medical profession and the public health insurers can be compared to single branding, namely insofat as the medical profession agxees with the public health insurers that the latter only 'purchase', i.e. refund, medical services provided by licensed professional service providers. This pattern of collective bargaining of prices results in the alteration of the market structure because new entrants with a competitive pricing policy are excluded from the bargaining of prices. Consequently, collective bargaining hinders the maintenance or growth of residual or potential competition. It results in a cumulative foreclosure effect and furthers coordination between the licensed professionals. ${ }^{1436}$

\subsubsection{Interim conclusions: Abuse of collective dominance by a profession - a question of degree?}

The special responsibility of dominant undertakings increases with their degree of dominance. This was first suggested in the case law in Tetra Pak II where the ECJ approved the findings of the CFI that "the actual scope of the special responsibility imposed on an undertaking in a dominant position must therefore be considered in the light of the specific circumstances of the case". ${ }^{1437}$ While the specific circumstances in the relevant case law ${ }^{1438}$ were identified with the very large market shates of the dominant undertakings 'verging on monopoly' (exceeding $90 \%$ ), specific circumstances as such are not limited to market shares. Although the latter are a good indicator, they are not necessarily conclusive on dominance. Super-dominance ${ }^{1439}$ is indicated by particularly effective powers of undertakings to behave

1435 Compare Commission Decision TACAII,(1999); on appeal Joined Cases T-191/98 and T-212/98 to T-214/98, $T A C A,[2003]$, establishing that the competitive structure of a market is abusively altered where new entrants to a dominated market are induced to do so within the collectively determined system.

1436 See European Commission, DG Competition discussion paper on exclusionary abuses, of 12/2005, para. 139: "The main possible negative effect of single branding obligations and rebate systems is foreclosure of the market to competing suppliers and potential suppliers, which maintains or strengthens the dominant position by hindering the maintenance or growth of residual or potential competition (horizontal foreclosure). In case such obligations or systems are used by several, collectively dominant, suppliers, this may have a cumulative foreclosure effect and may in addition further facilitate collusion. In case the buyers are retailers selling to final consumers the foreclosure may also lead to a loss of in-store inter-brand competition."

1437 Case T-83/91, Tetra Pak II, [1994], para. 115; Case C-333/94 P, Tetra Pak III, [1996], para. 24.

${ }_{1438}$ See also Joined Cases C-395/96 P and C-396/96 P, CMB (Cenval) II, [2000], paras. $112 \mathrm{ff}$. In this case the Court in particular established that a dominant undertaking with a high market share and only one competitor would be more likely to be found to have abused of its dominant position than a dominant undertaking with a lesser degrec of market power.

${ }^{1439}$ The expression of super-dominance was first used by joined Cases C-395/96 P and C-396/96 P, CMB (Cetval) II, [2000], para. 137: "To my mind, [Article $82 \mathrm{EC}$ ] cannot be interpreted as permitting monopolists or quasi-monopolists to exploit the very significant market power which their superdominance confers so as to preclude the emergence either of a new or additional competitor. Where an undertaking, or group of undertakings whose conduct must be assessed collectively, enjoys a position of such overubelming dominance verging on monopoly, comparable to that which existed in the present case at the moment when $G \& C$ entered the relevant market, it would not be consonant with the particularly onerous special obligation affecting such a dominant undertaking not to impair further the structure of the feeble existing competition for them to react, even to aggressive price 
independently of their competitors, their customers and ultimately of the consumer. Based on the considerations above it is suggested that self-tegulatory professions have an increased responsibility towards the market irrespective of whether their market shares are 'verging on monopoly'. The super-dominance of a profession might not only be established by reference to its collective market share but also by reference to, first of all, the statutory monopoly right to provide defined or typical professional services and, secondly, the profession's selfregulatory powers to determine market conditions in which professional services are (not) to be provided.

It is this combination of exclusive rights and self-regulatory powers that is specific to collectively organised professions, and in fact grants them a 'self-regulatory advantage' that they might exploit to their economic advantage. This self-regulatory ability to exclude competitors and to limit services, quantity and quality to the detriment of the (final) consumer grants a substantive competitive advantage. ${ }^{140}$ In other words the regulatory and supervisor powers afford the affiliated members of a professional association a regulatory lead to determine market conditions. ${ }^{1441}$ As long as this self-regulatory advantage is not challenged on a more principled stance, self-regulating professions should be subject to an increased standard of special obligation, first, not to make instrumental use of their market power and, second, not to impair further the structure of the remaining competition in professional services markets.

The starting point for establishing super-dominance of a particular profession is its monopoly for licensed or certified professional services. But also in respect of the broader market of typical professional services (e.g. legal services instead of licensed legal services, medical services instead of licensed medical advice and treatment, technical and managetial services instead of licensed architectural services) does the profession remain subject to the special responsibility towards the competitive process. The self-regulatory powers, where assumed, reinforce the collective dominant position of the profession even where the relevant professional services market is not protected by legal monopoly rights. ${ }^{1442}$ It is in

competition from a new entrant, with a policy of targeted, selective price cuts designed to eliminate that competitor. Contrary to the assertion of the appellants, the mere fact that such prices are not pitched at a level that is actually (or can be shown to be) below total average (or long-run marginal) costs does not, to my mind, render legitimate the application of such a pricing policy" (emphasis added). See also Jones A. / Sufrin B., (2004), 279; Goyder D.G., (2003), 272.

1440 See also Case C-302/94, British Telecommunications, [1996], paras. 34, 44 f., in which the Court found that the dominant parties enjoyed "a substantial competitive advantage over other [...] providets of telecommunications services."

1441 Sce also Joined Cases T-68 to 77 and 78/89, Italian Flat Glass, [1992], para. 358, in which the Court gave examples of when independent economic entities, on a specific market, are united by such economic links that, by virtue of that fact, together they hold a dominant position vis-aivis the other operators on the same market. In particular the Court refers to the example "where two or more independent undertakings jointly bave, through agreements or licences, $a$ technological lead affording them the power to behave to an appreciable extent independently of their competitors, their customers and ultimately of their consumers" (emphasis added).

${ }_{142}$ Not every profession enjoys legal monopoly rights / a more limited legal protection takes the form of title protection, for instance for architects in the Netherlands. See also Onderzoeksinstituut OTB, et al., Arcbitect en Titelvet: Een evaluatieonderzoek naar bet functioneren van de wet op de arcbitectentitel en bet arcbitectenregister (uitgeverij 010, 2001). However, I consider that the conclusions presented in this section also cover services for which no statutory monopoly has been granted to the practitioners of a particular profession, but rather are provided by professionals who can exercise their profession under title protection. While the professional title protection does not necessarily result in the grant of an exclusive right to exercise particular professional services, it nevertheless allows the professionals to distinguish themselves on the market with the 'brand' of their title that stands for a certain government or association defined level of education, training (including sometimes practical expetience) 
fact this self-regulatory advantage that puts a profession in the position to collectively and unilaterally impose rules that inhibit the competitive process in which customers should be in the position to choose the best price-performance-ratio for their needs. Neither customers nor competitors have the economic power to prevent a self-regulating profession from imposing rules that, for instance, exclude competition from (potential) competitors of other professional groups, or that raise the prices irrespective of the costs incurred by the individual professional in an individual transaction.

Where the self-regulatory measures are generally applied by the affiliated members (due to either coercion or understanding), or are even applied by the wider sector and the judiciary ${ }^{1443}$, the regulatory and disciplinary powers of a professional association endow it with an effective tool to influence the competitive process. They can be compared to the increased power by market shares of a (quasi)monopolist. In other words, the self-regulatory powers of a professional association, where exercised and followed by the members, grants the profession a position of supremacy $v i s-\grave{d}-v i s$ its customets and competitors, and ultimately the consumers. This suptemacy confers a particularly effective means to impair the competitive process. Consequently, the special responsibility of a dominant entity towards the competitive process makes a collectively dominant and self-regulating profession subject to a more onerous and comprehensive obligation not to engage in certain self-regulatory practices. ${ }^{1444}$ The Court in Wouters, by misjudging the connective links of the emanation of Dutch lawyers, lost the opportunity to establish such a clear obligation, which moreover should be self-evident for democratic forms of governance based on the rule of law.

The concept of super-dominance is helpful in establishing a specific category of responsibility for self-regulating dominant collectivities, which is at the interface with the prohibitions of exploitative abuses and effects-based abuses. This means that self-regulation perceivably stipulating normal competitive behaviour is on the verge of being qualified as instrumental conduct for which no objectivised intent or plan $^{1445}$ to eliminate competition, new business forms or new forms of services needs to be established on the part of the profession. The suggestion therefore is that it will generally not be necessary to prove whether a particular professional self-regulation has the purpose to strengthen the collective dominant position of the profession's members as long as it has the natural and foreseeable effect to alter the structure of the professional services market. This result is reasonable in view of the wide impact that professional self-regulation has in the market, especially since this impact does not emerge through competition on the merits but is based on the collective presentation and the support that self-regulation often receives from State authorities like the government or even the judiciary.

\subsection{Liability for an abuse of collective dominance}

In the event that an abuse of a joint dominance held by the members of a profession and

and disciplinary supervision. The fact that professionals, if they want to benefit from the title protection, are subject to a collective organisation that assumes self-regulatory and disciplinary competences differs in its impact on the market only in degree from the impact of collective organisation and self-regulation by professions that enjoy legal monopoly tights. For a less far-reaching interpretation of the effects of title protection see Adriaansens C.A., et al., (2005), 73.

${ }_{1443}$ As with the Standaardregling Rechtsverhouding adopted by the Dutch architects organised in the BNA, see above. 1444 Compare also Goyder D.G., (2003), 272.

1445 See also Whish R, (2003), 527 who argues that collective conduct is exploitative conduct, since prices are charged that are higher than they would be in a competitive market. 
their emanation can be established, both the professional association and its individual members may be held responsible for the abusive behaviour. This is the consequence of the ruling in Irish Sugar. ${ }^{146}$ For reasons of practical convenience the Commission and national competition authorities applying Article $82 \mathrm{EC}$ may prefer to address a decision to the professional association, in particular where the association has legal personality under national law. Should it lack legal personality, a decision of the competent competition authority can be sent to the society or association but will be addressed to the members of the profession in their collectivity. In that event the members and not their society will be liable to end the prohibited conduct and, as the case may be, to pay the fine that the competition authority may impose. ${ }^{1447}$

\section{Objective justification, efficiency gains and the principle of proportionality}

The concept of abuse is interpreted in a way that a distinction can be made between behaviour that is caught by Article $82 \mathrm{EC}$ as abusive and behaviour that is legitimate and thus outside the article's scope. While Article $82 \mathrm{EC}$ does not provide for an explicit exemption from its prohibition as does Article $81 \mathrm{EC}$ in its third paragtaph, both the Court and the Commission have accepted that prima facie abusive behaviour can be justified. ${ }^{1448}$ Accordingly, a behaviour is not prohibited under Article $82 \mathrm{EC}$ if it is necessary and proportionate to the pursuit of a legitimate interest of the dominant undertaking, however restrictive it may be. In other words dominant undertakings are entitled to improve their market position and act in a profit-oriented way. ${ }^{1449}$ Hence, the interpretation of the term 'abuse' is decisive in the assessment of the legitimacy of the behaviour of dominant firms since the possibility of justification is firmly perceived as part of the Article $82 \mathrm{EC}$ analysis.

In their analysis of Article $82 \mathrm{EC}$ the Court and the Commission use the concept of objective justification to determine the boundaries of justification. ${ }^{1450}$ In fact, due to the objective character of the Community concept of abuse, a justification of a prima facie abusive behaviour has to be based on objective grounds. More specifically, the examples of Article $82 \mathrm{EC}$ (a) to (d) indicate the limits that undertakings in a dominant position must tespect, even where the conduct falls outside the non-exhaustive examples of Article $82 \mathrm{EC}$. The ultimate limits of legitimate commercial interests ate the principle of proportionality and the prohibition of discrimination. ${ }^{1451}$

${ }^{1446}$ See however the critique by Faull J. / Nikpay A. (Eds.), (2007), para. 4.126: "While the logic underlying the notion of collective dominance implies that an oligopolist engaging in exclusionary behaviour is in a sense doing so on behalf of the collective entity [...], it seems now to be clearly established that it is nonetheless possible to prosecute oligopolists individually. Indeed, the notion of applying Article 82 to a firm which is not directly engaging in any exclusionary conduct seems to stretch the legal fiction of abuse of collective dominance beyond reasonable limits. The same seems all the more true in the case of an oligopolist engaging in exploitative behaviour."

1447 See also Chapter 4.1.1.2.3.

1448 For instance Case 27/76, United Brands, [1978], para. 190; Commission Decision BBI/Boosey or Hawkes, (1987);

AG Kirschner in Case T-51/89, Tetra Pak II, [1990], paras. $67 \mathrm{ff}$.

1449 AG Kirschner in Case T-51/89, Tetra Pak II, [1990], para. 68.

${ }_{1450}$ See for instance Case 78/70, Deutsche Grammopbon, [1971], para. 19; Case 27/76, United Brands, [1978], paras. 182 ff.; Case 311/84, Télémarketing (CBEM), [1985], para. 27; Case T-69/89, RTE (Magill TV Guide), [1991], para. 55; Case T-30/89, Hilti, [1991], paras. 102-119; Case T-83/91, Tetra Pak II, [1994], paras. 115, 136, 207; Case T228/97, Irish Sugar I, [1999], paras 167, 188 f., 218; Case C-163/99, Portuguese Republic v Commission, [2001], para. 53. Whish R., (2003), 208.

${ }^{1451}$ AG Kirschner in Case T-51/89, Tetra Pak II, [1990], para. 67. 
The Commission is currently developing a theoretical framework for possible defences under Article 82 EC. ${ }^{1452}$ From the existing case law and decisional practice the Commission systematises three general grounds of justification defences that dominant undertakings may put forward in their attempt to safeguard prima facie abusive behaviour. The first group are 'objective justifications' containing two grounds that ate referred to as 'meeting competition defence' and 'objective necessity defence'. 'The Commission also considers to systematise the treatment of an 'efficiency defence' according to which dominant undertakings argue that the anti-competitive effects of their behaviour are outweighed by 'efficiency gains' similarly to the grounds mentioned in Article 81(3) EC. This third ground is a category of its own. ${ }^{1453}$ While the Commission contrasts objective justification grounds with the proof of efficiency gains, it should be noted that all grounds of justification rely on objective considerations and should therefore indiscriminately be referred to as objective justification grounds. All three grounds shall be dealt with in turn to scrutinise in how far they constitute a conceivable defence for professional self-regulation. In principle, they apply indistinctly to exploitative, or discriminatory, abuses as well as to exclusionary abuses. ${ }^{1454}$

\subsection{Meeting competition defence}

The main starting point for considering justification is the idea that undertakings may have succeeded in becoming dominant through superior efficiency and competition on the merits. It therefore is legitimate that they are allowed to defend their commercial interests as are non-dominant firms. In principle,

"the fact that an undertaking is in a dominant position cannot deprive it of its entitlement to protect its own commercial interests when they are attacked, and [...] such an undertaking must be allowed the right to take such reasonable steps as it deems appropriate to protect those interests". 1455

This consideration has led to the 'meeting competition defence' which allows to show that the otherwise abusive behaviour is actually a loss-minimising reaction to competition from others.

The Commission in its discussion paper for public consultation on its internal review of its policy under Article $82 \mathrm{EC}$ wants to see this defence restricted in a twofold way: first of all, it should be limited to behaviour that would otherwise constitute pricing abuse and, secondly, it should be confined to conduct of single dominance. Whether the first limitation holds true in light of the Commission's own decisional practice ${ }^{1456}$ can be left open in respect

${ }^{1452}$ European Commission, DG Competition discussion paper on exclusionary abuses, of $12 / 2005$, paras. 77 ff.; European Commission, Guidance on exclusionary conduct, of 09.02.2009, paras. $28 \mathrm{ff}$.

1453 European Commission, DG Competition discussion papper on exclusionary abuses, of 12/2005, paras. 78, $81 \mathrm{ff} ., 84$ ff.; and European Commission, Guidance on exclusionary conduct, of 09.02 .2009 , para. 30. See already Lowe P. (Director General of DG Comp), "Speech at 30th Annual Conference on International AntitrustLaw and Policy", (23.10.2003), 6. See also Case C-171/05 P, Piau II, [2006], para, 119.

1454 See AG Kirschner in Case T-51/89, Tetra Pak II, [1990], para. 68; Lowe P. (Director General of DG Comp), "Speech at 30th Annual Conference on Intemational Antitrust Law and Policy", (23.10.2003), 6. Whilc in this review of the application of Article $82 \mathrm{EC}$ the Commission currently concentrates on exclusionary conduct as the more frequent type of abusive behaviour, the suggested grounds for justification can be applied also to exploitative behaviour since both categories of abusive conduct finally share the same nature of being equally abusive as such, see above section II.2.1.2. ('interim conclusions').

1455 Joined Cases T-24 to 26/93 and 28/93, CMB (Cewal) I, [1996], para. 107; Case T-65/89, BPB Industries, [1993], para. 69.

${ }_{1456}$ In Commission Decision BBI/Boosey of Hawkes, (1987), esp. para. 19, the Commission considered the 
of collective self-regulation if the second limitation presumed by the Commission is correct. ${ }^{1457}$ To start with and in bortowing from the terms of the Court the relevant question can be phrased as follows: is a collectively dominant profession (its emanation) entitled to protect the commercial interests of its members, and must it be allowed the right to take such reasonable steps as it deems appropriate to protect those interests when they are attacked?

The assertion of the Commission that the meeting competition defence is open only to individually dominant firms appears to be correct for the following reason. The whole purpose of establishing connective links (coordination of collective behaviour) is the pursuit of the commercial interests of the collectivity. ${ }^{1458}$ To accept that the collective behaviour could be justified by reference to the commercial interest of the collectivity would be tantamount to declare the coordination inherently justifies the abuse thereof. Collective dominance per definitionem is not achieved on the collective merits and through the competitive process, but is the tesult of willful coordination between the members of the collectivity. Moreover, the existence of a collective dominant position indicates that the market is not competitive, at least not as competitive as it could be. Even if a situation of collective dominance comprised only two members who have achieved their individual position on the market on the merits of competition, the presentation as one collective entity on the market independently of their trading partner, competitors and ultimately the consumers is not on the merits but on the basis of their (tacit or explicit) coordination.

The next question then is whether a professional association is entitled to defend the commercial interests of the individual members in light of the fact that the individual members themselves are allowed to defend their commercial interest. However, where the individual member of a dominant collectivity pursues her interests in conformity with the self-regulatory collective rules, she no longer determines her actions individually but conspires. In that instance her acts are in fact a manifestation of the collective dominant position and amount to an abuse of the collective dominant position by the single member (abuse by proxy). ${ }^{1459}$ The result therefore is that neither professional associations nor their members can invoke the meeting competition defence.

\subsection{Objective necessity defence}

The second justification ground of an objective necessity defence is based on factors external to the parties involved, i.e. any player in the relevant market, whether customer of or competitor to the dominant undertaking, and in particular external to the dominant

reasonableness of a refusal to supply, or rather the immediate withdrawal of supplies. "There is no obligation placed on a dominant producer to subsidise competition to itself. In the case where a customer transfers its central activity to the promotion of a competing brand it may be that even a dominant producer is entitled to review its commercial relations with that customer and on giving adequate notice terminate any special relationship." The final result was, however, that the immediateness of the withdrawal as business reaction was not proportionate and therefore found to be abusive.

${ }_{1457}$ The Commission does not explain why the meeting competition defence should be restricted to individually dominant undertakings only. NB In its most recent document on the review of Article 82 EC the Commission does not mention the meeting competition defence anymore, see European Commission, Guidance on exclusionary conduct, of 09.02.2009, paras. 28-31.

${ }_{1458}$ NB A professional association normally does not engage in an economic activity of its own and therefore should not be able to put forward any commercial interest of its own as a justification for what otherwise are abusive self-regulatory measures.

${ }^{1450}$ See above section II.1. 
company itself. ${ }^{1460}$ This makes sense as especially the dominant undertaking should not be put in the position to determine the reasons for justifying its apparently abusive behaviout. In 2003 Director General Philip Lowe formulated a conceivable test along the lines of 'legitimate public interest objectives', such as health for consumers. At first sight this justification ground seems to be receptive to professional associations invoking various public interests to justify anti-competitive self-regulation, like public health and health of patients, (public) safety (e.g. in building), the good administration of justice, the public faith of registers (notaries), and the rule of law. However, upon careful examination the reference to this form of the objective necessity defence made by the Director General reads mote like a hypothetical rather than a real justification possibility for dominant undertakings, ${ }^{1461}$ and the relevant case law so far has not provided much comfort to dominant undertakings. ${ }^{1462}$ The Commission in its 2005 discussion paper and 2009 guidance document nevertheless recognises the possibility of a dominant company to show that the conduct in question is objectively necessary.

In particular, the Commission specifies that the proof of necessity must be based on objective factors that apply in general for all undertakings in the market ${ }^{1463}$, i.e. factors that would affect all undertakings equally in the conduct of their business. On the basis of such objective factors the dominant entity needs to demonstrate that without the prima facie abusive behaviour ${ }^{1464}$ the service concerned cannot or will not be provided in the market. ${ }^{1465}$

${ }_{1460}$ European Commission, DG Competition discussion paper on exclusionary abuses, of 12/2005, paras. 78, 80. Sce also Joined Cases C-215/96 and C-216/96, Bagnasco, [1999], paras. 54 ff.: "59. Without its being necessary to consider whether the banks which are members of the ABI hold a collective dominant position within the meaning of Article [82 EC], it need merely be stated that, since [...] any change in the interest rate for a current-account credit facility depends on objective factors, such as changes occurring in the money market, that conduct cannot, in any circumstances, constitute an abusc of a dominant position within the meaning of Article [82 EC]."

1461 Lowe P. (Director General of DG Comp), "Speech at 30th Annual Conference on International Antitrust Law and Policy", (23.10.2003), 6: "a defendant undertaking might try to argue that its practice pursues a legitimate public interest objective" (emphasis added).

${ }_{1462}$ Casc T-30/89, Hilti, [1991], para. 118; Case T-83/91, Tetra Pak II, [1994], paras. 83 f., 138. Jones A. / Sufrin B., (2004), 286. The case of Hilit is exemplificd shortly below.

${ }_{1463}$ Europcan Commission, DG Competition discussion paper on exclusionary abuses, of 12/2005, para. 80. European Commission, Guidance on exclusionary conduct, of 09.02.2009, para. 29: "The question of whether conduct is objectively necessary and proportionate must be determined on the basis of factors external to the dominant undertaking. Exclusionary conduct may, for example, be considered objectively necessary for health or safety reasons related to the nature of the product in question."

1464 NB exclusionary conduct, in contrast to instrumental use of market power (discriminatory and exploitative behaviour), prima facie concerns normal business conduct and can be proven to be abusive only where its purpose is to influence the structure of the market, see for instance Case 85/76, Hoffmann-La Roche, [1979], and above section II.2.1.2. The scrutiny of purpose or 'objectivised intent' intrinsically includes an assessment of whether the behaviour has an abusive character. Therefore it seems logical that the issue of a possible justification of exclusionary behaviour cannot be strictly severed from the issue of whether that behaviour is abusive, in order to avoid that, first, an abusive character is established and subsequently eliminated again. The question then is whether a behaviour can be objectively justified despite an intention to exclude or eliminate competitors from the market. A case by case assessment leads to a balancing of the interests of the dominant undertaking in pursuing a prima facie normal business conduct and the aim of Article $82 \mathrm{EC}$ to protect the competitive process. - The picture changes a bit in case of instrumental use of market power because such conduct is abusive as such without a query into the 'objectivised' intent of the dominant entity. In such an instance the issue of justification can be treated separately from the issue of abuse. In light of the contradistinction between prima facie normal business behaviour and behaviour that is abusive in its own right, one could even wonder whether the latter type abuses are justifiable at all. However, in essence the Court and the Commission recognise that there may be objective reasons why it might be necessary to discriminate against competitors, customers and consumers. The threshold of what is necessary is probably higher than in respect of exclusionary behaviour, and the principle of 
This might arguably be the case of, for instance, quality regulations adopted by professional associations in the absence of national legislation to that effect. ${ }^{1466}$ An illustration may be given on the basis of Hilti. In that case the Court subjected the challenged behaviour to strict conditions of objective necessity or indispensability. ${ }^{1467}$ The contested practice by Hilti was to require purchasers of Hilti nail cartridges or nail-guns to also purchase Hilti nails. Hilti had alleged that this practice was justified on grounds of safety considerations and the prevention of false and misleading advertising since, it claimed, the use of its competitors' nails in Hilti tools was dangerous. ${ }^{1468}$

The Court, however, dismissed these arguments for two reasons in particular. First of all, national legislation vested national authorities with powers to safeguard the alleged interests. Secondly, the Court concluded that "in those circumstances it is cleatly not the task of an undertaking in a dominant position to take steps on its own initiative to eliminate products which, rightly or wrongly, it regards as dangerous or at least as inferior in quality to its own products." "1469 The equally valid reverse of this statement of the Court could be interpreted to mean that, in the absence of relevant State rules and authorities charged with their enforcement, dominant undertakings could advance as a defence the pursuit of general interest objectives, like consumer protection. The point may be clatified with reference to Piau where the absence of relevant regulation played a role.

More particularly the CFI in Pian considered the possibility to assimilate under Article $82 \mathrm{EC}$ the justification considerations laid down in Article 81 (3) EC. ${ }^{1470}$ The relevant aspect thereof for present purposes is that the undertakings suspected of anti-competitive behaviour may impose only such restrictions that are indispensable. The CFI in Pian accepted that it was indispensable to subject candidates for the profession of football players' agent to a compulsory license, which the CFI previously had qualified as a barrier to access (a restriction of competition by object). The reason for accepting the legitimacy of the license system was the fact that the license was based on a qualitative selection rather than a

proportionality should find a strict application. One could compare the issue to anti-discrimination law whereat least in a closed system - only cases of indirect discrimination can be justified for objective grounds. In cases of direct discrimination the grounds for justification have to be stated in the law, or at least have to have the character of overriding teasons.

${ }^{1465}$ It would be interesting to consider in how far an objective necessity test under Article 82 EC should be developed in terms of an ancillary restraints testing, despite the Commission not making an allegation to that effect.

${ }_{1466}$ See Case T-193/02, Piau I, [2005], para. 117 in conjunction with para. 103.

${ }_{1467}$ Case T-30/89, Hilti, [1991], paras. 102-119. See also Case 311/84, Télémarketing (CBEM), [1985], para. 26. It is actually not clear to which extent the 'objective necessity' test is a form of the proportionality test underlying all objective justification tests in EC law. The principle of proportionality derives from German law and its application is to legislation. The principle has been adopted by the ECJ in the area of the fundamental free movement rights, which indeed apply (primarily) to State measures and (now also) to private measures motivated collectively. See Case C-415/93, Bosman, [1995]; Joined Cases C-51/96 and C-191/97, Deliège, [2000]; Case C281 /98, Angonese, [2000]; Case 43/75, Defrenne II, [1976]; Case C-341/05, Laval un Partneri, [2007]; Case C-438/05, Finnish Seamen's Union v Viking Line, [2007]. Critiques warn that it is dangerous to introduce the principle of proportionality in Article 82 EC, summarised in Goyder D.G., (2003), $330 \mathrm{f}$. This critique is, however, weak as pointed out Goyder D.G., (2003), $330 \mathrm{f}$. In any event, collective self-regulation in its effects is to a certain extent comparable to regulatory measures by Member State, in particular where they are compulsory for the members and can be enforced by supervisory bodies and cventually before national courts.

${ }^{1468}$ See Commission Decision Hilti, (1988).

1469 Case T-30/89, Hilti, [1991], para. 118.

1470 Case T-193/02, Piau I, [2005], paras. 102 ff. and 119. For details on Article 81(3) EC see Chapter 7.I. 
quantitative restriction on access to that occupation. ${ }^{1471}$ The Court explained that the qualitative selection was appropriate for the attainment of the objective of raising professional standards for the occupation of players' agent. The FIFA indeed had argued that it had adopted the disputed rules in the pursuit of a dual objective, namely, first, to raise professional and ethical standards for players' agents in view of, second, the protection of football players who, the Court acknowledged, have a short career. The Court insinuated that the financial protection of the clubs played a role as well in accepting the legitimacy of the rules at stake.

The objectives of raising professional standards and protecting vulnerable parties sound of course laudable. However, what literally goes without saying in the case, and thus is particularly noteworthy, is the fact that the Court accepts that the dominant collectivity determines what constitutes a legitimate objective interest. The CFI in fact asserted two things. First, the regulation of professional and ethical standards is necessary as such. Second, it is legitimate under competition law for a self-regulatory dominant collectivity to pursue particular aims of professionalism. While the circumstances of the case wete determined by the absence of national rules governing the occupation of football players' agents ${ }^{1472}$ and the lack of an internal organisation of the profession of agents, these circumstances do not necessarily justify the adoption of self-regulatory measures that have the object to testrict competition (barrier to access a profession). In fact the findings of Piau can hatdly be squared with the case law in Hilti. ${ }^{1473}$ In particular the CFI gives no reason why the genuine regulation of a profession and of players protection would be the task of the collectively dominant entity rather than the parties looking after their business themselves. Where disadvantageous contracts have been concluded surely the broader consumer protection and unfair contract terms legislation should be a sufficient tool to protect the parties in accordance with the line adopted in Hilti.

Comparing the CFI's considerations in Pian with the considerations regarding the 'objective necessity defence' as indicated in Hilti and the Commission's discussion paper may, however, not be completely conclusive, for the indispensability criterion under Piau is not the same as in Hilti and the discussion paper. The former refers to a proportionality test in view of an economic objective in terms of efficiency gains generated by the conduct of the dominant undertakings whilst the latter is based on general objective factors that are not particular to the services or products of the dominant undertakings. Whether the respective arguments ventilated by the Court in Piau hold true with regard to Article 81(3) EC, or for that purpose the efficiency defence under Article $82 \mathrm{EC}$ analogue to Article $81(3) \mathrm{EC}$, is considered below. ${ }^{1474}$ The question here, i.e. with regard to the objective necessity defence adumbrated in Hilli under Article $82 \mathrm{EC}$ proper, is whether a particular service cannot or will not be provided in the market without the prima facie abusive behaviour.

Applied to the situation, for instance, of the Piau case the question would have been whether the FIFA could have claimed equally successful that without the compulsory

1471 Para. 103 of the judgment in Piau.

1472 An intriguing detail of the case is that at the material time of the case France, the country where Mr Piau was established, had already national rules governing the occupation. The CFI, however, gave priority to the perspective of the FIFA percciving the absence in other countries to decide a case of a claimant established outside such countries, therewith - one could argue - granting the rules of a collective organisation priority over the applicable State rules.

1473 Case T-30/89, Hilti, [1991], para. 118 (discussed above). See also Case T-83/91, Tetra Pak II, [1994], paras. 83 f., 138; Case 311/84, Télémarketing (CBEM), [1985].

${ }_{1174}$ Respectively in this chapter (section II.3.3.) and in Chapter 7.I. on Article 81(3) EC. 
licensing requirement for players' agents and a qualitative selection the services of players' agents cannot or will not be provided in the market. ${ }^{1475}$ Such an argumentation is obviously defeated by the past reality. The result might be different when the question is reformulated to ask whether without the compulsory licensing the services of players' agents cannot or will not be provided at a particular qualitative level in the market. In view of the past experience referred to by the CFI in Piau ${ }^{1476}$ the question should be answered in the affirmative. However, it is doubtful whether in that way the pertinent question is asked.

First of all, the reformulation bears the tisk of being manipulative. If the level of quality control is set rather low the answer will be in the negative because most of the providers will have met those standards before they were set. The higher the quality level is set the fewer the practitioners will be who would have aimed for those standards without compulsion in the first place, and hence the greater the influence on the competitive process will be. Nonetheless, by allowing to reformulate the focus of the objective necessity defence the chance of the dominant collectivity to get away with its restrictive tegulations will increase with the level of quality control. This is not in coherence with the aim of Article $82 \mathrm{EC}$. The wrong incentive is given to dominant entities who bear a special responsibility towards the competitive process. Secondly, the question does not square with the effectiveness of EC competition law. In Hilli the Court convincingly held that "the effectiveness of the Community rules on competition would be jeopardized if the interpretation by an undertaking of the laws of the various Member States regarding product liability were to take precedence over [the EC competition] rules."1477

Applied to the field of professional self-regulation this means that professional associations must not adopt and implement rules that interpret national rules on specific public interest related issues ${ }^{1478}$, e.g. on public security in designing and constructing ${ }^{1479}$ or on security in medical treatment. This incapacity of a collective dominant entity with selfregulatory competences extends mutatis mutandis to situations where no specific State rules have been adopted with regard to the provision of professional services and where the general laws can be applied. The effectiveness of the Community tules on competition would be particularly jeopardised if the self-regulatory rule-setting by a collective dominant entity were to take precedence over the EC competition rules.

In light of the strict case law $^{1480}$ it shall be stressed that the defence along the lines of an alleged legitimate public interest objective cannot be accepted in view of the effectiveness of EC competition rules. In summary, a public interest defence should not be allowed where such an interest has been unilaterally determined by the dominant undertakings. Any market player, whether dominant or not, is bound to produce safe services of fair quality, for otherwise the general laws in damages and of professional or even criminal liability will apply. It is not for the market players other than through spurring the competitive process to make sure that their competitors comply faithfully with the legal obligations imposed by

\footnotetext{
1475 Compare European Commission, DG Competition discussion paper on exclusionary abuses, of $12 / 2005$, para. 80. 1476 At para. 102 the CFI emphasised that "certain practices on the part of players" agents could, in the past, have harmed players and clubs, financially and professionally."

1477 Casc T-30/89, Hilli, [1991], para. 119 (emphasis added). That question comes close to the issue of supremacy of EC law, recognised ever since Case 26/62, Van Gend \& Loos, [1963]; and Case 6/64, Costa v ENEL, [1964]. ${ }^{1478}$ It shall be recalled that professional associations, despite their possible statute under public law, generally are no emanation of the State that would assume public authority, see Chapter IV.1.2.2.

1479 Poor design leads to civil and professional liability.

1480 Case 311/84, Télémarketing (CBEM), [1985]; Case T-30/89, Hilli, [1991]; Case T-83/91, Tetra Pak II, [1994], para. 138; Case C-333/94 P, Tetra Pak III, [1996], para. 37.
} 
the State. Elsewhere in this book it is argued that it is indeed the democtatic responsibility of the legislator to determine the relevant public interests policies, and to determine the possible limitations to the freedom of trade. The brevity with which the Commission comments on what it calls the objective necessity defence seems to evidence that the Commission itself has difficulties with that defence. ${ }^{1481}$ On the overall it can be concluded that a public interest defence does not bear realistic importance, at least with regard to selfregulatory professional regulations, if such interest were formulated by the dominant profession itself.

At this juncture a following question arises, namely of whether this asscssment changes in light of the hybrid character that professional associations have, on the one hand, as an association of undertakings pursuing their members' collective commercial interests and, on the other, as a collective regulator. The consequence of such a subtle distinction ${ }^{1482}$ would, however, be that undertakings could evade Article $82 \mathrm{EC}$ by establishing self-regulatory associations and claiming that they are legitimated to take steps on their own initiative to eliminate or prevent professional conduct and services that they regard, rightly or wrongly, as dangerous and inferior to their standards of quality, consumer protection etc. As explained earlier the fact that professional associations assume self-regulatory and supervisory powers puts them in the position to make use of a highly effective tool to influence the competitive process in the market and, consequently, puts them in a position of supremacy or superdominance. Their special responsibility towards the competitive process as one public interest therefore amounts to a 'super-special' responsibility. No such special responsibility exists for them towards other public interests - unless they were laid down in the law. However, as has been seen in the overview of national tules in Chapter 4.I.2.4, the protection of public interests is not, to a sufficient degree, required from associations by national law.

Even if the objective necessity defence does not constitute a merely hypothetical test ${ }^{1483}$, and even if the professional associations could sufficicntly motivate the adoption of restrictive professional self-regulatory rules, those rules must pass a proportionality test. They must be a reasonable and proportionate response to the (intended) business actions of their members, their members' competitors and customers. ${ }^{1484}$ Generally speaking, it is for the company invoking the benefit of a defence against a finding of a prima facie restriction to demonstrate to the required legal standard of proof that the conditions for applying such defence are satisfied. ${ }^{1485}$ The Commission therefore rightly points out that the burden of proof for an objective justification defence under Article $82 \mathrm{EC}$ will be on the dominant companies. ${ }^{1486}$

\subsection{Efficiency defence}

As a third justification ground the Commission ventilates the efficiency defence which

${ }^{1481}$ European Commission, DG Competition discussion paper on exclusionary abuses, of 12/2005, para. 80.

1482 See also above note 1478.

1483 For instance where intetpreted similarly to the ancillary restraints doctrine, see above notc 1465.

1484 See Joincd Cases T-24 to 26/93 and 28/93, CMB (Cevval) I, [1996], para. 148.

1485 Council Regulation (EC) No 1/2003 of 16.12.2002 on the implementation of the rules on competition laid down in Articles 81 and 82 of the Treaty, recital 5 and Article 2.

1486 European Commission, DG Competition discussion paper on exclusionary abuses, of $12 / 2005$, para. 77; European Commission, Guidantce on exclusionary conduct, of 09.02.2009, para. 31. See Case T-203/01, Micbelin II, [2003], paras. $107 \mathrm{ff}$. 
basically parallels the exemption of Article 81(3) EC. Since Article 81(3) EC is dealt with in Chapter 7.I. it shall suffice at this point to summarise the four conditions common to Article 81(3) EC and the efficiency defence presented by the Commission in its discussion paper on the internal review on the application of Article 82 EC. According to those four conditions the behaviour of the (association of) undertakings should, first of all, contribute "to improving the production or distribution of goods or to promoting technical or economic progress"1487 by resulting in "efficiencies [that] are realised or likely to be realised". ${ }^{1488}$ Secondly, the conduct has to be indispensable to realise the efficiencies; thirdly, the efficiencies have to benefit consumers; and fourthly, competition must not be eliminated in respect of a substantial part of the products or services concerned. Translated to the professional services sector this means that it has to be proven that the self-regulatory rules of a profession are the indispensable means that result in efficiency gains benefiting the consumers and not eliminating competition in a substantial part of the relevant professional services market.

It is remarkable that the Commission attempts to transpose the law of Article 81(3) EC to apply also to Article $82 \mathrm{EC}$ situations despite the fact that the latter provision, in contradistinction to the former, does not provide for an explicit derogation from the abuse prohibition. ${ }^{1489}$ Parallelling Article 81 (3) EC results in recognising that a derogation is inherent to Article $82 \mathrm{EC}$ despite its wording. As both articles pursue the aim of maintaining effective competition on the market the question then is why it would have been necessary for the founding fathers of the Treaty to formulated the exemption in explicit terms within the frame of Article $81 \mathrm{EC}$, but allowing for the same exemption being assumed implicitly within the frame of Atticle $82 \mathrm{EC}$. The Commission itself argues that "consistency" tequires Atticle 81(3) EC not to be available to companies that abuse of a dominant position. At the same time, the Commission pursues that a company holding a dominant position may also benefit from an exemption under Article 81(3) EC (when its conditions are fulfilled) and that its conduct should not be classified as an abuse under Article $82 \mathrm{EC}^{1490}$ The rationale is of course to avoid conflicting decision, i.e. the finding of, on the one hand, no infringement of competition law under Article 81 EC because of a successful exemption under its third paragraph following an individual or block exemption, but on the other, an infringement of competition law for an abuse of dominance due to the lack of the same explicit justification ground in Article 82 EC. ${ }^{1491}$

1487 Article 81(3) EC, and European Commission, DG Competition discussion paper on exclusionary abuses, of 12/2005, para. 85.

${ }_{1488}$ European Commission, DG Competition discussion paper on exclusionary abuses, of 12/2005, para. 84.

1489 The only case that the Commission refers to is Case T-228/97, Irish SugarI, [1999], para. 189: "the protection of the commercial position of an undertaking in a dominant position [...] must, at the very least, in order to be lawful, be based on criteria of economic efficicncy and consistent with the interests of consumers."

1490 The Commission refers to European Commission, Guidelines on the application of Article 81(3) EC, para. 106, and Case 27/76, United Brands, [1978], para. 113; Case 85/76, Hoffmann-La Roche, [1979], paras. 39 and 90; AG Kirschner in Case T-51/89, Tetra Pak II, [1990], in particular para. 28; Joined Cases T-191/98 and T-212/98 to T-214/98, TACA, [2003], para. 1456; Case T-193/02, Piau I, [2005], para. 119.

${ }_{1491}$ According to settled case law Articles 81 and $82 \mathrm{EC}$ arc not mutually exclusive but may apply simultaneously. On the parallel application of Articles 81 and 82 EC see Joined Cases T-191/98 and T-212/98 to T-214/98, $T A C A$, [2003], para. 610: 'Tast, contrary to what the applicants claim, the fact that an agreement is prohibited by Article [81(1) EC] does not prevent the Commission from taking such an agreement into consideration in order to conclude, in the context of the application of Article [82 EC], that the position of the undertakings concerned on the relevant matket is a collective one [...] (whether or not covered by an exemption under Article [81(3) EC])". See also Joined Cases C-395/96 P and C-396/96 P, CMB (Ceval) II, [2000], para. 33. 
This consideration is not necessarily conclusive though. An argument can be drawn from the maritime sector, which describes a typical situation of collective dominance and in which the application of Article $82 \mathrm{EC}$ plays a particular role. For this sector a block exemption regulation exists that exempts certain practices and agreements of liner conferences from the prohibition of Article $81 \mathrm{EC}$. In spite of that block exemption regulation the Commission has in the past successfully pursued shipping liner conferences for breach of Article $82 \mathrm{EC}^{1492}$ The reason is that in respect of Article $82 \mathrm{EC}$ the Article 81 (3) EC (block) exemption may prevail only where the competent authority, on a case-by-case basis, has taken account of the particular circumstances in which the prima facie anti-competitive coordination occurred. This means that the competent authority granting an individual exemption under Article 81(3) EC intrinsically should also consider the risk of an infringement of Article $82 \mathrm{EC} .{ }^{1493}$ By contrast, in respect of a block exemption no case-bycase analysis of the circumstances and no positive assessment of the overall market situation takes place by definition. ${ }^{1494}$

In summary, for situations assessed individually under Article 81(3) $\mathrm{EC}^{1495}$ and Article $82 \mathrm{EC}$ and in light of the Commission's logic in its discussion paper, the interim conclusion is that, on the one hand, Article 81(3) EC does not apply to situations where there is abusive behaviour ${ }^{1496}$ and, on the other, that there is no abusive behaviour where the conditions of Article 81(3) EC are fulfilled. ${ }^{1497}$ Evil unto him who evil thinks, i.e. that this would be a contradiction in terms. The conclusion to be drawn rather seems to be that in their interpretation Articles 81(3) and $82 \mathrm{EC}$ influence one another: the classification of abuse depends on whether the conditions of Article 81(3) EC are met. Where they are not, Article 81(3) EC does not apply - but not as a question of principle. Rather it does not take effect in terms of its legal consequence(exemption). While this conclusion may be acceptable, it must be observed that in consequence the scope of Articles 81(1) and $82 \mathrm{EC}$ interfere, and to a certain extent even integrate, since the infringements of both may be justified, according to the Court and the Commission, on the grounds mentioned in Article 81(3) EC. ${ }^{1498}$

The ensuing question then is why collective situations have to meet the aggravated dominance element of Article $82 \mathrm{EC}$ if there is no abuse in a case that meets the conditions

${ }^{1492}$ See Joined Cases T-24 to 26/93 and 28/93, CMB (Cenval) I, [1996]; Commission Decision TACA II, (1999); Joined Cases T-191/98 and T-212/98 to T-214/98, TACA, [2003].

${ }_{1493}$ Monti G., (2001), his note 35.

1494 Goyder D.G., (2003), 333 f. In Case T-51/89, Tetra Pak II, [1990], Tetra Pak argued that its behaviour covered by $\Lambda$ rticle $82 \mathrm{EC}$ could be justified in accordance with the then Patent Block Excmption Regulation 2349/84 (Tetra Pak had engaged in the takeover of Liquipak by which it had acquired Liquipak's licences that in turn were covered by the block exemption), and based its claim on the following reasoning. In order to avoid, within the scope of Article $82 \mathrm{EC}$, the application of the block exemption regulation the Commission should have used its discretion to withdraw the exemption under the terms of that regulation. The CFI however upheld the Commission decision on the ground that such a withdrawal can have effect only for the future but not for the past behaviour, and that Articles 81 and $82 \mathrm{EC}$ are independent legal instruments that, within the overall scheme of the Treaty, address different situations.

1495 To the extent that the Commission still conducts such an individual assessment under Council Regulation (EC) No 1/2003 of 16.12.2002 on the implementation of the rules on competition laid down in Articles 81 and 82 of the Treaty the result of which has been that the notification system for the grant of an exemption of negative clearance under Article $81 \mathrm{EC}$ has been abolished.

1496 European Commission, DG Competition discussion paper on exclusionary abuses, of 12/2005, para. 8: "Consistency requires that Article 81(3) EC be interpreted as precluding any application of this provision to restrictive agreements that constitute an abuse of a dominant position."

${ }_{1497}$ This consideration has been confirmed by the CFI in Case T-193/02, Piau I, [2005], para. 119, see below.

${ }^{1498}$ See references in note 1490. 
of Article 81(3)? It would for instance be conceivable that some sort of a de minimis rule (as applied for Article $81 \mathrm{EC}^{1499}$ ) would suffice to distinguish restrictions of competition that are particularly large in extent. However, such an approach would obviously thwart the aim of Article 82 EC. Instead, a sensible consequence of the Court's and Commission's approach to the efficiency defence under Article $82 \mathrm{EC}$ is to give a more restrictive application to the requirements of Article 81 (3) EC in the context of a dominant collectivity. Such an approach is sensible as it takes account of the special responsibility of the collectivity towards the competitive process.

Since this responsibility even has a super-special quality in the case of collective selfregulation, the concession of an efficiency defences for professional associations seems particularly problematic. The CFI in Piau had less scruple about accepting an efficiency defence as a matter of principle and emphasised that in any event (i.e. despite the error in law made by the Commission in taking the view that Article $82 \mathrm{EC}$ did not apply) the application of Article $82 \mathrm{EC}$ to the FIFA regulations could not have resulted in a finding of an abuse of a dominant position in view of the findings that the Commission, according to the Court, rightly had made with regard to Article $81(3)$ EC. ${ }^{1500}$ What is questionable about this approach is that the Court thereby instructs a 'recycling' ${ }^{1501}$ of the facts, which leads to an exemption justification. Such a recycling is problematic not least in view of the principle that exceptions to a rule, if accepted, have to be interpreted restrictively.

Assuming that the legal assessment of the facts by the CFI in the Piau case was correct, i.e. that the FIFA regulations fulfil the four conditions of Article 81(3) EC despite the collective dominance and the super-special responsibility of the FIFA, there is nevertheless a flaw to the final finding of the CFI for the following reason. As established by the CFI the Commission wrongly considered Article $82 \mathrm{EC}$ not to apply to the FIFA regulations. Consequently, the assessment, which the Commission had carried out correctly for the purpose of Article $81 \mathrm{EC}$, necessarily did not take account of the risk of abusive effects of the FIFA regulations under Article $82 \mathrm{EC}$. It is suggested that the Commission should have done so in order for the exemption of Article 81(3) EC to extend to the prima facie abusive self-regulation. ${ }^{1502}$ Conversely, assuming that the Commission's reasoning in respect of Article 81(3) EC and with tegard to a prima facie Article 81(1) EC testriction is equally valid for assessing whether or not the FIFA regulations have been abusive, the Court seems to say the following. It is not necessary to take account of the specific circumstance that constitute the collective dominance.

The critique on Piau is the following. Regardless of whether the assessment of the

\footnotetext{
1499 See European Commission, Commission Notice on agreements of minor importance which do not appreciably restrict competition under Article 81(1) of the Treaty establishing the European Community (de minimis), basically systematising the relevant case law.

1500 Para. 119 of the judgment in Piau. Since the standards in that case (specific licence, written entry examination, professional liability insurance police, obedience to a code of professional conduct, the use of written standard representation contract with players) do not impose quantitative but qualitative restrictions that can be exempted under Article 81(3) EC, the CFI considered them as justified, i.e. implicitly to be within the interpretation of the term 'abuse' as not restrictive of/detrimental to competition, see in particular para. 103 of the judgment.

1501 The idea of a prohibition of 'recycling' facts was established with regard to the establishment of an infringement of both Articles 81 and 82 EC, Joined Cases T-68 to 77 and 78/89, Italian Flat Glass, [1992]. In Case T-228/97, Irish Sugar I, [1999], para. 67, it was applied with regard to the establishment of collective dominance and an abuse thereof. See also above, p. 271.

1502 See also Monti G., (2001), notc 35.
} 
requirements of Article 81(3) EC hold true on substance ${ }^{1503}$, the Court has assumed the competences of the Commission to conduct the necessaty assessment under Article $82 \mathrm{EC}$ and in respect of Article 81(3) EC criteria. Unsutprisingly, the judgment has been appealed, among other, on the ground that "in the absence of enquiries by the Commission into the dominant position of FIFA and into [a] possible abuse thereof, the Court of First Instance could not assume the role of the Commission, after having established the existence of that dominant position, and find that there was no abuse, erring in law and thus infringing Article 82 EC." 1504 Notwithstanding, the ECJ issued an order ${ }^{1505}$ that upheld the CFI's judgment, and in particular sustained the point that a possible abuse may be assessed in the light of the justification argument drawn from the criteria required in Article 81(3) EC. ${ }^{1506}$ In fact, the ECJ was unwilling to understand Mr. Piau's appeal as challenging the justification, but limited its understanding of the appeal to Mr. Piau challenging the CFI's classification of the FIFA regulations as abusive behaviour. The ECJ stated that "il convient de relever que le simple fait de donner une autre qualification juridique à une situation [...] ne nécessite pas nécessairement une nouvelle enquête afin de vérifier si le comportement de la position dominante collective est abusif '. ${ }^{1507}$ More specifically, the ECJ added that the applicant had not contested the CFI's findings that the FIFA regulations did not impose quantitative restrictions on access to the occupation of players' agents, but qualitative restrictions.

However, in this assertion the ECJ seems to go further than what was intended by the applicant, because the ECJ added that the "restrictions de nature qualitative [...] pouvait, dans les circonstances données, être justifiées" ${ }^{\prime 1508}$, and thereby seem to put into Mr. Piau's mouth that he not only accepted the classification of the FIFA regulations as qualitative restrictions, but that he neither disputed the consideration of the CFI that those qualitative restrictions may be justified under Article $82 \mathrm{EC}$ in the circumstances of the case. The ECJ thereby has given a very literal understanding of $\mathrm{Mr}$. Piau's challenge that the Commission had not conducted enquiries into a possible abuse of FIFA's dominant position. Technically this is possible because Article $82 \mathrm{EC}$ does not provide for an explicit justification ground similar to Article 81(3) EC, and strictly speaking the consideration of the four criteria of the latter have to form an integral part of the assessment of whether a certain conduct constitutes an abuse in the sense of Article $82 \mathrm{EC}$. This is different from the mechanism in Article $81 \mathrm{EC}$ where it is possible, if not necessary, to first conclude on a restriction of competition before one may consider whether the probibition of Atticle 81(1) EC does not apply due to a positive testing under Article 81(3) EC.

In consequence, it is suggested that Mr. Piau's appeal challenging the CFI's competence to substitute the Commission's assessment of abuse should have been interpreted as to also challenging the finding of the CFI that the qualitative testriction may be justified within the scope of Article $82 \mathrm{EC}$, taking account of the criteria of Article 81(3) EC. Only thereby the Court could have come to the conclusion that the substantive criterion of Article $82 \mathrm{EC}$ had not been fulfilled. Backed by the ECJ the CFI theteby salvaged the Commission's omission of addressing Article $82 \mathrm{EC}$ within its assessment of Article 81(3) EC. Whether the CFI

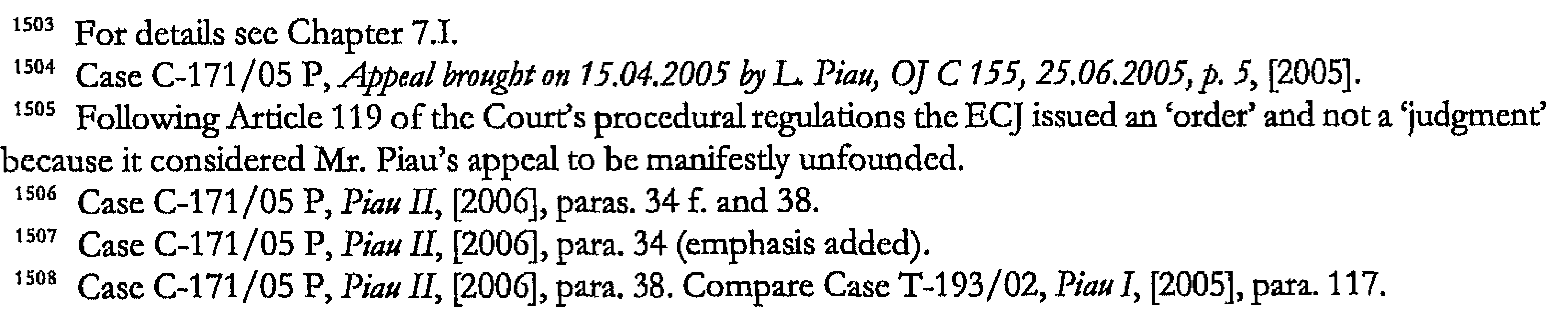


legitimately could have done so is a complex question which probably has become redundant after the coming into force of Regulation 1/2003. At the time the Commission erred in law by not addressing FIFA's collective dominant position it still had the exclusive competence to grant an exemption in accordance with Article 81 (3) EC. ${ }^{1509}$ The CFI could only review whether the Commission had committed errors in law in applying Article 81(3) EC, but not proceed to the appropriate assessment of the facts itself. Therefore, had the CFI in Pian found that the Commission wrongly had omitted an assessment also of the possible effects of the FIFA regulations with regard to an abuse of its collective dominant position, the CFI could only have annulled the Commission's decision with regard to the granted exemption. However, since the CFI addressed the issue of the efficiency defence only within the scope of Article $82 \mathrm{EC}$ it could justify its reference to the Article 81(3) EC assessment (conducted by the Commission) with the direct applicability that Article $82 \mathrm{EC}$ had even before Regulation 1/2003 came into force on 1 May 2004.

Starting from the idea that the appreciation of an exemption of the FIFA regulations under Article 81(3) EC had to be made also in light of FIFA's collective dominance and the risk of an abuse thereof, the question persists whether the Court should have annulled the Commission's decision for omitting to do so, or whether - in an alternative case of collective regulation - it legitimately could conduct the necessary assessment itself after Article 81(3) EC has become directly applicable due to Article 1(2) of Regulation 1/2003. It is my guess that also in th future the ECJ will not find a manifest error of law if the CFI henceforth proceeds to such an assessment under Article 81(3) EC since in Piau neither the CFI nor the ECJ considered the super-special responsibility of the collectively dominant entity towards the competitive process. In that regard it is insignificant under which article, either Article 81(3) EC or Article $82 \mathrm{EC}$, they omitted to address that responsibility. However, not identifying such a super-special responsibility of self-regulating dominant collectivities is the real ground why the CFI's judgment and the Commission's decision should have been annulled.

\subsection{State compulsion defence}

Where professional associations engage in self-regulation on the basis of powers granted by the public authorities they may invoke a State action defence, which equally applies with tegard to behaviour coming within Article $82 \mathrm{EC}$. For brevity reference is made to Chapter 6.II.3.

\footnotetext{
1509 Council Regulation No. 17 of 10.02.1962, First Regulation implementing Articles 85 and 86 of the Treaty (now Arts. 81 and 82 EC), replaced by Council Regulation (EC) No 1/2003 of 16.12 .2002 on the implementation of the rules on competition laid down in Articles 81 and 82 of the Treaty.
} 


\section{Closing Chapters 4 and 5: comparing the application of Articles 81 and $82 \mathrm{EC}$ in respect of professional self- regulation}

The first observation to be drawn from the survey in Chapters 4 and 5 of the two competition prohibitions is that self-regulatory measures emanating from a professional body qualify as both decisions of an association of undertakings under Article 81(1) EC and as manifestation of the collectivity under Article $82 \mathrm{EC}$. While the exercise of collective dominance generally is about tacit conduct, the case of professional self-regulation demonstrates that tacitness is not a requirement for the applicability of Article $82 \mathrm{EC}$. The ensuing question is: of what avail is the application of Article $82 \mathrm{EC}$ if the same selfregulatory situation can also be covered by Article 81(1) EC? A first difference between the application of the two provisions is that the concept of abuse, according to the case law, allows to also cover objective justification grounds; with the result that prima facie exploitative or exclusionary conduct may be qualified as not being abusive, and hence not falling under the prohibition of Article $82 \mathrm{EC}$. This contrasts with the design of Article $81 \mathrm{EC}$, which excludes such an interpretation of the substantive concept of restriction of competition, as has been explicitly demonstrated by the Court in Wouters. ${ }^{1510}$ On the other hand, it is problematic to limit the scope of Article $82 \mathrm{EC}$ by interpreting its substantive concept of abuse to include a test of efficiency that corresponds with Article 81(3) EC; such method seems to be in sharp conflict with the design of Article $82 \mathrm{EC}$. Yet, both the Court and the Commission allow for such an approach, understandably in an attempt to avoid conflicting decisions under the two competition provisions. ${ }^{1511}$

From the considerations ventilated in Chapter 5 it furthermore emerges that Article $82 \mathrm{EC}$ applies only where a profession is formally organised in an emanation. It is the combination of the emanation adopting professional rules and the implementation of these rules by its members that manifest an abuse of the collective dominance 'by proxy'. ${ }^{1512}$ 'This point differs from Article 81(1) EC under which measures adopted by the association do not need to be implemented by its members to be prohibited; and conversely, also collective measures adopted as among the members are covered as either agreement of concerted practice of undertakings. ${ }^{1513}$

A particular substantive interest in applying Article $82 \mathrm{EC}$ is given where a profession

\footnotetext{
1510 Notwithstanding the Court invented what is here referred to as Wouters proviso, which shrinks the reach of the prohibition of Article 81(1) EC. For details see Chapter 4.II.4.2.2. and Chapter 7.1.2.5.3.

1511 For details see Chapter 5.II.3.3.

1512 For details see Chapter 5.II.1.

1513 See Commission Decision COAPI, (1995), para. 34 f. and Chapter 4.I.1.2.
} 
enjoys a statutory monopoly to exercise certain professional activities and where its emanation assumes the authority to regulate the entry and exercise thereof. First of all, this combination makes that exclusionary self-regulation is on the verge of exploitative conduct. Furthermore, it has been explained that this combination results in a super-dominance of the collectivity, and thus a super-special responsibility of the emanation not to abuse of the collective dominance. In particulat the super-special tesponsibility requires the emanation to maintain an efficient competition that has a positive impact on consumer welfare (positive obligation) and to abstain from behaviour that is detrimental to genuine undistorted competition (negative obligation). ${ }^{1514}$ The adoption and en forcement of both exploitative and exclusionary professional self-regulation ${ }^{3515}$ by the emanation of the profession is an instrumental use of the collective dominance to determine market conditions to the detriment of the consumer's choice in terms of variety, quality, quantity and price of professional services. Consequently, the substantive test of abuse will not be bifurcated in case of a collectively super-dominant profession, but will have to concentrate on the natural and foresceable effects of instrumental use made of a statutory monopoly to determine market conditions, regardless of the actual effects of the self-regulatory measures. While the demonstration of an objectivised intent to so influence market conditions is thus not strictly necessary, it will reinforce the case against collective self-regulatory measures.

Thus, different from Article 81(1) EC it is not strictly necessary to demonstrate a direct harm on the competitive process, since collective dominance manifested in self-regulation on the basis of statutory monopoly rights may be the objectionable means to impair market conditions to the direct detriment of customers and competitors, therewith reducing consumer choices and welfare. Exclusionary self-regulatory measures do not constitute the exercise of 'normal business behaviour' since 'normal business parties' do not normally enjoy a statutory monopoly to provide certain activities. The prominent exception are intellectual property tights. The motivation of these statutory monopoly rights is an economic one, namely to earn back the investment made, and thus to stimulate that the investment be made in order to increase consumer choice in variety and quality. ${ }^{1516}$ If a similar reasoning should be applied to the liberal professions, one may argue that practitioners should be rewarded for the investment in a university education and continuing education throughout their professional life; which is an investment that results in the protection of the professional title acquired. However, such title ptotection should, in principle, not be realised by preventing that consumers and customers have access to professional services of varied quality and prices. Whether the implementation of an extended title protection is legitimately justified to earn back the investment made in academic and continuing education is a question for careful balancing of the interests at stake. At all events, the super-special responsibility of self-regulating professions with statutory monopoly rights requires their emanation to catefully demonstrate that the prohibition of, e.g. multi-disciplinary partnerships ${ }^{1517}$, is proportionate to such an aim of title protection. In particular, the emanation needs to demonstrate that no less restrictive means exist than the particular professional selfregulation. ${ }^{\text {t518 }}$

1514 For details see Chapter 5.II.2.1.

${ }^{1515}$ For details see Chapter 5.II.2.2.

1516 To a certain extent this argument resembles the ancillary restraints doctrine under Article 81(1) EC, explained in Chapter 4.II.1.2.2.

${ }_{1517}$ See Chapter 5.II.2.2.1. taking the facts of Wouters as a starting point.

1518 The Court itself cast doubts on the necessity of the self-regulatory measures in Wouters by stating that indeed 
In summary, the consequence of the super-special responsibility under Article $82 \mathrm{EC}$ is that it is for the professional association to demonstrate that it has not made an instrumental use of the statutory monopoly of the collectivity to provide certain professional services. Conversely, claimants suffering from exclusionary and exploitative professional selfregulation do not need to demonstrate in how far such self-regulation has the effect of limiting the competitive process in professional markets. It is in this eased burden of proof for claimants that lies the substantive interest in applying Article $82 \mathrm{EC}$ to professional selfregulation. The corresponding positive obligation on the side of the emanation of a profession with a statutory monopoly for the exercise of certain professional activities converges with fundamentals of democratic rule making.

there were less restrictive means to achieve the aim of preserving a sufficient degree of competition on the legal services market. For details see Chapter 4.II.2.3. The thesis exposed in chapter may be tested on facts of the recent Joined Cases C-171/07 and C-172/07, DocMorris II, [2009], paras. $56 \mathrm{ff}$, in which the Court decided that Articles 43 and $48 \mathrm{EC}$ do not preclude national legislation allowing only persons having the status of pharmacists to own and operate pharmacies. Supposing that the case would have been about a self-regulatory measure (rather than State legislation), it may be squared with the super-special responsibility by taking title protection as a starting point. In DocMorris II the protected activities of pharmacists to run a pharmacy was protecting their title as far as the provision of pharmacy services and establishment are concerned, but not in tespect of the offering and distribution of medicine/ drugs. The latter activity is allowed for internet-pharmacies as proves Case C-322/01, DocMorris I, [2003]. 


\title{
State Involvement in Professional Regulation and its competition restrictive effects
}

\author{
State involvement in anti-competitive professional regulation meeting legal review
}

The previous chapters have dealt with the application of EC competition law to selfregulatory activities of the professions. Professional regulation is, however, not only about self-regulation. Also Member States act as regulators in the professional services sector with the effect that regulation in professional markets basically originate in a two layered hierarchy of rules. In economic terms legislative measures and other regulatory activities of the State can have similar effects on professional markets as self-regulatory measures. As such the regulatory origin of a measure does not lessen the implications it has on the competitive process. In fact national measures may be an effective means to overcome difficulties in realising concerted actions between economic operators and thus restrict competition in the internal market. ${ }^{1519}$ Articles 81 and 82 EC are, however, applicable to State actions only if they are the expression of an economic activity. While this requitement basically excludes legislative and regulatory State measures from the articles' scope, Member States are nevertheless subject to obligations in respect of EC competition law. Article 86(1) EC explicitly provides that "Member States shall neither enact nor maintain in force any measure contrary to the rules contained in this Treaty, in particular to those rules provided for in Article 12 and Articles 81 to $89 . " 1520$ While this provision appears to be confined to "public undertakings and undertakings to which Member States grant special or exclusive rights", the Court in INNO $v A T A B$ established some thirty years ago the likewise sounding principle that "Member States may not enact measures enabling private undertakings to escape from the constraints imposed by Articles [ 81 to $89 \mathrm{EC}$ ]". More concretely the Court argued on the basis of both Articles 10(2) and 86(1) EC that "the Treaty imposes a duty on Member States not to adopt or maintain in force any measure which could deprive [Article $82 \mathrm{EC}$ ] of its effectiveness". ${ }^{1521}$ Due to the supremacy of EC (competition) law the principle deriving from $I N N O \nu A T A B$ has a strong constitutional character of exposing State measures, even of a legislative nature, to a legal review process in which the legitimacy of a State law can be tested by a national judge or competition authority. More particularly, the INNO $v A T A B$ principle has founded the basis for a line of case law establishing an effet

1519 Schwarze J., (2001), 79.

${ }_{1520}$ The EC rules on competition are to be found in Title VI of the EC Treaty, which in its first chapter is divided into two sections; the first contains Articles 81 to $86 \mathrm{EC}$ and is called 'rules applying to undertakings'; the second contains the rules on State aid (Articles 87 to $89 \mathrm{EC}$ ).

1521 Case 13/77, INNO v $A T A B$, [1977], paras. 30-33 (emphasis added). 
utile argument according to which Member States must not defeat the purpose of the Community competition rules.

In the field of professional regulation the principle has been applied with varying results by the Commission and the Community Courts. Two contrasting applications seem to have been made in particular in CNSD on the one hand and Arduino and Macrino on the other. ${ }^{1522}$ In particulat the Commission undertook to give a fresh impetus to subjecting State regulation in the field of the professions to a general proportionality test. ${ }^{1523}$ The purpose of the present chapter is to explore the effectiveness of the constitutional principle as applied by the case law and its potential for future application in the field of professional regulation. First, the foundations of the original line of case law will be mapped. The second part of this chapter will subject the application made thereof by the subsequent case law to a critical teview. In the third part I will contemplate on the legitimate level of competition law control of State measures.

I. A duty on Member States to respect the competition provisions applicable to undertakings

This part will give an overview of the Treaty foundations underlying the duty of Membet States not to adopt or maintain in force any measure that could deprive Articles 81 and $82 \mathrm{EC}$ of their effectiveness. The Treaty's leads towards this duty are to be found in Articles $86(1), 10(2)$ and $3(1)(\mathrm{g})$ EC. Their provisions will be scrutinised from a pros and cons perspective in respect of imposing a duty on the Member States. Finally, a look shall be taken at the changes that the Treaty of Lisbon (if adopted ${ }^{1524}$ ) will introduce with its protocol no. 27 on the internal market and competition.

Like in the landmark decisions Van GenderLoos and Walt Wilbelm the Court in INNO $v$ $A T A B$ emphasised the idea of the practical effectiveness of the Treaty. With their commitment to the EC Treaty - the Court inexotably argued - the Member States have established a new legal order with its own system of law. ${ }^{1.25}$ "It would be contrary to the nature of such a system to allow Member States to introduce or to tetain measures capable of prejudicing the practical effectiveness of the Treaty." 1526 This purpositive interpretation of the Treaty actually paraphrases Article $10 \mathrm{EC}$. While Articles 81 and $82 \mathrm{EC}$ are not directly addressed to Member States but cover behaviour of undertakings, Member States should not be in a position to frustrate Articles 81 and $82 \mathrm{EC} .{ }^{1527}$ It cogently follows from

1522 The cases are summarised in Chapter 2.V.

${ }^{1523}$ See European Commission, Report on Competition in Professional Services, of 09.02.04; European Commission, Professional Services - Scope for more reform, of 05.09.2005. See also the observations of the Commission in Joined Cases C-94/04 and C-202/04, Cippolla and Macrino, [2006]. Compare also AG Jacobs in Joincd Cases C-180-184/98, Pavlov, [2000], paras. $161 \mathrm{ff}$.

1524 Currently, all but one Member State (Ireland) have already approved the Treaty and 23 have deposited their ratification instruments in Rome. The remaining four Member States to deposit are the Czech Republic, Germany, Poland (all in which the Presidents have yet to sign the instrument of ratification) and obviously Ireland.

${ }_{1525}$ Case 26/62, Van Gend J Loos, [1963]; Case 14/68, Walt Wilhelm, [1969], para. 6. See also Case 6/64, Costa $\nu$ ENEL, [1964], 1251, 1270 for the supremacy of EC law.

${ }_{1526}$ Case 14/68, Walt Wilhelm, [1969], para. 6.

${ }^{1527}$ Case 229/83, Leclerc v Au Blé Vert, [1985], para. 14: "Whilst it is true that the rules on competition are concerned with the conduct of undertakings and not with national legislation, Member States are none the less obliged under the second paragraph of [Article $10 \mathrm{EC}$ ] not to detract, by means of national legislation, from the full and uniform application of Community law or from the effectiveness of its implementing measures; nor may 
the case law that with the ratification of the EC Treaty Member States have bound themselves to a legal order that is autonomous from their national legal orders. Accordingly, the Court has developed the concept of effect util, or effectiveness, of Community law. It is a recurring theme in the case law of the Community Courts, which also covers the competition law provisions. The formulation of the INNO $v A T A B$ principle that the Treaty imposes a duty on Member States not to adopt or maintain in force any measure which could deprive the competition rules of their effectiveness therefore is a consequential continuation of the path struck in Van GenderLoos, Costa $v$ ENEL and Walt Wilbelm. The rationale underlying INNO $v A T A B$ is that it would be tather pointless to prevent economic operators from restricting competition if national authorities were entitled to testrict it in ways with the same or similar effects. ${ }^{1528}$ Since Articles 81 and $82 \mathrm{EC}$ are directly addressed at undertakings, the guarantee of the articles' effectiveness means that Member States may not enable private undertakings to escape from the application of these two prohibitions. ${ }^{1529}$ Applied to the field of professional regulation this means that the self-regulatory measures examined in the previous chapters may not escape the competition law scrutiny on the basis that they are adopted on the basis of a national enabling act. ${ }^{1530}$

In controlling State measures contravening the effectiveness of the competition tules the Court assumes a role comparable to that of a constitutional court. ${ }^{1.31}$ While the ECJ does not have the power to invalidate a State measure, it can declare that a measure - even of a legislative nature - is incompatible with the Treaty provisions and that a Member State has failed to fulfil its obligations under those provisions. Such declatation can be made directly in proceedings against a Member State on the basis of Article $226 \mathrm{EC} .{ }^{1532}$ An indirect declaration to the same effect may be made in a preliminary ruling under Article $234 \mathrm{EC}^{1533}$, or in proceedings that the Commission institutes against a self-regulatory association of undertakings on the basis of its powers in the field of competition law. ${ }^{1534}$ Where a Member State enacts or maintains regulation that allows economic operatots to restrict competition, Community law requires that the underlying national regulation has to be 'disapplied'. This entails that the competent national authorities have a duty to disapply the contested national provision. ${ }^{1535}$ Consequently, in the course of an investigation under Community competition law national authorities and courts have the power and the duty to declare national measures contraty to the combined provisions of Articles 10 and 81 or $82 \mathrm{EC}$ where these measures enable economic opetators to escape from the constraints imposed by Articles 81 and/ or 82 EC. ${ }^{1536}$

they introduce or maintain in force measures, even of a legislative nature, which may render ineffective the competition rules applicable to undertakings", with reference to Walt Wilhelm and INNO vATAB.

1528 Temple Lang J., (2001), $208 \mathrm{f}$. NB The same rationale underlies the Treaty rules on State aid, Articles 87 ff. EC. They confirm that the Treaty was intended to set up a comprebensive set of restraints on State action interfering with competition.

${ }_{1529}$ See mostrecently Joined cases T-259/02 to T-264/02 and T-271/02, Raiffeisen Zentralbank, [2006], para. 258; and AG Trstenjak in Case C-531/07, LIBRO, [2008], paras. $126 \mathrm{ff}$.

${ }^{1530}$ (Associations of) Undertakings may, however, invoke this fact as a defense against being fined. For details see below section $\Pi$.3.

1531 Hatje A., (2000), para. 9.

${ }_{1532}$ See for instance Case C-35/96, Commission v Italian Republic (CNSD II), [1998].

1533 For instance Case C-198/01, CIF ע AGCM, [2003].

${ }^{1534}$ For instance Commission Decision CNSD, (1993); Case T-513/93, CNSD III, [2000]; and Commission Decision EPI Code of Conduct, (1999); Case T-144/99, EPI, [2001].

${ }^{1535}$ See Case C-198/01, CIF $\nu A G C M$, [2003], paras. $48 \mathrm{ff}$.

1536 At para. 48 of the $C I F$ judgment the Court explicitly specifies that this duty exists regardless of whether the 
Once more the argument of the Court is that of the effectiveness of the competition rules. ${ }^{1537}$ National competition authorities and courts thereby enjoy a power that is unequalled under national law due to the hierarchy of laws and the separation of powers. A national competition law act cannot normally prevail another national legislative act as they both go back to the authority of national parliament and, consequently, a national competition authority or judicial body cannot overrule a conflicting national measure on the basis of national competition law. This assessment differs when we turn to the EC competition law rules. Here a different hierarchy of norms is put in place the moment the Member States committed themselves to the EC Treaty.

\section{Contemplating Articles 10(2), 3(1)(g) and 86(1) EC}

It shall be indicated that, despite the excellence of extending the logic of $V$ an Gend $\mathscr{O}^{\circ} L$ oos and Walt Wilhelm and the application of three general Treaty provisions, the Court was also criticised for its case law to impose the said duty on Member States in respect of competition law. In particular it has been claimed that the Community should show greater deference to Member States' economic choices and their wisdom in such choices. ${ }^{1538}$ This is a reference to the sovereignty of the parliamentary legislator to the extent that this legislator assumes democratic responsibility for the regulations that it adopts, even where these result in anticompetitive conduct of undertakings. In fact where professional regulation is organised in a semi-public fashion the competence of EC law to monitor competitive processes risks to interfere with the Member States' sovereignty to exercise their original legislative and administrative powers, and more particularly their powers to adopt economic regulation in a field for which the Community has no competence, i.e. the regulation of the professions. In this sense the legal assessment of regulatory interventions in the professional services markets under competition law may threaten the general sovereignty of Member States to adopt economic regulation.

The point is, however, none that would fall under the principle of subsidiarity laid down in Article 5(2) EC, as it does not apply in the field of competition, which belongs to the exclusive competence of the Community. Moreover, since the introduction of Articles 4 and $98 \mathrm{EC}$ by the Treaty of Maastricht, the Member States' sovereignty to adopt economic legislation appears to be an old-fashioned idea. Articles 4 and $98 \mathrm{EC}$ require not only the Community but also Member States to conduct their economic policies "in accordance with the principle of an open market economy with free competition, favouring an efficient allocation of resources, [...]". Thus, under EC law the principle of free competition does not only bind (associations of) undertakings as the direct addressees of Articles 81 and $82 \mathrm{EC}$, but clearly also Member States under Article 10(2) EC in conjunction with those articles. ${ }^{1539}$

State involvement may eventually have the effect of privileging certain groups of professionals to the detriment of others, thereby prejudicing the competitive process and, ultimately, the consumers. Consequently, State legislation and other State measures may be

provision of national law was adopted before or after the relevant Community law rule. To this effect see also Case 106/77, Simmenthal, [1978], paras. $21 \mathrm{ff}$.

1537 Case C-198/01, CIF y AGCM, [2003], para. 50.

1538 Neergaard U.B., (1999), 396.

1539 The Commission made a similar point in respect of Articles 4 and 98 EC in Joined Cases C-94/04 and C202/04, Cipolla and Macrino, [2006]. See also Szyszczak E., (2006), $100 \mathrm{ff}$., pointing out the constitutional character of the principle of free competition as emphasized in the case law. 
steps to manipulate markets in favour of a certain professional group and to the detriment of another. In Wouters, for instance, the national legislator provided the legislative basis for the Dutch lawyers association to adopt rules that result in excluding accountants from competing with lawyers on the same or a new services market. It is, however, difficult to secondguess the motivation of a Member State, i.e. whether it implements economic regulation for reason of ordo-political considerations or rather for reasons of political opportunism (triggered by lobbying). Whether a restrictive professional rule is legitimate, i.e. whether it can be justified under competition law will, however, be dealt with only in the following chapter. ${ }^{1540}$ The present section focusses on the legitimacy of imposing on Member States the duty that derives from Articles $10(2), 86(1)$ and $3(1)(\mathrm{g})$ EC in conjunction with Articles 81 and $82 \mathrm{EC}$.

Legal writers have criticised the Court for having used an unhelp ful legal basis to impose a duty that is not explicitly stated in the Treaty. Critics have based their arguments in particular on the vagueness and lack of legal precision of Article $3(1)$ (g) EC $\mathrm{E}^{1541}$ and the orbiter dictum character that Article $10 \mathrm{EC}$ arguably has in the Treaty. ${ }^{1542}$ On face value Articles $3(1)(\mathrm{g}), 10(2)$ and $86(1) \mathrm{EC}$ do not have direct effect in their own tight because they refer to other provisions of the Treaty that regulate more concretely the activities of the Community. Meanwhile, interpretative use can be made of Articles 3(1) and 10(2) EC in support of a broader interpretation of many other Treaty provisions. ${ }^{1543}$ In a nutshell, the competition prohibitions of Articles 81 and $82 \mathrm{EC}$ are an elaboration of Article 3(1)(g) EC, which reflects one of the aims of the Community that Article 10(2) EC refers to.

\section{The character of Articles 10(2) EC and 3(1)(g) EC}

The INNO $\nu A T A B$ principle formulates a negative integration duty comparable to the explicit prohibition clauses of the free movement tights of goods, persons, services and capital. Its stipulation to control Member State measures is based on the yardstick of Article 10(2) EC. This provision states that Member States "shall abstain from any measure which could jeopardise the attainment of the objectives of this Treaty." The mention of "the objectives of this Treaty" obviously refers to Articles 2 and 3 EC, and for present purposes in particular to Article $3(1)(\mathrm{g})$ EC. ${ }^{1544}$ Hence one can read Article $10(2)$ EC as follows: Member States shall abstain from any measures which could jeopardize the attainment of the institution of a system ensuring that competition in the internal market is not distorted.

It used to be doubted whether Article $10 \mathrm{EC}$ at all constitutes a legally binding rule. It has been said that Article 10(2) EC, together with Article $3 \mathrm{EC}$, merely is a reflection of the

\footnotetext{
${ }^{1540}$ For details see Chapter 7, where policy considerations of public interest will be ventilated, like providing equal access to justice, health carc, or guaranteeing professionalism to the advantage of customers.

1541 Schermers H.G. / Pearson P.J., (1990), 1373.

${ }^{1542}$ See Neergaard U.B., (1998), 23. Schermers H.G. / Pearson P.J., (1990), 1359.

1543 See Neergaard U.B., (1998), 22.

1544 Article 2 EC: "The Community shall have as its task, by establishing a common market and an economic and monetary union and by implementing common policies or activities referred to in $\Lambda$ rticles 3 and 4 , to promote throughout the Community [...] a high degree of competitiveness and convergence of economic performance, [...]." Neergaard U.B., (1998), 22, 28: "Although undistorted competition in Article 3 EC is referred to as an activity that the Community shall include, it is just as correct to perceive it as an objective of the Community". See however Loozen E., (2009), 108, stating that "Onvervalste mededinging is nooit een doelstelling van de Gemeenschap c.q. de Unie geweest", a view which is in conflict with the case law quoted below in note 1553 .
} 
"principle of consideration"1545, which is a principle independent" ${ }^{1546}$ of the "duties of cooperation"1547 or "principle of solidarity". ${ }^{1548}$ Meanwhile the legal value of Article $10 \mathrm{EC}$ has been recognised. ${ }^{1549}$ Notwithstanding, the INNO $v A T A B$ principle has basically been criticised for imposing a duty on $\mathrm{Mcmber}$ States that is not put in more explicit terms in Articles 81 and 82 EC. At first sight this critique sounds plausible when comparing Article 10(2) EC to the negative integration clauses that prohibit Member States in tangible terms to impose trade barriers to the free movement of goods, persons, services and capital in the internal market. ${ }^{1500}$ This comparison raises the question whether the INNO $v A T A B$ principle goes bcyond the distribution of powers as agreed between the Member States in the Treaty.

"Similar to Article [3(1)(g)] EC, Article [10(2)] EC is considered not to have direct effect and it is, as a point of departure, to be characterised as having been written as an orbiter dictum, and consequently without independent legal forcc. Again, however, this provision is applied as a supportive provision when interpreting other Treaty provisions. In fact, Article [10] EC has grown in significance, and is now often seen as filling up holes of Community law. The exact extent of the provision's scope is, however, surrounded with uncertainty and great doctrinal disagreement. It is not possible to find much guidance from the European Court of Justice, as illustrated by the following sentence which has been designated the role of being the European Court of Justice's point of departure when interpreting Article [10(2)] EC: ${ }^{\text {Th }}$ This provision lays down a general duty for the Member States, the actual tenor of which depends in each individual case on the provisions of the Treaty or on the rules detived from its general scheme. ${ }^{1551}$

I disagree with the viewpoint that the Court would have used Article 10(2) EC in a way that exceeds the boundaries of interpretation technique to establish the negative obligation that the INNO $v A T A B$ principle states. The general stipulation of Article 10(2) EC becomes clear when read in conjunction with Articles 81 or 82 EC. Obviously the interpretation of Article $10 \mathrm{EC}$ should not go as far as to replace the original addressees of Articles 81 and $82 \mathrm{EC}$. The case law therefore has carefully emphasised that Articles 10(2) and 86(1) EC prohibit Member States to enable private undertakings to escape their obligations under Articles 81 and $82 \mathrm{EC}$. Therewith, the duty imposed by the Court's case law with reference to Articles $3(1)(\mathrm{g}), 10(2), 86(1)$ and $81 / 82 \mathrm{EC}$ is not without limits. It remains connected to a behaviour of private undertakings that otherwise, i.e. on the basis of a national State measure, would escape the application of the competition rules. ${ }^{1552}$ The INNO $v$ ATAB principle reinforces the objectives of the Treaty to abolish not only trade barriers imposed by State measures but also barriers to free competition originating with undertakings but go back to State measures. Therewith the aim of the EC Treaty under both the free movement rights and the competition provisions is to ensure a level playing field for business and consumers (see also Articles 2, 4 and $98 \mathrm{EC}$ ).

Hence, the duty on Member States to refrain from measures enabling economic actors

1545 "Prinzip der Rüicksichnabmen", Kahl W., (1999), paras. 3 ff., esp. 6 and 8.

1546 Kahl W., (1999), paras. $8 \mathrm{ff.}, 51$ and 52.

1517 Temple Lang J., (1990), 646.

${ }^{1548}$ Ellis E. / Tridimas T., (1995), 71 ff.; Louis J.-V., (1993), 71.

1549 Hatje A., (2000), para. 1.

1550 These articles aim at achieving market integration by prohibiting State measures that hamper market integration. They are therefore called negative integration clauses. See Gyselen L., (2006), $7 \mathrm{f}$.

${ }_{1551}$ Case 78/70, Deutsche Grammophon, [1971], p. 497. The excerpt is taken from Neergaard U.B., (1998), $23 \mathrm{f}$. 1552 From time to time it is discussed whether anti-competitive State measures necessarily require an underlying infringement by the undertakings or their association to find a Member State to have failed to fulfil its obligations under the doctrine of the combined application of Articles $3(1)(\mathrm{g}), 10(2)$ and $81 / 82 \mathrm{EC}$. See $\Lambda \mathrm{G}$ Jacobs in Joincd Cases C-180-184/98, Pavlov, [2000]; see also Joined Cases C-94/04 and C-202/04, Cipolla and Macrino, [2006]. 
to escape from the constraints imposed by Articles 81 and $82 \mathrm{EC}$ is a sensible complement to the enforcement of the Treaty tules on the free movement of goods, persons, services and capital. This complementarity between market integration and undistorted competition is elucidated by the prominent reference to the single market system that the Court made in INNO $v A T A B .^{1553}$ This complementarity and the negative integration force of both can be said to actually find their melting pot in Article 10(2) EC. The latter is a general provision that applies equally to the free movement and competition provisions. As such the provision does not stress a particular role neither of the free movement rights not of the competition provisions in the process of market integration. Yet the Treaty ptovisions on the four freedoms stipulate a negative limit to the economic choices of Member States. It is therefore hardly comprehensible why the imposition of a negative integration requirement following from the combined application of Articles $10(2), 3(1)(\mathrm{g}), 86(1)$ in respect of competition law would mean an undue transgression on the sovereignty of Member States to make economic choices.

What I want to point out is that Article 10(2) EC states the same obligation for Member States in respect of the free movement rights. In contradistinction to the competition provisions the reference to Article 10(2) EC is, however, not required seen the concrete formulation of 'Treaty's negative integration clauses. Consequently, the Court held that

"Article 10 requires Member States to carry out their obligations under Community law in good faith. It is, however, settled case-law that this provision cannot be applied independently when the situation concemed is governed by a specific provision of the Treaty."

This quote first of all demonstrates that Article $10 \mathrm{EC}$ combines even with specific Treaty provisions like the negative integration clauses of the free movement rights. Moreover, it indicates that Article $10 \mathrm{EC}$ only tips the scales, and actually does so, where no such provision specifies the duties of the Member States. This means that in respect of competition law Article 10(2) EC is the correct legal source, while the competition prohibitions are the yardstick to ascertain the concrete content of the general negative integration duty of Member States. Therewith the legal review of State measures under Article 10(2) EC serves a similar function as the control mechanism of the Treaty's free movement rules. Both review mechanisms fundamentally have the same constitutional character in respect of the legitimacy of State measures. While the fundamental freedom rules prevent trade bartiers imposed by Member States or collective regulation, Article $10(2) \mathrm{EC}$ in conjunction with the competition law provisions aims at preventing Member States from enabling economic operators to maintain similar bartiers by restricting competition in the internal market. Thus, the INNO $v A T A B$ principle does not extent the scope of the competition prohibitions ratione personae, but corroborates and specifies the

${ }^{1553}$ See paras. 28 and 29 of the judgment in INNO $v$ AT AB: "First, the single market system which the Treaty secks to create excludes any national system of regulation hindering directly or indirectly, actually or potentially, trade within the Community. Secondly, the general objective set out in Article $[3(1)(\mathrm{g}) \mathrm{EC}]$ is made specific in several Treaty provisions concerning the rules on competition, including Article $[82 \mathrm{EC}]$, which states that any abuse by one or more undertakings of a dominant position shall be prohibited as incompatible with the common market in so far as it may affect trade between Member States." Gyselen L., (2006), 8: "In essence, according to the Court there is an implied constitutional limitation on anti-competitive state measures that supplements the E.C. Treaty's 'negative integration' provisions which impose express constitutional limitations on state measures restricting the free movement of goods, persons, services and capital or which create specific distortions of competition (e.g., legal monopolies). States are therefore - in principle - liable for adopting anti-competitive measures."

${ }^{1554}$ Case C-387/93, Banchero, [1995], para. 17. 
original responsibility of Member States in adopting measures that impact on the internal market. The thus limited weight of competition law in respect of State measures is ensured by the fact that the INNO $\vee A T A B$ principle applies only to instances in which a Member State enables economic operators to escape their own obligations under Articles 81 and $82 \mathrm{EC}$.

The critique on the INNO $y A T A B$ principle has also stressed that Atticle $3(1)(\mathrm{g}) \mathrm{EC}$ is not suited to impose a concrete obligation on Member States. Since Article 3 EC establishes a number of the aims of the Treaty that ate mainly implemented by the more concrete provisions of the Third Part of the Treaty, the critique on imposing a duty on Member States in respect of competition law is that Article 3(1)(g) EC "does not contain separate rights and obligations of the Member States, the citizens and the companies, as these ate to be found among other Treaty provisions and various legislation enacted by the institutions of the Community." "I555 In a nutshell the critique is that the Court's reference to Article $3(1)(\mathrm{g}) \mathrm{EC}$ is a creative, if not abusive, use of the provision in that it leads to the imposition of a direct obligation on the Member States. Conversely, the provision's equivalent for the field of the four freedoms, lit. (c), does not - and in fact does not need to - inflict a creative obligation based on Article $10 \mathrm{EC}$. This is due to the fact that the Treaty's free movement provisions directly order Member States not to hamper the realisation of the aims expressed in Article 3(1)(c) EC. From the critics' point of view Articles 81 and $82 \mathrm{EC}$ do not order direct obligations on Member States, and the reverse conclusion should be that Article 3(1)(g) EC cannot impose something that is not foreseen in the relevant Treaty provisions implementing Article $3 \mathrm{EC}$.

The critique on the INNO v $A T A B$ principle can thus be summarised as follows. Article 3(1) (g) EC is not formulated in any more concrete terms than is Article 3(1)(c) EC, and even in combination with Article 10(2) EC these articles do not particularly add to the concreteness of the obligations formulated in Articles 81 and $82 \mathrm{EC}$ with the envisaged consequence of extending their law to the Member States. In contradistinction, Articles $25 \mathrm{EC}$ etc. are directly addressed to Member States and therefore one does not need to have recourse to Articles 3(1) and 10(2) EC for their effectiveness vis-à-vis Member States. While it can be drawn on Articles 3(1) and 10(2) EC for the interpretation of the obligations stated in Articles $25 \mathrm{EC}$ etc., they could not justify the imposition of obligations that are not put in the wording of Articles 81 and $82 \mathrm{EC}$. The critique thus is that the reference to Articles $3(1)(\mathrm{g})$ and 10(2) EC is more than an interpretation of Articles 81 and $82 \mathrm{EC}$ and actually would impose additional obligations.

In essence the critique seems to be once more that the respective scope of Articles 81 and $82 \mathrm{EC}$ would be broadened rationae personae. In excess to the explanation given before it can be observed that the attempt to debilitate the INNO $\vee A T A B$ principle on this point is limited where it is based on the comparison of the negative integration provisions in the field of free movement with the lack of comparable prohibitions written into the Treaty chapter on competition. Also in the field of free movement the Court has used the effet util argument to extend the scope of Treaty provisions to parties that originally were no addressees thereof. 'Thus, the Court established the horizontal direct effect of certain Treaty rules originally aimed to cover State measures. In particular with reference to Article $3(1)$ (c) EC and the internal market aim of abolishing trade barriers the case law imposes obligations also on private parties, who are not explicitly mentioned in, for instance, Articles 39 and 43 EC. ${ }^{1556}$ Moreover, more recent case law evidences that the critique in

1555 Neergaard U.B., (1998), $21 \mathrm{f}$.

1556 On collective regulation infringing the free movement rules see for instance Case 36/74, Walrave and Koch, 
respect of Article 3(1)(g) EC may have become obsolete. For instance, in the Italian Customs Officers case CNSD the Court let go of the reference to Article 3(1)(g) EC. ${ }^{1557}$

\section{Parallelism between Article 86(1) EC and the general duty under Articles 10(2) EC}

To round off the picture on the legitimacy of the INNO $v A T A B$ principle it is necessaty to take a closer look at the third general provision that the judgment tefers to, Article 86(1) EC states that "In the case of public undertakings and undertakings to which Member States grant special or exclusive tights, Member States shall neither enact nor maintain in force any measure contraty to the rules contained in this Treaty, in particular to those rules provided for in Article 12 and Articles 81 to 89." Despite its place in the Treaty chapter on competition the provision is of general application. ${ }^{1558}$ It teminds Member States that the obligations to which they have committed themselves under the EC Treaty ate applicable also, or rather even ${ }^{1559}$, in case of public undertakings and undertakings to which they grant special or exclusive rights. Apart from this qualification the provision reads like a paraphrase of Article $10 \mathrm{EC}$. "Neither enact nor maintain in force any measure contrary" to the Treaty rules corresponds to the wording according to which Member States must "abstain from any measure which could jeopardise the attainment of the objectives of this 'Treaty". The particular reference to Articles 12 and 81 to $89 \mathrm{EC}$ does not change this reading as it is emphasising those provisions but not limiting the scope of Article 86(1) EC. Its value can be understood as either the justification to place Article 86(1) EC in the Treaty chapter on competition or, rather, as a token of reinforcing the importance of the competition rules for the attainment of the internal market. ${ }^{1560}$ It is this emphasis that Article 10(2) EC omits and triggered the critique (presented above) on the combined application of Articles 10(2), 3(1)(g) and 81/82 EC. Therefore, if Articles 10(2) and 86(1) EC state the same law, it can easily be concluded that the reference to Article 3(1)(g) EC indeed is a correct, but marginal authority in subjecting Member States to obligations in respect of EC competition law.

The only caveat that distinguishes the general rule of Article 86(1) EC from Article 10(2) EC is the reference to public undertakings and undertakings to which Member States grant special of exclusive tights. The scope of Article $86(1)$ EC is limited to these types of certain undertakings, while Article $10 \mathrm{EC}$ is open in this respect. Therefore, the

[1974], paras. 18 f.; Case 43/75, Defrenne II, [1976]; Case C-415/93, Bosman, [1995]; Case C-281/98, Angonese, [2000]; Case C-438/05, Finnish Seamen's Union v Viking Line, [2007]; Case C-341/05, Laval un Partneri, [2007]. See also Baquero Cruz J., (2002), ch 7.

${ }_{1557}$ Case C-35/96, Commission v Italian Republic (CNSD II), [1998]. See already Case 13/77, INNO v ATAB, [1977], paras. 28-33, where Article 3(1)(g) EC has been used as a starting point, but where the Court finally has stressed the fundamental role of the specific competition law provisions.

${ }^{1558}$ See for instance Case T-266/97, Vlaamse Televisie Maatschapij NV v Commission, [1999].

1559 Sce Temple Lang J., (2001), 207, 211, stressing correctly that Article 86(1) EC "would be clearer if it had been written 'Even in the case of public undertakings... (and a fortiori in the case of all other enterprises) Member States shall not enact or maintain...' To further substantiate his point he refers to Article 86(3) EC which "creates a specially effective procedure (which the Commission is unfortunately reluctant to use) for dealing with State measures relating to the enterprises referred to in Article 86(1), and it [bcing Article 86(1) EC] creates the exception to normal rules found in Article 86(2), but it does not create any other special rule of any kind. That is why the Court has said that it is only an example of the general principle stated in Article 10." See Case 13/77, INNO ע $A T A B,[1977]$, paras. $30 \mathrm{f}$.

1560 Article 12 EC prohibits any discrimination on grounds of nationality, which is the most shrill form of discrimination leading to a compartmentalisation of the common market along national borders. 
Court in INNO vATAB came to the conclusion that Article 86(1) EC "is only a particular application of certain general principles which bind the Member States". ${ }^{1561}$ Article 86(1) EC thus is a lex specialis to Article 10(2) EC. Meanwhile, the case law has specified that "The obligations which Member States must perform in good faith under Article [10 EC] include the obligation, set out in Article [86(1) EC]". ${ }^{152}$ The use of the word "include" can be interpreted as follows. Based on their textual congruence, Article 86(1) EC can be said to cover specific cases in an identical manner to Article 10(2) EC, namely in tespect of "certain general principles which bind Member States". Consequently, Article 10(2) EC can be read as stating the same substantive rule as Article 86(1) EC, albeit without the specification on public undertakings and undertakings to which a Member State has granted special or exclusive rights. It therefore is not important whether the power of an association to adopt professional regulation can be qualified as a special or exclusive right in the sense of Article 86(1) EC. The national measure eventually enabling a restriction of competition can in any event be tested under Article 10(2) EC. ${ }^{1563}$

On the basis of the foregoing it can be concluded that the combined application of Article $10(2)$ and 81 or $82 \mathrm{EC}$ does not constitute a judge made law but a consequent, i.e. a comparative, reading of Articles $86(1)$ and $10(2) \mathrm{EC}$ that remains within the boundaries of the interpretation of the law. In fact, Article 86(1) EC can be understood to make up for any vagueness possibly contained in the wording of Articles $10(2)$ and $3(1)(\mathrm{g})$ EC. With its reference to all three these articles the INNO $v A T A B$ ptinciple ${ }^{1564}$ confirms the point. Moteover, the comparison made before to the Treaty's provisions on the free movement of goods, persons, services and capital demonstrates that the negative integration chatacter of the INNO $\vee A T A B$ principle is nothing new. In fact it is necessary from a constitutional point of view that requires the possibility to legal review of State measures. Moreover, the requirements of the constitutional principle of democracy, neither in its Community guise in the Treaty nor its recognition at Member State level, conflicts fundamentally with the imposition of obligations on Member States - at least as long as those obligations can be deducted from the Treaty with sufficient certainty. ${ }^{1565}$ The relevant obligations on Member States in respect of competition law have been correctly delimited by the case law, which crucially stresses that Member States may not enable economic operators to escape from the application of Articles 81 and 82 EC. ${ }^{1566}$

\section{Contemplating Protocol no 27 on the internal market and competition (Treaty of Lisbon)}

The Treaty of Maastricht's introduction of the obligation of Member States to conduct their economic policies in accordance with the principle of an open market economy with free competition (Articles 4 and 98 EC) has evidenced, right after the fall of various

${ }^{1561}$ Case 13/77, INNO $ข A T A B$, [1977], para. 42: "it has already been indicated in [paras. 30-33 of the judgement] that in any case Article [86 EC] is only a particular application of certain general principles which bind the Member States". See also Schwarze J., (2001), 95 f.; Hochbaum, (1999), para. 5; Temple I.ang J., (2001), 219. ${ }_{1562}$ Case C-387/93, Bancbero, [1995], para. 46. See also above note 1559.

${ }^{1563}$ This comprehension should not be detracted by the existence of what appears to be two different branches of case law, depending on whether the conjunction with Articles 81 or $82 \mathrm{EC}$ is based on Article 10(2) EC or Article 86(1) EC. Refcrence to the latter article is usually made in cases concerning the liberalisation of (network) utilities.

1564 Paras. $28-33$ and 42 of the judgment in INNO $v A T A B$.

1565 Sec also Steinberger D., (1994), $3 \mathrm{ff}$.

${ }^{1566}$ For details on this connecting factor see below part II of this chapter. 
communistic tegimes in Europe, an enthusiasm for less State intervention in market processes; however, the most recent negotiations for the reform of the EU and EC Treaties may indicate a dwindling thercof. At the EU summit in June 2007 the French president Sarkozy had managed to have the wording of Article 3(1)(g) EC removed from what will become the Treaty on the Functioning of the European Union. ${ }^{1567}$ Upon intervention of the British government, however, a protocol has been annexed to the prospective reformed Treaties on European Union (TEU) and on the Functioning of the European Union (TFEU) $)^{1568}$, in which it is stated that "the internal market as set out in Article 3 of the Treaty on European Union includes a system ensuring that competition is not distorted" ${ }^{1569}$ Thus, what seems to be a cutback, at first glance, in the objectives and purposes of the Union requires a more thotough scrutiny of the text of both reformed Treaties.

From the previous analysis of the current Treaty provisions it follows that Article 10(2) EC is the foundation for the Member States' duty to abstain from measures that enable (associations of) undertakings to act in conflict with the competition law provisions. Under the Treaty of Lisbon this article will make promotion from the EC Treaty to Article 4(3) TEU, therewith imposing on Member States the duty to abstain from jeopardising any of the objectives of the European Union. ${ }^{1570}$ At this juncture the question is whether a system of undistorted competition will still be an objective of the Union, with the consequence that the INNO $\vee A T A B$ principle will temain intact, or even be reinforced, in the future.

The reference of Article 4(3) TEU (Article 10(2) EC) to the Union's tasks and objectives should not in the first place be interpreted to refer to a protocol ${ }^{1571}$, despite the fact that according to Article 51 TEU (Article $311 \mathrm{EC}$ ) protocols to the Treaties form an integral part thereof. First of all, the Union's tasks and objectives mentioned in Article 4(3) TEU refer to the relevant Tteaty articles of both the TEU and TFEU. The most important reference point will be Article 3(3) TEU, which states that "The Union shall establish an internal

1567 The media referred to this action by the French president as 'coup Sarkozy'. The Financial Times, on 25.07.2007, quoted the question the French president asked during the European Union summit "Competition as an ideology, as a dogma: what has it done for Europe?", to retort acutely: "It is a good question, perhaps best answered by the citizens of Estonia or the Czech Republic, new EU member states with painful memories of what an economy without free competition looks like." See $<$ http://us.ft.com/ftgateway/superpage.ft?news_id=fto062520071427051645>.

1568 Article 1(3) TEU: 'The Union shall be founded on the present'Treaty and on the Treaty on the Functioning of the European Union (hereinafter referred to as 'the Treaties'). Those two Treaties shall have the same legal value. The Union shall replace and succeed the European Community." NB To avoid all risk of confusion about the version of an article the following abbreviations are used in this book: EC for the EC Treaty and EU for the Treaty on European Union when referring to the numbering of the articles after the Treaty of Amsterdam (see also "Note on the citation of articles of the Treaties in the publications of the Court of Justice and the Court of First Instance", at <http://curia.europa.eu/en/content/juris/index_infos.htm>); TEU for the Treaty on European Union and TFEU for the Treaty on the Functioning of the European Union when referring to the numbering of the articles after the Reform Treaty of Lisbon.

1569 Protocol (No 27) on the Internal Market and Competition, OJ C 115, 09.05.2008, p. 309.

1570 Article $10 \mathrm{EC}$ will remain unchanged except for textual adaptations in the English version, which the French and German version, for instance, will not undergo.

1571 Riley V.A., (2007), $705 \mathrm{f}$., who is sceptic about a devaluation of Article 3(1)(g) EC and the case law on the combined application of Articles 10(2), 3(1)(g) in conjunction with Articles 81 and $82 \mathrm{EC}$ - In fact, I may agree with one of his arguments, namely that the Preamble and the first few articles of the Treaty have a special interpretative effect compared with other provisions of the Treaty. However, Riley focusses exclusively on the EC Treaty and what he calls the excision of Article $3(1)(\mathrm{g})$ EC without taking account of the other changes in both the TEU and the TFEU described here. 
market. It shall work for the sustainable development of Europe based on [...] a bighly competitive social market economy, [...]." ${ }^{\prime 1572}$ With its placing in the TEU this aim of competition policy will reemerge in a fortified manner. Secondly, the purposes and objectives of Article 3 TEU are explicitly referred to in Article 119 TFEU (Article $4 \mathrm{EC}$ ) and Article 120 TFEU (Article $98 \mathrm{EC}$ ). In the adoption of economic policies both the Member States and the Union shall act in accordance with the principle of an open market economy with free competition, favouring an efficient allocation of resources. In other words, this principle of an open market economy with free competition shall explicitly be followed in achieving the objectives and purposes of Article $3 \mathrm{TEU}$, including the establishment of the internal market, which in turn is to be based on a highly competitive market economy. Thirdly, Article 3(1)(b) TFEU will reinforce the exclusive competence of the Union for "the establishing of the competition rules necessary for the functioning of the internal market". This provision, almost stronger than Protocol No 27, emphasises the amalgamation of the internal market and undistorted competition since it inherently affirms that the competition rules are necessary for the functioning of the internal market. ${ }^{1573}$ This viewpoint is finally confirmed by Protocol No 27 with its consideration that the internal market includes a system ensuring that competition is not distorted.

Thus, what seemed to be a coup against free competition at first sight reveals to be merely a coup de main that cannot undermine the value and legitimacy of the INNO $v$ $A T A B$ principle, merely because the text of Article 3(1)(g) EC will be relocated to Protocol No 27 under the Treaty of Lisbon. Three considerations in particular document this point. First, the more recent case law on the INNO $v A T A B$ principle has let go of Article $3(1)(\mathrm{g}) \mathrm{EC}$ to mainly emphasise Article $10 \mathrm{EC}$ as reference point for the Membet States' duty not to adopt or maintain in force any measure that could deprive Articles 81 or $82 \mathrm{EC}$ (Articles 101 and 102 TFEU) of their effectiveness. Second, the interpretation of Article 4(3) TEU will continue to benefit from the lex specialis provision of Article 86(1) EC (Article 106(1) TFEU). Third, Protocol No 27 has the same legally binding force than the Treaties' provisions themselves (Article $311 \mathrm{EC}$; Article $51 \mathrm{TEU}$ ). Therefore, I disagree that the objective of undistorted competition "risks becoming a point of interest in legal arguments, not a starting point." 1574

${ }^{1572}$ Compare with Article 2 EC: "The Community shall have as its task, by establishing a common market and an economic and monetary union and by implementing common policies or activities referred to in Articles 3 and 4 , to promote throughout the Community $[. .$.$] a high degree of competitiveness and convergence of economic$ performance, [...]." - In the current EU Treaty only Article 43(f) requires that enhanced cooperation between Member States "does not constitute a barrier to or discrimination in trade between the Member States and docs not distort competition between them".

${ }^{1573}$ See also Steenbergen ]., (2008), [under heading 4.3, sentence with fn 19]: “Volgens het Protocol betreffende de interne markt en de mededinging impliceert het tot stand brengen van de interne markt immers dat er een regime is dat verzekert dat de mededinging niet wordt verstoord. Het mededingingsbeleid is dus in de logica van art. 3 VEU een kerntaak van de Unie die echter wel gezien moet worden in het perspecief van het realiseren van de interne markt. Verder is het mededingingsbeleid een instrument voor het bevorderen van het concurrentievermogen en duurzame werkgelegenheid."

1574 The Financial Times of 25.06.2007, <http://us.ft.com/ftgateway/superpage.ft?news $\mathrm{id}=$ fto062520071427051645>. On the basis of the arguments made here I also disagree with Riley V.A., (2007), 703, who "argues that the agreement reached by the Member States in June [2007] to remove the competition phrase contained in Art.3(1)(g) EC from the new Reform Treaty [...] and create a 'competition protocol' which includes the words from $A r t .3(1)(\mathrm{g})$ is inadequate to protect the current competition acquis and the healthy future development of Community competition law." See also Steenbergen J., (2008) [at the end]: "De Unie is dus echt iets anders dan een staatsrechtelijke structuur die alleen een kader creëertvoor het vocren van een beleid (of mecr algemeen voor de uitoefening van staatsmacht). De Unie blijft ook na het Verdrag van Lissabon een sui generis 


\section{Summary}

The internal market as an area without frontiers is more than the guarantee of the free movement of goods, persons, services and capital. Article 14(2) EC stresses that this guarantee "is ensured in accordance with the provisions of this Treaty". This includes "a system ensuring that competition in the internal market is not distorted". ${ }^{1575}$ In this it is logic that the new Article 3(1)(b) TFEU restates the fact that "the competition rules [are] necessary for the functioning of the internal market". The EC competition law rules are the necessary complement to the negative integration clauses contained in the Treaty provisions on the free movement of goods, persons, services and capital. Article 10(2) EC reinforces the negative integration obligation of Member States not only in respect of the Treaty's free movement provisions ${ }^{1576}$, but also in respect of the principle vetbalised in Article 86(1) EC. Accordingly, "Member States shall neither enact nor maintain in force any measure contrary to the rules contained in [...] Articles 81 to 89 ". While the competition law provisions are addressed to undertakings and their associations, the effet util of these provisions require that Member States take responsibility for enabling (an association of) undertakings to raise the defence that the conduct restrictive of competition had been induced by a State measure. ${ }^{1577}$ Due to Articles 4 and $98 \mathrm{EC}$, introduced by the Treaty of Maastricht, the idea of the Member States' sovereignty to adopt economic legislation has become an old-fashioned idea as these articles require Member States to conduct their economic policies "in accordance with the principle of an open market economy with free competition, favouring an efficient allocation of resources, [....".

\section{Case law built standard to control State intervention in self-regulatory markets}

While the previous part has introduced the Treaty foundations underlying the duty of Member States not to adopt or maintain in force any measure that could deprive Articles 81 and $82 \mathrm{EC}$ of their effectiveness, this part will turn to the application made of the INNO $\nu$ $A T A B$ principle in the subsequent case law, and in particular in the field of professional regulation. As explained in the previous part the emphasis of the principle that a Member State may not enable private undertakings to escape from the constraints imposed by Articles 81 and $82^{1578}$ refers to the legal responsibility that Member States have to assume for interfering with market conduct of economic operators.

Over the years the Court has developed a yardstick to test State regulation in respect of the competition law requirements by interpreting the Member States obligation under Articles 10 and 86(1) EC in order to cover a harmful gap between EC competition rules and national anti-competitive measures. This yardstick has taken a final shape in Van Eycke ${ }^{1579}$ (in respect of Article 81(1) EC) and in Spediporto ${ }^{1580}$ (in respect of Article $82 \mathrm{EC}$ ) and will be presented in the following section. Despite the fundamental character of the INNO $\nu A T A B$

entiteit met min of meer limitatief omschreven, min of meer gebonden, maar alleszins niet discretionaire gedelegeerde bevoegdheden (art. 4 VEU)."

1575 Art. 3(1)(g) EC and Protocol no 27 to the Treaty of Lisbon.

1576 For an even more far-reaching obligation under Article $10 \mathrm{EC}$ and the free movement of goods see for instance C-265/95, French Farmers case, [1997], para. 32; Case C-112/00, Schmidberger, [2003], paras. 57 ff.

1577 For details on the State compulsion defence, see below section II.3.

1578 Case $13 / 77$, INNO $v A T A B,[1977]$, para. 33.

1579 Case 267/86, Van Eycke, [1988].

1580 Case C-96/94, Spediporto, [1995]. 
principle being reiterated by the case law to the present day ${ }^{1581}$, only few cases have concluded on the actual infringement by a State of Article $10 \mathrm{EC}$ in conjunction with the competition law requirements. ${ }^{1582}$ In particular, it took the Court 20 years before disapptoving a State measure in the field of professional regulation. ${ }^{1583}$ The second section will turn to scrutinise the considerations that have guided the Court in its positive and negative applications of the INNO $v A T A B$ principle in the field of professional regulation and subject them to a critical review.

\section{The application of the INNO $v$ ATAB principle}

The Court in INNO v ATAB established a comprehensive duty for Member States in respect of both Articles 81 and $82 \mathrm{EC}$. In respect of both articles the Court had the occasion to specify the yardstick to be applied on the basis of the INNO $v A T A B$ principle.

\subsection{Member States' duty in respect of Article 81 EC: the Van Eycke standard}

The development that the Court had kicked off in Walt Wilhelm and INNO $v$ ATAB culminated in a formula established in the Van Eycke case, which has become settled case law. ${ }^{1584}$ The formula reiterates that a Member State must neither introduce nor maintain in force any measure, even of a legislative nature, that may render ineffective the competition rules applicable to undertakings and their associations. The Van Eycke formula specifies that a Member State renders the competition rules ineffective if it

"were to require or favour the adoption of agreements, decisions or concerted practices contrary to [Article $81 \mathrm{EC}$ ] or to reinforce their effects, or to deprive its own legislation of its official character by delegating to private traders responsibility for taking decisions affecting the economic spherc". 1585

The quote reveals that the Court envisages three situations in particular in which a Member State can be found to frustrate the effet util of Article 81 EC. First of all, a Member State must not require or favour that undertakings or their association adopt methods that are prohibited under Article $81 \mathrm{EC}$ (which have here been discussed in Chapter 4.II.). The first instance thus describes a situation in which a State measure initiates an infringement of Article $81 \mathrm{EC}$ by (an association of) economic operators. In this instance the question is whether the State measure was intended to require or favour the adoption of new restrictive

1581 For a concise overview on the development towards INNO $\nu A T A B$ and the application made thereof in the case law in the 20 years following INNO $\nu A T A B$, see Bøegh Henriksen U., (1994) and Neergaard U.B., (1998).

${ }^{1582}$ The first being Case 311/85, Vlaamse Reisbureaus, [1987]. There are only three other cases so far in which the Court concluded that a Member State had failed to fulfil its obligations under the combined articles, see Case 136/86, BNIC v Aubert, [1987]; Case 66/86, Abmed Saeed, [1989]; and Case C-35/96, Commission v Italian Republic (CNSD II), [1998].

${ }_{1583}$ Case C-35/96, Commission vItalian Republic (CNSD II), [1998]. The case will be discussed in some detail below. 1584 The Court in Case 267/86, Van Eycke, [1988], para. 16, stressed that already before it had "consistently held [...] that Articles [ 81 and $82 \mathrm{EC}$, in conjunction with Article [10 EC], require the Member States not to introduce or maintain in force measures, even of a legislative nature, which may render ineffective the competition rules applicable to undertakings", referring not only to INNO $v A T A B$, but also to Walt Wilhelm and Leclerc $v A u B l e ́$ Vert.

${ }^{1585}$ Case 267/86, Van Eycke, [1988], para. 16 (emphasis added). The formula has found manifold academic attention. For the development of the case law before and after van Eycke, see Neergaard U.B., (1998); Castillo de la Torre F., (2005). 
agreements or the implementation of new practices. ${ }^{1586}$ The effet util of competition law would be frustrated by a State measure where the (association of) undertakings could legitimately taise the defence that they could not doubt the validity of the State measure as a result of which they adopted or implemented new methods restrictive of competition. ${ }^{1587}$ In fact, the (association of) undertakings would be confronted with a conflict between the directly effective EC competition law provisions and the national law, both of which they must assume to be valid, but which give conflicting orders. This conflict endangers legal certainty where in fact it would allow a State measures to deliver (an association of) undertakings to (or screen it from) the application of EC competition law without calling the Member State to account for the inducement that its (legislative) act provided for the (association of) undertakings to adopt measures having the object or effect to restrict competition.

Similarly, a Mcmber State has to assume responsibility under Article $10 \mathrm{EC}$ where it reinforces the effects of anti-competitive conduct of (an association of) undertakings. The Court "has consistently held [that] legislation may be regarded as intended to reinforce the effects of pre-existing agreements, decisions or concerted practices only if it incorporates either wholly or in part the terms of agreements concluded between undertakings and requires or encourages compliance on the part of those undertakings." ${ }^{1588}$ This is the case where a State measurc affirms a decision or an agreement by 'rubber-stamping' the content thereof, for instance by adopting its content into a ministerial decree. ${ }^{1589}$ The Court stresses that by reinforcing in this way the effects of pre-existing coordination of economic conduct, a Member State confers upon the method adopted by a professional association or its members the appeatance of official regulation and facilitates the application of the method in the relevant sector. ${ }^{1590}$

In a thitd situation the Van Eycke formula prohibits Member States to deprive their legislation of its official character. This is the casc where a Member State would delegate to private traders the responsibility for taking decisions that affect the economic sphere, i.e. basically to adopt economic regulation. The third limb of the Van Eycke standard describes the scenario of a legislator who allows economic operators to assume the Member State's responsibility of public authority to interfere with the functioning of markets. As the Member State thereby does not retain full responsibility for the restriction of the freedom of action of market players, it desists from its legislatives prerogatives to the benefit of certain undertakings and does so to the detriment of competition. First of all, the question is whether delegation has taken place. Certainly 'delegation' does not need to be understood in a formal sense since the requirements of EC competition law are established autonomously from any national interpretation thereof. ${ }^{1591}$ Some distinguishable State act capable of rendering ineffective the competition rules applicable to undertakings is necessary though. In other words, only where a positive State act exists is a first step taken towards the

\footnotetext{
1586 Case 267/86, Van Eycke, [1988], para. 17.

1587 For details on the State compulsion defence, see below section II.3.

1588 Case 267/86, Van Eycke, [1988], para. 18.

1589 In other words, a Member State infringes Article 10 where a (professional) association adopts rules restrictive of competition either at the instigation of the Member State (first prong: "if the Member State were to require or favour the adoption...") or 'of its own motion', but with the subsequent approval by the State authorities (second prong: if the Member State were to "reinforce their cffects"). See Case 311/85, Vlaamse Reisbureaus, [1987]; Case 136/86, BNIC v Aubert, [1987]; Case 66/86, Abmed Saeed, [1989].

1590 Case C-35/96, Commission y Italian Republic (CNSD II), [1998], para. 59

1591 See already Chapter 3.I. and Chapter 4.I.
} 
Member State's liability for infringing its duties in respect of the third prong. ${ }^{1592}$ The next step under the third limb of Van Eycke is to verify whether the State measure concedes economic actors and/ or their representatives the capacity to affect the economic sphere through, for instance the enactment of professional regulation that will have the effect of restricting competition (e.g. where relative prices for professional services are raised).

The Van Eycke test thus presents itself in three prongs, which are alternatives that are to be read disjunctively. This follows from the formulation of the Court using the conjunction 'or' between the limbs. Moreover, each limb describes a distinguishable type of situation. Its first two limbs clearly require a link between, on the one hand, the State measure and, on the other, the conduct of the (association of) undertakings. The rationale of the case law on the application of Article $10 \mathrm{EC}$ in conjunction with Article $81 \mathrm{EC}$ is that a Member State actively assumes a responsible role in the conduct of (an association of) undertakings, which in turn results in the restriction of competition. In essence the difference between the first two instances covered by the Van Eycke formula is one of sequence, where the relevant question is whether the conduct of (an association of) undertakings took place before or after the State measure that underpins the content thereof. ${ }^{1593}$

The first two prongs can furthermore be distinguished from the last one with regard to the roles that economic operators and Member States respectively take in the process of adopting and implementing professional regulations. ${ }^{1594}$ Mores specifically, the assessment of State measures under the last limb is construed differently. Instead of associating a State measure directly with an anti-competitive conduct by undertakings (and the effects thereof) the last prong refers to a Member State that undermines and renders illusionary the official character of its own legislation or authoritative measures. It is this aim of the thitd prong of the Van Eycke test that has been referred to as a "double-sided". ${ }^{1595}$ This double-sidedness intends, first, to catch situations where the delegated powers bring the empowered collectivity together as if they were bound by an anti-competitive agreement, decision or concerted practice and, secondly, it intends to catch situations in which "the delegated regulatory power is in reality not an expression of an affirmatively articulated State policy, but rather a cover designed to make it possible [for (associations of) undertakings] to engage in anti-competitive acts to the detriment of the achievement of the aims of the Community. ${ }^{.1596}$ Such situation must be distinguished from a Member State that retains full democtatic responsibility for rules having an impact on the market conditions of a particular sector. The latter type of rules constitutes genuine economic regulation outside the scope of

1592 Not covered by the third Van Eycke limb is the omission of a Member State to put a stop to anti-competitive conduct of an (association of) undertaking(s). The Member State can be hold responsible for a different type of omission only under Van Eycke, namely where it neglects to repeal a positive State measures as described just before.

1593 The first two prongs of the Van Eycke standard are barely controversial in legal writing. Neergaard U.B., (1998), 117, stresses that the strength of the first two limbs is that they are faitly logical, i.e. that they are not too removed from an immediate reading of Articles 3(1)(g), 10(2) and 81 EC. Sec, however, Chung C.-M., (1995), 90 , advocating a reinforced effet util approach. Conversely, Gyselen L., (2006), states that the first two prongs of the $V$ an Eycke standard have kept little relevance nowadays.

1594 See Gyselen L., (2006); Gilliams H., (2006). AG Poiares Maduro in Cases C-94/04 and C-202/04, Cipolla and Macrito, [2006], paras. $31 \mathrm{f}$.

${ }^{1595}$ Neergaard U.B., (1998), $118 \mathrm{f}$.

1596 See Fenger N. / Broberg M.P., (1995), $365 \mathrm{f}$. Neergaard's conclusion is that the double-sided aim is far more distant from a more immediate reading of Articles 3,10 and $81 \mathrm{EC}$ than the first two limbs of Van Eycke, and far more complicated. For details see below sections II.2.1. and II.2.2. 
Article $81 \mathrm{EC}^{1597}$ - at least as long as such rules do not fall under the first two prongs of $V a n$ Eycke, i.e. that they do not to require or favour the adoption or implementation of new restrictive methods and do not reinforce the effects thereof.

\subsection{Member States' duty in respect of Article 82 EC: the Spediporto test}

The application of Article $10 \mathrm{EC}$ in conjunction with Article $82 \mathrm{EC}$ found its first application in INNO $v A T A B$ itself..$^{1598}$ From this case law it follows that a national measure which has the effect of facilitating the abuse of a dominant position and capable of affecting trade between Member States will generally be incompatible with Community law. ${ }^{1599}$ The Court emphasised that in order to assess the compatibility of a national measure with Article $82 \mathrm{EC}$, in conjunction with Article $3(1)(\mathrm{g}) \mathrm{EC}$ and the second paragraph of Article $10 \mathrm{EC}$, it must be determined whether the legislative arrangements might encourage any abuse of a dominant position. ${ }^{1600}$

The focus of the ruling on facilitating and encouraging merits two observations. First of all, it is noticeable how similar INNO $\cup A T A B$ reads, in respect of Article $82 \mathrm{EC}$, when compared to the first prong of the Van Eycke standard applied to State measures in respect of Article $81 \mathrm{EC}$. Thus, under Article 10(2) EC a Member State is prohibited to facilitate, encourage, require or favour either conduct prohibited under Articles 81 and 82 EC respectively. Secondly, it follows the question whether also the second and third limb of the Van Eycke formula can be extrapolated to the duty of a Member State in respect of Article 82 EC. ${ }^{1601}$ In drawing a parallel to that formula a Member State would render Article $82 \mathrm{EC}$ ineffective not only if it were to require or favour the abuse of a (collective) dominant position, but also if it were to reinforce the effects of such an abuse ${ }^{1602}$, or to deprive its own legislation of its official character by delegating to private traders responsibility for taking decisions affecting the economic sphere, and more specifically in the form of an unilateral conduct constituting an abuse of a (collective) dominant position. Like in INNO v ATAB this extrapolation concentrates on the conduct, i.e. the abuse of one or more undertakings prohibited by Article $82 \mathrm{EC}$. While it has been pointed out earlier that the conduct of undertakings is indeed a necessary link for the imposition of the negative integration duty under Article 10(2) EC, the question is whether the subsequent case law, in respect of Article $82 \mathrm{EC}$, effectively adopted an approach similar to the Van Eycke test.

The first opportunity after INNO vATAB to rule on Article 82 in conjunction with Article $10 \mathrm{EC}$ was in the late 1980s. In Abmed Saeed the Court reasoned that bilateral or multilateral agreements concluded between air carriers serving a particular toute eliminated

1597 See for instance case Case 231/83, Cullet $v$ Leclerc, [1985], paras. $17 \mathrm{f}$, according to which Articles 3(1)(g), 10 and 81 EC do not prohibit a Member State to adopt rules providing for the retail sale prices to be fixed by the public authorities. This is in keeping with the case law on the exercise of public authority according to which entities that do not regulate economic activities do not qualify as (associations of) undertakings. For details see Chapter 3.I.2.2. and Chapter 4.I.2.1.

${ }^{1598}$ Paras. $26 \mathrm{ff}$. of the INNO $\nu A T A B$ judgment. Also $V$ an Eycke (at para. 116) teiterated the INNO $\vee A T A B$ principle in respect of Article $82 \mathrm{EC}$.

1599 At para. 35 of the INNO $\nu A T A B$ judgment.

1600 See the second ruling and para. 34 of the INNO v ATAB judgment. See also Case C-260/89, ERT, [1991], para. 38.

1601 See also Neergaard U.B., (1998), 114 f., who, however, stresses too much the 'general requirements' or "more traditional analysis" of Article $82 \mathrm{EC}$ instead of working out particularly the specific criteria according to which one can test whether a Member State infringes its obligations with regard to Articles 10(2) and $82 \mathrm{EC}$.

${ }^{1602}$ See also Joined Cases C-94/04 and C-202/04, Cipolla and Macrino, [2006], para. 52. 
price competition among the airlines and that, consequently, the application of tariffs imposed by a dominant air cartier on other air carriers operating on the same toute constitutes an abuse of a dominant position. ${ }^{1603} \mathrm{~W}$ ith regard to the possible infringement by Germany as the Member State concetned the Court repeated in paragraph 52 of the judgment that the Treaty strictly prohibits Member States from encouraging, in any form whatsoever, undertakings to adopt conduct prohibited by the Treaty provisions on competition. In fact the challenged tariff agreements had been approved by the competent aeronautic authorities. Finally the ruling stated that the approval of the tariff agreements under the disputed regulation infringed Article 10(2) EC in respect of Article $81 \mathrm{EC}^{1604}$, but left it to the national court to determine whether the approval was also in conflict with Article 10(2) EC together with Article $82 \mathrm{EC}$. While the Court suggested that the elimination of price competition among airlines could place these in a collective dominant position ${ }^{1605}$, the judgment lacked more tangible criteria to guide a national court in applying the INNO v $A T A B$ principle with regard to Article $82 \mathrm{EC}$.

Legal scholars have been pointing out that the turning point in bringing about the conceptual and practical limitations to using Article $82 \mathrm{EC}$ on its own against acts of the Member States had to wait until the mid-1990s. ${ }^{1606}$ Spediporto concerned Italian road-haulage tariffs that were approved and brought into force by the State on the basis of proposals submitted by a committee, in which participated also representatives of the economic agents concerned. The Court ruled that Articles 3(1)(g), 10 and $82 \mathrm{EC}$ apply "if it were proved that the legislation concerned placed an undertaking in a position of economic strength enabling it to prevent effective competition from being maintained on the relevant market by placing it in a position to behave to an appreciable extent independently of its competitors, of its customers and ultimately of the consumers". ${ }^{1607}$ What Spediporto therewith reveals is a shift in focus. While the link between the State measure and competition law in INNO $\nu A T A B$, Abmed Saeed and the first and second prong of $V$ an Eycke is concerned with the anticompetitive conduct of undertakings, Spediporto focusses on the position of dominance that is being created by a State measure. This means that a Member State infringes Article 10(2) EC in conjunction with Article $82 \mathrm{EC}$ where it puts one or more undertakings in a (collective) dominant position.

For the reasons in Chapter 5 the present description will focus on situations of collective, rather than single, dominance. It follows from Spediporto that State measures are contray to Articles 10(2), 3(1)(g) and $82 \mathrm{EC}$ where they temove competition between competitors and thus place economic operators in a collective dominant position. ${ }^{1608}$ Moreover, the Court in Spediporto provided for a further specification of the Member States' duty under Article $10 \mathrm{EC}$ by recalling that, for collective dominance to exist, the undertakings in the group must be linked in such a way that they adopt the same conduct on the market. ${ }^{1609}$ The Court specified the point later by requiring that national rules either "place individual undertakings ... in a dominant position or tesult in the creation of

${ }^{1603}$ Case 66/86, Abmed Saeed, [1989], paras. $37 \mathrm{ff}$, and $47 \mathrm{ff}$.

1604 At para. 49 of the Ahmed Saeed judgment.

1605 See para. 50 of the Abmed Saeed judgment. Szyszczak E., (2007), 101; Neergaard U.B., (1998).

1606 Szyszczak E., (2007), 95. Also Neergaard U.B., (1998), 99 f., 114.

1607 Case C-96/94, Spediporto, [1995], para. 31. The Court referred to Case 85/76, Hoffmann-La Rocbe, [1979], para.

38. The quote is repeated in Case C-38/97, Autotrasporti Librandi, [1998], para. 27.

${ }^{1608}$ See para. 34 of the Spediporto judgment. Also Joined Cases C-140-142/94, DIP, [1995], para. 27.

1609 The Court referrcd to Case C-393/92, Almelo, [1994], para. 42. For details sce Chapter 5.I. 
sufficiently strong links between them as to give rise to a collective dominant position."1610 By simply reverting to the requirements on collective dominance the Court effectively assures a coherent development of its case law in respect of both undertakings and Member States.

\subsection{Comparing the standards under Van Eycke and Spediporto}

In turning back to the comparison between Spediporto and Van Eycke a couple of intermediate observations can be made. First of all, and in respect of Article $82 \mathrm{EC}$, the Court has interpreted the Member States' duty not to facilitate or encourage the abuse of a dominant position in a way that prohibits Member States from putting undertakings in a (collective) dominant position. Thus, instead of tying in with the conduct prohibited under Article $82 \mathrm{EC}$, the Spediporto standard ties in with the as such permitted dominance of undertakings. In this there scems to be a first difference between the two standards. More particularly, Spediporto recalls the substantive test applied in concentration control cases to assess whether a particular concentration is compatible with the common market. ${ }^{1611}$ According to the Guidelines on the assessment of horizontal mergers the creation or the strengthening of a dominant position is a primary form of a competitive harm. ${ }^{1612}$ Presumably, the rationale for the substantive concentration control test and the control of State measures are synchronous, namely of being wary of artificially creating or strengthening a dominant position that is not grown from the competitive ability of one or more undertakings.

Hence, in developing the INNO $\nu A T A B$ principle in respect of Article $82 \mathrm{EC}$ the Court in Spediporto was not content with literally extrapolating the first and second prong of the $V$ an Eycke standard, i.e. to merely prohibit situations in which a State measure would require or favour a new abuse of a pre-existing position of dominance, or reinforce the effects of an pre-existing abuse of a pre-existing dominant position. While such blatant cases are certainly covered by the INNO $\vee A T A B$ principle, the case law has specified that the duty of Member States not to frustrate Article $82 \mathrm{EC}$ commences already at an earlier stage, namely where a State measure puts one or more undertakings in a position to act independently of their competitors, customers and ultimately the consumer, without it being necessary that an actual abuse of that position has already materialised. ${ }^{1613} \mathrm{Member}$ States thus have a duty not

${ }^{1610}$ Case C-70/95, Sodemare, [1997], para. 47. In this case the national measure at stake had as its effect that only non-profit-making companies were entitled to be reimbursed by the public authorities the costs of providing social welfare services of a health care nature.

1611 Article 2(2) and (3) of Council Regulation (EC) No 139/2004 of 20.01.2004 on the control of concentrations between undertakings (the ECMerger Regulation). See also Case T-342/99, Airtours/FirstCboice, [2002], para. 62; and Case C-413/06 P, Impala II, [2008], paras. $124 \mathrm{ff}$.

${ }_{1612}$ European Commission, Guidelines on the assessment of borizontal mergers under the Council Regulation on the control of concentrations between undertakings, points 2 and 4: "The creation or strengthening of a dominant position held by a single firm as a result of a merger has been the most common basis for finding that a concentration would result in a significant impediment to effective competition. Furthermore, the concept of dominance has also been applied in an oligopolistic setting to cases of collective dominance. As a consequence, it is expected that most cases of incompatibility of a concentration with the common market will continue to be based upon a finding of dominance. That concept therefore provides an important indication as to the standard of competitive harm that is applicable when determining whether a concentration is likely to impede effective competition to a significant degree, and hence, as to the likelihood of intervention."

${ }_{1613}$ With regard to State measures creating new or strengthening existing dominance there is no nced to apply the "test of likelihood" of abuse (recalling the merger control test), Temple Lang J., (2001), 215. Compare also 
to adopt measures that create a dominant position, therewith preparing to finally facilitate of encourage a breach of Article $82 \mathrm{EC}$ on the side of the (collectivity of) undertakings.

Secondly, while it follows from the foregoing that Spediporto is not congruent with $V$ an Eycke, it can be observed that Spediporto makes up for the first and second prong of Van Eycke. The third prong, however, has not been exemplified in Spediporto in respect of Article 82 EC. The third prong of Van Eycke nevertheless appears to state a more generally applicable rule, namely that Member States may not deprive their legislation of its official character. Consequently, the duty under Article 10(2) EC, in respect of Article $82 \mathrm{EC}$, does not allow Member States to delegate to one or more private traders the responsibility to regulate the sector in which they are dominant. In contrast to the specifications made in Spediporto this last conceivable instance requires a pre-existing dominant position, since otherwise only an insufficient link would be provided between the Member States' duty under Article 10(2) EC and the reference to Article 82 EC. ${ }^{1614}$ Inspiration for the content of the duty of Member States in this respect may be drawn from Hilti, which has been reviewed in Chapter 5.II.3.3. One can argue along similar lines that Member States may not delegate to one or more undertakings in a dominant position the task to take steps to eliminate products or services of other economic operators that the dominant entity, rightly or wrongly, regards as dangerous or at least as inferior in quality to its own standards. ${ }^{1615}$ As the Court in Hilli rightly pointed out this is a task for national legislation to take carc of, subject to strict conditions of objective necessity or indispensability. ${ }^{1616}$ "There is never any justification for a supposedly impartial regulator to delegate its powers to companies which have a conflict of interest." ${ }^{p 1617}$ On the overall, taking account of the specificities of either

the case law referring to Articles 86(1) and $82 \mathrm{EC}$, see for instanceCase C-49/07, MOTOE, [2008], paras. $39 \mathrm{ff}$. "it should be recalled that the mere creation or reinforcement of a dominant position through the grant of special or exclusive rights within the meaning of Article 86(1) EC is not in itself incompatible with Article $82 \mathrm{EC} .49 \mathrm{On}$ the other hand, a Member State will be in breach of the prohibitions laid down by those two provisions if the undertaking in question, merely by exercising the special or exclusive rights conferred upon it, is led to abuse its dominant position or where such rights are liable to create a situation in which that undertaking is led to commit such abuses. In this respect, it is not necessary that any abuse should actually occur. $50 \mathrm{In}$ any event, Articles $82 \mathrm{EC}$ and 86(1) EC are infringed where a measure imputable to a Member State, and in particular a measure by which a Member State confers special or exclusive rights within the meaning of Article 86(1) EC, gives tise to a risk of an abuse of a dominant position." (Emphasis added). The Court refers to Case C-41/90, Höfner and Elser, [1991], para. 29; Case C-260/89, ERT, [1991], para. 37; Case C-179/90, Merci Convenzionali, [1991], paras. 16 f.; Case C-323/93, Centre d'Insémination de la Crespelle, [1994], para. 18; Case C-55/96, Job Centre coop, arl., [1997], para. 36; and Case C-380/05, Centro Europa 7, [2008], para. 60.

${ }_{1614}$ To date the case law has not elaborate this conceivable instance in respect of Articles 82 and 10(2) EC, but kept any delegation issue in reference to Article 81(1) EC.

1615 See Case T-30/89, Hilli, [1991], para. 118. Hilti argued that its practice of requiring purchasers of Hilti nail cartridges or nail-guns to also purchase Hilti nails was justified on grounds of safety considerations and the prevention of false and misleading advertising. In particular Hilti claimed that that the use of its competitors' nails in Hilti tools was dangerous.

${ }_{1616}$ Case T-30/89, Hilti, [1991], paras. 102-119. See also Case 311/84, Télémarketing (CBEM), [1985], para. 26. It is actually not clear to which extent the 'objective necessity' test is a form of the proportionality test underlying all objective justification tests in EC law. The principle of proportionality derives from German law and its application is to legislation. For details see Chapter 5.П.3.2.

${ }_{1617}$ Temple Lang J., (2001), 212 ff., 216-221. See also Case 267/86, Van Eycke, [1988], 4769; Case C-202/88, Frencb Republic $\nu$ Commission (Telecommunications Terminal Equipment), [1991], para. 51: "It should be observed that a system of undistorted competition, as laid down in the Treaty, can be guaranteed only if equality of opportunity is secured as between the various economic operators. To entrust an undertaking which markets terminal equipment with the task of drawing up the specifications for such equipment, monitoring their application and granting type-approval in respect thereof is tantamount to conferring upon it the power to determine at will which 
competition prohibition leads to the conclusion that the third limb of the Van Eycke standard serves fairly for an extrapolation to the duty of Member States also in respect of Article 82 EC.

It is remarkable that the thitd prong of the $V$ an Eycke test has not yet been extrapolated in the case law in respect of Article 82 EC. A few cases made reference to both Articles 81(1) and $82 \mathrm{EC}$ in respect of the duty under Article 10(2) EC, but most cases eventually concluded that no neglect of that duty had taken. Most of the cases on the combined application of Articles $10(2), 3(1)(\mathrm{g})$ and the competition rules have focussed on Article 81(1) EC. Since most cases were answered in the negative in respect of Article 81(1) EC, it may not be surprising that also in respect of Article $82 \mathrm{EC}$ finally a negative answer was given. However, after the more recent case law of Piau ${ }^{1618}$ coining the concept of emanation the question arises whether, in addition to an autonomous infringement of Article $82 \mathrm{EC}$ by self-regulatory groups, a Member State infringes Article 10(2) EC in respect of that article where it empowers an emanation of economic opetators to unilaterally adopt and apply regulations that restrict competition in the way discussed in Chapter 5.II. ${ }^{1619}$

An infringement of the Member States' duty in respect of Article 82 EC is conceivable in a couple of situations. First, to tequire by law the establishment of a professional association could mean the establishment of sufficient links between undertakings to place them in a collective dominant position through the creation of an emanation. Such a finding would be even more conceivable where a Member State grants the emanation powers to regulate economic conduct of its members and competitors. The risk of an abuse as described in Chapter 5.II. of a collective dominant position arguably becomes more tangible once this position is installed by law. However, it may be doubted whether the Court would conclude on this form of neglect of the Member States' duty under Articles 10(2) and $82 \mathrm{EC}$. The reason for rejecting such a finding will probably be that, despite the described effects of installing an emanation in the sense of Piau, the emanation will be open to an unspecified number of undertakings. Thus, while establishing sufficient links between the members of an association to act independently vis-à-vis their competitors, customers and finally the consumer, a State measure requiring the establishment of the emanation will not notmally put specific undertakings in a position of collective dominance. ${ }^{1620}$ In fact a professional association usually is open to an unidentified number of practitioners who are eligible for membership on the basis of objective criteria. Moreover, it is to be expected that the Court, strictly following Spediporto, will not conclude that a national law requiring the establishment of a professional association and granting regulatory powers eliminates competition between affiliated practitioners. The conclusiveness of such an approach - where it should be applied across the board - may be doubted in light of the case law referenced above in note footnote

terminal equipment may be connected to the public network, and thereby placing that undertaking at an obvious advantage over its competitors." See also Case 18/88, RTT v Inno, [1991]; AG van Gerven in Joined Cases C48/90 and C-66/90, PTTNederland, [1992], 616; Case C-163/96, Silvano Raso, [1998]; and Case C-49/07, MOTOE, [2008], para. 51.

${ }_{1618}$ Case T-193/02, Pian I, [2005].

1619 See also above note footnote 1617.

${ }^{1620}$ See Joined Cases C-140-142/94, DIP, [1995], para. 27: "National trules which require a licence to be obtained before a new shop can be opened and limit the number of shops in the municipality in order to achieve a balance between supply and demand cannot be considered to put individual traders in dominant positions or all the traders established in a municipality in a collective dominant position, a salient feature of which would be that traders did not compete against one another" (emphasis added). 
1617. A sensible distinction would be, however, to cumulatively look at whether the State measures simultaneously empowers the emanation established by statute to define the essential conditions under which the professions offer their services. ${ }^{1621}$

A second form of neglecting a Member State's duty under Article 10(2) EC is conceivable with regard to the third prong of the Van Eycke test, as extrapolated to Article $82 \mathrm{EC}$ situations. In respect of a professional association as the emanation of a specific professional group the same idea as elaborated above can be applied. Drawing on the case law in Hilti and Pian it can be stated that the collectively dominant emanation may not be authorised by a Member State to regulate its members' economic activities or those of their competitors, for otherwise the Member State will deprive its legislation of its official character. Whether the case law will develop in this direction to apply Spediporto (and in particular the extrapolated third limb from Van Eycke) to State intervention in professional regulation remains, however, to be seen. So far the case law applying Article 10(2) EC in respect of Article $82 \mathrm{EC}$ did not conclude on an actual infringement thereof. Even in respect of Article 81(1) EC the case law has condemned State measures only in four instances, of which one concerned professional self-regulation adopted in a State rule context. ${ }^{1622}$ The following section will therefore concentrate on the Van Eycke standard as applied to professional regulation.

\section{The case law's application of Article $10 \mathrm{EC}$ to State intervention in the professional services sector}

Professional regulation of the type discussed in Chapters 4 and 5 is regulatly adopted in a mix of self-regulation and State regulation. As indicated by the Van Eycke test various forms of State intervention in the adoption process of (self-)regulatory measures are conceivable. The question ultimately is who has to bear responsibility for the adoption of professional rules that have the object or effect of restricting competition. More particularly, the question is in how fat a Member State can be held tesponsible for restrictive professional regulation that is the product of an adoption process in which representatives of a particular profession are involved. This section will undertake to scrutinise and compare in particular two cases in which the Van Eycke test has been applied to State intervention in the field of professional regulation. The first case to look at is that of the Italian customs agents. ${ }^{1623}$ In 1998 the Court found in CNSD II that Italy had failed to fulfill its obligations under Articles 10 and $81 \mathrm{EC}$ since its law on the legal recognition of the profession of customs agent had granted the relative decision making power to the profession's association (Consiglio Nazionale degli Spedizionieri Doganali, CNSD). In contradistinction the Court in Arduino four yeats later found that another Italian law (governing the profession of avvocati and procuratorr) was not contrary to Articles 10 and 81 EC. While the competent minister approved fee tariffs drawn up by the professional body, the Court this time was satisfied that the law in question laid down particular procedural guatantees that satisfy the INNO $\vee A T A B$ principle. ${ }^{1624}$ The comparison of the diverging results of the two cases will fathom the way

${ }^{1621}$ Close to this conclusion comes Case 136/86, BNIC $\nu$ Aubert, [1987], albeit in respect of Article 81 EC, see below text with note footnote 1633 Reference can also be made to the modernisation that the legal profession undergoes currently in the UK As a result the representative and regulatory functions are going to be separated; for details see Chapter 4.I.2.4.

${ }_{1622}$ Case C-35/96, Commission vItalian Republic (CNSD II), [1998]. The other three cases are Case 311/85, Vlaamse Reisbureaus, [1987]; Case 136/86, BNIC v Aubert, [1987]; and Case 66/86, Abmed Saeed, [1989].

${ }^{1623}$ Case C-35/96, Commission v Italian Republic (CNSD II), [1998]. The case is summarised in Chapter 2.V.

${ }^{1624}$ Case C-35/99, Manuele Arduino, [2002]. The same law, but different provisions, was challenged again in 
in which the Court applies the three prongs of the Van Eycke test to the professional sector.

\subsection{The three prongs of the Van Eycke test applied}

CNSD II is the latest of four cases in which the Court concluded that a Member State had failed to fulfill its duty under the INNO $v A T A B$ principle. ${ }^{1625}$ In this case the Court explicitly was satisfied that Italy had neglected its duty under the INNO $v A T A B$ principle under the first prong of the Van Eycke test since the Italian law "in granting the relative decision-making power, requires" the CNSD to compile a compulsory and uniform tariff for the services of all custom agents. Moreover, the competent minister had enacted a decree implementing the minimum and maximum tariffs adopted by the CNSD. This implementation by ministerial decree was not required under the national law, and it therefore appeared to reinforce the effects of the association's decision, therewith violating also the second prong of the Van Eycke test. This conclusion is supported by paras. 58 and 59 of the judgment, in which the Court emphasised facts that indicate that Italy had sustained the legal effects of the CNSD's tariffs. Not only had the Italian legislation expressly prohibited - on pain of exclusion, suspersion or removal from the register - that registered customs agents derogate from the thus adopted tariff. Italy also had bestowed upon the tariff scheme adopted by the association the appearance of a public regulation - irrespective the fact that the competent minister had no explicit power to approve the tatiff. ${ }^{1626}$ To qualify this conferral of official character to fall under the second prong is congruous with para. 55 in which the Court introduced its reasoning with regard to the concrete failures of Italy, and where the Court announced that Italy "not only required the conclusion of an agreement contraty to [Article $81 \mathrm{EC}$ ] and declined to influence its terms, but also assists in ensuring compliance with that agreement" (emphasis added). ${ }^{1627}$

A further analysis of the judgement suggests that in paragraph 57 the Court moreover was satisfied Italy had met the last prong. ${ }^{1628}$ To sustain the finding that Italy had unduly delegated responsibilities to the CNSD to take decisions influencing the economic sphere the Court referred to paragraphs 41 to 44 of the judgment. There the Court had scrutinized the pertinent facts in order to conclude that the CNSD did neither exercise public authority that is outside the jurisdictional scope of Article 81(1) EC, nor was composed of independent experts obliged to take account of public interest criteria. This reference is perplexing in that it draws on facts that are relevant to decide whether an association is one of economic operators. A detailed discussion of the point has therefore been conducted in Chapter 4.I.1.1. and 4.I.2.2. While the reference to paragxaphs 41 to 44 of the judgment thus merely reinforces that the CNSD is an association of economic operators, paragraph 57 at the same time underlines that the national legislation had "wholly relinquished to private economic operators the powers of public authorities". No further criteria have, however,

Joined Cases C-94/04 and C-202/04, Cäpolla and Macrino, [2006].

1625 See above note footnote 1622.

${ }^{1626}$ Para. 59 of the CNSD II judgment: "First, publication in the General Series' of the Gazzetta Ufficiale della Repubblica Italiana gave rise to a presumption of knowledge of the tariff on the part of third parties, to which the CNSD's decision could never have laid claim. Second, the official character thus conferred on the tariff facilitates the application by customs agents of the prices that it sets. Lastly, its nature is such as to deter customers who might wish to contest the prices demanded by customs agents."

1627 This reading meets the case law concerning the incorporation of the text of an association's decision into a State measure, see Joined Cases 209 to $213 / 84$, Asjes, [1986].

${ }_{1628}$ Others have understood the Court in this way, e.g. Gyselen L., (2006), 16; and Neergaard U.B., (1999). 
been indicated in the judgment to differentiate prohibited from allowed delegation of regulatory powers to a professional association. The Court seized the occasion to do so only four years later in Arduino. However, before analysing the subsequent case law, more light shall be shed on the relationship between the third prong, on the one hand, and the first two prongs, on the other, in order to verify whether the Court in CNSD II could legitimately proceed to test all three prongs of the Van Eycke test and find all three violated.

Member States depriving their legislation of its official character: gross violation of a democratic principle

To deprive a Member State's legislation of its official character (third prong) appcars to be different from bestowing private (pre-existing) regulation with the appearance of official regulation, thcreby reinforcing the effects of the private regulation under the second prong. Delegation under the third prong means that the Member State gives away its influence in the rule making process. It cannot, by the same measure, reinforce the effects of an restrictive arrangement since the second prong requires the anti-competitive arrangement to be preexisting. ${ }^{1629}$ Conversely, the third prong may share a common feature with the first prong, namely where the delegation would take a mandatory form so as to require (an association of) undertakings to assume responsibility to adopt economic regulation. In this the finding in CNSD II with regard to the third prong is coherent in that the legal requirement to compile a compulsory, uniform tariff for the services of customs agents effectively can be understood as a delegation issue.

The reason for the Court to find that a Member State has failed its obligations according to the third prong of the Van Eycke test is that the Member State deprives its legislation of its official character. This means that by delegating powers to economic operators to set restrictive rules the legislator did not retain the full democratic responsibility for the restriction of competition. The failure is that the Member State actively desists its legislative prerogative and leaves it to the (association of) economic operators to exercise it. Conversely, under the first two prongs a Member State can perfectly keep full democratic responsibility for the restriction of competition by adopting itself rules the restrictive effect of which is not primarily attributable to, for instance, a professional association. This means that by requiring the adoption of restrictive regulations or reinforcing the effects thereof (first two prongs) the Member State, on its own account, contributes to the restrictive effect without depriving its measures of their official character as under the last prong.

Where a Member State retains its full democratic responsibility for the adoption of economic regulation, but therewith would require the adoption of testrictive arrangements ( $1^{\text {st }}$ prong) or reinforce the effects thereof $\left(2^{\text {nd }}\right.$ prong), the Member State infringes its duty under the INNO $\vee A T A B$ principle. In the light of the Court's case law the question in respect of the first two prongs thus is whether the State measure has the purpose to require or favour anti-competitive action on the part of (professional) associations, or to teinforce the effects of such conduct. ${ }^{1630}$ Rubber-stamping self-tegulatory measures is a clear example of an infringement of the second prong of the Van Eycke test. The point can be illustrated with the case Vlaamse Reisbureaus ${ }^{1631}$ where Belgium was held to expost have teinforced the effects of a pre-existing agreement through the adoption of a toyal decree, which confirmed

${ }^{1629}$ See Case C-35/96, Commission v Italian Republic (CNSD II), [1998], para. 59.

${ }_{1630}$ Neergaard U.B., (1998).

${ }_{1631}$ See Gyselen L., (1989), 47 f. 
the prohibition of the transfer of travel agents' commissions to customers (discounts). ${ }^{1632}$ Similarly, in BNIC $\nu A$ Aubert France was held to have reinforced, by a ministerial order, the effects of a quota production system previously agreed upon within the framework of an inter-trade body in the wine and cognac sector (BNIC, itself set up by ministerial order). ${ }^{1633}$

Conversely, a 'real' delegation would not imply a subsequent action on the side of the Member State. Thus, where a Member State entrusts a (professional) association with the adoption of restrictive arrangements but retains for itself the powers to effectively alter or ignore the produced arrangements it may not have deprived its legislation of its official character, and no delegation in the sense of the third prong has taken place. The fact that a Member State reserves to itself the exercise of its legislative prerogatives after the involvement of the (professional) association suggests that the Member State's conduct does not constitute an infringement under the third prong. ${ }^{1634}$ This means that the exercise of legislative prerogatives may not be interpreted to be identical with an infringement of the second prong of the Van Eycke test. In CNSD II the Court ultimately did not find sufficient procedural safeguards that would have withdrawn the Italian tules from the third prong. As pointed out before it shall be noted, however, that CNSD II did not squarely address whether and in which form delegation had taken place. Rather, the reference made in paragraph 57 of the judgment ("wholly relinquished") reads like a presumption of an even worse infringement of the Van Eycke test. In fact the third prong describes a 'gross violation' of democratic principles accepted in the Member States, namely that no delegation of regulatory powers can take place without (effective) safeguards exercised by the public authorities, themselves democratically legitimised. In the context of competition law this means that Member States must not delegate to representatives of economic operators responsibility to influence the economic sphere. ${ }^{1635}$

While it is conceivable that the Court will not easily establish such gross violation in order not to unduly interfere with the parliamentary sovereignty of the national legislators ${ }^{1636}$, it must be noted that, according to the disjunctive reading of the Van Eycke test, the first two prongs remain applicable even where a Member State does not deptive its measures of their official character. ${ }^{1637}$ It thereby becomes apparent that the first two prongs can actually be understood as a sharper knife to cut economic regulation adopted by Member States. In essence, it may be stated that a violation of the third prong may coincide with a violation of the first prong of the Van Eycke test. In respect of the second and third prong the same

${ }^{1632}$ Case 311/85, Vlaamse Reirbureaus, [1987], para. 23. The social service organisation had assumed the role of a travel agent for government employees and the association of travel agents accused the social service organisation of having passed on commissions normally paid to travel agents, thereby granting the employees a discount. See also Joined Cases 209 to 213/84, Asjes, [1986], 77.

1633 Case 136/86, BNIC v Aubert, [1987].

1634 See also Case 188/86, Régis Lefêre, [1987], para. 7: "As regards the application of [Articles 3(1)(g) and $81 \mathrm{EC}$ ] to price rules such as those referred to by the national court, it must also be observed that the purpose of such rules is not to compel traders to conclude agreements or to take any other action of the kind prohibited by [Article 81(1) EC] but to entrust responsibility in pricing matters to the public authorities." (emphasis added). However, and as Gyselen points out, it may be a matter of degree whether the involvement of the public authorities is substantial enough to exclude their responsibility for the restriction of competition, Gyselen L., (2006), 17.

1635 Note that where a Member State takes the diligence to confine the delegated powers to decisions that do not affect the economic sphere the delegation does not fall within the competence of competition law anyway.

${ }^{1636}$ For details see below on cases Arduino and Macrino. The reference to the sovereignty does not refer to the principle of subsidiarity as pointed out correctly by Neergaard U.B., (1998), since competition law does not fall within the shared competencics as meant in Article 5(2) EC.

${ }^{1637}$ See Gyselen I.., (2006), 13. 
statement can be made only to a very limited extent. As CNSD II illustrates a simultaneous infringement of the second and third prong is conceivable only if the reinforcement is not contained in the same measure as the delegation, since the reinforcement criterion requires a pre-existing decision of an association that the delegation of regulatory powers will only lead to. ${ }^{1638}$ Moreover, although a gross violation of the democratic principle not to divest legislation of its official character, at first sight, seems to constitute a graver case of the first prong, it is perfectly conceivable that in a given case a Member State merely delegates the relevant powers without strictly requiring the (association of) undertakings to adopt anticompetitive arrangements. ${ }^{1639}$ The question then arises whether such a case still falls foul of the third prong of the Van Eycke test, namely where a Member State grants economically interested parties powers to interfere with the economic sphere, without the empowered parties necessarily making use of that capacity.

In fact, whether or not the empowered body consummates the delegated responsibility does not affect the wording of the State measure that provides the basis for, for instance, the regulatory powers of a professional association to adopt anti-competitive measures. ${ }^{1640}$ From the wording of the last prong of the Van Eycke test it is not overt that the actual putting into existence of an anti-competitive arrangement on the part of the (association of) undertakings would be required in order to find that the delegating Member State has transgressed its obligations under Articles 3(1)(g), 10(2) and 81 EC. On face value the Van Eycke test in its last limb is agnostic in this respect. It is therefore doubtful whether, an effective interaction between the Member State and the economically interested parties or their representatives is an intrinsic requirement of the last prong of the Van Eycke test.

Instead of requiring such an accessoriness of the Member States' liability for effective anti-competitive conduct by (an association of) undertakings, the question can be raised whether it is sufficient to show that the national legislation necessarily has or will have the effect of inducing economic operators to such conduct, despite the fact that no anticompetitive conduct on the part of the undertakings may be found to exist yet. ${ }^{1641}$ Such a conclusion can be rationalised with reference to the mote general duty of the Member States under Article 10(2) EC. As the Court in Van Eycke stressed, it "has consistently held ... that Articles [81 and $82 \mathrm{EC}$ ], in conjunction with Article [10 EC], require the Member States not to introduce or maintain in force measures, even of a legislative nature, which may render ineffective the competition rules applicable to undertakings". ${ }^{1642}$ The emphasis on the potential ("may") rather than on a concrete result of a State measure to influence the conduct of

${ }^{1638}$ Gyselen L., (2006), $13 \mathrm{f}$, who, however, points out that it is contradictory to apply both the first two prongs and last prong cumulatively.

${ }^{1639}$ Conversely, while a Member State may neglect its dutics in respect of the first prong, it may perfectly withhold its democratic responsibility for adopting economic regulation and thus not contravene its duties in respect of the third prong of the Van Eycke test.

1640 Anti-competitive professional regulations are illustrated in Chapters 4.II. and 5.II.

1641 This conclusion can be drawn from Case C-185/91, Reiff, [1993]; Casc C-153/93, Delta, [1994]; Joined Cases C-140-142/94, DIP, [1995]. See also Fenger N. / Broberg M.P., (1995), 365 f.; Neergaard U.B., (1998), 113.

${ }_{1642}$ Case 267/86, Van Eycke, [1988], para. 16 (emphasis added). Case 13/77, INNO v ATAB, [1977], para. 30: "The second paragraph of Article [10 EC] provides that Member States shall abstain from any measure which could jeopardize the attainment of the objectives of the Treaty" (emphasis added). Case 229/83, Leclerc vAu Ble Vert, [1985], para. 14: "Member States are none the less obliged under the second paragraph of Article [10 EC] not to detract, by means of national legislation, from the full and uniform application of Community law or from the effectiveness of its implementing measures; nor may they introduce or maintain in force measures, even of a legislative nature, which may render ineffective the competition rules applicable to undertakings" (emphasis added). The Court refers to Case 14/68, Walt Wilhelm, [1969]; and Case 13/77, INNO v ATAB, [1977]. 
undertakings in a competition-testrictive manner recalls that the Treaty, and in particular its competition rules, are intended not only to remedy but also to forestall anti-competitive effects where they are the foreseeable and natural consequence of a certain behaviour. ${ }^{1643}$

Therefore, similat to the object requirement under Article 81(1) EC - according to which an agreement, decision or concerted practice is presumed to have the object to restrict competition where it necessarily bas or will bave the effect of restricting competition - a State measure can be presumed to render the EC competition tules ineffective, and thus infringe Articles 3(1)(g) and 10(2) EC in conjunction with Article 81(1) EC, where it necessarily has or will have the effect of inducing economic operators to engage in such conduct. ${ }^{1644}$ Such a test not only is the consequential reflection of the spirit of Article 81(1) EC but also of the interpretation practised by the Court with regard to that article's object requirement. ${ }^{1645}$

However, even in the event that the association of economic operators effectively consummates the delegated powers to adopt economic regulation, it is conceivable that on the basis of the $V$ an Eycke test a Member State does not deprive its legislation of its official character. This may be the case where specific safeguards are put in place to control the exercise of the delegated powers. Where such safeguards prove to be effective, a Member State may be said to have retained its democratic responsibility for the rules that are finally applicable in a specific sector. In essence a situation of effective retention will lead to the conclusion that no violation whatsoever of the INNO $v A T A B$ principle will have taken place.

A last point to be made in this section concerns an issue that may be hypothetical only. The question is whether the delegation to private traders of responsibilities that allow to affect the economic sphere by itself is sufficient to prove that a Member State has deprived its own legislation of its official character. From the wording of the third Van Eycke limb one can conclude in the affirmative. However, the question of whether a Member State has deprived its own legislation of its official chatacter can be interpteted to constitute a separate, i.e. positive requirement in the search for an answer to the more general question, namely of whether a Member State has introduced or maintained a measure that may tender the competition rules ineffective. A grammatical interpretation of the Van Eycke test at first glance opposes this conclusion. However, where an association has consumed its delegated powers, an analysis of the more recent case law may prove that first the delegation and, second the susceptibility of the delegated powers to be 'misused' by the (association of) undertakings are obvious but mere illustrations of a third requirement, namely the positive assessment of whether a Member State deptived its own legislation of its official character. $^{1646}$

\section{The last prong of the Van Eycke test prevailing?}

Finally, Arduino gave a different twist to the relationship between the three prongs of the $\operatorname{Van}$ Eycke test. The circumstances of the case are remarkable in that they indicated that Italy effectively had required the national council of the Bar to adopt a decision contrary to

\footnotetext{
${ }^{1643}$ See also Chapter 4.II.1. and Chapter 5.II.2.1. on the concept of an objectified intent (as different from subjective intention, which cannot be proven).

1614 See Case 311/85, Vlaamse Reisbureaus, [1987], para. 24.

1645 For details see Chapter 4.II.1.1.

1646 See especially Case C-35/99, Manuele Arduimo, [2002], paras. 36 ff.
} 
Article $81 \mathrm{EC}^{1647}$, and possibly also reinforced the effects thereof. ${ }^{1648}$ However, after having found that the Italian legislation governing the legal profession did not violate the third prong, the Court stated that "Nor, for the reasons set out in paragraphs 41 and 42 above, is the Italian State open to the criticism that it requires or encourages the adoption of agreements, decisions or concerted practices contrary to Article [81 EC] or reinforces their effects."1649 Interestingly, paragraphs 41 and 42 of Arduino refer back to the arguments that motivated the Court's finding that Italy had not deprived its legislation of its official character under the thitd prong of Van Eycke. In particular the Court in Arduino assessed a number of factual circumstances to find that Italy had not deprived its rules of their legislative character. Before going into those reasons in the next section, it is noteworthy that paragraph 43 of the Arduino judgment patently recycled, in respect of the first and second prong of $V$ an Eycke, the considerations used to reject a violation of its third prong. Thus, it can be observed that with Arduino the Court seems to have moved to a 'refreshed' (or degraded) version of Van Eycke in the sense that the test becomes an integrated one. ${ }^{1650}$

Such a development goes further than what the Court in CNSD II alluded with its reference to all three prongs. Comparing CNSD II and Arduino at this juncture leads to the conclusion that it is not necessarily sufficient anymore to establish that a State measure falls under the criteria of either the first or second prong. ${ }^{1651}$ The Court in Arduino held that "the fact that a Member State requires a professional otganisation to produce a draft tariff for services does not automatically divest the tariff finally adopted of the character of legislation." 1652 The lesson form Arduino thus seems to be that, even where one can prove that a case meets the criteria of requiring or reinforcing anti-competitive arrangements, one also needs to prove that a Member State has delegated an association of economic operators responsibility for taking economic decisions. The Van Eycke test after Arduino could therefore be reformulated to change the conjunction introducing the last prong from 'or' to 'and': a Member State renders ineffective the competition provisions if it 'were to require or favour the adoption... or to reinforce their effects, and [therewith] to deprive its own rules of the character of legislation by delegating...'. Such an interpretation of Arduino would, however, crack the Van Eycke standard, as the first two prongs thereby risk to become redundant. ${ }^{1653}$ This conclusion may be moderated only by emphasising that, in addressing each prong

1647 Sec para. 38 of the judgement in Arduino: "In the main proceedings, it is clear from the description of the national legislation that the Italian State obliges the CNF, composed exclusively of members of the Bar elected by their fellow members, to present every two years a draft tariff for fees payable to members of the Barincluding minimum and maximum limits."

${ }^{1648}$ See para. 6 of the judgment in Arduino: "When the CNF has decided upon the tariff, it must be approved by the Minister after he has obtained the opinion of the Comitato interministeriale dei prezzi (Interministerial Committee on Prices, the CIP) [...] and consulted the Consiglio di Stato (Council of State) [...]."

${ }^{1649}$ Para. 43 of the Arduino judgment (emphasis added). The same line of argumentation has been used by the Court in Case C-250/03, Mauri, [2005], para 37; and Joined Cases C-94/04 and C-202/04, Cipolla and Macrino, [2006], para. 53.

${ }^{1650}$ See Gyselen L., (2006), 14 ff., who argues that since Van Eycke the Court has moved towards a 'single standard' test.

1651 As for instance in Case 311/85, Vlaamse Reisbureaus, [1987]; Case 66/86, Ahmed Saeed, [1989]; Case 136/86, BNIC ע/Aubert, [1987], but also Case C-35/96, Commission vItalian Republic (CNSD II), [1998]. See also Joined Cases 209 to 213/84, Asjes, [1986], for which commentators are divided whether the Court clearly concluded on the failure of the Member State or whether it left the decision on the facts to the national court.

1652 Casc C-35/99, Manuele Arduino, [2002], para. 36 (emphasis added).

1653 See also Gyselen L., (2006). See also Case C-250/03, Mauri, [2005] (discussed immediately hereafter) in para. 37 of the order, where the Court held that "for the same reasons" the Member State cannot be criticised under either prong of the Van Eycke test. 
individually, the judgement literally upheld the tripartition of the test - however, at the price of underexposing the sharper specification that the first two prongs give to the INNO $v$ $A T A B$ principle.

\subsection{Focussing on the third Van Eycke prong: Arduino and after}

The factual and regulatory circumstances, which according to the Court in Arduino safeguarded that the legislation at stake finally had not been deprived of its official character, concerned the following points: the composition and task of the national council of the Bar, the ministerial approval of the tariffs adopted by the professional association, the actual control exercised by the minister and the role taken by the judiciary in settling fees. ${ }^{1654}$ While the Court did not find all circumstance to be equally effective to prevent that the tariff finally adopted be divested of the character of legislation, all four categories need to be explored here. The possible public control mechanisms that a Member State can adopt to safeguatd the official character of its legislation can be distinguished by reference to the moment at which the professional association adopts its decision. Any requirement in respect of the composition or task of the body has to be laid down before its involvement; the other safeguard measures occur thereafter.

\subsubsection{Revien of public ex ante control mechanisms}

The Court in Arduino addressed an ex ante public control mechanism that could have influenced the content of the proposed tariffs prior to their adoption by the association of undertakings (the CNF). To start with, and formulated in the words of the first prong of the Van Eycke test, Italy had required the CNF to produce a draft tatiff. ${ }^{1655}$ This, according to the Court, would not "automatically" amount to a divestment of the chatacter of legislation ${ }^{1656}$ under the third prong, if the members of the association could be chatacterised as independent experts who, in their decision-taking, are tequired under the law to take into account "also the public interest and the interests of undertakings in other sectors or users of the services in question". ${ }^{1657}$ This is a similar argument to the one formulated in CNSD II (discussed above); and it has also been tried in subsequent case law. ${ }^{1658}$

In fact, cases concerning the question of whether unlawful delegation has taken place often concern State measures that allow or foresee a committee to interfere with the functioning of particular markets. ${ }^{1659}$ As seen earlier in Chapter 4.I.2.2. the Court has developed a specific body of law with regard to regulatory bodies other than public authorities. This specific case law imposes particular criteria in order to decide whether a self-regulatory body comes within the ambit of Article 81 (1) EC ratione personae. The relevant requirements refer to the composition of such bodies, i.e. whether their members are

1654 These factors have been confirmed subsequently in Joined Cases C-94/04and C-202/04, Cipolla and Macrino, [2006], paras. 49-51.

1655 See para. 36 of the judgment in Arduino.

1656 Para. 36 of the judgment in Arduino.

1657 Para. 37 of the judgment in Arduino. The Court referred to Case C-185/91, Reiff, [1993], paras. 17 to 19; Case C-153/93, Delta, [1994], paras. 16 to 18; Joined Cases C-140-142/94, DIP, [1995], paras. 18 f; Case C-35/96, Commission vItalian Republic (CNSD II), [1998], para. 44, which have been discussed in this book in Chapter 4.I.2.2. ${ }_{1658}$ See Case C-250/03, Mouri, [2005]; Case C-446/05, Doulamis, [2008]; AG Kokott in Case C-49/07, MOTOE, [2008].

1659 See Case C-185/91, Reiff, [1993]; Joined Cases C-140-142/94, DIP, [1995]; Case C-153/93, Delta, [1994]. 
independent experts not bound by interests of the sectors concerned by the regulation, and their possible obligations to take account of public interest criteria as if they were exercising regulatory powers in place of the public authorities. In respect of the responsability of Member States the Court has been criticised for applying the last prong of the Van Eycke test in a too formalistic manner. On the one hand, the Court is reproached for "primarily putting emphasis on whether the pertinent [State] measures themselves expressly undetline the indcpendence of the committee members and thereby prevent them from following instructions on how to vote" ${ }^{1660}$ On the other hand, critics rightly point out that the control of whether the members of a regulatory committee take due account of particular policy considerations of public interest is not sufficient to change the anti-competitive nature of decisions adopted in a corporatist framework. ${ }^{1661}$

This book advances the view that it is delicate, if not erroneous, to discuss the case law on committees within the substantive test of whether a Member State has neglected its obligations under Article 10(2) EC with regard to Article $81 \mathrm{EC}$. While the way in which the Court presents the specific tequirements with regard to regulatory committees looks as if they are intrinsically linked to the third prong of the Van Eycke standard, this impression is fundamentally wrong. As explained in Chapter 4 the particular requirements with regard to the composition and the obligations of self-regulatory committees to take account of public interest considerations touches upon the scope of Article $81 \mathrm{EC}$ ratione personae, i.e. the question of whether the committee qualifies as an association of undertakings in the sense of Article 81(1) EC. Once this question is answered in the affitmative, the committee's decisions and the Member State's measures delegating the respective regulatory powers should not escape the duty of Article 10(2) EC simply because of the same critctia for which the committee has been found to come within the scope of Article 81(1) EC ratione personae. ${ }^{162}$ To accept such an argument at the present stage of legal review would contradict the Court's interpretation of the jurisdictional concept of 'association of undertakings'. In Arduino the Court avoided such a contradiction due to the fact that the membets of the CNF could not possibly qualify as independent experts acting in the public interest. Had they done so the CNF would not have qualified as an association of undertakings in the first place and the question of Italy's duty under Article 10(2) EC in respect of Article 81(1) EC would not have arisen. ${ }^{1663}$ In the hypothesis that a regulatory body would not qualify as an association in the sense of competition law, it would lack an essential characteristic to be covered by any of the prongs of the Van Eycke test. ${ }^{164}$

The aspect of composition played a tole in the more recent case Maur ${ }^{1665}$, in which the Court chose to address the Member State's responsibility by consciously skipping the underlying, but jurisdictional, issue of whether the case involved undertakings in the sense

\footnotetext{
${ }^{1660}$ Neergaard U.B., (1998), 119

1661 See Fenger N. / Broberg M.P., (1995), 366 f.; Bach A., (1994), 1368.

${ }_{1662}$ The fallacious assumption that the specific case law on committees is amalgamated with the Van Eycke test has led Neergaard U.B., (1998), 112, to the conclusion that the combination of the first and second prong of the standard together with the specific case law on committees "should be seen as analogous to" the third limb of the Van Eycke test.

${ }_{1663}$ Compare also Case C-446/05, Doulamis, [2008], paras. $22 \mathrm{f}$.

${ }^{1664}$ See also Case C-35/96, Commission p Italian Republic (CNSD II), [1998], paras. 33 ff., where the Court considered it necessary to first establish the underlying restriction of competition by the professional association before turning to the liability of the Member State.

${ }^{1665}$ Case C-250/03, Mauri, [2005].
} 
of competition law. ${ }^{1666}$ The case concerned the influence exerted by the Italian public authorities on the composition of the examination board and in the admission procedure for advocate candidates. In the light of the existing case law the Court felt that the case was a straight forward one, and instead of handing down a full judgment the Court decided by reasoned order, in accordance with Article 104(3) of its Rules of Ptocedure. ${ }^{1667}$ In paragraphs 31 to 38 of the order the Court once more confirmed its case law on the powers of the public authorities on the composition and appointment of bodies taking decisions affecting the economic sphere, and on their decisions effectively taking account of public interest. On that basis the Court concluded that in Mauri Italy had not infringed its duty under Article $10 \mathrm{EC}$ in respect of the competition law provisions.

In summary, the gateway for EC law to control Member State measures in the field of competition is not the economic regulation that results from State measures (and which comes within the "Member State's right to economic self-determination" ${ }^{\text {"1668) }}$ ) but the role that a Member State grants (an association of) undertakings to take in economic regulation. This tole is crucial in verifying whether the State measure itself is in conflict with Article 10(2) EC. While focussing on the role of the empowered (association of) undertakings, it is the State measure that is at stake under Article 10(2) EC. Put differently, the role played by the (association of) undertakings is the reference point to demarcate the fine line that separates the Community competence in competition law from that of the Member States to adopt 'genuine' economic State regulation.

Once the jurisdictional hurdle is cleared, i.e. once a Member State has delegated powers to (an association of) economic operators, it seems that the Member State cannot ex ante guarantee that its legislation will retain its official character under the thitd limb of the Van Eycke test. It is conceivable, however, that ex post control mechanisms ultimately prevent national legislation to be deprived of its official character.

\subsubsection{Review of public ex post control mecbanisms}

In Arduino the Court considered a number of specific control mechanisms that were provided for by the Italian legislation for the time after the CNF had played its role in the process of adopting the fee tariff for lawyers.

\section{The approval of the decision by the competent minister}

First of all, the Court emphasised that the fee schedule drafted by the professional body was not compulsory in its own right but needed ministerial approval to become binding in law. The Court assesses the approval required by the Italian law as the opportunity for the competent minister to influence the content of the tariffs and eventually have the CNF change their decision. In particular, the Court emphasised that without the approval the draft tatiffs would not have acquire binding force in law, and that instead the tatiff approved two yeats earlier would have remained applicable. The Court concluded that "Accordingly, the

1666 See para. 31 of the order in Mauri. See also para. 36 where the Court concluded that "The supervision carried out by the State at each stage of the examination at issue in the main proceedings leads to the conclusion that it has not given up the exercise of its powers in favour of private economic operators" (cmphasis added), thereby also stating indirectly that the examination board does not qualify as an association of undertakings.

1667 Para. 12 of the order.

${ }^{1668}$ Neergaard U.B., (1998), 121. 
Minister has the power to bave the draft amended by the CNF." ${ }^{1669}$ In essence the argument of the Court is that, despite the tariff scheme drafted by the professional body being a decision of an association within the meaning of Article 81(1) $\mathrm{EC}^{1670}$, the State rules provided the State with the power to control the content put in the tatiff scheme, namely by eventually forcing the association to tevise the content of its decision as otherwise the minister should tefuse to approve the decision into the form of a State decree.

While it is legitimate and necessaty to assess the ministerial power in determining the final content of the association's decision that is being promoted into State regulation, the legislation at stake in Arduino reveals a crucial weakness. Had the minister refused its approval, the tariff approved two years earlier would have remained applicable. By emphasising this fact the Court - rather than sustaining its own reasoning - risks to perpetuate a situation that falls foul of the third Van Eycke prong. If one accepted that the ministerial approval was nothing else than the reinforcement of the effects of an anticompetitive arrangement, for the adoption of which the professional association had been delegated regulatory powers, the earlier approval equally reinforced the effects of the earlier tariff adopted in the same way. Thus, even if the minister would fail to approve the 'draft' tariff, the earlier anti-competitive arrangement would temain being reinforced by the earlier ministerial approval.

\section{The degree of public contral exercised}

Depending on the degree of actual control or influence exerted by the competent authorities the approval of an association's decision may either amount to a mere 'rubberstamping' of the proposed arrangement or to a proper reassessment thereof. As pointed out above rubber-stamping, i.e. the State approval without (major) textual changes, is not accepted by the Court. ${ }^{1671}$ This was not the case in Arduino. According to the Italian law the competent minister had to obtain the advise of two independent bodies representing the interests of the more general public (an inter-ministerial committee on prices, CIP, and the Consiglio di Stato), before he could promote the proposed tariff scheme into a ministerial decree. Upon the observations of the CIP the minister had effectively adjusted the draft tariffs to allow the proposed increase in the fee scale to take place only in two successive tranches staggered by half a year. ${ }^{1672}$ Under these factual circumstance the Court in Arduino was satisfied that the minister effectively had made use of his powers to review the proposed tariffs. In the words of the Court the Italian State therefore had not waived "its power to make decisions of last tesort or to teview implementation of the tariff'. ${ }^{1673}$

What is striking, however, is that the Court was satisfied with the minister merely

1669 Para. 41 of the Arduino judgement (emphasis added).

${ }^{1670}$ For details see Chapter 4.I.1.2.: according to the relevant case law it is irrelevant whether a decision of an association is binding in law to fall within the ambit of Article 81(1) EC.

${ }^{1671}$ The relevant case law is referenced above in section II.1.1. At this point it becomes apparent that rubber stamping concerns State measures that may be prohibited under the second or the third prong of the Van Eycke test, depending on whether the association's decision pre-existed the State measure rubber stamping it (second prong) or whether the association was delegated powers to adopt a decision finally rubber stamped (third prong). This illustrates the complementary nature of the third prong in respect of the first two prongs. Complementary does not mean identical, however, and in my opinion the distinct nature of the third prong is laid down in its gross violation character of democratic principles.

${ }_{1672}$ Paras. 41, 6 and 10 of the Arduino judgment.

1673 Para. 40 of the Arduino judgement. 
staggering the proposed increase of the fees. ${ }^{1674}$ In my opinion this State influence is rather marginal, as the (probably reasonable) increase in the fee tariffs were merely delayed, but remained nominally unchanged. Certainly the minister influcnced the height of the fee scale during six month, but no longer than that. It therefore seems to follow from Arduino that, in order to escape its obligation under the INNO $v A T A B$ principle, it is probably sufficient for a Member State to stipulate the possibility that public authorities exercise powers of control to alter or refuse decisions of (professional) associations. This point had been finely identified by the Raad van State, the referting national court in Wouters. With its sixth question for a preliminary ruling it asked whether a Member State infringes its duty under the INNO $\nu A T A B$ principle when review by the relevant public authority of professional regulations (adopted on the basis of State legislation) "is limited to the power to annul such a rule without the authority's being able to adopt a rule in its stead". ${ }^{1675}$ Unfortunately, this question was left unanswered as the Coutt in Wouters adopted a reasoning according to which the decision of the professional body was not prohibited under Article 81(1) EC in the first place.

The impression of a marginal testing in Arduino is nurtured even mote importantly by the fact that the ministerial decree left other provisions of the association's decision unaffected. In particulat the self-regulatory measure of the Italian Bar prohibited derogation from the set minimum and maximum tariffs. ${ }^{1676}$ Any derogation tequires settlement on the basis of an opinion of the Bar council, i.e. representatives of the very professional group. The question therefore arises which degree of public control to alter or refuse an association's decision should be required to assure that the competent State authorities and not the representatives of economic operators make decisions affecting the economic sphere. On closer inspection, the Court in Arduino appears to apply a rather deferential review of the powers exercised by the competent minister to conclude that the latter has taken a decision of last resort independent of the influence granted to the sector concerned. While it is true that the Italian legislation itself provided for minimum and maximum limits to be set by the professional association ${ }^{1677}$ (and therewith actually required the professional association to adopt a decision in conflict with Article 81(1) EC within the meaning of the first prong), the fact that the settlement procedure for derogation cases remained under the influence of the same professional association and was not tevisited by the competent minister would actually

1674 Also Advocate General Léget was not comfortable with this fact, see para. 108 of his opinion in Arduino: "The information relating to the postponement of the tariff increases suggests that the public authorities excrcise genuine control over the CNF's decisions. Nevertheless, this information must, in my view, be confirmed by further evidence before the [national judge]... The decisive criterion in this respect is not whether the public authoritics have required numerous changes to the draft scale. It lies in establishing that the Italian authorities do indeed intervene to control the content of CNF decisions on aspects which are essential for the profession and third parties" (emphasis added). Moreover, it is also remarkable that, according to the information provided by the Italian government, the competent minister had no power to substitute his own decisions for those of the CNF. He could, however, amend the content of those decisions on his own initiative, see para. 103 of the opinion of AG Léger. - In respect of the same Italian legislation the Court in AG Poiares Maduro in Cases C-94/04 and C202/04, Cipolla and Macrino, [2006], para. 39, records that "At the hearing the Italian Government pointed out that in 1973 the decree approving the scale of lawyers' fees had been adopted 11 months after the date of the CNF proposal. In 2004 also supervision of the decision-making process by the State was noticeable from the fact that, initially, the Consiglio di Stato refused to approve that proposal, considering that it did not have all the evidence it required in order to give its opinion on the draft scale which was submitted to it."

1675 See para. 39 of the Wouters judgement.

1676 Para. 11 of the Arduino judgment.

1677 See para. 7 of the Arduino judgment. 
have justified to come to a different conclusion in Arduino in respect of the third prong of the Van Eycke test. Indirectly, the Court confirmed this train of thought when going into the role taken by the judiciary in establishing individual fees.

\section{The role taken by the judiciary in establishing individual fees}

The third factual element assessed by the Court in Arduino to support that Italy had not failed its obligations under Article 10(2) EC in respect of Article 81(1) EC refers to the role taken by national courts in establishing the concrete fee of a lawyer in an individual case. According to the Italian law fees - where disputed between the parties - are to be settled by the courts on the basis of the challenged tariff scheme, "having regatd to the seriousness and number of the issues dealt with. Moreover, in certain exceptional circumstances and by duly reasoned decision, the court may depart from the maximum and minimum limits fixed" ${ }^{1678}$ According to the Court these provisions contribute to justify the conclusion that the Italian State had not "waived its powers to make decisions of last resort or to teview implementation". ${ }^{1679}$ It is thus implied that providing for judicial review withdraws, as it were, delegation issues from the prohibition of the third ptong of the Van Eycke test. The point has been substantiated by Advocate General Poiares Maduro in respect of the same Italian provisions. Despite acknowledging the anti-competitive effect of the lawyers' fee scale, the Advocate General in Cipolla and Macrino embraced the finding in Arduino by emphasising the duty of a national court to interpret national law in conformity with Community law. Considering that, according to the Italian law, a national court "may also disregard the minimum and maximum limits of the scale" he took the view that, "in order not to increase the anti-competitive effect of the scale, the national court will be required, so far as possible, to use its discretion when it decides a dispute concerning the amount of fees laid down in that scale for out-of-court services.",1680

It is however doubtful that a non-systematic check of individual fees by the judiciaty is an appropriate measure to generally guatantee that legislative power is withheld with the competent regulatory public authorities. Such a mechanism does not seem to reconcile with the separation of powers, legal certainty and the general character of legislation. In particular, the precedent suggests that, to escape the duty under Article 10(2) EC, it is sufficient that a judicial review rule specifies the content of the general guarantee of access to justice. Even if this point should not raise concerns of the separation of powers - which is doubted here - the specific mechanism accepted in Arduino is a very uncertain one as it requires customets to litigate about the fees to pay. In most cases the review of the minimum and maximum fee limits thus remains potential but is not actual. While this may be acceptable under national law, it cannot under Article 10(2) EC: the effectiveness of Article 81(1) EC is curtailed where the effects of powers delegated to (an association of) economic operators are corrected only potentially by the public authorities. Emphasising of the duty of national courts to interpret national law in conformity with Community law seems, in the circumstances of Arduino, to result in the schizophrenic obligation to derogate from what is regulated as compulsory minimum and maximum limits. While the tariff limits are compulsory for the parties under national law, a national court called upon has the obligation under EC law to distegard the otherwise compulsory tariff limits. Moreover, where a condition of judicial review is

1678 Para. 42 of the Arduino judgment.

1679 Para. 40 of the Arduino judgment.

1680 AG Poiares Maduro in Cases C-94/04 and C-202/04, Cipolla and Macrino, [2006], para. 45. 
accepted in respect of the third prong of Van Eycke, this will merely increases the investment to be made in terms of time and money; it hardly contributes to the legitimacy of a State measure delegating regulatory powers to (an association of) economic operators.

\subsubsection{The standard to build: effective control}

While one may guess that in Arduino the Court had raised no objection to the Italian legislation due to the combination of factual circumstances, and in particular the tole provided for in the law and effectively exercised by the competent minister, Advocate General Léger, the Commission and Advocate General Poiares Maduro did not feel comfortable about this assessment.

Advocate General Léger in Arduino proposed a three-staged test to justify, on the basis of Article 10(2) EC, State measures that at first limit the effet util of the competition rules. ${ }^{1681}$ According to his test a State measure "is compatible with Articles [10 and $81 \mathrm{EC}]$ provided that: (1) the public authorities of the Member State concerned exercise effective control over the content of the agreement, decision or concerted practice; (2) the State measure pursues a legitimate aim in the public interest, and (3) the State measure is proportionate to the aim which it pursues." ${ }^{\text {"1682 }}$ At this juncture it suffice to go into the first condition; possible justification grounds for restrictive professional regulation will be dealt with in Chapter $7 .^{1683}$ "The first condition, of effective control, would ensure that the State does in fact examine the content of the agreement, decision or concerted practice. It would therefore be intended to ensure that the State authorities do not give free rein to the economic operators." When turning to the factual evidence in Arduino Advocate General Léger was, however, not convinced that it was sufficient to conclude that Italy had not infringed its duty. He therefore preferred that the national judge should further investigate the minister's acts and whether the public authorities had made any objections or substantive observations vis-à-vis the decision of the professional association. ${ }^{1684}$ In particular he suggested to examine whether the minister in the past had already refused to approve a decision by the professional association on the ground that the tariff increases had been too high. The Court, however, as has been explained above, considered that it had adequate evidence to make the necessary

1681 AG Léger in Case C-35/99, Manuele Arduino, [2002], paras. 91, 99 ff., 126 f. See already AG Jacobs in Joined Cases C-180-184/98, Pavlov, [2000], paras. $162 \mathrm{ff}$.

${ }^{1682}$ Para. 91 of his opinion in Arduino.

1683 "The second condition would make it possible to verify that the State measure has indeed been adopted in the public interest, because it can be presumed that private economic actors normally act in their own and not in the public interest when they conclude agreements between themselves. Thus, the consequences of their agreements are not necessarily in the public interest. By virtue of the second condition, the State authorities would thus be authorised to reinforce the effects of the concertation between the private operators if they are certain that the content of that concertation is in the public interest. Lastly, the third condition would be intended to ensure that the effects restrictive of competition produced by the State measure are confined to that which is necessary in order to achieve the objective pursued." As a legitimate aim in the public interest Advocate General accepted the guarantee of a high level of quality in the provision of legal services, see paras. $109 \mathrm{ff}$. of his opinion in Arduino. In applying the proportionality test he rightly diagnosed that a mandatory system of minimum and maximum tariffs is not suitable for the purpose of maintaining the quality of services provided by the legal profession, and thus could not be justified, see paras. $117 \mathrm{f}$. of his opinion.

1684 Para. 108 of the opinion in Arduino. "The decisive criterion in this respect is not whether the public authorities have required numerous changes to the draft scale. It lies in establishing that the Italian authorities do indeed intervene to control the content of CNF decisions on aspects which are essential for the profession and third parties." 
assessment itself.

The Commission adopted a similar line of argument in the subsequent case of Macrino in which it explicitly asked for the reversal of the case law of Arduino. ${ }^{1685}$ Like Advocate Gencral Léger the Commission intended to subject State measures falling under the third prong of Van Eycke to a requirement of public interest justification with a proportionality testing. ${ }^{1686}$ In fact the cases Macrino and Cipolla ${ }^{1687}$ provided the opportunity to reassess the Court's review standard in respect of the third prong of the Van Eycke test. More particularly, the two cases concerned two specific aspects stemming from the application of the same Italian provisions that had already been at stake in Arduino. In Macrino the lawyer and his clients litigated about the amount of fees that the lawyer claimed to have earned for legal advise unconnected to court proceedings ('out-of-court services'), i.e. services not reserved to members of the Bar. According to the clients the amount of the fees fixed in accordance with the statutory scale were disproportionate in relation to the services finally provided. In Cipolla the conflict concerned the prohibition on lawyers and their clients to derogate from the compulsory fee scale approved by the competent minister.

While Advocate General Poiares Maduro in Macrino withstood the explicit plea of the Commission for a reversal of the case law of Arduino, he pleaded for a refinement thereof and required that effective supervision be exercised by State authorities over the association's measure in order to establish the compatibility of the national provisions with Articles 10(2) EC and 81(1) EC. ${ }^{1688}$ The Court, however, did not take on the suggestions made by either the Commission or its Advocate General, but reiterated its findings from Arduino in respect of Articles $10(2)$ and $81(1)$ EC. ${ }^{169}$ Despite the criticism uttered in this respect above, it is noteworthy that the Court in Cipolla clearly established that the Italian provisions on the compulsory tariff scheme are in principle prohibited under EC law as they restrict the freedom to provide services under Article $49 \mathrm{EC}$. They thus can be accepted only if they can be justified on the basis of acceptable justification grounds and in accordance with the proportionality principle. ${ }^{1690}$ The interesting point here is that the Court did not take the legitimacy of the Italian law for granted. Instead the Court considered it necessary to instruct the national court on the factors to be taken into account when making its decision

1685 The Commission's position is referenced in AG Poiares Maduro in Cases C-94/04 and C-202/04, Cipolla and Macrino, [2006], paras. 27, 43.

${ }_{1686}$ See also already AG Jacobs in Joined Cases C-180-184/98, Pavlov, [2000], paras. 162 ff. See also European Commission, Report on Competition in Professional Services, of 09.02.04; European Commission, Professional Services Scope for more reform, of 05.09.2005. See also Temple Lang J., (2001), 212, who (with reference to postal services monopolies) states that: "A [State] measure which restricts competition is notjustified merely because the resulting profits are to be used for a legitimate purpose in the general interest, even when that is true: the restriction on competition must be necessary in order to achieve the purpose in question."

1687 Joined Cases C-94/04 and C-202/04, Cipplla and Macrino, [2006]. The cases are summarised in Chapter 2.V. ${ }_{1688}$ AG Poiares Maduro in Cases C-94/04 and C-202/04, Cipolla and Macrino, [2006], para. 46: "Finally, I suggest that the Court should find that it is clear from the judgment in Arduino that Article $81 \mathrm{EC}$ in conjunction with Article $10 \mathrm{EC}$ does not preclude a national measure fixing a scale for lawyers' fees, even as regards out-of-court services, provided that the measure bas been subjected to effective supervision by the State and where the power of the court to derogate from the amounts fixed by the scale is interpreted in accordance with Community law in a way that limits the anti-competitive effect of that measure" (emphasis added).

${ }^{1689}$ Joined Cases C-94/04 and C-202/04, Cipolla and Macrino, [2006], paras. 46-54. NB The case was decided by the plenary formation of the Court.

${ }_{1690}$ At para. 64 of the Cipolla judgment the Court considered the protection of consumers (i.e. recipients of the legal services) and the safeguarding of the proper administration of justice as objectives which may be regarded as overriding requirements relating to the public interest capable of justifying a restriction on freedom to provide services. The potential of both these interests as justification grounds will be fathomed in Chapter 7 . 
on the necessity of the Italian provisions at stake. ${ }^{1691}$ Therewith the Court at last embraced the Commission's plea of the application of the proportionality test to anti-competitive legislation - albeit not with regard to the State's duty under Article 10(2) EC and in respect of competition law.

\section{Interim conclusions}

As has been pointed out by others the Court is satisfied with a formalistic application of the $V$ an Eycke test ${ }^{1692}$, i.e. whether the Member State, according to its legislation, reserves the ultimate control on the delegated responsibilities exercised by the economic operators. As is apparent from the case law reviewed here the Court seems to be agnostic as to whether that control is effectively exercised by the competent State authorities. Thus, where the deferential application of the delegation prong actually supersedes the application of the (as such disjunctively applicable) first two prongs, the latter become redundant. Therewith the question arises whether the whole of the strong constitutional INNO $v A T A B$ principle becomes illusionary by the Court's practice. ${ }^{1693}$ In this respect it would be helpful if the Court in the future would shed more light on whether it is correct to consider that the nature of the third prong of Van Eycke is different from the first two prongs, namely that the third prong applies only to cases of gross violations of democratic principles accepted in the Member States. ${ }^{1694}$

The conclusion here is that, in order not to engage their liability under the third prong, Member States need to take full democtatic responsibility for their measures leading to restrictions of competition. Ex post mechanisms of influence have to tesult in effective control being exercised by the competent public authorities. By the same token, but on the jurisdictional level discussed in Chapter 4.I., ex ante control mechanism concerning the composition and public interest obligations of a regulatory committee may be accepted where the Member State takes full democratic responsibility for the regulatory committee by again exercising effective control. The first two prongs of the $V$ an Eycke test could finally be lifted on the same level with the freedom of movement rights, namely to prohibit State measures that allow undertakings to restrict the freedom of competition.

The case law as it stands, however, is an open door for a Member State to evade its liability under Articles $3(1)(\mathrm{g}), 10(2)$ and $81 / 82 \mathrm{EC}$ : where a Member State designs the domestic system of professional regulation to assume the formal responsibility for the restriction of competition itself, the Court is unlikely to find that the Member State has neglected its obligation under Articles 3(1)(g), 10(2) and 81/82 EC. Without an effective test as to the substance of a law, the current case law is an incitement for pressure groups to lobby even more with legislators to assimilate anti-competitive standards developed by a profession itself.

\section{State compulsion defence}

Where national law provides the legal basis for associations to adopt professional

1691 Paras. 65-70 of the Cipolla judgment.

${ }_{1692}$ See e.g. Neergaard U.B., (1998), 19, 119, 396; Monti G., (2002); Gilliams H., (2006). Gysclen L., (2006).

${ }_{1693} \mathrm{NB}$ In respect of Article $82 \mathrm{EC}$ and the Spediporto test there is a fair chance that the Court might adopt a similarly deferential approach as with regard to the Van Eycke test.

1694 For details see above section II.2.1. 
regulations, the question is whether a professional association engages its own responsibility for anti-competitive rules in parallel to a Member State, or whether it may validly taise the defence that any restrictive effect ensuing from its self-regulatory measures is the result of the statutory obligation imposed by the State authorities to adopt certain regulations. This defence is know as the State action defence or State compulsion defence. ${ }^{1695}$ It has been recognised in the case law of the Community Courts since the late $1990 \mathrm{~s}$. ${ }^{1696}$ The underlying idea of the defence is that undertakings would not be liable under Article 81(1) EC of Article $82 \mathrm{EC}$ where a Member State, by means of public authority measures, requires them to engage in anti-competitive conduct. ${ }^{1697}$

Conversely, Articles 81 and $82 \mathrm{EC}$ apply only to anti-competitive conduct in which undertakings engage on their own initiative. ${ }^{1698}$ Under the principle of the 'State compulsion defence' undertakings can claim that they are not liable for the restriction of competition caused by their actions where that conduct was required by national legislation or where the national legal framework itself eliminated any possibility of competitive activity on their part. In such a situation, the restriction of competition is not attributable, as is implied by the two provisions, to the autonomous conduct of the undertakings. The possibility of excluding to sanction specific anti-competitive conduct, on the ground that the undertakings in question had been required by national legislation to behave in that way, has bcen applied restrictively by the Community judicature. ${ }^{1699}$ Accordingly, Articles 81 and 82 EC apply, if it is found that the State measure does not preclude undertakings from engaging in autonomous conduct which prevents, testricts or distorts competition. ${ }^{1700}$ Consequently, if a national law merely allows, encourages or makes it easier for undertakings to engage in autonomous anti-competitive conduct, the undertakings in question remain subject to the Treaty competition tules. ${ }^{1701}$

While the State action defence has been developed with regard to the autonomous

1695 European Commission, Report on Competition in Professional Services, of 09,02.04, para. $76 \mathrm{ff}$.

1696 Beginning with Joined Cases C-359/95 P and C-379/95 P, Commission and France v Ladbrake Racing, [1997], paras. $33 \mathrm{ff}$., referring however to earlier case law "to that effect", and as regards Article $82 \mathrm{EC}$, Case 41/83, British Telecommunication, [1985], paras. 18 to 20; Case C-202/88, French Republic $\nu$ Commission (Telecommunications Terminal Equipment), [1991], para. 55; and Case 18/88, RTT $\nu$ Inno, [1991], para. 20.

1697 See already Case 13/77, INNO $v A T A B,[1977]$, paras. 25, $33 \mathrm{f}$., and the case law teferred to in the following notes.

${ }^{1698}$ See e.g. Joined cases T-259/02 to T-264/02 and T-271/02, Raiffeisen Zentralbank, [2006].

1699 Joined Cases 209 to 215 and 218/78, van Landenyck, [1980], paras. 130, 133; Case 41/83, British Telecommunication, [1985], para. 19; Case T-513/93, CNSDIII, [2000], para. 60; Case T-65/99, Strintzis Liner, [2003], paras. 119 to 124; Case T-66/99, Minoan Lines, [2003], paras. 176-181. Where undertakings have invoked the defence they have invariably failed it, Rizza C., (2004), note 1 . See also Joined cases T-259/02 to T-264/02 and T-271/02, Raiffeisen Zentralbank, [2006], paras. $258 \mathrm{f}$., reinforcing the idea of autonomous conduct despite encouragement or facilitation by the public authorities. The judgment tefers to INNO v ATAB. The question is whether the judgment adds something new by coining a 'concept' of "irresistible pressure" by the national authorities brought to bear upon particular undertakings.

1700 Joined Cases C-359/95 P and C-379/95 P, Commission and France v Ladbroke Racing, [1997], paras. 33 ff.; Case C-198/01, CIF v AGCM, [2003], paras 52 ff.; Case C-207/01, Altair Cbimica, [2003], paras. 30 ff.; Case T-111/96, ITT Promédia, [1998], para. 96; Case T-228/97, Irish Sugar I, [1999], para. 130; Case T-513/93, CNSD III, [2000], paras. 58 f.; Case T-154/98, Asia Motor, [2000], paras. 78-91; Joined Cases T-191/98 and T-212/98 to T-214/98, TACA, [2003], para. 1130.

1701 Joined Cases 209 to 215 and 218/78, van Landenyck, [1980], para. 126; Joined Cases 89, 104, 114, 116, 117 and 125 to 129/85, Ablström, [1988], para. 20; Case C-198/01, CIF ע AGCM, [2003], para. 56; Joined Cases T191/98 and T-212/98 to T-214/98, TACA, [2003], para. 1130; Joined cases T-259/02 to T-264/02 and T271/02, Raiffeisen Zentralbank, [2006]. 
conduct of undertakings, nothing should withhold professional associations to invoke the same defence as the case may be. ${ }^{1702}$ It is a doctrine of general application, since it is based on fundamental principles of the Community legal order, notably the principle of legal certainty and the associated prohibition of retroactive penalisation of conduct. ${ }^{1703}$ Due to the fact that associations of undertakings are not normally engaged in an economic activity themselves ${ }^{1704}$ the test of the autonomous conduct on the part of the undertakings has to be adapted in order to make allowance for the fact that any restrictions in the professional markets originate in the relationship between State tegulation and self-regulation by the associations (i.e. tesulting in a two layered hieratchy of tegulation). The CFI has neatly done so with regard to the professional association of the Italian customs agents in case CNSD III. ${ }^{1705}$ It was held that the professional association "enjoyed a margin of discretion in the implementation of the national legislation such that the nature and scope of competition in that business sector was in practice dependent on its decisions". ${ }^{1706}$

In order to come to this conclusion the CFI established, on the one hand, that there had been a certain degree of competition between the undertakings concerned that the undertakings themselves could autonomously influence (i.e. "prevent, restrict or distort"). Secondly, with regard to the regulatory activities of the association the CFI held that the CNSD had "room for manoeuvte in performing the obligations imposed on it by the [national] legislation". The CNSD "could and ought to have acted" within that margin of discretion "in such a way as not to restrict the existing level of competition." In the factual circumstance of the case the CNSD indeed had used its discretion to determine the level of minimum and maximum prices (thereby restricting competition in the sector), to grant derogations from the tariffs thus fixed (thereby creating price competition in the sector), and to impose mandatory invoicing methods not required under the national law (hence preventing the custom agents to reduce costs related with their internal organisation). It follows from that case that the State action defence cannot be successfully invoked as long as the professional association enjoys a certain discretion in their regulatory and supervisory activities.

Advocate General Jacobs in $A O K$ developed the standard of autonomous conduct to be applied to associations of undertakings along the lines of a two-step approach. ${ }^{1707} \mathrm{He}$ first poses the question whether an association is able to avoid the fixing of rules as foreseen in the national legislation, in which case there is no compulsion from the side of the State. Conversely, where an association is subject to a "clear and categorical obligation to act" one has to scrutinise in a second step whether a prima facie breach of competition law (e.g. tariff fixing) is attributable to the association. 'This can be done in two ways. First of all, one has to assess whether the restriction of competition is wholly attributable to the discretion exercised by the association in the decision-making process. Where this has to be answered in the negative the anti-competitive effect of the rule adopted by the association may at least

1702 See Case T-513/93, CNSD III, [2000], paras. 57 ff.; and AG Jacobs in Joined Cases C-264/01, C-306/01, C-354/01, C-355/01, $A O K$, [2004], paras. $73 \mathrm{ff}$.

${ }^{1703}$ Nullapoena sine lege. See AG Jacobs in Joined Cases C-264/01, C-306/01, C-354/01, C-355/01, $A O K$, [2004], para. 75; AG Jacobs in Case C-198/01, CIF ע AGCM, [2003], paras. 48-50.

1704 See Chapter 3.I.

1705 Case T-513/93, CNSD III, [2000], paras. $57 \mathrm{ff}$.

1706 Case T-513/93, CNSD III, [2000], paras. 61-72, esp. 71 (emphasis added).

1707 AG Jacobs in Joined Cases C-264/01, C-306/01, C-354/01, C-355/01, AOK, [2004], paras. $81 \mathrm{ff.}$

${ }^{1708}$ Para. 81 of AG Jacobs' opinion. 
have been exacerbated by the choices made by the association. ${ }^{1709}$ Secondly, one has to inquire whether any discretion vested in the association to adopt anti-competitive decisions has been used to generate an appreciably greater restriction on compctition than would have resulted from another measure on the permissible range of determinations open to it. ${ }^{1710}$

National legal frameworks normally leave the professional associations the discretion whether or not to regulate certain aspects of the practice of a profession. ${ }^{1711}$ Not least due to the re-regulatory efforts in the field of liberal professions in the Member States and at Community level is it unlikely that a Member State is to prescribe professional associations in great detail the exact regulatory steps in the fixing of various trading conditions; tather a State would directly impose the wished conditions for the professional sectors. ${ }^{1712}$ Furthermore, even where the national regulatory framework can be interpreted to categotically require professional associations to adopt measures regulating the profession ${ }^{1713}$, the State compulsion defence will cut ice only if no room for discretion is left with regard to the content of the self-regulatory measure. To raise the State compulsion defence effectively would require strict State regulation and supervision in prescribing the

1709 Para. 82 of AG Jacobs' opinion.

1710 Para. 84 of his opinion in $A O K$. It should be noted that the Court in $A O K$ avoided to consider the State action defence, and instead concluded that the associations of sickness funds in Germany had not infringed Article 81(1) EC because, in the view of the Court, they did not engage in an economic activity separate from the exclusively social objective of the sickness funds. The Court found that the determination of fixed maximum amounts for purchase prices of medicinal products is mercly a task for management of the German social security system that is imposed upon the associations by legislation. On a comparative reading of the opinion of AG Jacobs and the Court's decision one might think that the Court wanted to avoid that measures, which its AG qualified as being in the economic sphere, are in some more or less remote connection with the social security system of a Member State, Joined Cases C-264/01, C-306/01, C-354/01 and C-355/01, AOK, [2004], paras. 58 ff.

${ }_{1711}$ See for instance the Dutch Lawyers Act in its Article 28 that provides the governing body of the lawyers association with the power but not the obligation to regulate. See Article 28(1) AW: "The College of Delegates may adopt regulations in the interests of the proper practice of the profession, including regulations concerning provision for members of the Bar affected by old age or total or partial incapacity for work, and provision for the next-of-kin of deceased members. Furthermore, the College shall adopt the necessary regulations concerming the administration and organisation of the Bar" (emphasis add). Compare also Article $30 \mathrm{AW}$, which provides for the possibility for the Crown to interfere only if self-regulation by the lawyers association has come about previously, and is contrary to the law or the public interest.

${ }^{1712}$ Compare also the developments in the field of accountancy services where one sees that the dissatisfaction with the regulatory standards, in particular in respect of statutory audits, has lead to the adoption of harmonised rules imposed on the sector. In particular, the European Union has codified some minimum requirements for international statutory audits and the professionals engaged in these activities. Accordingly, there has to be a licensing-model in all Member States. Member States have, however, used their margin of appreciation in how to transpose such licensing requirement, and not all Member States have adopted a compulsory membership model. - See also the proposal for a directive "Accountancy" to combat fraud and malpractice (16.03.2004), with further details on <http://europa.cu.int/comm/internal_market/auditing/index_en.htm>: the Commission states that the objective of a new directive on statutory audit in the EU is to ensure that investors and other interested parties can rely fully on the accuracy of audited accounts. It also aims to enhance the EU's protection against the type of scandals that recently occurred in companies such as Parmalat in Italy and Ahold in the Netherlands. The proposed Directive would clarify the duties of statutory auditors and set out certain ethical principles to ensure their objectivity and independence. It would introduce a requirement for external quality assurance, ensure robust public oversight over the audit profession and improve co-operation between regulatory authorities in the EU. Single Market news, no. 33, April 2004, p. 8.

1713 See for instance $\$ 59 \mathrm{~b}$ (1) BRAO: "Further details regarding professional rights and duties shall be set out in the rules of a code of professional conduct" (emphasis added). See also the rules applicable to the Italian association of customs agents, Case C-35/96, Commission v Italian Republic (CNSD II), [1998], para. 56. 
professional association the content and shape of the measures to adopt, with the result that competition between the members of the profession is limited or even excluded. ${ }^{1714}$ It is not enough, however, that the statutory rules scrupulously prescribe the criteria with regard to one factor of competition, e.g. concerning tariff fixing, since other forms of effective competition will persist. ${ }^{1715}$ Where a possibility for a certain degree of competition in the regulated sector is left open by the national statutory framework, the self-regulatory body retains a certain room for manoeuvre in which it can chose to refrain from restricting or eliminating competition between its members. ${ }^{1716}$

In the absence of binding national legislation that explicitly specifies the content of selfregulatory measures, it is nevertheless conceivable that the professional associations find themselves forced by non-statutory State measures to adopt specific measures to regulate the profession concerned. This is at least a cogitable line of argumentation in the light of the reregulatory efforts in certain of the Member States, e.g. in the UK or the Netherlands, and the competition advocacy of the Commission in this context. ${ }^{1717}$ In the particular case that binding national legislation is absent one can conclude that an autonomous behaviour is excluded only if it appears on the basis of objective, relevant and consistent evidence that that conduct was unilaterally imposed by the national authorities through the exercise of irresistible pressure, such as, the threat to adopt State measures likely to cause the sector to sustain substantial losses. ${ }^{1718}$ The professional association invoking such a defence will have to satisfy a particular high burden of proof. It will have to demonstrate that the form of its self-regulatory measures has its origin in the practices and policy of the national authorities and not, not even to some extent, in the will of the collectivity as represented by the association and its governing bodies. The task is to establish that the legislative and regulatory framework and the policy of the competent national authorities have the cumulative effect, on the one hand, of deptiving the professional associations of its discretion in adopting professional tegulation in compliance with competition and, on the other, of restricting or even removing any possibility of competition between the associations ${ }^{2}$ members. ${ }^{1719}$ It should be noted that the State compulsion defence can be assessed only as of the moment that a restriction, distortion or elimination of competition can be established. Absent a statement to that effect it will not be possible to judge whether the association engages in an autonomous conduct, i.e. whether it enjoys a sufficient degree of discretion in establishing professional regulations that turn out to restrict competition between its members.

\section{State compulsion in perspective}

The State compulsion defence is adjacent to the two lines of case law discussed in Chapter 4.I.2. that undermine or out-compete the universal application of competition law

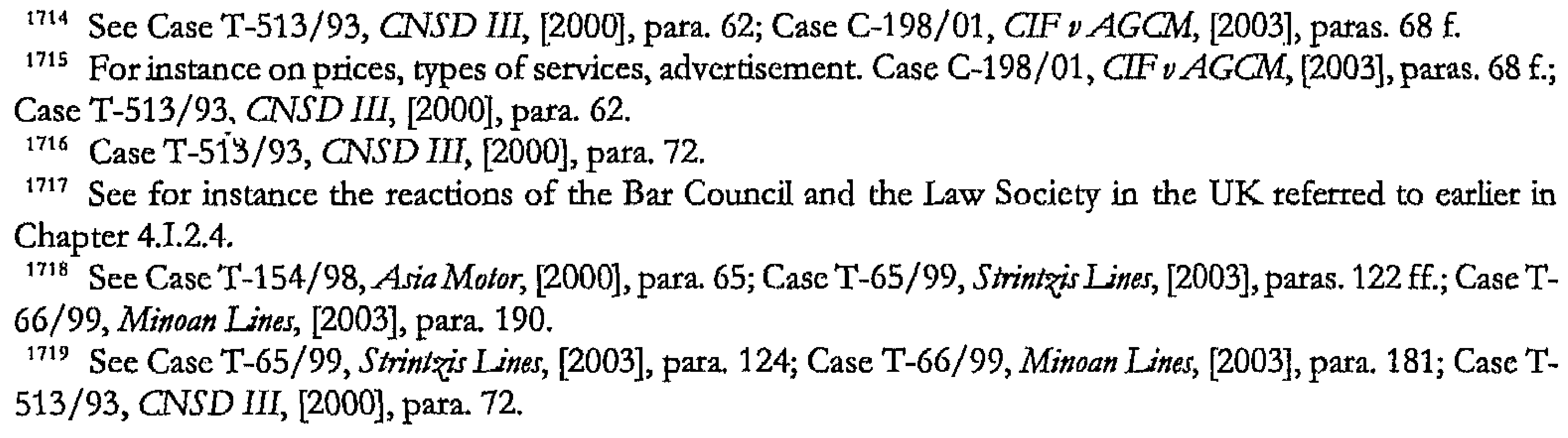


and that exclude the applicability of competition law to self-regulatory bodies due to either the exercise of public authority or the fact of adopting decisions like an arm of the State. Also with regard to the State compulsion defence it is the role of the State that is determinative for the assessment of the primary actor presumably restricting competition. The difference with the two particulat lines of case law discussed in Chapter 4 is, however, that under the State compulsion doctrine of the Community Courts no explicit reference to a public interest criterion is strictly necessary. It does, however, play an indirect tole. The absence of a public interest commitment may indicate that a body does act autonomously of the public authorities. This indicator is, however, not absolute. It is the choice of the national legislator whether to limit the room of action of a body (with or without a public interest motivation in mind) to such an extent that the latter may not be able to act otherwise than restrictive of competition.

The proximity of the State compulsion defence with the exceptions to the scope to Article 81(1) EC has been illustrated in CIF. There the Court presented the criteria on the composition of, and the interests taken into account by, a collective body as part of the question whether national legislation prevented the body to act autonomously. ${ }^{1720}$ The relevant question thus is whether a self-regulatory body has the choice to restrict competition in the interest of the sector, or whether its acts are motivated by other considerations that have been determined by the State authorities or legislator.

The US State action doctrine ${ }^{1721}$ has a different approach from the EC State compulsion defence. The former is more similar to the 'exercise of public authority' exception of the ECJ cases $S A T /$ Eurocontrol and Cali ${ }^{1722}$, but is still different from the case law on the control by a public authority ${ }^{1723}$ and the EC State compulsion defence. The reason for this is that the State action defence under US anti-trust law draws exclusively on the institutional requirement of State involvement. More than 60 years ago the Supreme Court ruled that the Sherman Act applies only to business and not politics. ${ }^{1724}$ This means that regulations or measures emanating from the public authorities are immune of the application of anti-trust law irrespective of any anti-competitive effects they may have. The anti-trust law scrutiny stands aside where restrictive acts involve the State authorities. The Supreme Court thereby has defined an institutional requirement in order to decide which agreement come within the ambit of anti-trust law depending on the author thereof. Any reference to the fact that an anti-competitive act is based on the public interest will not be welcomed by the Supreme Court regardless of whether procedural or substantive guarantees have been in place to safeguard the public interest. The understanding of the Supreme Court is that the political process should be left to determine what is best in the public interest. ${ }^{1725}$ Non-state authors that interfere in the market cannot invoke the public interest as grounds for restricting competition. To recognise such an argumentation is, according to the Supreme Court's neoliberal conviction, a "frontal assault on the basic policy of the Sherman Act". ${ }^{1726}$ No procedural or substantive guarantee can result in the exclusion of a measure from the ambit

${ }^{1720}$ Case C-198/01, CIF $\nu A G C M$, [2003], paras. $66 \mathrm{ff}$, and $76 \mathrm{ff}$.

${ }^{1721}$ See for instance Fox E.M., (2004).

${ }^{1722}$ For details see Chapter 4.I.2.1.

${ }^{1723}$ For details see Chapter 4.I.2.2.

1724 Supteme Court of the United States - "Parker v Brown" [1943], 317 US 341.

1725 Schepel H., (2002), 41.

1726 Supreme Court of the United States - "National Society of Professional Enginecrs vUS" [1978], 435 US 679, 695. 
of US anti-trust law the author of which is not a public authority. ${ }^{1727}$

The advantage of the State action defence as developed in US anti-trust law lies in the clear distinction that can be made with regard to the author of a restrictive agreement. ${ }^{1728}$ Conversely, the State compulsion doctrine as developed by the Community Courts and starting with the Ladbroke case pays tribute to the relative concept of undertaking and association of undertakings in that it focusses on the conduct of a body rather than the status of the author of a testrictive measure. If that conduct is attributable to an (association of) undertaking(s) it will be caught by EC competition rules. This has can be linked to the conceptual difference between Article $81 \mathrm{EC}$ and the Sherman Act. The former has a large ambit to cover all behaviour of autonomously acting economic operators and their associations, to tefine the rule of EC competition law by way of explicit exemptions in Article 81(3) and 86(2) EC. Conversely, the Sherman Act does not contain such exemptions and the application of US antitrust law is therefore dependent on limiting the rule at the gate. As seen above such a restriction at the gate, i.e. delimiting the scope of Article 81(1) EC with regard to the addressee, is the rare exception in EC competition law. A restriction ratione materiae is just as tare in $\mathrm{EC}$ competition law.

\section{Closing remarks: Some pointers towards a legitimate level of competition law control of State measures}

Under the third prong of the Van Eycke test the Court has developed the relevant question into whether a Member State - rather than giving (an association of) undertakings a free hand in affecting or regulating markets (at which point EC competition law takes over) - has retained its powers to make decisions of last resort or to review the implementation of its measures ${ }^{1729}$ in exercising its "right to economic self-determination". ${ }^{1730}$ As insinuated above this yardstick in the Court's testing under the third prong of the Van Eycke test opposes the question under the first two prongs, namely of whether a Member State fallaciously conferred the appearance of official regulation upon the (association of) undertakings' measure by requiring or favouring the adoption of anti-competitive conduct, or by reinforcing the effects thereof. ${ }^{1731}$ Once the Court under the first two prongs comes to the conclusion that Member State regulation only has the apparent character of official regulation the finding will be that the Member State has infringed its obligations under Articles 3(1)(g), 10(2) and 81(1) EC. Conversely, where the Court is convinced that under the third prong a specific measure is genuine State regulation because the Member State has retained its power to take decisions of last resort, the Member State will not have contravened its duties under the said articles.

Putting the respective prongs in the perspective of verifying the genuineness of the character of State measure leads to the question of whether the retention of a Member State's power to take decisions of last resort necessarily is restricted to the last prong of the Van Eycke test. One may wonder whether the power of last resort represents a broader principle

${ }^{1727}$ Sec Supreme Court of the United States - "Northwest Stationers v Pacific Stationery" [1985], 472 US 284

${ }^{1728}$ This is not to say that the US State action doctrine would be devoid of inconsistencies or incoherence, sec Schepel H., (2002), 41, and the literature cited there.

1729 Case C-35/99, Manuele Arduino, [2002], paras. $40 \mathrm{ff}$.

1730 Neergaard U.B., (1998), 121.

1731 See Case C-35/96, Commission v Italian Republic (CNSD II), [1998], para. 59. 
that overarches the whole of the Van Eycke test. In fact the case law, and in particular the case Arduino, seems to develop into this direction, thereby potentially amalgamating the third prong into the first two ones. ${ }^{1732}$ What has still to be set out here is that one can understand the Court's standard under the third prong of Van Eycke as a two-staged. First of all, a Member State contravenes its obligations under Article 10(2) EC where it delegates regulatory tesponsibility to private traders. This stage refers to the accessoriness of Articles 86(1) and 10(2) EC. This means that where a State measure necessarily has the effect to lead (an association of) undertakings to conduct that necessarily restricts or will restrict competition, the inhibition of the effectiveness of Article 81(1) EC will be presumed and thus result in the conclusion on a violation of Articles 86(1), 10(2) and 3(1)(g) EC. Secondly, a Member State may tebut the presumption and remedy its 'fault' by proving that it retained its power to make decisions of last resort. ${ }^{1733}$

As such the standard to retain powers of last resort sounds sensible in order to solve the conflict of a potential clash between, on the one hand, the exclusive competence of Community law to guarantee the effective implementation of the competition rules ${ }^{1734}$ and, on the other, the Member States' competence to enact genuine economic State regulation. ${ }^{1735}$ However, the yardstick developed by the Court, especially in case Arduino, refers to the procedure that has been laid down in the Member State's own legislation. ${ }^{1736}$ The test so far applied in this respect is limited to establish whether the competent Member State authorities have the formal ability to influence the process of rule-forming. Whether they indeed have exercised such competence to balance the substance of the economic regulation remains in the obscurity of the Member State's administration though. This has been exemplified above in section II.2.2.2. in respect of the example of Arduino. While the standard applied in Arduino requires that a certain control system is being set up by a Member State, the deferential testing of the effectiveness thereof enables the guard to decide on the degree with which it controls the fox it set to keep the geese.

The question atises whether it is desirable that a Member State has full discretion in how to monitor regulatory committees that qualify as association of undertakings. Put differently the question is whether the Court in Arduino in fact unnecessarily testricted the extent of a legitimate competition law control of State measures that delegate to private economic operators responsibility for taking decisions that, in turn, affect the economic sphere. The deferential approach followed in Arduino bears the tisk of hollowing the Member States' obligation under the EC Treaty not to introduce or maintain in force any measure that may render the competition rules ineffective. In order to better warrant the effectiveness of the EC competition rules a few suggestions shall be presented in this part on how to deal with State intervention in professional regulation that has the object of effect to restrict competition.

In order to strike a fair balance between subjecting State measures to the INNO $v A T A B$ principle and the State's competence to adopt economic regulation as reinforced by Arduino and Macrino, the suggestion to be made here is to apply a common standard overarching the

\footnotetext{
1732 See Case C-35/99, Manuele Arduino, [2002], paras. 43 and 36. See also Case C-35/96, Commission v Italian Republic (CNSD II), [1998], para. 59.

1733 For details see part II of this chapter.

1734 As far as trade between Member States may be affected, see Chapter 3.II.

${ }_{1735}$ See also AG Trstenjak in Case C-531/07, LIBRO, [2008], para 129, addressing the issue squarely, with reference to Emmerich, W., in Dauses, M., Handbuch des EU-Wirtschaftsrechts, H. I. $\$ 1,9^{\text {th }}$ complement, n. 12. ${ }^{1736}$ Case C-35/99, Manuele Arduino, [2002], para. 44.
} 
three prongs of Van Eycke. Instead of having the third prong of Van Eycke in practical consequence prevail its first two prongs, the suggestion is that the genuineness ${ }^{1737}$ of the character of State measure is a useful benchmark to ascertain whether competition law is the appropriate standard to assess the legitimacy of a State measure under Articles 10(2) and 86(1) EC. While the previous patt was about how to assess the genuineness of State character of a provision, the idea of this part is to sketch options for a sliding scale of legal review of State intervention in professional regulation. Depending on the degree of influence that a State takes in the rule making process of a professional rule, it is possible to distinguish three categories of State regulation. Accordingly, three different substantive tests for legal review shall be suggested. First of all, it is conceivable that a State measure covers up a decision of an association of undertakings (or an abuse by the collectivity ${ }^{1738}$ ), thus representing a hidden decision (or abuse). In a second situation a State measure ultimately takes the form of genuine State measure, irrespective the involvement of a self-regulatory body at a certain stage of the rule making process. Thirdly, the State measure may take the form of a general law, which is binding for members of a profession but without involvement of a professional association in the rule setting.

Where the Member State measure is a hidden decision of an association of undertakings, the Court has made clear that a Member State infringes its obligations under Articles 86(1), 10(2) and 3(1)(g) EC where it "deprive[s] its own legislation of its official character by delegating to private traders responsibility for taking decisions affecting the economic sphere". A scrutiny on the substance of the State measure delegating that responsibility prima facie is not necessary. The question, however, arises whether a Member State should be allowed to justify such an intervention in the market. It is for instance conceivable that the restrictive regulation is necessary to achieve a goal different from leading to a restriction of competition by professionals. In Chapter 4.II.1.1. and 4.II.1.2. it has been explained how the pursuit of an aim fostering competition leads to a restriction being ancillary. ${ }^{1739}$ Similarly, a Member State may rebut the presumption that it would have intended its measures to have the natural and foreseeable effect of requiring/ favouring/ reinforcing anti-competitive self-regulation by the sector, or of delegated regulatory powers being exercised in an anti-competitive way. It is in fact conceivable that Member States invoke the ancillary restraints doctrine for their acts in respect of Van Eycke and Spediporto. The conceivable argument under the first two prongs would be that the competent Member State authorities did not intend to require or favour anti-competitive agreements between undertakings to be adopted, not to reinforce their effects. Instead Member State authorities would need to objectively demonstrate that they pursued a different aim, e.g. to increase the variety or quality of professional services. Similarly, and under the third prong, the conceivable atgument may be that the Member State authorities did not intend delegated powers to be used in an anti-competitive way. Instead they would need to demonstrate that the (association of) undertakings misused their delegated powers to adopt and propose anticompetitive rules. Similar rules on the burden of proof as discussed in Chapter 4 will have to be applied in respect of the Member State authorities.

\section{${ }^{1737}$ Szyszczak E., (2007), 96.}

${ }^{1738}$ Alternatively, it is sufficient that the State measure puts one or more undertakings in a position to act independently of their competitors, customers and the ultimate consumer to infringe Articles 10(2) and 86(1) EC. For details see above sections II.1.2. and II.1.3.

${ }^{1739}$ The same idea of ancillary restraints may be applied in the context of the Spediporto test, see Chapter 5.П1.2.1.2. (last paragtaph). 
In a situation where a State measure ultimately has the nature of a genuine State measure (i.e. irrespective the involvement of a self-regulatory body at a certain stage of the rule making process), the Court so far has not taken a stance in respect of whether an analysis of the substance of the State measure is allowed. The scrutiny rather ends in the case law where the Court came to the conclusion that a Member State had not 'deprived its own legislation of its official character by delegating'. The position of the Commission in Macrino, and the opinions taken by Advocate General Léger and Jacobs in Arduino and Pavlov respectively demonstrate, however, that $V$ an Eycke and Spediporto do not represent a closed enumeration. The Commission and the Advocate Generals have initiated a discussion on the future development of Van Eycke (and, consequently, also of Spediporto). The aim thereof is to subject State measures to a proportionality test where they have been adopted under the influence of regulatory bodies from the relevant sector. A proportionality testing is legitimate because once the Member State measures are subject to the exclusive competition control of the Community by virtue of the Member States' obligation under Article 10(2) EC, it is legitimate to also scrutinise the necessity of the substance of those State measures. In other words, the burden of proof should be reversed as soon as a Member State involves a selfregulatory body in the rule-setting process.

In fact the Court in Cipalla did subject the Italian rules to such a proportionality test, albeit in respect of the freedom to provide services. ${ }^{1740}$ The ensuing question is whether there remains at all a point in subjecting State measures to the scrutiny of Atticles $86(1), 10(2), 81$ and $82 \mathrm{EC}$. More particularly, ever since Bosman ${ }^{1741}$ and the application of Article $49 \mathrm{EC}$ to (non-State) collective regulation, it may seem redundant at first to further develop the case law of Van Eycke and Spediporto. The difference in applying Articles 86(1) and 10(2) EC is that their standard (as exemplified in INNO $v A T A B, V$ an Eycke and Spediporto) allows to assess the role taken by a professional association in the rule setting process. Conversely, an assessment of a State measure under Article $49 \mathrm{EC}$ is conducted without regard to the involvement of an association of undertakings. A substantive review in respect of competition law appears, however, more appropriate where a Member State chose to involve the sector in the rule making process of economic regulation, i.e. to give the sector a chance for institutionalised lobbying. Compared to State measures 'making it less attractive for a service provider to trade in her services across the border ${ }^{1742}$, a restrictive State measure encouraging/ requiring etc. the self-regulatory distortion of economic behaviour in the internal market may be perceived as even more invasive to the economic freedoms. In particular, a State measure delegating responsibility (to influence economic patterns) but retaining for instance ministerial control, is not any better than a measure restrictive of the freedom to provide services. The deferential application of INNO vATAB and Van Eycke in Arduino, however, creates the fiction that State measures involving institutionalised lobbying by the sector are general laws, which could not be subjected to a competition law standard. Such an understanding, however, misconceives the nature of Article 10(2) EC set out in the beginning of this chapter.

Remains the question of how to reconcile the qualitative test of proportionality with the hitherto formalistic or deferential standard applied by the Court, which determines the responsibilities of the State authorities and self-regulatory bodies respectively when they

1740 For details see above section $\Pi$.2.2.3.

1741 NB The development of Bosman took place after INNO $\vee A T A B, V$ an Eycke and Spediporto.

1742 This formulation mimics the one used in the case law on the various free movement rights to describe indirect (or non-) discriminatory State measures. 
interfere with markets. The solution could be obtained by asking whether the Member State "encouraged" professional bodies to adopt proportionate measures; in which case the Membet State measure would be safe. A further question results from this, namely which benchmark to take: is the proportionality of the self-regulatory measure decisive? Or the proportionality of the State measure? Let us assume for instance that the proposal by the association would not be proportionate but nevertheless backed by the minister. Even where not rubberstamping the association's draft, the State measure would still not be proportionate. This should clearly result in finding an infringement because of the disproportionate character of the State measure. Conversely, in case the association's proposal would be proportionate but the minister changes it into an disproportionate measure, it is not clear whether this would constitute an infringement because the State assumed its own responsibility. In particulat no delegation and no incitement to adopt disproportionate measures took place as the association proposed a proportionate measure. The comparative result between the two instance would be an unequal treatment of rules that actually may have the same (disproportionate) content. Looked at from this perspective the Commission's proposal in Cipolla and Macrino will necessarily intervene with the autonomy of the public rule-maker. ${ }^{1743}$

Even where a State measure has been adopted without the involvement of a professional association, some control in respect of competition law could be conceivable. A relevant measure takes the form of a general law and directly obliges undertakings to conform their economic behaviour in a certain way. The practical effects of e.g. tariff schemes for doctors, lawyers, notaries fixed by the State ate the same that result from concerted price collusion or price dictates adopted by (an association or emanation ${ }^{1744}$ of) undertakings. Once more the issue of the Member States' right to economic self-determination competes with the Community's exclusive competence to control restrictions of the freedom of competition. The compulsory character of an economic State regulation inhibits the undertakings from behaving in a way that conforms with competition law. In other words, the undertakings cannot avoid infringing the competition law provisions. ${ }^{1745}$ In view of Articles 86(1), 10(2), 4 and $98 \mathrm{EC}$ some form of Community competition law control may be contemplated even for general laws limiting competition between undertakings. Some deference towards the Member States' competence to adopt economic regulation is however appropriate, especially in fields for which the Community is not (exclusively) competent like the regulation of liberal professions. ${ }^{1746}$ To balance the tespective interests of the Community and the Member

1743 However, the Commission's standpoint in the cases Cipolla and Macrino may also be understood to parallel the development that the case law has taken with regard to Article 86(1) EC where two approaches havc developed. The first is one of limited sovereignty according to which Member States are free to grant monopoly rights; see Case C-41/90, Höfner and ELser, [1991]; Case C-323/93, Centre d'Insémination de la Crespelle, [1994]. The second is a limited competition approach according to which the Court turns to Article 86(2) EC and requires the formulation of a legitimate national objective that the legal monopoly must pursue and applies a proportionality test, Edward D.A.O. / Hoskins M., (1995), 164 and 167. Case C-67/96, Albany, [1999]. The decisive case is Case C-320/91, Corbeau, [1993], which in effect reversed the burden of proof: exclusive rights are not prima facie legal, but prima facie illegal unless they are objectively justified or fulfill the Article 86(2) EC criteria. Buendia Sierra in Faull J. / Nikpay A. (Eds.), (1999), para. 6.80, points out that the "effect of Corbeaw was simply to bring the approach in relation to Articles $86(1)$ and $82 \mathrm{EC}$ in line with that concerning the free movement of goods. That is, restrictions on trade and free competition were in principle prohibited unless they existed because of mandatory requirements of general interest and they respected the principle of proportionality. See also Jones A. / Sufrin B., (2004), 557; and Hancher I., (1994), 111.

1744 For details on the concept of emanation see Chapter 5.I.

1745 They may of course raise the State action defence, see above section II.3.

1746 The same idea applies with regard to State rules (e.g. in tax matters) that testrict the internal markct. 
States, the aim would be to subject this third category of State measures merely to a reasonableness testing instead of a full proportionality test. This point has potential for the future and requires teleological reasoning with regard to Atticles 86(1), 10(2) EC, the effet util of competition law and the impact that the founding fathers of the Treaty foresaw for Member States. 


\title{
Justifying Professional Regulation-Solutions Reflecting the Structure and Broad Logic of the Treaty
}

\author{
Which roads lead to Rome? - Immunity in competition law and the structure of the Treaty
}

The previous chapters fathomed the effects that professional self- and State regulations have on competition. This chapter will turn to the regulatory motives pursued in adopting professional regulation. On substance the chapter will address the question which justification grounds allow to spare restrictive rules from being reviewed by a yardstick of competition law. Where legitimate tegulatory concerns are identified, the ensuing point is whether they fit, and can be realised within, "the structure and broad logic of the Treaty provisions". ${ }^{1747}$ To recognise their legitimacy in law will result in a professional rule that ultimately is immune against the application of the competition law prohibitions.

Several avenues may lead to the conclusion of immunity. To start with, professional rules are immune from competition law where they do not meet the criteria of either prohibition (Article 81(1) EC or $82 \mathrm{EC}$ ). That is the case where they do not regulate an economic activity of the members of a profession, which is an event conceivable only in very exceptional circumstances. ${ }^{1748}$ Secondly, a professional rule will not restrict competition and thus not be prohibited, if its restrictive effects ate ancillary, i.e. an unavoidable consequence of a measure whose overall effect is to objectively increase competitive forces across the market. In testing whether a professional rule is suitable and necessary to the pursuit of a legitimate commercial aim, the Court will apply the proportionality principle strictly. ${ }^{179}$ Thirdly, the Coutt in Wouters has limited the reach of Article 81(1) EC where it finds that anti-competitive professional regulation is "connected with the need to make rules relating to organisation, qualifications, professional ethics, supervision and liability, in order to ensure that the ultimate consumers of legal services and the sound administration of justice are provided with the necessary guatantees in relation to integrity and experience". ${ }^{1750}$ The reasoning of (what is called here) the Wouters proviso ${ }^{1751}$ is, however, untelated to the interpretation of the

\footnotetext{
${ }^{1747}$ See already Chapter 1.II. where this quote taken from AG Léger in Case C-309/99, Wouters et al. vNOvA, [2002], para. 111, has been chosen to determine the tune of the present book.

${ }_{1748}$ For details see Chapter 3.I. and Chapter 4.I.

1749 This is clearly demonstrated in Wouters at paras. $87 \mathrm{ff}$. of the judgment. For details on the ancillary restraints doctrine, see Chapter 4.II.1.2. and Chapter 4.II.2.3.

1750 Para. 97 of the Wouters judgment. See also the diagram illustrating the effect of the Wouters proviso on the scope of Article 81(1) EC by shrinking the reach of its prohibition in Chapter 4.II.4.2.2.

1751 The expression 'Wouters proviso' is used in this book as shorthand for identifying the part of the Wouters judgment that, as some have observed, reads like a dissenting opinion (i.e. paras. $97-110$ of the judgment). The notion 'Wouters proviso' is preferred here to the notion 'Wouters rule' or 'Wouters exception' in order to avoid the
} 
elements of Article 81(1) EC, and is mostly understood as an exception. Presumably the Court's motivation in creating this supplementaty rule of immunity (as such alien to EC competition law) was to prevent that - as a consequence of a judgment to the contraty numerous professional services sectors in the EU would have been left without regulation, or at least with fragmentary regulation only. ${ }^{1752}$ Conversely, in respect of Article $82 \mathrm{EC}$ a similar plot device is not required: according to the case law it is possible to limit the reach of Article $82 \mathrm{EC}$ through the interpretation of the concept of abuse. In particular, objective justifications and efficiency gains may allow to salvage a prima facie restrictive measure. ${ }^{1753}$

Fourthly, Article 81(3) EC provides for an exemption from the application of the probibition contained in Article 81(1) EC. The provision stipulates four cumulative conditions, which express particular policy choices and will be elaborated on in the first part of this chapter. On the basis of the conclusions drawn in Chapter 4 the considerations of the $W$ outers proviso will be pit against these four conditions. Not only had the case been decided before Regulation 1/2003 attributed direct effect to the third paragraph of Article 81 EC. The Wouters proviso also shares with Article 81(3) EC the structural similarity of limiting the reach of the prohibition in Article 81(1) EC, despite it being a judge made extra-statutory exemption. ${ }^{1754} \mathrm{~A}$ conceivable extrapolation of the Wouters proviso will, however, have to refocus the operation of limiting the reach of the prohibition in objective terms. Moreover, when interpreting the concept of abuse the Court has revealed in Piau that considerations similar to Article 81(3) EC may apply even in respect of Article 82 EC. ${ }^{1755}$

Finally and fifthly, EC law provides for a general justification avenue under Article 86(2) EC, which is applicable in respect of both Articles 81(1) and $82 \mathrm{EC}$, but also other Treaty provisions, and will be elaborated on in the second part of this chapter. It applies where the application of the(se) Treaty rules should lead to obstructing the performance, in law or in fact, of a particulat task assigned to certain undertakings. The core question will be whether the different professions are charged with a 'service of general economic interest'. A positive answer had been given by Advocate General Léger in Wouters, arguing the case of the legal profession.

A number of these avenues to immunity have alteady been discussed in the previous chapters. ${ }^{1756}$ The present chapter will concentrate on the two justification grounds explicitly embodied in the EC Treaty to systematise their application in the field of prima facie anticompetitive professional regulation. In light of the Wouters proviso and its contra legem development of the law, a closer look will have to be taken at the aptness of the Treaty's two-legged exemption system to deal with concerns of professional conduct and integrity. Should neither justification ground prove to cater for legitimate policy considerations in regulating the professions, the question will be whether the Court's choice in Wouters ultimately is a teasonable one in maintaining legitimate rules regulating the access to and the exercise of the professions. This point is all the more pressing in view of the recent

impression that the Court has established an accepted standard in applying the law. For details sce Chapter 4.II.4.1.

${ }^{1752}$ For details on the $W$ outers proviso being a contra legem development of the law, and the alternative of limiting the legal consequences of Article 81(2) EC, see Chapter 4.II.4.2.2.

1753 For details see Chapter 5.II.3.

1754 Fot details sce Chapter 4.II.4.

1755 For details see Chapter 5.II.3.3. For reasons of clarity the present chapter will concentrate on Article 81(3) EC as applied in the context of Article 81(1) EC.

${ }^{1756}$ Similarly AG Léger in Wouters has referred to a reading plan listing the second, fourth and fifth avenue itemised here, see para. 111 of his opinion. 
judgment in Meca-Medina II, in which the ECJ reinforced the position that, in order to decide whether a decision of an association of undertakings falls under the prohibition of competition law, it has to be considered whether the consequential effects restrictive of competition are inberent in the pursuit of the objectives of that decision. ${ }^{1757}$ Conversely, if legitimate regulatory objectives may be equally captured on substance by the considerations embodied in Articles $81(3)$ and/ or $86(2) \mathrm{EC}$, it would be pointless to maintain the supplementary case law built exemption that is the Wouters proviso.

In search of the appropriate legal avenue, part I and part II of this chapter will put the Wouters proviso into perspective with the elements of the two exemption articles. In particular, the economic element of the competition law prohibitions meets a systemic public interest defence put forward by both representatives of the professions and State authorities involved in professional regulation. This defence refers to the fact that the modus operandi of the (liberal) professions of restricting entry and practice is claimed to be in the public interest. The general assertion thus is that the professions, besides their importance in economic terms, also assume a societal or public role. This requires not only respect for individual interests of clients from whom professionals earn their livings, but also for the interest of society at large to have effective systems of, for instance public health care, the administration of justice, ot other values recognised to guatantee the fundamentals for the functioning of a society based on the rule of law. ${ }^{1758}$ The aim of this chapter is to identify the extent to which various public interest arguments are in tune with $\mathrm{EC}$ competition law, bearing in mind that competition policy is one policy choice of public interest, albeit a specific one. For this exercise it will be necessary to scrutinise to which degree a distinction can be drawn between, on the one hand, regulatory objectives having beneficial effects in economic terms and, on the other, regulatory objectives safeguarding other, i.e. noneconomic values recognised in (liberal) democracies based on the rule of law.

Ultimately, this book will look in to the possibilities that the Commission may have in giving guidance on how to apply the exemption provisions of Articles 81(3) and 86(2) EC to the professions. Specifically the regime under which the defence of Article 81(3) EC can be enforced merits further attention. The article allows for the formulation of categories of agreements, decisions or concerted practices, for which the provisions of Article 81(1) EC may be declared inapplicable. Protection from the application of Article 81(1) EC can thus be granted collectively in the form of a regulation. Whether the Commission could, or should, adopt a block exemption regulation - a 'Schengen visa' for competition restrictions $^{1759}$ - in the field of professional regulations will be scrutinised in the chapter conclusions. ${ }^{1760}$

${ }^{1757}$ Case C-519/04 P, Meca-Medina II, [2006], para. 42, with reference to para. 97 of the Wouters judgment (i.e. the Wouters proviso, see above note footnote 1751 , footnote 2163 ).

${ }^{1758}$ In concurrence with the better regulation agenda of the Community to modernise the liberal professions, a number of Member States have undertaken to develop a public interest test in the liberal profession. For details see Chapter 2.VI.2.

1759 See Article 3(2) of Regulation 1/2003.

1760 The Court has explicitly indicated this possibility for the field of the liberal professions, Casc C-309/99, Wouters et al. v NOvA, [2002], para. 69: "it is always open to the Commission inter alia to issue a block exemption regulation pursuant to Article [81(3) EC]". 


\section{Article 81(3) EC: the competition specific exemption}

Taken as a whole, the fundamental objective of Article $81 \mathrm{EC}$ is to ascertain the overall impact that an agreement or decision has on the consumer within the relevant market and to ensure an efficient allocation of resources. ${ }^{1761}$ As explained earlier the substantive scheme of Article $81 \mathrm{EC}$ is a bifurcated one, which effectively allows a close control of arrangements having an anti-competitive object or effect. While Article 81(1) EC does not provide for a selection $a b$ initio of pro-competitive agreements and decisions, Article 81(3) EC provides a defence against the finding of an infringement of competition law. ${ }^{1762}$ Since the application of competition law has been modernised by Regulation 1/2003 the Community and State authotities share the competence to enforce also the exemption provision of Article 81(3) EC. It is directly applicable by all competent national authorities and can thus invariably be invoked directly before national courts ${ }^{1763}$ - despite the wording of Article 81(3) EC, which stipulates that the prohibition of Article 81(1) EC "may ... be declared inapplicable" and therewith suggests that a decision to that effect would be required. Hereafter, the substantive scheme of Article 81(3) EC shall be briefly outlined to in troduce its four cumulative criteria. Their application to the case of the professions will be analysed in turn in sections 2 to 4 . Therein the analysis will be compared with the Wouters proviso to discern whether the latter assimilates similar principles or rather establishes a more general justification ground of $\mathrm{EC}$ law for restrictions on trade and competition in the internal market.

\section{A positive balancing act: the four cumulative criteria of Article 81(3) EC introduced}

The case law confirms that the analysis under the first paragraph of Article $81 \mathrm{EC}$ is confined to whether an agreement or decision restricting the freedom of action produces anti-competitive effects. Whether it also produces pro-competitive effects that outweigh its anti-competitive effects must be determined in accordance with the specific framework of Article 81 (3) EC. ${ }^{1764}$ There is thus a clear relationship between the first and third paragraph of Article $81 \mathrm{EC}$. Consequently, the broader the interpretation of the prohibition provision, the more lenient Article 81(3) EC may be interpreted to salvage agreements and decisions that are beneficial to the overall market situation, and vice versa. ${ }^{1765}$ Anti-competitive effects within the meaning of Article 81(1) EC are described as a loss of allocative efficiencies (to the detriment of the final consumer) and can be expressed in a relative increase in price (or a relative decrease in quality or quantity). ${ }^{1766}$ Subsequently, the assessment under the third paragraph of Article 81 EC consist of putting the loss of allocative efficiencies into

${ }^{1761}$ European Commission, Guidelines on the application of Article 81(3) EC, paras. 13, 103.

${ }^{1762}$ European Commission, Guidelines on the application of Article 81(3)EC, paras. 1,41. This approach is essentially different from US anti-trust law and its rule of reason. For details see Chapter 4.II.1.2.1. $\Lambda \mathbf{n}$ ab inilio selection of pro-competitive arrangements is avoided in EC law to preserve in particular the effectiveness of Article 81(3) EC, Case T-112/99, Métropole (M6), [2001], para. 77.

${ }^{1763}$ The burden of proof is on the undertaking that invokes the exemption, Atticle 2 of Regulation 1/2003.

1764 Case T-112/99, Métropole (M6), [2001], paras. 76 f. Lugard P. / Hancher L., (2004), 411. See also Joined Cases 56 to 58/64, Consten and Grundig, [1966], and European Commission, Guidelines on the application of Article 81(3)EC, paras. 50 and 101. Bourgeois J.H.J. / Bocken J., (2005), 119; Monti G., (2002); Nicolaides P., (2005), 134.

1765 The Commission observes, however, that a stricter interpretation of both provisions is currently taking place, sec European Commission, Guidelines on the application of Article 81(3) EC.

${ }^{1766}$ For details see Chapter 4.II.1. 
perspective with possible pro-competitive efficiency gains of the prima facie restrictive arrangement. This process is commonly referred to as a balancing act.

Earlier it has been pointed out that the scrutiny under Article 81(3) EC is different from the ancillary restraints doctrine established in respect of what does not constitute a restriction of the freedom of competition under the article's first paragraph. ${ }^{1767}$ While the concept of ancillary restraints requires a negative assessment that no anti-competitive factors will be realised across the market, the scrutiny under Article 81(3) EC requires the balancing of positive efficiencies on competition. This is the question whether an agreement or decision contributes to "improving the production or distribution of goods [or services] ${ }^{1768}$ or to promoting technical or economic progress". In a spccific case it has to be demonstrated that the thus worded efficiencies ate realised, or are likely to be realised. ${ }^{1769}$ This requires a prognosis assessment $e x$ nunc. Three further conditions have to be met, which together with the first are cumulative and exhaustive. ${ }^{1770}$ As second condition Article 81(3) EC stipulates that consumers must receive "a fair share of the resulting benefits". Thirdly, the restrictions ensuing from the agreement or decision must be "indispensable to the attainment of these objectives". Fourthly, the agreement or decision must not afford the undertakings concerned (i.e. the parties to an agreement or the members of an association) "the possibility of eliminating competition in respect of a substantial part of the products [or services] in question". On pondering in particular the second condition of the exemption it becomes apparent that the aim of Article 81 (3) EC is to strike a fair balance between the interests of the undertakings involved and those of consumers. Since consumets ate the ones who suffer from the loss of allocative efficiencies within the meaning of Article 81(1) EC, Article 81(3) EC requires that consumers participate in the efficiency gains that result from the prima facie restrictive agreement or decision. ${ }^{1771}$

The four specific conditions of Article 81(3) EC will be scrutinised in the following with a view to ascertaining whether they are suitable to meet the particular concerns put forward by the professional sector and governments to justify restrictions imposed on practitioners of their competitors. The Commission stresses that any type of agreement or decision that is prima facie restrictive of competition within the meaning of Article 81(1) EC may be made subject to the salvaging scrutiny of Atticle $81(3) \mathrm{EC}$, and that as a matter of principle all restrictive agreements and decisions that fulfill the four conditions of Article 81 (3) $\mathrm{EC}$ are covered by this exception rule. ${ }^{1772}$ There is no general argument that the exemption would

\footnotetext{
1767 For details see Chapter 4.II.1.2.2.

1768 The European Commission, Guidelines on the application of Article 81(3) EC, para. 48, rightly stresses that although Article 81 (3) EC refers expressly only to goods, it applies by analogy to services. This is indeed evident as EC competition law also applies to restrictions in services markets.

${ }^{1769}$ European Commission, D G Competition discussion paper on exclusionary abuses, of 12/2005, para. 84.

1770 For instance Joined Cases T-528/93, T-543/93 and T-546/93, Métropole télévision, [1996].

1771 Economic operators may see their arrangement, which prima facie is restrictive of competition, exempted from the prohibition and voidance that Article 81(1) and (2) EC provide for by accepting the imposition of conditions that are intended to realise the broader economic efficiencies of their arrangements. "[Conditions] may relate to the period of exemption, to supervision by the Commission, or to reporting and even attendance conditions. The exemption is normally for a fixed period, usually a minimum of three years and up to twelve or fifteen years. The supervision required by DG Comp will vary according to the circumstances and may in some cases be limited to the simple provision of annual accounts by undertakings, or of lists of members in or persons refused membership of an association, ranging up to detailed review by the Commission of individual contracts or the business dealings of the parties exempted,", Goyder D.G., (2003), $137 \mathrm{f}$.

1772 European Commission, Guidelines on the application of Article 81(3) EC, para. 46. See Case T-17/93, Matra, [1994], para. 85. NB The Commission does not strike a semantic distinction (anymore) between 'exception' and
} 
not apply in the field of professional regulations. Consequently, Advocate General Léger in Wouters rightly specified that

"in Community competition law there are no infringements which are inherently incapable of qualifying for an exemption under Article [81(3) EC]. According to the case-law, the wording of Article [81(3) EC] makes it possible to take account of the particular nature of different branches of the economy, social concerns and, to a certain extent, considerations connected with the pursuit of the public interest. Professional rules which, in the light of those criteria, produce economic effects which are positive, taken as a whole, should therefore be eligible for exemption under Article [81(3) EC]..$^{21773}$

In brief, applying the four requirements of Article 81(3) EC to the professional services sector requires to assess whether restrictions in professional regulation result in objective efficiency gains that are compatible with the objectives of Community competition law, i.e. gains that ensure the effective allocation of resources (first condition; section 2.). Moreover, restrictive professional rules will have to be the indispensable means to achieve the identified efficiency gains (third condition; section 2.4.), thereby enhancing consumer welfare ${ }^{1774}$ (second condition; section 3.). Finally, the (implementation of the) restrictive professional rules must not afford the members of the profession concerned the possibility of eliminating competition in respect of a substantial part of the relevant professional services market (fourth condition; section 4.). For the purpose of having a short hand for the individual requirements of Article 81(3) EC, a numbering in squared brackets will be added to the article; e.g. Article 81(3)-[3] EC will indicate the indispensability criterion. For a more coherent presentation of the four cumulative criteria of Article 81(3) EC its second and third condition will, however, be discussed in inversed order. ${ }^{1775}$ Not least for reasons of coherence with other works the numbering in squared brackets will respect the authentic order in which Article 81(3) EC lists the four criteria.

It is often stated that Article 81(3) EC contains two positive and two negative criteria. ${ }^{1776}$ I do not attach a particular value to such a grammatical observation but sympathise with the view of Nicolaides that Article 81(3) EC applies successive filters to eliminate agreements and decisions that contain excessive restrictions of competition. ${ }^{1777}$ The idea of successive filters also underpins why it is sensible to deal with the third condition of Atticle 81(3) EC before its second condition. Where certain restrictions are unnecessary to achieve the procompetitive efficiencies (third condition) they should not, in establishing the fair share of benefits for consumers (second condition), be balanced against the anti-competitive effects of the agreement or decision. ${ }^{1778}$ Hereafter follows a graphical overview of the necessary

'exemption'.

1773 AG Léger in Case C-309/99, Wouters et al. v NOvA, [2002], para. 113.

$1774 \mathrm{Viz}$ in particular the welfare of the customers of professionals, see European Commission, Guidelines on the application of Article 81(3) EC, paras. 33, $84 \mathrm{f}$. The concept of consumers to which Article 81(3) EC refers encompasses all direct and indirect users of the products or services covered by an agreement or decision. This includes producers who use the products or services as input, wholesalets, retailers and final consumers, i.e. natural persons who are acting for the purposes that can be regarded as outside their trade or profession.

1775 Done also in European Commission, Guidelines on the application of Article $81(3)$ EC, paras. $73 \mathrm{ff}$. and $83 \mathrm{ff}$.

1776 For instance Goyder D.G., (2003); LenkJ., (2006). The first two conditions on the objective efficiencies and the fair share for consumers are said to be positive; Articles 81(3)-[3] and 81(3)-[4] EC are said to be negative. 1777 Nicolaides P., (2005), $125 \mathrm{ff} ., 142 \mathrm{f}$.

1778 "If it were otherwise an agreement might be denied the benefit of Article 81(3) in its entirety even though the second condition could be satisfied [by the agreement or decision as a whole] if certain unnecessary restrictions were eliminated. This is particularly relevantin cases where a restriction can be eliminated or modified without undermining the commercial arrangement covered by the agrecment.", Faull J. / Nikpay A. (Eds.), (2007), para. 3.436. 
370 Justifications Reflecting the Logic of the Treaty

operation to be undertaken. It illustrates the relation between the relevant criteria of both the first and third paragraph of Article $81 \mathrm{EC}$; it also prerecords more specific facets explained in the following sections. 
The Competition Specific Exemption

371

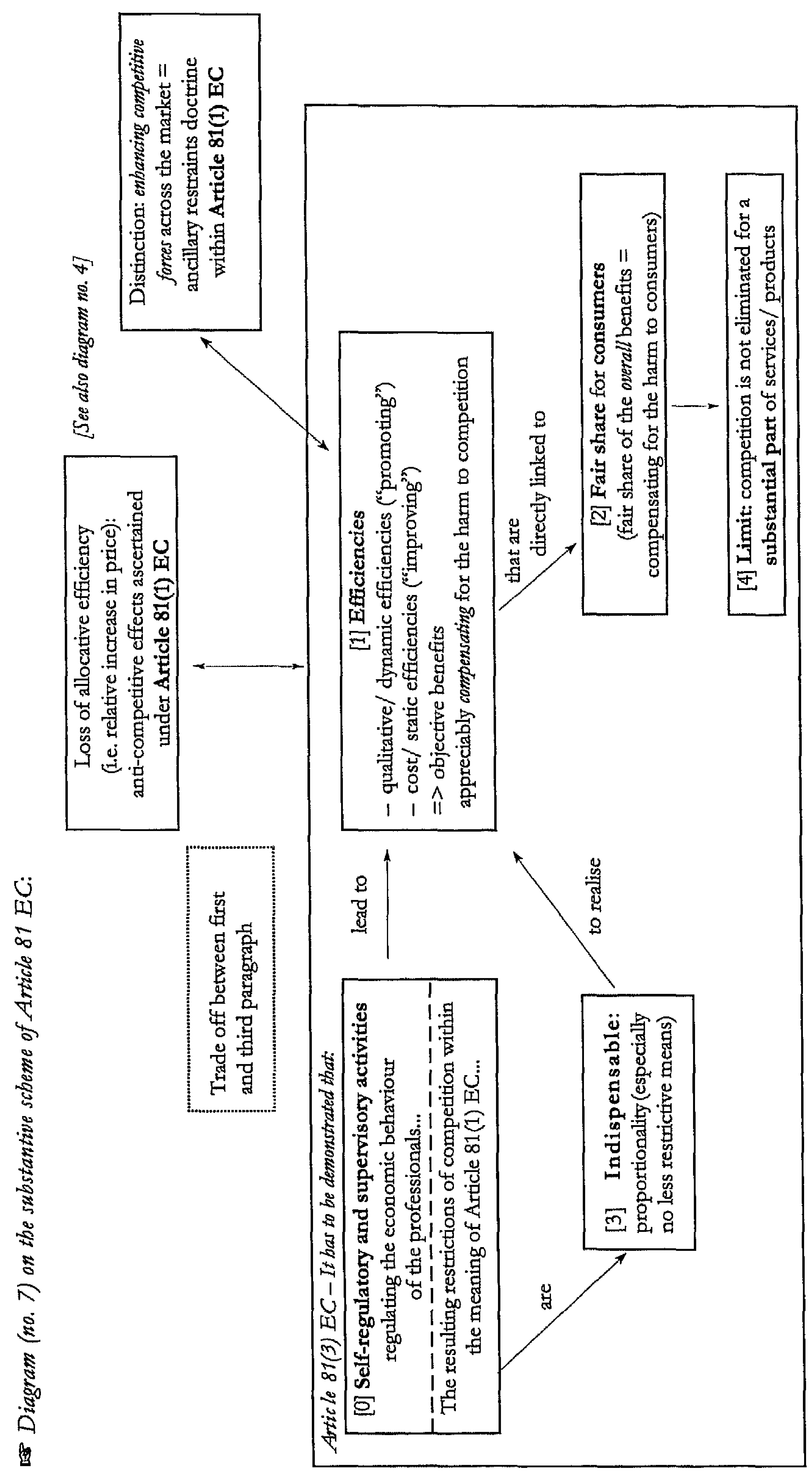




\section{Objective efficiencies indispensable to compensate restrictive effects}

The first condition of Article 81(3) EC (in the following referred to as Article 81(3)-[1] EC) requires that agreements between undertakings or decisions by associations must contribute either "to improving the production or distribution of goods [or services]" or "to promoting technical or economic progress". The language of these two heads of the first condition is not particularly accessible, and even less so for the case of services markets. Especially in respect of professional services the question arises whether the two heads protect restrictions that ate adopted, for instance, "to ensure the proper practice of the profession". ${ }^{1779}$

Goyder rightly pointed out that in assessing the purpose of the two heads less regard has to be taken of their textual meaning; rather they have to be read in the context of the remainder of Article $81 \mathrm{EC}$ and other Treaty provisions, as well as in the light of the many cases in which they have already been applied. ${ }^{1780}$ Although the two heads overlap in part, their assessment does not imply the same level of difficulty. On the one hand, an 'improvement of the provision or distribution of services' is fairly tangible and can include almost any kind of beneficial alteration to the operation of a service sector, including the elimination of barriers to entry, increased output from a given number of inputs, better quality in the provision of services, greater speed or quality control in providing output, a greater range of services provided from the same inputs, or the possibility of providing a wider range of services. On the other hand, the requirement of 'technical or economic progress' is a good deal more shadowy. More than the 'improvement' head it requires a prognosis of the future effects of an agreement or decision in the expected market conditions. ${ }^{1781}$

Meanwhile, a more catchy paraphrasing has developed for Article 81(3)-[1] EC. Its two heads are more commonly referred to as 'efficiency gains', which an agreement or decision must generate. The purpose of Article 81(3)-[1] EC is to define the types of benefits produced by an agreement or decision that can be taken into account and be subject to the further tests enshrined in the third and second criteria of Article 81(3) EC. ${ }^{1782}$ The Commission in its 2004 guidelines on the application of Article 81(3) EC uses the term 'efficiency' short and sweet to capture various economic benefits covered by that provision. Therewith the scope of the Commission's term is wider than that flowing from the traditional definition in economics, where 'efficiency' generally refers to the production of a certain product using fewer resoutces. ${ }^{1783}$

Before briefly describing in section 2.1. the efficiencies that the Commission recognises to be eligible for an exception under Article 81(3) EC, an observation about their more general nature has to be made. According to settled case law any advantage resulting from

1779 The term 'proper practice' has been used by the Court in Wouters at paras. 107 and 109 of the judgment. In Chapter 4 it has been demonstrated that the objective of 'proper practice' is, however, not suitable to limit neither the jurisdictional scope nor the substantive assessment of $\Lambda$ rticle 81(1) EC.

1780 Goyder D.G., (2003), $119 \mathrm{ff}$. Goyder also pointed out that a textual analysis of the four conditions of Article 81 (3) EC is not a useful or productive way of understanding how they are dealt with by either the Commission or the Community Courts. As a common law jurist he observed that the four conditions of Article 81(3) EC are treated as broad statements of principle, i.e. more like provisions in a civil code.

${ }_{1781}$ Goyder D.G., (2003), 121, pointed out that the expression of 'technical or economic progress' is familiar in French law where it requires a reasonable conjecture to be made about the likely outcome of an agreement.

1782 European Commission, Guidelines on the application of Article 81(3) EC, para. 50.

${ }^{1783}$ Faull J. / Nikpay A. (Eds.), (2007), para. 3.425. See also Rodger B.J. / MacCulloch A., (2001), 145 ff.] 
an agreement or decision must be objective in character. ${ }^{1784}$ Objective a benefit is where no subjective business justifications will be taken in to account that the parties covered by the agreement or decision may intend to reap. ${ }^{1785}$ This means that the pro-competitive benefits created, e.g. cost savings, should be of such a nature to result in a relative price decrease or relative increase of quality. ${ }^{1786}$ Put differently, the occurrence of cost savings as such does not necessarily beat an objective benefit. The Commission in its guidelines on the application of Article 81(3) EC emphasises this point by observing that cost savings arising from the mere exercise of market power by the parties cannot be taken into account. ${ }^{1787}$ Arguably, where companies agree to fix prices or share markets they reduce output and thereby reduce costs. However, this cost reduction does not produce pro-competitive effects on the market but merely allows the undertakings concerned to increase their profits to the detriment of competition as ascertained under the first paragraph of Article $81 \mathrm{EC}$. In that instance a different pro-competitive, i.e. objective advantage has to be identified by the parties covered by the agreement or decision. This means that Article 81(3)-[1] EC protects only those efficiency gains that have the potential of outweighing the anti-competitive effects of, for instance, price fixing or market sharing. ${ }^{1788}$ The potential to outweigh the anti-competitive effects implies that alleged efficiency gains have to be 'appreciable'. ${ }^{1789}$ 'Thus the degree of importance of the objective benefit is relative in the sense that it depends on the magnitude of the anti-competitive effect that has been identified in respect of Article 81(1) EC.

Conversely, economic efficiencies that benefit only the subjective interests of colluding market players are not protected under Article 81(3)-[1] EC (and are thus prohibited by Article 81(1) EC). Therewith, EC competition law implies a policy choice of distributional justice (equity). It implies a value judgment accotding to which the idea of fair distribution of resources prevails over a narrow economic view. ${ }^{1790}$ Distributional benefits under Article 81(3) EC have to be mainly for consumers ${ }^{1791}$ as they suffer mostly from a prima facie restriction of competition. Moreover, the policy choice not to allow subjective economic

1784 Joined Cases 56 to 58/64, Consten and Grundig, [1960], p. 348; Case T-65/98, Van den Bergh Foods, [2003], para. 141. Whish R, (2003), 151; Van Bael I. / Bellis J.-F., (2005), 87.

${ }_{1785}$ Joined Cases 56 to 58/64, Consten and Grundig, [1966], p. 348. European Commission, Guidelines on the application of Article 81(3) EC, para. 49.

${ }_{1786}$ For details on the relativity of price in- or decrease, see Chapter 4.Ul.1.

1787 European Commission, Guidelines on the application of Article 81(3) EC, para. 49.

${ }_{1788}$ Case T-65/98, Van den Bengh Foods, [2003], para. 141. Joined Cases 209 to 215 and 218/78, van Landenyck, [1980], para. 185; Cases 25 and 26/84, Ford, [1985], para. 33. As restrictions by object the two examples mentioned (price fixing and market sharing) are not very likely to benefit from an exemption under Article 81(3) EC. It is, however, not excluded that in exceptional circumstances and on an individual assessment it may be established that they yield objective advantages, Whish R., (2003), 150.

1789 See Joined Cases 56 to 58/64, Consten and Grundig, [1969], p. 348. European Commission, Guidelines on the application of Article 81(3) EC, para, 51, and note 80, stressing that the improvements must show appreciable objective advantages of such a character as to compensate for the disadvantages which they cause in the field of competition. 'Appreciability' is a recurring theme in competition law. For instance, a restriction of competition has to be appreciable in order to fall within the scope of application of EC competition law (see Chapter 4.II.1.), but also any effect on trade between Member States has to be appreciable as a jurisdictional criterion for Community competition law to apply rather than national competition law (see Chapter 3.II.).

1790 Van den Bergh R.J. / Camesasca P.D., (2006), 53. As explains Monti G., (2002), 1059-1062, this is an ordoliberal policy choice.

1791 NB The Commission refers to consumer welfare as an overall concept of Article 81(3) EC. Compare also Case T-168/01, GlaxoSmitbKline, [2006], paras. 118 and 171: according to Faull J. / Nikpay A. (Eds.), (2007), 292 (footnote 669A), "the CFI confirmed that the objective of the Community competition rules is to prevent undertakings from reducing consumer welfare" (emphasis added). 
interests to justify restrictive measures corresponds with the interpretation of the internal market rules on the four fundamental freedoms. In respect of the mandatory requirements doctrine ${ }^{1792}$, which provides a justification for measures that prima facie restrict cross-botder movements of goods, persons, services or capital, the Court strictly rules that "aims of a purely economic nature cannot constitute pressing reasons of public interest justifying a restriction of a fundamental freedom guatanteed by the Treaty." 1793

Applied to the professions the aforesaid means that restrictive regulations have to result in objective benefits that can compensate the harm they (are likely to) cause to competition. ${ }^{1794}$ This means that the objectives pursued by professional rules may not be limited to meeting the interests of the practitioners who are subject to a specific professional code. Regardless of whether those rules are adopted as an agreement between the members of a profession or as a decision of a professional body, the objectives pursued have to be capable of appreciably improving the distribution and provision of professional services and/ or promote the progress in professional services markets to the benefit of consumers and society as a whole. ${ }^{1795}$

\subsection{Cost efficiencies and qualitative efficiencies}

Two types of objective efficiencies are generally distinguished as being protected by Article 81(3)-[1] EC. One takes the form of savings or synergies that may be calculated in terms of a monetary value ('cost efficiencies'). The other takes the form of new or improved services ('qualitative efficiencies'). ${ }^{1796}$ This bipartite categorisation confirms what has been

1792 Sce Case 120/78, Cassis de Dijon, [1979], para. 8, referring to: "mandatory requirements relating in particular to the effectiveness of fiscal supervision, the protection of public health, the fairness of commercial transactions and the defence of the consumer."

${ }^{1793}$ Case C-109/04, Kranemann, [2005], para. 34 (emphasis added). See also Case 352/85, Bond van Adverteerders, [1988], para. 34; Case C-288/89, Gouda, [1991], para 11; Case C-398/95, SETTG, [1997], para. 23; Case C-35/98, Verkooijen, [2000], para. 48; Case C-388/01, Commission ultalian Republit, [2003], para. 22. The same principle applies in anti-discrimination law.

1794 For illustrations of professional rules restricting competition, see Chapter 4.II. and Chapter 5.II.

1795 See European Commission, Guidelines on the spplication of Article 81(3) EC, para. 85. Compare also Ministerie van Economische Zaken, Pamphlet on the Liberal Professions - apractical guide to public interests and regulalory instruments, of 10.12.2004, which identifies two types of public interest for the professional sector: quality and physical accessibility, which are defined into four sub-categories: first, quality as encompassing expertise and independence of the professional, satisfactory complaints handling and added value of the service for the customer and society as a whole. Second, physical accessibility of the professional service as including time, location and convenient opening hours; third, financial accessibility of the service, i.e. affordable services for all, e.g. legal aid (see also my Chapter 3.I.2.2.4.); fourth, macro affordability as meaning the level of collective expenditure.

${ }^{1796}$ European Commission, Guidelines on the application of Article 81(3) EC, para. 59. Economists call cost efficiencies also static efficiencies, and qualitative benefits also dynamic efficiencies. The attributes 'static' and 'dynamic' refer to the (absent) rate of innovation and development. For a concise overview of the relevant economic concepts related to efficiency in competition, see Van den Bergh R. / Camesasca P.D., (2006), $17 \mathrm{ff}$, $29 \mathrm{f}$. The concept of dynamic efficiencies (relating to quality) exceeds the limits of productive and allocative (in)efficiency. Productive and allocative (in)efficiency is "predicated on a static equilibrium where the technology is fixed and costs are related to a certain level. In reality, however, many markets are dynamic, evolving over time with new products and technology emerging. A more accurate assessment of consumer welfare is reached if the effects of such innovation are taken into account. This involves accepting that short-term positions of significant market power may arise but that this is not necessarily inimical to consumer welfare", Jones A. / Sufrin B., (2004), 11; Hildebrand D., (2002), $8 \mathrm{f}$. See also the concept of 'Schumpeterian rivalry' according to which firms compete in a constant race to bring new products on to the market, competition is dynamic and positions of market power are short-term as further innovation hands the advantage to another player, Schumpeter J.A., (1942). The value 
expressed in the previous paragraph, namely that the objective character of the efficiencies accepted under Article 81(3) EC can be established for an agreement or decision that leads to either a relative price decrease in the relevant service market or a relative increase in the quality of the services in question. The Commission corroborates this point by emphasising that competition is an important long-term driver of efficiency and innovation. ${ }^{1797}$ Moreover, understanding the criterion of objective benefits as a relative price decrease or increase in quality matches with the equally objective interpretation of the concept of restriction of competition in Article 81(1) EC. ${ }^{1798}$ Under Article 81(3)-[1] EC it is exactly such a restriction of competition that may be outbalanced by other effects, if they are beneficial to the economic process.

Cost efficiencies can arise in many different forms. The Commission's Guidelines list the following examples ${ }^{1799}$ :

- the development of new production technologies or methods (applied to services sectors this example translates to new methods in the provision of services);

- an integration of assets held by two or more undertakings that leads to a more efficient 'cost/ output configuration' than would be possible in the absence of the agreement or decision;

- an efficient combination of technologies (applied to services provided by professionals this example may translate as the efficient combination of professional know-how);

- an efficient combination of different links in the 'value chain' of providing professional services;

- economies of scale ${ }^{1800}$;

- economies of scope $\mathrm{e}^{1801}$; and

- better planning of production (read: the provision of services), so that the need to maintain an expensive inventory is reduced and capacity is put to better use (e.g. tationalisation of the provision of services across multiple facilities).

Conversely, the Guidelines' examples of qualitative efficiencies ate tather difficult to apply to services sectors. ${ }^{1802}$ The Commission adds to this difficulty in that it concentrates

of Schumpeter's conclusions are controversial, and empirical evidence still fails to demonstrate any definitive relationship between firm size, market concentration and the pace of innovation, Van den Bergh RJ. / Camesasca P.D., (2006), $86 \mathrm{f}$.

1797 European Commission, Guidelines on the application of Article 81(3) EC, para. 92.

1798 There should be no conflict in this with the ancillary restraints doctrine. Under Article 81(1) EC there is no restriction of competition if there is no relative price increase. For details see Chapter 4.II.1. Since the absence of a relative price increase is not prohibited, its counterpart, which is the absence of a relative price decrease, docs not require protection under Article 81(3)-[1] EC. Moreover, Odudu O., (2006), 179, points out that Article $81 \mathrm{EC}$ as a whole can be understood as operating to consider net efficiencies. This is a concept which may be understood as complementing net effect under Article 81(1) EC.

1799 European Commission, Guidelines on the application of Article 81(3) EC, paras. 6468.

1800 Economies of scalc means declining cost per unit of output as output increases. For the professions, unit of output can be a certain type of service provided, e.g. passing the deed of repetitive typcs of transfer of property by a notary, or repetitive types of operations carried out by doctors or dentists, or repetitive types of plans to be drawn up for buildings.

1801 Economies of scope refer to cost savings that derive from the production of multiple products through the use of a common input. For the professions such efficiencies may arisc from the fact that it is possible to use the same components and the same facilitics and personnel to provide a variety of services.

${ }^{1802}$ See European Commission, Guidelines on the application of Article 81(3) EC, paras. 69-72. The examples refer to research and development agreements; licence agreements; agreements providing for the joint production of new or improved goods or services; and agreements leading to improvements in product quality or service levels. 
very much on agreements between undertakings and thus gives little guidance with regard to the application of Article 81(3) EC to decisions adopted by associations of undertakings.

The general line that nevertheless can be distilled from the Commission notice is that efficiencies of a qualitative nature lead to:

- new or improved services ${ }^{1803}$;

- a mote rapid dissemination of new or improved services in the Community, i.e. allowing new or improved services to be introduced on the market more quickly or at a lower cost;

- services better tailored to consumer nceds; or

- better quality assurance (throughout a chain of provision of services).

The Commission expresses the general sentiment that efficiencies of a qualitative nature may be of equal if not greater importance than cost efficiencies. ${ }^{1804}$ This conjecture may prove to be particularly valid for professional services matkets as indeed the objectives pursued by professional regulation will invariably refer to safeguarding professional quality standards ${ }^{1805}$ - notwithstanding that both cost and qualitative efficiencies may occur in the sector of professional services.

In order to establish whether the first requirement of Article 81(3) EC is satisfied, it is necessary, first, to clearly identify the benefits that result from a professional tegulation and, second, to assess whether these benefits have the potential to appreciably outbalance the regulation's harm to competition as ascertained under Article 81(1) EC. Before elaborating on the extent to which Article 81(3)-[1] EC can protect various professional values, a brief excursus into economic theory shall be made in the following section. It will serve the purpose to verify a particular emphasis often made in literature, namely that the policy considerations of Article 81(3) EC concentrate 'merely' on economic benefits. ${ }^{1806}$ 'The point is about tracing the policy choices that Community competition law pursues. Whether these accommodate for the motives underlying professional regulation will be explored in section 2.3.

\subsection{Excursus into economic theory}

The exemption under Article 81(3) EC must be interpreted in the light of the objectives that underlie Article $81 \mathrm{EC}$ as a whole. The aim of this excursus into economic theory therefore is, first, to sketch the frame of reference against which the concept of efficiencies, as applied by the Community Courts and the Commission, can be set. Secondly, and perhaps

${ }^{803}$ The consequential question, which 1 will analyse below in section I.2.4., is whether professionals, in complying with professional regulations, "may be able to create efficiencies that would not have been possible without the restrictive [decision] or would have been possible only with substantial delay or at higher cost," see European Commission, Guidelines on the application of Article 81(3) EC, para. 70.

${ }^{1804}$ European Commission, Guidelines on the application of Article 81(3) EC, para. 69.

${ }^{1805}$ For instance OECD / Nicholas-Gervais V. (Eds.), (1997); Scarpa C., (1999); Scarpa C., (2001); van Gerven D., (2002); Vogels R.J.M., et al., Gegevensverzameling Notariaat, (2002); Commissic Monitoring Notariaat, Eindrapport: periode 1999-2003, of 12.02.2003; Nahuis R., et al., Competition and Quality in the Notary Profession, (2005); The Law Society, Quality Legal Services for Consumers: The response of the Consumer Complaints Board to the White Paper on Tbe Future of Legal Services - Putting Consumers First, of 20.01.2006; European Commission, The role of European codes of conduct (2007).

${ }_{1806}$ See for instance Nyssens H., (1999), 486; Lenk J., (2006), 269, with reference to Müller-Graff P.-C., (1992), 18. See also Lugard P. / Hancher I., (2004); Bourgeois J.H.J. / Bocken J., (2005). 
even mote importantly, the brief survey of economic theory shall broaden the understanding that, in competition law, there is no such thing as the economic approach. ${ }^{1807}$ The practical significance of this statement must not be underestimated. While the common emphasis that Article 81(3) EC caters for 'economic' efficiencies is appropriate, it has little value for a practical application of Article 81(3)-[1] EC, if made without explaining the width or narrowness of the stance taken with regard to the notion of 'economic'. ${ }^{1808}$ Therefore, one should be careful not to rush to conclude that considerations concerning professional and/ or ethical standards - like the integrity and experience of (liberal) professionals ${ }^{1809}$ - could hardly produce any economic efficiencies. In fact, Advocate General Léger's view in Wouters and quoted in the beginning of this chapter ${ }^{1810}$ is confirmed in economics. This means that in principle, every policy, business practice or consumer choice has an actual or monetary cost, and an opportunity cost or forgone revenue or value. ${ }^{1811}$ This means that any objective, which may be pursued with a particular restriction of competition, may be driven by a potentially legitimate motivation and can be expressed in efficiency terms.

Various stances in economic theory exist to explain which agreements and decisions would, at least on balance, not be harmful for competition. The starting point for economic theory is marked out by different aspects of 'surplus' and 'welfare' with which economic welfare can be described in micto economics: surpluses with the respective market participants (respectively consumers and producers/ providers of goods or services), total surplus and total welfare.

Consumer surplus is a concept used to describe the difference between what consumers are willing to pay for a good or service and what consumers actually pay when purchasing it (meaning a product or service the quality of which is best for the price paid). ${ }^{1812}$ Conversely, producer surplus refers to the variance between the price in the market that service providers collectively receive for their services and the sum of their respective marginal costs at each level of output. ${ }^{1813}$ Total surplus can then be determined in a rather

1807 Van den Bergh R.J. / Camesasca P.D., (2006), 56 f., 104. They stress that when it comes to policy in competition, economists differ in their opinions despite being grounded in the same formal economic theory. ${ }^{1808}$ See also Whish R, (2003), $152 \mathrm{ff}$. A narrow understanding (which one could understand from e.g. European Commission, White Paper on Modernisation of the Rules Implementing Articles 85 and 86 of the EC Treaty, of 28.04.1999; and European Commission, Guidelines on the application of Article 81(3) EC) will lead to the conclusion that only improvements in strict economic terms are acceptable, i.e. improvements in terms of an cconomic cost/ benefit analysis. Conversely, a broad reading, as suggested by the Court in e.g. Case 26/76, Metro I, [1977], para. 43, will also allow policy choices that are not mainly driven by concerns of a strict economic cost/ benefit analysis. For a distinction between economic and non-economic market concerns see below section I.2.3. on the bounds of Article 81(3)-[1] EC. See also Monti G., (2002), $1090 \mathrm{f}$.

${ }_{1809}$ Compare Case C-309/99, Wouters et al. vNOvA, [2002], para. 97. Sce also Case T-193/02, Piau I, [2005], para. 103, applying Article 81(3) EC to professional regulations that, as the Court recognised, were pursuing the objective of raising professional standards.

1810 See above note footnote 1773.

1811 Nicolaides P., (2005), 126.

1812 Van den Bergh R.J. / Camesasca P.D., (2006), 51.

${ }^{1813}$ Marginal cost is generally defined as the cost of producing an 'additional unit of output'. Competition theory normally concentrates on goods rather than on services. It is much easier to define what an additional unit of output' is when speaking about, for instance, cars: it is one car more, or one spare part more. When speaking about services the problem is how to standardise services. For business services this might be easier than for professional services. For instance, hair cuts may be easily standardised in the sense of 'unit of output'. For professional services this is somewhat more difficult. Certain professional services may tather easily be standardised, e.g. the standard planning for a terraced house in architect services; the filling of teeth in dentist services; the stich up of wounds in medical services, etc. But then the teeth of one patient might be more rotten 
mathematical way as the sum of producer surplus and consumer surplus. A slightly broadened perspective is reflected in the term of total welfare, which is designed to take account of the welfare effects on the entire economy, thereby bypassing the markets directly involved in the analysis of a particular sector (social welfare). ${ }^{1.14}$ These aspects are used in explaining different economic models like perfect competition, Pareto-efficiency and Kaldor-Hicks efficiency.

Where both consumers and service providers can maximise their respective surplus without detriment to the other group, economists embrace the concept of perfect competition according to which competition is untestricted betwcen market players. In other words, perfect competition translates in an equilibrium where the welfare of service providers (i.e. the producer surplus) cannot be increased without a detriment to consumer surplus, or vice-versa. In economics this situation is also called Pareto-efficient. ${ }^{1815} \mathrm{~A}$ number of conditions are requisite to assume perfect competition in a given market ${ }^{1816}$ : first of all, all market participants need to be perfectly informed about service characteristics and prices (transparency); secondly, a large number of identical (i.e. comparable) service providers is required, who cannot significantly influence price levels and who are selling homogeneous services; thirdly, the number of consumers needs to be large, who too cannot significantly influence price levels ${ }^{1817}$; fourthly, no externalities may occur, i.e. the utility or profit of one market player may not be directly influenced by the way of acting of another market player because the latter would not take this effect into account in the determination of her behaviour ${ }^{1818}$; lastly, the services need to be 'private goods' - that ate services the consumption of which can both be made at the expense of other matket participants and be excluded for certain market participants. ${ }^{1819}$

Applying the idea of perfect competition to the professional services sector means that economic resources necessary to provide professional services (like capital, labour, working facilities, infrastructure, education) are allocated in such a way that it is not possible to make either professionals or consumers better off without making either worse off. Accordingly,

than of another, or the wound to stich up gets infected so that more treatment has to be provided. For a lawyer every case is different although she has routine work as well. To remedy the difficulty services might be standardised, or rather 'measured', in hours of work. However, some professional may need more time for the same job than does another. Against pricing per hour see Faure M.G., et al., Honoraria van Belangenbehartigers in Letselschadezaken, (2008). - NB The concept of marginal costs include a sufficient profit margin to have the professional encouraged to invest her capital in education and business in the first place, but no more.

1814 Van den Bergh R.J. / Camesasca P.D., (2006), 51 f.

1815 Vilfredo Pareto (1909): Pareto-efficient allocations - An allocation is Pareto-efficient for a given set of consumer tastes, resources, and technology, if it is impossible to move to another allocation that would make some people better off and nobody worse off. Philipsen N.J., (2003), 10, fn. 8: "The Pareto criterion is very strict in the sense that even potential changes that would increase the utility of many people and that would only slightly decrease the utility of one person, would not be approved by it." See also e.g. Ogus A., (1994), 24 f.; Cooter R. / Ulen T., (2000), 43 f.; Van Velthoven B.C.J. / van Wijck P.W., (2001), 22 f., 29 f.

1816 Philipsen N.J., (2003), 11; Van den Bergh R.J. / Camesasca P.D., (2006), 19 ff.

1817 The related market failure is called monopsony, i.e. a situation where there is market power on the demand side of the market.

${ }^{1818}$ de Bijl P. / Van Damme E., (1996), 12.

1819 The counterpart to ptivate goods are public goods. For an assessment of the ensuing public interest arguments in favour of regulation in a professional sector, see Philipsen N.J., (2003), 19, 10 ff., 37 f., 42: "Tt is important to remember that the public interest approach only tells us when there is a prima facie case for regulation: that is, market failure always has to be compared with (possible) regulatory failure. Regulation may fail if the efficiency gains to which it does give rise are outweighed by increased transaction costs or misallocations in other sections of the economy." Also Ogus A., (1994), 30. 
consumer surplus - the net gain to a consumer when buying a professional service - is at its largest. Professional services are allocated between consumers according to the price they are prepared to pay, and price never rises above the marginal cost of providing professional services. In the economist's model allocative efficiency ${ }^{1820}$ is achieved because the service provider - assuming she is acting rationally and has a desire to maximise her profits - will expand her practice for as long as it is privately profitable to do so. As long as she can earn more by providing one extra unit of professional services than it costs to prepare it, she will presumably do so. Only when the costs of a further unit (the 'marginal cost') exceeds the price she would obtain for it (the 'marginal tevenue') will she cease to expand the provision of the professional service. ${ }^{1821}$

Despite the fact that allocative efficiency is a major policy goal of competition law, the model of perfect competition has the flaw that it does not foresee for changes that constantly take place in the general conditions of markets. The model thus is a static one. ${ }^{1822}$ While the concept of perfect competition with allocative (or Pareto) efficiency provides a strong theoretical basis for the desirability of competition law ${ }^{1823}$, perfect competition can hatdly be achieved. This is due to differentiation in products and services, which will not allow to have a perfectly transparent market in which products and services are homogeneous. ${ }^{1224}$ Also professional services are often not homogeneous and make it thus difficult in practical terms to make a fully informed decision before purchasing a particulat professional service. In particular, professional services markets are characterised by the fact that customers often do not have the same level of information than have the professional service providers. This information asymmetry between practitioners and customers is a main concern in economic theory as it enables professionals to use their position to the detriment of other market players. ${ }^{1825}$ Thereby the market mechanism is 'failing'. Regulatory intervention may be an option to remedy in particular the market failure of information asymmetry. ${ }^{1826}$

Since perfect competition can hardly be established, the aim of regulatory intervention should be to allow an increase in total welfare. The alternative to Pareto therefore offered by welfare economics is the criterion of Kaldor-Hicks efficiency, according to which it is sufficient that total welfare is maximised rather than the benefits of both service providers and their customers. This means that in a Kaldor-Hicks efficient situation there are individual winners and losers, but the winners win more than the losers loose, so that the surplus of the winners is potentially able to compensate fully for the loss of the losers while the winners still remain better off. The fact that under this test the gainers are not actually

1820 See already Chapter 4.II.1.

1821 Whish R, (2003), 2 ff., 3: 'Where competition is perfect, a reduction in a producer's own output cannot affect the market price and so there is no reason to limit it; the producer will therefore increase output to the point at which marginal cost and marginal revenue (the net addition to revenue of selling the last unit) coincide. This means that allocative efficiency is achieved, as consumers can obtain the amounts of goods or services they require at the price they are prepared to pay: resources are allocated precisely according to their wishes. A monopolist however can restrict output and increase his own marginal tevenue as a consequence of doing so." ${ }^{1822}$ Van den Bergh R.J. / Camesasca P.D., (2006), 52, 30.

1823 Van den Bergh R.J. / Camesasca P.D., (2006), 18 ff., 29.

1824 Van den Bergh R.J. / Camesasca P.D., (2006), 123, fn 70: 'Products [and services] can be differentiated in a number of ways, including characteristics relating to the product [or service] itself (such as by brands, physical characteristics or utility for the end user), or relating to how and to whom the product [or service] is sold (such by channel of distribution, customers, or being sold as a cluster)."

${ }_{1825}$ Philipsen N.J., (2003), 14 ff. See also Chapter 4.II.2.1.

1826 On information regulation and economic theory, see Philipsen N.J., (2003), 27 ff. 
required to compensate the losers means that in practice the test is satisfied when the gains (to whomsoever) exceed the losses (to whomsoever). The test of Kaldor-Hicks efficiency thus provides a theoretical base for standard cost-benefit analysis. ${ }^{1827}$

Total or social welfare may be increased by the two types of efficiencies protected by Article 81(3)-[1] EC, i.e. cost efficiencies and qualitative efficiencies. They may limit the attractiveness of allocative efficiency as the universal yardstick for competition policy and law. ${ }^{1828}$ On the one hand, cost efficiencies (in economic theory also called static, productive or technical efficiencies) imply that output is maximised by using the most effective combination of inputs, so that internal slack (also called X-inefficiency) is absent. The goal of these static efficiencies is that more efficient firms performing at lower costs should not be prevented from taking business away from less efficient firms. ${ }^{1829}$ On the other hand, qualitative efficiencies refer to the innovatory progress, development and diffusion of new products or services and new processes for the production of goods or the provision of services. They are therefore also called dynamic efficiencies. ${ }^{1830}$

\section{Competition poligy and market integration}

Since the aim of EC competition law is to promote and maintain a process of effective competition so as to achieve a more efficient allocation of tesources, it is sensible to assert that the considerations under Article 81(3)-[1] EC are based on an economic approach to assess the impact that (prima facie restrictive) agreements or decisions have on the market concerned. ${ }^{1831}$ This does not, however, mean that EC competition law would exclusively take account of efficiencies that can be subjected to a strict economic cost/ benefit analysis. The most eminent example of a broader understanding of what can be achieved with competition law is the aim of the European Community to warrant the integration of the internal market, which must not be delimitated by geographical borders. This means that, despite conceivable economic arguments in favour of geographical delimitations (for instance in exclusive distribution agreements) ${ }^{1832}$, market sharing is considered a restriction of competition by object under EC competition law. Thus, competition law is often enforced to promote the integration of the matket as a prerequisite for market access. ${ }^{1833}$ Contemplating the

${ }_{1827}$ Ogus A., (1994), $24 \mathrm{f}$. Whether regulation results in an increase of the level of total welfare can be shown by analysing the changes in consumer surplus, producer surplus, and the dead weight welfare loss resulting from such regulation.

${ }^{1828}$ Van den Bergh R.J. / Camesasca P.D., (2006), 29. On allocative efficiency see also Chapter 4.II.1.

${ }^{1829}$ Whish R, (2003), 2 ff.: "In perfect competition [productive efficiency] is achieved because a professional service provider is unable to sell above cost (if she did her customers would immediately turn to another provider) and she will not of course sell below it (because then she would make no profit). In the long run the tendency will be to force service providers to incur the lowest cost possible in order to be able to earn any profit at all. Eventually an equilibrium will be reached where price and the average cost of producing professional services necessarily coincide. This in turn means that price will never rise above cost. If on the other hand price werc to fall below cost, there would be an exit of capital form the industry and, as output would therefore decrease, price would be restored to the competitive level."

${ }^{1830}$ Whish $R_{2}$ (2003), 4: "A further benefit of competition, which cannot be proved scientifically, is that producers will constantly innovate and develop new products [and services] as part of the continual battle of striving for consumers' business. Thus competition may have the desirable dynamic effect of stimulating important technological research and development".

${ }^{1831}$ European Commission, Guidelines on the application of Article 81(3) EC, para. 5.

${ }^{1832}$ For a concise discussion of the arguments of economic theory for and against territorial protection in distribution agtecments, see Monti G., (2002), $1065 \mathrm{ff}$.

${ }^{1833}$ Monti G., (2002), 1062, note 21, rightly stresses that the use of competition law to achieve marketintegration 
imperative of market integration is also the starting point in the following for distinguishing three categories of interests in regulating economic activities. The following section will use these as a framework for selecting the professional values that Article 81(3)-[1] EC may serve to protect.

\subsection{The bounds of Article 81(3)-[1] EC}

Competition policy is one of the common policy fields that the Member States pursue through the EC Treaty and the European Union. It is a policy field that contributes to the well-functioning of the internal market. The latter has been established to eliminate obstacles to trade between the Member States and to remove distortions of competition within the Community. ${ }^{1834}$ These two aims essentially represent the interests of market participants to freely provide, but also access, products and services. Both the demand side and the supply side of the market have their own interests in negotiating transactions that have to satisfy their respective requirements. Their interests can therefore be referred to as market concerns. Accordingly, consumer protection can be considered to be a market objective since it relates to the demand side of the market. ${ }^{1835}$ Conversely, the protection of the consumer's health or safety is not a market objective since the driving concern of these objectives is not the economic cost/ benefit analysis. It is thus possible to distinguish market concerns from nonmarket objectives. The former are inherently economic. The latter describe a whole cluster of objectives including, for instance, the protection of the environment, social policy, cultural policy, the protection of health and safety, and the protection of fundamental rights. ${ }^{1836} \mathrm{Non}-$ market objectives do, however, not necessarily equal non-economic policy concerns. ${ }^{1837}$ Nonmarket objectives may in fact have economically beneficial effects, for instance where the protection of the health or safety of consumers leads to less costs being generated in the health care system, or prevents economic losses for the consumer's employer or family. Where they do, these objectives can therefore be called economic non-market concerns.

Conversely, where non-market objectives prove to have an essentially non-economic nature, their objectives can still be governed by Community law. This is the case where Member States decide that they want to achieve such goals, irrespective of whether there is an economic benefit involved in their achievement. In fact, common non-economic objectives are central to many policies of the EC, for instance in environmental, social, agriculture and migtation policy. ${ }^{1838}$ Non-economic policy choices are commonly teferted

\footnotetext{
is legitimate as it fits the intention of the draftsman of the EC Treaty who saw the competition rules applicable to undcrtakings as a means of ensuring that market integration achieved through the rules on the fundamental freedoms was not subsequently thwarted by private actors. Also Wesseling $\mathrm{R},(2000), 97 \mathrm{f}$.

1834 "These two aims correspond to the two most often cited justifications for uniformity of legal rules and principles in the cconomic analysis of law literature: transboundary externalities and fair competition." de Witte B., (2006), 61, with exemplary reference to Ogus A., (1999), 416.

${ }_{1835}$ de Witte B., (2006), 63.

${ }^{1836}$ See Articles 174 ff, 136 ff., 151, 152 EC and Article 6(2) EU.

1837 The following tripartite categorisation of regulatory objectives builds on de Witte's clear differentiation between (non-)market and (non-)economic objectives.

1838 de Witte B., (2006), 62. They are also very much present in internal market legislation alongside the typical 'market' objectives to eliminate obstacles to trade between the Member States and to remove distortions of competition within the Community. As de Witte explains there is ample scope of, and evidence of, non-market concerns being incorporated in internal market legislation. He gives the example of the directive on fitting safety belts in motor vehicles other than passenger cars (specifically, in coaches; see Directive 2005/40/EC based on the Commission's proposal COM(2003)363). While based on Article 95 EC, it clearly has as its principal aim the
} 
to as being in the - wider - public interest. There is however little consensus, if any, on what exactly constitutes the public interest. The concept of public interest will often appear to be indefinite, "an empty vessel, to be filled at different times with different content". ${ }^{1839}$ Its content may strongly depend on the political agenda of the party invoking the public interest as a justification for certain measures. Moreover, the term of public interest is regularly used to manipulate emotionally rather than rationally. ${ }^{1840}$ In an attempt to define the concept analytically (and against the background of the Anglo-Saxon legal systems) Feintuck observes that the significance of the public interest within liberal democracies can be best described as relating to democratic principles of social justice. As core hereof he identifies the equality of citizenship, whereby citizenship defines the right to have rights. To formulate a more tangible yardstick he refers to the expectations of citizenship. ${ }^{1841}$ Being a lawyer, Feintuck's analysis may not meet the richness of the discussion in political science on the concept of public interest ${ }^{1842}$; however, his effort to develop a tangible yardstick for lawyers safeguards the role of the law to grant justice. ${ }^{1843}$ In particular, his concept may prove useful for present purposes where it can be matched with the category of non-market concerns that are noneconomic in character. In the following this book therefore assumes that non-economic concerns are in the (wider) public interest if they have a beneficial effect for democratic values, i.e. for the expectations of citizenship.

\section{Diagram (no. 8) categorising economic and non-economic public interest concerns in regulation}

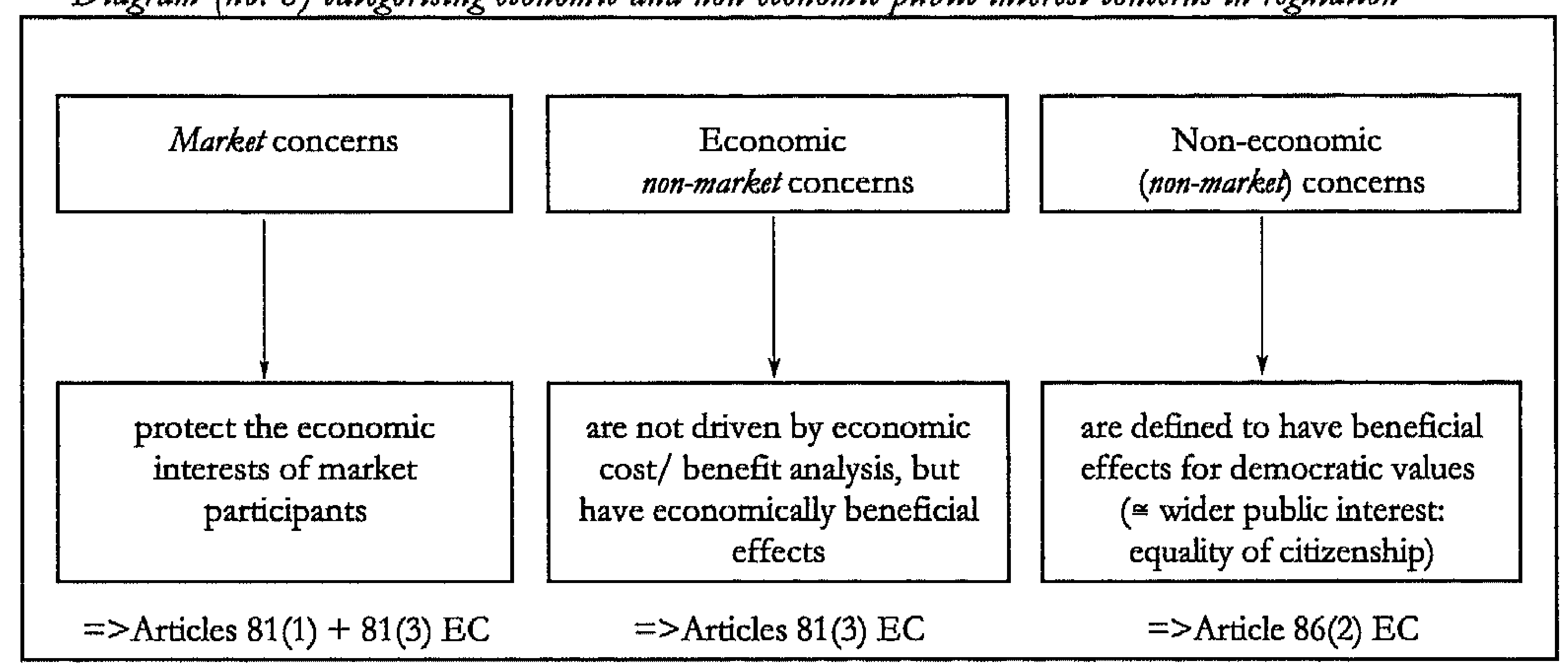

The main distinction can thus be drawn between economic and non-economic interests

improvement of safety on European roads. "As usual in such cases, some Member States have already made it compulsory to install seat belts in coaches, and other not, so that the Europe-wide extension of such a tequirement will also have the effect of facilitating the trade of buses. However, this transboundary externality can hardly be considered a central objective of this proposal, compared to the non-market concern of saving the lives or good health of coach passengers."

${ }^{1839}$ Feintuck M., (2004), 3.

${ }^{1840}$ Mastenbroek W., (2006), 96ff, 99: "De meest gebruikte manipulatie is die van insinuerend woordgebruik. Termen die sich daar goed voor lenen zijn [...], het lagemene belang, [...]. Door dergelijke termen aan de eigen voorstellen te verbinden probeert men ze onaantastbaar te maken [...]."

${ }_{1841}$ Feintuck M., (2004), 8, 25, 33. He emphasises that citizenship is not an end in itself but rather a compact whereby the individuals, in return for acknowledging responsibilities towards the collectivity that is society, can claim civil, political and social freedoms and powers to serve their own best interests.

${ }^{1842}$ See Nakamura R.T., (2005).

${ }^{1843}$ Ius est ars boni et aequi (the Digests, 1, 1, 1). 
in regulating economic activities. On balance, only two of the three types of regulatory objectives can be ptotected by Atticle 81(3)-[1] EC, as the objective of competition policy is to safeguatd economic concerns. A concept of the 'widet' public interest signalises that it groups subcategories of specific public interests. In fact also competition law putsues the public interest, albeit a specific one. ${ }^{1844}$ The public interest actually embraces both the categories of non-market and market concerns. ${ }^{1845}$ Usually in the context of discussing immunities from competition law the term of public interest is used to indicate non-market concerns. ${ }^{1846}$ Professional regulations on organisation, qualifications, professional ethics, supervision and liability, are usually defended by reference to the interests of the ultimate consumers of the professional services and the interest of society as a whole in the functioning of the relevant 'infrastructure' or 'asset' (i.e. a particular general or public interest objective). Depending on the professional group concerned the objective of professional regulation may refer to various aspects of public interest, for instance the sound administration of justice, the public health system, the safety of services and products (e.g. in the building sector or in the pharmaceutical sector), the reputation and credibility of a sector. ${ }^{1847}$ While the Court carefully avoided to explicitly tefer to the general or public interest in the operative part of the judgment in Wouters that deals with the justification of the restriction of competition ${ }^{1848}$, its considerations can be understood in these terms. ${ }^{1849}$ Such a qualification is not in principle extraneous to the exemption of Article 81(3) EC. As the CFI in Métropole suggested six years before Wouters, the conceivable scope of that article is sufficiently wide to include public interest criteria. ${ }^{1850}$

In fact it would be a limited reflex if one were induced to think of the public interest as necessarily representing non-economic concerns. An explicit distinction between economic public interest objectives and non-economic public interest objectives helps to define the principle stated in Métropole, where the Court held that "Admittedly, in the context of an overall assessment, the Commission is entitled to base itself on considerations connected with the pursuit of the public interest in order to grant exemption under Article [81(3) EC]. ${ }^{1851}$ While the conceivable scope of the exemption in Article 81(3) EC is sufficiently wide to include public interest criteria, not any public interest objective can be covered. Only economic public interest concerns can be considered under

1844 See e.g. Monti G., (2002), 1059 ff., surveying three public policy criteria used in EC competition: economic freedom, market integration and cfficiency. See also Case C-126/97, Eco Swiss, [1999], para. 36: "according to [Article 3(1)(g) EC], Article $81 \mathrm{EC}$ constitutes a fundamental provision which is essential for the accomplishment of the tasks entrusted to the Community and, in particular, for the functioning of the internal market. The importance of such a provision led the framers of the Treaty to provide expressly, in Article 81(2) EC, that any agreements or decisions prohibited pursuant to that article are to be automatically void."

1845 See Jones A. / Sufrin B., (2004), 18: "It is an unfortunate fact of life that competition produces winners and losets. Efficient firms will flourish at the expense of the less efficient. 'Fair' competition is notnecessarily the same as 'free' competition. 'The problem is that the free market may produce benefits to society as a whole in the long run but cause a great deal of pain to the losers in the meantime. This is not to say that there should not be social, regional, employment, environmental, or other policies. It is a matter of whether, and to what extent, these may be or should be pursucd as part of a competition policy and how far competition can be isolated from other policies." (emphasis in the original).

${ }^{1846}$ Wesseling R, (2000), $94 \mathrm{ff}$., $105 \mathrm{ff}$., who shows that "the Commission, in the wide discretion the Court allows it under Article 81(3) EC, toutinely bases its decision on non-competition concerns" (emphasis added).

${ }^{1847}$ See Case C-384/93, Alpine Investment, [1995], paras. $43 \mathrm{ff}$.

1848 Paras. $97 \mathrm{ff}$. of the judgment in Wouters.

1849 See also AG Léger in Case C-309/99, Wouters et al. v NOvA, [2002], para. 105. Gilliams H., (2006).

1850 Joined Cases T-528/93, T-543/93 and T-546/93, Métropole télévision, [1996], para. 118.

1851 Joined Cases T-528/93, T-543/93 and T-546/93, Métropole télévision, [1996], para. 118. 
Article 81(3)-[1] EC. Put in the words of the chairman of the OFT, "An important point to keep in mind is that competition - through its incentive properties and otherwise - is a valuable means towards a great range of ends, public as well as private. It simply isn't a question of competition on the one hand, and the public interest on the other. Competition and the public interest generally go hand in hand." 1852

In a given case Article 81(3) EC may thus allow an exemption for economic public interest considerations if they have economically beneficial effects and meet the further requirements of Article 81(3) EC. The intention of this book is to invite to renewed visions of efficiencies ${ }^{1853}$ and the following will therefore scrutinise whether and to what extent professional regulation protects market values that are not restricted to the subjective economic interests of the members of the profession. Secondly, where professional rules pursue non-market objectives it is crucial to determine whether their beneficial effects are economic in nature. This question will be scrutinised against the backgtound of the systemic public interest defence that regulators of the professions raise when confronted with competition law. Thus the goal of section 2.5 . will be to identify professional values that have economic beneficial effects and, moreover, are necessary to yield these effects in accordance with Article 81(3)-[3] EC. Section 2.4. will set out this proportionality testing before it will be applied to the ptofessional values identified in section 2.5. Conversely, the category of non-economic (professional) concerns that safeguard the expectations of citizenship cannot adequately be protected by Article 81(3)-[1] EC. Therefore, where professional regulation pursues non-economic objectives, these will have to be addressed with reference to the general justification clause of Article $86(2) \mathrm{EC}$ in part II of this chapter. ${ }^{1854}$ Once it is established which professional values can be protected under Article 81(3)-[1] EC, section 2.5.3.2. will turn to whether these values need to be determined at Community level or whether they can be determined at domestic level, and whether or not the professions themselves should play a role in determining these values.

\subsection{Indispensability under Article 81(3)-[3] EC}

Article 81(3) EC formulates the following condition in good lawyers language: an agreement or decision must not "impose on the undertakings concerned restrictions which are not indispensable to the attainment of these objectives". Formulated positively restrictions ascertained under the first paragraph of Article $81 \mathrm{EC}$ need to prove indispensable, or necessary, to realise the efficiencies that the agreement or decision pursue and, moteover, are encompassed by Article 81(3)-[1] EC. Consequently, a causal link needs to be established in order to show that the restrictions established are necessary to obtain the efficiencies that flow from the decision. ${ }^{1855}$ While this indispensability test therefore needs

${ }^{1852}$ Vickers J. / (Chairman of the Office of Fair Trading), (2004), $5 \mathrm{f}$.

${ }^{1853}$ In contradistinction to van de Gronden J.W., (2005), 89, who instead proposes a new vision on the task of general interest to provide more legal ccrtainty for the future, which has been undetmined in the Wouters approach.

${ }^{1854}$ Compare also Komninos A.P., (2006), who propagates the purity and independence of the competition analysis. To this end he proposes a balancing of competition concerns and public interest concerns outside Article $81 \mathrm{EC}$ as a whole rather than such balancing inside Article 81(3) EC.

1855 The point is visualised above in diagram no. 7 on the substantive scheme of Article $81 \mathrm{EC}$, above p. 371. Moreover, "The causal link between the agreement and the claimed efficiencies must normally also be direct. Claims based on indirect effects are as a general rule too uncertain and too remote to be taken into account. A direct causal link exists for instance where a technology transfer agreement allows the licensees to produce new 
to be dealt with second, Article 81(3) EC lists it thitd; in the following it is hence referred to as Article 81(3)-[3] EC.

The indispensability test requires an assessment of whether the efficiencies are specific to the agreement or decision and its individual restrictions. ${ }^{1856}$ In particular, Article 81(3)-[3] EC introduces a comparative element according to which the question is whether a restrictive decision or agreement produces more efficiencies than in the absence of the included restriction. ${ }^{1557}$ This is not the same as the question discussed in Chapter 4.II.1.2. of whether, in the absence of the restriction, the agreement would not have been concluded. In contradistinction to the ancillary restraints doctrine one has to consider restrictions that - while they are not necessary for the implementation of the main agreement of decision - produce direct and objective benefits. ${ }^{1858}$ This balancing act requires the drawing up of a balance sheet in which pro-competitive factors produced by a decision, and ascertained under Article 81(3)-[1] EC, are confronted and compared with its anticompetitive effects ascertained in respect of the first paragraph of Article $81 \mathrm{EC}$. The balancing itself can then take place in respect of Article 81(3)-[3] EC. More specifically, the applicable test is one of proportionality, namely of whether the restrictions are necessary to achieve the efficiencies. A restriction is indispensable if its absence would eliminate or significantly reduce the efficiencies achieved by the decision or make it significantly less likely that they will materialise. ${ }^{1859}$ Despite the stern term 'indispensable', the Commission in its Guidelines applies a yardstick of 'reasonable necessity' in contrast to a strict necessity test. This means: the more uncertain the success of the service covered by the decision, the more a restriction may be required to ensure that the efficiencies will materialise. ${ }^{1800}$ Conversely, the more restrictive the restraint, the stricter the indispensability test. ${ }^{1861}$

or improved products or a distribution agreement allows products to be distributed at lower cost or valuable services to be produced. An example of indirect effect would be a case where it is claimed that a restrictive agreement allows the undertakings concerned to increase their profits, enabling them to invest more in research and development to the ultimate benefit of consumers. While there may be a link between profitability and research and development, this link is generally not sufficiently direct to be taken into account in the context of Article 81(3).", European Commission, Guidelines on the application of Article 81(3) EC, para. 54.

1856 Faull J. / Nikpay A. (Eds.), (2007), para. 3.438. According to the Commission this condition implies a two-fold test. Both the restrictive decision as such and the individual restrictions of competition flowing from the decision must be reasonably necessary to attain the efficiencies, European Commission, Guidelines on the application of Article 81(3) EC, para. 73. One may observe that the twofold test does not actually follow from the very wording of Article 81(3)-[3] EC, which refers only to the agreement/ decision not to impose restrictions that are not indispensable.

1857 European Commission, Guidelines on the application of Article 81(3) EC, para. 74.

${ }^{1858}$ Sce Whish R, (2003), 157.

1859 European Commission, Guidelines on the application of Article 81(3) EC, para. 79. In some cases a restriction may be indispensable only for a certain period of time. In determining the necessary time span one has to consider the time that the parties need to achieve the efficiencies that justify an exception, see Joined Cases T-374/94, T375/94, T-384/94 and T-388/94, European Night Services Ltd (ENS) e.a., [1998], para. 230.

1860 European Commission, Guidelines on the application of Article 81(3) EC, para. 80. Sec also para. 75: "The Commission will not second guess the business judgment of the parties. It will only intervene where it is reasonably clear that there are realistic and attainable alternatives. The parties must only explain and demonstrate why such seemingly realistic and significantly less restrictive alternatives to the agreement would be significantly less efficient.". - "In a world where business decisions must be made on the basis of imperfect information and where enforcement agencies are not often well-placed to second guess such decisions, a certain margin of error is considered justified.", Faull J. / Nikpay A. (Eds.), (2007), para. 3.438.

${ }^{1861}$ Consequently, restrictions that are black listed in block exemption regulations or identified as hardcore restrictions in Commission guidelines and notices are unlikely to be considered indispensable, European Commission, Guidelines on the application of Article 81(3) EC, para. 79. The Commission explains that the test under 
Diagram (no.9) on objective justification testing

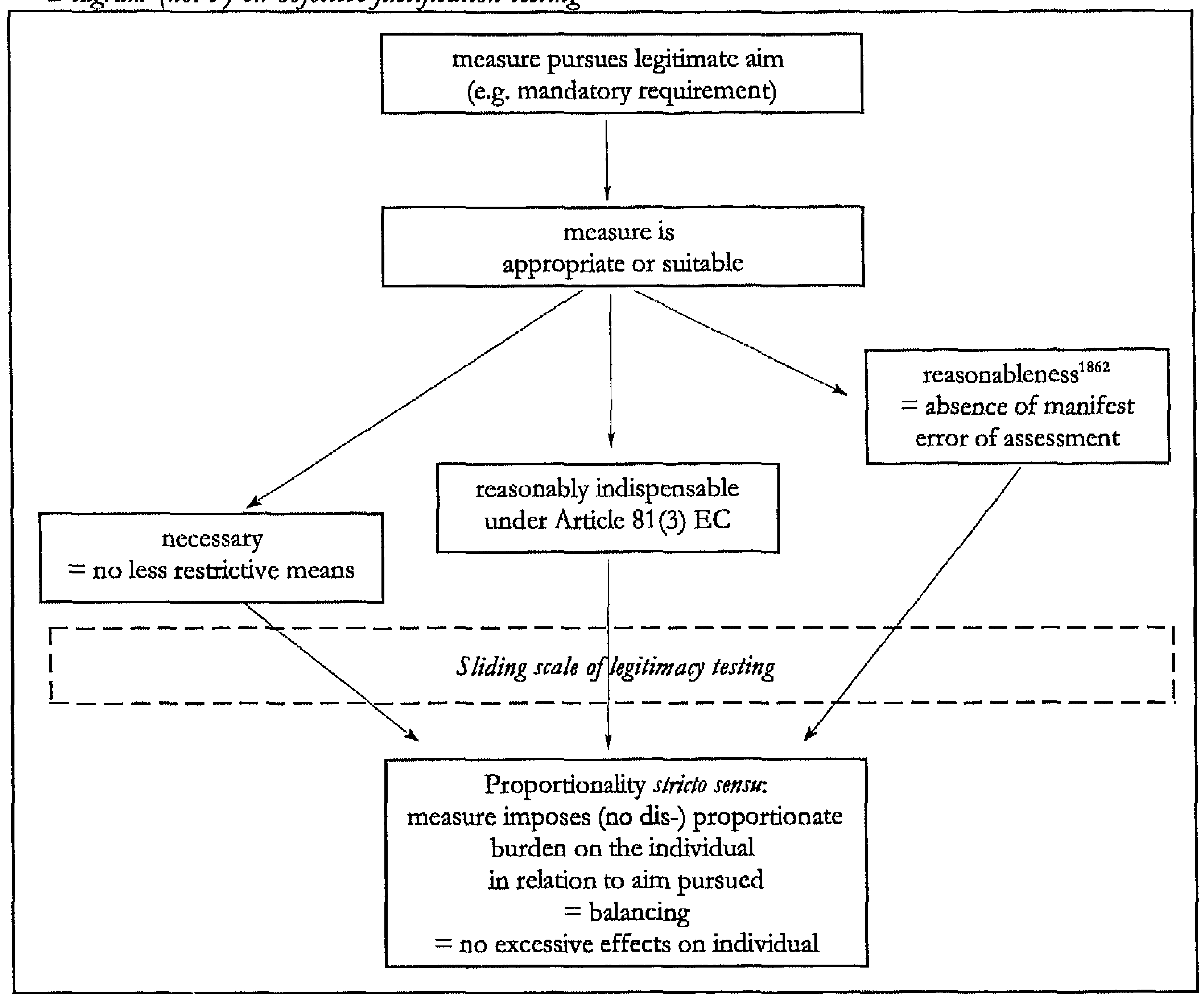

Article 81(3) EC is different for object and effect restrictions. The greater the restriction of competition found under Article 81(1) EC the greater must be both the efficiencies (Article 81(3)-[1] EC) and the "fair share" passed on to consumers (Article 81(3)-[2] EC). The Commission calls this a "sliding scale approach".

1862 The standard of reasonableness refers to the abuse of powers by administrative bodies and the standard of judicial teview of public body decisions. In English law it derives from Court of Appeal - "Associated Provincial Picture Houses v Wednesbury Corporation" [1948]1 KB 223, and is known as Wednesbury test. Other jurisdictions know similar test for the abuse of powers. United Kingdom courts cite the Wednesbury test as a reason for courts to be hesitant to interfere into the decisions of administrative law bodies. The Court of Appeal stated that it would only intervene to correct a bad administrative decision on grounds of its unreasonableness, meaning that the authority, in making that decision, either took into account factors that ought not to have been taken into account, or failed to take account of factors that ought to have been taken into account, or no reasonable authority would ever consider imposing the decision. According to Lord Greene MR, "It is true the discretion must be exercised reasonably. Now what does that mean? Lawyers familiat with the phraseology commonly used in relation to exercise of statutory discretions often use the word 'unreasonable' in a rather comprehensive sense. It has frequently been used and is frequently used as a general description of the things that must not be done. For instance, a person entrusted with a discretion must, so to speak, direct himself properly in law. He must call his own attention to the matters which he is bound to consider. He must exclude from his consideration matters which are irrelevant to what he has to consider. If he does not obey those rules, he may truly be said, and often is said, to be acting 'unreasonably.' Similarly, there may be something so absurd that no sensible person could ever dream that it lay within the powers of the authority. Warrington LJ in Short $\nu$ Poole Corporation [1926] Ch. 66, 90, 91 gave the example of the red-haired teacher, dismissed because she had red hair. That is unreasonable in one sense. In another sense it is taking into consideration extraneous matters. It is so unreasonable that it might almost be described as being done in bad faith; and, in fact, all these things run into one another." 


\subsection{Economically beneficial effects of professional regulations}

The aim of the present section is to verify whether, and to what extent, professional regulations may, on the one hand, lead to savings or synergies that may be calculated in terms of a monetary value (cost savings) or, on the other, lead to new or improved professional services (quality improvements). While efficiency gains can be categorised in these two different types they may easily coincide in a given case. Cost efficiencies may be prevalent in certain instances, qualitative efficiencies in others. Qualitative arguments are, as indicated before, of particular importance to advocates of professional regulation and the defence of codes of professional conduct. To cover different justificatory aspects this section on efficiencies in professional regulation follows a graded presentation. It illustrates a sclection of restrictive types of professional regulations the justification of which can be said to slide from cost to qualitative arguments. At the same time the presentation culminates in an illustration that allows to explore the issue of policy choices possibly falling outside the range of cost and qualitative efficiencies. The selection made for this purpose covers advertising restrictions, tariff schemes, entry tequirements, and tules testricting ownership in professional firms.

In a first subsection the example of advertising restrictions allows to sketch a case of justificatory arguments that concentrate on strict economic arguments, i.e. representing the interests of market participants (market concerns). Conceivable efficiencies in advertising restrictions may be qualified mainly as cost efficiencies since the quality of services offered does not change with the description and promotion of the services through advertising. ${ }^{1863}$ Arguments of cost efficiencies in professional regulation shall be further explored with the help of tariff schemes. They are still quite commonly tepresented in codes of professional conduct. In a second subsection entry requirements like licensing will be discussed. Their case will allow to scrutinise arguments of a more qualitative nature in justifying restrictions in professional regulation. The qualitative argument is further scrutinised in a third subsection that illustrates the proclaimed benefits of rules restricting ownership. At the same time this last example allows to look into the facts of the Wouters case and whether they effectively could fit Article 81(3)-[1] EC, or whether policy choices of a non-economic nature motivated the Court to accept the legitimacy of the prohibition of multi-disciplinary partnerships. The facts of the Wouters case thus constitute the touchstone of exploting the reach of Article 81(3)-[1] EC in justifying professional regulations.

\subsubsection{Cost efficiencies in advertising restrictions and tariff schemes}

Codes of conduct that restrict members of a profession from using certain forms of advertisement are in principle restrictive of competition within the meaning of

1863 A stimulus to develop also the quality of the services could be a secondary effect of advertising restrictions, but is a rather remote effect that depends on the ambitions of the service provider to distinguish herself with particular high quality services. Nonetheless, professional representatives still chetish the view that without advertising restrictions the quality of professional services would deteriorate because practitioners would be distracted from competing in terms of quality or performance (reiner Leistungswettbewerb), see for instance press release Bundesverbandes der Freien Berufe vom 11. Februar 2004, www. freie-berufe.de, last visited on 21.02.04; see also Ring G., (1989), 304. 
Article 81(1) EC because they inhibit practitioners from using an important means to market their activities. Advertising allows customers access to information on the services in question. ${ }^{1864}$ For practitioners it is a means to provide information, in particular, on costs and the conditions under which services are supplied. Furthermore, it allows for the promotion of the services offered, including a comparison with (the services of) a competitor. Advertising thus is an important element of the competitive process. ${ }^{1865}$ However, in order to warrant an increase of user (or consumer) information, advertising has to provide accurate and precise information that is verifiable and not misleading. This standard is already the state of EC law. ${ }^{1866}$

This standard implies a clear indication for the application of Article 81(3)-[1] EC. Rules that limit advertising to verifiable and non-misleading information cater for a number of advantages for the economic process. At first, they protect the competitive process from service providers who are prone to engage in misleading advertising. In the short term competitors who provide reliable information could suffer from potential clients being diverted to dubious service providers. In the long term the whole sector could suffer from a decrease in the reputation of the professionals' reliability and independence. ${ }^{1867}$ 'This effect is not mitigated by the argument that the business practices of dubious services providers are bound to be eliminated by market mechanisms because customers would soon learn from their experience and identify those members of a profession that do not intend or are not able to live up to the statements they make in advertising about the level of their services. There is no mitigating effect since in this process of gaining experience consumers incur costs for gathering the information and also for verifying that information. ${ }^{1868}$

More importantly non-reliable advertising is likely to taise relative prices because customers relying on such information will expect the services finally purchased to be of a higher level or different quality than advertised. Consequently, they are prepared to pay a

\footnotetext{
1864 Economists point out that consumers will not takc an innumerable amount of information before making a decision about which service, product, or contractual conditions to accept. However, the risk or sensation of stimulus satiation created by an abundance of advertising information should not be an argument to inhibit competitors from offering various forms of information about their services. Where a customer might feel overwhelmed by the amount of information she will in a natural reflex content herself with the information she considers necessary for her informed choices in purchasing professional services. Whether in doing so she might miss out a crucial detail is the tisk that life offers more generally and that she takes on balance with the extra efforts she would otherwise need to invest (in terms of time and/ or money) to broaden her awareness (on the basis of which she takes her transaction decisions). To allow customers to use a cost efficient way of information gathering it is important to warrant that the information offered (whether 'overwhclming' or not) is reliable, verifiable and non-misleading, but not to restrict the provision of information at the source. It is an expression of respect for the dignity of the customer not to patronise her in choosing which information to take and which to leave. On information regulation and economic theory, see Philipsen N.J., (2003), $27 \mathrm{ff.}$

1865 Commission Decision EPI Code of Conduct, (1999), para. 41.

1866 Council Directive 84/450/EEC of 10 September 1984 relating to the approximation of the laws, regulations and administrative provisions of the Member States concerning misleading advertising, Directive 97/55/EC of 6 October 1997 amending Directive $84 / 450 / \mathrm{EEC}$ concerning misleading advertising so as to include comparative advertising.

${ }^{1867}$ See Supreme Court of the United States - Case 97-1625 "Califomia Dental Association v Federal Trad Commission" [1999]526 U.S. 756 [also: 119 S.Ct. 1604].

${ }^{1868}$ Compare also Case C-384/93, Alpine Investment, [1995]. NB Since the provision of professional services more often than not implies a lead in knowledge, consumers are often not in the position to judge the quality of the services to be provided, and hence to verify the information they obtained in particular on the promised quality of the services to be provided. In economic theory the lead in knowledge is called information asymmetry, see above section I.2.2. For a description of information asymmetry in advertising restrictions, see Paterson I., et al., Economic impact of regulation - Main Report, (2003), 16.
} 
different price, namely a price that is appropriate for the qualities of the advertised rather than the actually provided service. In other words, without misleading advertising prices for the service level offered could be relatively lower. This implies that with reliable and nonmisleading advertising can customers not only better differentiate professional services as to their characteristics and quality level, but they can also make price differentiations. Advertising restrictions that bind professionals to provide truthful and verifiable information thus result in objective efficiencies (i.e. user information) that are not limited to the subjective benefit (i.e. promotion) of the service providers who already engage in reliable advertising. To limit advertising thus can be a stabilising factor with tegard to the provision of information on professional services, which improves the general conditions of service provisions. ${ }^{1869}$

It is then the particular shape of advertising restriction that under Article 81(3)-[3] EC has to be tested whether it is indispensable to tealise the objective efficiency gain of improving the general conditions of service provision. In assessing codes of professional conduct the relevant question thus is which provisions restricting advertising are confined to prohibiting only those advertising activities that do not meet the objective standard of disseminating verifiable and non-misleading information. Different forms of advertising restrictions exist. They concern, for instance, comparative advertising (comparison of the professional services of one member of the profession concerned with those of another), quantitative restrictions on advertising, restrictions on advertising that targets individual customers without their express consent, or advertising of tariff rates (per time unit or type of service, c.g. in telation to property transfer services or standardised medical treatment). Where these types of advertising restrictions go beyond the objective standard of prohibiting misleading advertising they are basically contrary to European secondary law.

In the particular field of the (liberal) professions Directive 84/450/EEC, as amended by Directive $97 / 55 / \mathrm{EC}$, provides for a flexible approach towatds advertising restrictions. ${ }^{1870}$ Its Article 7(5) stipulates that Member States shall not be precluded

"from, in compliance with the provisions of the Treaty, maintaining or introducing bans or limitations on the use of comparisons in the advertising of professional services, whether imposed directly or by a body or organization responsible, under the law of the Member States, for regulating the exercise of a professional activity."

While this provision permits Member States to establish a derogation from the scope of the Directive for advertising testrictions contained in codes of professional conduct, and thus to justify stricter restrictions in professional service provision, it does not go further than that. This means that the provision does not wartant an automatic exemption within the meaning of Article 81(3) EC. On the contrary, it explicitly stipulates that a derogation under the Directive has to be in compliance with the rules of the Trealy. In other words, the detogation

${ }_{1869}$ Compare Case 26/76, Metro I, [1977], para. 43, accepting under Article 81(3) EC the establishment of supply forecasts and their objective efficiency of stabilising employment. The case illustrates that it is not employment as such that is considered an objective factor, but the stabilising effect on employment (as a production factor), see Faull J. / Nikpay A. (Eds.), (2007), para. 3.407: "Fluctuating demand forces an undertaking at one point in time to reduce personnel and at another point in time to increase it. This imposes costs in the form of transaction costs, training costs and loss of valuable skills. The stabilising effect of an agreement on employment may thus translate into cost savings and other efficiency gains." It is thus not a policy consideration diverging from competition policy that tips the balance in granting an exception under Article 81(3)-[1] EC.

1870 Council Directive 84/450/EEC of 10 September 1984 relating to the approximation of the laws, regulations and administrative provisions of the Member States concerning misleading advertising; Directive $97 / 55 / \mathrm{EC}$ of 6 October 1997 amending Directive 84/450/EEC concerning misleading advertising so as to include comparative advertising. 
from the Directive does not take away that consumers of professional services have the same need for information as in any other sector. ${ }^{1871}$ An assessment in competition law terms has to take account of this need, and a recognition under Article 81(3)-[1] EC will be available only for those advertising restrictions that cater for the objective efficiencies of transparent information and hence allow customers to assess the relative price and quality level of the services. ${ }^{1872}$ In addition, the benefits of a particular advertising restriction have to be appreciable ${ }^{1873}$ to allow a decision on whether they outbalance and compensate for the prima facie restriction of competition. ${ }^{1874}$

The counter example to economically beneficial professional rules are tariff schemes. Tariff schemes are restrictions of competition by object. They are hardly an incentive for incumbents to improve quality or innovate; as such they create no 'objective' cost efficiencies. Nevertheless they are defended by regulators as an appropriate means to wartant the exercise of the (liberal) professions. In Chapter 4.II.2.1. on price fixing it has been demonstrated that the argumentation put forward with regard to price regulation for professional services has schizophrenic traits. On the one hand, the argument is that with minimum and/ or maximum fee scales competition in service provision would mainly focus on quality. The argument thus hints at a qualitative efficiency. At the same time, however, it is generally accepted that clients can hardly assess the quality of professional services because of an information asymmetry towards the professional. In economic theory professional services are described as credence goods. This means that because of the difference in knowledge - which is necessary to assess what the required level of the service should be - a customer cannot assess the quality of the service before she purchases it. Even after the professional service has been provided the customer may not be in the position to assess whether the consumed service had been the means to achieve the intended result, or whether the tesult achieved has helped her best. The reference to the information asymmetry thus contains the acknowledgement that competition on quality hardly takes place in professional services. While the justificatory line of argumentation is that without any price competition practitioners would be forced to concentrate to compete on quality, economic literature heavily and rightly doubts this effect. From an economic point of view, tariff

1871 Commission Decision EPI Code of Conduct, (1999), para. 42; Lenk J., (2006), $331 \mathrm{f}$.

1872 For a concise overview of the application of Article 81(3) EC to advertising restrictions illustrating in particular the codes of conduct of the German Bar (Berufsordnung fur Recbtsanwälte, BORA) and of the German Medical Association of Hesse, see I.enk J., (2006), 317-332. Different from my view, however, she qualifies the protection from misleading advertising as a non-economic aspect. Such a qualification disregards the market objective that consumer protection pursues, see de Witte B., (2006), 63.

${ }_{1873}$ See above note 1789.

1874 An example of professional regulations being exempted under Article 81(3) EC is Commission Decision EPI Code of Conduct, (1999), paras. 46-48. The Commission allowed for a transitional period of adaptation of the professional advertising rules at stake. The Commission granted an individual exemption until 23 April 2000, the deadline by which Member States must transpose Directive 97/55/EC of 6 October 1997 amending Directive $84 / 450 / \mathrm{EEC}$ concerning misleading advertising so as to include comparative advertising. Although the Commission found that the strict prohibition of individual advertising and the supply of unsolicited services is "unquestionably incompatible with the system of effective competition", it nevertheless held that a changeover from a system of virtually total prohibition to one of total freedom "involves a significant transformation of the framework within which professional representatives operate. If this changeover is made suddenly, there is a potential risk of confusion in the mind of the public such as might damage the image that professional representatives give to institutions participating in the administration of justice." See, however, the critique by AG Léger in Wouters at para. 116 that it is possible to explain the solution chosen by the Commission in EPI Code of Conduct by the concern to avoid notifying the professional rules adopted by the association in the various Member States. See already Chapter 4.II.4.2.2. 
schemes will only result in cost savings on the side of the practitioners and allow them to increase their profits. ${ }^{1875}$ The resulting benefit is thus not objective within the meaning that the case law has given Article 81(3)-[1] EC. Tariff schemes as such will not spur the practitionets to increase quality, i.e. to create value in the sense of a pro-competitive effects on the market. ${ }^{1876}$ Practitioners will feel even less stimulus to increase quality, first of all, where they have a statutory monopoly for the activities covered by the tariff scheme and, secondly, where their customers suffer from an information asymmetry.

An argument in favour of price regulation could be the resulting transparency of fees and the predictability of costs for consumers. Clients would need to invest less to no costs in gathering price information, therewith reducing their transaction costs. However, on closer investigation a thus identified objective cost efficiency proves to be apparent only. Professional tariffs are related to units of professional services. Due to the information asymmetry customers can in general hardly judge which and how many units of professional services are required to help them solving their problems. Costs are thus not predictable for clients. Moreover, the establishment of the concrete fee may require further information, namely where it is established as percentage of the value of the financial interest at stake, for instance of a legal claim or the value of the works realised in building. ${ }^{1877}$ Professional tariff schemes thus often prove 'illegible' to customers. This effect discredits the argument that price fixing would tesult in objective benefits.

Even where efficiencies appear to be conceivable, a further question arises. Could cost efficiencies on the side of the consumer outbalance the anti-competitive effects of the price fixing? In light of the fact that price fixing is a hard core restriction, the objective efficiencies must be particularly appreciable in accordance with the sliding scale approach coined by the Commission. ${ }^{1878}$ This obstacle can hardly be cleared. The moment clients seek information on the demanded professional services and the quality thereof, it appears to be of little effort to simultaneously ask for price information. On balance the possible pro-competitive effect sketched above thus appears to be relatively smaller than the anti-competitive effect deriving from fee schedules. Consequently, they do not meet the first requirement of Article 81(3) EC (objective efficiencies). Moreover, the opening of prices for notarial services in the Netherlands evidences that clients are sensitive to price information. Notaries notice that they are more and more often called to give price indications. As a result prices have developed, e.g. prices for estate transfers have decreased and prices for family deeds appear to have increased. This particular tariff development reflects the commonly acknowledged effect that prior to the Notarial Act 1999 the revenue of real estate activities were cross-subsidising activities in the field of family law. ${ }^{1879}$ It also shows that costs had not been made transparent for clients.

\footnotetext{
1875 See European Commission, Guidelines on the application of Article 81(3) EC, para. 49.

1876 See also König M., (1997), $157 \mathrm{ff}$., for a sceptical view on the possibility to exempt tariff schemes of liberal professions under Article 81 (3) EC.

${ }_{1877}$ See for instance Commission Decision Belgian architects, (2004), discussed in Chapter 4.II.2.1.

${ }_{1878}$ European Commission, Guidelines on the application of Article 81(3)EC, para. 90. See above note footnote 1861, footnote 2148 .

${ }^{1879}$ Kuijpers N., et al., Liberalisation of the Dutch notary profession - Reviewing its scope and impact, (2005); Nahuis R, et al., Compelition and Quality in the Notary Profession, (2005); Baarsma B., et al., Recbtszekerbeid als publiek belang, (2004); Plug P.J., et al., Mededinging versus domeinmonopolie en ministerieplicbt - Over de gevolgen van marktwerking in bet notariaat, (2003).
} 


\subsubsection{Entry requirements}

As regulated professions the (liberal) professions are regularly not open to 'unqualified', i.e non-licensed or non-certified service providers. $A$ licence system constitutes a batrier to access the regulated activity and therewith is a testriction of competition by object. ${ }^{1880}$ In Piau the Commission applied Article 81(3) EC to the FIFA's licencing rules for players' agents. According to FIFA its licensing rules pursue the objective of raising professional and ethical standards for players' agents with a view to protecting football players, whose career as a professional footballer is short. The Court endorsed the argument and, in striking a firm distinction between quantitative and qualitative restrictions on access to the profession, found that the objective of raising professional standards is a benefit within the ambit of Article 81(3) EC, assuming that the licence system results in a qualitative selection of service providers. ${ }^{181}$ Accordingly, it is the qualitative selection that first restricts competition but secondly has to yield economic benefits. Thus, to meet Article 81(3)-[1] EC a licence system should lead to - and here I mimic the terms of the Commission Guidelines - service providers who offer services better tailored to consumer needs. ${ }^{1882}$

In Piau the Court was satisfied that the licence system resulted in a qualitative selection of candidates for the profession of players' agents. ${ }^{1883}$ It is hence not sufficient to simply argue the raising of professional standards if these standards cannot be expressed in qualitative requirements of an objective nature. Moreover, to meet Article 81(3)-[3] EC the particular rules must be (reasonably) indispensable ${ }^{1884}$ to the attainment of these objectives. The Court in Pian clearly applied a test of reasonableness as it concluded that the Commission had not committed a manifest errot of assessment in considering that the restrictions stemming from the compulsory nature of the license system might benefit from Article 81(3) EC. ${ }^{1885}$ Intriguing is, however, the Coutt's motivation for recognising the reasonableness of the license system, which it linked directly to the appropriateness of (the licence as) qualitative selection to achieve the objective of raising professional standards. ${ }^{1886}$ While approptiateness forms part of a wider objective justification test, it is an element that has to be tested prior to the applicable standard of legitimacy control, which is either a yardstick of reasonableness or strict proportionality. ${ }^{1887}$

Moreover, while the Court emphasised the restriction was one by object, it did not overtly apply a tule of 'the more restrictive the restraint, the stricter the indispensability test' (sliding scale approach). In particular the Court did not consider any less restrictive alternatives to the compulsory licence system, like for instance a system of certification. ${ }^{1888}$

${ }^{1880}$ Case T-193/02, Piau I, [2005], para. 101. This substantive assessment under Article 81(1) EC may be less strict in case of certification. For details see Chapter 4.II.2.3. and Chapter 5.II.2.2.1.

${ }^{1881}$ Para. 103 of the judgment in Piau. A quantitative restriction was excluded in that case by the argument that at the beginning of 2003 the number of licensed players' agents was seven times higher than their number recorded in 1996, when the restrictive regulation was firstintroduced (in 1996 there had been 214 licensed agents). ${ }^{1882}$ See above section I.2.1.

${ }^{1883}$ See paras. 14-15 of the judgment in Piau I, described in Chapter 2.V. and Chapter 5.I.

1884 See above text with note footnote 1860.

1885 Para. 104 of the judgment in Pian I.

${ }^{1886}$ See para. 104 of the judgment in Piau I, which explicitly refers to para. 103 on the appropriateness of the measure.

${ }^{1887}$ See also diagram no. 9 above on page page 386.

1888 As has been explained in Chapter 4.II.2.3. certification is a less strict from of entry regulation since it organises the profession as a voluntary function that does not hinder access of non-certified individual to the market. 
Instead it relied on "various legal and factual circumstances" to justify the actual principle of the compulsory licence. ${ }^{1889}$ First, the Court noticed the quasi-absence of both national and self-regulatory rules to control the activities of players' agents. ${ }^{1890}$ In a second step the Court combined this with the non-contested observation that "certain practices on the part of players' agents could, in the past, have harmed players and clubs, financially and professionally." 1891 On this basis it appears to have been obvious to the Court that the activity of players' agents necessitate regulation, either at national or self-regulatory level. Its quasi-absence legitimised the FIFA, according to the Court, to adopt selection criteria for football players' agents in order to prevent them from causing harm to players. The FIFA rules must thus have appeared as minimum quality safeguards appropriate to attain a qualitative selection of players' agents in the sector of playcrs' agents. While the Court did not consider a time span for which the licence system may be required, it indirectly included the point by stressing that the Commission had rightly reserved the right to review the FIFA rules on players' agents. ${ }^{1892}$

\subsubsection{Restriction of ownership}

The law of Article 81(3) EC as an exemption to the application of Article 81(1) EC has met manifold attention in recent years not least due to the project of the Commission to modernise the application of Articles 81 and $82 \mathrm{EC}$, which goes back to spring $1999{ }^{1893}$ The abolition of the Commission's exclusive competence to grant an Article 81(3) EC exemption has lead some scholars to forecast an integrated (or conflated) application of Article $81 \mathrm{EC}$, meaning that no clear distinction would be made anymore by the competent competition authorities and courts between the field of application of the first paragraph and the exemption of the third paragraph. ${ }^{1894}$ Scholars have also suggested that the Court in Wouters

1889 Paras. 102 and 104 of the judgment in Piau.

1890 The Court observed that at the time France alone had adopted rules governing the occupation of sports agents. Remarkably the plaintiff Mr Piau was established in France. As a candidate to be a football players' agent Mr Piau should thus have been subject to the French rules on the occupation of sports agents. Apparently this path of argumentation was either not trodden by Mr Piau or dismissed by the Court for the sake of the argument that the Commission had not committed a manifest error of assessment when considering that the restrictions stemming from the compulsory nature of the licence might have benefited from an exemption on the basis of Article 81(3) EC, see paras. 102 to 104 of the judgment in Piau.

1891 Para. 102 of the judgment in Piau. It is interesting to note that the Court also accepted the protection of financial interests of the football clubs to justify a restrictive regulation. The harm players' agents could bring to clubs is to approach a player who is under contract with a club. The FIFA rules prohibit such conduct. The interests of the clubs represent market concerns, which may not be subjective if they are to fall within the protection of Article 81(3)-[1] EC. Financial interests fit this requirement only if they qualify as cost efficiencies. FIFA itself concentrated on the argument of raising the professional standards for players' agents rather than the financial interest of clubs.

1892 Para. 104 of the judgment in Piau.

1893 European Commission, White Paper on Modernisation of the Rules Implementing Articles 85 and 86 of the EC Treaty, of 28.04.1999. See also Proposal for a Council Regulation on the Implementation of the Rules on Competition Laid Down in Articles 81 and 82 of the Treaty and Amending Regulations (EEC) No 1017/68, (EEC) No 2988/74, (EEC) No 4056/86 and (EEC) No 3975/87.

1894 Goyder D.G., (2003), 94 f., suggested that the Court in Wouters operated a conflated application of Article $81 \mathrm{EC}$ as if its first and third paragraphs were a single provision. He compared the Court's approach in Wouters with Supreme Court of the United States - Casc 97-1625 "California Dental Association v Federal Trad Commission" [1999]526 U.S. 756 [also: 119 S.Ct. 1604] under section 1 of the Sherman Act. See also Van den Bergh R.J. / Camesasca P.D., (2006), 193. Goyder tried to predict the future in stating that a conflated application of Article 81 EC (as if it was stating a single provision) "may become the usual method of applying Article 81 
intertwined principles of competition law and free movement law, and from the latter transposed a rule of mandatory requirements into competition law. ${ }^{1895}$

These views have been provoked by the approach that the Court took in 2002 in Wouters as the Court did not revert to the explicit conditions of Article 81(3) EC. Instead it found that for the purpose of applying the first paragraph of Article $81 \mathrm{EC}$ account had to be taken of the overall context in which the professional regulation had been taken or produced its effects; more specifically, account had to be taken of its objectives. As such this statement is not new in EC competition law, and it has been formulated more often before regard to the scope of application of the first paragraph of Article $81 \mathrm{EC} .^{1896}$ The Wouters proviso, however, accorded particular importance to the overall context. In particular, emphasise was being put on whether the consequential effects restrictive of competition are inberent in the pursuit of the regulation's general objectives and are proportionate to them. ${ }^{1897}$ The ECJ reinforced this focus on "inherent" restrictions in Meca-Medina $I I^{1898}$, and the question thus arises whether, in light of the explicit and competition specific requirements enumerated in Article 81(3) EC, the Court has trodden new paths with these course it adopted in the two judgments. Should this course be pursued in self-regulatory sectors (as the CFI in MecaMedina I seems to suggest by referring to "the method of analysis derived from Wouters"1899, or will the direct applicability of Article 81(3) EC make the case law created justification redundant?

It has been explained in Chapter 4 that Article 81 (3) EC and the Wouters proviso are structurally similar as they both limit the reach of the prohibition in Article 81(1) EC. This

from 1 May [2004]", the moment that Regulation 1/2003 has become applicablc. However, it would be regrettable if the Commission would allow such a conflated application of Article $81 \mathrm{EC}$, as allude Jones and Sufrin with reference to European Commission, Report on Competition in Professional Services, of 09.02.04, para. 60, because such an enforcement practice would undermine the strict application of the competition rules, and even more so when taking account of the recent enlargements of the Community by 12 Member States, which supposedly are inexperienced in the application of the strict competition rules. Jones A. / Suftin B., (2004), 229, rightly stress that a conflated application of Article $81 \mathrm{EC}$ would blur the distinction that has to be drawn between restrictions of competition on the one hand and economic benefits on the other. It would in particular blur the fact that the economic benefits must not only outweigh the anti-competitive effects of a decision or agreement, but must also meet the further specific requirements of Article 81(3) EC. See also Komninos A.P., (2000), 2 (with further references in his note 7), who rightly points out that it is of utmost practical importance to keep the distinction between the conditions of the first and third paragraph of Article 81 EC since the two provisions result in different distribution of the burden of proof. Also Whish R., (2003), 107, stresses that while "there is no longer a procedural tail to wag the substantive dog [...] it is still important to apply Article 81(1) with intellectual rigour, and to apply it only to agreements that really do restrict competition: but a determination that an agreement infringes Article 81(1) no longer has the serious procedural consequences that it used to have."

1895 Monti G., (2002), 1083 ff., 1086 ff., claims that the Court in Wouters has transposed a Cassis de Dijon, or European-style rule of reason into Article 81(1) EC. See also Deckert M.R., (2000), who proposes to transpose the limitations implied in the Cassis rule also to Articles $81(1)$ and $82 \mathrm{EC}$. The propagated advantage of this approach is seen in the possibility to take account of concerns that may justify restrictions of competition, but which would transcend the specific requirements of Article 81(3) EC. See also Gilliams H., (2006), 23; O'Toughlin R., (2003); ForresterI.S., (2006); Martinazzi A.," The Effects of Wouters on Professiontal Regulation:Intertwining Public Policy, Proportionality and the Rule of Reason?" ; Loozen E., (2006); Baquero Cruz J., (2002), 153: "Wouters may [...] be seen as the pendant of Cassis de Dijon [...] and Bosman [...] for the Community competition rules." Wesseling R, (2005). ${ }_{1896}$ For details on the application of Article 81(1) EC as interpreted by the Court in respect of the relevant context, see Chapter 4.I.1.2.

1897 Para. 97 of the judgment in Wouters.

${ }^{1898}$ Case C-519/04 P, Meca-Medina II, [2006], para. 42.

1899 Case'T-313/02, Meca-MedinaI, [2004], para. 62 and 66. On appeal this formulation has not been corroborated by the ECJ. 
section will focus on comparing them. It will first address whether the justification grounds recognised in the Wouters proviso can be accommodated within the framework of Article 81(3) EC. It will then turn to scrutinise whether the Wouters proviso applied a similat criterion of (reasonable) indispensability as is required by that article. ${ }^{1900}$ Attention will also be paid to whether the perceptions of a profession prevailing nationally can be taken into account under Article 81(3) EC.

\subsubsection{Legitimate justification grounds in Wouters}

Here shall be tested whether the facts that are at the root of the Wouters case are at all open to a different legal assessment than undertaken by the Court in 2002. After all, no procedural considetation exists anymore that might prevent a purified application of competition law in the field of professional regulation. ${ }^{1901}$ It shall therefore be scrutinised to what extent the Wouters proviso reflects objective values compatible with Article 81(3)-[1] EC.

The Court stressed that the prohibition of Article 81(1) EC should not be applied to professional rules that are based on "the need to make rules relating to organisation, qualifications, professional ethics, supervision and liability" and the aim "to ensure that the ultimate consumers of legal services and the sound administration of justice are provided with the necessary guarantees in relation to integtity and experience" ${ }^{1902}$ Accordingly, selfregulatory rules can be justified that ultimately pursue the protection of the consumer and the sound administration of justice. In particular, the Court held that those interests require guarantees in terms of integrity and experience of the professionals. Moreover, the Court held that the mechanism to safeguard integrity and experience necessarily implies the making of rules relating to the "proper practice of the profession". ${ }^{1903}$ Following the logic of the Wouters ptoviso the two concepts of integrity and experience can thus be regarded as core values of the legal profession in the Netherlands. They are the more tangible expressions of the broader regulatory interests of protecting the consumer and the sound administration of justice. The proper practice can then be read as a synonym for the core values of a profession, classifying them in more generic terms. ${ }^{1904}$ It should, however, not be the 'proper practice' as such that is protected (as it is prone to value judgements) but concrete regulatory aims like, for instance, the sound administration of justice and the protection of the ultimate consumer.

At this juncture the matter can take two different directions. In respect of Article 81(3)-[1] EC the question is whether the relevant regulatory objectives represent

1900 See above the text with note footnote 1860.

1901 Since at the material time the national court was not at liberty to apply Article 81(3) EC, Jones A. / Sufrin B., (2004), 229, claim that one should resist the temptation to justify the ECJ's ruling by reference to an implied application of the article's third paragraph, or to claim, as does Goyder D.G., (2003), 94 f., that the Court had conflated the first and third paragraph of Article $81 \mathrm{EC}$ and operated them as if they were a single provision. See also Whish R, (2003), 107, cited above in note 1894.

1902 Para. 97 of the judgment in Wouters (emphasis added).

1903 Paras. 100-107 of the judgment in Wouters.

${ }^{1904}$ See also AG Léger in Case C-309/99, Wouters et al. v NOvA, [2002], paras. $105 \mathrm{ff.} \mathrm{"110.} \mathrm{It} \mathrm{seems} \mathrm{to} \mathrm{me} \mathrm{to}$ be impossible to identify a single formula which might cover all the professional rules relating to all the professions in the various Member States. Each professional rule must be examined on a case-by-case basis, depending on its subject-matter, context and purpose.", with reference to AG Jacobs in Joined Cases C-180184/98, Pavlov, [2000], paras. $89 \mathrm{f}$, and the heterogeneity of the professions. Looking at the specificities of markets is of course not any different in sectors other than the (liberal) professions. 
economically beneficial effects, possibly of a non-matket nature, i.e. objectives that ate not directly driven by interests of the supply or demand side in a strict economic cost/ benefit analysis. ${ }^{1005}$ On the other hand, the approach adopted in Wouters and Meca-Medina II might, in a broader perspective, be interpreted to pave the way for a mote general system of exemption grounds that penetrates Community law for cases that would not be sufficiently covered by the explicit exemption provisions in the Treaty. As pointed out before the approach adopted with the Wouters proviso has in fact provoked legal scholars to compare it to the Cassis de Dijon type of rule of mandatory requirements, and this latter point shall be addressed first hereafter.

\section{Syncbronising the Treaty rules on free movement and on competition?}

Where national obstacles to the free movement of goods, persons, services and capital within the Community result from disparities between the national laws, the rule of mandatory requirements allows to safeguard these obstacles. A parallel with the Wouters ptoviso may be drawn from the fact that the mandatory requirements rule in the field of the free movement rules started off doctrinally to be taken into account within the fabric of the prohibition clause (e.g. Article $28 \mathrm{EC}$ ) and it was separate from any analysis based upon the explicit exemptions provided for by particular Treaty provisions (e.g. Article $30 \mathrm{EC}$ ). A comparison between paragraphs 8 and 15 of the judgment in Cassis de Dijon ${ }^{1906}$ suggests that the national measure at stake could have fallen outside the probibition laid down in Article $28 \mathrm{EC}^{1907}$ if it had to be accepted "as being necessary in order to satisfy mandatory requirements". ${ }^{1908}$ The reason for starting a 'scope-in scope-out' story was the exhaustive character of the justification grounds listed in the Treaty (including e.g. public policy and public security) and allowing derogations from the relevant prohibition clause (cf. Articles 28 and 30; 39 and 39(4); 43 and $46(1) ; 49$ and 55; 56 and 58(1)(b) EC). ${ }^{1909}$ Later, i.e. after the

${ }^{1905}$ See above diagram no. 8 on page 382.

1906 Case 120/78, Cassis de Dijon, [1979].

1907 Para. 15 of the judgment in Cassis de Dijon: "Consequently, the first question should be answered to the effect that the concept of 'measures having an effect cquivalent to quantitative restrictions on imports' contained in Article $[28 \mathrm{EC}]$ is to be understood to mean that the fixing of a minimum alcohol content for alcoholic beverages intended for human consumption by the legislation of a Member State also falls within the probibition laid down in that provision where the importation of alcoholic beverages lawfully produced and marketed in another Member State is concerned" (emphasis added).

${ }_{1908}$ Para. 8: "Obstacles to movement within the Community resulting from disparities between the national laws relating to the marketing of the products in question must be accepted in so far as those provisions may be recognized as being necessary in order to satisfy mandatory requirements relating in particular to the effectiveness of fiscal supervision, the protection of public health, the fairness of commercial transactions and the defence of the consumer."

${ }^{1909}$ See also Timmermans C.W.A., (2005), viii f.: "[There does not exist], in my view, a generally accepted method of interpretation allowing the Community Courts to interpret hard rules and regulatory prohibitions as implying a rule of reason, that is, an unwritten rule allowing for reasonable exceptions. It is because of the absence of such a rule that the application by the Court of an unwritten Rule of Reason has attracted so much attention of legal doctrine. There is much more to this than a simple method of interpretation according to common sense. Indeed, is not the Court when applying an unwritten Rule of Reason, undoing what the legislature has done, or doing what the legislature has not considered necessary to do? [...] To give you my own answer or the beginning of an answer to my earlier question [...], I would regard it as too simple to argue the issue in such terms. Indeed, to come back to the free movement of goods, the prohibition of Article $28 \mathrm{EC}$ certainly is a hard rule, but the Treaty itself is not at all defining the object of that prohibition, that is, how the notion of a measure having equivalent effect should be understood. It is the Court that has interpreted that notion and that in a very strict 
inception of the concept of indistinctly applicable measures, the up-holding of a 'scope-in scopc-out' approach created problems. With the Cassis de Dijon doctrine the Court developed on the idea of a derogation for objective justifications based on public interest considerations. Although public interest considerations are not spelled out in the Treaty as a generic justification ground, the Court drew inspiration from the explicit derogations for public policy and public security to develop the mandatory requirements doctrine. Therefore, this rule slowly was understood as a justification ground, and hence as an exemption possibility for indistinctly applicable (State) measures that restrict the free movement of goods, persons, services and capital. In legal doctrine it is regularly put forward that this exemption has now become available next to the explicit exemptions of Articles 30, 39(3), $46(1), 55,58(1)$ (b) EC, and thus complements the grounds of exemption mentioned therein. ${ }^{1910}$ An (initial) preference of the Court for a 'scope-in scope-out' approach is reflected also in Meca-Medina $I I^{1911}$, where the ECJ does not seem to strike a 'conceptual' distinction between 'outside the scope' and 'justification of a prima facie infringement'. Also the professional objectives accepted in Wouters are equally taken into account within the fabric of Article 81(1) EC rather than the explicit exemption clause of Article 81(3) EC.

An application of the mandatory requirements doctrine in Wouters could in fact have been a 'reasonable' step ${ }^{1912}$ to avoid conflicting decisions in cases where both the provisions on the fundamental freedoms and the competition law provisions are, in principle, applicable. ${ }^{1913}$ Looked at from that perspective, the Court's approach in Wouters and Meca-

way. So you cold say, when the Court in a next stage is softening that strict interpretation by introducing a Rule of Reason, it is finally doing no more than accommodating its own interpretation. It is not changing the rule. It is simply trying to ensure that its interpretation of the law, in the end, achieves a reasonable result." - This accommodation as meant by Timmermans can be extrapolated to Article 81(1) EC for the ancillary restraints doctrine only but not for the Wouters proviso as the latter does not concern the interpretation of the substantive concept of restriction of competition. The Court in Wouters is thus changing the hard rule of Article 81(1) EC. For details see Chapter 4.II.4.2.

${ }_{1910}$ See Arnull A., et al., (2006), 625 ff.; Amtenbrink F. / Vedder H.H.B., (2008), 315 ff. Becker U., (2000), paras. $108 \mathrm{ff}$. argues convincingly that because of the proportionality testingin Cassis the rule of mandatory requirements can be claimed not to concern the scope of Article $28 \mathrm{EC}$ but to be on one level with the justification (exemption) of Article $30 \mathrm{EC}$. The stance that the mandatory requirements doctrine is an exemption rather than an exception is, however, not shared by the mainstream of German legal doctrine, see for instance Müller-GraffP.-C., (1997-8), para. 130 The case law itself is not consistent on the point, meaning that the Court itsclf sometimes scrutinises Article $30 \mathrm{EC}$ and the mandatory requirements justification in close relation and in this order, for instance Case 274/87, Commission v Federal Republic of Germany, [1989], paras. 6 ff, 12 ff.. See also AG Jacobs in Case C-379/98, PreussenElectra, [2001], para. 226, inviting the Court to dispose of the distinction between distinctly and indistinctly applicable measures, and just consider the mandatory requirements as additional grounds of justification for any type of measure. See also Oliver P., (1999); Barnard C., (2001).

1911 Case C-519/04 P, Meca-Medina II, [2006], para. 26. And actually also in Joined Cases C-267 and 268/91, Kecke and Mithouard, [1993], paras. 12-17, with its distinction between tules either stipulating product tequirements or selling arrangements.

1912 In the field of the free movement provisions of the Treaty legal scholars call the mandatory requirement justification also 'rule of reason', thereby helping to create confusion about that notion - at least in the field of EC competition law. It must not be mistaken for the equally so-called 'rule of reason' under US anti-trust law. The two rules 'of reason' (one of US law, the other of EC free movement law) must clearly be distinguished from each other since they are referring to two distinct concepts. Monti G., (2002), $1086 \mathrm{ff}$., therefore proposes to stress the difference by using - for the mandatory requirements doctrine - the term European-style rule of reason'. See already Chapter 4.II.1.2.1., and for instance Wils G., (1990); Bellamy \& Child / Rose V., (1993), point 2-062 ff.; Waelbroeck M. / Frignani A. (Eds.), (1997), para. 172.

1913 Compare in this respect the fact that the Court at para. 122 of the judgment in Wouters stressed - in the event of the NOvA rules being restrictive of the right of establishment and/or the freedom to provide services - that these restrictions were equally justified for the same reasons set out with regard to assessment made under the 
Medina II might be rationalised on a meta-level as an attempt to achieve concurrence, or synchronism, in the approach towards justifying restrictions of both the fundamental freedoms under Articles 30, 46, $55 \mathrm{EC}$, the Cassis de Dijon type of rule of mandatory requirements and the competition rules. Such an approach would result in an overarching exemption system. It must, however, be doubted whether the Court intended the Wouters proviso to be of a broader application, seen its contra legem birth and the tailor-made reference to integrity and experience of (legal) professionals. Probably the Court will have a hard time distinguishing Wouters from other cases to come. ${ }^{1914}$

Under the mandatory requirements doctrine the Court recognised that certain restrictions may be justified as necessary in order to satisfy overriding reasons in the public interest or general interest. ${ }^{1915}$ The list of imperative requirements accepted by the Court is not exhaustive. The public interest grounds recognised in the field of the fundamental freedoms cover, for instance, professional rules intended to protect the recipients of a service ${ }^{1916}$, protection of intellectual property ${ }^{1917}$, (the tight to take collective action for) protection of workers ${ }^{1918}$, consumer protection ${ }^{1919}$, road safety ${ }^{1920}$, conservation of the national historic and artistic heritage ${ }^{1921}$, turning to account the archaeological, historical, and artistic heritage of a country and the widest possible dissemination of knowledge of the artistic and cultural heritage of a country ${ }^{1922}$, and cultural policy ${ }^{1923}$, reputation of the domestic financial services market and ptotecting the investing public ${ }^{1924}$, social ills of gambling ${ }^{1925}$, the coherence of a scheme of taxation ${ }^{1026}$, the effectiveness of fiscal

compctition rules (i.e. the Wouters proviso in paras. 97 to 109 of the judgment). See also Gilliams H., (2006).

1914 In Joined Cases T-49 to 51/02, Brasserie national v Commsission, [2005], paras. $84 \mathrm{ff}$., the CFI excluded the application of a Cassis de Dijon and Wouters proviso, basically because the measures at stake had the object of restricting competition (allocation of clients). That is, however, not 'in tune' with Wouters as that case also concerned a restriction by object. See also Joined Cases T-217/03 and T-245/03, FNCBV, [2006], para. 89: "Furthermore, it must be noted that the reference to the judgment in Wouters and Others, is irrelevant here because the factual circumstances and the legal problems raised by that case, which concerned the regulation by a professional association of the practice of the profession of lawyer and its organisation, are not comparable with those of the present casc." 'The interesting, or intriguing, bit in this quote is the CFI's emphasis on the legal problems raised by Wouters that should have warranted the extra-statutory exemption from Article 81(1) EC. Intriguing it is because the ECJ in Wouters did not broach the issue of legal uncertainty, regulatory vacuum or legal stability. See also Forrester I.S., (2006), 18.

1915 See Case C-3/95, Reisebüro Breede v Gerd Sandker, [1996], para. 28.

1916 Joined Cases 110 and 111/78, van Wesemael, [1979], para. 28.

1917 Case 62/79, Coditel, [1980] ECR 881.

1918 Case 279/80, Webb, [1981], para. 19; Case C-438/05, Finnish Seamen's Union v Viking Line, [2007], para. 77.

1919 Case 220/83, Co-insurance (France), [1 980], para.20; Case 252/83, Co-insurance (Denmark), [1980], para. 20; Case 205/84, Insurance (Germany), [1986], para. 30; Case 206/84, Co-insurance (Ireland), [1986], para. 20; Case C-180/89, Commission v Italian Republic (tourist guides), [1991], para. 20.

${ }_{1220}$ Case C-55/93, Van Schaik, [1994], para. 19; Case C-314/98, Snellers Auto's, [2000], para. 55; and Case C-451/99 Cura Anlagen [2002] ECR I-3193, paragraph 59.

1921 Case C-180/89, Commission v Italian Republic (tourist guides), [1991], para. 20.

${ }_{1922}$ Case C-154/89, Commission v French Republic, [1991], para. 17; Case C-198/89, Commission v Hellenic Republic, [1991], para. 21.

1923 Case C-288/89, Gouda, [1991], paras. 22-23; Case C-353/89, Commission v Kingdom of The Netherlands, [1991]; Case C-23/93, TV10 SA v Commissariaat voor de Media, [1994].

1924 Case Case C-384/93, Alpine Investment, [1995], para. 44.

1925 Case C-275/92, Scbindler, [1994], para. 60. See also Case C-124/97, Läärä, [1999].

1926 Case C-204/90, Bacbmann v Belgian State, [1992]; Case C-300/90, Commission v Kingdom of Belgium, [1992]; Case C-294/97, Eurowings, [1999], para. 19. However, this has been marginalised in more recent case law: see e.g. Case C-264/96, ICI, [1998], para. 29, possibly being confined to the sphere of pensions and insurance policies. 
supervision ${ }^{1927}$, preserving the financial balance of a social security schem $\mathrm{e}^{1928}$, preventing wastage of financial, technical and human resources ${ }^{1929}$, guaranteeing the quality of skilled trade wotk and protecting those who have commissioned such work ${ }^{1930}$, maintenance of pluralism in the press ${ }^{1931}$, the protection of creditors and the proper administration of justice, ${ }^{1932}$ etc. Despite the extensiveness of the justification grounds recognised, the Court has not extended the list indefinitely and is particularly sceptical of national justifications which hint at economic protectionism. ${ }^{1933}$

If the Wouters proviso had been famous for a unique scrutiny in respect of the Treaty's free movement rules, the regulatory objectives recognised therein would easily rank among the justification grounds of overriding reasons in the public interest. ${ }^{1934}$ The ensuing question is whether such a recognition leads to qualify the Wouters proviso as a mechanism to protect public interest concerns that are outside Article 81 (3) EC. ${ }^{1935}$ A general presumption to this effect would, however, neglect that also competition protects a public interest, albeit of a specific nature. Put differently the question is whether self-regulatory objectives tepresent economically beneficial effects, possibly of a non-market nature.

\section{Professional values safeguarding (economic) public interests}

Gyselen contests that the Wouters proviso concerns public interest considerations. ${ }^{1936}$ In qualifying the Wouters proviso as volte-face he states that such a finding would be in conflict with paragraph 62 of the judgment where the Court explicitly addressed the issue of public interest criteria. In that earlier section of the judgment the question had been whether the NOvA had been required by law to exercise its regulatory powers in the public interest, i.e. independently from the interests of the members of the regulated profession. If it had, the NOvA would not have qualified as an association of undertakings. ${ }^{1937}$

The point made by Gyselen is a crucial one as it indirectly confirms that the in tegrity and experience guarantees referred to in the Wouters proviso can be understood to represent economic interests, albeit of a non-market nature. Both views, i.e. by Gyselen and the revers view that the Wouters proviso embraces public interest objectives, are conceivable but differ

1927 Case C-55/98, Vestergaard, [1999], para. 23.

${ }^{1928}$ Case C-158/96, Kobll, [1998], para. 41.

1929 Case C-157/99, Geraets-Smits and Peerbooms, [2001], paras. 78-79.

1930 Case C-58/98, Josef Corsten, [2000], para. 38.

1931 Case C-368/95, Familiapress, [1997], para. 18.

1932 Case C-3/95, Reisebüro Broede $\nu$ Gerd Sandker, [1996], paras. 36 and 38.

1933 See Barnard C., (2004), 243.

1034 In fact para. 122 of the judgment in Wouters emphasises that - on the assumption that a prohibition of any multi-disciplinary partnerships between members of the Bar and accountants constitutes a restriction on the right of establishment and/ or the freedom to provide services - that restriction would in any event appear to be justified for the reasons set out in the Wouters proviso.

1935 See also Vickers J. / (Chairman of the Office of Fair Trading), (2004), 5 f.: "Defenders of anti-competitive restrictions often say that liberalisation of regulation, though it would lead to more competition, would be detrimental to the 'wider public interest'. Since competition is but a means to ends, defences on these lines cannot and should not be dismissed out of hand. But they should not hold sway unless certain conditions are shown to hold."

${ }^{1936}$ Gyselen L., (2006), 20. See also Gilliams H., (2006), 27, who claims that the judgment creates a paradox where the Court would have hold that, on the one hand, the professional rules of conduct cannot be said to pursue goals that have been sufficiently clearly articulated by the public authorities, and, on the other, they can escape the application of competition rules if it appears that they pursue public interest goals.

${ }^{1937}$ For details see Chapter 4.I.2. 
from the tripartite distinction presented in this book. ${ }^{1938}$ The two views can, however, be reconciled where the distinction is made between competition specific (or economic) public interest objectives and non-economic public interest objectives.

One may in fact not assume that any public interest consideration would be outside the scope of Article 81(3) EC or the Wouters proviso (paragraphs $97-110$ of the judgment). ${ }^{1939}$ Put differently, to read the public interest criteria at paragtaph 62 of the Wouters judgment as tepresenting a wider, i.e. non-economic public interest concern, opens the possibility to (re)address a more specific public interest, namely in respect of a justification under competition law. Nothing prevents to bring the matter within Article 81(3)-[1] EC where the justification is based on economic public interest concerns. Conversely, where one would have to read the public interest defence as one that refers to non-economic objectives with beneficial effects for democratic values, one leaves the specific policy area of competition law and moves towards Article 86(2) EC, which - despite being included in the Treaty's chapter on competition rules - is a general justification rule applicable to all Treaty provisions. Non-economic concerns cannot replace efficiency considerations within the framework of Article 81(3) EC. Yet non-market objectives can be combined with them where they yield economically beneficial effects. Especially public policy goals set out in the Treaty make candidates for economic public interest objectives. ${ }^{1940}$

This conclusion is still disputed in legal writing.

"The first condition is the most controversial becausc its scope is uncertain: does it mean that an agreement is exempted because it yields economic efficiency (the narrow view), or does it also mean that an agreement may be excmpted if it makes a contribution to other matters of interest to the EC (the wide view) ${ }^{1941}$ [...] Neither the Decisions of the Commission, nor the Courts' judgments, have provided an unambiguous answer to this question, although most commentators have suggested that nom-economic factors play some role in influencing the decision to exempt an agreement, and others have also insisted that this is correct as a matter of law."1942

In fact, the controversial discussion of the scope of Article 81(3)-[1] EC can be attributed to the simple fact that scholars often do not distinguish finely between non-market objectives with economic benefits and non-economic objectives. Instead the words 'economic' and 'noneconomic' are used actoss the board as if they were the only valid facets in defining the scope of Article 81(3) EC. As illustrated before in the excursus into economic theory there is no such thing as the economic approach in competition law. Probably the obsession with seeing economic interests and public interests as mutually exclusive ${ }^{1943}$ is the result of lawyers having looked into economic literature where 'economic', 'commercial', 'market' interests seem to describe similar and above all measurable phenomena. Conversely, a legal or sociopolitical concept of 'public interest' may be characterised by reference to non-measurable values. This book maintains, however, that even non-quantifiable interests can have

\footnotetext{
${ }^{1938}$ As argued above on p. 382 the concept of public interest is indefinite, "an empty vessel, to be filled at different times with different content" (Feintuck).

1939 See above p. 382.

1940 For details see above section I.2.3.

1941 For detail on the differences between the narrow and wide view, see Whish R, (2003), 151-156.

1942 G.Monti in Chalmers D., et al., (2006), 1006 f. (emphasis added), with reference to Bouterse R.B., (1994), chapters 1-4; and Sauter W., (1997), chapter 4; Wesseling R., (2000), 105-112.

${ }^{1943}$ See for instance Cooke J.D., (2006), 7: "On balance, however, it seems highly unlikely that Article 81(3) EC could have availed the Netherlands Bar in the circumstances of the case [in Wouters]. The criteria of paragraph (3) remained the criteria of competition while the European Court of Justice dis-applied paragraph (1) by reference to the totally distinct criterion of a public intcrest objective" (emphasis added).
} 
perceivable economic effects. ${ }^{1944}$ Moreover, accepting non-market objectives with concrete economic implications to come within the scope of Article 81(3)-[1] EC reinforces the internal market paradigm of $\mathrm{EC}$ law. The decisions in Métropole and CECED allowing a wide application of Article 81(3)-[1] EC do then not surprise anymore. ${ }^{1945}$ This book therefore concludes that certain limitations flowing from professional regulation can - at least in theory - be justified within the framework of Article $81 \mathrm{EC}$ even by reference to general interest objectives.

Moreover, recognising the legitimacy of invoking economic public or general interest objectives as a justification ground in competition law to a large extent allows coherence with the well established practice of EC law in respect of the free movement rights. In contemplating the above list of justifications recognised in the case law as overriding teasons in the general interest one may observe that also the mandatory requirements doctrine can be interpreted to cover also economic public interests. Put differently, the doctrine can be regarded as protecting non-market interests, even where they have beneficial effects in economic terms. It is, however, not necessary in the context of the free movement law to distinguish between economic and non-economic public interests. Competition law, on the other hand, needs this refinement due to the wording of Article 81(3) EC and the context of translating a very specific public policy choice. This distinction leaves the coherence between the free movement rights and competition unchallenged. In particular restrictions of either free trade or free competition cannot be justified by reference to 'purely' economic interests. ${ }^{1946}$

\section{Comparing the Wouters proviso and Atticle 81(3)-[1] EC}

When looking more concretely at the question of whether the specific objectives of the Wouters proviso may constitute efficiencies within the meaning of Atticle 81(3)-[1] EC, incumbent views can be challenged. Gilliams, who represented Mr Wouters before the ECJ, argues that the facts of the case would not fit Article 81(3) EC, even if that provision had already been directly applicable at the time the Court handed down its judgment (i.e. before Regulation $1 / 2003$ became applicable). ${ }^{1947}$ In his opinion the professional rules prohibiting multi-disciplinary partnerships do not produce efficiency gains. He argues that to ensure the proper practice of the profession is intended to preclude 'unfair' competition from large

1944 See de Witte B., (2006), 62.

1945 Para. 118 of the judgment in Métropole, see above the text with note 1851; and Commission Decision CECED, (2000), paras. $47 \mathrm{ff}$. In this case an association representing manufactures of domestic appliances had decided to phase out from the market certain types of washing machines with low energy efficiency. In granting an excmption under Article 81(3) EC the Commission took account of individual economic benefits but also collective environmental benefits that arise from the development and distribution of energy efficient washing machines.

1946 Under both policy fields 'purely' economic reasons are excluded as a basis to justify restrictive measures, see above the text with note 1793. For the free movement tights, see e.g. Case C-120/95, Decker, [1998], para. 39; Case C-322/01, DocMorris I, [2003], para. 122; Case C-109/04, Kranemamt, [2005], para. 34: "According to settled case-law, aims of a purely economic nature cannot constitute pressing reasons of public interest justifying a restriction of a fundamental freedom guaranteed by the Treaty" (emphasis added). Likewise the justification grounds recognised under Article 81(3)-[1] EC must refer to objective benefits, i.e. irrespective of subjective economic interests of the undertakings involved in an agreement or decision, see above the text with note 1784 . ${ }^{1947}$ Gilliams H., (2006), 23. Gilliams concludes that a lack of efficiencies would have decided the matter in favour of finding the solution in Wouters within the fabric of Article 81(1) EC rather than to leave the issue for the Commission to take a decision under Article 81(3) EC. 
accounting firms. Gilliams refers to the Commission Guidelines, which emphasise that "Any claim that restrictive agreements ate justified because they aim at ensuring fair conditions of competition on the market is by nature unfounded and must be discarded. The purpose of Article 81 is to protect effective competition by ensuring that markets remain open and competitive. The protection of fair conditions of competition is a task for the legislator in compliance with Community law obligations and not for undertakings to regulate themselves" ${ }^{1948}$ The objection by Gilliams is obviously prompted by the - welcomed - idea that regulatory competences should be independent from partial interests and excrcised in an unbiased and objective manner. Hence, if the protection of the consumer and the sound administration of justice were to ensure fair conditions of competition, the prohibition of multi-disciplinary partnerships in Wouters could indeed not be exempted under Article 81(3)-[1] EC.

This assessment can, however, not be upheld for the protection of the consumer. It is a market objective safeguarding concerns of the demand side of the market ${ }^{1949}$ and it is therefore properly included in the second condition of Article 81(3) EC. ${ }^{1950}$ In respect of the objective to protect the sound administration of justice the assessment requires a more thorough scrutiny. First of all, one has to realise that protection of fair conditions of competition reflects market objectives. Its efficiencies are a concern shated by both the supply and demand side of the market. However, while the protection of fair conditions of competition as such could fit the requirement of Article 81(3)-[1] EC, it is rightly excluded thereof. It is the immanent task of the legislator as an independent tegulator to ensure such conditions and to establish and maintain a level playing field. ${ }^{1951}$ In accotdance with the tripartite categorisation made earlier this value judgment to move the 'fair competition' objective to the category of non-economic public interests leads to the conclusion that it is a democratic value to have genuine State authorities, i.e. [truly] objective bodies, watch the game of fair competition. This value judgment therefore has a constitutional quality.

Conversely, in respect of the objective of protecting the sound administration of justice the assumption here is that it represents a non-market concern, since it is not primarily subjected to a strict economic cost/ benefit analysis defining market interests. The question then is whether it is an economic non-market objective, i.e. one that leads to cost efficiencies and/ or ensures that (the quality of) professional services ate better tailored to consumer needs. In a given case, one would obviously need to establish at this juncture the content of the sound administration of justice in concrete terms, the risk otherwise being that it can be filled at different times with different content like the concept of public interest. ${ }^{1952}$ The Court in Wouters did not specify the (Dutch) content of the sound administration of justice and its particular value for the economy and/ or society at large, assuming that the lawyers involved in the case (i.e. all actors, including the judges) would seamlessly agree on its contents. Instead it swiftly associated the sound administration of justice with the experience and integrity of the professional groups concerned.

The implementation of a system of justice soundly administered by both public

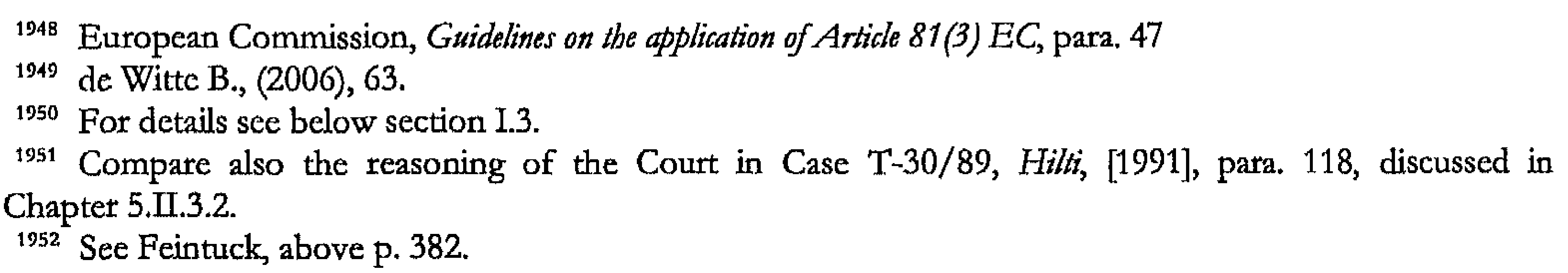


institutions and private actors (like lawyers but also for instance bailiffs ${ }^{1953}$ ) is certainly intended to reduce costs in the realisation and enforcement of claims and rights. While the building of experience of lawyers does not constitute an absolute guarantee for the wellfunctioning of a system of justice ${ }^{1954}$, it increases the likelihood for better quality services. As to the integrity of lawyers the regulatory approach in the Netherlands distinguishes three professional duties, namely to act for clients in complete independence and their sole interest, to avoid conflicts of interest and to observe strict professional secrecy. ${ }^{1955}$ To interpret the duty to act in the sole interest of a client as a public interest concern is almost ridiculed by the fact that the professional activity in the first place is an economic one. ${ }^{1956}$ Conversely, professional secrecy and the duty to avoid conflicts of interest cleatly yield economically beneficial effects for the administration of justice. All actors involved in the (implementation of) legal relations, e.g. clients, business partners, law enforcers, judges, bailiffs, etc., depend on reliable information. Business and legal transactions ate destabilised if the actors have to assume that a professional does not avoid conflicts of interest in the service provision. Destabilisation means a higher risk and thus extra efforts in safeguarding the actors' interests. Hence, conflicting interests come at an economic cost. Also professional secrecy has a particular value, especially for clients. Where they cannot confide in the professional at the exclusion of third parties they will have to provide for the risk that other parties may obtain the information they share with the professional. Some activities or transactions may even not take place for fear of the secrecy being violated. Hence, also nonrespect for professional secrecy comes at a cost, just like conflicting interests.

From this perspective the objective of a sound administration of justice almost qualifies as a market interest; it certainly tepresents an economic public interest. ${ }^{1957}$ This conclusion does not exclude that certain aspects of a system of justice safeguard non-economic concerns. For instance, while the guarantee of access to justice has important economic benefits in the tealisation of business and legal relations, one might argue contratiwise for the objective to safeguard equal access to justice. The example of equality in having access to justice may indicate that a system of justice also has a function relating to democratic

${ }^{1953}$ Current reform projects aim to privatise the activities of bailiffs. In Germany a bill has been introduced with the Bundesrat (upper house), Entunurf eines Gesetzes zur Reform des Gericbtsvoll ziebervesens of 11.05.2007. In preparation of accession Bulgaria launched a similar reform, see Ivanova S. / (Germany Trade and Invest),"Reform der Recbtsdurchsetzung in Bulgarien unter EU-Druck", (2006).

${ }^{1954}$ As has been indicated in Chapter 4.II. one may not assume that, only because a lawyer is officially qualified, she provides good quality services matching best the requirements of clients in terms of quality and price. The level of her experience will correspond to the high or low quality of the services she provided in the past.

1955 See para. 100 of the judgment in Wouters. It is necessary to note, however, that the regulatory approach in the Netherlands is pretty much determined by the rules adopted by the Dutch bar association. First of all, Article 28 of the Advocatenwetmerely stipulates that the NOvA "may adopt regulations in the interest of the proper practice of the profession" and furthermore "shall adopt the necessary regulations concerning the administration and organisation of the Bar" (emphasis added). I cannot read into this indefinite wording a 'proper' conceptualisation of the 'sound administration of justice' as apparently the ECJ has done. Secondly, all more detailed professional duties discussed by the Court in Wouters are drawn from the rules adopted by the NOvA, see paras. 3-23 of the judgment.

1956 For details see Chapter 3.I.

1957 Parties usually act on the assumption that they can conduct their affairs without the intervention of the judge; one thus can argue that the driving force to establish and provide a system of justice is not based on the economic cost/ benefit analysis and thus represents a non-market objective. Conversely, one can also argue that a sound system of justice also represents market interests. For instance certain transactions cannot be managed without the involvement of public registers (e.g. property transactions or transactions under company law); from the perspective of the parties involved this part of the system of justice is subjected to a cost/ benefit analysis. 
principles of social justice. However, once equal access to justice is safeguarded the administration thereof can be considered to belong to the economic public interest. The conclusion hete therefore is that the professional rules at stake in Wouters would perfectly have been eligible for the application of Article 81(3) EC, if only the provision had already have direct effect at the material time.

\subsubsection{Prevailing perceptions of a profession}

In Wouters the Court established that the aims legitimately pursued by restrictive professional regulation have to be ascertained with regard to the prevailing perceptions in the Member State concerned. ${ }^{1958}$ In other words, the Court allowed for the consideration of objectives established domestically. This is remarkable since Article $81 \mathrm{EC}$ is concerned with the competition policy concerns of the Community and the common market. In the curtent comparison between the Wouters proviso and Article 81(3)-[1] EC atises therefore the question whether the reference to domestic public interests would cxclude the application of Article 81(3) EC to the facts of Wouters - so far affirmed in this book. The wording of Article 81(3) EC does not indicate a direct answer, neither in the affirmative nor in the negative. A first indication may be found by reference to the field of free movement law as it is the second foothold of the basic binomial structure of Community economic constitutional law. ${ }^{1959}$ There, the motives for restrictive (State) measures necessarily reflect domestic policy choices. In the field of free movement express provisions of the Treaty recognise domestic interests, referring in particular to public policy and public security (see Articles 30,39(3), 46(1), 55, 58(1)(b) EC). Consequently - and in the absence of Community harmonisation in a particular policy field - each Member State is in principle free to regulate, for instance, the exercise of the (liberal) professions. ${ }^{1960}$ Hence, the recognition of domestically determined interests pursued by a measure that prima facie restricts a free movement right is the result of the disparities of the laws of the Member States.

\section{Domestic policy choices}

Two antithetic assumptions can be drawn from the foregoing. On the one hand, the express reference to public policy and public security in the free movement provisions may induce to interpret the lack thereof in Article $81 \mathrm{EC}$ as an indication for denying the recognition of domestic interests in respect of Article 81(3) EC. On the other hand, the fact that competition law and free movement law are both togethet establishing the basic binomial structure of Community economic constitutional law may lead to the conclusion that their rapprochement ${ }^{1961}$ results in accepting domestic public interests also within the

1958 Para. 105 of the judgment in Wouters.

1959 See Baquero Cruz J., (2002), 2 f.

${ }^{1960}$ Conversely, no mandatory requirement can be invoked in the field of the free movement rights if a Community-wide harmonisation has taken place. Community harmonisation thereby limits the Member States' compctence to justify restrictions of the fundamental freedoms.

1961 Baquero Cruz J., (2002), 3, rightly points out that "a division of the economic constitutional law along private/ public lines [...] no longer corresponds to the actual structure of the economy, but to an ideal division of the actors and their responsibilities regarding the economic objectives of the Treaty. Community law has had to be adapted by means of judge-made law and legislation to contemporary economic realities that do not squarely fit the private/ public divide (the mixed economy, State involvement in the economy, privatisation, private regulation, etc.). Thus, the European Court of Justicc has extended the scope of the application of free movement 
framework of Article 81(3) EC.

To begin with, Article 81(3) EC is concerned with the Community interest to ensure that competition in the internal market is not distorted by undertakings. Following an overall assessment it is a tool to achieve public policy goals that are set out in the EC Treaty. ${ }^{1962}$ The policy goals thus taken aboard are generally speaking those of the Community rather than the Member States. According to some Article 81(3) EC can therefore not be used to justify domestic interests - unlike the derogations in the field of free movement.

"Granted, in some cases by safeguarding the Community interest the Commission is also acting to benefit particular Member States (e.g. in granting exemption to an agreement which leads to improved employment prospects in Portugal, the Portuguese economy also benefits), but this is a coincidence and not the aim of Article 81(3). National interests cannot justify an exemption under Article 81(3): where a Member State has the right to request that national interests justify the non-application of the full force of $E C$ law, the Treaty has made express provisions (e.g. Articles 30 and 86(2) EC) and the range of domestic policy considerations are carefully circumscribed." 1963

Giorgio Monti therefore argues that "absent an express renvo?" in Article 81 EC national interests cannot be taken into account in the balancing process of Article 81(3) EC.

However, this principled stance risks to abstract away from the fact that a Member State is a substantial part of the Community and it is unfortunate to exclude from the outset conceivable efficiencies occurring in a substantial part of the Community's territory. ${ }^{1964}$ In particulat it is conceivable that the context in which the decision of the association of undertakings applies is 'homeward bound', e.g. the efficiencies are restricted to occur in the circumstances of a particular domestic market. Ultimately Article 81(3)-[1] EC guatantees that efficiencies, even of a domestic origin, are determined objectively. Moreover, the case of professional self-regulation under Article 81(3) EC is not about State measures stipulating values of the proper professional practice but about a decision taken by an association of undertakings, which influences the conditions of the market on which its members operate. Where this market turns out to be defined domestically the economic public interest objectives pursued by professional self-regulation may just as well be domestically determined. Therefore, while restrictions of competition are not necessarily defined by domestic policy choices, the facts of a given case may prove that the economic public interest objectives pursued by an association's decision are very much defined by the domestic context in which the self-regulatory professional rules apply and yield efficiencies. ${ }^{1965}$ Thus,

rules to certain forms of private action, and the application of the principles enshrined in the competition rules to certain forms of State action. It is in this body of case law, which is neither coherent nor settled, that one may find relevant data about the interaction between competition and free movement and, more generally, about the economic bent of the constitutional law of the Community."

${ }^{1062}$ Sec European Commission, Guidelines on the application of Article 81(3) EC, para. 42: "Goals pursued by other Treaty provisions can be taken into account to the extent that they can be subsumed under the four conditions of Article 81(3)." This statement, the Commission notes, can be deferred implicitly from Case T-17/93, Matra, [1994], para. 139, and Case 26/76, Metro I, [1977], para. 43.

1963 Monti G., (2002), 1083 (emphasis in the original). He refers generally to Weatherill S. / Beaumont, (1999), ch. 16 .

1964 Moreover, the question can be linked to the observation that with the extensive interpretation of the scope of the first paragraph of Article $81 \mathrm{EC}$ also the interpretation of the third paragraph may be extended. See Whish $\mathrm{R}$, (2003), $152 \mathrm{ff}$., who underlines that it is necessary to come to a resolution between the broad and the narrow approach because with Article 81(3) EC directly applicable the NCAs and the national courts must know the limits of their discretion under 81(3). See also Lugard P. / Hancher L., (2004); Bourgeois J.H.J. / Bocken J., (2005).

1965 Also AG Jacobs indicates the necessity of balancing competition law with interests expressed in domestic professional regulation, AG Jacobs in Joined Cases C-180-184/98, Pavlov, [2000], paras. 88-92, esp. 92. He takes 
their pursuit do not need to conflict with the interest of the Community to achieve procompetitive efficiencies in (a substantial part of) the internal market.

\section{Reasonably indispensable}

The ensuing question concerns the yardstick on the basis of which one needs to decide whether a particular professional self-regulatory rule or code is indispensable to achieve the (domestically) determined efficiencies of economic public interest. The Commission Guidelines distinguish the indispensability test of Article 81(3)-[3] EC as a two-fold test, according to which both the restrictive decision as such and the individual restrictions that flow from the decision must be reasonably necessary for the attainment of the efficiencies. ${ }^{1966}$ Applied to the facts of Wouters a distinction has thus to be drawn between, first, the concept of prohibiting multi-disciplinary partnerships and, second, the individual rules intended to implement that concept (e.g. the prohibition that the professionals involved practice their respective ptofessions for the joint account and at the joint risk or that they share control or financial responsibility; prohibition of joint activity with accountants, but not with other professional groups, e.g. notaries, tax accountants and patent agents).

Following the Commission Guidelines the first test contained in the thitd condition of Article 81(3) EC requites that the efficiencies of a sound administration of justice (i.e. in casu through the professional duties to avoid conflicts of interest and to observe strict professional secrecy) be specific to the prohibition of multi-disciplinary partnerships in the sense that there are no other economically practicable and less restrictive means of achieving the efficiencies. In making this latter assessment account has to be taken of the market conditions and business realities that face the parties governed by the decision of the association. This does, however, not mean that the judgment of the professional association

up the cudgels for the regulatory autonomy of the professions, while stressing the challenge for every competition law system to prevent abuses of regulatory powers. See also Case C-360/92 P, The Publishers Association v Commission (no.3), [1995], where the ECJ requested that the Commission takes note of the policy reasons advanced by the English courts to allow resale price maintenance. Even G.Monti (in his note 116) states that this reference might indeed offer some indirect support for using national interests to justify a restriction of competition, but that the ECJ did not address this point fully. In Case C-360/92 P, The Publishers Association v Commission (no.3), [1995], para. 19, the EC] had held: "The [RPC] held with regard to the agreement concluded between [the parties] that (1) the abolition of the NBA [Net Book Agreement] would deprive the public of special benefits or advantages because it would entail the raising of prices, the reduction of stockholding book shops and a decline in the number and variety of published titles, (ii) the public would not suffer any appreciable harm from the maintenance of the NBA as compared with the disadvantages which would arise from its abolition, and (iii) the NBA was, accordingly, not contrary to the public interest." See also AG Lenz in Case C-360/92 P, The Publishers Association v Commission (no. 3), [1995], para. 60: "As the Booksellers Association has correctly stated, a duty to take [cultural] aspects into account already followed from the case-law of the Court of Justice. As a result of the Treaty on European Union, that duty is now expressly mentioned in the EC Treaty (Article [151(4) EC])." Article 151(4) EC on cultural policy is a 'cross-sectional clause' and in view of the lack of true lcgislative Community competence the article seems to imply a reference to national cultural policy, Schmid, (2000), 164. See also Bouterse R.B., (1994), 120, and her chapters 4 and 7.

1966 European Commission, Guidelines on the application of Article 81(3) EC, paras. $73 \mathrm{ff}$. "In the context of the third condition of Article 81(3) the decisive factor is whether or not the restrictive agreement and individual restrictions make it possible to perform the activity in question more efficiently than would likely have been the case in the absence of the agreement or the restriction concerned. The question is not whether in the absence of the restriction the agreement would not have been concluded [cf. ancillary restraints], but whether more efficiencies are produced with the agreement or restriction than in the absence of the agreement or restriction." 
in respect of these business conditions will be second guessed. ${ }^{1967}$ According to the Commission's guidelines intervention will only be required "where it is reasonably clear that there are realistic and attainable alternatives. The parties must only explain and demonstrate why such seemingly realistic and significantly less restrictive alternatives to the agreement would be significantly less efficient." In accordance with the second test contained in the third condition of Article 81(3) EC an association of undertakings will have to substantiate the indispensability of both the nature of the individual restriction and its intensity ${ }^{1968}$ To answer the initial question on the applicability of Article 81(3) EC to the facts of Wouters, the following will compare the standard of indispensability with the yardstick applied in the Wouters proviso.

\section{Wouters: reasonableness versus strict proportionality}

In Wouters the Court finally held that the rules at stake were "necessary for the proper practice of the profession" and did not go beyond what is necessary to ensure that practice. ${ }^{1969}$ Accordingly, the Wouters proviso seems to apply a strict proportionality test, according to which a measure must be necessary to achieve the aim pursued. This means in particular that no less restrictive means (equally effective) may conceivably have been available to achievc the legitimate objective; if there are, the measure is not proportionate. On the basis of its phrasing the Wouters proviso thus seems to go further than the 'reasonable indispensability' test under Article 81(3) EC. The question here is which standard of legitimacy testing the Court in Wouters effectively applied in the end.

Even before teverting to what is here called the Wouters proviso the Court had seized the opportunity to delve into a proportionality verification. Alteady in respect of the ancillary restraints argument raised by the government of Luxemburg had the judgment addressed the point of proportionality. The ancillary restraints doctrine evaluates considerations of a commercial character and therefore is of the exclusive competence of (Community) competition law. The ECJ thus rightly assumes the competence to conduct a strict proportionality assessment in light of the facts of a case. This means that the Court undertakes to decide whether a restrictive measure (such as the ones at stake in the national proceedings) is suitable and necessary for the attainment of the primary commercial aim (pursued with the overall agreement or decision rather than with a particulat restriction), and whether there are no less restrictive means for its attainment. Paras. 91 to 94 of the judgment in Wouters are a clear application hereof. While the Court accepted that an absolute ban of multi-disciplinary partnerships may be suitable and necessary to maintain a high number of service providers on the legal market, it emphasised that there are clearly less restrictive means than an outright ban to achieve the said competition aim. The Court suggested that, for instance, a limited prohibition defined by the respective size of the firms of lawyers and accountants concerned would have been equally suitable to protect the objective of preserving a sufficient degree of competition on the market in legal services.

1967 See already above section 1.2.4. - Consider also the following. By adding "as it is organised in the Member State concerned" the Court in Wouters (at para. 107) actually applied a similar idea as in Article 81(3)-[3] EC that can be understood to parallel the concern not-to-second-guess 'business judgments', which are necessarily made on the basis of imperfect information; enforcement agencies are not often well-placed to second guess such decisions, so that a certain margin of error is considered justified.

${ }^{1968}$ See para. 78 of the Guidelines.

1969 Paras. 107 and 109 of the judgment in Wouters. 
Conversely, the second part of the judgment (that is the Wouters proviso, which starts with para. 97) turns to assess a distinct objective, namely the pursuit of a public interest to protect the sound administration of justice. ${ }^{1970}$ The Wouters proviso tested the means to achieve this regulatory objective for its necessity but not - at least not explicitly - for its suitability or appropriateness. In particular, the Wouters proviso has conceded the NOvA discretion with regatd to the appropriateness of the prohibition of multi-disciplinary partnerships and the appreciation of the objectives pursued. In other words the Court refrained from substituting the association's assessment with its own judgment on the suitability or appropriateness of the prohibition of multi-disciplinary partnerships to achieve a sound administration of justice. Ultimately, the extent of control exercised has been limited by the Court to assessing the reasonableness of the assessment that the NOvA had conducted in respect of whether the regulatory objectives (proper practice, sound administration of justice) could not have been attained by less restrictive means. ${ }^{1971}$ The concepts of integrity and experience (as core values to the proper practice of the profession in the Netherlands) have been used as mere stepping stones in this.

The conclusion at this juncture therefore is that just as in Article 81(3)-[3] EC the Court evaluated whether the choices made by the self-regulatory body have been ' reasonably necessary'. This entails that the Court in Wouters was willing to assess only the legitimacy of the objectives pursued in the light of the prevailing national perceptions, but leaves a great discretion to the association in considering whether the objectives could reasonably have been protected by less restrictive means. ${ }^{1972}$ Puzzling in this respect is the forcefulness with which the Court in Wouters established the 'reasonableness' of the assumptions made by the NOvA in adopting the professional regulations in question. Despite the fact that the Wouters case came before the Court as a teference for a preliminary ruling and that the Court had to give an interpretation of EC law merely in light of the facts of the case, it actually anticipated the decision of the case on the merits. The Court unmistakably formulated that

"the 1993 Regulation ... does not infringe [Article 81(1) EC], since [the NOvA] could reasonably have considered that that regulation ... is necessary for the proper practice of the legal profession, as organised in the Member State concerned."1973

By using the word 'since' instead of 'where' the ECJ dropped its reserve as to the assessment of the facts of the case and went further than merely providing guidance to the Dutch Court. ${ }^{1974}$ Its formulation did not leave the national court any toom of manoeuver, first, to establish which are the prevailing perceptions in the Netherlands and, second, to scrutinise whether (the NOvA could reasonably have considered that) the prohibition of multidisciplinary partnership was necessary for the proper practice of the legal profession. ${ }^{1975}$ The ECJ thereby seems to assume that, first, the prevailing perceptions about the legal profession in the Netherlands were fully and correctly presented by the parties involved and/or, second,

1970 The Court also refers to the protection of the ultimate consumers. This objective is made explicit in Article 81(3)-[2] EC and will therefore be dealt with below in section I.3.

1971 See in particular paras. 107-109 of the judgment.

1972 See also Terry L.S., (2002), 889 ff.

1973 Para. 110 of the judgment in Wouters (emphasis added).

1974 See also Case C-79/01, Payroll Data Services and Others, [2002], para. 29: "Although, as regards the division of jurisdiction between the Community judicature and national courts, it is in principle for the national court to determine whether those conditions are fulfilled in the case pending before it, the Court, when giving a preliminary tuling, may, where appropriate, provide clarification designed to give the national court guidance in its interpretation", not ready-made solutions (emphasis added).

1975 Compare para. 105 of the judgment. 
itself had correctly grasped the prevailing perceptions in the Member State concerned.

In paragraphs 100 to 106 of the judgment the Court has made a general comparison between the different toles and duties of lawyets and statutory accountants in the Netherlands, finding that they are not of the same level and that therefore the NOvA regulation prohibiting multi-disciplinary partnerships with accountants could "reasonably be considered to be necessary in order to ensure the proper practice of the legal profession, as it is organised in [the Nethetlands]" ${ }^{1976}$ However, the Court could have distinguished stronger between statutory auditing and non-statutory auditing. ${ }^{1977}$ Only concerning the first type of auditing is an auditor not required to act independently of the public authorities and in the sole interest of her clients, and does she not benefit from a rule of professional secrecy as does a lawyer. Conversely, following a judgment of the Hoge Raad ${ }^{1978}$, an accountant cooperating with a lawyer not providing statutory audit benefits from the professional sectecy rule applicable to the lawyer for her communication exchanged with the lawyer on a specific case. This is obviously a derived, not a genuine protection of documents seized with the accountant.

Only once has the Court in Wouters alluded that the prohibition of multi-disciplinary partnerships between lawyers and accountants is justified only in respect of professional services that are related to transactions for which statutory auditing is carried out: "The Bar of the Netherlands was entitled to consider that members of the Bar might no longer be in a position to advise and represent their clients independently and in the observance of strict professional secrecy if they belonged to an organisation which is also responsible for producing an account of the financial results of the transactions in respect of which their services were called upon and for certifying those accounts." ${ }^{.1799}$ While this complex tefinement acknowledges that a prohibition of multi-disciplinary partnerships may not be absolute, the Court eventually dropped the qualification towards the end of the Wouters proviso (in paragraph 110) and in the second operative provision of the judgment. ${ }^{1980}$ In practical result the ECJ therewith expressed that the NOvA rules might even be justified if the accountants would not conduct statutory auditing. As Gilliams points out it appears that this rather deferential assessment of the NOvA rules has to do with the fact that the ECJ judges are lawyers and, by their nature, receptive to claims that restrictions are necessary to ensure the sound administration of justice. Moreover, he observes that there may well have existed more than just a temporal coincidence between the Court's consideration of the Wouters case and the demise of Arthur Andersen in the wake of the Enron debacle. ${ }^{1981} \mathrm{Be}$ it as it may, the conclusion drawn here is that the standard of review of the Wouters proviso mimics the

1976 Para. 107 of the judgment in Wouters.

1977 See also shortly below note 1981.

1978 Hoge Raad - "In behalf of my lawyer" [1994], HR, NJ 552.

1979 In para. 105 (emphasis added).

${ }^{1980}$ See above the text with note 1973, 2161.

${ }^{1981}$ Gilliams H., (2006), 34. See also Terry L.S., (2002), 881, who suggests that the Enron debacle does not necessarily be the death knell for multi-disciplinary partnerships in the US. To preserve an auditor's independence a regulator could for instance require that the audit firm may not offer significant consulting services to a client that it audits. While such a solution may take away much of the momentum for multi-disciplinary partnerships by the big accountancy firms, it may be a catalyst for dissolving opposition to multi-disciplinary partnerships and thus allow a development of 'small' multi-disciplinary partnerships available to "Main Street" clients. Such a rule of separating auditing and consulting would thus meet both the competition concerns clearly articulated in Wouters and the reservations of the Court (expressed in its Wouters proviso) to unrestrictedly allow multi-disciplinary partnerships. Allowing for 'small' or 'separated' multi-disciplinary partnerships would also reflect the original development of multi-disciplinary partnerships, which took off in Germany. See Terry L.S., (2000). 
indispensability test of Article 81(3)-[3] EC with its testing of reasonable necessity that the Commission applies in its guidelines on Article 81(3) EC. ${ }^{1982}$

Notwithstanding it is admitted that the Wouters proviso reads simultaneously as requiring a strict proportionality testing and applying a test of reasonableness. It is therefore not surprising that legal writers have sought to compare the Wouters proviso with the mandatory requirements doctrine. In fact, while the Wouters proviso finally applies a deferential standard to the self-regulatory professional rules, it uses formulations that recall the strict proportionality test generally applied in the field of the free movement rights. Accordingly, a restrictive measure must be suitable for securing the attainment of the objective it pursues and it must not go beyond what is necessary in order to attain that objective. ${ }^{1983}$ Member States may, however, have a certain degree of discretion in determining the necessary measures in view of safeguarding mandatory requirements. ${ }^{1984} \mathrm{Th}$ is implies that the level of protection of an imperative requirement can differ from Member State to Member State. In fact the Court held that the existence of less restrictive means in one Member State does not necessarily imply that the stricter rule in another Member State would not be proportionate. This comes back to the general rule of free movement law that as long as there is no Community harmonisation in the concerned matter, each Member State is, first of all, free to regulate the exercise of a profession on its territory and, secondly, entitled to consider that the objectives pursued by the national provision cannot be attained, as regards that activity, by less restrictive means. ${ }^{1985}$

The Wouters proviso refers three times to established case law of free movement law. ${ }^{1986}$ It follows from the foregoing that these references to the free movement case law are confusing but harmless since most of the justification grounds recognised as overtiding reasons of general interest can be identified as economic public interest objectives as defined earlier in section 1.2.3. The references to the free movement case law in the Wouters proviso can therefore be understood to reveal the judge-made character of its exemption in the field of competition law. This inconsistency with competition law is further reinforced by the proviso's reference to acts of Member States instead of associations of economic actors: "As regards members of the Bar, it has consistently been held that, in the absence of specific Community rules in the field, each Member State is in principle free to regulate the exercise of the legal profession in its territory". ${ }^{1987}$ Originally this is a reference to the sovereignty, i.e.

\footnotetext{
1982 The reference to Gottrup-Klim v DLG and the ancillary restraints doctrine at para. 109 of the judgment in Wouters does therefore not constitute an approptiate reference to support its judge-made extra-statutory exemption from Article 81(1) EC; the reference is misplaced. The only 'advantage' of the reference to $D L G$ is that the case lies in the field of competition law. For details on comparing Gottrup-Klim v DLG and Wouters, see Chapter 4.II.4.2.

${ }_{1983}$ See e.g. Case C-55/94, Gebhard, [1995], para. 37; Case C-3/95, Reisebüro Brode v Gerd Sandker, [1996], para. 28.

1984 See also above the diagram on page 386 and note 1862.

1985 See Case C-3/95, Reisebüro Broede ע Gerd Sandker, [1996], paras. 37, $41 \mathrm{ff}$., to which the Court in Wouters refers and from which it takes the formulation that the NOvA was "entitled to consider that the objectives pursued [...] cannot [...] be attained by less restrictive means". The French wording in Reisebüro Breede is "est en droit de considérer que les objectifs poursuivis [...] ne peuvent pas [...] être atteints par des moyens moins restrictifs." See also Case 107/83, Klopp, [1984], para. 17.

1986 Paras. 97,99 and 108 of the judgment in Wouteres refer to Case C-3/95, Reisebüro Broede $\nu$ Gerd Sandker, [1996], paras. 37, 38 and 41; and to Case 107/83, Klopp, [1984], para. 17. By referring to para. 38 of the judgment in Reisebirro Broede the Wouters proviso includes also reference to older case law from the field of free movement, e.g. Case 292/86, Gullung, [1988]; Case 33/74, van Bindsbergen, [1974].

1987 Para. 99 of the judgment in Wouters (emphasis added).
} 
competence of a Member State to adopt regulation where the EC is not (exclusively) competent in accordance with Article 5(2) EC. Before continuing to discuss the legitimacy of collective regulation adopted by self-regulatory bodies that are not part of the legislature (or the exercise of public authority), it is first necessary to establish who - in accordance with the Wouters proviso - is entitled to domestically establish the relevant professional standards.

\section{Whose role to determine professional standards}

The ECJ in Wouters observed that the (liberal) professions are (still) regulated differently in the Member States and recognised that the Member States have diverging rules on (whether and) how to regulate particular professional issues. ${ }^{1988}$ This does, however, not imply an unlimited waiver for professional rules. The yardstick applied in Wouters requites that professional regulations have to have "regard to the prevailing perceptions of the profession" in the State concerned. ${ }^{1989}$ "This formulation of the English language version of the judgment could be ambiguous ("perceptions of the profession"). As Gilliams rightly points out this formulation should not be misinterpreted to accept the perceptions maintained by the profession itself. Instead, the perceptions to be taken aboard are those prevailing in a particular Member State more generally with different societal groups. ${ }^{1990}$ The other language versions of the judgment demonstrate that this reading is indeed appropriate. ${ }^{1991}$ Thus, it is for the competent authorities confronted with a particular case (i.e. the national courts and competition authorities) to assess and ascertain the perceptions prevailing in respect of a particular profession and within the relevant (national) territory, and to ascertain the public interests having regard to those perceptions. This is in accordance with Article 81(3)-[1] EC, which requires that the relevant efficiencies are established in an objective way. Therefore, it is necessary to establish a minimum requirement, which prevents that the perceptions in respect of a particular profession are dominantly determined by the professional representatives themselves. The key characteristics of a profession thus need to be established in an objective way. The necessity to apply an objective standard suggests itself for several reasons that are basically of a constitutional nature. Hereafter follows an illustration of this point.

Before 1987 the German rules on conduct for lawyers on the exercise of the lawyer's profession were mainly set by the federal but self-regulatory professional body (Berufsordnung für Recbtsanwälte, $B O R A$, adopted by the Bundesrechtsanwaltskammer, $B R A K$ ). These tules were understood to concretise the general professional duty laid down in the law. According to federal statute ( $\$ 43 \mathrm{BRAO}$ ) a lawyer has the obligation to exercise her profession in a

\footnotetext{
${ }^{1288}$ See in particular the case law in the field of free movement concerning (liberal) professions, e.g. Case 107/83, Klopp, [1984]; Case 33/74, van Bindsbergen, [1974]; Case C-55/94, Gebbard, [1995]; Case C-3/95, Reisebüro Broede $\nu$ Gerd Sandker, [1996].

${ }^{1989}$ Para. 105 of the judgment in Wouters.

1990 Gilliams H., (2006), 27.

1991 For instance in Dutch, the language of the case, no confusion can be made about the broader and more general character of the reference to the "prevailing perceptions" ("gelet op de in die lidstaat beersende opvattingen over dit beroep"). Also in French, the working language at the Court, the point is clear ("compte tenu des conceptions de cette profession qui $y$ (i.c. in the specific Member State) prévalen'"). Also other language versions are unambiguous ("tenuto conto delle concezioni di tale professionei vi vigenti"; "y que habida cuenta de la concepción que en dicho Estado se tiene de esta profesión"). Only the German translation could be ambiguous in the sense that it refers to the 'professional principles' in the Member State ("in Anbetracht der dortigen berufsständischen Grundsätze'), which could be defined by the profession itself. On the interpretation inGermany see however the paragraph hereafter.
} 
conscientious manner. In the exercise of her profession as well as in other aspects of life she is required to behave in a way that suits the respect of and the confidence in the lawyer. Before the decision of the German constitutional court (Bundesverfassungsgericht, BVerfG) in 1987 the self-regulatory rules interpreting this professional duty were not imposed or reinforced by legislation within the meaning of Van Eycke ${ }^{1992}$; enforcement thereof was, however, through State courts (disciplinary courts). With time the conduct rules of the BRAK were treated in the case law of the disciplinary courts as binding rather than a mere reference for the interpretation of the general and indefinite professional duty in $\$ 43 \mathrm{BRAO}$. The constitutional court quashed the conduct rules in 1987 as contrary to Article 12 of the German constitution on the ground that they were imposed without a proper legal basis. ${ }^{1993}$ The article provides for the freedom of profession and occupation, drawing a distinction between rules that concern the access to a profession and those that concern the exercise of a profession. This means that, on the one hand, all Germans have the right to freely cboose their profession or occupation, their place of work, and their place of study or training. This basic frcedom cannot be restricted, even not by law. On the other hand, the practice of a profession and occupation can be regulated, but only by or pursuant to a statute.

Depending on the intensity with which the exercise of a profession is restricted the BVerfG differcntiates between two different kinds of professional regulations. Rules on the exercise of a profession concerning the legal status of the professionals (statusbildende Berufsausiibungsregeln) are necessatily within the competence of the legislator. This competence is not alienable. The compctence to adopt regulations with a less grave impact on the free exercise of professional activity may be delegated to professional bodies. The BVerfG rightly found that the reference in the statute, $₫ 43 \mathrm{BRAO}$, to the conscientious exercise of the profession, the respect of and confidence in a lawyer are, however, too vague to form a proper legal basis for delegated powers of the German bar association. As a consequence of the two decisions by the constitutional court a new provision has been introduced by the Federal legislator to explicitly empower the German bar association to set rules concerning particular subject matters. The point I want to make here is the following: had a case like Wouters been decided in Germany before the reversal of the German case law, the prevailing perceptions of the profession would clearly have been those defined by the self-regulatory professional association since they had been accepted as binding by the previous national case law.

Regardless its historic chatacter the example of the interpretative rules of the BRAK demonstrates the constitutional impact that self-regulatory professional rules have. Most noticeably is the distinction struck by the German constitutional court that a core regulatory competence is not alienable to self-regulatory bodies, as they are not democratically legitimised. ${ }^{1994}$ Accordingly, rules framing the legal status of a profession are necessarily within the competence of the legislator. Similarly, it makes sense not to allow a profession or its associations to determine the public interests to be promoted by professional tegulation in a particular Member State - for otherwise one would allow the self-regulatory

${ }^{1992}$ For details see Chapter 6.II.

1993 BVerfG - [1987], BVerfGE 76, 171; and BVerfG - [1987], BVerfGE 76, 196; also reported as BVerfG "Richtlinien des anwaltlichen Standesrechts kein Hilfsmittel zur Auslegung", Anwaltsblatt(1987), 598; and BVerfG - "Zurverfassungsrechtlichen Berurteilung des anwaltlichen Werbeverbots", Anwaltsblatt(1987), 603. In Chapter 4 the BRAK has been identified as a body not exercising public authority, which indirectly is confirmed by the decisions of the BVerfG.

1994 See also ILoozen E., (2007). 
body to set the yardstick against which its actions are to be measured and thus set the fox to keep the geese.

Even where the legal status of a profession is determined by the legislator, the prevailing perceptions in respect of a profession's main characteristics will be influenced by the profession itself. Certainly, the prevailing perceptions have evolved over time. They are open to further development and a (self-regulated) profession obviously takes a role itself in carving out those perceptions. Judge Cooke has vividly illustrated how professions grasp the opportunity to have restrictive regulations put in place by lobbying in the process of political decision making and preferably with government or the legislator. ${ }^{1995}$ Their representation of the main characteristics of a certain profession therewith have the power to influence the perceptions of legislators, the judiciary and the general public. There is thus the inherent risk that professional interest groups lobby with the policy makers, even at Community level. In June 2008 the Commission therefore has launched a (voluntary) lobbyists register as part of the wider transparency initiative initiated by the Commission Directorate General for Administration and Anti-Fraud in $2005 .{ }^{1996}$ So far only few lobbyists have signed the register. ${ }^{1997}$ The risk of self-interest being implemented in State regulation may possibly be

1995 Cooke J.D., (2006), 3 ff.: "Once the association becomes identified with the occupation, access to membership becomes more difficult (in the interest, of course, of promoting higher standards) and in the final stage the ultimate badge of professional standing is the installation of a monopoly by persuading government that the particular service should, by law, be available only from members of the professional association in question. In the common law countries incorporation by charter, especially royal charter, is especially advantageous" (emphasis in the original).

${ }_{1996}$ See <http://www.euractiv.com/en/pa/commission-launches-lobbyists-register/article-173591>, 24.06.208: The European Commission adopted a code of conduct regulating lobbyists' behaviour on 28.05.2008 as a forerunner to the voluntary register. The European Parliament (on 08.05.2008) called for the creation of a mandatory public register common to all three institutions, providing for "full financial disclosure" and accompanied by a code of conduct complete with a mechanism for expelling lobbyists who infringe its tules. The voluntary register "will serve as a testing ground" for the feasibility of a register common to all EU institutions. At the end of a one-year 'experimental phase', the Commission will assess whether it has been effective in increasing the transparency of lobbying activities in Brussels. The register features three main categories of lobbyists: 'professional consultancies and law firms', 'corporate lobbyists and trade associations' and NGOs and think tanks'. The requirements for inclusion in the register vary for all three. Signatories in the first category (professional consultancies and law firms) must disclose total revenue related to lobbying the EU institutions, either by placing their clients in boxes representing absolute amounts (brackets of $€ 50,000$ ) or percentages (brackets of 10\%). The second category (corporate 'in-house' lobbyists and trade associations) must provide an estimate of their costs associated with the direct lobbying of all the EU institutions. Those wishing to be included in the third category (NGOs and think-tanks) must publish the overall budget of their organisation and indicate their main sources of funding, for example public monies (European, national or sub-national). Lobbyists wishing to register must also either sign up to the Commission's 'Code of Conduct for Interest Representatives' or abide by their own equivalent lobbyists code with identical or more stringent requirements. In return for fulfilling these criteria, registered lobbyists will receive alerts from the EU executive giving details of upcoming public consultations on policy areas of interest to them.

1997 See <http://www.euractiv.com/en/pa/survey-lobbyists-reluctant-sign-register/article-180017>, 09.03.2009: Large numbers of businesses, consultancies and industry federations do not intend to sign up to the European Commission's lobbyists register. $55 \%$ of federations, $53 \%$ of consultancies and $41 \%$ of businesses do not intend to participate at all in the voluntary lobbyists register. Corporate respondents have been quicker to sign up to the register than consultancies and federations, according to the limited survey sample (presented at the eighth annual conference of the European Centre for Public Affairs (ECPA) in Brussels). Over half (55\%) of corporate respondents have already joined, while consultancies $(33 \%)$ and federations $(17 \%)$ have been slightly slower off the mark. One industry insider, who did not wish to be named, suggested this shows that the corporate world may consider registration necessary to maintain reputations. Public affairs practitioners would like to see further clarification of a number of issues related to the register, including financial disclosure and the distinction between 
counterbalanced by other societal groups, like consumers. As a dispersed group consumers are, however, not as well organised or represented with policy makers and the legislator. In particular in respect of the policy field of professional competences consumers and their organisations struggle with the information asymmetry (described elsewhere in this book). One of the main atguments for allowing self-regulatory structures therefore refers to the concentration of 'expertise' and knowledge about the professions with the professions. This attitude must, however, not lead to interptet the formulation of the Wouters proviso to tefer to professional characteristics as interpreted by the stake bolders themselves, quite to the contrary. ${ }^{1998}$

On the basis that also non-market objectives of professional regulation, even of a domestic character, come within the scope of Article 81(3) $\mathrm{EC}^{1999}$, the conclusion of this book so far is that the Wouters proviso so far proves to be an application of Article 81(3) EC in disguise. Especially the standard of reasonableness applied therein corresponds with the interpretation of the indispensability criterion of Article 81(3)-[3] EC. The ensuing question is, however, whether a standard of reasonableness is an appropriate yardstick in justifying collective self-regulatory professional rules that are, in principle, restrictive of competition.

\section{Prospects: strict proportionality in case of collective regulation}

In its guidelines on the application of Article 81(3) EC the Commission concentrates on the requirements that agreements between economic operators have to meet in order to profit from the exemption. While the Commission, according to the first note of its guidelines, acts on the assumption that 'the term 'agreement' includes concerted practices and decisions of associations of undertakings", it has little considered to make adjustments for decisions of associations, i.e. of non-economic operators. Decisions of associations are collective regulation: they ate formulated in abstract terms and apply to a group of cases. Thus, these decisions do not constitute concrete business judgments of economic entities that the Commission does not intend to second guess in respect of the indispensability tequirement

direct lobbying and other advocacy activities. Professionals are also equally divided as to the European transparency initiative's future, with a majority of corporate respondents $(27 \%)$ expecting the scheme to become mandatory but remain similar. $34 \%$ of federations expect the register to remain voluntary, while $28 \%$ of consultancies expect it to be simplified. Other factors identified by the survey as preventing consultancies from registering include the excessive amount of data required (30\%) or risks that such data will be misused (19\%). The majority of organisations spend over half of their EU public affairs budgets in Brussels, but less than a quarter of this goes on direct lobbying. - See also <http://www.publications.parliament.uk/pa/cm200809/cmselect/ cmpubadm/36/3612.htm> publishing a "Paper by Special Adviser on Regulation of Lobbying Activities outside the UK", which features an overview of the regulation of lobbying in Canada, Germany, Australia, the EU and the USA. - See also <http://www.tcd.ie/Political_Science/regulatelobbying/index.html $>$ which is a webpage on regulation of lobbying. The research group intends to soon release a new book on Regulating Lobbying: $A$ Global Comparison. "This book is concerned about comparing how lobby/interest groups are formally regulated throughout the world and the impact this has had, something which is a significant, if not surprising, omission in the literature."

${ }^{1998}$ See also Ogus A., (1994), 72, 73: "legislation can almost never be allocatively efficient in the Pareto sense, because it will invariably impose losses on some individuals. If legislation is the result of democratic processes and reflects, in broad terms, the range and extent of economic interests in a society at a given time, there is nevertheless a good chance that it will be Kaldor-Hicks efficient, the aggregate gains from the measure exceeding the aggregate losses. On the public choice hypothesis, however, private interest groups thwart the democratic process and concentrated, minority economic interests prevail over the more widespread, majority economic interests; and the Kaldor-Hicks test of efficiency is not satisfied."

${ }_{1999}$ Provided they yield economically beneficial effects, see European Commission, Guidelines on the application of Article 81(3) EC, para. 42; and Commission Decision CECED, (2000). 
of Article 81(3) EC. ${ }^{2000}$ For instance, the Dutch bar association has taken any concrete business judgment out of the hands of law firms and accountancy firms by prohibiting in general terms any multi-disciplinary partnership between these types of economic actors. In case of decisions of associations, i.e. non-economic operators, it is therefore mistaken to interptet the indispensability criterion from the starting point that business decisions must be made on the basis of imperfect information and that a certain margin of error would be justified. Several considetations tip the balance in favour of interpreting this criterion strictly rather than with the same standard of reasonableness applied to agreements between undertakings.

Above all, in restricting the competitive freedom of their members and non-members, a professional association assumes the power and competence to influence their future business decisions. This may serve a good cause (Article 81(3)-[1] EC) but is not concretely connected to the infinite number of business decisions taken subsequently by their members and non-members. The question then is whether a particular professional regulation strikes a fair balance of all economic interests potentially involved in the subsequent business decisions. A full-blown proportionality test rather than a yardstick of reasonableness will allow to assess specifically whether, for instance the prohibition of multi-disciplinary partnerships is, first, suitable for the attainment of the sound administration of justice and, second, the least restrictive but equally efficient means to achicve this objective.

At this juncture it would be once more necessary to refer to the particular aspects of the sound administration of justice that are to be protected by a prohibition of multi-disciplinary partnerships. To start with one could argue that the sound administration of a system of justice (i.e. a space where rights are established, recognised and ultimately enforced) depends, amongst others, on lawyers as they fulfil a skilled role in the communication between private actors (e.g. market participants and citizens) and public institutions (e.g. judges and law enforcers). They (should) also help the development of the law. In particular their role in the transfer of justice is to act in a reliable and skilled way towards both private actors and public authorities. ${ }^{2001}$ The question here is whether a prohibition of multi-disciplinary partnerships is a suitable means to attain such skilled and reliable role in the administration of justice. In addressing the point the Court in Wouters elaborated on the tisks that the (lack of equivalent) professional rules for accountants may pose for the independence and professionalism of lawyers (cf. 'proper practice of the legal profession'). ${ }^{2002}$

Assuming the suitability at this stage, the following step is to effectively demonstrate that the prohibition of multi-disciplinary partnerships is necessary, rather than to accept - as the Court did in Wouters ${ }^{2003}$ - that the professional association is 'entitled to consider' or 'could reasonably have considered' that the objective of a sound administration of justice cannot be attained by less restrictive means. On the basis of the reasonableness standard applied the Court avoided to look at concrete altetnatives that safeguard the particular aspects of a

${ }^{2000}$ See European Commission, Guidelines on the application of Article 81(3) EC, para. 75. In fact the concept of 'decision by associations of undertakings' is mentioned only four times in the guidelines, and each time only in respect of the first paragraph of Article $81 \mathrm{EC}$.

${ }^{2001}$ It is here that the traditional concepts of independence, professionalism and knowledge may be (te-)employed. See also para. 100 of the judgment in Wouters, which refers to the duty to act for clients in complete independence and in their sole interest, the duty to avoid all tisk of conflict of interest and the duty to observe strict professional secrecy.

${ }^{2002}$ Paras. $103 \mathrm{ff}$. of the judgment in Woulers.

2003 Paras. 108, 110 of the judgment in Wouters, with reference "to that effect" to Case C-3/95, Reisebirro Brode $\nu$ Gerd Sandker, [1996], para. 41. 
sound administration while allowing or imposing less restrictive rules for multi-disciplinary partnerships. A conceivable alternative would be the imposition of an internal code of transparency that requires both professional groups for instance to keep certain activities separate (e.g. statutory auditing) ${ }^{2004}$ and, moreover to share the transparency code with all clients who make use of the multi-disciplinary partnership services.

The application of a strict proportionality testing can be derived in particular from two considerations. First of all, in the event of agreements being restrictive as such even the Commission guidelines require the assessment of less restrictive alternatives. "The more restrictive the restraint the stricter the test under the third condition. ${ }^{2005}$ For instance in Piau, which like Wouters concerned a restriction of competition by object, the Court would very well have had the opportunity to elaborate that the raising of professional standatds and thus the protection of players (and clubs) would have been significantly less efficient with a certification system instead of a licence system. It can be guessed, however, that the Court could not require this demonstration from FIFA in the action brought by Mr Piau against the decision of the Commission addressed to him, but the point may possibly have been dealt differently if $M_{t}$ Piau had brought an action before a national court and invoked Article 81(1) EC there. A second consideration in favour of a strict proportionality testing is the lack of democtatic legitimacy of self-regulatory bodies. ${ }^{2006}$ Collective regulation that has an impact comparable to State regulation has to meet basic requirements of the rule of law. The standard of judicial review of professional regulations that pursue an economic public interest can be safeguarded within the framework of competition law, namely by interpreting the Article 81(3)-[3] EC strictly.

Before turning to the remaining two requirements of Article $81(3)$ EC one can draw the following conclusions. First of all, Wouters may be considered a necessary intermediate step towards developing the application of EC competition law in a policy field where so far no harmonisation has taken place and in which the Commission has not yet developed a strict policy defining the competition limits of collective regulation. Two points illustrate the importance of the Wouters judgement as a necessary intermediate: above all, it has reinforced the scrutiny of professional regulation in respect of competition law ${ }^{2007}$; moreover, the judgment has acuminated the discussion in competition law on the balancing of national public interests that have a non-market nature. ${ }^{2008}$ The second conclusion is that, even if the Wouters proviso did not constitute a contra legem interpretation of Article $81 \mathrm{EC}$ and could be identified as a disguised application of the third paragraph thereof, it is necessary to interpret the third condition of Article 81(3) EC (indispensability) strictly and apply a full

${ }^{2004}$ See also paras. 104 and 105 of the judgment in Wouters as compared with the case law of the Hoge Read on professional secrecy of accountants in the Netherlands, above the text with note 1978.

${ }^{2005}$ European Commission, Guidelines on the application of Article 81(3) EC, para. 79, with reference to Case T86/95, CMB III, [2002], paras. 392-395. Compare also above the diagram on page 386. Faull J. / Nikpay A. (Eds.), (2007), refer to the example where the very creation of a production joint venture restricts competition between the parties in a downstream market. "In such cases it is necessary to assess whether the efficiencies could have been achieved by means of a less restrictive alternative, whether by a different type of agreement or by the parties acting individually. The parties must explain and demonstrate why secmingly realistic and significantly less restrictive alternatives to the agreement would be significantly less efficient. - The Guidelines teflect the fact that in the new enforcernent system the Commission will focus on cases that give rise to real competition concerns and will not engage in micromanagement of agreements.

${ }^{2006}$ See above the example on the casc law of the German constitutional court.

2007 For details on the anti-competitive character of professional regulation see Chapter 4.II.2.

${ }^{2008}$ See e.g. Forrester I.S., (2006), 18, on the role of competition law in respect of professional regulation. On p. 16 he refers to the absence of 'national folly'. 
proportionality test where enforcement agencies or courts are confronted with collective regulation.

\section{Consumer welfare under Article $81(3)-[2] \mathrm{EC}$}

A third element requited by Article 81(3) EC is that an agreement or decision allows consumers a fair share of the resulting benefit. In the provision this requirement is listed second and in the following therefore referred to as Article 81(3)-[2] EC. The relevant question is whether consumers receive a fair share of the overall benefits ascertained under Article 81(3)-[1] EC. "It is not required that consumers receive a shate of each and every efficiency gain identified under the first condition. It suffices that sufficient benefits are passed on to compensate for the negative effects of the restrictive agreement."2009 Article 81(3)-[2] EC therewith adds an element of distributive equity according to which a fair distribution of resources prevails over a narrow economic view. ${ }^{2010}$ In EC competition law preference has been given to trade-offs between efficiency and equity. In other words, more weight is ultimately given to competitive prices for consumers than to cost efficiency savings for efficient firms (with resulting profits for their shareholders). Above in section I.2.3. it has been explained that consumer protection actually is a market interest; at the same time the concept is wider than market interests, namely where it includes for instance the right to information, health and safety. ${ }^{2011}$

The concept of 'consumer' within the framework of Article 81(3) EC is defined in relation to the agreement or decision and encompasses all direct or indirect users of the products or services covered thereby. ${ }^{2012}$ Obviously the concept of 'fair share' is defined in relation to those consumers. It implies that the pass-on of benefits must at least compensate consumers for any actual or likely negative impact caused to them by the restriction of competition found under Article 81(1) EC. ${ }^{2013}$ In determining a minimum level of fair share the Commission states that "In line with the overall objective of Article $81 \mathrm{EC}$ to prevent anti-competitive agreements, the net effect of the agreement [or decision] must at least be neutral from the point of view of those consumers directly or likely affected by the agreement [or decision]."2014 Therewith the concept of 'fair share' gives a margin of appreciation. ${ }^{2015}$ Decisive is the overall impact on consumers of the products or services within the relevant market and not the impact on individual members of this group of consumers. ${ }^{2016}$ "The fact that particular customers are not entirely compensated does not prevent Article 81(3) EC from applying, as long as the 'average' customer benefits and the efficiency gains are consequently such as to produce a positive effects on the market

${ }^{2009}$ European Commission, Guidelines on the application of Article 81(3) EC, paras. $84 \mathrm{ff}$., with reference to Case 26/76, Metro I, [1977], para. 48.

${ }^{2010}$ See above page 373. Distributive equity refers to consumer welfate, even to their surplus, but does notequal total welfare. It reflects a pragmatic consumer welfare standard with underlying value judgments and policy choices, see Van den Bergh R.J. / Camesasca P.D., (2006), 51 ff. The terminology employed ranges from "consumer welfare", "benefit of consumers", "added value for consumers", see European Commission, Guidelines on the application of Article 81(3) EC, para. 62; and "consumer surplus", see Lugard P. / Hancher L., (2004), $412 \mathrm{ff.}$ Compare also Case T-168/01, GlaxoSmithKline, [2006], para. 118.

2011 See Article 153(1) EC; and Monti G., (2002), 1075.

2012 European Commission, Guidelines on the application of Article 81(3) EC, para. 84.

${ }^{2013}$ See also paras. $85 \mathrm{ff}$. of the Commission guidelines.

${ }^{2014}$ European Commission, Guidelines on the application of Article 81(3) EC, para. 85.

2015 Whish R, (2003), 156.

${ }^{2016}$ Para. 86 of the Commission guidelines. 
generally." ${ }^{2017}$ Moreover, the second condition of Article 81(3) EC represents a balancing test and incorporates a sliding scale. This means that

"The greater the restriction of competition found under Article 81 (1) the greater must be the efficiencies and the pass-on to consumers. This sliding scale approach implies that if the restrictive effects of an agreement are relatively limited and the efficiencies are substantial it is likcly that a fair share of the cost savings will be passed on to consumers. In such cases it is therefore normally not necessary to engage in a detailed analysis of the second condition of $\Lambda$ rticle 81(3), provided that the three other conditions for the application of this provision are fulfilled. If, on the other hand, the restrictive effects of the agreement are substantial and the cost savings are relatively insignificant, it is very unlikely that the second condition of Article 81(3) will be fulfilled. The impact of the restriction of competition depends on the intensity of the restriction and the degrec of competition that remains following the agrcement. If the agreement has both substantial anti-competitive cffects and substantial pro-competitive effects a careful analysis is required. In the application of the balancing test in such cases it must be taken into account that competition is an important long-term driver of efficicncy and innovation. Undertakings that are not subject to effective competitive constraints - such as for instance dominant firms have less incentive to maintain or build on the efficiencies. The more substantial the impact of the agreement on competition, the more likely it is that consumers will suffer in the long run."2018

In the example of professional regulation in Piau the groups protected by the FIFA rules where above all the players (as 'users' of agents' services) but also their clubs. The Wouters proviso refers to the protection of the ultimate consumer of legal services and establishes their 'fair share' by reference to the necessary guarantees concerning integrity and experience of legal professionals. ${ }^{2019}$ While the necessary balancing in Piau was conducted indirectly ${ }^{2020}$, the Court in Wouters elaborated in more detail how the prohibition of multi-disciplinary partnerships may contribute to the efficiency of a sound administration of justice, the argument being that the prohibition is reasonably necessary to ensure the proper practice of the profession in the Netherlands. ${ }^{2021}$ However the Wouters proviso does not come full circle as it does not readdress the issue of how the proper practice allows the ultimate consumer a fair share to be gained of the overall benefit of improving the sound administration of justice. The implied logic seems to be that protecting the proper practice of the legal profession, i.e. protecting legal practitioners against the competition from multi-disciplinary partnerships, is to protect their clients and grant them a 'fair' share. It would appear less ironic and be mote convincing, however, to first demonstrate in a tangible way how the prohibition of multi-disciplinary partnerships contributes to the sound administration of justice ${ }^{2022}$; subsequently, it may possibly not have been too hard to explain how the thus substantiated aspects of the sound administration of justice benefit the consumers of both legal and accountancy services.

2017 Lugard P. / Hancher L., (2004), 417, their note 44 and referring to Case T-131/99, Shaw and Falla, [2002], para. 163.

${ }^{2018}$ European Commission, Guidelines on the application of Article 81(3) EC, paras. 90-92.

2019 Para. 97 of the judgment in Wouters.

${ }^{2020}$ See Case T-193/02, Piau I, [2005], para. 104: "In view of the circumstances set out in paragraphs 102 and 103 above and the current conditions governing the exercise of the occupation of players' agent, where there are virtually no national rules and no collective organisation for players' agents, the Commission did not commit a manifest error of assessment by considering that the restrictions stemming from the compulsory nature of the licence might benefit from an exemption on the basis of Article 81(3) EC, and, moreover, by rightly reserving the right to review the rules in question."

${ }^{2021}$ Paras. 98-110 of the judgment in Woulers.

${ }^{2022}$ For details see above section I.2.5.3.1. 
4. Limiting the limit in accordance with Article 81(3)-[4] EC: no elimination of competition in respect of a substantial part of the professional services

Finally, the last condition of Article 81(3) EC (in the following referred to as Article 81(3)-[4] EC) requires that an agreement between undertakings or decision by association of undertakings does not "afford such undertakings the possibility of eliminating competition in respect of a substantial part of the products [or services] in question". The purpose of this condition is to safeguatd the ultimate aim of Article $81 \mathrm{EC}$, which is to protect the competitive process: "rivalry between undertakings is an essential driver of economic efficiency, including dynamic efficiencies in the shape of innovation."2023

While Article 81(3) EC limits the application of the competition prohibition, its last requirement puts a limit, or a last filter ${ }^{2024}$, to the exemption: the protection of rivalry and the competitive process is a policy choice that is given priority over potentially pro-competitive efficiency gains which could result from restrictive agreements or decisions. ${ }^{2025}$ Therewith the fourth head of Article 81(3) EC should protect the wider interest of the public at large. ${ }^{2026}$ Whether competition is eliminated depends also on the degree of competition that existed prior to the decision and on the reduction of competition brought about by the decision. $^{2027}$

The case of professional regulation meets this last condition probably rather easily. Often professional services markets are heterogeneous and characterised by a high degree of internal competition ${ }^{2028}$ due to the fact that the professions traditionally were, and regularly still are, exercised in independent practices with a small number of professionals only. Regulating their activities will therefore not generally eliminate competition in respect of a substantial part of the professional services market concerned. Obviously this assessment depends on the factual circumstance of a particular professional services market and whether it presents itself in a rather oligopolistic way. A perceivable example could be restrictive selftegulation of accountancy services for internationally operating companies quoted on the stock exchange, which is a market dominated by less than ten accountancy firms. They have been referred to as the 'big eight', the 'big six', the 'big five' and finally the 'big four', depending on the season of theit mergets - or fall. ${ }^{2029}$

\section{Interim conclusions}

Befote leaving the competition specific justification gtound that is Article 81(3) EC and turning to the general justification avenue under Article $86(2) \mathrm{EC}$, the following shall be recorded. The cumulative and exhaustive character of the four criteria of Article 81(3) EC

2023 European Commission, Guidelines on the application of Article 81(3) EC, para. 105.

2024 On the concept of filters see above the text with note 1777.

2025 European Commission, Guidelites on the application of Article 81(3) EC, para. 105.

2026 Sce also European Commission, Guidelines on the application of Article 81(3) EC, para. 85: "Morcover, society as a whole benefits where the efficiencies lead either to fewer resources being used to produce the output consumed or to the production of more valuable products and thus to a more efficient allocation of resources."

2027 Faull J. / Nikpay A. (Eds.), (2007), para. 3.458.

2028 See para. 114 of the judgment in Wouters.

2029 After the first two concentrations in 1989 in the sector there were six big accountancy firms left from the initial eight. The most noted merger took place in 1998 with PriceWaterhousCoper emerging and leaving five big players. The fall of Arthur Anderson came to pass in 2001/2002 as a consequence to their reputation dissipating after the fraudulent bankruptcy of Enron. Arthur Anderson was sold to the remaining four players. 
speak against maintaining the extra-statutory exemption forwarded in Wouters and MecaMedina II. Once the economic character of a professional activity has been identified, it is conceivable that the (restrictive) regulation of that activity may yield economically beneficial effects for consumers, even where the regulation pursues a non-market objective. This obviously requires professional regulatory bodies to neatly identify the benefits that professional regulation is likely to produce (instead of systematically invoke a public interest defence). This requirement follows from the distribution of the burden of proof, according to which the party invoking the exemption has to demonstrate that its conduct meets the conditions thereof., ${ }^{2030}$ This requirement is all the more appropriate in case of self-regulatory professional bodies that are not democratically legitimised. ${ }^{2031}$ In reviewing professional selfregulation courts and law enforcers have to ensure that the necessary line of argumentation is respected. The Wouters proviso only provides a fragmentary model, in particular since the Court easily accepted that the (empty) national concept of the 'proper practice of the profession' provided by the legislator be filled in the way the self-regulatory body has done for the case of the Dutch legal profession. However, the determination of the crucial or key values of a profession has a constitutional dimension as has demonstrated the German constitutional court 15 years before Wouters. A systemic public interest defence should therefore not be accepted unsifted in competition law.

This is not to say that public interest considerations could not be invoked in competition to justify professional regulations. This book argues that the concept of public interest has to be undetstood as a generic category of policy objectives that not only comprises noneconomic values but also encompasses economic interests, possibly of a non-market nature. Article 81(3) EC provides a filtering that can be applied also appropriately to cases of professional regulations.

Where non-market objectives are determined by public interest concerns with a character transcending economic benefits (as defined in this chapter) so that they have beneficial effects for democratic values, and in particular for the equality of citizenship, the justification of the professional rules will have to be scrutinised in respect of the general justification avenue of Article 86(2) EC.

\section{Article 86(2) EC: the general justification avenue - professional regulation and services of general economic interest}

So far this chapter has concentrated on arguments of economic public interest to justify anti-competitive professional regulations. It has been argued that many of the regulatory aims pursued by professional rules can be associated with (wider) economic benefits. The present part turns to the question referred to briefly in section I.2.3. on non-economic public interest concerns. This category of public interest concerns has been defined by reference to democratic ptinciples of social justice that safeguard the equality and expectations of

\footnotetext{
${ }^{2030}$ For details on the analytical framework for assessing consumer pass-on of efficiency gains see European Commission, Guidelines on the application of Article 81(3) EC, paras. $93 \mathrm{ff}$., where it is pointed out that "in many cases it is difficult to accurately calculate the consumer pass-on rate and other types of consumer pass-on. Undertakings are only required to substantiate their claims by providing estimates and other data to the extent reasonably possible, taking account of the circumstances of the individual case."

${ }^{2031}$ If they were, their regulatory activities could possibly qualify as the exercise of public authority and therefore not come within the scope of competition law as consequence of the case law discussed in Chapter 4.I.2. See also Evans L., et al., (2006).
} 
citizenship. ${ }^{2032}$ These types of interests cannot be adequately protected within the justification system of Article 81(3) EC and the scrutiny hereafter will therefore focus on the general justification avenue included in the EC Treaty that is Article 86(2) EC. Its character is general as it applies not only in the field of competition law but also, for instance in the field of free movement law. ${ }^{2033}$ The article states that:

Undertakings entrusted with the operation of services of general economic interest or having the character of a tevenue-producing monopoly shall be subject to the rules contained in this Treaty, in particular to the rules on competition, in so far as the application of such rules does not obstruct the performance, in layp or in fact, of the particular tasks assigned to them. The development of trade must not be affected to such an extent as would be contrary to the interests of the Community (emphasis added).

Accordingly, the general question here is whether the application of either Article $81 \mathrm{EC}$ or Article $82 \mathrm{EC}$ obstructs the performance of a particular task assigned to a profession. The task must describe a service of general economic interest (SGEI) with which the different professions would need to be charged in order to benefit from the justification mechanism provided for in Article 86(2) EC. So far only little attention has been paid to a systematic application of Article 86(2) EC with regard to the liberal professions and their regulations. 'This is due to the complex character of either field of law and their rather late development. First of all, the interest for Article 86(2) EC had long been dormant. The debate about the scope of the exception only revived in 1993 with the judgment in Corbeau ${ }^{2034}$ in which the Court specified that for certain exclusive rights the exception of Atticle 86(2) EC applies. ${ }^{2035}$ A similatly late awakening took place in respect of applying competition law to professional regulation. ${ }^{2036}$ The same yeat that Corbeau was decided the Commission adopted its first decision against a professional association for an infringement of Article 81(1) EC. ${ }^{2037}$ Yet the coincidence in time has not led to applying Article 86(2) EC to professional regulation. ${ }^{2038}$ Theoretically speaking a concurrence in development of the two areas of law could have taken place in Wouters as one of the questions referted to the Court for a preliminary ruling concerned the interpretation of Article 86(2) EC. However, the Court did not address the issue. ${ }^{2039}$ Advocate General Léger, on the other hand, spent

${ }^{2032}$ See Feintuck, referenced above in note 1841, who defines citizenship as the tight to have rights.

${ }^{2033}$ The first free movement case making reference to Article 86(2) EC has been Case T-266/97, Vlaamse Televisie Maatschapij NV $\nu$ Commission, [1999].

${ }^{2034}$ Case C-320/91, Corbeau, [1993].

${ }^{2035}$ Until shortly before Corbeau the relevant prohibition clauses - Articles 31 and 86(1) EC - had been interpreted strictly in the case law so that an application of the exception mechanism of Article 86(2) EC had been redundant, see Buendia Sierra J.L., (1999), paras. 8.07 ff. See also Pernice / Wernicke S., (2003), para. 3. Buendia Sierra points out that due to the initially strict interpretation of the Treaty's prohibition clauses an initiative of academics of the early 1960s devoted to analysing Article 86(2) EC met no response from the Commission or the Court. See the Brussels Colloquium of the Ligue Internationale contre la concurrence déloyale, 5-6 March 1963, Concomenza tra settore pubblico e privato nella CCE.

${ }^{2036}$ For details see Chapter 2.IV.

${ }^{2037}$ Commission Decision CNSD, (1993), finding a professional association to infringe Article $81 \mathrm{EC}$ by adopting a tariff scheme for the provision of customs clearance services.

2038 The closest case so far has been Case C-475/99, Glöckner, [2001], in which independent operators were excluded from the provision of certain ambulance transport services, which are however not a 'liberal' activity. The Court and also AG Jacobs found that their exclusion was justified under Article 86(2) EC, provided that the medical aid organisations were able to meet demand for the different kinds of ambulant transport services. The case has been discussed in Chapter 3.1.2,2,2.2.

${ }^{2039}$ This is due to the logic of the Wouters proviso since, according to the Court, the restriction of competition at issuc did not fall under the prohibitions of Article $81 \mathrm{EC}$ in the first place. Theoretically, also the first professions case decided by the Commission under competition law (CNSD) could have already been an occasion 
almost 50 paragraphs of his opinion in Wouters on the issue of Article 86(2) EC..$^{2040}$

The complex chatacter of Article $86(2) \mathrm{EC}$ is due to the difficulty in defining the concept of services of general economic interest (SGEI). As the Court recently stated:

"in Community law and for the purpose of applying the EC'Treaty competition rules, there is no clear and precise regulatory definition of the concept of an SGEI mission and no establisbed legal concept definitively fixing the conditions that must be satisfied before a Member State can properly invoke the existence and protection of an SGEI mission". ${ }^{0041}$

Any definition of the concept as applied to the liberal professions in the present book therefote is tentative and is used as a working definition. The drafters of the Treaty consciously chose the admittedly equivocal term 'services of general economic interest' in order to distinguish the subject matter from expressions already predetermined nationally, especially in France. ${ }^{2042}$ The obvious importance of Article $86(2)$ EC is based on the recognition of general interests to guarantee certain public services. The drafters of the Treaty acknowledged that the continuance of tasks of GEI should not be jeopardised by an indiscriminate application of the Treaty prohibitions. The objective of Article 86(2) EC therefore is the efficient provision of services of general economic interest in view of balancing the Community's interest in economic integration with the Member States' interest in using certain undertakings as an instrument of economic, fiscal or social policy. ${ }^{2043}$ While the understanding of Article 86(2) EC initially was restricted to underline its character of exception for services of GEI (meaning that being a derogation Article 86(2) EC is in principle to be interpreted strictly ${ }^{2044}$, it has meanwhile shifted towards acknowledging the article's fundamental function as a basis for legitimate State intervention in markets. ${ }^{2045}$

After a debate of more than a decade on the concept of SGEI ${ }^{2046}$ the negotiations to the

to apply the general exception contained in Article 86(2) EC. The infringement of Article 81(1) EC found in that case could not be exempted under Article 81(3) EC. The Commission did not consider to scrutinise the exception contained in Article 86(2) EC, probably because the parties had not invoked the article. But also the 'clear obscurity' of Article 86 EC made a scrutiny less accessible at the time. On the 'cleat obscurity', see AG Tesauro in Case C-202/88, French Republic v Commission (Telecommunications Terminal Equipment), [1991], paras. 1 and 11.

${ }^{2040}$ AG Léger in Case C-309/99, Wouters et al. v NOvA, [2002], paras. 155-201. His viewpoints will be discussed below. An interesting elaboration on how to apply Article 86(2) EC to professional regulations adopted by professional bodies is presented by Lenk J., (2006), ch 5 .

${ }_{2041}$ Case T-289/03, BUPA $\nu$ Commission, [2008], para. 165 (emphasis added).

${ }^{2042}$ See Buendia Sierra J.L., (1999), paras. $8.31 \mathrm{ff}$.

${ }^{2043}$ Case C-202/88, French Republic $\nu$ Commission (Telecommunications Terminal Equipment), [1991], para. 12; Case C157/94, Commission v Kingdom of the Netherlands (Electricity), [1997], para. 39; Case C-67/96, Albany, [1999], para. 103. See also AG Jacobs in Case C-475/99, Glöckner, [2001], para. 184.

${ }^{2044}$ See for instance Case 127/73, BRT II, [1974], para. 19, and Case C-157/94, Commission v Kingdom of the Netherlands (Electricity), [1997], para. 37. However, this general consideration did not prevent the Court to develop a more lenient line, especially also in the Electricity cases. The Court confirmed that, for the derogation of Article 86(2) EC to apply, it is not necessary that the survival of the undertakings itself be threatened. Rather it is sufficient that the application of the Treaty rules obstruct the performance, in law or in fact, of the special obligations incumbent upon the undertakings, Case C-157/94, Commission v Kingdom of the Netherlands (Electricity), [1997], para. 43.

${ }_{2045}$ See Pernice / Wernicke S., (2003), para. 3. See also Case C-159/94, Commission v French Republic (Electricity and Gas), [1997]; Case C-157/94, Commission v Kingdom of the Netherlands (Electricity), [1997], paras. 37 ff.; Case C-158/94, Commission y Italian Republic (Electricity), [1997].

${ }^{2046}$ The Commission launched the discussion in the mid-1990s with European Commission, 1996 Communication on Senvices of general interest in Europe. In the new millennium the Commission adopted a number of documents on the topic, the most important being European Commission, 2001 Communication on Services of General Interest in Europe; European Commission, Report to the Laeken European Council - Services of General Interest, of 17.10.2001; European Commission, Green Paper on Services of General Interest, of 21.05.2003; and European Commission, White 
Treaty of Lisbon have led to an agrecment between the Member Statcs to adopt a protocol on services of general interest ${ }^{2047}$ and to amend Article $16 \mathrm{EC}^{2048}$ The Commission welcomes the protocol as a decisive step towards establishing a transparent and reliable EU framework. It stresses that a broad agreement has emerged on the need to ensure legal certainty and consistency across EU policies, while respecting the diversity of sectors and situations. ${ }^{2049}$ However, the ongoing debate focusses only indirectly on professional services, namely in respect of the particular situation of health services ${ }^{2050}$, in respect of which the Commission plans to bring forward proposals setting out a framework for safe, high-quality, and efficient cross-border healthcare services. ${ }^{2051}$

The current debate on Atticle 86(2) EC is determined by several key issues that equally transpose to the reflections in the field of liberal professions. It concentrates on, first, which social objectives mandate high-quality services (of general economic interest); second, whether liberalisation (i.e. the opening of markets, therewith instituting a system of competition) hampers the provision of such services; third, which role is appropriate for the public authorities to take in the provision of SGEI; and fourth, whether a Community legal framework (to further determine definitions, goals and rules) is required to take priority over

Paper on Services of General Interest, of 12.05.2004, which was built on the previous consultations. In European Commission, Services of general interest, including social services of general interest: a new Eumpean commitment (Communication accompanying the Conmunication on' A single market for 21 st century Europe'), of 20.11.2007, the Commission stresses the role of the resolution by the European Parliament, Report on the Commission White Paper on services of general interest, of 14.09.2006, in the debate to generate converging views on the role and approach of the EU with regard to services of general interest.

2047 Treaty of Lisbon - Protocol on Services of Genetal Interest: "The High Contracting Parties, wishing to emphasise the importance of services of general interest have agreed upon the following interpretative provisions, which shall be annexed to the Treaty on European Union and to the Treaty on the Functioning of the European Union:

Article 1: The shared values of the Union in respect of services of general economic interest within the meaning of Article 16 of the Treaty on the Functioning of the European Union include in particular:

- the essential role and the wide discretion of national, regional and local authorities in providing, commissioning and organising services of general economic interest as closely as possible to the needs of the users;

- the diversity between various services of general economic interest and the differences in the needs and preferences of users that may result from different geographical, social or cultural situations;

- a high level of quality, safety and affordability, equal treatment and the promotion of universal access and of user rights.

Article 2: The provisions of the Treaties do not affect in any way the competence of Member States to provide, commission and organise non-economic services of general interest."

${ }^{2048}$ New Article 14 of the Treaty on the Functioning of the European Union (amendments to Article 16 EC are put in italics): "Without prejudice to Article 4 of the Treaty on European Union [which is partly new, partly Article $10 \mathrm{EC}$ ] or to Articles 93, 106 and 107 of this Treaty [Articles 73, 86 and $87 \mathrm{EC}$ ], and given the place occupied by services of general economic interest in the shared values of the Union as well as their role in promoting social and territotial cohesion, the Union and the Member States, each within their respective powers and within the scope of application of the Treaties, shall take care that such services operate on the basis of principles and conditions, particularly economic and financial conditions, which enable them to fulfil their missions. The European Parliament and the Council, acting by means of regulations in accordance with the ordinary legislative procedure, shall establish these principles and set these conditions withoutprejudice to the competence of Member States, in compliance with the Treaties, to provide, to commission and to fund such services."

${ }^{2049}$ European Commission, Services of general interest, including social services of genteral interest: a new European commitment (Communication accompanying the Communication on 'A single market for 21 st century Europe'), of 20.11.2007, 3.

${ }^{2050}$ The Commission has recently held an open consultation, see European Commission, Consultation regarding Community action on bealth services, of 26.09.2006.

2051 See also the Council conclusions on "Common values and principles in European Union Health Systems" adopted in June 2006. 
competition law and/ or the internal market rules. ${ }^{2052}$

\section{Article 86(2) EC outlined}

The legal structure of the article is put in a rather complex rule to ensure the article's objective. The first sentence of Article 86(2) EC has two limbs describing, on the one hand, its scope and, on the other, the actual exception to the otherwise applicable prohibition provisions of the Treaty. The second sentence of the provision formulates a limit to the justification for cases in which the interests of the Community outweigh the interests in the effective provision of a specific SGEI.

The article thus covers undertakings that are entrusted with the provision of an SGEI. ${ }^{2053}$ This first limb refers to three criteria that determine the scope of Article 86(2) EC (section 1). Its first criterion is the core of the provision and concerns the question of whether the provision of a particular service actually constitutes an SGEI. The second criterion concerns the beneficiary of the exception (i.e who may invoke the article). The third criterion turns to the form that the act of entrusting needs to take. As yet these criteria do not constitute a sufficient justification ground. In other words, even where a profession could claim that it meets the jurisdictional elements of Article 86(2) EC, its restrictive professional rules are not at a save harbour yet. Quite to the contrary, the article emphasises that undertakings entrusted with an SGEI are equally subject to the (competition) rules of the Treaty as are any other type of undertaking. It is only the second limb of the first sentence that contains the exception to the Treaty rules. Accordingly, the prohibition clauses of the Treaty will not apply where their application would obstruct the performance of the SGEI in question. In the words of Article 86(2) EC a restrictive arrangement can be exempted only "in so far" as the application of the Treaty rules obstructs the performance of the SGEI. This entails a proportionality testing (section 2). The last condition is contained in the second sentence of Article $86(2)$ EC. It requires that the exemption of restrictive measures must not affect the development of trade to an extent contrary to the interest of the Community. This condition actually imposes a limit to the exception and therewith allows to reconcile certain Member States' interests with the Community interest of economic integration.

\section{The scope of Article 86(2) EC with regard to professional regulation}

To apply Article 86(2) EC to the professions is probably just as complex as is its application in any other field. The basic question here is: who is entrusted with which service of general economic interest? Section 1.1. will first address whether professional services qulify as being of a general interest. Section 1.2. will scrutinise who can invoke Article 86(2) EC in defence to the application of competition law (i.e. the collectivity of

${ }^{2052}$ The discussions on the 2003 Green Paper and 2004 White Paper on services of general economic interest have evidenced a tension between liberalisation efforts on the one hand and the role of subsidiarity in regulation of certain sectors on the other. Member States are of the opinion that they must retain sole competence over how their governments decide to provide public services, see House of Lords, Completing the Internal Market in Senvices Report with Evidence, of 07/2005, 50.

${ }^{2053}$ The variation of Article 86(2) EC referring to undertakings "having the character of a revenue-producing monopoly" can be disregarded for present purposes as liberal professions do not have the purpose of creating revenue for a Member State and it would actually be in contrast to their claim of being liberal', i.e. independent of State involvement, see Chapter 2.I. 
professionals, a Member State, or a self-regulatory professional association). Section 1.3. will turn to whether the relevant actor has been entrusted with an SGEI.

\subsection{Do professional services qualify as SGEI?}

One specific issue concerning the concept of SGEI shall be prerecorded. The formulation of 'services of general economic interest sounds intangible at first, especially in light of the tripartite categorisation made earlier in this chapter (see section 1.2.3.). The concept becomes more tangible when turning it around into 'economic services of general interest' ${ }^{2054}$ First of all, a service must be of an economic nature for otherwise neither the competition tules nor Article 86(2) EC will be applicable. This means that services of general interest that are not economic in nature do not come within the ambit of competition law in the first place, and need therefore not be justified by reference to Article $86(2) \mathrm{EC} .^{2055} \mathrm{It}$ therefore becomes clear that the qualification 'economic' relates to the activity in the context of which the exception is invoked ${ }^{2056}$; it does not play a role in defining the nature of the interestinvoked as justification ground. Nevertheless the customary abbreviation SGEI (rather than ESGI) is continued as a shorthand in the following to designate economic services of general interest.

The various interests that can be taken into account for the derogation of Article 86(2) EC are of a non-economic nature (at least in their final objective, see above section I.2.3.). This becomes clear from the purpose of the article, which - the Court has underlined - is to reconcile the interests of a Member State in using certain undertakings as instruments of economic, fiscal or social policy with the Community's interest in economic integration. ${ }^{2057}$ This is also the reason why, as pointed out above, the concept of SGEI is not a legally defined one. It is up to the Member States to define what they regard as SGEIs. Herein they enjoy a wide discretion that is not rivalled by any competence specially attributed to the Commission or any precise and complete definition in Community law. Consequently, various general interests ate eligible for the derogation and they are of a domestic nature. ${ }^{2058}$ This means that the determination of an eligible general interest can hardly be made in the abstract since the different Member States pursue a whole varicty of diverging interests. Their definition can be questioned by the Commission only in the event of manifest error. ${ }^{2059}$

${ }^{2054}$ Buendia Sierra J.L., (1999), para. 8.27.

2055 European Commission, Senvices of general interest, including social services of general interest: a new European commitment (Communication accompanying the Communication on 'A single market for 21 st century Europe'), of 20.11.2007, 4, 6.

${ }^{2056}$ For details on the economic nature of professional services, see Chapter 3.I. See also European Commission, Services of general interest, including social services of general interest: a new European commitment (Communication accompanying the Communication on ' $A$ single market for 21 st century Europe'), of 20.11.2007, 5, who neatly distinguishes the respective concepts of economic activity under competition law, on the one hand, and under the internal market rules on the other. See also European Commission, 1996 Communication on Services of general interest in Europe, para. 10, for the initial complex categorisation that services of general economic interest are part of a generic category of services of general interest, rather than straightforwardly distinguish economic services of public interest and noneconomic services of public interest.

${ }^{2057}$ See the case law teferenced above in note 2043.

${ }^{2058}$ Case T-17/02, Fred Olsen $\nu$ Commission, [2005], para. 216; Case T-106/95, FFS A v Commission, [1997], para. 99. In defining the SGEIs Member States "cannot be precluded from taking account of national policy objectives", AG Jacobs in Case C-475/99, Glöckerer, [2001], para. 185.

${ }^{2059}$ Ibid. Therefore, Faull J. / Nikpay A. (Eds.), (1999), paras. $5.148 \mathrm{f}$., suggest that the question of whether the interests of the Community would be adversely affected by a derogation from the Treaty rules (second sentence 
Also the considerable body of case law on the subject matter does not give a general definition of the concept but is very much facts based. Its content is approached by describing various factors that determine the provision of what can be perceived as SGEI. Reviewing the different applications of the concept made in the case law an SGEI could be defined as "a service of an economic nature the provision of which to the general public is considered essential, and which justifies a degree of intervention of the public authorities in order to show that a given service is actually provided and to control the conditions under which it is provided."2060 The Commission in its general initiative to develop the topic of services of general interest defines SGEI as market services, i.c. services of an economic nature, which the Member States subject to specific public service obligations, and do so by virtue of a general interest criterion. ${ }^{2061}$

Notwithstanding the wide discretion of the Member States in defining concrete public interests, a number of common elements can be drawn on to define a useful Community concept of services of general economic interest. These elements include in particular: universal service ${ }^{2062}$, continuity of supply ${ }^{2063}$, quality of service, affordability, as well as user and consumer ptotection. ${ }^{2064}$ In economic terms SGEI are closely related to universal service obligations. ${ }^{2065}$ This concept tefers to obligations imposed on one or more firms of a given industry to supply given products or services to all citizens. To guarantee equal access the universal service obligations typically are tailored to the needs of citizens within a certain relevant category (such as the sick in the case of certain medical services or citizens living in remote areas). ${ }^{2066}$ Obvious examples are network utilities, like the supply of broadcasting, telecommunication, electricity, water, gas, railways and postal services, for the provision of which Member States may grant exclusive rights to certain undertakings. The scope of Article 86(2) EC is, however, not restricted to any particular type of 'services of general economic interest', so that also professional services may be covered by the exception despite the fact that they are mostly provided on an individual basis by a multitude of providers. The rationale of SGEI assumes that market forces alone would not provide for

of Article 86(2) EC) is not a separate requirement but part of the overall proportionality requirement to which the first sentence is subject.

${ }^{2060}$ Buendia Sierra J.L., (1999), para. 8.23.

${ }^{2061}$ European Commission, 1996 Communication on Services of general interest in Exrope; European Commission, 2001 Communication on Services of General Interest in Europe, Annex II; European Commission, White Paper on Services of General Interest, of 12.05.2004, Annex I.

${ }^{2062}$ See for instance Case C-393/92, Almelo, [1994]; and Article 1 of Protocol (No 26) on Services of General Interest, see above note 2047.

${ }^{2063}$ Case C-393/92, Almelo, [1994]. The term 'basic supply' has been used in the decision Commission Decision Jabrbundertvertrag, (1993), 22. The case concerned a set of agteements according to which the German public electricity supply industry and the industrial producers of electricity had undertaken to purchase from operators in the German coal mining industry a certain amount of German coal for the purpose of generating electricity. ${ }^{2064}$ European Commission, Green Paper on Services of General Interest, of 21.05.2003, pt. 49.

${ }^{2065}$ AG Léger in Case C-309/99, Wouters et al. vNOvA, [2002], para. 161, has pointed out that concept of SGEI is virtually interchangeable with service of general interest, universal service and public service. On SGEI sce Case C-179/90, Merci Convenzionali, [1991], para. 27; Case C-242/95, GT-Link vDSB, [1997], para. 53; Case C-266/96, Corsica Ferries II France, [1998], para. 45; on services of general interest sec Case C-320/91, Corbeau, [1993], para. 19; on universal services see Case C-266/96, Corsica Ferries II France, [1998], para. 45; on public services see Case C-266/96, Corsica Ferries II France, [1998], para. 60.

${ }^{2066}$ Clemenz G., et al., Services of General Economic Interest, (2006), 2. See also Article 36 European Charter of Fundamental Rights: "The Union recognises and respects access to services of general economic interest as provided for in national laws and practices, in accordance with the Constitution, in order to promote the social and territorial cohesion of the Union." 
the defined public interest obligation with the consequence that certain groups of citizens would not have been served, or not in the foreseen manner. Therefore, public interest obligations by definition render the provision of services by firms to be at a loss, for otherwise there would be no need to impose a general interest obligation. ${ }^{2067}$

The suggestion therefore generally is that the concept of SGEI covers services that are considered to be essential to the general public and therefore justify a degree of intervention of the public authorities to guarantee that a given scrvice is actually provided, or rather provided in a specific manner. ${ }^{2068}$ The proposition made earlier in section 1.2.3. for a working definition of public interest considerations (which in this book are used synonymous to general interest objectives) fits into this conception of SGEI. Expectations of citizenship must certainly be understood to include equal access to services that guarantee democratic choices $^{2069}$ and universal access, equal treatment and affordability as well as user rights have been included into Article 1 of the Protocol (No 26) to the Lisbon Treaty. ${ }^{2070}$ In this sense it is conceivable that certain professional services are of such an importance to society that they should be accessible to a large public.

For instance, equal access to a system of justice (i.e. to the law and to courts) is an essential value in a State governed by the rules of law and therefore part of the expectations of citizenship. It is thus conceivable that services provided by lawyers may, to a certain extent, be understood to contribute to this access. According to Advocate General Léger in Wouters

"lawyers perform activities which are essential in a State governed by the rule of law. They make it possible for individuals to have a better knowledge and understanding of the rights granted to them and to enforce those rights more efficicntly. In other words, in a State governed by the rule of law, lawyers ensure the effectiveness of the principle of access to the law and to the courts."22071

Also medical doctors and pharmacists, in the exercise of their profession, are part of the healthcare system and have a role in the functioning of and access to the public health system. ${ }^{2072}$ Conversely, while the services of for instance architects and engineers without doubt contribute to the general interest of safe buildings and constructions (public safety), one cannot generally assume that their services in designing new structures respond to a univetsal service obligation. This does not exclude that under very specific circumstances it may be conceivable to invoke Article 86(2) EC, e.g. in a case of major batrage or dike works.

In particular the assumption of professional services otherwise not being provided, or

${ }^{2067}$ Clemenz G., et al., Services of General Eiconomic Interest, (2006), 2.

${ }^{2068}$ See for instance AG van Gerven in Case C-179/90, Merci Convenzionali, [1991], para. 27, who emphasised that the decisive question is whether or not the services are of direct benefit to society as a whole. A distinction has to be drawn, for instance, between management of a service (e.g. a port) and the carrying out of works (e.g. carrying out and organising dock work). If the carrying out or organising of dock work were considered to be of a general economic interest, then almost all economic activities would fall within this concept.

${ }^{2069}$ See European Commission, Services of general interest, including social services of general interest: a new European commitment (Communication accompanying the Communication on 'A single market for 21st century Europe'), of 20.11.2007, 4. In European Commission, White Paper on Services of General Interest, of 12.05.2004, the Commission stresses universal access as one of the guiding principles for services of general interest. - See also Ministerie van Economische Zaken, Pampblet on the Liberal Professions - a practical guide to public interests and regulatory instruments, of 10.12.2004, 3, stressing accessibility as one of the two public interest in professional services (next to quality). 2070 See above note 2047.

2071 AG Léger in Case C-309/99, Wouters et al. v NOvA, [2002], para. 175.

2072 See also the initiative of the Commission sct out a framework for safe, high-quality and efficientcross-border healthcare services, European Commission, Consultation regarding Community action on bealth services, of 26.09.2006; and the 2007 Communication on services of general interest, $8 \mathrm{f}$., $12 \mathrm{f}$. 
not being provided in a specific manner, to a certain group of citizens can help to determine the general service character thercof. For instance, if a legal aid system should prove to be restrictive of competition ${ }^{2073}$, it is easily conceivable that such a system should be exempted from the application of competition law where its performance would otherwise be obstructed. ${ }^{2074}$

At this juncture a sector-by-sector scrutiny would be required to assess which professional structures in the Member States yield non-economic benefits for society at large. With starting to analyse the particular situation of health services in respect of the application of EC law the Commission has taken a first step to possibly also scrutinise anti-competitive professional regulations as part of a healthcare system in a Member State. Such a specific scrutiny is, however, not expected to happen soon considering the initial stage at which the Commission's initiative currently is.

\subsection{Beneficiaries}

The object for an exception under Article 86(2) EC in the present book refers to the restriction of competition in the form of professional regulation. These can have differcnt authors. Since the wording of Article 86(2) EC refers to undertakings, the obvious beneficiary of the general exemption may only be the professionals themselves as economic operators. Professional regulation is, however, often not adopted in an agreement between professionals ${ }^{2075}$ but in either a decision of a self-regulatory body or a statutory measure. Therefore, the question hereafter is whether both Member States and professional associations can invoke the general exemption to justify their respective regulatory measures.

\subsubsection{State measures}

While the wording of Article 86(2) EC refers only to undertakings, it follows from the case law that under certain conditions the exception may also be relied upon by Member States to justify State measures that relate to conduct of undertakings entrusted by the State authotities with an SGEI. ${ }^{2076}$ It would be odd if the State tesponsible for defining and entrusting certain tasks of general interest to undertakings would not be entitled to invoke the exemption of the article to justify State measures which presumably are necessary for the functioning of the SGEI. The possibility to apply Article 86(2) EC also to Member State measures has been recognised gradually in the case law of the Court. In the beginning Article 86(2) EC was applicable only to infringements of Articles 81 and $82 \mathrm{EC}$ committed independently by undertakings, but gradually extended also to infringements that were committed as a result of State intervention contrary to Articles 86(1) and/ or 10(2) EC in conjunction with Articles 81 or 82 EC. ${ }^{2077}$

\footnotetext{
${ }^{2073}$ For considerations that a self-contained system of legal aid may not come within the jurisdictional scope of competition law, see Chapter 3.I.2.2.4.

${ }^{2074}$ On the criterion of obstruction see below section 11.2 .

${ }^{2075}$ For details see Chapter 2.I. and Chapter 4.I.1.2.

2076 For an overview see Buendia Sierra J.L., (1999), paras. 8.66 ff.; Van Bael I. / Bellis J.-F., (2005), 1009.

2077 See for instance Case 78/76, Steinike, [1977], paras. 16 ff.; Case 66/86, Ahmed Saeed, [1989], paras. 54 ff.; Case C-41/90, Höfner and Elser, [1991], paras. 24 ff.; Case C-179/90, Merci Convenzionali, [1991], paras. 27; Case C157/94, Commission v Kingdom of the Netherlands (Electricity), [1997], paras. 27 ff.; Case C-158/94, Commission vItalian Republic (Electricity), [1997], paras. 38 ff.; Case C-159/94, Commission v French Republic (Electricity and Gas), [1997], paras. $44 \mathrm{ff}$.
} 
There is also a structural argument flowing from the logic of the article, namely where its wording refers "in particular to the rules on competition" to which the entrusted undertakings are subject. Article 86(2) EC thereby includes to say that undertakings entrusted with an SGEI should also be subject to the other Treaty rules. However, at the time of the drafting of the Treaty there were no other Treaty rules directly applicable to undertakings other than the competition rules. The question then arises why Article 86(2) EC would refer to prohibitions other than the competition rules applicable to undertakings, if not intending to include also beneficiaries not explicitly named in Article 86(2) EC but related in the process of entrusting the undertakings with an SGEI. The addressees of the other Treaty prohibitions that Article 86(2) EC refers to are the Member States. Therefore, the conclusion must be that Member States may in principle invoke the exception with regard to State measures related to conduct of undertakings entrusted with an SGEI. This interpretation is moreover confirmed by Article 86(3) EC, which requires the Commission to ensure the application of the whole Article $86 \mathrm{EC}$ by addressing, where appropriate, directives or regulations to the Member States. If Member States could not invoke Article 86(2) EC the powers of the Commission under Article 86(3) EC would clutch at thin air with respect to SGEI. ${ }^{2078}$

In the case of the professions State regulation can take different contents; granting exclusivity tights is certainly one form. Sometimes Member States provide the professions with reserved tasks for certain professional activities. For instance notaries enjoy a legal monopoly for the drafting of authentic documents, or lawyers enjoy a legal monopoly for representation before certain courts. Where such legal monopoly rights come within the prohibition of Article 86(1) EC or the joint application of Articles 10(2), 3(1)(g) EC with Articles 81 and/ or $82 \mathrm{EC}^{2079} \mathrm{Member}$ States can in principle revert to invoke the exception of Article 86(2) EC to justify their restrictive measures. ${ }^{2080}$

The question arises whether a different answer has to be given in case of a Member State that imposes on the undertakings concerned a certain behaviour that is contrary to the competition rules. Where the undertakings could not engage in an autonomous behaviour testrictive of competition the undertakings will be successful in taising the State compulsion defence. The lacking liability on the part of the undertakings should not allow Member States to evade their liability with regard to their own behaviour under the joint application of Articles $10(2), 3(1)(\mathrm{g}), 81$ or $82 \mathrm{EC}^{2081}$ Yet there is no reason to exclude the ability of Member States to invoke Article 86(2) EC. The question of whether the State measure can be justified depends on whether the further tequirements of the article are fulfilled, especially whether the measure is proportionate (see further below). Thus, even where a Member State is found to in principle infringe Articles $10(2), 3(1)(\mathrm{g}), 86(1) \mathrm{EC}$, it can tevert to the exception of Article 86(2) EC. ${ }^{2082}$

\footnotetext{
${ }^{2078}$ On the case law and a detailed analysis of the arguments, including Article 12(1) EC, sce Buendia Sierra J.L., (1999), paras. $8.86 \mathrm{ff}$. Moreover, the inclusion of Article $16 \mathrm{EC}$ by the Treaty of Amsterdam and its future amendment following the Treaty of Lisbon (see above note 2048) reinforces the position of the SGEI and the powers of the Member States in their respect. The central example of Member States relying on Article 86(2) EC is the field of State aid law (Article 87 EC), e.g. in AG Léger in Case C-280/00, Altmark, [2003]; and Case T289/03, BUPA v Commission, [2008].

${ }^{2079}$ For details see Chapter 6.I.

${ }^{2080}$ Sce for instance Case C-320/91, Corbeau, [1993], paras. 13 ff.; Case C-157/94, Commission v Kingdom of the Netherlands (Electricity), [1997], para. 32. See also AG Stix-Hackl in Case C-231/03, Co.Na.Me., [2005], para. 65. ${ }^{2081}$ For details see Chapter 6.II.3.

${ }^{2082}$ See Case 66/86, Abmed Sazed [1989]. Conversely, professional obligations directly included in State legislation
} 


\subsubsection{Professional bodies}

Most of the times self-regulatory measures will be adopted either as a decision of an association of undertakings in the sense of Article 81(1) EC or as a measure of the emanation of its members in the sense of Article $82 \mathrm{EC}^{2083}$ Since the wording of Article 86(2) EC focuses solely on undertakings and not their associations, this type of professional regulation does not seem to be covered by the article. Associations or emanations are no undertakings themselves for want of an independent economic activity of their own. ${ }^{2084}$

In legal writing it has been suggested to apply the exception of Article $86(2) \mathrm{EC}$ to associations by way of analogy. ${ }^{2085}$ The question then is whether the scope of Article 86(2) EC contains a lacuna that would need to be covered by way of interpretation. The first argument against such an analogy is a textual one. ${ }^{2086}$ In fact, it would have been possible for the drafters of the Treaty to include also associations of undertakings within the scope of Article 86(2) EC if they had intended to do so. A comparison with the wording of Article $81 \mathrm{EC}$ suggests that the drafters had been aware of the role and influence that associations of undertakings may exert in the cconomic field. An analogy appears also to be in conflict with the requirement that a derogation (Article $86(2) \mathrm{EC}$ ) from the rule (Articles 81/ $82 \mathrm{EC}$ and Articles 10/ 86(1) EC) has to be interpreted natrowly.

It would, however, be conceivable to interpret the concept of 'undertaking' in Article 86(2) EC broader than in the other provisions of competition law, so as to comprise 'entities entrusted with the operation of services of general economic interest'. ${ }^{2087}$ An argument to the effect that the concept of undertaking needs to be interpreted uniformly does not necessarily cut ice. The reference in Article 86(2) EC "in particular to the rules on competition" proves that its law is not restricted to the field of competition law, and in light of Meca-Medina II it is at least conceivable to interpret the concept of undertaking (slightly) differently in competition law and the free movement law. However, to interpret the concept differently from the one used in competition law for the purpose of Article 86(2) EC would require a change in the settled case law applying a uniform concept of undertaking. This is hardly conceivable, or even desirable for cases that concern conduct restrictive of competition.

Hence, to find an argument in favour of applying Article 86(2) EC to associations by analogy requires to identify a lacuna. In other words the question is whether the aim of the provision is to cover collective regulation adopted by an association. Inspiration can be drawn from the opinion of Advocate General Léger in Wouters ${ }^{2088}$ in which he applied

do not come within the ambit of Article 86(2) EC. As seen in Chapter 6 such direct professional State regulation is outside the competition rules altogether.

${ }^{2083}$ On the concept of an association being an emanation of its members stemming from the case law in Piau, see Chapter 5.I.

${ }^{2084}$ For details see Chapter 3.I.3.

2085 Drijber B.J., (2005), 532; Lenk J., (2006), 322 ff.; Idot L., (1997), 78.

${ }^{2086}$ AG Stix-Hackl in Case C-231/03, Co.Na.Me., [2005], para. 64, seems to take a principled formalistic stance on the point: "the sole addressees of [Article 86(2) EC] - in contrast with Article $10 \mathrm{EC}$, which applies to the Member States - are undertakings, and specifically only those which are entrusted with the operation of particular services or are revenue-producing monopolies. It therefore applies only to those entities awarding concessions which can be designated as undertakings of that kind."

${ }^{2087}$ An argument to this effect has been invoked by several of the interveners in Wouters, see AG I.éger in Case C-309/99, Wouters et al. $\nu N O v A$, [2002], para. 167.

${ }^{2088}$ AG Léger in Case C-309/99, Wouters et al. $v$ NOvA, [2002], paras. 155 ff. 
Article 86(2) EC to the self-regulatory measures adopted by the Dutch lawyers association.

\section{Advocate General Léger in Wouters applying Article 86(2) EC to the professional body}

Advocate General Léger in Wouters was faced with the problem that the obvious addressees of the exception, i.e. the undertakings presumably entrusted with the provision of an SGEI, were no party to the proceedings before the Court. ${ }^{2089} \mathrm{He}$ started by clearly stating that the Dutch lawyers association could not be covered directly by Article 86(2) EC due to the lack of an economic activity of its own. At the same time he concluded that the

"restriction of competition caused by the Regulation is necessary if [it protects] features which form part of the very essence of the legal profession in the Netherlands". 2090

Thereby, Advocate General Léger seems to have accepted that for the purpose of applying Article 86(2) EC the original measure provoking a restriction of competition (the decision adopted by the association) could be dissociated from the undertakings entrusted with an SGEI, i.e. the practising professionals.

Assuming that a profession like lawyers or doctors is entrusted with an eligible task of general economic interest (to guarantee for instance access to the law and to the courts, or access to health care) by an act of public authority ${ }^{2091}$, the question arises whether the issue of authorship is irrelevant for applying Article 86(2) EC to the case of professional selfregulation. In the context of the specific exemption in competition law dealt with earlier (Article 81(3) EC) it is obvious that the beneficiary of the exemption also has to be the author of the restriction falling under Article 81(1) EC. Within the ambit of Article 86(2) EC this issue is not that straight forward. As explained before it can be invoked also by Member States to justify State measures that are necessary for the performance of an SGEI (despite the fact that the factual beneficiary of the exemption will be the undertaking(s) entrusted).

A threefold hypothesis is conceivable to explain the position taken by Advocate General Léger (omitting an allegation that he would not have noticed the dissociation between the authot of the restriction and the beneficiary of the exemption). The first builds its argument on the necessity of the restriction contained in the self-regulation, the second on the idea of collective representation of the undertakings by the author of the self-regulation, and the third on the assumption that the restriction could just as well be laid down in State regulation. Associating self-regulation with rules adopted directly by either the undertakings themselves or a Member State would actually dissolve the dissociation of the author of the restrictive measure at stake and the addressee of Article 86(2) EC.

\section{Necessary exemption due to the subject matter of professional regulation?}

The first hypothesis partly anticipates on the (substantive) proportionality test. In his opinion Advocate General Léget argued that the prohibition on partnership laid down in the contested Regulation can be necessary to perform the particular task assigned to the practising

\footnotetext{
2089 Unless one wanted to presume that, in procedural terms, the professional body was acting as an agent of the collectivity of the Dutch lawyers. That is a question which would need to be solved under national procedural law though.

${ }^{2090}$ AG Léger in Case C-309/99, Wouters et al. vNOvA, [2002], para. 187 (emphasis added); see also para. 184 and compare with paras. $167 \mathrm{ff}$. of his opinion.

${ }^{2091}$ See respectively section $\Pi$.1.1. above and section $\Pi 1.1 .3$. below.
} 
lawyers in the Netherlands. ${ }^{2092}$ This comes down to an exemption by subject matter rather than to establish a strict link between the restriction at stake and the addressee of Article 86(2) EC. The conceivable argument would be that the authorship of a certain restrictive regulation is irrelevant because of the assumed sensibleness of that regulation. ${ }^{2093}$ This approach leads to determine the beneficiary of the exemption by reference to a substantive standard of 'reasonableness' of the measure adopted by the envisaged beneficiary. Such an approach thus expands the jurisdictional boundaries of Article 86(2) EC.

\section{Associating collective self-regulation with undertakings charged with an SGEI?}

Secondly, the lack of authorship on the side of the entrusted undertakings could be compensated by the atgument that for the purpose of rule setting the undertakings are collectively organised and represented by their professional body, and that therefore the restriction could be ascribed to the undertakings themselves. As seen earlier the argument of collective representation can make a difference in law to bring the professions, for instance, within the scope of Atticle $82 \mathrm{EC}$. In the case Piau involving the Fédération internationale de football association (FIFA) the CFI recognised that for the purpose of Article $82 \mathrm{EC}$ the individual professionals as organised within their association occupied a collective dominant position (see Chapter 5.I.) and therefore were subject to the scope of that article. The CFI stated that the association can be regarded as the emanation of its members due to their affiliation to the association and the binding character of the regulations adopted by the association. ${ }^{2094}$ It furthermore stated that, as regatds the application of Article $82 \mathrm{EC}$, it is irrelevant that the FIFA is not itself an economic operator on the relevant market, since it would operate on that market through its members as their emanation.

At first sight the atgumentation seems to be catching also in respect of Article 86(2) EC. In both instances the application of either article depends on whether entities that do not themselves exercise an economic activity can be brought within the scope of an article that tequires that they would be. Compared to Article 86(2) EC the situation under Article 82 EC is somewhat reversed. Under Article $82 \mathrm{EC}$ the question is whether the addressees, i.e. the undertakings, are linked in such a way that they present themselves on a certain matket as a collective entity vis-à-vis their competitors, their trading partners and consumers. The association and its rules may be considered to provide the necessary (infra)structure in this regard; they symbolise the collectivity needed for the application of Article $82 \mathrm{EC}^{2095}$ The rule adopted by the self-regulatory body, which are complied with by the individual professional on pain of sanctions, constitute the behaviour of the collectively organised undertakings. The behaviour aimed for by Article $82 \mathrm{EC}$ emanates from a body which itself is not an undertaking but which links up the undertakings to come within the concept of collective dominance and therefore within the ambit of Article $82 \mathrm{EC}$.

The situation under Article 86(2) EC is different. Here the undertakings are in principle already eligible for the scope of that article and do not need the 'vehicle' of their association to be linked up in a way that would bring them within the field of application ratione personae

${ }^{2092}$ See paras. $184 \mathrm{ff}$. of the opinion.

${ }^{2093}$ In casu AG Léger found that the restriction on partnership between lawyers and accountants can contribute to protect the independence of lawyers, their professional secrecy and the need to avoid conflict of interests. ${ }^{2094}$ Case T-193/02, Piau I, [2005], paras. 107 ff., esp. 112 and 116.

${ }^{2095}$ See Case T-193/02, Piau I, [2005], 113 ff. 
of the article. For Article 86(2) EC it is rather the other way round, i.e. the professional body would need the crutch of representing collectively its members to avail itself of the benefit of the detogation contained in Article 86(2) EC. The argument would continue that the association as the emanation of its members operates the SGEI through its members and therefore could issue rules that are necessary for the performance of the SGEI its members are entrusted with. Hence, the argument conceivably includes associations of undertakings in the scope of Article 86(2) EC. Interestingly enough national competition laws may explicitly include associations of undertakings in what otherwise is a provision phased with Article 86(2) EC. Article $11 \mathrm{Mw}$ (the Dutch competition Act) for instance clearly refers not only to undertakings but also associations that may be possibly entrusted with the management (bebeer) of an SGEI ${ }^{2096}$ This explicit reference can be understood as both acknowledging a lacuna in Article 86(2) EC and respecting the uniform concept of undertaking in competition law. If however the opinion of Advocate General Léger is to suggest that associations are included because collective self-regulation would fulfil a role similar to Member State regulation, the ensuing question in the third hypothesis will be on who defines the SGEI.

\section{Including collective self-regulation for their affinity with State measures?}

In view of the neutrality that the Treaty adopts towards the form of regulation (cf. Article $295 \mathrm{EC}$ ) the question here is whether, in respect of the dissociation of author and beneficiary of Article 86(2) EC, professional self-regulation adopted by a collective body may be regarded as coming close to State regulation and thus is eligible to be justified under Article 86(2) EC. The idea is that Member States could perhaps just as well have introduced the same restrictive rule as has been adopted by collective bodies. Also this hypothesis appears to be built on an argument of substance and not of scope. This point is indirectly confirmed by Advocate General Léger in Wouters who turns to addresses "the restriction of competition caused by the Regulation" adopted by the NOvA only with regard to the substantive question of 'obstruction' or the necessity test within Article 86(2) EC. ${ }^{2097}$

In favouring the possibility to broaden the scope of Article 86(2) EC, one would compare the presumed intention or function of the State measures and the self-regulatory measures in the field of the professions. The assumption that a Member State has entrusted (the members of) a profession with the task of an SGEI (see below section 1.3.) entails that it has done so in the general interest. A State measure contrary to Article 86(1) EC and/ or Articles $3(1)(\mathrm{g}), 10(2)$ EC in combination with Article 81(1) or $82 \mathrm{EC}$ could be justified in light of Article 86(2) EC if it turns out to be necessary for the performance of the task of SGEI. Similarly, where a self-regulatory measure adopted by a professional association could be considered to be necessary for the performance of the same SGEI, the presumption would be that the self-regulatory measure would serve the general interest in the particular

\footnotetext{
${ }^{2096}$ Dutch competition act: " $\$ 2$. Uitzondering in verband met het vervullen van bijzondere taken - Artikel 11: Voor overeenkomsten, besluiten en gedragingen als bedoeld in artikel 6, eerste lid, waarbij ten minste een onderneming of ondernemersvereniging betrokken is die bij wettelijk voorschrift of door een bestuursorgaan is belast met het beheer van diensten van algemeen economisch belang, geldt artikel 6 , eerste lid, voor zover de toepassing van dat artikel de vervulling van de aan die onderneming of ondernemersvereniging toevertrouwde bijzondere taak niet verhindert."

${ }^{2097}$ What AG Léger probably did is to extrapolate to the association the case law on 86(2) EC and State measures - as if the association was implementing interests of the State, see para. 187 of his opinion, quoted before with note 2090 .
} 
service. The question then arises whether self-regulations with anti-competitive repercussions (but adopted in the general interest) should be treated alike with are State measures safeguarding the performance of the SGEI. The point comes down to assuming that in certain circumstances self-regulation has a quasi-official character when considered necessary for the performance of an SGEI. ${ }^{2098}$ Such an approach is problematic in view of the lack of democratic legitimacy of professional self-regulation, especially where the legislator would not itself adopt rules on the legal status of a professional activity. ${ }^{2099}$ In particular, professional bodies should be prevented from assuming a prerogative similar to Member States to organise and guarantee the functioning of SGEI, especially in light of the large discretion that Member States enjoy in defining what constitutes an SGEI in a particular case.

The point can also be regarded from a different angle that does not associate the selfregulatory body to the role of the State regulator in determining an SGEI. Returning to the objective of Article 86(2) EC and the perspective of the State, the assertion is that it should be the choice of a Member State whether to involve professional association in organising equal access to for instance healthcare, as it is for the Member Statc to adopt the appropriate measures in view of the general interest. In particular the neutrality of the Treaty with regard to the form of regulation leads to EC law being agnostic vis-à-vis any argument in favour of self-tegulation and its alleged efficiencies. ${ }^{2100}$ This agnosticism is, however, valid only for the choices Member States make; it does not cover choices made by associations of undertakings. This means that it is conceivable to extend the scope of the article so as to also cover State decisions that aim to involve professional associations in the realisation of the State's policy choices. The logical consequence of such inclusion is that a professional association is included because of its role in safeguarding the performance of the SGEI. ${ }^{2101}$

The ensuing question then is whether it is the form of self-regulation or the content thereof that is necessary for the performance of the SGEI. The purpose of Atticle 86(2) EC is to safeguatd the interest of Member States to use certain undertakings as an instrument of certain policy considerations of general interest in balance with the Community interest in ensuring compliance with the competition rules and the idea of the common matket. In this the article emphasises the role of undertakings in the process of guaranteeing the provision of SGEI. If a professional association was to be regarded as entrusted with an SGEI, its modus operandi of not exercising an economic activity inevitably influences the character of a task assigned to it tather than to its practising professionals. This means that an SGEI entrusted to a professional association would necessarily relate to the regulation and/or supervision of the profession in question. Consequently, an argument in favour of including a self-regulatory body within the scope of Article 86(2) EC would relate to the

${ }^{2098}$ One could also argue in favour of allowing regulations adopted by professional bodies within the scope of Article 86(2) EC because of the fact that the broadening of the article's ambit will not take away the subsequent and more critical scrutiny of whether either source of restriction - State measures or professional rules adopted by a collective body - would in actual fact be necessary for the performance of a certain SGEI.

2099 See above in section 1.2.5.3.2. on the example of the case law of the German constitutional court in respect of the inappropriate legal basis originally enabling the Bundesrechtsanwaltskammer ( $B R A K$ ) to adopt various kinds of professional rules.

${ }_{2100}$ On the arguments for and against self-regulation see, for instance, Van den Bergh R., (2006); Andrews P., (2002); Bortolotti B. / Fiorentini G. (Eds.), (1999); Black J., (1996); Ogus A.y (1995). See also above section T.2.2. ${ }_{2101}$ For contrariwise one could argue that the inclusion of measures adopted by associations of undertakings would interfere with the powers of the Member States to actually change the Treaty if they considered it necessary to also include associations in the wording of Article 86(2) EC. 
necessity of regulation and its reasonableness. ${ }^{2102}$ That is once more a substantive issue and not one of scope. Therefore, accepting within the ambit of Article 86(2) EC professional rules that have been adopted by an association would tevert to a justification by subject matter, risking to undermine an objective interpretation of the scope of the provision. Taking the content of collective self-regulation as being necessary for the performance of an SGEI moreover blurs that collective self-regulation is private tegulation, namely adopted by representatives of economic operators.

The conclusion under EC competition law so far is that where self-regulatory professional bodies are not organised as impartial entities independent of the economic interests of its members, they cannot themselves be entrusted with an SGEI; only their members may be. The ultimate ground for immunity that (professional) associations can invoke for their anti-competitive self-regulation is the State compulsion defence tather than Article 86(2) EC. ${ }^{2103}$ Even if adopted in the pursuit of a general interest should collective regulation not be put on level with State measures.

\subsection{Entrusted}

In order for Article 86(2) EC to apply to the professions it is necessary that the management of a scrvice of general economic interest has been entrusted on the practitioners as undertakings by an act of public authority. The latter point might not be problematic in law depending on the form that the relevant act takes. More complex is the question of whether a collectivity, i.e. a generally anonymous group of practitioners could be entrusted specifically with a particular task of GEI.

\section{Act of public autbority}

The public entity that entrusts undertakings with the operation of an SGEI must do so in the exercise of its functions as public authority. ${ }^{2104}$ The assignment of the task can be operated through a legal provision ${ }^{2105}$ or through other public law instruments like regulations, public law contracts, grants, etc. No specific formal act is needed with regard to the criterion of entrusting as long as it can be distilled from the combination of rules. ${ }^{2106}$ In other words a Member State must have taken sufficient legal steps to secure the provision of the service by the undertakings in question. ${ }^{2107}$

National laws or provisions regulating the liberal professions in the Member States generally contain rules that touch on particular aspects and characteristics of a profession

${ }^{2102}$ See already above section 1.2.5.3.2. on reasonableness versus strict proportionality in respect of the Wouters proviso.

${ }_{2103}$ Under the condition that the restriction would not entail an autonomous conduct by the bodies, see Chapter 6.II.3.

${ }^{2104}$ Buendia Sicrra J.L., (1999), para. 8.50.

2105 Case 10/71, Muller (Port of Mertert), [1971], para. 11.

${ }^{2106}$ Case C-159/94, Commission v French Republic (Electricity and Gas), [1997], para. 66. See also Case C-203/96, Dusseldorp, [1998], para. 103. Commission Decision Dutch bealth insuratce system, (2005), para. 4.2.1. In the latter case the Commission endorsed the new Health Insurance Act creating one single market for private health insurance in the Netherlands. In order to ensure solidarity, health insurers will be obliged by the Dutch Government to accept all citizens, and will be prevented from differentiating premiums.

${ }^{2107}$ Van Bael I. / Bellis J.-F., (2005), 1010. It is not enough though that the competent authorities merely approved of certain activities by a private initiative and legally uphold the activity, see Commission Decision Uniform Eurocheques, (1985), para. 66. 
which may be interpteted as expressing the idea that the professionals "bear special responsibility when performing the duties involved in defending the interests of the members of the public". ${ }^{2108}$ Advocate General Léger in Wouters stated that several of the Dutch legislative provisions gave grounds for accepting that the lawyers registered in the Netherlands were in fact entrusted with particular tasks of general or public interest by act of the public authorities. ${ }^{2109}$ The tasks refer to the right of audience before all courts in the Netherlands given to all lawyers registered in the Netherlands, and the provisions relating to disciplinary supervision lawyers are subjected to. The first argument refers to the legal monopoly lawyers enjoy in representing their client as a member of the public before all courts. The example of the right of audience can more generally be translated as the right for the professionals to exercise one of the core aspects of the SGEI in question. The Member State has chosen to confer such a right upon a group of practitioners by a legal provision to the exclusion of other groups. This pattern of including into legislative provisions certain reserved rights concerning core aspects of the different SGEI can be observed in many Member States. The aspect of disciplinary supervision required by State law can be interpreted - as did Advocate General Léger in Wouters - to reinforce the specific professional duties that combine with the task of SGEI, and therefore to reinforce the criterion of the professionals being entrusted by act of public authority. ${ }^{2110} \mathrm{It}$ is defendable that national provisions granting particular rights to professionals (with regard to the exercise of a certain SGEI) qualify the formal requirement of entrusting. ${ }^{211}$ The question is, however, whether it is possible to entrust an unlimited number of practitioners with the specific performance of an SGEI.

The collectivity of the members of a professional group as specific undertakings entrusted in a distinguishable manner?

A professional group consists of a multitude of individual entities and their number is in principle unlimited. ${ }^{2112}$ This could cause a problem with regard to the further requirement that the task of GEI must be assigned to specific undertakings in a distinguishable manner. ${ }^{2113}$ It is not enough that national legislation in a general manner simply defines the rules applicable to the activities of companies that intend to undertake certain activities related to the public interest. In such a case the Court would not accept that one or a number of these undertakings has or have been particularly assigned a task of general interest. ${ }^{2114}$ This is due to the fact that the rules ostensibly conferting specific functions on a particular number of undertakings could not be distinguished from the rules governing the activity of

${ }^{2108}$ See AG Léger in Case C-309/99, Wouters et al. v NOvA, [2002], para. 177.

${ }^{2109}$ Para. 177 of his opinion in Wouters.

2110 See AG Léger in Case C-309/99, Wouters et al. v NOvA, [2002], para. 177. In the opinion of the Advocate General especially the fact of being answerable to disciplinary bodies assumes that the professionals bear special responsibility qualifying them as being entrusted.

${ }^{2111}$ See AG Léger in Case C-309/99, Wouters et al. v NOvA, [2002], para. 177.

${ }^{2112}$ In certain Member States a particular professional group can easily have more than 100,000 members and continue to grow, see Chapter 1.I.1. For instance the number of lawyers in Germany has risen to about 120,000 practitioners in 2005 . On a yearly basis it increases by ca. 7 percent. In Italy the number of lawyers in 2008 has even reached the number of 210,000 .

${ }^{2113}$ See Case C-159/94, Commission v French Republic (Electricity and Gas), [1997], paras. 65 ff.; AG Stix-Hackl in Joined Cases C-3438/01, Enirisorse, [2002], para. 92.

2114 See Case 7/82, GVL, [1983], para. 31. 
other undertakings. ${ }^{2115}$

Consequently, the public act must be designed so as to apply only to a particular (group of) undertaking(s) distinct from other undertakings (potentially) competing for the same services. The numbet of the undertakings thus determined should in principle not play a tole as long as the undertakings presumably entrusted with an SGEI can be identified. ${ }^{2116}$ 'The case law in other fields of EC law show that the potentially large number of a group is not decisive to determine whether individuals are in a specific position to claim certain rights. What counts is that a certain privileged group is definable tather than defined in order to determine whether a particular claim can be made by an individual. ${ }^{2117}$ In particular the issue can be compared to the selectivity criterion under the State aid rules according to which it is to be determined whether, under a particular statutory scheme, a State measure is such as to favour 'certain undertakings' in comparison with others which, in the light of the objective pursued by the system in question, are in a comparable legal and factual situation. ${ }^{2118}$ For instance, in a case concerning medical practitioners the Court has confirmed that the large number of beneficiaries does not exclude the aspect of selectivity. ${ }^{2119}$

"The fact that the number of undertakings able to claim entitlement under [the national measure at issue] is very large, or that they belong to different sectors of activity, is not sufficient to call into question its selective naturc and therefore, to rule out its classification as State aid ... Similarly, aid may concern a whole economic sector and still be covered by Article [87(1) EC]". 2120

The same reasoning can be applied to the criterion of particularity in the field of Article 86(2) EC, thereby fostering a uniform interpretation of similar concepts.

Members of one professional group can indeed be distinguished from members of other professional groups or companies in a comparable legal and factual situation by the fact of their affiliation to a certain professional body representing a certain professional group. ${ }^{2121}$ Although their number may be large, professionals can be individualised by reference to the roll or professional register. Moreover, even where a certain professional group might not be organised by a particular association the practitioners would be identifiable by way of the specific professional duties a Member State imposes on them but not on other economic actors (competing of wishing to compete for similar services). The necessary act of entrusting does not need to be a general law, i.e. a law that would address all companies equally that intend to undertake the activities related to a certain general interest. Again a comparable question is dealt with in the field of State aid law where one finds that measures of purely general scope do not qualify the so-called selectivity critetion. However, even State

\footnotetext{
2115 In the same way the Court rejected the argument that the need to protect the environment or regional policy requirements can be considered to be specific tasks of the gas and electricity monopolies, given that similar obligations arc imposed on all economic operators, see Case C-159/94, Commission v French Republic (Electricity and Gas), [1997], paras. 69 f.; Buendia Sierra J.L., (1999), para. 8.55.

${ }^{2116}$ Conversely, the fact that only one undertaking would be providing a particular scrvice does not imply it is necessarily entrusted with an SGEI.

${ }^{2117}$ See for instance Joined Cases C-104/89 and C-37/90, Mulder and Heinemann, [1992], in which milk producers were allowed to claim damages for a loss resulting from the application of a Council regulation, although they belonged to a potentially large group of affected persons that were identifiable only by the scope of the regulation and the damage they suffered.

${ }^{2118}$ See for instance Case C-172/03, Heiser, [2005], para. 40.

2119 Casc C-172/03, Heiser, [2005], paras. $40 \mathrm{ff}$.

${ }^{2120}$ Case C-172/03, Heiser, [2005], para. 42, with reference to earlier case law.

${ }^{2121}$ As demonstrated in Chapter 5.I. the professional body can be regarded as the emanation of its members by virtue of its regulatory and supervisory powers. See Case T-193/02, Piau I, [2005], paras. $107 \mathrm{ff}$.
} 
measures which "at first sight [are] applicable to undertakings in general may present a certain selectivity and, accordingly, be regarded as a measure intended to favour certain undertakings or certain products" under certain conditions. ${ }^{2122}$

The practical consequence hereof is that, in a situation where a professional would be involved in private enforcement proceedings before a court for having infringed competition law - e.g. for presumably having applied unnecessary high minimum standards that made the service mote costly - the professional would be able to invoke Article 86(2) EC by arguing that she in particular, but together with maybe (hundred)thousands of other colleagues, had been entrusted with an SGEI.

On the overall it follows here that a distinction has to be made for the case of selfregulation adopted by an association of undertakings. This distinction can be drawn between, first, the act that entrusts the collectivity (and which might just as well be addressed directly to the association, cf. $A$ rticle $11 \mathrm{Mw}$ ) and, second, the SGEI or the public interest obligation that the members have to fulfil in their activities. This distinction echos the objective of Article 86(2) EC to reconcile a Member State's interest in using undertakings as instruments of its policy in the general interest with the Community's interest in economic in tegration, which emphasises the role of undertakings in the process of guaranteeing the provision of SGEI. It shall also be emphasised that probably most associations are not entrusted with the management of a task of public interest. As has been demonstrated in Chapter 4.I.2. ptofessional associations are not usually obliged by the law to observe public interest criteria. While one must be careful not to equate the requirements of Article 86(2) EC with those of the case law limiting the jurisdictional scope of the competition prohibitions, the illustrations given in Chapter 4.I.2.4. give a certain indication for the strictness with which the jurisdictional elements of Article $86(2)$ EC have to be applied. An application of Article 86(2) EC to professional regulation has been done by the Dutch competition authority and will be illustrated after a brief introduction to the substantive element of the atticle.

\section{Proportionality test: obstruction of the performance of the undertakings' task to provide an SGEI}

In the example of the facts of Wouters the question here is whether the abolition of the prohibition of multi-disciplinary partnerships would obstruct the performance of equal access to justice or, in the words of Advocate General Léger, obstruct "the effectiveness of the principle of access to the law and to the courts" and the possibility of "individuals to have a better knowledge and understanding of the rights granted to them and to enforce those rights more efficiently". Advocate General Léger acknowledged that it is for the national court to investigate the evidence in order to settle this issue, in particular in tespect of the proportionality of the professional rule to achieve the identified non-economic general interest. The test is whether the elimination of the contested measure would comptomise the fulfilment of the public service functions (i.e. the entrusted task). ${ }^{2123}$ The burden of proof as to the proportionality, i.e. whether there are less restrictive means to achieve the identified non-economic general interest, is on the Commission. ${ }^{2124}$ The application of the principle of

${ }^{2122}$ Case T-36/99, Lenzing $A G v$ Commission, [2004], para. 129, with reference to earliet case law. ${ }^{2123}$ See Case C-159/94, Commission v French Republic (Electricity and Gas), [1997]; Case C-157/94, Commission v Kingdom of the Netherlands (Electricity), [1997]; Case C-158/94, Commission v Italian Republic (Electricity), [1997].

${ }^{2124}$ See Van Bael I. / Bellis J.-F., (2005), 1017. (see Gas + Electricity cases). In those cases the Court rejected the Commission's action because its arguments had merely be of a general and legal nature. 
propottionality has already been illustrated earlier in this chapter ${ }^{2125}$, to which reference is made for reasons of brevity.

\section{Professional regulation: area of political conflict}

The practical difficulty of identifying whether a large number of practitioners have particularly been entrusted with the performance of a specific SGEI can be avoided in the case of Article $11 \mathrm{Mw}$ (the Dutch Competition Act) since it includes associations as addressees for this general justification avenue. In contrast to Advocate General Léger in Wouters the Dutch competition authotity (NMa) in Engelgeer found that the NOvA is not entrusted by statute or an administrative body with a concrete task of genetal economic interest. ${ }^{2126}$ The case in which the $\mathrm{NMa}$ had the occasion to hold so concerned a rule adopted by the NOvA that prohibits lawyers from charging their fees in relation to the result that they achieve for their clients. For instance are prohibited 'no cure no pay' agreements according to which the client owes her lawyer a fee only if a particular favourable outcome has been reached by the lawyer. In a quota pars litis arrangement the parties agree that the lawyer can eatn a certain percentage of the value of the result that the lawyer brings to the case. The NMa found first of all that the prohibition of a no win no fee rule restricts competition as regards legal advice provided in the field of personal injuries. The NMa moreover found that the NOvA was not entrusted by statute or an administrative body with a concrete task of general economic interest - i.e. the task of safeguarding the integrity, independence and partiality of the legal profession. Furthermore, the $\mathrm{NMa}$ held that to discharge the alleged task of general interest (if one were to accept that the NOvA would be charged with one) it was not necessary for the NOvA to adopt tules restrictive of competition. This latter conclusion would also hold true in case one considered the members tather than the professional body to be entrusted with a public interest obligation. The reason for the NMa to fail the no win no fee rule on the basis of the proportionality test is that the restriction of competition (i.e. price regulation in the form of prohibiting the application of success fees) goes beyond what is necessary to safeguard the deontological characteristics of the profession (integrity, independence, partiality).

However, due to technical reasons linked to the legislative process in the Netherlands the NMa nevertheless rejected the application made by $\mathrm{Mr}$ Engelgeer and refrained from opening proceedings against the NOvA. ${ }^{2127}$ Moreover, it considered that due to the traditions in the majority of the civil law countries in the European Union to prohibit success fees ${ }^{2128}$ it would not be appropriate either to impose a fine on the NOvA for the anti-competitive effects of the prohibition. Instead the NMa engaged in negotiations with the NOvA to convince it to allow a limited-period experiment with fee agreements on the basis of a no cure no pay or a quota pars litis rule. In late March 2004 the NOvA effectively changed the

\footnotetext{
${ }^{2125}$ Especially in sections I.4. and I.2.5.3.2.

2126 Engelgeer tegen Nederlandse Orde van Advocaten - 'no cure, no pay', (2002).

${ }^{2127}$ At the time the NMa took the decision in Engelgeer an amendment to the Advocatenwet was envisaged according to which the rule setting powers of the NOvA with regard to prohibiting success fees would come under the explicit supervision of the minister of justice. According to Articles 107 and $16 \mathrm{Mw}$ the cartel prohibition would not be applicable anymore in case the conduct restrictive of competition comes under the supervisory powers of State authorities other than the NMa. This specific national exception to the application of the cartel prohibition has, however, been limited to five years after the $\mathrm{Mw}$ entered into force in 1998, and thus was still in force the moment the NMa took its decision in Engelgeer.

${ }^{2128}$ Success fees are allowed in Ireland, the UK and Greece.
} 
relevant regulation on professional practice. ${ }^{2129}$ The government, however, has not agree with the introduction of such an experiment or with the abolishment of the prohibition of success fees. Nearly one year later the minister of justice annulled the new regulation ${ }^{2130}$ because he considered that the authorisation of such a fee would be in conflict with the independence of lawyers and the legal system in which the lawyer exercises her profession. ${ }^{2131}$

The striking point is that with the NMa's decision in Engelgeer it becomes apparent that professional rules are treated differently by the various jurisdictions. On the one hand, the Commission in EPI Code of Conduct expressed a view that 'purely deontological rules' should not be subject to the competition prohibition. ${ }^{2132}$ Conversely, the Court in Wouters, while not reverting to the same concept of purely deontological tules, finally applied a judge-made test to allow the professional rules at stake immunity from the competition prohibition on the basis of 'reasonable necessity'. ${ }^{2133}$ 'The NMa, on the other hand, found that the self-regulatory rules were not proportionate to protect the (supposedly non-economic but) essential characteristics of (the services provided by) the profession (de wezenskenmerken of kernkarakteristieken van de advocatuur) under Article $11 \mathrm{Mw} .{ }^{2134}$ While the ECJ in Wouters and the NMa in Engelgeer scrutinised the same concepts of independence, partiality, integrity and the pursuit of the client's interests of lawyers in the Netherlands, they came to different legal solutions. Remarkable is that the decision of the NMa preceded the judgment in Wouters by exactly one day and therewith demonstrated its will to contribute to the legal discussion and the development of competition law in the field of professional rules. The relevant differentiation following from the three cases mentioned in this paragraph seems to be between, on the one hand, rules motivated to safeguard the deontological characteristics of a particular profession and, on the other, the essential characteristics of (the services provided by) a profession. Two observations have to be made. First of all, the policy statements of the Commission subsequent to EPI Code of Conduct suggest that the Commission will not necessarily recognise a concept of purely deontological rules anymore. ${ }^{2135}$ Secondly, a concept of essential characteristics applied in both Wouters and Engelgeer refers to the conceptions put forward by the professional group concened, and probably does so inevitably. However, in light of the constitutional character of the competition law control explained earlier in this book the question is whether a more strictly objectivised standard of determining legitimate justification grounds within both Article 81(3) EC and Article 86(2) EC should be aspired. In other words a minimum

\footnotetext{
${ }^{2129}$ Verordening op de praktijkuitovening (onderdeel Resultaatgerelateerde Beloning) (Regulation on professional practice (quota pars litis)) (2004).

${ }_{2130}$ Making use of the Crown's powers under Article $30 \mathrm{AW}$ to interfere with decisions adopted by the organs of the NOvA should they be contrary to the law or the public interest.

${ }^{2131}$ Annulment of NOvA regulation on quota pars litis, (2005); Dutch Government, Verslag van een algemeen overleg (no cure no pay, quota pars litis), of 09.11.2004.

${ }^{2132}$ For details see Chapter 4.I.2.5.

${ }^{2133}$ Compare also Case C -519/04 P, Meca-Medina II, [2006], paras. 42 and 45, with its reference to restrictions of competition inherent to the rules of the game that have the "very purpose to ensure healthy rivalry between athletes". Despite the Court's reference to the Wouters proviso, this last reference to the rivalry between athletes is more comparable to the aim of the ancillary restraints doctrine than is the Wouters proviso. For details on the ancillary restraints doctrine see Chapter 4.II.1.2.2. and 4.II.4.2.

${ }^{2134}$ Engelgeer tegen Nederlandse Orde yan Advocaten - 'no cure, no pay', (2002), paras. $64 \mathrm{ff.}$

${ }^{2135}$ See for instance Evans L., et al., (2006), 10: "It would be helpful, democratic even, if thesc justifications [for various professional rules] were made explicit, also because it would help to focus on whether they are truly justified and whether they are not simply a transfer of rent - extra profits - to the professional from the customer."
} 
requirement seems to be that in case a professional tule is restrictive of competition (rather than of the freedom of action) it is for the State authorities to determine the essential characteristics of the profession, as follows from the example of the German constitutional court. $^{2136}$

\section{Community interest}

The last condition of Article 86(2) EC refers back to the objective of the article, namely to reconcile Member States' interests with the Community's interest. The Court is strict with regard to this test. This means that the Commission has to spell out the Community interest in reference to which the development of intra-Community trade is to be evaluated. ${ }^{2137}$ For the case of professional regulation the argumentation would need to demonstrate, on a caseto-case basis, that the self-regulatory professional rules thwart the economic integration of professional services markets. The result of this weighing depends on the SGEI identified and the concrete restriction of competition and in particular whether the prohibition of the latter would obstruct the performance of, for instance the equal access to a system of justice or a health care system.

\section{Closing remarks: the possible prospect of formulating policy guidelines?}

This chapter has presented the last facet necessary to come full circle in the assessment of the competition law system as applied to professional regulation. While it is necessary to acknowledge that professional rules restrict competition between service providers to the detriment of the ultimate consumers, one also has to concede that there are a number of public interest concerns - be they of an economic or non-economic nature ${ }^{2138}$ - that may justify certain restrictions. In fact the tripartite categorisation of public interests in regulation allows to realise that it is not necessary to polarise between public interests and competition law interests.

The thesis of this chapter is that the two justification grounds stipulated in the Treaty (one competition specific and the other general in character) provide the necessary safety net also for cases of professional regulation. The consequence hereof is that the judge made exemption that is the Wouters proviso should be discontinued, not least due to its manifest contra legem interpretation of the law. ${ }^{2139}$ The question however is whether the complementary system of economic and non-economic general interest justifications under Article 81(3) EC and Article 86(2) EC is equally available for both State and self-regulation of the professions.

Article 81(3) EC is first of all applicable to decisions by associations of undertakings, while Article 86(2) does not, according to its wording, apply to such decisions; tather the latter article is tailored to accommodate for the interests of Member States in using certain undertakings as an instrument of economic, fiscal or social policy and to balance those concerns against the Community's interest in economic integration. It can, however, be

2136 Sce above the text with note 1993.

2137 See Case C-158/94, Commissionv Italian Republic (Electricity), [1997]; Case C-159/94, Commissionv French Republic (Electricity and Gas), [1997]; and esp. Case C-157/94, Commission v Kingdom of the Netherlands (Electricity), [1997], para. 113, where the Court reminded the Commission of its duty under Article 86(3) EC to guarantee the principles set out in Article 86(1) and (2) EC by adopting appropriate decisions and directives addressed to the Member States.

${ }^{2138}$ See above section I.2.3, and diagram no. 7.

2139 For details see Chapter 4.П.4.2. 
argued that Article 86(2) EC can, at least in theory, be extended to decisions of associations so as to cover also non-economic objectives pursued by self-regulation. This interpretation is justified not least in view of national competition laws that include an SGEI-provision to cover undertakings but also their associations.

Conversely, and following the logic of the case law scrutinised in Chapter 6, it is conceivable to also apply Article 81(3) EC in conjunction with Articles 10(2) and 3(1)(g) EC in case of State regulation that induces (associations of) undertakings to act in contradiction with Article 81(1) EC. ${ }^{2140}$ Where Article 10(2) EC imposes obligations on Member States to respect the effectiveness of inter alia $\Lambda$ rticle 81 (1) EC it should be possible to also invoke a defence built on Article 10(2) EC in conjunction with Article 81(3) EC. Applying the quadruple yardstick of the latter article to State measures means to impose an objective testing. In particular a Member State would need to demonstrate that its measure is indispensable (Article 81(3)-[3] EC) to lead to economic (non-market) efficiencies (Article 81(3)-[1] EC) that benefit consumers and society as a whole (Atticle 81(3)-[2] EC) and does not eliminate competition on a substantial part of the matket (Atticle 81(3)-[4] EC). This means that a State measure may be exempted from Article 10(2) EC because it will not jeopardise the attainment of the objectives of the Treaty. This approach will also allow to put into perspective the case law on regulatory committees discussed in Chapter 4.I.2.2., which so far provides an exception ratione personae in certain (regulatory) circumstances and evidences the Court's deferential attitude towards the observance of a public interest criterion. That specific case law underlines that "in order to ensure that their action does not prevent, restrict or distort the operation of competition, the Member States must necessarily take account of the public interest.".2141 While the relevant public interest considerations may be determined domestically (see above section I.2.5.3.2.), it is worthwhile reconsidering whether it is teally "for the Member States to determine the criteria which best allow the Community rules of competition to be observed."2142

The opinion defended in this book is that the criteria of Article 81(3) EC are both sufficiently clear and flexible to take account of national public interest objectives. It does therefore not appear necessary to divert the law written into Article 81(3) EC. ${ }^{2143}$ In particular it does not seem necessary to move the balancing of competition concerns and public interest concerns outside Article $81 \mathrm{EC}$ as a whole ${ }^{2144}$ in order to safeguatd the purity and independence of the competition analysis (defended here). The system of both Articles 81(3) and 86(2) EC allow to take account of non-matket public interest considerations, be they of an economic and non-economic nature. Finally both provisions lend themselves to be applied to both State and self-tegulation in professional services markets. Arguably, Article 86(2) EC may not be as meaningful for most professional services sectors for two reasons. First of all, most regulatory objectives in professional regulation may

\footnotetext{
2140 See also Van Bael I. / Bellis J.-F., (2005), 988, who speak about "situations where the pro-competitive clements of State actions outweigh their restrictive effects".

${ }^{2141}$ Case C-38/97, Autotrasporti Librandi, [1998], para. $45-47$.

2142 Ibid (emphasis added).

${ }^{2143}$ Morcover, with the new regime of direct applicability adopted in Regulation 1/2003 the question has become redundant on whether Member States could have been required to notify their rules prima facie restrictive of competition.

${ }^{2144}$ See however Komninos A.P., (2006), $8 \mathrm{f}$., who propagates such an approach. Such a balancing outside Article $81 \mathrm{EC}$ as a whole seems to be artificial as it only creates an apparent tespect for the purity of the competition law analysis. A public interest balancing outside Article $81 \mathrm{EC}$ would boil down to an operation similar to accepting a mandatory requirements test, which is neither neccssary nor opportune in competition law.
} 
be identified as pursuing an economic (albeit non-market) objective. Secondly, the discussion above in section II.1.1. suggests that only few professional regulations can be understood to safeguard equal access to particular profession services. The arguable case of medical services markets is still in its infancy as the Commission just recently started to look into the provision of cross-border healthcare services. An adequate scrutiny of this (self-)regulatory sector merits its own research to balance the interests of public health care systems, on the one hand, and economic market integration, on the other. ${ }^{2145}$

The tripartite categorisation of public interest concerns in regulation and the (indirect) possibility for Member States to invoke Article 81(3) EC answers the relationship between the two justification grounds addressed in this chapter. This relationship is not simply determined by Article 81(3) EC being the competition specific justification and Article $86(2)$ EC being a general justification. ${ }^{2146}$ It is also, and perhaps more importantly, determined by the nature of the public interest pursued by a professional regulation. It has been argued in this chapter that both justifications cover non-market interests ${ }^{2147}$ and that the difference between the two articles comes down to the distinction between concerns having economically beneficial effects (even if not being primarily driven by economic cost/ benefit analysis) and concerns having beneficial effects for democtatic values (i.e. in particular for the equality of citizenship).

A more fundamental difference between the two provisions appears to reside in the discretion that the beneficiary of either article enjoys. In respect of the competition specific justification the defendant will not usually be confronted with its business decision underlying the restrictive agreement or decision being challenged. ${ }^{2148}$ Rather the case law of the Community institutions applies a (sliding scale of) reasonableness testing under Article 81(3)-[3] EC. For the case of collective regulation this book atgues, however, that due to principles of democratic legitimacy it is appropriate to subject this type of regulation to a strict proportionality test. Also Article $86(2) \mathrm{EC}$ does not seem to foresee for a principled attenuation of the proportionality testing. The wide discretion enjoyed under this general justification provision simply refers to defining the object of the exemption, i.e. what Member States regard as SGEIs, which is without prejudice to the applicable proportionality standard. ${ }^{2149}$ It is, however, for the Commission to demonstrate under Article 86(2) EC that there are less restrictive means to achieve the identified non-economic general interest.

\footnotetext{
${ }^{2145}$ See also Commission Decision Dutch bealtb insurance system, (2005).

${ }^{2146}$ On the relationship between the derogations contained in Article 86(2) EC and Article 81(3) EC, see also Buendia Sierra J.L., (1999), para. 8.139. For details on using the considerations of Atticle 81(3) EC in respect of Article 82 EC, see Chapter 5.II.3.

2147 See also Joined Cases T-528/93, T-543/93 and T-546/93, Métropole télévision, [1996], para. 118.

${ }^{2148}$ I therefore hesitate to agree with an - apparently - more principled stance adopted by Whish R., (2008), 127:

"It also would seem from paragraphs 107 and 108 of the Wouters judgment that the ECJ was disinclined to interfere with the Bar Council's assessment of the need for, and content of, the rules in question; the position should be contrasted with Article 81(3), where the burden of proof rests on the undertaking(s) defending the agreement and where the Commission insists on convincing evidence of economic efficiencies." While the obseryation by Whish is correct, it has been demonstrated in this chapter that the standard of legitimacy applied in the Wouters proviso and Article 81(3) EC respectively is one of a reasonable standard (cf. the sliding scale approach under Article 81(3) EC, above note 1861, 2148).

${ }^{2149}$ It does not seem to be the linc of the case law that the wide discretion in respect of determining an SGEI would impact the degree of proportionality test applied. In particular the case law allows the demonstration of less restrictive means, albeit that the Commission has a particularly onerous task in demonstrating a plausible case of less restrictive means equally effective to achieve the SGEI identified by a Member State and in spelling out the Community interest in reference to which the development of intra-Community trade is to be evaluated.
} 
The impression provoked by the systemic public interest defence raised by representatives of professional (self-)regulatots is that of a difficult, if not impossible, application of competition law principles to professional regulation. This chapter has pointed out that the (apparent) complexity of the discussion is mainly influenced by the lack of a clear distinction between economic and non-economic public interest objectives. Once such a categorisation is acknowledged ${ }^{2150}$, the applicable competition principles appear more manageable. Not least in view of the sometimes passionate discussion of public interest concerns pursued by professional regulation would it be desirable to foster legal certainty about the status of individual professional regulations by further developing the Community policy in this field - rather than to wait for difficult legal disputes before national jurisdictions. While the Commission has already been active to coin a competition policy in respect of professional regulation ${ }^{2151}$, an even stronger use of its powers to develop policy documents could clatify better its policy position through what are called notices, communications or guidelines. Such guidelines not only provide a platform to present an outline of the current state of the case law of the Court of Justice; they also intent to explain the Commission's policy with regard to issues that have not been dealt with in the case law, or that are subject to interpretation. Obviously any position expressed in a guideline is without prejudice to the (future) case law of the Court of Justice and the Court of First Instance interpreting the law. ${ }^{2152}$ A notice on the application of Articles 81 and 82 to the professional services sector could be an attempt to distil practical conclusions from the issues analysed in this book. The policy documents of the Commission so fat have been satisfied with putting an emphasis on competition advocacy with professional associations and regulators to review existing rules and to stimulate case work by national competition authorities.

An even more pro-active measure to be adopted by the Commission would be a block exemption regulation - a 'Schengen visa' for competition testrictions - specifically addressing the issues of this chapter. ${ }^{2153}$ The competence to adopt such regulations lies with the Council, Article 83 EC, and with the Commission to whom the Council has delegated powers to adopt regulations granting block exemptions. ${ }^{2154}$ As indicates the wording of Article 81(3) EC, the prohibition of Article 81(1) EC can be declared inapplicable to specific categories of agreements or practices by way of an overall or group exemption in the form of a regulation. In accordance with Article $249 \mathrm{EC}$ such a regulation is directly applicable and national competition authorities as well as national courts are bound to apply it. So far no such block exemption tegulation has been adopted for the field of the (liberal) professions to exempt certain types of rules regulating entry or exercise. ${ }^{2155}$ For the future, it would be

\footnotetext{
${ }^{2150}$ See de Witte B., (2006), $62 \mathrm{f}$.

${ }^{2151}$ Especially within the framework of the ECN subgroup for liberal professions, see Chapter 2.VI.

${ }^{2152}$ Explicitly stated so for instance in European Commission, Guidelines on the application of Article 81(3)EC, para. 7.

${ }^{2153}$ See also para. 60 of the judgment in Wouters: “.... it is always open to the Commission inter alia to issue a block exemption regulation pursuant to Article [81(3) EC]."

2154 Regulation No 19/65/EEC of 2 March 1965 on the application of Article 85 (3) of the Treaty to certain categories of agreements and concerted practices.

${ }^{2155}$ Before 1999 the Commission issued block exemptions of limited scope only. Since then a new type of block exemption regulation developed that abandoned the approach of restrictiog the exemption to certain specific agreements and clauses identified in the regulation. The new type of exemption provides a general exemption for all agreements and all clauses in a given category, subject only to a list of prohibited restrictions ("blacklisted clauses').
} 
worth considering for the Commission whether to declare the prohibition of Article 81(1) EC inapplicable to certain categories of professional provisions. As a workable basis for this the Commission will need to define a distinction between professional regulations that cleatly distort competition and those that contribute to improving the provision or distribution of professional services and to promoting economic progress (i.e. that yield cost and/ or qualitative efficiencies). ${ }^{2156}$

A block exemption regulation and/ or a notice would be an opportunity to formulate a range of concrete legal solutions applicable as appropriate to various forms of professional regulation. The policy document would be a perfect platform to lay out in particular the five avenues of immunity summarised in the introduction to this chapter (of which the Wouters proviso should be 'repealed') and, moreover, to identify professional rules considered to be necessary, in view of the specific (national) context of a liberal profession, to ensure and guarantee core competences of a profession that contribute to either economic or noneconomic efficiencies to the benefit of the consumer or citizen. Efficiencies visited in this chapter have referred to, for instance impartiality, competence, integrity and responsibility of the profession's members, the prevention of conflicts of interests and misleading information of the client, the protection of professional secrecy or the guarantee of the proper functioning of institutions ${ }^{2157}$, like for instance, justice (in case of the legal profession) or the health care system.

${ }^{2156}$ See European Commission, Professional Senvices - Scope for more reform, of 05.09.2005, paras. $24 \mathrm{ff.}$., 29, calling on Member States to conduct a more substantial and structural analysis of professional rules in order to determine the authority and need of each rule.

${ }^{2157}$ Rather than of the profession itself, as mistakeably assumed in the Wouters proviso; see Chapter 4.I.4.2. for details. 


\section{Conclusions}

The ambition of this book has been to identify solutions that will reflect the structure and broad logic of the Treaty provisions. This was the main theme around which an account of the legal questions posed by EC competition law - when applied to the professions - was centred. In particular the question has been to what extent EC competition law caters for public interest considerations that are being debated to motivate restrictive professional regulation. The main conclusions have been elaborated on during and at the end of each chapter, and throughout the chapters (especially in Chapters 3 and 4) concrete illustrations of some of my thoughts have been given on the basis of a few national examples. This chapter will nevertheless provide a mote concise answer to the main theme and offer some thoughts on the thesis of this research.

\section{$A$ matter of timing}

The conclusion of this book inevitably is that the judgment in Wouters has been rendered at an unfortunate moment in time. Since the application of competition law in respect of professional rules had only been gaining shape in the 1990s, the Commission had not yet established a firm policy or even enforccment practice when the Raad van State referred the case in 1999 for a preliminary ruling. Eventually, in the months preceding the judgment unfolded the fraudulent accountancy debacle of Enton (a US based trading powerhouse) unfolded as did the consequential reputation failure of the Arthur Anderson accountants, who ultimately were convicted for obstruction of justice because of having destroyed Enron documents. It is fairly safe to speculate that these events helped to convince the Court to effectively acknowledge some degree of permissibility of prohibiting multi-disciplinary partnerships between lawyers and accountants, in particular since Arthur Anderson had been the envisaged partner of Mr Wouters. ${ }^{2158}$ Only in 2002 the ECJ had not (yet) been at liberty to grant the Dutch bar association an exemption on the basis of the competition specific justification (Article 81(3) EC). ${ }^{2159}$ Consequently, having rightly ruled out in casu the applicability of the ancillary restraints doctrine, the Court could only have reverted to Article 86(2) EC - as had been suggested by Advocate General Léger. Notwithstanding the Court did not address the point, presumably since it felt the same legal difficulties that the $\mathrm{NMa}$ had expressed in Engelgeer, one day before Wouters, in determining a concrete public service obligation specifically entrusted to the members of the very professional

2158 For details on the facts of the case in Wouters sce Chapter 2.V.9.

${ }^{2159}$ For details on the procedural limitations at the time see Chapter 2.V.9. and Chapter 4.II.4.2.2. 
association. ${ }^{2160}$

While Advocate General Léger in July 2001, i.e. before the Enron debacle erupted, still was convinced that the national court should determine whether the prohibition of multidisciplinary partnerships was necessary in order to safeguard the independence and professional secrecy of Dutch lawyers, the ECJ, in late February 2002, did not leave things to chance and explicitly tuled that "the 1993 Regulation ... does not infringe [Article 81(1) EC], since [the NOvA] could reasonably have considered that that regulation $\ldots$ is necessary for the proper practice of the legal profession, as organised in the Member State concerned." 2161 A similarly resolute outcome was reached the same day in Arduino for State rules that, in the rule-making process, involve representatives of the profession regulated.

Ever since the adoption of these two judgments, the Commission seeks contact with national regulators, NCAs and stakeholders (professional associations and consumer organisations) in an effort to promote more structurally competition advocacy and policy building (rather than strict enforcement of the competition law principles) and to increase transparency and enhance consumer empowerment. ${ }^{2162}$ The Commission's advocacy has certainly raised the awareness of these parties, especially that of NCAs through the ECN's sub-group for the (liberal) professions. Examples of national policy building, but also of case work of law enforcement, have multiplied in the past few years, in particular also in those Member States that have joined the European Union only duting the new millennium. This book has repeatedly referred to a few national examples in order to illustrate the relevance of the competition law application in the professional services sector.

Admittedly, the option of handing down a judgment without the Wouters proviso ${ }^{2163}$ would potentially have had far reaching consequences for both the Commission and professional associations to assume and realise the notification obligation under the old Regulation 17. While an alternative solution could have avoided a (partial) regulatory vacuum even back in 2002, namely by simply limiting the legal effects of the competition prohibition in time (for instance by allowing a transitional period of two years or until the time that Regulation $1 / 2003$ came into force ${ }^{2164}$, the judgment in Wouters must perhaps nevertheless be considered a necessary intermediate step in developing EC competition law: first, it clearly has reinforced the application of competition law in respect of professional services sectors and, second, it certainly has acuminated the discussion on the balancing of national public interest considerations in competition law that have a non-market nature.

The initiative of DG Competition to advocate policy building and transparency with stakeholders shows that the Commission has understood well that after the creative case law of Wouters and the far less imaginative case law of Arduino there is a strong need to flesh out more concretely a sound approach towards competition law and the professions. While this

${ }^{2160}$ For details see Chapter 7.П.

${ }^{2161}$ Para. 110 and second dictum of the judgment in Wouters (emphasis added).

${ }^{2162}$ For details see Chapter 2.VI.

${ }^{2163}$ The expression 'Wouters proviso' is used in this book as shorthand for identifying the part of the Wouters judgment that, as some have observed, reads like a dissenting opinion (1.e. paras. 97-110 of the judgment). The notion 'Wouters proviso' is preferred here to the notion 'Wouters rule' or 'Wouters exception' in order to avoid the impression that the Court has established an accepted standard in applying the law. For details see Chapter 4.II.4.1.

${ }^{2164}$ For details see Chapter 4.II.4.2.2. Limiting the effect of Article 81(2) EC rather than limiting the ambit of Article 81(1) EC would have safeguarded the effectiveness and credibility of both the prohibition rule and the existing statutory grounds for justification. 
need seems to be less pressing without a case pending or, in the alternative, a transitional period for adaptation, the Commission itself has set the clock running with its ambition to "make good progress by 2010 " on better regulation of professional services as part of the broader context for the relaunched Lisbon strategy for growth and employment in the EU. ${ }^{2165}$ Before giving my own suggestions on the perspectives of the principle of free competition in the common market for professional services in part II of this chapter, the following will give a brief summary of the twofold systematisation achieved in this book of the concepts of EC competition law.

\section{A twofold systematisation}

The first systematisation undertaken concerned both the jurisdictional and substantive concepts of the two competition prohibitions; the second concerned the grounds for immunities from the competition prohibitions.

\section{Systematising the application of competition law to the professions}

The central concept for the applicability of competition law is that of 'undertaking', and therewith the economic chatacter of the activity that an entity exercises. As a consequence of the functional approach adopted in Höfner the further concept of 'association' of undertakings has an accessory nature. In Chapters 3.I. and 4.I. a critical account has been given of two lines of case law that result in limiting the jurisdictional scope in respect of, on the one hand, essential functions of the modern welfare State and, on the other, certain selfregulatory bodies. In respect of the first line of case law ${ }^{2166}$ my contention ultimately has been that after Glöckner the opportunity has emerged for the case law to develop towards a mote coherent approach in balancing between, on the one hand, activities that are necessarily carried out by or under the control of public authority (this relates to the imperative public authority criterion) and, on the other, those activities that can, at least in principle, be provided in order to make profits (this relates to the comparative market criterion). ${ }^{2167}$ Extrapolating the case law out-competing the Höfner tule to the professions is a delicate exercise and its application has been rejected by the Court in Wouters. The illustration by examples taken from several professional sectors in Chapter 3 has in any event not provided a definite answer as it significantly depends on the particular details of national statutory regulation recognising and building up the content of the relevant professional activity. In light of the fine distinction made in Meca-Medina II between rules regulating an activity and the persons exercising that activity, it is strongly doubted whether, for the particular case of the liberal professions, the case law based limitation to the universal application of competition law will catch on. Rather the suggestion made in Chapter 3 has been that a criterion of benefaction or charity would allow a mote objective exploration of the limits of the scope of competition law. According to such a criterion a market player may not obtain a competitive advantage. The benefit of such a critetion is that it can be applied independently of conventional, prevailing or typical views on what should be outside the remit of, and therefore not justiciable under, competition law. Applied to the sector of

\footnotetext{
${ }^{2165}$ For details see Chapter 1.I. and Chapter 2.VI.

${ }_{2166}$ In particular cases $S A T /$ Eurocontrol and Cati.

${ }^{2167}$ For details see Chapter 3.I.2. and diagram no. 3 on the latitude of the jurisdictional scope of (EC) competition law.
} 
professions services my criterion proves to be apt to exclude from the scope of application a self-contained system of legal aid - provided the service providers do not gain a competitive advantage.

In respect of the second line of case law ${ }^{2168}$, it has become clear that self-regulatory activities by professional associations, even where mandated by the legislator, are justiciable under competition law if national legislation does not strictly stipulate specific public interest requirements beyond the interests of the regulated sector. The case law rightly formulates this tequirement as an obligation ("must"). Consequently, it is for the parliamentary legislator to specify the relevant public interest criteria. Such statutory determination has to be in explicit terms. A general reference in the law to 'the general interest' will not do since the Court requires national legislation to foresee procedural arrangements and substantive requirements capable of ensuring, with reasonable probability, that a self-regulatory body conducts itself like an arm of the State working in the public interest. The fact that a professional association or its members assume a task in the public interest that is related to the exercise of the professions (e.g. integrity) will not suffice to declassify the professional body as an addressee of competition law. Most importantly, the Court in Wouters clearly identified the proper practice of the profession as a category of interests that it is not willing to accept as a public interest criterion in order to delimit the jurisdictional scope ratione personae. ${ }^{2169}$

Furthermore, it has been pointed out in Chapter 3.II. that the broad interpretation of the concept of effect on trade between Member States has a double importance. First of all, it allows a scrutiny of restrictive measures even where an actual cross-border element is absent, so that EC competition law may also apply to purely internal situations, provided that they represent a substantial part of the common market. Secondly and due to the effect stemming from the supremacy of Community law, national competition authorities and courts can, and are obliged to, set aside national rules, even of a legislative nature, where these influence market conduct of economic entities. In Chapter 6 the discussion of the relevant requirements imposed by the case law on Member States in respect of their obligations under Articles 10(2) and 86(1) EC and the effet util of competition law has shown that the Court is satisfied with a formalistic application of the three-pronged Van Eycke test. Put differently, the Court seems to be agnostic as to whether the ultimate control responsibilities of delegated to economic operators (or their representatives) is effectively exercised by the competent State authorities. Overall the caution of the Court to recognise the involvement of private parties in the process of sector specific rule-making can be understood as the intention of the Court not to interfere with the reason why Member States involve interest groups or 'experts'. My suggestion has, however, been that the third prong of the Van Eycke test is different from the first two prongs, namely that it applies only to cases of gross violations of democratic principles accepted in the Member States. ${ }^{2170}$ The first two prongs of the Van Eycke test could finally be lifted to the same level as the freedom of movement rights, namely to prohibit State measures that allow undertakings to testrict the freedom of competition.

The scrutiny of the substantive elements of the competition prohibitions in Chapters 4 and 5 yielded differing conclusions. For most part the systematisation in Chapter 4.II. was concerned with, first, demonstrating competition-testrictive features of professional

\footnotetext{
${ }^{2168}$ In particular cases CNSD II, Arduino, Cippolla and Macrino. For details see Chapter 4.II.

${ }^{2169}$ Para. 62 of the judgment in. Wouters.

${ }^{2170}$ For details see Chapter 6.П.2.1.
} 
regulations and, second, distinguishing the approach of the Wouters proviso from the concept of restriction and the concept of ancillary restraints. In Chapter 4.II. the Wouters proviso has been identified as a contra legem development of the law that grants a judge-made exemption extraneous to the system of competition law. This finding finally has allowed, in Chapter 7 , the putting of the Wouters proviso into perspective with the explicit justification possibilities foreseen in the Treaty.

Chapter 5 in its turn has allowed the development from sctatch of the application of Article $82 \mathrm{EC}$ to the professions. In respect of the jurisdictional elements of the two competition prohibitions, the first common conclusion from Chapters 4 and 5 has been that self-regulatory measures emanating from a professional body ${ }^{217}$ qualify as both decisions of an association of undertakings under Article 81(1) EC and manifestation of the collectivity under Article $82 \mathrm{EC}$. In respect of the substantive concept of abuse it has been argued that it is the combination of the emanation adopting professional rules and the implementation of these rules by its members that manifest an abuse of the dominant collectivity (or emanation) 'by proxy'. ${ }^{2172}$ Apart from the fact that the interpretation of Atticle $82 \mathrm{EC}$ is not burdened by the creative solution put forward with the Wouters proviso (shrinking the ambit of the article), the advantage of discussing also Article $82 \mathrm{EC}$ in respect of professional regulation is that certain features of the professions appear to be more pronounced. For instance, the concept of super-dominance is helpful in establishing a specific category of responsibility for self-regulating dominant collectivities, which is at the interface with the prohibitions of exploitative abuses and effects-based abuses. This means that self-regulation perceivably stipulating normal competitive behaviour is on the verge of being qualified as instrumental conduct. For this category of abusive conduct no objectivised intent or plan to eliminate competition, new business forms or new forms of services needs to be established on the part of the profession. The suggestion therefore is that it will generally not be necessary to prove whether a particular professional self-regulation has the purpose of strengthening the collective dominant position of the profession's members as long as it has the natural and foreseeable effect to alter the structure of the professional services market. This result is reasonable in view of the wide impact that professional self-tegulation has in the market, especially since this impact does not emerge through competition on the merits but is based on the collective presentation and the support that self-regulation often receives from State authorities like the government or even the judiciary. ${ }^{2173}$ In summary, the consequence of the super-special responsibility under Article $82 \mathrm{EC}$ is that it is for the ptofessional association to demonstrate that it has not made an instrumental use of the statutory monopoly of the collectivity to provide certain professional services. Conversely, claimants suffering from exclusionary and exploitative professional self-regulation do not need to demonstrate in how far such self-regulation has the effect of limiting the competitive process in professional markets. It is in this eased burden of proof for claimants (especially consumers) that lies the substantive interest in applying Article $82 \mathrm{EC}$ to professional selfregulation. The corresponding positive obligation on the side of the emanation of a ptofession with a statutory monopoly for the exercise of certain professional activities converges with fundamentals of democratic rule making.

The overall plea in respect of the jurisdictional and substantive elements of both competition prohibitions is in favour of an objective interpretation thereof that is

${ }^{2171}$ For details on the concept of emanation, see Chapter 5.I.

${ }^{2172}$ For details see Chapter 5.II.1.

${ }^{2173}$ For details see Chapter 5.II.2.2.1. 
independent of national preferences. With the adoption of a competition chapter in the EC Treaty the Member States have made a policy choice in favour of establishing a level playing field for market participants. A Communitarian interpretation of the competition prohibitions ensures that economic actors are prevented from delimiting the Common market alongside national borders. In particulat, taking account of the specific context in which an agreement or decision has been adopted, or is applied, must not lead to a watering down of the standard of the ancillary restraints doctrine and to limiting the ambit of the competition prohibition by reference to the "overall context" as has done the Wouters proviso. Any national particularities determining the regulation of professional setvices can be taken into account within the two justification grounds systematised in Chapter 7.

\section{Systematising the grounds of immunity}

The reason why it has been important to demonstrate that the Court in Wouters could have chosen an alternative solution more appropriate to the credibility and effectiveness of the competition prohibition has been to unscal a discussion on applying the competitionspecific exemption to the professional services sector. The impression is that advocates of strict professional regulation - after having lost the battle on the jurisdictional ground stress the professions' importance for the public interest in order to sustain that professional regulation would not fit the (further) system of competition law, including its explicit exemption in Article 81(3) EC, and thus merit a specific exemption from the general law.

However, the cumulative and exhaustive character of the four criteria of Article 81(3) EC speak against maintaining an extra-statutory exemption as proposed in Wouters and Meca-Medina II. In fact, once the economic character of a professional tule has been identified, it is clearly conceivable that despite its competition-restrictive effects it yields economically beneficial effects for consumers, even where the regulation pursues non-market objectives. This thesis obviously requires regulatory bodies (whether of a State or selfregulatory nature) to neatly identify the benefits that a particular professional regulation is likely to produce - instead of systematically invoking a public interest defence. This follows from the distribution of the burden of proof and matches the butden of proof standard developed here for collective emanations in respect of Article 82 EC.

It has been argued that, even if the Wouters ptoviso did not constitute a contra legem interpretation of Article $81 \mathrm{EC}$ and could be identified as a disguised application of the third paragraph, it is necessary to interpret the thitd condition of Article 81(3) EC (indispensability) strictly and to apply a full proportionality test - including the quest for less restrictive means - in case of enforcement agencies or courts being confronted with collective regulation. ${ }^{2174}$ The Wouters proviso only provides a fragmentary model, in particular since the Court easily accepted that the (empty) national concept of the 'proper practice of the profession' provided by the legislator be filled in the way the self-regulatory body has done for the case of the Dutch legal profession. However, the determination of the crucial or key values of a profession has a constitutional dimension, as has been demonstrated by the German constitutional court 15 years before $W$ outers. A systemic public interest defence should therefore not be accepted unsifted in competition law.

This is not to say that public interest considerations could not be invoked in competition law to justify professional regulations. This book argues that the concept of public interest

${ }^{2174}$ For details see Chapter 7.I. 
has to be understood as a generic category of policy objectives that not only comprises noneconomic values but also encompasses economic interests, possibly of a non-matket nature. ${ }^{2175}$ In particular it is not necessary to polarise public interests and competition law as the latter itself is a public interest concern. Moreover, it does not seem necessary to move the balancing of competition concerns and public interest concerns outside Article $81 \mathrm{EC}$ as a whole in order to safeguard the purity and independence of the competition analysis (defended here). The system of both Articles 81(3) and 86(2) EC allow account to be taken of non-market public interest considerations, be they of an economic or non-economic nature. Finally, both provisions lend themselves for application to both State and selfregulation in professional services markets. Arguably, Article 86(2) EC may not be as meaningful for most professional services sectors for two reasons. First of all, most regulatory objectives in professional regulation may be identified as pursuing an economic (albeit non-matket) objective. Secondly, the discussion in Chapter 7.II.1.1. has suggested that only few professional regulations can be understood to safeguard equal access to particular professional services. The arguable case of medical services markets is still in its infancy as the Commission just recently started to look into the provision of cross-border healthcare services. An adequate scrutiny of this (self-)regulatory sector merits its own research to balance the interests of public health care systems, on the one hand, and economic market integtation, on the other.

Article 86(2) EC accentuates that the system of Community law has to strike a balance between the need to protect undistorted competition within the common market, on the one hand, and the respect for the powers of the Member States to adopt economic regulation, on the other. This may, however, not lead to equating a task of general economic interest in the sense of Article 86(2) EC with powers exercised by or under the control of a public authority; otherwise economic services of general interest would not come within the scope of the competition prohibition in the first place and Article 86(2) EC would become devoid of any practical application.

In the ongoing debate on the relevance and competitiveness of professional (self- or State) regulation the underlying understanding is that some form of invigilation of the professions and their service provision should be exercised. My systematisation has set out to contribute to the ground from which to undertake a candid and mote detailed discussion of the detriments and benefits of professional regulation. The following is an essay on the prospects of developing an even mote coherent application of competition law to professional tegulation.

\section{Perspectives}

The twofold systematisation inevitably leads to the question whether further reflections can be had from the observations of this book. Finally, this part will offer some questions that the Community should clarify in its policy stance regarding professional regulation.

\section{Legal implications of the principle of free competition in the common market}

The two most remarkable issues emerging from the exercise of systematising the application of the competition law rules to the professions are the following: first, whether

${ }^{2175}$ For details see Chapter 7.I.2.3. 
in competition law the acceptance of a particular professional rule depends on the rule's regulatory origin, i.e. whether it is adopted through State rules or self-tegulatory ('private') rules. The second actually is a reflex of the first, namely whether professional rules restricting the trade patterns between Member States should be teviewed by the standards of competition law rather than by the standards of the free movement rules.

\section{Developing towards a uniform legal approach for professional State and self-regulation?}

In actual tetms, it is insignificant whether restrictions of professional service provision have their seeds in self-regulatory agreements/ decisions or in State regulatory measures. Moreover, also 'private' collective rules are formulated in abstract terms just as are 'public' laws - albeit that the former do not (usually) have the same legally binding force as State laws. The question then is whether to subject both types of regulation to a similar legal review standard in competition law. The Commission in its 2004 and 2005 reports on the competition in professional reform, but most importantly in Cipolla, set out to give a fresh impetus to subjecting in particular State regulation (where it incites economic operators or their representatives to act in contradiction to the principle of free competition) to a general proportionality test. Moreover, it seeks to establish this proportionality test as applicable across the board, i.e. also to self-regulatory rules. ${ }^{2176} \mathrm{~A}$ uniform legal approach for both types of regulation would lead to more clatity and plainness in the application of the law, but also to competition rules that ate simpler to administer.

As perennial favourite in EC law, the principle of proportionality obviously is an educated guess in determining the review standard of a restrictive measure. Also in this book it has been a tecurring topic, namely in respect of the ancillary restraints doctrine under Article 81(1) EC, the indispensability criterion of Article 81(3)-[3] EC, the concept of abuse under Article $82 \mathrm{EC}$, the 'obstruction' element of Article 86(2) EC, and even in respect of the $W$ outers proviso. The position specifically taken by DG Competition - the Commission's legal service is more conservative in this respect - has the merit of focussing the discussion of the competitiveness of professional rules on the effective review-ability of competitionrestrictive rules regulating the professions (in particular as an alternative to the formalistic approach adopted by the Court in respect of the Van Eycke test and State measures ${ }^{2177}$ ).

The question first is whether, in respect of the negative integration obligation under Article 10(2) EC, it is adequate to subject State measures to a general standard of proportionality. While this standard with its quest for suitable and necessary measures that do not go beyond what is necessary to achieve the objective(s) putsued by a restrictive measure provides for a detailed test, the question at this point can not be whether it would be appropriate to involve professional associations in the rule-making process. It is the Member States' competence to make certain policy choices and implement economic regulation (cf. Article 86(2) EC), and the Court will not interfere with the reasons why a Member State involves interest groups or 'experts'. Nevertheless, Chapter 6.III. has proposed a nuanced approach to a substantive testing of State intervention in professional services markets, using a threefold gradation of legal teview.

First, where the State measure covers up for a competition-restrictive decision of a professional association, the Court has made clear that a Member State infringes its obligations under Articles 86(1), 10(2) and 3(1)(g) EC where it "deprive[s] its own legislation

${ }^{2176}$ For details see Chapter 2.VI. and Chapter 6.II.2.2.3.

2177 For details see Chapter 6.II.2.2. 
of its official character by delegating to private traders responsibility for taking decisions affecting the economic sphere" (Van Eycke test, third prong). Yet, it is conceivable that Member States may invoke the ancillaty restraints doctrine for their acts in respect of $V$ an Eycke and Spediporto. Member State authorities would need to objectively demonstrate that they did not intend to require or favour the adoption of anti-competitive agreements between undertakings, nor to reinforce their effects, nor that they intended the delegated powers to be used in an anti-competitive way. Instead they would need to demonstrate that they pursued a different aim, e.g. to increase the variety or quality of professional services, or that the (association of) undertakings misused their delegated powers to adopt and propose anti-competitive rules. ${ }^{2178}$ Finally, it is necessary within the ancillary restraints test to demonstrate that the professional rule ultimately adopted is proportionate.

Second, in a situation where a State measure has the nature of a genuine State measure (i.e. irrespective the involvement of a self-regulatory body at a certain stage of the rulemaking process), the Court so far has not taken a stance in respect of whether an analysis of the substance of the State measure is allowed. The scrutiny rather ends in the case law where the Court came to the conclusion that a Member State had not 'deprived its own legislation of its official character by delegating'. The position of the Commission in Macrino, and the opinions issued by Advocate General Léger in Arduino and Advocate General Jacobs in Pavlov demonstrate, however, that Van Eycke and Spediporlo do not represent a closed enumeration. The Commission and the Advocate Generals have initiated a discussion on the future development of $V$ an Eycke (and, consequently, also of Spediporto). The aim thereof is to subject $S$ tate measures to a proportionality test where they have been adopted under the influence of regulatory bodies from the relevant sector. A proportionality test is legitimate because once the Member State measures are subject to the exclusive competition control of the Community by virtue of the Member States' obligation under Article 10(2) EC, it is legitimate also to scrutinise the necessity of the substance of those State measures. In other words, the burden of proof should be reversed as soon as a Member State involves a selfregulatory body in the rule-setting process. It is, however, conceivable that a Member State may successfully invoke Article 81(3) EC in conjunction with Article 10(2) EC, demonstrating that a professional rule restrictive of competition is justified on the basis of economic non-market considerations, and that it is proportionate.

Third, where the State measure has been adopted without the involvement of a professional body, it takes the form of a general law that is binding for the practitioners to conform their economic behaviour as such. Once more the issue of the Member States' tight to economic self-determination competes with the Community's exclusive competence to control testrictions of the freedom of competition. In view of Articles 86(1), 10(2), 4 and $98 \mathrm{EC}$ some form of Community competition law control should be contemplated even for general laws limiting competition between undertakings. Some deference towards the Member States' competence to adopt economic regulation is however appropriate, especially in fields for which the Community is not (exclusively) competent, like for the regulation of liberal professions. To balance the tespective interests of the Community and the Member States, the aim would be to subject this third category of State measures merely to a reasonableness testing (for the absence of a manifest error of assessment) instead of a full

${ }^{2178}$ In respect of the Member State authorities similar rules on the burden of proof as discussed in Chapter 4 will have to be applied. If the Member State complies with Articles 86(1) and 10(2) EC, only the professional association's decision will be investigated, without the possibility of invoking the State compulsion defence. For details see Chapter 6.II.3. 
proportionality test (with its quest for less restrictive means). This point has potential for the future and requires teleological reasoning with regard to Articles 86(1), 10(2) EC, the effet util of competition law and the impact that the founding fathers of the Treaty foresaw for Member States.

Conversely, for self-regulatory rules it is adequate to apply a strict proportionality test in justifying them, due to the fact that this type of regulation is adopted by a collectivity (with or without statutory monopoly rights). ${ }^{2179}$ The illustrations of national examples in Chapter 4.I.2.4. have suggested that self-regulatory professional bodies lack democratic legitimacy as they usually are composed of members of the very profession, therewith representing the specific interest of the group rather than of the general public. Protecting democratic values is a worthwhile task in constructing the equality, or expectation, of citizenship as the core of democratic principles of social justice. ${ }^{2180}$ It is crucial that it is exercised in an unbiased, i.e. objective way. Therefore, where professional representatives assume responsibility for protecting specific non-market values in respect of either Article 81(3) EC or Article 86(2) EC, they have to demonstrate that their competitionrestrictive measures are proportionate, and in particular that no less restrictive means could achieve the specific public interest objective.

\section{Monitoring the legality of professional regulation by competition rules}

The most significant difference between competition law and the rules of free movement for the topic of the present book is perhaps one of jurisdiction and competence, ultimately allowing the rationalisation of the application of diverging substantive tests under the two sets of Community rules. The interstate trade criterion of competition law is constructed in broader terms ("may affect trade") than that of the free movement rules, which require an actual trans-border element. Since cases of testrictive professional rules potentially fall within both fields of EC law one may be inclined to advocate on substance that, in order to avoid conflicting decisions between the two policy fields, both sets of rules should be applied in a converging way. ${ }^{2181} \mathrm{EC}$ competition law, however, also applies to cases in which the parties are domestic players - provided that the restrictive rules may have appreciable effects on a substantial part of the Community. ${ }^{2182}$ This fact asks for an appraisal of the potential that EC competition law has in monitoring the legality of rules regulating professional services markets, whether adopted by self-regulatory bodies or the State. In fact, the two sets of Treaty rules can no longer be seen to be divided in respect of their (public or private) addressees ever since cases like INNO $\nu A T A B$, on the one hand, and Bosman or Angonese on the other. ${ }^{2183}$

However, a certain divergence can be observed when turning to the legality standard of a general proportionality testing suggested in this book for collective rules that have the (natural and foreseeable) effect of restricting competition. Applying such a general test in respect of the principle of free competition may possibly lead to divergence with the decisional practice in respect of the principle of free trade. Which type of conceivable divergence do I mean? Every now and then, when applying the objective justification test

${ }^{2179}$ For details see Chapter 7.I.2.5.3.2. and Chapter 5.II.3.

2180 Whereby citizenship defines the right to have rights. For details see Chapter 7.I.2.3.

${ }^{2181}$ Compare for instance para. 122 of the judgment in Wouters.

2182 For details see Chapter 3.II.

${ }^{2183}$ For details see Chapter 3.II.2.2.5. 
under the free movement law, the Court reverts to a testing of teasonableness (i.e. assessing that no manifest error of assessment is committed) rather than to testing effectively less restrictive means. The hypothesis (to be verified) could be that the Court does so in cases where harmonisation measures of Community law are absent, and does so due to the shared competences between the Community and the Member States to adopt measures with the aim of progressivcly establishing the internal market in which the free movement of goods, persons, setvices and capital is ensured (Articles 95 and 14 EC). Only in case of full harmonisation does this (legislative) competence become an exclusive one of the Community - in which case the Court will not hesitate to subject national tules to strict proportionality testing.

Linking the assumption of leniency being applied by the Court in cases absent harmonisation measures with the view that it would be desirable to avoid conflicting decisions under the two sets of Treaty rules would mean that also in competition law a reasonableness standard would apply in the absence of Community measures harmonising conditions of the professional activities scrutinised. ${ }^{2184}$ My opinion is, however, that even in the absence of harmonisation measures, a strict proportionality test can and should be applied to collective self- and State rules regulating the professions in respect of competition law because this policy field is a matter of exclusive competence of the EC. ${ }^{2185}$ In particular Articles 81 and $82 \mathrm{EC}$, including their exemption system, provide for the necessary objective framework, which - as has been demonstrated in this book - can be applied to the professions like to any other sector of the economy. Any (national) peculiarities in the provision of professional services can be taken into account, provided they ultimately yicld beneficial effects for consumers, i.e. citizens. These benefits have to be identified and demonstrated by the self-regulatory bodies or State authorities adopting professional rules as part of their more general obligation of transparency and good governance. Thus, it is perfectly defensible to separate the development of interpreting concept(ion)s in the law on free movement and competition (as done for instance in Meca-Medina II for the concept of economic activity). Whether this is desirable finally transforms into the question of whether the intensity of the proportionality testing applied in the field of free movement should, in light of Article $10 \mathrm{EC}$, structurally follow that in competition law, rather than vice versa.

\section{Reason: what ought to be}

In an attempt to contribute its share to the development of competition law this book ends with offering some thoughts that the Community should further clatify in its policy stance regarding professional regulation. Some considerable stocktaking of the various forms of restrictive professional rules has been, and still will be, done by national (competition) authorities $^{2186}$, the moment has come to direct the debate on the modernisation of the professions towards exploring more systematically the exemption system that competition law offers in order to achieve better regulation ${ }^{2187}$, tather than deregulation. The future

${ }^{2184}$ See para. 99 of the judgment in Wouters where the Court seems to make this allegation. For details see Chapter 7.I.2.5.3.2.

${ }^{2185}$ In as far as its jurisdiction is concerned. For details see Chapter 3.II.

${ }^{2186}$ For instance in the framework of the National Reform Programmes that the Member States are requircd to adopt and implement under the Lisbon strategy. For details see Chapter 2.VI.

${ }^{2187} V$ iq. to improve new legislation and to review existing rules with the aim of simplifying professional regulation. 
development of the law depends on the power of persuasion with which the EC proposes to embrace the benefits of the completion of the internal market for services as set out in the relaunched Lisbon strategy.

In a future policy document (a notice, a sectoral action plan as a result of the National Reform Programmes, or even a Block Exemption Regulation), which the Commission is recommended to develop, the following issues in particular should be reasoned out in order to win the profession's heart for the modernisation of their rules from a competition law perspective, and to give guidance to practitioners, their clients and associations, NCAs and national courts.

\section{Concerming the field of application of the competition probibitions}

In respect of the field of application of competition law the concepts of Atticle 81(1) EC are by now fairly squared by the decisional practice of both the Commission and the Court with regard to professional regulation. While they should certainly be addressed in the policy document suggested, there is no specific need to highlight them here. Their application will further evolve with the case work by national competition authorities. The suggested policy document should, however, flesh out Article $82 \mathrm{EC}$ and its application to professional regulation and regulatory structures, which has not yet sufficiently been considered by the Community institutions. The CFI's judgment in Piau should be used as a stepping stone into concretising the concepts of emanation (as a particular form of collectivity), super dominance and super-special responsibility. The latter tests on collectively organised professions since, due to the regulatory powers they assume, they have particularly effective tools to behave independently of their competitors, their costumers and ultimately of their consumers, especially where they enjoy statutory monopoly rights to exercise (particular forms of) a professional activity. This book has demonstrated that professional regulation, where applied by the practitioners, can lead to both instrumental use of market power and matket structure abuses. ${ }^{2188}$ In summary, the consequence of the super-special responsibility under Article $82 \mathrm{EC}$ is that it is for the professional association to demonstrate that it has not made an instrumental use of the statutory monopoly of the collectivity to provide certain professional services. Conversely, claimants suffering from exclusionary and exploitative professional self-regulation do not need to demonstrate in how far such self-regulation has the effect of limiting the competitive process in professional markets. It is in this eased burden of proof for claimants that lies the substantive interest in applying Article $82 \mathrm{EC}$ to professional self-regulation. The corresponding positive obligation on the side of the emanation of a profession with a statutory monopoly for the exercise of certain professional activities converges with fundamentals of democratic rule making.

\section{Concerning regulatory structures involving State measures}

In order to strike a fair balance between subjecting State measures to the INNO $v A T A B$ principle and the State's competence to adopt economic regulation as reinforced by $A$ rduino and Macrino, the suggestion to be made here is to apply a common standard overarching the three prongs of Van Eycke. Instead of having the third prong of Van Eycke in practical consequence prevail over its first two prongs, the suggestion is that the genuineness of the

${ }^{2188}$ For details see Chapter 5. 
charactet of State measure is a useful benchmark to ascertain whether competition law is the approptiate standard to assess the legitimacy of a State measure under Articles 10(2) and 86(1) EC. ${ }^{2189}$ The point requiring further clarification is how to assess this genuineness. Subsequently, the operation will be to elaborate on the intensity of the legal review to which State measures shall be subjected, possibly achieving a sliding scale of legal review as suggested in this book. A hopeful start has already been made by the Community, first, by the Commission in its 2005 Report on professional services and the scope for more reform, in which Member States are called upon to identify and scrutinise the regulatory structures in professional regulation, i.e. the relationship between State regulation and selfregulation. Second, the Court in Cipolla has spelt out demanding steps that national courts have to take in order to test the proportionality of a national measure - albeit in respect of Article $49 \mathrm{EC}$. The aim in any event suggested in this book is to prevent that the guard decides on the degree to which it controls the fox it set to keep the geese.

\section{Concerning the justification system of competition law}

In respect of Article 81(3) EC one particular point should be clarified concerning (decisions of) associations. In its guidelines on the application of Article 81(3) EC the Commission has little considered to make adjustments for these. Decisions of associations are collective regulation: they are formulated in abstract terms and apply to a group of cases. Thus, these decisions do not constitute concrete business judgments of economic entities that the Commission does not intend to second guess in respect of the indispensability requirement of Article 81(3) EC. Collective professional rules effectively take business decisions out of the hands of individual practitioners when prohibiting in general terms, for instance, multi-disciplinary partnerships between law firms and accountancy firms. It is thus that a strict proportionality test should be applied, in contradistinction from the usual approach applied in respect of Article 81(3)-[3] EC. Moreover, the current effort of the Commission to modernise the application of Article $82 \mathrm{EC}$ should include to further clarify the relationship that the Article has with Article 81(3) EC.

More importantly, it would be helpful to map out concrete public interest criteria to legitimise professional regulation. The concept of public interest is the generic or superordinate category of policy objectives in regulation. In particular, it would enhance legal clarity and certainty to categotise regulatory interests along the lines proposed in Chapter 7 . Thete it has been demonstrated that also under Article 81(3) EC public interest objectives can serve as efficient grounds for justification, despite being of a non-market nature. In fact, a threefold categorisation has been suggested to define what are market interest (eligible for the ancillary restraints doctrine), economic non-market interest (eligible for Article 81(3) EC) and non-economic non-market interest (eligible for Article 86(2) EC). A sector-by-sector scrutiny in professional services markets would be required to assess which professional structures in the Member States yield non-economic benefits for society at large to benefit from the (general) exemption system of EC competition law. Here lie the chances for professional representatives to distinguish themselves, namely where they conclusively demonstrate fundamental benefits for consumers/ citizens that justify the non-application of the competition law prohibitions.

Moreover, the application of the proportionality test could be programmed in concrete

${ }^{2189}$ For details see Chapter 6.II. 
terms and thus tendered more tangible to become more predictable. More specifically it would be helpful to map the interests of professionalism for the various sectors and what are their market and non-market benefits (e.g. equal access). Especially also under Article 81(3) EC one may and should proceed to assess less restrictive means due to the collective character of professional regulation that is not democratically legitimised. At this juncture it appears important to clarify the relationship of the competition law standard with Directive 2006/123 and its minimum standard of legitimacy testing (the Services Directive). It stipulates that

"Member States shall ensure that commercial communications by the regulated professions comply with professional rules, in conformity with Community law, which relate, in particular, to the independence, dignity and integrity of the profession, as well as to professional secrecy, in a manner consistent with the specific nature of each profession. Professional rules on commercial communications shall be non-discriminatory, justified by an overtiding reason relating to the public interest and proportionate."2190

While limited to commercial communications (except in respect of estate agents), it gives an idea to where to develop the law. However, recital 114 of this directive stresses that

"Member States should encourage the setting up of codes of conduct, in particular, by professional bodies, organisations and associations at Community level. These codes of conduct should include, as appropriate to the specific nature of each profession, rules for commercial communications relating to the regulated professions and rules of professional ethics and conduct of the regulated professions which aim, in particular, at ensuring independence, impartiality and professional secrecy. In addition, the conditions to which the activities of estate agents are subject should be included in such codes of conduct. Member States should take accompanying measures to encourage professional bodies, organisations and associations to implementatnational level the codes of conduct adopted at Community level."

At first the stipulation appears sensible; its beginning and ending, however, elicit a state of alert as they could be (mis)interpreted as an invitation to contravene the spirit of Articles 86(1) and 10(2) EC. In this perspective there is a need to clarify the position of competition law in respect of institutionalised lobbying.

\section{Passion: to act professionally}

In Chapter 4 it has been demonstrated that the reference in Wouters to 'the proper practice of the profession' is a bogus argument to limit the scope of Article 81(3) EC. However, this book cannot end without paying homage to the many professionals who exercise their métier with a zeal for high competences and standards of quality in order to help their clients solve their problems. Professionalism is a question of attitude that applies not only to (liberal) professionals, but to anyone who exercises her activities and interests with dedication. In this sense the 'proper' exercise of a profession is one that is passionate - which in turn is rational behaviour (even if unconsciously adopted) since it leads to serving clients well - and happy clients make happy professionals.

${ }^{2190}$ Article 24(2) of Directive 2006/123/EC of the European Parliament and of the Council of 12 December 2006 on services in the internal market (Emphasis added). Recital 101 specifies that "Tt is necessary and in the interest of recipients, in particular consumers, to ensure that it is possible for providers to offer multidisciplinary services and that restrictions in this regard be limited to what is necessary to ensure the impartiality, independence and integrity of the regulated professions. This does not affect restrictions or prohibitions on carrying out particular activities which aim at ensuring independence in cases in which a Member State entrusts a provider with a particular task, notably in the area of urban development, nor should it affect the application of competition rules." 


\section{Samenvatting}

Het spanningsveld tussen regels die de (vrije) beroepen teguleren en het Europese mededingingsrecht

Sinds de jaren 1990 is het Europese mededingingstecht door de Europese Commissie en het Hof van Justitie van de Europese Gemeenschappen toegepast op de vrije beroepen. Het Hof van Justitie heeft echter in haar rechtspraak nooit het volledige scala aan rechtsvragen opgelost, of überhaupt behandeld, die worden opgeworpen wanneer het Europese mededingingsrecht wordt toegepast op de specifieke sector van de vrije beroepen. Dit boek beoogt een volledig beeld te geven van de teikwijdte van de ingreep van het mededingingsrecht in de markt van professionele diensten. Daarbij worden de oplossingen geïdentificeerd die de structuur en de systematiek van de verdragsbepalingen eerbiedigen. In het bijzonder wordt beoogd tot een tweeledige systematisering te komen.

Ten eerste worden de criteria voor de toepassing van de relevante verbodsbepalingen van het Europese mededingrecht (artikel 81 lid 1 en artikel $82 \mathrm{EG}$ ) gesystematiseerd met betrekking tot de regels die de toegang tot en de uitoefening van een betoep reguleren. $\mathrm{Om}$ volledig te zijn, beschrijft het boek de verplichtingen die volgens artikel 86 lid $1 \mathrm{EG}$ en artikel 10 lid 2 EG op de lidstaten rusten wanneer zij zich mengen bij de regulering van de vrije beroepen.

Omdat de modus operandi van de (vrije) beroepen niet alleen de tocgang en de beroepsuitoefening beperkt, maat vooral traditioneel beschouwd wordt als zijnde in het algemeen belang, beoogt het boek ten tweede de rechtvaardigingsgronden in kaart te brengen die immuniteit van de twee verbodsbepalingen waarborgen - welke anders het onvermijdbare juridische gevolg van onwettigheid of nietigheid te wegen zullen brengen. Het opstellen van een volledig overzicht van de immuniteitsgronden in het Europese mededingingstecht voor het gebied van professionele regulering is bijzonder uitdagend geworden tha het artest Wouters waar het Hof een uitzondering heeft uitgevonden die niet in de verdragsbepalingen voorzien was.

In feite is de fundamentele vraag die de complexiteit van de juridische problemen het beste karakteriseert als volgt: in hoeverte laat het Europese mededingingstecht overwegingen van openbaar belang toe, die worden bepleit om beroepsregulering te rechtvaardigen? Zoekend naat een antwoord is het nodig om de reikwijdte van de bescherming van beroepsregulering opnieuw te belichten. Het doel is om regelgevende belangen te concretiseren als onderdeel van een reeks specifieke normen die ontvankelijk zijn voor juridische toetsing. Het is in het bijzonder nodig om het gebruik van een diffuus begrip van algemeen belang te herzien. Dit gebruik heeft in het verleden geholpen om een veilige haven voot de beroepstegulering te creëren.

Deze fundamentele vraag overstijgt de directe toepassing van de rechtvaardigingsbepalingen van het EG-Verdrag. Beroepsregulering wordt vaak gedaan in de vorm van zelfregulering en staatsregulering. Omdat de distributie van respectievelijk regelgevende en toezichthoudende autoriteiten is overgelaten aan toeval in de zin dat elk 
beroep in elke lidstaat anders is georganiseerd, zou de kans om een bepaalde beroepstegel te rechtvaardigen afhangen van de afkomst van de regel. Dit zou op het eerste gezicht erg willekeurig zijn. Daarom wordt tenslotte onderzocht of en in hoeverre het mogelijk is om een uniforme juridische aanpak te ontwikkelen met betrekking tot het rechtvaardigen van zowel zelfregulerende maatregelen als staatsmaatregelen in beroepsregulering.

Het specifieke referentiekader van dit boek is te vinden in de verdragregels betreffende de mededinging "voor de ondernemingen", d.w.z. de artikelen 81 tot en met 86 EG. De materiële reikwijdte van dit boek is beperkt tot deze artikelen aangezien er geen secundaire wetgeving is op gemeenschapsniveau die de professionele dienstensector zou onderwerpen aan een marktorde die afwijkt van het algemene systeem van het Europese mededingingsrecht. Het onderzoek is echter niet beperkt tot zelfregulering, d.w.z. regels die door de beroepsbeoefenaars en hun vertegenwoordigers zijn aangenomen, maar neemt ook de nationale tegelgeving in beschouwing, en zodoende het nuttig effect van het Europese mededingingsrecht.

De vrije beroepen die in dit boek behandeld worden, betreffen de klassieke, d.w.z. de juridische, medische, technische en accountant berocpen. Tegenover het verweer dat deze beroepen een maatschappelijke of publieke rol aannemen (naast hun economische belang), wordt in dit boek gekeken naat het belang van de maatschappij om een effectief systeem te hebben voor, bijvoorbeeld de gezondheidszorg en de rechtsbedeling, en andere waarden waarvan etkend wordt dat ze de grondbeginselen zijn voor het functioneren van een maatschappij die gebaseerd is op de rechtsstaat.

De uitwerking over de mededingingsbeginselen en de systematiek van het Verdrag zal noodgedwongen vrij abstract blijven. Om de algemene thema's en juridische oplossingen nader uit te werken, worden vootbeelden van bestaande nationale regelgeving en beroepsorganisaties geintroduceerd in de verschillende hoofdstukken. De selectie is hoofdzakelijk afkomstig van vier jurisdicties: Frankrijk, Duitsland, Nederland en het Verenigd Koninkrijk. Hoewel deze vier landen een gevestigde traditie van beroepsreguleting hebben, zijn hun ervatingen met het toepassen van het mededingingsrecht op de vrije beroepensector verschillend. De mate van beroepstegulering in het Verenigd Koninkrijk en Nederland is relatief laag en gaat gepaard met proactieve mededingingsautoriteiten en ministeries die de vrije beroepen willen moderniseren door de invoering van marktwerking om zo de betreffende dienstenmarkt te openen. Het niveau van beroepsregulering in Frankrijk en Duitsland is in het algemeen hoger dan in het Verenigd Koninkrijk en Nederland. Terwijl de Franse mededingingsautotiteiten vroeg waren met het verbieden (d.m.v. het nationale mededingingsrecht) van bijvoorbeeld tariefregelingen die door beroepsvereniging waren aangenomen, zijn de Duitse mededingingsautoriteiten op hun beurt erg terughoudend geweest met het nemen van maatregelen ten aanzien van de beroepen ondanks het goed ontwikkelde nationale mededingingsrecht. Deze terughoudendheid verklaart zich door de wettelijke oorsprong van vele beroepstegels, welke het nationale mededingrecht niet kan toetsen in het licht van de machtenscheiding.

In de analyse van het Europese mededingingstecht en de beroepsregulering is er hoofdzakelijk gekozen voor een juridische, d.w.z., een op regels georiënteerde aanpak. Vanwege het algemene karakter en de bewoording van de toepasselijke regels (bijvoorbeeld artikel $10 \mathrm{EG}$ ), wordt in de juridische analyse zowel de praktijk van de Commissie als de jurisprudentie van het Hof onderzocht. Het onderzoek daarvan is niet beperkt tot het relatief kleine aantal sectorspecifieke zaken, maar besteed ook aandacht aan de gevestigde en minder gevestigde principes die afgeleid zijn uit de jurisprudentie in vetschillende sectoren; de 
bedoeling hiervan is bij te dragen aan de ontwikkeling van het recht op het gebied van de vrije beroepen. Uiteindelijk leidt deze aanpak tot een blik op de mogelijkheden die het Europese mededingingsrecht biedt met betrekking tot het houden van toezicht op de wettigheid van beroepstegelingen.

Bovendien concentreett het boek zich op een kwalitatieve analyse van zowel de bestanddelen die de twee verbodsbepalingen vormen, en de gronden voot immuniteit in het mededingingsrecht. Het onderwerp van deze juridische analyse is de regelgeving die de berocpen organiseert en reguleert. Hun status wordt buiten beschouwing gelaten, aangezien deze vooral afhankelijk is van de waatnemingen en tradities die moeilijk juridisch te definiëten zijn. De kwalitatieve analyse van de gronden voor immuniteit concentreert zich op de economische en niet-economische overwegingen waarover op nationaal niveau een discussie gaande is om de wettigheid van regelgevende ingreep in de beroepensector te toetsen. Om te kunnen controleren in welke mate deze gronden vergelijkbaar zijn of juist verschillen van inhoud voor zowel zelfregulerend en staatsregulerende beroepsregels, is het eerst noodzakelijk om de jurisprudentie die het toestaat om de respectievelijke vormen van beroepsregulering immuun te laten zijn van de mededingingsverboden, aan een nauwkeurig onderzoek te onderwerpen. Daarnaast is het noodzakelijk om een vergelijking te maken tussen de materiële overwegingen van het Hof die in concreto tot een acceptatie van immuniteit van de mededingingstechtverboden geleid hebben. Ook al zal zo een materiële vergelijking slechts een poging blijven, gezien de stand van de rechtspraak na Wouters en Meca-Medina II enerzijds en Arduino en Macrino anderzijds, brengt deze vergelijking de terughoudendheid naat buiten die het Hof heeft met betrekking tot betoepstegulering.

Om de systematiek en de structuur van de verdragsbepalingen te waarborgen en om de ongewenste consequenties van de juridische creativiteit van de Wouters uitspraak te vermijden, stelt het boek voor de discussie omtrent de afweging van nationale overwegingen van publieke belang in de beroepsreguleting opnieuw te definiëren. Het is vooral noodzakelijk om de tweedeling tussen het mededingingsrecht enerzijds en niet-economische belangen anderzijds, waar vaak aan wordt vastgehouden in juridisch en economische literatuur, te verlaten. Terwijl een duidelijkere definitie van niet-economische belangen de gevestigde belangen in twijfel trekt, is dit noodzakelijk met het oog op het feit dat het mededingingsrecht ook het algemene belang in acht neem $t$, ook al is dit een specifiek belang.

Niettegenstaande het duidelijke, al dan niet voorgenomen, effect van beroepstegels van de respectieve dienstmarkten, zal et geen expliciete economische of prestatiegerichte benadering worden aangenomen in dit boek. Hiet liggen twee redenen aan ten grondslag. Ten eerste zijn de algemene juridische thema's al voldoende complex. Het systematische toepassen van een concurrerende benadering creëert het risico de helderheid van de presentatie te vertroebelen. Ten tweede is de economische theotie over de reden en effectiviteit van de economische regulering goed ontwikkeld in de doctrine, in het bijzonder met betrekking tot de vrije beroepen. Dit boek beoogt daarom niet de huidige stand van de economische discussie te onderzoeken, maar gebruikt haat conclusies, welke, in ieder geval voor economisten, gemeen goed zijn geworden.

Verder volgen de geselecteerde nationale voorbeelden meer een illustratieve benadering dan een volledige dekking. Dit is gerechtvaardigd omdat, ten eerste, de gekozen vootbeelden een eerlijke representatie zijn van de verschillende facetten van beroepsregulering die Europa kent, heeft gekend of opnieuw zal zien verschijnen, wanneer aan de inspanningen van de Commissie om de vrije beroepen te moderniseren geen gehoor wordt gegeven door de verenigingen en de nationale regelgevers. Ten tweede is het bereik van beroepsactiviteiten 
dat beheerst door regelgevende instrumenten zeer divers. De beschrijvingen van het recht van specifieke beroepen zijn daarom niet uitputtend.

Hieronder wordt per hoofdstuk beschreven welke onderwerpen behandeld worden.

Hoofdstuk 1: Inleiding - Naast het uitleggen van het doel, de reikwijdte en de benadering van het boek, geeft dit hoofdstuk een schets van de economische, regelgevende en moderniserende context waar de beroepen voor staan in Europa. Het spanningsveld tussen beroepsregulering en het Europese mededingingsrecht wordt duidelijk tegen de achtergrond van de volhardende kracht waarmee sommige beroepsvertegenwoordigers en politici de waargenomen wettigheid van beroepstegels verdedigen. Echter, de traditionele argumenten ten gunste van beroepsreguleting, moeten worden getoetst aan de juridische argumenten als de betrouwbare basis om alle aspecten van het Europese mededingingsrecht te onderzoeken, inclusief het systeem van immuniteiten.

Hoofdstuk 2: Juridische problemen in perspectief - Opbouwend naar de uitgebreide inventarisatie van de reikwijdte voor ingreep door middel van het mededingingstecht in de hoofdstukken 3 tot en met 6 , geeft dit hoofdstuk een uitgebreide achtergrond naar de eerste systematisering toe. Dit bevat een overzicht van de historische ontwikkeling van de vrije beroepen, de noodzakelijke grondslagen in de cconomische theotie en de Europese mededingingsregels, de ontwikkeling en de toepassing van de medingingstegels op de vrije beroepen doot de Commissie en het Europese Hof van Justitie (dit bevat ook een overzicht van sectorspecifieke rechtszaken) en de meer recente beleidsontwikkelingen op Europees en nationaal niveau.

Hoofdstuk 3: Vrije beroepen en de reikwijdte van Europese mededingingsrecht - De twee algemene elementen voor de toepassing van Europese mededingingsrecht zijn kritisch onderzocht in dit hoofdstuk: ten eerste, de mate waarin beroepsactiviteiten een economisch karakter hebben, en ten tweede de potentiële invloed van beroepsregels op de handel tussen lidstaten. Er wordt vootal een kritische beschouwing gegeven van de rechtspraak die de toepassing van het mededingingstecht beperkt ten aanzien van de essentiële functies van de moderne welvaartstaat. Mijn standpunt is dat sinds Glöckner de mogelijkheid is opgekomen om een meer samenhangende benadering te erkennen bij het afwegen van enerzijds activiteiten die noodzakelijk worden uitgevoerd bij of onder de controle van de publieke autoriteit, en anderzijds activiteiten die in principe beogen winst te maken. Mijn illustratieve voorbeelden bewijzen dat een erkenning of bepaalde beroepen essentiële functies van de moderne welvaartstaat uitoefenen voornamelijk afhangt van de details van de toepasselijke nationale wettelijke regeling. Naat aanleiding van het subtiele onderscheid gemaakt in Meca-Medina II tussen regelingen gericht op een activiteit en regelingen gericht op personen die de activiteit uitoefenen, wordt in dit hoofdstuk gesuggereerd dat er een criterium van liefdadigheid is. Dit criterium maakt het mogelijk om beter de competentiegrenzen van het mededingingsrecht te verkennen, omdat dit criterium onafhankelijk van traditionele, heersende of typische inzichten kan worden toegepast op wat buiten de reikwijdte valt en daarom niet berechtbaar is onder het mededingingsrecht. Toegepast op de sector van professionele dienstverlening bewijst mijn criterium geschikt te zijn om bijvoorbeeld een zelfvoorzienend systeem van rechtshulp uit te sluiten, mits de dienstverlener niet een concurrentievoordeel verkrijgt.

Hoofdstuk 4 en boofdstuk 5: Artikel 81 lid 1 en artikel 82 EG - De twee hoofdstukken concentreren zich op de meer specifieke elementen van de twee mededingingsverboden en onderzoeken de rol van beroepsverenigingen in het regelgevingproces. De eerste gemeenschappelijke conclusie van de hoofdstukken 4 en 5 is dat zelfregulerende maatregelen 
afkomstig van een beroepslichaam gekwalificeerd kunnen worden als zowel besluiten van een ondernemersvereniging volgens artikel 81 lid $1 \mathrm{EG}$ als ook de uiting van de collectiviteit (en haar mogelijke machtspositie) volgens artikel $82 \mathrm{EG}$. De systematisering in hoofdstuk 4 onderzoekt ten eerste de mededingingsbeperkende kenmerken van een aantal beroepregels en onderscheidt ten tweede de benadering die wordt aangenomen doot het Hof in Wouters met betrekking tot de materiële concepten van beperking en bijkomstige belemmeringen. Het hoofdstuk stelt in het bijzonder vast dat het Wouters voorbehoud met zijn overdadige verwijzingen naar de context in plaats van de specifieke economische context van een zaak, een contra legem rechtsontwikkeling is, dat een doot de rechter gecreëerde uitzondering toekent, die buiten het verdragsysteem van het mededingingsrecht staat. In hoofdstuk 5 wordt voor het eerst artikel $82 \mathrm{EG}$ op de vrije beroepen toegepast. Daarmee geeft dit hoofdstuk een nieuwe impuls richting het moderniseren van de meest traditionele beroepen. De basisbevinding van dit hoofdstuk is dat de combinatie van betoepstegels afkomstig van een beroepsvereniging en de toepassing ervan door haar leden, zich manifesteert als een misbruik (bij volmacht) van de dominante collectiviteit. Het voordeel van het bespreken van artikel $82 \mathrm{EG}$ is dat bepaalde kenmerken van beroepen scherper naar voren komen. Het concept van superdominantie bijvoorbeeld, is behulpzaam bij het vaststellen van een specifieke categorie van verantwoordelijkheid van zelfregulerende dominante collectiviteiten. Samengevat, het gevolg van de superspeciale verantwoordelijkheid onder artikel $82 \mathrm{EG}$ is dat het aan een beroepsvereniging is om aan te tonen dat het geen instrumenteel gebruik heeft gemaakt van het wettelijke monopolie van de collectiviteit om bepaalde professioncle diensten aan te bieden. Daar tegenover staat dat eisers (in het bijzonder consumenten), die lijden onder uitsluitende en uitbuitende beroepszelfregulering niet hoeven aan te tonen in hoeverre dergelijke zelfregulering het mededingingsproces in een professionele markt beperkt. De corresponderende verplichting aan de zijde van het zelfregulerende lichaam convergeert met de fundamenten van democratische legitimiteit van regelgeving. Meer algemeen pleiten de hoofdstukken 4 en 5 voor een objectieve interpretatie en toepassing van beide mededingingsverboden onafhankelijk van nationale voorkeuten.

Hoofdstuk 6: Statsinterventie in beroepsregulering - Nationale mededingingsautoriteiten en rechtbanken hebben de plicht om nationale regelgeving buiten werking te stellen, zelfs als het wetgeving betreft, die professionele dienstverleners en hun vertegenwoordigers ertoe brengen de mededinging te beperken. Dit is het gevolg van het gemeenschapsrecht en het nuttig effect van het mededingingstecht. Dit hoofdstuk behandelt daarom de verplichtingen die op lidstaten rusten op grond van artikel 10 lid 2 en artikel 86 lid 1 EG. Het Hof lijkt echter terughoudend te zijn ten aanzien van de uiteindelijke controle van regelgevende verantwoordelijkheden die gedelegeerd zijn aan economische actoren (of haar vertegenwoordigers) en of deze effectief worden uitgeoefend door de bevoegde overheidsinstanties. In het algemeen kan de behoedzaamheid waarmee het Hof de betrokkenheid van private partijen in het regelgevingproces van specifieke sectoren erkent, begrepen worden als de intentie van het Hof om zich niet te bemoeien met de beweegredenen van lidstaten om betoepsverenigingen als 'experts' te gebruiken. Ik bepleit echter dat de formalistische toepassing van de laatste variant van de Van Eyke toets verlaten moet worden ten gunste van de betechtbaatheid van grove schendingen van de geldende democratische principes in de lidstaten. De eerste twee varianten van de Van Eyke toets kunnen uiteindelijk tot hetzelfde niveau worden verheven als de regels van vrij verkeet uit het Verdrag. Als gevolg hiervan kan de nationale regelgeving aan ondernemingen (of hun vertegenwoordigers) niet meer toestaat om de mededingingsvrijheid te beperken. Dit 
hoofdstuk geeft uiteindelijk een drievoudige gradatie van jutidische toetsing van staatsinterventie in de markten voor professionele dienstverlening.

Hoofdstuk 7: Het recbtvaardigen van beroepsregelgeving - Rekening houdende met het algemene belang van het rcguleren van de beroepen, komt dit hoofdstuk uiteindelijk bij de tweede systematisering, namelijk het onderzoeken van oplossingen van rechtvaardigingen die de structuur en de systematiek van het Verdrag spiegelen. Hoewel voorstanders van strikte betoepstegulering volhouden dat beroepsregulering niet past in het systcem van mededingingsrecht, en zodoende een sector-specifieke uitzondering op de algemene regel verdienen, opent dit hoofdstuk de discussie over het toepassen van de mededingingsspecifieke uitzondering op de professionele dienstensector. Het concludeert dat het cumulatieve en uitputtende karakter van de vier criteria van artikel 81 lid $3 \mathrm{EG}$ het behoud van een buitenwettelijke uitzondering als voorgesteld in Wouters en Meca-Medina II tegenspreken. Zelfs als de Wouters voorbehoud niet een contra legem interpretatie van artikel $81 \mathrm{EG}$ voorstelt en geïdentificeerd kan worden als een vermomde toepassing van artikel 83 lid $3 \mathrm{EG}$, is het nodig om de derde voorwaarde van het artikel (onmisbaarheid) strikt te interpreteren en een volledige proportionaliteitstoets toe te passen, inclusief de zoektocht naar zo min mogelijk beperkende matregelen. De Wouters voorbehoud voorziet alleen in een fragmentarisch model, zeker nu het Hof te eenvoudig aanvaardt dat het (lege) nationale concept van de 'goede uitoefening van het beroep' wordt ingevuld op een wijze die het zelfregulerende lichaam - in plaats van de parlementaire wetgever - gedaan heeft in het voorbeeld van de Nederlandse advocatuur. Dit standpunt conflicteert met het feit dat de bepaling van de kernwaarde van een beroep een constitutionele dimensie heeft, zoals 15 jaar voor Wouters gedemonstreerd is door het Duitse constitutionele hof. Een systematische verdediging van het publieke belang zou daarom nooit ongecontroleerd geaccepteerd moeten worden in het mededingingsrecht. Dit boek bepleit dat het concept van publiek of algemene belang begrepen moet worden als een oorspronkelijke categorie van beleidsdoelen die niet alleen niet-economische waarden waarborgen die buiten het belang van het mededingingsrecht zijn. Het systeem van artikel 81 lid 3 en artikel 86 lid 2 EG staat namelijk toe dat overwegingen van algemeen belang zonder een ditect marktgerelateerd karakter meegewogen worden. Daarbij maakt het niet uit of deze niet-marktgerelateerde overwegingen van economische of niet-economische aard zijn. Uiteindelijk zijn beide bepalingen toepasbaar op staats- en zelfregulering in professionele dienstmarkten. Hoewel artikel 86 lid 2 EG doelt op het in evenwicht brengen van enerzijds de bevoegdheden van de lidstaten om economische regels aan te nemen en anderzijds de bescherming van ongehinderde mededinging in de interne markt, zal deze tweede rechtvaardigingsbepaling om twee redenen niet even betekenisvol zijn voor de meeste professionele dienstmarkten. Ten eerste, kunnen de meeste doelstellingen in beroepsregulering aangemerkt worden als strevend naar een economisch doel, ook al zijn deze doelen niet altijd marktgerelateerd. Ten tweede, de bespreking van de nationale voorbeelden suggereert dat maar weinig beroepstegelingen aangemerkt kunnen worden als bescherming van gelijke toegang tot specifieke diensten van de (vrije) betoepssectoren. Een mogelijk voorbeeld is de markt van medische dienstverlening. Deze staat echter nog steeds in de kinderschoenen aangezien de Commissie pas recentelijk is begonnen met het onderzoeken van de bepalingen ten aanzien van grensoverschrijdende medische dienstverlening. Adequaat onderzoek naar deze (zelf-)regulerende sector verdient zijn eigen onderzoek om de belangen van publieke gezondheidszorgsystemen enerzijds en economische marktintegratie anderzijds in evenwicht te brengen. 
Hoofdstuk 8: Conclusies - De tweeledige systematisering van de voorgaande hoofdstukken leidt onafwendbaar tot de vraag of verdere consequenties kunnen worden afgeleid van de conclusies uit dit boek. Dit hoofdstuk overweegt dat de gemeenschap haar beleidspositie over beroepsregulering verder moet verhelderen. Een inventarisatie van de verschillende vormen van restrictieve beroepsregels is, en zal vooralsnog, gedaan worden door de nationale mededingingsautoriteiten. Het moment is daatom gekomen om het debat over de modernisering van beroepen te richten op een meer systematische verkenning van het spectrum van uitzonderingen dat het mededingingstecht biedt om betere reguleting in plaats van dereguleting te bereiken. De toekomstige ontwikkeling van het recht hangt af van de overtuigingskracht waarmee de Europese Gemeenschap voorstelt om de voordelen van de voltooiing van de interne matkt voor diensten, zoals is uitgestippeld in de Iissabon strategie, te omarmen. Daarom eindigt het boek met de aanbeveling om een beleidsdocument door de Europese Commissie te laten ontwikkelen, mogelijk in de vorm van een mededeling, een Sectoraal plan van aanpak resulterend uit de nationaal hervormingsprogramma's, of zelfs een groepsvrijstellingsverordening. Dit beleidsdocument zou de volgende onderwerpen moeten dekken: het toepassingsgebied van de mededingingsverboden, de rol van de overheid in beroepsteguleting, en het rechtvaardigingssysteem van het mededingingstecht. 


\section{About the Author}

Ida was born on 26 July 1973 in Grünstadt, in the South-West of Germany. From 1983 she went to Gymnasium, first in Grünstadt and later in Worms, where she graduated with the Abitur exam in 1992. The same year Ida began to read law, first at Mainz University and then at Saarbrücken University (following full courses in French law), University of Lausanne (Switzerland), Maastricht University to finally obtained her law degree from Heidelberg University (Erstes Staatsexamen) in 1998. In 1999 she graduated cum laude from the joint master programme of the universities of Maastricht and Nottingham (Magister Iuris Communis, LL.M.). Ida is fully qualified to practice law since 2001/2002 (Zweites Staatsexamen, Düsseldorf). In 2002 she started working as a junior lecturer at the law faculty of Maastricht University; not after long she became a PhD candidate there. In 2007 she accepted the position of university lecturer in European law at the Erasmus School of Law in Rotterdam. As a part-time position she serves as legal secretary of the Adviescommissie bezwaarschriften Mededingingswet. 


\section{Bibliography}

\section{Table of cases}

\section{Court of First Instance}

Case T-1/89, Rbône-Poulenc SA v Commission, [1991] ECR II-867.

Case T-7/89, SA Hercules Chemicals NV $\nu$ Commission, [1991] ECR II-1711.

Case T-8/89, DSM NV ע Commission of the European Communities, [1991] ECR II-1833.

Case T-30/89, Hilti AG v Commission, [1991] ECR II-1439.

Case T-51/89, Tetra Pak Rausing SA v Commission (Tetra Pak I), [1990] ECR II-309.

AG Kirschner in Case T-51/89, Tetra Pak Rausing SA v Commission (Tetra Pak I), [1990] ECR II-312.

Case T-61/89, Dansk Pelsdyravlerforening (DPF) v Commission, [1992] ECR II-1931.

Case T-65/89, BPB Industries and British Gypsum v Commission, [1993] ECR II-389.

Case 'T-66/89, Publishers' Association v Commission no. 2, [1992] ECR II-1995.

Joined Cases T-68 to 77 and 78/89, Società Italiana Vetro SpA (SIV), Fabbrica Pisana SpA and PPG Vernante Pennitalia SpA $\nu$ Commission (Italian Flat Glass), [1992] ECR II-1403.

Casc T-69/89, Radio Telefis Eireann v Commission (Magill TV Guide), [1991] ECR II-485.

Case T-83/91, Tetra Pak International SA v Commission (Tetra Pak II), [1994] ECR II-755.

Case T-19/92, Groupement d'Achat Édoward Leclerc v Commission (Yves Saint Laurent Parfums), [1996] ECR II-1851.

Case T-29/92, Vereniging van Samenwerkende Prijsregelende Organisaties in de Bouwnijverbeid and others v Commission, [1995] ECR II-289.

Case T-35/92, Jobn Deere $\nu$ Commission, [1994] ECR II-957.

Case T-77/92, Parker Pen Ltd. $\nu$ Commission, [1994] ECR II-549.

Case T-88/92, Groupement d'Acbat Édouard Leclerc v Commission (Parfums Givencby), [1996] ECR II-1961.

Case T-7/93, Langnese Iglo GmbH v Commission, [1995] ECR II-1533.

Case T-9/93, Schöller Lebensmittel GmbH \& Co. KG v Commission, [1995] ECR II-1611.

Case T-17/93, Matra Hachette SA v Commission, [1994] ECR II-595.

Joined Cases T-24 to 26/93 and 28/93, Compagnie maritime belge transports $S A$ and Compagnie maritime belge $S A$, DafraLines A/S, Deutsche Afrika-Linien GmbH \&o Co. and Nedlloyd Lijnen BV v Commission (Cenval), [1996] ECR II1201.

Case T-513/93, Consiglio Nazionale degli Spedizionieri Doganali v Commission (CNSD III), [2000] ECR II-1807.

Joined Cases T-25 to 26/95, T-30 to 32/95, T-34 to 39/95, T-42 to 46/95, T-48/95, T-50 to 65/95, T-68 to 71/95, T-87 to 88/95, T-103/95 and T-104/95, Cimenteries CBR SAv Commission, [2000] ECR II-491.

Joined Cases T-528/93, T-543/93 and T-546/93, Métropole télévision SA and Reti Televisive Italiane SpA and Gestevisión Telecinco SA and Antena 3 de Televisión $\nu$ Commission, [1996] ECR II-649.

Case T-77/94, Vereniging van Groothandelaren in Bloemkevekerijprodukten, Florimex BV, Inkoop Service Aalsmeer BV and M. Verbaar BV $\nu$ Commission, [1997] ECR II-759.

Case T-84/94, Bundesverband der Bilanzbucbhalter e.V. v Commission, [1995] ECR II-101.

Joined Cases T-305 to 307/94, T-313/94 to T-316/94, T-318/94, T-325/94, T-328/94, T-329/94 and T-335/94 Limburgse Vinyl Maatschappij NV, Elf Atochem SA, BASF AG, Sbell International Chemical Company Ltd, DSM NV, DSM Kunststoffen BV, W acker-Chemie GmbH, Hoechst $A G$, Société artésienne de vinyle, Montedison SpA, Imperial Chemical Industries plc, Hüls $A G$ and Enichem $S p A \nu$ Commission, [1999] ECR II-931.

Case 'T-86/95, Compagniegénérale maritime, Hapag-L Loyd AG, Kawasaki Kisen Kaisha Ltd and Others v Commission, [2002] ECR II-1011.

Case T-106/95, Fédération frangaise des societés d'assurances (FFS A) and others v Commission, [1997] ECR II-229.

Case T-41/96, Bayer AG v Commission, [2000] ECR ПI-3383.

Case T-111/96, ITT Promedia NV v Commission, [1998] ECR II-2937.

Joined Cases T-374/94, T-375/94, T-384/94 and T-388/94, European Night Services L $₫ d$ (ENS) e.a., [1998] ECR II-3141.

Case T-228/97, Irish Sugar plc v Commission, [1999] ECR II-2969.

Case T-266/97, Vlaamse Televisie Maatschapij NV v Commission, [1999] ECR II-2329. 
Case T-62/98, Volkswagen AG v Commission, [2000] ECR II-2707.

Case T-65/98, Van den Bergh Foods L $₫$ d $v$ Commission, [2003] ECR II-4653.

Case T-128/98, Aéroports de Paris v Commission, [2000] ECR II-3929.

Case T-154/98, Asia Motor France and Others $\nu$ Commission, [2000] ECR II-3453.

Case T-36/99, Lenzing AG v Commission, [2004] ECR II-3597.

Case T-112/99, Métropole télévision (M6) v Commission, [2001] ECR II-2459.

Case T-144/99, Institute of Professional Representatives before the Eurapean Patent Office (EPI) v Commission, [2001] ECR II-1087.

Case T-144/99 R, Institute of Professional Representatives before the European Patent Office (EPI) $\nu$ Commission (interim relief), [2000] ECR II-2067.

Case T-131/99, Michael Hamilton Shaw and Timotby John Falla v Commission, [2002] ECR II-2023.

Case T-219/99, British Ainvays plc v Commission, [2003] ECR II-5917.

Case T-319/99, Federación Nacional de Empresas de Instrumentación Cientifica, Médica, Técnica y Dental (FENIN) v Commission, [2003] ECR ПI-357.

Case T-342/99, Airtours plc v Commission (Airtours/First Choice), [2002] ECR II-2585.

Case T-65/99, Strintzis Lines Sbipping SA v Commission, [2003] ECR II-5433.

Case T-66/99, Minoan Lines SAv Commission, [2003] ECR II-5515.

Case T-213/00, CMA CGM and others $\nu$ Commission, [2003] ECR II-913.

Case T-374/00, Verband der freien Robrverke eV, Eisen- und Metallwerke Ferndorf GmbH and Rudolf Flender GmbH of Co. KG v Commission, [2003] ECR II-2275.

Case T-168/01, GlaxoSmithKline Services Unlimited v Commission, [2006] ECR II-2969.

Case T-203/01, Manufacture française des pneumatiques Michelin v Commission (Micbelin II), [2003] ECR II-4071.

Case T-17/02, Fred Olsen "Commission, [2005] ECR II-2031.

Case T-48/02, Brounerij Haacht NV v Commission, [2005] ECR II-5259.

Joined Cases'T-49 to 51/02, Brasserie Nationale S A (formerly Brasseries Funck-Bricher and Bofferding), BrasserieJules Simon et Cie SCS, Brasserie Battin SNC v Commission, [2005] ECR II-3033.

Case T-59/02, Arcber Daniels Midland Co. v Commission, [2006 ECR II-3627.

Case T-193/02, Laurent Piau v Commission (FIFA), [2005] ECR II-209.

Joined cases T-259/02 to T-264/02 and T-271/02, Raiffeisen Zentralbank Österreich v Commission, [2006] ECR II5169.

Case T-313/02, David Meca-Medina and Igor Majcen v Commission, [2004] ECR II-3291.

Joined Cases T-217/03 and T-245/03, Fédération nationale de la coopération bétail and viande (FNCBV) et al. $v$ Commission, [2006] ECR ECR П-4987.

Case T-289/03, British United Provident Association Ltd (BUPA) et al v Commission, [2008] ECR II-81.

Case T-328/03, O2 (Germany) GmbH \& Co. OHG v Commission, [2006] ECR II-1231.

Case T-155/04, SELEX Sistemi Integrati SpA v Commission (Eurocontrol), [2006] ECR ПI-4797.

Case T-201/04, Microsoft Corp. $v$ Commission, [2007] ECR II-3601.

T-464/04, Independent Music Publishers and Labels Association (Impala, intermational association) $\nu$ Commission, [2006] ECR III-2289.

Court of Justice

Case 26/62, NV Algemene Transport- en Expeditie Onderneming van Gend \& Loos tegen Nederlandse administratie der belastingen, [1963] ECR 3.

Case 6/64, Flaminio Costa v ENEL, [1964] ECR 585.

Joined Cases 56 to 58/64, Etablissements Consten SARL and Grundig-Verkaufs-GmbH $\nu$ Commission, [1966] ECR 299.

Case 56/65, Société Tecbnique Minière v Maschinetrbau Ulm GmbH, [1966] ECR 235.

Case 23/67, SA Brasserie de Haecbt v Consorts Wilkin-Janssen, [1967] ECR 407.

Case 14/68, Walt Wilhelm and Others $v$ Bundeskartelamt, [1969] ECR 1.

Case 5/69, Franz Völk v S.P.R.L. Ets J. Vervaecke, [1969] ECR 295.

Case 78/70, Deutsche Grammophon Gesellschaft mbH v Metro-SB-Großmärkte GmbH \&o Co KG, [1971] ECR 487.

Case 10/71, Criminal proceedings against Madeleine Muller, Veuve J.P. Hein and others (Port of Mertert), [1971] ECR 723.

Case 22/71, Béguelin Import Co. v S.A.G.L Import Export, [1971] ECR 949.

Case 6/72, Europemballage Corporation and Continental Can Company Inc. $\nu$ Commission, [1973] ECR 215.

Case 8/72, Vereeniging van Cementhandelaren v Commission, [1972] ECR 977.

Joined Cases 6 and 7/73, Istituto Chemioterapico Italiano SpA and Commercial Solvents Corportation $\nu$ Commission, [1974] ECR 223. 
Joined Cases 40 to 48/73,50/73, 54 to 56/73,111/73,113 and 114/73, Coöperatieve Vereniging "Suiker Unie" UA and others $\nu$ Commission, [1975] ECR 1663.

Case 127/73, Belgische Radio en Televisie v SV SABAM and NV Fonior (BRT II), [1974] ECR 313.

Case 2/74, Jean Reyners $v$ Belgian State, [1974] ECR 631.

AG Mayras in Case 2/74, Jean Reyners v Belgian State, [1974] ECR 657.

Case 8/74, Criminal proceedings against Benoît and Gustave Dassonville, [1974] ECR 837.

Case 33/74, J.H.M. van Binsbergen v Bestuur van de Bedrijfsvereniging voor de Metaalnijverbeid, [1974] ECR 1299.

Case 36/74, B.N.O. Walrave and LJ.N. Koch v Association Union gycliste internationale, Koninklijke Nederlandsche Wielren Unie and Federación Española Ciclismo, [1974] ECR 1405.

Case 71/74, Nederlandse Vereniging voor de fruit- en groentenimporthandel, Nederlandse Bond van grossiers in zuidvruchten en ander geimporteerd fruit "Frubo" $v$ Commission, [1975] ECR 563.

Case 26/75, General Motors Continental NV v Commission, [1975] ECR 1367.

Case 43/75, Gabrielle Defrenne v Société anonyme belge de navigation aérienne Sabena, [1976] ECR 455.

Case 13/76, Gaetano Donà v Mario Mantero, [1976] ECR 1333.

Case 26/76, Melro SB-Großmärkte GmbH \& Co. KG v Commission (Metro I), [1977] ECR 1875.

Case 29/76, LTU Lufttransportuntermehmen GmbH \& Co. KG p Eurocontrol, [1976] ECR 1541.

Case 27/76, United Brands Company and United Brands Continentaal BV v Commission, [1978] ECR 207.

Case 71/76, Jean Thieffry $v$ Conseil de l'ordre des avocats a la cour de Paris, [1977] ECR 765.

Case 78/76, Steinike ơ Weinlig v Federal Republic of Germany, [1977] ECR 595.

Case 85/76, Hoffmann-La Roche \& Co. AGv Commission (Vilamins), [1979] ECR 461.

Joined Cases 9 and 10/77, Bavaria Fluggesellscbaft Schwabe \& Co. KG and Germanair Bedarfslufffabrt GmbH \&o Co. KG $\nu$ Eurocontrol, [1977] ECR 1517.

Case 11/77, Richard Hugh Patrick v Ministre des affaires culturelles, [1977] ECR 1199.

Case 13/77, SA G.B.-INNO-B.M. ע Association des détaillants en tabac, [1977] ECR 2115.

Case 19/77, Miller International Scballplatten GmbH v Commission, [1978] ECR 131.

Case 106/77, Amministrazione delle Finanze dello Stato v Simmenthal SpA, [1978] ECR 629.

Case 22/78, Hugin Kassaregister $A B$ and Hugin Cash Registers L td v Commission, [1979] ECR 1869.

Case 30/78, Distillers Company Limited v Commission, [1980] ECR 2229.

Joined Cases 32 and 36 to 82/78, BMW Belgium SA and others v Commission, [1979] ECR 2435.

Joined Cases 110 and 111/78, Ministère public and Chambre syndicale des agents artistiques et impresarii de Belgique" ASBL $v$ Willy van Wesemael and others, [1979] ECR 35.

Case 120/78, Reve-Zentral AG v Bundesmonopolverwaltung für Branntwein, [1979] ECR 649.

Case 175/78, The Queen v Vera Ann Saunders, [1979] ECR 1129.

Joined Cases 209 to 215 and 218/78, Heintz van Landenyck SARL and others $v$ Commission, [1980] ECR 3125.

Case 258/78, LC. Nungesser KG and Kurt Eisele $\nu$ Commission, [1982] ECR 2015.

Case 31/80, NV L'Oréal and SA L'Oréal v PVBA "De Nieuwe AMCK", [1980] ECR 3775.

Case 279/80, Criminal Proceedings against Webb, [1981] ECR 3305.

Case 262/81, Coditel SA, Companie Générale pour la diffusion de la têlévision, a.o. $\nu$ Ciné-Vog Films $S A$ and others, [1982] ECR 3381.

Case 322/81, NV Nederlandsche Banden-Industrie Micbelin v Commission, [1983] ECR 3461.

Case 7/82, Gesellschaft zur Verwertung von Leislungsschulerechten mbH (GVL) v Commission, [1983] ECR 483.

Case 96/82, LAZ International Belgium NV v Commission, [1983] ECR 3369.

Case 107/82, Allgemeine Elektrizitäts-Gesellschaft AEG-Telefunken AG v Commission, [1983] ECR 3151.

Joined Cases 286/82 and 26/83, Graziana Luisi and Giuseppe Carbone v Ministero del Tesoro, [1984] ECR 377.

Joined Cases 29/83 and 30/83, Compagnie Royale Asturienne des Mines (CRAM) SA and Rbeinzinte GmbH $v$ Commission, [1984] ECR 1679.

Case 41/83, Italian Republic v Commission (British Telecommunication), [1985] ECR 873.

Case 107/83, Ordre des avocats au barreau de Paris ע Onno Klopp, [1984] ECR 2971.

Case 123/83, Bureau national interprofessionnel du cognac (BNIC) v Guy Clair, [1985] ECR 391.

AG Slynn in Case 123/83, Bureau national interprofessionnel du cognac (BNIC) v Guy Clair, [1985] ECR 392.

Case 170/83, Hydrotherm Gerätebau GmbH v Compact del Dott. Ing. Mario Andreoli \&o C. Sas, [1984] ECR 2999.

Case 182/83, Robert Fearon of Company Limited v Irish Land Commission, [1984] ECR 3677.

Case 193/83, Windsurfing International Inc. $\nu$ Commission, [1980] ECR 611.

Case 220/83, Commission v French Republic (Co-insurance), [1986] ECR 3663.

Case 229/83, Association des Centres distributeurs Edouard Leclerc and others v SARL'Au Blé Vert' and otbers, [1985] ECR. 1. 
Case 231/83, Henri Cullet and Chambre syndicale des réparateurs automobiles et détaillants de produitspétroliers v Centre Leclerc à Toulouse and Centre Leclerc à Saint-Orens-de-Gameville, [1985] ECR 305.

Case 252/83, Commission v Kingdom of Denmark (Co-insurance), [1986] ECR 3713.

Cases 25 and 26/84, Ford - Werke AG and Ford of Europe Inc. $\nu$ Commission, [1985] ECR 2725.

Case 42/84, Remia BV and Verenigde Bedrijven Nutricia NV $\nu$ Commission, [1985] ECR 2545.

Case 107/84, Commission v Federal Republic of Germany, [1985] ECR 2655.

Case 161/84, Pronuplia de Paris GmbH v Pronuptia de Paris Irmgard Scbillgalis, [1986] ECR 353.

Case 205/84, Commission v Federal Republic of Germany (Insurance), [1986] ECR 3755.

Case 206/84, Commission v Ireland (Co-insurance), [1986] ECR 3817.

Joined Cases 209 to 213/84, Criminal proceedings against Lucas Arjes and others, Andrew Gray and others, Andrew Gray and others, Jacques Maillot and others and Léo Ludwig and others, [1986] ECR 1425.

Case 226/84, British Leyland Public Limited Company v Commission, [1986] ECR 3263.

Case 298/84, Paolo Torio v Azienda autonoma delle ferrovie dello Stato, [1986] ECR 247.

Case 311/84, Centre belge d'études de marcbé - Télémarketing (CBEM) v SA Compagnie luxembourgeoise de télédiffusion (CLT) and Information publicité Benelux (IPB), [1985] ECR 3261.

Case 31/85, ETA Fabriques d"Ébauches v SA DK Investment and others, [1985] ECR 3933.

Case 45/85, Verband der Sacbversicherer e.V. v Commission, [1987] ECR 405.

Case 118/85, Commission v Italian Republic (AAMS), [1987] ECR 2599.

AG Mischo in Case 118/85, Commission v Italian Republic (AAMS), [1987] ECR 2609.

Case 211/85, Commission v Belgium (Clinical Biology Services), [1987] ECR 791.

Case 235/85, Commission v Kingdom of the Netherlands, [1987] ECR 1471.

Case 311/85, Vereniging van Vlaamse Reisbureaus v Saciale Dienst van de Plaatselijke en Gewestelijke Overbeidsdiensten, [1987] ECR 3801.

Case 352/85, Bond van Adverteerders and others v The Netherlands State, [1988] ECR 2085.

Joined Cases 89, 104, 114, 116, 117 and 125 to 129/85, A. Ablström Osakeybtiö and otbers v Commission, [1988] ECR 5193.

Case 62/86, AKZO Chemie BV v Commission, [1991] ECR I-3359.

Case 66/86, Abmed Saeed Flugreisen and Silver Line Reiseburo GmbH v Zentrale zur Bekampfung unlauteren Wettbewerbs e.V., [1989] ECR 803.

Case 136/86, Bureau national interprofessionnel du cognac (BNIC) v Yves Aubert, [1987] ECR 4789.

Case 188/86, Ministère public v Régis Lefêre, [1987] ECR 2963.

Case 222/86, Union nationale des entrainneurs et cadres tecbniquesprofessionnels du football (Unectef) $v$ Georges Heylens and others, [1987] ECR 4097.

Case 247/86, Société alsacientre et lorraine de télécommunications et d'éléctronique (Alsatel) vSANovasam, [1988] ECR 5987.

Case 263/86, Belgian State $\nu$ René Humbel and Marie-Thérèse Edel, [1988] ECR 5365.

Case 267/86, Pascal Van Eycke ע ASPA NV, [1988] ECR 4769.

Case 292/86, Claude Gullung v Conseil de l'ordre des avocats du barreau de Colmar et de Saverne, [1988] ECR 111.

Case 27/87, SPRL Louis Erauw-Jacquery v La Hesbignonne SC, [1988] ECR 1919.

Case 30/87, Corinne Bodson v SA Pompes funèbres des régions libérées, [1988] ECR 2479.

Case 274/87, Commission v Federal Republic of Germany, [1989] ECR 229.

Case 18/88, Régie des télégraphes et des téléphones v GB-Inno-BM SA, [1991] ECR I-5941.

Case 103/88, Fratelli Costanzo SpA v Comune di Milano, [1989] ECR 1839.

AG van Gerven in Case C-145/88, Torfaen Borough Council v B \& $Q$ plc, [1989] ECR 3865.

Case C-202/88, French Republic v Commission (Telecommunications Terminal Equipment), [1991] ECR I-1223.

Joined Cases C-104/89 and C-37/90, J.M. Mulder a.o. and Otto Heinemann v Council and Commission, [1992] ECR I3061.

Case C-154/89, Commission v French Republic, [1991] ECR I-659.

Case C-180/89, Commission v Italian Republic (tourist guides), [1991] ECR I-709.

Case C-198/89, Commission v Hellenic Republic, [1991] ECR I-727.

Case C-234/89, Stergios Delimitis v Henninger Bräu AG, [1991] ECR I-935.

Case C-260/89, Elliniki Radiophonia Tiléorassi AE and Panellinia Omospondia Syllogon Prossopikou v Dimotiki Etairia Pliroforissis and Sotirios Kouvelas and Nicolaos Avdellas and others, [1991] ECR I-2925.

Case C-288/89, Sticbting Collectieve Antennevoorziening Gouda and others v Commissariaal voor de Media, [1991] ECR I4007.

Case C-340/89, Irène Vlassopoulou v Ministerium für Justiz, Bundes-und Europaangelegenbeiten Baden-Württemberg, [1991] ECR I-2357. 
Case C-353/89, Commission v Kingdom of The Netherlands, [1991] ECR I-4069.

Case C-41/90, Klaus Höfner and Fritz Elser v Macrotron GmbH, [1991] ECR I-1979.

AG van Gerven in Joined Cases C-48/90 and C-66/90, Kingdom of the Netherlands and Koninklijke PTT Nederland NV and PTT Post BV $\nu$ Commission, [1992] ECR I-589.

Case C-76/90, Manfred Säger v Dennemeyer \& Ca. Ltd, [1991] ECR I-4221.

Case C-179/90, Merci Convenzionali Porto di Genova SpA v Siderurgica Gabrielli SpA, [1991] ECR I-5889.

AG van Gerven in Case C-179/90, Merci Convenzionali Porto di Genova SpA v Siderurgica Gabrielli SpA, [1991] ECR 5905.

Case C-204/90, Bachmann v Belgian State, [1992] ECR I-249.

Case C-300/90, Commission v Kingdom of Belgium, [1992] ECR I-305.

Case C-2/91, Criminal proceedings against Wolf W. Meng, [1993] ECR I-5751.

Case C-104/91, Colegio Oficial de Agentes de la Propriedad Inmobiliaria v Jose Luis Aguirre Borrell, S.K. Newman and others, [1992] ECR I-3003.

Case C-106/91, Claus Ramrath v Ministre de La Justice, and l'Instivut des réviseurs d'entreprises, [1992] ECR I-3351.

Joined Cases C-159/91 and C-160/91, Christian Poucet v Assurances Générales de France (AGF) and Caisse Mutuelle Régionale du Languedoc-Roussillon and Daniel Pistre v Caisse Autonome Nationale de Compensation de l' Assurance Vieillesse des Artisans (Cancava), [1993] ECR I-637.

AG Tesauro in Joined Cases C-159/91 and C-160/91, Cbristian Poucet v Assurances Générales de France (AGF) and Caisse Mutuelle Régionale du Languedoc-Roussillon and Daniel Pistre v Caisse Autonome Nationale de Compensation de l' Assurance Vieillesse des Artisans (Cancava), [1993] ECR I-658.

Case C-185/91, Bundesanstalt für den Güterfermverkehr v Gebrüder Reiff GmbH \& Co. KG, [1993] ECR I-5801.

Casc C-245/91, Criminal proceedings against Obra Schadeverqekeringen NV, [1993] ECR I-5851.

Joined Cases C-267 and 268/91, Criminal proceedings against Bermard Kecke and Daniel Mithouard, [1993] ECR I-6097.

Case C-320/91, Criminal proceedings against Paul Corbeau, [1993] ECR I-2533.

Case C-19/92, Kraus v Land Baden-Württemberg, [1993] ECR I-1663.

Case C-109/92, Stephan Max Wirth v Landeshauptstadt Hannover, [1993] ECR I-6447.

Case C-119/92, Commission v Italian Republic (CNSD 0), [1994] ECR I-393.

Case C-235/92 P, Montecatini SpA v Commission, [1999] ECR I-4539.

Case C-250/92, Gottrup-Klim Grovvareforeninger v Dansk Landburgs Grovvareselskab (DLG), [1994] ECR I-5641.

AG Tesauro in Case C-250/92, Gettrup-Klim Grovvareforeninger v Dansk Landburys Growvareselskab (DLG), [1994] ECR I-5644.

Case C-275/92, Her Majesty's Customs and Exercise v Schindler, [1994] ECR I-1039.

Case C-360/92 P, The Publishers Association v Commission (no.3), [1995] ECR I-23.

AG Lenz in Case C-360/92 P, The Publishers Association v Commission (no. 3), [1995] ECR I-25.

Case C-364/92, SAT Fluggesellschaft mbH v Eurocontrol, [1994] ECR I-43.

AG Tesauro in Case C-364/92, SAT Fluggesellschaft v Eurocontrol, [1994] ECR I-45.

Case C-393/92, Municipality of Almelo and others $\nu$ NV Energiebedrij Ijsselmij, [1994] ECR I-1477.

Case C-23/93, TV10 SA v Commissariaat voor de Media, [1994] ECR I-4795.

Case C-55/93, Criminal proceedings against J.G.C. van Schaik, [1994] ECR I-4837.

Case C-153/93, Bundesrepublik Deutscbland v Delta Schiffahrts- und Speditionsgesellschaft mbH, [1994] ECR I-2517.

Joined Cases C-319/93, C-40/94 and C-224/94, Hendrik Evert Dijkstra v Friesland (Frico Domo) Coöperatie BA and Cornelis van Roessel and others v De coöperatieve vereniging Zuivelcoöperatie Campina Melkunie VA and Willem de Bie and others v De Coöperatieve Zuivelcoöperatie Campina Melkunie BA, [1995] ECR I-4471.

Case C-323/93, Sociêté Civile Agricole du Centre d'Insémination de la Crespelle v Coopérative d"Elevage et d'Insémination Artificielle du Département de la Mayenne, [1994] ECR I-5077.

Case C-381/93, Commission $\nu$ France (Cabotage maritime), [1994] ECR I-5145.

Case C-384/93, Alpine Investment BV v Minister van Financien, [1995] ECR I-1141.

Case C-387/93, Criminal proceedings against Giongio Domingo Banchero, [1995] ECR I-4663.

Case C-399/93, H. G. Oude Luttikbuis and others v Verenigde Coöperatieve Melkindustrie Coberco BA, [1995] ECR I-4515.

Case C-415/93, Union royale belge des societés de foolball association ASBL v Jean-Marc Bosman, [1995] ECR I-4921.

AG Lenz in Case C-415/93, Union royale belge des societés de football association ASBL v Jean-Marc Bosman, [1995] ECR $\mathrm{I}-4930$.

Case C-55/94, Gebhard $\nu$ Consiglio dell'Ordine degli Avvocati e Procuratori di Milano, [1995] ECR I-4165.

Joined Cases C-68/94 and C-30/95, Frencb Republic and Société commerciale despotasses et de l' azote (SCPA) and Entreprise minière et cbimique (EMC) v Commission (Kali Ð́ Salv), [1998] ECR I-1375.

Case C-96/94, Centro Servizi Spediporto Srl v Spedizzoni Marittima del Golfo Srl, [1995] ECR I-2883. 
Joined Cases C-140-142/94, DIP spa et al. $\nu$ Commune di Bassano del Grappa et al., [1995] ECR I-3257.

Case C-157/94, Commission v Kingdom of the Netherlands (Electricity), [1997] ECR I-5699.

Case C-158/94, Commission v Italian Republic (Electricity), [1997] ECR I-5789.

Case C-159/94, Commission v French Republic (Electricity and Gas), [1997] ECR I-5851.

Case C-244/94, Fédération Franfaise des Sociétés d'Assurances and Others (FFSA) v Ministère de l'Agriculture et de la Pêcbe (MAP), [1995] ECR I-4013.

Case C-302/94, The Queen v Secretary of State for Trade and Industry, ex parte British Telecommunications, [1990] ECR I6417.

Joined Cases C-321/94 to C-324/94, Criminal proceedings against Jacques Pistre, Michele Bartbes, Yves Milhau and Didier Oberti, [1997] ECR I-2343.

Case C-333/94 P, Tetra Pak International SA v Commission (Telra Pak III), [1996] ECR I-5951.

Case C-3/95, Reisebüro Broede v Gerd Sandker, [1996] ECR I-6511.

Case C-7/95P, John Deere Ltd v Commission, [1998] ECR I-3111.

Case C-70/95, Sodemare SA, Anni AzRuri Holdings SpA \& Anni AzZuri Rezzato Srlv Regione Lombardia, [1997] ECR I-3395.

Case C-107/95P, Bundesverband der Bilangbucbbalter e.V. „ Commission, [1997] ECR I-947.

Casc C-120/95, Nicolas Decker and Caisse de Maladie des Employés Privés, [1998] ECR I-1831.

Case C-219/95 P, Ferriere Nord SpA v Commission, [1997] ECR I-4411.

Case C-242/95, GT-Link, A/S v de Danske Stadsbaner (DSB), [1997] ECR I-4449.

Case C-265/95, Commission v French Republic, [1997] ECR I-6959.

Case C-299/95, Friedrich Kremzonv v Republik Österreich, [1997] ECR I-2629.

Case C-343/95, Diego Cali do Figli Srl v Servizi ecologici porlo di Genova SpA (SEPG), [1997] ECR I-1547.

Case C-368/95, Vereinigte Familiapress Zeitungsverlags- und vertriebs GmbH v Heinrich Bauer Verlag, [1997] ECR I-3689.

Case C-398/95, Syndesmos ton en Eilladi Touristikon kai Taxidiotikon Grafeion v Ypourgos Engasias, [1997] ECR I-3091.

Joined Cases C-359/95 P and C-379/95 P, Commission and France v Ladbroke Racing, [1997] ECR I-6265.

Case C-35/96, Commission v Italian Republic (CNSD II), [1998] ECR I-3851.

AG Cosmas in Case C-35/96, Commission v Italian Republic (CNSD II), [1998] ECR I-3855.

Case C-55/96, Job Centre coop. arl., [1997] ECR I-7119.

Case C-67/96, Albany Intermational BV v Sticbting Bedrijfspensioenfonds Textielindustrie, [1999] ECR I-5751.

AG Jacobs in Case C-67/96, Joined Cases C-115/97, C-116/97 and C-117/97 and Case C-219/97, Albany Intermational BV, Brentiens' Handelsonderneming BV, and BV Maatschappij Drijvende Bokken, [1999] ECR I-5754.

Case C-158/96, Kobll v Union des Caisses de Maladie, [1998] ECR I-1931.

Case C-163/96, Criminal proceedings against Silvano Raso and Others, [1998] ECR I-533.

Case C-176/96, Lebtonen and Castors Canada Dry Namur-Braine ASBL v Fédération royale belge des socieétés de basket-ball ASBL (FRSBB), [2000] ECR I-2681.

Case C-203/96, Chemische Afvalstoffen Dusseldorp BV and others v Minister van Volkshuisvesting, Ruimtelijke Ordening en Milieubeheer, [1998] ECR I-4075.

Joined Cases C-215/96 and C-216/96, Carlo Bagnasco v Banca Popolare di Novara soc. coop. arl (BPN) and Cassa di Risparmio di Genova e Imperia SpA, [1999] ECR I-135.

Case C-264/96, Imperial Chemical Industriesplc (ICI) v Kenneth Hall Colmer (HerMajesty's Inspector of Taxes), [1998] ECR I-4695.

Case C-266/96, Corsica Ferries France SA v Gruppo Antichi Ormeggiatori del Porto di Genova Coop. Arl, [1998] ECR I3949.

AG Fennelly in Case C-266/96, Corsica Ferries France SA $\nu$ Gruppo Anticbi Ormeggiatori del Porto di Genova Coop. Arl et al.s [1998] ECR I-3855.

Case C-306/96, Javico International and Javico AG v Yves Saint Laurent Parfums SA, [1998] ECR I-1983.

Joined Cases C-395/96 P and C-396/96 P, Compagnie maritime belge transports SA and Others v Commission (Cewal II), [2000] ECR I-1365.

Case C-7/97, Oscar Bronter GmbH \& Co. KG vMediaprint Zeitungs- und Zeitschriftenverlag GmbH \& Co. KG, Mediaprint Zeitungsvertriebsgesellschaft mbH \& Co. KG and Mediaprint Anzeigengesellschaft mbH \& Co. KG, [1998] ECR I-7791.

Case C-38/97, Autotrasporti Librandi v Cuttica Spedizioni, [1998] ECR I-5955.

AG Alber in Case C-38/97, Autotrasporti Librandi v Cuttica Spedizioni, [1998] ECR I-5957.

Joined Cases C-51/96 and C-191/97, Deliège v Ligue Francopbone de Judo et Disciplines Associés ASBL, [2000] ECR I-2549.

AG Cosmas in Joined Cases C-51/96 and C-191/97, Delì̀ge v Ligue Francophone de Judo et Disciplines Associés ASBL, [2000] ECR I-2553. 
Case C-114/97, Commission v Kingdom of Spain, [1998] ECR I-6717.

Joined Cases C-115 to 117/97, Brentjens' Handelonderneming BV v Stichting Bedrijspensioenfonds voor de bandel in boummaterialen, [1999] ECR I-6025.

Case C-124/97, Markeku Juhani Läärä, Cotswold Microsystems Lıd and Oy Transatlantic Softhyare Lıd v Kiblakunnansyyttäjä (1yväskylä) and Suomen valtio (Finnish State), [1999] ECR I-6067.

Case C-126/97, Eco Swiss China Time Ltd and Benetton International NV, [1999] ECR I-3055.

Joined Cases C-147/97 and C-148/97, Deutsche Post AG $\nu$ Gesellschaft für Zablungssysteme mbH (GZS) and Citicorp Kartenservice GmbH, [2000] ECR I-825.

Case C-219/97, Maatscbappij Drijvende Bokken BV v Stichting Pensioenfonds voor de Vervoer-en Havenbedrijven, [1999] ECR I-6121.

Case C-294/97, Eurowings Luftverkebrs AG v Finanzamt Dortmund-Unna, [1999] ECR I-7447.

Case C-22/98, Criminal proceedings against Jean Claude Becu, Annie Verveire, NV Smeg and NV Adia Interim, [1999] ECR I-5665.

Case C-35/98, Staatssecretaris van Financiën v. B.G.M. Verkooijen, [2000] ECR I-4071.

Case C-55/98, Skatteministeriet v Bent Vestergaard, [1999] ECR I-7641.

Case C-58/98, Josef Corsten, [2000] ECR I-7919.

Joined Cases C-180 to 184/98, Pavel Pavlov e.a. v Sticbting Pensioenfonds Medische Specialisten, [2000] ECR I-6451.

AG Jacobs in Joined Cases C-180-184/98, Pavel Pavlov e.a. v Sticbting Pensioenfonds Mediscbe Specialisten, [2000] ECR I-6456.

Joined Cases T-191/98 and T-212/98 to T-214/98, Atlantic Container Line AB and otbers v Commission (TACA), [2003] ECR I-3275.

Case C-281/98, Roman Angonese and Cassa di Risparmio di Bolqano SpA, [2000] ECR I-4139.

Case C-314/98, Snellers Auto's BV v Algemeen Directeur van de Dienst Wegverkeer, [2000] ECR I-8633.

AG Jacobs in Case C-379/98, PreussenElectra AG v Scbleswag AG, [2001] ECR I-2103.

Case C-405/98, Konsumentombudsmannen v Gourmet Intemational Products AB, [2001] ECR I-1795.

Case C-448/98, Criminal proceedings against Jean-Pierre Guimont, [2000] ECR I-10663.

Case C-35/99, Manuele Arduino, [2002] ECR I-1529.

AG Léger in Case C-35/99, Manuele Arduino, [2002].

Case C-157/99, Geraets-Smits and Peerbooms, [2001] ECR I-5473.

Case C-163/99, Portuguese Republic ע Commission, [2001] ECR I-2613.

Case C-221/99, Guiseppe Conte v Stefania Rossi, [2001] ECR I-9359.

AG Jacobs in Case C-283/99, Commission v Italian (private security services), [2001] ECR I-4365.

Case C-309/99, J.C.J. Wouters, J.W. Savelbergh, Price Waterbouse Belastingadviseurs BV and Algemene Raad van de Nederlandse Orde van Advocaten (NOvA), [2002] ECR I-1577.

AG Léger in Case C-309/99, J.C.J. Wouters, J.W. Savelbergh, Price Waterbouse Belastingadviseurs BV and Algemene Raad van de Nederlandse Orde van Advocaten (NOvA), [2002] ECR I-1582.

Case C-475/99, Ambulañ Glöckner v Landkreis Südwestpfalz, [2001] ECR I-8089.

AG Jacobs in Case C-475/99, Ambulanz Glöckner v Landkreis Südwestpfalz [2001].

Case C-497/99 P, Irish Sugar plc v Commission, [2001] ECR I-5333.

Case C-112/00, Eugen Schmidberger, Intermationale Transporte und Planzüge v Austria, [2003] ECR I-5659.

Case C-218/00, Cisal di Battistello Venanzio ơ C. Sas v Istituto nazionale per l'assicurazione contro gli infortuni sul lavoro (INAIL), [2002] ECR I-691.

AG Stix-Hackl in Case C-233/00, Commission v French Republic (envimonmental information), [2003] ECR I-6629.

AG Léger in Case C-280/00, Altmark Trans G'mbH, Regierungspräsidium Magdeburg v Nabverkebrsgesellschaft Altmark GmbH, [2003] ECR I-7747.

Case C-6/01, Anomar and Others, [2003] ECR I-8621.

AG Stix-Hackl in Joined Cases C-34-38/01, Enirisorse SpA v Ministero delle Finanze, [2002] ECR I-14247.

Case C-79/01, Payroll Data Services and Others, [2002] ECR I-8923.

AG Jacobs in Case C-198/01, Consorzio Industrie Fiammiferi (CIF) v Autorità Garante della Concorrenza e del Mercato, [2003] ECR I-8058.

Case C-198/01, Consorzio Industrie Fiammiferi (CIF) v Autorità Garante della Concorrenza e del Mercato, [2003] ECR I8055.

Case C-207/01, Altair Chimica SpA v ENEL Distriburione SpA, [2003] ECR I-8875.

Case C-322/01, Deutscher Apothekerverband e.V. v DocMorris NV, J. Waterval, [2003] ECR I-14887.

Case C-359/01 P, British Sugar ple and Tate \& Lyle plc and others v Commission, [2004] ECR I-4933.

Case C-388/01, Commission v Italian Republic, [2003] ECR I-721. 
Case C-405/01, Colegio de Oficiales de la Marina Mercante Española v Administración del Estato, [2003] ECR I-10391.

AG Colomer in Case C-345/02, Pearle BV and Others, [2004] ECR I-7142.

Case C-418/01, IMS Health v NDC Health, [2004] ECR I-5039.

Joined Cases C-264/01, C-306/01, C-354/01 and C-355/01, AOK-Bundesverband and Otbers, [2004] ECR I-2493.

AG Jacobs in Joined Cases C-264/01, C-306/01, C-354/01, C-355/01, AOK-Bundesverband and Others, [2004] ECR I-2495.

Case C-442/02, CaixaBank France v Ministère de l'Économie, des Fïnances et de IIIndustrie, [2004] ECR I-8961.

Case C-172/03, Wolfgang Heiser v Finanzamt Innsbruck, [2005] ECR I-1627.

Case C-205/03 P, Federación Española de Empresas de Tecnologia Sanitaria (FENIN) v Commission, [2006] ECR I-6295.

AG Poiares Maduro in Case C-205/03 P, Federación Española de Empresas de Tecnologia Sanitaria (FENIN), formerly Federación Nacional de Empresas, Instrumentación Cientifica, Médica, Técnicay Dental Commission, [2006] ECR I-6297.

AG Stix-Hackl in Case C-231/03, Consorzio Aziende Metano (Co.Na.Me.) v Comune di Cingia de Botti, [2005] ECR I-7289.

Case C-250/03, Giorgio Emanuele Mauri v Ministero della Giustizia, Commissione per gli esami di avvocato presso La Conte d'appello di Milano, [2005] ECR I-1267.

AG Kokott in Case C-283/03, A. H. Kuipers, [2005] ECR I-4275.

Case C-451/03, Servizi Ausiliari Dottori Commercialisti Srl v Giuseppe Calafiori, [2006] ECR I-2941.

Joined Cases C-94/04 and C-202/04, Federico Cipolla v Rosaria Fazari (née Portolese) and Stefano Macrino, Claudia Capodarte $v$ Roberto Meloni, [2009] ECR I-11421.

AG Poiares Maduto in Cases C-94/04 and C-202/04, Fiederico Cipolla v Rosaria Fazari (née Portolese) and Stefano Macrino, Claudia Capodarte v Roberto Meloni, [2006] ECR I-11426.

AG Kokott in Case C-95/04 P, British Ainvays plcv Commission, [2007] ECR I-2336.

Case C-109/04, Karl Robert Kranemann v Land Nordrbein-IWestfalen, [2005] ECR I-2421.

Case C-222/04, Ministero dell'Economia e delle Finanze v Cassa di Risparmio di Firenze SpA and Fondazione Cassa di Risparmio di San Miniato and Cassa di Risparmio di San Miniato SpA (Cassa di Risparmio di Firenze), [2006] ECR I289.

AG Jacobs in Case C-222/04, Ministero dell'Economia delle Finanze $\nu$ Cassa di Risparmio di Firenze SpA and Fondazione Cassa di Risparmio di San Miniato and Cassa di Risparmio di San Miniato SpA (Cassa di Risparmio di Finenze), [2006] ECR I-295.

AG Kokott in Case C-284/04, T-Mobile Austria GmbH and Otbers v Republic of Austria, [2007] ECR I-5192.

Joined Cases C-295/04 to C-298/04, Vincenzo Manfredi v Ldoyd Adriatico Assicurapioni SpA, Antonio Cantito v Fondiaria Sai SpA, and Nicalò Tricarico, Pasqualina Murgolo v Assitalia SpA, [2006] ECR I-6691.

AG Kokott in Case C-369/04, Hutchison 3G UK L td and Others v Commissioners of Customs of Excise, [2007] ECR I5250 .

Joined Cases C-403/04 P and C-405/04 P, Sumitomo Metal Industries Ltd et al. v Commission, [2007] ECR I-729.

Case C-407/04 P, Dalmine SpA v Commission, [2007] ECR I-829.

Case C-519/04 P, David Meca-Medina and Igor Majcen v Commission (appeal), [2006] ECR I-6991.

AG Léget in Case C-519/04 P, David Meca-Medina and Igor Majcen v Commission, [200G] ECR I-6995.

Case C-76/05, Herbert Schwary, Marga Goobjes-Schwary v Finanzamt Bergisch Gladbach, [2007] ECR I-6849.

Case C-171/05 P, Appeal brougbt on 15.04.2005 by L Piau, OJ C 155, 25.06.2005, p. 5, [2005].

Case C-171/05 P, Laurent Piau v Commission (FIFA), [2006] ECR I-37.

Case C-217/05, Confederación Española de Empresarios de Estaciones de Servicio v Compaña Española de Petróleos $S A$ (CEPSA), [2006] ECR I-11987.

Case C-238/05, Asnef-Equifax, Senvicios de Información sobre Solvencia y Crédito, SL, Administración delEstado v Asociación de Usuarios de Servicios Bancarios (Ausbanc), [2006] ECR I-11125.

Case C-341/05, Laval un Partneri Ltd v Suenska Byggnadsarbetareförbundet, Svenska Byggnadsarbetareförbundets avd. 1, Byggettan, Svenskea Elektrikerforbundet, [2007] ECR I-11767.

Case C-380/05, Centro Europa 7 SrlvMinistero delle Comunicazioni e. Autorità per le garanzie nelle comunicazioni, Direzione generale per le concessioni e le autorizzazioni del Ministero delle Comunicazioni, [2008] ECR I-349.

Case C-438/05, Intermational Transport Workers' Federation, Finnish Seamen's Unionv Viking Line ABP, OÜ Viking Line Eesti, [2007] ECR I-10779.

AG Poiares Maduro in Case C-438/05, The International Transport Workers' Federation (TTF) and The Finnish Seamen's Union v Viking Line ABP and OÜ Viking Line Eesti, [2007] ECR I-10782.

Case C-446/05, Ioannis Doulamis, Union des Dentistes et Stomatologistes de Belgique (UPR) and Jean Totolidis, [2008] ECR I-1377.

Case C-465/05, Commission v Italian Republic (private security services), [2005] ECR I-11091. 
Case C-413/06 P, Bertelsmann AG, Sony Corporation of America v Independent Music Publishers and Labels Association (Impala), [2008] ECR n.y.t.

C-531/06, Commission v Italian Republic (pharmacies by pharmacists), [2009] ECR n.y.r.

Case C-49/07, Motosykletistiki Omospondia Ellados NPID (MOTOE) v Elliniko Dimosio, [2008] ECR n.y.r.

AG Kokott in Casc C-49/07, Motosykletistiki Omospondia Ellados NPID (MOTOE), [2008] ECR n.y.r.

Joined Cases C-171/07 and C-172/07, Apotbekerkammer des Saarlandes, Marion Scbneider, Michael Holzapfel, Fritz Trennheuser, Deutscher Apothekerverband eV, Helga Neumann-Seiwert v Saarland (DocMorris), [2009] ECR n.y.r.

AG Trstenjak in Case C-209/07, The Competition Authority v Beef Industry Development Society Ltd and Barry Brothers (Carrigmore) Meats Ltd, [2008] ECR n.y.r.

AG Trstenjak in Case C-531/07, Fachverband der Buch- und Medienwirtschaft v LIBRO Handelsgesellschaft mbH, [2008] ECR n.y.r.

Belgium

Cour d'Appel de Bruxelles,

Case 2002/MR/3 2003/MR/8 "Koninklijke Gilde van Vlaamse Antiquaires v MSA" [2004], at $<$ http://ec.europa.cu/competition/antitrust/national_courts/court_2004_009_nl.pdf>.

\section{Germany}

BVerfG,

"Richtlinien des anwaltlichen Standesrechts kein Hilfsmittel zur Auslegung" Anwaltsblatt (1987) 598.

--., "Zur verfassungsrechtlichen Berurteilung des anwaltlichen Werbeverbots" Anwvaltsblatt (1987) 603.

$---, \quad[1960], B V_{e r f}$ GE 10, 354.

-.., [1987], BV erfGE 76, 171.

---, [1987], BVerfGE 76, 196.

Reichsgericht,

"Abortion" [1927], RGSt 61, 242.

Netherlands

Hoge Raad,

"In behalf of my lawyer" [1994], HR, NJ 552.

UK

Competition Appeals Tribunal,

Case 1006/2/1/01 "BetterCare Group Ltd v DGFT" [2002], CAT 7, at $<$ http://www.catribunal.org.uk/documents/JdgBCG010802.pdf>.

Court of Appeal,

"Associated Provincial Picture Houses v Wednesbury Corporation" [1948], 1 KB 223.

House of Lords,

"Institute of Chartered Accountants in England and Wales (appellants) v Commissioners of Customs and Excise (respondents)" [1999], 2 All ER 449, 2 CMLR 1333, at <http://www.publications.parliament.uk/ $\mathrm{pa} /$ ld199899/ldjudgmt/jd990325/insti.htm>.

US

Supreme Court of the United States,

"Parker v Brown" [1943], 317 US 341.

---, "National Society of Professional Engineers v US" [1978], 435 US 679.

--., "Northwest Stationers v Pacific Stationery" [1985], 472 US 284.

-.-, Case 97-1625 "California Dental Association v Federal Trad Commission" [1999], 526 U.S. 756 [also: 119 S.Ct. 1604], at <http://supct.law.cornell.edu/supct/index.html>.

--, (Opinion by Judge Posner),

"Olympia EquipmentLeasing Company and Othersv Western Union Telegraph Company" [1986, 797 F.2d 370 (7th Cir. 1986).

European Commission,

Commission Decision 71/337/EEC of 24.09.1971 (IV/181 - CEMATEX), Of L 227, 08.10.1971, p.26, [referenced in footnotes as: Commission Decision CEMATEX]. 


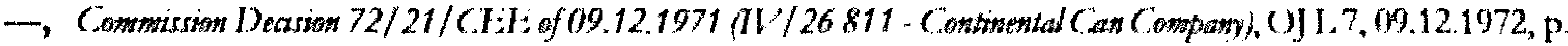

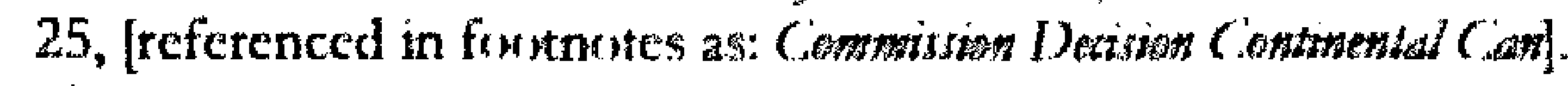

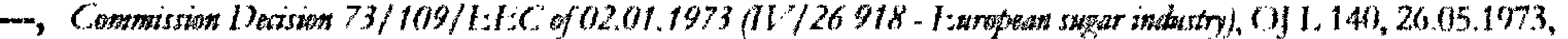

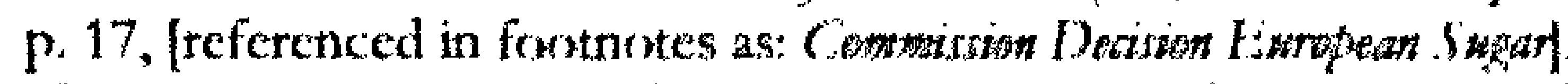

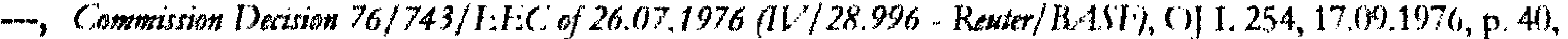

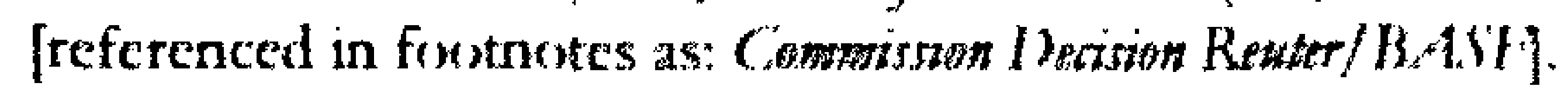

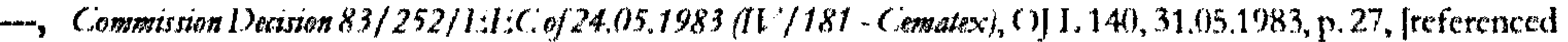
in fortnotes as: Commission Decision Cematex.

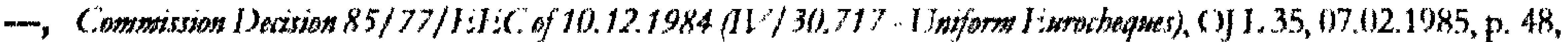
[referenced in foutnutes as: Commission Decison Liniform I:uracheques].

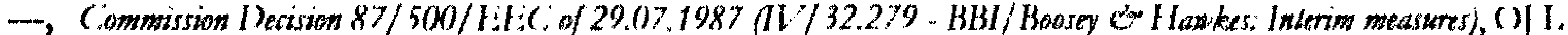

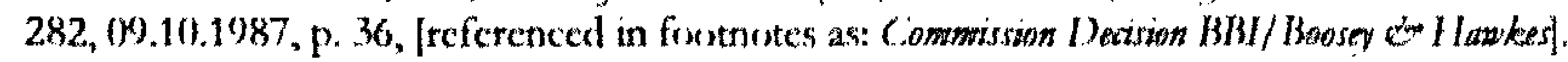

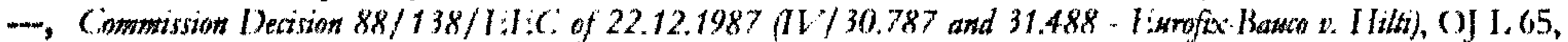
11.03.1988, p.19, [referenced in foritnotes as: Commission Decision IIilta].

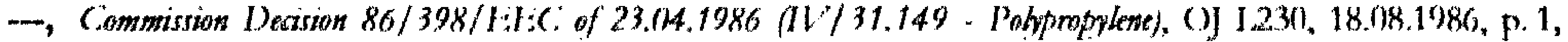
[referenced in fintnetes as: (ommission Decision P'ohponopylent.

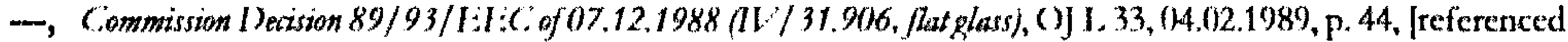
in foutnotes as: (ommission Decision flat glass.

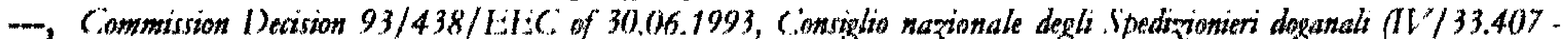
CNSD), OJ L. 203, 13.08.19)3, p. 27, [referenced in foxtnotes as: Commission Decision (N)S1).

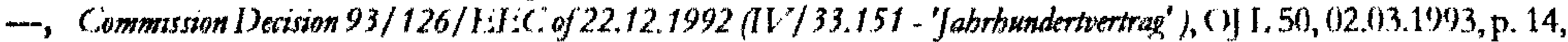
[refercnced in footnotes as: Commission Decision Jabrhundertvertragl.

--, Commission Decision 95/188 of 30.01.1995 (IV/33.686 - COAPI), of 30.01.1995, () L 1.122, 02.06.1995, p. 37, [referenced in footnotes as: Commission Decision COAPI].

-, Commission Dezision 6/438/LCof 5.06.1996 (1V/34.983 - I enex), OJ L 181 , 20.07.1996, p. 28, [referenced in footnotes as: Commission Decision Fenex.

-, Commission Decision 1999/152/EC of 20.05.1998 (IV/M.1016 - Price Waterbouse/Coopers do Lytrand), of 20.05.1998, Of L. 50, 26.02.1999, p.27, p. 27, [referenced in fexotnotes as: Commission Decision Price Waterbouse/Coopers of Lybrand.

-, Commission Decision 98/538/LC of 17.06.1998 (IV/36.010-1'3 - Amministrazione Autonoma dei Monopoli di Sitato) (notified under document number C(1998) 1437), OJ I. 252, 12.09.1998, p. 47, [referenced in fiotnotes as: Commission Decision AAMST.

-, Conmission Decision 1999/267/HC of 7.04.1999 (2V/36.147 EPI cade of conduct), of 07.04.1999, OJ I. 106, 23.04.1999, p. 14, [referenced in footnotes as: Commission Decision EiPI Code of Conduct.

-, Commission Decision 1999/243/I:C of 16.09.1998, (IV/35.134 - Trans-Atlantic Conference Agreement), OJ L 95, 9.04.1999, p.1, [referenced in footnotes as: Commission Decision TACAII].

--, Commission Decision 1999/329/LC of 12.04.1999 (IV/D-1/30.373-P I Clubs, IGA and NoIV/D. 1/37.143 - P er I Clubs, Pooling Agreement), OJ L 125, 19.05.1999, p.12, [referenced in footnotes as: Commission Decision $P$ \& $I$ Clubs].

- Cammission Dexision 2000/627/LC of 16.05.2000 (IV/34.018 - Far Last Trade Tariff Charges and Surcbarges Agreement (FF:TTCS.A)) (notified under document number C(2000) 1170), OJ L. 268, 20.10.2000, p. 1, [referenced in footnotes as: Commission Decision HETTCSA 1 .

-. Commission Decision 2000/12/EC of 20.07.1999 (Case IV/36.888 - 1998 Football World Cup), OJ L 5, 08.01 .2000$, p. 55, [referenced in footnotes as: Commission Derision Football World Cxp 1998].

-, Commission Decision 2000/74/EC of 14.07.1999 (IV/D-2/34.780 - Vingin/British Ainvays), Of L 30, 4.02.2000, p. 1, [referenced in footnotes as: Commission Decision Lingin/BA].

-, Commission Decision 2000/475/EC of 24.01.1999 (Case IV.F.1/36.718. CECED), of 24.01.2000, OJ L 184, 26.07 .2000$, p. 47, last visited on 18.06.2009, [referenced in footnotes as: Commission Decision CECEED].

-, Commission Decision 2001/418/EC of 07.06.2000 (Case COMP/36.545/F3 - Amino Acids), OJ L.152, 7.06.2001, p.24, [referenced in footnotes as: Commission Decision Amino Arids.

- Commission Decision 2001/892/HC of 25.07. 2001 (COMP/C-1/36.915 - Deutsche Post $A G$ - Interception of cross-border mail), OJ I. 331, 15.12.2001, p. 40, [referenced in footnotes as: Commission Decision Deutscbe PasA].

--, Commission Derision of 16.04.2002 - Piau v FIIA (COMP/37.124, non-confidential version), of 16.04.2002, at $<$ http://ec.europa.eu/competition/antitrust/cases/decisions/37124/fr.pdf>, last visited on 18.06.2009, [referenced in footnotes as: Commission l)ecision l'iax].

--, Commission Decision of 24.06.2004, Recommended prices for Belgian Arcbilects (COMP/38.549), at 
<http://www.ec.europa.eu/comm/competition/antitrust/cases/decisions/38549/en.pdf>, last visited on 18.06.2009, [referenced in footnotes as: Commission Decision Belgian architects].

--, Commission Decision of 03.05.2005 Retention of financial reserves by Dutch Healtb Insurance Funds and Introduction of a Risk equalisation system in the Dutch Health Insurance (N 541/2004 and $N$ 542/2004), at $<$ http://ec.europa.eu/community_law/state_aids/comp-2004/n541-542-04.pdf>, last visited on 14.06.2009, [referenced in footnotes as: Commission Decision Dutch bealth insurance system].

\section{France}

\section{Conseil de la Concurrence,}

Decision Conseil de la Concurrence - Pratiques mises en oewure par le Conseil national de l'Ordre des architectes, no. 97D45 of 10.06.1007.

\section{Netherlands}

Letter of 23.12.2004 to the Tweede Kamer (Instellen van Commissie Advocatuur), at <http://www.justitie.nl $>$. No cure no pay en letselschadezaken - Letter of 04.03.2005 to the Tweede Kamer, at <http://www.justitie.nl>.

\section{Koninklijk Besluit,} Annulment of NOvA regulation on quota pars litis, of 09.03.2005, Staatsblad 123.

Nederlandse mededingingsautoriteit (NMa), Engelgeer tegen Nederlandse Orde van Advocaten - 'no cure, no pay', no. 560 of 21.02 .2002 , at <http://www.nmanet.nl/nl/Images/11_2369.pdf>.

\section{Table of public acts}

EU Heads of State and Government, Agreement on Social Policy concluded between the Member States of the European Community with the exception of the United Kingdom of Great Britain and Northern Ireland, OJ C 191, 29.7.1992, p. 91.

---, Treaty of Lisbon - Protocol on Services of General Interest, OJ C 306, 17.12.2007, p. 158.

\section{European Commission,}

Commission Regulation (EC) No 2790/1999 of 22 December 1999 on the application of Article 81(3) of the Treaty to categories of vertical agreements and concerted practices, OJ L 336, 29.12.1999, p. 21.

\section{European Council,}

Council Regulation No. 17 of 10.02.1962, First Regulation implementing Articles 85 and 86 of the Treaty (now Arts. 81 and 82 EC), OJ 13, 21.02.1962, p. 204.

---, Regulation No 19/65/EEC of 2 March 1965 on the application of Article 85 (3) of the Treaty to certain categories of agreements and concerted practices, OJ L 36, 06.03.1965, p. 533.

---, Council Directive 75/362/EEC of 16.06 .1975 concerning the mutual recognition of diplomas, certificates and other evidence of formal qualifications in medicine, including measures to facilitate the effective exercise of the right of establishment and freedom to provide services (doctors), OJ L 167, 30.06.1975, p. 1.

--, Council Directive 77/249/EEC of 22 March 1977 to facilitate the effective exercise by lawyers of freedom to provide services, OJ L 78, 26.03.1977, p. 17.

--, Council Directive 84/450/EEC of 10 September 1984 relating to the approximation of the laws, regulations and administrative provisions of the Member States concerning misleading advertising, OJL 250, 19.09.1984, p. 17.

-.-., Council Directive 85/384/EEC of 10 June 1985 on the mutual recognition of diplomas, certificates and other evidence of formal qualifications in architecture, including measures to facilitate the effective excrcise of the right of establishment and freedom to provide services, OJ L 223, 21.08.1985, p. 15.

---, Council Directive 85/433/EEC of 16.09 .1985 concerning the mutual recognition of diplomas, certificates and other evidence of formal qualifications in pharmacy, including measures to facilitate the effective exercise of the right of establishment relating to certain activities in the ficld of pharmacy (pharmacistsrecognition), OJ L 253, 24.09.1985, p. 37. 
---, Council Regulation (EEC) No 4056/86 of 22.12.1986 laying down detailed rules for the application of Articles 85 and 86 of the Treaty to maritime transport, OJ L 378, 31.12.1986, p. 4.

---, Council Directive 89/48 of 21 December 1988 on a gencral system for the recognition of higher-education diplomas awarded on completion of professional education and training of at least three years' duration, $O J$ L 19, 24.01.1989, p. 16.

---, Council Directive $92 / 51 /$ EEC of 18 June 1992 on a second general system for the recognition of professional education and training to supplement Directive 89/48/EEC, OJ L 209, 24.07.1992, p. 25.

---, Council Regulation (EEC) No 2408/92 of 23.07 .1992 on access for Community air catriers to intraCommunity air routes, OJ L 240, 24.08.1992, p. 8.

-.-. Council Directive $98 / 5$ of 16 February 1998 to facilitate practice of the profession of lawyers on a permanent basis in a Member State other than that in which the qualification was obtaincd, OJ L 77, 14.03.1998, p. 36 .

---, Council Regulation (EC) No 1/2003 of 16.12.2002 on the implementation of the rules on competition laid down in Articles 81 and 82 of the Treaty, OJ L 1, 04.01.2003, p. 1.

---, Council Regulation (EC) No 139/2004 of 20.01.2004 on the control of concentrations between undertakings (the EC Merger Regulation), OJ L 24, 29.01.2004, p. 1.

European Council / European Parliament, Directive 97/55/EC of 6 October 1997 amending Directive 84/450/EEC concerning misleading advertising so as to include comparative advertising, OJ L 290, 23.10.1997, p. 18.

---, Directive 1999/42/EC of the European Parliament and of the Council of 07.06.1999 establishing a mechanism for the recognition of qualifications in respect of the professional activities covered by the Directives on liberalisation and transitional measures and supplementing the general systcms for the recognition of qualifications, OJ L 201, 31.07.1999, p. 77.

---, Directive 2001/19/EC of the European Parliament and of the Council of 14 May 2001 amending Council Directives $89 / 48 / \mathrm{EEC}$ and $92 / 51 / \mathrm{EEC}$ on the general system for the recognition of professional qualifications and Council Directives 77/452/EEC, 77/453/EEC, 78/686/EEC, 78/687/EEC, 78/1026/EEC, 78/1027/EEC, 80/154/EEC, 80/155/EEC, 85/384/EEC, 85/432/EEC, 85/433/EEC and $93 / 16 / \mathrm{EEC}$ concerning the professions of nurse responsible for general care, dental practitioner, vetetinary surgeon, midwife, architect, pharmacist and doctor, OJ L 206, 31.07.2001, p. 1.

---, Directive 95/46/EC of 24 October 1995 on the protection of individuals with regard to the processing of personal data and on the free movement of such data, OJ L 281, 23.11.1995, p. 31.

---, Directive 2005/36/EC of 7 September 2005 on the recognition of professional qualifications, OJ L 255, 30.09 .2005 , p. 22

--., Directive 2006/123/EC of the European Parliament and of the Council of 12 December 2006 on services in the internal market, OJ L 376, 27.12.2006, p. 36, at <http://eur-lex.europa.eu/LexUriScrv/LexUriServ .do?uri=OJ:L:2006:376:0036:0068:EN:PDF>.

--, Directive 2006/123/EC of 12 December 2006 on services in the internal market, OJ L 376, 27.12.2006, p. 36.

\section{France - French Govemement}

Ordonnance n. 45-2590 relative au statut du notariat of 02.11.1945 (Regulation on the status of the profession of notary (public)), JORF 03.11.1945, at <http://www.legifrance.gouv.fr >

---, Décret n*45-0117 pris pour l'application du statut du notariat of 19.12.1945 (Implementing decree on the status of the profession of notary (public)), JORF 22.12.1945, at <http://www.legifrance.gouv.fr $>$.

--, Décret n. 91-1197 organisant la profession d'avocat (Decree organising the lawyer's profession), JORF $n$. $277 \mathrm{du} 28.11 .1991$, at < http://www.cnb.avocat.fr or http://www.legifrance.gouv.fr>.

\section{Germany - Deutscher Bundestag,}

Bundesgebührenordnung für Rechtsanwälte of 26 July 1957 (Lawyer Fees Act), BGBL I, 861, 907 (BGBl. III 368-1).

\section{Netherlands}

Advocatenwet (as amended on 02.02.1989) (Lawyers Act), 1952 Stb. 365, 1989 Stb. 15.

Wet op het notarisambt (WNA) (Notarial Act 1999), at <http://wettenbank.sdu.nl>. 


\section{UK - Parliament,}

Courts and Legal Services Act 1990, at <http://www.hmso.gov.uk/acts/acts1990/Ukpga_19900041_ en 1. htm $>$.

---, Architects Act 1997, at <http://www.hmso.gov.uk/acts/acts1997/1997022.htm>.

--, Access to Justice Act 1999, at <http://www.opsi.gov.uk/acts>. --, National Health Service Reform and Health Care Professions Act 2002, at
<http://www.opsi.gov.uk/acts.htm $>$.

---, Legal Services Act 2007, at <http://www.opsi.gov.uk/acts/acts2007/ukpga_20070029_cn_1>.

\section{Table of bills}

\section{European Commission,}

Proposal for a Council Regulation on the Implementation of the Rules on Competition Laid Donn in Articles 81 and 82 of the Treaty and Amending Regulations (EEC) No 1017/68, (EEC) No 2988/74, (EEC) No 4056/86 and (EEEC) No 3975/87, COM(2000) 582 final, OJ C 365E, 19.12.2000, p. 284.

Germany - 105. Bauministerkonferenz (ARGEBAU),

Musterarcbitektengesetz (MArchG) of 23.05.2002, at<http://www.is-argebau.de/Dokumente/MArchG.pdf > .

\section{Bundestat,}

Entwurf eines Gesetzes zur Reform des Gerichtsvollqieberwesens of 11.05.2007, Drucksache 150/07 (Beschluss), at $<$ http://www.justiz.baden-wuerttemberg.de/servlet/PB/show/1205914/BR\%20DRs.\%200150-07.pdf>.

UK - Government,

Legal Services Bill - Full Regulatory Impact_Assessement of 24.11.2006, at<http://www.dca.gov.uk/ risk/ ria-legalservices.pdf>.

EC - Conférence des Notariats de l'Union Européenne (CNUE),

Code Européen de déontologie notariale, at $<\mathrm{htt}: / /$ www.cnue.be/f-code.htm; the German translation of the French text can be found at http://www.bnotde/texte_berufsrecht/kodex/europacischer_kodex_ franz.htm >.

\section{Netherlands - NOvA,}

Verordeningop de praktijkuitovening (onderdeel Resultaatgerelateerde Beloning) (Regulation on professional practice (quota pars litis)), at <http://www.advocatenorde.nl/ $>$.

\section{Non-binding legal documents}

\section{Council of Europe,}

Recommendation of the Committee of Ministers to Member States on the freedom of exercise of the profession of lanyer of 25.10.2000, Rec(2000)21, (Strasbourg), 26 p., at <http://www.cm.coe.int/ta/rec/2000/2000r21.htm>.

European Commission,

Report on the Bebaviour of the Oil Companies during the period from October 1973 to March 1974 of 10.12.1975, COM (75) 675, [referenced in footnotes as: Report on the Behaviour of the Oil Companies].

--., White Paper on completing the intermal market of $14.06 .1985, \mathrm{COM}(85) 310$.

---, Commission Notice on Ancillary Restraints OJ C 20, 01.08 .1990 , p. 5.

--.-. The impact and effectiveness of the Single Market - Communication from the Commission to the European Parliament and Council of 30.10.1996, COM(96)520 final (Luxembourg), 36 p., [referenced in footnotes as: The impant and effectiveness of the Single Market].

---, 1996 Communication on Services of general interest in Europe OJ C 281, 26.09.1996, p. 7.

--., Commission Notice on agreements of minor importance which do not appreciably restrict competition under Article 81(1) of the 
Treaty establisbing the European Community (de minimis) OJ C 372, 09.12.1997, p. 13.

---, Commission Notice - Guidelines on the method of setting fines imposed pursuant to Article 15(2) of Regulation No 17 and Article 65(5) of the ECSC Treaty OJ C 9, 14.1.1998, p. 3, [referenced in footnotes as: Guidelines on the method of setting fines].

---, White Paper on Modernisation of the Rules Implementing Articles 85 and 86 of the EC Treaty of 28.04.1999, COM(1999) 101 final, OJ C 132, 12.05.1999, p. 1.

---, The Strategy for Europe's Intemal Market - Communication from the Commission to the European Parliament and the Council of 29.11.1999, COM(1999)624 final/2 (Brussels), 28 p., [referenced in footnotes as: The Strategy for Europe's Internal Market].

---, An Intermal Market Strategy for Services - Communication From the Commission to the Council and the European Parliament of 29.12.2000, COM(2000)888 final (Brussels), 21 p., [referenced in footnotes as: An Internal Market Strategy for Services].

---, XXIXtb Report on Competition Policy 1999 SEC(1999) final, at $<$ http://ec.europa.eu/competition/annual_reports/>.

-.-., Commission Notice on agreements of minor importance which do not appreciably restrict competition under Article 81(1) of the Treaty establishing the European Community (de minimis) OJ C 368, 22.12.2001, p. 13.

---, 2001 Communication on Services of Gentral Interest in Europe OJ C 17, 19.01.2001, p. 4 (Brussels), 20 p., at $<$ http://eur-lex.curopa.eu/LexUriServ/site/en/oj/2001/c_017/c_01720010119en00040023.pdf>, last visited on 05.05.2009.

---, Commission Notice on restrictions directly related and necessary to concentrations OJ C 188, 04.07.2001, p. 5.

--, Report to the Laeken European Council - Services of General Interest of 17.10.2001, COM(2001) 598 final, 23 p., at $<$ http://ec.europa.eu/services_general_interest/documents_en.htm>, last visited on 05.05.2009.

---, Report from the Commission to the Council and the European Parliament on The State of the Interral Market for Services of 30.07.2002, $\operatorname{COM}(2002) 441$ final (Brussels), 74 p., at <http://curopa.eu.int/curlex/en/com/rpt/2002/com2002_0441en01.pdf>.

---, The application of the EU's competition rules to sports of 05.06 .2002 , at $<$ http://ec.europa.eu/competition/sectors/sports/overvicw_en.html>.

--, Commission Notice on immunity from fines and reduction in fines in cartel cases OJ C 45, 19.2.2002, p. 3.

---, Regultation in Liberal Professions and its Effects - Invitation to comment of 27.03.2003, (Brussels), 17 p., at $<$ http://europa.eu.int/comm/competition/general_info/invitation/en.pdf>.

---, Stocktaking Exercise on Regulation of Professional Services - Overview of Regulations in the EUMember States of October 2003, Conference document, $20 \mathrm{p}$.

---, Invitation to Comment-Regulation in Liberal Professions an its Effects - Summary of Responses of October 2003, 22 p.,

$<$ http://ec.europa.eu/competition/sectors/professional_services/studies/summary_of_consultation_re sponses.pdf>.

---, Green Paper on Services of General Interest of 21.05.2003, $\operatorname{COM}(2003) 270$ final, 63 p., at $<\mathrm{http}: / /$ ec.europa.eu/services_general_interest/green_en.htm>, last visited on 05.05.2009.

---, Communication from the Commission - Report on Competition in Professional Services of 09.02.04, COM(2004)83 final (Brussels), 27 p., at <http://eur-lex.europa.eu/LexUriServ/LexUriServ.do?uri=COM:2004:0083:FIN:EN: PDF>, last visited on 30.05.2009, [referenced in footnotes as: Report on Competition in Professional Services].

---, Commission Notice - Guidelines on the application of Article 81(3) of the Trealy OJ C 101, 27.04.2004, p.97, [referenced in footnotes as: Guidelintes on the application of Article 81(3) EC].

---, White Paper on Services of General Interest. Communication from the Commission to the European Parliament, the Council, the European Economic and Social Committee and the Committee of the Regions of 12.05.2004, COM(2004) 374 final, 28 p., at <http://eur-lex.europa.eu/LexUriServ/LexUriServ.do?uri=COM:2004:0374:FIN:EN:PDF>, [referenced in footnotes as: White Paper on Services of General Interest].

---, Commission Notice on informal guidance relating to novel questions concerming. Articles 81 and 82 of the ECTreaty that arise in individual cases (guidance letters) OJ C 101,27.04.2004, p. 78, [referenced in footnotes as: Notice on guidance letters].

--, Stocktaking Exercise on Regulation of Professional Services - Overview of Regulation in the New EU Member States of 10/2004, COMP/D3/MK/D(2004), (Brussels), 20 p., at <http://ec.europa.eu/competition/sectors/ professional_services/studics/overview_of_regulation_in_the_eu_professions.pdf $>$, last visited on 30.05.2009, [referenced in footnotes as: Stocktaking Exercise on Regulation of Professional Services].

--, Commission Notice on cooperation within the Network of Competition Authorities OJ C 101, 27.04.2004, p. 43.

---, Commission Notice - Guidelines on the effect on trade concept contained in Articles 81 and 82 of the Treaty OJ C 1001, 
27.04.2004, p. 81, [referenced in footnotes as: Guidelines on the effect on trade concept].

---, Guidelines on the assessment of borizontal mergers under the Council Regulation on the control of concentrations between undertakings OJ C 31, 05.02.2004, p. 5.

-- , Commission Notice on restrictions directly related and necessary to concentrations OJ C 56, 05.03.2005, p. 24.

---, Communication from the Commission: Professional Services - Scope formore reform of 05.09.2005, COM(2005) 405 final, 11 p., at <http://cur-lex.europa.eu/LexUriServ/LexUriServ.do?uri=COM:2005:0405:FIN:EN:PDF>, [referenced in footnotes as: Professional Services - Scope for more reform].

---, Commission Staff Working Document: Progress by Member States in reviewing and eliminating restrictions to Competition in the area of Professional Services of 05.09.2005, SEC(2005) 1064, 38 p., at $<$ http://www.cco.public.lu/attributions/cconc/staffworkingdoc.pdf >, [referenced in footnotes as: Progress by Member States in reviewing professional services].

---, Common Actions for Growth and Employment: The Community Lisbon Programme of 20.07.2005, COM(2005) 330 final, (Brussels), 10p., at < http://ec.europa.eu/growthandjobs/pdf/COM2005_330_en.pdf>, [referenced in footnotes as: Common Actions for Growth and Employment.

--, Report on Competition Policy 2004 - Volume 1 SEC(2005) 805 final, 202 p., at $<$ http://ec.europa.eu/competition/annual_reports/>.

-D D Competition discussion paper on the application of Article 82 of the Treaty to exclusionary abuses - Public consultation of 12/2005, (Brussels), 72 p., at <http://ec.europa.eu/competition/antitrust/art82/discpaper2005.pdf>, last visited on 02.05.2006, [referenced in footnotes as: DG Competition discussion paper on exclusionary abuses].

--, Consultation regarding Community action on bealth services of 26.09.2006, SEC(2006) 1195/4, 11 p., at $<\mathrm{http}: / /$ ec.europa.eu/health/ph_overview/keydocs_overvicw_en.htm>, last visited on 05.05.2009.

--, Enhancing the quality of services in the Internal Market: The role of European codes of conduct (2007), 19 p., at <http://ec.europa,eu/internal_market/services/docs/services $\mathrm{dir} /$ codeconduct/the_role_of_european_codes_of_conduct_en.pdf $>$, last visited on 17.12.2008, [referenced in footnotes as: The role of European codes of conduct].

---, Services of general interest, including social services of general interest: a new European commitment (Communication accompanying the Communication on 'A single market for 21 st century Europe') of 20.11.2007, COM(2007) 725 final, 14 p., at <http://cc.europa.cu/services_general_interest/interest_en.htm>, last visited on 05.05.2009.

--, Report on Competition Policy 2006 - Including Commission Staff Working Document SEC(2007) 860, 140 p., at $<\mathrm{http}: / /$ cc.curopa.eu/competition/annual_reports/>.

---, Guidance on the Commission's enforcement priorities in applying Article 82 of the EC Treaty to abusive exclusionary conduct by dominant undertakings of $09.02 .2009, \mathrm{C}(2009) 864 \mathrm{final}$, OJ C 45, 24.02.2009, p. 7, at <http://eurlex.curopa.eu/LexUriServ/LexUriServ.do?uri=OJ:C:2009:045:0007:0020:EN:PDF>, last visited on 30.05.2009, [referenced in footnotes as: Guidance on exclusionary conduct].

European Council, Presidengy Conclusions of 23./24.03.2000, (Lisbon), 16 p., at <http://europa.eu.int/ISPO/docs/services/ docs $/ 2000 /$ jan-march/doc_00_8_en.doc $>$, last visited on 13.03.2007.

--, Presidency Conclusions of 23.03.2005, 7619/1/05 REV 1, (Brussel), 38 p., at $<$ http://ue.eu.int/ueDocs/cms_Data/docs/pressdata/en/ec/84335.pdf>, last visited on 22.04.2007.

---, Presidency Conclusions of 23./24.03.2006, (Brussel), 35 p., at <http://uc.cu.int/ueDocs/cms_Data/docs/ pressData/en/ec/89013.pdf>, last visited on 17.12.2008.

\section{Reports}

\section{European Parliament,}

Report on the Commission White Paper on services of general inlerest of 14.09.2006, A6-0275/2006, 42 p., at $<$ http://www.curoparl.europa.eu/RcgData/seance_pleniere/textes_deposes/rapports/2006/0275/P6 A(2006)0275_EN.pdf>, last visited on 05.05.2009.

European Parliament's Committee on Internal Market and Consumer Protection / T.C.M Asser Institute / Edge Hill College Lancaster University,

Professional Sport in the Intermal Market (commissioned by the European Parliament) of 09/2005, PE 358 378, (Den Haag), 95 p., at <http://www.europarl.eu.int/comparl/imco/studies/0905_study_sport_en.pdf>, last 
visited on 22.03.2006.

Eurostat,

Statistics in Focus 11/2005: Industry, Trade and Services - Developments for turnover and employment indices for services during the third quarter of 2004 (Iuxembourg) (2005), 12 p., at <http: \lwww.edsdestatis.de/en/downloads/sif/np_05_11.pdf>.

Germany - Bundesministerium für Wirtschaft und Technologie (BMWI),

Bericht der Bundesregierung über die Lage der Freient Berufe of June 2002, (Berlin), 50 p., at <http://www.bmwi.de/Redaktion/Inhalte/Downloads/bericht-der-bundestegicrung-freieberufe.pdf,property=pdf.pdf $>$, [referenced in footnotes as: Die Lage der Freien Berufe].

Bundestegierung, Bericht der Bundesregierung ïber die Lage der freien Berufe in der Bundesrepublik Deutschland BT-DrS. 8/3139 (Bonn) (1979), [referenced in footnotes as: Die Lage der Freien Beruff].

--., Antwort auf die Kleine Anfrage zur 'Lage der Freien Beruff' BT-DrS. 9/2358, 9/2385 (Bonn) (1983).

---, Lage der Freien Berufe im Zuge der Scbaffung des europäischen Binnenmarktes BT-DrS. 11/5640 (Bonn) (1989).

-.-. Fortscbreibung des Berichts der Bundesregierung über die Lage der Freien Berufe in der Bundesrepublik Deutschland BT-DrS. 12/21 (Bonn) (1991), [referenced in footnotes as: Fortscbreibung des Berichts über die Lage der Freien Berufe].

Ireland Indecon International Economic Consultants, Assessment of Restrictions in the Supply of Professional Services (Prepared for the Irish Competition Authority) of 20.03.2003, at <www.tca.ie/professions.html>.

The [Irish] Competition Authority, Study of Professional Services - Preliminary Consultation Document of 01.05.2001, 6 p.

---, Study of Competition in Legal Services - Preliminary Report of 24.02.2005, 138 p., at $<$ http://www.tca.ie/professions/legal_preliminary_reportpdf $>$.

Italy - Autorità Garante della Concorrenza e del Mercato, Indagine conoscitiva nel settore degli ordini e collegi professionali Suppl. n. 1 al Boll. n. 40/1997 - Anno VII (Roma) $(1997), \quad 327$ p., at <http://w w w a g cm.it/D $31 . \mathrm{htm}>$; <http://www.agcm.it/agem_ita/DSAP/DSAP_IC.NSF/bcf0799f25d242c6c12564ac004bf2a5/c49e916 6f4b6e5dec12564c3004594ab?OpenDocument>.

---, Indagine conoscitiva nel settore farmaceutico IC 14, (Roma) (1997), 81 p., at<http://www.agcm.it/; http://www.agcm.it/agcm_ita/DSAP/DSAP_IC.NSF/bcf0799f25d242c6c12564ac004bf2a5/3a250fe3 093bed4ac12564c3004594a7/\$FILE/Ic14.pdf>.

Netherlands

Marktwerking, Deregulering, Wetgevingskwaliteit (MDW), Gezondheidszorg (Den Haag) (1997), [referenced in footnotes as: (MDW), Gezondheidszorg].

Marktwerking, Deregulering, Wetyevingskewaliteit(MDW), Accountancy (Den Haag) (1997), [referenced in footnotes as: (MDW), Accotutang].

Marktwerking, Deregulering, Wetgevingskualiteit (MDWV), Makelaars (Den Haag) (1998), [referenced in footnotes as: (MDW), Makelaars].

Marktwerking, Deregulering, Wetgevingskwaliteit (MDW), Nooit meer wacbten. Minder toetredingsbelemmeringen voor medische vrije beroepen of 07/2001, (Den Haag), [referenced in footnotes as: (MDW), medische vrije beroeper]. Marktwerking, Deregulering, Wetgevingskwaliteit (MDW), Kosten nog moeite. Drempels slechten voor de switchende consument (Den Haag) (2002), [referenced in footnotes as: (MDW), Drempels slecbten voor de switchende consument].

Centraal Plan Bureau (CPB) - Netherlands Bureau for Economic Policy Analysis, A quantative assessment of the EU proposals for the Internal Market for Services of 05.10.2005 (revised), (Den Haag), 16 p., at <http://www.cpb.nl/nl/pub/cpbreeksen/notitie/23sep2004/notitic.pdf>, last visited on 10.03.2006.

Commissie cassatie-advocatuur, Advies Commissie cassatie-advocatuur of 21.07.2004 (presented to the Ministry of Justice on 17.08.2004), (Den Haag), 17 p., at <http://www.justitie.nl/Images/11_56192.pdf>.

Commissie evaluatie wet op het notarisambt, Het beste van twee werelden - Hammerstein Report of 09/2005, 153 p., at 
<http://www.justitie.nl/Images/wet_op_notarisambt_tcm74-90099.pdf>, [referenced in footnotes as: Hammerstein Report.

Commissie Monitoring Notariaat,

Eindrapport Commissie Monitoring Notariaat: periode 1999-2003 of 12.02.2003, (Den Haag), 28 p., at

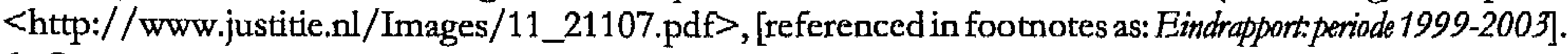

Dutch Government,

Verslag van een algemeen overleg (no cure no pay, quota pars litis) of 09.11.2004, Kamerstukken 2004/05, 29800, VI, nr. 94.

--, Reactie van bet kabinet op de aanbevelingen van de Commissie advocatuur of 13.10.2006, Tweede Kamer, vergaderjaar 2006-2007, 30800 VI, nr. 13, 26 p., at <http://www.justitie.nl/images/KST101879_tcm3421737.pdf>, last visited on 11.03.2008.

Ministerie van Economische Zaken,

Kansen voor meer marktwerking in de urije beroepen (Den Haag) (2003).

---, Pampblet on the Liberal Professions - a practical guide to public interests and regulatory instruments of 10.12.2004, (Den Haag), 13 p., at <http://appz.ez.nl/publicatics/pdfs/04EP14.pdfs.

---, Marktwerking en Regulering: Theoretiscbe aspecten en ervaringen in Nederland en bet buitenland (Den Haag) (1995).

Ministerie van Justitie, Marktwerking, Deregulering, Wetgevingskewaliteit (MDW), Domeinmonopolie adwocatuur (Den Haag) (1995), [referenced in footnotes as: (MDW), Domeinmonopolie advocatuur].

Nederlandse mededingingsautoriteit (NMa), Agenda 2004 of 23.01.2004, (Den Haag), at <http://www.nmanet.nl/nl/nieuws_en_publicaties/publica ties/nmaagenda_2004.asp>.

--, Consultatiedocument NMa-agenda 2004 (Den Haag), at <http://www.nmanet.nl/nl/Images/11_10663.pdf>.

--, Consultatiedocument NMa-agenda 2006 (Den Haag), at <http://www.nmanet.nl>.

---, Inventarisatie vrije beroepen: notariaat of 03/2006, (Den Haag), 40 p., at $<$ http://www.nmanet.nl/Images/CoDo\%20Inventarisatie\%20Notatissen_tcm16-85610.pdf>, lastvisited on 18.08.2006.

Onderzoeksinstituut OTB / Instituut voor Bouwrecht / Rijksuniversiteit Groningen, Arcbitect en Titelwet: Een evaluatieonderzoek naar bet functioneren van de wet op de architectentitel en bet architectenregister (Rotterdam) (uitgeverij 010, 2001).

Wetenschappelijke Raad voor het Regeringsbeleid (WRR - Netherlands Scientific Council for Government Policy),

Safeguarding the Public Interest - Summary of the 56th Report to the Government (Den Haag) (2001), 77 p., at $<$ http://www.wrr.nl/content.jsp?objectid=2702>, last visited on 03.05.2006.

UK - Competition Commission,

Veterinary Medicines - A report on the supply within the United Kingdom of prescription-only veterinary medicines of 03/2003, 540 p., at <http://www.competition-commission.org.uk/reports/478vetmeds.htm>.

Department for Constitutional Affairs,

Constitutional reform: the future of Queen's Counsel of 07/2003, (London), 73 p., at $<$ http://www.dca.gov.uk/consult/qcfuture/qc.pdf> .

---, White Paper: The Future of Legal Services: Putting Consumers First of 17.10.2005, Cm 6679, 158 p., at $<$ http://www.dca.gov.uk/legalsys/lsteform.htm>.

Foreign and Commonwealth Office, Private Military Companies: Options for Regulation of 12.02.2002, HC 577, (London, The Stationery Office), 48 p., at <http://www.fco.gov.uk/Files/kfile/mercenaries,0.pdf>, last visited on 10.03.2006.

House of Lords,

Completing the Internal Market in Senvices - Report with Evidence of 07/2005, HL Paper 23, (London), 242 p., at $<\mathrm{http}: / /$ www.parliament.uk/parliamentary_committees/lords_eu_select_committee.cfm>.

Law Society,

A discussion draft of the Lay Society's response to the consultation paper of the Review of the regulation of legal services in England and Wales of $02.02 .2004,55 \mathrm{p}$.

Lord Chancellor's Department,

In the public interest? - $A$ consultation by the Lord Chancellor's Department following the OFT report on Competition in Professions of July 2002, Cm. 570 (London), 79 p., at <http://www.dca.gov.uk/consult/general/oftrept.pdf>, [referenced in footnotes as: In the public interest']. 
Monopolies and Mergers Commission,

Report on the general effect on the public interest of certain restrictive practices so far as they prevail in relation to the supply of professional services Cmnd 4463, (1970).

--, Barristers' services. A report on the supply of barristers' services in relation to restrittions on advertising (London) (1976), $24 \mathrm{p}$.

---, Advocates' services. A report on the supply of advocates' services in relation to restrictions on advertising (London) (1976), $23 \mathrm{p}$.

---, Barristers' services. A report on the supply by Her Majesty's Counsel alone of their senvices (London) (1970), $57 \mathrm{p}$.

--, Advocates' services. A report on the supply by Senior Counsel alone of their services (London) (1976), $51 \mathrm{p}$.

Office of Fair Trading,

Trade Associations, Professions and Self-Regulating Bodies OFT 408, UKCLR 178 (1998), 13 p., at $<\mathrm{http}: / /$ www.oftgov.uk/News/Publications/Leaflet+Ordering.htm>.

---, Competition in Professions of March 2001, OFT 328, 19 p. + annex LECG report "Restrictions on Competition in the Provision of Professional Services", 143 p., at $<$ http://www.oftgov.uk/shared_oft/reports/professional_bodies/oft328.pdf>, lastvisited on 10.03.2008.

---, Competition in Professions - Progress statement of April 2002, OFT 385, 22 p., at $<$ http://www.oftgov.uk/shared_oft/reports/professional_bodies/oft385.pdf>, lastvisited on 10.03.2008.

-.-., The control of entry regulations and retail pharmacy services in the UK of 17.01.2003 (revised in March 2003), OFT 609,75 p., at <http://www.oft.gov.uk/NR/rdonlyres/BABF839A-3088-4EBB-B3A9. 00D955719EE0/0/oft609.pdf>, last visited on 18.04.2006.

---, The privale dentistry market in the UK of 03/2003, OFT 630, (London), 131 p., at <http://www.oft.gov.uk/NR/rdonlyres/ell5067dmn3j3wvmfmkkoszwuhbGumyat3lylex3vl62lc5ujk3xsf fuhkgogi6ko6ohex4x3lmwwwn72uvcxzlwkne/oft630.pdf>.

--, Trade associations, professions and self-regulating bodies of December 2004, OFT 408, 28 p., at <http://www.oft.gov.uk/NR/rdonlyres/E13DECC7-48CF-49E0-95AD-AF968E10762B/0/oft408.pdf>.

---, Consultation on the future regulatory framework, for legal services in England and Wales - Response from the Office of Fair Trading of June 2004, OFT 722, 35 p., at <http://www.oft.gov.uk/nt/rdonlyres/fb2a9f14-7cd7-4f99-a2ca1f4cee4981bb/0/oft722.pdf>.

---, The Competition Act 1998 and public bodies of 08/2004, Policy note 1/2004, OFT 443, 9 p., at <http://www.oftgov.uk/NR/rdonlyres/B63ACCDC-73BC-49F9-B452-A8B46535D0B9/0/oft443.pdf>, last visited on 07.03.2006.

---, Assessment of market power of 12/2004, 26 p., at <http://www.oft.gov.uk/NR/rdonlyres/A92F91BC-B5564724-8D2B-7002F6CDEA65/0/oft415.pdf>, last visited on 18.04.2006.

---, Abuse of a dominantposition - Understanding competition law of 2004, OFT 402, 20p., at <http://www.oft.gov.uk $>$.

The Law Society, The Future of Legal Services - Putting Consumers First. Response of the Law Society's Regulation Board to the White Paper

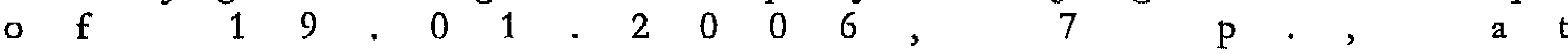
<http://www.lawsociety.org.uk/documents/downloads/dynamic/whitepaperresponseregboard190106 .pdf $>$, last visited on 08.03.2006.

--, Quality Legal Services for Consumers: The response of the Consumer Complaints Board to the White Paper on The Future of Legal Services - Putting Consumers First of 20.01.2006, 29 p., at < http://www.lawsociety.org.uk/documents/ downloads/dynamic/whitepaperresponseccboard200106web.pdf>, last visited on 08.03.2006.

UK Government,

Competition and regulation in the legal services market - A report following the consultation "In the public interest?" of 27.07.2003, CP(R2) 07/02 DCA, 25 p. + annexes p., at <http://www.dca.gov.uk/consult/general/oftrept conc.htm>, [referenced in footnotes as: Competition and regulation in the legal services market]. 


\section{Press releases}

Autorità Garante della Concorrenza e del Mercato,

"The Competition Authority has submitted a report on competition and regulation", press release of 16.01.2002, at<http://www.agcm.it>.

\section{BRAK,}

"Abnahme der Rechtsanwalts-GmbHs 1999 um 56,4 Prozent - Zunahme der Partnerschaftsgesellschaft um 44,9 Prozent", press release of 11.04.2000, at <http://www.brak.de>.

European Commission (European Commission),

"Commission concentrates on nine cases of mobile telephony prices", press release IP/98/707 of 22.07.1998, at <http://europa.eu/rapid/>.

--, "Lisbon Strategy for Growth and Jobs: Commission's annual progress report - frequently asked questions", press release MEMO/06/23 of 25.01.2006, at <http://europa.eu/rapid/pressReleasesAction.do?reference $=\mathrm{MEMO} / 06 / 23 \&$ format $=\mathrm{HTML} \&$ aged $=0$ \&language $=\mathrm{EN} \&$ guil anguagc $=\mathrm{fr}>$.

---, "Commission launches inquiry into mobile and fixed telephony prices in the European Union", press release IP/98/141 of 09.02.1998, at <http://europa.eu/rapid/>.

-.- "Commission closes mobile telecommunications cases after price cuts", press release IP/98/1036 of 26.11.1998, at <http://europa.eu/rapid/>.

--., "Commission objects to recommended minimum fee scale of Belgian Architects' $\Lambda$ ssociation", press release $\mathrm{IP} / 03 / 1500$ of 05.11 .2003 , at <http://curopa.cu/rapid/>.

---, "Commission condemns Belgian architects' fee systcm", press release IP/04/800 of 24.06 .2004 , at $<$ http://europa.eu/rapid/>.

-.-, "Nationality requirements for notarics: Commission acts to ensure correct implementation of EU law in 16 Member States", press release IP/06/1385 of 12.10.2006, at <http://ec.europa.eu/internal_market/ qualifications/infringements_en.htm>, last visited on 30.05.2007.

--, "Competition: Commission publishes study on EU conveyancing services market", press release IP/08/101 of 29.01.2008, at <http://europa.cu/rapid/>, last visited on 16.05.2009.

Ministerie van Justitie, "Publieke functie notaris staat voorop", press release of 03.02.2006, at <http://www.minjus.nl/pers/persberichten/archief/Archief_2006/60203Publieke_functic_notaris_staa t_voorop.asp>.

NOvA (Nederlandse Orde van Advocaten),

"Advocaten akkoord met experiment no cure no pay", press release of 26,03.2004

---, "No cure no pay geen Trojaans paard", press release of 08.10.2004, at <http://www.advocatenorde.nl/>. 


\section{Literature}

Adriaansens, C.A. / Maks, J.A.H. / Philipsen, Niels J.,

"A Law and Economics Analysis of the Regulatory Framework for Architects in the Netherlands", in Crals, Evy / Verceck, Lode (Eds.), Regulation of Arcbitects in Belgium and tbe Netherlands - A Law and Economics Approach, (Leuven, I.annoo) (2005), 47-78.

Aicher / Schuhmacher,

"Art. 81 EGV", in Grabitz, Eberhard / Hilf, Meinhard (Eds.), Das Recht der Europäischen Union, (München, Beck) (2004), 3c-7g.

Akerlof, G.,

"The Markets for Lemons: Quality, Uncertainty and the Market Mechanism", (1970) Quarterly Jourmal of Economics, 488-500.

Albers, Michael, (Head of Unit, Directorate General for Competition),

Competition Screening - Conference on Better Regulation of Professional Services, (2005), at $<$ http://ec.europa.eu/competition/sectors/professional_scrvices/conferences/20051121/index.html>.

Al-Dabbah, Maher M.,

"Conduct, Dominance and Abuse in "Market Relationship": Analysis of Some Conceptual Issues under Article 82 E.C." (2000) European Competition Law Review, 45-50.

Aman, Alfred C. Jr.,

"Privatisation, Prisons, Democracy and Human Rights: The Need to Extend the Province of Administrative Iaw", in De Feyter, Koen / Gómez Isa, Felipe (Eds.), Privatisation and Human Rigbts in the Age of Globalisation, (Antwerpen; Oxford, Intersentia; Hart Publishing) (2005), 91-128, at $<$ http://papers.sstn.com/sol3/papers.cfm?abstract_id=820424>.

Amato, Filippo / Collins, Ben / De Waele, Sandra / Paserman, Ruth, "Professional services: more competition, more competitiveness, more consumer orientation", (2004) Competition Policy Newsletter, Number 2, 71-74, at <http://ec.europa.eu/competition/publications/cpn/>.

Amato, Giuliano, Antitrust and the Bounds of Power: The Dilemma of Liberal Democracy in the History of the Market, (Oxford, Hart Publishing) (1997).

Amtenbrink, Fabian / Vedder, Hans H.B., Recht van de Europese Unie, (Boom Juridische uitgevers) (2008), 593.

Andrews, Philip,

"Is Mecting Competition a Defence to Predatory Pricing? The Irish Sugar Decision Suggests a New Approach", (1998) European Competition Law Review, 49-57.

--,-, "Self-Regulation by Professions - The Approach Under E.U. and U.S. Competition Rules", (2002) European Campetilion Law Review, 281-285.

Arnull, Anthony / Dashwood, Alan / Dougan, Michael / Ross, Malcolm / Spaventa, Eleanor / Wyatt, Derrick, Wyatt and Dashwood's Eiuropean Union Law, (London, Sweet \& Maxwell) (5th ed., 2006), 1224.

Atruñada, Benito, "Managing Competition in Professional Services and the Burden of Inertia", in Ehlermann, Claus-Dieter / Atanasiu, Isabela (Eds.), European Competition Lan Annual 2004: The Relationship between Competition Law and (Liberal) Professions, (Oxford \& Portland/Oregon, Hart Publishing) (2006), (in the present study reference is being made to the page numbers of the version published online), at <http://www.iue.it/RSCAS/Research/Competition/2004(papers).shtml>.

Azevedo, J.P. / Walker, Mike, "Dominance: Meaning and Measurement", (2002) European Competition Law Review, 363.

Baarsma, Barbara / Koopmans, Carl / Mulder, José / de Nooij, Michiel / Zijderveld, Corine, Goed(koop) geregeld: Een kosten-baten analyse van wetgeving en zelfregulering SEO-rapport nr. 720 of 03/2004 (Stichting voor Economisch Onderzoek der Universiteit van Amsterdam, Amsterdam), 109, at $<$ http://www.marktordening.nl/aspx/dossier/Kostenbaten $\% 20$ analyse $\% 20 \mathrm{van} \% 20$ zelfregulering.pdf>.

Baarsma, Barbara / Felsō, Flóra,

Het proces als domein - Over de effecten van bet procesmonopolie van de advocatuur - Eindrapport (commissioned by the association of insurers - Verbond van V erzekeraars) SEO-rapportnt.846 of 11/2005 (SEO economisch onderzoek, Amsterdam), 95, at <http://www.seo.nl/nl/publicaties/rapporten/2005/846.html>. 
Baarsma, Batbara / Felsö, Flóra / van Geffen, Sjoerd / Mulder, José / Oostdijk, André, Zelf deen? Inventarisatiestudie van zelfreguleringsinstrumenten SEO-rapport nr. 664 of April 2003 (Ministerie van Economische Zaken, Amsterdam), 158, at <http://www.marktordening.nl/>.

Baarsma, Barbara / Mulder, José / Teulings, Coen,

Rechtszekerbeid als publiek belang - Over de notaris, zijn domein en de markt - Onderzoek in opdracht van het ministerie van Economische Zaken SEO-rapport nr. 765; EZ publicatienummer: 04EP09 of 10/2004 (Stichting voor Economisch Onderzoek der Universiteit van Amsterdam (SEO), Amsterdam), 86, at $<$ http://appz.ez.nl/publicaties/pdfs/04EP09.pdf>, [referenced in footnotes as: Rechtszekerbeid als publiek belang].

Bach, Albrecht,

"Case C-185/91, Bundesanstalt für den Güterfernverkehr v Gebrüder Reiff GmbH \& Co. KG; Case C2/91, Meng; Case C-245/91, OHRA Schadeverzekeringen NV", (1994) Common Market Law Review, [ 1368].

Baquero Cruz, Julio,

Between Competition and Free Movement - The Economic Constitutional Law of the European Community, (Oxford; Portland, Oregon, Hart Publishing) (2002), 176.

Barnard, Catherine,

"Fitting the Remaining Pieces into the Goods and Persons Jigsaw", (2001) European Law Review, 35-39.

---, The Substantive Law of the EU - The Four Freedoms, (Oxford, Oxford University Press) (2004), 549.

Bavasso, Antonio, "The Role of Intent Under Article 82 EC: From "Flushing the Turkeys" to "Spotting lionesses in Regent's Park"', (2005) European Competition Law Review, 616-623.

Becker, Ulrich,

"Artikel 28 EGV", in Schwarze, Jürgen (Ed.) EU-Kommentar, (Baden-Baden, Nomos) (2000), 429-462.

Beeston, Sarah / Hoehn, Tom,

"Boundaries of the Firm in EC Competition Law", in Grayston, John (Ed.) Eumpean Economics or Law: Competition - Single Market - Trade, (Bembridge, Palladian Law Publishing) (1999), 27-51, at $<$ http://www.palladianlaw.com>.

Bellamy \& Child / Rose, Vivien, Common Market Lay of Competition, (London, Sweet \& Maxwell) (4th ed., 1993).

Bicho, Maria-José,

"Professions libérales: aspects essenticls de l'action de la Commission en matière d'application des règles de concurrence", (1999) 2, Competition Poligy Newsletter, 24-26, at <http://cc.europa.eu/competition/publica tions/cpn/>.

---, "Concurrence dans les professions libérales: quels avantages pour le consommateur?" (2000) at

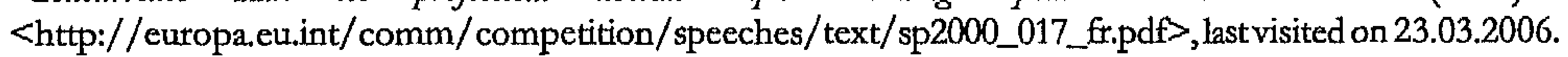

Bishop, Simon / Walker, Mike, The economics of EC competition law : concepts, application and measurement, (London, Sweet \& Maxwell) (2nd ed., 2002), 636 .

Black, Julia, "Constitutionalising Self-Regulation", (1996) 1, The Modern Law Review, 24-55.

Bøegh Henriksen, vila, Anti-competitive State Measures in the European Community - An Analysis of Decisions of the European Court of Justice, (Copenhagen, Handelshøjskolens Forlag) (1994), 149.

Bolze, Christian, "Règles de concurrence. Droit des ententes et positions dominantes." (1995) 2, Revue trimestrielle de droit commercial, avtil-juin, 554-558.

Bortolotti, Bernardo / Fiorentini, Gianluca (Eds.), Organized Interests and Self-Regulation - An Economic Approach, (Oxford, Oxford University Press) (1999), 268.

Bourgeois, Jacques H.J. / Bocken, Jan,

"Guidelines on the Application of Atticle 81(3) of the EC Treaty or How to Restrict a Restriction", (2005) 2, Legal Issues of European Integration - Special Edition "European Competition Law Retisited: The 'Great Overhaul' of 2004 Analysed", 111-121.

Boutard-Labarde, Marie-Chantal,

"Droit communautaire-Coopérative d'achat. Achats parallèles. Règle de raison. Ententelicite. Renforcement licite d'une position dominante d'acheteur." (1995) 11, Semaine juridique édition générale, I. doctrine 3831, 127128. 
Bouterse, Rosita Bianca,

Competition and Integration - What Goals Count? EEC Competition Law and Goals of Industrial, Monetary and Cultural Poligy, (Deventer; Boston, Kluwer) (1994), 145.

BRAK,

"Anwaltstätigkeitunterliegtnicht derGewerbesteuerpflicht", (2002) at<http://www.brak.de/seiten/04_02_05.php>, last visited on 30-09-2002.

BRAK - Ausschuss Verfassungsrecht und Ausschuss Steuerrecht,

Stellungnabme der Bundesrecbtsanwaltskammer zu der Anfrage des Präsidenten des Bundesverfassungsgerichts vom 25.01.2007 zur Geverbesteuer (1 BuL 2/04) BRAK-Stellungnahme-Nr. 17/2007 of $04 / 2007,15$, at <http://www.brak.de/seiten/pdf/Stellungnahmen/2007/Stn17.pdf>, last visited on 06.09.2007.

Briones, Juan / Padilla, Atilano Jorge,

"The Complex Landscape of Oligopolies under EU Competition Policy - Is Collective Dominance Ripe for Guidelines?" (2001) 3, World Competition, 307-318.

Brosio, Giorgio,

The Regulation of Professions in Italy, (Milano, Pressure Groups, Self-Regulation and Collective Decision-Making) (1997), at <http://www.feem.it/NR/rdonlyres/E15C9A71-7B 86-4E26-AC2CDBB6EAB9900B/461/3697.pdf>.

Bruzzone, Ginevra,

"Deregulation of structurally competitive services: economic analysis and competition advocacy", in Amato, Giuliano / Laudati, Laraine L. (Eds.), The Anticompetitive Impact of Regulation, (Cheltenham, UK, Edward Elgar) (2001), 5-28.

Buendia Sierra, José Luis,

Exclusive Rights and State Monopolies Under EC Law - Arlicle 86 (Formerly Article 90 of the EC Treaty), (Oxford, Oxford University Press) (1999), 458.

Bundesverband der Freien Berufe (BFB), "Gewerbesteuer/ Gemeindefinatrveform Stellungnahme", (2003) at <http://www.freie-berufe.de/GewerbesteucrGemeindefinanzr.107.0.html>, last visited on 06.09.2007.

Caimoto Duarte, Joaquim, "A Portuguese Court substantially upholds the competition authority's decision finding the association of veterinaries liable for imposing mitimum fees (Fixacâa de honorários por uma ordem profissional)", (2006) e-Competitions, No 19797, at $<w w w$. concurrences.com $>$, last visited on 19.06.2008.

Castillo de la Torre, Fernando, "Reglamentaciones públicas anticompetitivas", in Beneyto Pérez, José María / González-Orús, Jerónimo Maillo (Eds.), Tratado de derecho de la competencia, Tomo II, (Bosch) (2005), 1302-1391.

CEPLIS - European Council of Liberal Professions, "European Council of Liberal Professions - CEPLIS", (2000) Institut des Sciences du travail, at <http://www.trav.ucl.ac.be/partenaires/eu-3-en.html>, last visited on 16.10.2001.

Chalmers, Damian / Hadjijemmanuil, Christos / Monti, Giorgio / Tomkins, Adam, European Union Law - text and materials, (Cambridge, Cambridge University Press) (2006), 1235.

Chung, Chan-Mo, "The Relationship between State Regulation and EC Competition Law: Two Proposals for a Coherent Approach", (1995) 2, European Competition Law Revien, 87-97.

Claessens, Sjoerd, Free Movement of Lanyers in the European Union, (Nijmegen, Wolf Legal Publishing) (2008), 383, at $<$ http://arno.unimaas.nl/show.cgi?fid $=14501>$.

Clementi, David,

Review of the Regulatory Frameevork for Legal Services in England and Wales - $A$ Consultation Paper of 03/2004 (Department for Constitutional Affairs, London), 80, at $<\mathrm{http://www.legal-services-}$ review.org.uk/index.htm>, [referenced in footnotes as: $A$ Consultation Paper].

--, Review of the Regulatory Framework for Legal Services in England and W ales - Final Roport of 12/2004 (Secretary of State for Constitutional Affairs), 163, at <http://www.legal-services-review.org.uk/ $>$.

Clemenz, Gerhard / Dewatripont, Mathias / Motta, Massimo / Neven, Damien / Seabright, Paul / Zemplinerova,

Services of General Economic Interest of 29.06.2006 (Opinion prepared by the State Aid Group of the Economic Advisory Group (to the Commission) on Competition Policy, EAGCP), 8, at $<\mathrm{http://ec.europa.eu/dgs/competition/economist/eagcp.html>,} \mathrm{last} \mathrm{visited} \mathrm{on} \mathrm{06.05.2009.}$ 
Commissie Advocatuur / van Wijmen, P.C.E. / Van den Bergh, Roger J. / Gerritsen-Bosselaar, A. / Kortmann, S.C.J.J. / Kranenburgh, J.C. / Loorbach, J.D. / Loth, M.A. / Maan, E.A., Een maatschappelijke Orde of 24.04.2006 (Ministerie van Justitie,), 63, at $<$ http://www.minjus.nl/images/rapport\%20commissie\%20advocatuur.doc_7016_tcm3478624.pdf>, last visited on 11.03.2008.

Cooke, John D.,

"Vocation as a Commodity", in Ehlermann, Claus-Dieter / Atanasiu, Isabela (Eds.), European Competition Law Annual 2004: The Relationship between Competition Law and (Liberal) Professions, (Oxford \& Portland/Oregon, Hart Publishing) (2006), (in the present study reference is being made to the page numbers of the version published online), at <http://www.iue.it/RSCAS/Rescarch/Competition/2004(papers).shtml>.

Cooter, R. / Ulen, T., Law \& Economics, (Addison Wesley Longman) (3rd cd., 2000).

Council of Europe,

The independence of lanyers, (Strasbourg, 28th Colloquy on European Law) (2003), 149, at <http://www.coe.int/T/E/Legal_Affairs/Legal_co-operation/Legal_professionals/Lawyers/Colloquy _on_European_law/bayonne $\% 20$ Actes $\% 20$ E.pdf $>$.

Cox, C. / Foster, S.,

The Costs and Benefits of Occupational Regulation, (Economic Issues) (1990).

Crayencour, J.-P.,

The professions in the European Community: lowvards freedom of movement and mutual recognition of qualification, (Brussels, European Community Information Service,) (1982), 137.

Creel, Jérôme / Laurent, Éloi / Le Cacheux, Jacques, Delegation in Inconsisteng: The "Lisbon strategy » Record as an Institutional Failure, (Paris) (2005).

Dabbah, Maher M., ECand UK Competition Lan - Commentary, Cases andMaterials, (Cambridge, Cambridge University Press) (2004), 725.

de Bijl, P. / Van Damme, Eric, Regulering en Zelfregulering in Markten met Kavaliteitsonzekerbeid, (Tilburg, Center for Economic Research) (1996).

De Waele, Sandra (European Commission - agent of DG Competition),

"Intervention", (10-11.11.2005) Speech at the 1st Congress of EU Civil Law Notaries in Rome, at $<$ http://cc.curopa.eu/competition/speeches/text/sp2005_023_fr.pdf>.

de Witte, Bruno,

"Non-market values in internal market legislation", in Nic Shuibhne, Niamh (Ed.) Regulating the Intermal Market, (Cheltenham, UK, Edward Elgar) (2006), 61-86.

Deckert, Martina Renate,

"Some preliminary remarks on the limitations of European Competition Law", (2000) European Revien of Private Law, 173-185.

Di Via, Luciano,

"Brevi note sul criterio di economicità e l'impresa rilevante per il diritto della concorrenza nella recente giurisprudenza della Corte di giustizia (SAT Fluggesellschaft mbH v Eurocontrol)", (1994) Il Foro Italiano, Parte IV, 297-315.

Dobelle, Florence,

"Prohibitions on Incorporation and Alternative Approaches", in OECD / Nicholas-Gervais, Vera (Eds.), International Trade in Professional Services - Advancing Liberalisation Tbrough Regulatory Reform, (Paris, OECD) (1997), 27-30, at <http://www.oecd.org/daf/cmis/SERVICES/PRSERWS3.HTM>.

Drijber, Berend Jan,

"Case C-364-92, SAT Fluggesellschaft mbH v. European Organization for the Safety of Air Navigation (Eurocontrol)", (1995) Common Market Law Review, 1039-1050.

-., "Joined cases C-264/01, C-306/01, C-453/01 and C-355/01, AOK Bundesverband a.o., judgment of the Full Court of 16 March 2004, not yet reported." (2005) Common Market Law Review, 523-533.

Edward, David A. O.,

"The significance of independent legal professions for the rule of law", in Bundesministerium für Justiz der Republik Österreich (Ed.) Die Bedeulung der freien Rechtsberufe im integrierten Europa, (Wien, Manz) (1999), 143150.

Edward, David A. O. / Hoskins, Mark,

"Article 90: Deregulation and EC Law. Reflections Arising from the XVI FIDE Conference", (1995) Common 
Market Law Revien, 157-186.

Ehlermann, Claus-Dieter,

"Concurrcnce et professions libérales: antagonisme ou compatibilité?" (1993) 365, Revue du Marché commun et de l'Union européenne, 136-144.

-.-., "Wettbewerb und freie Berufe: Antagonismus oder Kompatibilität?" in Rechenschaffslegung im Wandel, Festscbrift für Wolfgang Dieter Budde, (München, Beck) (1995), 157-180.

Ehlermann, Claus-Dieter / Atanasiu, Isabela (Eds.),

European Competition Law Annual 2004: The Relationship between Competilion Law and (Liberal) Professions, (Oxford \& Portland/Oregon, Hart Publishing) (2006), 430, at <http://www.iue.it/RSCAS/Research/Competition/2004.shtml> and $<$ http://www.iue.it/RSCAS/Research/Competition/2004(papers).shtmll .

Eilmansberger, Thomas,

"How to Distinguish Good From Bad Competition Under Article 82 EC: in Search of Clearer and More Coherent Standards for Anti-Competitive Abuses", (2005) Common Market Law Review, 129-177.

Ellis, E. / Tridimas, [Takis], Public Law of the EC, (Iondon) (1995).

European Commission, "Article 82 Review",(2006) at < http://europa.eu.int/comm/competition/antitrust/others/article_82_review .html>, last visited on 26.04.2006.

Evans, Lowri / Laurila, Maija / Paserman, Ruth,

"Professional Services: Recent EU Developments and Work in Progress", in Ehlermann, Claus-Dieter / Atanasiu, Isabela (Eds.), European Competilion Law Annual 2004: The Relationship between Competition Law and (Liberal) Professions, (Oxford \& Portland/Oregon, Hart Publishing) (2006), (in the present study reference is being made to the page numbers of the version published online), at <http://www.iue.it/RSCAS/Research/Competition/2004(papers).shtml>.

Faull, Jonathan / Nikpay, Ali (Eds.),

-- (Eds.), The EC Law of Competition, (Oxford, Oxford University Press) (1999), 961, at <w>.

The EC Law of Competition, (Oxford, Oxford University Press) (2nd ed., 2007), 1844.

Faure, Michael G. / Maks, J.A.H. / Philipsen, Niels J., "(Zelf)-regulering van de Apothekersmarkt", (2001) Maandschrift Economie, 208-228.

Faure, Michael G. / Philipsen, Niels J. / Fernhout, Fokke J., Honoraria van Belangenbebartigers in Letselschadezaken of 23.01.2008 (METRO, Universiteit Maastricht Onderzoek in opdracht van de Stichting Personenschade Instituut van Verzekeraars).

Feintuck, Mike, The Public Interest in Regulation, (Oxford, Oxford University Press) (2004), 299.

Fenger, Niels / Broberg, Morten P.,

"National Organisation of Regulatory Powers and Community Compctition Law", (1995) 6, European Competition Law Review, 365-375.

Forrester, Ian S.,

"Where Law Meets Competition: Is Wouters Like a Cassis de Dijon or a Platypus?" in Ehlermann, ClausDieter / Atanasiu, Isabela (Eds.), European Competition Law Annual 2004: The Relationship between Competition Law and (Liberal) Professions, (Oxford \& Portland/Oregon, Hart Publishing) (2006), (in the present study reference is being made to the page numbers of the version published online), at <http://www.iue.it/RSCAS/Research/Competition/2004(papers).shtmll>.

Fox, Eleanor M.,

"State Action in Comparative Context: What if Parker v. Brown were Italian?" in Hawk, B. (Ed.) 2003 Fordham (Annual Conference) International Antitrust Lav and Polity, (2004), 436-??

Frenz, Walter, Handbuch Europarecht (Band 2) - Europäisches Kartellrecbt, (Berlin; Heidelberg, Springer) (2006).

Furse, Mark, Competition Lay of the UK and EC, (New York, Oxford University Press) (3rd ed., 2002), 348.

---, "On a darkling plain: The confused alarms of Article 82 EC", (2004) European Competition Law Review, 317 319.

Galli, Barbara,

"Italian firms face foreign invasion", (1998) May, Intermational Financial Law Review, 32-34. 


\section{General Council of the Bar,}

Model for the Separation of the Regulatory and Representative Functions of the Bar Council: Consultation Paper of 25.02.2005 (The General Council of the Bar,), at <http://www.barcouncil.org.uk>.

Gerber, David J.,

Law and Competition in Twentieth Century Europe: Protecting Prometheus, (Oxford, Claredon Press) (1998), 472.

Gilliams, Hans,

"Competition Law and Public Interest: Do We Need to Change the Law for the (Liberal) Professions?" in Ehlermann, Claus-Dieter / Atanasiu, Isabela (Eds.), European Competition Law Annual 2004: The Relationship between Competition Lan and (Liberal) Professions, (Oxford \& Portland/Oregon, Hart Publishing) (2006), [NB the page numbers referenced in this study refer to the version published online], at $<$ http://www.iue.it/RSCAS/Research/Competition/2004(papers).shtml>.

Gormley, Laurence, "Cassis de Dijon and the Communication from the Commission", (1981) European Law Review, 454-459.

Goyder, D.G.,

EC Competition Law, (Oxford, Oxford University Press) (4th ed., 2003), 592.

Grady, Jane / Paserman, Ruth,

"Professional services: scope for more reform", (2005) Competition Policy Newsletter, Number 3, 65-67, at $<$ http://ec.europa.eu/competition/publications/cpn/>.

Gyselen, Luc

"State Action and the Effectiveness of the EEC Treaty's Competition Provisions", (1989) 26, Common Market Law Revien, 33-60.

---, Rebates: Competition on the Merits or Exclusionarly Practice?, (Firenze, 8th annual EU Competition Law and Policy Workshop, EUI) (2003), at <http://europa.eu.int/comm/competition/speeches>.

---, "Anti-Compctitive State Action in the Area of Libcral Professions: An EU/US Comparative Law Perspective", in Ehlermann, Claus-Dieter / Atanasiu, Isabela (Eds.), European Competition Lay Annual 2004. The Relationship between Competition Law and (Liberal) Professions, (Oxford \& Portland/Oregon, Hart Publishing) (2006), [NB the page numbers referenced in this study refer to the version published online], at <http://www.iue.it/RSCAS/Research/Competition/2004(papers).shtmll>

Hallo de Wolf, Antenor,

"Wordt oorlog geprivatiseerd? Het inzetten van particuliere militaire bedrijven in Irak in het licht van internationaal recht en de rechten van de mens", (2004) Nederlands Juristenblad, 1687-1695.

Hameleers, Marc / van den Heuvel Rijnders, J. / Baljé, S. H.,

"Towards a Smarter Protection of Public Interest in the Liberal Professions", in Ehlermann, Claus-Dieter / Atanasiu, Isabela (Eds.), European Competition Law Annual 2004: The Relationship between Competition Law and (Liberal) Professions, (Oxford \& Portland/Oregon, Hart Publishing) (2006), [NB the page numbers referenced in this study refer to the version published online], at $<$ http://www.iue.it/RSCAS/Research/Competition/2004(papers).shtml>.

Hancher, L., "Casenote on Corbeau", (1994) Common Market Law Review, 105.

Harrison, Stephen,

"Prohibitions on Incorporation and Alternative Approaches", in OECD / Nicholas-Gervais, Vera (Eds.), International Trade in Professional Services - AdvancingLiberalisation Tbrough Regulatory Reform, (Paris, OECD) (1997), 31-36, at <http://www.oecd.org//daf/cmis/SERVICES/PRSERWS3.HTM>.

Hatje, Armin,

"Artikcl 10 EGV", in Schwarze, Jürgen (Ed.) EU-Kommentar, (Baden-Baden, Nomos) (2000), 296-314.

Hatzopoulos, Vassilis,

"Recent Developments on the Case Law of the ECJ in the Field of Services", (2000) Common Market Law Revien, 43-82.

Hawk, B. E., United States, Common Market and International Antitrust. A Comparative Guide, (Aspen Law \& Business) (2nd ed., 1990).

Hegel, Georg Wilhelm Friedrich, Enzyklopädie der philosophischen Wissenschaft, (1830).

Heinsohn, Gunnar / Steiger, Otto,

Die Vernicbtung der weisen Frauen - Beiträge zur Theorie und Gescbicbte von Bevölkerung und Kindheit; Hexenverfolgung, Kinderwelten, Bevölkerungswissenschaft, Menschenproduktion, (München, Wilhelm Heyne Verlag) (3rd, expanded ed., 
1989), 454.

---, Eigentum, Zins und Geld - Ungelöste Rätsel der Wirtschaftswissenscbaft, (Hamburg, Rowohlt) (1996), 544.

Heinz, Karl Eckhart,

"Die Partnerschaftgesellschaft und ihre Haftungsregeln", (1998) 1, Zeitscbrift für Recbtssoziologie, 73-84.

Herrmann, Harald,

Recbt der Kammern und Verbände Freier Berufe: europäischer Ländervergleich und USA, (Baden-Baden, Nomos) (1996), 596.

Hildebrand, Doris, Role of Economic Analysis in the EC Competition Rules, (The Hague - I ondon - Boston, Kluwet) (2nd ed., 2001).

--, "The European School in EC Competition Law", (2002) 1, World Competition - Law and Economics Review, 3-23.

Hochbaum,

"[Artikel 90]", in Groeben, Hans von / Thiesing, Jochen / Ehlermann, Claus-Dieter (Eds.), Kommentar zum EU-/EG-Vertrag, (1999).

Idot, Laurence,

"Quelques réflexions sur l'application du droit communautaire de la concurrence aux ordres professionels", (1997) Journal des tribunaux - droit européen, 73-79.

IFB (Institut für Freie Berufe),

"Freier Beruf oder Geverbe? - Kurzfassung", (2006) at <http://www.ifbgruendung.de/pdf_etc/Freier_Beruf_oder_Gewerbe-kurzfassung.pdf $>$, last visited on 06.09.2007.

Ivanova, Stela / (Germany Trade and Invest),

"Reform der Recbtsdurchsetzung in Bulgarien unter EU-Druck", (2006) at <http://www.gtai.de/DE/Navigation/Datenbank-Recherche/Recht/Recherche-Recht/recherche-rechtnode.html>, last visited on 20.04.2009.

Jellinek, Georg, Allgemeine Staatslebre, (Bcrlin, O. Häring) (3rd ed., 1914), 837.

Jennings, Robert Y. / Watts, Arthur D., Oppenheim's international law, Vol. I, (I.ondon, Longman) (1992).

Jenny, Frédéric,

"Regulation, Competition and the Professions", in Ehlermann, Claus-Dicter / Atanasiu, Isabela (Eds.), European Competition Law Annual 2004: The Relationship between Competition Law and (Liberal) Professions, (Oxford \& Portland/Oregon, Hart Publishing) (2006), [NB the page numbers referenced in this study refer to the version published online], at <http://www.iue.it/RSCAS/Research/Competition/2004(papers).shtml>.

Jones, Alison / Sufrin, Brenda, EC Competition Law - Text, Cases, and Materials, (Oxford, Oxford University Press) (2nd ed., 2004).

Kahl, Wolfgang,

"Art. 10", in Calliess, Christian / Ruffert, Matthias (Eds.), Kommentar des Vertrages über die Europäiscbe Union und des Verlrages zur Gründung der Europäischen Gemeinschaft, (Neuwied; Kriftel, Luchterhand) (1999), 365-398.

Kienapfel, Philip / Stein, Andreas,

"The application of Articles 81 and $82 \mathrm{EC}$ in the sport sector", (2007) Competition Policy Newsletter, Number 3, 6-13, at <http://ec.europa.eu/competition/publications/cpn/>.

Komninos, Assimakis P.,

"Non-Competition Concerns Resolution of Conflicts in the Integrated Article 81 EC", in Ehlermann, ClausDieter / Atanasiu, Isabela (Eds.), European Competition Law Annual 2004: The Relationship between Competilion Law and (Liberal) Professions, (Oxford \& Portland/Oregon, Hart Publishing) (2006), (in the present study reference is being made to the page numbers of the version published online), at <http://www.iue.it/RSCAS/Research/Competition/2004(papers).shtml>.

König, Michal, Standesrecbilicbe Wettbewerbsbeschränkungen im gemeinsamen Markt: eine Studie zur gemeinschaftskartellrechtlichen Problematik wettbewerbsbeschränkenden Standesrecbts der freien Berufe unter Berücksicbtigung des deutschen, britischen und französichen Recbts, (Baden-Baden, Nomos) (1997), 282.

Korah, Valentine, An Introductory Guide to EC Competition Law and Practice, (Oxford, Hart Publishing) (7th ed., 2000).

Kroes, Neelie (Competition Policy Commissioner),

"Better Regulation of Professional Services", (21.11.2005) SPEECH/05/711, Speech at the UK Presidency Seminar: Better Regulation of Professional Services, at <http://europa.eu/rapid/>.

---, "Preliminary Thoughts on Policy Review of Article 82", (23.09.2005) SPEECH/05/537, Speech at the 
Fordham Corporate Law Institute, New York, at <http://europa.eu/rapid/>, last visited on 26.04.2006.

Kuijpers, Nicole / Noailly, Joëlle / Vollaard, Ben,

Liberalisation of the Dutch notary profession - Reviewing its scope and impact No 93 of 09/2005 (Centraal Plan Bureau (CPB) - Netherlands Bureau for Economic Policy Analysis), 72, at <http://www.cpb.nl/eng/pub/cpbreeksen/document/93/doc93.pdf>, last visited on 10.03.2006.

Lasok Q.C., K.P.E.,

"When is an Undertaking not an Undertaking?" (2004) 7, European Competition Law Review, 383-385.

Lenk, Jennifer,

Die.Ausnabme standesrechtlicher Werbeverbote aus dem EG-Kartellrecht-Zugleich ein Beitrag zu der Frage der Beeinflussung des EG-Kartellrechts durch Aspekte des Gemeinwohls, (Baden-Baden, Nomos) (2006), 403.

Leroy, Christophe,

"L'intérêt général comme régulateur des marchés: a propos de deux arrêts CJCE du 5 octobre 1995 Centro Servizi Spediporto (C-96/94) et du 1er octobre 1998 Autotrasporti Librandi (C-38/97)", (2001) 1, janviermars, Revue trimestrielle de droit européen, 49-61.

Lianos, Ioannis,

"Collusion in Verlical Relations under Article 81 EC", (2007) at <http://www.ucl.ac.uk/laws/clge/wpseries/ucl_clge_001_07.pdf>, last visited on 28.03.2008.

Loozen, Edith, "Professional Ethics and Restraints of Competition", (2006) European Law Review, 28-47.

--, "Zelfregulering door en voor de vrije beroepen: toch maar liever geen algemeen belang rule of reasan", (2007) Nederlands tijdschrift voor Europees recht, 153-162.

--, "Reactie op 'Economisch recht en het Verdrag van Lissabon I: mededinging en interne markt' van prof. dr. F. Amtenbrink en prof. mr. J.W. van de Gronden (SEW 2008, 146)", (2009) Sociaal-economiscbe Wetgeving, 108110.

Louis, J.-V., Die Recbtsordnung der EG, (Brussels) (3rd ed., 1993).

Louri, Victoria, "'Undertaking' as a Jurisdictional Element for the Application of EC Competition Rules", (2002) 2, Legal Issues of European Integration, 143-176.

Lowe, Philip (Director General of DG Comp), "Speech at 30th Annual Conference on International Antitrust Law and Policy", (23.10.2003) Fordham Corporate Law Institute, at <http://ec.europa.eu/comm/competition/speeches/text/sp2003_040_en $. p d f>$, last visited on 12.05.2006.

--, "Preservingand Promoting Competition: A European Response", (2006) Competition Poligy Newsletter, Number 2, 1-5, at <http://ec.europa.eu/competition/publications/cpn/>.

Lugard, Paul / Hancher, Leigh, "Honey, I shrunk the Article! A critical assessment of the Commission's Notice on Article 81(3) EC", (2004) European Competition Law Review, 410-420.

-- (Eds.),

On the Merits - Current Issues in Competition Law and Poligy. Liber Amicorum for Peter Plompen, (IIntersentia and others]) (2005).

Maks, J.A.H. / Philipsen, Niels J.,

"An economic analysis of the regulation of professions", in Vereeck, L. (Ed.) The Regulations of Architects, (Antwerpen, Intersentia) (2002).

Manzini, P.,

"The European Rule of Reason - Crossing the Sea of Doubt", (2002) European Competition Law Review, 392 399.

Marenco, Giuliano,

"Competition Between National Economies and Competition Between Business - A Response to Judge Pescatore", (1987) Fordham Intermational Lav Joumal, 420-443.

Martin, Paul C. / in collaboration with Lüftl, Walter, Der Kapitalismus-Ein System, dasfunktioniert, (München, WirtschaftsverlagLangen-Müller/Herbig) (1986), 456.

Martinazzi, Alberto, "The Effects of Wouters on Professional Regulation: Intertwining Public Policy, Proportionality and the Rule of Reason?" at <http://www.cahiers.org/new/htm/articoli/martinazzi_wouters.htm\#_ednref15>, last visited on 29.03.2006. 
Mastenbroek, Willem,

Vaardiger onderbandelen, (Heemstede, Holland Business Publications) (7th ed., 2006), 120.

Michalski, Lutz,

Der Begriff des freien Berufs im Standes- und in Sleuerrecbt, (Köln, Dt. Ärzte-Verlag) (1989).

--, Das Gesellschaffs- und Kartellrecht der berufsrechtlich gebundenen freien Berufe, (Köln, Schmidt) (1989), 548.

Michalski, Lutz / Römermann, Volker,

"Das europäische Kartellrecht der Freien Berufe - Auswirkungen auf die künftige anwaltliche Berufsordnung", (1996) Anvaltsblatt, 191-201.

Ministère de 1'Économie et du Commerce extérieur, "11e Journée eumpéenne de la concurrence - 3 mai 2005 à Luxembourg - The competition rules and the liberal professions", (2005) at < http://www.eco.public.lu/actualites/conferences/2005/05/03_journee_conc/>, last visited on 31.01.2006.

Monti, Giorgio,

"The Scope of Collective Dominance Under Article 82 EC", (2001) 1, Common Market Law Review, 131-157.

---, "Article 81 EC and Public Policy", (2002) Common Market Law Review, 1057-1099.

Monti, Mario (Competition Policy Commissioner),

"Competition in Professional Services: Ncw Light and New Challenges", (21.03.2003) Speech of the Compctition Policy Commissioner befor the BRAK (Bundesrechtsanwaltskammer) in Berlin, at $<$ http://ec.europa.eu/competition/speeches/text/sp2003_070_en.pdf>.

--, "Comments and concluding remarks of Commissioner Monti at the Conference on Professional Regulation", (28.10.2003) Speech at the occasion of the Commission's Conference on Professional Regulation, at <http://ec.europa.eu/comm/competition/sectors/professional_services/conferences/ 20031028/mmonti_final_speech_cabinet.pdf $>$, last visited on 13.03.2007.

Mortelmans, Kamiel, "Towards convergence in the application of the rules on free movement and on competition?" (2001) 3 , Common Market Law Review, 613-649.

Moussé, Jean, "Le régime juridique des redevances de route et la Court de justice des Communautés européennes", (1994) Revue Française de droit aérien et spacial, 7-41.

Müller-Graff, Peter-Christian, "Die Freistellung vom Kartellverbot", (1992) Europarecht, 1-40.

---, "Artikel 30", in von der Groeben, Hans / Thiesing, Jochen / Ehlermann, Claus-Dieter (Eds.), Kommentar zum EUV/EGV, (Baden-Baden, Nomos) (5th ed., 1997-8).

Muñiz Fernandez, "Increasing Powers and Increasing Uncertainty: Collective Dominance and Pricing Abuses", (2000) European Law Review, 645-653.

Nahuis, Richard / Noailly, Joëlle / With cooperation of: Aouragh, Ali / Verbruggen, Jeannette, Competition and Quality in the Notary Profession No 94 of 09/2005 (Centraal Plan Bureau (CPB) - Netherlands Bureau for Economic Policy Analysis, Den Haag), 74, at <http://www.cpb.nl/eng/pub/cpbreeksen/ document/94/doc94.pdf>, last visited on 10.03.2006.

Nakamura, Robert T., "Book review - The Public Interest in Regulation, by Mikc Feintuck", (2005) 8, Law \& Politics Book Review, 793-796, at <http://www.bsos.umd.edu/gvpt/lpbr/subpages/reviews/feintuck805.htm>.

Neergaard, Ulla B., Competition do Competences: The Tensions Between European Competition Law and Anti-Competitive Measures by the Member States, (Copenhagen, DJøF Publishing) (1998), 385.

---, "State Action and European Competition Rules : A New Path?" (1999) 4, Maastricbt Journal of European and Comparative Law, 380-396.

Nicolaides, Phedon,

"Compensation for public service obligations: the floodgates of state aid?" (2003) European Competition Law Reviens, 561-573.

--, "The Balancing Myth: The Economics of Article 81(1) \& (3)", (2005) 2, Legal Issues of European Integration Special Edition "European Competition Law Revisited: The 'Great Overbaul' of 2004 Analysed", 123-145.

Niels, Gunnar, "Collective dominance: more than just oligopolistic interdependence", (2001) 5, European Competition Lan Review, 168-172. 
Niels, Gunnar / Jenkins, Helen,

"Reform of Article 82: Where the Link Between Dominance and Effects Breaks Down", (2005) European Competition Law Revien, 605-610.

Nyssens, H.,

"Concurrence et ordres professionnels: les trompettes de Jéricho sonnent-elles?" (1999) Revue de Droit Commercial Belge, 475.

O'Donoghue, Robert,

"Over-Regulating Lower Prices: Time for a Rethink on Pricing Abuses Under Article 82EC", in Ehlermann, Claus-Dieter / Atanasiu, Isabela (Eds.), European Competition Lan Annual 2003 - What Is an Abuse of a Dominant Position?, (Oxford, Hart Publishing) (2006), at <http://www.iue.it/RSCAS/Reseatch/Competition/2003 (papers).shtml>.

Odudu, Okeoghene,

"Interpreting Article 81(1): demonstrating restrictive effect", (2001) 3, European Law Review, 261-274, [referenced in footnotes as: "Demonstrating restrictive effect"].

--, "Interpreting Article 81(1): object as subjective intention", (2001) 1, European Law Revien, 60-75, [referenced in footnotes as: "Object as subjective intention"].

--, "Interpreting Article 81(1): the object requirement revisited", (2001) 4, European Law Review, 379-390, [referenced in footnotes as: "The object requirement revisited"].

---, The Boundaries of EC Competition Law: the Scope of Article 81, (Oxford, Oxford University Press) (2006), 228.

OECD, Competition Policy and the Professions, (Paris, OECD) (1985), 111.

--, The OECD Report on Regulatory Reform - Volume I: Sectoral Studies (OECD, Paris), at <http://www.oecd.org/pdf/M00007000/M00007872.pdf>.

---, Competition in Professional Services DAFFE/CLP(2000)2 of 22.02.2000 (OECD, Paris), 214, at $<$ http://www.oecd.org/dataoced/35/4/1920231.pdf>.

--, Regulatory Reform in Ireland - Regulatory Reform in Electricity, Gas, Pharmacies, and Legal Services (2001) (OECD, Paris), 50, at <http://www.oecd.org/dataoecd/30/55/2511011.pdf>.

OECD / Nicholas-Gervais, Vera (Eds.), International Trade in Professional Services-Advancing Liberalisation Through Regulatory Reform, (Paris, OECD) (1997), 259, at <http://www.oecd.org//daf/cmis/SERVICES/PRSERWS3.HTM>.

Ogus, Anthony, Regulation - Legal Form and Economic Theory, (New York, Oxford University Press) (1994), 341.

--, "Rethinking Self-Regulation", (1995) Oxford Joumal of L egal Studies, 97-108.

-, "Competition between national legal systems: A contribution of economic analysis to comparative law", (1999) Intermational and Comparative Law Quarterly, 405-418.

---, Costs and Cautionary Tales - Economic Insights for the Law, (Oxford and Portland (Oregon), Hart Publishing) (2006), 320.

Oliver, P., "Some further reflections on the scope of Art. 28-30 (ex 30-36) EC", (1999) Common Market Law Review, 783.

O'Loughlin, Rosemary,

"EC Competition Rules and Free Movement Rules: An Examination of the Parallels and their Furtherance by the ECJ Wouters Decision", (2003) European Competition Law Review, 62-69.

Paterson, Iain / Fink, Marcel / Ogus, Anthony / et al.,

Economic impact of regulation in the field of liberal professions in different Member States - Regulation of Professional Services Final Report (for the European Commission) - Part 1 - Main Report of January 2003 (Institut für Höhere Studien (IHS) = Institute for Advanced Studies, Wien), 1-128, at <http://europa.eu.int/comm/competition/ publications/prof_services/prof_services_ihs_part_1.pdf $>$, [referenced in footnotes as: Economic impact of regulation - Main Report.

---, Economic impact of negulation in the field of liberalprofessions in different Member States-Regulation of Professional Services Fittal Report (for the European Commission) - Part 2 - Case studies of January 2003 (Institut für Höhere Studien (IHS) = Institute for Advanced Studies, Wien), 130-392, at <http://curopa.eu.int/comm/competition/ publications/prof_services/prof_sservices_ihs_part_2.pdf $>$, [referenced in footnotes as: Economic impact of regulation - Case studies].

Pernice / Wernicke, Stephan,

"Art. 86 EGV", in Grabnitz, Eberhard / Hilf, Meinhard (Eds.), Das Recbt der Europäischen Union, Band II, (München, Beck) (2003). 
Pescatore, $\mathbf{P}$.,

"Public and Private Aspects of Community Competition Law", in Hawk, B (Ed.) Fordham International Law Journal, (1987), 373-419.

Philipsen, Niels J.,

Regulation of and by Pharmacists in the Netherlands and Belgium: An Economic Approach, (Antwerpen, Intersentia) (2003), 195.

Plug, P.J. / Dekker, A.S.E. / van der Hurk, S.E. / Baarsma, Barbara / Felsö, Flóra,

Mededinging versus domeinmonopolie en ministerieplicht - Over de gevolgen van marktwerking in het notariaat of April 2003 (Berenschot; Stichting voor Economisch Onderzoek der Universiteit van Amsterdam (SEO), Den Haag), 120, at <http://appz.ez.nl/publicatics/pdfs/03ME15_Notatiaat.pdf>.

Posner, R. A. "Theories of Economic Regulation", (1974) Bell Joumal of Economics and Management Science, 335.

---, Economic Analysis of Law, (Wolters Kluwer Law \& Business) (1998).

Radbruch, Gustav, Einfübrung in die Recbtswissenschaff, (9th ed., 1952).

Reich, Norbert, "Europe's Economic Constitution, or: A New Look at Keck", (1999) Oxford Journal of Legal Studies, 337-344.

Ridyard,

"Exclusionary Pricing and Price discrimination Abuses Under Article 82: An Economic Analysis", (2002) European Competition Law Review, 286.

Riley, V Alan, "The EU Reform Treaty and the Competition Protocol: Undermining EC Competition Law", (2007) European Competition Law Review, 703-707.

Ring, Gerhard, Wettbewerbsrecht der freien Berufe - Unlauterer Wettbewerb durch standeswidriges Verbalten, (Baden-Baden, Nomos) (1989), 607.

Ritter, Lennart / Braun, W. David, EC Competition Law : A Practitioner's Guide, (Den Haag, Kluwer Law International) (3rd ed., 2004), 1226.

Ritter, Lennart / Braun, W. David / Rawlinson, Francis, EC Competition Law - A Practitioner's Guide, (Den Haag, Kluwer Law International) (2nd ed., 2000), 963.

Rivkin, Donald H., "Prohibitions on Incorporation and Alternative Approaches", in OECD / Nicholas-Gervais, Vera (Eds.), Intermational Trade in Professional Services - Advancing Liberalisation Through Regulatory Reform, (Paris, OECD) (1997), $37-40$.

Rizza, Cesare,

"The Duty of National Competition Authorities to Disapply Anti-Competitive Domestic Legislation and the Resulting Limitations on the Availability of the State Action Defence (Case C-198/01 CIF)", (2004) 2, European Competition Law Review, 126-131.

Rodger, Barry J., "The Competition Act 1998 and State Entities as Undertakings: promises to be an interesting debate", (2003) at <http://www.clasf.org/assets/CLaSF\%20Working\%20Paper\%2001.pdf>, last visited on 29.03.2006.

Rodger, Barry J. / MacCulloch, Angus, Competition Law and Poligy in the EC and the UK, (London, Cavendish Publishing) (1999), 315.

---, Competition Law and Policy in the EC and the UK, (London, Cavendish Publishing) (2nd ed., 2001), 313.

Römermann, Volker / Hartung, Wolfgang, Anwwaltiches Berufsrecbt: ein Lebrbuch, (München, Beck) (2002).

Roth, P.M., Bellamy \& Cbild: European Community Law of Competition, (London, Sweet \& Maxwell) (5th ed., 2001).

Russel, Bertrand, Our Sexual Ethics, (originally published in The American Mercury) (1936).

Sauter, Wolf, Competition Law and Industrial Poligy in the EU, (Oxford, Clardon Press) (1997), 255.

Scarpa, Carlo,

"The theory of quality regulation and self-regulation: towards an application to financial markets", in Bortolotti, Bernardo / Fiorentini, Gianluca (Eds.), Organized Interests and Self-Regulation-AnEconomic Approach, (Oxford, Oxford University Press) (1999), 136-260. 
--, "The anticompetitive effects of minimum quality standards: the role of self-regulation", in Amato, Giuliano / Laudat, Laraine L. (Eds.), The Anticompetitive Impact of Regulation, (Cheltenham, UK, Edward Elgar) (2001), 29-48.

Schaumans, Catherine / Verboven, Frank, Entry and Regulation - Evidence from Health Care Professions, (2006).

Schepel, Harm,

"Delegation of Regulatory Powers to Private Parties Under EC Competition Law: Towards a Procedural Public Interest Test", (2002) Common Market Law Revien, 31-51.

Schermers, Henry G. / Pearson, Patrick J.,

"Some Comments on Article 5 of the EEC Treaty", in Baur, Jürgen F. / Hopt, Klaus J. / Mailänder, Petcr K. (Eds.), Festschrift für Emst Steindorff zum 70. Geburtstag am 13. März 1990, (Berlin, de Gruyter) (1990), 1359 1378.

Schmalensee, R.,

"Another Look at Market Power", (1981) 95, Harvard Law Review, 1789.

Schmid,

"Diagonal Competence Conflicts between European Competition Iaw and National Regulation - A Conflict of Laws Reconstruction of the Dispute on Book Price Fixing", (2000) European Review of Private Law, 155-172.

Schmid, Christoph U. / Sebastian, Steffen / Lee, Gabriel S. / Fink, Marcel / Paterson, Iain, Conveyancing Services Market-Study for the European Commission, COMP/2006/D3/003 (Centre of European Law and Politics (ZERP, University of Bremen), International Real Estate Business School (University of Regensburg), University of Vienna, Institute for Advanced Studies (IHS, Vienna)), 260, at $<\mathrm{http}: / /$ cc.europa.eu/comm/competition/sectors/professional_services/studies/studies.html>, lastvisited on 14.02.2008

Schneider, Egon,

Logike für Juristen - Die Grundlagen der Denklebre und der Recbtsantwendung, (München, Verlag Franz Vahlen) (4th ed., 1995), 270.

Schneider, Hildegard E. G. S., Die Anerkennung von Diplomen in der Europäischen Gemeinscbaft, (Antwerpen, Maklu) (1995), 527.

Schneider, Hildegard E. G. S. / Claessens, Sjoerd,

"The Recognition of Diplomas and the Free Movement of Professionals in the European Union", in Schneider, Hildegard E. G. S. (Ed.) Migration, Integration and Citizenship- A Challange for Europe's Future, Volume I, (Maastricht, Forum Maastricht) (2005), 123-166.

Schumpeter, Joseph A., Capitalism, Socialism and Democracy, (Harper) (1942).

Schwarze, Jürgen,

"Der Staat als Adressat des Europäischen Wettbewerbstechts", in Schwarze, Jürgen (Ed.) Europäisches Wettbewverbsrecht im Wandel, (Baden-Baden, Nomos) (2001), 69-108.

Seibert, Ulrich,

"Aktuelle Änderungen des Partnerschaftsgesellschaftsgesetzes: Neuc Haftungsregelung für Freiberufler", (1998) 5, BRAK-Mitteilungen, 210-211.

Seidl-Hohenvelder, Ignaz,

"Eurocontrol und EWG-Wettbewerbsrecht", in Ginther, Konrad / Hafner, Gerhard / Lang, Winfried / Neuhold, Hanspeter / Sucharipa-Behrmann, Lilly (Eds.), Völkerrecht quiscben normativem Anspruch undpolitischer Realität - Festscbriff für Karl Zemanek zum 65. Geburtstag, (Berlin, Duncker\&Humblodt) (1994), 251-273.

Serras, Françoise, "Droit communautaire et international des groupements - no. 7. Cooperatives. Reconnaissance de leur spécificité dans le cadre de l'application des articles 85 er 86 du Traité CEE", (1995) 36, La Semaine Juridique Edition Entreprise, 484 - I - études et chroniques, 344-345.

Shapiro, $\mathrm{C}$.,

"Theories of Oligopoly Behaviour", in Schmalensee, R / Willig, R.D. (Eds.), Handbook of Industrial Organization, (Amsterdam, Elsevier) (1989), 329-414.

Simon, Denys,

L'interpretation judiciaire des traités d'organisations internationales - Morphologie des conventions et fonction juridicionnelle, (Paris, Editions A. Pedone) (1981), 936.

Singer, Peter Warren,

Corporate Warriors: The Rise of the Privatized Military Industry, (Ithaca, Cornell University Press) (2003), 330. 
Steenbergen, Jacques,

"Het mededingingsbeleid en het Verdrag van Lissabon", (2008) 4, Tijdschrift voor Europees en economisch recht. Steinberger, Daniela,

Staatliche Wirtschaftsinterventionen als Verstoß gegen die Wettbewerbsregeln des EG-Vertrages: eine Untersuchung unter besonderer Berïcksicbtigung der Recbtsprecbung des EuGH, (Köln; Berlin; Bonn;München, Heymanns) (1994), 149.

Stigler, G. J.,

"The Economic Theory of Regulation", (1971) Bell Journal of Economics and Management Science, 3.

Stigler, G. J. / Friedland, C.,

"What Can Regulators Regulate? the Case of Electricity", (1962) Joumal of Lay and Economics, 1.

Stockenhuber, Peter,

"Art. 81 EGV", in Grabitz, Eberhard / Hilf, Meinhard (Eds.), Das Recbt der Europäischen Union, (München, Beck) (2001), 8-70.

Szyszczak, Erika,

"Competition and the liberalised market", in Nic Shuibhne, Niamh (Ed.) Regulating the Intermal Market, (Cheltenham, UK, Edward Elgar) (2006), 87-104.

--, The Regulation of the State in Competitive Markets in the EU, (Oxford; Portland (Oregon), Hart Publishing) (2007), 293.

Temple Lang, John,

"Monopolisation and the Definition of 'Abuse' of a Dominant Position under Article 86 EEC Treaty", (1979) Common Market Law Revien, 345.

---, "Community Constitutional Law: Article 5 EEC Treaty", (1990) Common Market Law Review, 645.

--, "State Measures Restricting Competition", (2001) 2, Europarätslig Tidskrift, 206-223.

Terry, Laurel S.,

"German MDPs: Lessons to Learn", (2000) 6, Minnesota Law Retriew, 1547-1624.

--, "MDPs, "Spinning", and Wouters v. NOVA", (2002) Case Westerm Law Review, 867-894.

Tesauro, Giuseppe

"Regulation of Professional Services", (28.10.2003) Speech at the occasion of the Commission's Confetence on Professional Regulation, at <http://ec.europa.eu/comm/competition/sectors/professional_services/ conferences/20031028/giuseppe_tesauro.pdf $>$, last visited on 13.03.2007.

Tettinger, Peter J., Kammerrecbt - Das Recbt der wirtschaftlichen und der freiberuflichen Selbstvernvaltung, (München, C.H. Beck) (1997).

Tillotson, John / MacCulloch, Angus,

"EC Competition Rules, Collective Dominace and Maritime Transport", (1998) World Competition, 51-70.

Timmermans, Christiaan W.A,

"Rule of Reason, Rethinking another Classic of Europcan Legal Doctrine", in Schrauwen, Annette (Ed.) Rule of Reason-Retbinking another Classic ofEuropean Legal Doctrine, (Groningen, Europa Law Publishing) (2005), vi-x.

Tirole, J.,

The Theory of Industrial Organization, (Cambridge Massachusetts, MIT Press) (5th ed., 1992).

Unger, $\mathbf{E}$.,

(algemeen deken Nederlandse Orde van Advocaten), Deregulering in de advocatuur en de taak van de Orde, (Den Haag, Advocatuur en notariaat: tussen profijt en professie) (2006), 33-34.

Van Bael, Ivo / Bellis, Jean-François, Competition Law of the European Community, (Den Haag, Kluwer Law International) (4th ed., 2005), 1682.

van de Gronden, Johan Willem,

"The Rule of Reason and Convergence in Internal Market and Competition Law", in Schrauwen, Annette (Ed.) Rule of Reason - Retbinking another Classic of European Legal Doctrine, (Groningen, Europa Law Publishing) (2005), 77-94.

van de Gronden, Johan Willem / Mortelmans, Kamiel J.M., "Wouters: is het beroep van advocaat een aparte tak van sport", (2002) Ars Aequi, 441.

van de Scheur, Sebastian,

The Limits of Articles 81 and $82 \mathrm{EC}$ in the Control of Oligopolies (working title), (European University Institute Florence) (forthcoming).

van de Ven, Martin E. A. J. / Koopmans, Ivy, Vrije beroepen tussen marktwerking en regulering, (Den Haag, Sdu Uitgevers) (1997), 172.

Van den Bergh, Roger, "Self-regulation of the medical and legal professions: remaining bartiers to competition and EC law", in 
Bortolotti, Bernardo / Fiorentini, Gianluca (Eds.), Organized Interests and Self-Regulation - An Economic Approach, (Oxford, Oxford University Press) (1999), 89-130.

Van den Bergh, Roger J.,

"Towards Efficient Self-Regulation in Markets for Professional Services", in Ehlermann, Claus-Dieter / Atanasiu, Isabela (Eds.), European Competition Law Annual 2004: The Relationship between Competition Law and (Liberal) Professions, (Oxford \& Portland/Orcgon, Hart Publishing) (2006), [NB the page numbers referenced in this study refer to the version published online], at <http:/ / www.iue.it/RSCAS/Research/Competition/ 2004(papers).shtml>.

Van den Bergh, Roger J. / Camesasca, Peter D., European Competition Lav and Economics: A Comparative Perspective, (London, Sweet \& Maxwell) (2nd ed., 2006), 463.

Van den Bogaert, Stefaan,

"Horizontality: The Court Attacks?" in Barnard, Catherine / Scott, Joanne (Eds.), The Law of the Single European Market - Unpacking the Premises, (Oxford, Hart Publishing) (2002), 123-152.

---, Practical Regulation of the Mobility of Sportsmen in the EU Post Bosman, (Den Haag, Kluwer Law International) (2005), 455.

Van den Bossche, A.-M.,

"Voor economische vrijheid en mededingingsrecht: Hoe vrij is de plichtenleet in het beperken van de economische keuzevrijheid van vrije beroepers?" (2000) 1, Tijdscbrift voor privaatrecht, 13-54.

van den Heuvel Rijnders, Jeroen / Lackner, Iris / Verkerk, Hans,

Public interests and market regulation in the liberal professions of March 2004 (Ministerie van Economische Zaken Ministry of Economic Affairs), 101, at <http://appz.cz.nl/publicaties/pdfs/04ME05.pdf>.

van der Mei, Anne Pieter,

Free Movement of Persons witbin the European Community - Cross-Border Access to Public Benefits, (2001).

van Gerven, Dirk,

"The law firm: a choice for a full integrated exercise of the legal profession in order to meet the high quality standards imposed by clients", in Raes, Koen / Claessens, Bart (Eds.), Towards a New Ethical Framework for a Legal Profession in Transition?, (Antwerpen, Intersentia) (2002), 41-72.

van Mourik, M.J.A.,

Het wezen van bet notarisambt, (Den Haag, Advocatuur en notariaat tussen profijt en professie) (2006), 13-17.

Van Velthoven, B.C.J. / van Wijck, P.W.,

Recbt en Efficiëntie: Een inleiding in de economische analyse van bet recht, (Deventer, Kluwer) (3rd ed., 2001).

Vedder, Christoph / Folz, Hans-Peter,

"A Survey of Principal Decisions of the European Court of Justice Pertaining to International Law in 1994", (1996) European Journal of International Law, 112-114.

Vickers, John (Chairman of the Office of Fair Trading),

How does the probibition of abuse of dominance fit with the rest of competition policy?, (Firenze, 8th annual EU competition law and policy workshop at the European University Institute) (2003), 10, at <http://www.oft.gov.uk/shared_oft/speeches/spe0303.pdf>, last visited on 07.06.2008.

Vickers, John / (Chairman of the Office of Fair Trading), Good govermment for free markets, (Competition Policy conference of the Regulatory Policy Institute, Oxford) (2004), 8, at <http://www.oft.gov.uk/shared_oft/speeches/spe0404.pdf>.

Vogelaar, Floris O.W. / Stuyck, Jules H.V. / van Reeken, Bart L.P. (Eds.), Competition Law in the EU, its Member States and Switzerland I, (2000), 858.

Vogels, R.J.M. / de Jong, J.P.J. / van der Zeijden, P.Th. / Snel, D. / Mosselman, M., Gegevensverzameling ten beboeve van de Commissie Monitor Notariaat - Eindrapportage of 01.10.2002 (EIM Onderzock voor Bedrijf en Beleid, Zoetermecr), 142, at <http://www.justitie.nl/Images/11_21111.pdf>, [referenced in footnotes as: Gegevensverzameling Notariaat].

Völcker, Sven B., "Development in EC Competition Law in 2004: an Overview", (2005) Common Market Law Review, 16911736.

Waelbroeck, Michel / Frignani, Aldo (Eds.), Commentaire J. Mégret: Le droit de la CE - Concurrence, (Bruxelles, Éditions de l'Université de Bruxelles) (2nd ed., 1997), 1112.

Wasilewski, Rainer, Freie Berufe in Europa - Daten, Fakten, Informationen, (Bonn) (1993). 
Weatherill, Stephen,

"Anti-Doping Rules and EC Law", (2005) European Competition Law Review, 416.

--, "Anti-doping revisted - the demise of the rule of "purely sporting interest"?" (2006) European Competition Law Review, 645-657.

Weatherill, Stephen / Beaumont, EU Law, (Penguin) (2nd ed., 1999).

Webb, Thomas R, "Fixing the Price Fixing Confusion: A Rule of Reason Approach", (1983) Yale Law Joumal, 706-730.

Wesseling, Rein, The Modermization of EC Antitrust Law, (Hart Publishing) (2000).

---, "The Rule of Reason and Competition Law: Various Rules, Vatious Reasons", in Schrauwen, Annette (Ed.) Rule of Reason - Retbinking anotber Classic of European LegalDoctrine, (Groningen, Europa Law Publishing) (2005), 57-76.

Whelan, Christopher J.,

"Ethics Beyond the Horizon: Why Regulate the Global Practice of Law?" (2001) 4, Vanderbilt Joumal of Transnational Law, 931-952.

Whish, Richard,

"Collective Dominance", in O'Keeffe, David / Bavasso, Antonio (Eds.), Judicial Review in European Union Law - Liber Amicorum in Honour of Lord Slym of Hadley, (Den Haag, Kluwer Law International) (2000), 581-609.

---, Competition law, (London, LexisNexis UK) (5th ed., 2003), 989.

--., Competition law, (Oxford, Oxford University Press) (Gth ed., 2008), 1006.

Wils, Geert,

"«Rule of reason» : une règle raisonnable en droit communautaire?" (1990) Cabiers de droit européen, 19-74.

Wils, Wouter,

"The undertaking as subject of E.C. competition law and the imputation of infringements to natural or legal persons", (2000) 2, European Law Review, 99-116.

Zippelius, Reinhold,

Juristische Methodenlebre, (München, Beck) (9th ed., 2005), 120.

Zuck, Rüdiger,

"Die Anwalts-GmbH nach $\iint 59$ c ff BRAO", (1998) 22, Monatsschrift des Deutschen Rechts, 1317-1322.

Zweigert, Konrad / Kötz, Hein,

An Introduction to Comparative Law, (Oxford, Clarendon Press) (3rd ed., 1998), 714. 